-

r.m

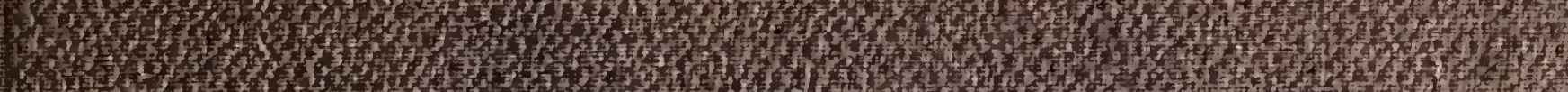

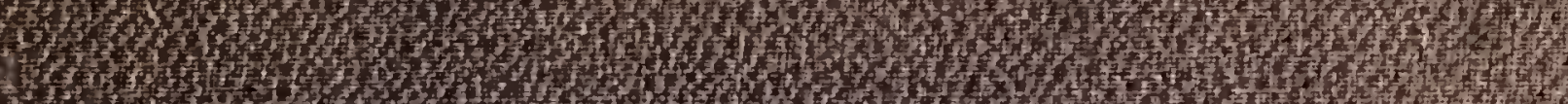

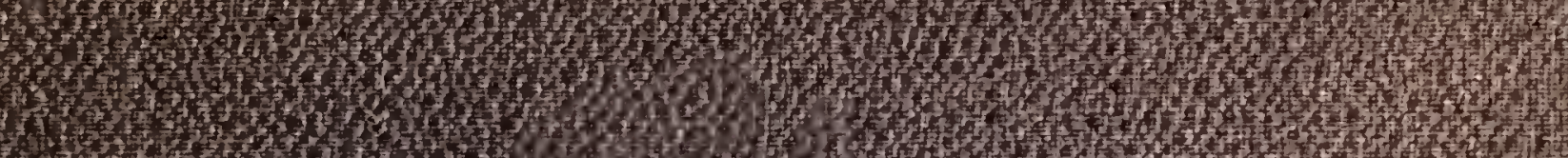

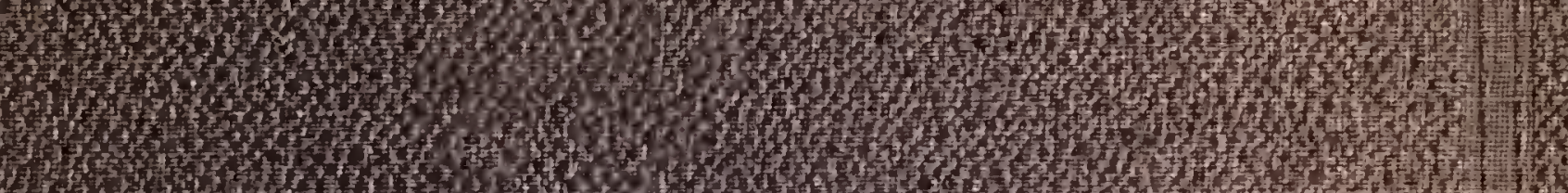

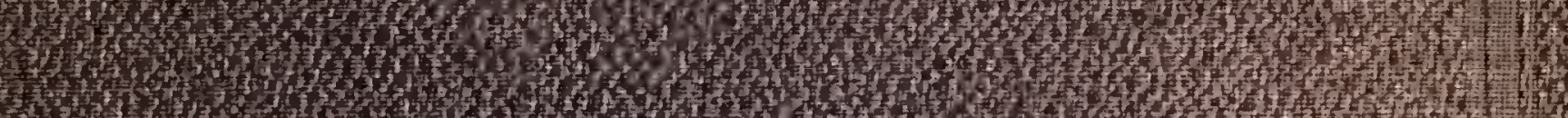

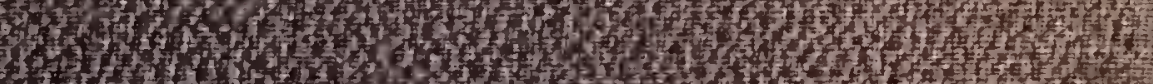

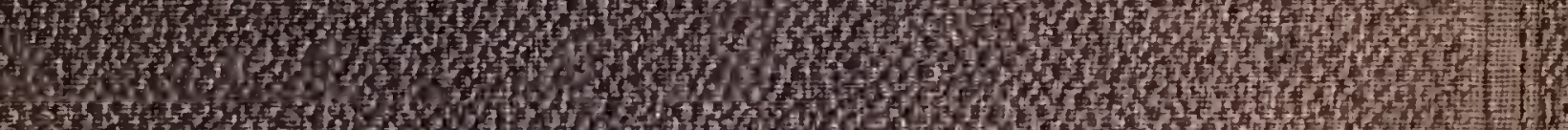
13 1.7.

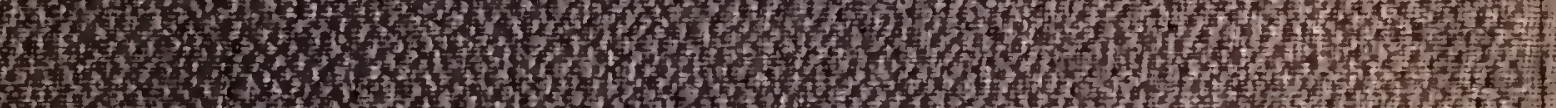

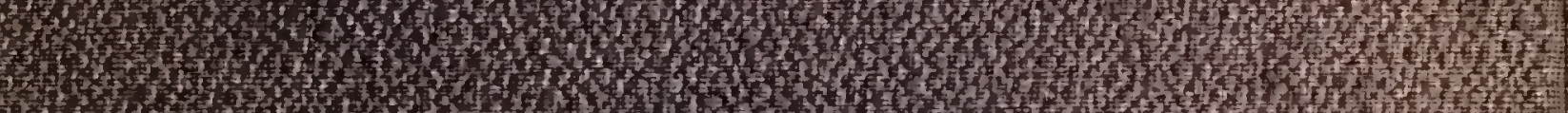
HW

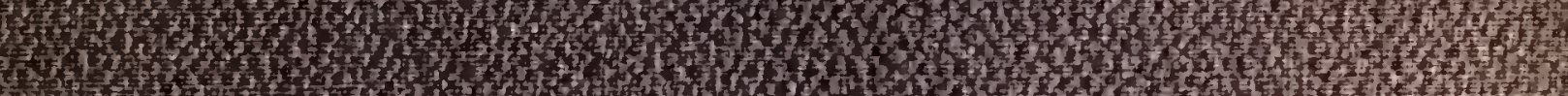

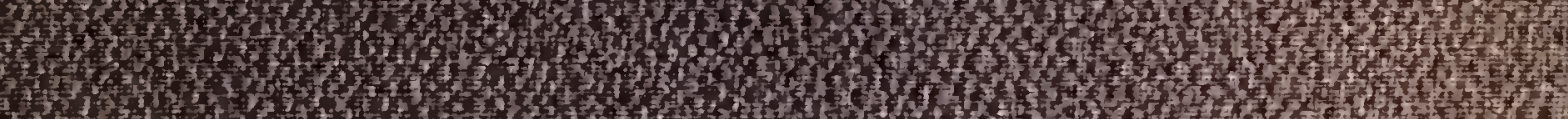




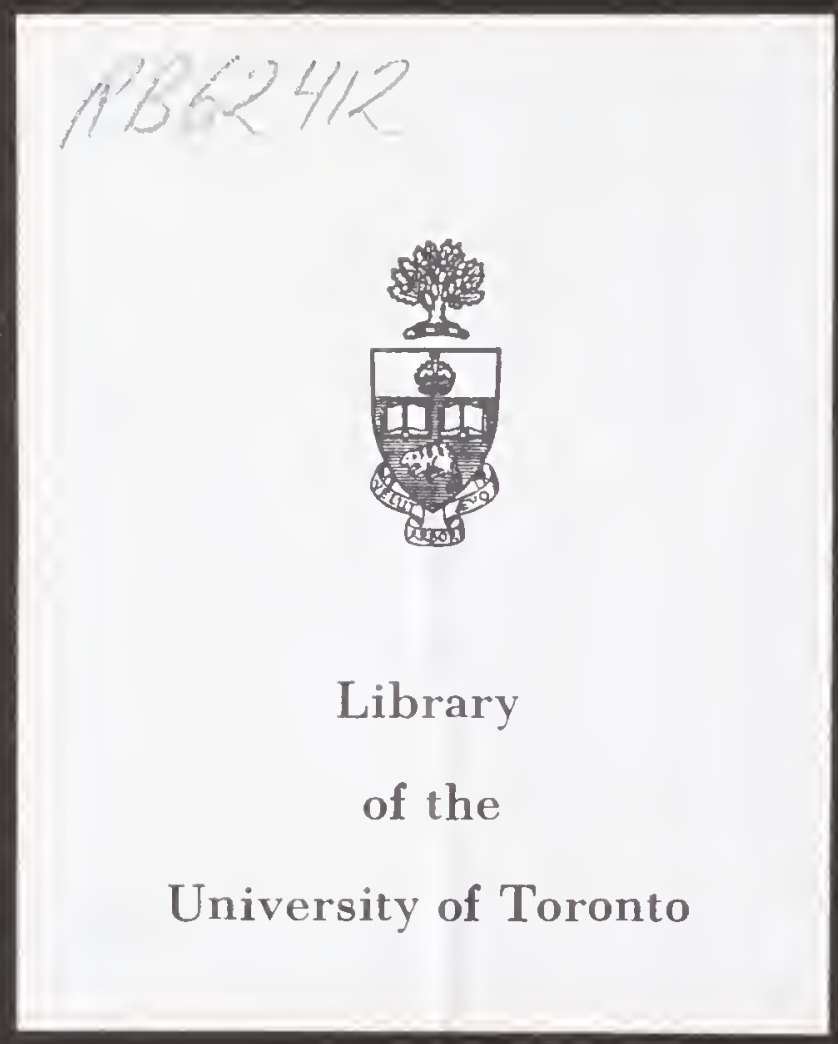




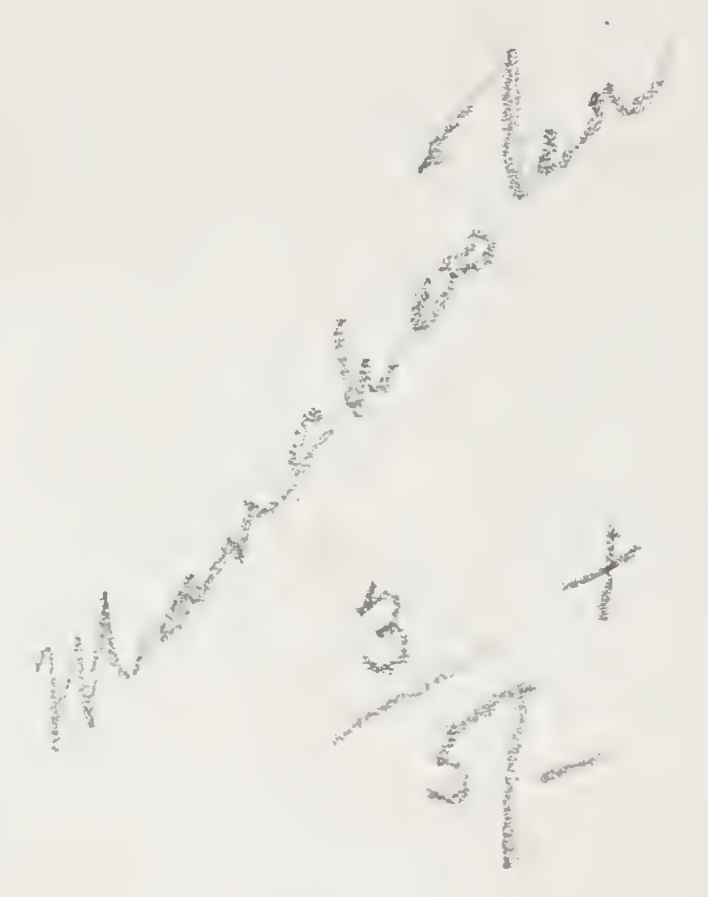




\section{DICTIONARY}

OF

\section{NATURAL HISTORY TERMS}

WITH THEIR DERIVATIONS.

INCLUTNG

THE VARIOUS ORDERS, GENERA, AND SPECIES.

$\mathrm{BY}$

DAVID H. MCNICOLI, M.D.

MENBLR OF THE ROTA1, COLLEGE OF PHYSICIANS

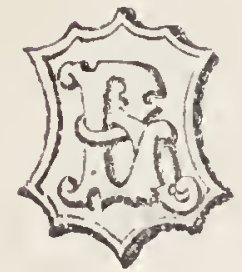

ardond:

LOVELL REEVE \& CO., 5, HENRIETTA STREET, COVENT GARDEN.

1803. 

JOHN FERNLEY, HSQ., OF CLAIRVILI,E, SOUTHPORT,

IX

RECOGNITION OF THE VALUE ATTACHEI 'TO A FRIENDSHIP

IVHICH

HAS BEEY ENJOYED BOTH BY MY FATIIS

AYD MYSELF. 


\section{Digitized by the Internet Archive in 2018 with funding from University of Toronto}




\section{PREFACE.}

This Volume is intended as a library companion for the lovers of Natural History. Endeavour has been made to give as many terms as a portable and conveniently-sized volume would contain, without burdening it with obsolete names. This has rendered necessary the omission of much illustrative matter that was intended to be added, it being thought better to have a numerous list of names than to take up space with that which could be dispensed witl.

No apology will be expected for deficiencies. A book of this nature must needs be deficient, on account of the daily additions made to science, and of the immensity of the existing materials. The intelligent naturalist who may use it will judge it by what it contains, not by what the very nature of the work keeps out, or renders the absence of quite excusable.

It would be easy to multiply instances to show how obscure and difficult of discovery have been the reasons which have influenced nomenclators, and allowance may therefore be made for those too numerous cases in which I have failed in ny researches. Tpomea catarcuctce was so named by Baner." 
from a place in Norfolk Island, called "The Cascade." Baron Walcknäer named a species of spider carolinum, after his second son Charles, the discoverer. Dr. P. L. Sclater has well shewn the difficulties which arise from this cause in the following words:- "Ornithologists, and, I believe I may venture to say, naturalists in general of the present generation, are not always very particular as to the pure Latinity of the names used as specific appellations for the objects described by them, $\mathrm{Or}^{\circ}$ as to their meaning being immediately obvious to the uninitiated. It would puzzle Edipus himself to gness at the derivation of some of the terms applied to members of the animated creation, and the name of the present Tanager is, I think, by no means one of the least obscure in its interpretation. I confess I was totally at a loss to conceive what was the meaning of calling this bird labradorides, until I was informed by an eminent French ornithologist that it was intended to signify that it shone like Labrador Spar !"

A fair number of instances of this kind of eccentric nomencliture has been traced out and giren in the following pages; and those who may be in possession of other similar cases would confer upon me a great favour by their communication.

In regard to accentuation I cannot hope to please all, since, in some cases, I have failed to satisfy myself. In the general and adjectival terms there is little difficulty, whilst in the names of genera there is considerable discrepancy in the usage of eminent naturalists themselves, at the same time that any authoritative standard is out of the question. The attempt has been made to reconcile the claims of the rules of composition on the one hand, and of euphony on the other. 
Such as it is, the work is presented to those who may consult it with diffidence, and with a hope that it may not unfrequently solve the difficulties of at least the younger students of the Natural History Sciences. It has the merit, at any rate, of being the first attempt of the kind.

Southront, September 19, 1863. 



\title{
ETYMOLOGICAL DICTIONARY
}

Or

\section{NATURAL HISTORY TERMS.}

\author{
$A B A-A B N$
}

Abaz (Ent.) the Greek name of an abacus, or calculating board; from its fquare markings.

Abbe'nsis (Zool.) applied by Prof. E. Forbes to a fpecies of goniafter found near St. Abb's Head.

A'bdera (Ent.) a priv. inpós, lafting; of long continuance.

Abdo'men (Zool.) abdo, to conceal ; (the vifcera.)

Abdomina'les (Ichth.) abdomen; a fection of malacopterygian or foft-finned fines.

Abdomina'lis (Ent.) the abdomen being rufous.

Aloe'rrant (Zool.) $a b$, from; erro, to wander; differing from the type.

A'bies (Bot.) Lat. a fir-tree; the "Abies pulcherrima of Virgil" is probably

A. picea ; for although common on the continent, it is not a native of England, and the Abies is one of the trees which Cæfar ftates that he did not find in Britain.

Abieti'nus (Bot.) Lat. relating to the pine-tree.

$\left.\begin{array}{l}\text { Abieta'ria (Ent.) } \\ \text { Abietella (Ent.) }\end{array}\right\}$ feeding on the pine;-Pinus Abies.

A bi'etum (Zool.) gen. pl. of abies, the pine-tree.

Abilgaa'rdia (Bot.) P. N. from Prof. Abilgaard, of Copenhagen.

Abjec'tus-a-um (Zool., Ent.) Lat. caft away; worthlefs.

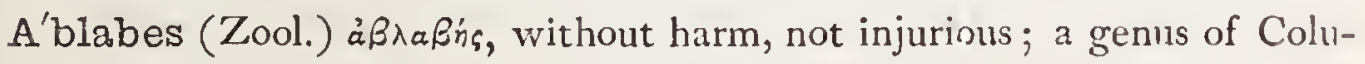
brine ophidians.

Ableph'amis (Zool.) a. priv. Bhśsapoy, the eyelids; a genus of Reptilia. Abluta'lis (Ent.) ablutus, wahled; i.e. faint wing-markings.

Abno'rmal (Zool.) ab, from, norm $b$, a rulc; difiering from the type. 
Abo'rtive (Bot.) abortions, born prematurely; rudimentary, not fully developed.

A'bramis (Ichth.) a'Bpacic, a bream.

Abra'xas (Ent.) a myftical Coptic word.

Abra'nchus (Zool.) a priv. Bpázx

Abrœ'us (Ent.) aßßpó, delicate.

A.bro'ma (Bot.) a priv. Bpõua, food; not fit to be eaten.

A'bropus (Ent.) áBpós, foft, tender, roũs, a foot.

Abro'stola (Ent.) áBpós, delicate, $\sigma \tau o \lambda \dot{n}$, a robe; a genus of Lepidoptera.

Abrotanifo'lius-a-um (Bot.) abrotanum, fouthernwood, folia, leaves.

Abro'tanum (Bot.) äBporos, immortal, i. c. evergreen; facred to the gods; the word was ufed by Hippocrates and Theophrafus, and adopted by Pliny and others; fouthernwood.

A'orothrix (Zool.) áBpiss, foft, $\theta$ pi $i \xi$, hair.

Abrupta'ria(Ent.) abruptus, broken off; from the wavy markings of the wings. A'brus (Bot.) aßjós, foft; from extreme tendernefs of leaves. All the words derived from $\dot{a} \beta_{\text {gos }}$ fhould have commenced with $\mathrm{H}$.

Abso'rbent (Zool., Bot.) absorbeo, to fuck in.

Abscis'ana (Ent.) abscissus, torn off, abrupt.

Absinthi'ata (Ent.) feeds on the wormwood, absinthium.

Abu'tilon (Bot.) Arabic, yellow.

Abyssi'nicus-a-um (Bot.) Lat. Abyfininian.

Aca'cia (Bot.) 'áa's', to Tharpen; from many fpecies being thorny.

Acæ'na (Bot.) àxí, a thorn.

Aca'lepha (Bot.) )

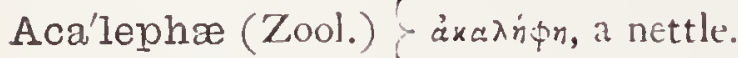

Aca'lephus (Zool.)

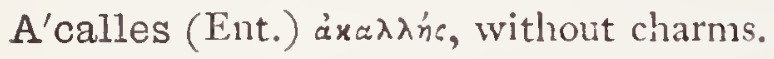

Aca'lycis (Bot.) a priv. calyx, a flower-cup.

$\left.\begin{array}{l}\text { Aca'ntha } \\ \text { Acantha'cex }\end{array}\right\}$ (Bot.) áxarta, a thorn or prickle.

Acanthi'na (Ent.) ärarta, a fpine; a genus of Dipter.

Acanthi'za (Ornith.) axal is, the fikin; the word is applied by Ariftotle to the bird, and by Diofcorides to a thorny plant.

Acantho'cera (Ent.) àxava a fpine, xépas, a horn; a genus of Diptera. Acanthoce'rcus (Zool.) äxavaa, a fpine, x'́pxos, a tail.

Acanthoda'ctylus (Zool., Ent.) à $x a v a$, a prickle, $\delta \dot{x} x \tau \lambda_{0} \circ$, a finger,a plume.

Aca'nthodes (Fos. Zool.) àravaidns, fpiny, thorny; from the nrong thorn-ike $f_{n}$-fpines. 
Acanthola'brus (Zool.) äxav日a, a fpine, labrum, a lip.

Acanthome'ra (Ent.) äxaita, a fpine, unpós, the thigh; a genus of Diptera.

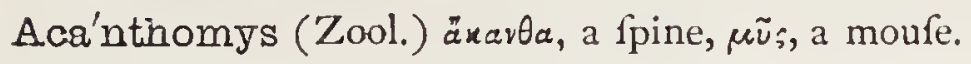

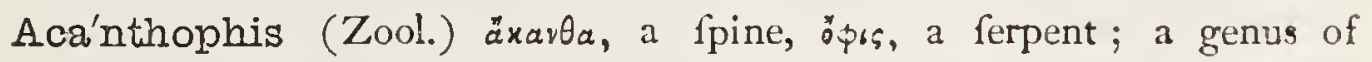
poifonous Ophidians which have a double row of tharp curved teeth.

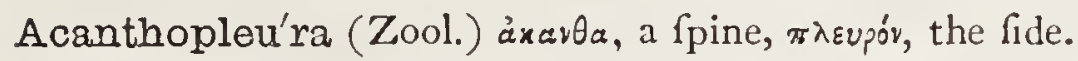

Acanthoptery'gii (Ichth.) äxavaa, a thorn, zsepúgsor, a little fin; the firt or bony-finned order of fishes.

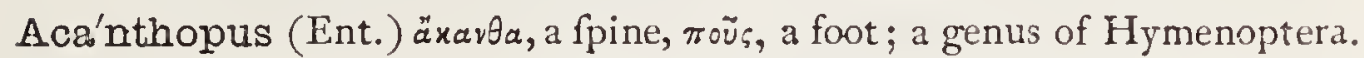

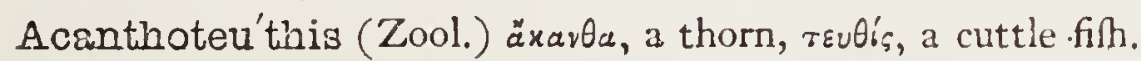

Acanthu'rus (Zool., Ichth.) àxava, a thorn, oùpá, a tail.

Acanthothy'ris (Zool.) äxav $\theta_{\alpha}$, a fpine, $\theta$ up's, a door.

Aca'nthus (Bot.) äxavta, a thorn.

In all probability Virgil fpeaks in different paftages of two distinct plants under this name, the one a tree, the other a herb; as a tree - "baccas femper frondentis acanthi," Georg. ii. II9; and as a twining plant—"flexi vimen acanthi," Georg. iv. Izz. Moreover, he fhortly afterwards fpeaks of it as a garden plant_- Ille comam mollis jam tum tondebat acanthi." A. fpinofus feems to be the plant which adorns the handles of Alcimedon's cups in the 3 rd Eclogue; and alfo that whofe leaves growing round the banket, fuggefted the Corinthian capital to Callimachus.

Aca'ridæ (Ent.) acamis; a family of the Arachnidx.

A'carus (Ent.) ärapns, minute, from a neg. ueípa, to cut; not divifible.

Acau'lis (Bot.) a priv. caulis, a ftem; ftemlers.

A'cavas (Zool.) Lat., not hollowed.

Ac'oentor (Ornith.) Lat. a finger, one who joins another in finging.

Accli'matise (Zool.) French, acclimater, to naturalife in our climes.

Acci'pitres (Ornith.) pl. of accipiter, a hawk, from accipio, to take by force; applied to the rapacious birds, or the Raptores of Cuvier.

$\left.\begin{array}{l}\text { Ace'phala } \\ \text { Ace'phalous }\end{array}\right\}$ (Zool.) a priv. $x \varepsilon \phi \alpha \lambda \dot{n}$, the head; headlefs. $\left.\begin{array}{l}\text { Acephalobra'chia } \\ \text { Acephalobra'chius }\end{array}\right\}$ (Zool.) $\left\{\begin{array}{l}\text { a priv, xepann, the head, Bpaxiar, the } \\ \text { arm; without head or arms. }\end{array}\right.$

Acephaloca'rcius (Zool.) a priv. xepanin, a head, xaposi $\alpha$, the heart:

having neither head nor heart.

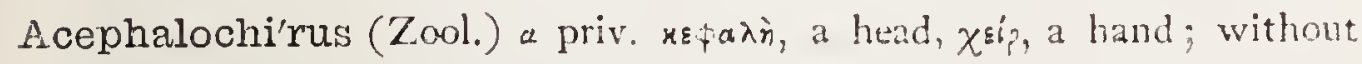
head or hands. 


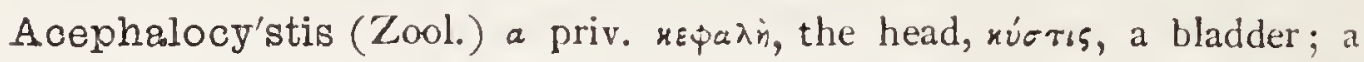
bladder-like, headlers entozoon.

Acephaloga'ster (Zool.) a priv. $x \varsigma \phi a \lambda \dot{n}$, a head, yacrìp, the belly.

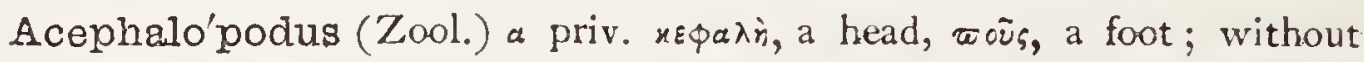
head or feet.

$\left.\begin{array}{l}\text { Acephalora'chia } \\ \text { Acephalora'chius }\end{array}\right\}$ (Zool.) $\left\{\begin{array}{l}\text { a priv. } x \varepsilon \phi a \lambda \dot{n}, \text { the head, pax } \chi \text { เs. the fpine: } \\ \text { wanting head and fpinal column. }\end{array}\right.$

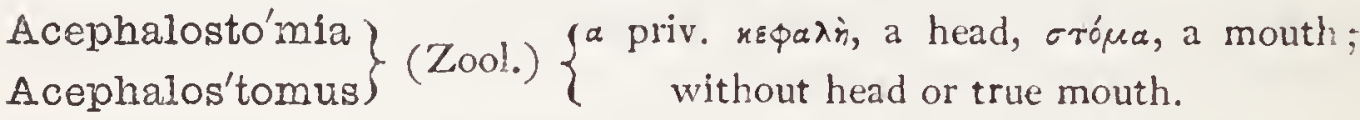

Acer (Bot.) Lat. the maple-tree.

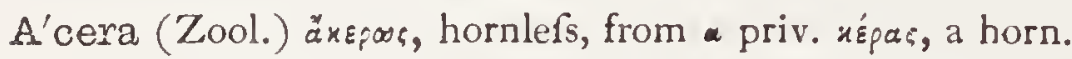

$A^{\prime}$ ceras (Bot.) a neg., xépac, a horn, in allufion to the abfence of a fpur.

A'ceris (Ent.) feeds on fycamore, Acer pjeudo-platanus.

Aceri'na (Ichth.) acer, Iharp ; referring to the pointed head.

Aceria'na (Ent.) acer, a maple-tree.

Acetabuli'fera (Zool.) actabulum, fero, to carry; a fection of Cephalopodous mollufes.

Aceta'bulum (Zool. \& Bot.) Lat. a Thallow cup, at firft ufed to hold vinegar ; in Zoology, the fuckers of polypi ; in Botany, the cup of flowers. Aceto'sa (Bot.) aceo, to be four ; forrel.

Acetosella (Bot.) dim. of acetofa, the forrel.

Aceto'sæ (Ent.) feeds on the Rumex Acetofa.

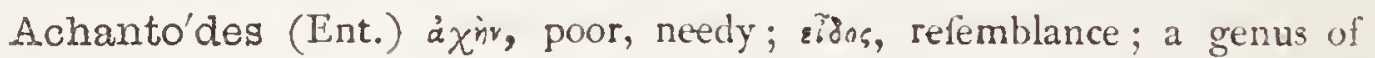

Lepidoptera.

Achata'na (Ent.) áxátni, the agate.

Achati'na (Zool.) a $\chi^{\alpha}$ srs, an agate; the agate-thell.

Achatinel'la (Zool.) dim. of the above.

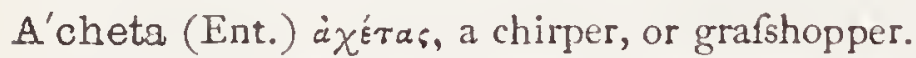

Ache'tiaia (Ent.) acheta; a family of neuroptera.

Achero'ntia (Ent.) P. N. from Acheron, a mythological river.

Ache'nium (Ent.) à $\chi^{\grave{n} v}$, poor, from its mabby marking.

Ache'nium (Bot.) a priv. $\chi^{a i v w}$, to gape; the pericarp not fplitting.

Achille'a (Bot.) Achilles, becaufe its healing virtues were faid to be firft difcovered by him.

Achi'rus (Zool.) a priv. Xeip, the hand.

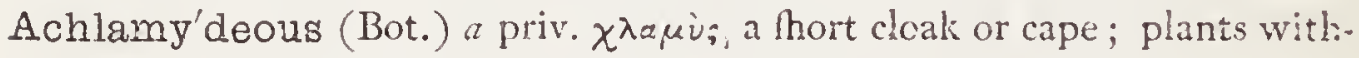
out calyx or corolla.

Achna'nthis (Bot.) "̈x $\chi^{\text {ve, }}$, chaff, $\alpha^{\prime}: \theta_{0}$, a flower; a genus of Cryptogamia. Achnodo'nton (Bot.) "xx $\chi^{y x}$, chaff, ifoús, odórsos, a tonth. 
A'chras (Bot.) the Greek name of the wild pear-tree.

Achyro'nia (Bot.) «ँxupov, chaft; the branches and leaves being chaffy.

Achyra'nthes (Bot.) äxupov, chaff, äv $\theta_{0 \xi}$, a fower; in allufion to the chaffy nature of the floral leaves.

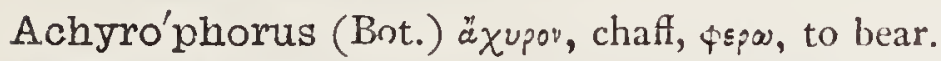

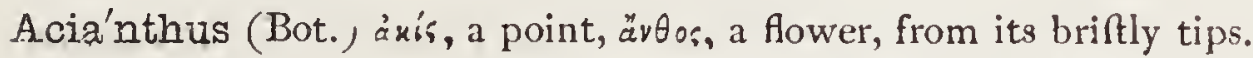

Acica'rpha (Bot.) a'xí, a point, xápфn, palea; the appendage being fpiny. Aci'cula (Zonl.) Lat. a fmall needle.

Acicu'lidæ (Zool.) acicula ; fam. term. ide; a family of mollufcs.

Aci'cular (Bot.) acies, (harp-pointed.

Acida'lia (Ent.) P. N., a name of Venus.

Acidali'idæ (Ent.) acidalia, fam. term. ide; a family of Lepidoptera.

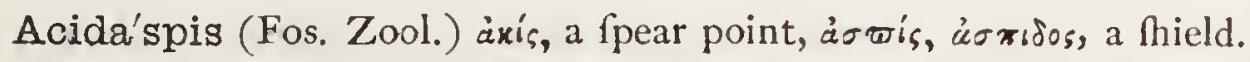

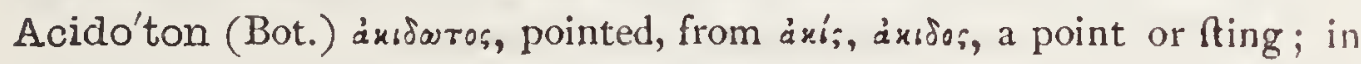
allufion to the ftinging hairs on the leaves.

Acido'ta (Ent.) a'xidaros, pointed.

Aci'lius (Ent.) axunos, the fruit or nut of the holm-oak.

Acinacifo'rm (Bot.) acinaces, a fcimitar, forma, hape.

Aci'niform (Bot.) acinus, a grape, forma, refemblance.

Aci'netæ (Zool.) duiunto:, motionlefs.

A'cinos (Bot.) äxivos, the ftone of grapes; alfo a herb.

Acinoden'dron (Bot.) acenos, der ppor, a tree.

Aci'nopus (Ent.) acinus, a grape, woṽ

Acio'tis (Bot.) àxís, a point, ov̌s, '̉rós, an ear; from hape of petals.

Acipen'ser (Ichth.) Lat. the ancient (and modern) name for the fturgeon.

Acipense'ridæ (Ichth.) acipenser, family term. ida.

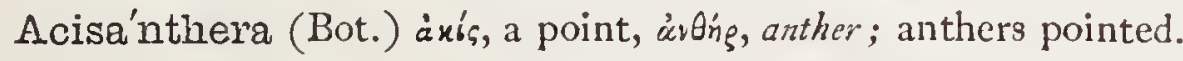

$A^{\prime}$ cis (Ent.) P. N., well known in connexion with Galatea.

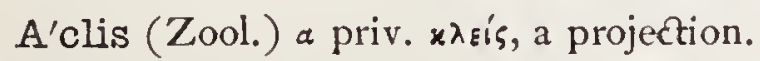

A'cmæa (Zool.) ảxuŕ, a point.

Acmade'nia (Bot.)

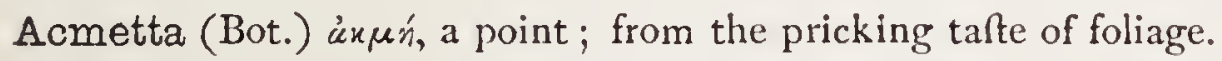

Acni'da (Bot.) a priv. xuidn, a nettle; without ftings.

Ac'œli (Zool.) a priv. xo' $\lambda_{n}$, a hollow; without dorfal or ventral grooves.

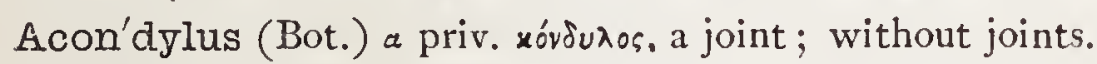

Aco'ntias (Zool.) áxorrias, a quick-darting ferpent; from äxosv, a dart.

Acon'tia (Ent.) from "ánovrias, a fpecies of fnake; from their quick movements." Treitscuke.

Aconti'idæ (Ent.) acontia; a family of Lepidoptera. 
Aco'ntium (Zool.) din. of äxav, a dart, javelin.

Aconiti'na (Bot.) having a refemblance to aconitum, wolfs-bane, q. v.

Aconi'tum (Bot.) cixóvciov, a dart, becaufe formerly ufed to poifon arrows, though fome have thought from being plentiful about Acona in Bithynia.

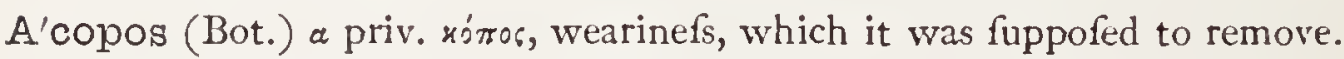
$A^{\prime}$ corus (Bot.) äxopov, a fweet-fmelling plant.

Acosme'tia (Ent.) a'xó $\sigma \mu n \tau o s$, unadorned.

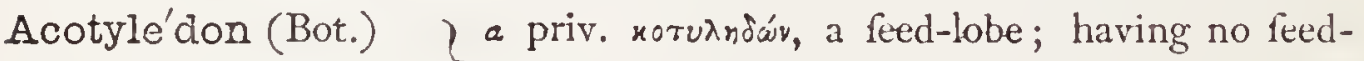
Acotyle'donous(Bot.) $\}$ lobe.

Acranthe'ra (Bot.) acris, Tharp, anther.

Acrias (Ent.)

Acrifo'lius-a-um (Bot.) acris, Sharp, folium, a leaf; applied either to a prickly leaf or to a plant having acrid properties.

Acris, Acre (Bot.) Lat. acrid, biting.

$\mathrm{A}^{\prime}$ crita (Zool.) äxpıros, indeterminate.

Acroco'mia (Bot. äxpos, top, xó $\mu$, a tuft ; referring to leaves.

Acrobrya (Bot.) axpos, the top, Bpúw, to burft forth; from the growth of the ftem taking place at its fummit.

Acrocho'rous (Zool.) üx̧orogóár, a thin-necked wart, which from äxpo, the extremity, Xopon, a ftring; a genus of Ophidians.

Acrochæ'ta (Ent.) äxpos, the fummit, xairn, hair; a genus of Diptera.

$\left.\begin{array}{l}\text { A'crodont } \\ \text { A'crodus }\end{array}\right\}$ (Fos. Zool.) $\left\{\begin{array}{l}\text { üxpos, a fummit, or pointed top, ỏoós, ósćvros, } \\ \text { a tooth; foffil fifhes having pavement- } \\ \text { like teeth. }\end{array}\right.$

A'crogens (Bot.) ) axxpos, the top, zivvasw, to beget; from the growth Acro'genous (Bot.) $\}$ of the ftem taking place at the fummit.

Acro'glochin (Bot.) äipos, fummit, yìuxiv, a point.

Acrogna'thus (Fos. Zool.) ăxpos, high, yráto;, the jaw.

Acrole'pis (Fos. Zool.) äregor, fummit, $\lambda \varepsilon \pi i \xi$, a fcale; a genus of fofil ganoid filhes with ridged fcales.

Acrole'psia (Ent.) äxpov, the head, $\lambda \in \pi$ is, a fale; the crown and back of the head being rough.

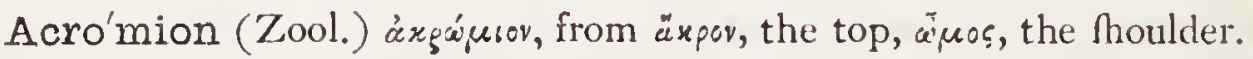

Acro'melas (Zool.) äxpov, point or extremity, $\mu \dot{\varepsilon} \lambda \alpha \varsigma$, black.

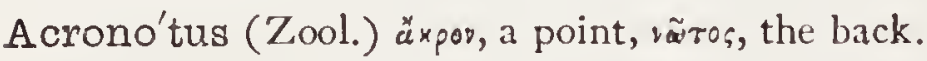

Acranyc'ta (Ent.) áxpovón ros, the beginning of night.

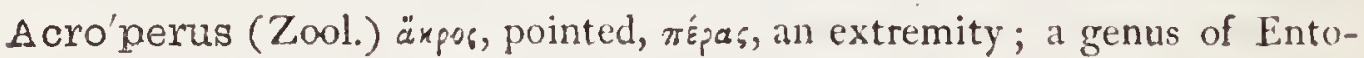
moftraca. 
Acrophy'ton (Bot.) ảxpos, high, fupreme, фurò, a plant.

Acrosa'urus (Fos. Zool.) axpos, the fummit, saúpa (Lat. faurus) a lizard.

Acrospe'rmum (Bot.) äxpos, the fummit, $\sigma \pi \varepsilon_{p} \mu \alpha$, a feed, from its fituation.

Acrospo'rium (Bot.) äxpos, the fummit, orópos, a fporule; upon fummit of filaments.

A'crospire (Bot.) axpos, the fummit, orzipa, a fpiral object.

Acro'stichum (Bot.) fuppofed to refer to the beginning of a verfe, on account of the back furfaces of the leaves being fo lined as to refemble, in fome degree, the commencement of lines in poetry.-P'AxToN.

Acro'triche (Bot.) anxpos, the point, $\theta_{p} i \xi$, rp'xंs, a hair, alluding to the corolla.

Actæa (Bot.) a'xraia, the elder-tree, from fome refemblance of the leaves.

Actæo on (Ent.) P. N., a well-known mythological hunter.

Acteonel'la ?

Acteoni'na $\}$ (Zool.) P. N., dim. from Actæon.

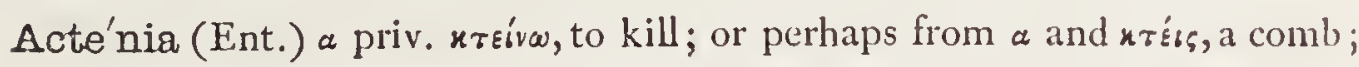

a genus of Lepidoptera.

Acte'philus (Ent.) áx $\tau^{\prime} \dot{n}$, ground corn, $\phi\left\langle\lambda \hat{E}^{\prime} \omega\right.$, to love.

A'ctina (Ent.) áx riv, a ray ; a genus of Diptera.

Acti'nia (Zool.) ảrsı, a ray; fea-anemone; a genus of Zoophytes.

Actini'adæ (Zool.) a family of Zoophytes; Aczinia, fam. term. ada.

Aotinina (Zool.) ¿̇xriv, a ray, fam. term. ina; a divifion of Zoophytes.

Acti'niform (Zool.) áx $\dot{x} i$, a ray, forma, hape; having a radiated form.

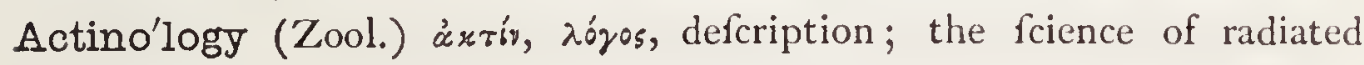
animals.

Actinocar'pus (Bot.) ảx ív, a ray, xaprós, fruit, in reference to its radiated fruit.

Actino'tus (Bot.) áxrivaros, radiated, like the fpokes of a wheel; from the wheel-like appearance of the involucrum.

Actinochlo'a (Bot.) ảkrír, a ray, $\chi^{\lambda o_{\alpha}}$, grafs.

Actinocri'nite (Fos. Zool.) )

Antinocri'nus (Fos. Zool.) $\}$ àurí, a ray, xpivov, a lily, terminal, ites.

Acti'tis (Ornith.) áxтirns, a dweller on the coaft.

Acti'nophrys (Zool.) àriv, a ray, oфpú:, the eyebrow.

Actinothy'rium (Bot.) áxтí, a ray, Oúprov, a little door.

Acu'leate (Bot.) aculeus, a prickle.

Aculea'tus-a-um (Ichth. \& Ent.) Lat. fharp-pointed, ftinging.

Aculea'ta (Ent.) aculeatus, fharp-pointed, from aculeus, a fting; a divifion of Hymenoptera. 
Acu'lei (Bot.) plural of aculeus, a fting; fcientific name of the prickles of rofes, briars, \&c.

Acuminata'ria (Ent.) acumino, to make pointed.

Acu'minate (Zool. \& Bot.) acumen, a point; harp-pointed.

Acutan'gular (Bot.) acutus, harp, angulus, an angle or corner.

Acutico'rnis (Zool.) acutus, pointed, cornu, a horn.

Acutiros'tris (Ichth.) acutus, fharp, rostrum, a beak.

Acutius'culus-a-um (Bot.) dim. of acutus; Aightly acute.

A'cynos (Bot.) an old Greek name of a balfamic plant.

Ada'ctyla (Ent.) a priv. fáxzùos, a plume, or ray; not being divided

like the other plume-moths.

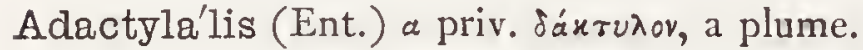

Adam'sia (Zool.) P. N. in honour of John Adams; a genus of Zoophytes.

Adanso'nia (Bot.) P. N. in honour of Michael Adanfon, a French bot-

anif; the genus contains the baobab, or African calabalh-tree.

A'dapis (Fos. Zool.) a neg. dámbs, a carpet; having a rough or prickly furface refembling the hedgehog.

Adder (Zool.) Anglo-Sax., neddre, and atter, a ferpent, atter, poifon.

Ade'la (Ent.) ״̈ $\delta_{r} \lambda \bullet \varsigma$, unfeen.

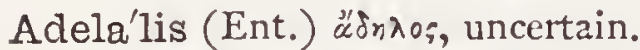

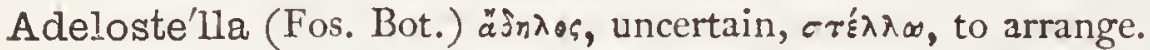

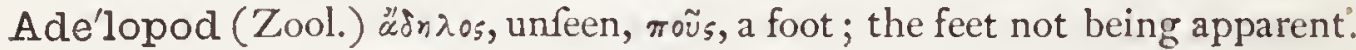

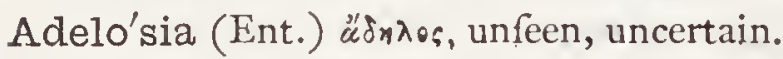

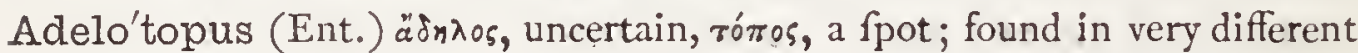
fituations.

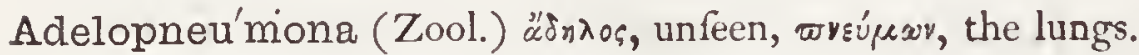

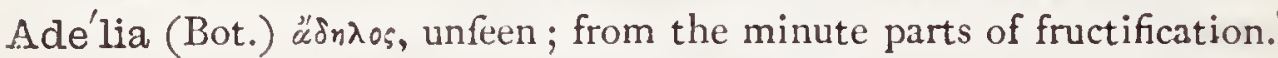

Adena'ndra (Bot.) ảdìv, a gland, «̈ınp, a male.

Adenanthe'ra (Bot.) ádivv, a gland, àvónp, an anther.

Adéniform (Zool.) àjiv, a gland or acorn, forma, refemblance.

Adenoca'rpus (Bot.) àdriv, a gland, xaptrós, fruit.

A'denoid (Zool.) ảirv, a gland, sidos, like, refemblance; acorn-fhaped.

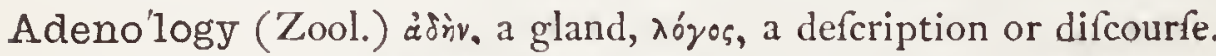

Adeno'phora (Bot.) àdìv, a gland, фopia, to bear.

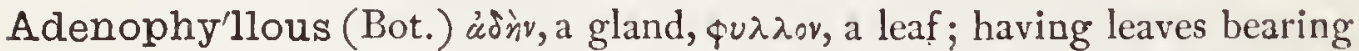
or ftudded with glands.

Adeno'se (Zool.) ádr̀v, a gland; relating to or fhaped like a gland.

Adenotri'chia (Bot.) ảdì, a gland, Opį́, a hair.

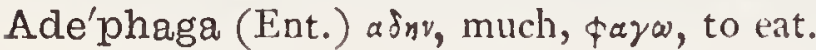


Ade'rus (Ent.) a priv. Inposs, lafting, fhort-lived.

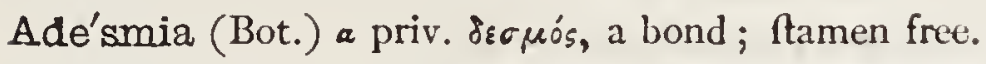

Adian'tum (Bot.) a priv. diaiva, to moiften; the plant is not eafily wetted.

Adimo'nia (Ent.) a priv. ¿sırés, fear.

Adi'na (Bot.) àdเvós, cluftered; its flowers form heads.

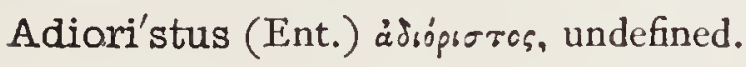

Adi'ppe (Ent.) a variation of Cydippe.

Adlu'mia (Bot.) adlumino, to rringe with purple.

Adna'tus-a-um (Bot.) adnascor, to grow to ; joined, fixed.

Ado'nis (Bot.) P. N. Its deep red colour fuggefted the idea of its being fained by the blood of Adonis.

Ado'xa (Bot.) a neg. $\delta^{\prime} \xi a$, glory; not lhowy, from its humble and infignificant afpect.

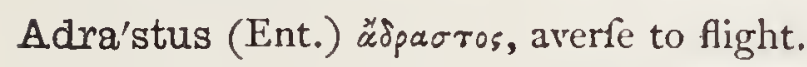

Adscite1la (Ent.) dim. of adscitus, aflumed, foreign.

Adult (Bot., Zool.) adolesco, to grow; arrived at maturity.

Adu'ncus-a-um (Bot.) Lat., bent in, hooked.

Adusta'ta (Ent.) adustus, fcorched.

Advena'ria (Ent.) advena, a franger.

Advenel'la (Ent.) dim. of advena, a ftranger.

Adversus-a-um (Zool., Bot.) Lat. turned towards.

स巴ci'dium (Bot.) alkîov, a wheal, sidos, like; from the puftules; a genus of parafitic fungi.

玥'chmea (Bot.) ,

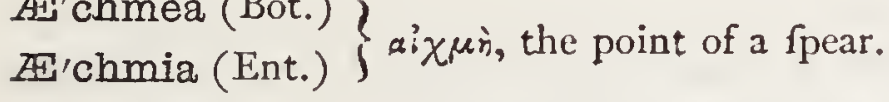

咂'chmialis (Ent.) refembling the genus Ëchmia.

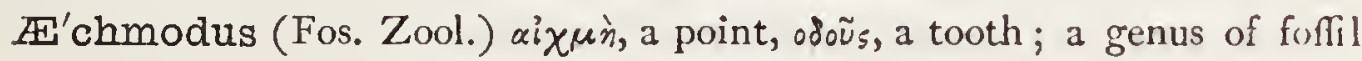
filhes having fmall Tharp-pointed teeth.

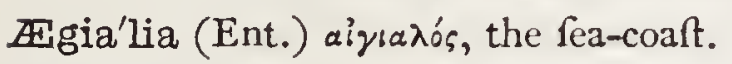

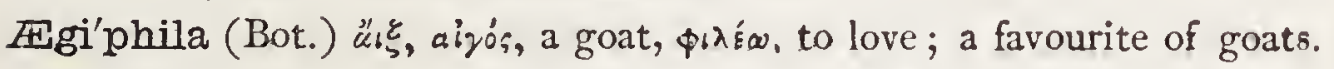

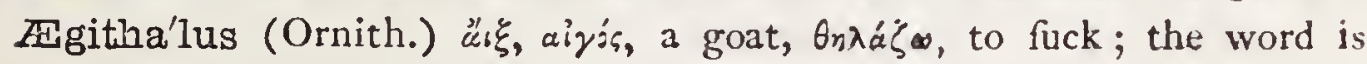
exactly equivalent to caprimulgus.

F'gilops (Bot.) $\alpha^{\prime} i \xi$, aiyos, a goat, $\ddot{\omega} \psi$, the face; goat-faced.

FEgle'finus (Ichth.) aijnoparns, brilliant, luftrous.

AEgle (Bot.) P. N., one of the Hefperides, which from $a i \gamma \lambda \eta$, fplendour.

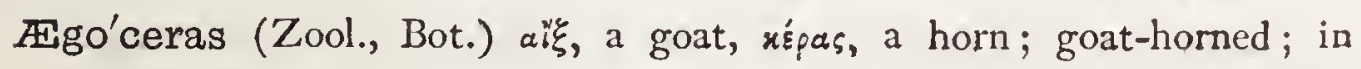
botany from a refemblance of the pods.

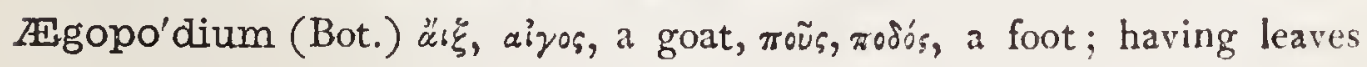
cleft like the goat's foot. 
IF'gon (Ent.) P. N., a Roman Thepherd.

Fisgopo'gon (Bot.) a žs, aíyós, a goat, wáywy, a beard.

Ægypti'acus-a-um (Ornith.) relating to Egypt.

Aello (Zool.) this name was applied by Heflod to the ftormy-peterel, and by Ovid to a hound.

Æmmula'lis (Ent.) cmula, a rival.

F'mula (Bot.) Lat. a rival.

Enea'lis (Ent.) reneus, bronze-coloured.

Eneopi'ceus (Ent.) cenews, bronzed, piceus, made of pitch; pitchy, braflcoloured.

Fneus, \#nea (Ent.) Lat. bronzed.

Fnic'tus (Ent.) aivsxтós, like a riddle, puzzling; a genus of Hymenoptera.

Æo'liaß (Zool.) rolis, fam. term. ida.

Æ'olis (Zool.) P. N., the daughter of Elolus.

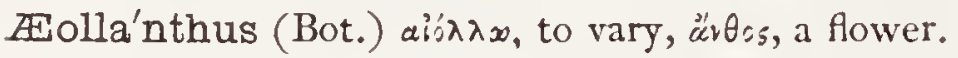

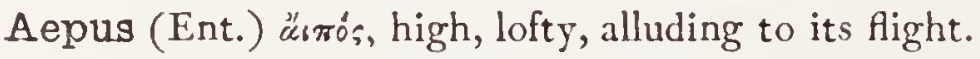

Equore'ade (Zonl.) aquorews, belonging to the rea; a divifion of the naked-eyed molluica.

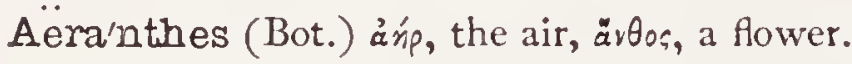

\#ra'tus-a-um (Ent.) Lat. bronzed.

Ae'rides (Bot.) án, the air; in allufion to the power pollefled by the fpecies of this, as well as other orchidaceous genera, of living apparently by atmofpheric abforption.

Aerophy'tes (Bot.) áńp, the air, фuróv, a plant; applied to certain lichens, which appear to subfift exclufively on the air.

Frugina'lis (Ent.) arugo, ruft of brafs, verdigris.

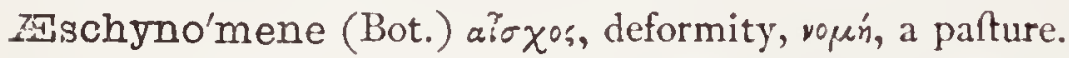

Erugino'sus-a-um (Ent., Bot.) Lat. the colour of verdigris.

无scula'ria (Ent.) aeculus, the horfe-cheftnut, on which the larva feeds F'sculi (Ent.) $\}$ and burrows.

F'stival (Bot.) aftas, fummer.

Fistiva'tion (Bot.) cestivo, to retire for the fummer.

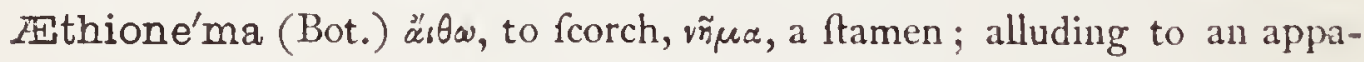
rently fcorched or fun-burnt tinge of the ftamens.

Ethiopa'lis (Ent.) ethiops, a black man; referring to colour of wings.

Fithu'sa (Bot.) áıtúrsa, to make hot; acrid; fool's parfley.

Afer, Afra (Zool.) Lat. African.

A'flinis (Ent.) Lat. related, neighbouring. 
Affinita'na (Ent.))

Affinita'ta (Ent.) $\}$ affinis, q. i.

Affusalis (Ent.) affufus, poured upon; alluding to wing-fpots.

Afze'lia (Bot.) P. N. from Afzelius, a Swedilh profeffor.

Agale'na (Ent.) agalena and agebena feem to have exactly the fame derivation;

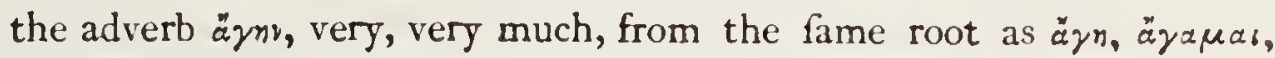
$\& c .$, which have all the idea of love, wonder, beauty; and $\lambda \tilde{a}$ vo , or $\lambda \tilde{r}$ roo, wool, ufed here for cobwebs. The words thus mean, beautiful or wonderful web-fpinner.

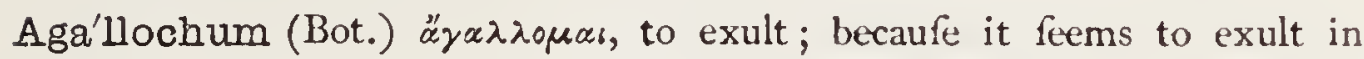
exhaling its odours.

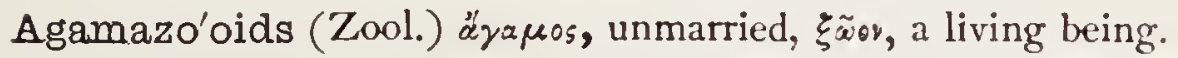

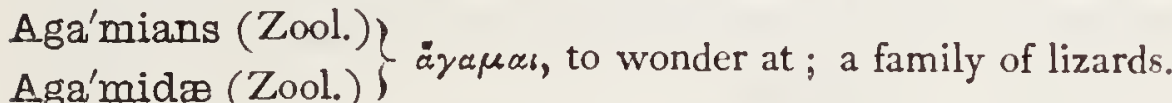

Aga'mic (Bot.) a priv. yá $\mu \circ \varsigma$, marriage; equivalent to cryptogamic.

Agáon (Ent.) àyavós, noble.

Agao'nida (Ent.) agaon; a family of Hymenoptera.

Agapan'thus (Bot.) áyárn, love, ävtos, a flower.

Agapophy'tus (Ent.) áyaráa, to love, furór, a plant; a genus of Diptera. Aga'ric (Bot.) P. N. from the river Agarus, in ancient Sarmatia.

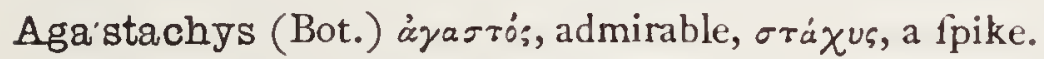

Agathæ'a (Bot.) á a $^{\prime} \theta_{5}$, excellent; from its beautiful flowers.

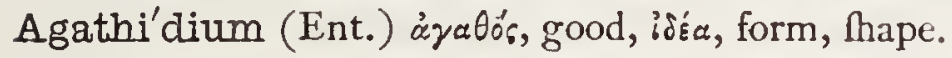

Agathi'na (Ent.) áyató, good.

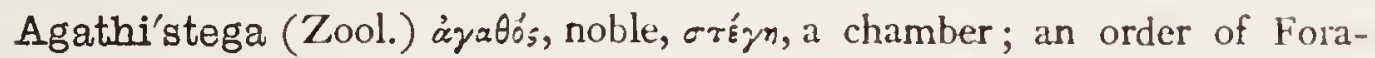
minifera, confifting of fegments wound round an axis.

Agath'odes (Ent.) à $y a \theta_{0}^{\circ}$, ufeful, good; a genus of Lepidoptera.

Agatho'sma (Bot.) áyalo's, good, ó $\sigma \mu \dot{n}$, fmell.

Age'ratum (Bot.) a priv. yñ Ages'tis (Ent.) perhaps a typographical error for Agreftis, a ruftic.

Age'strata (Ent.) aggero, to heap up, in allufion to the habit of the beetles in gathering materials for their cocoons; a genus of Cetoniidæ.

A'gilis (Zool.) Lat. agile, quick.

A'ggeris (Ent.) gen. of agger, a mound or heap of rubbifh.

Agglo'merate (Zool. 'Bot.) agglomero, to form into a heap.

Aggrega'ta (Zool.) aggrego, to collect together.

Aglä (Ent.) P. N., a genus of Hymenoptera.

Aglaia (Ent.) P. N., one of the Graces.

Aglo'ius (Ornith.) ’xydata, fplendour. 
Aglo'ssa (Ent.) a priv. $\gamma^{\lambda} \omega \sigma \tau a$, the tongue; the fpiral tongue being nearly obfolete.

Agnine (Zool.) agrus, a lamb; relating to a lamb.

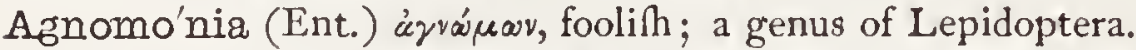

Agnus (Zool.) Lat. a lamb, from áyos, chafte, becaufe fit for facrifice.

Agnus Castus (Bot.) the word Agnus in Greek has the fame fignification as Castus in Latin, and chafte in Englin. The name refers to the celebrity the feeds of this Thrub enjoyed in old times for promoting chaftity.

A'gonum (Ent.) a priv. ycovia, an angle.

Agou'ti (Zool.) a native name.

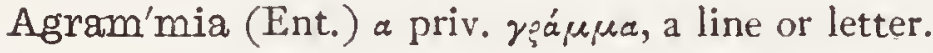

A'graphis (Bot.) ) äypałos, unwritten, without markings, equivalent to Agra'phalis (Ent.) $\}$ non foriptus.

Agre'stis (Ent. Bot.) Lat. pertaining to the fields; rough, coarse.

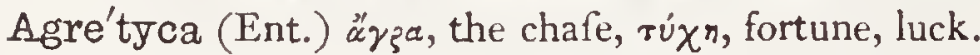

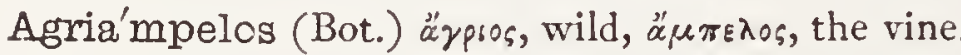

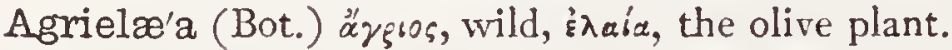

Agrilorhi'nus (Ornith.) ürgso;, rough, $\dot{p} เ v$, the nofe.

Agrilus (Ent.) «̋røı๘, wild.

Agrimo'nia (Bot.) corrupted from Argemone, the name given by the Greeks

to a plant fuppofed to cure the cataract in the eye, called "丷o

Agrioca'stanum (Bot.) "̈ypro;, wild, xirravov, the cheftnut.

Agriome1a (Bot.) ״̈ypros, wild, $\mu \tilde{n} \lambda \circ v$, an apple; the crab-apple.

Ag'rion (Bot.) «̈ypros, wild.

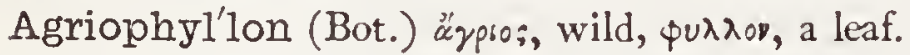

$\left.\begin{array}{l}\text { Agrio'pis (Enț.) } \\ \text { Agrio'pus (Zool.) }\end{array}\right\}$ ápproorós, wild-looking.

Agri'otis (Ent.) ảysı́rns, rufticity.

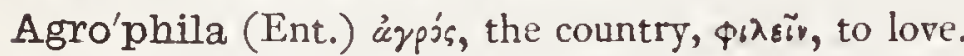

Agro'rum (Ent.) gen. pl. of ager, a field.

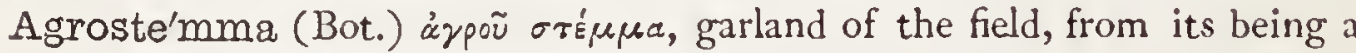
great ornament to corn-fields.

Agro'stis (Bot.) the Greek name for all graffes, from áypós, a field.

Agro'tera (Ent.) áypótepos, wild, favage; a genus of Lepidoptera.

A'grotis (Ent.) áypórıs, dwelling in the country.

Agro'pnia ?

Agry'pnus $\{$ (Ent.) a priv. yputiós, curved.

A'gyra (Ent.) a priv. zupós, round; or perhaps from üyupis, an affembly. 
AgJ'rium (Bot.) äyupis, a crnwd, from its cluftered arrangement.

AgJ'rtes (Ent.) àyúp rns, a juggler.

Ahene'lla (Ent.) aheneus, brafly, i. e. colour.

Aila'nthus or Aila'ntus (Bot.) the Latinized form of the native name Aylanto, fignifying tree of heaven.

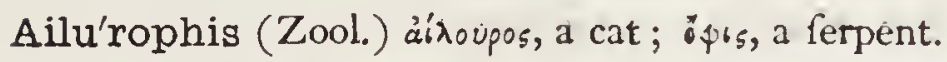

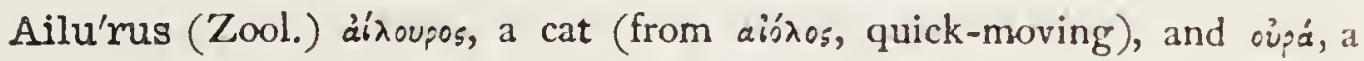
tail; a genus of Mammalia.

Aipta'sia (Zool.) airìs, lofty; társ, Atretching.

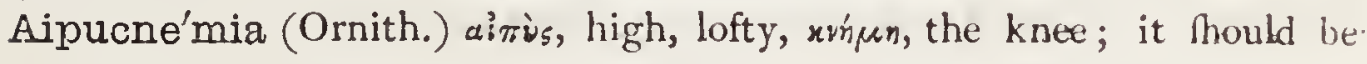
written Epycnemia.

Al'ra (Bot.) the Greek name of our Lolium temulentum (from abs, to deftroy, on account of its injurious effects); now applied to another genus of grafles.

Airo'psis (Bot.) aira, hair-grafs, ö $\psi \varsigma$, refemblance.

Aito'nia (Bot.) P. N. from $W$. Aiton, formerly head gardener at Kew Gardens.

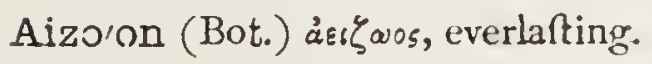

A'juga (Bot.) a priv. Guyóv, a yoke; perhaps from its fuppofed property of caufing abortion.

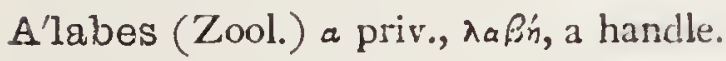

Alace'1la (Ent.) dim. of alacer, quick.

A'lacris (Zool.) Lat. nimble.

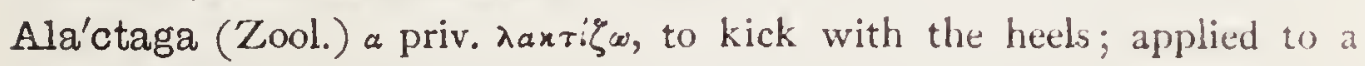
Jerboa.

Ala'ngium (Bot.) from Alangi, its Malabar name.

Ala'ria (Bot.) ala, a wing.

Ala'stor (Ent.) 'A $\lambda$ ás rop, the Avenger.

Ala'tus-a-um (Bot.) Lat. winged, i. e. with membranes.

Alou'da (Ornith.) Lat. a lark; faid to have been formed by the Romans

from the old Celtic al, high, great, and aud, fong.

Alauda'rius (Ornith.) Alauda; lark-like.

Albellus (Ornith.) dim. form of albus, white.

Albersa'na (Ent.) P. N. in honour of $J$. A. Albers, a German entomologift.

Albica'uda (Zool.) albus, white, couda a tail; white-tailed.

A'lbicans (Zool., Bot.) albico, to grow white.

A'lbiceps (Ent.) albus, white, caput, head.

Albici'lla (Ornith.) dim. of albus. 
Albico'llis (Ornith.) albus, white, collum, a neck.

Albico'lon (Ent.) albus, white, colon, a dot; from its markings.

Albico'sta (Ent) albus, white, costa, the front margin of wing.

Allbidus-a-um (Zool., Bot.) Lat., whitifh.

Albifrons (Ornith.) Lat., white-faced.

Albifronterlla (Ent.) dim. of albifrons, white-faced.

Albi'one (Zool.) albineus, whitifh; a genus of Annelids, parafitic on the kate.

Albima'cula (Ent.) albus, white, macula, a fpot.

Albipalpe'lla (Ent.) albus, white, palpus, a feeler, dim. ella.

Albipes (Ent.) albus, white, pes, a foot.

Albipunctella (Ent.) albus, white, punctum, a dot, dim. ella.

Albi'stria (Ent.) albus, white, friga, a ftreak.

Albitarse'lla (Ent.) albus, white, tarsus.

Albistriga/lis (Ent.) albus, white, striga, a ftreak.

Albooærule'scens (Bot.) albus, white, ceruleus, $\mathrm{k} y$-coloured, blue.

Alboda'otylus (Ent.) albus, white, sàrsùos, a finger.

Albofascia'lis (Ent.) albus, white, fafcia, a band.

Albogula'ris (Zool.) albus, white, gula, the throat.

Albola'bris (Zool.) albus, white, labrum, a lip.

Albu'ca (Bot.) albus, white, i.e. the fowers.

Albulata (Ent.) albulus, whitih.

Albu'mum (Bot.) albus, white, i.e. the white portion of the tree within the bark.

A'lce, Alces (Zool.) alce, the elk, which from é $\lambda x^{\prime}$, bodily Atrength.

Alcedi'nidæ (Ornith.) alcedo, fam. term. ida.

Aloe'do (Ornith.) Lat., the king-finer.

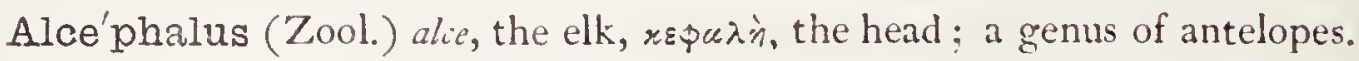
Alchemilla (Bot.) Arabic, alkêmelyeh, alchemy, from its pretended alchemical virtues.

Alcicornis (Zool.) alce, an elk, cornu, a horn; having elk.-like horns.

Alci'ppe (Zool.) P. N., mentioned by Theocritus; a genus of Cirripedes.

A'loyon (Ornith.) properly Halcyon, àxxisur, the king-filher: the word means also "fea-foam," from "ä $\lambda_{\xi}$, the fea, xús, to conceive; faid to hatch its eggs upon the fea.

Alcyonellia (Zool.) dim. of alcyon.

Alcyoni'dium (Zool.) alcyon; implying fome fancied refemblance

Alcyonipenne'lla (Ent.) alcyon, the king-filher, penna, a feathe1.

Alcyornium (Zool.) from Alcyone, the daughter of Eolus. 
Alde'ria (Zool.) P. N. after Joshwa Alder, a writer on the Mollufca.

Aldrova'nda (Bot.) P. N. from Uly Jes Aldrovandis, an Italian naturalift.

Alecto (Zool.) P. N. one of the Furies, having ferpents round her head inftead of hair.

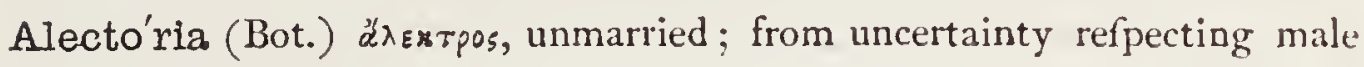
flowers; a genus of Lichens.

Aleella (Ent.) ales, winged, dim. ella.

Aleocha'ra (Ent.) $\dot{\alpha} \lambda_{s} \infty$, to grind or bruife, chara, a water-plant.

Aleochari'næ (Ent.) aleochara, fam. term. ine; a fub-family of Coleoptera.

A'lepas (Zool.) a priv. $\lambda \varepsilon \pi \dot{\alpha} 5$, a promontory or projection.

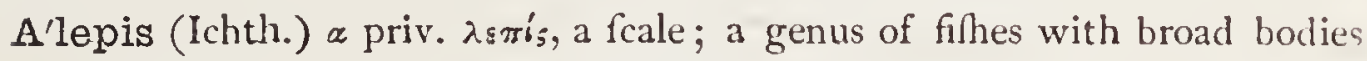
and fmall heads, and nearly fcalelefs.

Alepisau'rus (Ichth.) $\propto$ priv. $\lambda_{\varepsilon} \pi i_{5}$, a fcale, caúpos, a lizard.

Alepoce'phalus (Zool.) a priv. $\lambda_{\varepsilon} \pi i_{s}$, a fcale, $x \varepsilon \varphi \propto \lambda \dot{n}$, the head.

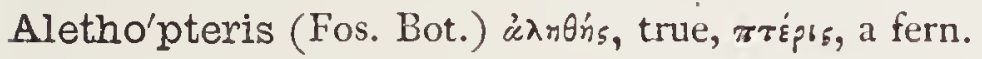

Aleu'cis (Ent.) $\lambda$ surós, white; i.e. indiftinct, obfcure.

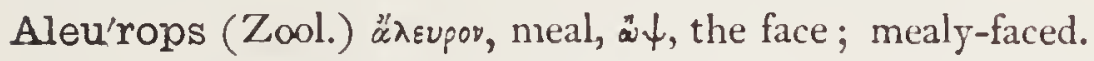

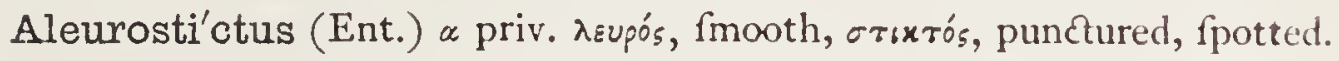

Alexanders (Bot.) corrupt, of Olusatrum, which from olus, pot-herb, ater, black.

Ale'xia (Zool., Ent.) ¿ $\lambda^{\lambda} \dot{\xi} \xi \infty$, to ward off.

Ale'xis (Ent.) P. N., a Roman hepherd.

Alga (Bot.) alga, a marine plant, which from algor, coldnefs, or perhaps from alligo, to entangle.

Algo'logy (Bot.) alga, a marine plant, גoyós, defcription.

A'liform (Zool.) wing-hhaped, from ala, a wing, forma, refemblance.

Ali'sma (Bot.) the water-plantain, faid to be from the Celtic alis, water.

Alisma'ceæ (Bot.) alisma, term. for natural order acex.

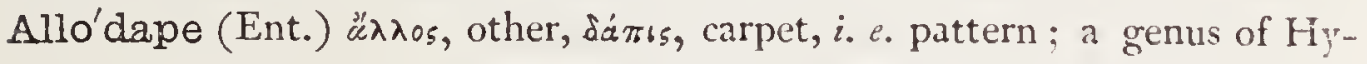
menoptera.

Allantifo'rmis (Ent.) allantus, a faw-Aly, forma, refemblance.

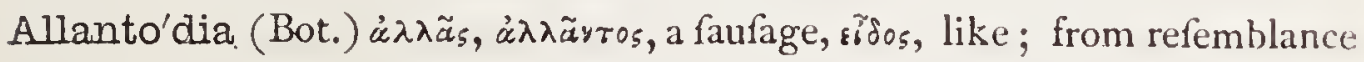
in indufia.

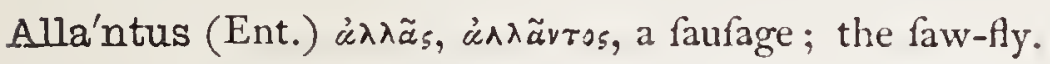

Alleghannie'nsis-e (Zool.) belonging to the Alleghany mountains.

Allia'ceus-a-um (Bot.) allium; garlic-leaved.

Allia'ria (Bot.) allium, garlic ; the leaves having a fimilar odour.

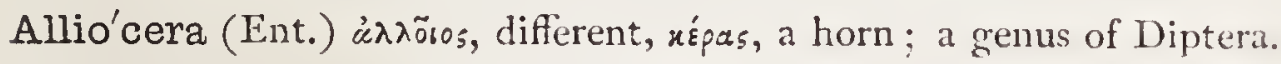

Alliga'tor (Zool.) Spanifh el legato, the lizard. 
Allione'lla (Ent.) P. N. in honour of Carlo Allioni, an Italian naturalift. Allisell'a (Ent.) P. N. from J. H. Allis, of York.

A'llium (Bot.) a' $\lambda \varepsilon^{\prime}$, to avoid, becaufe of its offenfive fmell; garlic.

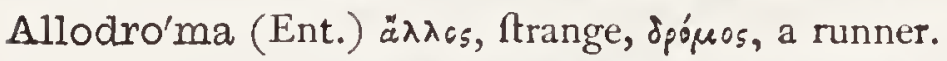

Alloso'rus (Bot.) à $\lambda \lambda_{0}$, various, forus; the fori changing at different periods.

Almond (Bot.) through French amande, from Latin amygdalus.

A'lnus (Bot.) perhaps from Celtic al, near, lan, a river, from its habitat.

$A^{\prime} l n i$

Alnia'ria $\}$ (Ent.) the infects feed on the alder, Alnus.

Alnifolie'lla (Ent.) alnus, an alder, folium, a leaf, dim. ella; i. e. its ordinary food plant.

Aloe (Bot.) Hebrew, ahlah, or Arabic, alloch, growing near the fea.

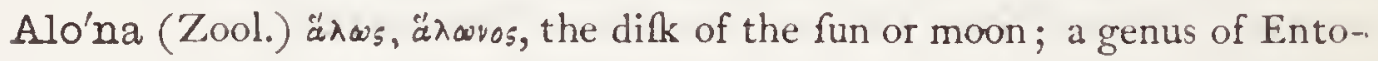
moltraca; Thould be Halona.

Alope'cida (Ichth.) alopex, fam. term. ida.

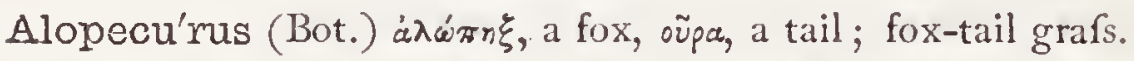

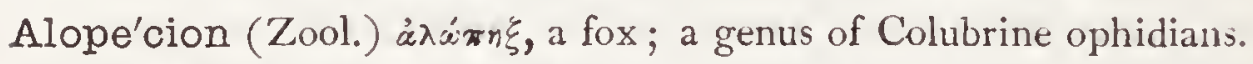

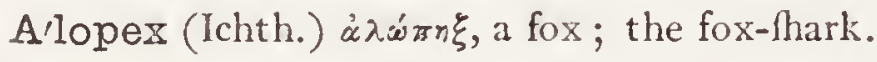

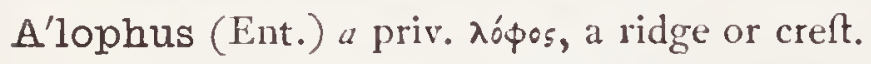

Alo'sa (Ichth.) probably a corruption of the old name of the Thad, Lochia.

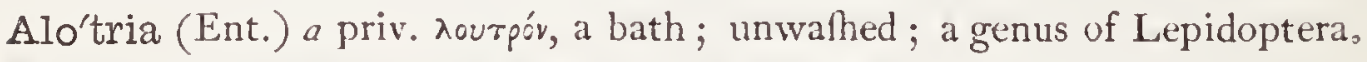

Aipe'lla (Ent.) alpes, mountains; from its habitat.

Alpestra'lis (Ent.) alpefris, mountainous.

Alpe'stris, Alpe'stre (Ornith., Bot.) Lat. alpine.

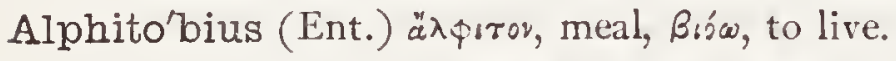

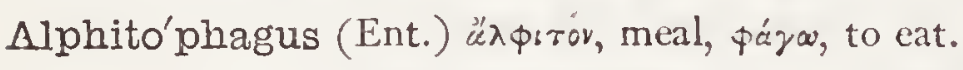

A'lpigene (Zool.) alpes, mountains, gigno, to produce; belonging to or found upon the Alps and other mountains.

Alpina'lis (Ent.) alpinus, dwelling upon mountains.

Alpina'na (Ent.) alpinus, dwelling upon mountains.

Alpi'nia (Bot) P. N. in honour of Alpini, an Italian phyfician.

Alpi'nus-a-um (Zool., Ent.) Lat. alpine.

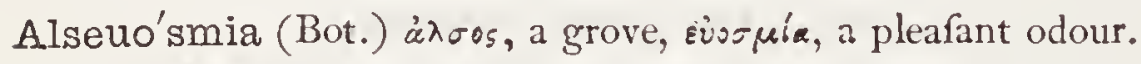

Alsi'ne (Bot.) áx $\lambda=0$, a grove or hady place; from its habitat.

Alsi'nes (Ent.) feeds on chickweed, al/me media.

Alsinifo'lius-a-um (Bot.) alfine, chickweed, folium, a leaf.

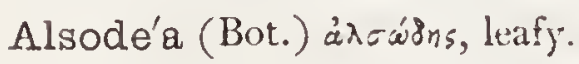

Also'phila (Bot.) ù $\lambda=2 s$, a grove, $\$ \lambda \varepsilon \varepsilon$, to love. 
Alsto'nia (Bot.) P. N. from Dr. G. Alfton, Prof. of Medicine, Edinburgh. Alstrœme'ria (Bot.) P. N. in honour of Claude Alfrömer, a Swedih naturalift.

Alstrœmeria'na (Ent.) P. N. in honour of Claude Alfrömer, a Swedifh naturalift.

A'lsus (Ent.) P. N., one of Virgil's thepherds.

Altaicus-a-um (Zool., Bot.) belonging to the Altai mountains.

Alterna'na (Ent.) alternus, interchangeable, alternate.

Alternanthe'ra (Bot.) alternus, antherus; the ftamens being alternately fertile and barren.

Alterna'tus-a-um (Zool., Bot.) Lat. alternate.

Alterniflo'rus-a-um (Bot.) alternus, flores, Howers.

Alteu'tha (Zool.) the Latin name of Berwick-upon-Tweed.

Althæ'a (Bot.) ״̈ $\lambda \theta \omega$, to cure, from its healing properties.

Althæoi'des (Bot.) althea, sidos, like; having leaves like the marhmallow. A'lticeps (Ent.) altus, high, lofty; caput, the head.

Alti'velis (Ichth.) altus, high, relum, a fail.

Alti'volans (Zool.) Lat. fying high.

Alu'cita (Ent.) Lat., a gnat.

Aluci'tidæ (Ent.) alucita, fam. term. ida.

Aluciti'na (Ent.) alucita, a gnat.

A'lula (Ornith.) dim. of ala, a wing; applied to the fmall quill feathers or fpurious wing of a bird; alfo to an infect.

Alvearie'lla (Ent.) alvearium, a bee-hive.

Alve'olites (Fos. Zool.) alveolus, a little trough; a genus of foffil corals.

Alve'olus (Ent.) Lat. a chefs-board; from the chequered markings of the infect.

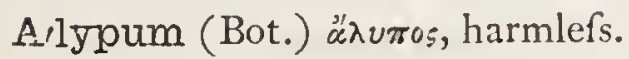

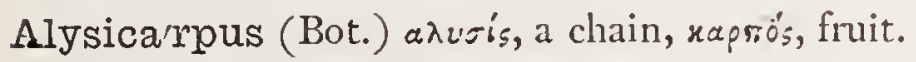

Aly'ssum (Bot.) a priv. $\lambda \dot{v} \sigma \sigma \alpha$, canine madnefs; becaufe it was fuppofed

to cure hydrophobia.

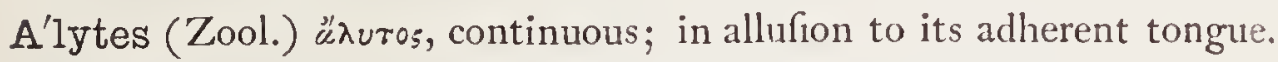

Aly'xia (Bot.) $\ddot{u}^{\prime} \lambda \nu \xi_{\llcorner 5}$, anxiety; from its gloomy appearance.

Alzate'a (Bot.) P. N. from $\mathcal{F}$. A. de Alzate, a Spanifh naturalift.

Ama'bilis-e (Zool., Bot.) Lat. lovely.

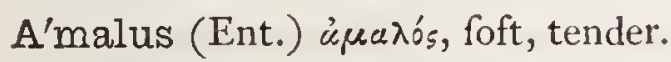

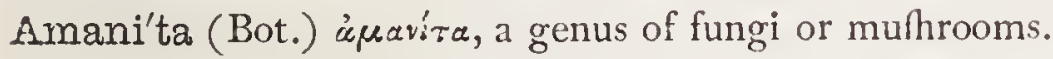

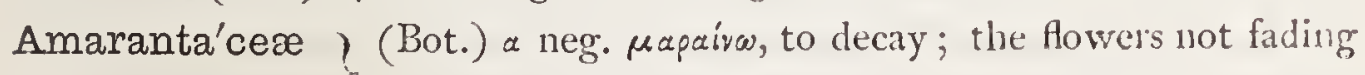
Amara'nthus $\zeta$ long after being plucked. 
Amari'ssimus-a-um (Bot.) Lat. molt bitter.

Ama'rus-a-um (Bot.) Lat. bitter.

Amaryllida'ceæ?

Amary'llis

(Bot.) Amaryllis, term. for nat. order, acee.

Amary'llis (Bot.) P.N., Amaryllis was one of Virgil's nymphs; "the lilies of the field," are fuppofed by fome authors to refer to Amaryllis or Sternbergia lutea.

Amaso'nia (Bot.) P. N. from Thomas Amafon, an American traveller.

Amata'ria (Ent.) amatus, loved.

Ambigua'lis (Ent.) ambiguts, uncertain.

Ambigua'na (Ent.) ambirzus, uncertain.

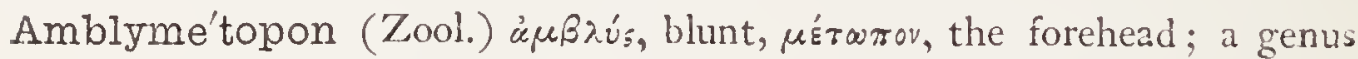
of Colubrine ophidians.

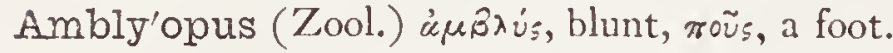

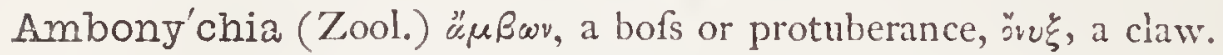

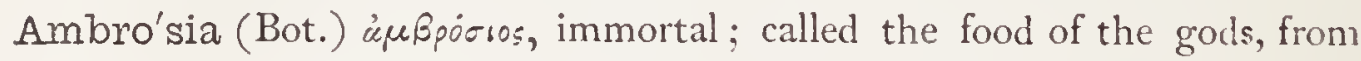
the fragrant bruifed leaves of the plant originally fo called.

Ambula'cra (Zool.) ambulacrum, a gallery or place to walk in.

Amei'va (Zool.) a asísw, to change?

Amela'nchier (Bot.) the Savoy name for the Medlar; a genus of Pomacex. Ame'ilus (Bot.) employed by Virgil to denote fome plant which grew on the banks of the river Mella.

Amenta'ceæ (Bot.) amentum, term. for nat. order acea.

Amenta'les (Bot.) amentum, a catkin.

Ame'ntum (Bot.) Lat. a frap or thong; a catkin.

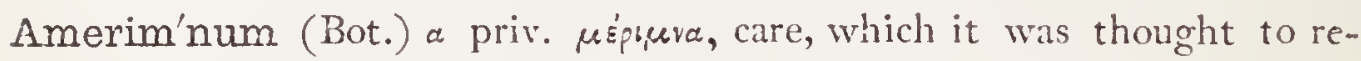
move; heart's-eafe; now applied to another plant.

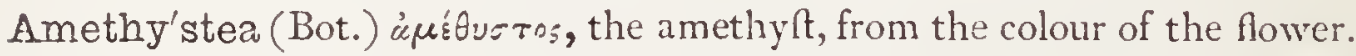
Amhe'rstia (Ornith., Bot.) P. N., in honour of Lady Amherf.

Amma'nnia (Bot.) P. N., from F. Ammann, Profeflor at St. Peterfburg.

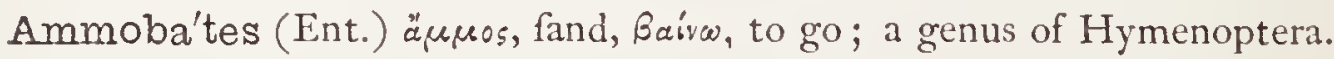

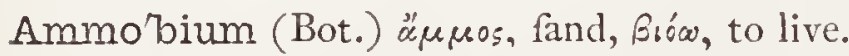

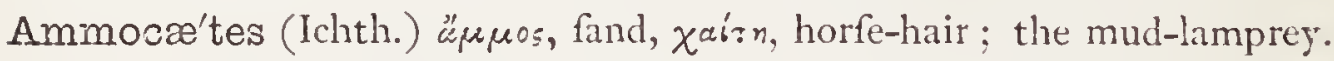

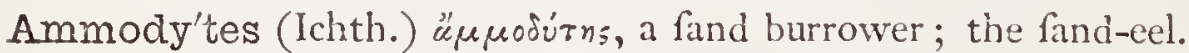

Ammoni'acum (Bot.) as applied to a gum this name is a corruption of Armeniacum, the plant which produces it being a native of Perfia.

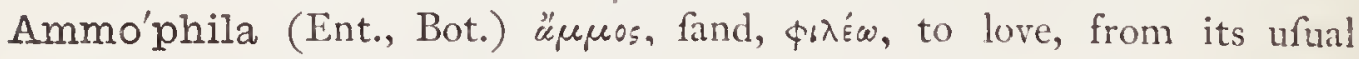
habitat; a genus of Hymenoptera; alfo a genus of grafles.

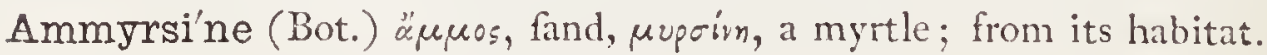




\section{Amœ'ba

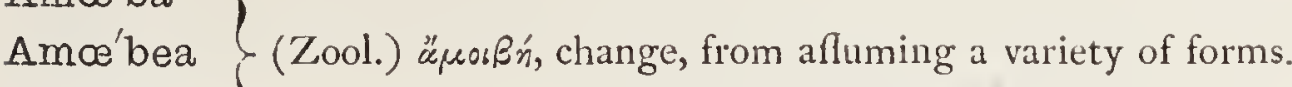 \\ Amœbi'na}

Amœ'nus-a-um (Bot.) Lat. delightful, fhowy.

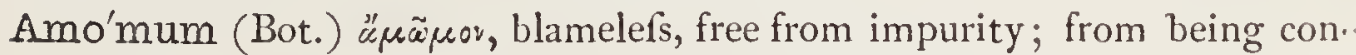

fidered a counter-poifon.

Amo'rphous (Zool.) a neg. ropфń, form.

Ampelida'ceæ (Bot.) ampelis, term. for nat. order acea.

Ampe'lidæ (Ornith.) ampelis, fam. term. ida; a family of Incellores.

A'mpelis (Ornith.) an old Greek name of a bird, now applied to the

Bohemian wax-wing; alfo a name in Botany.

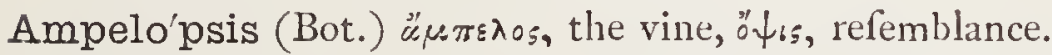

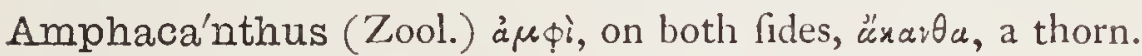

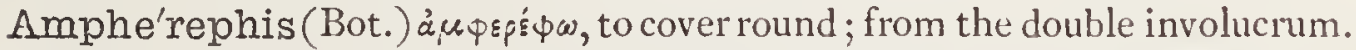
Amphibi'chthys (Zool.) amphibius, ' $\chi^{\theta} \dot{s} s$, a fifh; a name propofed for the

Lepidofiren.

Amphi'bious (Zool., Bot.) a elements.

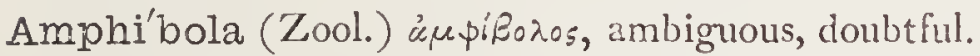

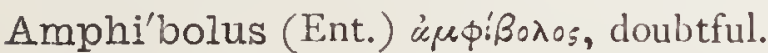

Amphibry'a (Bot.) úuфì, around, Bpúov, mofs.

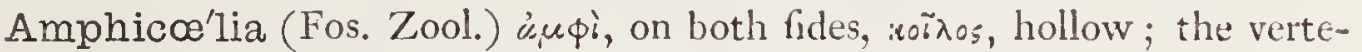
bræ being hollowed at both ends.

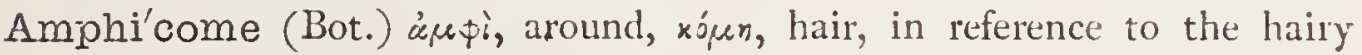
appendages to the feeds.

Amphida'sydiæ (Ent.) amphidafys, fam. term. ida.

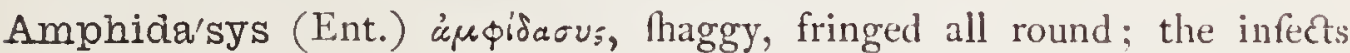

being covered with hair.

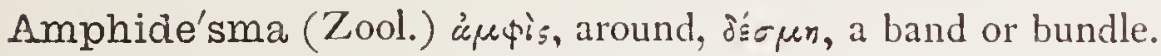

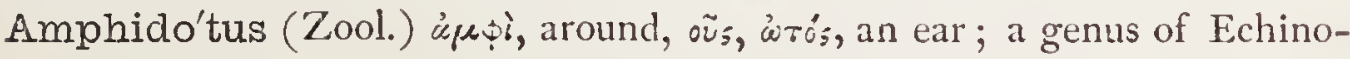
dermata.

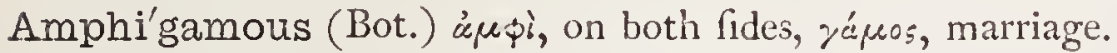

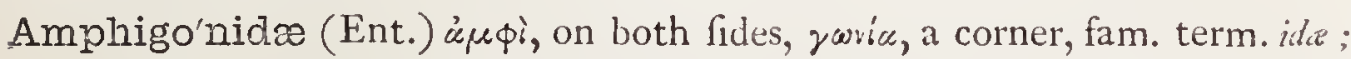

a genus of Lepidoptera.

Amphi'monas (Zool.) úp фis, on both fides, monas; having lateral filaments.

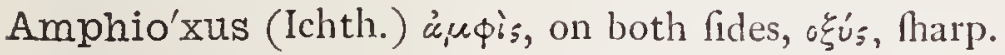

Amphipe'plea (Zool.) ¿́uфi, around, $\pi \dot{\varepsilon} \pi \lambda 0_{0}$, a mantle.

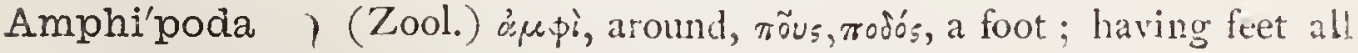
Amphi'podous round. 


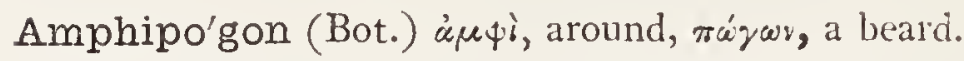

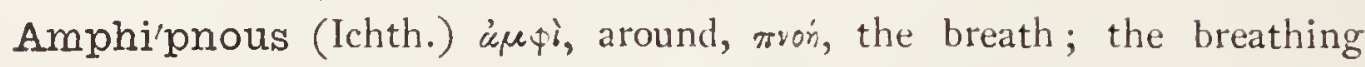
apparatus being fituated along the fides.

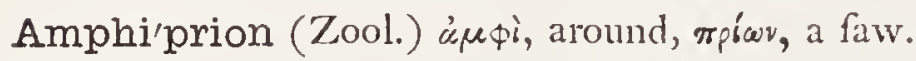

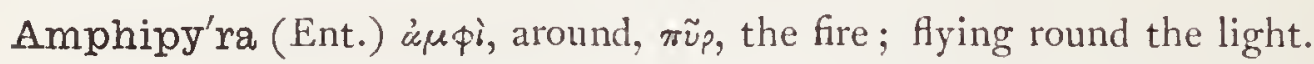

Amphipy'ridæ (Ent.) amphipyra, fam. term, ida.

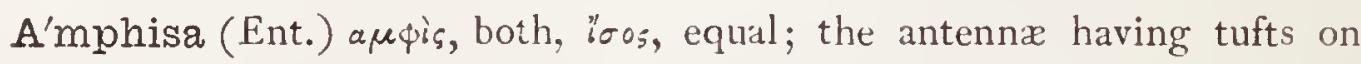
both fides.

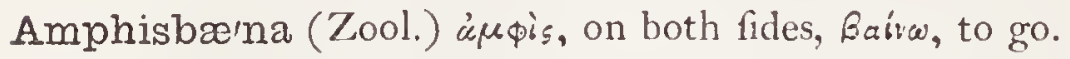

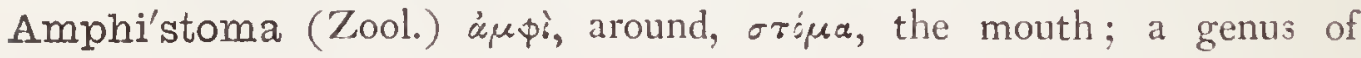
Entozoa.

Amplexicauda'tus-a-um (Zool.) amplector, to furround, canda, a tail. Amplexicau'line)

Amplexicau'lis $\}$ (Bot.) amplector, to furround, caulis, a ftem.

Ampullaria (Zool.) ampulla, a globular flak.

Amso'nia (Lot.) P. N. from Charies Amfon, an American traveller.

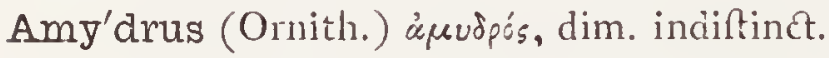

Amy'gdalus (Bot.) $\dot{\mu} \mu u \xi \xi$, to ftrain milk; from the refemblance of

blanched almond curd; or from $\dot{\mu} \mu v \sigma \sigma \omega$, to lacerate, in allufion to the

fiflured thell.

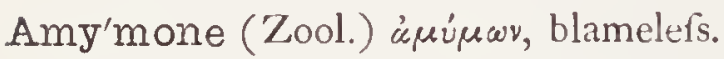

Amy'na (Ent.) ¿̌suva, defence, revenge?

Amyote'lla (Ent.) P. N. in honour of C. J.B. Amyot, a French naturalift.

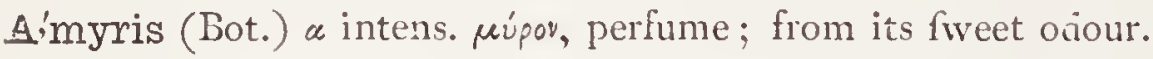

A'nabas (Zool.) a arabaivw, to afcend, from the filh occafionally leaving the Ana'basis (Bot.) $\}$ water and climbing the banks; climbing trees.

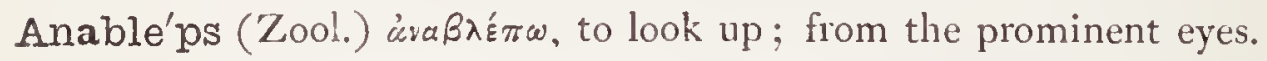

Anabo'lia (Ent.) ¿́vaBodń, a cloak, in allufion to the pupa-cafe; a genus of the Phryganidæ.

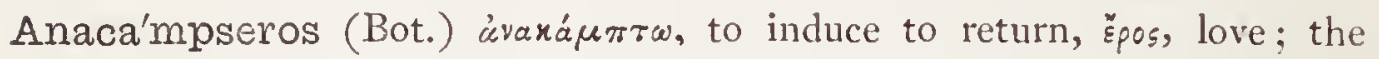
name of a plant to which the ancients attributed the power of reftoring lore.

Anaca'mptis (Bot.) 'uvaxá $\mu \pi \tau w$, to bend back, i. e. the pollen maffes.

Anaca'rdium (Bot.) 'ara, like, xapdia, a heart; from the form of the nut.

Anach'aris (Bot.) àvá, like, charis; from its refemblunce to the Hydrocharis.

Anacy'clus (Bot.) ává, upon, xúx $\lambda_{0 ;}$, a circle; in allufion to the rows of ovaries placed round the diR.

Anaga'llis (Bot.) áva $r \varepsilon \lambda a ́ w$, to laugh loud; thought to remove defpondency. Anagy'ris (Bot.) àvá, backward, zupós, a circle; from the curved pod. 
Anai'tis (Ent.) P. N., an ancient divinity.

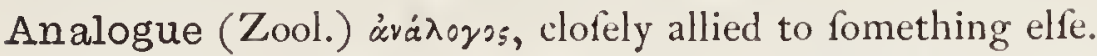

Anana'ssa (Bot.) from nanas, its name in Guiana.

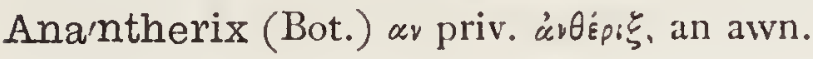

Anapepta'menus (Fos. Zool.) fp. name of a foflil crinoid, from áva, with, $\pi \varepsilon \pi \tau a \mu \varepsilon v o s$, part. of $\pi \varepsilon \tau \dot{a} v u \mu u$, to fpread, ftretch out.

Ana'pheles (Zool.) $\propto$ intenr. 'ù $\psi \varepsilon \lambda \dot{n} s$, flender, fmooth.

Ana'rsia (Ent.) àváporos, incongruous.

Anarrhi'chas (Ichth.) ávapponzruse, to break through; the wolf-fifh.

Anarrhi'num (Bot.) av priv. pir, the nofe; the plants being allied to Antirrhinum, but the flowers different.

Ana'rta (Ent.) "a fea-cockle mentioned by Pliny."-'Treirschí.

Anas (Ornith.) Lat. a duck.

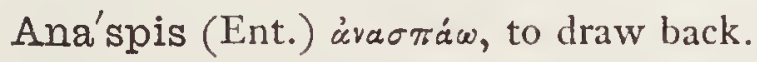

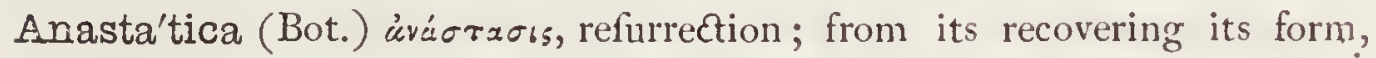
however dry, when immerfed in water.

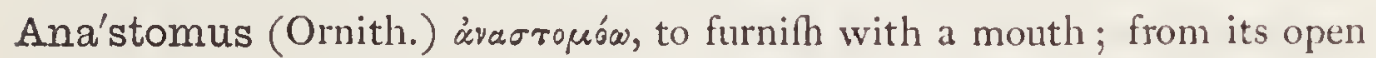
bill.

Anati'fera (Zool.) anas, a duck, fero, to bear; an allufion to the old notion of barnacles turning into geefe.

Ana'tina (Zool.) anatinus, pertaining to a duck; from form of thell.

Ana'tidæ) (Ornith.) anas, fam. term. ide, and inc; the family and fubAna'tinæ $\}$ family of ducks.

Anatine'lla (Zool.) dim. of anatinus, pertaining to a duck; duck-like.

Anatipenne'lla (Ent.) anas, a duck, penna, a feather.

A'nceps (Zool., Bot.) Lat. doubtful; having two heads, double-edged.

Anchoce'lis (Ent.) " " $2 \chi \chi$, to ftrangle, $x \eta \lambda 6_{5}^{\prime}$, a fpot."-Guenee.

Anchoracarpa'cea (Zool.) äyuvpa, an anchor, xąтós, the arm, or rather wrift; from the mode of attachment of this parafite; a tribe of Entomoftraca.

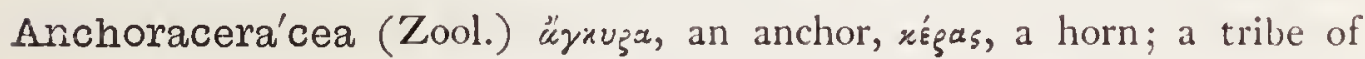
Entomoltraca.

Anchorastoma'cea (Zool.) "̈rruģa, an anchor, orópa, a mouth; from the mode of attachment of thefe parafites; a tribe of Entomoltraca.

Anchore'lla (Zool.) «̋ $\gamma$ «upa, an anchor, dim. terminal ella.

Anchu'sa (Bot.) "« $₹ \chi \omega$, to conftringe the fauces; from its aftringent quality. Ancilla'ria (Zool.) ancilla, a maiden.

Anci'strum (Bot.) «ँ $\gamma \chi 1 \sigma \tau 0$, next or neareft?

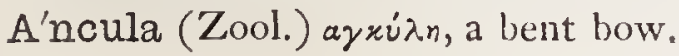




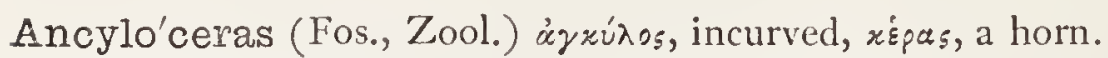

Ancylochei'ra (Ent.) "̈yrúnos, bent, $\chi$ Eip, the hand.

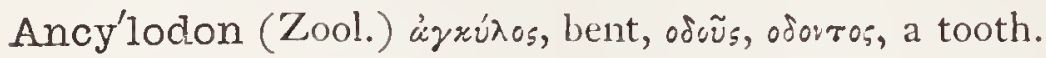

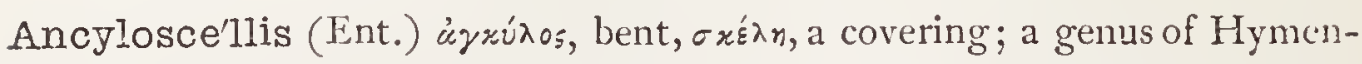
optera.

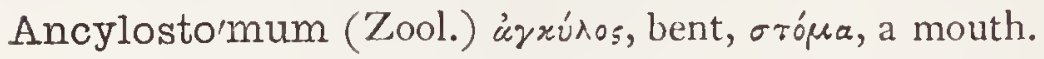

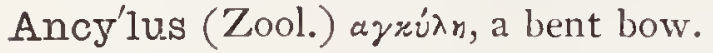

Andereggie'lla (Ent.) P. N. in honour of Herr Anderegg, a Swiis entomologift.

Andra'chne (Bot.) an old Greek botanical term for purflane.

Andreni'vora (Ent.) andrina, a genus of Hymenoptera; voro, to devour.

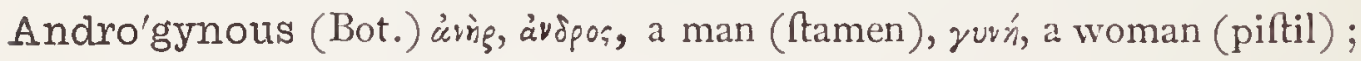
hermaphrodite.

Andro'meda (Bot.) P. N. from the Virgin Andromeda.

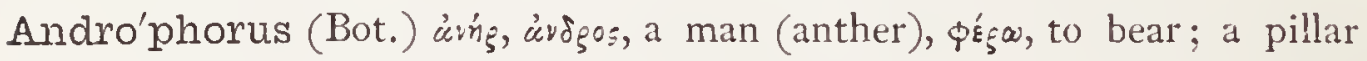
supporting a number of united anthers.

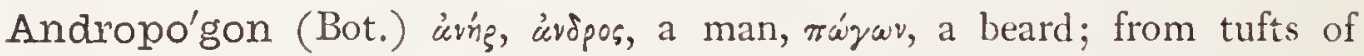
hairs on flowers.

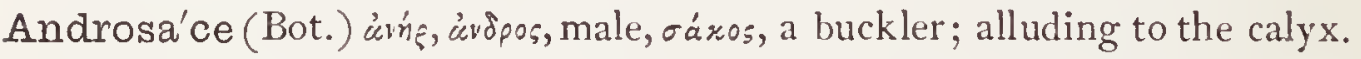

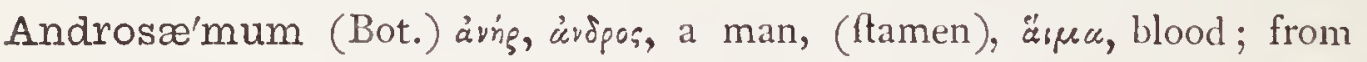
the blood-colour of the berries.

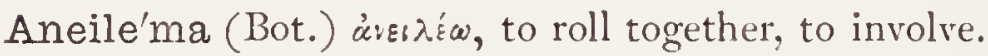

Anei'mia (Bot.) úreícav, not clothed; from its naked fructification.

Anela'sma (Zool.) av priv. ì $\lambda a ́ z r \omega$, to wander; a genus of Cirripedes.

Ane'lla (Ent.) anus, an old woman; from its grey appearance.

Ane'mone (Bot.) ävsuos, wind; becaufe the flowers are eally moved by the wind; or from growing in expofed places; Anemo'ne is the claffical accent, Ane'mone the Englifh one.

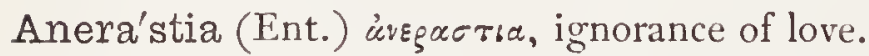

Anesy'chia (Ent.) av priv. rovxia, reft; from its reftlefs movement.

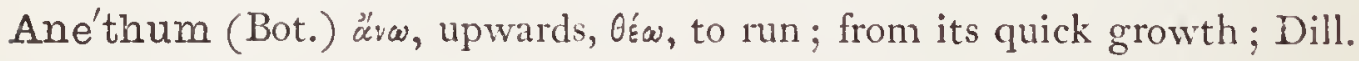
Anfrac'tus-a-um (Bot.) Lat. curved, bent.

Ange'lica (Bot.) angelus, an angel; from its cordial medicinal virtues.

Angelice'lla (Ent.) feeds on angelica fylveftris.

Angero'na (Ent.) P. N. the godders of Silence.

Angioca'rpi (Bot.) úysıiov, a veflel, $x_{\xi} \pi o_{s}$, fruit or feed with its covering: a divifion of Fungi.

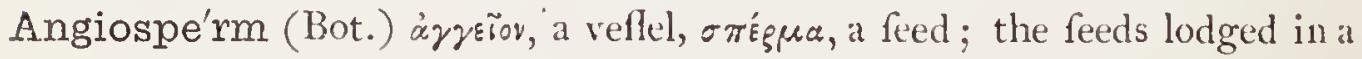
pericarp. 
Angiospo'res (Bot.) áyziǒ, a veflel, sporus, the feed of a cryptogamic plant.

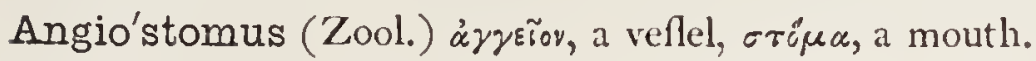

A'nglicus-a-um (Ornith., Bot.) Lat. Englifh.

Angræ'cum (Bot.) Latinized from Angurek, the Malayan name of the plant.

Angui'lla (Ichth.) Lat. an eel.

Angui'llidæ)

Anguilli'næ $\{$ (Ichth.) anguilla, fam. term. ida and ins.

An'guis (Zool.) Lat. a fnake.

An'gulifer (Zool.) angulus, a corner or angle, fero, to bear.

Angui'lliform (Ichth.) anguilla, an eel, forma, thape.

Anguina'lis (Ent.) anguineus, ferpent-like.

Anguina'ria (Zool.) anguis, a fnake; zoophytes having cells bearing fomc refemblance.

Anguisu'rus (Ichth.) anguis, a fnake, oüga, a tail.

Angula'ria (Ent.) angulus, a corner.

A'ngulate (Bot.) angulus, a corner or angle.

Angulifascie'lla (Ent.) anguhus, an angle, faficia, a band; dim. term. clla.

Anguliro'stres (Ornith.) angulus, an angle, roftrum, a beak.

Angu'ria (Bot.) the Greek name for a cucumber.

Angusta'lis (Ent.) anguftus, narrow.

Angusticolle'lla (Ent.) anguffus, narrow, collum, a neck; dim. term. ella.

Angustico'llis (Ent.) angryfus, narrow, collum, a neck.

Angustiora'na (Ent.) anguffior, more narrow.

Angustu'ra (Bot.) from Anguftura, New Guiana, whence it comes.

Anicta'ngium (Bot.) üvoькros, open, «yreiov, a veflel; having an open theca.

Anigozan'thus (Bot.) ávoíga, to expand, àvoós, a flower.

Anima'lcule (Zool.) dim. of animal, a living creature.

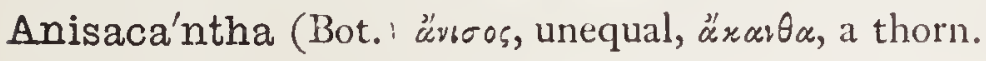

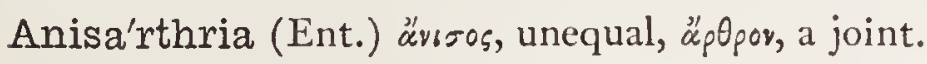

A'niseed (Bot.) Lat. anifum; Arabic, anyfum.

Aniso'ceras (Ent.) "üvoos, unequal, xḱpas, a horn (antenna.)

$\left.\begin{array}{l}\text { Anisoda'ctylus (Ent.) } \\ \text { Anisoda'ctyli (Ornith.) }\end{array}\right\} \ddot{\prime v เ \sigma o s, ~ u n e q u a l, ~ \delta a \varkappa \tau u \lambda ० s, ~ a ~ f e a t h e r . ~}$

Ani'sodus (Bot.) àvเoos, unequal, odovs, a tooth; from the unequal divifions of the calyx.

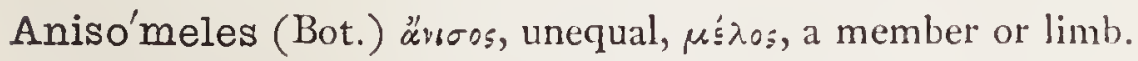

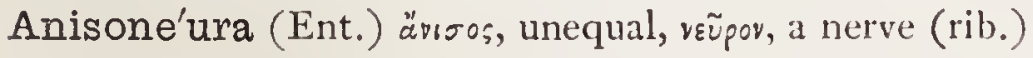

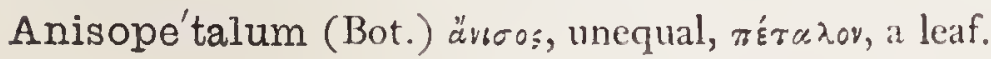




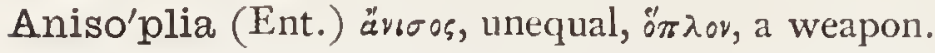

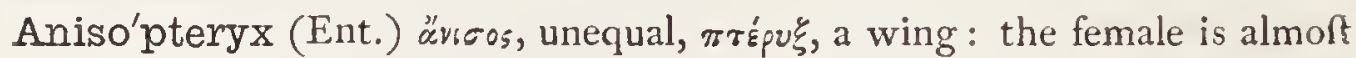
winglefs.

$\left.\begin{array}{l}\text { Anisoto'ma } \\ \text { Anisoto'midæ }\end{array}\right\}$ (Ent.) üvเo

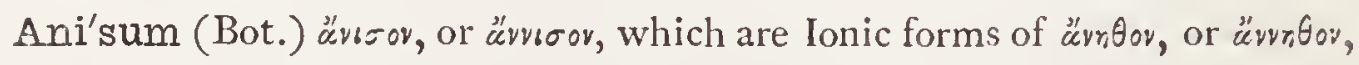
whence Anethum.

Annella'ta (Zool.) annellus, a little ring.

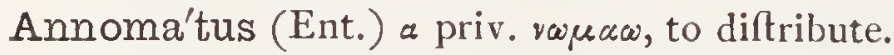

Annula'ta (Zool.) annulus, a ring.

Annulate'lla (Ent.) annulus, a ring, dim. term. ella; from the white and brown rings on the antennæ.

Annulico'rnis (Ent.) annulas, a ring, cornu, a horn; antennæ ringed with colour.

A'noa (Zool,) ävoos, foolih, ftupid; applied to one of the antelopes.

Ano'bium (Ent.) "̈̌v, above, Brów, to live.

A'nodon (Zool.) ávoderrós, without teeth; the fwan-muffel.

Anodonto'psis (Zool.) anodon, the fwan-muffel, oै $\psi$ เs, appearance.

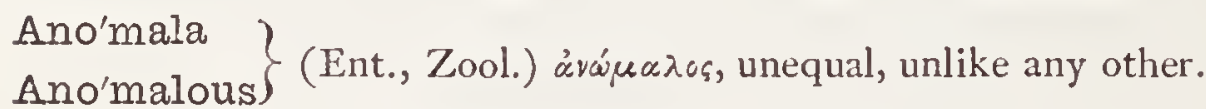

Anomale'lla (Ent.) ¿́víuaros, unequal, dim. term. ella.

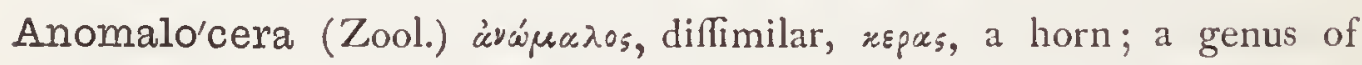
Entomostraca.

Anomalu'rus (Zool.) ávósaros, unequal, oũpa, a tail.

Anomathe'ca (Bot.) ävcres, singular, $\theta \dot{n} x$, a theath or capfule.

Ano'mia (Zool.) úvoperos, unlike.

Anomodo'ntia (Fos. Zool.) avopos, without law (type), ofevs, odovros, a tooth.

Ano'modon (Bot.) do.; referring to periftome.

Ano'na (Bot.) from Menona, its Eaftern name.

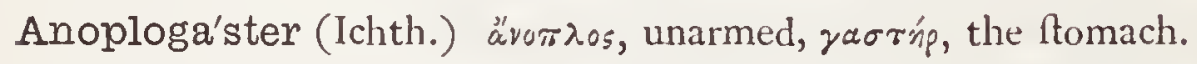

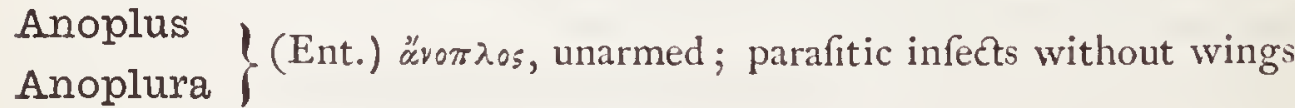

Anou'ra (Zool.) av priv. õ̃pa, a tail.

A'nous (Ornith.) a priv. voũs, the mind; alluding to the Pupidity of the

Noddy.

A'nser (Ornith.) Lat. a goofe.

A'nserine (Zool.) anser, a goofe; goofe-like.

Anseri'næ (Ornith.) anfer; fub. fam. term. ince.

Anta'rcticus (Zool.) Lat. relating to the Antarctic regions. 
Antechi'nus (Zool.) àvı, implying comparifon, Éxเvos, a hedge-hog; ufed for the Pouched-moufe.

A'ntelope (Zool.) probably from «̈v日os, a flower, or any thing beautiful, and $\ddot{\circ} \psi$, the eye.

Ante'nnæ (Ent.) ante, before, teneo, to hold.

Antenna'ria (Bot.) from the antenna of infeets, to which the down of the pappus bears fome refemblance.

Antennula'ria (Zool.) antennula, dim. of antenna, an infeet's feeler; from refemblance of polyps.

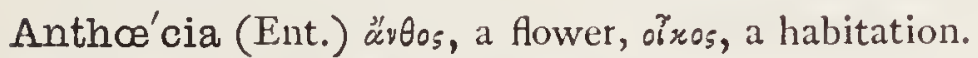

Anthe'a (Zool.) "̈ँvos, a flower.

Anthemida'na (Ent.) feeds on the finking chamomile, Anthemis cotula.

A'nthemis (Bot.) $\dot{u} v \theta \dot{\varepsilon} \omega$, to flower; from its profufion of flowers.

A'nther (Bot.) àvinpos, flowery.

Anthe'ricum (Bot.) $\ddot{\alpha}^{\prime} \theta_{05}$, a flower, $\ddot{\varepsilon}_{p}$ ros, a hedge; a name faid to have been applied by the Greeks to the ftem of the afphodel.

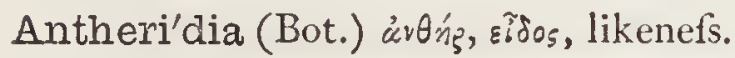

Anthero'phagus (Ent.) àvinp, an anther, $\phi \dot{\alpha} \gamma \omega$, to eat.

Anthi'diam (Ent.) äv $\theta_{05}$, a flower; a genus of Hymenoptera.

Anthoce'rcis (Bot.) ״̈ㅂo, a flower, xspxís, a ray; from the radiated corolla.

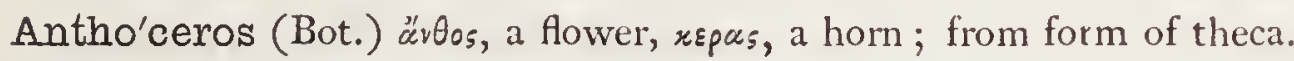

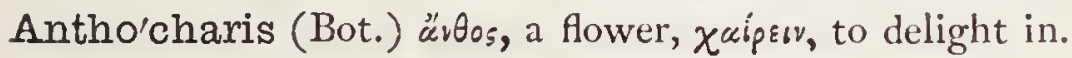

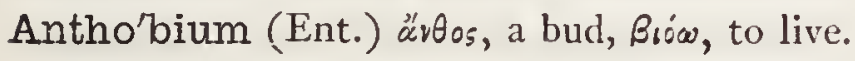

Anthobo'sca (Ent.) «̈v日os, a flower, Borww, to feed; a genus of Hymen.. optera.

Antho'dium (Bot.) äv $\theta_{0 s}$, a flower; containing many flowers.

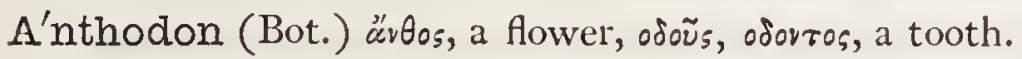

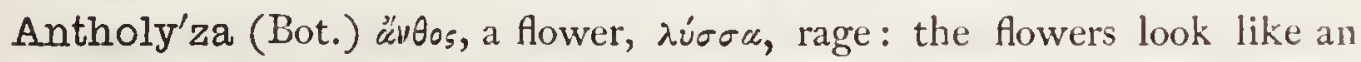
animal ready to bite.

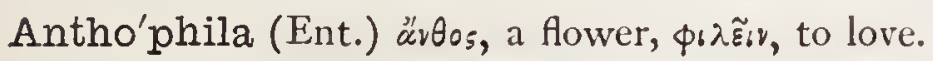

Anthophi'lidæ (Ent.) anthophila, fam. term. ida.

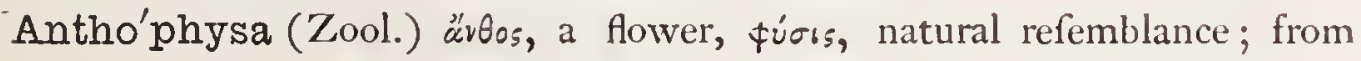
being collected in clufters at the extremities of a branching ftem or polypidom; a genus of Infuforia.

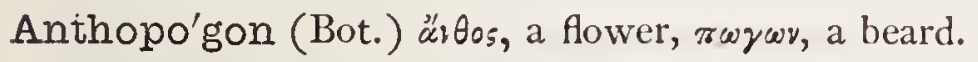

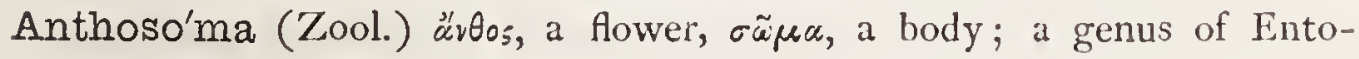
moftraca.

Anthoso'madæ (Zool.) anthosoma, fam. term. adce. 


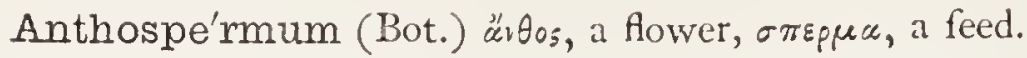

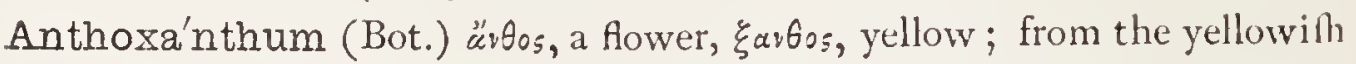
hue of the fpikes, efpecially in age.

Anti'ca (Ent.) Lat. that is in front, foremoft.

Anticle'a (Ent.) P.N., the mother of Ulyfles.

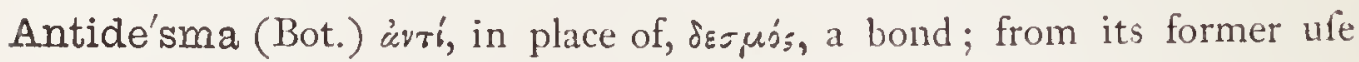
in making ropes.

Antiopa (Ent.) P. N., the mother of Amphion.

Antiqua'na (Ent.) antiqurs, antient.

Anti'quus-a-um (Zool.) Lat. antient.

Antirrhi'num (Bot.) ávrs, like, approaching, porv, the nofe; from the refemblance of the flowers to an animal's fnout.

Antispila (Ent.) ¿uvrı, oppofite, $\sigma \pi \tilde{i} \lambda o ;$, a fpot.

Antithe'sia (Ent.) àri $\theta \varepsilon \sigma s s$, oppofition; from the contraft of colours.

Anthraci'nus-a-um (Ent.) Lat. black as a coal, from anthrax, a coal.

Anthra'xia (Ent.) «ँv

Anthrenei'dæ (Ent.) anthrenus, हi்os, like; a family of Coleoptera.

Anthre'nus (Ent.) áv̧pnv'́n, a wild bee; a genus of Beetles.

Antri'ada (Ent.) ávrpıás, ùvtpเádos, dwelling in caverns.

Anthri'bus (Ent.) av neg. rpißw, to grind down.

Anthri'scus (Bot.) a name given by Pliny to the herb chervil.

Antro/phium (Bot.) "̈̌spos, a cavern, фúw, to grow; from its habitat.

Antro'stomus (Ornith.) "̈vтюov, a cavern, $\tau \tau о \mu \mu$, a mouth; from its wide gape; the genus of Goatfuckers, to which the Whip-poor-Will belongs.

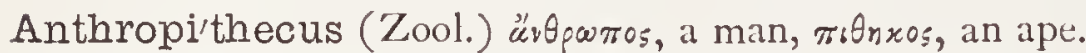

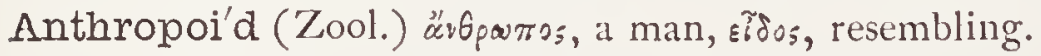

Anthus (Ornith.) Lat. a titlark or pipit.

Anthyllide'lla (Ent.) feeds on the kidney-retch, Anthyllis rulneraria.

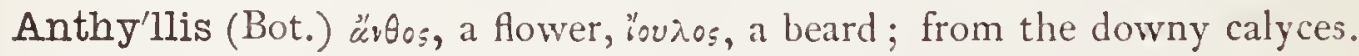

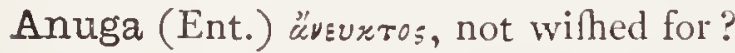

A'nura (Zool.) av priv. oũpa, a tail ; an order of Batrachians.

A'nxius (Ent.) Lat. uncertain, i.e. in colour.

Any'bia (Ent.) P. N. Anybis or Ambis, an Egyptian deity.

Any'chia (Bot.) from its affinity to Paronychia.

Aomyx (Zool.) a priv. örv

A'otes (Zool.) « piiv. ỡ̇s, $\dot{\omega} \tau o ́ s$, an ear; earlefs.

Aotus (Bot.) a priv. ous, 'wrós, the ear; having no earlike appendages to calyx.

Apame'a (Ent.) àrapáa, to cut off: 
Apame'idæ (Ent.) apamea, fam. term. ida.

Apa'rgia (Bot.) the Greek name of fome plant not now known.

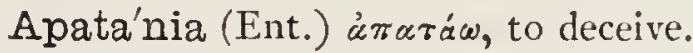

Apa'te (Ent.) árárn, ftratagem.

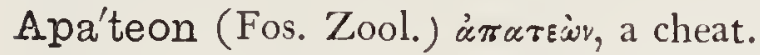

Apatu'ra (Ent.) P. N., a furname of Venus

Ape'talous ?

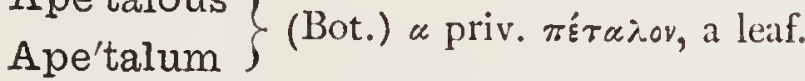

A'pex (Zool.) Lat. the point or top of a thing.

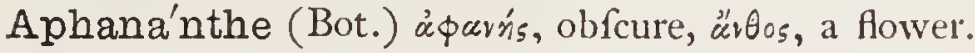

A'phanes (Bot.) áфarńs, obfcure.

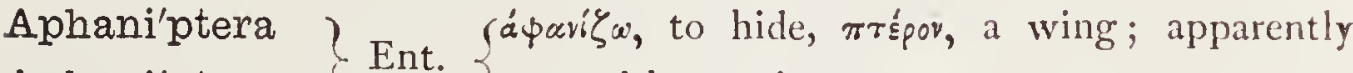
Aphani'pterous $\}$ Ent. $\{$ without wings.

Aphani'sticus (Ent.) ả $₫ a v i \zeta \omega$, to hide.

Aphanizo'menon (Bot.) ảфavi $\zeta \omega$, to hide; a genus of Conferv $x$.

A'phareus (Zool.) the word ¿ðфapévs was applied by Arifotle to the belly-

fin of the female tunny; or it may be from $\alpha \dot{\phi} \propto \dot{\gamma}^{\prime}$, naked.

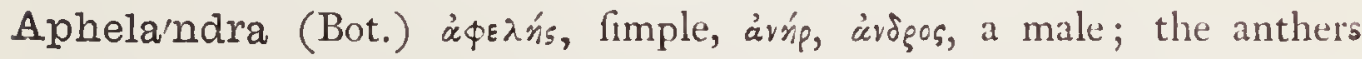
being one-celled.

Aphe'lia (Ent.) $\dot{\phi} \phi \varepsilon \lambda_{s}$, plain, from the fimplicity of the wing markings. Aphele/xis (Bot.) á $\phi \varepsilon \lambda \dot{n} s$, fimple, $\varepsilon \xi_{b 5}$, habit.

Aphelo'toma (Ent.) á $\phi \varepsilon \lambda \dot{r} s$, fimple, $\tau \dot{\varepsilon} \mu v m$, to cut.

Aphodi'adæ (Ent.) aphodius, fam. term. ada.

Apho'dius (Ent.) üpodos, going back?

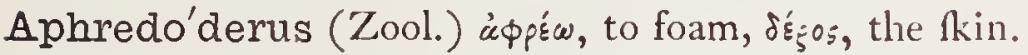

Aphrites (Zool.) á $\phi_{\zeta} \tilde{i} \tau b \varsigma$, the foam-fifh.

Aphrodi'te (Zool.) P. N., the Greek name of Venus. In its application

to a fea-worm there may be fome allufion to the fuppofed derivation

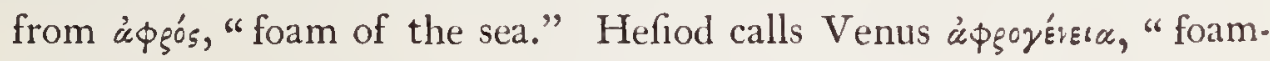
fprung."

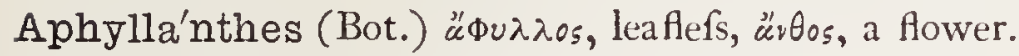

Aphy'llous (Bot.) a neg. фú $\lambda \lambda . \%$, a leaf; leaflefs.

Apia'ster (Ornith.) Lat. a bee-eater.

Apica'lis (Ent.) apex, a point.

Apica'ta (Ent.) Lat. adorned as it were with a cap or mitre (apex); conically pointed.

Apice'lla (Ent.) dim. of apex-the apex of the wing is bright ochreous.

Apicia'ria (Ent.) apex, the top; from the direction of its freaks.

Api'cra (Bot.) a neg. ms; 
A'pidæ (Ent.) apis, fam. term. ide.

Apifo'rmis (Ent.) apis, a bee, forma, refemblance.

Apiifo'lius-a-um (Bot.) apium, folia, leaves; parfley-leaved.

Apis (Ent.) Lat. a bee; probably from $\dot{a} \pi 0^{2}$, without feet, in allufion to their appearance in the pupal ftate; or from the old word apio, to cling, in reference to the curtain formed by the bees.

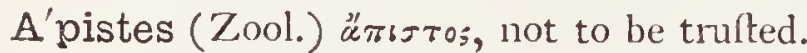

A'pium (Bot.) apex, the fummit or crown of the head, becaufe the head was crowned with it in the ancient triumphs; fome, however, deduce it from the Celtic apoin, water, in allufion to its common habitat; parlley and celery.

Api'vorus (Ornith.) apis, a bee, voro, to eat.

Apple (Bot.) Anglo-Sax. apl.

Apla'na (Ent.) ad, planus, even, flat.

Aple'cta (Ent.) \& priv. $\pi \lambda \varepsilon \varkappa \tau \dot{s}_{s}$, folded; becaufe the wings are not wrinkled.

Apli'dium (Zool.) $\ddot{\alpha} \pi \lambda_{.0} \tilde{\nu}_{5}$, fimple.

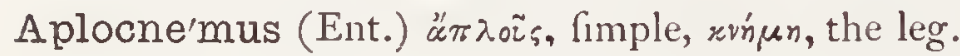

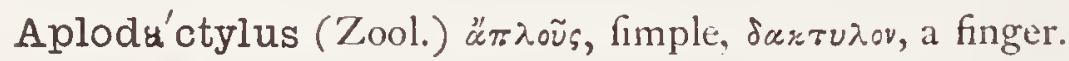

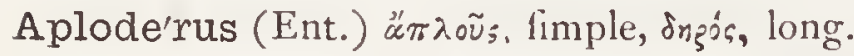

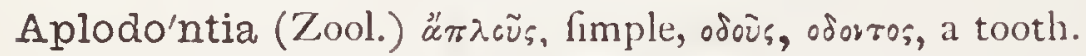

Aplu'strum (Zool. Lat. a hip's Alag.

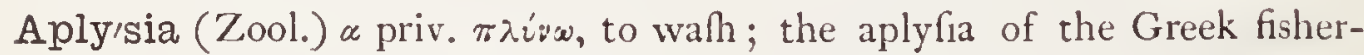
men were fponges unfit for walhing.

Apocli'sa (Ent.) árò and $x \lambda \varepsilon i \omega$, to hut or clofe.

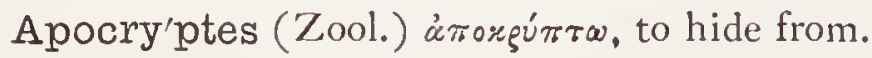

Apocyna'ceæ (Bot.) apocynum, term. for order, acece.

Apo'cynum (Bot.) árò, away from, xúwv, xuvos, a dog ; becaufe thought to

be poifonous to them; the dogs'-bane.

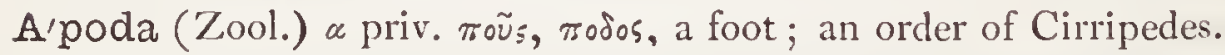

A'poda (Ornith.) ärroũs, aroodos, without feet; this name was given by

Limaus to a Bird of Paradife, from the circumftance that all the fpecimens that arrived in Europe were without feet, having been thus mutilated by the natives before drying the Rins.

A'podal (Zool.) a priv. roũs, rodós, a foot.

A'podemes (Zool.) \&́rrodéw, to bind fant; applied to projections of chitine, for the attachment of mufcles in the Cirripedes.

Apo'gon (Zool.) a priv. $\pi \dot{\alpha} \gamma \omega v$, a beard.

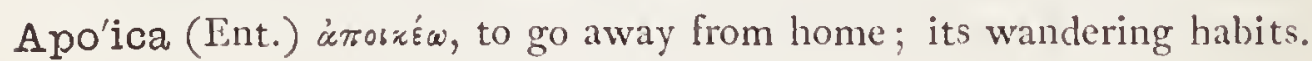


Aponoge'ton (Bot.) from Celtic apon or avon, water, yeircav, a neighbour.

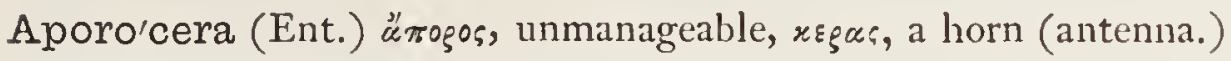

Aporo'des (Ent.) «̈rogos, stupid, dull.

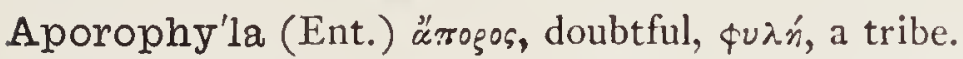

Aporrha'is (Zool.) 'atoppéw, to flow away; the fprout-fhell.

Appendicula'ria (Zool.) appendicula, a little appendage.

Appro'ximate (Bot.) ad, to ; proximus, a neighbour.

Aprica'rius (Ent.) apricor, to bafk in the fun.

Apricot (Bot.) formerly fpelt aprecock, and by our earlieft writers aprecocke; probably from the Arabic Bericach, or Bercock, whence the Greeks pro bably derived their $\pi \varepsilon$ sжúx $x$, and the French their abricot, from whom we probably derived the word. Some think it from Lat. precox, being the earlieft of the kind to ripen.

Aprili'na (Ent.) Aprilis, from the month in which it appears.

A'prion (Zool.) a priv. rpíar, a faw.

Aprosmi'ctus (O1'nith.) úrpósusxroi, holding no communion with; from its folitary habits.

A'psilus (Zool.) a priv. $\psi$ ' $\lambda_{\text {ós }}$, naked, bare.

A'pus (Ornith.) «ँzous, without feet; from appearance in flying.

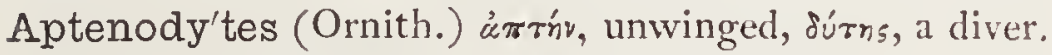

Apte'rnus (Ornith.) a priv. zrépra, a heel.

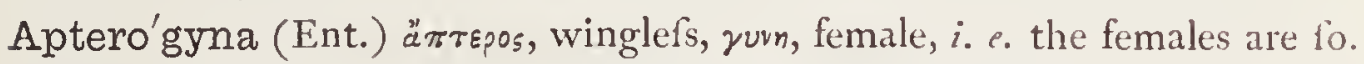

Aptero'peda (Ent.) äzrepos, unwinged, pes, pedis, a foot.

Aptery'ginæ (Ornith.) apteryx, fam. term. ina.

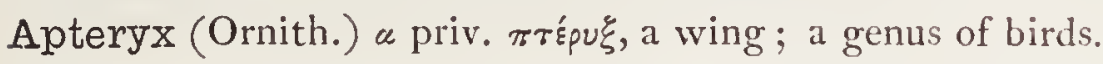

Apthalmicthys (Ichth.) a priv. $\theta \dot{\alpha} \lambda \lambda \omega$, to abound, ' $\chi \theta \dot{\theta}$, a filh.

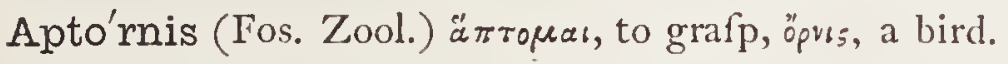

Apyga'lis (Ent.) a priv. muy'n, the rump.

A'ptychus (Fos. Zool.) \& priv. $\pi \tau u \chi^{n}$, a fold, the plates or valves being without fold or hinge.

Aqua'rtia (Bot.) P. N. from B. Aquart, Jacquin's companion in America. Aqua'ticus-a-um (Zool., Bot.) Lat. relating to water, aquatic.

Aqui'ferous (Zool.) aqua, water, fero, to carry.

Aquifolia'ceæ (Bot.) aquifolium, term. for nat. order acce:

Aquifo'lium (Bot.) acus, a needle, folium, a leaf; becaufe its leaves are prickly; the holly.

A'quila (Ornith.) Lat. an eagle.

Aquila'ria (Bot.) aquila, an eagle; called bois d'aigle by French colonins. Aquilaria'cex (Bot.) aquiluria, term. for nat. order aced. 
Aquile'gia (Bot.) aquila, an eagle, whose claws the nectaries refemble.

Aquili'na (Ent.) aquilus, dark-coloured.

Aquili'næ (Ornith.) aquila, fam. term. ine.

A'rachis (Bot.) a priv. ṕáxbs, a branch.

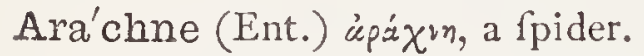

Ara'chnida (Ent.) '́pá $\chi^{\nu n}$, a fpider, with fam. term.; one divifion of the Articulata.

Ara'chnides (Ent.) ápá $\chi^{\imath}$, a fpider, édós, refemblance.

Arachnothe'ra (Ornith.) àpá $\chi^{v n}$, a fpider, and $\theta \dot{n} \xi$, a wild bealt.

Ara'bicus-a-um (Zool., Bot.) Lat. Arabian.

Arabi'dese (Bot.) arabis, ordinal term. idec.

A'rabis (Bot.) an old name of Diofcorides, now applied to the wall-crefs.

Aragua'to (Zool.) native name of one of the howling monkeys.

Ara'lia (Bot.) apa, annoyance; now applied to another plant.

Aralia'cex (Bot.) aralia, ordinal term. acea.

Ara'neus (Zool.) Lat. a Mrew.

Arane'idæ (Ent.) aranea, a fpider, term. ida.

Arara'una (Ornith.) from the Brazilian word arara; one of the Macaws. Arauca'ria (Bot.) from araucanos, its Chilian name.

Arauca'rites (Fos. Bot.) applied to certain foffil coniferous plants refem. bling the araucaria.

Arbo'reus-a-um (Zool. \& Bot.) Lat. belonging to trees.

Arbore'scent (Bot.) arborefco, to grow into a tree.

Arbuta'na (Ent.) arbutus, the wild Itrawberry, on which it is fuppofed to feed.

Ar'butus (Bot.) the ftrawberry tree; from Celtic ar boife, auftere bulh, on account of its rough fruit.

A'rca (Zool.) Lat. a cheft or cell.

A'rcadæ (Zool.) arca, fam. term. ada; a family of Mollufa,

Arce'lla (Ent.) dim. of arca, a cell.

Arceu'thina (Ent.) áprevbivos, belonging to the Juniper.

Archangelica (Bot.) from its fuppofed archangelic virtues.

Archegosau'rus (Fos. Zool.) ápxryós, beginning, oaupos, a lizard; primeval lizard.

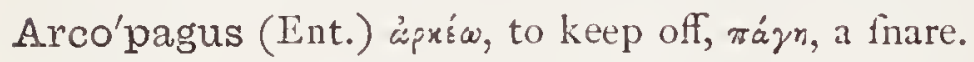

Ar'ctia (Ent.) "eprros, a bear; the larva is popularly called the "woolly bear." Arcti'beus (Zool.) ״̈љжros, a bear.

Arctic'tis ('Zool.) äpxros, a bear, íxьৎ, a weafel; a genus of Mammalia, the Binturong of Nepál. 
Ar'ctium (Bot.) "upжros, a bear, from the coarfe texture of the involucres; the plant Burdock.

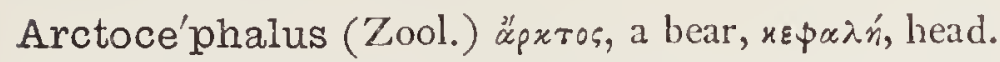

Arctocephali'na (Zool.) arctocephalus, fam. term. ina.

A'rctomys (Zool.) äpxros, a bear, $\mu \tilde{v}$, a moufe; the family of Marmots.

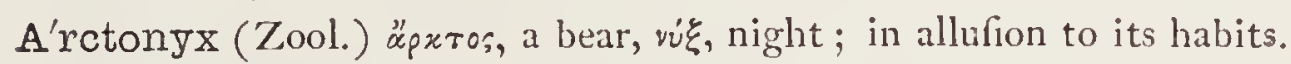

Arctopithe'cus (Zool.) äpxro;, a bear, rínxo;, a monkey.

Árctos (Zool.) äprros, a bear.

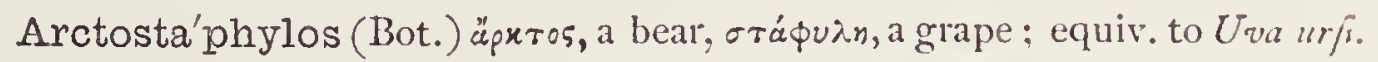
Arctothe'ca (Bot.) ospros, a bear, Onxn, a capfule, fo named from the roughnefs of the fruit.

Arcto'tis (Bot.) äprros, a bear, ov̌s, an ear; from the Thaggy fruit.

Arcuate'lla (Ent.) dim. of arcuatus, curved like a bow.

Arcuatus-a-um (Zool.) Lat., arched, curved, from arcuo, to bend like a bow.

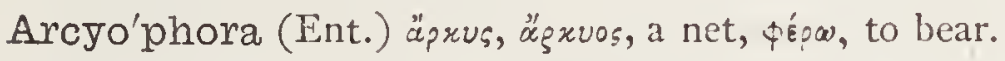

A'rdea (Ornith.) equiv. to ardua, fem. of arduus, lofty, from its high flight. Arce'idæ (Ornith.) ardea, fam. term. ida.

Ardi'sia (Bot.) $\dot{a}_{p} \delta$, a f fpear point; from the fegments of corolla.

Ardui'na (Bot.) P. N. in honour of Pietro Arduini, an Italian botanift.

Arena'ria (Ornith. \& Bot.) arena, fand; becaufe growing in fandy places in the one cafe, and the bird frequenting fimilar localities in the other. Areno'sus (Ent.) Lat. fandy.

Are'tia (Bot.) P. N. from Benoit Aretius, a Swifs botanift.

A'rgala (Ornith.) the native name of the Adjutant.

Arge (Ent.) áprós, white.

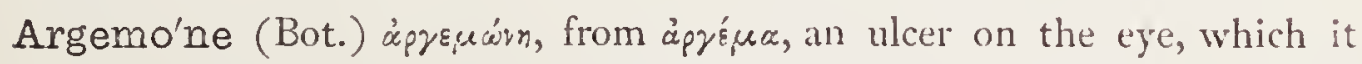
was thought to cure.

Argenta'lis (Ent.) argentum, filver; referring to colour.

Argenta'tus (Ornith.) Lat. plated with filver.

Argente'ola (Ichth.) Lat. filvered, plated with filver.

Argentimacule'lla (Ent.) argentum, filver, macula, a fpot, dim. ella.

Argenti'na (Ichth.) argentum, filver; from the pearly-looking fubftance in

the air-bladder; a genus of the family Salmonidæ.

Argentipede'lla (Ent.) argentum, filver, pes, a foot, dim. ella.

Argen'tula (Ent.) argentum, filver.

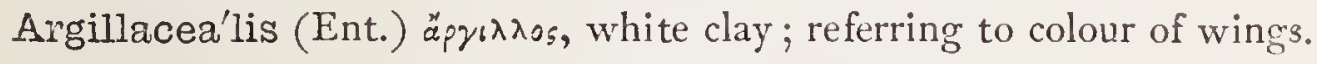

Argi olus (Ent.) P. N., dim. of Argos.

Argi'ope (Zool.) P. N., the name of a nymph, the meaning of which is white-footed. 
Argi'va (Ent.) Linnæus gave this name to a divifion of Lepidopterous infects; it is taken from the old name of the Greeks, Argives, which is from Argos: there were feveral cities fo called.

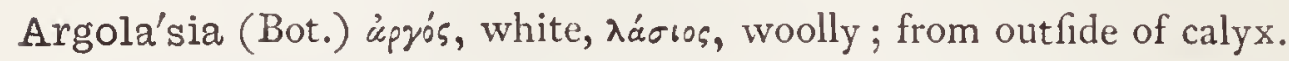

Argo'ondah (Zool.) the native name; this word fhould have been written Argunda.

Argona'uta (Zool.) P. N., the Argonauts were the failors in the fhip Argo; applied to the Paper Nautilus.

Argona'utidæ (Zool.) argonauta, fam. term.ide; a family of the Mollufca. Argu'lidæ (Zool.) argulus, fam. term. ide; a family of Entomoftraca.

A'rgulus (Zool.) Etymology unknown to me.

Argu'ta (Bot.) Lat. clear, fharp, i. e. in form.

A'rgus (Ornith.) P. N. from Argus, the hundred-eyed Thepherd, on account of the numerous eye-like fpots on its plumage.

Argu'tor (Ent.) argutus, (hrill, loud, i. e. the noife it makes in its fight. Argy'nnis (Ent.) P. N. a furname of Venus.

$\left.\begin{array}{l}\text { Argyra'lis (Ent.) } \\ \text { Argyra'na (Ent.) }\end{array}\right\}$ äpropos, filver; the filvery colour of the infects.

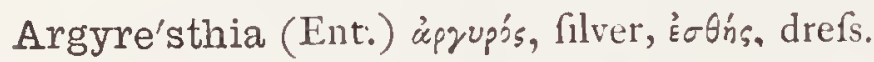

Argyresthi'idæ (Ent.) argyresthia, fam. term. idce.

Argyro'come (Bot.) äprupos, filver, x's»n, hair.

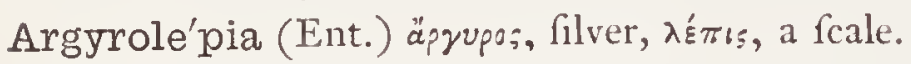

Argyrone'ta (Ent.) äsyupos, filver, vnтos, heaped up; alluding to the large filvery globules of air in which this fpider envelopes itfelf in diving into the water.

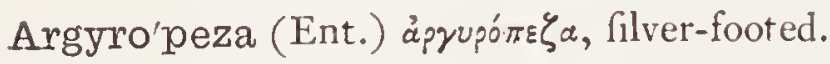

Argyroto'xa (Ent.) áprupóró̧os, bearer of the filver bow, an epithet of Apollo.

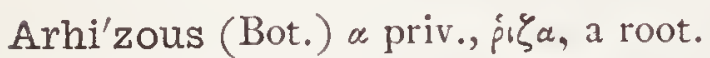

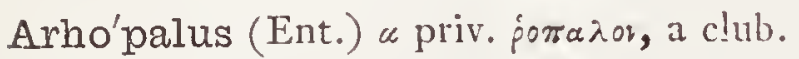

A'riel (Zool.) a Greek proper name; the Gazelle.

A'ries (Zool.) Lat. a ram.

Ari'etans (Zool.) Lat. butting like a ram.

Arion (Ent.) P. N. an ancient lyric poet.

Ariphron (Ent.) ápı фpa óns, eafily known.

Ari'sta (Bot.) from areo, to be dry, becaufe it is always so; the awn.

Arista'tum (Bot.) Lat. bearded, awned.

Ariste'a (Bot.) arifa, a point or beard; the leaves.

Ari'stida (Bot.) arifa, an ear of com, or rather the awn or beard. 


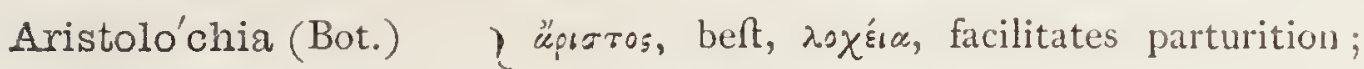
Aristolochia'cer (Bot.) $\}^{\zeta}$ from its former ufes.

Armeni'aca (Bot.) P. N. from Armenia, whence it was brought.

Arme'ria (Bot.) Latin name for Sweet-william.

Armerioi'des (Bot.) armeria, sioos, like.

Armi'gera (Ent.) armiger, a fhield-bearer.

Armi'llæ (Ornith.) Lat. armlets, bracelets.

Armora'cia (Bot.) fo named by the Romans from Armorica or Brittany, where it was fuppofed to grow abundantly.

A'rniæ (Ent.) àpriov, a little lamb.

A'rnica (Bot.) úprărí, a Theep's lkin, which is from ápvóa, a lamb; from the refemblance of its leaf to the foft coat of the lamb.

Arnoglo'ssus (Ichth.) àpvós, a lamb, $\gamma \lambda \tilde{\omega} \sigma \sigma \alpha$, a tongue.

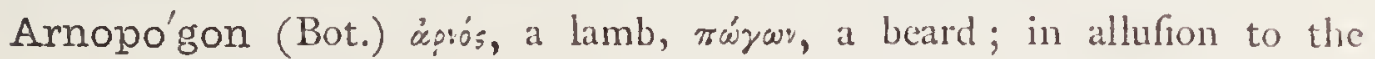
bearded feeds.

Arno'tto (Bot.) a native American name.

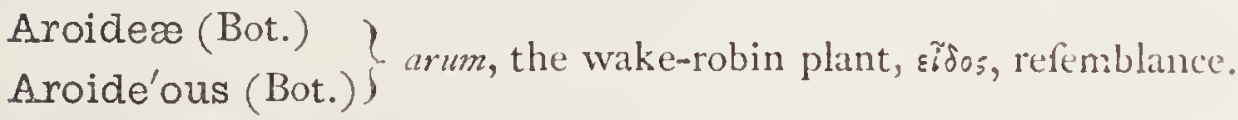

Aro'ma (Bot.) «̈pos $\mu \alpha$, a fweet-herb.

Arpa'cticus (Zool.) $\hat{a}_{\rho} \pi \alpha \xi$, rapacious; a genus of Entomoltraca.

Arqua'tus (Ornith.) Lat. arched.

Arrow-root (Bot.) probably from the form of the root-ftock or rhizome.

Artabo'trys (Bot.) üpría, to fufpend, Rítpus, a bunch of grapes; fuggefted by the mode of fufpenfion of the fruit.

A'rtanus (Ornith.) üprănos, a butcher; fometimes called the fwallowThrikes.

Arte'dia (Bot.) P. N. in honour of Pietro Artedi.

Artemi'sia (Bot.) P. N. from Artemis, the Diana of the Greeks.

Artemisiel'la (Ent.) feeding on the above plant.

Artho'nia (Bot.) unexplained.

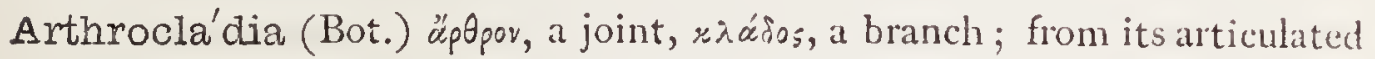
frond.

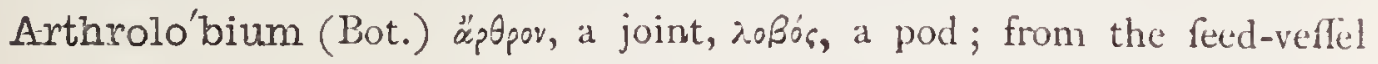
being jointed.

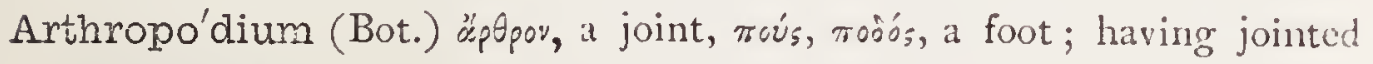
foot-ftalks.

Articula'ta ('Lool.) articulatus, jointed; in oppofition to vertebruth ; one of the great divifions of the animal kingdom. 
Artocarpa'ceœ (Bot.)) äpros, bread, xapros, fruit; the bread-fruit tree Artoca'rpus (Bot.) $\}$ and family.

A'rum (Bot.) äpor, the Greek equivalent ; fuppofed to be from an Egyptian word; the wake-robin or cuckoo-pint.

Aruncel'la (Ent.) frequents Spirca Aruncus.

Arundina'ceus-a-um (Ornith., Bot.) Lat. reed-like, frequenting reeds. Aru'ndo (Bot.) Lat. a reed, qu. from Celtic aru, water.

Arve'nsis-e (Bot.) aroum, a ploughed field, referring to habitat.

Arvicoli'na (Zool.) aroum, a field, colo, to inhabit.

A'saphes (Ent.) úrăф'śs, indiftinct, obfcure.

A'saphus (Fos. Zool.) ḋ $\sigma \tilde{a} \uparrow \dot{n}$, obfcure; a genus of foffil Cruftacea.

Asarifo'lius-a-um (Bot.) afarum, folia, leaves; afarum-leaved.

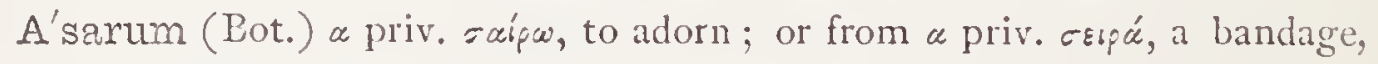

being unfit for garlands.

Ascalabo'tes (Zool.) árxáiafor, the Greek name of a lizard.

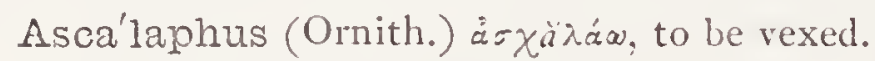

Asca'rides (Zool.) plural of afuris.

Ascarici'da (Bot.) afiaris, cado, to kill.

A'scaris (Zool.) a redundant, oxceipes, to leap; a genus of inteftinal worms.

Asci (Bot.) árxós, a leathern bag.

$\left.\begin{array}{l}\text { Asci'dia } \\ \text { Asci'dians }\end{array}\right\}$ (Zool.) ürxós, a leather bag; a genus of Mollufes.

Asci'dium (Bot.) ácxidrov, a fmall leather bottle; applied to the hollow receptacle called the pitcher.

Asclepia'dex (Bot.) afclepias, with fam. term.

Ascle'pias (Bot.) P. N. from Afclepiades, a Greek phyfician.

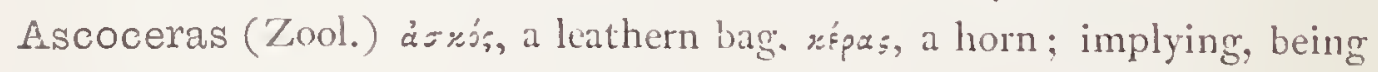
bent on itfelf.

Ascy'rum (Bot.) a priv. exipov, hard: being foft to the touch?

Ase'llidae (Zool.) afollus, fam. term. ide: a family of Cruftaceans.

Ase'llus (Zool.) Lat. an af́s colt; the name is alfo given to a genus of

Cruftaceans.

A'semum (Ent.) äsruos, without mark.

Aseti'gera (Zool.) u priv. fita, a briftle, gero. to bear.

Ashwo'rthii (Ent.) P. N. from the late 7 . H. Afictorth. of Manchifter.

Asidi'cola (Zool.) äzrs, mud, colere, to inhabit.

Asilifo'rmis (Ent.) aftus. forma, refemblance.

A'silus (Ent.) afilio, to afail hafily; the gad-fy. 
Asina'lis (Ent.) Lat. the colour of an afs.

A'sinus (Zool.) Lat. the ass; from ás̆̌ns, harmlets, in reference to its difpofition.

Asipho'nida (Zool.) a priv. fíw, a fucker; a family of Mollusca.

Aso'pia (Ent.) P. N., a name of Ceres.

Asopi'idæ (Ent.) afopia, fam. term. ide; a family of Moths.

Aspa'lathus (Bot.) \& priv. $\sigma \pi \alpha$ s, to extract, probably in reference to the thorns.

A'spalax (Zool.) the Greek name for a mole.

Aspa'ragus (Bot.) $\propto$ intens. $\sigma \pi \alpha \xi \alpha s \sigma a$, to tear; 'Thunberg fays that the

"Cape afparagus" is called by the natives, suaht en beetje (wait al bit),

becaufe its crooked thorns catch their clothes in paffing.

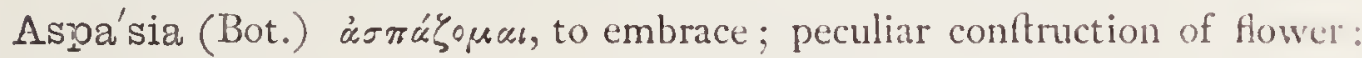

a genus of Orchids.

A'sper, A'spera, A'sperum (Zool.) Lat. rough.

Aspere'lla (Ent.) dim. of asper, rough.

Aspergi'llum (Zool.) Lat. a watering-pot.

Aspergi'llus (Bot.) a genus of Fungi.

Asperococ'cus (Bot.) aper, rough, coccus, a berry; from the appearance of

its fructification.

Asper'rimus-a-um (Bot.) Lat. molt rough.

Aspersa'na (Ent.) asperfus, fprinkled

Aspe'rugo (Bot.) asper, rough.

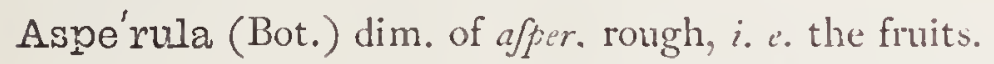

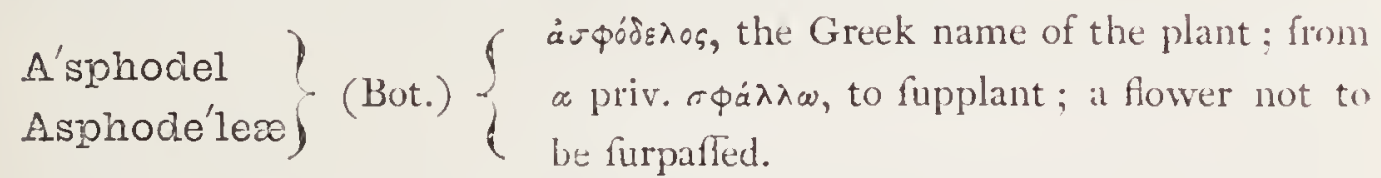

Asplan'chna (Zool.) a priv. orida $\chi^{r \alpha, ~ t h e ~ v i f c e r a . ~}$

Aspleniifo'lius-a-um (Bot.) applenium, folia, leaves; afplenium-leaved.

Asple'nium (Bot.) üs $=\pi$ nvov, a medicine to cure difeates of the fpleen.

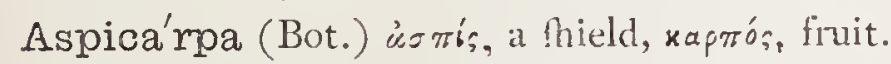

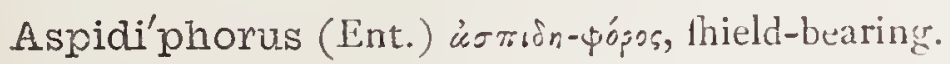

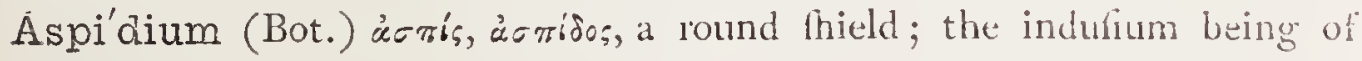
this form.

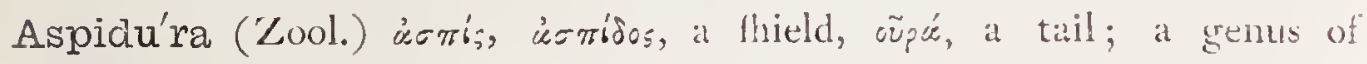
Colubrine ophidians.

Aspilates (Ent.) a priv. erĩas, a fpot. Pliny mentions a precious ftonte

by this name.

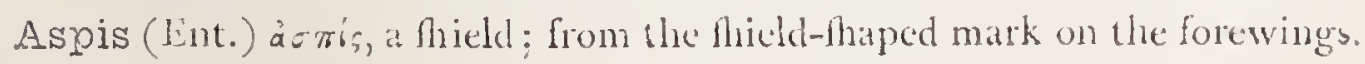


Assafoe'tida (Bot.) probably from the Perfian lafer, with the addition of the Latin fatidus, ftinking. The word leems to have been introduced by the monks into the fchool of Salernum.

Assimila'ta)

Assi'milis $\}$ (Ent.) affimilis, refembling the neighbouring fpecies.

Asso'nia (Bot.) P. N. from Tgnatius de AfJo, a Spanifh botanift.

Assu'rgent (Bot.) affuroo, to rife up.

A'stacus (Zool.) àctaxís, a lobfter.

Astarte (Zool.) P. N., an antient Syro-Phonician godders.

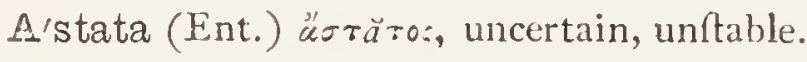

Astélia (Bot.) a priv. $\sigma \tau \dot{\varepsilon} \lambda \varepsilon \chi^{05}$, a ltem.

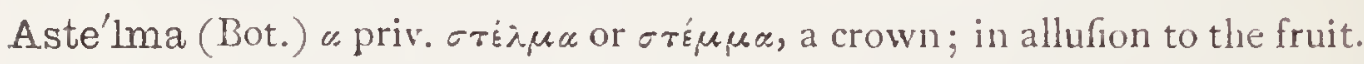

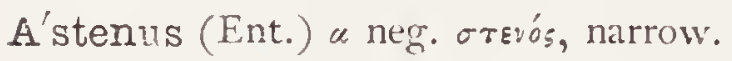

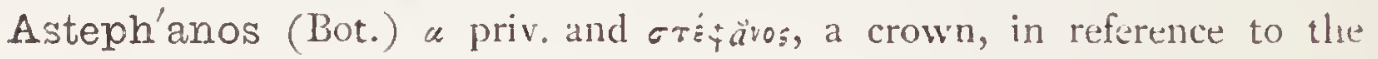
ftamens.

A'ster (Zool., Bot.) à críp, a ftar.

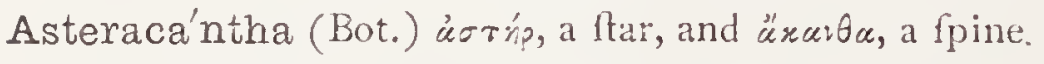

Asteri'adæ (Zool.) astirias, fam. term. adce.

Astérias (Zool.) àrríg, a ftar; a genus of Star-fithes.

Aste'ricum (Bot.) arró, a ftar; from the form of its flower's.

A'steris (Ent.) feeds on After Chinernis.

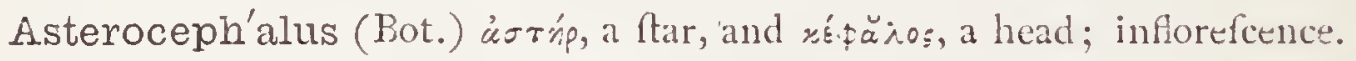

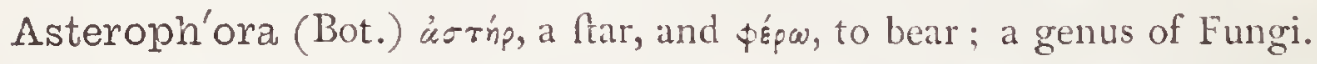

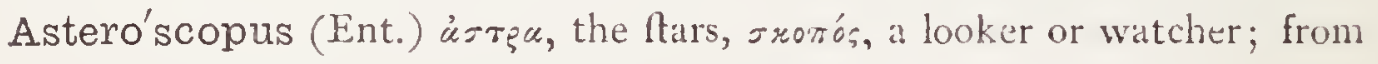

the upward-pointed attitude of the larvæ.

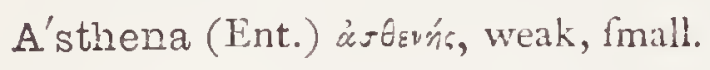

Asti'lbe (Bot.) '

Asti'lbus (Ent.)

A'stomus (Bot.) a priv. rróra, a mouth.

Astragalo'ides (Bot.) afiragalus, ebos, like.

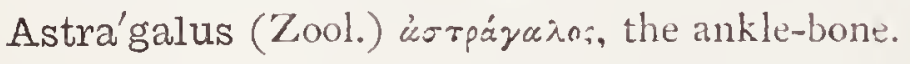

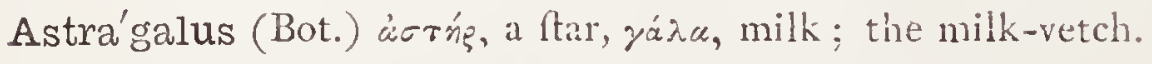

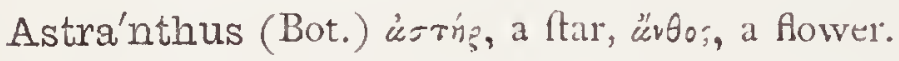

Astra'ntia (Bot.) üorgov, a ftar, àví, comparifon : referring to the umbels.

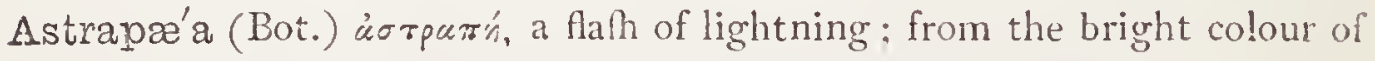

the flowers.

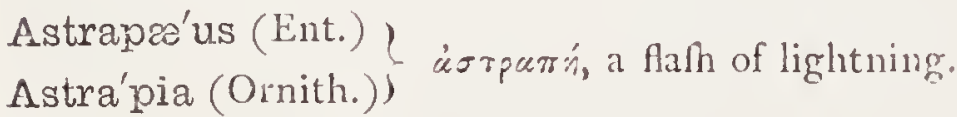

Astroca'ryum (Bot.) àst⿳亠丷, a ftar, xx́susy, a nut. 


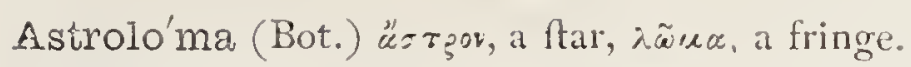

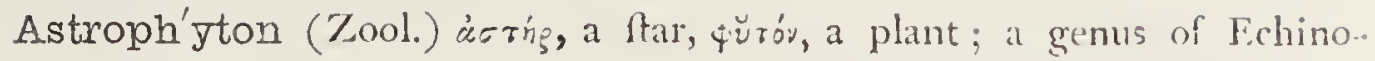
dermata.

A'stur (Ornith.) Lat. a hawk or buzzard.

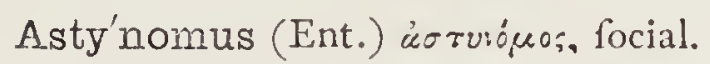

Asy'chna (Ent.) a priv. ovxrós, frequent; the uncommon.

Atala'nta (Ent.) P. N., an antient celebrated beauty.

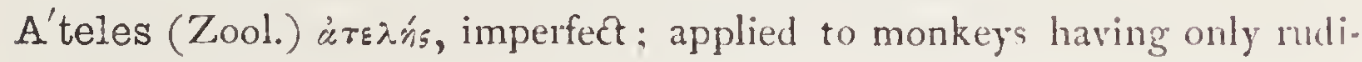
mentary thumbs.

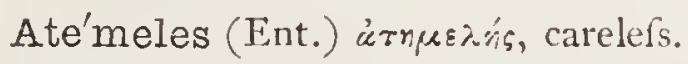

Ater, Atra, Atrum (Zool., Ent.) Lat. black.

Ate'rrimus (Ent.) Lat. very black.

Athali'a (Ent.) P. N., daughter of Ahab, king of Ifrael.

Athama'nta (Bot.) P. N. from Mount Athamas, in Sicily.

Atheri'na (Ichth.) perhaps from a priv. Os:ürós, fummer-time, as I find that the firh is feldom caught except during the winter months.

Atherospe'rma (Bot.) ditńp, an awn, orépua, a feed.

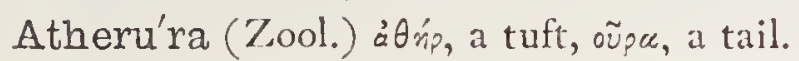

Athe'tmia (Ent.) àszor, rejected, void.

Athoüs (Ent.) ¿̇äis; harmlers.

Athri'xia (Bot.) a priv. $\theta_{\text {pi }}$, hair; being abfent from receptacle.

Athy'ris ( Zool.) a priv. Oupís, a door.

Athy'rium (Bot.) a priv. Oupis, a door.

Athy'rma (Ent.) ¿ैoupos, without any entrance.

Atla'nta (Zool.) , found in the Atlantic; a genus and family of MolAtla'ntidæ (Zool.)) lufca.

Atoma'lis (Ent.) atomus, an atom, a fpeck.

Atoma'ria (Ent.) atomus, a fpeck; the wings being fprinkled with dark dots.

Atopa (Ent.) «̈rotos, Atrange, out of place.

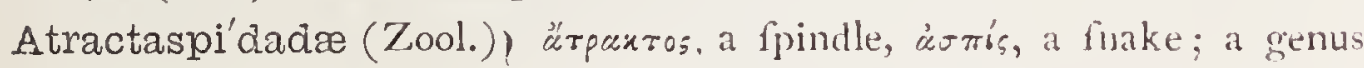
Atracta'spis (Zool.) $\zeta$ of Colubrine ophidians.

Atra'ctylis (Bot.) ärpaxtos, a fpindle; from its light ftems being formerly ufed for making fpindles.

Atrage'ne (Bot.) a name applied by 'Theophraftus to a fpecies of Clematis. Atra'lis (Ent.) ater, black.

Atrapha'xis (Bot.) a priv. $\tau p \varepsilon \notin \$ \omega$, to nourith.

Atra'tus-a-um (Ornith.) blackened, dark-coloured.

Atre'lla (Ent.) ater, black. 
A'trica (Ent.) ater, black.

Atricapi'1la (Ornith.) ater, black, capillus, hair.

A.tricapita'na (Ent.) ater, black, caput, the head.

A.tricilla (Ornith.) ater, black, and cilla, as in Motacilla.

Atrico'llis (Ent.) ater, black, collwm, the neck; alluding to the larra.

Atricome'lla (Ent.) ater, black, coma, hair, dim. ella.

Atrifronte'lla (Ent.) ater, black, frons, frontis, the brow, dim. ella.

A'triplex (Ent., Bot.) Pliny's name for the Orache, or Golden herb; from ater, black.

Atriplice'lla (Ent.)

Atripli'cis (Ent.) $\}$ the infects feed upon Orache, Atriplex.

A'tropa (Bot.) Atropos, one of the Fates, whofe fpecial duty it was to cut

the thread of life; on account of its deadly effects.

A'tropos (Zool.) P. N., one of the three Fates; a genus of Ophidians.

Atry'pa (Zool.) a neg. трũ ra, a foramen or hole.

Atta'genus (Ent.) attagen, a fnipe; fnipe-lhaped.

A'ttagis (Ornith.) àrrăgã:, a long-billed thore-bird, which Dr Adams thinks was the Godwit.

Atta'lia (Bot.) attalicus, brilliant, fplendid.

Attela'bida (Ent.) attelabus ; a family of Beetles.

Atte'labus (Ent.) the Greek name for fome infect like the locuft.

Aty'pus (Ent.) a priv. тútos, a reprefentative; a genus of Arachnida.

Auche'nia (Ent.) uixín, the throat.

Au'cuba (Bot.) the original Japanefe name of the thrub.

Audonina'na (Ent.) P. N. in honour of 7 . $V$. Autonin, a French natliralift.

Auguste'lla (Ent.) dim. of auguftus, princely.

Aulaco'des (Ent.) a $\bar{\imath} \lambda \alpha \xi-\alpha x \sigma$, a furrow; a genus of Lepidoptera.

Aulacorhy'nchus (Ornith.) $\alpha \tilde{i} \lambda a \xi$, a furrow, fíyxos, a beak.

$\mathrm{Au}$ lax (Bot.) $a \tilde{\lambda} \lambda a \xi$, a furrow; from the appearance of the under fide of the leaf.

Au'lica (Bot.) Lat. princely, courtly.

Aura'go (Ent.) aurum, gold, i. e. golden-coloured.

Auranti'aca (Zool.) Lat. orange-coloured.

Aurantia'cea (Bot.) aurantium, term. for order aceu.

Aura'ntium (Bot.) Lat. an orange.

Aurelia (Zool.) fame as chryfalis, and refers to the golden colour

Aurella (Ent.) Lat. aureus, of a golden colour.

Aureola (Onith.) Iat. aurolus, golden. 
A'ureus-a-um (Zool.) Lat. golden.

Aurico'ma (Ent.) aurum, gold, coma, hair.

Aurico'mada (Zool.) auricona, fam. term. ade; a family of Annelids.

Auri'cula (Zool., Bot.) Lat. a little ear.

Auricu'lidæ (Zool.) auricula, fam. term. idke.

Aurimacule'lla (Ent.) aurmm, gold, macula, a fpot, dim. el'a.

Auris-felis (Zool.) Lat. cats'-eared.

Auris-Midæ (Zool.) Lat. Midas-eared.

Auris-Judæ (Zool.) Lat. Judas-eared.

Auris-vulpi'na (Zool.) Lat. wolf-eared.

Aurite'lla (Ent.) auritus, eared; referring to the eyre-caps.

Auri'tus-a-um (Zool. Lat. eared.

Aurive'nter (Zool.) aurum, gold (colour), venter, the belly.

Aurocosta'lis (Ent.) aurum, gold (colour), cofta, the fide.

Aurogutte'lla (Ent.) aurum, gold, gutta, a fpot, dim. ellu.

Aurora'ria (Ent.) P. N., from Aurora, the goddefs of morning.

Aurulente'lla (Ent.) anrulentus, golden-coloured.

Ausonia'lis (Ent.)

Austra'lis, Australe (Ornith.) Lat. Southern.

Australa'sicus (Zool.) Lat. Auftralafian.

Auto'genous (Zool.) aurós, itfelf, yevicus, to beget.

Auto'phagæ (Ornith.) felf-feeders, applied to thofe birds whole young can provide for themfelves early.

Autumna'lis-e (Bot.) appearing in Autumn.

Avellana (Bot.) fpec. name of the hazel-nut. The more antient name of thefe nuts was Abellince, from the name of their country.

Avellana'rius (Zool.) avellana, a filbert.

Avellane'1la (Ent.) feeds on the hazel, Corylus arvellana.

Ave'na (Bot.) aveo, to defire, becaufe cattle are fond of it : or perhaps from

ferum, hay.

Ave'ntia (Ent.) perhaps from Mons Aventinus.

- Aventi'idæ (Ent.) aventia, fam. term. ide; a family of Moths.

Averrho'a (Bot.) P. N. from Averrhoes of Cordora, a celebrated phyficitn. Aversa'lis (Ent.) averjus, turned back.

Aversa'tus (Ent.) Lat. turned away, avoided.

Aves (Ornith.) Lat. birds, pl. of avis, a bird.

Avicénnia (Bot.) P. N. in honour of Aaicenna, a famous Peufian phyfician.

Avi'cula (Zool., Ornith.) Lat. a little bird. 
Avicu'lida (Zool.) avicula, fam. term. idae; a family of Mollufa.

A'rida (Ent.) Lat. greedy, voracious.

Avoce'tta (Ornith.) dim. formed from avoco, to call off.

Awn (Bot.) the fharp point or beard of the hufk of graffes.

Axilla (Zool., Bot.) axis, on which a wheel revolves, ala, a wing; the arm-pit; the inner angle formed by a branch and the ftem.

Axillariflo'ræ (Bot.) axillaris, fores, flowers; whorls of flowers axillary. Axilla'ris-e (Bot.) Lat. axle-fhaped, or growing in the axils.

$A^{\prime}$ xogams (Bot.) the molles and liverworts.

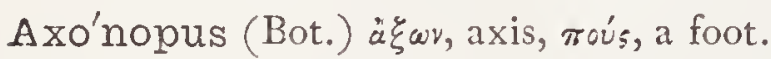

Axy'lia (Ent.) \& intens. ६úrov, wood; from its wood-like appearance.

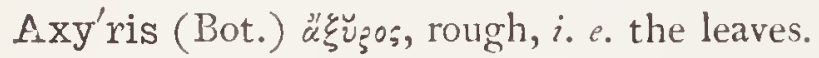

Aye'nia (Bot.) P. N. in honour of the Duc D'Ayer, of the houfe of Noailles.

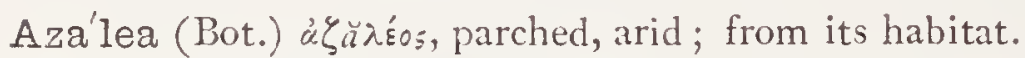

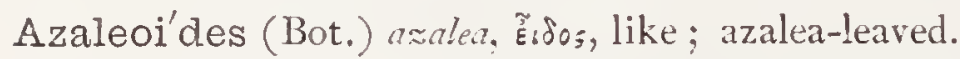

Aze'ta (Ent.) 'us nтon, auguft, venerable; a genus of Lepidoptera.

Azo'ricus-a-um (Bot.) Iratinized, belonging to the Azores.

Azu'reous (Ent.) azureus, of an azure blue colour.

Babia'na (Bot.) derived by $M_{r} . J . B$. Ker from babianer, becaufe the roots are the favourite food of baboons.-PAxтoN.

Babingto'nii (Bot.) P. N. from Dr. C. C. Babington, of Cambridge.

Bacca'tus-a-um (Zool.) Lat. having berries; with berry-like excrefcences.

Bac'charis (Bot.) a name given by the Greeks to a plant dedicated to Bacchus; applied to the Ploughman's fpikenard, from its vinous odour.

Bacilla'ria (Bot.) bacillum, a little ftick; from the arrangement of the fruftules; a divifion of Diatomacex.

Bacilllum (Bot.) Lat. a wand or ftaff; Elhrenberg's term for the fruftule of the Diatoms.

Ba'ctra (Ent.) P. N. from Bactra, the chief town of Bactria.

Bactria'nus (Zool.) Lat. belonging or relating to Bactria; ufed as the fpec. name of the camel.

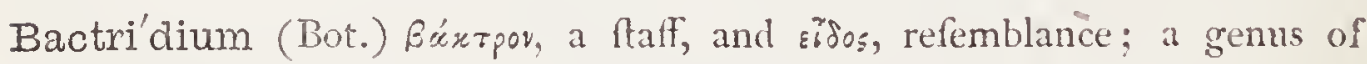
Fungi.

Ba'ctris (Bot.) Bárrgsv, a cane, on account of the fmall ftems being ufed for walking-ltick: 
Baculiform (Fos. Zool.) baculum, a walking-ftick, forma, fhape.

Ba'culite (Fos. Zool.) bacalum, a ftaff; from the ftraight tapering form of the fhell.

Badia'na (Ent.) badius, brown, cheftnut-coloured.

Badiipenne'lla (Ent.) badius, bay, cheftnut·coloured, penna, a wing.

Badi'ster (Ent.) Budırı́s, a walker.

Ba'dius-a-um (Bot.) badius, brown, cheftnut-coloured.

Ba'dius (Zool.) Lat. brown, cheftnut-coloured.

Bæ'ckia (Bot.) P. N. from A. Back, a phyfician to the King of Sweder.

Bæobo'trys (Bot.) Baı́s, fmall, Bór ̧̌ a, a bunch of grapes.

Bæomy'ces (Bot.) Bató, fmall, uúsns, a fungus; a genus of Cryptogamia.

Ba'eria (Bot.) in honour of Profe/for Baer, of the Univerfity of Dorpat.

Bai'a (Ent.) P. N., a town in Italy.

Baillo'nii (Ornith.) P. N. from M. Baillon, a French naturalift.

Bajula'lis (Ent.) bajulo, to carry a burden.

Balæ'niceps (Ornith.) balana, a whale, caput, the head; having a largı. head with broad depreffed bill.

Balæ'nidæ (Zool.) balcena, a whale, fam. term. ida; a family of Mammalia.

Balæ'nidæ (Zool.) balanus, a barnacle, primarily an acorn; a divifion of Cirripedes.

Balæno'ptera (Zool.) balana, a whale, $\pi \tau \varepsilon \xi^{\prime o r}$, a fin; finned whale.

Bala'nodon (Fos. Zool.) balcena, a whale, udoús, ódóvros, a tooth.

Ba'lanite (Fos. Zool.) balanus, a barnacle.

Balano'ides (Zool.) balanus, a barnacle, ểंos, refemblance.

Ba'lanus (Zool.) Lat. a barnacle, but primarily an acorn.

Balbi'sia (Bot.) P. N. in honour of John Baptift Balbis, a writer on Potany.

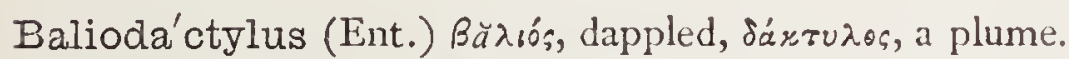

Bali'stes (Ichth.) baleftra, an implement of war; from a refemhlance

between fome part of the filh's ftructure to a part of a gun-lock.

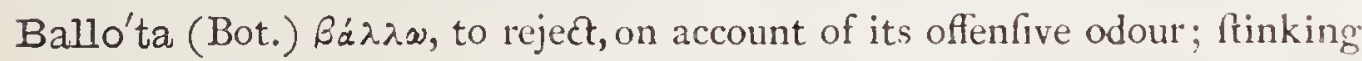
horehound.

Balsa'mita (Bot.) balfamum, balm or balfam.

Baltim'ora (Bot.) P. N. in honour of Lord Baltiwore, proprietor of Maryland.

Ba'ltimore (Ornith.) fp. name of an American Oriole. The name was given from its black and orange plumage, thefe colours being the livery of Lord Baltimore, the former proprietor of Maryland. 
Bambu'sa (Bot.) from Bambos, its name in India.

Bángia (Bot.) P. N. in honour of Chriftian Frederick Bang, a botanical teacher; a genus of Cryptogamia.

Baniste'ria (Bot.) P. N. in honour of Rer. John Banifter, a diligent botanift.

Ba'nlssia (Bot.) P. N. in honour of Sir Jofeph Banks, Bart., F.R.S., it diftinguifhed patron of the Naturai Hiftory Sciences.

Ba'nksia (Ent.) P. N. in honour of Sir Jofepls Banks; a genus of Lepidoptera.

Ba'phetes (Fos. Zool.) Rértw, to dip or dive; in reference to the depth of its pofition and the fhape of its head.

Bapti'sia (Bot.) Bárra, to dye, alluding to the application of fome fpecies.

Barba'lis (Ent.) barba, a beard, alluding to a tuft upon the fore-feet.

Barbare'a (Bot.) P. N. on account of its having been formerly called the herb of St. Barbara.

Ba'rbarus (Zool.) Lat. relating to Barbary.

Barbaste'llus (Zool.) French, barbaftelle.

Barba'tulus (Ichth.) Lat. having a little beard.

Barbatus-a-um ('Zool., Ornith., Bot.) Lat. bearded.

Ba'rbus (Ichth.) Lat. the barbel; from the fin having a pendent beard.

Barke'ria (Bot.) P. N. in honour of George Barker, Efq., of Springfield, Birmingham.

- Barle'ria (Bot.) P.N. in honour of the Rev. James Barrelier, a Dominican, and M.D. of Paris.

Barley (Bot.) from beard and ley, i. e. lew, or "bearded grafs."

Ba'rnacle (Zool.) Sax. bearn, child, aac, oak, expreffive of the old belief that the barnacle or acorn-lhell grew on trees.

Barringto'nia (Bot.) P. N. from the Hon. Daines Barrington, F.R.S.

Bartholi'na P. N. in honour of the celebrated Danilh anatomift and phyfiologift, Thomas Bartholin.

Barto'nia (Bot.) P. N. in honour of Dr. B.S. Barton, a botanift in Philadelphia.

Bartrámia (Bot.) P. N. from Fohn Bartram, an American botanilt; a genus of Molfes.

Ba'rtsia (Bot.) P. N., dedicated by Linnæus to his friend John Bartfch, M.D.

Baryno'tus (Ent.) Rupús, heavy, vĩro:, the back.

Basalis (Ent.) bafis, the bafe of the wing. 
Base'lla (Bot.) its native Malabar name.

Ba'sil (Bot.) from Bă-бһย́vs, a king, becaufe formerly efteemed fo highly that its ufe was limited to royal tables.

Basili'nea (Ent.) bafis, a bafe or border, linea, a line; in allufion to a wing-mark.

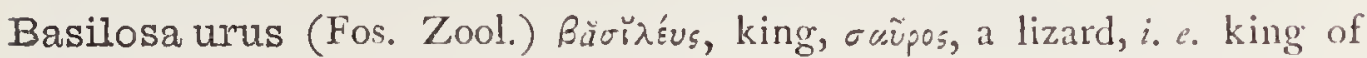
the Saurians.

Bassa'na (Ornith.) from being found in great numbers on the Bafs-rock, in the Firth of Forth.

Ba'ssaris (Zool.) Barzápa, a fox.

Ba'ssia (Bot.) P. N. in honour of Ferdinando Baffi, curator of the Botanic Garden at Bologna.

Bata'ra (Ornith.) name applied by the Guaranis of South America to the birds of the genus Thamnophilus.

Bata'tas (Bot.) a native Mexican name; the fweet-potato.

Bathye'rgidæ (Zool.) bathyergus, fan, term. ida.

Bathye'rgus (Zool.) Batis, deep, Ëprov, a work (of induftry); applied to the fand-mole.

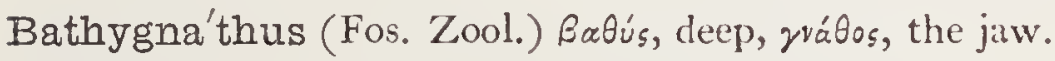

Batilla'ria (Zool.) batilla, a hovel, from the lengthened form of the Anell, and the conformation of the bafe of the aperture.

Ba'tis (Ent.) Ráris, a bramble, on which the larva feeds.

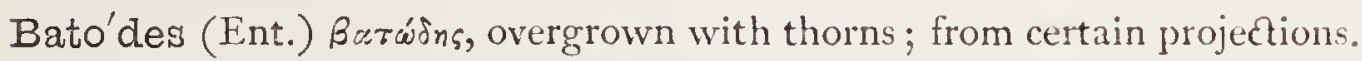

Batono'ta (Ent.) Bàros, a thorn, vãtos, the back; applied to the thornbacked Caffidx.

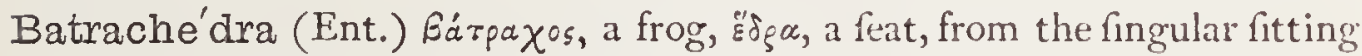
pofition of the infect.

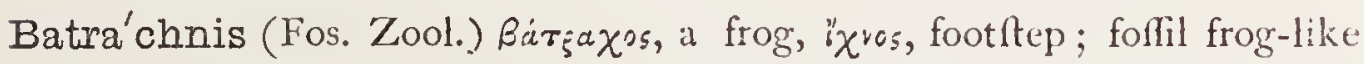
footprints.

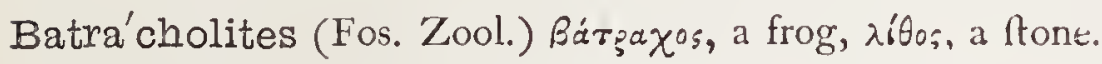

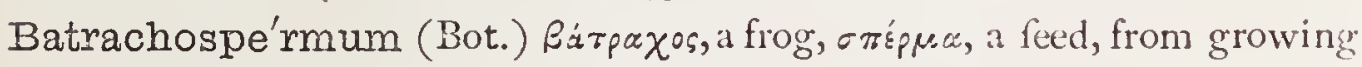
in marhes; a genus of Algx.

Bat'schia (Bot.) P. N. in honour of John George Batfch, a Profeflor of Botany in Germany.

Bau'era (Bot.) P. N. in honour of Francis and Ferdinand Bauer, celebrated German botanical draughtfmen.

Bauhi'nia (Bot.) P. N. in honour of John and Cafpar Bauhin, botanifts of the fixteenth century.

Baumannia'na (Ent.) P. N. in honour of Scnator Banman, of Lcipfig. 
Be'ania (Zool.) P. N. in honour of Mr. William Bean, of Scarborough, a moft laborious, intelligent, and fuccefsful naturalift; a genus of Polyzoa.

Bear (Zool.) Anglo-Sax. bera ; Germ. bar; Dutch, bear.

Beast (Zool.) Lat. beftia; Ital. and Sp. befita; Fr. bêfle; Dutch, beef.

Beaufo'rtia (Bot.) P. N. in compliment to Mary, Duchefs of Beaufort, a botanical patroners.

Be'aver (Zool.) Lat. fiber; Anglo-Sax. befer; Germ. biber: Dutch, hever; Fr. bière.

Becafi'co (Ornith.) Ital. becafico, from beccare, to peck.

Beche-de-mer (Zool.) Fr. fea-fpade; applied to the prepared fea-cucumber or trepang; a fpecies of Holothuria.

Be'chei (Fos. Zool.) P. N. in honour of Sir H. de la Beche.

Bechsteinii (Zool.) P. N. in honour of _-Bechfein, a German naturalift.

Beckma'nnia (Bot.) P. N. in honour of Becknan, author of "The Hiftory of Inventions."

Bede'llia (Ent.) P. N. in honour of Mr. George Bedell, of London.

Bed-straw (Bot.) the popular name of certain plants, particularly Galinm verum, from their ufe in olden times.

Bee (Ent.) Anglo-Sax, beo; Dutch, bic.

"So work the honey bees,

Creatures that by a ruling nature teach

'Ihe art of order to a peopled kingdom."-SHakspear.

Beech (Bot.) Anglo-Sax. bece or boc; Germ. büche; Dutch, bueche.

Beet (Bot.) Lat. beta; Germ. beete; Fr. bette.

Beetle (Ent.) Anglo-Sax, betl or bite?.

Bego'nia (Bot.) P. N. given by Linnzus in honour of Michael Begron, a promoter of Botany.

Bejária (Bot.) P. N. in honour of $M$. Bejar, a Spanin botanift.

Belcheri (Zool.) P. N. in honour of Sir E. Beliher, R.N.

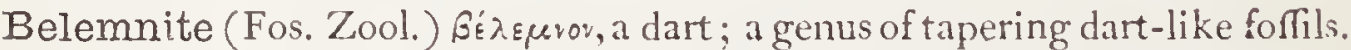

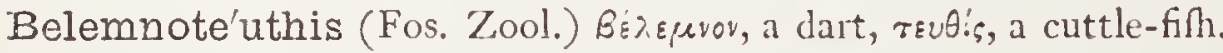

Bellado'nna (Bot.) Ital. beautiful lady; refers to the ufe once made of its berries by the Italian ladies as a cormetic.

Be'llii (Zool.) P. N. in honour of Thomas Bell, Efq., F.R.S.

Be'liis (Bot.) Lat. a daify, fo called from its beauty.

Be'llium (Bot.) bellis, a daify, from fome fimilarity of fowers.

Be'llulus (Zool.) Lat. pretty, elegant.

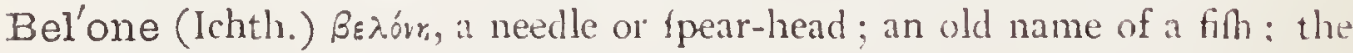
rea-pike. 
Belo'nia (Bot.) Bèón, a needle or fpear-point; a genus of Alga.

Belonoga'ster (Ent.) Beróm, a fpear-point, yuarńs, the belly; a genus of Hymenoptera.

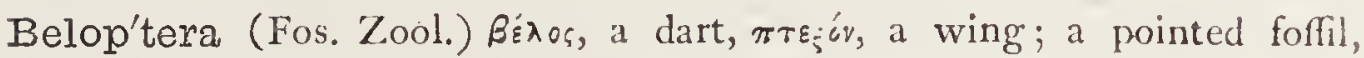
having a wing-like projection or procefs on each fide.

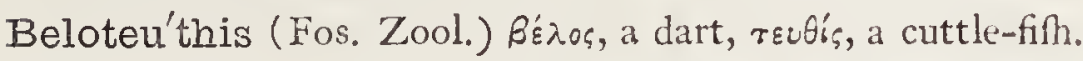

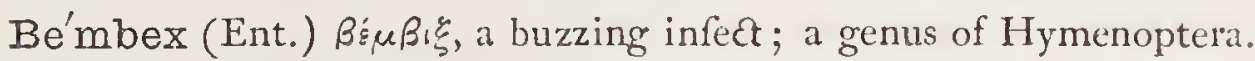

Bembi'cidæ (Ent.) bembex; a family of Hymenoptera.

Bembicifor'mis (Ent.) bembex, a Hymenopterous infect, forma, thape.

Bembidi'ides (Ent.) a group of Coleopterous infects, of which bembidium is the type.

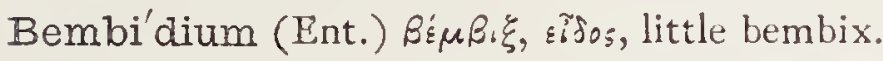

Bembycifo'rmis (Ent.) refembling a bembex, one of the Aculeate Hymenoptera.

Benedictus (Bot.) fpecial name of a Centaurea, obtained its name from the extraordinary medical virtues it was thought to poffers.

Bengale'nsis (Zool.) Lat. belonging to Bengal.

Berbera'ta (Ent.) feeds on Berberis vulgaris, the Berbery.

Be'rberis (Bot.) from berberys, its Arabic name.

Berbery (Bot.) Lat. berberis ; Arabic, berberys.

Berckle'ya (Bot.) P. N. in honour of Fohn Lefrane de Berckley, a Dutch botanift.

Be'rgamot (Bot.) the variety of Citrus Medica from which this perfume is obtained, was firft cultivated at Bergamo in Italy.

Bergmannia'na (Ent.) P. N. in honour of T. O. Bergmann, a Swedish entomologift.

Berkeleya (Bot.) P. N. in honour of Rev. M. F. Berkeley, a well-known writer on cryptogamic botany.

Berma'rdus (Zool.) P. N. from St. Bernard of Menthon, the benevolent founder of the Great and Little St. Bernard.

Beroe (Zool.) P. N. taken from Ovid; the nurfe of Semele, the mother of Bacchus; applied to a genus of marine animals.

Bero'sus (Ent.) P. N., one of Pliny's names arbitrarily applied.

Berry (Bot.) Anglo-Sax. beria, berga, a grape or berry, from beran, to bear. Bertholle'tia (Bot.) P.N. in honour of Berthollet, the celebrated chemift. Berycidæ (Ichth.) Beryx, fam. term. ida; a family of Acanthopterygian filhes.

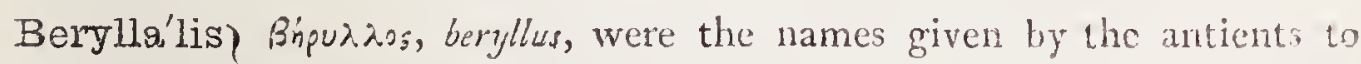
Bery'llus $\int$ precious Rones of a fea-green colour. 
Beryx (Ichth.)

Besle'ria (Bot.) P. N. in honour of Bafil Besler, an apothecary at Nuremberg.

Besse'ra (Bot.) in honour of Dr. Befer, a German botanift.

Beta (Bot.) the word is ufed by Pliny, Cicero, and Martial, and was probably applied to our bect; certainly it was infipid: " ut fapiant fatuæ fabrorum prandia betæ." Mart. xiii. I3.

Betcke'a (Bot.) in honour of $M$. Betcke, who has defcribed many pecies of Valerianella.

Be'tel (Bot.) an Indian name.

Beto'nica) from beautonie its Celtic name; or perhaps from the antient Be'tony i Vettones.

Be'tula (Bot.) from betu, its Celtic name.

Betula'ria (Ent.) betula, a birch-tree, on which the infect was erroneoully thought to feed.

Be'tulæ (Ent.) feeds on the Betula alba, the birch.

Betuleta'na (Ent.) betula, a birch-tree.

Betulletel'la (Ent.) betuletum, a birch-grove.

Betuli'cola (Ent.) betula, birch, colere, to frequent.

Bewic'kii (Ornith.) P. N. in honour of the celebrated Bervick, of Newcaftle.

Beyric'hia (Fos. Zool.) P. N. in honour of M. Beyrich, a German geologilt. Bezoar (Zool.) from the Arabic bâd-zahr, poifon-expeller.

Bi (Zool., Bot.) bis, twice; a prefix implying two, twice, or in twos. as bimana, two-handed, biennial, living for two years, bifurcate, two-forked, \&c.

Biaculeatus (Ichth.) bi, two, aculeatus, pointed, ftinging.

Biartículate (Zool.) bis, twice, articulatus, jointed.

Bias'tes (Ent.) Bıørńs, ftrong, forceful; a genus of Diptera.

Biatome'lla (Ent.) bis, twice, atomus, a fpeck.

Biauri'culate (Zool.) bis, twice, auricula, an auricle or little car.

Bi'bio (Ent.) B.ßáw, to take large ftrides.

Bibio'nidx (Ent.) a fub-family of dipterous infects, of which bibio is the type.

Bibitrix (Ent.) F. Fsa, to take long ftrides.

Bibos (Zool.) a genus of Ruminant animals.

Bibrónii (Zool.) P. N. in honour of $M$. Bibron, joint author of the "Eipetologie Générale."

Bi'bulous ('Lool., Bot.) bibulus, abforbing moilture, from bibo, to drink. Bica'psular (bot.) bis, twice, capfult, a little box; having two capfules. 
Bicaud'alis (Zool.) bis, double, cauda, a tail.

Bicolor (Ornith., Ent., Bot.) Lat. of two colours.

Picolora'go)

Bicolora'lis 5 (Ent.) bicolor, of two colours.

Bicornis (Zool., Ent., Bot.) bis, twice, cornu, a horn.

Bicu'spid (Zool., Ent., Bot.) bis, twice, cuppis, the point of a fpear ; in the cafe of the infect, from having double-tailed larvæ.

Biddulphia (Bot.) a genus of Diatoms.

Bidens (Bot.) bis, twice, dens, a tooth, alluding to the feed.

Bidentatus-a-um (Zool., Ent., Bot.) bidens, having two teeth ; in the carfe of the infect, from the form of the wings.

Biennial (Bot.) bis, anmus, a year; living two years.

\section{Bifascia'lis)}

Bifascia'na (Ent.) bis, twice, fufcia, a band; having two Atripes.

Bifascia'ta

Bifida (Ent.)
Bifid (Zool., Bot.)? bifidus, cleft in two.

Bif'orate (Zool.) bis, twice, foris, a door; having two openings.

Biformis-e (Bot.) Lat. two-fhaped.

Bifrons (Ent.) bis, twice, frons, the forehead.

Bifu'rcated ) (Zool, Bot.) bis, twice, furca, a fork; having two lieads or Bifurcation $\zeta$ branches.

Bige'minal (Zool.) bis, twice, gemini, twins; implying arrangement in pairs.

Bignónia (Bot.) P. N. in honou of $M$. Bignon, a celebrated French writer.

Bignonia'ceæ (Bot.) bignonia, term. for natural order, acea.

Bigoroon (Bot.) a cherry is fo called from Bigorre, the French province where it is grown.

Biju'gate (Bot.) bis, double, jugum, a yoke; from the pinnate leaves confifting of two pairs of leaflets.

Bila'biate (Bot..) bis, twice, labium, a lip; two-lipped.

Bilamella'tus (Bot.) bis, twice, lamella, a little plate.

Bila'teral (Zool., Bot.) bis, twice, latus-eris, the fide.

Bi'lberry (Bot.) Sax. bilig, a bladder, and berry; one of the names of the

Vaccinium myrtillus.

Bili'gula (Ent.) bis, two, ligula, a ftrap; in allufion to wing-markings.

Bilinea (Ent.) bis, twice, linea, a line, i. e. on the wings.

Bilinea'ta (Ent.) bis, twice, lineatus, lined, nuled. 
Bili'tura (Ent.) bis, twice, litura, a blot or fmear, i.e. on the wings.

Bilix (Ent.) Lat. having a double thread.

Biloculi'næ (Zool.) bis, twice, loculus, a fmall compartment.

Bimacula'na (Ent.) bis, twice, macula, a fpot.

Bimacula'tus (Ichth.) bis, twice, macula, a fpot, two-fpotted.

Bimaculo'sa (Ent.) bis, twice, maculofus, fpotted.

Bima'na (Zool.) bis, twice, manus, a hand; having two hands.

Bi'nary (Zool., Bot.) bini, two and two, arranged in pairs.

Bi'nneyi (Fos. Zool.) P. N. from E. Binney, the geologift, of Manchefter.

Bino'culus (Zool.) bis twice, oculus, an eye; a genus of Phyllopods.

Bino'mial (Zool.) bis, nomen, a name; the fyftem of Linnæus which gives two names to each animal or plant, the firft to imply genus, the other Species.

Binotapenne'lla (Ent.) bis, twice, nota, a mark, penna, a wing.

Biocula'tus (Zool.) bis, twice, oculus, an eye.

Bio'logy (Zool.) Bios, life, nóyos, a difcourfe or doctrine; the feience of life.

Biolo'gical (Zool.) relating to biology, or the fcience of living things.

Biophlœ'us (Ent.) Biow, to live, фrovos, the bark of trees.

Biorna'ta (Ent. Bot.) bis, twice, ornatus, adorned.

Biparti'te (Ent., Bot.) bis, twice, partitus, divided.

Bipe'1tate (Zool.) bis, double, petta, a target or buckler; two-fhiclded.

Bipes (Zool.) bis, twice, pes, a foot; having two feet.

Bipi'nnate (Bot.) bis, double, pinna, a leafer.

Bipla'ga (Ent.) bis, twice, plaga, a fripe.

Biplica'tus (Zool.) bis, twice, plicatus, folded.

Bipuncta'ria)

Bipuncta'ta $\{$ (Ent.) bis, twice, punctutus, dotted.

Bipunctel'la (Ent.) bis, twice, punctum, a fpot.

Bipunctidac'tylus (Ent.) bis, twice, puncum, a dot, dactylus, a plume.

Bipunctína)

Bipuncto'sa)

(Ent.) bis, twice, punctim, a dot.

Birch (Bot.) Anglo-Sax. birce; Dutch, berke; Germ. birke; it is thought to be from brechen, to be bright.

Bird (Ornith.) Anglo-Sax. bird or bridde, from bradan, to fpread out.

Birdel'la (Ent.) P. N. in honour of the late C. S. Bird, of Liverpool.

Biscute'lla (Bot.) bis, twice or double, foutella, a faucer; from the form of the feed-veffel when burfting.

Biselliei'la (Ent.) dim, of hiffllum, a feat of hollowr. 
Bironæ'a (Bot.) P. N., dedicated to Antoine Birone Bernardi, a Profeflor of botany in Sicily; a genus of Cruciferæ.

Biser'rula (Bot.) bis, twice, ferrula, a fmall faw; the pods being furnilhed with teeth fomething like a faw.

Biseta'ta (Ent.) bis, twice, feta, a briftle.

Bi'son (Zool.) the name is derived from the flefh fmelling of muk, the native name of which is bifam.

Bisontel'la (Ent.) Birav, the bifon, in allufion to the thick antennx.

Bi'ston (Ent.) P. N. from Bifton, a Thracian; the Bisrouns were a tribe dwelling between Mount Rhodope and the Rgean fea.

Bi'stort (Bot.) bis, twice, tortus, twifted; from its crooked root.

Bistria'ris (Ent.) bis, twice, fria, a furrow; in allufion to wing-markings Bistriga'ta (Ent.) bis, twice, friga, a ftripe or furrow; referring to wingmarkings.

Bistrigella (Ent.) bis, twice, friga, a freak, a ftripe.

Bisuffarciana'tus (Fos. Lool.) bis, twice, fuffarcino, to Auff full; double Ituffed or fwollen.

Bisulcaius ('Zool.) Lat. having two furrows.

Bitænia'tus (Ichth.) bis, twice, tenia, a fillet; having two villi below the lateral line.

Bi'toma (Ent.) bis, twice, touń, a cut.

Bittern (Ornith.) Ital. bittore; Span. bitor; French, butor; Dutch, butoor: formerly fpelt bittore and bittour.

"And as a bittore bumbleth in the mire."--Cnaucer.

"And as a bittour bumps within a reed."- Dryden.

Biundula'ria (Ent.) bis, twice, undu!atıs, marked wit! wavy lines.

Bivalve $\{$ biva'tvalar twice, valuce or volve, becaufe they fold inwards.

Bi'xa (Bot.) a native South American name.

Blackwa'llii ('Lool.) P. N. in honour of Willian Blackwall, of Llanrwft, a writer on the Arachnida.

Blackwe'llia (Bot.) P. N. in honour of Elialbeth Blackrvell, artift, and authorefs of a celebrated Herbal.

Blæ'ria (Bot) P. N. in complement to Patrick Blair, a phyfician at Bofton, in Lincolnthire.

Bla'kea (Bot.) in honour of Martin Blake.

Blanda'lis (Ent.) blandus, fmooth.

Blandfor'dia (Bot.) P. N. in honour of George, Marquefs of Blandford.

Blandia'ta )

Blandi'atrix $f$ (Fint.) blandus, winning, pleating. 
Blandi'na (Ent.) P. N. from one of the early Chriftian martyrs.

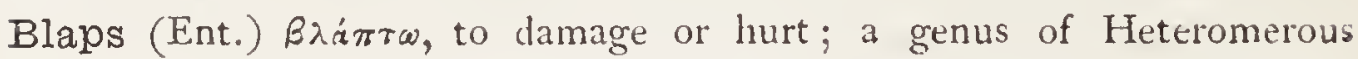
coleoptera.

Blapsidæ (Ent.) blaps, fam. term. ida.

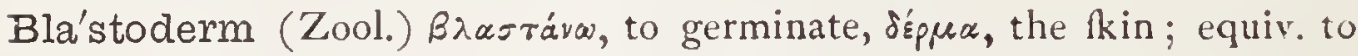
the germinal membrane.

Bla'tta (Ent.) Brúrtw, to hurt or injure; the cockroach.

Bla'ttidæ (Ent.) blatta, fam. term. idce.

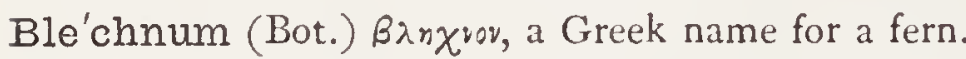

Ble'chum (Bot.) taken from the Greek name of a plant refembling marjoram.

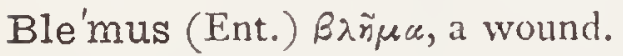

$\left.\begin{array}{l}\text { Ble'nnius } \\ \text { Blenny }\end{array}\right\}$ (Ichth.) Brérros, antient name of a fith, from $\beta$ rérva, mucus.

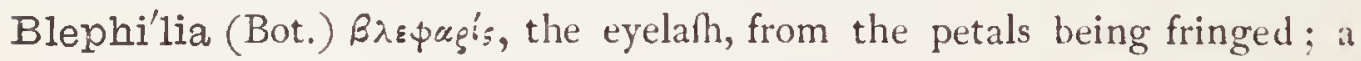
genus of Labiatie.

Blepti'na (Ent.) B $\lambda \varepsilon \pi \tau \tau_{i ́ s}$, worth feeing.

Bletia (Bot.) P. N. in honour of Don Louis Blet, a Spanifh phyfician and botanift.

Bli'ghia (Bot.) P. N. in honour of Captain Bligh, who firft carried the breadfruit to the Weft Indies.

Blinks (Bot.) becaufe it opens and clofes its little white flowers, with fun and Thade, like winking.

Bli'tum (Bot.) the name Britov was given by the antients to fome unre. cognized plant, perhaps the ftrawberry-blite.

Blumenba'chia (Bot.) etymology same as following; a genus of Loasácer. Blumenba'chii (Zool.) P. N. from F. F. Blumenbach, the celebrated phyfiologift.

Boa (Zool.) Pliny's name for a large fnake; a genus of Ophidians.

Boar (Zool.) Anglo-Sax. bar; Latin, aper; Sanjerit, varaha.

Boar'mia (Ent.) Boärmix, "the ox-yoker," an epithet of the goddefs Athene.

Boarmi'idæ (Ent.) Boarmia ; fam. term. idd ; a family of Lepidoptera. Boarmioides (Ent.) Boärmia, oьds, like.

Boarula (Ornith.)

Boba'rtia (Bot.) P. N. from Jacob Bobart, a celebrated profeflor of botany at Oxford; a genus of Iridacex.

Bocco'nia (Bot.) P. N. derived from a Sicilian monk and M.D., named $P_{\text {aclo }}$ Boccone.

Bodo (Zool.) etymol. unknown to me; a genus of Infuforia. 
Boe'bera (Bot.) P. N. from Boeber, a Ruflian profeflor of botany; a genus of Compositæ.

Bœhme'ria (Bot.) P. N. in honour of George Rudolph Bochmer, a German botanift.

Boerhaa'via (Bot.) P. N. in honour of the famous Dutch phyfician, Boerhaave.

Bo'idæ (Zool.) boa, fam. term. ida; a family of Ophidians.

Boisduva'lii (Ent.) P. N. from $M$. Boisduval, a French writer on the Lepidoptera.

Bolbo'cerus (Ent.) Boגßós, a bulb, xépas, a horn.

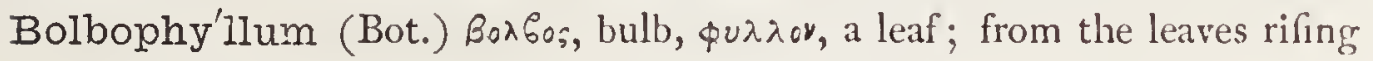
from a preudo-bulb; a genus of Orchidaceæ.

Boldo'a (Bot.) P. N. from D. Boldo, a Spanifh naturalift; a. genus of Nyctaginaceæ.

Bole'ti (Ent.) boletus, a fungus on which it feeds.

Boleto'bia (Ent.) boletus, a muhroom, a fungus.

Boletobi'idæ (Ent.) boletobia, fam. term. idce; a family of Lepidoptera.

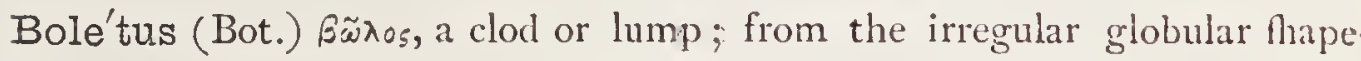
of this fungus.

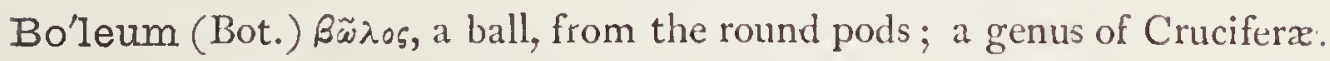

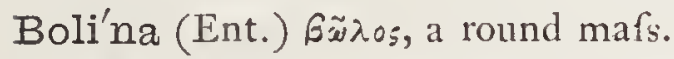

Boli'nidæ (Ent.) bolina, fam. term. ida.

Bolino'ides (Ent.) bolina, zĩos, refemblance.

Bolito'bius (Ent.) Bódırov, dung, manure, frów, to live.

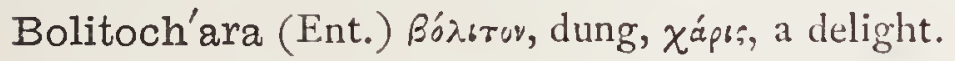

Bolito'phagus (Ent.) Bìrrov, dung, фóy $\omega$, to eat.

Boliva'ria (Bot.) P. N. from the patriot Bolivar; a genus of Jafminacex.

Bolo'cera (Zool.) Bá $\lambda \lambda \omega$, to cast, xépas, the horn.

Bolto'nia (Bot.) P. N. dedicated to $J$. B. Bolton, an Englifh botanif.

Bolye'ria (Zool.) etymology unknown; a genus of Ophidians.

Bomba'ceæ (Bot.) bombax, term. for nat. order, acea.

Bo'mbax (Bot.) Bó $\mu$ By $\xi$, the filk-worm, in allufion to the flocculent pods; the filk-cotton tree.

Bombina'tor (Zool.) bombio, to buzz.

Bo'mbus (Ent.) Bóußos, a buzzing noife; a genus of Hymenoptera.

Bombyca'lis (Ent.) having a refemblance to bombyx.

Bo'mbyces (Ent.) pl. of bombyx.

Bomby'cidæ (Ent.) a family of Lepidoptera. of which the genus Bombzr: is the type. 
Bombyci'vora (Ornith.) bombyces, moths, voro, to devour.

Bombycoi'dæ (Ent.) a family of Lepidoptera refembling the bombyces; the hairy larvæ being eafily miftaken for thofe of bombyces.

Bombylifor'mis (Ent.) bonbylius, a family of Diptera, forma, refemblance. Bom'byx (Ent.) Bóußu६, a filk-worm.

Bonapa'rtea (Bot.) P. N. in honour of Napoleon Bonaparti.

Bona'sus (Zool.) Bóvceros, applied by Ariftotle to a wild ox.

Bona'tea (Bot.) P. N. from $M$. Bonat, a celebrated botanift and profellor at Padua; a genus of Orchidaceæ.

Bonito (Ichth.) the Spanith name of the filh.

Bonna'ya (Bot.) P. N. from - Bonnay, a German botanift; a genus of Schrophulariacex.

Bonnemaiso'nia (Bot.) P. N. from M. Bonnemaifon, a French cryptogamic botanift; a genus of Cryptogamia.

Bonne'tia (Bot.) P. N. from Charles Bonnet, a celebrated French naturalint; a genus of Ternftromiacex.

Bonpla'ndia (Bot.) P. N. in honour of $M$. Bonpland, the companion of Humboldt.

Eo'ntia (Bot.) P. N. from Jumes Bont, a Dutch phyfician; a genus of Myoporacex.

Booby (Ornith.) Germ. bube; Span. bobo, dunce, bubo, an owl; in confequence of the bird's Itupidity.

Boödon (Zool.) Eoüs, an ox, ódoús, odórtos, a tooth; a genus of Colubrine ophidians.

Bö'pis (Ent.) Fö̈mis, ox-eyed.

Boöps (Zool.) Bow̃ $\pi 6$, ox-eyed.

Bora'go (Bot.) Bspá, food, from the nourihing qualities of the plant.

Bora'ssus (Bot.) Boparvos, the date; the Palmyra or Fan-palm.

Borbo'nia (Bot.) P. N. from Gafton de Bourbon, Duke of Orleans, fon of Henry IV. of France.

Borea'ta (Ent.) Boreas, the north wind.

Bo'reus (Ent.) Boreas, the north; from the infect having always been found in the winter.

Borkhau'sia (Bot.) P. N. from Moritz Borkhaufen, a German profellor of botany; a genus of Compofitx.

Boro'nia (Bot.) P. N. in memory of Francesco Boroin, an italian attendani of Dr. Sibthorp.

Borre'ra) (Bot.) P. N. in honour of $7 . W$. Borrer, F.t.s., an eminent Borréris cryptogamin. 
Borre'ria (Bot.) same etymol. as Burrera; a genus of Cinchonacex.

Bory'a (Bot.) P. N. in honour of Colonel Bory de St. Fincent, a French traveller, and promoter of natural hiftory.

Bory'phora (Ent.) Bopá, food, фépw, to carry.

Bos (Zool.) Lat. a bull or ox.

Bo'schas (Ornith.) applied by Ariftotle to a kind of duck; literally, " well-fed," from Bós $x \omega$, to feed.

Bo'scia (Bot.) P. N. in honour of Louis Bofc, a French agriculturif.

Bo'sea (Bot.) P. N. in honour of Erneft Gottlieb Bofe, a German botanift.

Bose'laphus (Zool.) bos, an ox, elephas, an elephant; ufed for the Eland.

Bo'smina (Zool.) P. N. from Bofmina, the daughter of Fingal.

Bossiz'a (Bot.) P. N. in honour of $M$. Bofleu Lamartinière, a French naturalin, who accompanied the unfortunate Ia Peroufe round the world.

Bostri'chidæe (Ent.) bostrichus, fam. term. ide.

Bostri'chus (Ent.) Bórqpuxos, a lock of hair.

Boswe'llia (Bot.) P. N. from Dr. Fohn Bofrell of Edinburgh; a genus of Burieraceæ.

Botany (Bot.) Porain, a plant.

Bota'urus (Ornith.) Boáw, to call ont, raũpos, a bull; from the refemblance of the cry of the bittern to a bull's bellowing.

Bothre'nchyma (Bot.) Bípos, a pit or cavity, हैy $\chi \tilde{u} \mu \varkappa$, an infufion, juice; valiform or pitted tiffue.

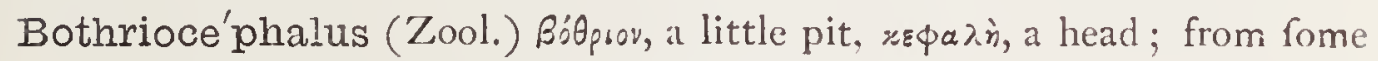
depreftions on the head of the tape-worm.

Bothrode'naron (Fos. Bot.) Bólpos, a pit or cavity, dévopov, a tree; in allufion to the oval depreffions on the furface of the foffil.

Bothyno'deres (Ent.) Bótuvos, a pit, dśpn, the neck; indentations on neck. Botia (Ichth.) Borńs, a herdfman?

Botryadénia (Bot.) Bórȩus, a clufter, ád̛́v, a gland; a genus of Compofitæ.

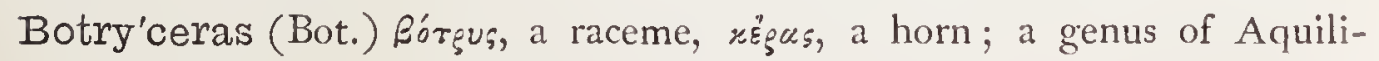
foliacex.

Botry'chium (Bot.) Bór pus, a bunch of grapes; from the clufter-like form of the fructification.

Botry'dium (Bot.) Bótpus, a bunch of grapes; a genus of Fungi.

Botryoi'des (Bot.) Bórpus, a clufter of grapes, हijos, like; refembling a bunch of grapes.

Botrys (Bot.) Bótpus, a clufter of grapes. 
Botrytis (Bot.) Bórgus, a bunch of grapes, which the feed-veffels refemble. Bo'tydæ (Ent.) a family of Lepidoptera, of which the genus Botys is the type. Botyda'lis (Ent.) from fome refemblance to Botys.

Botyo'des (Ent.) refembling Botys.

Botyo'ides (Ent.) Botys, Ei⿱dos, refemblance.

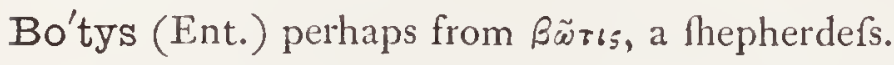

Bougainvi'llea (Zonl.) P. N. in honour of the French Admiral Bougainville; alfo a genus in Botany.

Bourgueticri'nus (Fos. Zool.) P. N. in honour of $M$. Bourgut ; a genus of Encrinites.

Bourre'ria (Bot.) P. N. from Bourrer, an apothecary of Nuremberg; a genus of Cordiaceæ.

Boussingau'ltia (Bot.) P. N. from F. B. Bouffingault, the celebrated naturalift and traveller; a genus of Chenopodiacex.

Bou'tia (Bot.) P. N. from James Bout, a Dutch phyfician.

Bouva'rdia (Bot.) P. N.) from $M$. Bouvard, a French botanift.

Bo'vidæ (Zool.) bos, bovis, an ox; the ox-tribe.

Bo'viform (Zool.) bos, bovis, an ox, forma, refemblance.

Bovi'sta (Bot.) Latinized from bofft its German name.

Bowerba'nkia (Zool.) P. N. in honour of $M_{r}$. Bowerbank, an eminent naturalift.

Bowie'a (Bot.) P. N. from 7. Borvie, a collector of plants for Kew; a genus of Liliacex.

Bowle'sia (Bot.) P. N. from Borcles, an Irih botanift; a genus of Umbelliferæ.

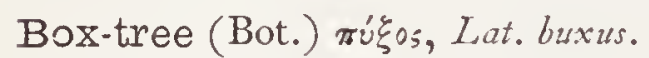

Boyere'lla (Ent.) P. N. in honour of Boyer de Fonscolombe, a French entomologift.

Brabe'jum (Bot.) Bpaßs.ov, a fceptre; from the form of its racemes of flowers.

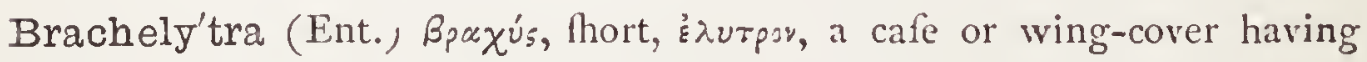
fhort elytra; a family of Coleoptera.

Brachia'tus-a-um (Zool., Bot.) Lat. branched.

Brachi'nidæ (Ent.) brachinus, fam. term. ide.

Brachi'nus (Ent.) Bpa $\chi^{u}$;, thort.

Brachioli'tes (Fos. Zool.) Bpaxiwr, an arm, $\lambda i^{i} \theta_{s}$, a ftone; from the lateral procelles.

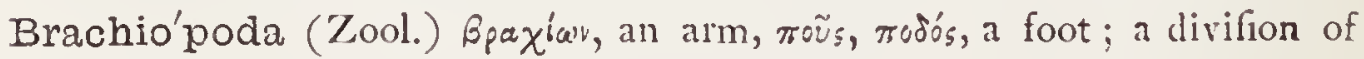
Mollufa. 
Brachy-(Fos. Zool.) Bpaxús, Mhort; a prefix frequently occurring in fcientific compounds.

Brachyce'ntrus (Ichth., Ent.) Bpaxús, fhort, xívrpov, a fpur,

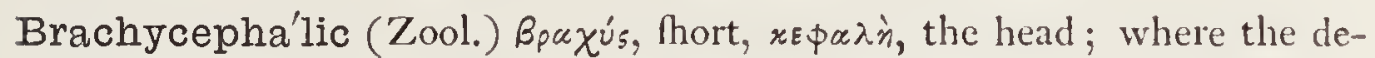
velopment of the $\mathrm{k}$ kull is in the parietal diameter.

Brachy'cera (Ent.) Bpaxús, Mhort, xépas, a horn; an order of Diptera.

Brachy'cerus (Zool.) Bpaxús, fhort, xépas, a horn.

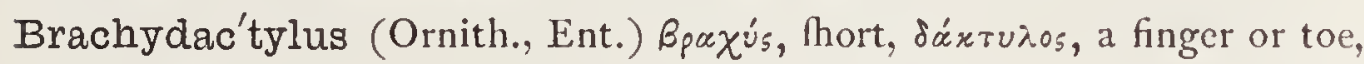
a plume.

Brach'yderes (Ent.) Bpaxús, hhort, JÉpn, the neck.

Brachyglo'ttis (Bot.) Gpaxús, fhort, $\gamma \lambda \tilde{\omega} \tau \tau a$, the tongue; a genus of Compolitæ.

Brachygo'num (Bot.) Bpaxús, fhort, youria, an angle; fp. name of a Diatom.

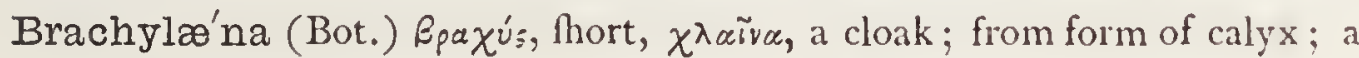
genus of Compofitx.

Brachyor'rhos (Zool.) Bpaxús, fhort, oppos, the tail or rump; a genus of Colubrine ophidians.

Brachy'otus (Ornith.) Bpaxú, thort, ơv, ¿̇rós, an ear.

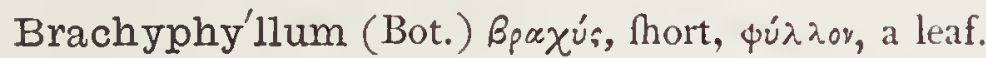

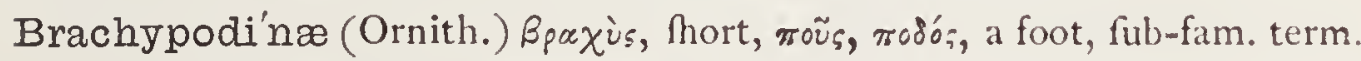
inc; a fub-family of Inceffores.

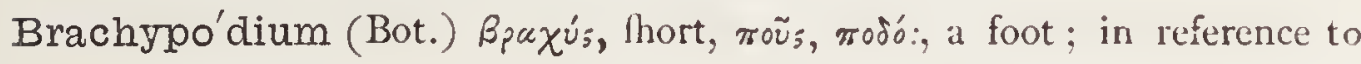
its thort ftalks.

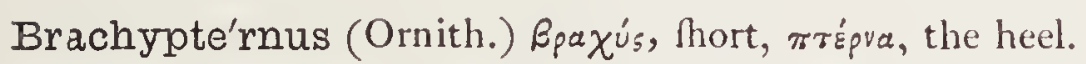

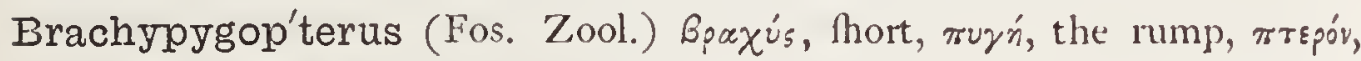
a fin; having a thort fub-dorfal fin.

Brachyrhy'nchus (Ichth.) Bpaxús, fhort, púyxos, a beak.

Brachyse'ma (Bot.) Bpaxú, hort, oñua, a ftandard; the flowers having a very fhort itandard.

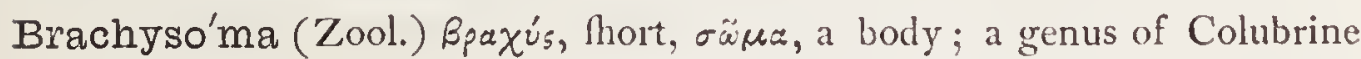
ophidians.

Brachysomophis (Ichth.) Bpaxús, hort, $\sigma \tilde{\omega} \mu a$, a body, ö $\$ b 5$, a fnake.

Brachyso'mus (Ent.) Bpaxús, thort, $\sigma \tilde{a} \mu \alpha$, a body.

Brachyste'lma (Bot.) Bpaxús, fhort, $\sigma \tau \dot{\varepsilon} \lambda \mu \alpha$, a crown.

Brachyta'rsus (Ent.) Bpaxi's, fhort, tarsis.

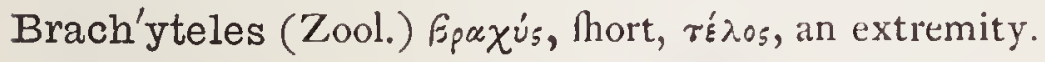

Brachyu'ra

Brachyu'rous $\{$ (Zool.) Epaxús, thort, oupa, a tail; Thort-tailed.

Brachyu'rus ) 
Bracken (Bot.) Scotch form of Brake, Pteris aquilina.

Brac'tea (Bot.) Bpáx $\omega$, to crepitate.

Bractea'tus (Bot.) having floral leaves, from bractea.

Bractéola (Bot.) Lat. a little floral leaf.

Bradle'ya (Bot.) P. N. from Richard Bradley, profeffor of botany at Cam .

bridge; a genus of Euphorbiaceæ.

Bradynobx'nus (Ent.) Bpadúrw, to delay, Baírw, to go; a genus of Hymenoptera.

Brady'pidæ (Zool.) bradypus ; a family of Mammalia; the Sloths.

Bra'dypus (Zool.) Bọdús, llow, heavy, moṽs, a foot; the Sloth.

Bra'dytus (Ent.) Bpadús, llow, heavy.

Bra'ma (Ichth.) Lat. a bream.

Bramble (Bot.) Anglo-Sax. brembel.

Brambling (Ornith.) a name for the mountain-finch; called alfo bramble by Bewick.

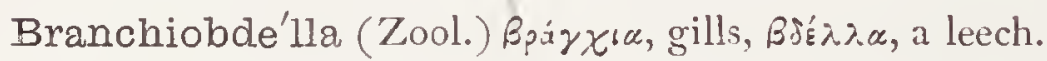

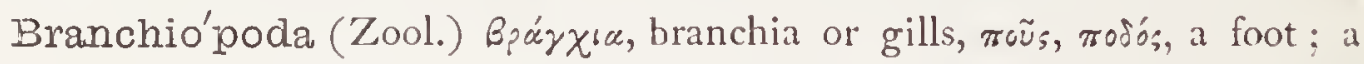
divifion of Entomoftraca.

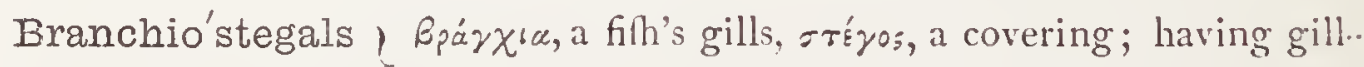
Branchio'stegous 5 covers.

Branderia'na (Ent.) P. N. from Guftawus Brander, a Swede.

Brántsii (Zool.) P. N. in honour of - Brants, a Dutch naturalift.

Brasilien'sis (Zool.) Lat. relating to Brazil.

Brassa'vola (Bot.) P. N. from Antonio Mufa Brafarola, a noble Venetian. Bra'ssia (Bot.) P. N. in honour of $M r$. Brafs, an intelligent gardener, who collected feeds and plants in Africa, about the year 1790 , for Sir Jos. Banks, Dr. Fothergill, and Dr. Pitcairn.

Bra'ssica (Bot.) from brefic, the Celtic name of the cabbage.

Brassica'ceæ (Bot.) brafica, term, for natural order, acea.

Bras'sicæ (Ent) feeds on Braffica oleracea, the common cabbage.

Bra'ula (Ent.) Fíúvia, a loufe.

Bra'ya (Bot.) P. N. from Count Bray, a German botanift.

Bremiel'la (Ent.) P. N. in honour of Bremi-Wolff, of Zurich.

Bremontie'ra (Bot.) P. N. from M. Bremontier, a French botanift: a genus of Leguminofx.

Bre'nta (Ornith.)
Bre'ntus (Ent.) $\}$ Bśstos, arrogance:

Bre'phos (Ent.) faid by 'Treitfche to be derived from Bpśtós, al chilel.

Brevicauda'tus (Zool.) Lat. Mort-tailed. 
Bre'viceps ('Lool.) brevis, hort, caput, the head.

Brevipa'lpis (Ent.) having thort palpi.

Bre'vipes (Ent.) brervis, hort, pes, a foot.

Breviro'stris (Ichth.) brevis, fhort, roftrum, a beak or inout; thort-beaked.

Brevis, Breve (Zool., Bot.) Lat. Mort.

Brevise'tum (Bot.) brevis, fhort, feta, a briftle.

Bre'xia (Bot.) Bp $\varepsilon^{\prime \xi}, 5$, a wetting; faid to be fo called from the protection againft rain afforded by fome of the large leaves.

Brexia'ceæ (Bot.) brexia, term for natural order acea.

Bride'lia (Bot.) P. N. from Profiffor Bridel, a great bryologift.

Brigno'lia (Bot.) P. N. from J. L. Brignoli, a Profeflor at Vienna; a genus of Umbelliferæ.

Bristle (Zool.) Anglo-Sax. brifl; in Lat. scta.

Bri'za (Bot.) Bpi ${ }^{\prime} \omega$, to nod, on account of the quaking of the fpikelets.

Brizopy'rum (Bot.) briza, and zuzón, wheat.

Brochel'la (Ent.) P. N. in honour of $\mathcal{F}$. K. Broch, a German entomologilt.

Brodiæ'a (Bot.) P. N. in honour of James $\mathcal{F}$. Brodie. a Scotch cryptogamirt.

Brodie'i (Fos. Zool.) P. N. in honour of Mr. Brodie, author of "Folfil Infects."

Brodri'cii (Zool.) P. N. in honour of $M r$. Broderick.

Brome'lia (Bot.) P. N. from Olaus Bromel, a Swedith botanift.

Bro'mius (Ent.) Rp'́s,

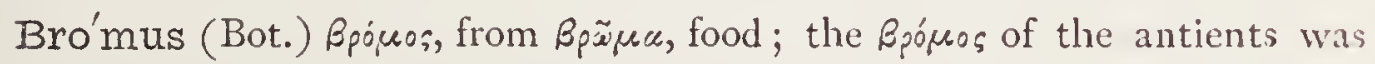
the Avena fativa of Linnæus.

Brongnia'rtea (Bot.) P. N. in honour of Adolple Brongniart, a French botanift.

Brongniarte'1lum (Ent.) P. N. in honour of Alexander Brongriart, a Brongnia'rti (Fos. Bot.) $\int$ French naturalift.

Bro'ntes (Fos. Zool.) Bpórns, a giant, originally one of the Cyclopes, called the Thunderer; applied to a genus of Trilobites.

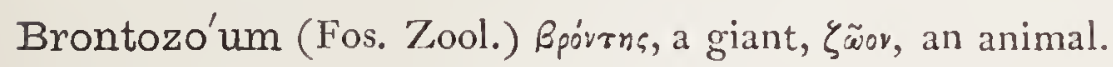

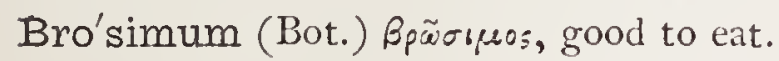

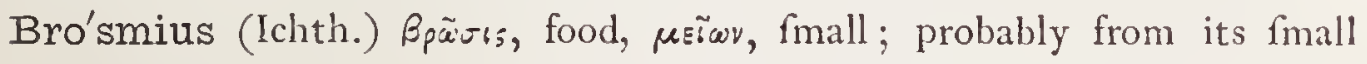
throat.

Bross'æa (Bot.) P. N. from Guy de la Brofsc, phyfician to Louis XIII.

Bro'tera (Bot.) P. N. in honour of Felix A. Brotero, a Portuguefe botanift. Broughto'nia (Bot.) P. N. in honour of Mr. Arthur Broughton, an Englith botanift. 
Broussone'tia (Bot.) P. N. in honour of P.N.V. Broufsonet, a French naturalif.

Browa'llia (Bot.) P. N. in honour of J. Browallius, Bifhop of Abo.

Bro'wnea (Bot.) P. N. in honour of Dr. Patrick Browne.

Brownia'na) (Fos. Bot.) P. N. in honour of the late Robert Brown, the Bro'wnii $\}$ profound botanift.

Brownlo'via (Bot.) P. N. in honour of the late Lady Brownlow, daughter of Sir A. Hume; a genus of Tiliaceæ.

Bru'cea (Bot.) P. N. in honour of James Bruce, the Abyffinian traveller.

Bru'chidæ (Ent.) bruchus, fam. term. ide.

Bru'chus (Ent.) Bpúxw, to bite, or from Bpúxa, to roar, bellow?

Brugma'nsia (Bot.) P. N. from Profeffor S. F. Brugmans; a genus of Solanaceæ.

Bruma'ta (Ent.) bruma, winter.

Bru'nia (Bot.) P. N. in honour of Cornelius Brun, a traveller in the Levant and Ruffia.

Brunia'cea (Bot.) brinia, term. for nat. order, acea.

Bru'nneus-a-um (Zool., Ent., Bot.) Low Latin, brown.

Brunniche'lla (Ent.) P. N. in honour of M. T. Brïnnich, a Danifh Brunni'chia (Bot.) $\}$ naturalift.

Bruno'nia (Bot.) P. N. in honour of Robert Brozun, the celebrated botanift; the typical genus of Brunoniaceæ.

Brunsfe'lsia (Bot) P. N. in honour of Osho Brunffels, of Mentz.

Brunsvi'gia (Bot.) P. N. in honour of the Royal Family of Brunfwick.

Bru'ta)

Brute $\int$ (Zool.) brutus, heavy, ftupid; Ital. and Span. bruto; French, brute.

Bry'a (Bot.) B Búw, to fprout, becaufe the feeds commence germination while on the parent plant; a genus of Leguminof $x$.

Brya'xis (Ent.) Bpuása, to teem with plenty, to overflow.

Bryo'bium (Bot.) etymology uncertain; a genus of Orchidaceæ.

Bryo'nia (Bot.) Bpuavía, from Bpvaw, to pulh or fprout; in allufion to its rapid growth.

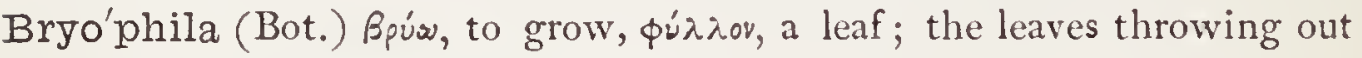
roots when laid upon damp earth.

Bryo'phila (Ent.) Bpúov, mors, фíros, fond of: the larvx feed on lichens.

Bryophi'lidæo (Ent.) a family of Lepidoptera, of which the genus Bryophila is the type. 


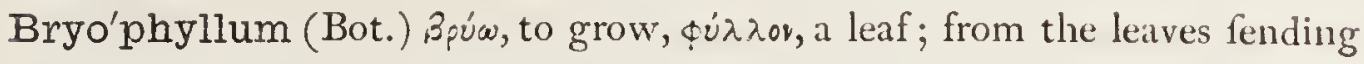
out roots when laid on damp earth.

Bryo'psis (Bot.) Bpúov, mors, oै łs, refemblance; a genus of Cryptogamia.

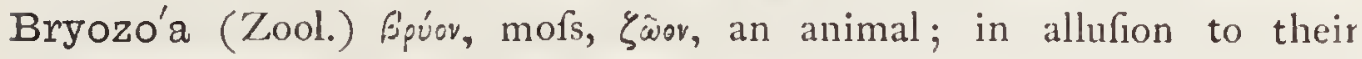
branched and mors-like aggregation.

Bry'um (Bot.) Epuiw, to abound, becaufe it flourifhes everywhere; a genus of Mufci.

Bu'balus (Zool.) Lat. a buffalo, or wild ox.

$\mathrm{Bu}$ 'bo (Ornith.) Lat. a long-eared owl.

Bu'bon (Bot.) Boußúv, the groin; in allufron to its medicinal qualities.

Buccino'idea (Fos. Zool.) refembling the fhell buccinum.

Bu'ccinum (Zool.) Lat. a trumpet or horn.

Bu'cco (Ornith.) bucca, a cheek.

Bucconi'næ (Ornith.) a fub-family of Pafleres, of which bucco is the type.

Buccula'trix (Ent.) buccula, a little mouth or cheek.

Buce'phala (Ent.) Boṽs, a bull, $є є ф a \lambda n$, the head; from its large head.

Buce'phalus (Zool.) Boũs, an ox or bull, $x \equiv ф a \lambda n^{\prime}$, the head; a genus of Colubrine ophidians.

Bu'ceros , (Ornith.) Eożs, an ox, répas, a horn; a genus, family, and Bucero'tidæ $\{$ fub-family of Pafleres; from fome refemblance of the Buceroti'næ bill to an ox's horn.

Buchana'nia (Bot.) P. N. from Dr. F. Buchanan; a genus of Anacaldiacex.

Buchne'ra (Bot.) P. N. in honour of J. G. Buchner, a German naturalin. Buci'da (Bot.) Boũs, an ox ; having fruit like an ox's horn.

Buck (Zool.) applied to a he-goat; from Anglo-Sax. bucca.

Buckbean (Bot.) properly "bog-bean" from its marhy habitat, Menyanthes trifoliata.

Buckla'ndi (Fos. Zool.) P. N. in honour of Dr. Buckland, Dean of Weftminfter, and a celebrated geological writer.

Bucku (Bot.) native Caffre or Hottentot name of the Diofma crenata.

Buckwheat (Bot.) i. e. beech-wheat, (Fagopyrum efculentum) the triangular fruits (mifcalled feeds), refemble beech-maft in thape, and are full of fweet white farina.

Buddle'a (Bot.) P. N. from Adam Buddle, a celebrated Englifh botanift. Bu'falis (Ent.) bufo, a toad; alluding to its wing-marks.

Bu'ffalo (Zool.) Bóußaxos; Lat. bubalus; Fr. buffle.

Buffo'nia (Bot.) P. N. in honour of Count de Buffon, the celebrated naturalift. $\mathrm{Bu}$ fo (Zool.) Lat. a toad. 
Bu'fonite (Fos. Z.ool.) bufo, a toad; referring to the vulgar notion that thefe organifms were originally formed in the heads of frogs and toads.

Bug (Ent.) Gothic and Icelandic puke, a fpectre or demon; Welf, brug :

"The bug, which you would fright me with, I feek."-Shakespeare.

Bugle (Bot.) appears to be a corruption of bugula, a contracted dim. of bugloflum.

Bulb (Bot.) Boxkés, Lat. bulbus; French, bulbe; akin to volvere, from the layers or folds of a bulb.

Bulbiferous (Bot.) bulbus, a bulb, fero, to bear.

Bulbi'ne (Bot.) bulbus, a bulb; a genus of Liliaceæ.

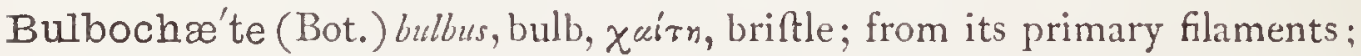
a genus of Algx.

Bulboco'dium (Bot.) bulbus, a bulb, zẃdเcv, a fleece; the bulb being wrapped in a woolly covering.

Bulga'ria (Bot.) bulga, a leather bag; a genus of Fungi.

Bu'lla (Zool.) Lat. a bubble.

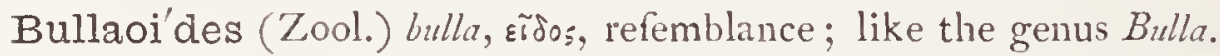

Bulla'tus-a-um (Bot.) bullata fignifies "decked with ftuds," and is given in allusion to the ftudded appearance which the anthers produce in the raceme of flowers.

Bullia'rda (Bot.) P. N. from M. Bulliard, a French botanift; a genus of Craflulaceæ.

Bull-rush (Bot.) the bull-rufh of Scripture was the Papýrus antiquorum. Bumal'da (Bot.) P. N. in honour of $J$. A. de Bumalda, a botanift of Bologna.

Buma'stus (Fos. Zool.) "a bunch of large grapes-literally each large

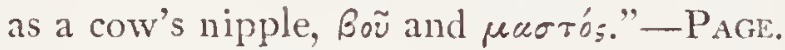

Bume'lia (Bot.) the Greek name of the common afh.

Buncho'sia (Bot.) etymol. unknown to me; a genus of Malpighiacex.

Bu'ngarus (Zool.) etymology unknown; a genus of Colubrine ophidians.

Bu'nias (Bot.) fame etymol. as Bunium; now applied to a different plant.

Bu'nium (Bot.) Boviós, a hill, from its habitat.

Bunting (Ornith.) etymology unknown.

Buolia'na (Ent.) P. N. in honour of Baron Buol, of Vienna.

Bu'phaga (Ornith.) Boũs, an ox, $\phi^{\prime}$ y $\omega$, to eat; the Ox-pecker or Beef-eater of Africa.

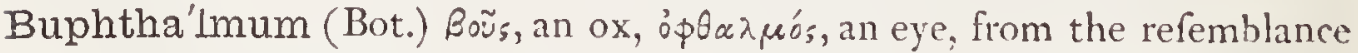
of the difk of flowers. 
Bupleu'rum (Bot.) not explained fatisfactorily; a genus of Umbelliferæ. Bupre'stidæ (Ent.) a family of Coleoptera of which bupreftis is the type.

Bupre'stis (Ent.) "Boṽ, an augmentative particle; or $\beta$ õ̃s, an ox, and

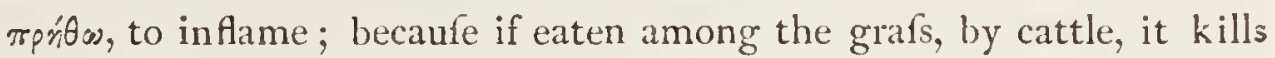
them."-Mayne.

Bur or Burr (Bot.) French, bourre, the prickles on herbs and fruits.

Burcha'rdia (Bot.) P. N. from Henry Burchard, M.D., a botanical author; a genus of Melanthaceæ.

Burche'lli (Zool.) P. N. in honour of $W$. Birchell, ESg., LL.D.

Burche'llia (Bot.) P. N., fame etymol. as Burchelli; a genus of Cinchonaceæ.

Burdock (Bot.) common name of the Arctium Lappa.

Burhi'nus (Ornith.) Boũ, monftrous, porv, a nofe; a genus of Birds.

Burlace (Bot.) a corruption of Bourdelais, from which part of France the plum came.

Burlingto'nia (Bot.) P.N. in honour of the amiable and accomplinhed Countefs of Burlington; a genus of Orchidacex.

Burnet (Bot.) derivation uncertain.

Burrie'lia (Bot.) P. N. in honour of John Mark Burriel, who publifhed, in $175^{8}$, the journey of Venegas into California; a genus of Compofita. Bu'rsa ('Zool.) Lat. a purfe or pouch.

'Bu'rsaria (Bot.) burfa, a pouch.

Bu'rsera (Bot.) P. N. in honour of Foachin Burfer, a botanift of Naples.

Burto'nia (Bot.) P. N. in compliment to D. Burton, who collected for the Kew Garden.

Bury (Bot.) applied to a pear, from beurré, melting.

Bu'talis (Ent.) "Bivtánss, a night-bird," (Treitfche), from the fomewhat fombre colours.

Bu'tea (Bot.) P. N. from Joln, Earl of Bute, a lover and patron of botany; a fplendid genus of Leguminofre.

Bu'teo (Ornith.) Lat. a buzzard.

Buteoni'næ (Ornith.) a fub-family of birds, of the order Raptores, of which bnteo is the type.

Bu'tomus (Bot.) Boṽs, an ox, réseve, to cut; caufing the mouths of cattle to bleed when eaten by them.

Butterfly (Ent.) Anglo-Sax. buttor fleoge or buter flere.

Buxbau'mia (Bot.) P. N. from John Chriftian Buxbaum, a German botanift;

a genus of Mufci. 
Bux'us (Bot.) Lat. buxus, from $\pi \dot{\text { y }}$ os, the pale evergreen box..tree; Ovid has-"buxus denfa foliis," and "ora buxo pallidiora."

Buz'zard (Ornith.) French, busard; Germ. buszaar.

By'blis (Bot.) P. N., the daughter of Miletus; a genus of Droferacex.

Byrsoni'na (Bot.) burfa, a hide, being ufeful in tanning; a genus of Malpighiaceæ.

Byssa'ceus-a-um (Bot.) Lat. byflus-like.

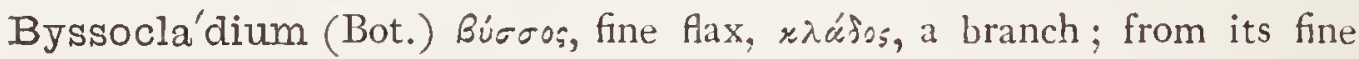
branches; a genus of Algx.

By'ssus (Zool.) Búroos, fine flax; the fibres by which fome marine animals are attached to rocks, \&c.; alfo, in Botany, a genus of Cryptogamia.

Bystropo'gon (Bot.) Búw, to clofe, zw'sur, a beard; the throat of the corolla being clofed by hairs.

By'thinus (Ent.) Bútrov, a water animal.

Byttne'ria (Bot.) P.N. from D. S. A. Bütner, Profeffor of Botany at Gottingen.

Byttneria'ceæ (Bot.) byttneria, term. for nat. order, acea.

Caba'llus (Zool.) Lat. a pack-horle.

Cabe'ra (Ent.) P. N., the daughter of Proteus.

Cabera'lis (Ent.) implying fome refemblance to the genus Cabera.

Cabe'ridæ (Ent.) cabera ; a family of Lepidoptera.

Cacaja'o (Zool.) native name of a monkey-Pithecia melanocephala.

Caca'lia (Bot.) raxós, bad, גiav, exceedingly, from being fuppofed to be hurtful to the foil.

Cacatu'a (Ornith.) Latinized form of the found it makes, which refembles the word kakatoé.

Ca'ccabis (Ornith.) $x \alpha x * \alpha \beta i s$, a partridge.

Cac'hinnans (Ornith.) Lat. laughing:

Cac'hrys (Bot.) ráxpus was ufed by the antients for the young bloflom:

buds of the oak. or perhaps for a kind of gall that grows upon them.

Cacomi'xle (Zool.) native Mexican name of the Báftaris aftuta.

Caco'sis (Ent.) xaró, bad; a genus of Diptera.

Cacto'rnis (Ornith.) cactus, opves, a bird; the Cactus bird.

Ca'ctus (Bot.) the rarró: of the ancients was a prickly plant with edible. ftalks.

Cacumina'lis (Ent.) cucumen, a point or tip.

Ca'dia (Bot.) from its Arabic name qadhy. 
Ca'dmia (Ent.) Lat. the drofs or flag of a furnace i. e. in colour.

$\left.\begin{array}{l}\text { Cadu'ca (Ent.) } \\ \text { Cadu'cous (Bot.) }\end{array}\right\}$ caducus, eafily falling.

Caducibra'nchiate (Zool.) caducus, eafily falling, branchia, the gills of a fin.

Cæci'lia (Zool.) Lat. a kind of lizard; a genus of Batrachians.

Cæcima'cula (Ent.) cacus, blind, macula, a fpot, alluding to certain Cæcimacula'na fpots on the fore-wings.

Cælesti'na (Bot.) caleftis, the colour of the $\mathrm{ky}$, referring to the blue flowers; a genus of Compofitæ.

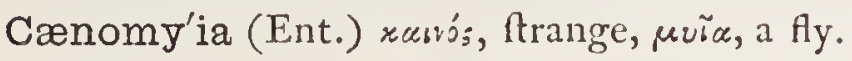

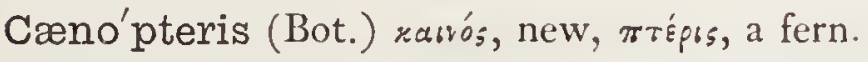

Cæno'sus-a-um (Ent., Bot.) canosus, marlhy; growing in mud, or nudddy places.

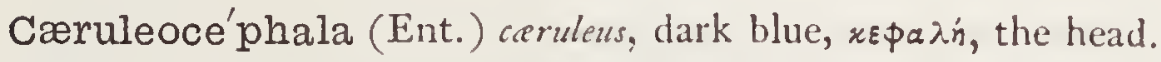

Cærule'scens (Ent.) fomewhat blue.

Cæru'leus-a-um (Ornith., Bot.) Lat. dark blue, azure.

Cæsa'lia (Bot.) crefus, beaten, trampled upon.

Cæsalpi'nia (Bot.) P.N. in honour of C. Cafalpinus, phyfician to Clement VIII.

Cæ'sia (Bot.) P. N. from Frederico Casio, who died 1703.

Cæsia'ta (Ent.) ca/uss, gray.

Cæsie'lla (Ent.) dim. form of cajius, bluifh gray.

Cæ'sius-a-um (Ornith., Bot.) casius, bluilh gray.

Cæspita'lis)

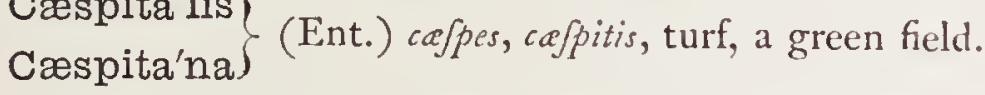

Cæspititie'lla (Ent.) cafpes, caepitis, turf, dim. ella.

Cæsu'lia (Bot.) cafus, beaten, as if trampled upon; a genus of Compofitæ. Caffer (Zool.) Lat. relating to the Cape of Good Hope.

Ca'ia (Ent.) P. N. ; a Roman proper name.

Caja'nus (Bot.) alteration of Malabar name catjang; a genus of Leguminoræ.

Caki'le (Bot.) the Arabic name of the plant.

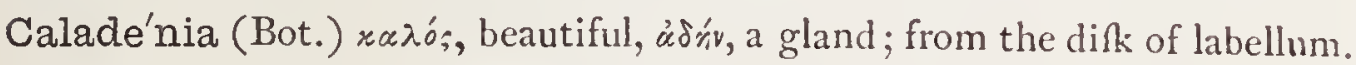
Caladium (Bot.) etymology unknown.

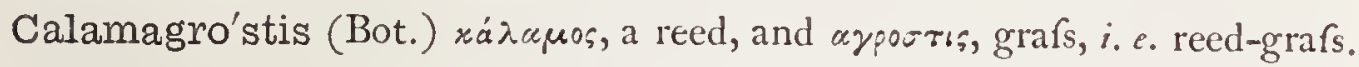
Calama'ria (Zool.) calamarius, refembling a writing-reed or fifhingCalamáridæ $\int$ rod; a genus and family of Colubrine ophidians; in

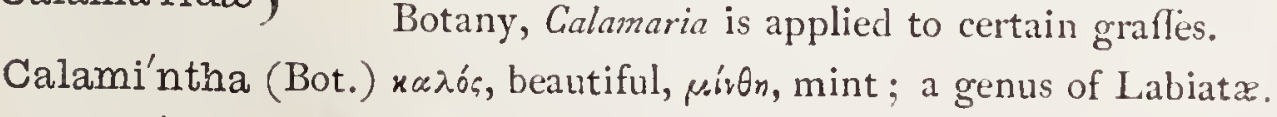

Calamo'philus (Ornith.) calamus, фıرદ́a, to love. 


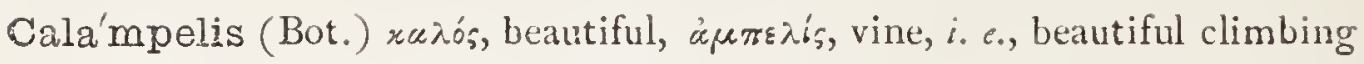
plant; a genus of Bignoniacex.

Calamus (Bot.) from Arabic kalam, a reed.

Cala'ndra (Ornith.) zú $\lambda u v \delta p o$, a kind of lark.

Calandrínia (Bot.) P. N. from 7. L. Calandrini.

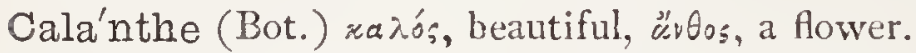

Cala'thea (Bot.) ráiatos, a baket; from the form of the figma.

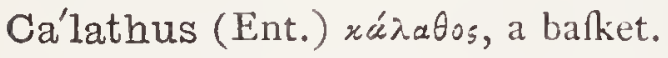

C-album (Ent.) Lat. the white C; from the mark on the polterior wings.

Calca'ria (Ornith.) calcar, calcaris, a fpur; the fpurs of birds.

Calceola'ria (Bot.) calceolus, a little flipper; in allufion to the Thape of the lower lip.

Calce'olus (Zool. Bot.) Lat. a little fipper.

Calda'sia (Bot.) P. N. from 7. Caldas, a Bogotan botanift.

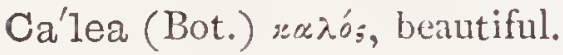

Caleacte (Bot.) $x a \lambda \dot{o}_{s}$, beautiful, $\dot{a} x \tau \dot{n}$, the fea-fhore, which it ornaments; a genus of Compofitæ.

Caleana (Bot.) fame etymology as Caleya; a genus of Orchidacex.

Cale'ndula (Bot.) from calende, the calends or firt day of the month, becaufe it flowers monthly.

Calepi'na (Bot.) not explained; a genus of Cruciferæ.

Cale'ya (Bot.) P. N. from George Caley, the celebrated Manchefter botanif, fometime fuperintendent of Botanic garden at St. Vincent.

Cali'cium (Bot.) dim. of calyx, a little cup; a genus of Lichenes.

Cali'dipes (Ent.) calidus, fwift, pes, a foot.

Cali'dris (Ornith.) ra $\lambda_{o s}$, beautiful, 'opos, knowing, Rilful.

Cali'gidæ (Zool.) caligus, fam. term. ida; a family of Entomoftraca.

Caligino'sa (Ent.) Lat. obfcure, gloomy.

Cali'gus (Zool.) caligo, dimnefs, obfcurity.

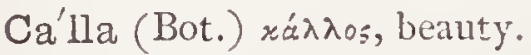

Calla'rias (Ichth.) the Greek name for the cod-fin.

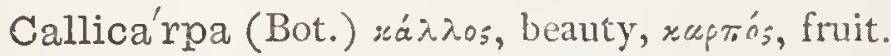

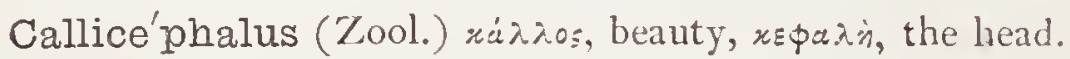

Calli'cerus (Ent.) $x \dot{\lambda} \lambda \lambda 0 s$, beauty, *ย́pac, horn.

Calliche'lys (Ichth.) $x \dot{x} \lambda \lambda \sigma s$, beauty, $\chi \chi^{\prime} \lambda v ;$, a tortoife.

Callico'ma (Bot.) xá $\lambda \lambda_{0}$, beauty, xókr, hair.

Calli'dium (Ent.) xá $\lambda \lambda_{0}$, beauty, dass, noble.

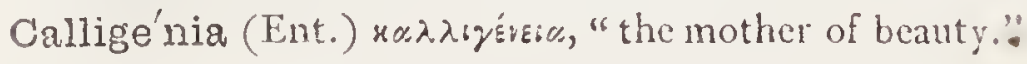




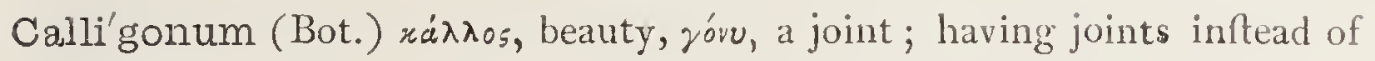
leaves.

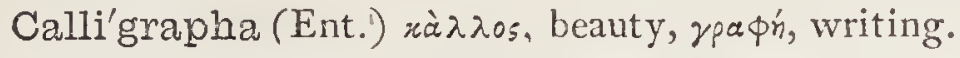

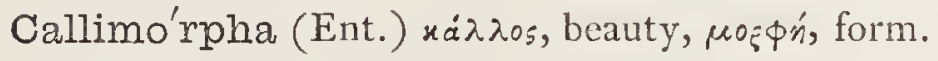

Callio'nymus (Ichth.) жá $\lambda \lambda \circ$ s, beauty, o’vora, a name; a fanciful name of Linnæus, applied to a prettily marked fpecies.

Calliope' (Ornith.) P. N., the chief of the Mufes.

Calliope'a (Bot.) P. N., fame etym. as Calliope; a genus of Compofitæ.

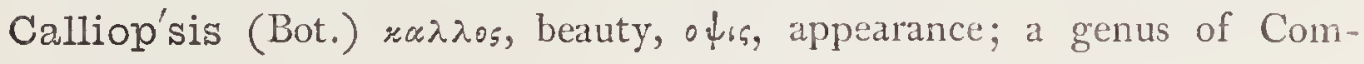
pofitre.

Callipe'pla (Ornith.) $x a \lambda \lambda i \pi \varepsilon \pi \lambda 05$, with beautiful robe.

Callipro'ra (Bot.) $x \omega \lambda \lambda 05$, pretty, $\pi \rho \omega \rho$, front, from its pretty appearance; a handfome liliaceous plant.

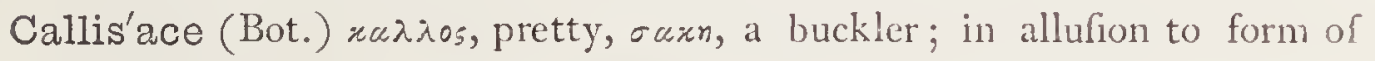
feeds; a genus of Umbelliferæ.

Calli'sia (Bot.) $\pi \alpha \lambda \lambda^{\prime} \dot{s}$, pretty.

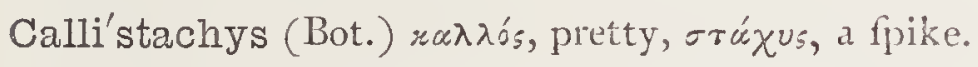

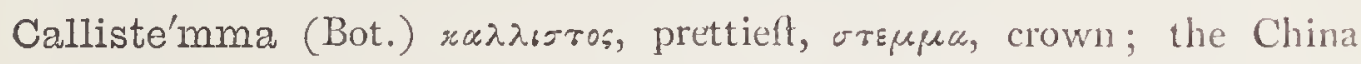
After.

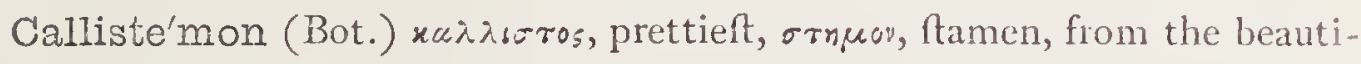
ful farlet colour of the ftamens; a lovely genus of Leguminof

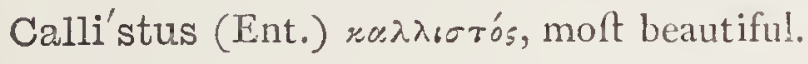

Callitha'mnion (Bot.) fame etymology as Calothamnus.

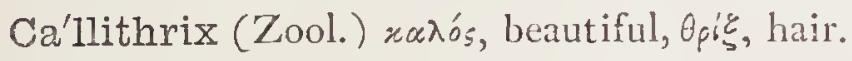

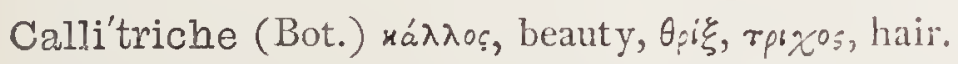

Ca'llitris (Bot.) $x a^{\prime} \lambda \lambda \circ$, beauty, in allufion to its appearance; a genus of Coniferx.

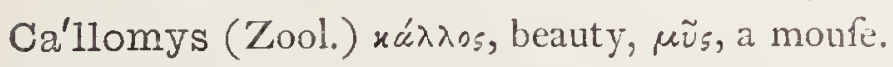

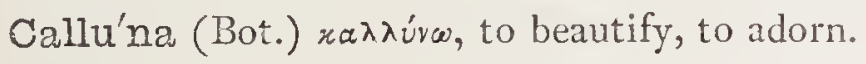

Cally'na (Ent.) $x a \lambda \lambda u^{\prime} r w$, to beautify.

Caloca'lia (Ornith.) xú̀os, beautiful, raxia, a bird's neft; the genus of birds to which belongs the fwallow which builds the edible nefts confumed in China.

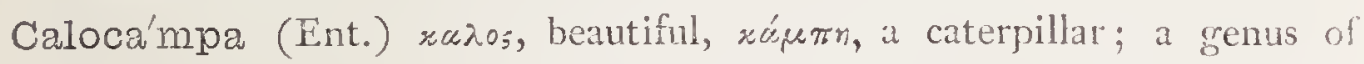

Lepidoptera.

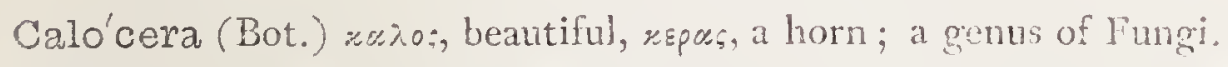

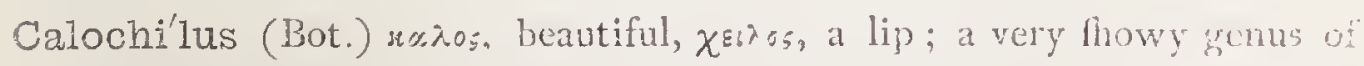

Orchids, with purple lip, covered with rich brown hatirs. 


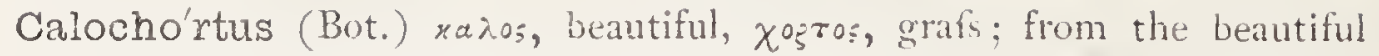
fowers borne by grally herbage.

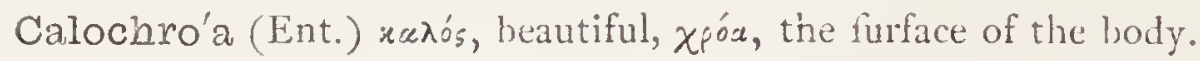

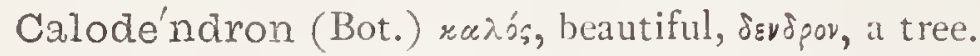

Calo'dera (Ornith., Ent.) zaxós, beautiful, féprn, the neck.

Caloe'nas (Ornith.) xasos, beautiful, oencs, fp. name of the fock-dore.

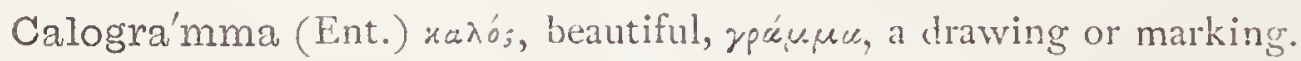

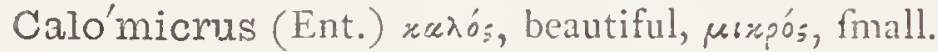

Calo'phaca (Bot.) ruגos quru, beantiful vetch; a genus of Leguminofx.

Calo'phanes (Bot.) xaros, beautiful, pasv, to appear, from its elegant flower's; a genus of Acanthacer.

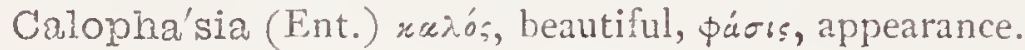

Calophy'lla $\left\{\begin{array}{l}(\text { Ent. }) \\ \text { (Bot. })\end{array}\right\}$ zàós, beautiful, s

Calopo'gon (Bot.) xàos, beautiful, rwyov, a beard; from the fringe of the lip.

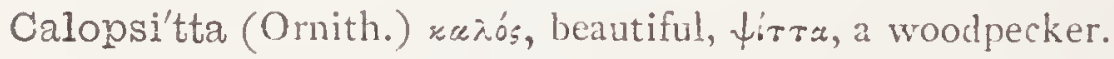

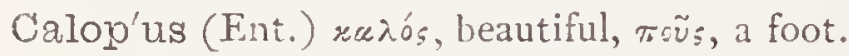

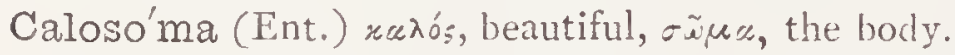

Caloso'ter (Ent.) zàós, beautiful, swrńp, a preferver.

Calospi'za (Ornith.) xaxós, beautiful, fpiza, a bunting.

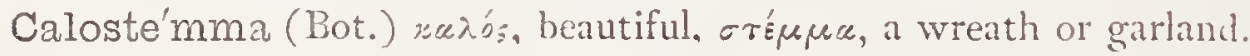

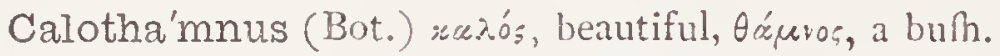

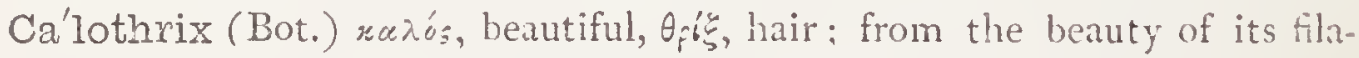
ments; a genus of Cryptogamia.

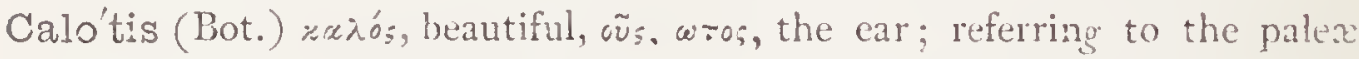
of pappus.

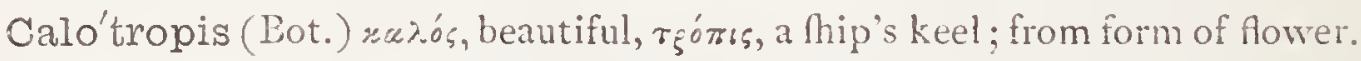
Ca'ltha (Bot.) a contraction of rá $\lambda_{a} \theta_{0}$, a goblet; from the cup-fhape of the flower.

Calve'scens (Ent.) Lat. becoming bald.

Calyciflo'ra (Bot.) calyx, calycis; flos, foris ; ftamens on the calyx.

Caly'pso (Bot.) P. N. a well-known mythological perfonage; a genus of Orchids.

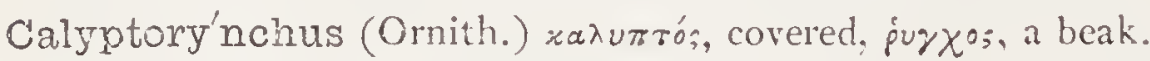

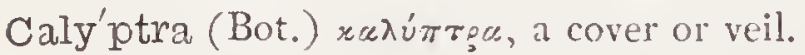

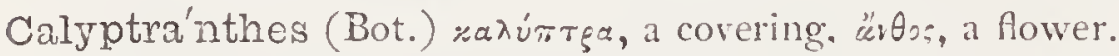

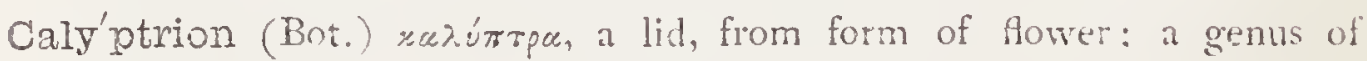

Violne:. 
Calve'lla (Ent.) calvus, bald, without hair.

Calycarntinus (Bot.) calyx, «̋Gos, a flower; from the coloured calyx.

Calyste'gia (Bot.) calyx, and $\sigma \tau \varepsilon y n$, a covering, from the large brafts outfide the flower. 'The common white convolvulus.

Ca'lythrix (Bot.) calyx, and $\epsilon_{\xi}(\xi$, hair; from the attenuated points of the iepals.

Ca'lyz (Bot.) xáxu६, the cup or calyx of a flower.

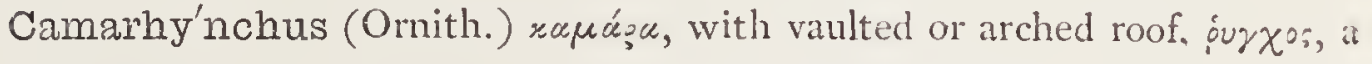
beak.

Camari'dium (Bot.) xuнúza, a vaulted or arched roof; from the tip of ftigma being arched.

Camaro'tis (Bot.) Camera, a vault, in allufion to the chambered lip: at genus of Orchidaceæ.

Cama'ssia (Bot.) camass, its native North American name; a genus of Afphodeleæ.

Cambogia'lis (Ent.) exprefive of its gamboge colour.

Ca'mbricus-a-um' (Ent.) Lat. Wellh; from Cambria, the antient name of

Wales; growing in; or connected with, Wales.

Cambrica'ria (Ent.) from Cambria, the antient name of Wales.

Cambri'dgii (Ent.) P. N. in honour of the Rev. O. P. Cambridge of Bloxworth, Dorfet.

Cameli'na (Ent.) camelus, a camel; from the projecting hump; alfo it genus in Botany.

Camellia (Bot.) P. N. from George Foleph Kamel, or Camellus, a Jefuit.

Camelopa'rdalis (Zool.) camelus, a camel, pardalis, a panther.

Came'lus (Zool.) Lat. a camel.

Camera'ria (Bot.) P. N. from F. Camerarius, a botanift of Nuremberg.

Campánula (Bot.) Lat. a little bell.

Campanula'ria, (Zool.) campanula, a little bell; a genus and family Campanuiari'adre $\int$ of Zoophytes.

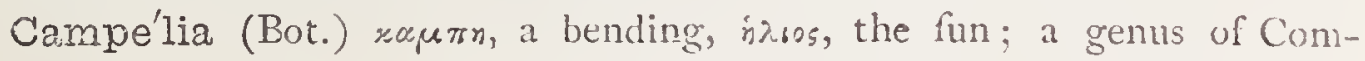
melinacer.

Campe'phaga (Ornith.) xáumn, a caterpillar, фayw, to eat.

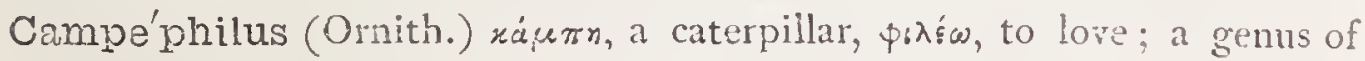
foreign Woodpeckers.

Campe'stres (Ornith.) campefter, a level country or plain.

Campe'stris, Campestre (Bot.) Lat. growing in the open fields.

Camphoros'rina (Bot.) eamphora, camphor, of un, fmel!.

Campolilia'na (Ent.) cumpur, a field. lilim, a lily. 


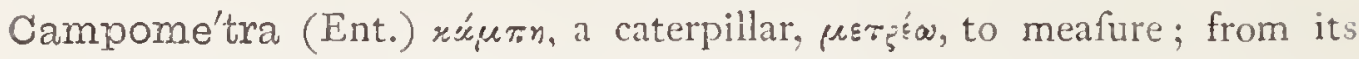
fingular mode of progreftion, as if it were meafuring the ground.

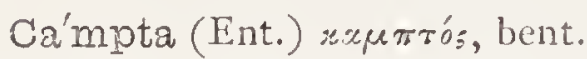

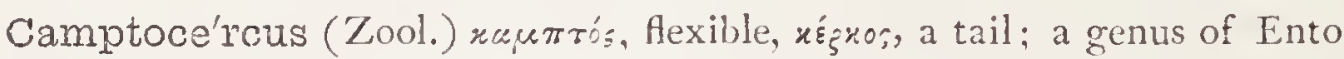
moltraca.

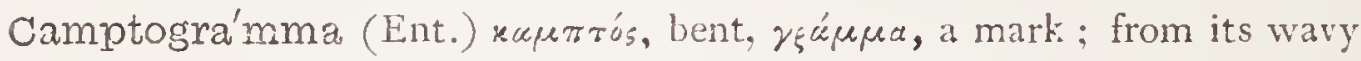
lines.

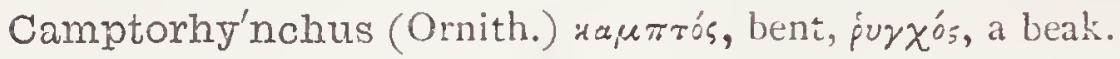

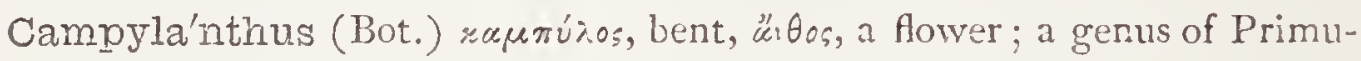
laceæ.

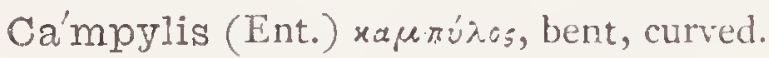

Canade'nsis-e (Zool., Bot.) Lat. relating to Canada.

C.analicula'ti (Zool.) pl. of canaliculus, a little channel.

Canari'na (Bot.) a native of the Canaries.

Canava'lia (Bot.) canavali is its native Malabar name; a genus of Lerrliminosæ.

Cancella'tus-a-um (Bot.) Lat. net-like, crofs-barred.

Cancrifo'rmis ('Zool.) Lat. crab-Ahaped.

Cancri'vora ('Zool.) cencer. a crab, soro, to devour.

Cancro'ma (Onith.) etymology unknown to me.

Candefa'cta (Ent.) cindefacio, to bleach, to make red hot.

Can'dens (Ent.) Lat. bright, fhining.

Candida'na)

Candida'ta\} (Ent.) cunduitus, white.

Ca'ndious-a-um (Zool., Bot.) Lat. white and thining.

Cando'llea (Bot.) P. N. from Augufus Pyramus De Candolle, of Genera, one of the greateft botanifts of the age: a genus of Dilleniacex.

Cando'na (Zool.) xavdóv, gaping? a genus of Entomoftraca.

Canel'la (Ent., Bot.) dim. of cams, gray, afly.

Canes'cens (Ornith., Ent., Bot.) Latin participle, fignifying hoary.

Ca'niceps (7.ool.) Lat. gray-headed, ahy-headed.

Cani'cula (Ichth.) Lat. a little dog.

Cani'na (Zool.) canis ; a fub-family of Mammalia.

Cani'na (Bot.) fit only for dogss.

Canis (Zool.) Lat. a dog.

Ca'nna (Bot.) cama, a reed.

Cannabina (Ornith.) Lat. relating to hemp.

Can'nabis (?ot.) from cellic ian, reed, ah, fmall; or from qan', its Arabic name. 
Canna'bium (Bot.) refembling hemp camnabis.

Cano'rus (Ornith.) Lat. tuneful, melodious.

Can'talupe (Bot.) from a place of that name near Rome, where melons have been cultivated fince the time of the Mithridatic war. The originals of thefe varieties are faid to have been brought from Armenia by Lucullus.

Canthare'llus (Bot.) altered from the French chanterlle; a genus of Fungi.

Cantha'ridæ (Ent.) cantharis, fam. term. ida.

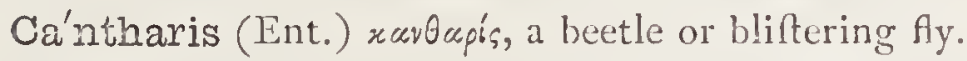

Can'tharus (Ichth.) Lat. one of Pliny's names for a fpiny fift.

Ca'nthium (Bot.) cantix is the Malabar name of the Cinchonaceæ.

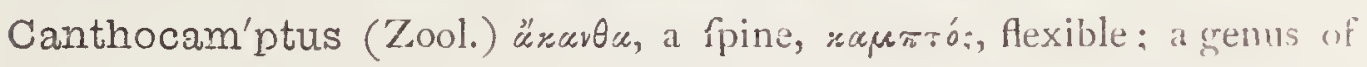
Entomoltraca.

Canti'aca )

Cantia'nus\} (Ornith.) Lat. relating to the county of Kent.

Ca'nus-a-um (Ornith., Bot.) Lat. white, gray.

Canu'tus-a-um (Ornith.) gray-coloured.

Cape'nsis-e (Zool., Bot.) Lat. of the Cape of Good Hope.

Capillalis (Ent.)

Capilla'ris-e (Bot.) capillus, hair.

Capis'tratus (Zool.) Lat. muzzled, haltered.

Ca'pnea (Zool.) zámın, a chimney, from its tubular thape; a genus of Zoophytes.

Capno'des (Ent.) *urvos, fmoke, eídos, like; fmoke-coloured.

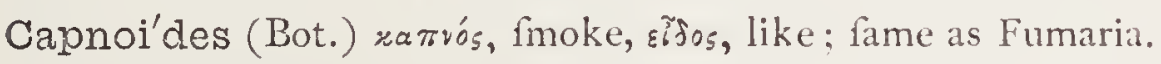

Capnophy'llum (Bot.) xaъros, fmoke, quanov, leaf; Greek form of Fumaria.

Ca'pparis (Bot.) Arabic, kabar, capers; the caper-tree.

Capræa'na (Ent.) feeds on Salix caprea.

Capra'ria (Bot.) cupra, a goat; the leaves being chofen by thefe animals.

Capreole'lla (Ent.) capreola, a wild-goat, alluding to colour.

Caprico'rnis (Zool.) capra, a the-goat, cormu, a horn.

Caprifo'lium (Bot.) capra, a the-goat, folium, leaf; goat-leaf, in reference to its clambering habit; honeyfuckle.

Caprimulgel'la (Ent.) dim. of caprimulgus, the goat-fucker, from a refemblance in the feathers.

Caprimul'gidæ (Ornith.) caprimulgus, fam. term. ide; the Goat-fuckers. Caprimu'lgus (Ornith.) capra, a the-goat, mulgeo, to milk, from a miftaken idea as to the habits of the bird. 
Ca'pros (Ichth.) rámsos, the wild boar; the boar-filh.

Capse'lla (Bot.) dim. of capfula.

Ca'psicum (Bot.) xú $\pi \tau$ r. to bite; from its pungent qualities.

Capsin' cola (Ent.) capfa, a capfule or feed-pod, incola, an inhabitant.

Capso'phila (Ent.) capfa, a feed-pod, $\phi: \lambda \varepsilon \dot{\varepsilon}$, to love.

Capsula'ris (Ent.) capfula, a cheft or cafket.

Ca'pua (Ent.) P. N. from Capra, in Italy.

Capula'ris (Ent.) Lat. pertaining to a coffin, from the form of its wingmarkings.

Caput-Medu'sæ (Bot.) fo called from the circumftance of the prime fhoots

or branches producing from their extremities numerous fmall branches round a fort of head which is formed there.

Cara'bidæ (Ent.) carabus, fam. term. ide.

Ca'rabus (Ent.) sásaßos, a beetle, i. e. fcarabæus: the word was alfo ufed by the antients for a thell-filh.

Ca'racal (Zoo!.) from the Turkilh, fignifying "black-eared," equiv. to the fpecific name, melanotis.

Carac ara (Ornith.) is faid to derive its name from its peculiar guttural cry, which is compared by Mr. Darwin " to the found of the Spanilh guttural, g, followed by a rough double $r, r . "$

Caradrína (Ent.) P. N. of a river in Albania.

Caradrina'lis (Ent.) refembling caradrina.

Caradrínidæ (Ent.) caradrina, fam. term. idce; a family of Lepidoptera. Caradrino'ides (Ent.) caradrina, eĩdos, refemblance.

Caraga'na (Bot.) carachana, its name in Tartary; a genus of Leguminofa. Caragna'ta (Bot.) its name in South America; a genus of Bromeliacex.

Cara'llia (Bot.) carillie, the name of C. Lucida, in Hindooftan; a genus of Ternftröniaceæ.

Carallu'ma (Bot.) its Indian name; a genus of Afclepiadaceæ.

Ca'rapa (Bot.) caraipe, the name of $C$. Guianenjis, in Guiana; a genus of Meliacex.

Ca'raway (Bot.) Lat. carmm; mative of Caria. (Pliny) Cleland, however, ftates that it is " corrupted from Celtic garwin, feeds that produce the expulfion of wind."

Cara'nx (Ichth.) derived from the French; C. trachurus is the thad or Horfe-mackerel.

Ca'rapace (Zool.) the dorfal thield of a tortoife.

Ca'rapus (Ichth.) xúper, top or fummit, toũs, a foot.

Ca'rbo (1)rnith., Ent.) Lat. a coal, referring to colom. 
Carbona'lis (Ent,) implying coal colour.

Carbona'na (Ent.) carbo, coal, charcoal.

Carbona'ria (Ent.) carbo, charcoal.

Carbona'rius (Ichth.) Lat. pertaining to charcoal; a name of the coal-fin.

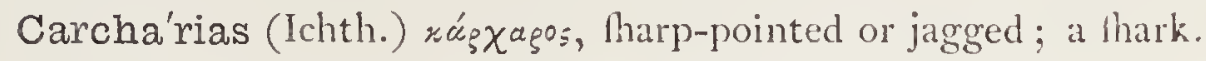

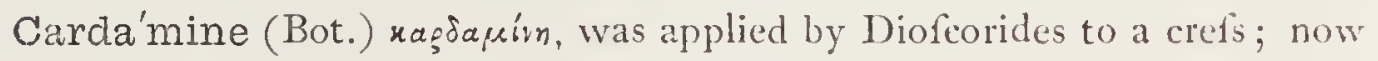
ufed for Lady's fmock and allied plants.

Carda'mines (Ent.) feeds on Cardumine impatiens, and others of the genus.

Cardiapu's (Ent.) $x$ as fíc, heart, $\pi \tilde{c} \tilde{s}$, a foot.

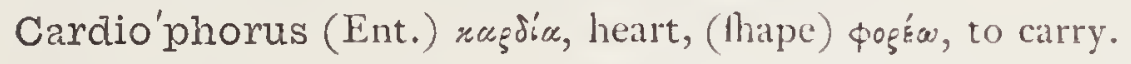

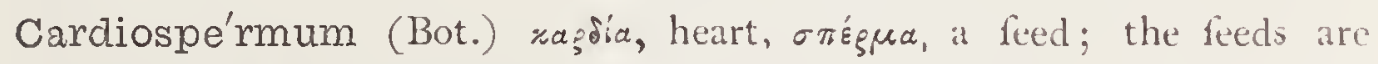
marked with a heart-fhaped pot.

Cardo'patum (Bot.) carduns, a thiftle, wátos, a beaten path; from its habitat and appearance.

Carcue'lis (Ornith.) applied by Pliny to a bird which feeds amongt thiftles.

Cardue'lla (Ent.) dim. of curdus, a thiftle, on which it fecds.

Ca'rdui (Ent.) feeds on Carduus nutans, the thiftle.

Cardun'celus (Bot.) dim. of cardunculus, the cardoon; a grenus of Compofitx.

Ca'rduus (Bot.) Lat. a thiitle.

Care'bara (Ent.) rapniougns, heavy in tlee head.

Ca'rex (Bot.) careo, to want; the upper fpikes being without feeds.

Care'ya (Bot.) P. N. in honour of its difcoverer, Willium Carey.

Cargi'llia (Bot.) P. N. from Fumes Cargill, M.D., Aberdeen; a genus of Ebenaceæ.

Cari'acus (Zool.) Latinized form of the native name carjacou.

Ca'rica (Bot.) fp. name of Ficus, from its abundance in Caria.

Cario'sus-a-um (Zool.) Lat. worm-eaten, rotten.

Caripe'nsis (Ornith.) Latinized form of the cavern of Caripe, in South America.

Cari'ssa (Bot.) etymology unknown.

Carli'na (Bot.) the Carline thiftle is ftated to have derived its name from

Charlemagne, who is faid to have preferved his army from the plague by its ufe.

Carlowiz'ia (Bot.) P. N. from Garlowiz, an unknown, probably Polifh, botanift.

Carludovi'ca (Bot.) P. N. from Charles IF., of Spain, and Louifa, his gueen, noble patrons of botany; a genus of Compofitx. 
Carmeli'ta (Ent.) from the hoods of the Carmelite friars.

Carmelitoi'des (F.nt.) carmelita, $\tilde{E}$ ifos, like.

Carmicha'elia (Dot.) P. N. from Captain Dugald Carmichael, F.R.S., author of the "Flora of Triftan de Acunha;" a genus of Leguminof

$\left.\begin{array}{l}\text { Ca'rnea } \\ \text { Carnea'lis }\end{array}\right\}$ (Ent.) caro, carnis, flefh.

Carnea'go (Ent.) caro, carnis, fiefh.

Carneico'sta (Ent.) cameus, flefh-coloured, costa, the fide.

Carnei'gera (Ent.) caro, carnis, flefh, gero, to carry.

Carne'lla (Ent.) carneus, flehy, flefh-coloured.

Carne'ola (Ent.) dim. of carnets, flehy.

Carneomácula (Ent.) carneus, flefhy, macula, a fpot; having rofe-coloured wing-fpots.

Ca'rneus-a-um (Zool., Bot.) Lat. Aleh-coloured.

Ca'rnica (Ent.) carneus, flefhy; referring to colour.

Carno'sus-a-um (Zool., Bot.) Lat. Alethy.

Ca'rob (Bot.) Arabic, Kharroub. It is thought by fome that the thells of the Carob tree were the "huks" of the parable of the Prodigal Son.

Caroli'nea (Bot.) P. N. from Sophia Caroline, Margravine of Baden; a genus of Sterculiaceæ.

Caroline'nsis (Zool.) Lat. relating to Carolina, N. A.

Caroli'num (Ent.) carolus; French, carolin; Charles; given to a fpecies of

fpider (gen. Theridion) by Baron Walckenaar in honour of his fon

Charles, the difcoverer. Hilt. Ins. Apt. tom. II. $3^{16 .}$

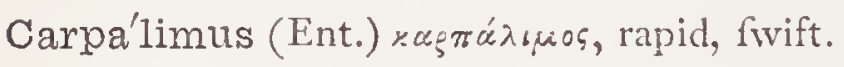

Carpe'1la (Bot.) xastos, fruit; the component cells of a compound fruit.

Carpe'sium (Bot.) Galen applies xagrírsov to an aromatic wood.

Ca'mphophis (Zool.) xásфos, a dry ftick, oфı, a ferpent; from refemblance to a $\log$ of wood; a genus of Colubrine ophidians.

Carpinicole'lla (Ent.) carpinus, the horn-beam, colere, to frequent, dim. term ella.

Carpi'nus (Bot.) faid to be from Celtic car, wood, pin, head: becaufe the Hornbeam was formerly ufed for making yokes.

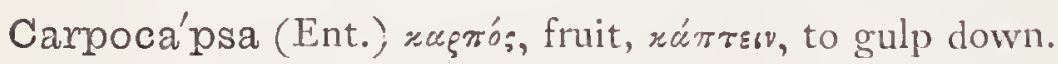

Carpo'dacus (Ornith.) rupros, fruit, dúxos, a bite; fruit-biter.

Carpod'inus (Bot.) xapwos, fruit, dıvos, a circle, from its round fruit: a genus of A pocynaceæ.

Carpodon'tos (Bot.) xapros, fruit, odovros, toothed, from the carpels being toothed at the apex; a genus of Hypericacex. 


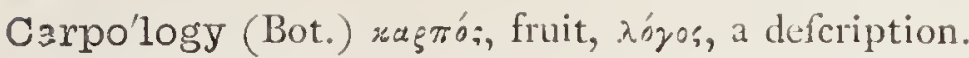

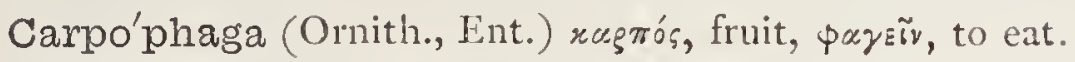

Carpo'philus (Ent.) $x \alpha_{\xi} \pi o_{s}$, fruit, $\phi\llcorner\lambda \varepsilon \omega$, to love.

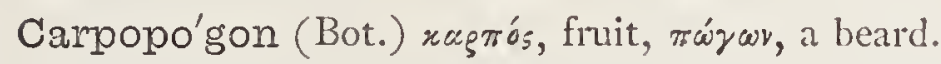

Carrich'tera (Bot.) etymology unknown; a genus of Cruciferæ.

Ca'rsia (Ent.) xúgsıs, croflwife; from its wing-markings.

Ca'rteri (Ent.) P. N. in honour of $M r$. Samul Carter. of Manchefter.

Ca'rthamus (Bot.) conftucted from the Arabic quortom, to paint: red paint having been prepared from the florets.

Ca'rum (Bot.) P. N. from Caria, in Afia Minor.

Caru'nculæ (Ornith.) Lat. little pieces of Alefh; the wattles of birds.

Cartone'ma (Bot.) «agrós, fhorn, vinea, a thread or filament.

Cary'chium (Zool.) $\alpha_{\xi}^{\prime} v \xi$, Dor. for $\varkappa \tilde{n}_{\xi} u \xi$, a herald.

Caryo'borus (Ent.) ráguov, a nut, bogós, devouring.

Caryocata'ctes (Ornith.) xúguov, a nut, xarágrup, to break in pieces: equiv. to mucifraga.

Caryophy'llia (Zool.) rupuov, a nut, $\phi u \lambda \lambda \circ v$, a leaf, the plates being confidered as a " nut of leaves;" a genus of Zoophytes.

Caryophy'llus (Bot.) the Carnation is fo called becaufe it imells like cloves.

Caryo'ta (Bot.) the Greek name of the cultivated date, fo named from the refemblance to a walnut, xép̧ov.

Ca'rythus (Ornith.) xáfuor, a nut; its food.

Cassentinie'llus (Ent.) P. N. from the infect being firft taken in the valley of Gafjentino, in Tufcany.

Ca'ssia (Bot.) from Arabic katfa, to tear off; from the bark being ftripped off the tree.

Ca'ssicus (Ornith.) rarevw, to few together: from its interweaving vegetable fibres to form a penfile nert.

Ca'ssida (Ent.)

Cassida']is (Ent.) refembling cafyda in fome refpects.

Cassi'didæ (Ent.) cafida, fam. term. ida.

Cassi'ne (Bot.) its name among the Indians of Florida.

Cassi'nia (Ent.) P. N. in honour of Fohn Dominic Gafini, the aftronomer.

Cassínia (Bot.) P. N. from M. Henri Cafmi, a celebrated French botanift.

Cassiope' (Ent.) P. N., the mother of Andromeda.

Ca'ssis (Zool.) Lat. a helmet; the helmet-fhell.

Ca'ssytha (Bot.) the Greek name of the Dodder, which it refembles. 
Casta'lis (Ent.) caftus, pure.

Casta'lia (Bot.) Lat. pure; the white water-lily.

Casta'nea (Bot.) Lat. a cheftnut tree; it took its name from a town of 'Theflaly.

Castanospe'rmum (Bot.) the feeds tante like chentnuts; a genus of Leguminofx.

Caste'lea (Bot.) P. N. from $M$. Cafel, author of a poem upon plants.

Castiga'ta (Ent.) caftigatus, fmall, flender.

Castille'ja (Bot.) P. N. from Don Caftilleja, a Spanilh botanilt.

Calstor (Zoo!.) Lat. a beaver.

Castori'na (Zool.) caftor; a fub-family of Mammalia.

Castre'nsis (Ent.) Lat. living in a camp: the larva being gregarious.

Ca'stus-a-um (Zool., Bot.) Lat. chafte.

Casuari'na (Bot.) from fuppofed refemblance to the feathers of the Callowaly.

Casua'rius (Ornith.) a genus of Birds.

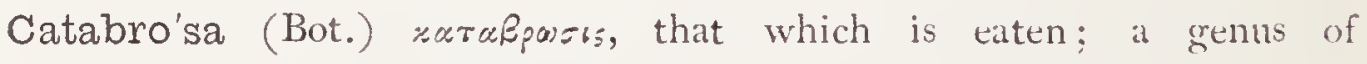
Gramina.

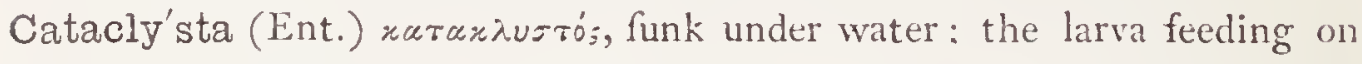
aquatic plants.

Cata'lpa (Bot.) an Indian name.

Catanan'che (Bot.) rataváyzn, ftrong incentive; formerly ufed in philtres, or rather the plant mentioned by Diofcorides, which cannot now be identified.

Cata'phanes (Ent.) raтał̧arńs, clearly feen, vilible.

Cataphra'cta (Zool.) жarappartos covered up, thut in: the lhielded reptiles.

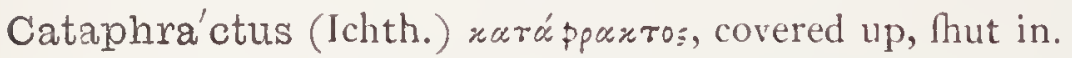

Catarra'ctes (Ornith.) xarappáxтns, broken, precipitous: from «arapp'izrupr, to break in pieces.

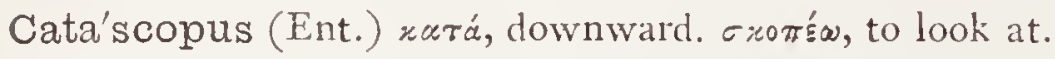

Catase'tum (Bot.) $\%$ crix, downward, feta, briftle; from the two horns of corolla.

Cata'stomus (Ichth.) xúrw, downwards, eróse, a mouth.

Cate'1la (Ent.) Lat. a little chain.

Cate'na (Ent.) Lat. a chain; alfo, in Botany fp. name of a Diatom.

Catena'lis (Ent.) catona, a chain.

Catene'lla (Bot.) dim. of catent, a chain; a genus of C'ryptogamia.

Cateno'sa (Ent.) catenu, a chain. 
Cate'phia (Ent.) жатафís, downcalt, obfcure.

Catephi'idx (Ent.) catephia, fam. tern. idc.

Catephioi'des (Ent.) catephia, ordos, refemblance.

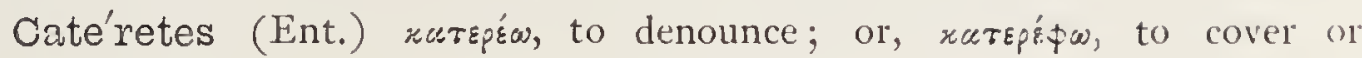
roof?

Catesbra (Bot.) P. N. in honour of $M$. Cateby, author of the Natural Hiftory of Carolina.

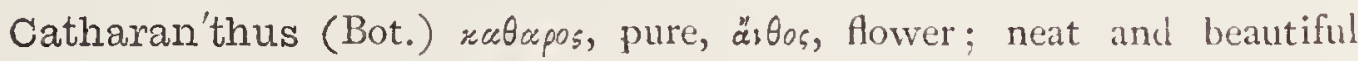
fowers; a genus of Apocynacex.

Catha'rtes (Ornith.) nataprńs, a cleanfer, or purifier; applied to certain vultures."

Cathartice'lla (Ent.) feeds on Rhamnus catharticus, buckthorn.

Cathartocar'pus (Bot.) rutcipw, to purge, rapwos, fruit; a genus of Leguminofx, to which the purgative caffia belongs.

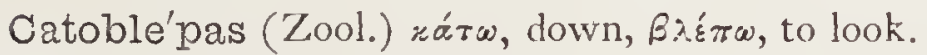

Cato'cala (Ent.) xúrs, below, xaros, beautiful, alluding to the underwings.

Catoca'lidæ (Ent.) catocala; a family of Lepidoptera.

Catocaloi'des (Ent.) catocala, eidos, refemblance.

Ca'todon (Ichth.) xárw, below, ofovo, edsvros, a tooth; having tecth in the lower jaw.

Catodon'tidæ (Ichth.) the family of Toothed whales, of which preceding is the type.

Catophrag'mus (Zool.) rarú, againft, фpáyucu, a defence ol protection.

Cato'ps (Ent.) xárw, below, $\ddot{\psi} \psi$, the face.

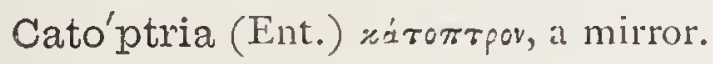

Ca'ttleya (Bot.) P. N. fo called by Dr. Lindley, in honour of $W$. Cattley, ESq., of Barnet, Hertfordhire.

Cauca'iis (Bot.) a Greek name ufed by 'Theophraftus, now applied to the Bur parfley.

Caudacu'ta (Ornith.) cauda, a tail, acutus, fharp.

Cauda'na (Ent.) eauda, a tail.

Cauda'tus-a-um (Zool., Ornith., Bot.) having a tail, tailed.

Caude'lla (Ent.) cauda, a tail, dim. ella.

Caudimacula'tum (Ichth.) cauda, a tail, maculatus, fpotted.

Caudivol'vulus-a-um (Zool.) canda, a tail, volvere, to curl.

Caule'rpa (Bot.) caslis, a ftem, Ëprw, to creep; a genus of Cryptogamia.

Caule'rpites (Fos. Bot.) fame etymology; a fofil genus alliced to former. 
Cau'liflower (Bot.) caulis, a ftem, flos, a flower; $i . c$. the flowering ftem or ftalk.

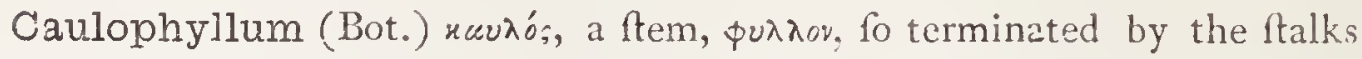
that the leaves feem to be a continuation of the ftem: a genus of Berberaceæ.

Cau'sus (Zool.) xuṽos, a burning heat, referring to its bite; a genus of Ophidians.

Cau'ta (Ent.) cautus, fafe, fecure, cautious.

Cave'lla (Ent.) cavus, hollow.

Caverno'sa (Ent.) cavernofus, having hollows.

Ca'via (Zool.) a genus of Mammalia.

Cavoli'na (Zool.) cavus, hollow, full of holes.

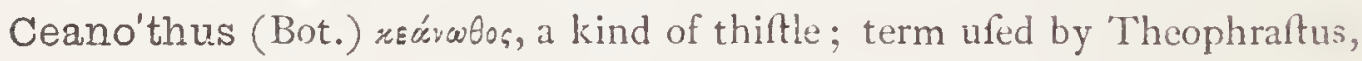
from $x \varepsilon \omega$, to cleave.

Ce'bidæ (Zool.) cebus, fam. term. ida; a family of Mammalia.

Ceblepyri'næe (Ornith.) ceblepyris, the Red Caps; a fub-family of the Inceflores.

Ceblepy'ris (Ornith.) xikzn for $x \varepsilon ф u \lambda n^{\prime}$, the head, $\pi \tilde{\nu}_{\tilde{\gamma}}$, fire: from the bright colour of the head; the Red Caps.

Ce'brio (Ent.) a genus of Coleoptera.

Cebriónidæ (Ent.)

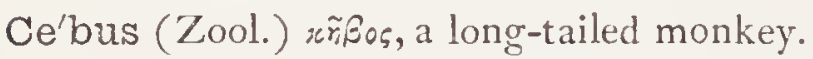

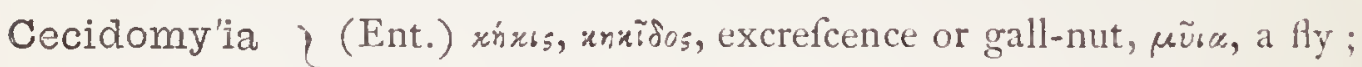
Cecidomy'idz) a genus and family of Diptera.

Cecro'pia (Bot.) P. N., fo called from Cecrops, King of Athens, whofe legs were fabled to be fnakes; fnake-wood.

Cecro'pide (Zool.) Cicrops, fam. term. ide; a family of Entomoftaca. Cecróps (Zool.)

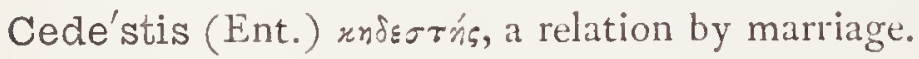

Cedre'la (Bot.) cedrus, the cedar-tıee; from its aromatic refin.

Cedrela'cere (Bot.) the mahogany-tree family, of which cedrela is the type.

Ce'drus (Bot.) Hebrew name Latinized. Brook Cedron?

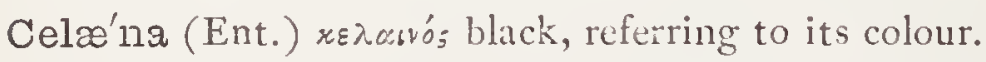

Cela'ndine (Bot.) derived from the name of Chelidonium, given to it by Gerarde and Parkinfon, becaufe the plant which comes in bloom when the $\chi \chi^{2}$ són, $^{2}$ (fwallow) appears.

Celastra'cere (Bot.) the family of spindle-trees, of which celufurs is the type 
Celas'trus (Bot.) xń $\lambda \alpha \sigma \tau p o s$, an evergreen tree, according to fome, privet, to others, holly; now applied to the Spindle tree.

Cela'ta (Ent.) part. of celo, to conceal; concealed.

Celebe'nsis (Zool.) Lat. relating to the illand of Celebes.

Celerel'la (Ent.) celer, fwift, dim. term. ella.

Celer'io (Ent.) celer, fwift; applied to one of the Hawk-moths.

Ce'lery (Bot.) from $\sigma \underline{s} \lambda$ เvev?

Ce'lia (Ent.) x'́n:s, a fpot.

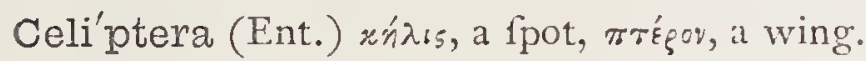

Cellepo'ra (Zool.) cella, a cell, porus, a pore or little pole; a genus of Polyzoa.

Cellepo'ridæ (Zool.) cellepora, fam. term. ide; a family of Polyzoa.

Cellulla'lis (Eni.) cellula, a little chamber.

Cellula'ria (Zool. cellula, a little cell or chamber; a genus of Polyzoa.

Celo'sia (Bot.) жnגos, burnt; the flowers of fome fpecies appear finged; a genus of Amarantaceæ.

Ce'lsia (Ent., Bot.) P. N. from Olaus Gelfus, Greek Profeflor at Upfal, a friend of Linnæus.

Ce'ltis (Bot.) one of the names antiently given to the lotus; applied by Tournefort to a genus of the modern Ulmacex.

Cembra'lis (Ent.) from the Pinus Cembra, being found on fir-trees.

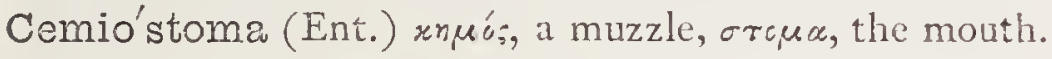

Ce'monus (Ent.) rr,ós, a muzzle; a genus of Hymenoptera.

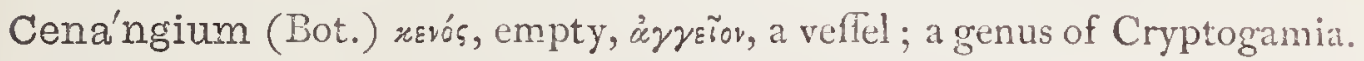
Ce'nchris (Zool.) a genus of Ophidians.

Ce'nchrus (Bot.) xérxpos, the Greek name of the Millet Latinized: a genus of Gramina.

Cenia (Bot.) xnros, empty? from inflated calyx; a genus of Compofitx.

Cenocoćcum (Bot.) rrvos, empty, noxros, a berry; a genus of Fungi.

Cenomy'ce (Bot.) *uros, empty, and $\mu$ vn, a fungus; from the little hollow receptacles; a genus of $\mathrm{Lichenes.}$

Centau'rea (Bot.) xerruvęí, the herb centaury.

Centaurea'ta (Ent.) feeds on Centaurea fcabiofa.

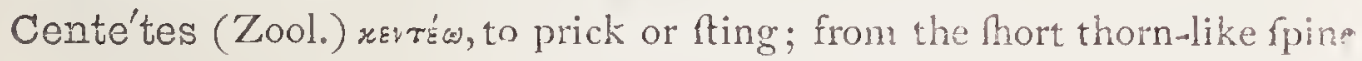
on the body.

Centothe'ca (Bot.) xevratr, to prick, and Gnxa, a fheath; a genus of Gramina.

Centran'thus (Bot.) xstrpor, a fpur, arson, a flower; the fpurred corolla; a genus of Valerianacea. 
Ce'ntris (Ent.) a genus of Hymenoptera.

Centri'scus (Ichth.) $x \varepsilon_{5} \tau_{5}$ 'b $\omega$, to prick; the 'Trumpet-fin.

Centrocar'pha (Bot.) xevrpov, a Tharp point, xupфn, chaff; the palex being briftly; a genus of Compofitz.

Centrocli'nium (Bot.) xevrpov, a point, $x \lambda_{6} n$, a bed; a genus of Compofitæx. Centroglo'ssa (Ent.) rívtgov, a Tharp point, $\gamma \lambda \tilde{\omega} \sigma \sigma \alpha$, the tongue.

Centrolo'phus (Ichth.) x'stgov, a tharp point, $\lambda \dot{s} \phi o s$, the back of the neck; the Blackfish.

Centropo'mus (Ichth.) xévт ̧̧ov, a point, $\pi \tilde{\omega} \mu \alpha$, a lic or cover; a genus of the family Percidx.

Centropri'stes (Ichth.) x'vr pov, a prick, zporsís, the faw-fifh.

Centro'pus (Ornith.) uśrgov, a fpur, roũs; from the great length of the claw of the hind toe.

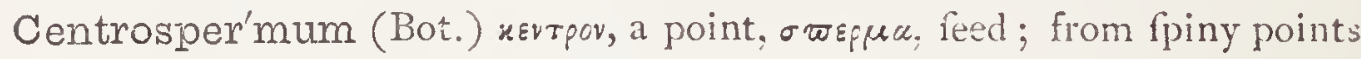
of pappus; a genus of Compofitz.

Centrou'rus (Ornith.) xérţ̧ov, a fharp point, oṽga, the tail; it thould be centrurus.

Centru'rophis (Ichth.) x'́vтpov, a point, cúpá, a tail, ö\$sś, a ferpent.

Centu'nculus (Bot.) Lat. a genus of Primulacex.

Centu'rio (Zool.) Lat. a commander; applied to the Epaulet bat.

Centu'rus (Ornith.) xérrpov, a point, oṽpá, a tail; a genus of Woodpeckers Ce'pa (Bot.) from caput, the head; in allufion to its round form; the Onion. Cephae'lis (Bot.) from жєфuди́, a head; it flowers in heads or bunches.

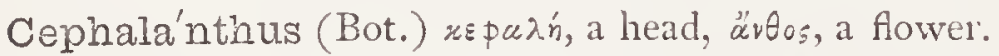

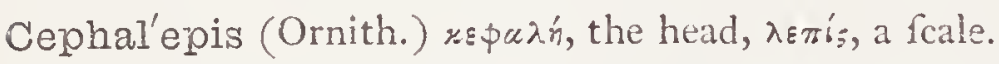

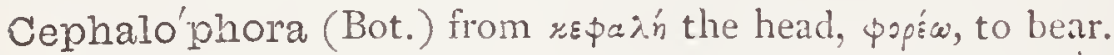

Cephalo'phorus (Zool.) $x \varepsilon q a \lambda \dot{n}$, a head, $\phi^{\varepsilon} p \omega$, to bear or carry.

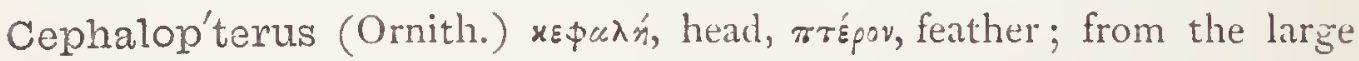
and fpreading creft; the Umbrella bird.

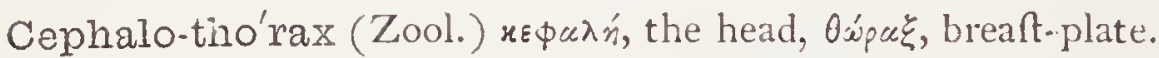

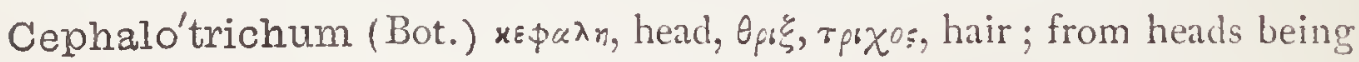
covered with hair; a genus of Fungi.

Cephalo'tus (Bot.) $x \varepsilon ф а \lambda о \tau \eta_{s}$, headed. capitate ftamens, being type of order Cephalotaceæ.

Ce'pola (Ichth.) etymology unknown.

Cera'go (Ent.) cera, wax.

Cerambi'cidæ (Ent.) cerambyx, fam. term. ids.

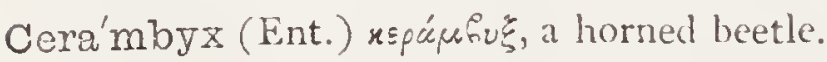

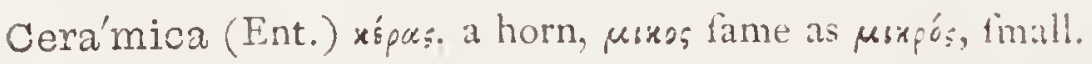


Cerami'dium (Bot.) ceramium, हi่ os, form.

Cera'mium (Bot.) xepúurov, a pitcher; it has the appearance of capfules; a genus of Algx.

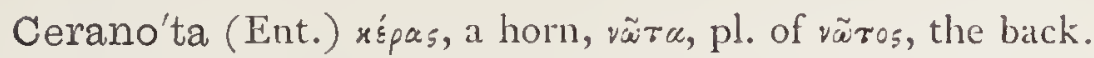

Ceranthera (Bot.) xepas, a horn, ur $\theta$ np; from the horned lobes of anthers:

a genus of Violacea.

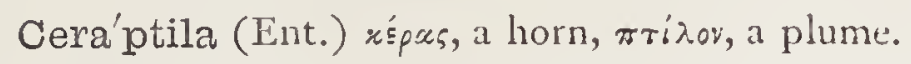

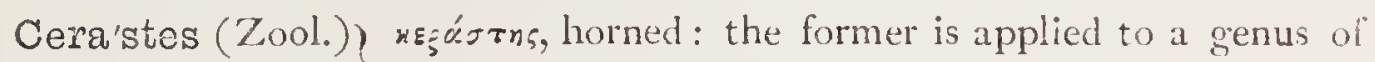
Cera'stis (Ent.) $\}$ Ophidians; the latter, to a beetle.

Cera'stium (Bot.) xépas, a horn.

Cera'sus (Bot.) firft brought from Cerafus, a town of Afia Minor; the cherry.

Cera'tiola (Bot.) xr,pcsıง, a little horn, which the Atigma refembles: it genus of Empetracex.

Ceratiso'len (Zool.) xepós sov, a pod, $\sigma a \lambda \dot{x}$, the lazor-fhell.

Cera'tium (Bot.) fame derivation; a genus of Fungi.

Ceratoca'rpus (Bot.) xépus-atos, a horn, xaptrós, fruit

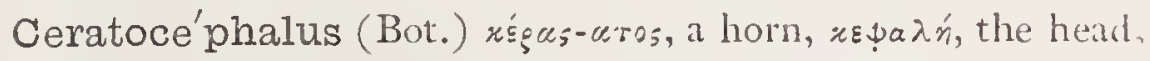

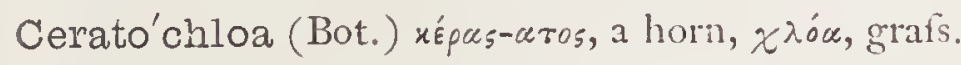

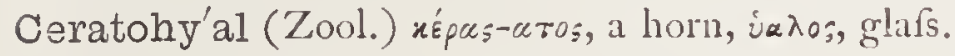

Cerato'nia (Bot.) xépas-aros, a horn: it has horn-like pods.

Ceratoniel'la (Ent.) xépos-uros, a hom, diim. term. ellu.

Ceratope'talon (Bot.) xépa;-aros, a horn, trera.hov, from the form if petals; a genus of Cunoniacex.

Cerato'phorus (Ent.) xípss-aros, a horn, \$épa, to bear; a genus of Hymenoptera.

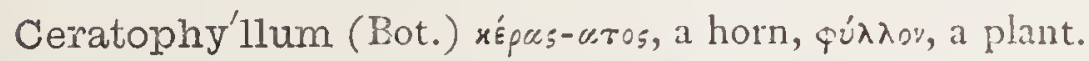

Ceratosa'nthes (Bot.) xépas- $\alpha_{r o s}$, a horn, $\alpha_{1} \theta_{0}$, from the form of petals: a genus of Cucurbitacex.

Ce'rbera (Bot.) P. N. from Cerberus, the famous dog of Mythology; from being poifonous; a genus of Apocynacex.

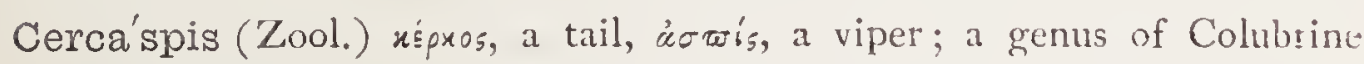
ophidians.

Cerceris (Ent.) a genus of Hymenoptera.

Ce'rcis (Bot.) xepris, a name uied by Theophraftus; its common name, Judas-tree, is derived from its having been fuppofed to be the tree upon which Judas hanged himfelf; but Gerarde gravely aftures us that this was not the cafe, as he hanged himfelf on an Elder !

Cercoce'bus (Zool.) xépros, a tail, xñ̄os, a monkey. 


\section{Cercocelus \\ Chœrop'sis $\}$ (Zool.) a genus of Quadrumana. \\ Cephalophus}

Cercola'bes (Zool.) xépros, a tail, $\lambda \omega^{\prime} \dot{n}^{\prime}$, a handle.

Cercole'ptes (Zool.) xépros, a tail, $\lambda \leq \pi \tau_{0} o_{-}$, flender.

Cerco'monas (Zool.) xeprós, a tail, monas; a genus of Infuforia.

Cercopithe'cus (Zool.) xípros, a tail, mînnos, a monkey.

Ce'rcyon (Ent.)

Cere'lla (Ent.) cera, wax; from the larva being found in bees' neits.

Cereo'psis (Ornith.) xnpós, wax, ö $\downarrow$ เ , refemblance.

Cere'sia (Bot.) P. N. from Ceres, inventrefs of tillage; a genus of Gramina.

Ce'reus (Bot.) cereus fignifies pliant, like wax, from cera, wax; being eafily bent in fome fpecies; a genus of Cactacex.

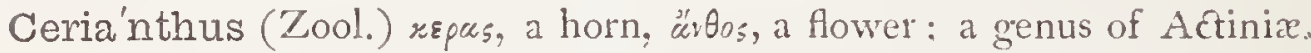

Ceri'go (Ent.) P. N., the modern name of the ifland of Cythera.

Ceri'ntha (Ent.) xnpós, wax.

Ceri'nthe (Bot.) unpós, wax. Bees obtain a large fupply of wax from it

Cerio'rnis (Ornith.) xépas, a horn, öpus, a bird: the Horned pheafant of Nepaul.

Cerithi'idæe (Zool.) cerithium, fam. term. ide.

Ceri'thium (Zool.) etymology uncertain; a genus of Mollufca.

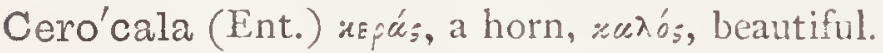

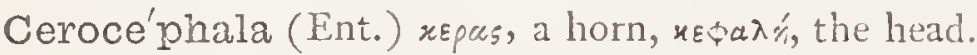

Cero'coma (Ent.) xépac, a horn, xóun, hair, from peculiarity of antenna:

a genus of Coleoptera.

Cero'macra (Eut.) xépas, a horn, uaupós, long.

Cero'pales (Ent.) xrpós, wax, $\pi \dot{a} \lambda n$, fine meal; a genus of Hymenoptera,

Ceropégia (Bot.) xnpos, wax, mrýn, a fountain.

Cero'phytum (Ent.) xnṕśs, wax, фũ̃ós, a plant.

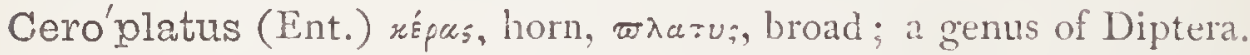

Cero'stoma (Ent.) xnpos, wax, orísu, a mouth.

Cero'xylon (Bot.) znpó, wax, छúrov, wood: the Wax-palm of South

America.

Certa'ta (Ent.) certus, eftablimed, fure

Ce'rinia (Ornith.) Lat. for a tree-creeper.

Certhi'idxe (Ornith.) cortha, fam. tem. ide: the Creeper hantis

Certhila'uda (Onith.) certhia, wher, a lark.

Ce'rthiola (Ornith.) dim, of the preceding: 
Cerusico'sta (Ent.) ceruffi, white lead, cofta, the fide.

Cerusse'lla (Ent.) ceruffa, white lead, cerve, alluding to colour.

Cerusse'llus (Ent.) cerufa, white lead, referring to colour.

Cerva'lis (Ent.) cerva, a doe; being fawn-coloured.

Cervante'sia (Bot.) P. N. after the celebrated Cervantes; a genus of Santalaceæ.

Cervica'pra (Zool.) cervus, a ftag, capra, a goat.

Cervi'na (Zool.) cervus, a ftag; a fub-family of Mammalia.,

Cervina'ria (Ent.) cervinus, belonging to a deer, either from its fawn-colour, or from fome refemblance of the markings to ftags' horns.

Cervi'nus-a-um (Bot.) pertaining to a deer.

Ce'rvus (Zool.) Lat. a ftag.

Ce'rylon (Ent.) xદ́pas, a horn, ởวss, entire.

Cespita'lis (Ent.) cefpes-itis, turf.

Cespiti'colis (Ent.) cefpes-itis, turf, colo, to inhabit.

Ce'spitis (Ent.) ceppes, cespitis, turf; on which it feeds.

Ce'stode (Zool.) xєsrós, a girdle, or band.

Cestoi'dea (Zool.) refembling ceftode.

Cestra'cion (Ichth.) xéstpx, a fifh held in efteem among the Greeks, doubtful whether a pike or a conger; now ufed for the New Holland harks.

Cestri'nus (Bot.) P. N., the fon of Hector and Andromache; a genus of Compofitx.

Ces'trum (Bot.) x's spor, the name applied by Diofcorides to the Betony. Ce'te (Zool.) xйros, or xйтn, a whale; an order of Mammalia.

Ce'terach (Bot.) Arab. and Pergan chetherak, French ceterac, Wellh cedory urach, the double rake; a genus of Ferns.

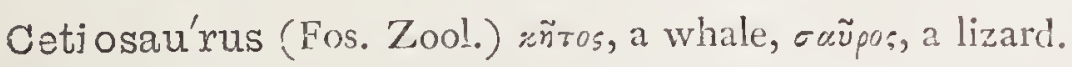

Cetockilididæ (Zool.) xr̃ros, a whale, $\chi \bullet \lambda_{\circ}$ s, food; a family of Entomoftraca.

Cetóchilus (Zool.) xйros, a whale, $\chi \lambda^{\circ} \dot{o}_{s}$, food; a genus of Entomoltraca.

Cetónia (Ent.) unexplained.

Cetoni'idze (Ent.) cetonia, fám. term. idce.

- Cetrária (Bot.) cetra, a buckler; a genus of Lichenes.

Ceuthoca'rpus (Bot.) кеú $\theta \omega$, to hide, raprós, fruit.

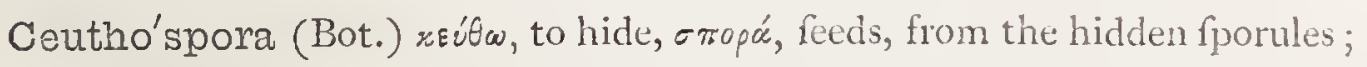

a genus of Fungi.

Ceutorhy'nchus (Ent.) us: $\theta \omega$, to hide, firxos, a bsak.

Chabro'lii (Ichth.) P. N. from the celebrated M. Chabrol, 
Chae'ma (Zool.) native Hottentot name of a baboon.

Chærophylla'ta (Ent.) feeds on Chorophyllum fylveftre, the Cow parfley. Chærophylle'llus (Ent.) dim. of charophyllum, the plant which it frequents. Chærophy'lli (Ent.) feeds on Charophyllum temulentum, rough Cow parley.

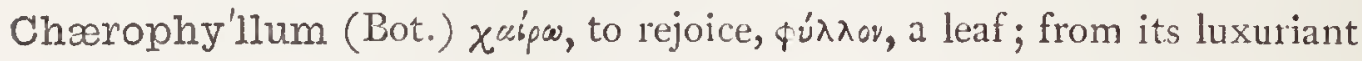
foliage.

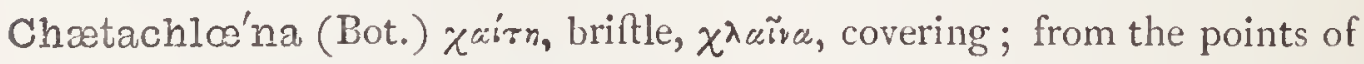
involucre being concealed; a genus of Compofitx.

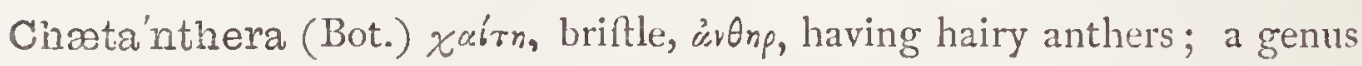
of Compofitæ.

Chrta'ria (Bot.) xuirn, brifle; a genus of Gramina.

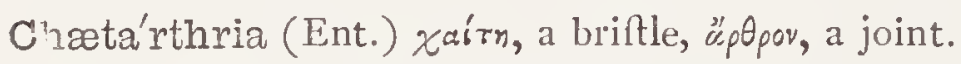

Chæto'calyx (Bot.) xuín, briftle, $\varkappa ⿻ \lambda v \xi$, calyx; covered with brifles; a genus of Leguminofx.

Chætocne'ma (Ent.) xuirn, a briftle, xrm, nn, the leg.

Chæ'todon (Ichth.) xairn, a mane, ódov's, odorros, a tooth.

Chætodo'ntidæe (Ichth.) chetodon, fam. term. ide; a family of Acanthopterygious filhes.

Chatoga'stra (Bot.) Xairn, briftle, yarrinp, the belly; the tube of calyx briftly; a genus of Melaftomacez.

Chæto'mium (Bot.) xairn, briftie ; from the hairy appearance; a genus of Fungi.

Ch'æetomys (Zool.) xuín, long flowing hair, sĩs, a moufe.

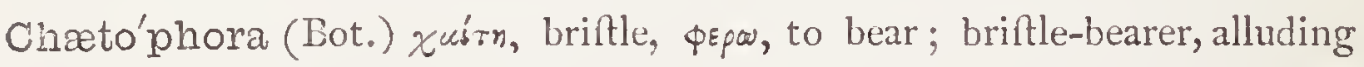
to the form; a genus of Alga.

Chato'phora (Bot.) xairn, a briltle, tépw, to bear, from the branched filaments; a family of Confervoid algx.

Chætophora'ceæ (Bot.) chatophora, fam. term. acee.

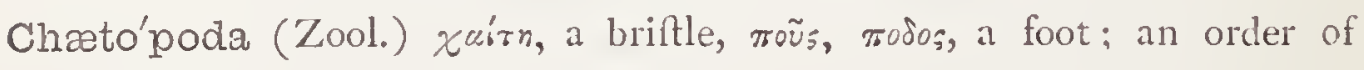
Annelida.

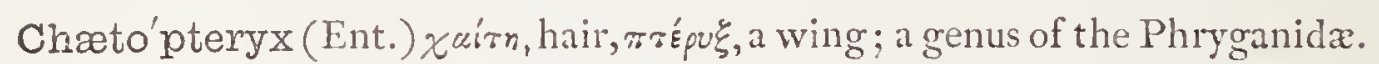
Chæeto'spora (Bot.) xuirn, a briftle, блopó, feed; a genus of Algre.

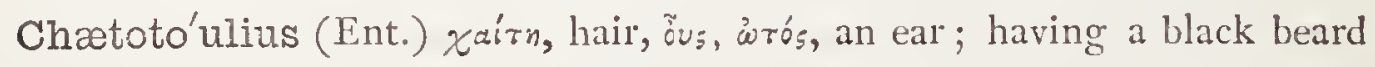
on the apex of the polterior wings.

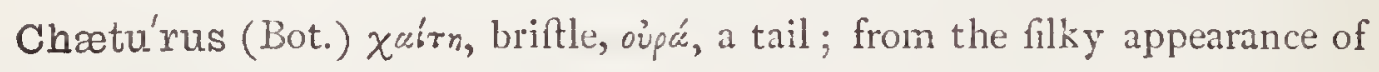
panicle; a genus of Gramina.

Chagri'nea (Ichth.) Lat. Thagreened.

Chaille'tia (Bot.) from M. Ghaillet, a Swifs botanift; the typical genus of Chailletiacex. 
Chalcedónia (Ent.) xá̇xn, a purple colour.

Chalcedo'nicus-a-um (Bot.) the colour of Chalcedony.

Cha'lcidæ (Zool.) chalcis, fam. term. ida.

Cha'lcidæ

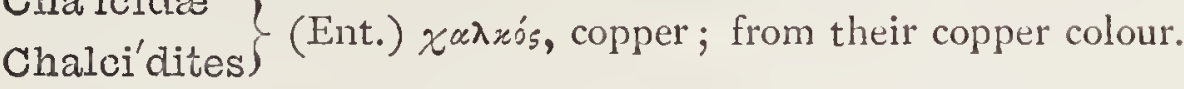

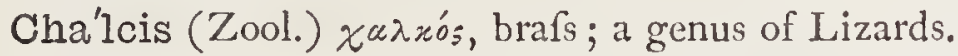

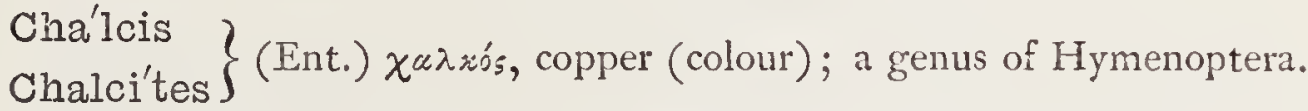

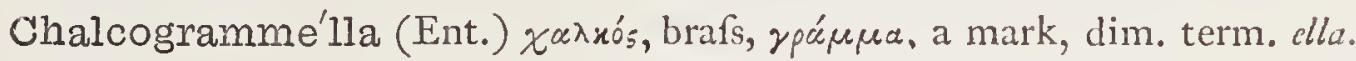

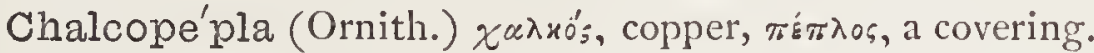

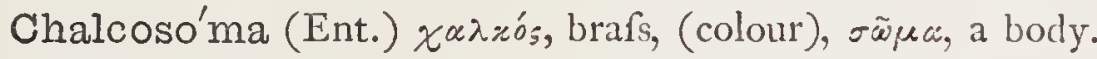

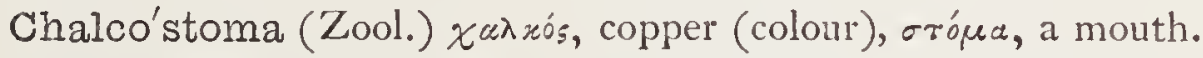

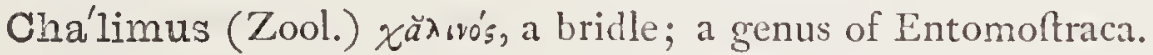

Chalybæ'us (Ornith.) $\chi a$ av $\psi$-vßos, fteel, from the metallic colours of the Birds.

Cha'lybe (Ent.) $\chi x^{\prime} \lambda \nu \psi-v \beta_{0 s}$, hard iron or fteel; referring to colour.

Cha'ma (Zool.) $\chi^{\text {nn } \mu n, ~ a ~ c o c k l e, ~ w h i c h ~ f r o m ~} \chi \alpha$ irw, to gape; a genus of Mollufca.

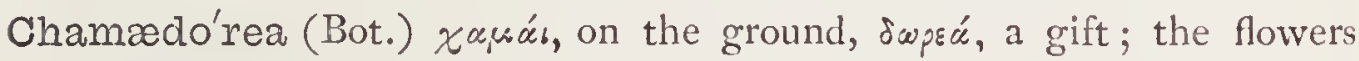
hanging low.

Chamæ'drys (Bot.) $\chi \alpha \mu a$, $^{\prime}$ on the ground, $\delta \rho \tilde{z}$, the oak; the germander is named Teucrium Chamcedrys.

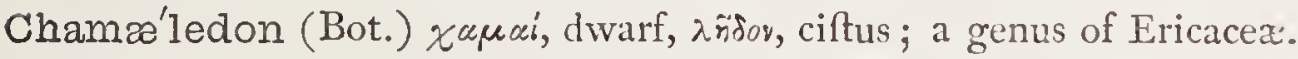

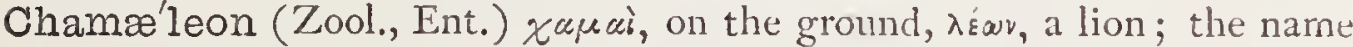
is not apt either to the lizard or the infect; when applied to the latter, the reference is to its varying in colour.

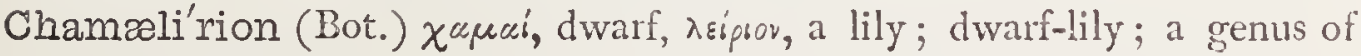
Melanthaceæ.

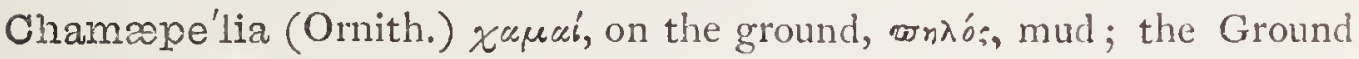

Dove. The latter part of the name probably from its afhy-brown colour.

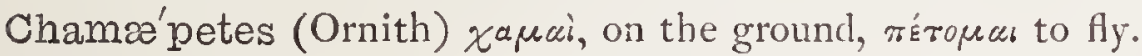

Chamæe'pitys (Bot.) xafui, on the ground, mirvs, the pine-tree.

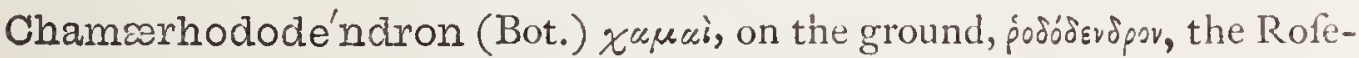
laurel.

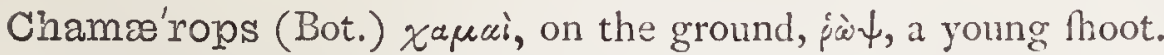

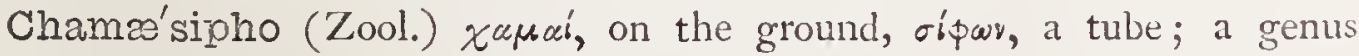
of Cirripedes.

Cha'mecls (Zool.) native name of a monkey of the family Cebidx; Ateles Chameck. 


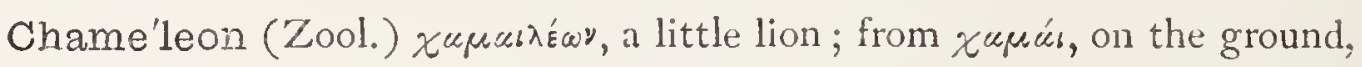
$\lambda \dot{\varepsilon} \omega v$, a lion.

Cha'midre (Zool.) a family of Mollufca of which chama is the type.

Chamiss'oa (Bot.) P. N. from M. Chamiffo, a celebrated botanift; a genus of Amarantaceæ.

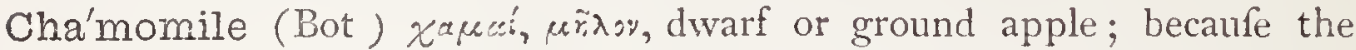
plant fmells like apples, or rather like quinces.

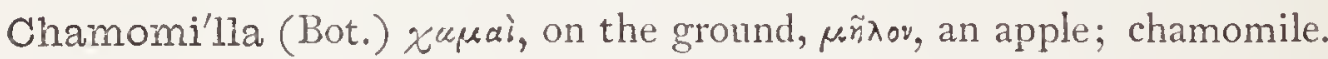

Chamomi'llæ (Ent.) feeds on the Chamomile.

Chamo'strea (Zool.) chama, a genus of thells, ofrea, the oyfter; a genus of bivalve Moilufca.

Chao'nia (Ent.) P. N, a diftrict in Epirus.

Chapta'lia (Bot.) P. N. from M. Chaptal, a famous French chemif.

Cha'ra (Bot.) xuipw, to delight; it delights in water; a genus of Cryptogamia.

Charadri'nidæ (Ornith.) the Plovers; charadrius, fam. term. ina.

Chara'drius (Ornith.) xapajsios, dwelling in clefts or gullies; the curlew.

Charze'as (Ent.) xúzss, grace; beauty of thape.

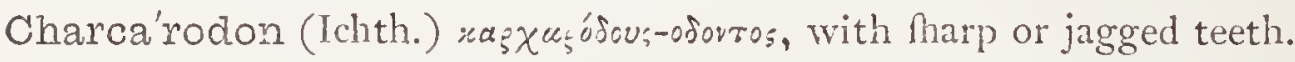

Charicle'a (Ent.) P. N. from Charicles, a tyrant of Athens.

Chari'dea (Ent.) chara, ểंos, refemblance.

Charip'tera (Ent.) chara, tręór, a wing, i. e. refembling that genus.

Charlwo'cdia (Bot.) P. N. from G. Charlwood, Efq., F.L.S., an enthufiafic Englih botanif; a beautiful genus of Liliaceæ.

Charmos'yna (Ornith.) a beautiful parrot.

Charter'gus (Ent.) xáprns, paper, Ěprov, work; becaufe this Hymenopterous infect makes its neft of a fubftance like paper.

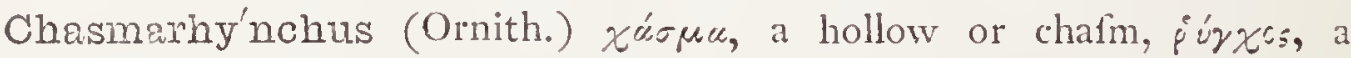
beak.

Chasmo'nia (Bot.) $\chi a \sigma \mu \alpha a \omega$, to gape wide, from the expanded calyx; at genus of Labiatæ.

Chau'liodes (Ornith.) $\chi \chi^{\alpha} u \lambda_{s c r}$, gaping.

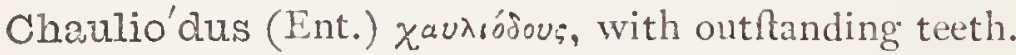

Cha'una (Ornith., Ent.) xã̃vos, gaping.

Chaunomuræ'na (Ichth.) xeũvos gaping, rúpesve, an eel.

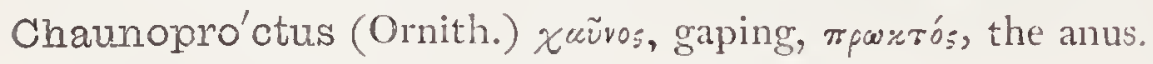

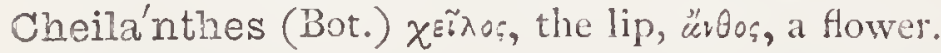

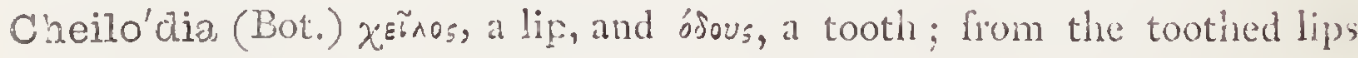
of the corolla; a genus of Iabiate. 
Cheiloglo'ttis $\chi^{\varepsilon \tilde{\imath} \lambda \sigma_{s}}$, lip, $\gamma^{\lambda \tilde{\omega} \tau \tau u, ~ t o n g u e ; ~ t o n g u e-l i k e ~ a p p e n d a g e ~ t o ~ t h e ~}$ lip of corolla; a genus of Orchidacex.

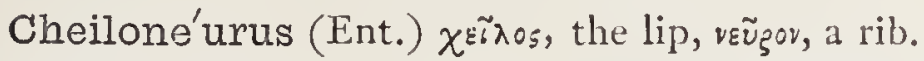

Cheimatobi'a (Ent.) $\chi \varepsilon \tilde{i} \mu \alpha, \alpha \tau o s$, winter, Bios, life ; appearing in winter.

Cheira'nthus (Bot.) $\chi$ kip, the hand, üvos, a flower; becaufe fuited for carrying in the hand? ol perhaps from Arabic, kheyrey, and "̈voos, a flower.

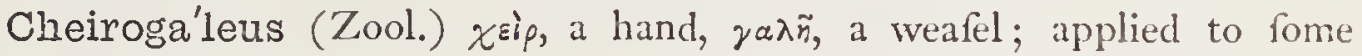
quadrumanous Lemurs.

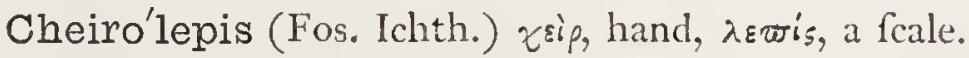

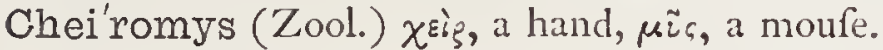

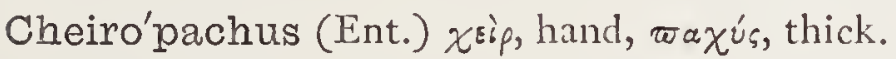

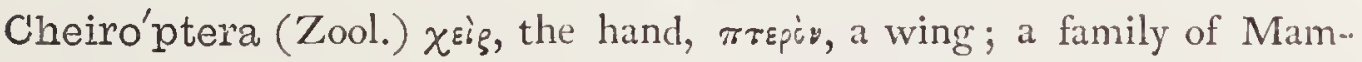
malia; the Bats.

Cheiroste'mon (Bot.) from the friking refemblance of the fine erect anthers to the fingers of a hand.

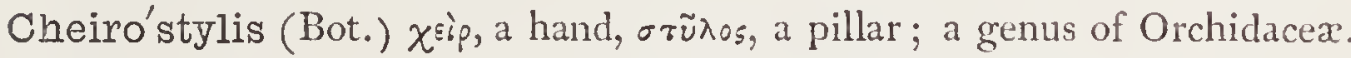

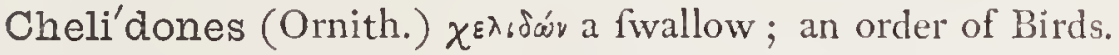

Chelido'nium (Bot.) $\chi^{\varepsilon \lambda}$ s $\delta$ 's, the fwallow; in allufion to its time of flowering.

Chel'ifer (Zool.) $\chi \eta \lambda \dot{n}$, a claw, $\phi^{\prime} \xi_{\xi} \omega$, to bear.

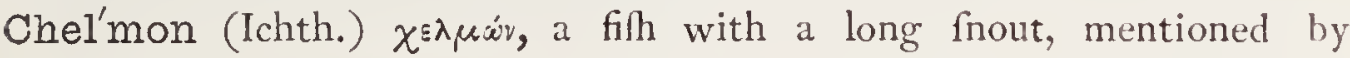
Ariftotle.

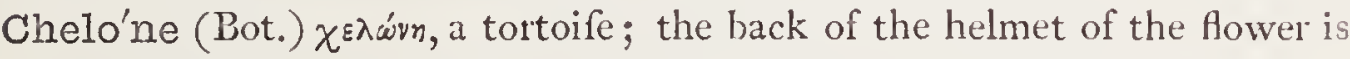
compared to a tortoife.

Chelo'nia (Zool.) $\chi \varepsilon \lambda a ́ r n$, a tortoife; an order of Reptilia.

Chelo'nia (Ent.) $\chi £ \lambda$ ávias, a fpotted beetle.

Cheloni'idæ (Ent.) chelonia, fam. term. ide ; a family of Lepidoptera.

Chelono'bia (Zool.) $\chi \varepsilon \lambda \omega^{\prime \prime n}$, a Mell, Bios, exiftence; a genus of Cirripedes.

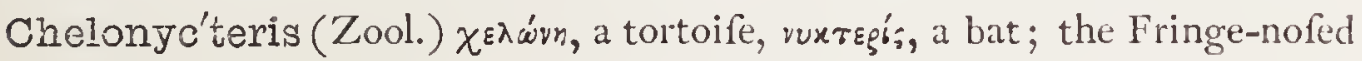

bat.

Chelo'stoma (Ent.) a genus of Hymenoptera.

Chely'dra (Zool.) $x^{\varepsilon} \dot{\lambda}$;, a tortoife, i $\delta \rho x$, a water-ferpent.

Che'lys (Zool.) $\chi^{\prime} \dot{\lambda} \nu_{s}$, a tortoife.

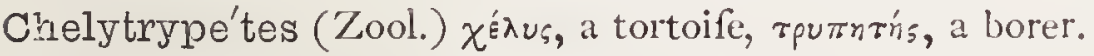

Chen (Ornith.) $\chi^{\prime n}$, a goofe.

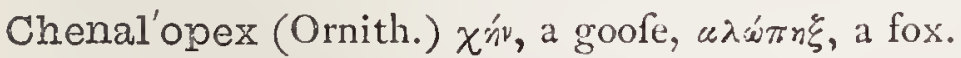

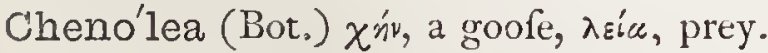

Chenopodiel'la (Ent.) chenopodium the goofe-foot, on which it feeds. 
Chenopodi'pohaga (Ent.) chenopodium, $\phi \dot{\alpha} \gamma \omega$, to eat; alluding to the infects' food.

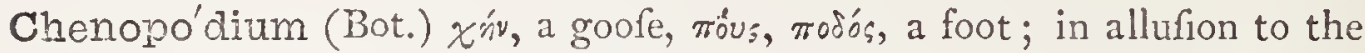
Thape of its leaves; the plant goofefoot.

Cherle'ria (Bot.) P. N. from Fohn Henry Cherler, who affifted John Baukin in the compilation of his Hiftory of Plants; a genus of Caryophyllaceæ.

Cherry (Bot.) is from Gerafus, in Afia Minor.

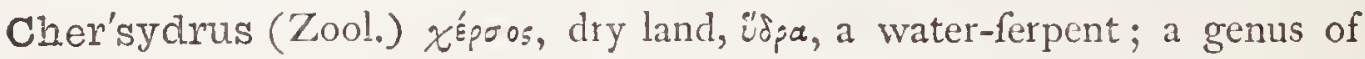
Ophidians.

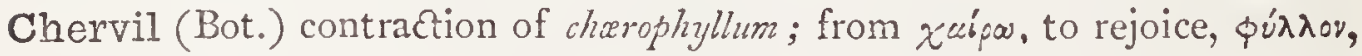
a leaf; luxuriant foliage.

Che'sias (Ent.) P. N. a name of Diana.

Chesnut (Bot.) Lat. cafanea.

Che'taln (Zool.) a native name.

$\mathrm{Chi}^{\prime}$ (Ent.) from a wing-mark refembling the Greek letter $\chi$.

Chicken (Ornith.) Anglo-Sax. cicen; Germ. kucklein.

Chicory (Bot.) Arabic, chikouryeh.

Chilidæ (Ent.) chilo; a family of Lepidoptera.

Chilien'sis (Zool., Ent.) relating to Ghili.

Chilo (Ent.) $\chi \varepsilon \tilde{\varepsilon} \lambda_{05}$, a lip; from the elongated palpi.

Chilobo'thrus (Zool.) xeìos, a lip, Bópos, a hole; a genus of Ophidians.

Chiloch'loa (Bot.) $\chi^{6} \lambda_{o}^{\prime}$, fodder, $\chi^{\lambda_{o}^{\prime} \alpha}$, grafs; a genus of Gramina.

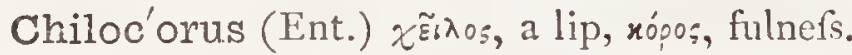

Chilogna'tha (Zool.) $\chi \tilde{E}_{i} \lambda_{05}$, a lip, quátos, a jaw; an order of Annulofa.

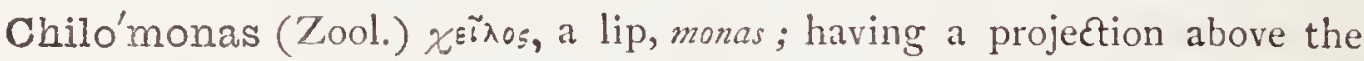
mouth of a lip-like appearance.

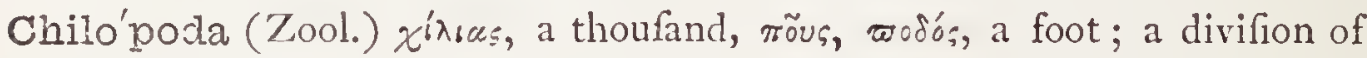
the Annulofa.

Chimæ'ra, Chimæ'ridæ (Ichth.) xíf «spa, the Chimæra, a reputed monfter.

Chime'roid (Ichth.) chimara-like.

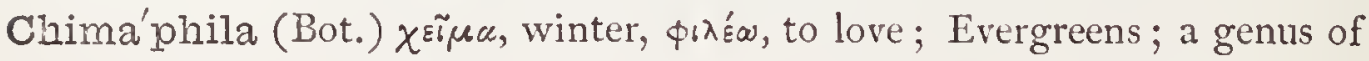
Pyrolaceæ.

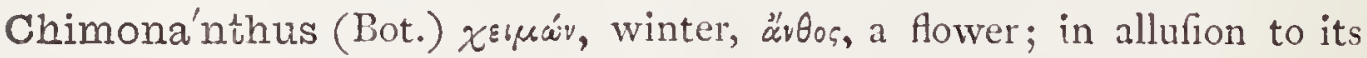
time of flowering.

Chinchil'la (Zool.)

Chinchilli'na (Zool.) chinchilla; a fub-family of Mammalia.

Chine'nsis (Zool., Bot.) Lat. relating or belonging to China. 
Chioco'cca (Bot.) xráv, fnow, róxros, a berry.

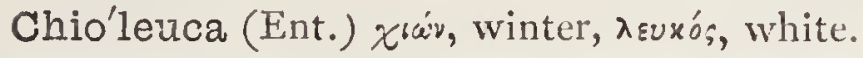

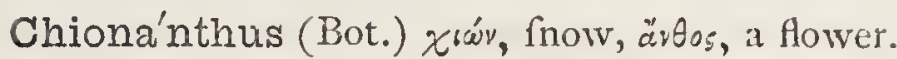

Chione (Zool.) P. N., the daughter of Deucalion.

Chionea'lis (Ent.) xróvıs, fnowy.

Chioni'dida (Ornith.) chionis, fam. term. ida; a family of the Gallina.

Chio'nis (Ornith.) xiẃr, x xóros, fnow.

Chiosogna'thus (Ent.) a genus of Exotic ftag-beetles.

Chiroce'phalus (Zool.) $x \varepsilon \dot{p}$, a hand, $x \varepsilon \ngtr a \lambda \dot{n}$, the head; a genus of Entomoftraca.

Chiro'dota (Zool.) Xeıgódoros, given by the hand; a genus of Echinodermata.

Chiroga'leus (Zool.) $\chi^{\varepsilon i \xi}$, the hand, $\gamma a \lambda \tilde{n}$, a weafel.

Chirone'ctes (Ichth.) $x$ kip, hand, vńx ns, a fwimmer; the Hand-filh.

Chiro'nia (Bot.) P. N. from Chiron, one of the fathers of medicine, botany, and furgery.

Chiron'omus (Ent.) a genus of Dipterous infects.

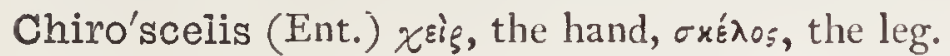

Chirrhœ'a (Bot.) xıppó: yellow or fulvous; from colour of flowers.

Chito'nia (Bot.) $\chi$ เ fcales; a genus of Melaftomacex.

Chitu'lia (Zool.) etymology unknown.

Chlæ'nius (Ent.) $x^{\lambda \alpha i v a, ~ a ~ c l o a k . ~}$

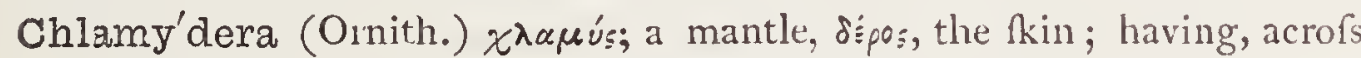
the back of the neck, a rofe-coloured band.

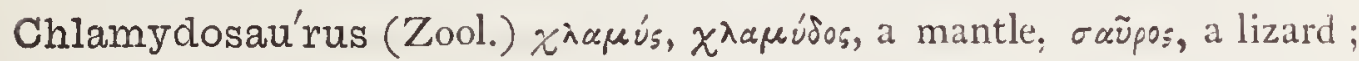
the Frilled lizard.

Chlida'nthus (Bot.) $\chi^{\lambda} \delta_{\delta} \alpha \alpha_{\omega}$, to be delicate, $\alpha^{\prime \prime} \theta_{0 s}$, a flower.

Chloa'nthes (Bot.) $\chi^{\lambda o^{\prime}}$, grafs, $\ddot{\alpha} v \theta_{0}$, a flower; from its green flowers; a genus of Verbenacex.

Chlœ'phaga (Ornith.) $\chi^{\lambda o ́ n}$, grafs, фayerr, to eat; lhould be written Chloëphaga.

Chlo'ra (Bot.) $x^{\lambda \text { woós, green. }}$

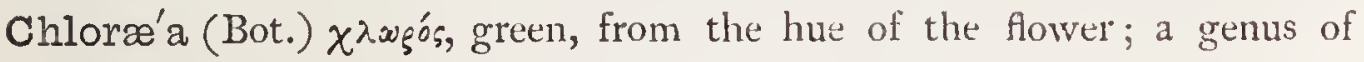
Orchidacex.

Chlora'na (Ent.) $\chi^{\lambda \omega}$ wós, light-green.

Chlora'nthus (Bot.) $\chi^{\lambda}$ sopós, green, $\ddot{u}_{2} \theta_{25}$, a flower.

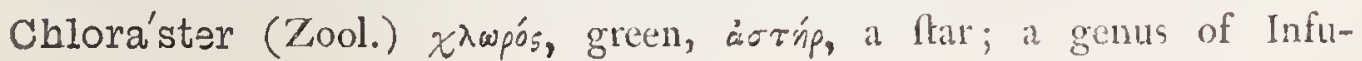
foria. 
$\left.\begin{array}{l}\text { Chlo'rea } \\ \text { Chlo'rion }\end{array}\right\}$ (Ent.) $x^{\lambda \omega \omega}$ pos, greetn.

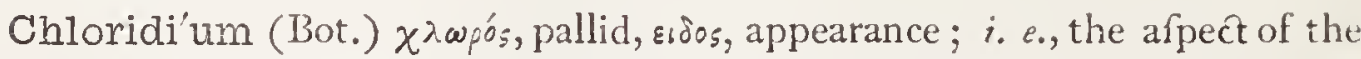
plants; a genus of Fungi.

Chlo'ris (Ornith.) $\chi^{\lambda \omega}$ opis, was the name anciently applied to a bird, probably the Greenfinch.

Chlo'ris (Bot.) $\chi^{\lambda \omega}$ pos , green; from the colour of the herbage.

Chlori'za (Ent.) $\chi^{\lambda \omega \omega_{p} \zeta} \zeta \omega$, to be greenifh or pale.

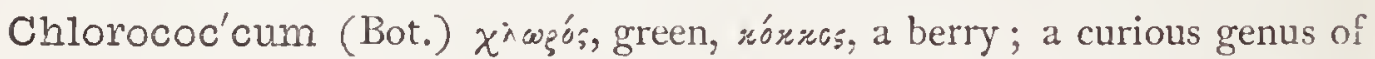
Algx.

Chlorola'mpis (Ornith.) $\chi^{\lambda \omega \omega^{\prime} o}=$, green, $\lambda \dot{\alpha} \mu \pi \omega$, to thine; a genus of Humming-birds.

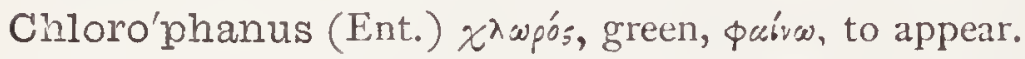

Chloro'phytum (Bot.) $\chi^{\lambda \omega \rho^{\prime}}$ s, green, фuróv, a plant.

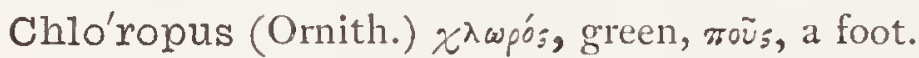

Chlororhy'nchos (Ornith.) $\chi^{\lambda \omega p^{\prime} s}$, green, púvxos, a beak.

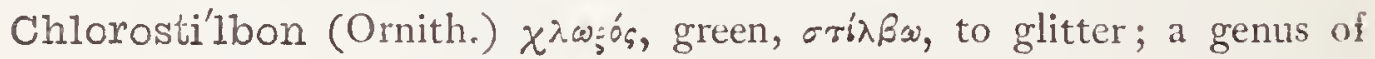
Humming-birds.

Chloro'ticus-a-um (Bot.) Lat. pale-green.

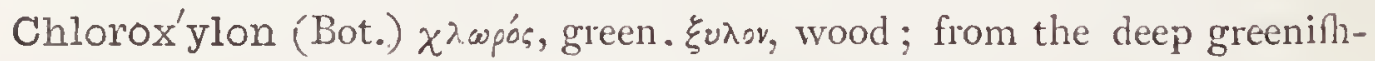
yellow colour of the wood; a genus of Cedrelacex.

Chceroca'mpa (Ent.) xoífos, a hog, ни́ $\mu \pi n$, a caterpillar, from the extended neck of the larva refembling a hog's fnout.

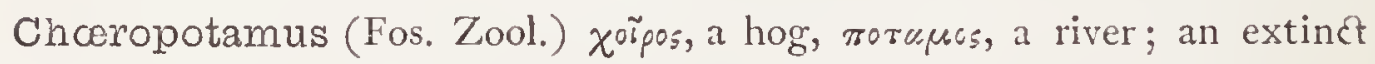
genus of Mammalia.

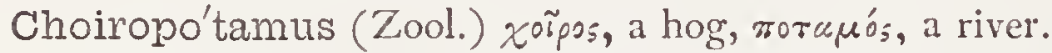

Cho'isya (Bot.) P N. from Choify, a Genevefe botanift; an ornamental genus of Rutacex.

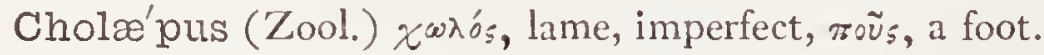

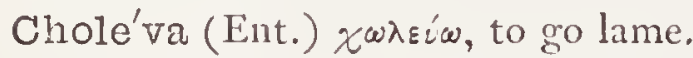

Chome'lia (Bot.) P. N. from F. B. Chomel, a French botanift, Phyfician to Louis XV.

Chonde'stes (Ornith.) unexplained.

Chondracan'thidæ ('Zool.) chondracanthus, fam. term. ide; a family of Entomoftraca.

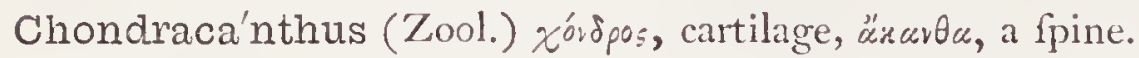

Chon'dria (Bot.) xóroos, a cartilage, referring to texture of plant; a genus of Algx. 
Chondri'lla (Bot.) xóvpos, a lump; in allufion to the lumps of gummy matter on the ftems.

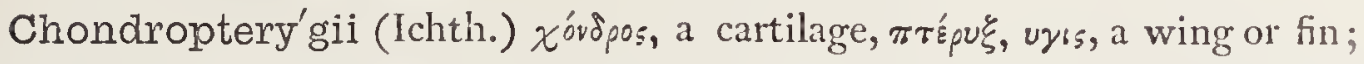
an order of Fifhes.

Chon'drus (Bot.) xóropos, a lump; a genus of Algæ.

Cho'ninea (Ent.) xárn, a funnel, iviov, the nape of the neck.

Chora'gus (Ent.) xopayós, a chorus-leader.

Cho'rda (Bot.) xopoń, a cord; a genus of Algæ.

Chorda'ria (Bot.) xopoń, a cord; in allufion to the appearance of the plants; a genus of Algx.

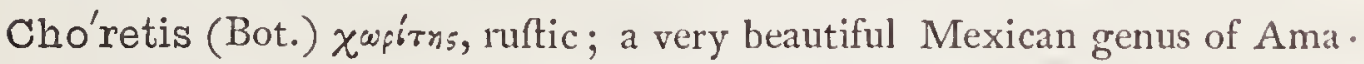
ryllidaceæ, the flowers refembling thofe of Ifmene.

Choreu'tes (Ent.) xopsúrns, a dancer.

Chorine'mus (Ichth.) unexplained.

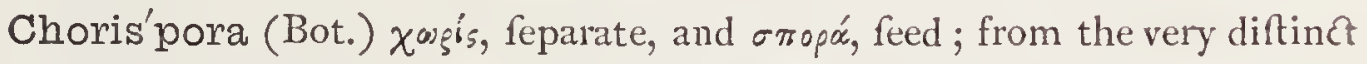
feeds in pods; a pretty genus of Cruciferæ.

Choroze'ma (Bot.) Sir J. E. Smith remarks, with reference to this name, "M. Labillardière originally difcovered this plant (C. ilicifolium, the fpecies firft found, and which was introduced in I 803) on the Southern coaft of New Holland, at the foot of the mountains, in a loamy foil, near a fpot where, after being tantalized with finding many falt fprings, his party had juft met with an ample fupply of frefh water. This welcome refrefhment feems to have fuggefted a name for his plant, which he had properly determined to conftitute a new genus. He called it Chorizema, evidently, as I prefume, from xopos, a dance or joyful affembly, and '̧'sua, a drink ; in allufion to the circumftance juit mentioned. 'This occafioned me to take the liberty of changing the gender of the name, which he had made feminine; and I have taken the further liberty of changing the $i$ for an $o$, an alteration which the derivation feems to authorize and, indeed, to render indifpenfable."

Chorto'bius (Ent.) xópros, grafs, Bios, life.

Christatel'la (Ent.) cristatus, crefted.

Christiernina'na (Ent.) P. N. in honour of Chrifiernin, a friend nt Linnæus.

Christula'lis (Ent.) crifula, a fmall creft.

Chroma'lis (Ent.) xpẽua, colour.

Chroma'tium (Zool.) a genus of Infuforia pofleffing brilliant colonss from $\chi \tilde{\xi} \tilde{\mu} \mu u$, colour.

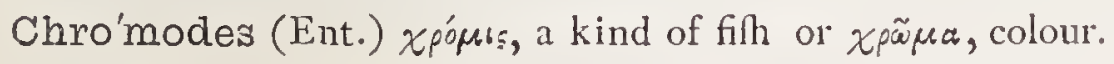




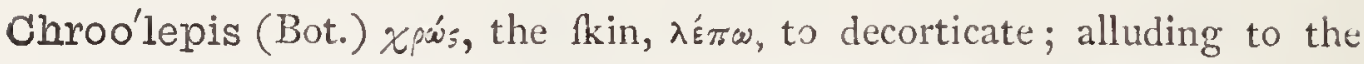
inner membrane changing to powder; a genus of Cryptogamia.

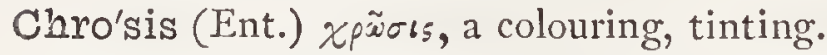

Chry'ophrys (Ichth.) xgvoós, gold, ơfús, the eyebrow; the fif called the Gilt-head.

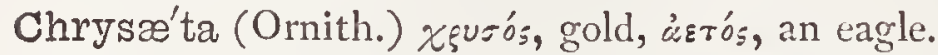

Chrysali'dina (Zool.) refembling a chryfalis in its form; a genus of Fora. minifera.

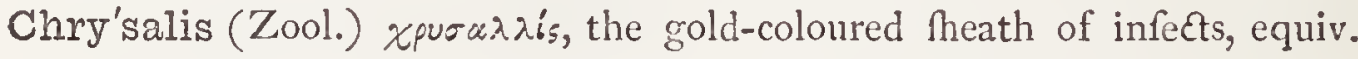
to Aurelian.

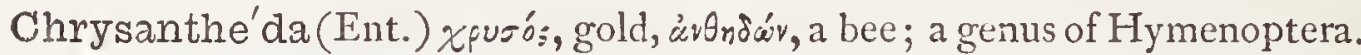
C'arysanthel'lum (Bot.) dim. of Chryfanthemum; an uninterefting genus. Chrysa'nthemi (Ent.) feeds on the following plant.

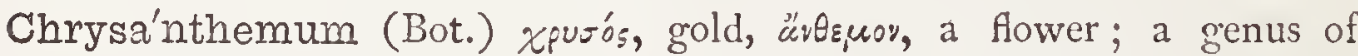
Compofitæ.

Chryse'is (Bot.) P. N., Homer's famous beauty and heroine, Chryfeis; alluding to the brilliancy of flowers; a genus of Papaveraceæ.

Chrysidifo'rmis (Ent.) chryfis-idis, a ruby-tail fly, forma.

Chrysiphi'ala (Bot.) $\chi_{\xi}^{v}=\sigma_{s}$, gold, flowers; a genus of Amaryllidacex.

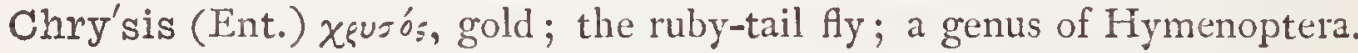

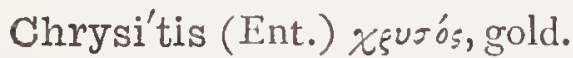

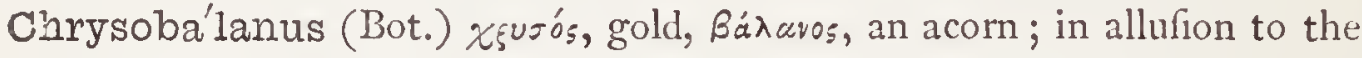
fruit.

Chrysobo'thris (Ent.) x̧usó;, gold, Bóg gos, a hole.

C'hrysochlo'ra (Ent.) a genus of Diptera.

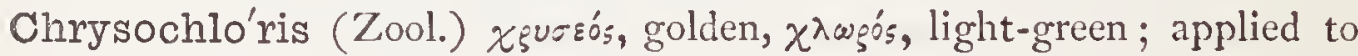
the changeable or golden mole.

Chrysoe'la (Zool.) xpuós, gold, ñर̀o, a nail; i.e. "ftudded with golden nails."

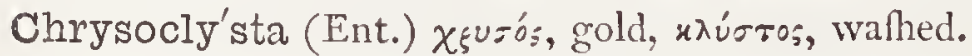

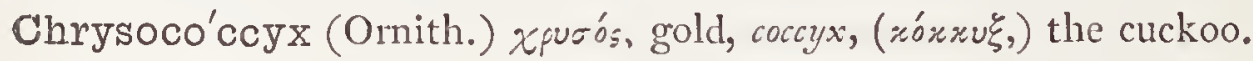

Chryso'coma (Bot.) xevós, gold, xóp.n, hair; in allufion to the tufts of yellow flowers.

Chryso'corys (Ent.) xpusó;, gold, xósus, a helmet.

Chrysoga'ster (Zool.) zgurós, gold, yarrís, the belly.

Chrysog'omum (Bot.) Xevóos, gold, yoru, a knee; the yellow flowers are moltly produced at joints of the ftem; a pretty genus of Compositx.

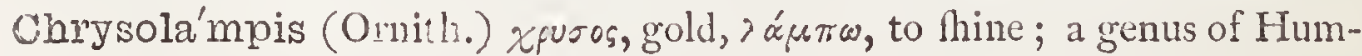
ming-birds. 


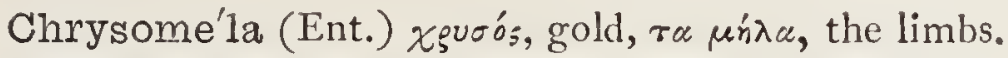

Chrysome'lidæ (Ent.) cliryfomela, fam. term. ida.

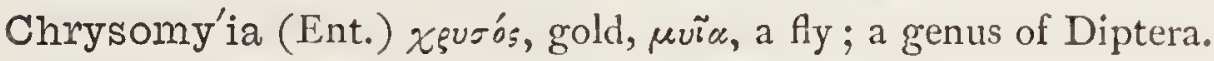

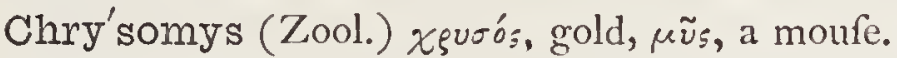

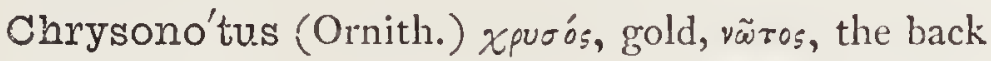

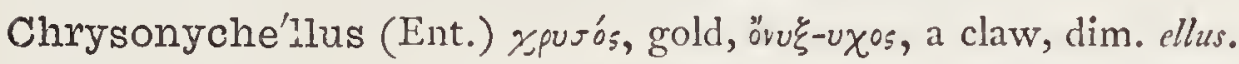

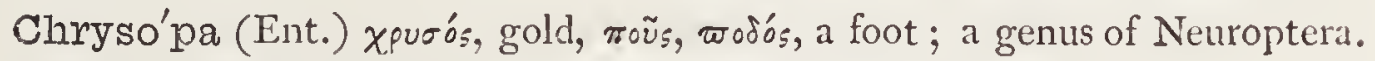
Chrysopelea (Zool.) a genus of Colubrine ophidians.

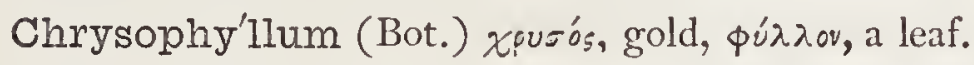

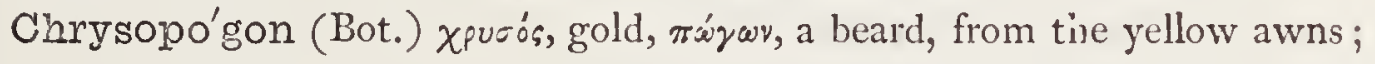
a beautiful genus of Gramina.

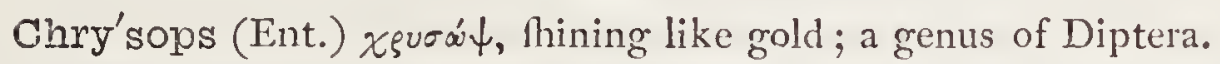

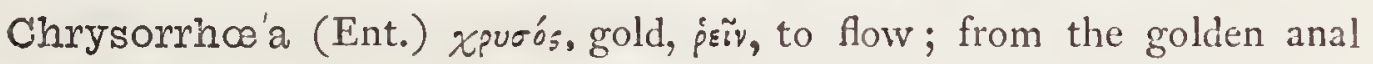
tuft.

Chrysosple'nium (Bot.) $x_{\xi} v_{=}^{\prime} s$, gold, $\sigma \pi \lambda \dot{r} v$, fpleen.

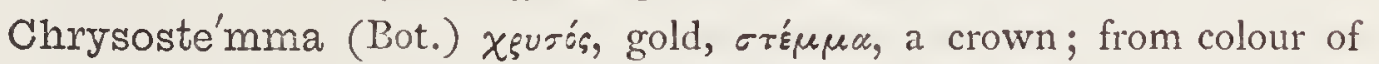

flowers; a very pretty genus of Compofitx.

Chryso'tis (Ornith.) xpurós, gold, oũs, wrós, an ear.

Chrysuro'nia (Ornith.) Xsvoós, gold, oủá, a tail ; a genus of Hummingbirds.

Chrysu'rus (Bot.) xpueós, gold, oupó, a tail; in allufion to the flowers.

Chthamali'na (Zool.) chlhamalus, fam. term. ince; a fub-family of Cirripedes.

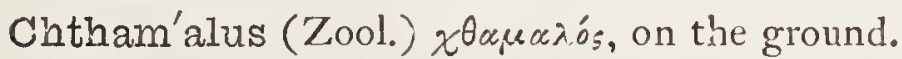

Chu'va (Zool.) native name of one of the fpider mon'ieys.

Chydo'rus (Zool.) etymology unknown; a genus of Entomoftraca.

Chylocla'dia (Bot.) a genus of Algx.

Chy'sis (Bot.) xúrı, fufion, becaufe the pollen mafles appear to be fured

together; a fplendid, but very rare, Orchidaceous plant from Venezuela.

Ci'a (Ornith.) etymology unknown.

Cibo'tium (Bot.) xißw'rıv, a little cheft; from form of indufium. A noble tree-fern from New Holland.

Cica'da (Ent.) the Latin cicada is from rıxas, the arcufative of which is xъrada. The ancients ufed cicada for the cricket, not the grafl-hopper, which they called locufta.

Cicade'lla (Ent.) cicada, a grafl-hopper.

Cica'didæ (Ent.) cicada, fam. term. ida.

Cicairice'llus (Ent.) cicatrix, a fiar.

Ci'cca (Eot.) P. N. flom Peter Gicia, who wrote in $\$ 553$. 
Ci'cer (Bot.) xĩ\%vs, force; in allufion to its qualities.

Cicho'rium (Bot.) an Egyptian name adopted by the Greeks; fuccory. The Greeks ufed fometimes $i$ and fometimes ei diphthong; thus Horace has :-

$$
\text { "me Cichorea levefque malvæ." }
$$

Cicinde'la (Ent.) Lat. a glow-worm.

Cicinde'lidæ (Ent.) cicindela, fam. term. ida.

Cicinu'rus (Ornith.) rixเvчos, curled hair, oũó, a tail; from the long fpiral filaments of the extremity of the tail.

Cico'nia (Ornith.) Lat. a ftork.

Cicu'ta (Bot.) a name of doubtful meaning.

Cidarel'la (Ent.) dim. of cidaris, a head-drefs or diadem.

Cida'ria (Ent.) P. N., a name of Ceres, according to Treitfchke; or perhaps from cidaris, a Perfian diadem, tiara.

Ci'daris (Zool.) Lat. a diadem; a genus of Echinodermata.

Cilie'lla (Ent.) cilia, fringe, dim. ella.

Cili'gera (Ent.) cilium, an eyelid, gerere, to bear.

Ci'lium (Ent.) Lat. the eyelid.

Ci'lix (Ent.) Lat. a Cilician.

Cille'nium (Ent.) cilleo, to move or twinkle.

Cimici'fuga (Bot.) cimex, a bug, fugo, to drive away.

Cimo'lia (Ent.) жькалiє, fuller's-earth, referring to colour.

Cincho'na (Bot.) P. N. from the Countess of Cinchon, whom it cured of a fever.

Cinclid'otus (Bot.) $x เ y \times \lambda_{i s}$, a lattice, odoṽs, odovтós, a tooth; a genus of Mufci.

Ci'nclis, plural Cinclides (Zool.) ufed by Mr. Gofle to exprefs certain orifices in Actinix, refembling the fpiracula of infects.

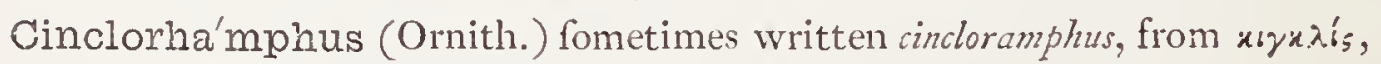
a lattice, 'pó $\mu \$ \$ s$, a beak.

Ci'nclus (Ornith.) $x$ ryx.ris, a lattice.

Cincta'lis (Ent.) cinctus, girt about; being ftriped.

Cincta'ria (Ent.) cinctus, girt, ringed.

Cinera'ceus-a-um (Ornith.. Ent.) Lat. afh-coloured.

Cinera'ria (Bot.) cineres, afhes; from the afl-coloured down covering the furfaces of the leaves.

Cinerel'la (Ent.) cineres, afhes; afh-coloured.

Cinereo-argenta'tus (Zool.) filvery-grey.

Cine'reola (Ent.) dim. of cinereus, aht-coloured. 
Cinereopunctel'la (Ent.) cinereus, afh-coloured, punctum, a fpot.

Cine'reus-a-um (Zool., Bot.) Lat. colour of afhes.

Cinero'sa (Ent.) cineres, afhes, in reference to colour.

Cingellel'la (Ent.) cingillum, a fmall girdle, or band.

Cingula'lis (Ent.) cingula, a girdle; referring to the bands acrofs the wings

Cin'iflo (Ent.) Lat. a flave.

Ciniflonel'la (Ent.) ciniflo, a hair-curler.

Ciniflo'nidæ (Ent.) cinifo; a family of Arachnida.

Ci'nna (Bot.) P. N., an ancient town in Italy.

Cinnabari'nus (Ent.) xเvvábaps, an Indian gum; vegetable fcarlet.

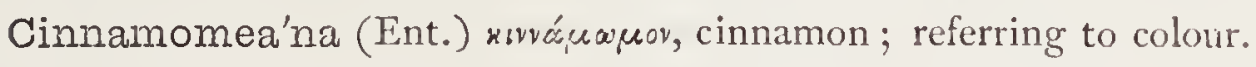

Cinnamo'mum (Bot.) Latinized from the Arabic name.

Cinnamo'nica (Ent.) colour of cimamon.

Cin'xia (Ent.) P. N., a furname of Juno, connected with cingulus, a girdle.

Ci'onus (Ent.) rovis a fmall pillar?

Circœ'a (Bot.) P. N. from Circe, the famous enchantrefs of mythology.

The fruit, being covered with little hooks, lays hold of the clothes, as

Circe did of the attention with her voice. A well-known and pretty

genus of Onagracex; enchanter's night-hhade.

Cir'ce (Zool., Ent.) P. N., an ancient enchantrefs.

Circe'adæ (Zool.) Circe, fam. term. ida; a divifion of naked-eyed Medufx.

Circella'ta (Ent.) circellus, a fmail ring.

Cir'cia (Ornith.) xípros, a falcon or kite.

Circina'lis (Bot.) circus, a circle; from the ring-like joints of the trunk.

Circœ'tus (Ornith.) xípxos, a falcon, äerós, an eagle.

Circumfle'xa Circumflexa'lis $\}$ (Ent.) circumflecto, to bend round.

Circumscrip'ta (Bot.) circum, around, friptus, written.

Circumsigna'ta (Ent.) circum, round, Jgnatus, marked.

Circumspe'cta (Ent.) Lat. prudent, cautious.

Ci'rous (Ornith.) xipros, a hawk, which fies in wheels or circles.

Cir'lus (Ornith.)

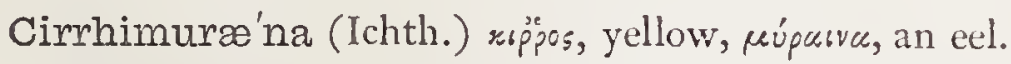

Ci'rrhoa (Bot.) cirrtus, a tendril, fm. form of flower; a genus of

Orchidacex.

Cirrhœ'dia (Ent.) xuṕposıśns, tawny.

Cirrhope'talum (Bot.) cirrhus, a tendril, and $\pi \dot{\tau} \tau u \lambda$ or, fm. form of flower;

a genus of Orchidacex. 
Cirri'pedes) (Zool.) cirrhins, a lock of hair, pes, a foot; a clafs of the Cirripe'dia) Annulofa.

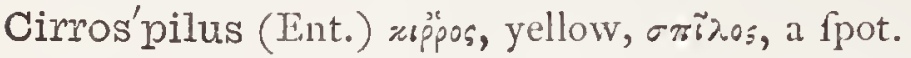

Cirsia'na (Ent.) cirfum, a thiftle, on which it feeds.

Cirsi'um (Bot.) xipros, a fwelled vein, from fuppofed healing properties; a genus of Compofita.

Cis (Ent.) xis, riós, a wood-worm, a weevil; a genus of Beetles belonging to the family Ptinidæ.

Cisa'lpina (Ornith.) cis, on this frde, Alpes, the Alps, i.e., the fouth fide of thofe mountains.

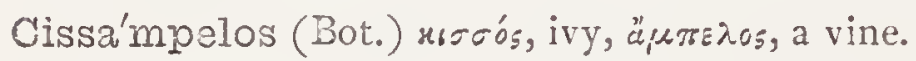

Cis'sus (Bot.) xıбós, ivy.

Ciste'la (Ent.) dinn. of $x i=\tau n$, a box or cheft.

Ciste'liciar (Ent.) sificlla, fam. term. ida.

Cisti'cola (Ornith.) fometimes written cyficola, from cifus, and colo, to frequent.

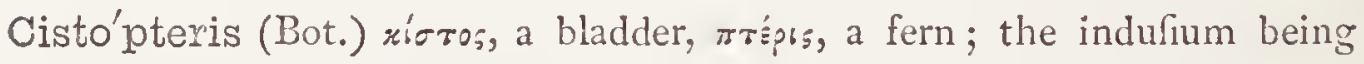
like a bladder.

Cis'tus (Bot.) xísn, a box.

Cithare'xylum (Bot.) й̈ápa, a lyre, 乡únov, wood.

Citra'go (Ent.) citrus, the citron-tree, referring to colour.

Citra'ria (Ent.) citrus, the citron ; lemon-coloured.

Citrinel'la (Ornith.) dim. of citrinus, of a citron colour.

Citrio'batus (Bot.) Citrus, and Ráros, a thorn; "Orange-thorn;" a genus of Pittosporacex.

Citrus (Bot.) Lat. a citron-tree.

Civett'a (Zool.) Arab. zebed, a fcent.

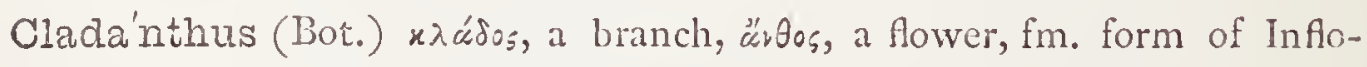
refence; a genus of Compofitx.

Cla'dium (Bot.) x入ásos, a brauch.

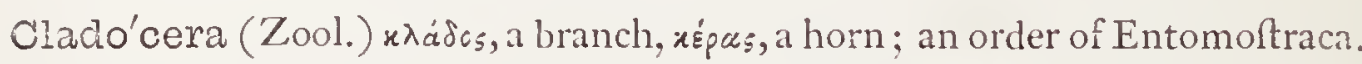

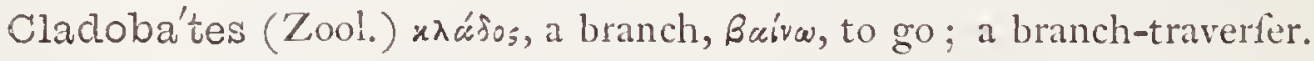

Cladocrínites (Fos. Zool.) $x \lambda \ddot{c} \delta$ sos, a branch, xpivov, a lily.

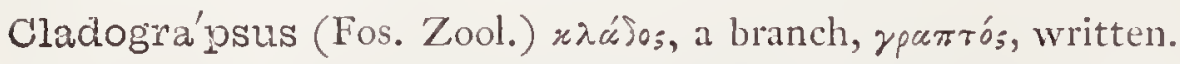

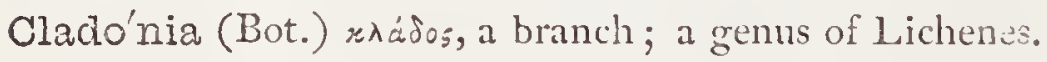

Cla'dosporium (Bot.) $x \lambda a_{a} \delta o_{s}$, a branch, and fpora, form of fructification ; a genus of Fungi.

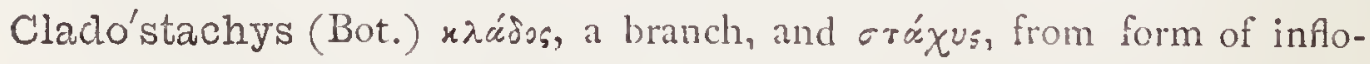
refcence: a genus of fimarantacex. 


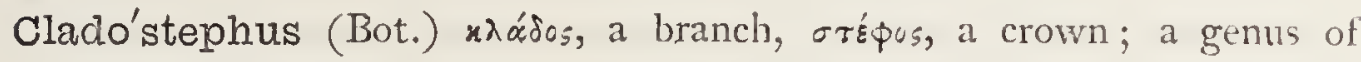
Cryptogamia.

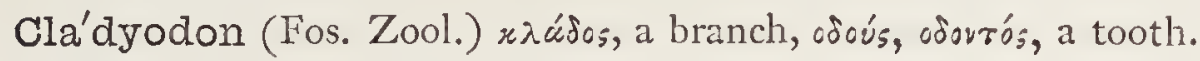

Cla'mbus (Ent.) xланßós, mutilated.

Clan'culus (Zool.) clanculo, by ftealth.

Clan'gula (Ornith.) Lat. the noife made by a goofe.

Clany'ma (Ent.) $x \lambda a \dot{a} \omega$, to break, in $\mu \alpha$, a thread.

Cla'ra (Ent.) Lat. clear, bright.

Clararia (Bot.) Clara, a club, fm. form of plant; a genus of Fungi.

Clares'cens (Ent.) clarefco, to grow bright.

Clarkia (Bot.) P. N. fm. Captain Clark, a North American botanift and traveller; a genus of Onagraceæ.

Cla'rkii (Ent.) P. N. in honour of the Rev. Hamlet Clarke.

Clary (Bot.) is the name of feveral fpecies of fage, and is corrupted from clear-eye, becaufe the feeds, powdered and mixed with honey, were fuppofed to clear the fight.

Clathra'lis (Ent.) clathrum, a lattice.

Clathra'ta (Ent.) clathratus, latticed.

Cla'thrum (Ent.) Lat. a bar or lattice.

Clau'dicans (Ent.) Lat. halting, limping.

Clau'sena (Bot.) unexplained; a genus of Aurantiaceæ.

Cla'va (Zool.) Lat. a club.

Clava'lis (Ent.) clava, a club.

Clavi'ga (Bot.) P. N. from F. Clavijo Faxardo, a Spanith naturalift.

Cla'viger (Ent.) Lat. one who bears a club.

Clayto'nia (Bot.) P. N. from J. Clayton, a botanical collector in Virginia.

Cleiso'stoma (Bot.) unexplained; a genus of Orchidaceæ.

Cledeo'bia (Ent.) $x \lambda n \delta o s$ (?), a hedge, $\beta$ เow, to live.

Cle'matis (Bot.) $x \lambda \tilde{n} \mu a c$, a tendril.

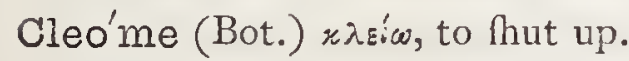

Cleo'nia (Bot.) a Greek name employed by Theophraftus.

Cleo'nymus (Ent.) r x'os, fame, óvouce, a name.

Cleopha'na (Ent.) $x \lambda$ ćs, honour, paivw, to appear.

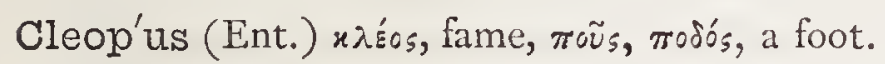

Cleo'ra (Ent.) P. N., the wife of one of the kings of Sparta.

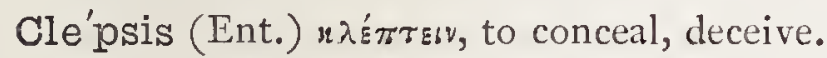

Cler'ckii (Ent.) P. N. in honour of Carl Clerck, F.R.S.S., Upfal, in the I 8 th century.

Clerode'zaron (Bot.) x ñ pos, a lot, séropor, a tree. 
Cle'rus (Ent.) Pliny applies this word to a worm which breeds in bee-hives. Cle'thra (Bot.) $\times \lambda \dot{\lambda} \theta$ pa, the Greek name for the Alder.

Cleye'ra (Bot.) P. N. from Andrew Cleyer, a Dutch botanift; a genus of Fernftromiacex.

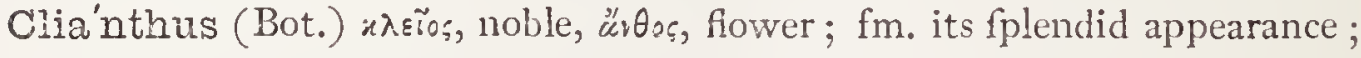
a genus of Leguminosœ.

Clide'mia (Bot.) P. N. from Clidemi, an ancient Greek botanift; a genus of Melantomaceæ.

Cliffo'rtia (Bot.) P. N. from G. Cliffort, of Holland, the firft patron of Linnæus.

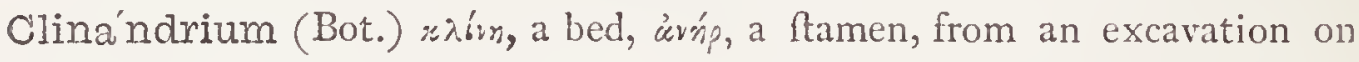
its extremity.

Clinio'des (Ent.) $x$ iin, a couch, termination expreffing refemblance- $\omega \delta$ s. Clio'stomum (Bot.) $x \lambda \varepsilon i ́ \omega$, to thut up, crópce, a mouth.

Clinopo'dium (Bot.) $x \lambda i v n$, a bed, $\pi 0 v_{s}, \pi 0 \delta \sigma^{\prime}$, a foot.

Clintónia (Bot.) P. N. from De Witt Clinton, governor of New York; a genus of Lobeliaceæ.

Clitella'ria (Ent.) a genus of Diptera.

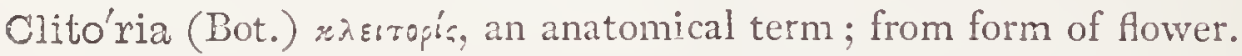

Cli'via (Bot.) P. N. from Duchess of Northumberland; a genus of Amaryl. lidaceæ.

Cloace'lla (Ent.) cloaca, a fewer.

Cloa'ntha (Ent.) P. N. from Cloanthus, one of the companions of Fineas;

a genus of Lepidoptera.

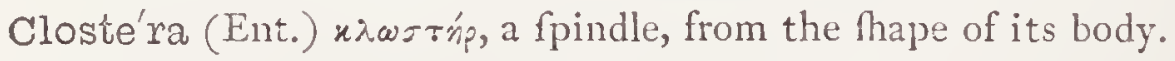

Clo'tho ,

Clotho'nial

(Zool.) $x \lambda c^{\prime} \theta_{\infty}$, to twift or fpin round: genera of Ophidians.

Cloti'lda (Ent.) P. N. Clotild:

Cloud. berry (Bot.) from the lofty nebulous fituations in which it grows. Clove (Bot.) from Frencb, clou, a nail; which it refembles in form.

Clover (Bot.) the plant with the cloven or three-cleft leaf.

Clu'pea (Ichth.) Lat. Pliny's name for a fmall firh.

Clupei'dæ (Ichth.) clupea; the family of the Herrings.

Clu'sia (Bot.) P N. from Charles de l'Echue, a celebrated botanift of the I 6 th century.

Cluy'tia (Bot.) P N. from Outgers Chuyt, a Dutchman, Profellor of botany at Leyden.

Siyp'eata (Omith.) clypeus, a fhich.

Clyp'eola (Bot.) clypers, a thiceld. 
Cly'tia (Ent.) ùvтós, noble, fplendid.

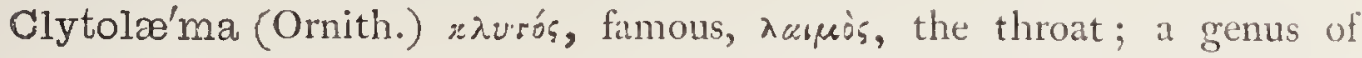
Humming-birds.

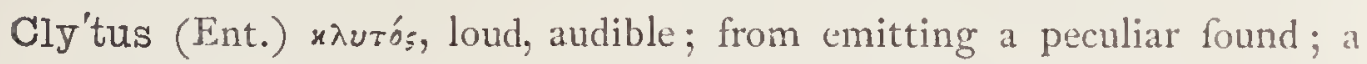
genus of Coleoptera.

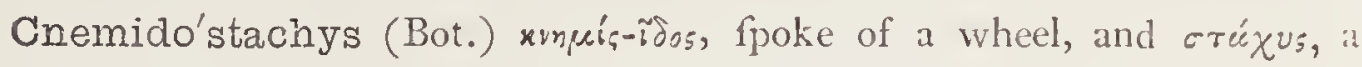
fpike; a genus of Euphorbiacex.

Cnomido'tus (Ent.) xiruis-ioos, armour.

Cneo'rum (Bot.) rvéapov, Theophraftus applies this name to a fhrub refembling the Olive.

Cnepha'sia (Ent.) xiśфa., darknefs.

Cne'stis (Bot.) urúw, to frratch; from the prickly capfules; a genus of Connaraceæ

Cnethoca'mpa (Ent.) xin'tw, to excite great itching, xú, a genus of nocturnal Lepidoptera.

Cnica'na (Ent.) cnicus, a thiftle.

Cni'cus (Bot.) xvrrmos, the Greek name of a plant of the thiftle kind, the leaves of which were ufed like rennet to curdle the milk in making cheefe.

Cni'dæe ('Zool.) name given by Mr. Gofte to the thread-cells of the Actinix, from siín, a nettle.

Cnidium (Bot.) the ancient name of the Orache; a genus of Umbellifera. C-ni'grum (Ent.) Lat. the black C, i. e. a wing-fpot.

Coarcta'lis (Ent.) coarctare, to comprefs, to narrow; referring to the wings.

Coa'ssus (Zool.) Latinized form of the native word cuguacu.

Cobi'tis (Ichth.) xaßirns, a fifh, probably the fmelt or loach.

Cobœ'a (Bot.) P. N. in honour of $B$. Cobo, a Spanifh botanift.

Cobu'rghia (Bot.) P. N. in honour of Prince Leopold of Saxe Coburg; a genus of Amaryllidacex.

Co'ccidæ (Ent.) coccus, fam. term. idu.

Coccídium (Bot.) róxzos, a berry, g'sos, like.

Coccillophis (Ichth.) xórxos, fcarlet, iśsos, a creft.

Coccine'lla (Ent.) dim. of coicus, a red berry, from appearance.

Coccinel'lidæ (Ent.) coccinella, fam. term. i.ke.

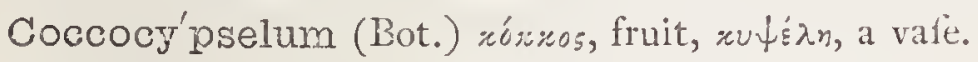

Cocco'loba (Bot.) r'sros, a berry, noßós, a lobe.

Cocco'phagus (Ent.) rónuos, a kernel, qáyss, an eater.

Cocc'osteus (Fos. Zool.) xóxxos, a berry, $\partial ; \tau^{\prime} s=$, al bone. 
Coccothrau'stes (Ornith.) zonnofpaúrns, a kernel-breaker.

Coc'culus (Bot.) x́́хro;, a berry; a genus of Menifpermacex.

Coc'cus (Ent.) xóxкos, a berry; a genus of Coleoptera.

Coccy'stes (Ornith.) coccyx, a cuckoo.

Coc'cyx (Zool., Ent.) xóxxu乡, the cuckoo.

Coccy'zus (Ornith.) xокxi'̧w, to cry like a cuckoo.

Cochineal' (Ent.) Spanilh cochinella.

Cochlea'ria (Bot.) cochlear, a fpoon; alluding to the thape of its leaves.

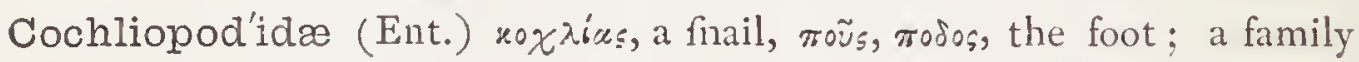
of Lepidoptera.

Cochlospe'rmum (Bot.) xóx $\lambda_{0}$ s, any thing twifted fpirally, $\sigma \pi \varepsilon \varepsilon^{\prime} \mu \varepsilon, a$ feed.

Cochylio'ides (Ent.) cochylis, sídos, like.

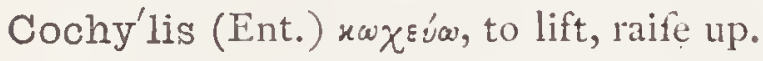

Cock (Ornith.) AnglowSax. coc; Fr. coq.

Cockatoo' (Ornith.) taken from the peculiar cry of the birds.

Cocos (Bot.) Portug. coco; the end of the nut is like a monkey's head:

the coco-nut tree.

Cocyta'lis ?

Cocyto'des $\}$ (Ent.) reftembling cocytus.

Cocy'tus (Ent.) rwxurós, a Thrieking, wailing.

Coda'rium (Bot.) rwdx́prov, a leathern pouch; alluding to the pods.

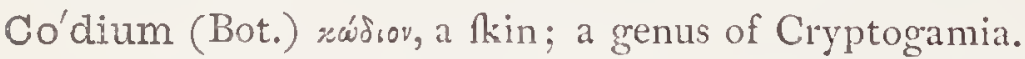

Co'don (Bot.) xẃdwr, a bell, from the corolla.

Codono'idea (Bot.) codon, sisos, refemblance.

Cociono'phora (Bot.) xẃdwv, a little bell, and $\phi^{\prime} p \omega$, to carry; a genus of Gefneracex.

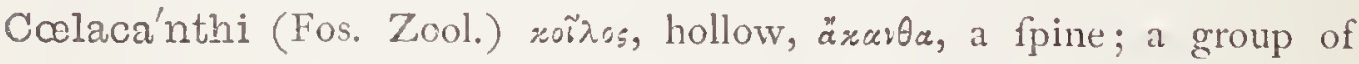
foffil fauroid fifhes, deriving their name from the central cavity in their fin rays.

Cœla'strum (Bot.) *oĩos, hollow, ủoríp, a frar; hexangular cells arranged to form a hollow globular frond; a genus of Defmidiex.

Cœlebogy'ne (Bot.) crelebs, a bachelor, and yum, a piftil ; feeds produced apparently by virgin power alone; a genus of Euphorbiaceæ.

Cœ'lebs (Ornith.) calebs, a bachelor; Linnæus ftates that the female bird migrates during the winter.

Cœlentera'ta (Zool.) roĩ ${ }^{\prime}$ s, hol'ow, Érrepov, the inteftine.

Cœ'lia (Bot.) unexplained; a genus of Orchidaceæ.

Colio'xys (Ent.) roĩros. hollow, isus, Tharp; a genus of Hymenoptera. 


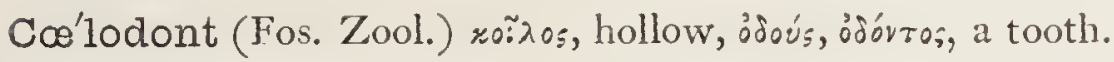

Cœlo'genys (Zool.) roĩros, hollow, y'v́vs, the cheek.

Cœlogy'ne (Bot.) woínos, hollow, and yurn, a pinil; from form thereof; a genus of Orchidaceæ.

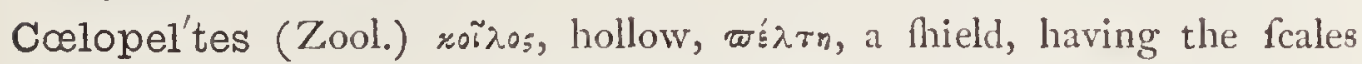
grooved; a genus of Colubrine ophidians.

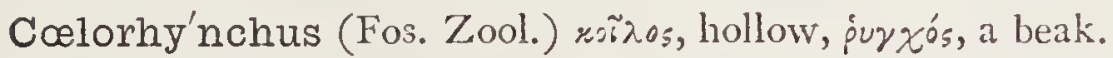

Cœlo'tes (Zool.) roinotns, a cavity, hollow; a genus of Arachnida.

Cœno'sus-a-um (Ent., Bot.) Lat. marfhy.

Coffee (Bot.) the Arabic name of this plant is Quahouch; and of this word the Perfian Cahrva, the Turkith Cahvey, the French Café, and our Coffee, are evident corruptions.

Co'ita, or Quata (Zool.) native name of a monkey.

Coix (Bot.) the name of a reed-leaved plant, ufed by Theophraftus.

Cola'ptes (Ornith.) rsגáørw, to peck with the bill; a genus of Woodpeckers.

Colbe'rtia (Bot.) P. N. in honour of M. Colbert, a patron of the cultivators of the fcience of botany.

Co'lchicum (Bot.) P. N. from Colchis, its native country.

Col'chicus (Ornith.) P. N. from Colchis, whence the pheafant came.

Colde'nia (Bot.) P. N. in honour of C. Colden, a North American botanift. Colebro'okia (Bot.) P. N. in honour of $H . T$. Colcbrooke, an accomplithed botanif ; a genus of Labiatæ.

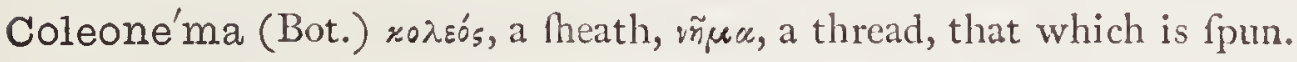

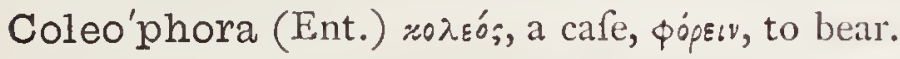

Coleopho'ridæ (Ent.) a family of Lepidoptera.

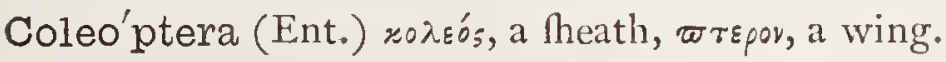

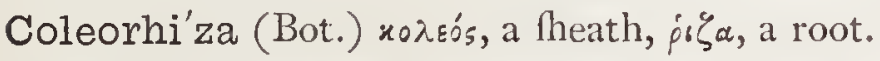

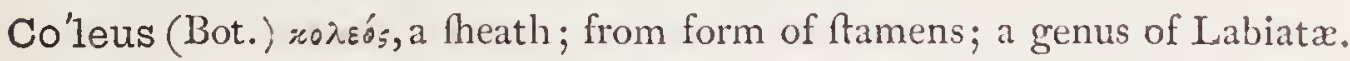

Cole'wort (Bot.) Anglo-Sax. carvliuyrt

Co'lias (Ichth.) Lat. ancient name of a fih.

Co'lius (Ornith.) $x_{0} \iota_{6} o_{s}$, Ariftotle's name for a kind of woodpecker.

Colla'ris (Ornith.) collare, a collar or neckerchief.

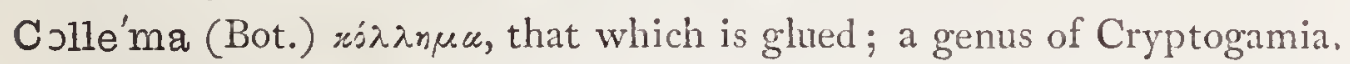

Colle'tia (Bot.) P.N. in honour of Collet, author of a book on the plants of Breft; a genus of Rhamnacex.

Colligu'aya (Bot.) native name; a genus of Euphorbiacex.

Colli'nsia (Bot.) P. N. in honour of Zachariah Collins, of Philadelphia: a genus of Scrophulariaceæ. 
Collinso'nia (Bot.) P. N. in honour of P. Collinfon, a diftinguifhed promoter of botany.

Co'llix (Ent.) xo' $\lambda \lambda_{1} \xi$, a roll of bread.

Coilo'mia (Bot.) róxגa, glue, the feeds are covered with a glue-like fubrance.

Colluricin'cla (Ornith.) compounded of collurio and cinclus; the Port Jackfon thrufn.

Collu'rio (Ornith.) $x u \lambda \lambda \bar{u}$ i wr, a bird probably of the thrulh kind (Ariftotle.) Colmar (Bot.) this pear takes its name from Colmar, in Alface.

Co'lobus (Zool.) rodoßas, ftunted, maimed; from the rudimentary condition of the thumbs on the anterior members.

Coloca'sia (Bot.) roiorufic, the root of the Egyptian bean.

Cologa'nia (Bot.) P.N. in honour of the family of Cologon, of Teneriffe; a genus of Leguminof

Colopho'nia (Bot.) altered from its native name in the Ine of France; a genus of Burferacex.

Colop'tera (Ent.) xódos, ftunted, rzrépy, a wing; a genus of Hymenoptera.

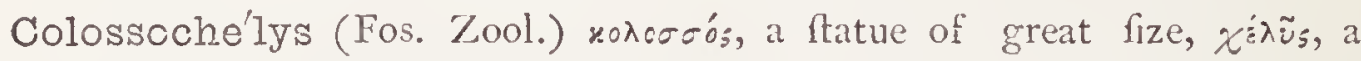
tortoife.

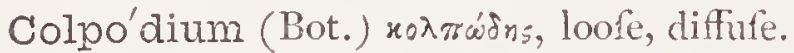

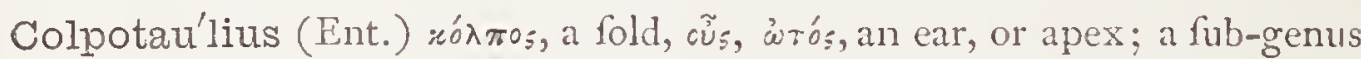
of the Phryganidx.

Colquhona'na (Ent.) P. N. in honour of Dr. Colquhoun, of Glafgow.

Co'luber (Zool.) Lat. a ferpent.

Colube'ridae (Zool.) coluber, a ferpent, fam. term. idue; a family of Ophidians.

Colubra'lis (Ent.) coluber, a ferpent; in allufion to its wing-marks.

Colubri'na (Zool.) coluber, fam. term. inx; the Water-fnakes and Boas; alfo a genus in Botany.

Colu'mba

Colu'mbro $\}$ (Ornith.) Lat. a pigeon.

Columba'lis (Ent.) columba, a dove, $i$. $i$ in colour.

Columbine (Bot.) columba, a dove, which bird the nectaries refemble.

Colume'llia P. N. in honour of L. J. M. Columella, who lived A.c. 42.

Colu'mnea (Bot.) P. N. in honour of Fubius Columa, a member of the Colonna family in Italy.

Colu'ria (Bot.) xódovfos, ftump-tailed; a genus of Rofacex.

Colu'tea (Bot.) swivia, to cut fhort. 
Colvi'llea (Bot.) P. N. from Charles Colville, Governor of the Mauritius; a genus of Leguminofæ.

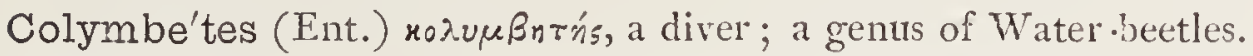

Coly'mbidae (Ornith.) colymbus, fam. term. ida; the Divers.

Coly'mbus (Ornith.) Lat. a pond to fwim in; the Diver.

Coma'lis (Ent.) coma, a lock of hair.

Comándra (Bot.) coma, hair, and úvńp, ftamen; from the tufted ftamens; a genus of Santalaceæ.

Comarop'sis (Bot.) comarum and $\partial \psi^{\prime} ;$, becaufe it refembles that plant; a genus of Rofacez.

Co'marum (Bot.) xócusp; the Greek name for the Arbutus.

Coma'ta (Ornith) comatus, having hair or locks.

Coma'tula (Zool.) dim. of coma, a bufh of hair; a genus of Echinodermata. Combre'tum (Bot.) a name given by Pliny to a climbing plant.

Combusta'lis (Ent.) combuftus, burnt, i. e., in colour.

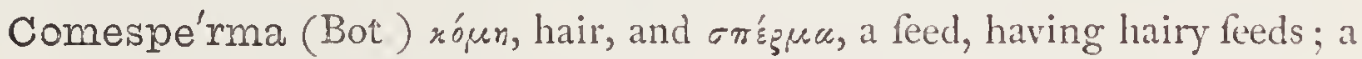
genus of Polygalaceæ.

C's'metes (Ornith.) ropríry;, a comet, from its brilliant appearance; a genus of Humming-birds.

Comita'ta (Ent.) comitatus, accompanied, attended.

Com'ma (Ent.) Lat. comma, from the mark on the fore-wings.

Commeli'na (Bot.) P. N. in honour of $\mathcal{F}$. and G. Commelin, Dutch botanifts.

Commerso'nia (Bot.) P. N. in honour of $M$. Commerfon, a French traveller and botanift.

Commu'nis-e (Zool., Bot.) Lat. common.

Commuta'ta (Ent., Bot.) commutatus, changed entirely.

Comocla'dia (Bot.) xóun, a tuft, u^ásos, a branch.

Compare'ltia (Bot.) P. N. in honour of Andreas Comparelti, Profeflor at Padua; a genus of Orchidaceæ.

Compla'na (Ent.) complanare, to level.

Complanell'a (Ent.) complanare, to make even or level; "the mined oak leaves remain perfectly flat."-STAINTon.

Complánula (Ent.) dim. of complana.

Complecta'lis (Ent.) complector, to clafp or encircle.

Complica'tus-a-um (Bot.) Lat. folded or twifted together.

Composána (Ent.) compofitus, well-difpofed, ornamental.

Compre'ssus-a-um (Bot.) Lat. prefled together.

Compso'coma (Ornith.) rop \’ó, well-drefled, xónn, hair; a genus of Humming-birds. 
Compta'lis (Ent.) )

Compta'na (Ent.) $\}$ comptus, fmart, fpruce.

Compto'nia (Bot.) P. N. in honour of Henry Compton, Bifhop of London.

Comptula'iis (Ent.) comptus, fmart, fpruce.

Conanthe'ra (Bot.) xũvos, a cone, avonpós, flowery.

Concha (Bot.) Greek name for a large fhell.

Concha'na (Ent.) conchatus, Shell.. haped.

Conchi'fera (Zool.) xóyxn, a fhell, fero, to bear.

Conchoder'ma (Zool.) concha, a thell, dépuce, integument; a genus of Cirripedes.

Conchot'rya (Zool.) concha, a Ihell, rpúw, to rub.

Conchyla'lis (Ent.) refembling conchylis.

Conchy'lidæ (Ent.) conchylis-ide, a family of Lepidoptera.

Conchylidel'la (Ent.) conchylis, from a refemblance.

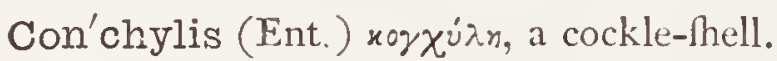

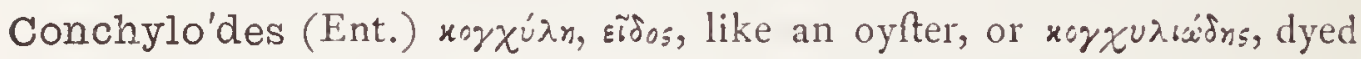
of a purple colour; the firft is beft, unlefs it be a specific name.

Concin'nus-a-um (Zool., Ichth., Bot.) Lat. elegant.

Con'color (Zool., Ornith., Bot.) Lat. of a fimilar colour.

Concorda'lis (Ent.) concordia, harmony.

Conda'lia (Bot.) P. N. in honour of A. Condal, a Spanifh phyfician.

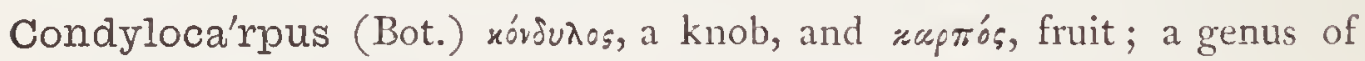
Umbelliferæ.

Conepatus (Zool.) unexplained.

Confe'rtus-a-um (Bot.) Lat. full, thick, clofe together.

Confe'rva (Bot.) conferveo, to confolidate, to knit together; a genus of Algx.

Confervi'tes (Fos. Bot.) Foffil plants allied to the aquatic confervæ.

Con'flua (Ent.) confluere, to fow together, i. e., the friped markings.

Conflu'ens (Bot.) Lat. part. confuens, flowing into.

Confusa'lis (Ent.) confufus, obfcure, confufed, i. e., in colour.

Con'ger (Ichth.) rórypos, a fea-eel; the Conger-eel.

Congermuræ'na (Ichth.) conger, murena.

Con'gicus (Zool.) Lat. relating to Congo.

Con'ica (Ent.) conus, a cone; conical.

Conifera'na (Ent.) found amongt the Coniferc, cone-bearing trees.

Coniomyce'tes (Bot.) róvios, dufty, uéxns-nтos, a mufhroom.

Coniosau'rus (Fos. Zool.) róvses, róvos, chalk, ouũpos, a lizard; being found in chalk Atrata. 
Coniros'tres (Ornith.) conus, a cone, roftrum, a beak; an order of Pafferes.

Coni'um (Bot.) zwrés, to whirl round; in allufion to its caufing giddinefs and death when taken.

Conjuga'tæ (Bot.) equivalent to Zygnemex.

Conjuge'lla (Ent.) conjux, a confort.

Con'narus (Bot.) P. N. an ancient Greek name; the type of nat. order, Connaracex.

Conne'xa (Ent.) connexus, tied together, connected.

Connubia'lis (Ent.) Lat. conjugal.

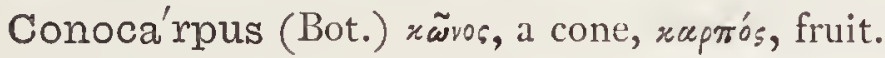

Conoce'phalus (Zool.) a genus of Colubrine ophidians.

Conogna'tha (Ent.) rüvos, à cone, yuátos, a jaw.

Cono'idea (Bot.) xĩvos, a cone.

Conopa'lpus (Ent.) the palpi being conical.

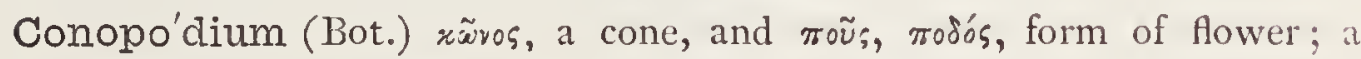
genus of Umbelliferæ.

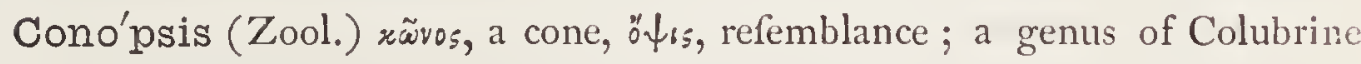
ophidians.

Conospe'rmum (Bot.) iãro:, a cone, and $\sigma \pi \hat{\varepsilon} p \mu \alpha$; a genus of Proteaceæ.

Cono'stomum (Bot.) xâvos, a cone, $\sigma$ rópu, a mouth; the teeth of the theca being united; a genus of Cryptogamia.

Cono'styles (Bot.) xầvos, a cone, $\sigma \tau \tilde{u} \lambda o s$, a pillar, or pistil.

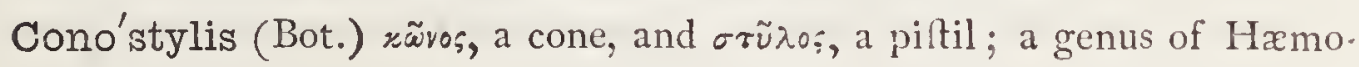
doracex.

Conquisita'lis (Ent.) conquijitus, felect, chofen.

Consanguina'lis (Ent.) confanguineus, related by blood.

Consigna'ta (Ent.) confygrnatus, ftamped, marked.

Consi'milis (Ent.) Lat. very like, i. e. refembling neighbouring genera.

Consobri'na (Ent.) Lat. a relative.

Consocie'lla (Ent.) confocius, united, connected.

Co'nsona (Ent.) Lat. harmonious.

Consona'ria (Ent.) confonus, harmonious, fuitable.

Con'sors (Ent.) Lat. a colleague.

Consorta'lis (Ent.) ?

Consorta'na (Ent.) $\}$ confors, a colleague.

Consorta'ria (Ent.) confors, allied; i. e. to its neighbouring fpecies.

Consorte'lla (Ent.) confors, a confort, colleague.

Conspe'rsa (Ent.) confperfus, fprinkled. 
Conspicilla'ris

Conspicilla'tor (Ent.) confpicillum, a pair of fpectacles.

Conspicilla'tus-a-um (Zool., Ornith.) confpicillum, a pair of fpectacles.

$\left.\begin{array}{l}\text { Conspicua'ta (Ent.) } \\ \text { Conspicue'lla (Ent.) }\end{array}\right\}$ confpicuns, confpicuous, remarkable.

Constricta'ta (Ent.) confrictatus, drawn together.

Constric'tor (Zool.) confringo, to bind faft.

Contamina'na (Ent.) contaminare, to ftain, to fpot.

Contamine'llus (Ent.) contaminatus, Itained.

Contermine'lla (Ent.) conterminus, bordering near; the larva being found in the terminal thoots of Sallows.

Contigua'ria (Ent.) contigurs, near, allied to.

Contorta'lis (Ent.) contortus, twifted.

Conturbate'lla (Ent.) conturbatus, confufed.

Conula'ria (Zool.) conulus, a little cone.

Conu'rus (Ent.) xìvos, a cone, ẽ̃pú, a tail.

Convalla'ria (Bot.) convallis, a valley, in allufion to the localities in which it is found.

Convo'lvuli (Ent.) feeds on Convolvulus arvenfis, the birdweed.

Convol'vulus (Bot.) convolvere, to entwine; i. e. its ftems.

Conwaya'na (Ent.) P. N. in honour of _- Conway, an Englih entomologift.

Cony'za (Bot.) xórs, duft; the powder fprinkled to kill fleas.

Co'okia (Bot.) P. N. in honour of Captain Cook, the celebrated navigator; a genus of Aurantiacex.

Copai'fera (Bot.) copaiba, Brazilian name of a balfam, fero, to bear.

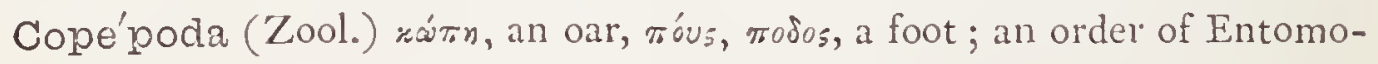
Atraca.

Coope'ria (Bot.) P. N. in honour of Foseph Cooper, a botanift; a genus of Amaryllidacex.

Copho'sus (Ent.) xúpwets, torpor.

Copri'nus (Bot.) xotfice, a dunghill; in allufion to the place where it is found. Co'pris (Ent.) rómpos, dung.

Copro'philus (Ent.) xótipos, dung, фíxos, a lover.

Copros'ma (Bot.) xórpos, dung, or pin, finell.

Co'ptis (Bot.) rómsw, to cut; in allufion to its leaves.

Coptoce'rcus (Ent.) нótra, to cut off, réprus, the tail.

Coptop'terus (Ent.) rorrós, cut off, $\pi \tau \varepsilon$ for, a wing.

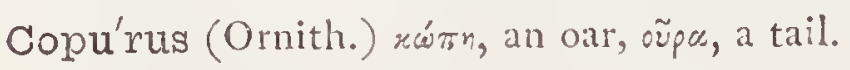


Cora'cias (Ornith.) xópał, жsparos, a raven.

Corallo'ides (Bot.) corallium, a coral, eidos, like.

Corallorhi'za (Bot.) xopá $\lambda \lambda$. sov, a coral, ṕís $\alpha$, a root.

Cora'llus (Zool.) a genus of Ophidians.

Co'rax (Ornith.) Gr. xópą, a raven.

Corbula'ria (Bot.) corbula, a little bakket; Shape of nectary; a genus of

Amaryllidacex.

Corrchorus (Bot.) xópn, the pupil of the eye, ropéw, to purge.

Corda'tus-a-um (Zool., Bot.) Lat. heart-fhaped.

Co'rdia (Bot.) P. N. in honour of E. Cordus, a German botanift of the I 6 th century.

Cordi'gera (Ent.) cor, a heart, gerere, to bear.

Cordyli'ne (Bot.) $\varkappa_{\xi} \delta \dot{d} \lambda n$, a club; a genus of Liliaceæ.

Cordylo'phora (Zool.) xopdúzos, a water-newt, фopú, a burden.

Core'gonus (Ichth.) ropéswus, to satisfy, to fill.

Core'ma (Bot.) xópnpu, a broom.

Core'mia (Ent.) rop'ńsı, fweepings, refufe.

Corene'tes (Ent.) unexplained.

Corenium (Bot.) rópn $\mu \alpha$, filth, from its habitat; a genus of Fungi,

Coreop'sis (Bot.) xógr, a bug, and ö $\psi$ s, refemblance, from form of feeds;

a genus of Compofitæ.

Coria'ndrum (Bot.) xóps, a bug; in allufion to the fmell of its leares.

Coria'ria (Bot.) corium, a hide; it is ufed in tanning.

Co'ris (Bot.) a Greek name ufed by Diofcorides.

Coris'cium (Ent.) róprorıv, dim. from róšr, a little maiden.

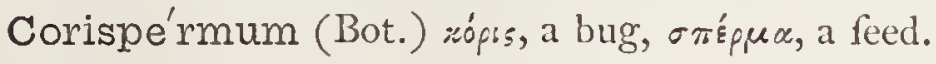

Cork (Bot.) from cortex, bark; fome fay from quercus, the oak.

Corne'lia (Ornith.) P. N. given by Prince Bonaparte in honour of the lady of Dr. Schlegel, of Amfterdam.

Cornicula'ria (Bot.) corniculus, a little horn; a genus of Cryptogamia.

Co'rnix (Ornith.) Lat. a crow.

Cornubie'nsis (Ichth., Bot.) Lat. Cornifh.

Cornuco'piæ (Bot.) cormu, a horn, copia, plenty.

Cor'nus (Bot.) cormu, a horn; in allufion to the hardnefs of the wood.

Cornu'tia (Bot.) P. N. from F. Cornutus, a phyfician of Paris.

Cornu'tus-a-um (Ornith., Bot.) Lat. horned.

Coro'lla (Bot.) Lat. a garland, a little crown.

Corolliflo'ræ (Bot.) corolla, flores, flowers; having ftamens on the corolla.

Corona'tus (Ent.) Lat crowned, from corona, a crown. 
Coro'ne (Ornith.) xopónn, a fea-bird, fea-crow.

Corone'lla (Zool.)
Coronel'lidæ (Zool.) Lat. a little crown.

Coroni'lla (Bot.) Lat. a little crown, from the inflorefcence; a genus of

Leguminofx.

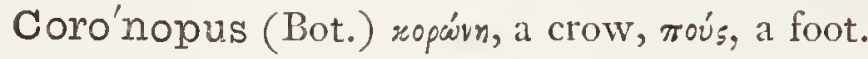

Coro'nula (Zool.) dim. of corona, a crown; a genus of Cirripedes.

Corophi'adæ (Zool.) corophium, with fam. term.; a family of Cruftacea.

Coro'phium (Zool.) this name was applied by Pliny to a kind of crab-fifh.

Corræ'a (Bot.) P. N. in honour of 7 . Correa de Serra, a celebrated Portuguefe botanift.

Corrig'iola (Bot.) dim. of corrigia, a leather thong.

Corruga'tus-a-um (Zool, Bot.) Lat. wrinkled.

Corsi'ra (Zool.) unexplained.

Cortica'lis (Ent.) adj. from cortex, bark.

Cortica'na (Ent.) cortex, bark.

Corti'cea (Ent.) cortex, bark.

Corticel'ia (Ent.) cortex, bark.

Cortu'sa (Bot.) P. N. in honour of F. A. Cortufus, Profeflor of Botany at Padua.

Coru'phium (Ent.) ropuqn', the top of the head.

Cor'vidæ (Ornith.) corvus, fam. term. ide; a family of Coniroftres.

Corvisa'rtia (Bot.) P. N. in honour of Corvifart, a Continental botanift; a genus of Compofitæ.

Corvu'ltur (Ornith.) corvus, a crow, vultur, a vulture; the Crow-vulture of Caffiaria.

Cor'vus (Ornith.) Lat. a crow.

Corya'nthes (Bot.) xópus, helmet, and $\ddot{a} v \theta_{\circ s}$, from form of flower; a genus of Orchidaceæ.

Coryca'rpus (Bot.) xósvs, helmet, and xagtós, fruit, from form thereof; a genus of Graminacex.

Cory'cia (Ent.) P. N., the name of a nymph.

Cory'cium (Bot.) xóšs, a helmet, from form of flower; a genus of Orchidacex.

Coryda'lis (Bot.) the old Greek name for fumitory.

Coryla'lis )

Coryla'na $\}$ (Ent.) corylus, the hazel, on which the infects feed.

Coryla'ta (Ent.) feeds on Corylus avellana, the hazel.

Cor'yli (Ent.) corylus, the hazel, on which it feeds. 
Corylifolie'lla (Ent.) corylus, the hazel, folium, a leaf.

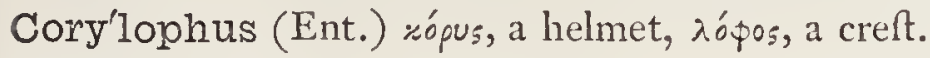

Co'rylus (Bot.) rópus, a helmet.

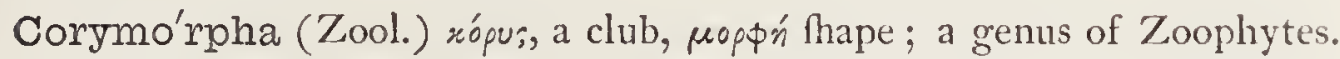

Cory'na (Ent.) xopúrn, a club.

Coryna'ctis (Zool.) xopúrn, a club, úxrís, a ray; a genus of Zoophytes.

Cory'ne (Zool.) xopúrn, a club.

Cory'neum (Bot.) seopurn, a club, from form of plant; a genus of Fungi.

Cory'nidæe (Zool.) coryne, fam. term. ide; a family of Zoophytes.

Coryne'phorus (Bot.) xopúrn, a club, фépw, to bear; a genus of Grafles; alfo a genus of Algæ.

Corynoca'rpus (Bot.) ropúm, and xceøós, from its club-fhaped fruit; a genus of Myıfinacex.

Co'rypha (Bot.) xopusn', a fummit; the leaves being only at the top.

Cory'pllodon (Zool.) xopuф́n, fummit, ódoús, ódortós, a genus of Colubrine

ophidians.

Corysan'thes (Bot.) rópus, a helmet, and avbos, flower; from the helmetlike flower; a genus of Orchidacex.

Corytha'ix (Ornith.) xорuөáił, with waving plume.

Co'rythus (Ornith.) xóputos, a crefted bird of the wagtail or fand-piper kind.

Cosci'nium (Bot.) roб*íssov, a little fieve; from the perforated cotyledons;

a genus of Menifpermacex.

Coscinodis'cus (Bot.) rosxivov, a little fieve, and sír ros, a thield; a folfil diatom, circular and dotted.

Cosinea (Bot.) literally "adorned;" a genus of Compofitæ.

Cosmelia (Bot.) roб $\mu^{\prime} \varepsilon \omega$, to adorn; a genus of Epacridacez.

Co'smia (Ent.) róruros, adorned; a genus of Lepidoptera.

Cosmi'idæ (Ent.) cofmia; a family of Lepidoptera.

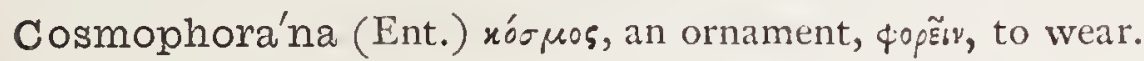

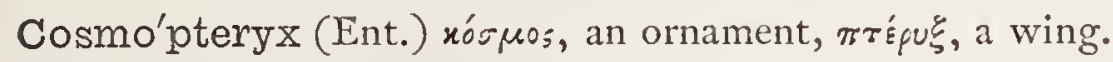

Co'smus (Bot.) róruos, beautiful; a genus of Compofitæ.

Cossig'nia (Bot.) P. N. in honour of M. Coffgrny, a French naturalift who

travelled in the Eaft Indies.

Cossonus (Ent.) unexplained.

Co'ssus (Ent.) a name given by Pliny to a larva found under the bark of trees.

Cos'syphus (Ichth.) xórøupos, a fea-fifh, from its dark colour.

Costrestriga'lis (Ent.) colta, the anterior margin of the wing, friga, a ftreak. 
Costa'na (Ent.) )

Costel'la (Ent.) $\{$ cofta, the anterior margin of the wings.

Costella'ris (Zool.) cofta, a rib.

Costiflexalis (Ent.) cofta, anterior margin of wing, flexus, bent.

Costipuncta'na (Ent.) cofar, the anterior margin, punctatus, fpotted.

Costo'sa (Ent.) coftofis, ribbed.

Costus (Bot.) Arabic name; a genus of Scitamineæ.

Cotonea'ster (Bot.) Cotoneum, a quince-tree after; alluding to its downy leaves.

Co'ttidæ (Ichth.) the family to which the Bull-head belongs.

Cot'toid)

Co'ttus $\}$ (Ichth.) rórsos, Greek name of the Bull-head.

Co'tula (Bot.) dim. of cota, an old name for a fpecies of Anthemis.

Coturni'culus (Ornith.) dim. of coturnix.

Cotu'rnix (Ornith.) Lat. a quail.

Coty'le (Ornith.) xoтúr, a fhallow cup; in allufion to its neft.

Cotyle'don (Bot.) xotúdn, a cavity; in allufion to its cuplike leaves.

Coulteria (Bot.) P. N. in honour of Thos. Coulter, M.D.; a genus of Leguminofx.

Couta'rea (Bot.) from coutari, its name in Guiana; a genus of Cinchonaceæ.

Coutou'bea (Bot.) native name in Guiana; a genus of Gentianacex.

Coverts (Ornith.) name applied to the foft feathers of birds, fiom concealing the bafes of the tail-feathers.

Cowa'nia (Bot.) P. N. in honour of the late Mr. Fames Cozvan, who introduced many plants from Mexico and Peru; a genus of Rofacex.

Crab (Zool.) Anglo-Sax. crabba.

Cra'bro (Ent.) Lat. a wafp; a genus of Hymenoptera.

Crabro'nidæe (Ent.) crabro, fam. term. ida.

Cra'cida (Ornith.) crax, fam. term. ida; the Curaftows.

Cra'cticus (Ornith.) xpurrirós, clamorous.

Cramba'lis (Ent.) from fome refemblance to crambus.

Cra'mbe (Bot.) a Greek name for fea-cabbage, or colewort.

Cra'mbidx (Ent.) Crambus; a family of Lepidoptera.

Cra'mbodes (Ent.) refembling cramluss.

Cra'mbus (Ent.) xpáußos, dry, fhrivelled.

Cramera'lis) (Ent.) P. N. in honour of $P$. Cramer, a German lepidopCramere'lla\} terift.

Cránia (Fos. Zuol.) rpávos, a helmet. 
Craspedoce'phalus (Zool.) xpás $\varepsilon \varepsilon \delta$ ov, an edge or border, $z \varepsilon ф \alpha . \dot{n}$, the head; the rat-tailed ferpent; a genus of Ophidians.

Cra'spedum (Zool.) xpás $\pi$ Ejov, the edge or border; from refemblance to the bolt-rope of a fhip's fails.

Cras'salis (Ent.) crafjus, folid, grofs, i. e., from its thick body.

Crassicorna'lis (Ent.) crafjus, folid, comu, a horn.

Cras'sula (Bot.) dim. of crafius, thick, folid.

Cras'sus-a-um (Bot.) Lat. folid.

Cratæga'lis (Ent.) )

Cratæga'na (Ent.) $\}$ cratcogus, the hawthorn, on which it feeds.

Cratæega'ta (Ent.) feeds on cratagus oxyacantha, the hawthorn.

Cratægel'la (Ent.) cratcegis, on which it feeds.

Cratæ'gi (Ent.) feeds on the cratagus oxyacantha, the hawthorn.

Cratre'gus (Bot.) \%púros, ftrength; alluding to the hardnefs of the wood; the havthorn.

Crata'va (Bot.) P. N. in honour of Cratcerus, a Greek botanift.

Crate'rium (Bot.) from the cup-like involucre; a genus of Fungi.

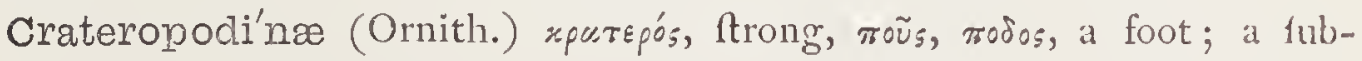
family of Incellores.

Cra'x (Ornith.) xpác $\omega$, to fcream, or cry aloud; a genus of the Gallinæ.

Crécca (Ornith.) xp'św, to make a harp noife.

Crena'na (Ent.) crenatus, wrinkled, crenate.

Crena'tus-a-um (Zool., Bot.) Lat. crenate, having rounded notches.

Crenila'brus (Ichth.) crena, a notch, labrum, the lip; notch-lipped.

Creo'philus (Ent.) xpéas, flelh, фii ${ }^{\circ}$, a lover.

Crepita'ns (Ornith.) part. of crepito, to crackle.

Cre'pis (Bot.) a name given by Pliny to a plant of which he gave no defcription; now the Lady's-ीipper.

Crepusculel'la (Ent.) crepufculum, twilight, duk.

Crepido'dera (Ent.) crepido, the top or edge, Jépn, the neck.

Cresce'ntia (Bot.) P. N. in honour of Pietro Crefcenti, of Bologna.

Cress (Bot.) Anglo-Sax. cerfe; Lat. crefcere?

Cres'sa (Bot.) from Crete, where the plant is plentiful; a genus of Convolvulacex.

Crex (Ornith.) «p' $\varepsilon^{\prime}$, a bird with a harp notched bill; now applied to the Corn-crake.

Cribe'lla (Zool.) cribelum, a little fieve; a genus of Echinodermata.

Cribra'ria (Bot.) cribrum, a fieve, the upper part of the peridium being perforated; a genus of Fungi. 


\section{Cribra'lis) (Ent.) cribrum, a fieve.}

Cri'brum (Ent.) Lat. a freve, from the crofled wing-markings.

Crice'tomys (Zool.) cricetus, the hamfter, mus, a moufe.

Cri'cetus (Zool.) xpísw, to fcreech or fqueak; the Hamfters.

Crina'lis (Ent.) Lat. pertaining to hair.

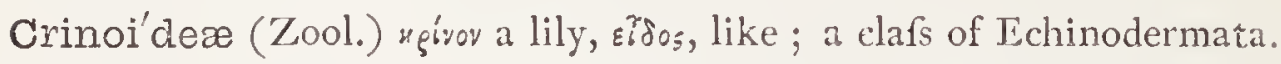

Cri'num (Bot.) xpivov, Greek name of the lily.

Crio'ceras (Fos. Zool.) *uíos, a ram, xépas, a horn.

$\left.\begin{array}{l}\text { Crioce'ridæ } \\ \text { Crio'cerio }\end{array}\right\}$ (Ent.) xpíos, a ram, xśşus, a horn.

Cripti'colens (Ent.) crypta, a vault, colens, dwelling in.

Cri'sia (Zool.) xpíos, feparation; a genus of Polyzoa.

Crisi'dia (Zool.) formed from crifia; a genus of Polyzoa.

Crispus-a-um (Ornith., Bot.) Lat. curled.

Crista'na (Ent.) crifa, a creft or tuft.

Crista'ria (Bot.) crifta, a creft.

Crista'ta (Ent.) Lat. crefted.

Cristatel'la (Zool.) dim. of criftatu, crefted; a genus of Polyzoa.

Cristatel'lidæe (Zool.) crifatella, fam. term. ida; a family of Polyzoa.

Crista'tus-a-um (Ornith., Bot.) Lat. crefted.

Cri'thida (Zool.) xptonn, barley, ểंos, likenefs.

Cri'thmum (Bot.) $x p .6 n$, barley; in allufion to the fimilarity of its feeds.

Crocal'lis (Ent.) crocallis, a precious ftone, probably of a faffron colour.

Croca'tus-a-um (Bot.) Lat. yellow-juiced.

Crocea'go (Ent.) ?

Crocea'lis (Ent.) $\}$ croceus, faffron-coloured.

Crociau'ra (Zool.) xpórn, a thread, oũpa, a tail; applied to the fhrew-mice. Croci'sa (Ent.) zepoxúz, a woolly nap; a genus of Hymenoptera.

Crocodilurína (Zool.) crocodiliss, oü̧a, a tail.

Cro'cus (Bot.) Chaldee, krokin.

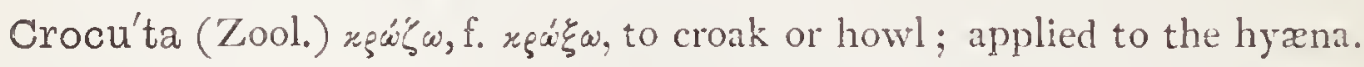

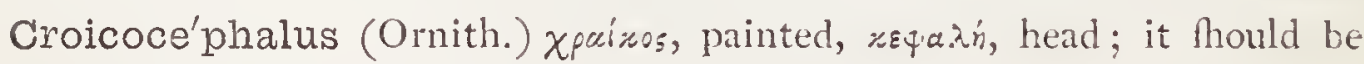
chracocephalus.

Crossa'ndra (Bot.) xpos sos, a fringe, aving, avepos, avdpos, a male,

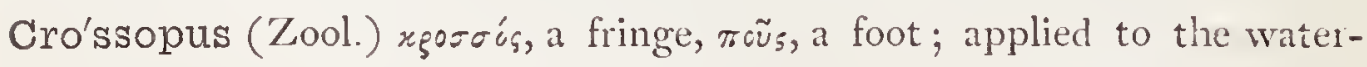
fhrew.

Crosso'stoma (Zool.) ugoreós, a fringe, oróka, the mouth: a genus of Annelids. 
Crotala'ria (Bot.) xpórador, a rattle; in allufion to the rattling of the feeds.

Crota'lidæ (Zool.) xpóra

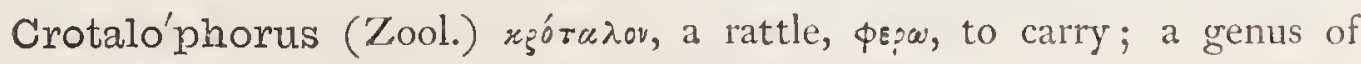
Ophidians.

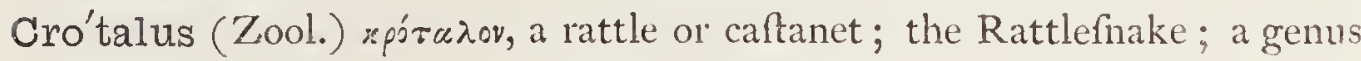
of Ophidians.

Cro'ton (Bot.) rpotwiv, a tick; from the refemblance of the feeds.

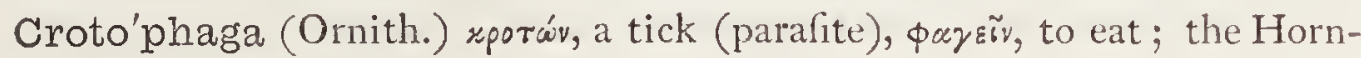
bill cuckoos.

Cro'wea (Bot.) P. N. in honour of $\mathcal{F}$. Crozue of Norwich, a celebrated Brition botanift.

Crozo'phora (Bot.) unexplained; a genus of Euphorbiacex.

Cruciane'lla (Bot.) dim. of crux, a crofs.

Grucifera'rum (Ent.) cruciferce, on which clafs of plants it feeds.

Cru'da (Ent.) Lat. rough, unpolifhed.

Cruenta'lis (Ent.) cruentatus, dyed with blood; i. e. in colour.

Crupi'na (Bot.) fpecific name of a centaurea; from Dutch, cruypen, to creep; becaufe the pappus is fo ftiff as to make the feeds creep when held in the hand.

Crura'lis (Ent.) Lat. belonging to the leg or knee.

Crybe (Bot.) xpúßras, concealed, i.e., the column in the floral envelopes; a genus of Orchidace $x$.

Crymo'des (Ent.) rpurcásns, froft-like.

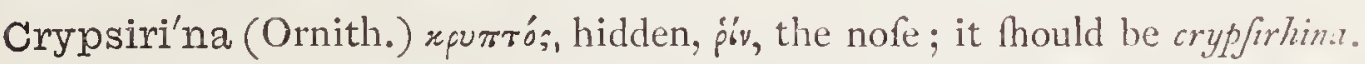
Cry'psis (Bot.) apútriw, to conceal; the flowers concealed in the leaves.

Cryptandra (Bot.) i. e., "hidden ftamens;" a genus of Rhamnaceæ.

Crypta'rchus (Ent.) xpurtós, covered, ügros, a defence.

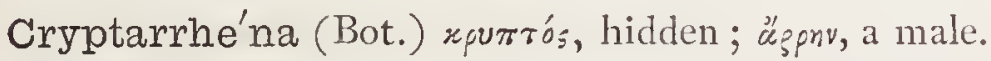

Crypte'lla (Ent.) dim. rputrós, hidden.

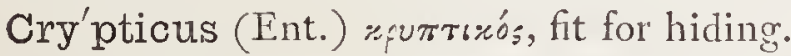

Crypto'bium (Ent.) xpurtós, concealed, B.ów, to live.

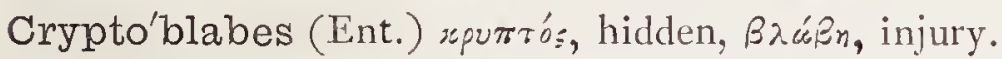

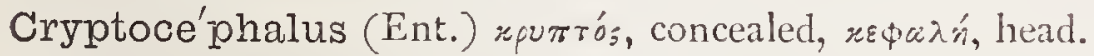

Cryptochilus (Bot.) i. e., "hidden lip;" a genus of Orchidacex.

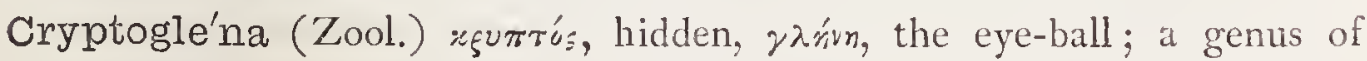
Infuforia.

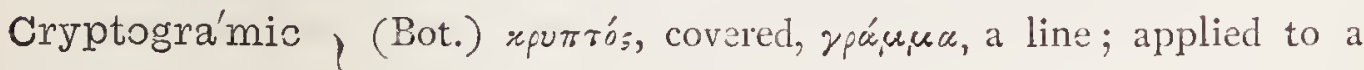
Cryptogra'mma) genus of Ferns; from the concealed lines of thecx. 
Cryptohy'pnus (Ent.) xgutrós, concealed, ürvos, fleep.

Crypto'lepis (Bot.) xpuшrós, $\lambda \varepsilon \varpi \iota \varsigma$, hidden, i.e., fcale-covered, feeds; a genus of Apocynacex.

Cryptomonadi'na) (Zool.) xpurtós, hidden, monas, a monad; a fection of Cryptomo'nas $\}$ Infuforia; having diftinct gelatinous coverings.

Cryptomyces (Bot.) literally "hidden fungus;" from the minuteners of the plant; a genus of Fungi.

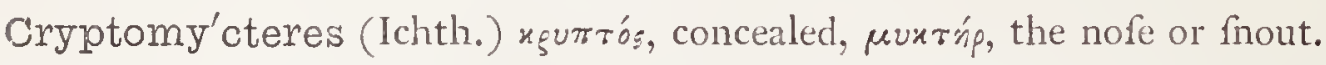
Cryptophi'alus (Zool.) xpurrós, hidden, фiáin, a fhallow cup; a genus of

Cirripedes.

Cryptopro'cta (Zool.) xрuтrós, hidden, торито's, the hinder parts.

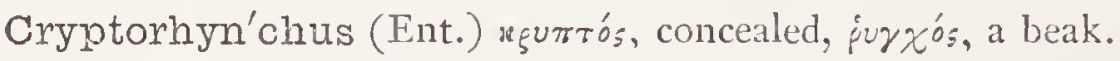

Cryptosper'mum (Bot.) feeds concealed in involucrum; a genus of Cinchonacex.

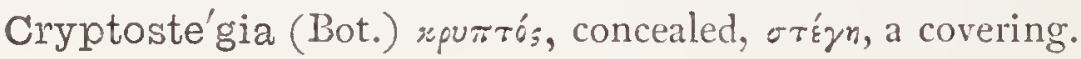

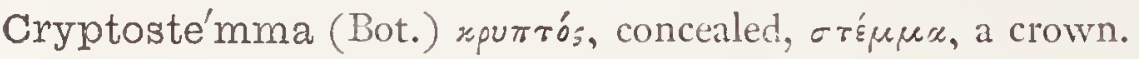

Cryptosty'lis (Bot.) literally "hidden Atyle;" a genus of Orchidacex.

Cryptu'rus (Ornith.) жpúrtw, to conceal, oupó, the tail.

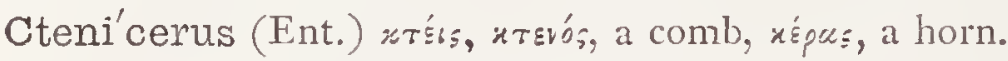

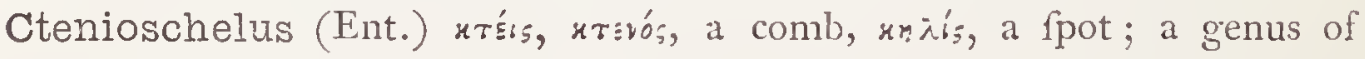
Hymenoptera.

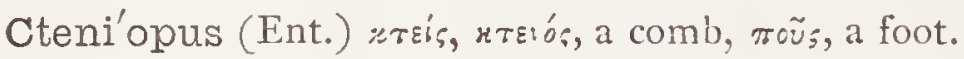

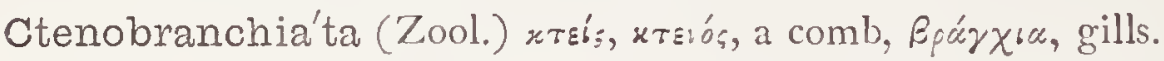

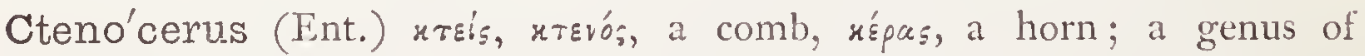
Hymenoptera.

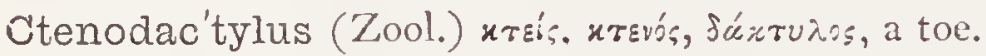

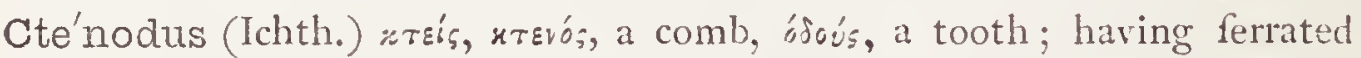
teeth.

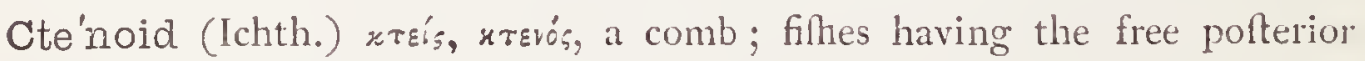
margin ferrated or pectinated.

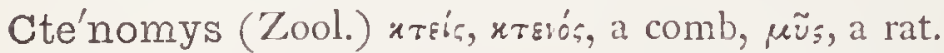

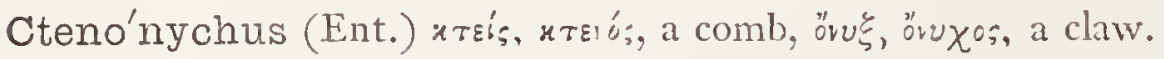

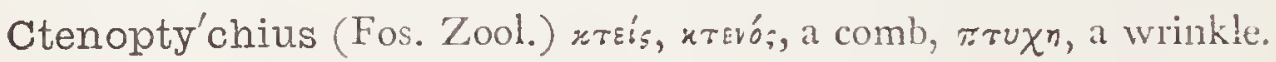

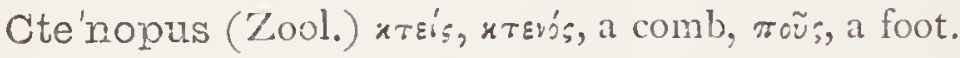

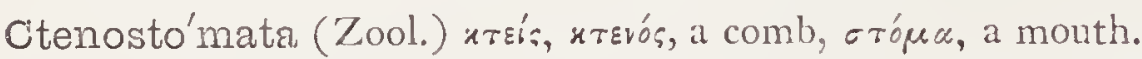

Cubicula'ris (Ent.) Lat belonging to a bed-chamber; occurring in outhonfes.

Cucu'balus (Bot.) altered from carobolus, which from zaxós, bad, fós.os, a thoot. 
Cucu'jidæ (Ent.) cucujus, fam. term. idz ; a family of Coleoptera.

Cucu'jus (Ent.) etymology unknown.

Cucu'lidæ (Ornith.) cuculus, a cuckoo, fam. term. ide; the cuckoos.

Cuculipenne'llum (Ent.) cuculus, a cuckoo, penna, a feather.

Cucullate'lla (Ent.) cucullus, a hood, dim. terminal ella.

Cuculla'tus (Ornith.) Lat. hooded.

Cucu'llia (Ent.) cucullus, a hood; "the collar well developed, and raifed in the form of a hood."-STAinTon.

Cuculli'na (Ent.) cucullus, a hood.

Cucu'lus (Ornith.) Lat. a cuckoo.

Cucuma'ria (Zool.) from refemblance to a cucumbur.

Cu'cumis (Bot.) the Roman name for a cucumber.

Cucuribita Curbitácez (Bot.) cucurbita, a gourd.

Cucurbiti'na (Ent.) cucurbita, a gourd, on which it feeds.

Culci'tium (Bot.) culcitr, a ftuffed bed; referring to heads of paler; a genus of Compofitæ.

Culicifor'mis (Ent.) culex, a gnat, forma, Thape.

Cullu'mia (Bot.) P. N. in honour of Sir Thomas Cullum, F.R.S., F.L.S'.

Culméllus (Ent.) dim. of culmus, a ftalk or ftem.

Cultripa'lpi (Ent.) cultrum, a knife, palpus, a feeler.

Cumínum

Cu'mmin $\}$ (Bot.) Arabic, qamoìn.

Cummin'gia (Bot.) P. N., dedicated to Lady Cumning Goriton.

Cuneate'lla (Ent.) cuneus, a wedge; from certain markings.

Cunicula'lis (Ent.) cuniculus, a rabbit; referring to colour.

Cunicula'ria (Ornith.) cunicularis, pertaining to a rabbit, burrowing like a rabbit.

Cuni'la (Bot.) P. N. from Cunila, the name of a town.

Cunningha'mia (Bot) $J$. and A. Cunningham, botanical travellers in N. S. Wales; a genus of Coniferx.

Cuno'nia (Bot.) P. N. in honour of $\mathcal{F}$. C. Cuno of Amfterdam.

Cúon (Zool.) xíwr, a dog.

Cupa'nia (Bot.) P. N. in honour of Futher Francis Cupani, an Italian monk

and botanical author, who died in $17 \mathrm{ro}$.

Cuphe'a (Bot.) xuqus, curved, from the curved tube of the calyx.

Cu'pia (Bot.) Cupi is the Malabar name of one of the fpecies of Cinclos. naceæ. 
Cuprea'lis (Ent.) cupreus, copper-coloured, $i . c$, the wings.

Cupre'lla (Ent.) cupreus, coppery.

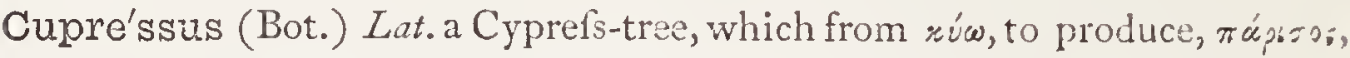
equal, from its regular branches.

Curpreus-a-um (Zool., Bot.) Lat. copper-coloured.

Cupriacel'lus (Ent.) cupreus, coppery.

Cupula'ris (Bot.) cupula, a little cup.

Curate'lla (Bot.) xupsuw, to thave; the natives in Guiana wie the leaves to polifh their bows.

Curcu'ligo (Bot.) curculio, a weevil.

Curcu'lio (Ent.) Lat. a weevil.

Curculio'nida (Ent.) curculio, fam. term. iti.

Curcu'ma (Bot.) Arabic, kurkum.

Currant (Bot.) corrupted from Uve Corinthizce, Corinthian grapes, which they are, being a variety of Vitis vinifera.

Curru'ca (Ornith.) Lat. the Hedge-fparrow.

$\left.\begin{array}{l}\text { Curso'ria (Ent.) } \\ \text { Curso'rius (Ornith.) }\end{array}\right\}$ curfor, a runner.

Curtisel'1us (Ent.)) P. N. in honour of IVillium Curtis, founder of the Curti'sia (Bot.) $\quad$ " "Botanical Magazine."

Curto'gyne (Bot.) literally "curved Atyle;" a genus of Crafiulacex.

Curtome'rus (Ent.) xuprós, curved, unfos, the thigh.

Curtono'tus (Ent.) xuprós, curved, vẽros, the back.

Cu'ritula (Ent.) dim. of curtus, broken, Thort.

Cu'rtus (Ichth.) Lat. Thort.

Curvel'la (Ent.) curva, a curve.

Curviro'stra (Ornith.))

Curviro'stris (Zool.) $\}$ curvus, crooked, roffrum, a bill.

Cu'scus (Zool.) Latinized form of native name, ioufious.

Cu'scuta (Bot.) Arabic, kechout.

Cuso'ria (Zool.) cufor, one who Arikes, from cudo, to ftrike; a genus of Ophidians.

Cuspiclatus-a-um (Zool., Bot.) Lat. part. of $c u / p i d o$, to make pointed,

Cusso'nia (Bot.) P. N. in honour of $M$. Cuffon, a celebrated French botanift.

Cuteria (Bot.) etymology unknown; a genus of Cryptogamia.

Cu'xis (Zool.) native name of a monkey-Brachyúrus Sátanas.

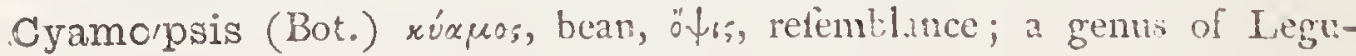
minofe. 
Cya'nea (Ornith.) ruóvsos, dark blue.

Cyane'lla (Bot.) dimin. of xúcros, blue; in allufion to the colour of its flowers.

Cya'neus (Ornith.) xvávess, dark-blue.

Cyanomy'ia (Ornith.) xíavs, dark-blue, «uíce, a ly; a genus of Hunming-birds.

Cyano'tis (Bot.) literally "blue ear," from the colour of flowers; a genu, of Commelynacex.

Cyanu'rus (Ornith.) rúaros, blue, oũpa, tail; the Biue Jay.

Cy'anus (Ornith., Bot.) rýavos, dark blue.

Cyathe'a (Bot.) xuáf๕เov, a little cup.

Cyatho'des (Bot.) literally "cup-like," i. e. the nectary; a genus of Epacridacex.

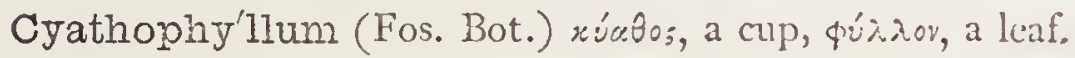

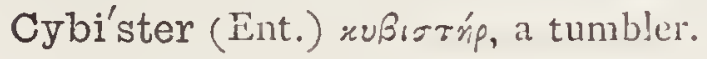

Cy'cas (Bot.) the Greek name of a palm faid to grow in Ethiopis.

Cyclado'ides (Zool.) cyclas, हĩoos, like.

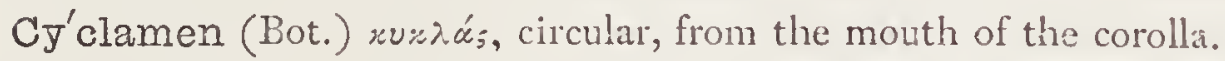

Cyclan'thus (Bot.) literally "circle-flower," from the inforefcence; type genus of Cyclanthacex.

Cycla'rhis (Ornith.) $\dot{u}^{\prime} x \lambda_{0}$, a ring or circle, fis, a nofe.

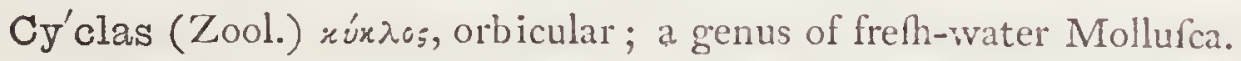

Cy'clica (Ent.) zúr divifion of Coleoptera.

Cyclíäium (Zool.) «úxגos, a circle; a genus of Infusoria.

Cyclobo'thra (Bot.) literally "circle pit," from form of calyx; a genus of Liliaceæ.

Cycloc'orus (Zool.) xúxzos, a circle, rófus, a helmet; a genus of Colubrine ophidians.

Cyjclodes (Ent.) xúx

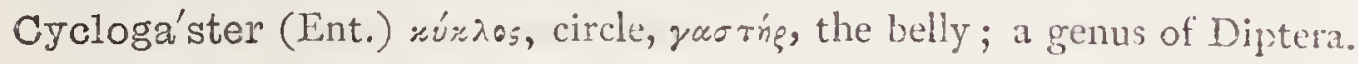
Cy'cloid (Ichth.) xúx $\lambda_{05}$, a circle, from the rounded form.

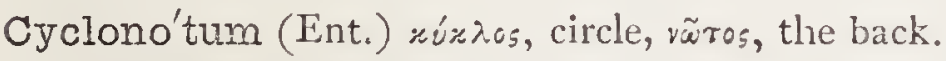

Cyclo'phis (Zool. Ent.) ะúxגos, öprs, a ferpent; a genus of Coluhine ophidians.

Cyclo'pia (Bot.) rúx ros, a circle, mov́s, at foot.

Cyclo'pis (Ent.) refembling cyclops.

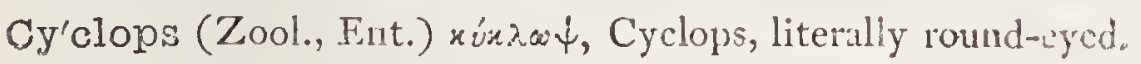

Cyclopsi'na (Zool.) cycion's, with family terminal. 
Cyclopte'ridre (Ichth.) cyclopterus, the family of the Sucking-filhes.

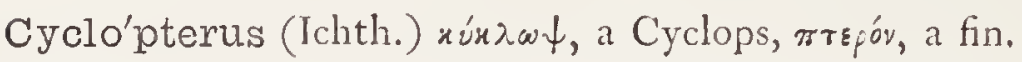

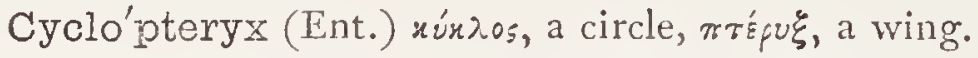

Cy'clorhis (Ornith.) $x \dot{u} x \lambda \circ s$, a circle, $\dot{p} s$, the noftril.

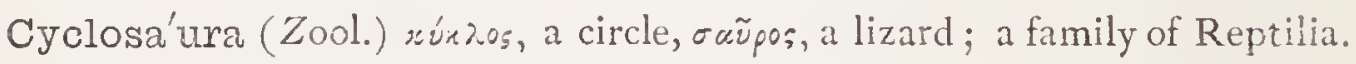

Cyclo'sis (Bot.) implying molecules in circular movement.

Cjolo'stoma (Zool.) )

Cyclo'stomi (Ichth.) \}rúrios, a circle, vróra, a mouth.

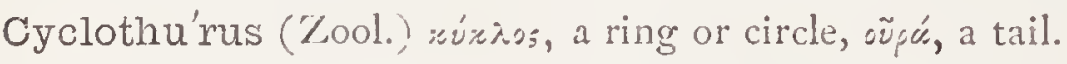

Cyclo' um ( $/$ ool.) u úx $x_{05}$, a circle, wov, an egg, in reference to the arrangement of the ova.

Cyclu'ra (Zool.) zúxzos, a circle, oṽpa, tail ; a genus of Reptiles.

Cycno'ches (Bot.) rúzvo, al fwan; from the gracefully bent form of the flender column.

Cydo'ria (Bot.) P. N., a native of Cydon in Crete.

Cydonia'lis (Ent.) feeds upon cydonia.

Cygnipenne'lla (Ent.) cygnus, a fwan; pema, a feather.

Cy'gnus (Ornith.) Lat. a fwan.

Cylin'dera (Ent) $x \dot{\imath} \lambda$ เvopos, a cylinder, $\delta \xi \xi n$, the neck.

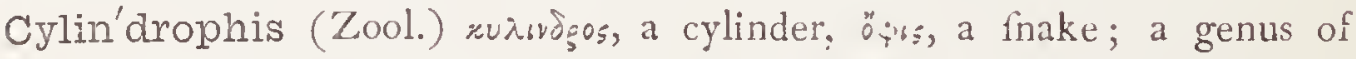
Ophidians.

Cylindrospo'rium (Bot.) rúxsidpos, a cylinder, cropú, a feed; from form of feeds; a genus of Fungi.

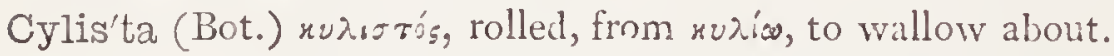

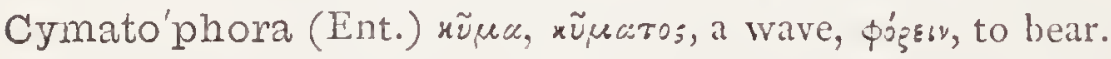

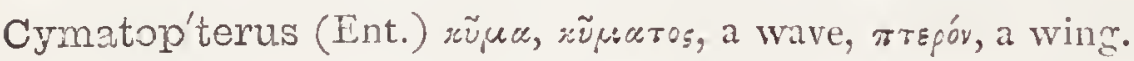

Cymbafor'mis (Zool.) boat-lhaped; from cymba, a boat, forma, thape.

Cymba'ria (Bot.) xúußn, a boat; in allufion to the lhape of the fruit.

Cymbe'lla (Bot.) dimin. of cymba, a boat; a genus of Algx.

Cymbe'llex (Bot.) cymbella; a divifion of Algx equiv. to Diatomacex.

Cym'bidae (Ent.) cymba, a boat; a family with boat-haped larvæ.

Cymbi'dium (Bot.) ríren, a boat.

Cymbifor'mis (Zool., Bot.) zúkßn, a boat, forma, hape.

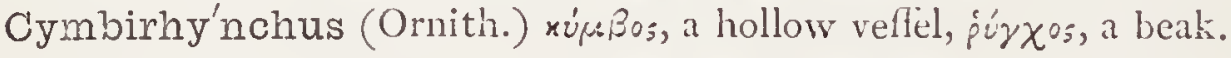

Cymbopo'gon (But.) xýk are boat-fhaped and hairy; a genus of Grafles.

Cymin'dinæ (Ornith.) cumindis, the night-hawk; a fu'J-family of Birds, of the order Raptores.

Cyminosina (Bot.) fruit fwells like Cumin feed; a genus of Rutacex. 
Cymodo'cea (Zool.) P. N. of a fea-nymph mentioned by Viroil.

Cymori'za (Ent.) $x \tilde{v} \mu \alpha$, a wave, $\boldsymbol{i}_{3}^{\prime} \alpha$, the courfe or origin.

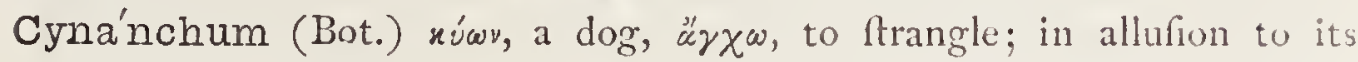
poifonous properties.

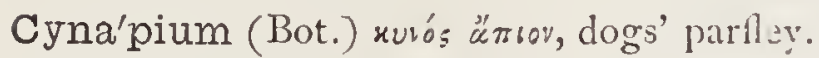

Cy'nara (Bot.) xúwy, a dog.

Cyni'ctis (Zool.) xúw", xuvos, a dog, "̈xть5, a weafel; one of the Viverriclix.

Cynipifor'mis (Ent.) cynips, the gall-Hy, forma.

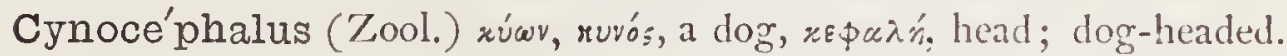

Cyno'don (Bot.) Dog's-tooth grafs, from av́wy, uvvós, a dog, ojovis, odovto: a tooth.

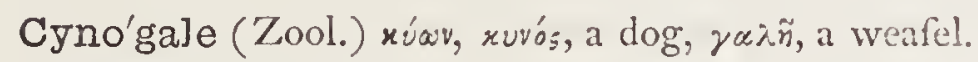

Cynoglos'sum (Bot.) xúwv, xviós, a dog, $\gamma \lambda \tilde{\omega} \sigma \tau \alpha$, a tongli.

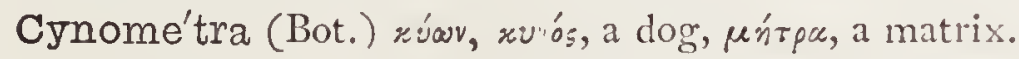

Cyno'phis (Zool.) xúwv, xurss, a dog, öprs, a ferpent; a genus of Col.. ubrine ophidians.

Cynop'terus (Zool.) xúsv, xuvós, a dog, $\pi$ repót, a wing; the winged dog.

Cyno'rchis (Bot.) the double bulbs refemble certain parts of a dog ( $x$ úwr, öp $\left.x^{b s}\right)$; a genus of Orchidacere.

Cynosba'na (Ent.) zuiósßasos, a dog-thorn.

Cynosu'rus (Bot.) xúwv, «vrós, a dog, ovpá, a tail.

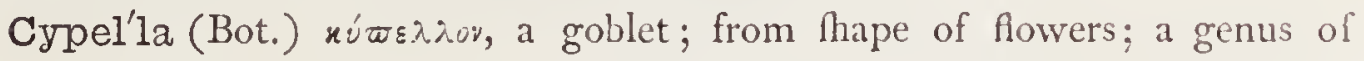
Iridaceæ.

Cype'rus (Bot.) P. N. from Cypris, a name of Venus; the roots are aphrodifiacal.

Cyphe'lium (Bot.)

Cy'phia (Bot.) $\} x u \$ o s$, curved.

Cyphom'yia (Ent.) xuфó, bent forward, $\mu$ ĩ

$\mathrm{Cy}^{\prime}$ phon (Ent.) xuфós, bent.

Cyphónidæe (Ent.) cyphon, fam. term. idx.

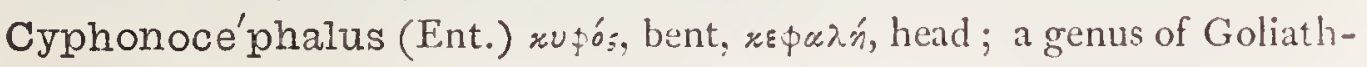
beetles.

Cyphoso'ma (Ent.) xu中ó; bent forward, ox̃ua, the body.

Cy'pridæ ) (Zool.) P. N., Cypris, a name of Aphrodite; a family of Cypridi'nadæ ${ }^{\prime} \quad$ Entomoftraca.

Cypridi'na (Zool.) a genus of Entomoltraca.

Cypri'nidæ (Ichth.) the family of the Carps.

Cypri'nus (Ichth.) Lat. a carp.

Cypripe'dium (Bot.) xúrpss, a name of Venus, tóšrov, a lipper. 
Cy'pris (Zool.) Cypris, a name of Aphrodite; a genus of Entomoltraca.

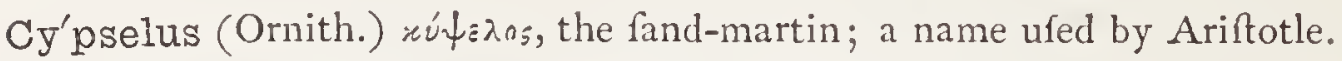
Cypsna'gra (Ornith.) an intolerable word, compounded by a French writer from Cypfelus and Tanagra.

Cyre'bia (Ent.) feeds on rúprísı, bran.

Cyri'lla (Bot.) P. N. in honour of Dominico Cyrillo, M.D., Profeftor of botany at Naples, and F. R. S. London.

Cyrta'nthus (Bot.) жyprós, curved, ävess, a flower.

Cyrtochi'lum (Bot.) literally "concave lip;" from form of corolla; a genus of Orchidacex.

Cyrto'derus (Ent.) zuprós, curved, dśpn, the neck.

Cýrtodon (Bot.) zuprós, curved, ósóvs, óóorros, a tooth; a genus of Cryptogamia.

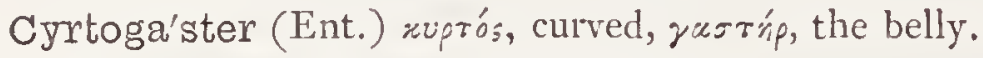

Cy'rtophis (Zool.) vuprós, curved, öpss, a ferpent; a genus of Colubrine ophidians.

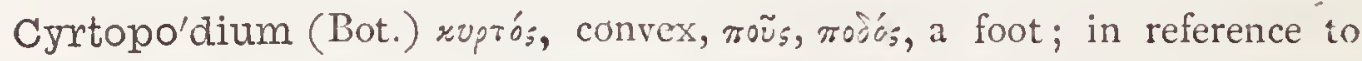
the convex claw of the labellum.

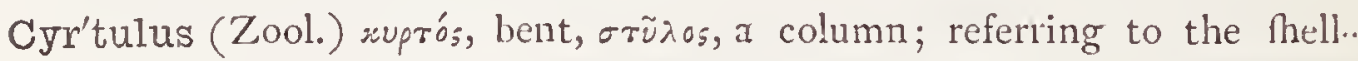
pillar.

Cystica'pnos (Bot.) xúsтьs, a bladder, xarvós, fmoke.

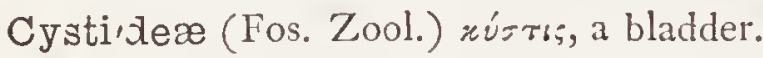

Cystophori'na (Zool.) a fub-family of Mammalia.

Cystosei'ra (Bot.) a genus of Cryptogamia.

Cythe're (Zool.) P. N. from Cytherea, a furname of Aphrodite; a genus of Entomofraca.

Cythere'a (Ent.) P. N. a furmame of Venus; from the illand of Cythera. Cythere'is (Zool.) P. N. from Cytherea, a furname of Aphrodite; a genus of Entomontraca.

Cythe'ridæ (Zool.) P. N. from Cytherea, a furname of Aphrodite; a family of Entomoltraca.

Cytisa'ria (Ent.) feeds on Cytifus nigricans.

Cy'tisus (Bot.) faid to be derived from Cyythnos, one of the Cyclades, where it was firf found. The Cytifus foparius, was probably the flowering cytifus mentioned by Virgil:-

"Florentem cytifum fequitur lafciva capella."-VIR. Ecl. ii. 64. 
Da'ce (Ichth.) Dutch, daas.

Dacryd'ium (Bot.) Jáspu, a tear; from the gumny exudation; a genus of Taxaceæ.

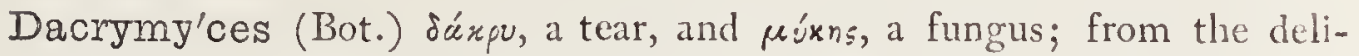
quefcent nature of plant; a genus of Fungi.

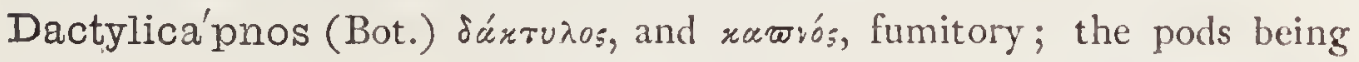
finger-haped; a genus of Fumariacer.

Dactyli'fera (Bot.) fpecific name of the date-tree, from $\delta \dot{\alpha} x \tau \nu_{0}$; , a finger, $\phi^{\prime}$ p $\omega$, to bear; from the refemblance of the bunches of dates to a hand.

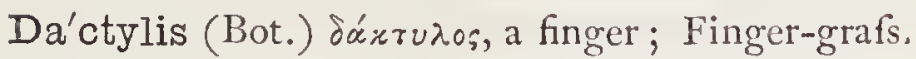

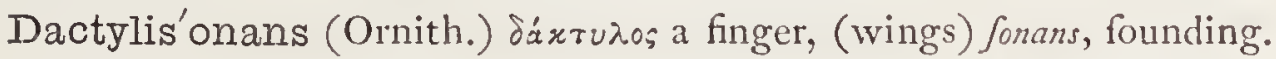

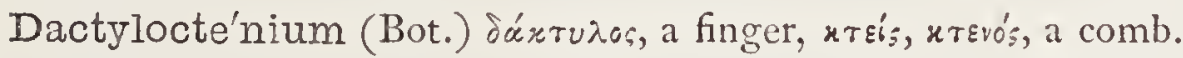

Dæda'lea (Bot.) $\delta a b \delta a \varepsilon_{o s}$, curioully wrought; from the appearance of finuofities; a genus of Fungi.

Dæ'mia (Bot.) from the Arabic name.

Daffodil (Bot.) query, corrupted from Afphodelus?

Da'fila (Ornith.) etymology unknown.

Dah'lia (Bot.) P. N. in honour of Andrec Inalh, a Swedifh botanift. and pupil of Linnæus.

Da'is (Bot.) unknown.

Dai'sy (Bot.) the "day's eye;" Chaucer fays:-

"The daifie or els the eye of daie."

Dalbe'rgia (Bot.) P. N. in honour of Nicholas Dalberg, a Swedifh botanift. Da'lea (Bot.) P. N. in honour of Thomas Dale, an Englifh botanif.

Dalecha'mpia (Bot.) P. N. in honour of James Dalechamp, a French botanift of the 16 th century.

Daliba'rda (Bot.) P. N. in honour of Denis Dalibard, a French botanift.

Dalrym'plea (Bot.) P. N. in honour of Alexander D.slrymple, author of the "Oriental Repertory."

Dalto'nia (Bot.) P. N. in honour of Rv. James Dalton, an Englih bryologift; a genus of Mufci.

Da'ma (Zool.) Lat. a Fallow-deer.

Damæco'rnis (Zool.) dama, a deer, cormu, a horn ; deer-horned.

Dama'lis (Ent.) appertaining to a deer ; fawn-coloured.

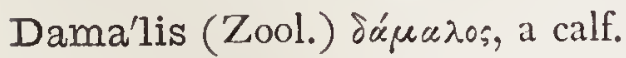

Damaso'nium (Bot.) $\delta \alpha \mu \alpha^{\prime} \zeta \omega$, to fubdue.

Da'mmara (Bot.) its name in Amboyna; the dammar pine.

Dampie'ra (Bot.) P. N. in honour of Captain $W$. Dampier, a celebrated traveller and botanift. 
Da'msons (Bot.) "Old writers have called thofe that grow in Syria, near Damafcus, damfons, or damafe plums, and thofe that grow in Spain, Spanifh prunes or plums; others, from the countries, are called prunes of Hungary, France, \&c." 'The Counts of Anjou introduced the "prunes damyfyns" into Europe.--HarLand's Illuftrations of Shuttlezworth Accts.

Danæ'a (Bot.) in honour of Pierre Martin Dana, who wrote on the plants of Piedmont.

Dan'delion (Bot.) French, dent de lion, lion's tooth.

Da'ne-wort (Bot.) this fœtid plant (Sambucus ebulus) was fuppofed, by our anceltors, to have fprung from the blood of their enemies the Danes.

Dantho'nia (Bot.) P. N. in honour of $M$. Danthoine, a French botanift.

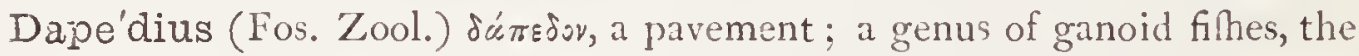
arrangement of the rhomboidal fcales of which refembles a teffelated pavenent.

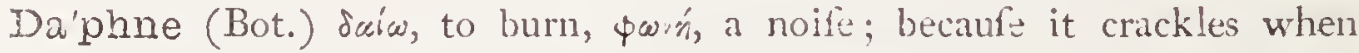
burning.

Daphne'lla (Zool.) dim. of Daphne; a genus of Entomoftraca.

Daph'nia (Zool.) P. N. from Daphne.

Daphni'adæe

Daphni'na $\}$ (Zool.) Daphnia; with family and fub-family term.

Dap'tion (Ornith.) $\delta \alpha \dot{\pi} \pi \omega$, to devour.

Darlingto'nia (Bot.) P. N. from Dr. Darlington, an American botanift.

Da'rnel (Bot.) Anglo-Sax. derian, to hurt; darnel is in all probability the $\zeta \zeta_{\zeta} \alpha \dot{v} \iota \alpha$ of St. Matthew, ch. xiii.

Darvallia'na (Bot.) P. N. in honour of Dr. Darzall, of Birmingham.

Darwi'nia (Bot.) P. N. from Dr. Darwin, author of "The Botanic Gar.. den."

Da'sya (Bot.) dasús, hairy; a genus of Cryptogamia.

Dasy'basis (Ent.) dusí, hairy, farcs, a foot; a genus of Diptera.

Dasy'pidæ (Zool.) dafypus; a family of Mammalia.

Dasypi'na (Zool.) dafypus; a fub-family of Mammalia.

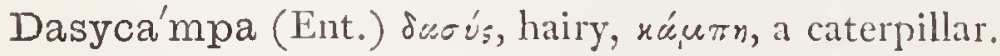

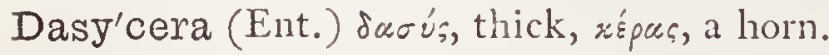

Dasy'dia (Ent.) $\delta a \sigma v^{\prime} s$, covered with hair.

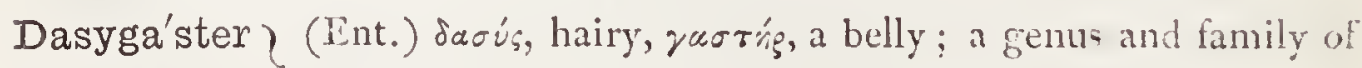
Dasyga'stræ) Hymenoptera.

Dasyor'nis (Ornith.) dusú, hairy, $\ddot{o}_{\xi} v ;$, a bird. 


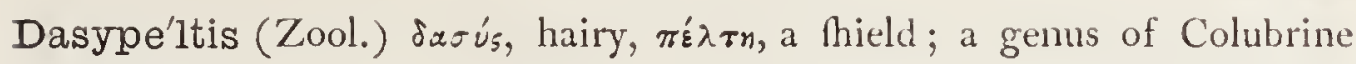
ophidians.

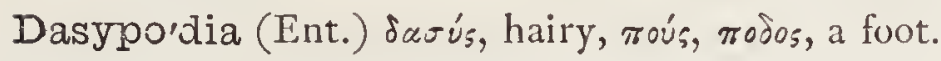

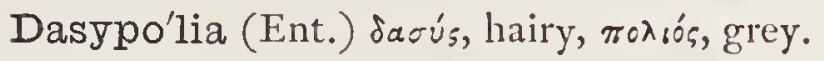

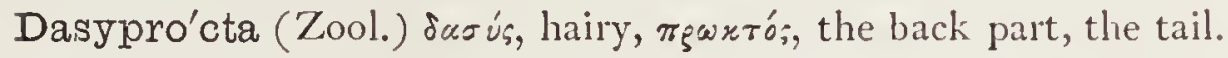

Dasyproctína (Zool.) dafyprocta; a fub-family of Mammalia.

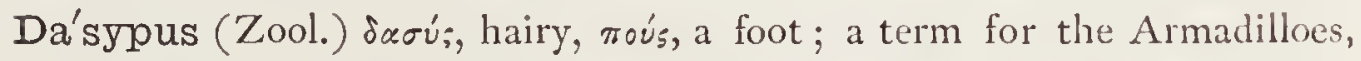
alluding to the fact of the foles of their feet being covered with hair.

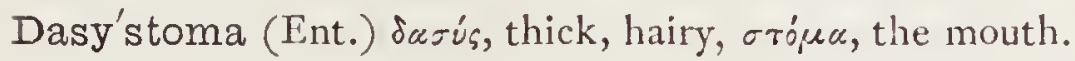

Das'ytes (Ent.) jarúrne, roughnefs, hairinefs.

Dasyu'rina (Zool.) the fub-family of Marfupials, of which Dafyurus is the type.

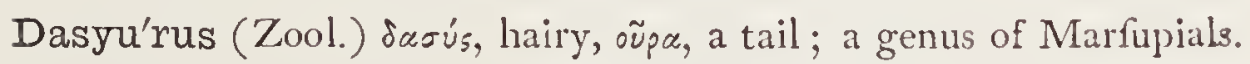

Date (Bot.) from $\delta a x \tau u \lambda_{05}$, a finger; Thape of fruit.

Datu'ra (Bot.) alteration of the Arabic name tâtônah, the 'Thorn-apple.

Daubento'nia (Bot.) P. N. from M. Daubenton, a celebrated naturalift.

Dau'cus (Bot.) Saí, to divide; the carrot.

Dava'llia (Bot.) P. N. from Edmund Davall, a Swifs botanift.

Davie'sia (Bot.) P. N. from Rev. H. Davies, F.L.S., a Wellh botanift.

Daw (Ornith.) fo called from the found it utters.

Deca'ctis (Zool.) dérã, ten, áxтís, a ray.

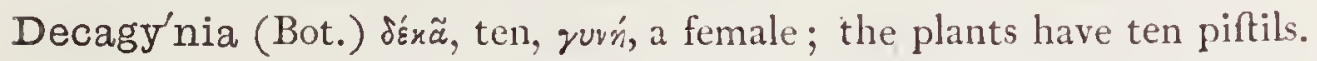

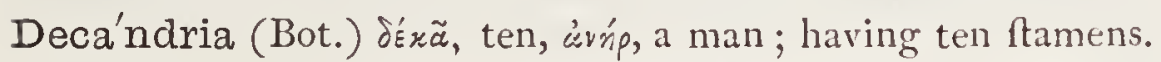

Deca'poda (Zool.) déxã, ten, moús, módos, a foot; the higheft order of Cruftacea.

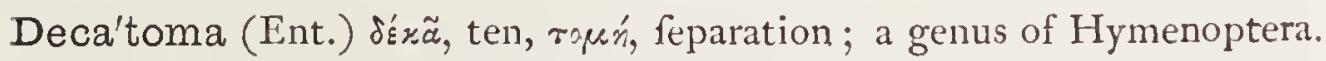

Decli'vis (Zool.) Lat. bending downwards, fteep.

Deco'rus (Zool.) Lat. handfome.

Decuma'ria (Bot.) decuma, a tenth; in allufion to the ten-fold fructure of the flower and fruit.

Decuma'nus (Zool.) Lat. the tenth.

Deer (Zool.) Anglo-Sax. deor.

Deeri'ngia (Bot.) P. N. from Dr. C. Deering, an Englinh botanilt.

Degee'rii (Ent.) P N. in honour of $D_{\varepsilon}$ Geer, a celebrated naturalift.

Deile'phila (Ent.) $\delta \varepsilon i \lambda n$, the evening,

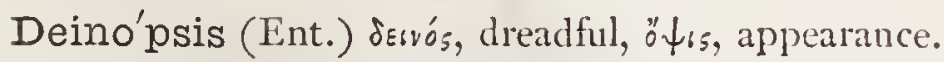

Deino'rnis (Fos. Zool.) des's,s, terrible, ögr:s, a bird.

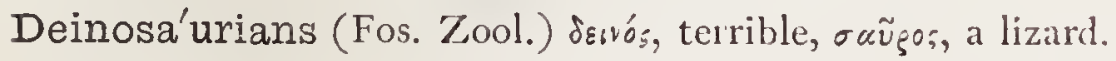

Deinothe'rium (Fos. Zool.) desós, terrible, enş̧or, a wild beatt. 
Deiopei'a (Ent.) $\Delta$ nıтвix, one of Juno's nymphs.

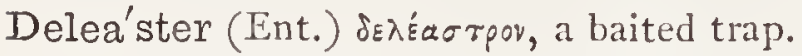

Delesse'ria (Bot.) P. N. from M. Benjamin Dileffert, a French botanical patron; a genus of Algx.

Delica'talus (Zool.) Lat. fomewhat dainty or delicate.

De'liphrum (Erit.)

Delphi'nidæ (Zool.) delphinus, a dolphin.

Delphi'nium (Bot.) delphin, a dolphin, its unexpanded fowers having been fuppofed to refemble the imaginary figures of the dolphin.

Delphi'nus (Ichth.) Lat. a dolphin.

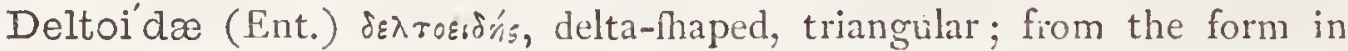
which they arrange their wings when in repore.

De'mas (Ent.) $\Delta$ ńxas, a proper name.

Demeta'na (Zool.) given by Mr. Gofle to a variety of Sagartia; from the circumftance of being found on the Pembroke coaft, formerly inhabited by the Demeti.

Dendraspi'dida (Zool.) dendrajpis, fan. term. ida; a family of Colubrine ophidians.

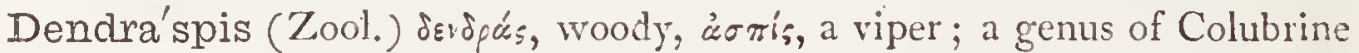
ophidians.

Dendrérpeton (Fos. Zool.) dévòpov, a tree, Ěpretóv, a lizard.

Dendro'bium (Bot.) J'vipor, a tree, Bróa, to live; in allufion to its growing on trees.

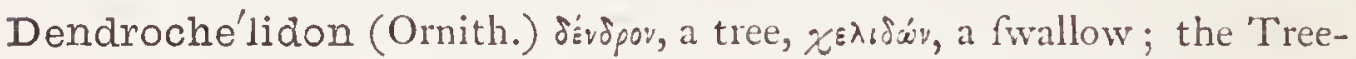
fivallow.

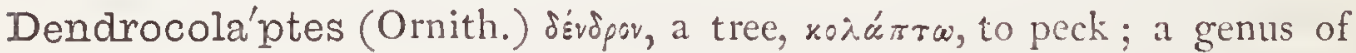
Tree-creepers.

Dendrodo'a (Zool.) Sévopov, a tree, '̌ór, an egg; a fub-genus of 'Tunicated mollufcs; fo called from the ramified form of the orarium.

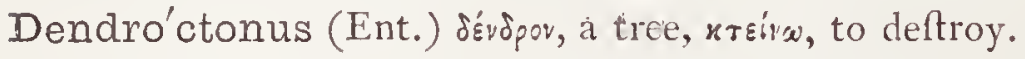

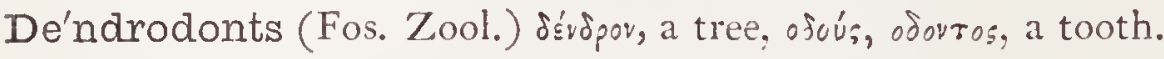

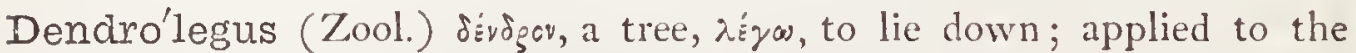
Tree-kangaroo.

De'ndrolite (Fos. Bot.) Sívopor, a tree, $\lambda i \theta_{05}$, a ftone: a general term for foffil wood.

Den'dromys (Zool.) dévopov, a tree, $\mu \tilde{v} s$, a moufe; a South African genus of rodents, refembling mice but inhabiting trees.

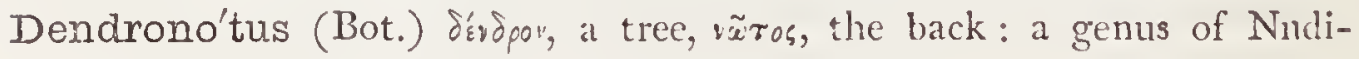
branchiate mollufa. 
Dendro'phidæ ('Zool.) dendrobhis, fam. term. ida; a family of Colubrine ophidians.

Dendro'philus (Ent.) Jévopov, a tree, фínos, a lovel.

Den'drophis (Zool.) dévigor, a tree, öpss, a ferpent; a genus of Colubrine ophidians.

Dendrosau'ra (Zool.) dśrogov, a tree, exípa, a lizard; the Tree-lizards.

Dentalium (Zool.) dens, a tooth; the Tooth-lhell; a genus of Mollufca.

Denta'ria (Bot.) dens, a tooth; alluding to the tooth-like fructure of the roots.

Denta'tus-a-um (Ent., Bot.) Lat. toothed.

Dente'lla (Bot.) dim. of dens, a tooth.

Den'tex (Ichth.) Lat. the ancient name of a filh.

Denticula'tum (Ent.) Lat. having teeth; in allufion to the toothed or vandyked ftripes on the abdomen.

Denticula'tus-a-um (Bot.) denticulus, a little tooth.

Dentiro'stres (Ornith.) dens, dentis, a tooth, rofrum, a beak; a divifion of the order Inceffores.

Denuda'tæ (Ent.) denudatus a-zm, ftripped; a fub-family of Hymenoptera.

Deppe'ana (Bot.) P. N. in honour of F. Deppe, a collector and traveller in Mexico.

Depressa'ria (Ent.) deprefus, flat; in allufion to their flat bodies.

Depressico'rnis (Zool.) depreffus, lying low, deprefled, cornu, a horn.

Depre'ssus-a-um (Zool., Ent., Bot.) Lat. flat, funk.

Derasa'lis (Ent.) derafus, fhaved, fcraped off.

Derbia'nus (Zool.) P. N. in honour of one of the great patrons of Natural Hiftory, the late Lord Derby.

Derce'tis (Fos. Zool.) P. N., a fea-god; a ganoid, eel-like filh of the chalk formation.

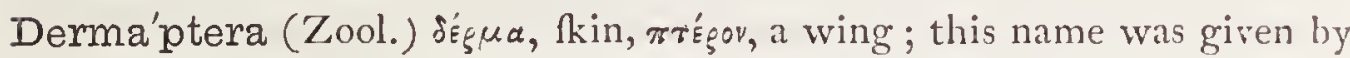
Ariftotle to the Bats, and may be considered equivalent to the Cheiroptera of Cuvier.

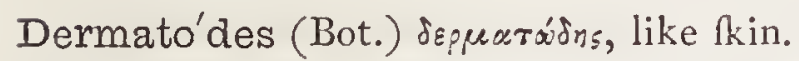

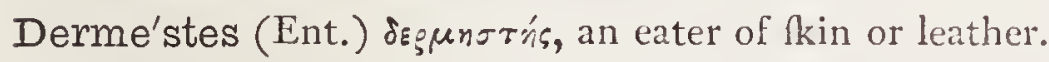

Derme'stidæ (Ent.) dermeftes, fam. term. ida.

Descham'psia (Bot.) P. N. in honour of Dr. Defchampes, a French botanin.

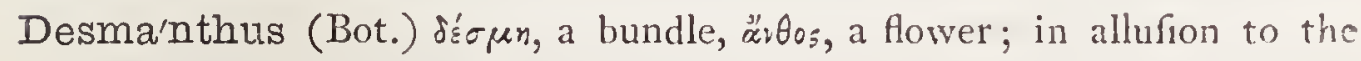
fafcicles of the flowers.

Desmare'stia (Bot.) a genus of Algx; fame etymology as the nest. 
Desmare'stii (Ornith.) P. N. in hononr of $M$. Defmaref, a French naturalift.

De'smia (Ent.) dérun, a bundle; from the fafces-like markings.

Desmidi'eæ (Bot.) defmidium, with fam. term.; a divifion of Algx.

Desmid'ium (Bot.) $\delta \varepsilon=\mu s_{s}$, a bond; from the parts cohering when in a ftate of diflolution.

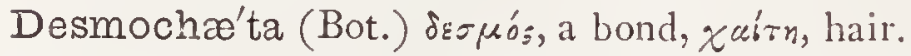

Desmo'dium (Bot.) $\delta \varepsilon \sigma \mu o_{s}$, a band.

Desmo'ncus (Bot.) $\delta \varepsilon \sigma \mu o_{s}$, a band, öyros, a hook; alluding to the tendrils at the apex of the leaves.

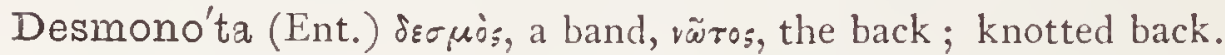

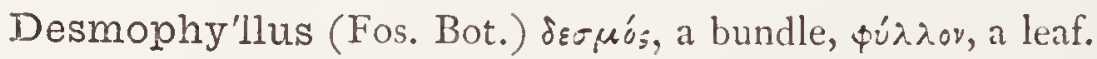

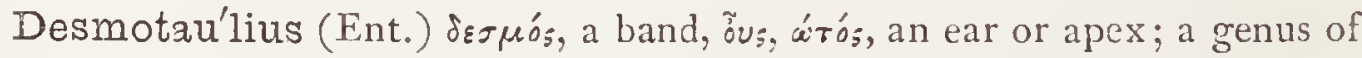
the Phryganidæ.

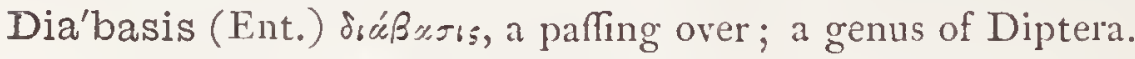

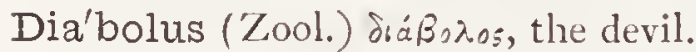

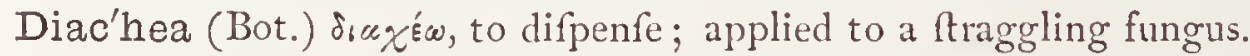

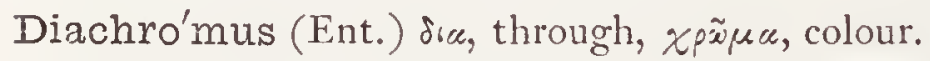

Diade'ma (Ichth., Ent.) Lat. a diadem, the emblem of royalty.

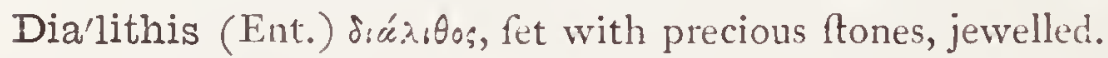

Dial'ysis (Ent.) dićxusıs, a feparation, parting; a genus of Diptera.

Diam'ma (Ent.) dıáspes, very fandy; a genus of Hymenoptera.

Dian'a ('Zool.) P. N., applied to a monkey on account of the crefcentfhaped line of white hairs on the forehead.

Dia'ndria (Bot.) dis, two, árńp, a man; having two ftamens.

Diane'lla (Bot.) P. N. from Diana, the fylvan goddefs; it inhabits woods.

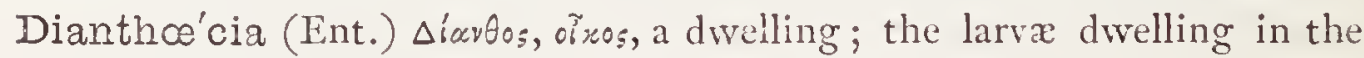
feed-pods of Dianthus.

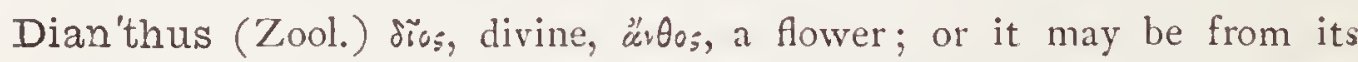
tendency to become double, $\delta_{b}$, the fign of duplication, $a^{2} v \theta_{s}$, a flower, having full or double flowers.

Diapemsia (Bot.) dı́a

Diape'ridæe (Ent.) diaperis, fam. term. ida.

Dia'peris (Ent.) sıcuspúce, to go over.

Diaphana'lis (Ent.) diaфains, tranfparent.

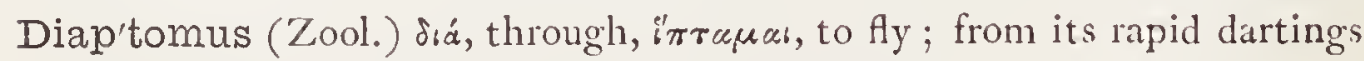
through the water.

Dia'scia (Bot.) dis, two, ar xiov, a little bladder; alluding to the two protuberances at the bafe of the corolla. 


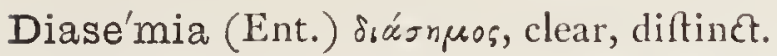

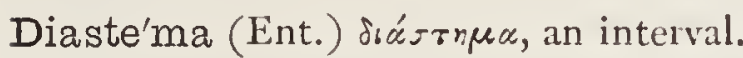

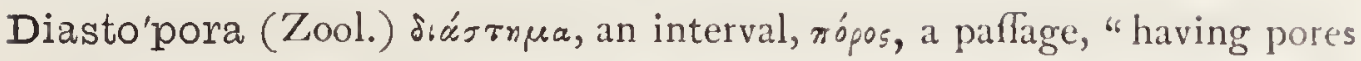
at intervals;" a genus of Polyzoa.

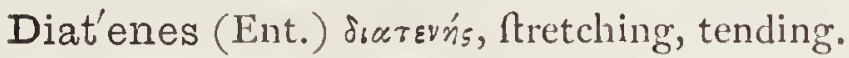

Diato'ma (Bot.) $\delta i \alpha$, through, rśsuw, to cut; the fruftules being almolt feparated.

Diatoma'ceæ (Bot.) diatoma, fam. term. acec; a great divifion of the Algæ.

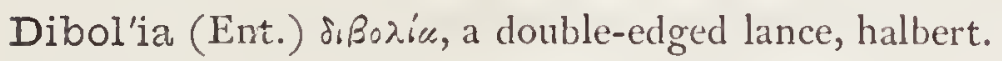

Di'ceras (Fos. Zool.) dís, twice, répas, a horn.

Dicer'ca (Ent.) $\delta i_{\xi}^{\prime}$, twice, répros, a tail.

Dicer'ma (Bot.) fís, twice, $\ddot{\varepsilon}_{p} \mu \alpha$, a prop.

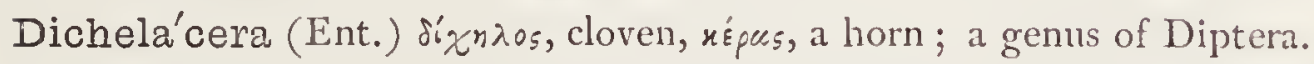

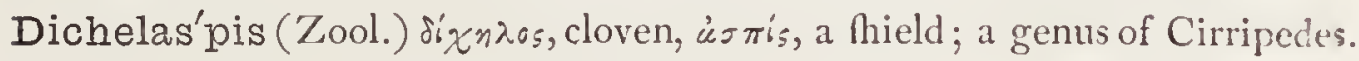

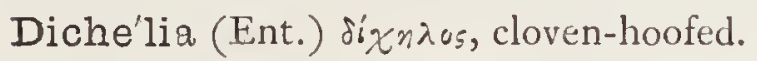

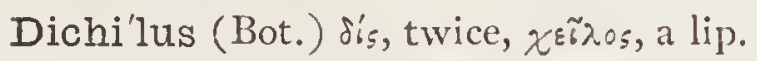

Dichlamy'deous (Bot.) dís, twice, $\chi$ husús, a cloak; having both calyx and corolla.

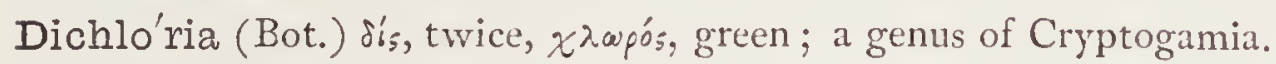

Dichobu'ne (Fos. Zool.) si $x \alpha$, divided, Rouros, a ridge; fo called from the deeply-cleft ridges of the upper molars.

Di'chodon (Fos. Zool.) sixu, in two parts, ésós, odovro; a tooth ; fo called from the double crefcent-fhaped lines of enamel on the upper furface of its true molars.

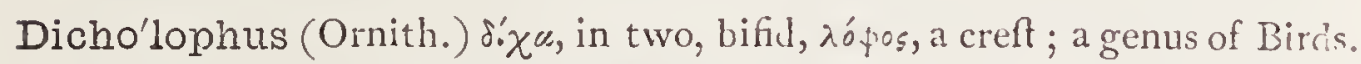
Dicho'ndra (Bot.) fís, twice, xóropos, a grain.

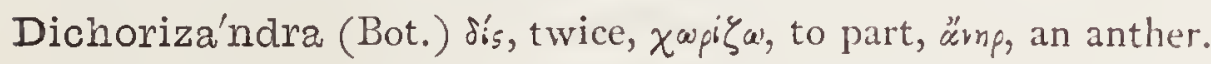

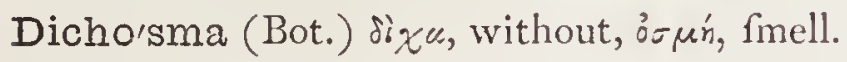

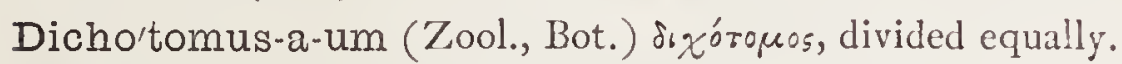

Dichro'mia (Ent.) $\delta \xi_{s}$, twice, $\chi p \tilde{x} \mu \alpha$, colour.

Dickso'nia (Bot.) P. N. from Fames Dickson, a Britih cryptogamift.

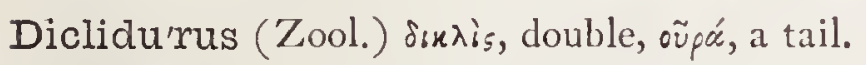

Diclip'tera (Bot.) dis, double, $x \lambda \varepsilon i \omega$, to thut.

Dicotyle'donous (Bot.) dís, double, rotunnsón, feed-lobe; a divifon comprifing all plants whofe feeds are compofed of two lobes.

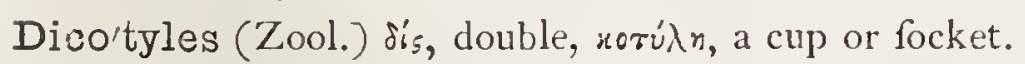

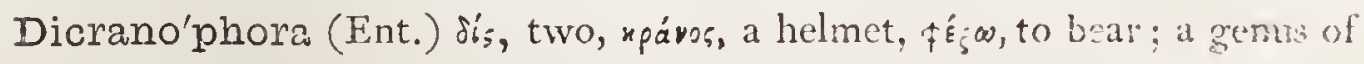
Diptera.

Dicra'num (Bot.) sixpavo;, two-headed. 
Dicranu'ra (Ent.) dixpavos, forked, oũpá, a tail.

Dicranu'ridæ (Ent.) dicranura, fam. term. ide.

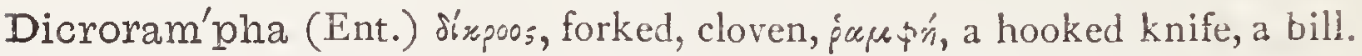

Dicruri'næ (Ornith.) dicrurus, fam. term. inc; a fub-family of Inceflores.

Dicrurrus (Ornith.) dís, double, oũpá, a tail; having a long forked tail.

Dicta'mnus (Bot.) P. N., a Cretan city, on the mountains near which it grows.

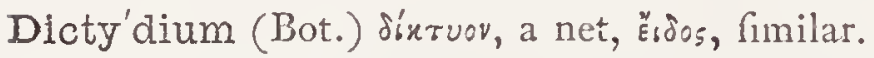

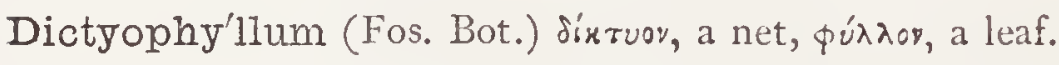

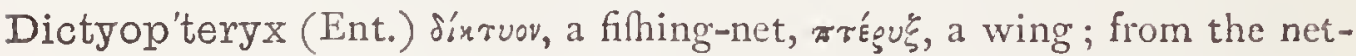

like markings of the wings.

Dictyo'siphon (Bot.) Síxtusv, a net, oífwr, a reed or tube; a genus of

Cryptogamia.

Dictyo'ta (Bot.) díxtuov, a net; a genus of Cryptogamia.

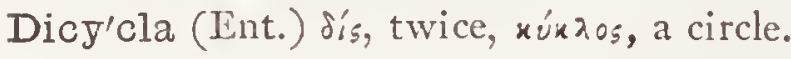

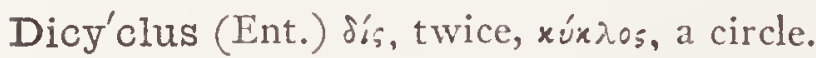

Dicy'nodon (Fos. Zool.) dis, two, xuródous, a canine tooth.

Didelphi'na (Zool.) a fub-family of Mammalia, of which didelphys is the typical genus.

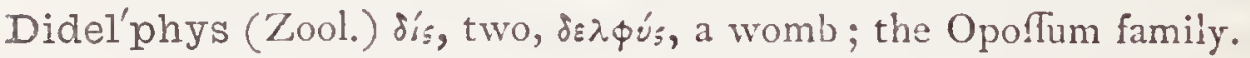

Dide'lta (Bot.) sis, double; $\Delta$, the Greek letter delta.

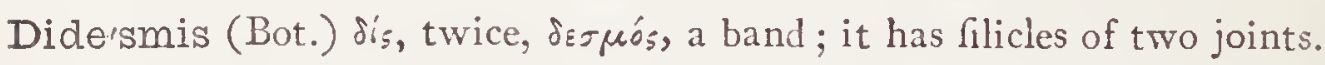

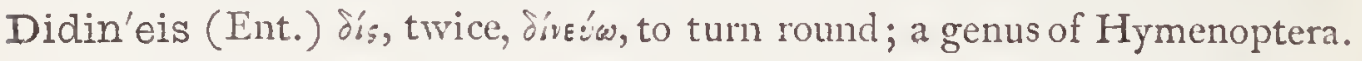

Didun'culus (Ornith.) dim. of didus; the bird being the neareft living reprefentative of the latter.

Di'dus (Ornith.) Latinized form of the Dodo.

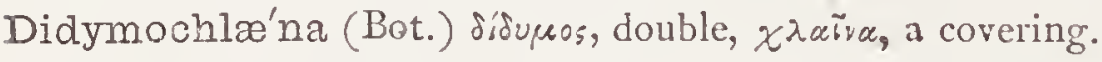

Didy'modon (Bot.) disures, double, odous, a tooth; the teeth of the fringe are in pairs; a genus of Mufci.

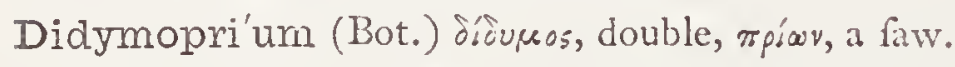

Didy'namous (Bot.) having two long and two fhort ftamens.

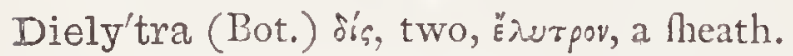

Diervi'lla (Bot.) P. N. from Dierville, a French furgeon, who travelled in Arcadia.

Diffu'gia (Zool.) diffuo, to flow, to diflolve.

Difiusa'lis (Ent.) diffufus, fcattered.

Digitagra'da (Zool.) digitus, the toe, gradus, a nep; an extenfive tribe of carnivorous animals whofe feet are conltructed for walking on the 1 oes. 
Digita'lis (Bot.) digitale, the finger of a glove; alluding to the form of the flower; the Foxglove.

Digita'ria (Bot.) digitus, a finger; from the heads being fingered; fingergrais.

Digita'tus"a-um (Zool., Bot.) that has fingers, toes, or claws.

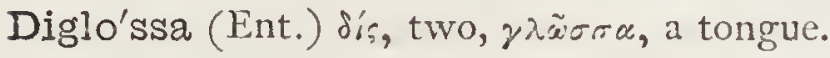

Digly'phus (Ent.) $\delta i \gamma \lambda \nu \uparrow 25$, doubly indented.

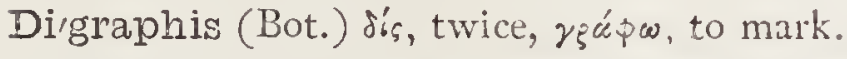

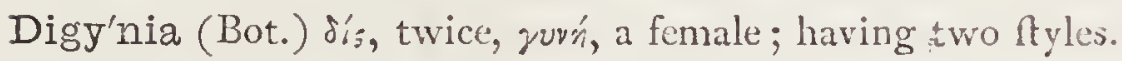

Di'latris (Bot.) dis, two, later, a tile.

Dille'nia (Bot.) P. N. from J. J. Dillenius, Profeflor of botany at Oxford.

Dillwy'nia (Bot.) P. N. from $L$. W. Dillwyn, a celebrated botanift.

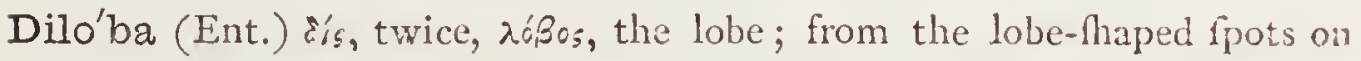
the forewings.

Dilucida'lis (Ent.) dilucidus, clear, bright.

Di'mades (Zool.) sicexdns, very wet; a genus of Ophidians.

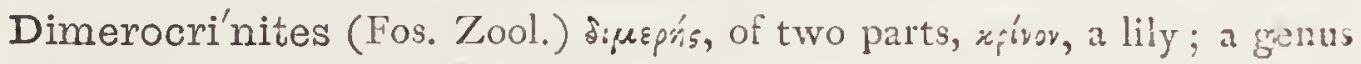
of Clinoidea.

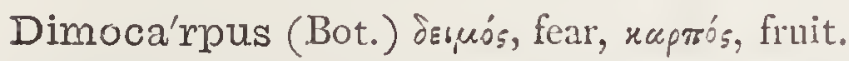

Dimo'rphodon (Fos. Zool.) dípepфos, two-formed, ódús, odórtos, at tooth: having two kinds of tecth.

Dimya'ṛia (Zool.) $\delta_{i s,}$ twice, $\mu \tilde{v}_{s}$, a mufcle; the Thells of thefe bivalva: being clofed by two adductor mufcles.

Din'ebra (Bot.) the Arabic name.

Dine'ma (Zool.) Jís, twice, iñuce, a thread.

Dinemou'ra (Zool.) fís, two, iñ $\mu \alpha$ a thread, oupra, a tail; a genus of Ento moltraca.

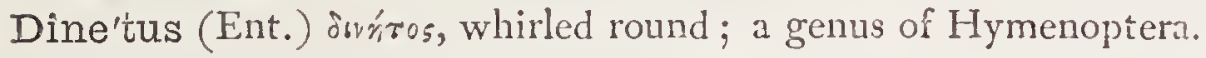

Dino'derus (Ent.) díros, twifted, dépn, the neck.

Di'odon (Zool., Ichth.) dis, double, ofous, oforros, a tooth; this name is applied to a whale, a funfin, and a thell.

Diodon'tus (Ent.) sis, twice, doove, odorros, a tooth; a genus of Hymenoptera.

Diœ'cia (Bot.) sis, double, o'xic, a houfe; having ftamen-bearing flowers on one plant, and piftil-bearing flowers on another.

Diomede'a (Ornith.) P. N. from Diomeds; a genus of Sea-.birds.

Diome'dia (Bot.) P. N. from Diomeda, the daughter of Phorbas.

Diona's (Bot.) P. N. one of the mames of Venus. 
Diosco'rea (Bot.) P. N. from Pedacius Diofcorides, a Greek phyfician.

Dio'sma (Bot.) jiss, divine, ósuń, a fmell.

Dios'pyros (Bot.) dios, divine, $\pi u_{5} o_{s}$, wheat; the diofpyros lotils is the European Date-plum.

Dio'stolus (Zool.) dı́s, excellent, $\sigma \tau о \lambda \dot{r}$, a garment.

Dio'tis (Bot.) dis, double, oũs, $\tilde{\omega} \tau o s$, an ear; it has two appendages at the bafe of florets

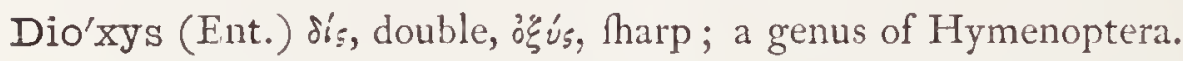

Di'phaca (Bot.) d'́s, two, фaxñ, a lentil; it has two feeds in the pods.

Diphaglo'ssa (Ent.) Sí $\propto \alpha$, a kind of ferpent, $\gamma \lambda \tilde{\omega} \sigma \sigma \alpha$, a tongue; a genus of Hymenoptera.

Diph'thera (Ent.) $\delta เ \phi \theta \varepsilon$ pa, a Frepared lide.

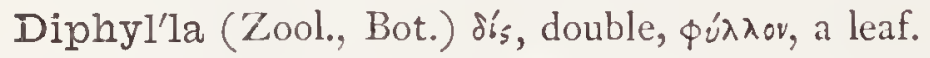

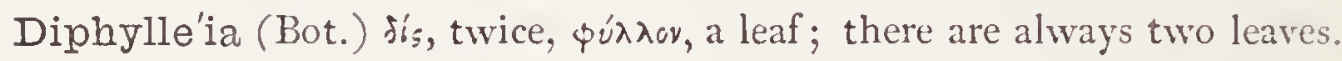

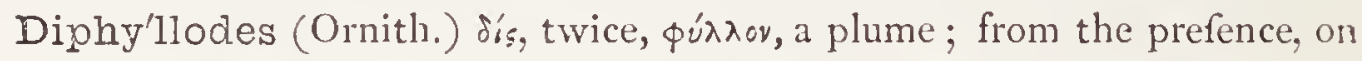
each fide of the neck, of two peculiar tufts of feathers.

Diphy'odonts (Zool.) disun's, of double form, joovs, a tooth; the term ufed by Profeftor Owen to denote thofe animals which have two fuccefive fets of teeth.

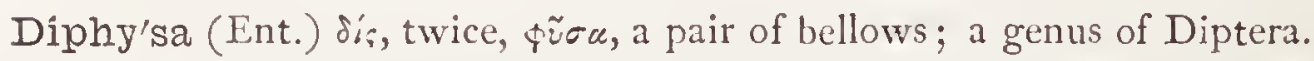

Diphy'sa (Bot.) dís, two, фũrce, a bladder; it has two inflated appendages to pods.

Diphy'scium (Bot.) Jí, twice, фúzxn, a bladder; a genus of Mufci.

Di'pina (Zool.) dipus ; a fub-family of Mammalia.

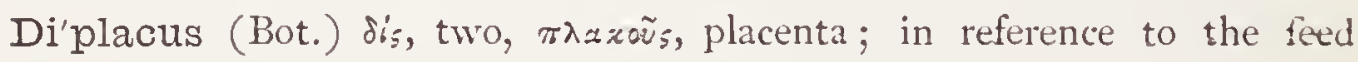
having two placentæ.

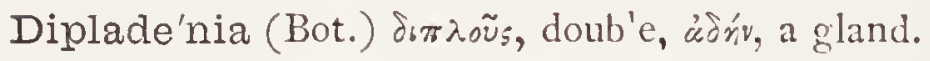

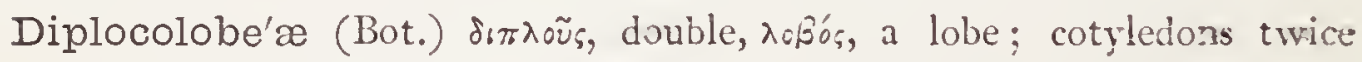
folded tranfverfely.

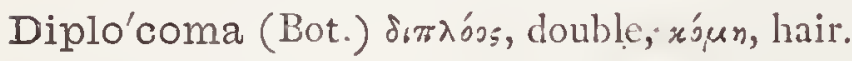

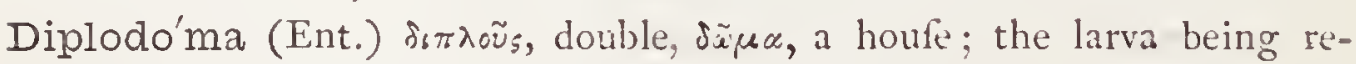
markable for its double cafe.

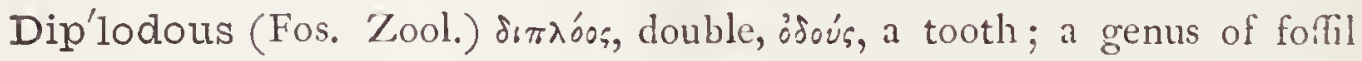
placoid fithes found in the coal formation.

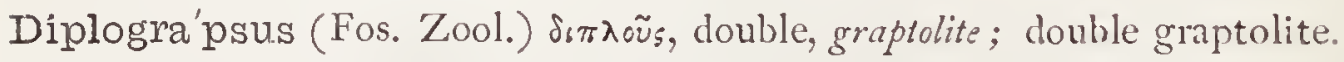

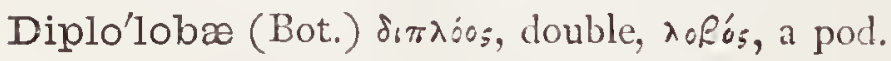

Dipla'zium (Bot.) $\delta: \pi \lambda a^{\prime} \zeta \omega$, to double.

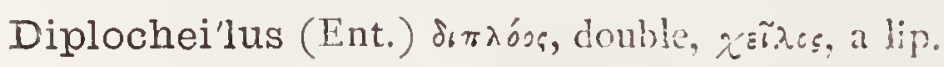

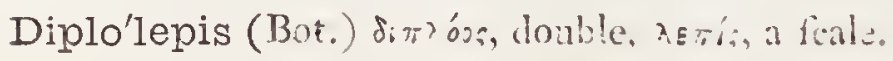


Diplo'prion (Ichth.) $\delta 6 \pi \lambda \circ \tilde{u}_{5}$, double, $\pi$ píwr, a faw; a genus of the family Percidæ.

Diplop'tera (Ent.) $\delta_{6} \pi \lambda_{0} \tilde{u}_{5}$, double, $\pi \tau \varepsilon$ pór, a wing; a tribe of Hymenoptera.

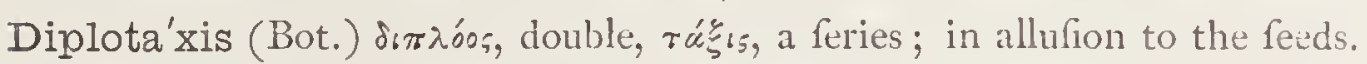

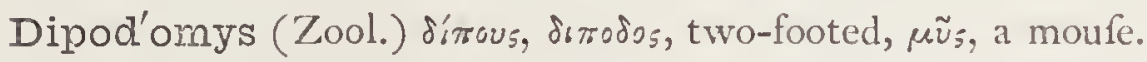

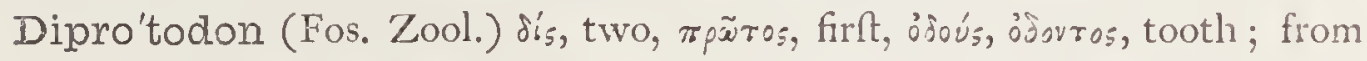
the large fcalpriform character of its incifors or fiont teeth.

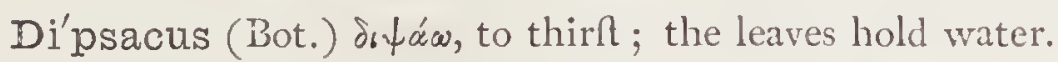

Dipsa'didæ (Zool.) dipfas, fam. term. ide; a family of Colubrine ophidians.

Dipsadobo'a (Zool.) a genus of Colubrine ophidians.

Dipsadomo'rphus (Zool.) a genus of Colubrine ophidians.

Di'psas (Zool.) dułús, a venemous ferpent, whofe bite caufed intenfe thirft; a genus of Colubrine ophidians.

Di'ptera (Ent.) öirrepos, with two wings.

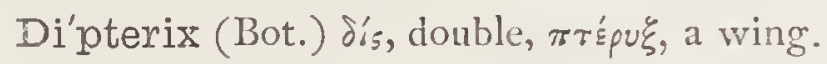

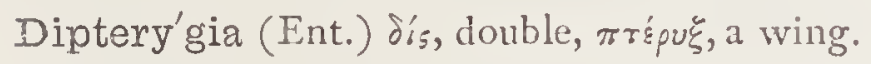

Di'pus (Zool.) dírous, two-footed.

Dircæ'a (Ent.) P. N. from Dirce, the wife of Lycus, king of Thebes.

Dischi'dæ (Zool.) equiv. to bifulcate; applied by Ariftotle to animals having divided hoofs; from $\delta ; \%$, double, and $\sigma \chi \zeta \omega \omega$, to divide.

Dischi'dia (Bot.) $\delta^{\prime}, 5$, twice, $\tau \chi^{\prime} \zeta \omega$, to fplit.

Discoe'lius (Ent.) ficros, a diR, $\dot{n} \lambda 6 \%$, the fun; a genus of Hymenoptera.

Dis'color (Zool.) Lat. party-coloured.

Discoloralis (Ent., Bot.) difcolor, party-coloured.

Disco'pora (Zool.) dírxos, a dikk, tópos, a paftige or pore.

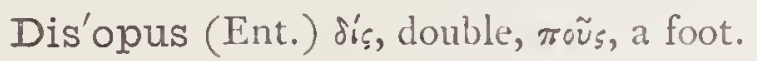

Dis'par (Ornith.) Lat. unequal.

Dispara'lis (Ent.) difpar, unequal.

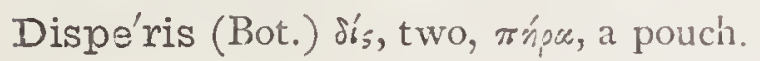

Di'sporum (Bot.) dis, twice, wópos, a palfage or pore.

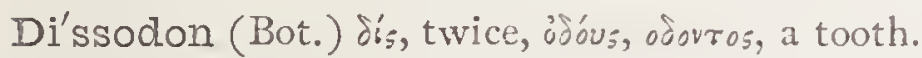

Dissole'na (Bot.) $\delta^{\prime}$; twice, $\sigma \omega \lambda \dot{n}^{\prime}$, a tube; referring to the tube of the corolla.

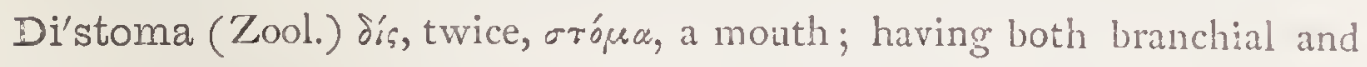
anal orifices.

Di'stomus (Ent.) Jis, twice, orónc, a mouth.

Dithyro'caris (Fos. Zool.) $\delta$ : 9 upon, having two valves, xupis, a thrimp.

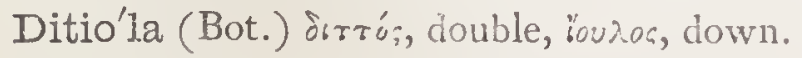

Dit'ula (Ent.) dirv.2n, with two humps. 
Diurna'lis (Ent.) diurnus, of the day.

Diur'nea (Ent.) diurnus, of the day, daily.

Diur'ni (Ent.) Lat. pl. of diumus, daily, applied to the Day-Rying moths.

Diu'ris (Bot.) Éci, double, ớcú, a tail.

Dixo'ni (Fos. Zool.) P. N. from - Dixon, author of "The Foffils of Suffex."

Dock (Bot.) Anglo-Sax. docce; name of plants of the genus Rumex.

Dodar'tia (Bot.) P. N. from F. Dodart, a French botanift.

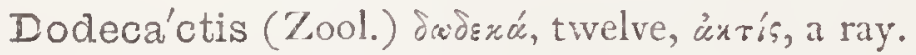

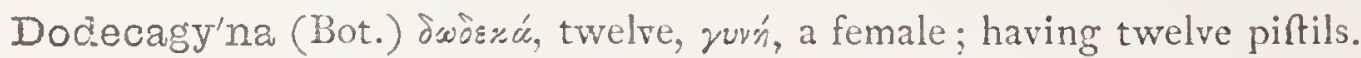

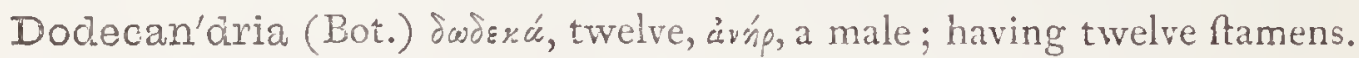

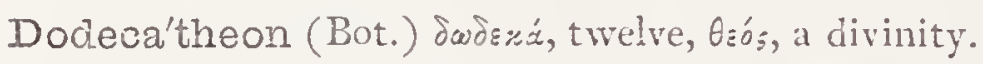

Do'do (Ornith.) Ital., Span., Port., and French, name of a bird now extinct, difcovered by the Portuguefe in 1499.

Dodonæ'a (Bot.) P. N. from R. Dodocns, a celebrated botanift.

Doe (Zool.) Anglo-Sax. du, Lat. duma.

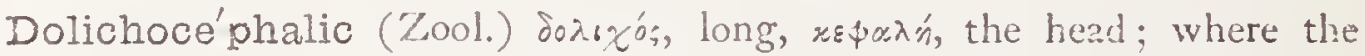
development of the $1 \mathrm{kull}$ is in the occipito-frontal diameter.

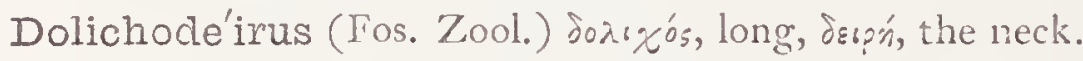

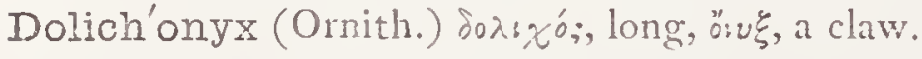

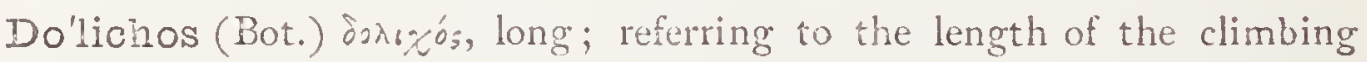
Atem.

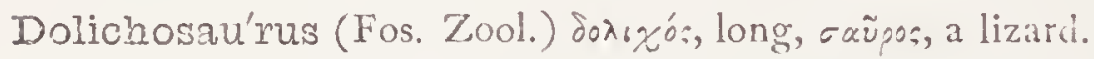

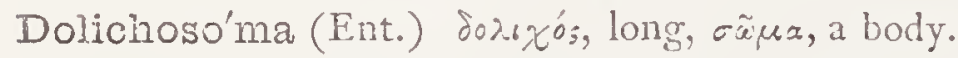

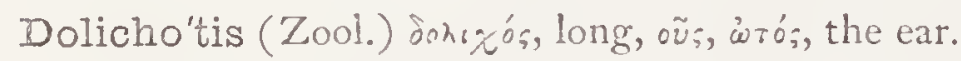

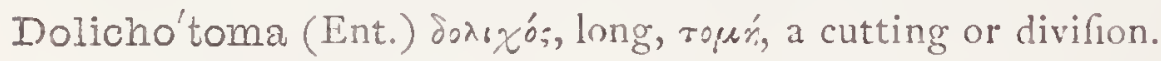

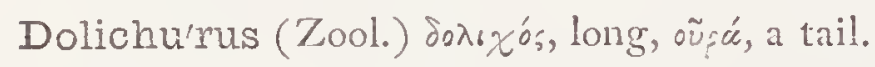

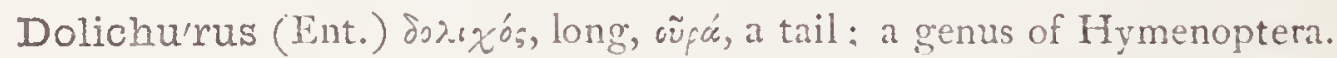

Dolioca'rpuss (Bot.) Jónsos, deceitful, rapøos, fruit; in allufion to its poifonous qualities.

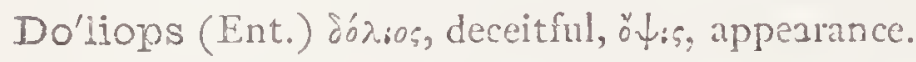

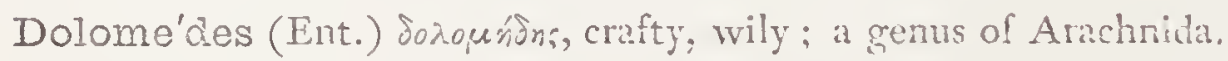

Dolo'pius (Ent.) jonowosós, treacherous, enlinaring.

Dolohin ?

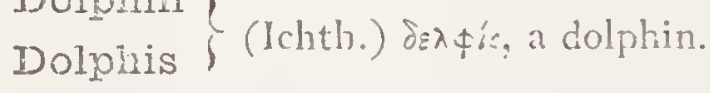

Dombe'ya (Eot.) P. N. in honour of Jofeph Dombey, a celebrated French botanif.

Domestica'lis (Ent.) doneficus, tame.

Domes'ticus-a-um (Ornith., Bot.) Lat. tame. 
Don'dia (Bot.) P. N. in honour of Dondie Duprée, a French botanift.

Doo'dia (Bot.) P. N. in honour of Samuel Doody, a London apothecary, and firt Britilh cryptogamilt.

Dor (Ent.) Anglo-Sax. dora, a locunt, a drone.

Do'ris (Zool.) P. N., the mother of the fea-nymphs, called Nereides.

Do'rmouse (Zool.) Anglo-Sax. dora, a drone, fleeping, mus, a moufe.

Dorste'nia (Bot.) P. N. from T. Dorften, a German botanift.

Do'ry (Ichth.) French, dorée, gilded; John Dory is probably from jaune dorée, from its golden yellow colour.

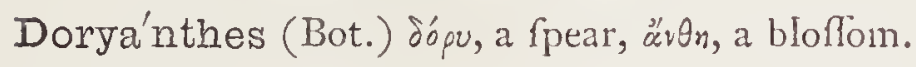

Dory'cnium (Bot.) Jopu, a fpear; the ancient plant was poifonous.

Dory'liảæ (Ent.) dorylus, fam. term. ida; a family of Hymenoptera.

Do'rylus (Ent.) Sópú, a fpear; a genus of Hymenoptera.

Dory'tomus (Ent.) dópu, thaft of a fpear, rouń, a part cut off.

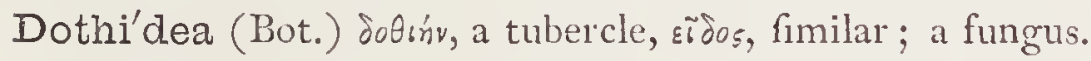

Douga'llii (Ornith.) P. N. in honour of $M$. Dougall, an eminent ornithologint.

Dougla'sia (Ent.) P. N. in honour of $M r . J . W$. Douglas, author of the "World of Infects."

Douronco'uli (Zool.) native name of a monkey-Nyctipithécus Tri. vergátus.

Doxococ'sus (Zool.) doxéx, to feem, rórxos, a berry; a genus of Infuforia. Dra'ba (Bot.) a plant mentioned by Diofcorides.

Dracæ'na (Bot.) Spáraıvo, a the-dragon; the juice is like dragon's blood.

Dra'co (Zool.) Lat. a dragon; this dreaded name has been given by modern naturalifts to an innocent winged genus of Reptiles.

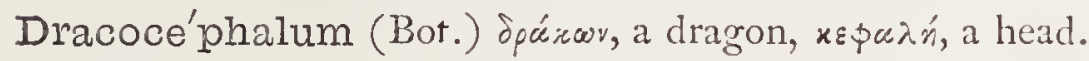

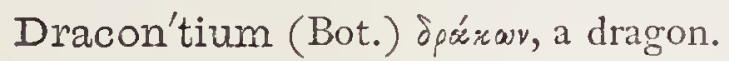

Dracun'cuius (Ichth.) Lat. dim. of draco, a dragon, equivalent to the popular name, dragonet.

Drake (Ornith.) perhaps from Dutch and German dreck, mud, becaufe it delights in mud.

Draparna'1dia (Bot.) P. N. in honour of Fames Philip Ralf. Draparnand, a French botanift.

Dra'ssidze (Ent.) dra/fus, fam. term. ide.

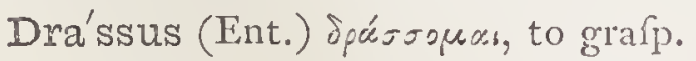

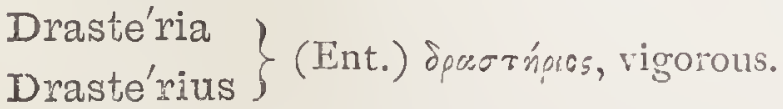

Dre'pane (Ichth.) Sperán, a fickle; the Reaper-filh. 
Dre'panis (Ornith.) Spenúvn, a fickle, from the thape of the bill; a genus of Birds.

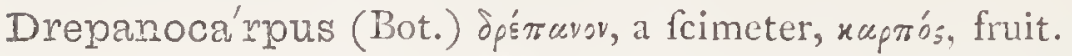

Drepanu'lidæ (Ent.) Spśzavov, a reaping-hook or fickle; moths having their wings hooked at the tip.

Dri'mia (Bot.) opsesés, bitter, from the juice of the roots being bitter.

Dromada'rius (Zool.) Lat. a dromedary.

Droma'ius (Ornith.) Spouaĩss, fwift; generic name of the Emeu

Dromathe'rium (Fos. Zool.) Spaceceros, fwift-running, enpiov, beaft.

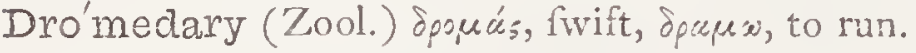

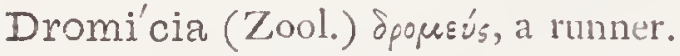

Dro'micus (Zool.) Spoutrós, good at running; a genus of Colubrine ophidians.

Dro'mius (Ent.) Dpousis, a runner.

Dro'sera (Bot.) Spórss, dew ; from the dewlike glands on the leaves.

Diummóndii (Zool.) P. N. from Mr. Drummond.

Dru'sa (Bot.) P. N. from $M$. Le Dru, a botanift.

Drya'didæ (Zool.) Sryas, fam. term. ida; a family of Colubrine ophidians. Drya'ndra (Bot.) P. N. from Fofeph Dryander, a diftinguifhed botanift.

Dry'as (Bot.) having leaves like the oak, which was facred to the Dryads. Dryio'phidae (Zool.) dryiophis, fam. term. idx, a family of Colubrine ophidians.

Dryio'phis (Zool.) Epǚras, a ferpent living in hollow oaks; öşs, a ferpent.

Dryma'ria (Bot.) Spunós, a wood; referring to its habitation.

Drymo'des (Ornith.) Spunśóns, woody; a lover of woodland places.

Dryoba'tes (Ornith.) opiss, a wood or thicket, Baíw, to go.

Dryoca'lamus (Zool.) opüs, an oak, calamus, a reed, from refemblance : a genus of Colubrine ophidians.

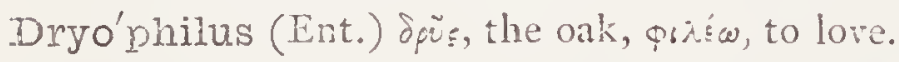

Dryopithe cus (Fos. Zool.) dpũs, Dpúos, a tree, ribrzos, an ape.

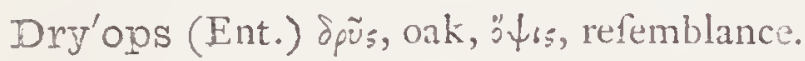

Dryor'teris (Bot.) Spustreps, a fern refembling the oak in profile.

Dry'ípetes (Bot.) Spertarw, to lacerate.

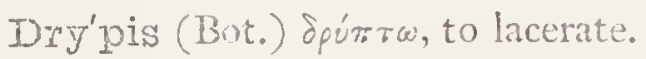

Dryp'ta (Ent.) opétrow, to lacerate.

Dubius-am ('Lool, Bot.) I.ait. doutitiul.

Duck (Ornith.) Dutili, dukiz.

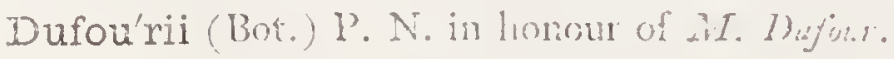


Dulcama'ra (Bot.) dulcis, fweet, amarus, bitter; becaufe the tafte of th: ftem and root is at firf bitter and afterwards fweet.

Duli'chium (Bot.) P. N., the name of the ifland where it is found.

Duma'sia (Bot.) P. N. in honour of M. Dumas, one of the Editors of the "Annals of Natural Hiftory."

Dumetícola ('Zool.) dumetum, a copfe, colo, to frequent.

Dumeto'sus (Zool.) Lat. bufhy, tufty.

Dumóntia (Bot.) P. N., a genus of Cryptogamia.

Dura'nta (Bot.) P. N. from Caftor Durantes, a phyfician and botanift of the I6th century.

Duva'llia (Bot.) P. N. from M. Duval, a French botanift.

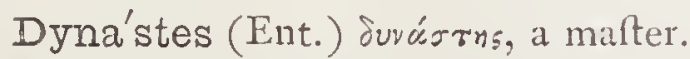

Dyna'stidæ (Ent.) dynaftes, fam. term. ide.

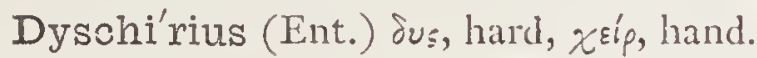

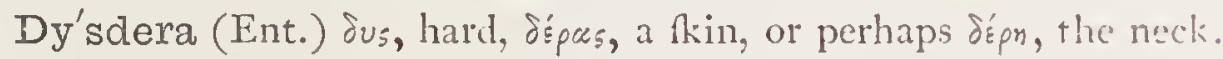

Dyti'cida (Ent.) dyticus, fam. term. ide?.

Dy'ticus (Ent.) Jutırós, fond of diving.

Eari'na (Bot.) हैup, the fpring; a gुenus of Orchidacex.

Ea'ris (Ent.) eäp, fpring, from the time of its appearance; a genus of Lepidoptera.

Eato'nia (Bot.) P. N. in honour of ——Eaton; a genus of Grafles.

Ebarba'tus (Zool.)
Ebarbula'tus (Ornith.) $\}$ Lat. without barbs, or beards, or fringes; the
the caltowary's wing.

Ebelin'gia (Bot.) P. N. in honour of $M$. Ebeling, a German botanift: a genus of Simarubacex.

Ebena'cex (Bot.) ebenus, fam. term. acea.

E'benus (Bot.) Heb. Hebnim, Gr. "ॄssvos, Lat. ebenus, the ebony-tree; the typical genus of Ebenaceæ.

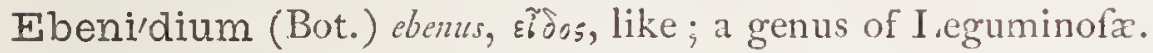

Ebermey'era (Bot.) P. N. in honour of $M$. Ebermeyer, a German botanit; a genus of Acanthaceæ.

झbu'lea (Ent.) ebulus, the dwarf elder-tree, on which it feeds.

Ebu'ria (Ent.) ebur, ivory, from the yellowifh ivory fpots on the tytra;

a genus of Coleoptera.

Ebur'na (Zool.) cbur, ivory; the ivory-fhell; a genus of Mollufca.

Fbur'neus-a-um (Zool.) Lat. white, like ivory. 
Ecalyp'tria (Bot.) '́x, out, ж $\alpha \lambda \dot{u} \pi \tau \rho \alpha$, a lid or covering.

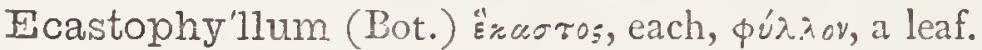

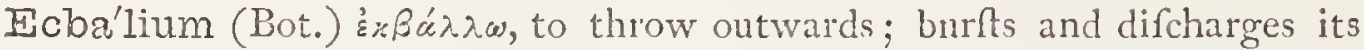
feeds when ripe; a genus of Cucurbitaceæ; "the Spirting cucumber." Eccliso'pteryx (Ent.) 's\% peculiarity of the pofterior wings; a genus of Phryganidæ.

Eccremocar'pus (Bot.) 'šsperkís, pendent, zapтós, fruit.

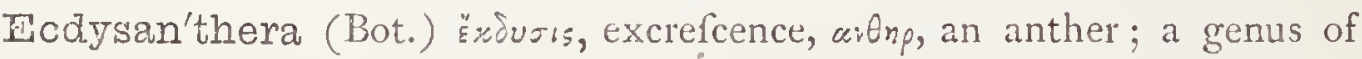
Apocynacex.

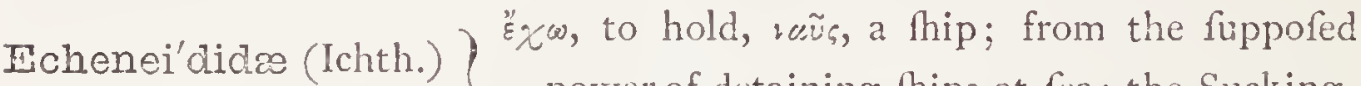
Ischene'is (Ichth.) $\quad$ power of detaining thips at fea; the SuckingIschena'is (Ichth.) $\dot{\varepsilon} \chi \varepsilon v \alpha_{s}$, holding thips back; from the reputed action of the Sucking-fifh; alfo, in Botany, a genus of Compofitx.

Echeve'ria (Bot.) P. N. from M. Echeveri, artift of the fplendid drawings of the "Flora Mexicana;" a genus of Craftulacex.

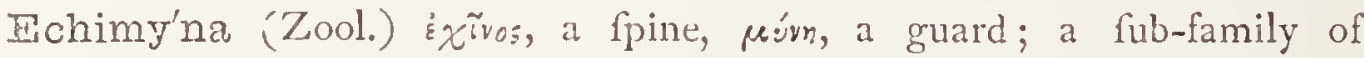
Mammalia.

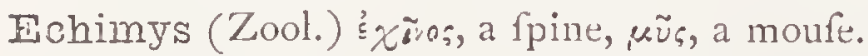

Echinaca'nthus (Bot.) '́x:vos, rough, acantlus ; a genus of Compofitæ.

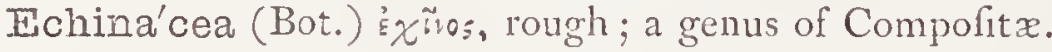

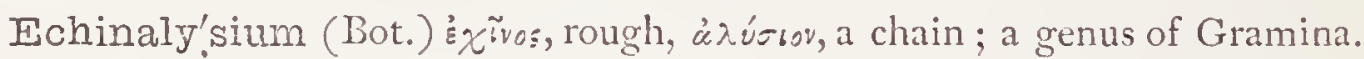

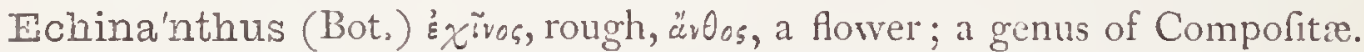

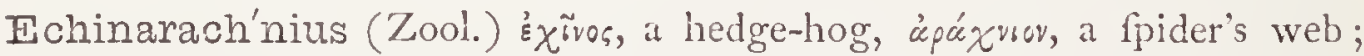
a genus of Echinodermata.

Echina'ria (Bot.) Éxivos, rough; a genus of Graminacex.

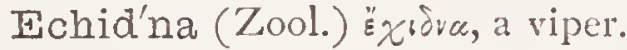

Echine'lla (Zool., Bot.) dim. of echinus, a fpine, from its briftly appearance; alfo a genus of Animalcules.

Echi'nidæe (Zool.) $\varepsilon$ ¿rvos, the fea-urchin; fam. term. idce.

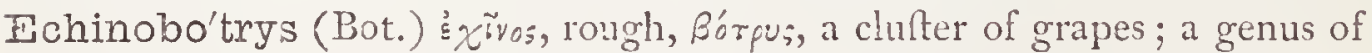
Fungi.

Fchinobo'tryum (Bot.) Éx'vos, rough, fórfü, a clufter; a genus of Fungi. Echinoca'ctus (Bot.) '̇, xiros, a fea-urchin, cactus ; refemblance of plant to the animal; a genus of Cactaceæ.

Fchinoca'rpus (Bot.) Éxivss, rough, xapтós, fruit; a genus of Flacourtiacex.

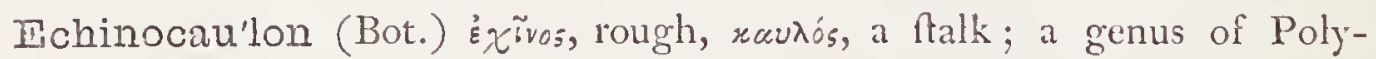
gonacer.

Fchino'ceras (Bot.) દ̇, xĩvos, rough, repás, a horn; a genus of Alga. 


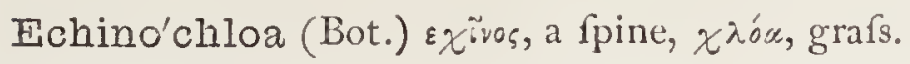

Echinocri'nus (Fos. Zool.) Ex ซvon, a fpine, xpivo\%, a lily; a gemus of Crinoidex.

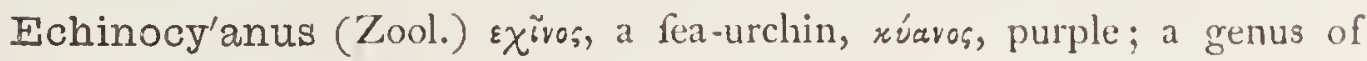
Echinodermata.

Echinocy'stis (Bot.) Éxĩvos, rough, xúrrıs, a pouch; a genus of Cucurbitacex.

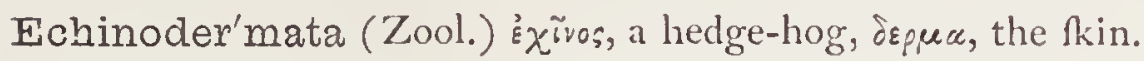

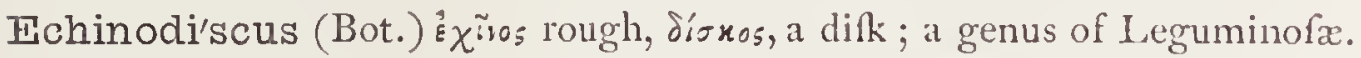

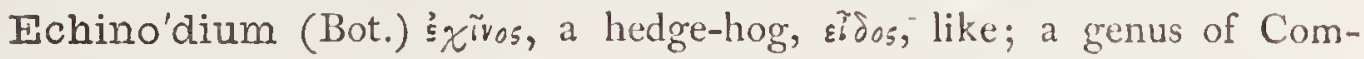
pofitx.

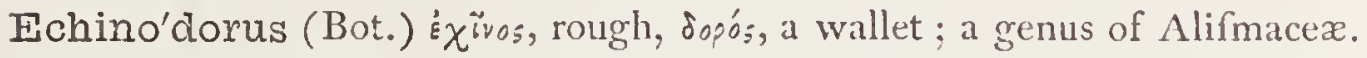

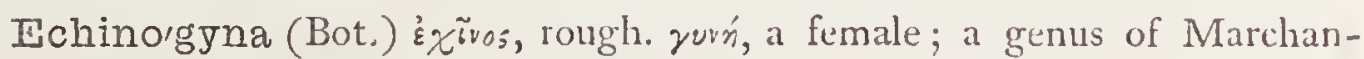
tiaceæ.

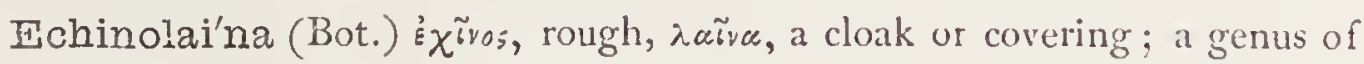
Gramina.

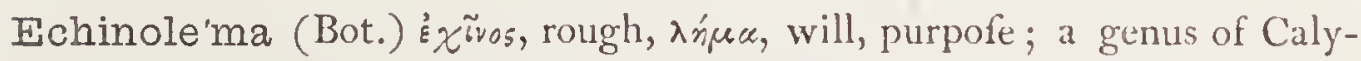
ceraceæ.

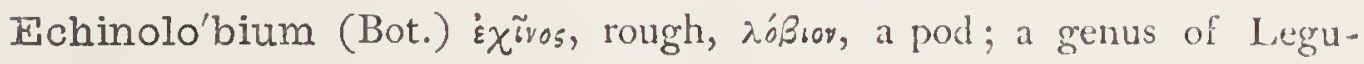
minof

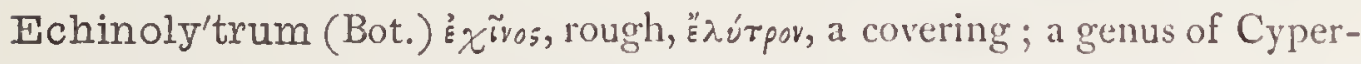
aceæ.

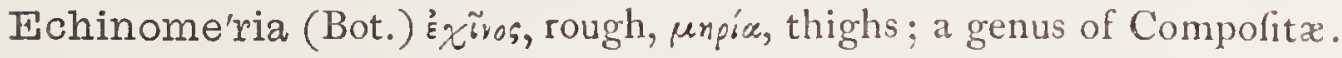

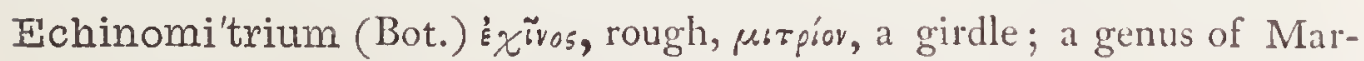
chantiacex.

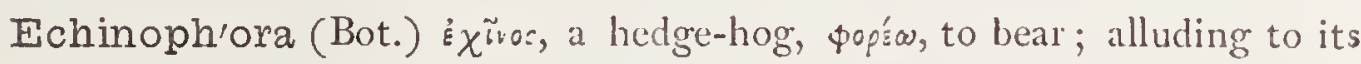
Howers; a genus of Umbelliferx.

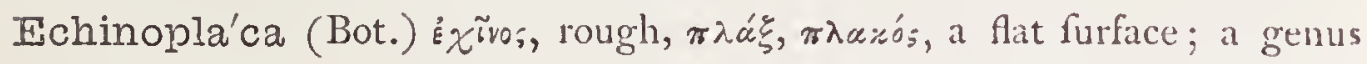
of Lichenes.

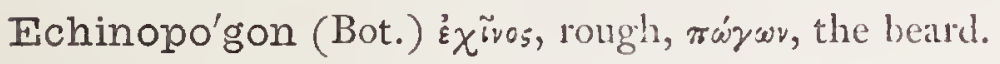

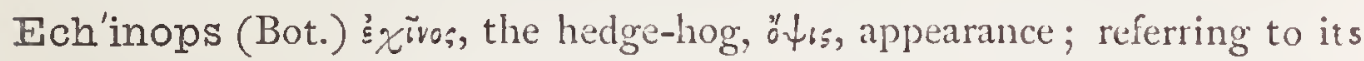
heads; the Globe-thiftle.

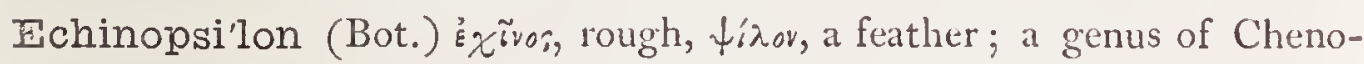
podiacex.

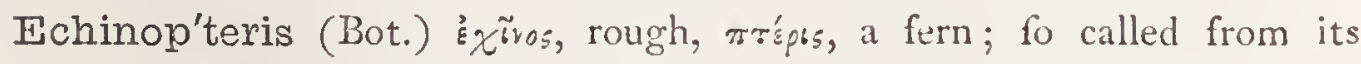
feathery leaves; a genus of Malpighiacex.

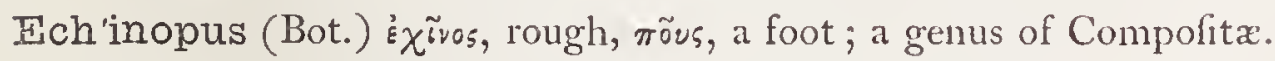

Echinorhi'nus (Ichth.) $\dot{\varepsilon} \chi$ ivos, rough, prvos, the fkin.

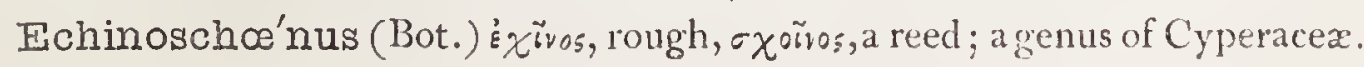




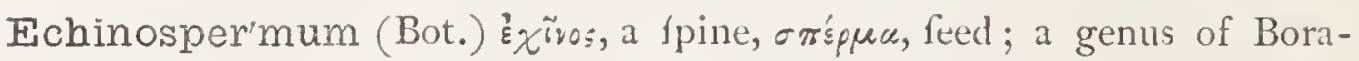
ginacer.

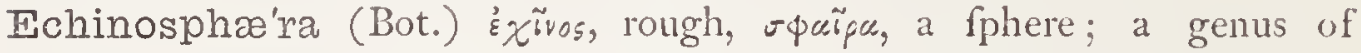
Euphorbiaceæ.

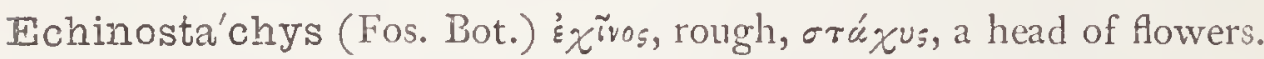

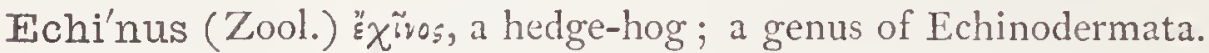

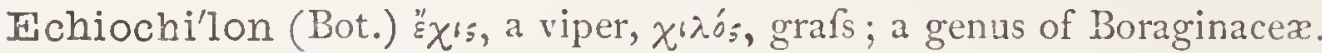

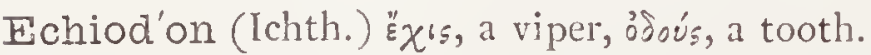

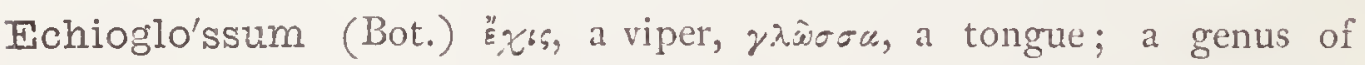
Orchidaceæ.

Echioi'des (Bot.) echimm, and हidos, like; refemblance to the Echium; a genus of Boraginacex; alfo, an adjective term denoting prickly.

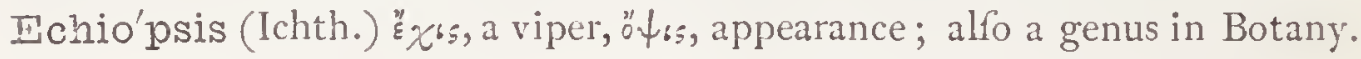

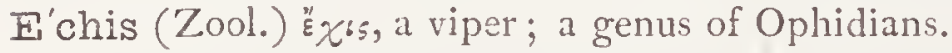

Echi'tes (Bot.) ${ }^{\prime \prime} \chi^{t}$, a viper, in allufion to its fmooth fhining fhoots; a genus of Apocynacex.

E'chium (Bot.) "'xss, a viper, referring to its feeds; a genus of Boraginacea.

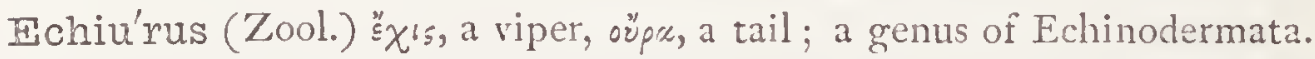

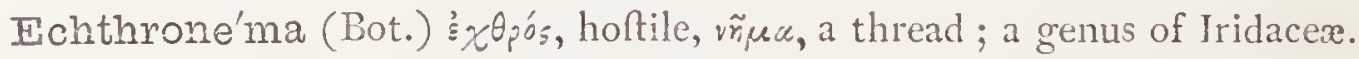

Ecka'rdia (Bot.) P. N. in honour of $M$. Eckard, a German botanift: a genus of Orchidacex.

Ecklo'nia (Bot.) P. N. in honour of $M$. Ecklon, a German botanift; a genus of Algx.

Eclec'tus-a-um (Zool., Ornith.) $\varepsilon \lambda_{2} \varepsilon \tau^{\prime} o_{s}$, chofen, felect.

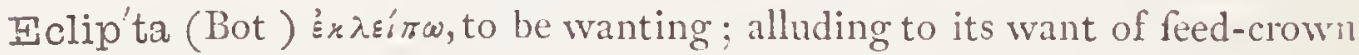
or wing.

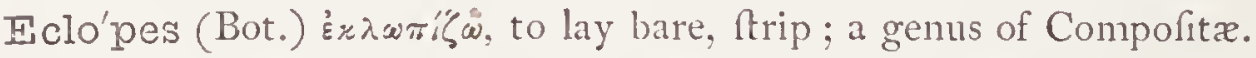

Ecta'dium (Bot.) '́zrúsıos, n, ov, ftretched out; a genus of Afclepiadacer.

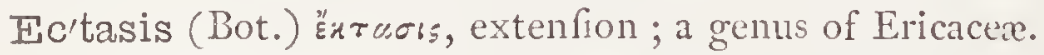

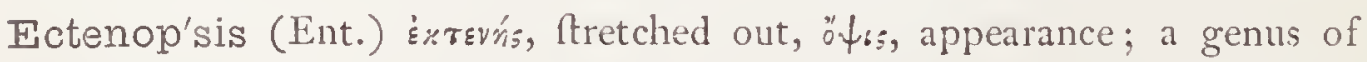
Diptera.

Ecthoræe'um (Zool.) Ext's, to run, or fally out; a term applied by Mr.

Golle to certain wire-like organs of the Actinia.

Ec'thrus (Bot.) $\dot{\varepsilon} x \theta \rho \dot{\omega} \sigma * \omega$, to leap forth ; fudden expanfion of flower; a genus of Papaveraceæ.

Ecti'nus (Ent.) '̇xrivo, to take vengeance; a genus of Coleoptera. Ecto'bia (Ent.) Éx $\tau^{\prime} o_{5}$, without, Bsow, to live; a genus of Coleoptern. Ectoca'rpus (Bot.) Érтós, outfide, raprós, fruit; a genus of Algæ. Ectocune'iform (Zool.) Exxros, outfide, and the cuneiform bone. 


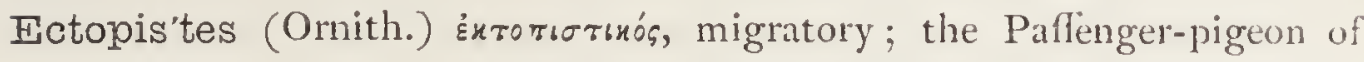
America.

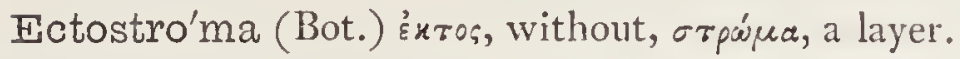

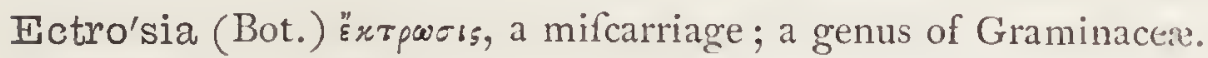

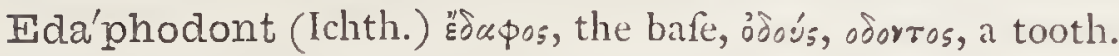

Edenta'ta (Zool.) edentula, toothlefs.

Edere'sa (Ent.) etymology unknown; a genus of Lepidoptera.

Fdgwor'thia (Bot.) P. N. in honour of Edgrworth; a genus of 'Thymelacex.

Edmo'ndia (Bot.) P. N. in honour of - Edmond; a genus of Compofitx.

Fido'lius (Ornith.) $\Sigma \delta \omega \dot{\lambda}$ เov, a feat for rowers; from the form of the two outer feathers of the tail.

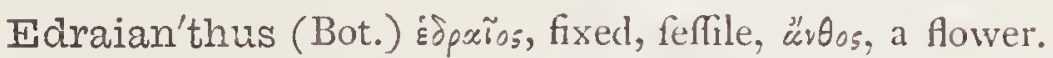

Edraiophthal'ma (Zool.) Édpaíos, fixed, $\circ \phi \theta \alpha \lambda \mu{ }^{\prime}{ }^{\prime}$, an eye; an order of

Cruftacea, with feffile eyes, fituated on the fides of the head.

Edu'lis-e (Zool., Bot.) Lat. eatable.

Edu'sa (Ent.) P. N. from Edufa, a Roman divinity, worfhipped as the protectrefs of children, and fuppofed to blefs their food (edere, to eat); a fpecies of Lepidoptera.

Edwara'sia (Bot.) P. N. from S. Edruards, a celebrated botanical draughtfman; a genus of Leguminofx.

Fel (Ichth.) Anglo-Sax. ael.

Effræ'nis (Zool.) Lat. unbridled.

Egena'ria (Ent.) egenus, poor, needy ; a fpecies of Geometra.

Ege'ria (Bot.) P. N. a nymph changed into a fountain by Diana; a genus of plants.

Egerto'ni (Fos. Zool.) P. N. from Sir Philip Egerton, an eminent foffil ichthyologirt.

Egregia'lis (Ent.) egregius, excellent, fingular.

Ehre'tia (Bot.) P. N., a family and genus of plants named in honour
Ehretia'cer) of D. G. Ehret, a celebrated German botanical draughts-
man.

Ehrhar'tia (Bot.) P. N. from F. Ehrhart, a Swifs naturalift.

Ehrenbe'rgia (Bot.) P. N. from M. Ehrenberg, the celebrated Pruffian microfcopift.

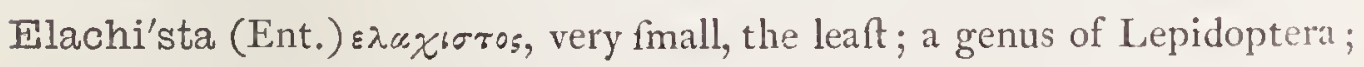
alfo a genus in Botany.

Elachi'stea (Bot.) '̇̀úxเซros, the fmalleft; a genus of Alga. 


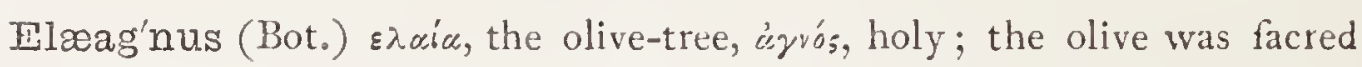
to Athena; the typical genus of Elxagnaceæ.

Eslæ'ina (Bot.) $\varepsilon \lambda \alpha i c$, the olive-tree.

I $\mathrm{I}^{\prime}$ 'is (Bot.) $\varepsilon \lambda \alpha^{\prime} \alpha$, olive; the natives of Guinea extract an oil from the fruit; the Oily Palm.

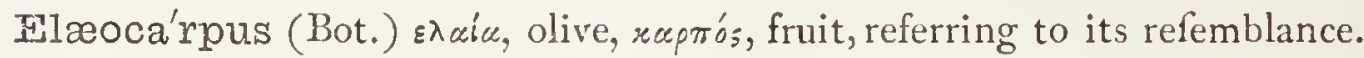

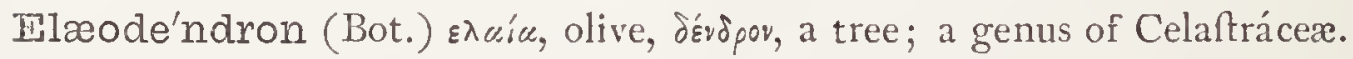
Pla'nus (Ornith.) this kite is faid to pounce upon its prey with the rapidity of lightning, and has therefore probably got its name from the French élan.

Elaphoglos'sum (Bot.) $\varepsilon \lambda \propto \phi \circ s$, a deer, $\gamma \lambda \tilde{\omega} \sigma \sigma \kappa$, tongue.

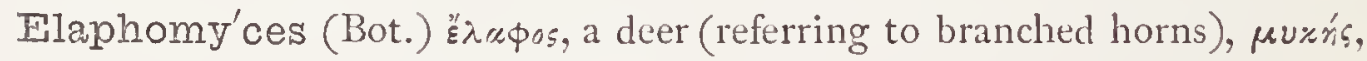
a fungus; a genus of Fungi.

巨la'phridæ (Ent.) elaphrus, fam. term. ida.

Ela'phrium (Bot.) $\varepsilon \lambda \propto \phi^{\prime} o_{s}$, light in weight; referring to its wood.

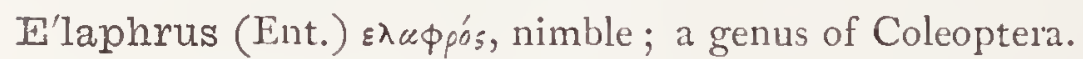

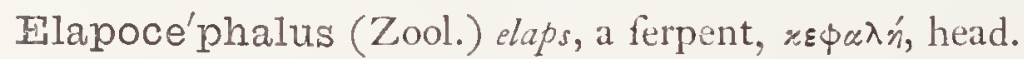

Ela'ps (Zool.) a name ufed by Pliny for a ferpent; a genus of Colubrine ophidians.

Elap'sidæ (Zool.) elaps, fam. term. ide; a family of Colubrine ophidians. Elapso'pis (Ichth.) elaps, a ferpent, $\ddot{\omega} \downarrow$, face ; a genus of Ichthyology.

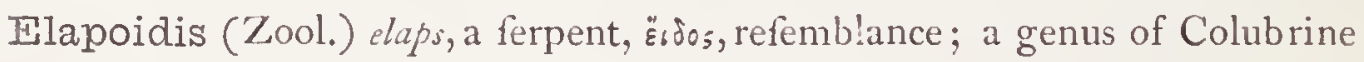
ophidians.

Elasmati'na (Zool.) $\varepsilon \lambda \alpha \sigma \mu \alpha$, a thin plate.

Elas'modus (Fos. Zool.) $\varepsilon \lambda \alpha \sigma \mu \mu$, a plate, ósoì, a tooth.

Ela'smus (Ent.) $\varepsilon \lambda \alpha \sigma \mu \alpha$, a plate.

E'late (Bot.) $\varepsilon \lambda u ́ r n$, the pine.

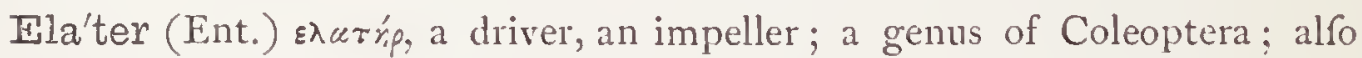
the name for the organs, which eject the feeds in Jungermaunias.

Elate'ridæ (Ent.) elater, fam. term. ida.

Flaterrium (Bot.) $₫ \lambda a \tau$ ińp, an impeller; it has elaftic feed-reflels.

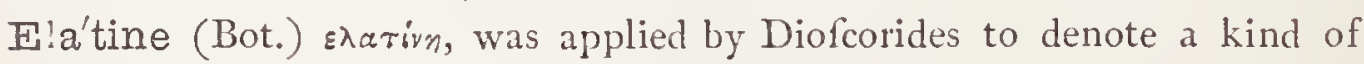
toad-flax; now applied to another plant.

El'der (Bot.) Anglo-Sax. elbarn.

Elecampa'ne (Bot.) from the Spanifh Enula Campana, Field Inula.

Elec'tra (Ent.) P. N., the daughter of Agamemnon, and fifter of Oreftes; a genus of Lepidoptera; alfo a genus in Botany.

Eledo'ne (Zool.) $\dot{\varepsilon} \lambda \varepsilon \delta \omega^{\prime} n$, a name applied by Ariftotle to a kind of polypus. 玉l'egans (Ornith., Bot.) Lat. handfome, graceful. 
Eleganta'lis (Ent.) elegans, graceful.

Fle'gia (Bot.) E้ $\lambda \varepsilon g^{\prime \prime s}$, a lament; referring to the fad colour of the plants.

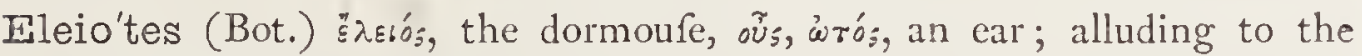
appearance of its leaves.

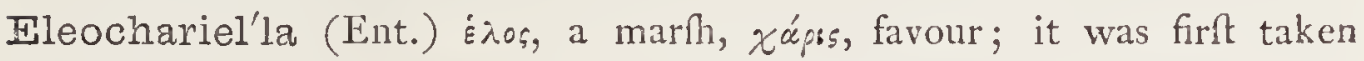
among rufhes.

Eleo'charis (Bot.) "̈̀nos, a marh, xu'pa, to delight.

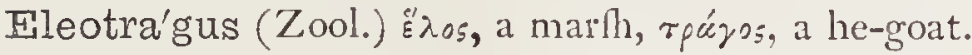

Elepha'ntipes (Bot.) elephas, an elephant, and pes, a foot; form of rhizome.

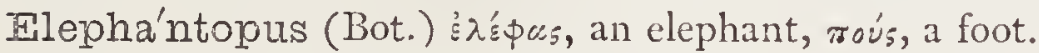

El'ephas (Zool.) Lat. an elephant.

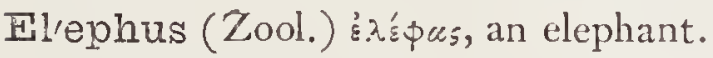

Eleusi'ne (Bot.) P. N., Eleufis, one of the appellations of Ceres; a genus of Indian Grafles, yielding grain.

Eleutherococ'cus (Bot.) '̇ $\lambda \varepsilon \dot{\theta} \theta \varepsilon \rho \circ$, free, xózжоs, a berry.

Eleutheropo'mi (Ichth.) $\varepsilon \lambda \varepsilon \dot{\theta} \theta_{\varepsilon p o s}$, free, $\pi \tilde{\omega} \mu \alpha$, a lid or cover; a fub-orde ${ }^{\text {. }}$ of Filhes.

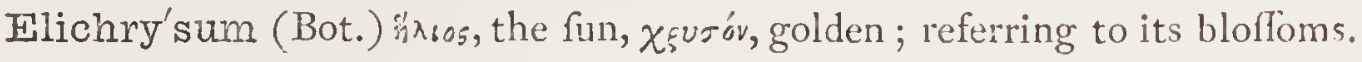
Elingua'ria (Ent.) elinguis, tonguelefs; the fpiral tongue being obfolete.

玉'limus (Ent.) etymology unknown; a genus of Hymenoptera.

Flk (Zool.) Anglo-Sax. elch; the largeft of the genus Cervus.

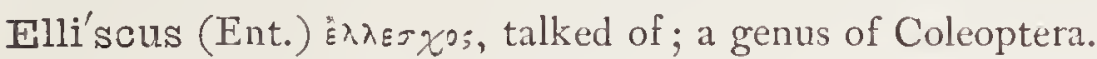

Elliot'tia (Bot.) P. N. from Stephen Elliott, a North American botanift.

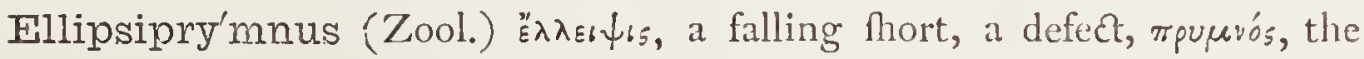

hind part; from the greyilh-white oval patch round the bafe of the tail.

Elli'sia (Bot.) P. N. from F. Ellis, an eminent naturalift.

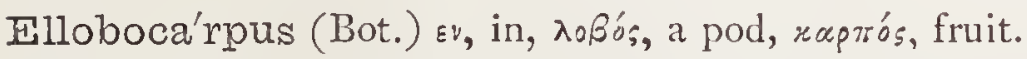

Ello'pia (Ent.) the ancient name of the ifland of Eubœa, now Negropont;

a genus of Lepidoptera.

Æim (Bot.) Lat. ulmus.

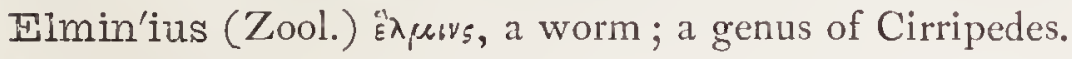

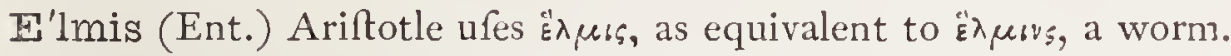

Elo'dea (Bot.) Excions, marhy; referring to the places where it grows.

Elpe'nor (Ent.) P. N. from Elpenor, a friend of Ulylles; a fpecies of Lepidoptera.

Elsholtzia (Bot.) P. N. from J. S. Elboltz, a Pruffian botanift; a genus of Labiatre.

Eluta'lis (Ent.) elutus, wafhed.

Fluta'ta (Ent.) elutus, wafhed out; a fpecies of Geometra. 
Eluviel'la (Ent.) eluvies, a deluge.

E'lymus (Bot.) $\varepsilon \lambda u ́ w$, to cover ; Lyme grafs.

Fly'na (Bot.) $\varepsilon \lambda \dot{\omega} \omega$, to cover; a genus of Cyperaceæ.

Elytra'ria (Bot.) "̇urpov, a fheath; alluding to its faly ftem.

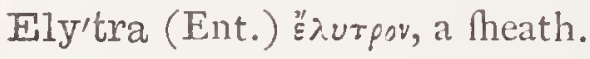

Ely'traform (Zool.) elytra and formis, i. e., fhaped like an infect's wing-cover.

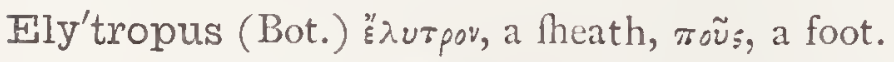

Emargina'ta (Ent.) emarginatus, taken out of the margin; the margins of the wings being angulated.

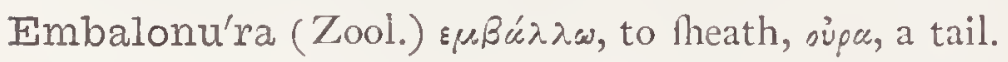

Emberi'za (Ornith.) etymology unknown.

Emeritel'la (Ent.) emeritus, confpicuous

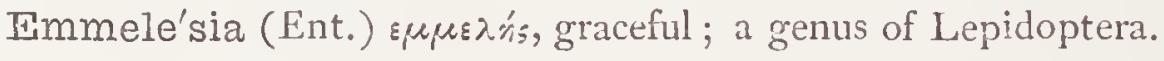

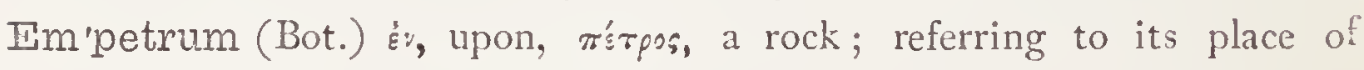
growth; the typical genus of Empetracex.

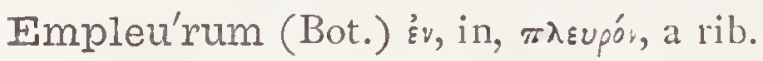

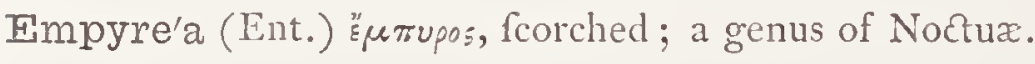

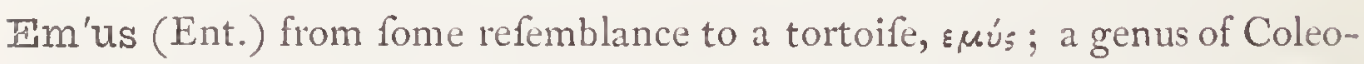
ptera.

Emuta'ria (Ent.) emutare, to change; a fpecies of Geometrre.

Emy'dia (Ent.) Esús, a frefh-water tortoife.

Emy'dium (Zool.) $\dot{\varepsilon} \mu \dot{u}_{s}$, a water-tortoife; a genus of Polygaftric animalcules.

Emydosau'ri (Zool.) вuи́, a tortoife, ouũpss, a lizard.

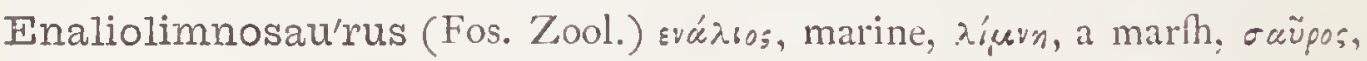
a lizard.

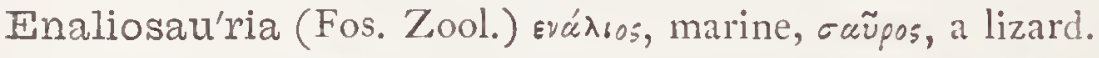

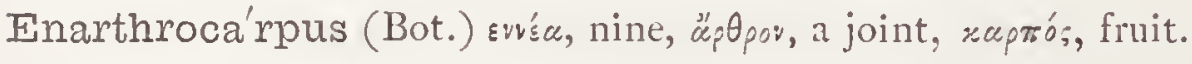

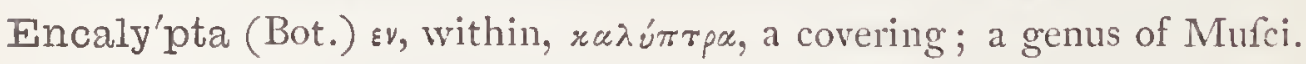

Ence'lia (Bot.) $\varepsilon \gamma x^{\prime} \xi \lambda$ เov, a little eel; referring to the feeds.

Enchelycare (Ichth.) $\varepsilon^{\prime} \gamma \chi \varepsilon \nu_{5}$, an eel.

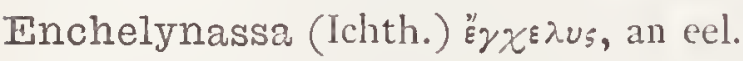

En'chodus (Fos. Zool.) Ėyxos, a fpear, ósois, a tooth; a genus of fpeartoothed foffil fihes of the Mackerel family.

Ence'phalus (Ent.) $\dot{\varepsilon}$, in, $x \notin \phi a \lambda n^{\prime}$, the head; a genus of Coleoptera.

Enche'lia ,

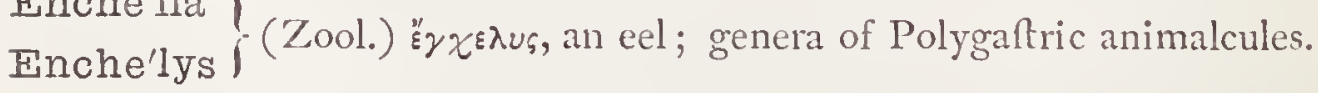

Encœ'lium (Bot.) $\varepsilon v$, within, rob̃ns, a hollow; the fronds are tubular and bladdery. 
Encrasi'cholus (Ichth.) Eyrparixodos, mixed with bitter.

En'crinite (Fos. Bot.) $\dot{\varepsilon}$, in, rgívov, a lily; a fpecies of ftar-fifh, having a radiated lily-thaped difk.

Encyone'ma (Zool.) Éyxvos, pregnant, vñece, a thread; a genus of Polygaftric animalcules.

Ency'rtidæ (Ent.) encyrtus, fam. term. ide; a family of Hymenoptera.

Ency'rtus (Ent.) śv, in, zuprós, curved, arched.

Fn'deca (Zool.) švosza, eleven; having eleven rays.

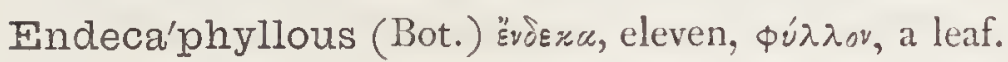

Endero'nic (Zool.) Ėv, upon, dśpos, the kkin; new term propofed by Profeffor Huxley in place of "dermal" in certain cafes.

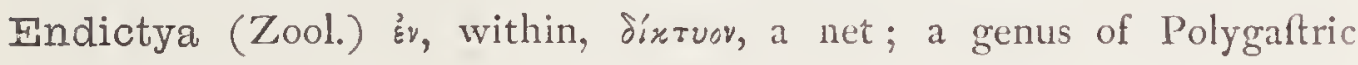
animalcules.

En'dive (Bot.) Latin, Intybus; Arabic, hendibeh.

Endoca'rpon (Bot.) Ëvjov; within, xaptós, fruit; a genus of Mufci.

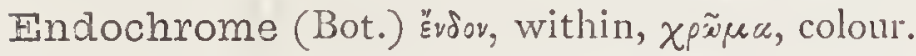

Enüodro'mia (Bot.) Ëvov, within, Spópess, a runner; a genus of Fungi.

En'dogens (Bot.) हैvoov, within, y\&vvaw, to produce.

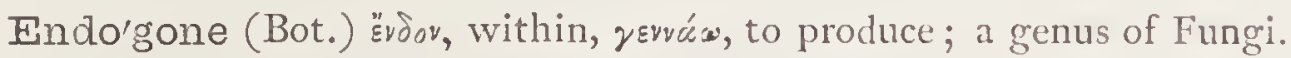

Findomy'chidæ (Ent.) endomychus, fam. term. ida.

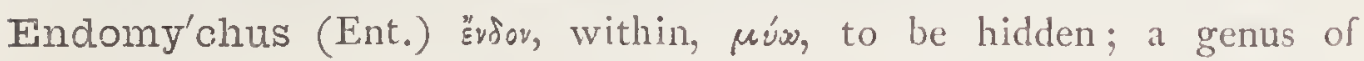
Coleoptera.

Endoparasi'tic (Zool.) Ëvôv, within, тupúsıтоs, a parafite, or one who) feeds upon another.

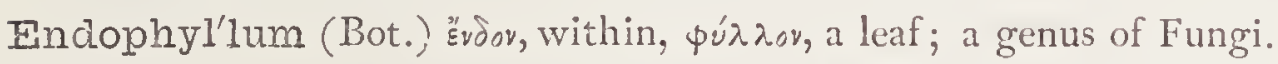

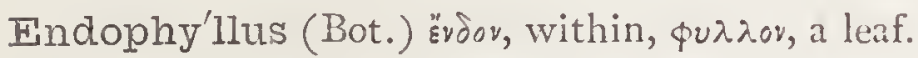

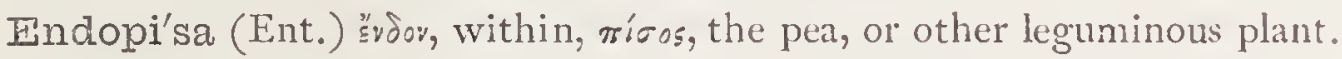

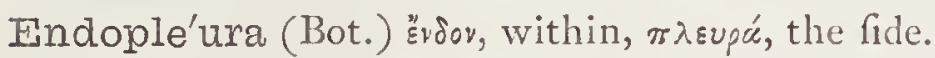

Endorhi'za (Bot.) "ैvoov, within, pi $\zeta \alpha$, a root.

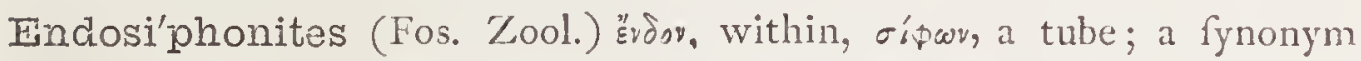
of Profefor Anfted's for the nautiloid Thell, whofe fiphuncle is on the inner fide of the whorls.

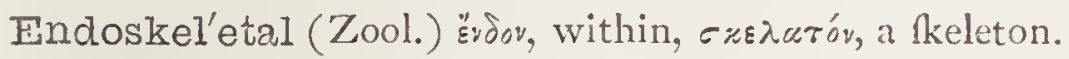

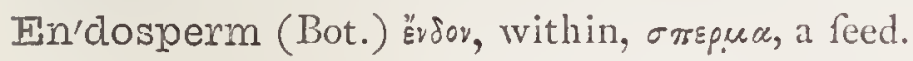

Indo'thia (Bot.) śv $\delta_{0} \theta \varepsilon v$, from within; a genus of Fungi.

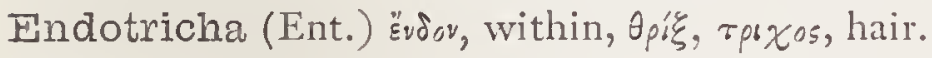

Endro'micla (Ent.) the family of which Endromis is type.

En'dromis (Ent.) Evopopís, a rough coarfe garment; alluding to the hairy abdomen of the imago; a genus of Lepidoptera. 
En'drosis (Ent.) "̌voporos, bedewed, dewy.

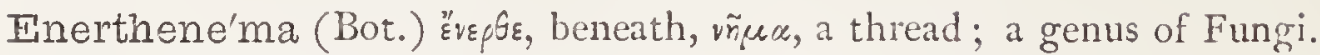

En'gidæ (Ent.) engis, fam. term. ida.

?ngis (Ent.) etymology unknown; a genus of Coleoptera.

Englenes (Ent.) a genus of Coleoptera.

Enhydra (Zool.) žvodpos, living in water; the Sea-otter.

Enhydrina (Zool.) "zvodpos, living in water; a genus of Ophidians.

Inico'cerus (Ent.) '́visós, fingle, répes, horn; a genus of Coleoptera.

Enicopus (Ent.) '̇vrós, fingle, $\pi \tilde{u}_{s}$, a foot; a genus of Coleoptera.

巴nico'stoma (Ent.) '́virós, fingle, oróra, a mouth; a genus of Lepidoptera.

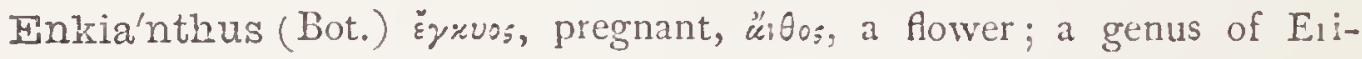
caceæ.

Enneac'tis (Zool.) Evvé $\alpha$, nine, úzris, a ray.

Enno'midæ (Ent.) हैvopss, fam. term. ida.

Fn'nomos (Ent.) švorus, lawful, jutt; a genus of Lepidoptera.

Ennych'ia (Ent.) swúxoss, in the night.

Ennychi'idre (Ent.) the family of which Ennychia is the type; a genus of

Lepidoptera.

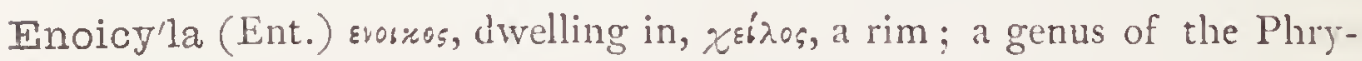
ganidx.

Ensa'te (Bot.) $\mathrm{cn} / \mathrm{is}$, a fword; fword-hhaped.

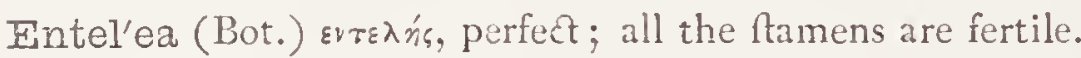

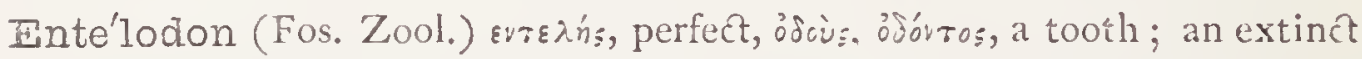
genus of Mammalia.

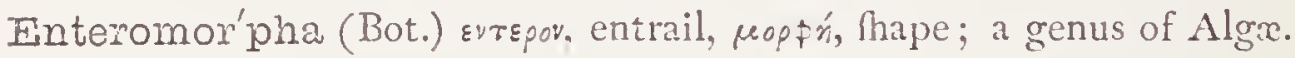

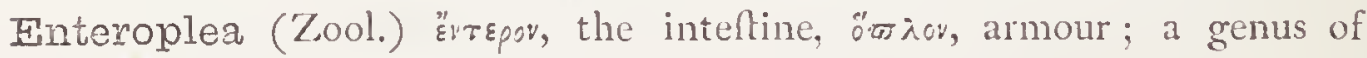
Polygaftric animalcules.

刃ntolo'ma (Bot.) źvtón, within, $\lambda \tilde{x} \mu \mu a$, a fringe; a genus of Fungi,

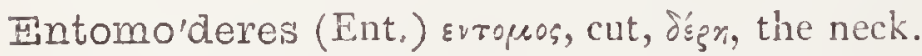

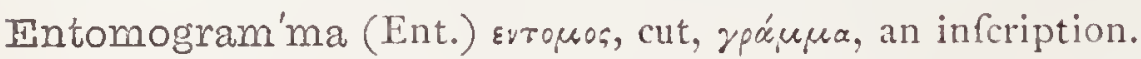

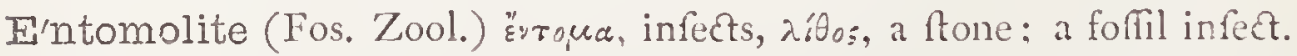

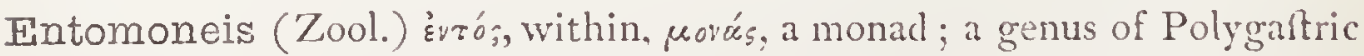
animalcules.

Entomosce'lis (Ent.) Evtopuos, cut, xnגis, a fpot.

Entomo'straca (Zool.) Evтopeos, an infect, ofotprxov, a thell; a divifion of the Cruftacea.

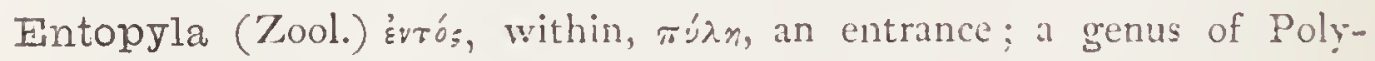
gaftric animalcules. 
Entoste'rnal (Zool.) svrós, within, or'spros, the brear.

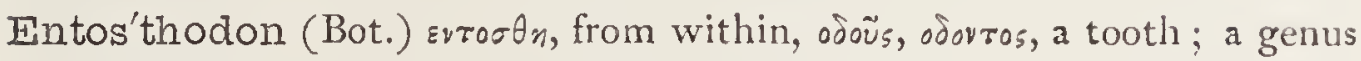
of Mufci.

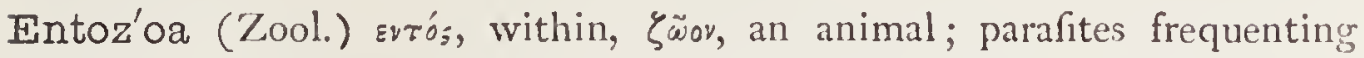
internal organs.

Enuclea'tor (Ornith.) Lat. one who gets at the kernel or muclus.

Eny'grus (Zool.) ev, in, ủyáa, moifture; a genus of Ophidians.

E'ocene (Fos. Zool.) inw;, the dawn, ravós, new.

Eo'gena (Ent.) inj, the dawn, yzun, birth; appearing in the early morning.

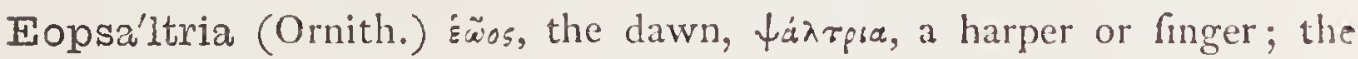
Auftralian Robin.

Eo'sphora (Zool.) غ̇woфópos, the morning.ftar; a genus of Polygaftric animalcules.

Ep'acris (Bot.) $\varepsilon$ ri, upon, axxpos, the top, referring to its mountainous habitat; the typical genus of Epacridacex.

Epaph'ius (Ent.) $\varepsilon \pi \alpha ф \dot{n}$, a painful touch ; hurting when handled.

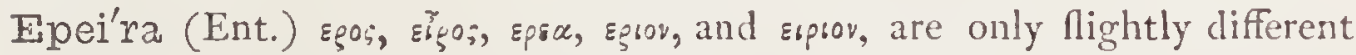

forms of the fame word, which means wool or cotton, and sugra $\tau \tilde{n}$; úáx $x_{n s}$ is ufed for the fpider's web, $\varepsilon \pi$, is intenfive. The more correct fpelling would be epi-eira, or epi-eria, and may be tranflated the web-. maker, or the large web-maker!

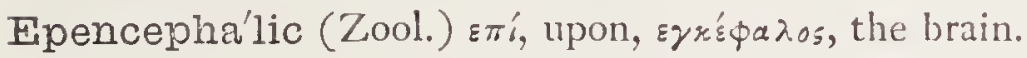

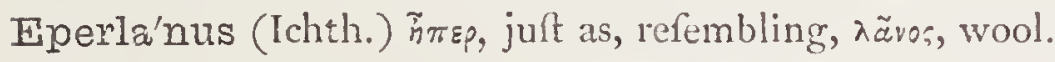

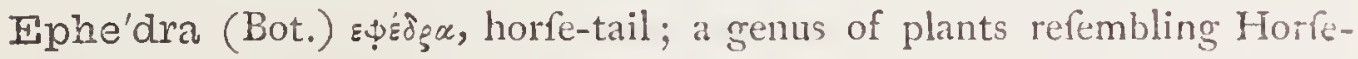
tail.

Ephes'tia (Ent.) $\varepsilon \phi^{\prime} \sigma \tau$ ros, attached to the houfe, domeftic.

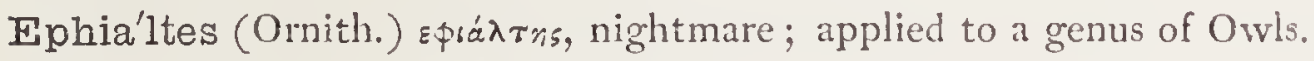

Ephippa'na (Ent.) Éфi $\pi \pi \iota \alpha$, a faddle.

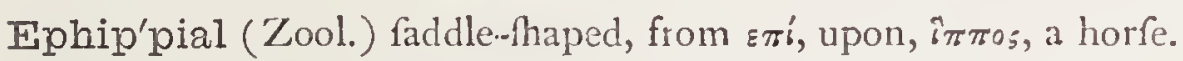

Ephippiph'ora (Ent.) $\varepsilon ф i \pi \pi \iota$, a faddle, фogér. to wear; alluding to the form of the markings on the anterior wings.

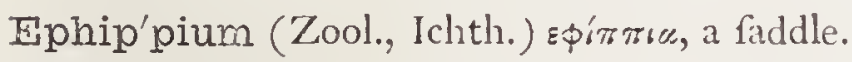

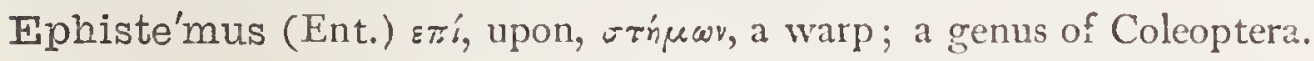

Ephip'piger (Ent.) ephippium, a fiddle, grerere, to carry; a genus of Coleoptera.

Ephthianu'ra (Ornith.) $\dot{\varepsilon} \phi \theta_{0}^{\circ}$ s, languid, oü̧a, a tail; applied to a genus of Auftualian Wagtails.

Ephyro'des (Ent.) refembling ephyra 
Fph'yra (Ent.) P. N., the ancient name of Corinth; a genus of Geometræ.

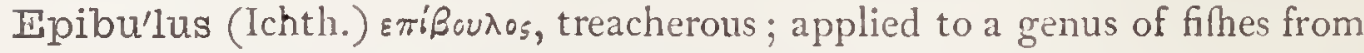
the mode of entrapping their prey.

Epich'aris (Ent.) $\varepsilon \pi^{\prime} \chi \chi^{\prime} a p \downarrow \xi$, pleafing, agreeable; a genus of Hymenoptera. Epichi'lium (Bot.) $\varepsilon \pi \dot{\imath}$, upon, $\chi \varepsilon \tilde{i} \lambda \wedge s$, the lip.

Epic'lopus (Ent.) $\varepsilon \pi i r \lambda \circ \pi \circ$, thievih ; a genus of Hymenoptera.

Epicoc'cum (Bot.) غ̇тi, upon, xórzos, a berry; a genus of Fungi.

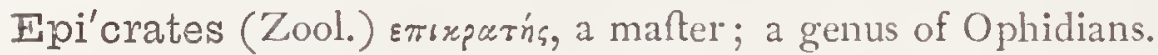

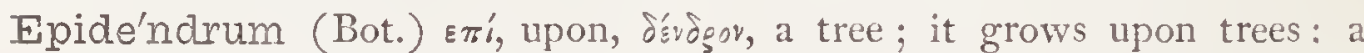
genus of epipnytic Orchidacex.

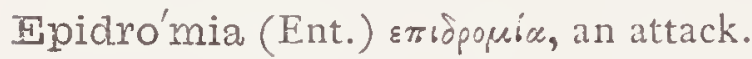

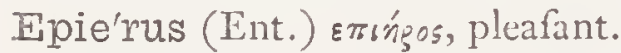

Epigæ'a (Bot.) $\varepsilon \pi i$, upon, yєá, the earth; its ftems grow upon the ground; a genus of Ericacex.

Epigraph'ia (Ent.) $\varepsilon \pi i$ pá $\phi \omega$, to write upon; from the letter-like markings on the anterior wings.

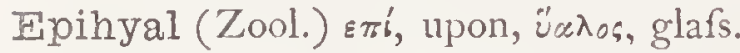

Epilo'bium (Bot.) $\varepsilon \pi i$, upon, $\lambda_{0} \beta^{\prime} \circ$ s, a pod. Flower is feated upon a long ovary refembling a peduncle; a genus of Onagracex.

Epima'chinæ,

Epi'machus $\}$ (Ornith.) $\varepsilon \pi i \mu a \chi 0 s$, open to attack.

Epime'dium (Bot.) the name ufed by Pliny and Diofcorides for a plant, now called Barren-wwort; a genus of Berberidaceæ.

Epi'melas (Ent.) $\varepsilon \pi i$ and $\mu^{\prime} \dot{s}^{\prime} \alpha_{s}$, black.

Epi'one (Ent.) P. N. from Epione, the wife of AEfculapius; a genus of Lepidoptera.

Epipa'ctis (Bot.) $\varepsilon \pi เ \pi \dot{n} \gamma v \dot{u} w$, to coagulate ; referring to its effect upon milk; a genus of terreftrial Orchidacex.

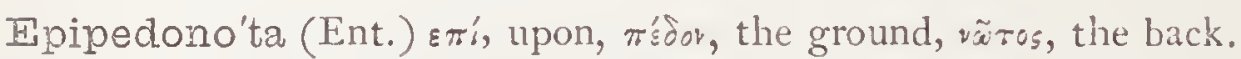

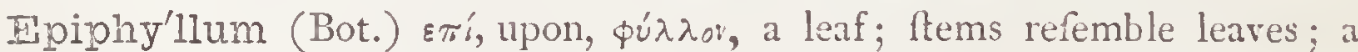
genus of Cactacex.

Mpiphytic (Bot.) $\varepsilon \pi i$, upon, фuró, a plant; an epipliyte fimply grafps with its roots the plant upon which it vegetates; the parafite derives its nourifhment from the plant to which it is attached.

Epipo'gon (Bot.) $\varepsilon \pi i$, upon, $\pi \dot{w} \gamma \omega v$, a beard; a genus of terreftrial Orchidacex.

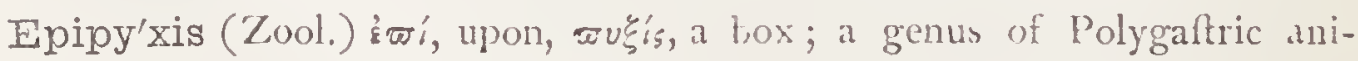
malcules. 
Epise'ma (Ent.) Éтíñ doptera.

Epise'midæ (Ent.) epifema, fam. term. ide.

Episte'nia (Ent.) $\varepsilon \pi i ́$, intenfive, $\sigma \tau \varepsilon v^{\prime} s$, narrow; $i$. e. very narrow.

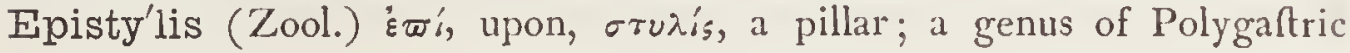
animalcules.

Epitra'nus (Ent.) étrí, intenfive, тpavós, clear, diftinct ; i. e. very diftinct.

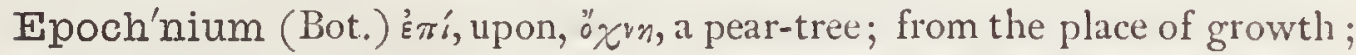
a genus of parafitic Fungi.

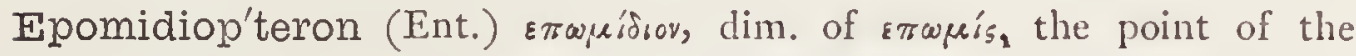

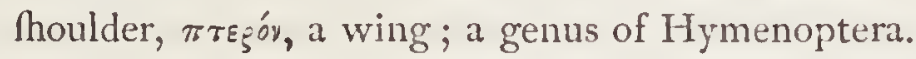

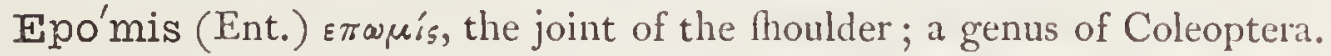

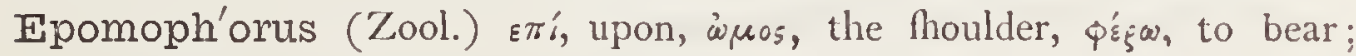
applied to the Shoulder-knot Bat.

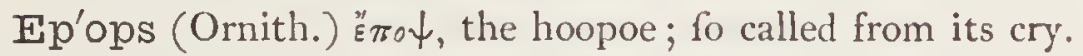

Epu'nda (Ent.) P. N., a mythological name.

Eque'stris-e (Zool.) Lat. belonging to a horfe.

Equitel'la (Ent.) eques, a horfeman.

Equus (Zool.) Lat. a horfe.

Equise'tum (Bot.) equus, a horfe, Jeta, hair; in allufion to its fine branches;

the typical genus of Equifetacex.

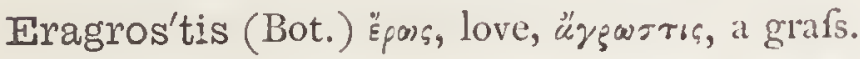

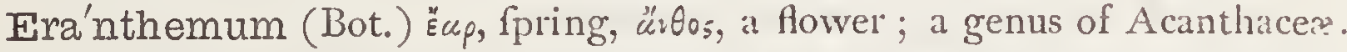
Fra'nthis (Bot.) Ëpo, the earth, üutos, a flower; the flowers are on hort ftalks; a genus of Ranunculacex.

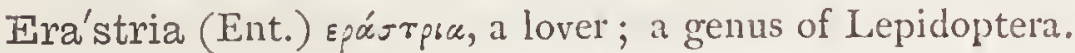

Erastri'idae (Ent.) eraftria, fam. term. idue.

Ere'bia $\}$ (Ent.) Erebus, the region of darknefs; from their dark colour.

Er'ebus (Ent.) implying dark colour, from Erebus.

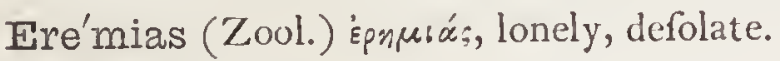

Eremo'bia (Ent.) Éprpos, the defert, Bios, life; a genus of Lepidoptera.

Eremo'charis (Bot.) Épripos, the defert, $\chi \chi_{\text {úf }}$, preference.

Eremu'rus (Bot.) epprnos, folitary, oupó, a tail.

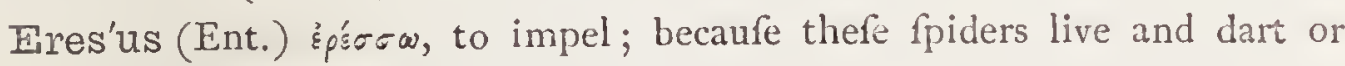
jump on trees; a genus of Arachnida.

Eret'es (Zool.) épérns, rowers; a genus of Polygaftric animalcules.

Erethi'zon (Zool.) $\varepsilon p \varepsilon €$ i $\zeta \omega$, to provoke, irritate.

Ereune'tes (Ornith.) épsurntŕs, an cxplorer; a genus of Birds. 
Erga'tis (Ent.) Epyárns, a workman, artificer; a genus of Arachnida.

Ergote'tia (Bot.) French, ergot; a genus of Fungi.

Eria (Bot.) Eprov, wool; alluding to the woollinefs of the flower.

Eri'ca (Bot.) epsixw, to break, probably from its fragile branches.

Ericæ'a (Ent.) cricaus, from erica, heath.

Ericata'lea (Ent.) found among erica, heather.

Ericata'ta (Ent.) erica, heath; a fpecies of Geometræ.

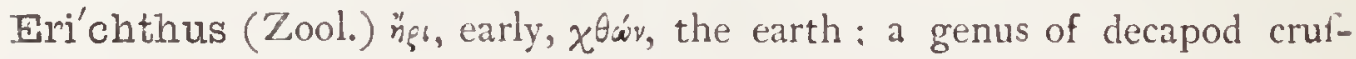
taceans found in tropical feas.

Ericy'dnus (Ent.) éps-rujvós, very glorious.

Eri'geron (Bot.) $\tilde{n}$, rpring, y'spwr, an old man; from its being hoary in Ipring; a genus of Compolitie.

Erina'ceus (Zool.) Lat. a Hedge-hog.

Fri'nus (Bot.) equros, a wild fig-tree; now applied to a genus of Lobeliacex.

Mriobo'trya (Bot.) Ëprov, wool, Bórpv;, a bunch of grapes.

Eriocau'lon (Bot.) šprov, wool, raùós, a ftem.

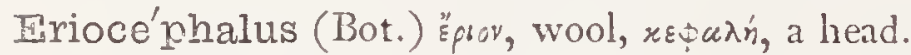

Eriócera (Ent.) Éprov, wool, xepás, a horn.

Eriocne'mis (Ornith.) Éprov, wool, «rń tufts of feathers on the legs; a genus of Humming-birds.

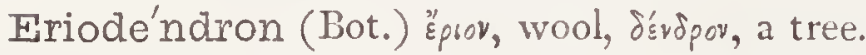

Erioga'ster (Ent.) Éprov, wool, garı'่ men of the female; a genus of Lepidoptera.

Erio'gonum (Bot.) Éprov, wool, you, a joint; referring to the ftems.

Eriolæ'na (Bot.) Ëprov, wool, $\chi$ גawa, a cloak; the calyx is woolly.

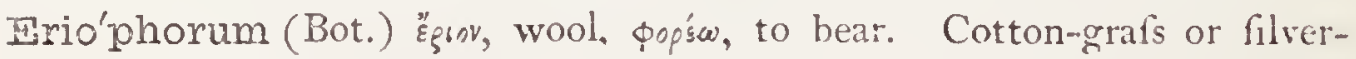
talfels.

Eriopse'la (Bot.) Éprov, wool, $\psi \alpha \dot{\alpha} \lambda \lambda \varepsilon$ \%, to pull, to touch.

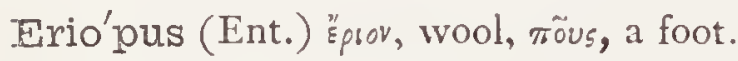

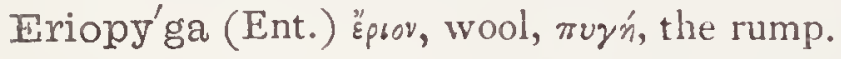

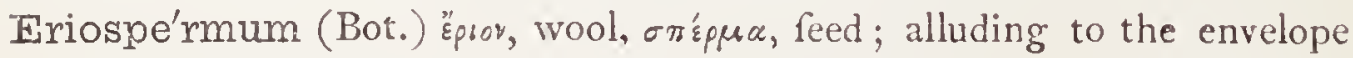
of the feed.

Erio'spora (Bot.) "̌psov, wool, oropú, a fpore; a genus of Fungi.

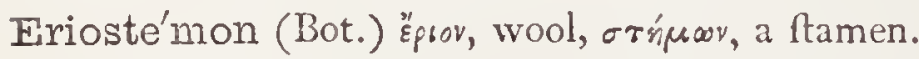

Eríphia (Zool.) Epípn, a kid; a genus of fhort-tailed Crustaceans.

Erirhi'nus (Ent.) ip $\rho$, very much, $\dot{\rho}$ iv, the fnout; a genus of Coleoptera.

Erith'acus (Zool.) Épilaros, the Redbrealt.

Erith'alis (Bot.) the name of an unknown plant mentioned by Pliny.

Ermin'ea (Zool.) Latinized form of the French hermine, or Englifh ermine. 
Ernode'a (Bot.) epvásns, a branching; alluding to the habit of the plant.

Erodiorhyn'cus (Ent.) Epwosios, the heron, fúrxos, a beak; a genus of Diptera.

Ero'dium (Bot.) Eparóos, a heron; the fruit is like the head and beak of the heron; a genus of Geraniacex.

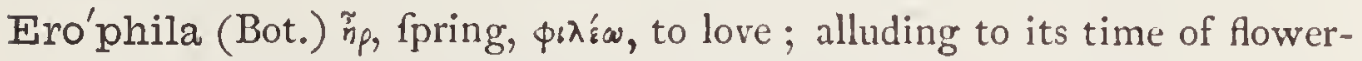
ing; a genus of Cruciferæ.

Erosa'ria (Ent. erofus, gnawed off, eaten away; a fpecies of Lepidoptera.

Froty'lidæ)

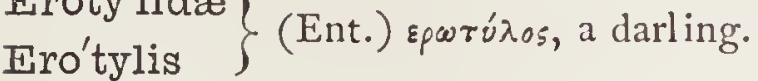

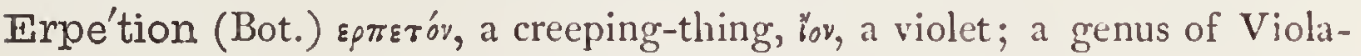
cex.

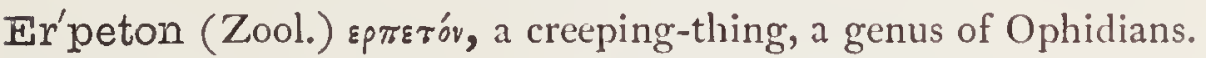

Er'rans (Ent.) part. of erro, to wander; wandering.

Erube'scens (Zool., Bot.) part. of erubefco, to be red, to blufh.

Eruca'ria (Bot.) from eruca, the herb-rocket, which probably from uro, to burn; alluding to its biting qualities.

E'rvum (Bot.) Celt errv, tilled land; it is a peft in tilled land; tares; a genus of Leguminofie.

Erxlebenel'la (Ent.) P. N. from Foham Chrifian Polycarp Erxleben, Profeflor in the Univerfity of Gottingen.

Eryci'nidæ (Ent.) the family of which Erycina, a genus of exotic butterflies, is the type.

Ery'ngium (Bot.) ipúrzrov of the ancients, perhaps from в̨uryáva, to difgorge; it expels wind; a genus of Umbelliferæ.

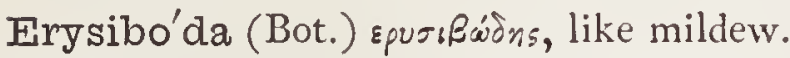

Ery'simum (Bot.) epíw, to draw; it draws and produces blifters; a genus of Cruciferæ.

Ery'siphe (Bot.) épúw, to draw, cíqwi, a fiphon; a genus of Fungi.

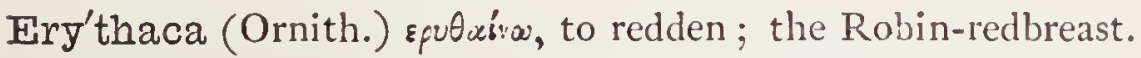

Erythræ'a (Bot.) epuppaia, red, from the colour of the flowers; a genus of Gentianacer.

Erythri'na (Bot.) $\varepsilon$ putgos, red, the colour of the flowers; the coral-tree, a genus of Leguminofx; alfo, in Entomology.

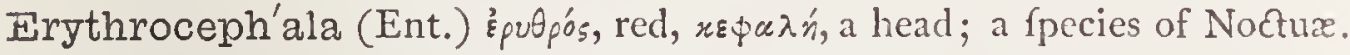
Erythro'genys (Zool.) Epupón, red, y'vv:, the cheek; red cheeked.

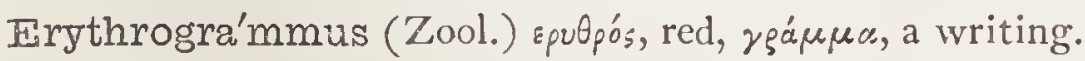

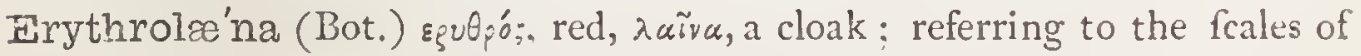
the calyx. 


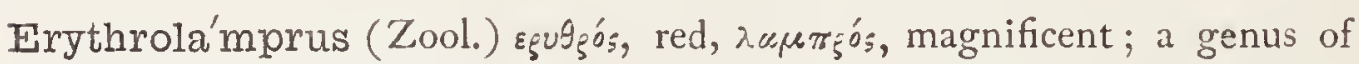
Colubrine ophidians.

Erythro'nium (Bot.) вputpó, red; alluding to the leaves and flowers; a genus of Liliaceæ.

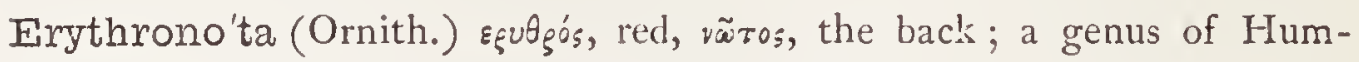
ming-birds.

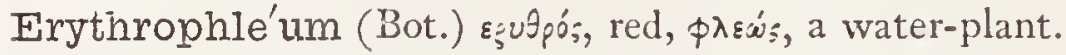

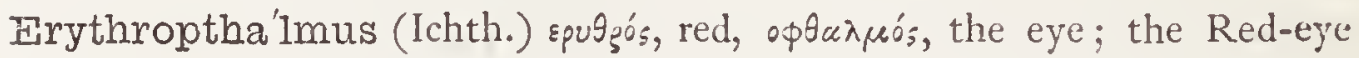
fifh.

Erythrospi'za (Ornith.) epu९pós, red, $\sigma \pi \zeta^{\zeta} a$, a fmall piping bird, a kind of finch.

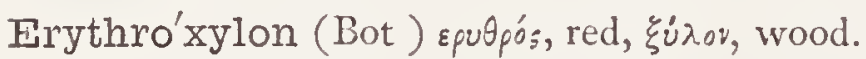

Eryx (Zool.) P. N., the fon of Butes; a genus of Ophidians; alfo applied in Entomology to a genus of Coleoptera.

Escallo'nia (Bot.) P. N. from Efcallon, a Spaniard, and American traveller; the typical genus of Efcalloniacer.

Es'chara \}'s xápx, the fear from a burn; a genus and family of Eschar'idæ $\}$ Polyzoa.

Eschscho'1tzia (Bot.) P. N. from Dr. Efchfcholtz, a German botanift; a genus of Papaveracte.

Eso'cidæ (Ichth.) the Pike family of filhes, of which Efox is the type.

E'sox (Ichth.) Lat. a Pike.

Esun'culus (Ichth.) dim. of efox, the fcientific name of the Pike.

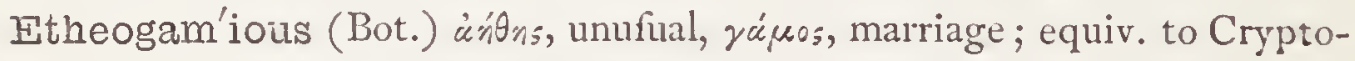
gamic; it thould be Ætheogamous.

Ethu'lia (Bot.) meaning unknown.

Eua'strum (Bot.) عủ, beautiful, afrum, a ftar; a genus of Defmidiex.

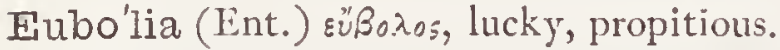

Euboli'idæ (Ent.) eubolia, fam. term. ida.

Eu'bria (Ent.) вi, beautiful, Rpsapós, ftrong; a genus of Coleoptera.

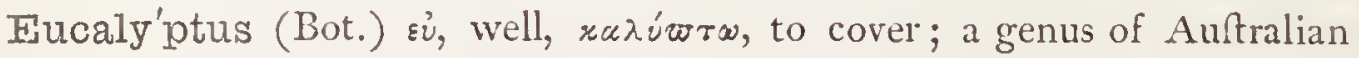
Myrtacea.

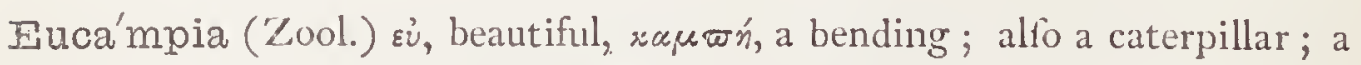
genus of Polygaftric animalcules.

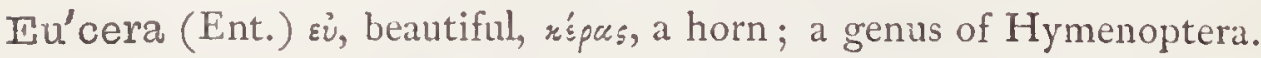
Eucha'ridæ (Ent.) eucharis, fam. term. ida; a family of Hymenoptera. Eu'charis (Ent., Bot.) દüxups, pleafing; a genus of Brazilian Liliacea. Euche'lia (Ent.) $\varepsilon \dot{u}$, well, $\chi n \lambda n$, a claw ; a genus of Lepidoptera. Eucheli'idæ (Ent.) euchelia, fam. term. ide. 


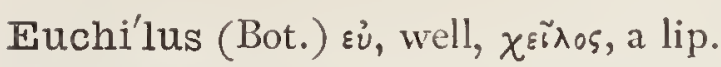

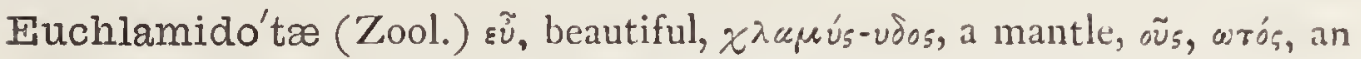
ear; a genus of Polygaftric animalcules.

Euchla'nis (Zool.) $\varepsilon \dot{u}$, well, $\chi^{\lambda \alpha^{\prime}{ }^{\prime}}$, a garment of wool; a genus of Polygaftric animalcules.

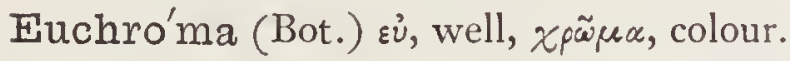

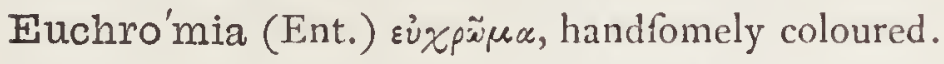

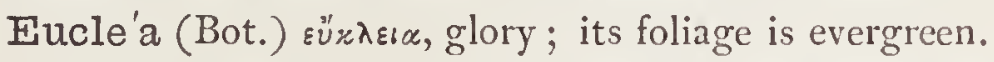

Eucli'dia (Ent.) P. N. from Euclid, the celebrated geometrician; referring to the geometrical markings.

Euclidi'idæ (Ent.) Euclidia, fam. term. idx.

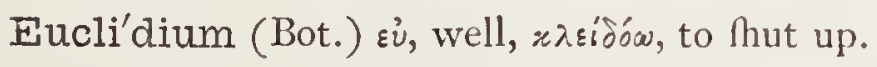

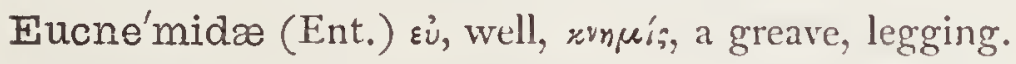

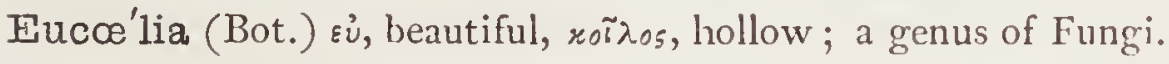

Eucome'tis (Ornith.) єủ, beautiful, rouńrns, long-haired: a genus of Tanagers.

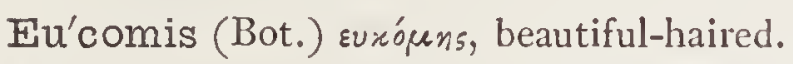

Eucra'tea (Zool.) P. N. from Eucräte, one of the Nereids; a genus of Polyzoa.

Eucrati'adæ (Zool.) a family of Polyzoa.

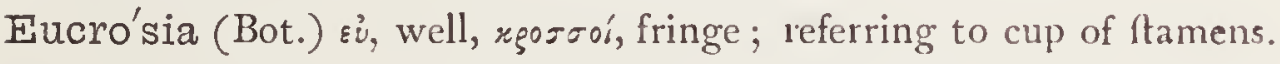

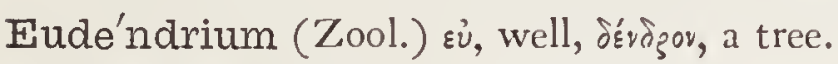

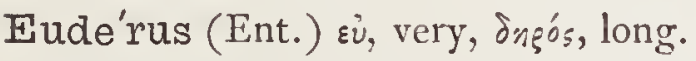

Eudes'mia (Bot.) $\varepsilon \dot{u}$, well, $\delta^{\prime}=\mu n$, a bundle.

Eudip'sas (Zool.) $\varepsilon \dot{u}$, beautiful, $\delta\left\llcorner\psi_{\alpha} \alpha_{s}\right.$, a water-ferpent; a genus of Colıbrine ophidians.

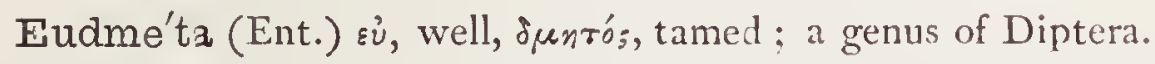

Eudori'na (Zool.) $\varepsilon \dot{u}$, beautiful, Eópe, a fpear; a genus of Polygaftric animalcules.

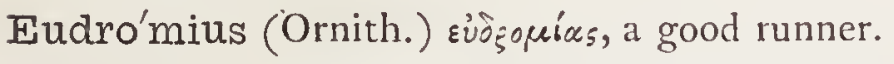

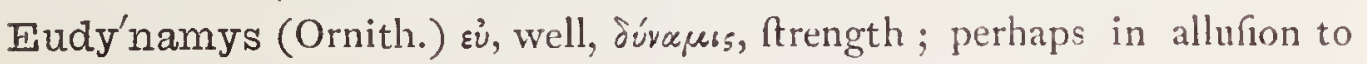
its loud note.

Eudy'tes (Ornith.) вủ, well, eafy, dúrns, a diver ; a genus of Birds.

Euel'ephas (Fos. Zool.) घu, beantiful, elephas.

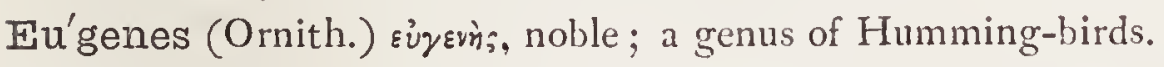

Euge'nia (Bot., Ornith.) P. N. from Prince Eugene of Savoy, patron of Botany ; the Clove-tree; alfo a genus of Humming-birds.

Eugle'na (Zool.) เủ, beautiful, gin'vn, the pupil of the eye; a genus of Polygaftric animalcules. 
Eugle'nes (Ent.) Eüy $\lambda$ หos, bright-eyed.

Euglo'ssa (Ent.) $\varepsilon \dot{\nu}$, beautiful, $\gamma \lambda \tilde{u} \sigma \sigma u$, a tongue ; a genus of Hymenoptera. Eugly'pha (Zool.) $\varepsilon \dot{u}$, handfome, $\gamma \lambda u \phi n ́$, a carving; a genus of Polygaftric animalcules.

Euhyme'nia (Bot.) $\varepsilon \dot{u}$, beautiful, ¿̇unr, a membrane; a genus of Algæ.

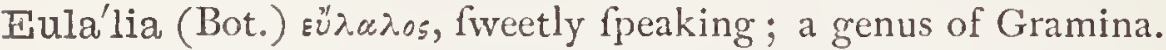

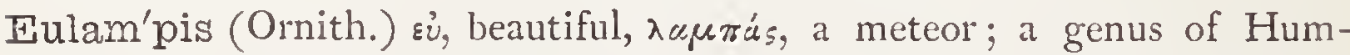
ming-birds.

Eule'pia (Ent.) $\varepsilon \tilde{u}$, beautiful, $\lambda \varepsilon \pi i \xi$, a fcale; a genus of Lepidoptera.

Eu'lobus (Bot.) Eủ, beautiful, noßós, a pod, becaufe the inferior ovary refembles a beautiful peduncle; a genus of Onagraceæ.

Eulo'phia (Bot.) Eünoфos, well-crefted.

Eu'lophus (Ent.) \&ünoф०s, well-crefted.

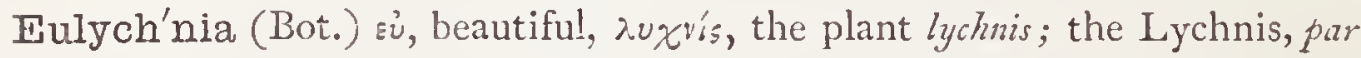
excellence.

Euma'chia (Bot.) घưućrns, lengthy, tall; a genus of Cinchonaceæ.

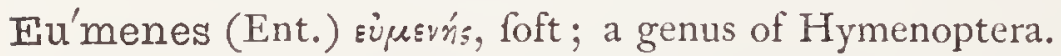

Eume'nidæ (Ent.) ermenes, fam. term. idx; a genus of Hymenoptera.

Eumerídion (Zool.) evं, beautiful, $\mu \varepsilon$ ṕs, a part; a genus of Polygaltric animalcules.

Eumi'crus (Ent.) $\varepsilon^{\tilde{u},}$ beautiful, and $\mu เ x \xi o ́ s$, fmall.

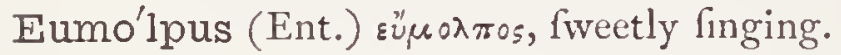

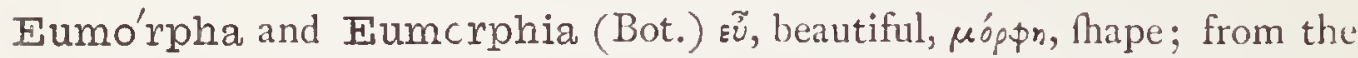
elegant change of pofition of carpels while ripening; genera of Compolitæ.

Euna'nus (Bot.) вũ, beautiful, várvos, a dwarf; a genus of Scrophulariacex. Eunec'tes (Zool.) в

Euno'tia (Bot.) Eú, beautiful, vãros, a back or ridge; a genus of Diatomaceæ.

Euno'tia (Zool.) Eüraros, ftout-backed; a genus of Polygaftric animalcules. Euno'tus (Ent.) Euं, beautiful, vĩ̄ros, the back.

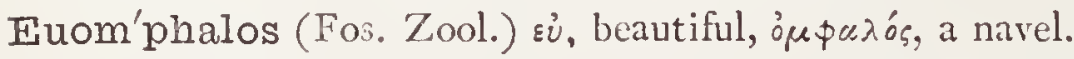

Euon'ymus (Bot.) $\varepsilon \dot{u}$, well, övoru, a name; a genus of Celaftraceæ.

Euoph'rys (Zool.) вủ, beautiful, ópús, the eye-brow.

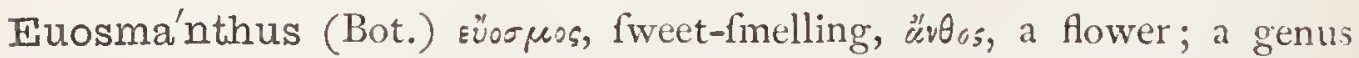
of Chamælauciacer.

Euo'sma ,

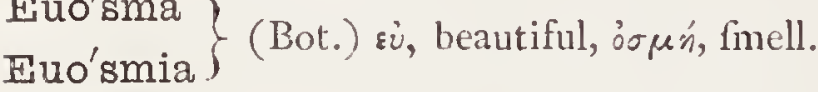

Eupa'sea (Bot.) Eurráfeıs, having fair cheeks; a genus of Primulacex. 
Eupato'rium (Bot.) P. N. from Mithridates Eupator, who ufed it as a counter poifon; a genus of Compofitx.

Fupe'lmidæ (Ent.) eupelmus, fam. term. ida; a family of Hymenoptera.

Eupe'lmus (Ent.) $\varepsilon^{\prime}$, beautiful, $\pi \hat{\varepsilon} \lambda \mu \alpha$, the extremity ; a genus of Hymenoptera.

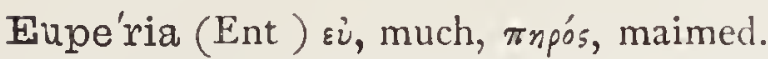

Eupe'talum (Bot.) $\varepsilon \tilde{z}$, beautiful, $\pi \dot{\varepsilon} \tau \alpha \lambda \circ v$, a petal; from the beauty of the perianth; a genus of Begoniaceæ.

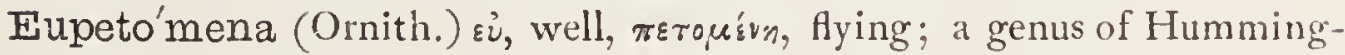
birds.

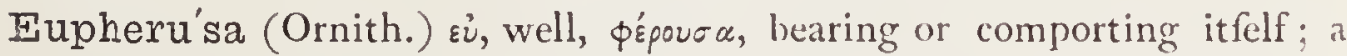
genus of Humming.birds.

Eupho'nia (Ornith.) $\varepsilon \dot{u}$, good, фwoŕ, a found.

Eupho'rbia (Bot.) P. N. from Euphorbus, phyfician to Juba, king of Mauritania.

Euphorbias'trum (Bot.) euphorbium, and aftrum, a ftar.

Euphorbia'na (Ent.) named from the fpurge, Euphorbia.

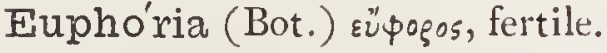

Euphra'sia (Bot.) Eủppaivw, to delight; a genus of Scrophulariacex.

Euphrosi'nia (Bot.) P.N. from Euphrofyne, one of the three Graces; a genus of Compoliti?.

Euphro'syne (Ent.) P. N. from Euphrofyne, one of the Graces.

Euphro'syne (Bot.) P.N. from Euphrofyne; a genus of Compolitx.

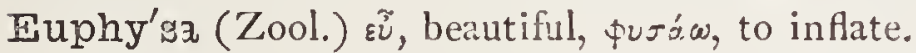

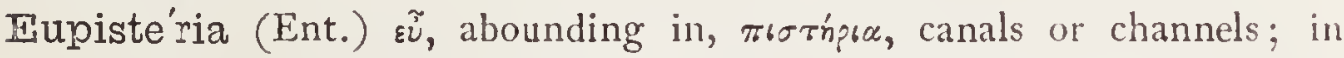
allufion to the numerous ftreaks acrofs the wings.

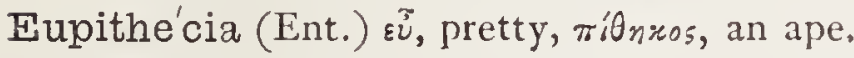

Euplec'trus (Ent.) $\varepsilon \tilde{u}$, beautiful, $\varpi \lambda^{\prime} \dot{x}$ тpor, the plectrum of infects.

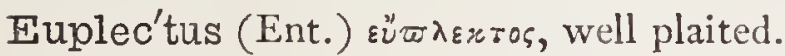

Euple'xia (Ent.) $\varepsilon \tilde{i}$, prettily, $\lambda^{\prime} \kappa \omega$, to fold; the anteriol wings during repofe are longitudinally wrinkled.

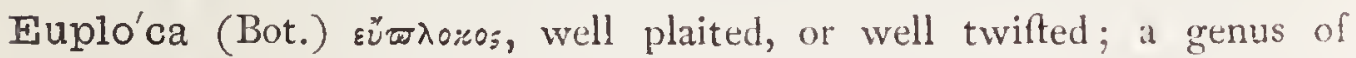
Ehretiaceæ; alfo ufed as an adjective, euplocus-a-um.

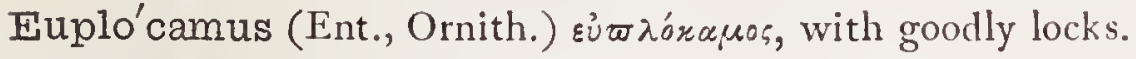

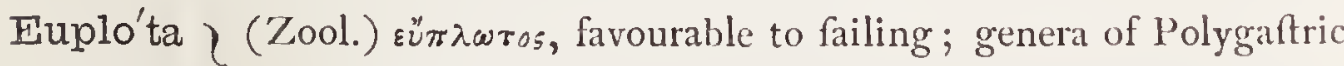
Euplo'tes $\}$ animalcules.

Eu'poda (Ent.) Eũ, good, woús, wofós, a foot.

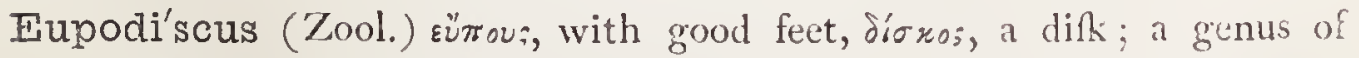
Polygaftric animalcules. 


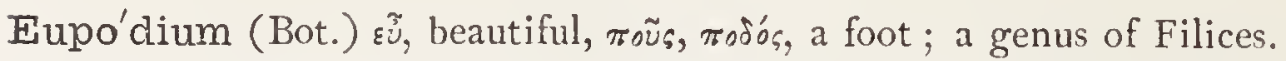

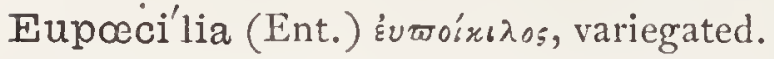

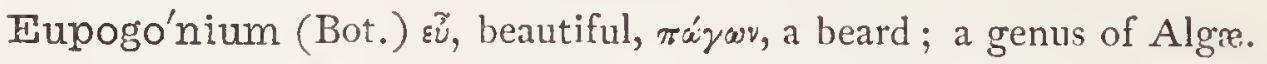

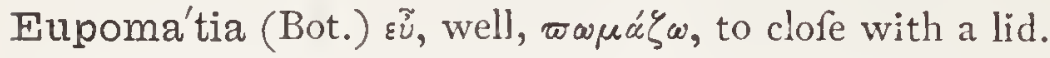

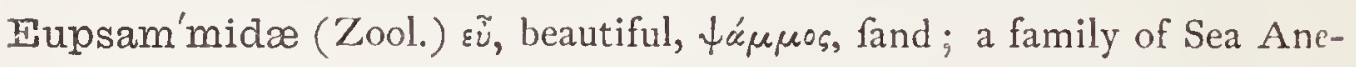
mones.

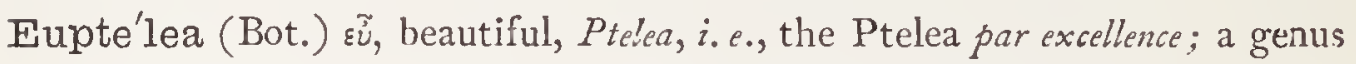
of Ulmacex.

Eupyre'na (Bot.) $\varepsilon^{\tilde{u}}$, beautiful, ruporv, the ftone of fruit, as the olive, date, \&c.; a genus of Cinchonacex.

Eurha'phe (Bot.) implying the Rhaphis in its higheft development; a Eurha'phis $\quad$ genus of Cinchonaceæ and of Palmæ refpectively.

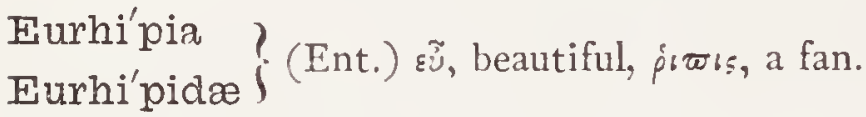

Europæ'us (Ornith., Bot.) Lat. European.

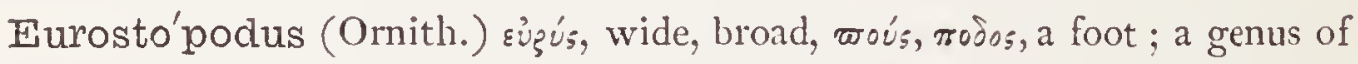
Goatfuckers.

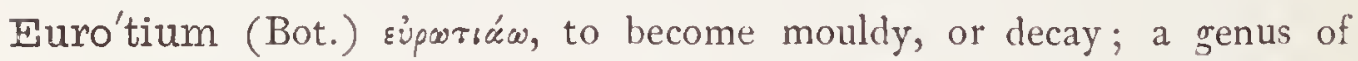
Fungi.

Eu'rhypis (Ent.) $\varepsilon \tilde{u}$, very, puøos, dirt, filth ; very dirty.

Eury'ale (Bot.) P. N. from Euryale, one of the Gorgons; alluding to its thorny menacing habit; a genus of Water-lilies.

Eurya'ndra (Bot.) Eủpús, broad, cúñp, a ftamen, from the dilated ftamens;

a genus of Dilleniaceæ.

Eury'basis (Bot.) épés, broad, bafis: a genus of Mufci.

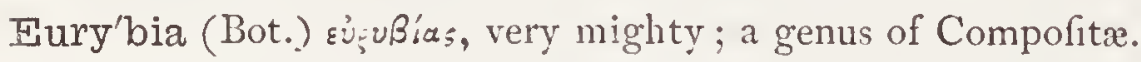

Eurybio'psis (Bot.) eurybia and ö s , refemblance; a genus of Compofitx.

Euryce'rcus (Zool.) Ev̉és, broad, xépxos, a tail ; a genus of Entomoftraca.

Eury'cerus (Zool.) Eùpús, broad, xśg̨as, a horn.

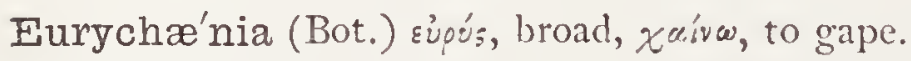

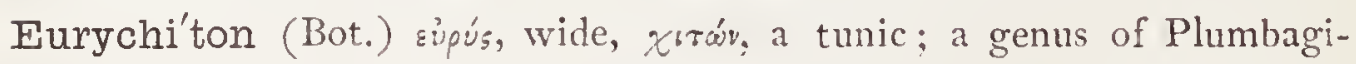
nacex.

Eu'rycles (Bot.) P. N. from Eurycles, a prophet.

Eury'coma (Bot.) súpé , broad, róun, a lock of hair; a genus of Connaraceณ.

Eury'dera (Ent.) súpús, broad, d'sn, the neck.

Eury'dice (Bot.) P. N., taken from mythology ; a genus of Iridacex. Eury'labis (Ent.) Eupús, wide, $\lambda a \beta_{i s}^{\prime}$, pincers; from the anal forceps.

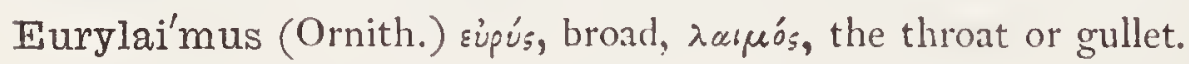


Eury'lepis (Bot.) घupús, broad, $\lambda \varepsilon \pi \iota \varsigma$, a fcale; a genus of Ericaceæ.

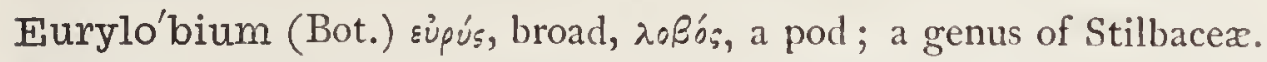

Eurylo'ma (Bot.) eủpús, broad, $\lambda \tilde{\omega} \mu \alpha$, a fringe or border; a genus of Ericaceæ.

Eury'mene (Ent.) P. N., a town in 'Theflaly ; a genus of Lepidoptera.

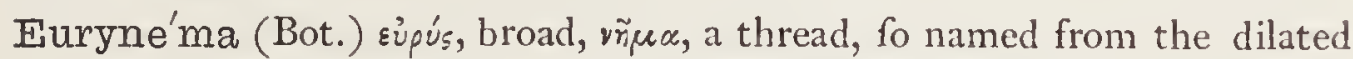

filaments of the ftamens; a genus of Zygophyllacex.

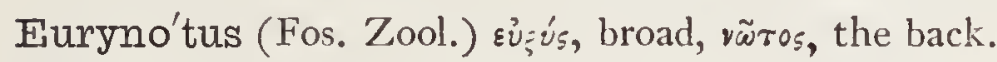

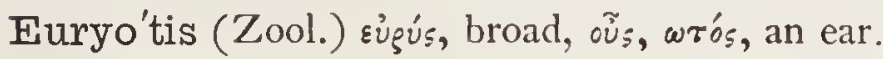

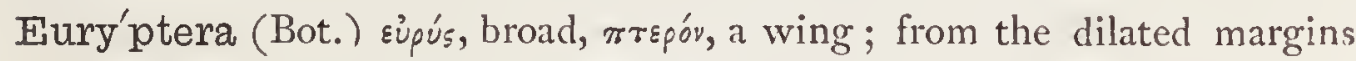
of the fruit; a genus of Umbelliferæ.

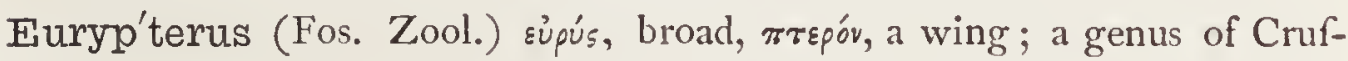
taceans.

Eury'pyga (Ornith.) Eùpús, broad, ఐuýn, the rump.

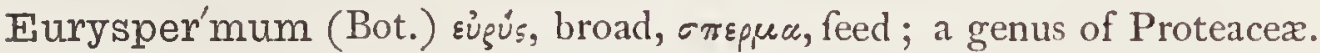

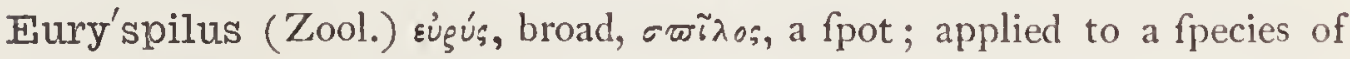

Sun Bear.

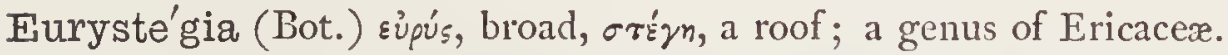

Eury'stoma (Bot.) Eupús, wide, orópca, a mouth, from the wide orifice of corolla; a genus of Ericaceæ.

Eury'stomus-a-um (Ornith.) sủgús, wide, oróra, a mouth; from the widely cloven beak.

Eurytæ'nia (Bot.) eủpús, broad, raivia, a band or fillet; a genus of Umbelliferæ.

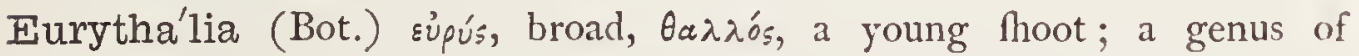
Gentianaceæ.

Eury'tion (Bot.) sủpúrns, width or breadth; a genus of Algx.

Eury'tis (Ent.) eủzús, broad; a genus of Hymenoptera.

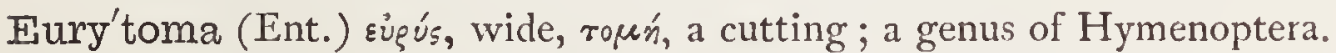

Euryto'midæ (Ent.) Eurytoma, fam. term. ida.

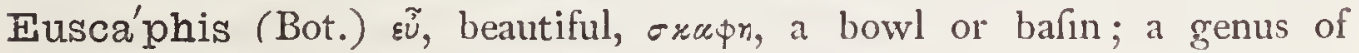
Staphyleaceæ.

Euse'pala (Bot.) $\varepsilon$ ũ, beautiful, Sepal, in allufion to the beautiful calyx; a genus of Primulaceæ.

Euspi'za (Ornith.) $\varepsilon \dot{v}$, good, fpiza, a bunting.

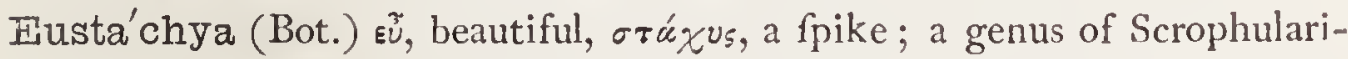
aceæ.

Eusta'chys (Bot.) fame etymology ; a genus of Gramina.

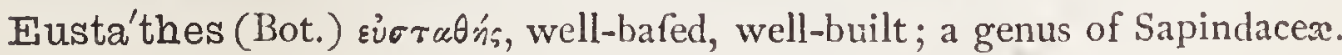




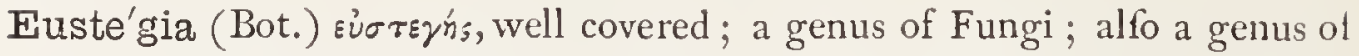
Afclepiadaceæ.

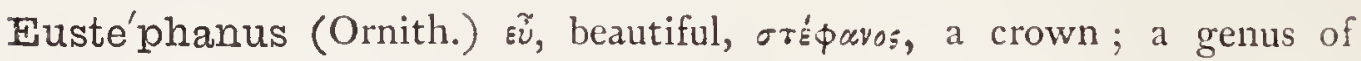
Humming-birds.

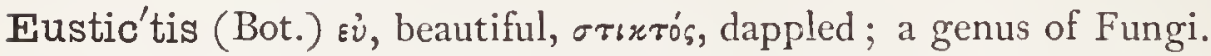

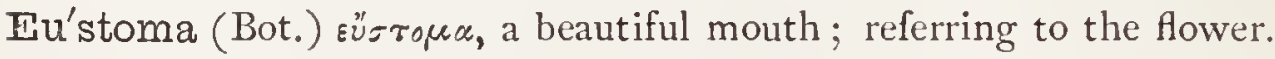

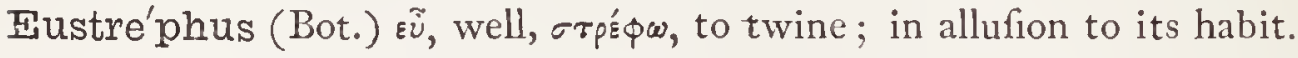

Fustro'bilus (Bot.) $\varepsilon \tilde{u}$, beautiful, frobilus, from its handfome cone-like inflorefcence; a genus of Proteaceæ.

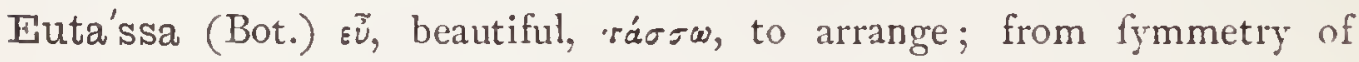
branches; a genus of Coniferæ.

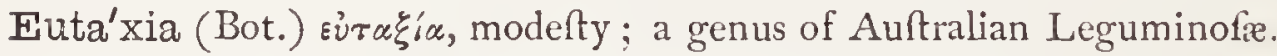

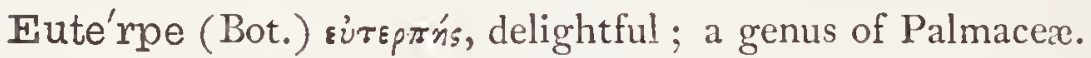

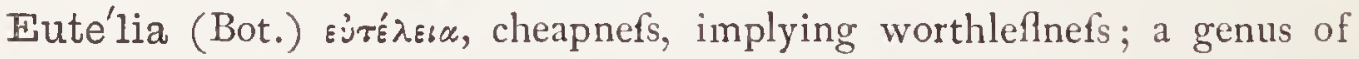
Lythraceæ.

Eu'thales (Bot.) $\varepsilon \tilde{u}$, well, $\theta a \lambda \varepsilon \dot{\omega} \omega$, to puth or fprout.

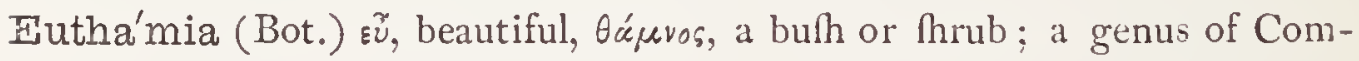
pofitæ.

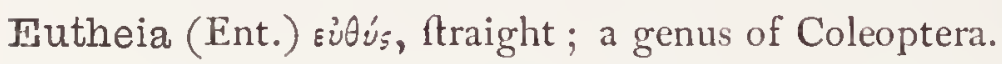

Eu'themis (Bot.) $\varepsilon \tilde{u}$, beautiful, $\theta_{\xi}^{\prime} \mu s_{s}$, law; a genus of Ochnaceæ.

Eutherno'nia (Ent.) в:ैaspos, pleafant in fummer; a genus of Lepidoptera. Eu'toca (Bot.) вüroros, bringing forth eafily; a genus of Hydrophyllaceæ.

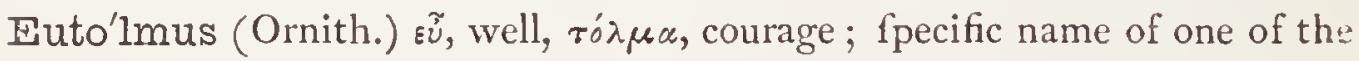
Falcons.

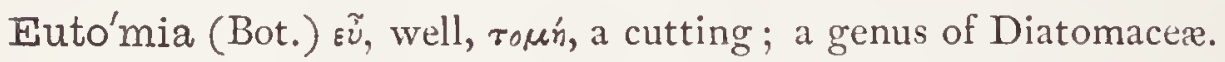

Euto'xeres (Ornith.) a genus of Humming-birds.

Eutre'ma (Bot.) $\varepsilon \tilde{u}$, well, $\tau$ pr $\mu_{\mu} \alpha$, that which is pierced; a genus of Cruciferæ.

Eutrópia (Bot.) $\varepsilon \tilde{u}$, well, $\tau \xi^{\prime} \xi \omega \omega$, to turn; a genus of Euphorbiacex.

Eutro'pis (Bot.) fame etymology; a genus of Afclepiadacex.

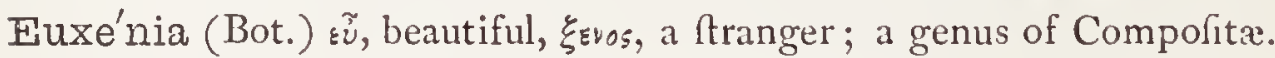

Eva'dne (Zool.) P. N.; a genus of Entomoftracan cruftaceans.

Evæsthe'tus (Ent.) в Coleoptera.

Evalla'ria (Bot.) evallo, to put out of doors; a genus of Liliaceæ.

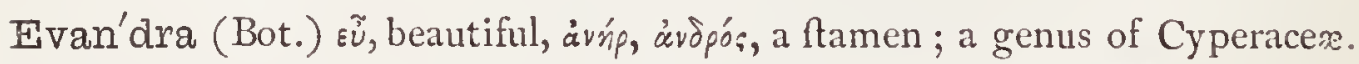
巴vax (Bot.) Lat. an exclamation of joy; a genus of Compofitr.

Evely'na (Bot.) P. N. in honour of John Evolyn, the celebrated autlior of "Sylva;" a genus of Orchidacex. 
Eve'rnia (Bot.) $\varepsilon \varepsilon^{\tilde{u}}$, well, દ̌pvos, a thoot or branch; a genus of Lichenes.

Eversma'nnia (Bot.) P. N. in honour of Everfmasn, a German botanift; a genus of Leguminofx.

Evo'dia (Bot.) เúẇ่ns, fweet-fmelling, fragrant; a genus of Rutacex; alfo a genus of Lauracex.

Evol'vulus (Bot.) evolvo, to roll out.

- Evonymoda'phne (Bot.) compounded of evonymus and dapline, as if to fay, evonymus-looking laurel; a genus of Lauracese.

Evo'nymus (Bot.) same as Euonymus, which fee.

Evo'smia (Bot.) eqiv. to errofmia; a genus of Cinchonaceæ.

Evo'ta (Bot.) $\varepsilon^{\dot{u}}$, beautiful, ỡs, wrós, an ear; a genus of Orchidacex.

Ewy'ckia (Bot.) P. N. in honour of Eruyck, a German botanift; a genus of Melaftomaceæ.

E'xacum (Bot.) ex, out of, ago, to drive; it expels poifon; a genus of Gentianaceæ.

Exade'nus (Bot.) ${ }^{\xi} \xi$, without, $\kappa \delta n v$, a gland; a genus of Gentianacex.

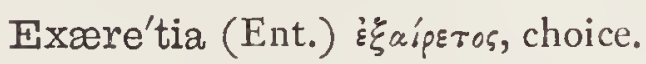

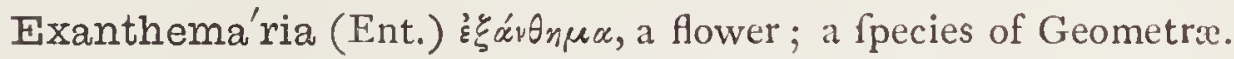

Exanthema'ticus (Bot.) $\varepsilon \xi \alpha v \theta^{\prime} s \omega$, to put out flowers.

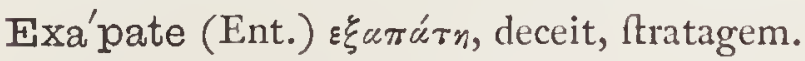

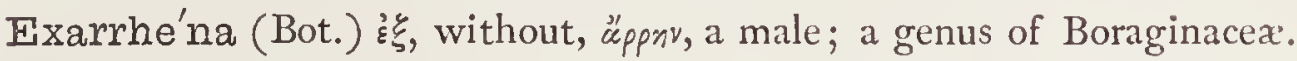

Excæca'ria (Bot.) excaco, to blind; a poifonous genus of Euphorbiacex, the juice of which, getting into the eye, caufes blindners.

Exci'pula (Bot.) excipio, to catch; alluding to its roughners; a genus of Fungi.

Excre'mis (Bot.) excremo, to burn utterly; a genus of Liliacex.

Excu'bitor (Ornith.) Lat. a fentinel; from the foreign ufe of the Shrike in trapping hawks. The bird is faftened down, and, on the approach of the hawk, gives notice to the Falconer by its fcreams.

Exei'rus (Ent.) $\varepsilon \xi \vdots ; \rho \tilde{\omega}$, to Atretch ; a genus of Hymenoptera.

Exi'dia (Bot.) exidio, to exude; a genus of Fungi.

$\left.\begin{array}{l}\text { Exigua'lis (Ent.) } \\ \text { Exigua'ta (Ent.) }\end{array}\right\}$ exiguıs, very fmall.

Đxi'guus-a-um (Ent., Bot.) Lat. Imall, or narrow; e.g. Eupliorbia exigua. Exila'ria (Bot.) exilis, flender; a genus of Diatoms.

Ex'ilis (Ent.) Lat. thin, lean, weak.

Exite'lia (Bot.) uncertain; a genns of Byttneriacex.

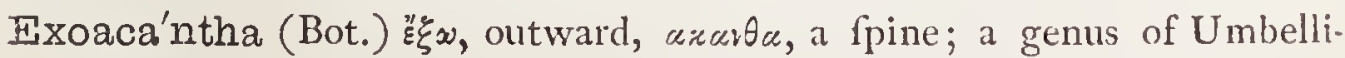
feræ. 
Fxoca'rpus (Bot.) ${ }^{\natural} \xi \omega$, outfide, жą๘ós, fruit.

Exoce'tus (Ichth.) ${ }^{\prime \prime} \xi \omega$, outfide, xoírn, a bed, a name applied to a fifh formerly fuppofed to fleep on land; the Flying-fifh.

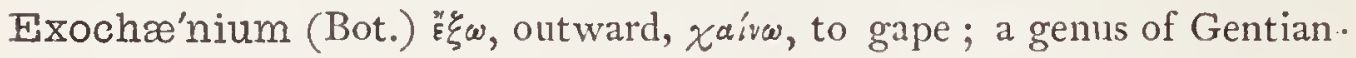
aceæ.

Exogy'ra (Fos. Zool.) ${ }^{\sharp} \xi \xi \omega$, without, yũpos, a circle.

Exole'ta (Ent.) exoletus, grown up, mature.

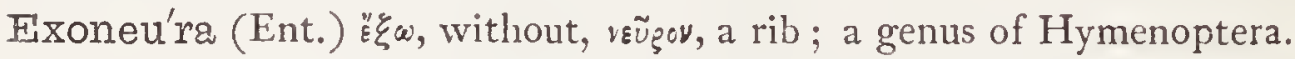

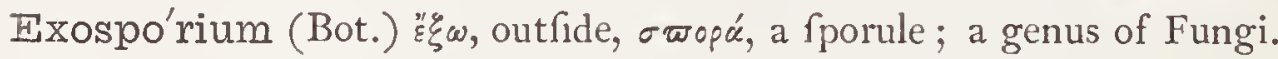

Exoste'mma (Bot.) ${ }^{\prime} \xi \omega$, without, $\sigma \tau \varepsilon \mu \mu \alpha$, a crown.

Exosty'les (Bot.) ${ }^{\prime \xi} \xi \omega$, outward, $\sigma \tau \tilde{\lambda}$ ov, a ftyle; a genus of Leguminofæ.

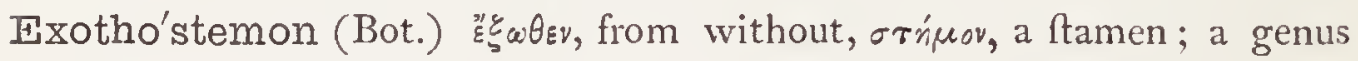
of Apocynacere.

Expallida'ta (Ent.) expallidus, very pale; a fpecies of Geometræ.

Expoli'ta (Ent.) expolitus, polifhed.

Exten'sus-a-um (Ent., Bot.) part. of extendo, to ftretch out.

Extersa'ria (Ent.) exterfus, wiped off, fmeared; a fpecies of Geometra.

Ex'ulans (Ornith.) Lat. wandering; applied to an Albatrors.

$E^{\prime}$ xulis (Ent.) exul, a wanderer; a fpecies of Noctuæ.

Exuviabi'litas (Zool.) exuvice, Rin; applied to animals which change the Rin without changing the form.

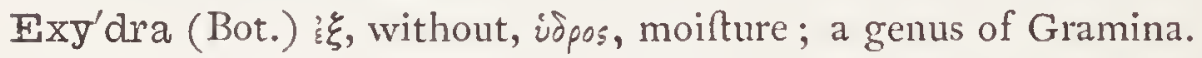

Eyse'lia (Bot.) P. N. in honour of __Ey Eel, a German botanift; a genus of Galiaceæ; alfo a genus of Compofitæ.

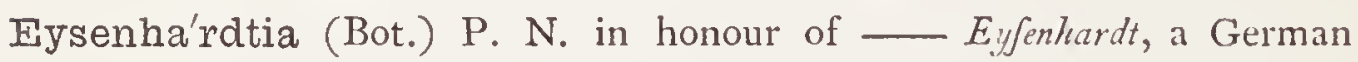
botanift; a genus of Leguminofi.

Fa'ba (Bot.) Lat. a bean, from фá́y , to eat, from being efculent; a genus of Leguminof $x$.

Faba'go (Bot.) faba, a bean, from refemblance of foliage; a genus of Zygophyllacex.

Fa'ber (Ichth.) Lat. a workman.

Fabia'na (Bot.) P. N. in honour of $M$. Fabian; a genus of Solanacer.

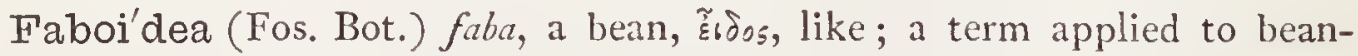
fhaped leguminous feeds found in the lower tertiary clays of the lile of Sheppey.

Fabri'a (Bot.) P. N. in honour of $M$. Fabre; a genus of Acanthacex. 
Fabri'cia (Bot., Ent.) P. N. from F. C. Fabricius, the celebrated Danith entomologift.

Fabro'nia (Bot.) P. N. in honour of Giovanni Valentino, Baron Fabroni, an Italian naturalift; a genus of Mufci.

Facchi'nia (Bot.) a genus of Caryophyllacex.

F'a'celis (Bot.) $\uparrow a ́ x \varepsilon \lambda \circ 5$, a bundle; a genus of Compofitx.

Fadge'nia (Bot.) a genus of Garryacex.

Fadye'nia (Bot.) P. N. in honour of M. Fadyen; a genus of Filices.

Faga'ra (Bot.) Arabic name ufed by Avicenna.

Fagara'strum (Bot.) fagus, the beech, aftrum, a ftar; a genus of Amyridacex.

Fage'lia (Bot.) derivation unknown.

Fagel'la (Ent.) fagus, the beech-tree, on which it feeds.

Fago'nia (Bot.) P. N. from $M$. Fagon, a great patron of botany.

Fagopy'rum (Bot.) from фnyós, zupóv, Beech-wheat; from the form of

fruit, fame as "Buck- (i. e. beech) wheat;" a genus of Polygonacea.

Fagræ'a (Bot.) P. N. from F. T. Fagreus, M.D., a friend of Thunberg.

Fa'gus (Bot.) Lat. the Beech-tree, from $\phi \dot{u} \gamma \infty$, to eat. It is probable that

the snyos of the Greeks was not the fagus of the Latins, but either the Cheftnut, or $2 u e r c u s$ IEfculus, as the name has evident reference to the fruit being ufed as food, and beech-malt would form a far inferior diet to cheftnuts.-BurnetT.

Fala'gria (Ent.) unexplained; a genus of Coleoptera.

Falca'ria (Bot.) falx, a fickle; a genus of Umbelliferr.

Falca'te (Bot.) falcatus, like a fickle.

Falca'tula (Bot.) falx, a fickle; from fickle-lhaped pods; a genus or Leguminofx.

Falcine'llus (Ornith.) dim. of falco.

Fa'lco (Ornith.) Lat. a falcon; fo called becaufe its nails or claws refemble a falx or hook.

Falcone'ria (Bot.) in honour of the celebrated $D r$. Falconer, the Eaft Indian botanift; a genus of Stilaginacex.

Falco'nidæ (Ornith.) a family of the order of which Falco is the type; a genus of Raptores.

Fal'cula (Ent.) falx, a fickle, a fcythe.

Falcu'nculus (Ornith.) dim. of Falco, a hawk; applied to the Shrike-tits of Aufralia.

Falderman'nia (Bot.) P. N. in honour of M. Faldermann; a genus of Labiatæ.

Fa'lkia (Bot.) P. N. from 7. P. Falk, a Swedilh botanift, who died in 1774. 
Fa'llax (Bot.) Lat. deceitful.

Fallo'pia (Bot.) P. N. in honour of the celebrated anatomift Fallopits ; a genus of Polygonaceæ.

Fallu'gia (Bot.) a genus of Rofacere.

Familia'ris (Zool., Ornith.) Lat. domeftic, tame.

Fara'ncia (Zool.) фága $\gamma \xi$, a chafm or cleft; a genus of Ophidians.

Farina'lis (Ent.) farina, meal, referring to furface of wings, or to the food of the larva.

Fa'rio (Ichth.) Lat. a Trout.

Farne'sia (Bot.) P. N. in honour of one of the Farnefe family of Naples; a genus of Leguminofæ.

Farobœ'a (Bot.) a genus of Compofitæ.

Farrel'la (Zool.) P. N. in honour of Dr. Arthur Farre, its difcoverer; a genus of Polyzoa.

Farse'tia (Bot.) P. N. from Philip Farfeti, a noble Venetian botanift; a genus of Cruciferæ.

Farti'nia (Bot.) a Nat. order in the fyftem of Dumortier (Flora Belgica). Farula'ria (Fos. Bot.) farus, a honeycomb; a genus of coal-meafure ftems marked with fcars like honeycomb.

Fasceli'na (Ent.) fafcis, a bundle; alluding to the tufts of hair on the larva.

Fascia'lis (Ent.) being marked with fafcice, or bands.

Fascia'tz (Bot.) fafcia, a band, diadem, or wreath; a genus of Algæ.

Fascia'tus (Zool.) Lat. banded.

Fascicula'ria (Fos. Zool.) fafciculus, a little bundle; a genus of Polyzoa, fo named from its bundle-like form.

Fascic'ulate (Bot., Zool.) fafciculus, a little bundle, collected or arranged in clufters.

Fas'ciola (Bot.) dim. of fafcia, a genus of Marchantiacer.

Fasciola'ria (Zool.) fafciola, a winding band; folds near the bafe of the columella, or neck.

Fasciun'cula (Ent.) fafcia, a band, uncus, a hook.

Fastigia'ria (Bot.) fafigium, a ridge; a genus of Alga.

Fauja'sia (Bot.) P. N. in honour of M. Faujas; a genus of Compofitæ.

Fau'na (Zool.) Lat. rural deities; a convenient term for the animals of any given epoch or area.

Faunu'la (Zool., Bot.) dim. of famna.

Fau'stula (Bot.) dim. of faufus, lucky, fortunate; a genus of Compofitæ.

Fave'lla (Bot.) dim. of favus, a honeycomb.

Favillacea'na (Ent.) favillaceus, any: from the colour. 
Favol'us (Bot.) dim. of favus, a honeycomb ; a genus of Fungi.

Favo'nium (Bot.) favonius, the weft wind; a genus of Compofitie.

Favosi'tes (Fos. Bot.) favis, a honeycomb.

Fawn (Zool.) French, faon.

Fe'dia (Bot.) a name of Adanfon's, probably without meaning; a genus of Valerianaceæ.

Fe'lidæ, (Zool.) felis, fam. term. ida and ina; a family and fub-family of Feli'na $\}$ Mammalia.

Fe'lis (Zool.) Lat. a cat.

Feneste'lla (Fos. Zool.) Lat. a little window.

Fenestra'tus-a-um (Bot.) Lat. refembling a lattice, as in the leaves of the Ouviranda feneftralis.

Fenestrel'la (Ent.) feneftra, a window; from its habit of fitting in the windows of houfes.

Fe'nnel (Bot.) contraction of Lat. freniculum.

Fen'nicus-a-um (Ent., Bot.) relating to Finland.

Fe'ræ ('Lool.) Lat. wild beafts.

Fera'nia (Zool.) unexplained; a genus of Ophidians.

Feri'na (Ornith.) ferinus, pertaining to wild beatts.

Fernande'sia (Bot.) P. N. from George Garcia Fernandez, a Spanith botanift.

Ferne'lia (Bot.) P. N. from J. Fernel, phyfician to Henry IJ., of France, died $155^{8}$.

Fero'nia (Ent., Bot.) P. N., the goddefs of forefts.

Feroni'idæ (Ent.) Feronia, fam. term. ida.

Fe'rox (Bot., Ichth.) Lat. ferocious, favage; metaphorically, covered with thorns.

Ferra'ria (Bot.) P. N. from J. B. Ferrari, an Italian botanift; a genus of Iridaceæ.

Ferre'ola (Ent.) dim. of ferreus, iron-coloured; a genus of Hymenoptera.

Fe'rret (Zool.) Dutch vret, Ger. frett.

Ferruga'lis (Ent.) ferrugo, ruft of iron; referring to colour.

Ferrugi'neus-a-um (Ent., Bot.) Lat. ruft coloured.

Fer'rum equi'num (Zool.) Lat. a horfe-lhoe.

Fe'rula (Bot.) ferio, to Atrike; the ftems are ufed for rods; a genus of Umbelliferæ.

Fe'rus-a-um (Ornith.) Lat. wild, untamed.

Festu'ca (Bot.) Celtic fft, pafture or food; Fefcue-grafs.

Feuilliæa (Bot.) P. N. in honour of Feuillée; a genus of Cucurbitacex. 
Fi'ber ('Zool.) Lat. a beaver; now ufed as the fpecific name of the animal, Caltor fiber.

Fibi'gia (Bot.) a genus of Cruciferæ.

Fibrau'rea (Bot.) fibra, a border, aureus-a-um, golden; a genus of Memifpermacex.

Fibrilla'ria (Bot.) fibrilla, a fmall thread; a genus of Fungi.

Fibri'na (Bot.) fura, a fprout; a genus of Fungi.

Fica'ria (Bot.) ficus, a fig; in allufion to the fig-like roots; a genus of Ranunculaceæ.

Ficel'la (Ent.) ficus, a fig; the larva feeds on dried figs.

Fich'tea (Bot.) P. N. in honour of 7. G. F. Fichte; a genus of Compofitæ. Fici'mia (Zool.) etymology unknown; a genus of Ophidians.

Fici'nia (Bot.) a genus of Cyperaceæ.

Ficoi'deæ (Bot.) ficus, a fig, sídos, like; ficoid or fig-like plants.

Fi'cus (Bot.) Lat. a fig ; "ficce fici ftomachum lædunt."-Pliny xxiii. 63 ; "a fico for the phrafe."-Shakefpeare.

Fido'nia (Ent.) P. N., the godders of the groves; a genus of Lepidoptera. Fidoni'idæ (Ent.) fidonia, fam. term. ida.

Fie'ldia (Bot.) P. N. from Baron Field, fometime Chief Judge in New South Wales.

Fig (Bot.) Lat. ficus, Fr. figuse.

Filaginop'sis (Bot.) the genus fllago, and ö $\downarrow$ ss, refemblance; a genus of Compofitæ.

Pila'go (Bot.) filum, a thread; in allufion to its being covered with threads;

a genus of Compofitx.

Fila'lis (Ent.) film, a thread.

Fila'riæ (Zool.) filarium, a thread; a genus of Entozoa.

Fi'lbert (Bot.) from Philibert, king of France, in the fame way as Pippin, from king Pepin.

Filices (Bot.) plural of filix, a fern.

Filifo'rmis-e (Zool., Bot.) flum, a thread, formis, refemblance.

Filipen'dulæ (Ent.) from the Common Dropwort (Spiræa Filipendula);

but the larva feeds on various leguminous plants.

Fi'lix (Bot.) Lat. a fern.

Fillœ'a (Bot.) a genus of Leguminofa.

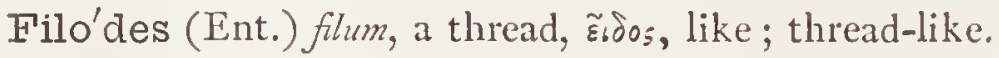

Fi'lum (Bot.) Lat. a thread; a genus of Algæ.

Fimbria'ria (Bot.) fimbria, a fringe; a genus of Algx.

Fimbria'tus-a-um (Ent., Bot.) Lat. bordered, from fimbria, a fringe. 
Fimbrilla'ria (Bot.) fimbria, a fringe; a genus of Compofitx.

Fimbristy'lis (Bot.) finbria, a fringe, fylus, a fyle.

Finch (Ornith.) from the note of the bird, which refembles Fink or Pink. Fincke'ya (Bot.) P. N. in honour of $M$. Fincke; a genus of Ericaces.

Findla'ya (Bot.) P. N. in honour of $M r$. Finlay; a genus of Primulacex. Fingerhu'thia (Bot.) P.N. in honour of $M$. Fingerhut; a genus of Grafles. Finlayso'nia (Bot.) P. N. in honour of Mr. Finlayfon; a genus of Afclepiadacex.

Fino'chis (Bot.) Ital. finocchio; a plant of the genus Anethum; Sweet fennel. Fintelman'nia (Bot.) 1 . N. in honour of $M$. Fintelman; a genus of $\mathrm{CJ}^{-}$peracex.

Fir (Bot.) Anglo-Sax. furh.

Firen'sia (Bot.) the Latin name of Florence; a genus of Cordiaceæ.

Firmia'na (Bot.) P. N. in honour of Count von Firmian, an Aufrian fatesman; a genus of Sterculiacese.

Fis'chera (Bot.) a genus of Ericacex.

Fische'ria (Bot.) P. N. in honour of Friedrich Ernft Ludwig von Fifcher; a genus of Afclepiadacer.

Fischeriel'1a (Ent.) P. N. from Fifcher von Waldheim, Author of "Enlonsugraplia Imperii Rufici," publimed at Mofcow, 1820-1822.

Fish (Ichth.) Anglo-Sax. fifc, Lat. pifcis.

Fis'sa (Bot.) fiffus-a-um, cleft, divided.

Fisse'nia (Bot.) etymology unknown; a grenus of Loafacea.

F'is'sidens (Bot.) fifus, cleft, dens, a tooth; a genus of Mufci.

Fissilia (Bot.) fiffilis, what is cleft or cloven; a genus of Olacaceat.

Fis'sion ( $Z$ ool.) fif $u s w a-u m$, cleft, divided.

Fissip arous (Zool., Bot.) fiffus, cleft, pario, to produce; denoting generation bv the divifion of the body of the parent into two parts, each of which becomes a perfect living animal.

Fis'siped (Zool) fiflus, cleft, pes, pedis, a foot; having the toes feparated. Fissuri'na (Bot.) fiffura, a cleft; a genus of Lichenes.

Fis'sus-a-um (Bot.) Lat. cleft, divided.

Fistula'ria (Bot.) fiftula, a reed; a genus of Algiw.

Fistuli'na (Bot.) fifula, a pipe; referring to its being tubular; a genus of Fungi.

Flabella'lis (Ent.) fabllum, a fan.

Flabella'ria (Bot.) fubellum, a fan; a genus of Algra.

Fiabel'liform (Zool., Bot.) fl.bellum, a fan ; furma, refemblance.

Flabeliina (7ool.) fubeluan, a fan; a genus of Foraminifua. 
Flacou'rtia (Bot.) P. N. from Etienne de Flacourt, a French botanift; the typical genus of Flacourtiacex.

Flagella'ria (Bot.) flagellım, a rod; it has long pliant branches.

Flage'lliform (Zool.) flagellum, a whip, forma, refemblanee.

Flamin'go (Ornith.) flamma, a flame; alluding to the colour of its" plumage.

Flammea'lis (Ent.) famma, a flame; referring to colour.

Flam'meus-a-um (Ornith., Bot.) Lat. flame-coloured.

Flam'mula (Bot.) Lat. a little flame or blaze; a genus of Fungi; alfo as

a fpecific name denoting acridity, e.g., Ranunculus Flammula.

Flava'go (Ent.)
Flava'lis (Ent.) f farus, yellow.

Flave'ria (Bot.) favus, yellow; ufed in Chili for dyeing yellow; a genus of Compolitx.

Flave'scens (Zool., Bot.) Lat. fomewhat yellow; e.g. Trifetum farvefens. Flavibasa'lis (Ent.) fuviss, yellow, bafis, the border of the wing.

Flavicor'nis (Ent., Bot.) fluvus, yellow, cornu, a horn; from the colour of the antennx; Viola favicornis, becaufe of the colour of the fpur of the corolla.

Flavig'ula ('Zool.) flavus, yellow, gold-coloured, gula, the throat.

Fla'vipes (Ent.) furvus, yellow, pes, the foot.

Flavomacula'tum (Ent.) flarus, tawny, maculatus, part., potted.

Flax (Bot.) Anglo-sax. fleax.

Flea (Ent.) Anglo-Sax. flea.

Flebila'lis (Ent.) flebilis, doleful.

Fleische'ria (Bot.) P. N. in honour of Fleifcher, a German botanitt ;

a genus of Byttneriacex and Compofitx.

Flemin'gia (Bot.) ,

Flemin'gii (Zool.) ) P. N. from Dr. Fleming, F.R.S. Éc., of Edinburgh.

Fle'ssus (Ichth.) etymology unknown.

Fle'urya (Bot.) P. N. in honour of $M$. Fleury; a genus of Urticacex.

Flinder'sia (Bot.) P. N. from Captain M. Flinders, a celebrated voyager.

Flix-weed (Bot.) corruption of fux-zved, being ufeful in hæmorrhage.

The Sifymbrium Sophia.

Plo'ra (Bot.) Lat. the goddefs of flowers; a convenient term for the vegetation of any given epoch or area.

Fiorestina (Bot.) a genus of Compolita.

Flori'cola (Ent) flos, floris, a flower, colo. to inhabit or frequent.

Flori'colens (Ent.) flos, foris, a flower; colens, inhabiting. 
Flori'dea (Bot.) fioridus, rofe-coloured; a fub-order of red Algx.

Florin'da (Bot.) a genus of Celaftraceæ.

Flori'suga (Onnith.) flores, flowers, fugo, to fuck; genus of Humming-birds. Flökea (Bot.) P. N. in honour of $M$. Flork, a Danilh writer.

Fllo'rula (Bot.) dim. of flora.

Flos'culus (Zool., Bot.) Lat. a little flower.

Floto'via (Bot.) P. N. in honour of - Flotof; a genus of Compofita.

Floure'nsia (Bot.) P. N. in honour of $M$. F. P. Flourens, the celebrated

French phyfiologift; a genus of Caryophyllacea and Compofita.

Fluctua'ta (Ent.) fuctuare, to undulate; the pale parts of the wings being much undulated with fine alhy ftreaks.

Fluggæ'a (Bot.) P. N. from Iohn Flugge, a German cryptogamic botanift.

Flulze (Ichth.) Anglo-Sax. floc.

Flu'stra (Zool.) from Sax. fluftrian, to weave; a name given by Linnæus to the Sea-mats; a genus of Polyzoa.

Flustrélla (Zool.) ảim. of fustra; a genus of Polyzoa.

Fluvia'les (Bot.) furvalis, pertaining to a river; the Pond-weed family.

Fluvia'tilis (Ornith., Bot.) Lat. pertaining to rivers; e.g. Ranunculus fuviatilis.

Focil'la (Ent.) focillo, to warm, or cherißh.

Focil'lidæ (Ent.) focilla, fam. term. idie.

Fodi'na (Ent.) Lat. a mine or quarry.

Fœda'lis (Ent.) fredus, dirty.

Fœni'culum (Bot.) Lat. the herb fennel, Pliny and Celfus; a genus of Umbelliferæ.

Fœ'num Græcum (Bot.) Lat. Greek hay; this, the name of a fpecies of Trigonella, is the ridúrapov of 'Theophraftus and Diofcorides; its abominable odour being then confidered a fweet perfume, as its old name imports. BURnETT.

Fœ'tidus-a-um (Bot.) Lat., foetid; referring to the odour of the plant. Fruntane'sia (Bot.) P. N. from M. Deffontuines, Profellor of Botany at Paris.

Fontenel'lea (Bot.) P. N. in honour of - Fontenelle; the celebrated author of "The Plurality of Worlds;" a genus of Rofacex.

Fontina'lis (Bot.) fons, fontis, a fountain; referring to its place of growth; a genus of Mufci.

Foramini'fera (Zool.) foramen, a hole, fero, to carry or bear; the partitions eparating the chambers of the thells, have in each a finall hole. 
Forbe'sia (Rot.) P. N. in honour of Fames Forbes, author of "Oriental Memoirs;" a genus of Hypoxidacex.

Fordo'nia (Zool.) etymology unknown; a genus of Ophidians.

Forestie'ra (Dot.) a genus of Scepacere.

Forfica'lis (Ent.) bearing fome refemblance to forficula.

Forfic'ula (Ent.) dim. of forfex, fcifiors; a genus of infects of which the common Earwig is the type.

Forficu'ria (Bot.) forfex, the thape of the letter $\mathrm{V}$; a genus of Orchidacer. Forgar'cia (Bot.) P. N. in honour of $M$. Forgard; a genus of Combretacte. Forge'sia (Bot.) a genus of $\mathrm{E}$. calloniacer.

Formicafor'mis (Ent.) formica, an ant, forma, likenefs.

Formicari'nx (Ornith.) formica, an ant; the Ant-Thrufhes.

Formica'rius (Ent.) formica, an ant.

Forni'cium (Bot.) fornix, an arch; a genus of Compofite.

Forre'stia (Bot.) P. N. in honour of Mrr. Forreft; a genus of Commelynacer.

Forsko'lea (Bot.) P. N. from Peter Forfkol, a traveller in Egypt.

For'stera (Bot.) P. N. in honour of the celebrated botanift, 7 . R. Forfer. Forsterop'sis (Bot.) the genus Forftera, and '\% $\psi$ s, refemblance: a genus of Stylidiacex.

Fortu'nya (Bot.) P. N. in honour of Robert Fortune, the traveller in China.

Foszelinia (Bot.) a genus of Crucifera.

Fossombro'nia (Bot.) P. N. in honour of Signor Fofjombroni; a genus of

Marchantiacex.

Fosso'res (Ent.) Lat. diggers; a tribe of Hymenoptera.

Forsy'thia (Bot.) P. N. in honour of MTr. Forfyth; a genus of Oleacex.

Fothergillia (Bot.) P. N. from Jolin Fothergill, M.D., a patron of botany.

Fouge'ria (liot.) P. N. in honour of M. Fouger, a French botanift; a genus of Compolite.

Fougerou'xia (Bot.) P. N. from M. Fougeroux; a genus of Compofinx. Fouquie'ra (Bot.) P. N. in honour of M. Fouquier.

Fourcro'ya (Bot.) P. N. in honour of MT. Fourcroy, the celebrated chemist; a genus of Amaryliidacer.

Fovea'lis (Ent.) fove a a pit.

Foveola'ria (Bot.) forrolus, it little pit a genus ol Styacacer.

Fowl (Ornith.) Anglo-Sax. fligel, quali from root of Latin fuyro, to By.

Fox (Zool.) Arghrowax. fox, Germ. fuch. 
Foxglove (Bot.) the glove or flower of the Folks or fairies: fome think the name was given from the refemblance of the flowers to the fingers of a glove, and that the plant was then dedicated to Fuchfus, a German botanift, i. e. Fuchfius' glove.

Fracta'lis (Ent.) fractus, broken.

Fraga'ria (Bot.) fragrans, fragrant, bscaufe the fruit is porfumed; the Strawberry; natural order Rofacex.

Fragila'ria (Bot.) fragilis, brittle, referring to its nature; a genus of Diatoms. Fra'gilis (Bot.) Lat. brittle; e. g. Ciftopteris fragilis.

Fragillis'simus-a-um (Zool.) Lat. very brittle.

Frago'sa (Bot.) fragofus, rough, uneven; a genus of Umbelliferis.

Francillona'na (Ent.) P. N. in honour of Francillon, an Englifh entomologift of the laft century.

Francis'cea (Bot.) P. N. in honour of Francis I., emperor of Auftria.

Francoli'nus (Ornith.) Italian, francolino; Spanij and French, francolin.

Franke'nia (Bot.) P. N. in honour of Fohn Frankenins, Profeffor of Botany at Upfal; typical genus of natural order Frankeniacex.

Frankla'ndia (Bot.) P. N. in honour of Mr. Frankland; a genus of Proteacex.

Frankli'nia (Bot.) P. N. in honour of Sir Fohr Franklin; a genus of Ternfrömiacex.

Franquevi'llia (Bot.) P. N. in honour of $M$. Franqueville, a French botanift; a genus of Gentianacex.

Franse'ria (Bot.) P. N. from Antony Franzer, M.D., a botanift.

Frase'ra (Bot.) P. N. from J. Frafer, a colledtor of plants in North America.

Frate'rcula (Ornith.) Lat. a little fifter.

Frauenho'fera (Bot.) P. N. in honour of Fratsenhofer, the celebrated experimentalift on light; a genus of Celaftracex.

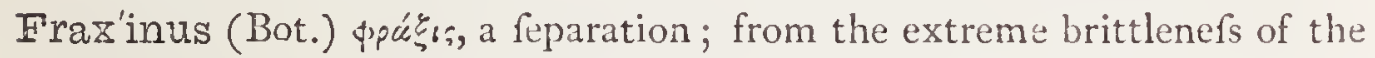
young ftems. The Afh-tree: natural order Oleaceæ.

Frederice'lla (Zool.) P.N. in honour of Frederick Cnvicr; a genus of Polyzoa. Fre'gilus (Ornith.) generic name of the Cornith chough, or red-legged crow; a rame applied for fome unknown reafon.

Frena'ta (Ent.) part. of freno, to bridle.

Frezie'ra (Bot.) P. N. in honour of Amedée François Frezier, a traveller in

Peru and Chili, who died in 1773 .

Frie'sia (Bot.) P. N. in honour of Elias Fries, a celebrated Swedifh botanif, Superintendent of the Mufeum and Botanic Garden at Upfal. 
Fringi'lla (Ornith.) Lat. a chaffinch; a genus of Birds.

Frischel'la (Ent.) P. N. from Johann Leonhard Frifch, an entomologift, who died in 1743 .

Fritilla'ria (Bot.) fritillus, a chefs-board; the Snake's-head lily.

Frog (Zool.) Anglo-Sax. froga, frogga, or frocca.

Frolichiel'la (Ent.) P. N. from F. A. G. Frölich, the author of "Erumeratio Tortricum Wurtemburgia," п 828 .

Frondicula'ria (Bot.) frondicula, a little frond; a genus of Foraminifera.

Frondo'sus-a-um (Zool., Bot.) Lat. leafy.

Fronta'lis (Ent.) frontale, an ornament for the forehead, from frors.

Fronta'ta (Ent.) Lat. made for the front.

Frugil'egus-a-um (Ornith.) Lat. picking or gathering fruit.

Frumenta'lis (Ent.) Frumenta'rius (Zool.) frumentum, corn; the infects feed on it.

Frus'tule (Bot.) frufulum, a fragment.

Frustu'lia (Bot.) frufula, fragments; a genus of Cryptogamia.

Fu'chsia (Bot.) P. N. in honour of IV. L. Fuchs, a celebrated German botanift; a genus of Onagracex.

Fucic'ola (Zool.) fucus, fea-weed, colo, to inhabit.

Fucifor'mis (Ent.) fucus, a drone, form, a thape; it refembles a drone.

I folfil fea-weed of unknown afinity.

Fu'cus (Bot.) füros, fea-weed; a genus of Algx.

Fuire'na (Bot.) P. N. in honour of G. Fitiren, a Danifh botanift.

Fu'lica (Ornith.) Lut. a marth fowl like our moor-hen, fo named from its dark colour; "in ficco ludunt fulicæ."-VIRGIL, Creor. i. $3 \sigma_{3}$.

Fuligi'nea (Ent.) Lat. foot-coloured.

Fuligino'sa (Ent.) fuligo, foot; the hind wings are blackin pink, with black margins.

Fuli'gula (Ornith.) dim. of fuligo, foot, from its colour.

Fulva'lis (Ent.) fulous, yellow, i. e., the wings.

Fulvidorsa'lis (Ent.) fulvus, yellow, dorfum, the back.

Fulvocilia'lis (Ent.) fulvus, yellow, cilium, an eyelah.

F'u'lvus-a-um (Ornith. Bot.) tawny or yellowifh-biown coloured.

Fuma'lis (Fnt.) fumus, fmoke, referring to the colour of the wings.

Fuma'ria (Bot.) fumus, fmoke; the bruifed root caufing tears to flow, is does fmoke; or from the glaucous herbage refernbling fmoke at a diftance; typical genus of fumariacees.

Fumosa'lis (Ent.) fumofus, smoky. 
Funa'ria (Bot.) funis, a rope, referring to the twifted Itructure of the fruit-ftalks; a genus of Mufci.

Funebra'lis (Ent.) funebris, mourning; from gloomy colour.

Funera'lis (Ent.) funerale, a funeral; from gloomy colour.

Fune'rea (Ornith.) funereus, relating to a burial; allufion to dark colour.

Funerel'la (Ent.) funus, a funeral; in allufion to the black and white wings - the half-mourning garb of the infect.

Fune'reus (Zool.) Lat difmal; generally applied in reference to colour.

Fu'ngia (Zool.) fungus, a muhroom; a genus of laminated Corals.

Fu'ngus (Bot.) Lat. a muhroom. Horace fays:"pratenfibus optima fungis

Natura eft, aliis malè creditur."

Fu'nkia (Bot.) P. N. in honour of Henry Funk, a German cryptogamint.

F'urcatel'lus (Ent.) furcatus, forked.

Furca'tus-a-um (Ornith., Bot.) Lat. forked.

Furcella'ria (Bot.) furcilla, a little fork, referring to the arrangement of the fronds; a genus of Algx.

Fur'cifer (Zool.) Lat. one who bears a fork or yoke on his neck.

Furcre'a (Bot.) P. N. in honour of M. Fourcroy, the celebrated chemilt.

Fur'cula (Ent.) furca, a fork, alluding to the two tails of the larva.

Furcula'ria (Bot.) furcula, a little fork; a genus of 'Tropeolacea and

Campanulaceæ.

Fur'culum (Ornith.) furcula, a forked prop; the anchylofed collar-bones or clavicles of a bird, and popularly called the Merrythought.

Furnaca'lis (Ent.) furnus, an oven, which it frequents.

Furun'cula (Ent.) furunculus, a petty thief.

Furva'lis (Ent.) furvus, dark, dukky.

Fu'rvus-a-um (Ent.) Lat. dark, duky.

Fusa'nus (Bot.) French, fufain, a fpindle-tree, which its fruit and leaves refemble.

Fusa'rium (Bot.) fufus, a fpindle, referring to the thape of the fporules; is genus of Fungi.

$\left.\begin{array}{l}\text { Fusca'lis } \\ \text { Fuscanta'ria }\end{array}\right\}$ (Ent.) fufcus, dufky.

Fuscel'lus-a-um (Bot.) dim. of fufcus, dukky, tawny.

Fu'scipes (Zool., Ent.) fufcus, dark, fwarthy, pes, a foot; brown-footed.

Fusco-æ'nea (Ent.) fufcus, duky, dull, aneus, brafly.

Fus'cus-a-um (Zool., Ornith., Bot.) Lat. dufky, tawny.

Fusid'ium (Bot.) furus, a fpindle. 
Fusifor'mis (Bot.) fufus, a fpindle, and forma, thape; fpindle-thaped: applied to certain roots.

Fusuli'na (Fos. Bot.) dim. of fufus, a fpindle; the earlieft type of Foraminifera yet difcovered.

Fu'sus (Zoo!.) Lat. a fpindle; a genus of Gafteropods belonging to the Muricidx, found both recent and foffil.

Gabe'rtia (Bot.) P. N. in honour of M. Gabert; a genus of Orchidacex.

Ga'brius (Ent.) etymology unknown; a genus of Coleoptera.

Ga'didæe (Ichth.) the family of the Cod-filh; from the old Linnean name, Gadus.

Ga'doids (Ichth.) gadus, the Cod-finh family, sidos, like.

Gadus (Ichth.) Lat. a cod-filh.

Gærtne'ra (Bot.) I. N. from F. Gertner, M.D., F.R.S., a celebrated botanift.

Ga'gea (Bot.) P. N. from Sir Thomas Care, an amateur botanift; a genus of Liliacex.

Gragnebi'na (Bot.) meaning unknown; a very ornamental genus of Leguminofx.

Gragu'edi (Bot.) native name in Abyflinia; a genus of Proteacer.

Gah'nia (Bot.) P. N. in honour of J. G. Galhn, a Swedifh botanift; a genus of Cyperacex.

Gailla'rdia (Bot.) P. N. in honour of M. Gaillard de Marentonneau, an amateur botanift; a handfome genus of Compofitx.

Gaillardtote'lla (Bot.) P. N. in honour of M. Gaillardt; a genus of Algx.

Gaillio'nia (Bot.) P. N., a genus of Cinchenacex.

Gaillo'na (Bot.) P. N., il genus of Algx.

Gaillone'lla (Bot.) dim. of Gaillona; a genus of Diatomacer.

Gaima'rdia (Bot.) P. N., a genus of Desvanxincer.

Gaiode'ndron (Bot.) jáüos, under earth, devopov, tree; a genus of Loranthacex.

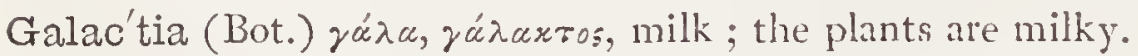

Galacti'tes (Bot.) yá $\lambda \alpha$, rá $\lambda \alpha x r o s$, milk; the veins of the leaves are white; a genus of Compofitx.

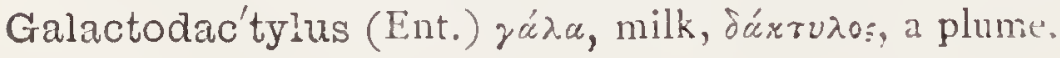




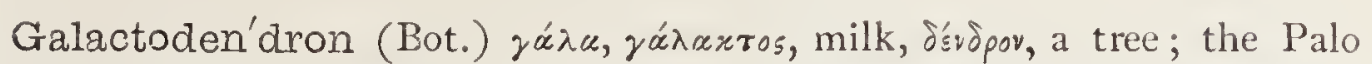
de Vaca or Cow-tree of Demerara, which yields a bland milk, ufed as a fubfitute for ordinary milk.

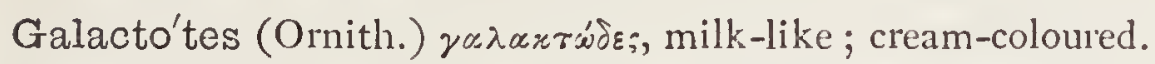

Gala'go (Zool.) a genus of fmall quadrumanous animals fubfifting chiefly on infects.

Ga'langale (Bot.) from Indian Galanga.

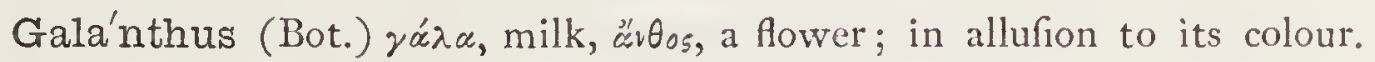
The Snowdrop, beautifully called by fome of the old botanifts, nparre $\lambda_{6} \circ \mathrm{v}$, the meflenger of Spring.

Gala'rdia (Bot.) fame as Gaillardia, $q . v$.

Galate'a (Bot.) P. N., a Nereid; a genus of Compofitx.

Galate'lla (Bot.) dim. of Galatea; a genus of Compofitx.

Galathe'a (Bot.) a genus of Amaryllidacex; alfo a genus of Iridacex.

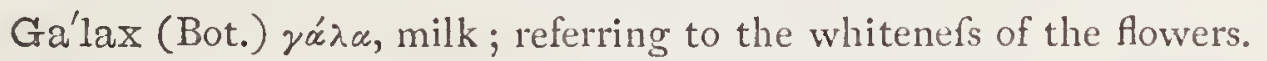

Gala'xia (Bot.) $\gamma \propto \lambda \propto \varkappa \tau \iota c ́ \omega$, to abound in milk; a genus of Iridaceæ.

Gal'banum (Bot.) the Roman name of a frong-fmelling gum; whether that to which the name is now applied is uncertain.

Ga'1bula (Ornith.) Lat. a yellow bird; now called the Wittal or Woodwall.

Gale (Bot.) fpecific name of the Myrica galë.

Galea'ndra (Bot.) probably in allufion to the helmet-fhaped labellum of the fowvers; a genus of Orchidacex.

Galea'ria (Bot.) galea, a helmet; a genus of Euphorbiacex.

Galea'tus (Zool.) Lat. that wears a helmet; helmet-fhaped.

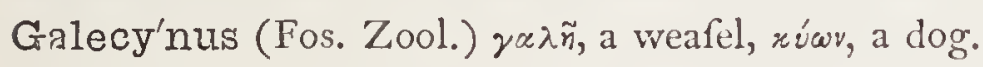

Gale'ga (Bot.) qá. $\alpha$, milk; increafes milk in animals eating it; a genus of Leguminofx.

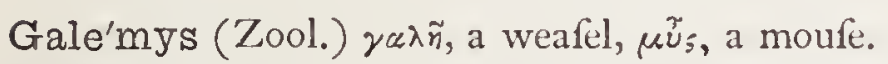

Gale'nia (Bot.) P. N. from C. Gabenus, a celebrated phyfician of Pergamus; a genus of Chenopodiacea.

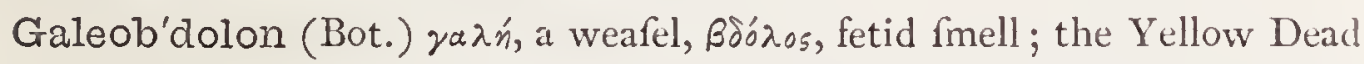
nettle; a genus of Labiatx.

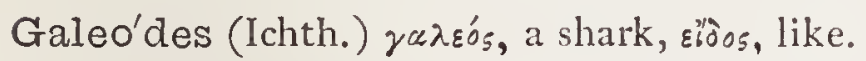

Graleo'des (Ent.) galeos, a thark, $\varepsilon \tilde{b} \delta o s$, like; from the rapacious habits of the infect; a genus of foreign Spiders.

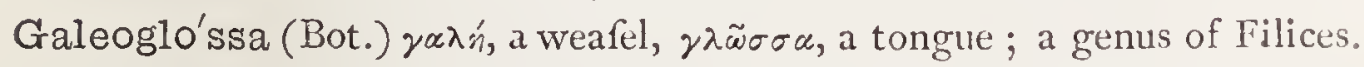
Galeoglo'ssum (Bot.) fame derivation; the Weafel Orchis; a genus of Orchidacex.

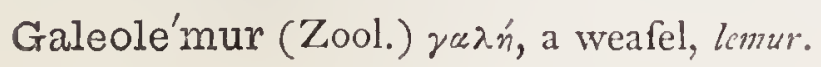


Galeopithe'cidæ ('Zool.) galeopithecus, fam. term. ida.

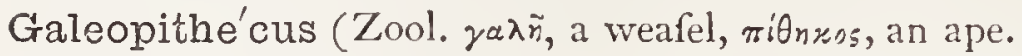

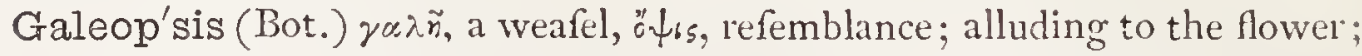
a genus of Labiatæ.

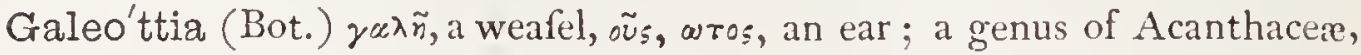
and of Orchidacex.

Ga'lera (Zool.) raגєрó;, cheerful; a genus of Fungi.

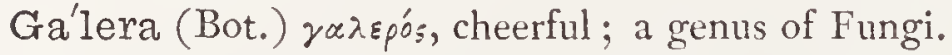

Graleri'tes (Fos. Zool.) galea, a helmet; a genus of folfil Sea-urchins.

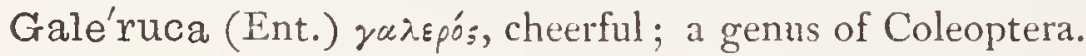

Galeru'cidæ (Ent.) galeruca, fam. term. idle.

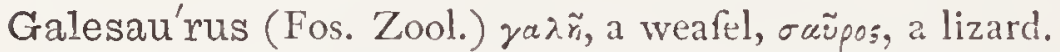

Ga'leus (Ichth.) galeos, an old name for a filh; the Tope.

Ga'lgula (Ent.) galea, a creft, gula, the neck.

Gali'lea (Bot.) P. N. in honour of the immortal Galileo; a genus of

Cyperacex.

Galin'ula (Ornith.) dim. of gallina, a hen.

Galinso'gea (Bot.) P. N. from M. M. Galinfoga, Superintendent of the Madrid gardens; a genus of Compolitre.

Galione'lla (Zool.) Lat. a fmall helmet; a genus of Polygaftric animalcules.

Galipe'a (Bot.) the name in Guiana; a genus of Rutacer.

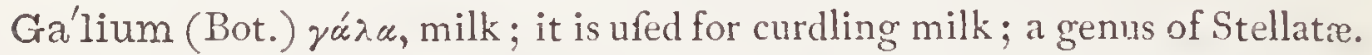
Galle'ria (Ent.) from the habit of the larva of forming galleries in honeycomb; a genus of Lepidoptera.

Gallina'go (Ornith.) Lat. a woodcock.

Ga'llus (Ornith.) Lat. the Cock, the barn-door fowl.

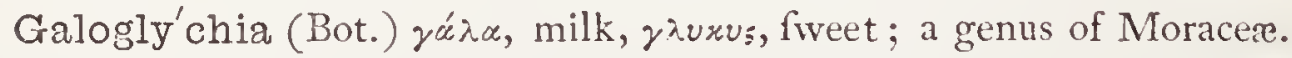

Galphi'mia (Bot.) an abfurd anagram of Malpighia ; a Mexican genus of Malpighiacex.

Galu'mna (Ent.) galumna, a covering; a genus of Arachnida.

Ga'masus (Ent.) a genus of Arachnida.

Gambe'lia (Bot.) a genus of Scrophulariaceæ.

Gambia'nus (Zool.) belonging to Gambia.

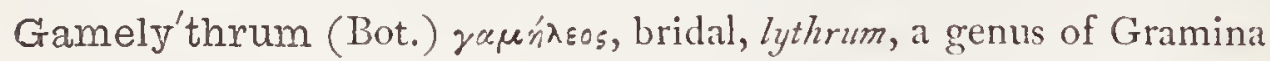

Gam'ma (Ent.) from the Greek letter $\gamma$, marked on the wings.

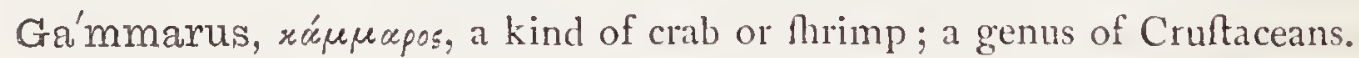

Gamoca'rpha (Bot.) júuos, marriage, rrippos, a dry ftick; a genus of

Cilyceracex. 
Gamo'lepis (Bot.) ráuos, union, $\lambda \varepsilon \pi s s$, a fcale; a genus of Compofitx.

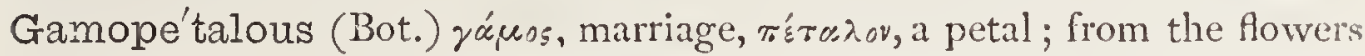
which, inftead of being compofed of one, are compofed of many laminx, united by their edges.

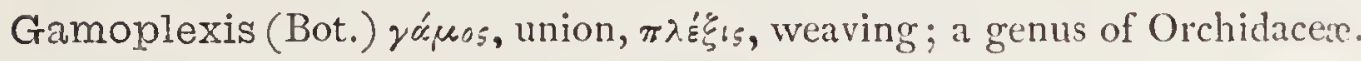

Ga'nder (Ornith.) Anglo-Sax. gandra.

Gandola (Bot.) a genus of Bafellacex.

Gandry'na (Zool.) a genus of Foraminifera.

Gandsu'lium (Bot.) a genus of Zingiberacex.

Gangabe'lla (Ent.) Perfan, gangaba, a porter.

Gani'trus (Bot.) yaváw, to glitter or thine; a genus of 'Tiliacex.

Ganja (Bot.) native Indian name; a genus of 'Tiliacex.

Ga'nnet (Ornith.) Anglo-Sax. ganot.

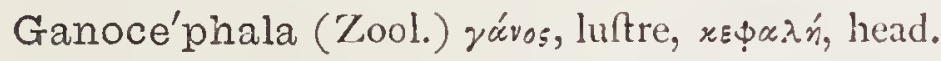

Ga'noid (Ichth.) rávos, fplendour, zídos, appearance.

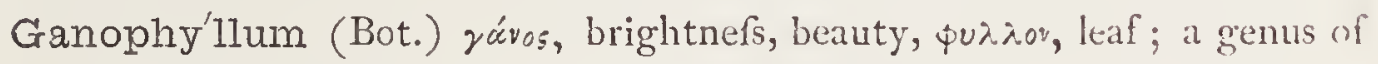
Amyridacex.

Ganyme'des (Bot.) P. N. from the fabled Ganymede; a genus of Amaryl.. lidacex.

Garcia (Bot.) P. N., a genus of Euphorbiacex.

Garcia'na (Bot.) P. N., a genus of Philydracex.

Garcila'ssa (Bot.) P. N., a genus of Compofitx.

Garci'nia (Bot.) P. N. from L. Garcin, M.D., F.R.S., an Oriental traveller. The Mangofteen; a genus of Guttiferx.

Garckea (Bot.) P. N. in honour of __ Garck; a genus of Mufci.

Garde'nia (Bot.) P. N. from A. Garden, M.D., of Charlefton; a genus of Cinchonaceæ.

Gardenio'la (Bot.) refemblance to Garderia ; a genus of Cinchonacex.

Gardne'ria (Bot.) P. N., George Gardner, a botanical traveller in Brazil; a genus of Loganiacer.

Gardo'quia (Bot.) P. N. in honour of Don Diego Gardoqui, who grtatly promoted the publication of the "Flora Peruviana;" a genus of Labiatæ.

Garide'lla (Bot.) P. N. from P. Garidel, M.D., of Provence, a writer on botany ; a genus of Ranunculaceæ.

Ga'rlic (Bot.) Anglo-Sax. garleac.

Garno'tia (Bot.) a genus of Gramina.

Gar'rulus-a-um (Ornith.) Lat. chattering; alfo a genus of Birds, which contains the Jay, Garrulus glandarius. 
Gar'rya (Bot.) the typical genus of Garryacex.

Gartne'ra (Bot.) P. N. in honour of the celebrated naturalift Gärtner; a genus of Malpighiaceæ.

Gar'uga (Bot.) garugo, its 'Telinga name.

Garze'tta (Ornith.) dim. of Italian garza, a heron.

Gasparinia (Bot.) P. N. in honour of M. Gaparin; a genus of Orobranchacex.

Gaste'ria (Bot.) yasring, a belly; referring to the bafe of the flowers; a genus of Liliacex.

Gasteromyce'tes (Bot.) yuornip, belly, uuxńs, a mulhroom; a fection of Fungi.

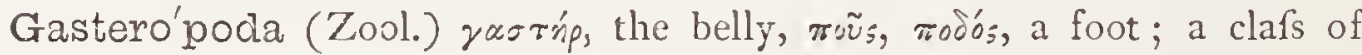
univalve Mollunks.

Gasterostei'dæ (Ichth.) gufterofteus, fam. term. idce; a family of Acantho.. pterygian filhes.

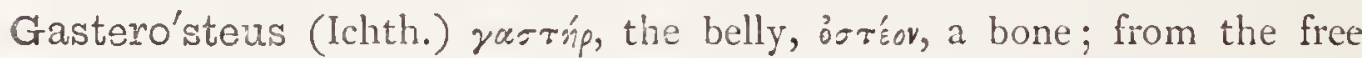
fpines anterior to the dorfal fin.

Gasto'nia (Bot.) P. N. from Gufpon de Bourbon, a fon of Henry IV., and a patron of botany; a genus of Araliaceæ.

Gastor'nis (Fos. Zool.) Gafton, after M. Gafton Plante, the difcoverer, öpvs, a bird.

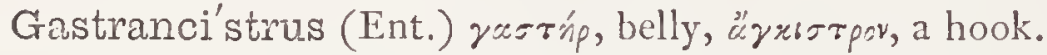

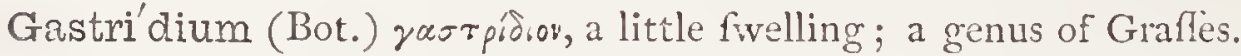

Gastrobra'nchus (Ichth.) yastrip, the Itomach, Bporxos, the windpipe; the Myxine.

Gastroca'rpha (Bot.) yartíp, a belly, xáppn, chaff; form of receptacle; a genus of Compolita.

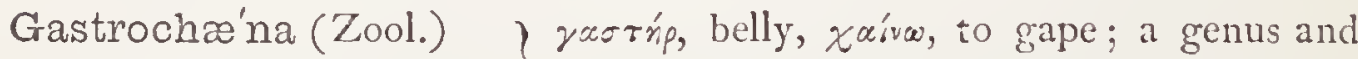
Gastrochæ'nidæ (Zool.) $\}$ family of bivalve Mollusca.

Grastrochæ'ta (Zool.) yarríp, the belly, $\chi^{a r \tau n, ~ a ~ b r i f t l e ; ~ a ~ g e n u s ~ o f ~}$ Polygaftric animalcules.

Gastrochi'lus (Bot.) yaoríp, belly, $\chi$ Einos, lip; the lip of the flowers being ventricofe or inflated.

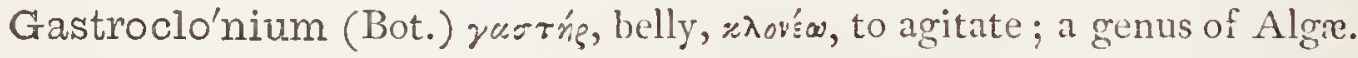
Gastroco'tyle (Bot.) yurrúp, belly, zorúdn, a fmall cup; a genus of Boraginaceæ.

Gastro'dia (Bot.) yartíp, belly, and odoũs, a tooth; from form of column of Hower; a New Holland genus of Orchidacex.

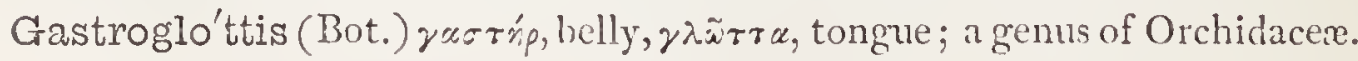


Gastrolo'bium (Bot.) vaorinp, a belly, nofós, pod, referring to its thape; it

New Holland genus of Leguminof $x$.

Gastroly'chnis (Bot.) vasrń, belly, and lychnis; from the inflated calyx; a genus of Caryophy'lacer.

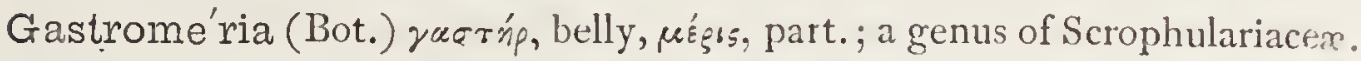

Gastrone'ma (Bot.) yusrńp, a belly, iñus, a thread, from the inflated filaments; a genus of Amaryllidaceæ.

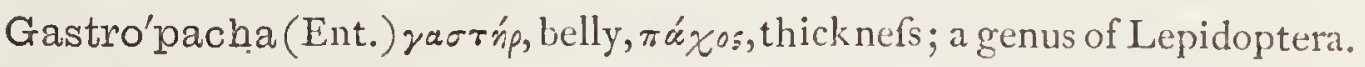

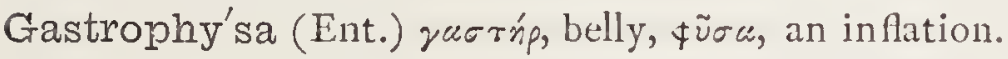

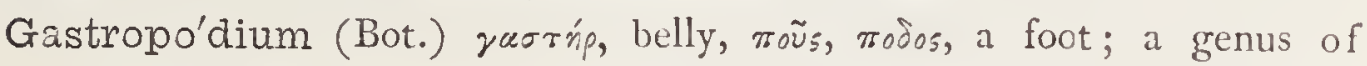
Orchidacex.

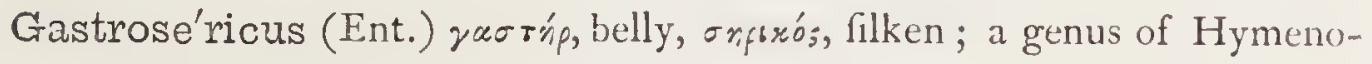
ptera.

Gastro'xidis (Ent.) yusrńp, belly, 'ớs, Tharp; a genus of Diptera.

Gattenho'fia (Bot.) P. N. in honour of M. Gattenhof; a genus of Compofitx.

Gattorugene (Ichth.) xuropúrew, to fink in the earth.

Gatyo'na (Bot.) P.N., a genus of Compofitr.

Gaudicha'udia (Bot.) P. N. in honour of the celebrated Charles Gandichaud, who accompanied Freycinet in his voyage round the world; a Mexican genus of Mialpighiacex.

Gaudi'nia (Bot.) P. N. from M. Gaudin, a Swifs botanift; a genus of Grafles.

Gaulthe'ria (Bot.) P. N. from M. Gaulthier, M.D., a French writer on maple fugar; a genus of Ericacex.

Gau'ra (Bot.) yaũpos, fuperb, referring to the flowers; a genus of Onagracez.

Gauri'dium (Bot.) the genus Gaura, e.jos, refemblance to that plant; a genus of Onagracex.

Gauro'psis (Bot.) the genus Gaura, ö $\psi$ bs, refemblance; a genus of Onagracex.

Gautie'ra (Bot.) P. N. in honour of $M$. Gautier; a genus of Ericacex; alfo a genus of Fungi.

Gavia'is (Zool.) from an Indian word; a genns of Crocodiles. Gavilea (Bot.) P. N. in honour of $M$. Guvile; a genus of Orchidacex. Ga'ya (Bot.) P. N.; a genus of Malracez; alfo a genus of Umbelliferæ. Gaye'lla (Ent.) a genus of Hymenoptera.

Gaylussa'cia (Eot.) P. N. in honour of MI. L. Gay Lufac, the eminet.t French philofopher and chemint; genus of Vacciniacese. 
Gayta'nia (Bot.) P. N. in honour of $M$. Gaytan; a genus of Umbelliferr. Gaza'nia (Bot.) rás" riches, treafure; alluding to the fplendour of the flowers; a handfome Cape genus of Compofitx.

Gaze'lla (Zool.) Italian, gazzella; Fronch, gazelle.

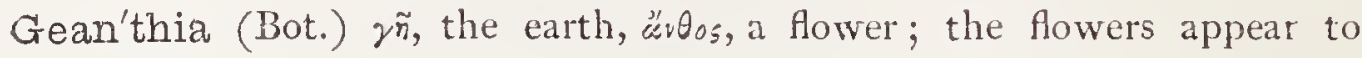
emerge from the earth; a genus of Melanthacex.

Gean'thus (Bot.) fame derivation, and for the fame reafon; a genus of Zingiberacex.

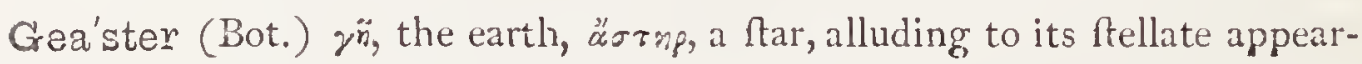
ance; a genus of Fungi.

Gebe'ria (Bot.) etymology doubtful.

Geble'ra (Bot.) P. N. in honour of Gebler, a German botanift; a genus of Euphorbiaceæ.

Geca'rcinus (Zool.) $\gamma^{\tilde{n}}$, the earth, carcinus, a crab; the Land crab.

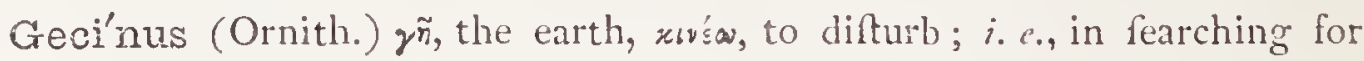
its food.

Ge'cko (Zool.) faid to be derived from the peculiar noife they make. which is like the found by which horfes are urged to greater fpeed.

Grecko'tidæ (Bot.) gecko, fum. term. idts; a family of Thick-tongued Lizards.

Geer'ia (Bot.) P. N. in honour of De Gier; a genus of Ternftröniacese.

Gei'gera (Bot.) P. N. ; a genus of Rutacex.

Geigerria (Bot.) P. N.; a genus of Compofitr.

Geise'nia (Bot.) P. N. ; a genus of Ranunculacex.

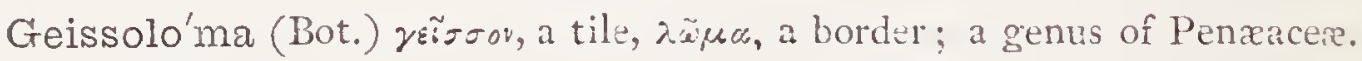

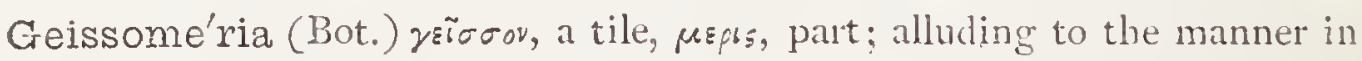
which the lobes of the calyx overlie each other; rery handfome Brazilian genus of Acanthacex.

Geissorhi'za (Bot.) yeĩzov, a tile, $\dot{\rho} \cdot \zeta u$, a root; a handfome Cape genus of Iridacex.

Geissosa'ura (Zool.) yeĩ rov, a tiled roof, ruúfä, a lizard.

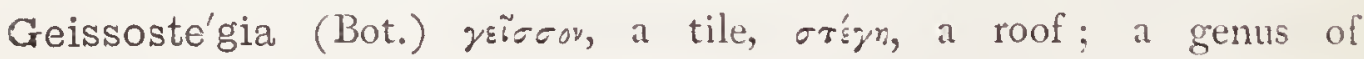
Ericacer.

Geitonople'sium (Bot.) reitav, a neighbour, and $\pi \lambda$ r sos, near, alluding to its frambling habit of growth; a genus of Auftralian Liliacere.

Ge'la (Bot) $\gamma^{\prime} \lambda^{\prime} x^{\prime}$, to Thine, fuppofed to refer to foliage; a genus of Rutacer.

Gela'sine (Bot.) literally "a fmiling dimple" ( $\gamma \pm \lambda c c \sigma m$ ), from its pretty dark-blue flowers; a South American genus of Iridacez. 
Gelatel'la (Ent.) gelatus, frozen; the moth appears in November and December.

Gelatina'ria (Bot.) gelatina, gelatine; a genus of Lichenes; alfo a genus of Algæ.

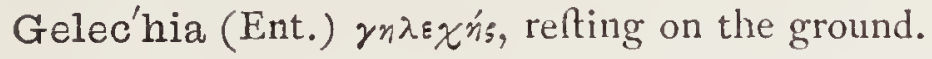

Gelechi'idæ (Ent.) the family of which the genus Gelechia is the type.

Geli'dium (Bot.) gelı, hoar-frolt, ẽıfos, like; a genus of Algæ.

Ge'lidus-a-um (Bot.) Lat. cold, ftiff.

Gelina'ria (Bot.) $\gamma^{\tilde{r}}$, the earth, linum, flax; a genus of Algæ.

Gelo'nium (Bot.) meaning unknown; an uninterefting genus of Euphorm biacex.

Gelse'mium (Bot.) gelfemino, the Italian name of the Jafmine; in American genus of Bignoniacex, called "Carolina Jafmine."

Gemban'ga (Bot.) native name; a genus of Palmie.

Geme'lla (Bot.) gemellus, paired; a genus of Sapindacex.

Gemella'ria (Zool.) gemellus, double; a genus of Polyzoa.

Geminipunc'ta (Ent.) geminus, twin, punctum, a fpot.

Gemma'tus-a-um (Bot., Ent.) Lat. adorned with gems, fparkling.

Gemmi'fera (Bot.) gemma, a gem, fero, to bear.

Gemmuli'na (Zool.) gemmula, a little bud or gem; a genus of Foraminifera. Gena'bea (Bot.) $\gamma^{n}$, the earth, $\ddot{\beta}$ เos, poor; a genus of Fungi.

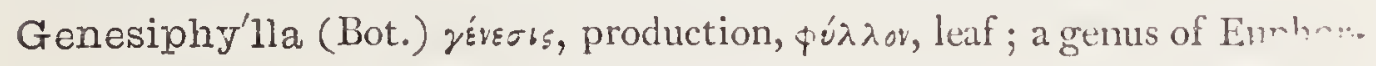
biacex.

Genet'ta (Zool.) French, genette.

Genety'llis (Bot.) a genus of Miyrtacex.

Genicula'ria (Bot.) geniculatus, bent, curved; a genus of Algie.

Geniculel'lus (Ent.) geniculus, a bend, an angle.

Geni'pa (Bot.) genepapo, its name in Guiana; the genip tree; a genus of Cinchonacese.

Genipel'la (Bot.) dim. of Genipa; a genus of Cinchonacex.

Geni'sta (Bot.) Ceitic, gen, a fmall bufh.

Genis'tæ (Ent.) feeds on feveral fpecies of broom (genifta).

Genli'sia (Bot.) P. N. in honour of Madame de Genlis; a Brazilian genus of Lentilulariacex.

Genople'sium (Bot.) y'śo ", race, $\pi \lambda$ n ós, near; a genus of Orchidaceat.

Geno'ria (Bot.) a genus of I,ythracex.

Genosi'ris (Bot.) z'śros, race, and iris; a genus of Iridacex.

Gentia'na (Bot.) its virtues were firft experienced by Gentius, king of

Illyria; the typical genus of Gentianacex. 
Genui'næe (Ent.) Lat. natural, genuine.

Geo'bius (Ent.) yñ, earth, elow, to live.

Geoca'lyx (Bot.) rñ , earth, calyx ; a genus of Marchantiaceæ.

Geochor'da (Bot.) zñ , earth, chorda, a fring; a genus of Scrophulariacex.

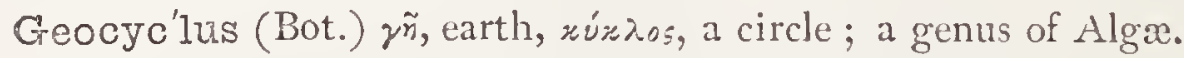

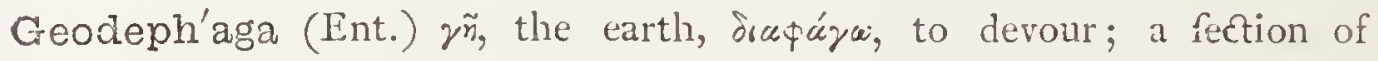
Carabideous infects.

Geo'dia (Zool.) yearfns, earth-like, a genus of marine Sponges.

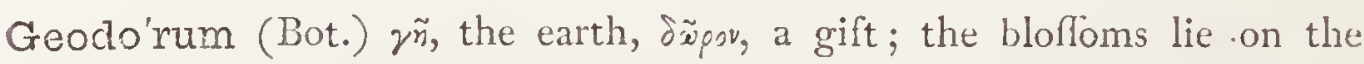
earth; a genus of Orchidacex.

Groemy'da (Zool.) yñ, the earth, cmys, a tortoife.

Geofiro'ya (Bot.) P. N. from E. F. Geoffroy, F.R.S., Profelfor of Botany at Paris; a genus of Leguminofx.

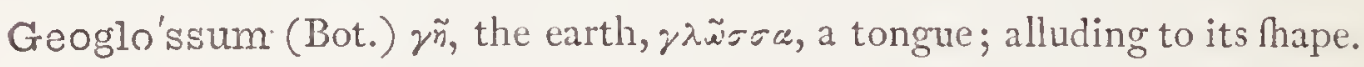

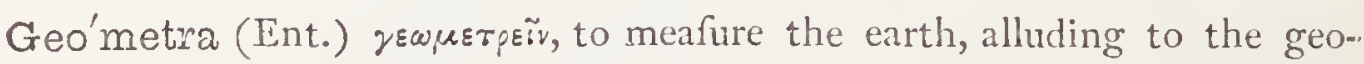
metrical mode of progreffion of the larvæ; a genus of Lepidoptera.

Geometra'lis (Ent.) refembling the genus Geometra.

Geo'noma (Bot.) ysavócus, fkilled in agriculture; alluding to its propaga. tion; a genus of American Palms.

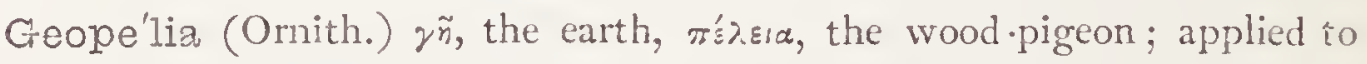
the Ground-doves.

Géophaps (Orinith.) r $\tilde{n}$, the earth, $\phi \dot{q} \psi$, a wild pigeon.

Geo'phila (Bot.) rin, the earth, $\phi_{i} \boldsymbol{x}^{\prime} \omega$, to love; a genus of Cinchonacex.

Geophi'lidx)

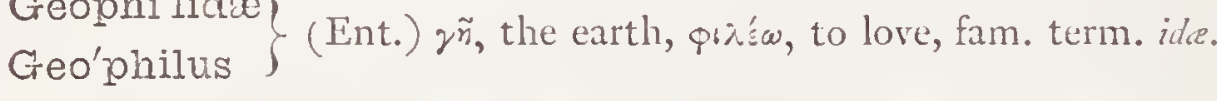

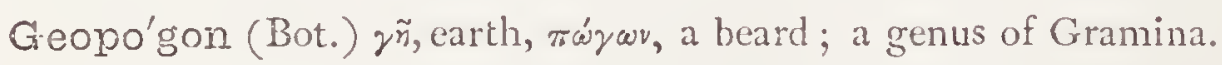

Geopy'xis (Bot.) rñ, earth, pyxis, a box; a genus of Fungi.

Geor'chis (Bot.) qñ earth, orchis; a genus of Orchidacex.

Geo'rgia (Bot.) P. N. ; a genus of Molles.

Georgi'na (Bot.) P. N. from J. G. Georgi, a Rufran botanift. The

Dahlia; natural order Compofitx.

Geory'chus (Zool.) qru, the earth, ópúrow, to dig up.

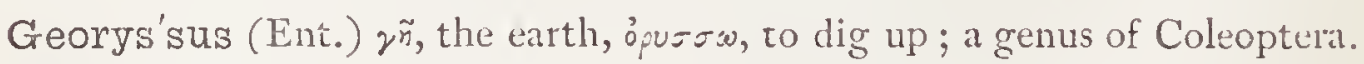

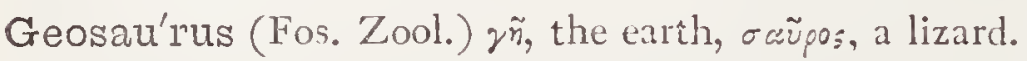

Geospi'za (Ornith.) $2 \tilde{n}$, the earth, $\int p i \approx a$, a finch; the Ground-finch.

Geoteu'this (Fos. Zool.) rin, earth, reutis, a clittle-filh.

Geo'tria (Ichth.) zr̃ , earth, rpéw, to rub.

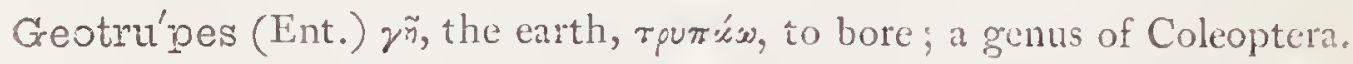
Geotru'pidae (Ent.) grotrupes, fam. term, idep. 
Gerania'ceæ (Bot.) the Crane's bill order of plants, of which Geranium is the type.

Gera'nium (Bot.) r'śpavos, a crane; it has capfules like the head and beak of a crane.

Gera'rda (Zool.) P. N., a genus of Ophidians.

Gera'rdia (Bot.) P. N. in honour of Fohn Gerarde, an old Englifh botanift; a handfome genus of Scrophulariacex.

Gerbe'ria (Bot.) P. N. in honour of T. Gerber, a German naturalift and traveller in Rufia ; a pretty Cape genus of Compofitæ.

Gerbi'llus (Zool.) unexplained.

Gerfa'lcon (Ornith.) Ger. geier, a vulture, falke, a hawk.

Germa'nder (Bot.) a corruption of Chamadrys.

Germara'na (Ent.) P. N. in honour of —-Germar, anthor of "Magazin der Entomologie," and other works.

Gerninga'na (Ent.) P. N. from - Gerning, an entomologift of the laft century, who refided at Frankfort.

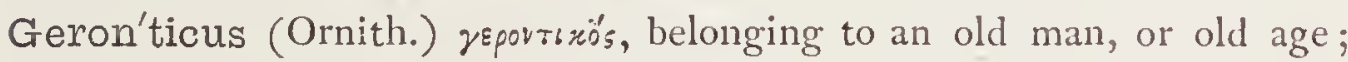
generic name of the Sacred Ibis.

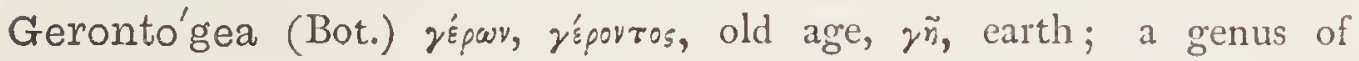
Cinchonaceæ.

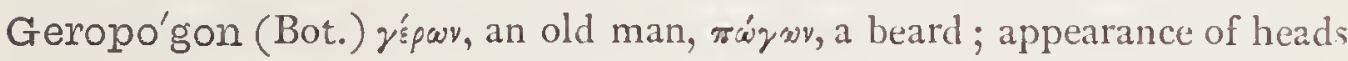
of feed; very pretty Italian genus of Compofitx.

Gerrhosau'ri (Zool.) réppov, a hield, oaũpos, a lizard; the Shield-lizards.

Ger'ris (Ent.) r'şpov, a wicker-work thield; from the wherry. haped body

of the infect; a genus of Hemiptera.

Gerronel'la (Ent.) r'sppov, wicker-work.

Gersi'nia (Bot.) P. N., a genus of Orchidacex,

Geru'ma (Bot.) ympurea, a voice or found; a genus of Vitaceæ.

Gervi'llea (Fos. Zool.) P. N. in honour of M. Gerville, a Frencil naturalist.

Geryónia (Zool.) reparsós, old-looking.

Geryoni'adæ (Zool.) geryonia; a divifion of naked-eyed Medufx.

Geryono'psis (Zool.) geryonia, ö $\psi$ ş, like.

Gesne'ra (Bot.) P. N. in honour of the celebrated Conrad Gefner, of Zurich; typical genus of Gefneracex.

Gesneria'na (Bot.) in compliment to Conrad Gefner; $\therefore . g$. 'Tulipa

Gefneriana.

Gesnouinia (Bot.) P. N., a genus of Urticacer. 
Gethy'llis (Bot.) $y \theta^{\prime} s w$, to rejoice; alluding to the perfume of the flowers;

Cape genus of Amaryllidaceæ.

Gethy'ra (Bot.) $\gamma \theta \dot{\varepsilon} \omega$, to rejoice; a genus of Zingiberaceæ.

Geto'nia (Bot.) meaning unknown; Eaft Indian genus of Combretacex.

Ge'um (Bot.) reviw, to give a relifh; a genus of Rofacex.

Geun'sia (Bot.) a genus of Verbenaceæ.

Ghiesbrech'tia (Bot.) P. N. in honour of $M$. Ghieforecht; a genus of

Orchidacex.

Ghi'nia (Bot.) P. N. from Ghini, an Italian botanift; a genus of Verbenaceæ.

Gibba'ria (Bot.) a genus of Compofitæ.

Gib'bera (Bot.) P. N., a genus of Fungi.

Gibbico'llis (Ent.) gibbus, a hump, collum, the neck; from protuberance on corfelet.

Gib'bium (Ent.) giburs, a hump; a genus of Coleoptera.

Gibbon (Zool.) perhaps from kophin, a Chaldaic word, fignifying an ape.

Gibbosa'lis (Ent.) gibbo/us, hump-backed.

Gibbo'sus-a-um (Zool., Ent.) Lat. hump-backed.

Gib'bous (Ichth., Bot.) gibbus, crooked.

Giese'kia (Bot.) P. N. in honour of Giefeke; a genus of Phytolaccacere.

Gi'fola (Bot.) a genus of Compofitæ.

Giga'ndra (Bot.) gigas, a giant, àrńp, a ftamen; a genus of Ericaceæ.

Gigan'teus-a-um (Bot.) Lat. gigantic.

Gigarti'na (Bot.) r'́raprov, a grape-ftone; a genus of marine Algx.

Giga'rum (Bot.) gigas, a giant and Arum; a genus of Araceæ.

Gi'lia (Bot.) P. N. in honour of Gilio, a Spanifh botanift; a genus of Polemoniacex.

Gille'nia (Bot.) probably the name of fome obfcure botanift; a genus of Rofacex.

Gillie'sia (Bot.) P. N. in honour of Dr. Gillies, of Conception in Chili ; typical genus of Gilliefracex.

Gilliflower (Bot.) Ital. giala, yellow ; or from July, when it is in perfection. Gilpkea (Bot.) P. N., a genus of Myrtacex.

Gilva'lis (Ent.) gilvus, pale-yellow.

Gimberna'tia (Bot.) P. N. in honour of $M$. Gimbernat; a genus of Combretacex.

Ginal'loa (Bot.) P. N., a genus of Loranthaceæ.

Gi'nger (Bot.) 'bryilesprs, Lat. zingiber: Ital. gingiowo; French, gingembre. 'Thefe are thought to be derived primarily from Sanfcrit, çinga-vêra, antler-Phaped. 
Gingi'dium (Bot.) a genus of Umbelliferæ.

Gingi'nsia (Bot.) a genus of Caryophyllacex.

Ginllo (Bot.) its Japanefe name. The Salifburia; a genus of Taxacex.

Gino'ra (Bot.) a genus of Lythracex.

Gira'ffa (Zool.) Ital. giraffi; French, girafe.

Gira'rdia (Bot.) P. N. ; a genus of Algæ.

Girardi'nia (Bot.) P. N. in honour of $M$. Girardin; a genus of Urticaceæ.

Girgenso'hnia (Bot.) P. N. in homour of Girgenfolin; a genus of Chenopodiaceæ.

Girode'lla (Bot.) P. N.; a genus of Diatomacex.

Gironnie'ra (Bot.) P. N. in honour of Gironnier; a genus of Urticacex.

Giro'tia (Bot.) P. N.; a genus of Euphorbiacex.

Gise'kia (Bot.) P. N. in honour of P. D. Gifeke, a Danifh botanift; a genus of Phytolaccacer.

Giso'pteris (Bot.) ysĩ ov, a cornice, $\pi$ répıs, a fern; a genus of Filices.

Githa'go (Bot.) Arabic, git or gith, a large black feed; Corn-cockle.

Glaber, Glabra-um (Bot.) Lat. fmooth, deftitute of down or hair.

Glabra'ria (Ent.) glaber, fmooth, without hair.

Glabra'ria (Bot.) glaber, fmooth, bald; a genus of Lauraceæ.

Glacia'lis (Ornith., Bot.) living in or near ice; e.g., Ranunculus glacialis.

Gladio'lus (Bot.) dim. of gladius, a fword; alluding to the leaves; a

fplendid genus of Iridaceæ.

Glanda'rius (Ornith.) Lat. relating to acorns.

Glan'dula (Zool.) Lat. a little kernel.

Glandula'ria (Bot.) glandula, little kernels; a genus of Verbenacex.

Glandul'ma (Zool.) glandulce, little kernels or acorns; a genus of Foraminifera.

Gla'nis (Ichth.) Lat. a name ufed by Pliny for a crafty fifh.

Glaphy'ra (Ent.) riaфupós, hollow, excavated.

Glaphyra'lis (Ent.) refembling glaphyra.

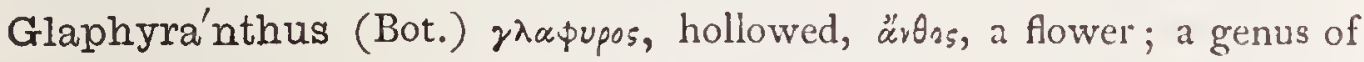

Myrtaceæ.

Glaph'yrea (Bot.) yna фupós, hollowed; a genus of Myrtacex.

Glare'ola (Ornith.) )

Glare'olus (Zool.) $\}$ dim. of glarea, gravel.

Glasta'ria (Bot.) from glafum, the old name for Ifatis tinctoria, Woad, which it refembles in habit; a genus of Cruciferæ.

Glastifo'lius-a-um (Bot.) from the refemblance of the leaves to woad,

Ifatis, the old name of which was Glafum, e.g. Centauria glaftifolia. 
Glastum (Bot.) the word ufed by Pliny for Woad, now called Ifatis tinctoria; a genus of Cruciferæ.

Glau'ca (Ichth.) Lat. blueilh-grey.

Glauci'dium (Bot.) the genus Glaucium, E⿱乛龰dos, refemblance; a genus of Ranunculaceæ.

Glauci'na (Bot.) glaucus, blueilh-grey.

Glaucina'lis (Ent.) glaucus, blueih-grey.

Glau'cis (Ornith.) glaucus, blueilh-grey; a genus of Humming-birds.

Glau'cium (Bot.) ynauxós, blueih-grey, referring to the colour of the plant; a genus of Papaveracex.

Glauco'ma (Zool.) riavros, blue; a genus of Polygaftric animalcules.

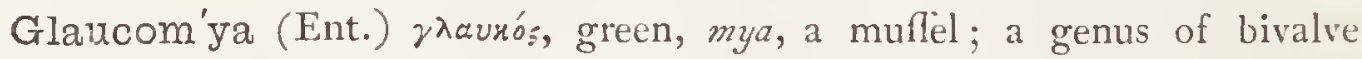
Thells.

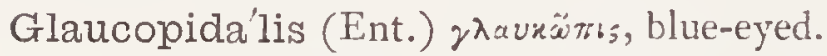

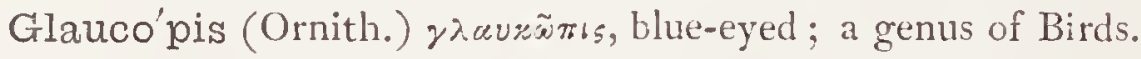

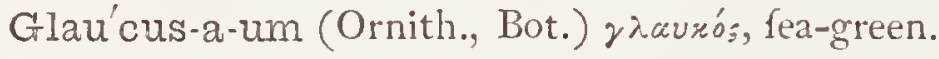

Gla'ux (Bot.) yiauró, blueifh-grey; the colour of the leaves; a maritime genus of Primulacex.

Gleioionis (Bot.) etymology unknown; a genus of Compolita.

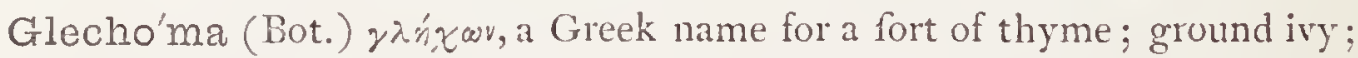
a genus of Labiatæ.

Gle'chon (Bot.) the name applied to Penny-royal, both in Greek and latin; a genus of Labiatre.

Gledi'tschia (Bot.) P. N. in honour of John Gottlieb Gleditfch, a botanift of Leipfig; a genus of Leguminora.

Gleichenel'la (Ent.) P. N. in houour of F. W. won Gleichen, author of various works on Natural Hiftory: died in $I 7 \delta_{3}$.

Gleiche'nia (Bot.) P. N. in honour of the Baron P. an Gleichen, a German botanift; a genus of Ferns.

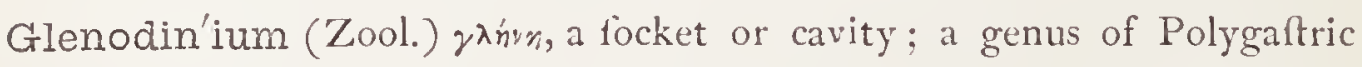
animalcules.

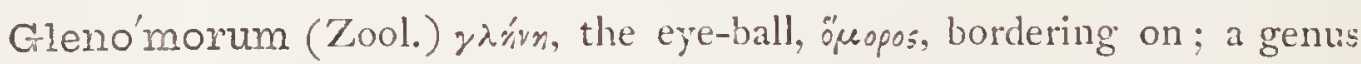
of Infuforia.

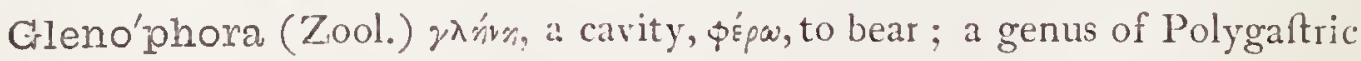
animalcules.

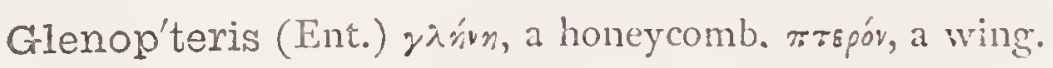

Gleno'spora (Bot.) $\gamma \lambda \dot{r} r n$, a cavity, or focket, fpora: a genus of Fungi.

Ginus (Bot.) y $\lambda \tilde{\text { ros }}$, applied by Theophraftus to a kind of maple; a genus of Caryopliyllacex. 


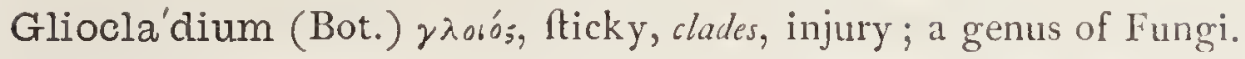

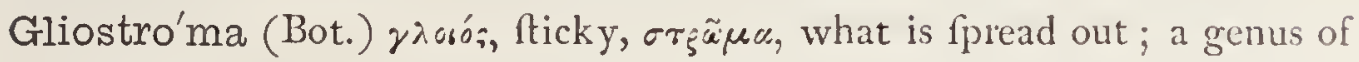
Fungi.

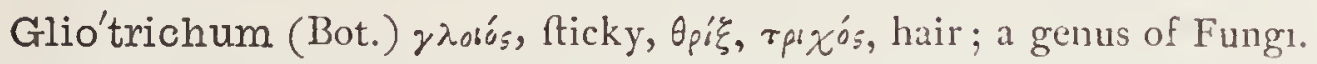

Gli'res (Zool.) plural of glis, a dormoufe; an order of Mammalia.

Glirici'dia (Bot.) a genus of Leguminofæe.

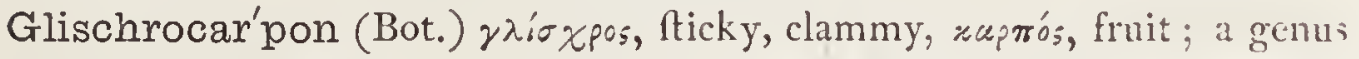
of Halorageacex.

Glissan'the (Bot.) a genus of Zingiberaceæ.

Glob'ba (Bot.) fo named in the Moluccas; a fplendid genus of Scitamineæ.

Globif'erus-a-um (Bot., Ent.) globus, a globe, fero, to carry.

Globigeri'na (Zool.) globus, a fphere, gereve, to carry; a genus of Foffil and recent Foraminifera.

Globula'ria (Bot., Ent.) the flowers are in globofe heads; typical genus of natural order Globulariaceæ.

Globu'lea (Bot.) globulus, a globule; alluding to the ftems.

Globuli'na (Bot.) globus, a ball; a genus of Algx.

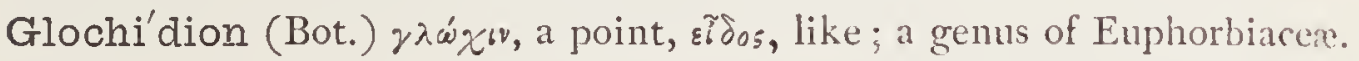
Glochidono'psis (Bot.) the genus Glochidion, ơ $\psi$, , refemblance; a gemus of Euphorbiacex.

Glo'chis (Bot.) $\gamma \lambda \omega_{\chi^{\prime}}^{\prime}$, a projecting point.

Glochisa'ndra (Bot.) $\lambda \omega \chi^{\prime} \varsigma$, a projecting point, úvńp, an anther ; a genus of Euphorbiaceæ.

Glo'citans (Ornith.) Lat. clucking like a hen.

Glœ'a (Ent.) yrobó, fticky; a genus of Lepidoptera.

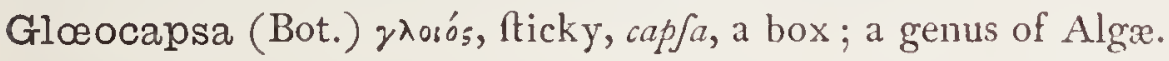

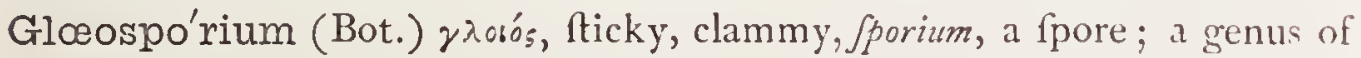
Fungi.

Glœotila (Bot.) y yosós, fticky, wrínov, a feather; a genus of Algx.

Gloiocla'dia (Bot.) fame meaning as Gliocladium, q.. ; a genus of Algx.

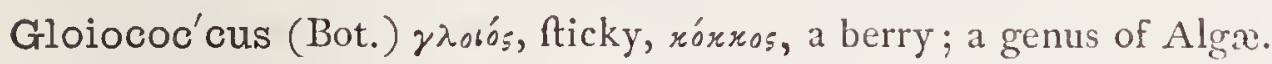

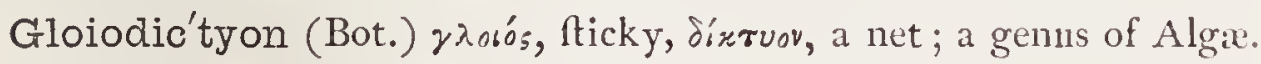

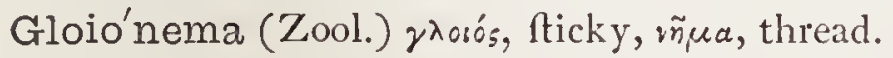

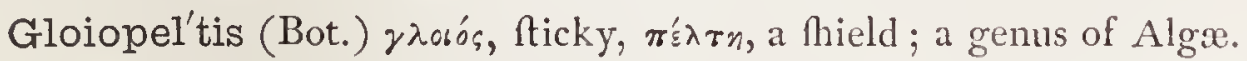

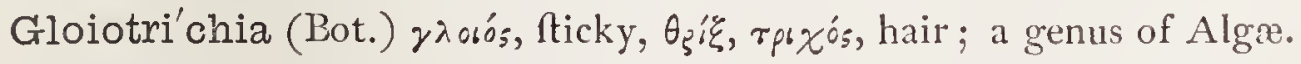

Glo'mera (Bot.) glomero, to form into a ball; a genus of Orchidaceæ.

Glomera'ria (Bot.) glomero, to form into a ball; a genus of Amarantacex. 
Glomera'tus-a-um (Bot.) glomus, a ball, applied to any thing cluftered; e. g. Campanula glomerata.

Glomo'psis (Bot.) glomus, a ball, ö $\psi$ ss, like; a genus of Fungi.

Glo'nium (Bot.) a genus of Fungi.

Glorio'sa (Bot.) gloriofus, magnificent; referring to the fplendour of its flowers; a fplendid Eaft Indian genus of Liliaceæ.

Glossan'thus (Bot.) a genus of Gefneraceæ.

Glossas'pis (Bot.) $\nu \lambda \tilde{\omega} \sigma \sigma \alpha$, a tongue, afpis, a viper; a genus of Orchidaceæ.

Glos'sina (Ent.) $\gamma \lambda \tilde{\omega} \tau \sigma \alpha$, a tongue.

Glossoca'rdia (Bot.) $\gamma \lambda \tilde{\tilde{x}} \sigma \sigma \alpha$, a tongue, rapdic, a heart; a genus of Compolitæ.

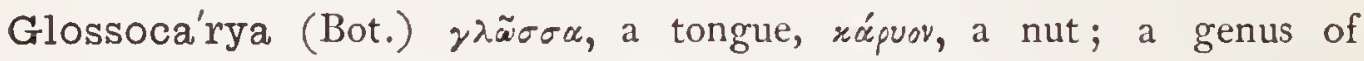
Verbenaceæ.

Glossochi'lus (Bot.) $\gamma \lambda \tilde{\omega} \sigma \sigma \alpha$, a tongue, $\chi \varepsilon \tilde{\imath} \lambda_{\circ}$, lip; a genus of Acanthacex.

Glossoco'mia (Bot.) $\gamma^{\lambda \tilde{\omega} \sigma \sigma \alpha, ~ a ~ t o n g u e, ~ x o ́ \mu n, ~ h a i r ; ~ a ~ g e n u s ~ o f ~ C a m-~}$ panulacex.

Glosso'dia (Bot.) $\gamma \lambda \tilde{\omega} \sigma \sigma \alpha$, a tongue, $\varepsilon_{i \delta} \delta_{s}$, like; referring to the appendage within the flower; a genus of Orchidaceæ.

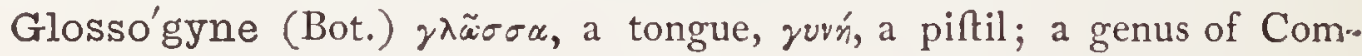
pofita.

Glossone'ma (Bot.) $\nu \lambda \tilde{\omega} \sigma \sigma \alpha$, a tongue, $\llcorner\tilde{n} \mu \kappa$, thread; a genus of Afclepiadacex.

Glossope talum (Bot.) $\nu \lambda \tilde{\omega} \sigma \sigma a$, a tongue, $\pi \dot{\varepsilon} \tau \alpha \lambda \circ \nu$, petal; a genus of Rofacex.

Glossope'tra (Fos. Zool.) $\lambda^{\prime} \tilde{\omega} \sigma \sigma \alpha$, a tongue, $z \dot{\varepsilon} \tau \rho \alpha$, a rock ; the "TongueAtone."

Glosso'phaga (Zool.) $\nu \lambda \tilde{\omega} \sigma \sigma \alpha$, a tongue, фúga, to eat; the Blood-fucker. Glosso'pteris (Fos. Bot.) $\gamma \lambda \tilde{\omega} \sigma \sigma \alpha$, tongue, $\pi \tau$ śpbs, a fern; a genus of Oolitic ferns.

Glossosper'mum (Bot.) $\gamma \lambda \tilde{a} \sigma \sigma a$, a tongue, $\sigma \pi^{\prime} \xi \xi \mu \alpha$, feed; a genus of Byttneriaceæ.

Glossoste'mon (Bot.) $\gamma \lambda \tilde{\omega} \sigma \sigma \alpha$, a tongue, $\sigma \tau \dot{n} \mu \infty^{\nu}$, a thread; a genus of Byttneriacex.

Glossoste'phanus (Bot.) $\gamma \lambda \tilde{\omega} \sigma \tau \alpha$, a tongue, $\sigma \tau \varepsilon ́ \phi \alpha v o s$, a wreath ; a genus of Afclepiadacer.

Glos'sula (Bot.) $y \lambda \tilde{\omega} \sigma \sigma u$, a tongue; alluding to the tongue-like fegments of the labellum.

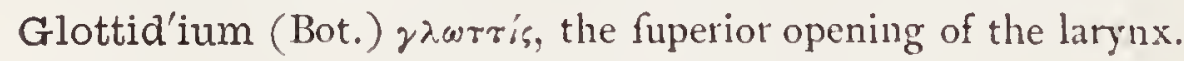


Glot'tis (Ornith.) Lat. a little bird not hitherto identified, mentioned by Pliny.

Glot'tula (Ent.) dim. of $\gamma \lambda \tilde{\omega} \tau \tau n$, a tongue.

Glottu'lidæ (Ent.) family of which the genus Glottula is the type.

Gloxi'nia (Bot.) P. N. in honour of Dr. Benjamin Peter Gloxin, of Colmar, a botanift.

Glu'ma (Bot.) Lat. a buR; the parts of Grafs-flowers are called glumes.

- Gluma'les (Bot.) gluma, the hurk of corn. 'The fection of Endogens which comprifes the Cyperacex and the Grafles.

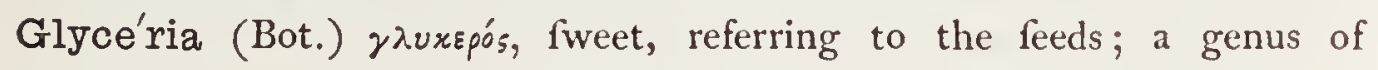
Graftes.

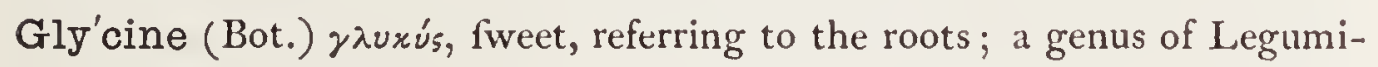
nofx.

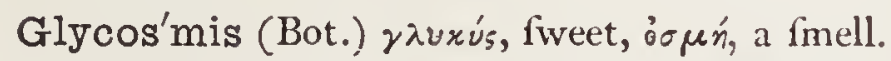

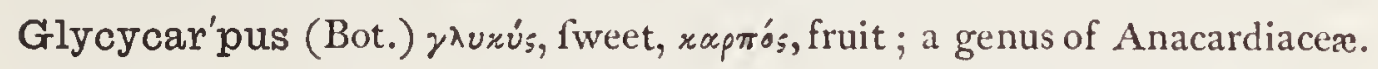

Glycyrrhi'za (Bot.) jzuxús, fweet, $\dot{\rho} b \zeta^{\alpha}$, a root; liquorice; a genus of Leguminofæ.

Glyph'ica (Ent.) $\gamma \lambda u \phi \dot{n}$, carved work; referring to the markings on the wings.

Glyphipteryg'idæ (Ent.) the family of which the genus Glyphipteryx is the type.

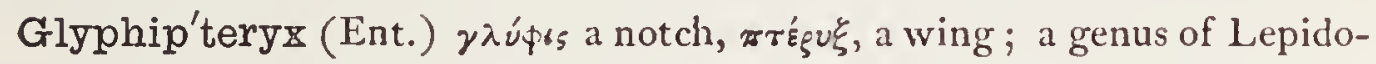
ptera.

Glyphis'ia (Ent.) yiupis, the notch in an arrow; from the pale lunate mark on the wing.

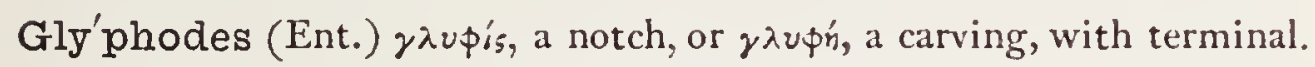

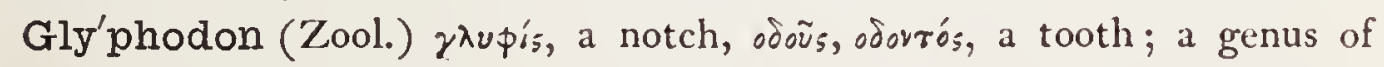
Colubrine ophidians.

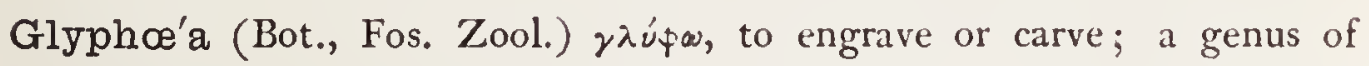
Tiliaceæ.

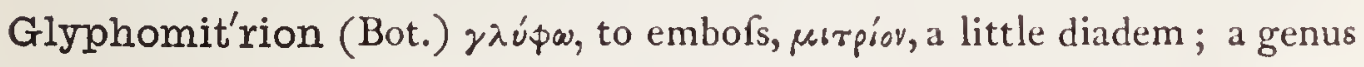
of Cryptogamia.

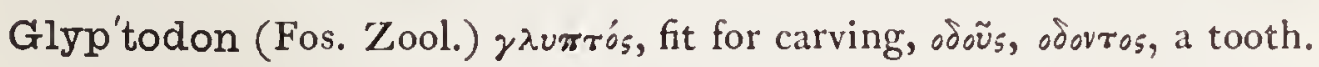

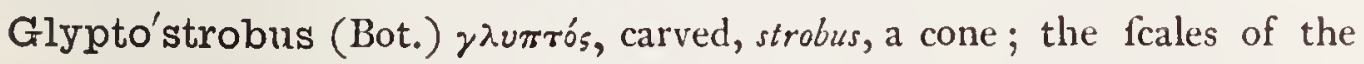
cone being emboffed on the face; a genus of Coniferæ.

Gmeli'na (Bot.) P. N. in honour of George Gmelin, a celebrated German naturalift and traveller.

Gnapha'lii (Ent.) named from Cudweed (Graphalium), but feeds on Golden Rod. 
Gnapha'lium (Bot.) yraфai

a genus of Compofitæ.

Gnaphalo'des (Bot.) the genus Gnaphalium, term. wons; a genus of Compolitx.

Gnaphalo'psis (Bot.) the genus Gnaphalium, ö $b_{5}$, like; a genus of Compolitæ.

Gnat (Ent.) Anglo-Sax. gnaet.

Gnathos'toma (Zool.) zrálos, the jaw, oróra, the mouth.

Gne'tum (Bot.) altered from gnemon, its name in the ifland of Ternate, Eaft Indies; a typical genus of Gnetacex.

Gni'dia (Bot.) the ancient name of the laurel; a genus of Thymelaceæ.

Gnoph'os (Ent.) rvóфos, darkners.

Goat (Zool.) Anglo-Sax. gat.

Gobioidæ (Ichth.) ? gobius, a gudgeon, with family term.; the family of Gobioids (Ichth.) the Gobies.

Go'bis (Ichth.) Lat. a gudgeon, in Greek, zwkìs.

Go bius (Ichth.) Lat. a gudgeon.

Gode'tia (Bot.) P. N., a genus of Cnagraceæ.

Godo'ya (Bot.) P. N. in honour of Godoy, the Prince of the Peace: a genus of Ochnacer.

Gœdartel'1a (Ent.) P. N. in honour of - Gödart, author of " Metamorphofis et Hiftoria Naturalis Infectorum," I 662-67.

Goërius (Ent.) yonpos, mournful, fad; "one of the commonert, and at the fame time largeft, infects of the family, is a black fpecies, rather more than an inch long, commonly called The Devil's Coach-Horfe." WEsTrood.-A genus of Coleoptera.

Goldba'chia (Bot.) P. N. in honour of C. L. Goldbach, of Peterfourg, botanift.

Golu'nda (Zool.) from the native name Gulandi.

Gome'za (Bot.) P. N. in honour of Senor Gomez, a Spanilh apothecary.

Gompha'ndra (Bot.) rópфos, a nail or bolt, àvńp, a ftamen; a genus of Olacacere.

Go'mphia (Bot.) róuфos a club; a genus of Ochnaceæ.

Gomphi'dius (Bot.) rórфos, a nail, sídos, like; a genus of Fungi.

Gomphina'ria (Bot.) róreథos, a nail; a genus of Fungi.

Gomphoca'rpus (Bot.) rópфos, a club, xaprós, fruit; a genus of Afclepiadacex. 
Gompho'cerus (Ent.) róuфos, a nail or wedge, r'spus, horn; a genus of Coleoptera.

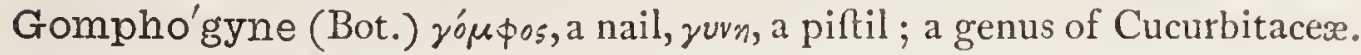

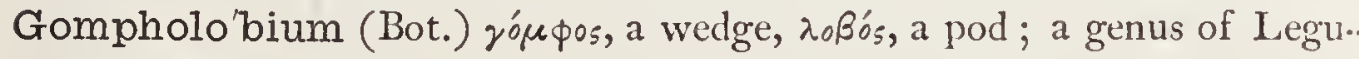
minofx.

Gomphone'ma (Bot.) ró $\phi_{\circ}$, a club, $\sim \tilde{n} \mu \alpha$, a thread; a genus of Algæ.

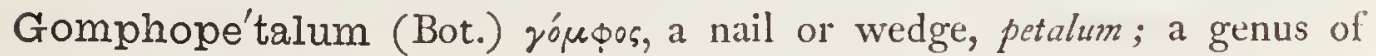
Umbelliferæ.

Gompho'phorus (Bot.) rópфos, a nail, $\phi^{\prime} p \omega$, to bear; a genus of Mufci.

Gompho'sia (Bot.) rópфos, a nail; a genus of Cinchonaceæ.

Gomphostem'ma (Bot.) ró $\mu ф \circ$, ftemma, a ftalk; a genus of Lamiaceæ.

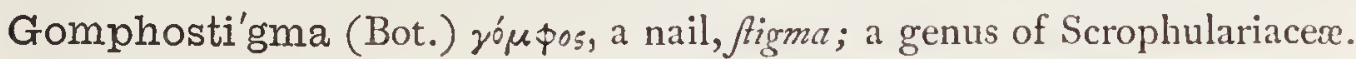

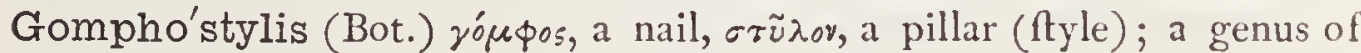
Orchidaceæ.

Gomphre'na (Bot.) rópфos, a club, фpriv, the midriff, referring to the flowers; the Globe-amaranth ; a genus of Amarantacex.

Go'mphus (Bot.) ró $\phi_{\circ}$, a club; alluding to its form.

Gomu'tus (Bot.) from its name in Malabar; a kind of Palm-tree.

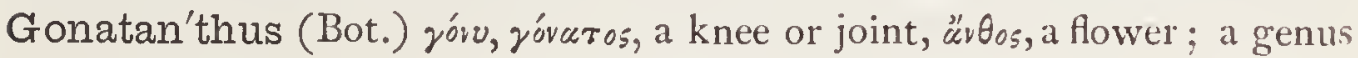
of Araceæ.

Gonatobo'trys (Bot.) yóvu, yóvcros, a joint, Bórpvs, a clufter; a genus of Hyphomycetous Fungi.

Gonatoca'rpus (Bot.) yór, jóvaros, a joint, zupтós, fruit; a genus of Halorageacex.

Gonatorho'dius (Bot.) yórv, yóvaros, a joint, podov, a rofe; a genus of Hyphomycetous Fungi.

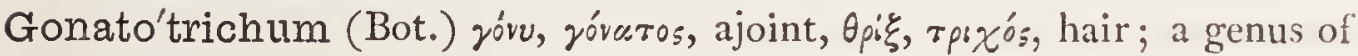
Fungi.

Gongo'ra (Bot.) P. N. in honour of Anton. Caballero y Gongora, a Spaniard and friend of Mutis; a genus of Orchidacere.

Gongro'ceras (Bot.) rórypos, an excrefcence, xépus, a projection; a genus of Algx.

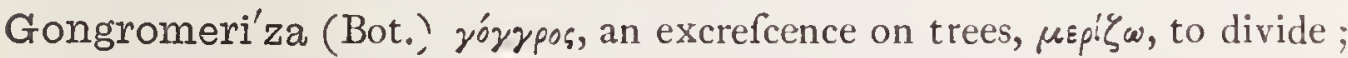
a genus of Fungi.

Gongrónea (Bot.) rórypos, an excrefcence; a genus of Afclepiadacex.

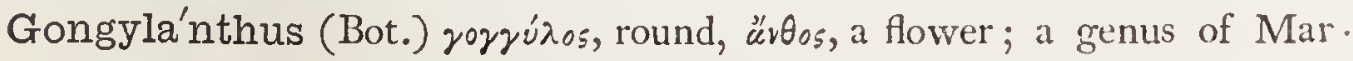
chantiacex.

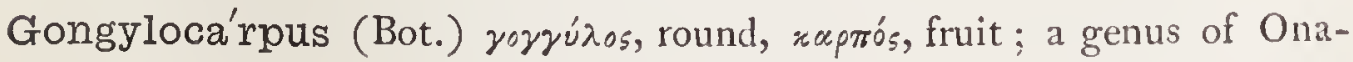
graceæ. 
Gongylocla'dium (Bot.) yorrúdos, round, clades, injury; a genus of Fungi. Gong'ylophis (Zool.) royrúdos, round, ö $\$$, , a ferpent.

Goniap'teryx (Ent.) yaria, an angle, $\pi \tau \varepsilon \varepsilon^{\prime} \xi$, a wing; a genus of Lepidoptera.

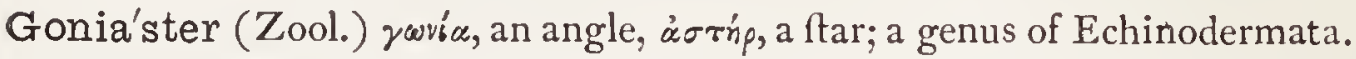

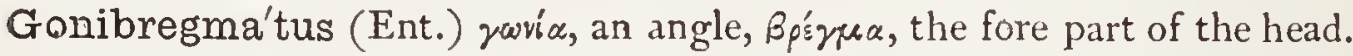
Goni'dium (Zool.) plural gonidia, from govń, the femen; miniature fronds which escape from the parent cell in the Infuforia.

Gonioca'rpus (Bot.) ywía, an angle, raprós, fruit; a genus of Halorageaceæ.

Goniochi'ton (Bot.) ywvi $\alpha$, an angle, $\chi^{\imath} \tau \omega^{\prime} v$, a covering; a genus of Meliaceæ.

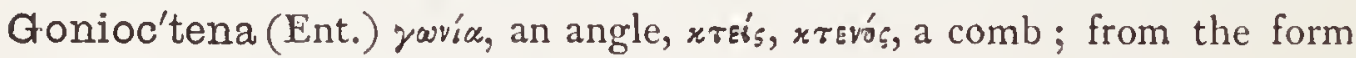
of the pectinated antennx.

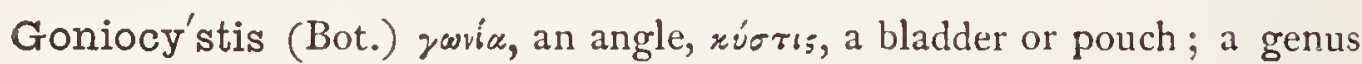
of Algæ.

Goniodo'ma (Ent.) youria, an angle, $\delta \tilde{\omega} \mu \alpha$, a house; referring to the cafe of the larva.

Gonioli'mon (Bot.) reovía, an angle, limon; a genus of Plumbaginaceæ.

Goniomy'cus, plural Goniomy'ci (Bot.) ravía, an angle, $\mu u ́ x$ s, a muthroom; a family of Fungi.

Goniono'tus (Zool.) yavíc, an angle, väros, the back; a genus of Ophi. dians.

Goniophle'bium (Bot.) roovía, an angle, $\Phi . \lambda^{\prime} \xi$ Bov, a little vein; a genus of Filices.

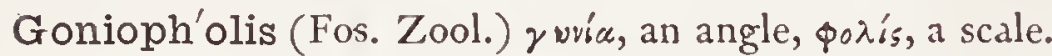

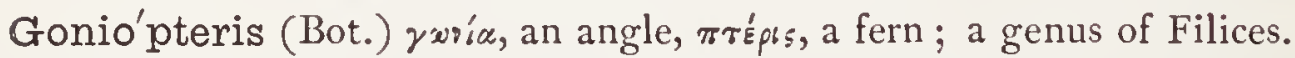

Goniostem'ma (Bot.) ravía, an angle, femma; a genus of Afclepiadacea.

Goniota'ulius (Ent.) yaví, an angle, ơus, ¿̇ंós, an ear or apex.

Goniotha'lamus (Bot.) 'ravía, an angle, thalamus, bed or receptacle; a genus of Anonaceæ.

Goniotri'chium (Bot.) ravíx, an angle, $\theta_{\rho}$ ' $\xi$, hair; a genus of Algæ.

Go'nium (Bot.) ravía, an angle; from the quadrangular form in which the monads are arranged; a genus of Infuforia.

Goniu'rus (Bot.) rwvia, an angle, oũpa, a tail; a genus of Orontiaceæ.

Gonocy'tisus (Bot.) yavía, an angle, cytifus; a genus of Leguminofx.

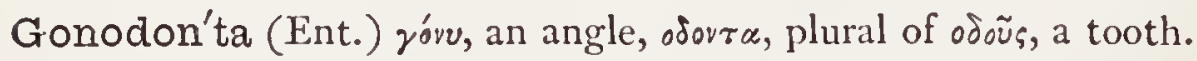

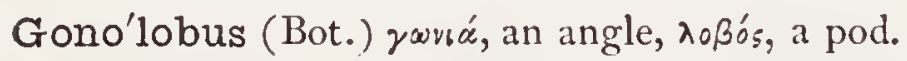

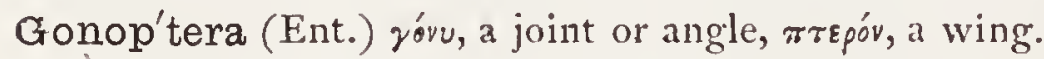

Gonopter'idæ (Ent.) a family of which Gonoptera is the type. 


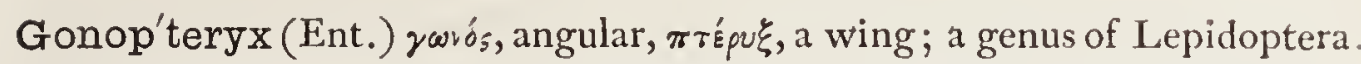
Gonopy'rum (Bot.) ravía, an angle, pyrus; a genus of Polygonaceæ.

Gonosper'mum (Bot.) roovía, an angle, $\sqrt{p}$ crma, feed; a genus of Compofitæ.

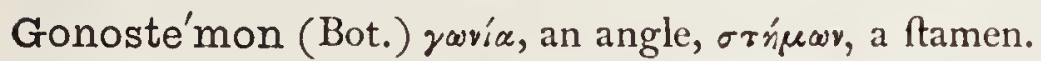

Gonostig'ma (Ent.) yarí, an angle, $\sigma \tau i g \mu \alpha$, a mark ; from the prominent fpot at the anal angle.

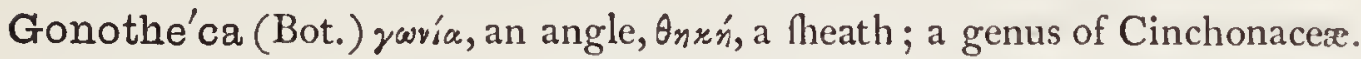
Gonyane'ra (Bot.) raovíx, an angle, ג̇vís, a ftamen; a genus of Cinchonaceæ. Gonyan'thes (Bot.) ravia, an angle, $\alpha^{\prime} \theta_{0}$, flower; a genus of Burmanniacex.

Gonyoso'ma (Zool.) rwria, $\sigma \tilde{\omega} \mu \alpha$, bent-body ; a genus of Colubrine ophidians.

Gonza'lea (Bot.) P. N., a genus of Cinchonacex.

Goode'nia (Bot.) P. N. from Dr Goodenough, bifhop of Carlifle; typical genus of Goodeniacex.

Goodeno'via (Bot.) P. N. in honour of the celebrated Dr. Goodenough, a writer on Carices; the typical genus of Goodenoviacex.

Good'ia (Bot.) P. N. in honour of Peter Good, a collector of plants for Kew gardens; a genus of Leguminof .

Goodsiri (Zool.) P. N. in honour of Mr. Goodfir, an eminent Zoologift.

Goodye'ra (Bot.) P. N. in honour of John Coodyer, a Britilh botanilt; a genus of terreftrial Orchidaceæ.

Goojratten'sis (Zool.) relating to Goojerat.

Goose (Ornith.) Anglo-Sax. gos.

Gooseberry (Bot.) corrupted from gorfe-berry. Some think it a corruption of grofs-berry, the fruit, from its refemblance to fmall unripe figs, (the groff of the ancients,) having been called grofularia by the Latins, whence alfo the French grofeille.

Gordo'nia (Bot.) P. N. in honour of James Gordon, a nurferyman at Mile-End.

Gorgo'nia (Zool.) P. N. Gorgon, a daughter of Phorcys, whofe locks of hair were changed into ferpents by Minerva.

Gorgoni'adæ (Zool.) a family of Zoophytes.

Gorin'kia (Bot.) P.N., a genus of Cruciferæ.

Gorte'ria (Bot.) P. N. in honour of David Gorter, Dutch Profeltor of Botany at Harderwych; a genus of Compolitæ.

Gorty'na (Ent.) Gortyna, a town of Crete.

Gortyn'idæ (Ent.) a family of which genus Gortyna is the type ; a genus of Lepidoptera. 
Gorytes (Ent.) rapurós, a quiver; a genus of Hymenoptera.

Go'sela (Bot.) a genus of Selaginacex.

Gossypia'nthus (Bot.) go/ypium, cotton, ävos, a flower; a geulus of Amarantacer.

Gossyp'iella (Ent.) a fmall moth, very deftructive to the cotton-plant in India.

Gossy'pium (Bot.) Lat. the Cotton-plant.

Gothofre'da (Bot.) P. N., a genus of Afclepiadaceæ, now included in Oxypetalum.

Goua'nia (Bot.) P. N. from Antoine Gouan, Profeffor of Botany at Montpelier.

Goudo'tia (Bot.) P. N. in honour of $M$. Goudot; a genus of Juncaceæ.

Gouffe'ia (Bot.) P. N., a genus of Caryophillaceæ.

Goug'hia (Bot.) P. N. in honour of - Gough; a genus of Euphorbiacex.

Gouldii (Zool.) P. N. in honour of $M r$. Gould, author of a fine work on Humming-birds.

Gou'pia (Bot.) P. N., a genus of Celaftracere.

Goupi'lia (Bot.) P. N., a genus of Fungi.

Gourlie'a (Bot.) P. N. in honour of William Gourlie, a Glafgow botanift; a genus of Leguminofre.

Gove'nia (Bot.) P. N. in honour of James Robert Gorven, Efq.

Grabow'skya (Bot.) P. N. in honour of __ Graborufky, a Polifh botanift;

a genus of Solanacex.

Gracila'ria (Ent.) gracilis, graceful, flender.

Gracilari'idæ (Ent.) gracilaria, fam. term. ida ; a genus of Lepidoptera.

Graci'lia (Ent.) gracilis ; a genus of Coleoptera.

Graci'lipes (Ent.) gracilis, flender, pes, a foot.

Grac'ilis-e (Zool., Ent., Bot.) Lat. flender.

Gracilo'des (Ent.) gracilis, flender.

Gra'culus (Ornith.) Lat. a jay.

Grade'ria (Bot.) P. N., a genus of Scrophulariacex.

Græ'llsia (Bot.) P. N., a genus of Cruciferæ.

Graining (Ichth.) from the Anglo-Sax. The Leuciscus Lancastriensis.

Gra'1læ (Ornith.) Lat. Atilts; an order of Birds with long legs; Wading birds.

Gra'mina (Bot.) plural of gramen, grafs; the Grafs family, often improperly called Graminaces.

Gramini'cola (Ent.) gramen, graminis, grafs, colo, to inhabit. 
Gram'inis (Ent.) gramen, grafs; the larva is found at the roots of grars and the imago flying in grafs fields.

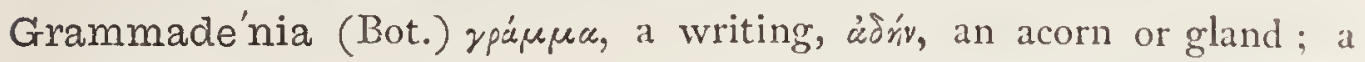
genus of Myrfinacex.

Gramma'lis (Ent.) ура́кене, a writing.

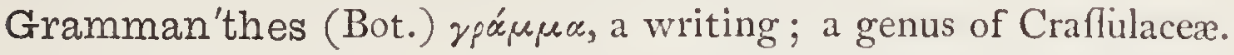

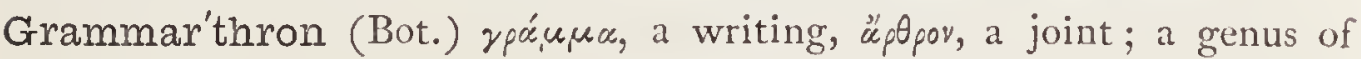
Compofitx.

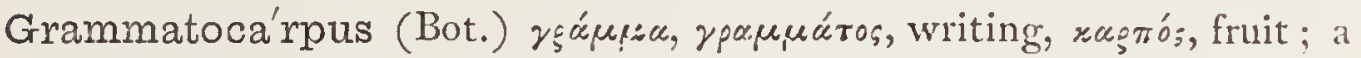
genus of Loafacex.

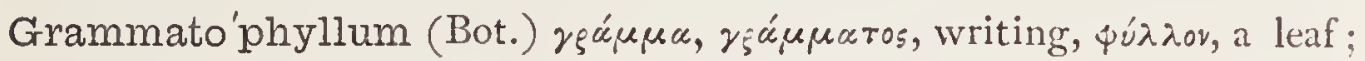
a genus of Orchidacex.

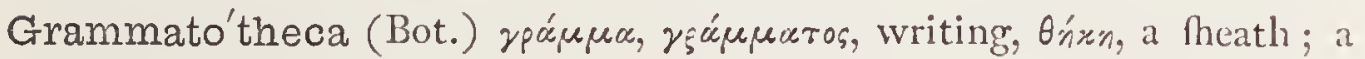
genus of Lobeliacex.

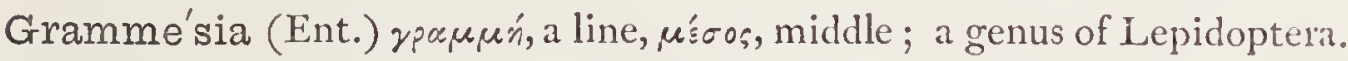

Grammi'stes (Ichth.) a genus of the family Percidx.

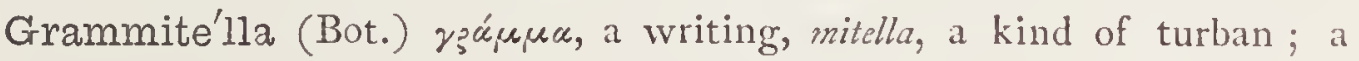
genus of Algæ.

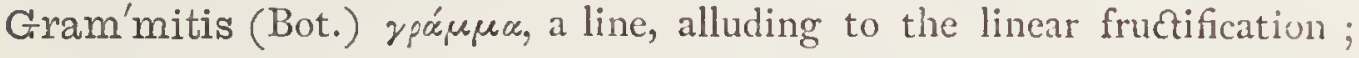
a genus of Ferns.

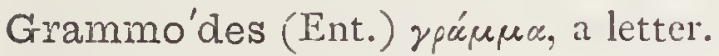

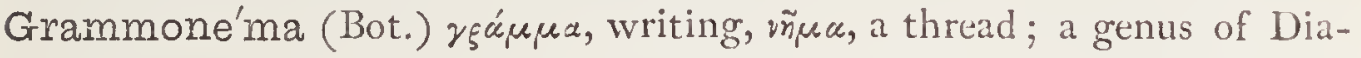
tomacex.

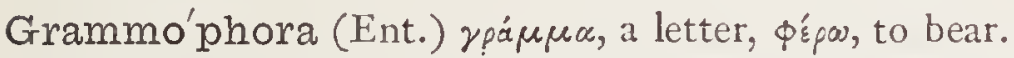

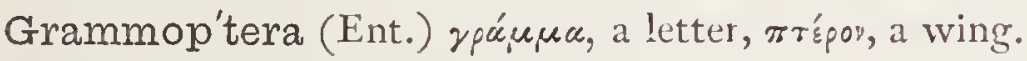

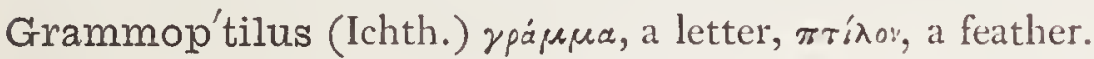

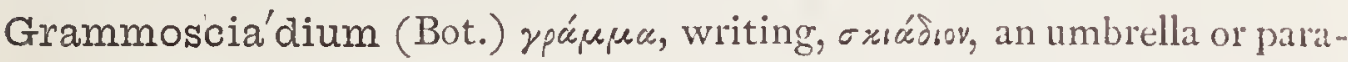
fol, metaphorically, an umbel; a genus of Umbelliferæ.

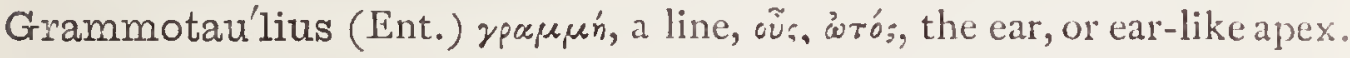

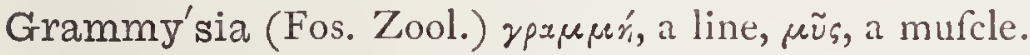

Gra'mpus (Zool.) corrupted from the French grand-poiffoin, great fifh.

Gran'gea (Bot.) Grange, probably a man's name.

Grange'ria (Bot.) P. N. in honour of $N$. Granger, a traveller in Egypt and Judæa.

Gran'ifer (Zool. and Bot.) Lat. that bears grains of Corn.

Graniv'ores (Ornith.) granm, a grain, voro. to devour.

Gran'tia (Bot.) P.N. in honour of - - Grant ; a genus of Piftiacex.

Granula'tus-a-um (Zool., Bot.) Lat covered with or compofed of grains. Grape (Bot.) Itul. grappo 
Graphi'ola (Bot.) dim. of graphium, a ftyle for writing; a genus of Fungi.

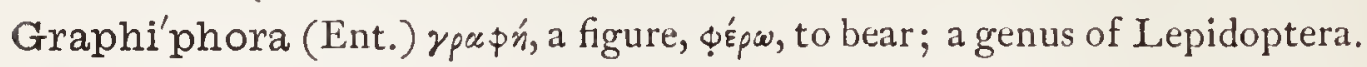
Graphis (Bot.) ypá I,ichenes.

Gra'phium (Bot.) graphium, a writing-nyle or pen, from the form of the apothecium; a genus of Fungi.

Graphiu'rus (Zool.) rpaф́ń, a figure, oũpa, a tail.

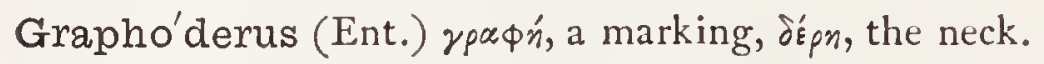

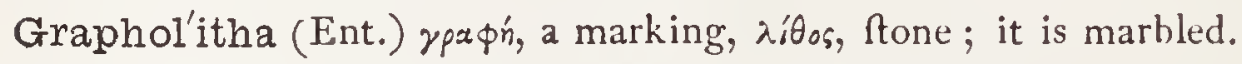

Grapholith'idæ (Ent.) grapholitha, fam. term. ida.

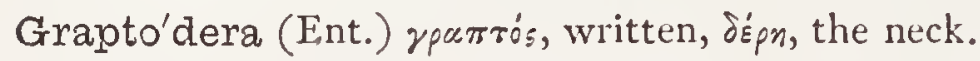

Grap'tolites (Fos. Zool.) yparró;, written, גí,os, a ftone.

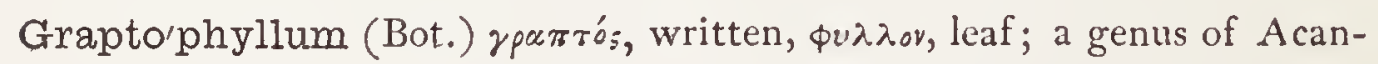
thaceæ.

Grapto'pora (Fos., Zool.) rpertós, infcribed, porus, a duct.

Grass (Bot.) is a very ancient word, and exifts, with light modifications, in all the Teutonic dialects; thus, in Anglo-Saxon, we find graes or gaers; in German gras; in Danilh gräs; in Swedilh and Icelandic gras; even in Greek there is rpá=1s, a word of exactly the fame meaning.

Grasshop'per (Ent.) Anglo-Sax. gaers-hoppa.

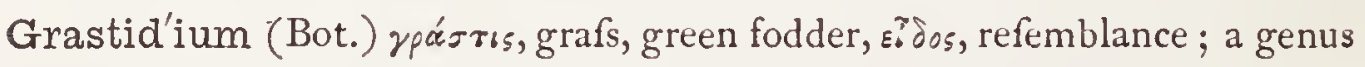
of Orchidaceæ.

Grateloupe'lla (Bot.) P.N. in honour of —_ Grateloup; a genus of Algæ. Grateloupia (Bot.) a genus of Cryptogamia.

Grati'ola (Bot.) gratia, grace of God; ufed as a purge; hedge-hyflop.

Graumüllera (Bot.) P. N. in honour of Graumiller; a genus of Zofteraceæ.

Gravenhor'stia (Bot.) P. N. in honour of Gravenhorf ; a genus of Bruniacex.

Grave'sia (Bot.) P.N. in honour of Mr. Graves; a genus of Melaftomaceæ.

Gra'ya (Bot.) P.N. in honour of __ Gray; a genus of Chenopodiaceæ. Grayia (Zoul.) P. N. in honour of Dr. F. E. Gray, of the Britilh Mufeum. Grayling (Ichth.) popular name of the Thymellus vulgaris.

Greenia (Bot.) P. N in honour of - Green; a genus of Gramina.

Greeno'via (Bot.) P. N. in honour of _-Greenhough; a genus of Craflulacex.

Greenwa'ya (Bot.) P. N. in honour of _- Greenzuay; a genus of Zingiberacex. 
Gregari'na (Zool.) grego, to collect or aflemble; a genus of Protozoa.

Gregari'nidæ (Zool.) a group of the Protozoa.

Gre'ggia (Bot.) P. N. in honour of - Gregg; a genus of Myrtacea.

Gre'ggia (Bot.) P.N. in honour of $M$. Gregg, an American batanift: a genus of Cruciferæ.

Grego'ria (Zool.) P. N. in honour of Walter Gregor, of Banff; a genus of Actiniz.

Gregso'ni (Ent.) P. N. in honour of Mr. C. S. Gregfon, of Liverpcal, who firt bred this fpecies.

Grenie'ra (Bot.) P.N. in honour of $M$. Grenier; a genus of Caryophyllacex.

Grevilla'na (Ent.) in honour of Dr. Groville, who captured the fpecies in Sutherlandfhire.

Grevi'llea (Bot.) P. N. in honour of C. F. Greville, a patron of natural fcience; a genus of Proteacer.

Gre'wia (Bot.) P. N. in honour of Nehemiah Grewe, M.D., F.R.S., a phyfiological botanift of the I 7 th century.

Greyhound (Zool.) Anglo-Sax. grighund.

Gri'as (Bot.) rpów, to eat; referring to the fruit.

Grie'lum (Bot.) rparos, old; alluding to its afpect.

Griesba'chia (Bot.) P. N. in honour of _- Griefbach; a genus of Ericacere.

Grieseli'nia (Bot.) a genus of Leguminofx.

Griffínia (Bot.) P. N. in honour of William Griffin, Efq., of South Lambeth. Griffithia (Bot.) P. N. in honour of __ Griffith; a genus of Mufci.

Griffthi'des (Fos., Zool.) P. N honour of Sir. R. Griffiths, the original expounder of the Carboniferous flates.

Griffith'sia (Bot.) P. N. in compliment to Mrs. Griffiths, of Devonfhire; a genus of marine Algx.

Grima'ldia (Bot.) P. N. in honour of - Grimald; a genus of Marchantiacex.

Grim'mia (Bot.) P. N. in honour of F. F. Grimm, a German botanif ; a genus of Mufci.

Grinde'lia (Bot.) P. N. in honour of Grindel, a German botanift.

Grischo'wia (Bot.) P.N. in honour of Griscov; a genus of Melantomaces.

Grisea'lis (Ent.) grifeus, grey.

Griseive'nter (Zool.) Lat. grey-bellied.

Griseus-a-um (Ornith.) Lat. grey.

Gris'lea (Bot.) P. N. in honour of G. Gijley: a Portuguefe furgeon and author. 
Gri'sola (Ornith.) grifeus, grey.

Gro'bya (Bot.) P.N. in honour of - Groby; a genus of Orchidacex.

Grom'well (Bot.) from the Celtic graun, a feed, mil, a ftone; thus fynonymous with the Latin generic name Lithofpermum.

Gro'na (Bot.) rpüros, eaten out, deep; a genus of Leguminofr.

Gro'nops (Ent.) ypórn, a cavern, ö $\downarrow \varsigma$, appearance ; a genus of Coleoptera.

Grono'via (Bot.) P.N. in honour of F. F. Gronovius, a botanift of Leyden.

Grossa'na (Ent.) groflus, thick, broad-built.

Grossula'ria (Bot.) fpecific name of the Hairy goofeberry, which is taken

from grossus, an unripe fig.

Grou'tia (Bot.) P. N., a genus of Olacacex.

Grub (Zool.) Anglo-Sax. graban, to dig up or burrow.

Gru'bbia (Bot.) P. N., a genus of Bruniacex.

Gru'idæ (Ornith.) grus, a crane, fam. term. ide.

Grumi'lia (Bot.) P.N., a genus of Cinchonaceæ.

Grus (Ornith.) Lat. a crane.

Gruve'lia (Bot.) P.N. in honour of $M$. Gruvel; a genus of Boraginacex. Gry'liidæ (Ent.) grylluss, fam. term. ida.

Gryllotal'pa (Ent.) gryllus, a cricket, talpa, a mole; the Mole-cricket.

Gry'llus (Ent.) Lat. a cricket.

Gryma'nia (Bot.) P.N, a genus of Chryfobalanacex.

Gryphæ'a (Fos. Zool.) y qupós, engraved.

Grypha'lis (Ent.) rpupós, engraved.

Gry'phus (Ornith.) the Greek name of the Griffin, from yquios, becaufe

of the hooked beak ; fpec. name of the Condor.

Grypi'dius (Ent.) rputió, curved; a genus of Coleoptera.

Gua'dua (Bot.) a genus of Gramina.

Guaia'cara (Bot.) guaiac, a native name; a genus of Ebenacex.

Guai'acum (Bot.) guaiac, its name in Guiana; Lignum Vitx.

Gua'ira (Bot.) a genus of Myrtacex.

Gualthe'ria (Bot.) P. N. in honour of M. Gualthier, M.D., a French

writer; a genus of Ericacer.

Guanaba'nus (Bot.) a genus of Anonacex.

Guana'co (Zool.) native name of the Llama.

Guandi'ola (Bot.) a genus of Compofita.

Guandi'ra (Zool.) native name.

Gua nia (Bot.) P.N., a genus of Orchidacex.

Gua'pea (Bot.) a genus of Sapotacea.

Guapu'rium (Bot.) a genus of Myrtacea. 
Guardi'ola (Bot.) a genus of Compolitæ.

Gua'rea (Bot.) Guara, its name in Cuba.

Guariru'ma (Bot.) a genus of Compolitæ.

Guatte'ria (Bot.) P. N. from F. B. Guatteri, Profeffor of Botany at Parma.

Gua'va (Bot.) from the American guayba.

Guazu'ma (Bot.) its name in Mexico; the Baftard cedar; a genus of Byttneriacex.

Gud'geon (Ichth.) French, goujon.

Guebi'na (Bot.) P.N. in honour of — Guebin; a genus of Orchidaces.

Guepa'rda (Zool.) native name.

Guepi'nia (Bot.) a genus of Fungi.

Guere'za (Zool.) the Abyffinian name of an ape, Cólobus Gueréza.

Guernsey Lily (Bot.) a hip from Japan, conveying plants of Amaryllis Sarnienfis, was wrecked on the coaft of Guernfey, where they grew and flourihed.

Guesmélia (Bot.) P.N. in honour of M. Guesmel; a genus of Bromeliaceæ.

Guetta'rda (Bot.) P. N. from Etienne Guettard, a French botanift.

Guevi'nia (Bot.) P. N.; a genus of Proteacex.

Guicheno'tia (Bot.) P. N.; a genus of Byttneriacex.

Guido'nia (Bot.) P. N. ; a genus of Samydacex.

Gui'era (Bot.) a genus of Combretaceæ.

Guilandi'na (Bot.) P. N. from M. Guilandin, a Prufian traveller in Africa; a genus of tropical Leguminofx.

Guildi'ngia (Bot.) P.N. in honour of the Rev. L. Guilding; a genus of Melaftomacex.

Guilie'lma (Bot.) P. N., a genus of Palmæ.

Guillemi'nia (Bot.) P.N. in honour of M. Guillemin; a genus of Amarantacex.

Guillemot (Ornith.) Wel/h, crvilarvg, whirling about; a genus of Sea-gulls. Guilli'mia (Bot.) P.N., a genus of Magnoliacex.

Guindi'lia (Bot.) a genus of Xanthoxylaceæ.

Guio'a (Bot.) a genus of Sapindaceæ.

Guiraoa (Bot.) P.N. in honour of Guiras; a genus of Cruciferie.

Guizo'tia (Bot.) P.N. in honour of M. Guizot; a genus of Compofitie. Guldenstœ'dtia (Bot.) P. N. from J. A. Guldenffedt, a naturalift.

Gull (Ornith.) gula, gluttony; from its voracity.

Gulo (Zool.) gula, the throat; applied to the Wolverene. 
Gumi'1lea (Bot.) a genus of Cunoniacer.

Gumi'ra (Bot.) a genus of Verbenacex.

Gundelshei'mera (Bot.) P. N. from Andrew Gundelfcheimer, a Germar botanift, its difcoverer; a genus of Compolitæ.

Gunne'ra (Bot.) P. N. from E. Gunner, bihop of Drontheim, a botanilt. Gunthe'ria (Bot.) P.N., a genus of Ricciacer.

Gupia (Bot.) fame as Goupia, q.v.

Gusso'nia (Bot.) P. N.; a genus of Euphorbiacer.

Gusta'via (Bot.) P. N. from Guffurus III., king of Sweden, patron of Linnæus.

Gutierrézia (Bot.) P.N., a genus of Compofitz.

Gutzla'fia (Bot.) P. N. in honour of Charles Gutflaff, the eminent Chinefe miffionary; a genus of Acanthacex.

Guzma'nnia (Bot.) P. N. from A. Guzman, collector of natural hiftory. Gyas (Bot.) P.N., one of the giants; a genus of Orchidacex.

Gymnaca'nthus (Bot.) yurús, naked, acanthus; a genus of Acanthacex.

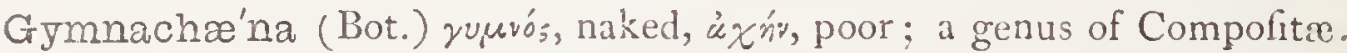
Gymnade'nia (Bot.) zuuvós, naked, áď́v, a gland; a genus of terreftrial

Orchidaceæ.

Gymnae'tron (Ent.) quurós, naked, rispov, the belly.

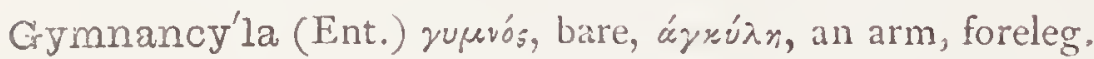

Gymna'ndra (Bot.) zuprós, naked, ảvñp, a ftamen; a genus of Selaginacex.

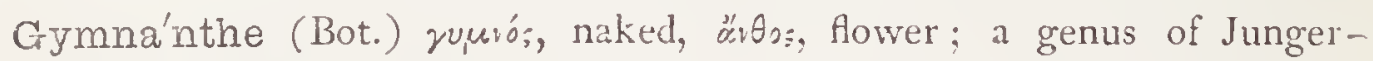
manniacex.

Gymnan'themum (Bot.) yuu:ós, naked, anthemis, chamomile; a genus of Compolitie.

Gymna'nthera (Bot.) rusuós, naked, anther; a genus of Afclepiadacex. Gymna'nthes (Bot.) zusuós, naked, üv日os, flower: a genus of Euphorbiacex. Gymnarrhe'na (Bot.) ruurós, naked, üpprnv, a male, (ftamen), a genus of Compofitx.

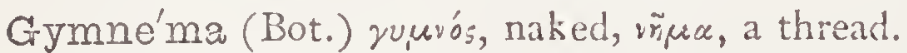

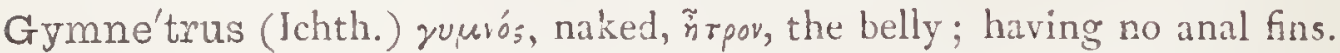

Gymnoba'lanus (Bot.) rupiós, naked, balamus, an acorn or gland; a genus of Lauraces.

Gymnoca'rpus (Bot.) quмvós, naked, xapтó;, fruit; a genus of Illecebraceæ.

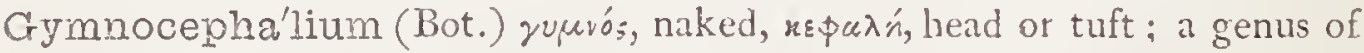
Artocarpacer.

Gymnoce'phalus (Bot.) ruurós, naked, жвфкxй, head; a genus of Murci.

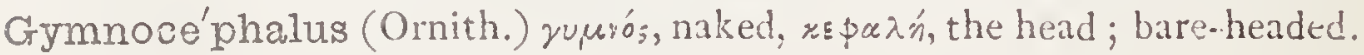




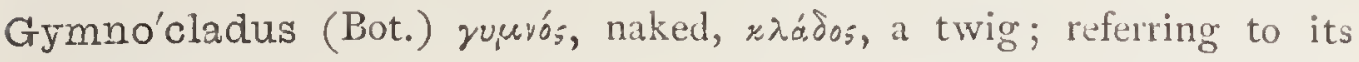
appearance.

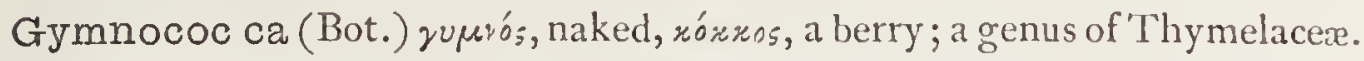

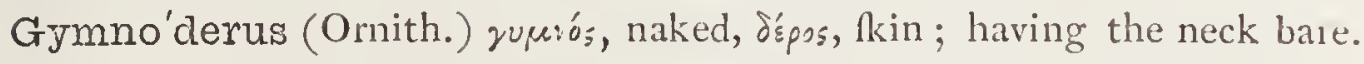
Gymnodi'scus (Bot.) zureró, naked, difcus; a genus of Compofita.

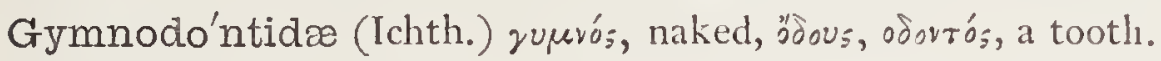

Gym'nogens (Bot.) zuprós, naked, zqviáa, to bring forth plants the feeds of which have no capfules.

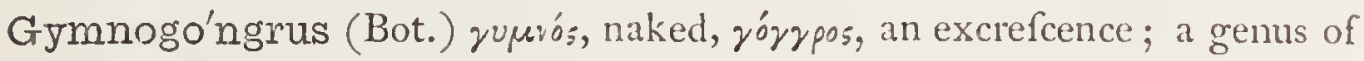
Algæ.

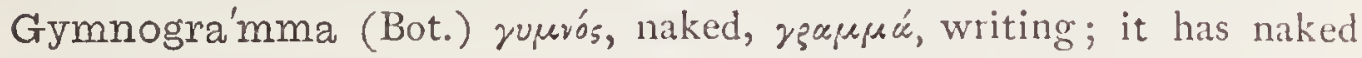
fori ; a genus of Filices.

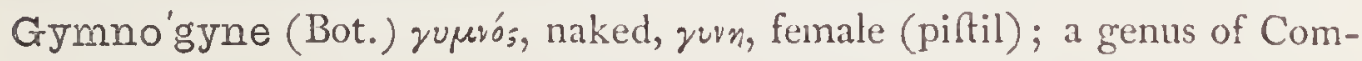
politx.

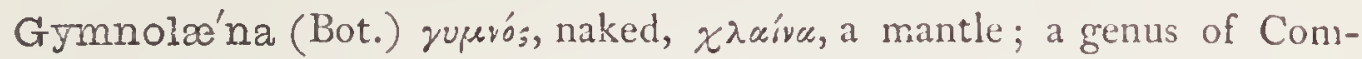
pofitx.

Gymnolo'ma (Bot.) zusuós, naked, $\lambda \tilde{\omega} \mu \mu$, fringe; a genus of Compofitx.

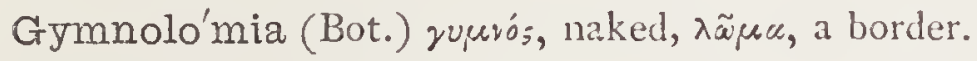

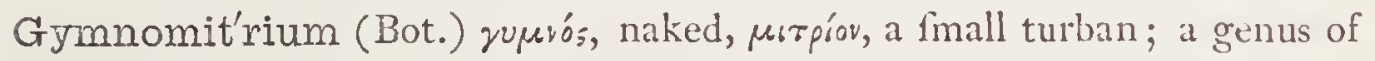
Jungermanniacex.

Gymnomuræ'na (Ichth.) quievó, bare, murena, an eel.

Gymnopare'ius (Ichth.) qusı́ó, naked, mapsiú, the cheek; naked-faced.

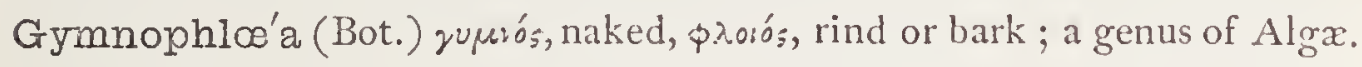

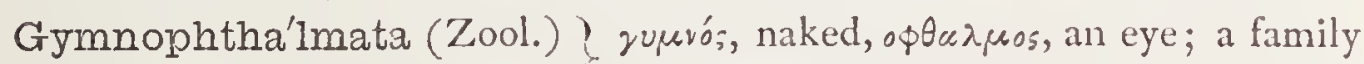
Gymnophtha'lmidæ (Zool.) $)^{5}$ of Lizards.

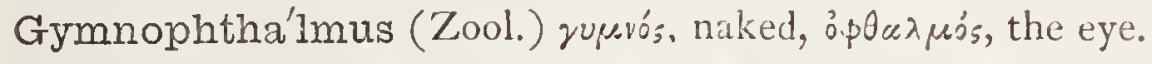

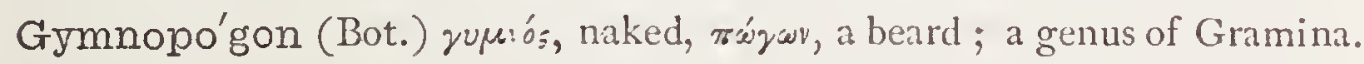

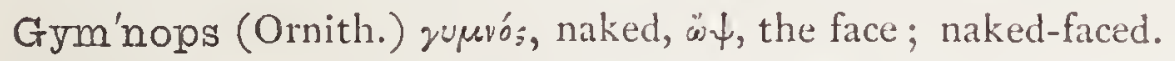

Gymnópsis (Bot.) zupurós, naked, ว̋łs, look; a genus of Afteraceæ.

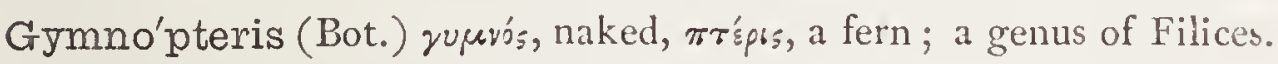
Gymnorhi'na (Ornith.) zuperós, naked, por, the noitril.

Gymnoscho'nus (Bot.) yurvós, naked, $\sigma$ xoorvos, a rulh; a genus of Cyperaceæ.

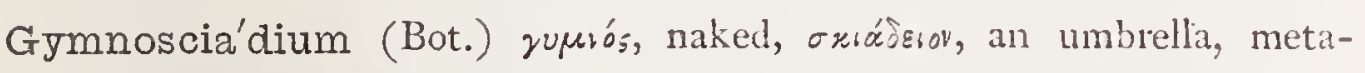
phorically an umbel; a genus of Umbellifera.

Gymnoscy'phus (Bot.) yupuós, naked, fcyphus, a goblet; a genus of Marchantiacex.

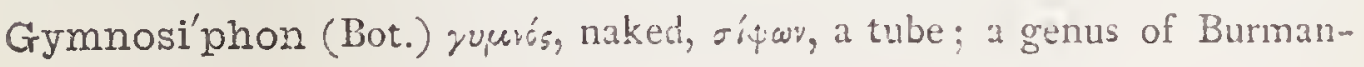
niacer. 
Gymnospe'rma (Bot.) ruprós, naked, $\sigma \pi \varepsilon$ p $\mu \alpha$, feed; a genus of Compolita. Gymnosphæ'ra (Bot.) zurvós, naked, $\sigma \phi \alpha i p \alpha$, a globe; a genus of Filices. Gymnospora'ngium (Bot.) yuuvós, naked, Sporangium; a genus of Fungi. Gymnospo'rium (Bot.) quréos, naked, Spora; a genus of Fungi. Gymnosta'chys (Bot.) ruprós, naked, бraxús, a fpike.

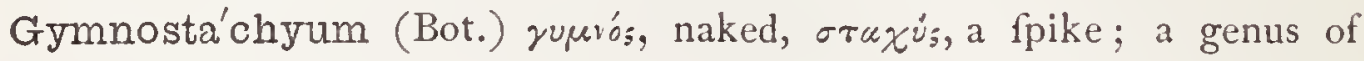
Acanthacex.

Gymno'stomum (Bot.) qurúós, naked, orórc, a mouth; a genus of Mufci. Gymnosty'les (Bot.) rupró, naked, fylum; a genus of Compofitæ.

Gymnothe'ca (Bot.) rupró;, naked, $\theta$ n'xn, a theath; a genus of Loafacea ; alfo a genus of Saururacea.

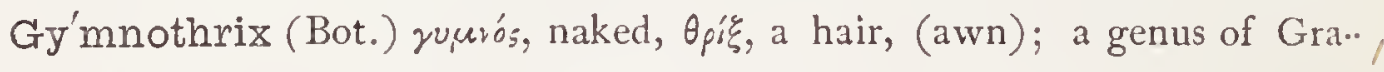
mina.

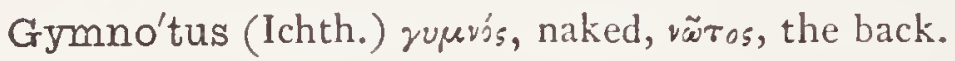

Gymnu'ra (Zool.) quevós, naked, oupá, a tail; a fort of threw found in Sumatra.

Gymnu'sa (Ent.) ruprós, naked; a genus of Coleoptera.

Gynandro'psis (Bot.) rúrardpos, hermaphrodite, öłis, appearance.

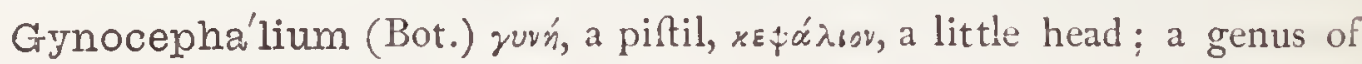

Phytocrenacex.

Gynozóoids (Zool.) ruvń, a female, '̌́n, life.

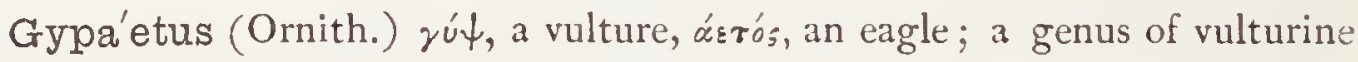
birds, fo called from their partaking of the character of both eagle and vulture.

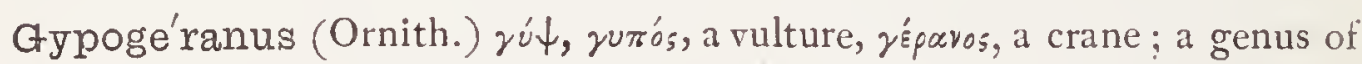
Birds.

Gypotha'mnum (Bot.) rúq, a vulture, eáxvos, a fhrub.

Grypso'phila (Bot.) rú $\psi_{05}$, chalk, $\phi \iota \lambda \dot{\varepsilon} \omega$, to love; referring to its habitation.

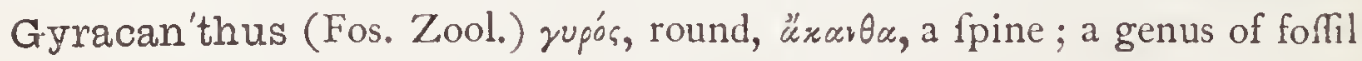
placoid filhes of the carboniferous fyltem.

Gyri'nidæ (Ent.) rupéw, to run round; alluding to their gyratory motion. Gyri'nus (Ent.) rupéa to run round, a genus of Coleoptera.

Gyrocar'pus (Bot.) rupós, round, xuprós, fruit.

Gy'rodus (Fos. Zool.) rupós, round, ỏdov́, a tooth.

Gyro'gonites (Fos. Bot.) rupos, round, yavia, an angle.

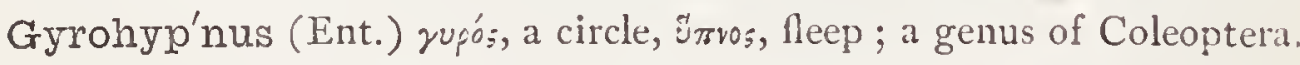

Gyrole'pis (Fos. Zool.) zusós, round, $\lambda \varepsilon \pi \kappa^{\prime} s$, a fcale.

Gyro'mitra (Bot.) yupo;, round, mitra, a turban; a genus of Fungi. 
Gyron'chus (Fos. Zool.) gupó;, round, öyxos, a curve; a genus of folfil ganoid fithes.

Gyrophæ'na (Ent.) rupós, round, quives, to appear.

Gyro'phora (Bot.) zũpos, a circle, фopếw, to bear; a genus of Lichenes.

Gyrophra'gmium (Bot.) zupós, round, фpáz,

Fungi.

Gyropo'dium (Bot.) yupós, round, $\pi \tilde{u}_{5}, \pi 00_{0}$, a foot ; a genus of Icicaceæ.

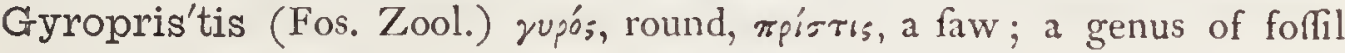
placoid filhes from the new red fanditone.

Gyrosig'ma (Bot.) yugos, round, and the letter forma; a genus of Diatomaceæ.

Gyroso'rium (Bot.) yupós, round, forus ; a genus of Filices.

Gyrotǽnia (Bot.) rupós, round, tenia, a ribband.

Gyrothe'ca (Bot.) yĩpos, a circle, $\theta \dot{n} x n$, a heath.

Gysselinel'la (Ent.) P. N. from J. V. Gyffelin, of Vienna, an affiduolis collector.

Haa'sia (Bot.) P. N., a genus of Lauracex.

Habena'ria (Bot.) habena, a leather ftrap; referring to the long fpur of the flower; a genus of terreftrial Orchidaceæ.

Habe'rlea (Bot.) P. N., a genus of Gefneracex.

Habe'rlia (Bot.) P. N., a genus of Anacardiaceæ.

Habli'tzia (Bot.) P. N. in honour of C. Von Hablitz, author of "Travels in the Crimea;" a genus of Amarantacex.

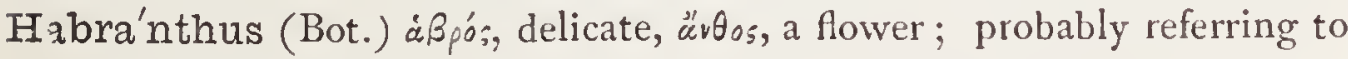
texture of bloffoms.

Habracan'thus (Bot.) ¿sosó, delicate, acanthus; a genus of Acanthaceæ. Habro'cerus (Ent.) ¿ßßón, delicate, repas, a horn.

Habro'phora (Ent.) $\dot{\alpha} \beta p^{\prime}{ }_{5}$, delicate, $\phi^{\prime} \varepsilon \xi \omega$, to bear; a genus of Hymenoptera.

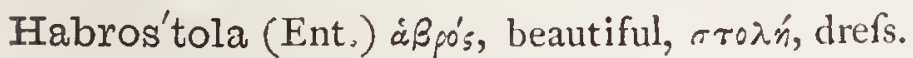

Habrotha'mnus (Bot.) \&ßßós, graceful, $\theta \alpha \dot{\alpha} \mu v o s$, a fhoot or branch; a genus of Solanaceæ.

Hackney (Zool.) as applied to a horfe, is fometimes faid to come from Hackney, near London, but the French haquenée is alfo.fuggefted.

Hacque'tia (Bot.) P. N. in honour of Balthafar Hacquet, a French naturalift and traveller, died 18 I 5 ; a genus of Umbelliferæ.

Hade'na (Ent.) \&̋ın, the nether world; on account of the dark colour of the species in this genus. 
Hade'nider (Ent.) hailena, fam. term. ida.

Haddock (Ichth.) Irifh, codog; old French, hadot.

Ha'drus (Ent.) ásós, thick, ftrong; a genus of Diptera.

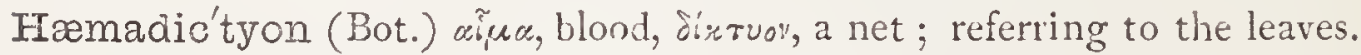

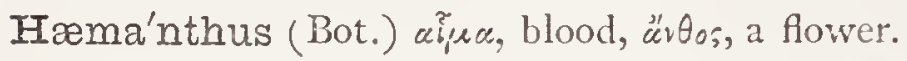

Hæmapo'physes (Zool.) aifua, blood, apophyfis; in allufion to their phyfrological relations with the great blood-ressels.

Hremato'bium (Zool.) cifres, blood, Brós, to live; fpecific name of a paralite found in the portal vein and other blood-veffels.

Hæmatoco'ccus (Bot.) uíus-тos, blood, xóxros, a berry; a microfcopic vegetable.

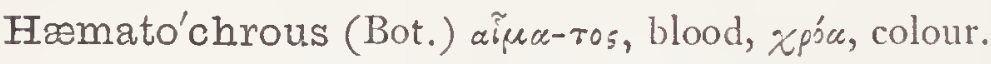

Hæmatocrya (Zool.) aipanros, blood, xpuos, froft ; correlative of the Hæmatotherma.

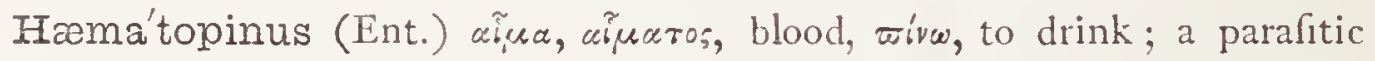
genus of Pediculidie.

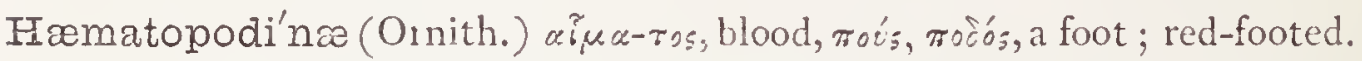

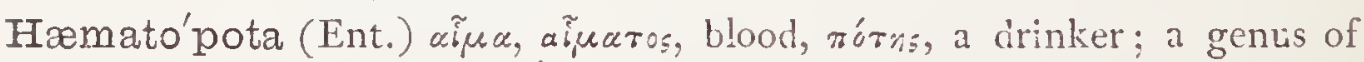
Diptera.

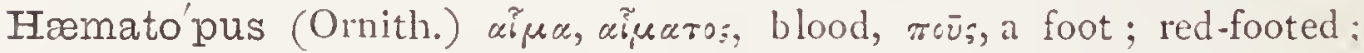
a genus of Birds.

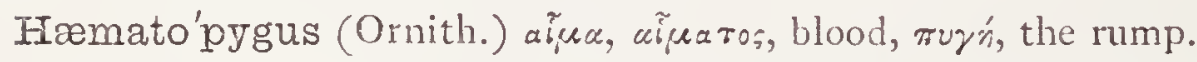

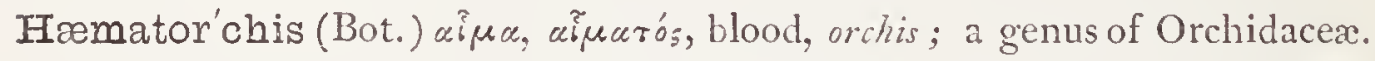

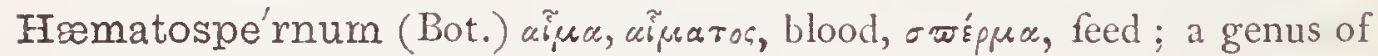
Euphorbiacex.

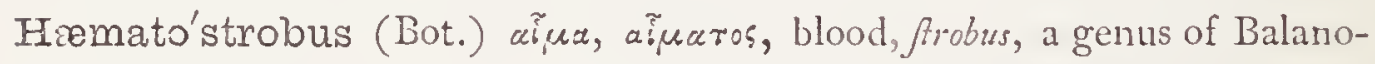
phoracex.

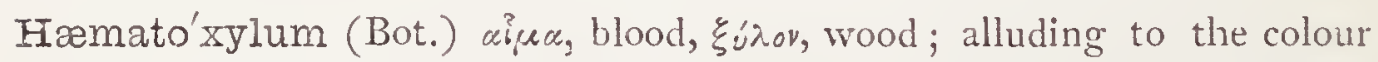
of the rood.

Hæmoca'rpus (Bot.) abua, blood, xapwó:, fruit ; a genus of Hypericacer.

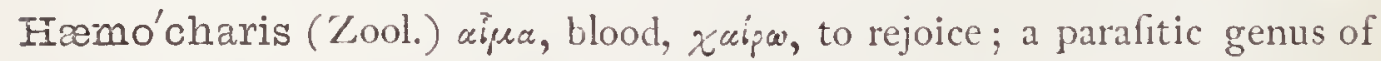
Annulata.

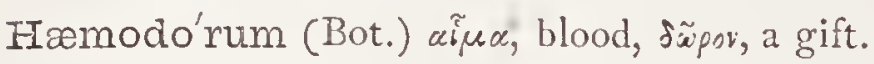

İæ'mopis (Zool.) a $\tilde{i} \mu \alpha$, blood; a genus of Annulata. H. Sanguiforba is the common Horfe-leech.

Ha'zea (Bot.) P.N. from Baron Hake, a German patron of botany ; a genus of Proteacex.

Hala'carus (Zool.) ä $\lambda_{\xi}$, the fea, acarus, a tick or mite; a genus of Arachnida. 
Hala'droma (Ornith.) à ádpopeos, one who courfes over the fea.

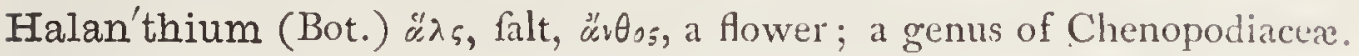

Ha'larachne (Zool.) ád $\lambda_{5}$, fea, ápáxvn, a fpider ; a genus of Arachnida.

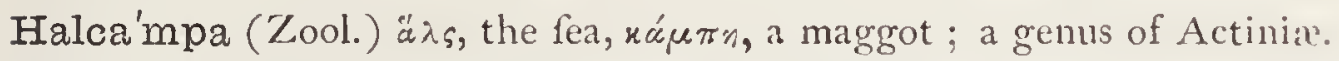

Halcyor'nis (Fos. Ornith.) halcyon, opus, bird; an extinct bird of the

Eocene.

Halecinum ( Lool.) relating to the fea.

Hale'cium (Zool.) " $\lambda s$, the sea; a genus of 'Zoophytes.

Hale'sia (Bot.) P.N. from S. Hales, D.D.. F.R.S., the Snowdrop-tree:

a genus of Nat. Ord. Styracacex.

Hal'ia (Ent.) P.N. a Nereid or fea-nymph.

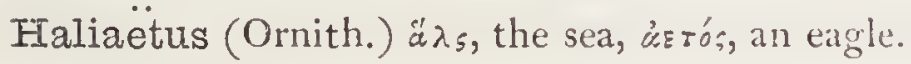

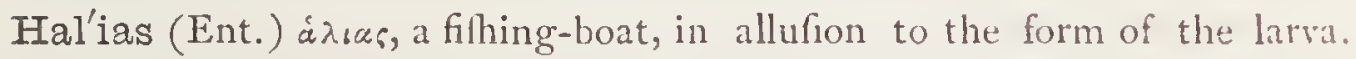

Or from $a \lambda_{s} \dot{\alpha} s$, belonging to the fea; perhaps in allufion to the colour of the perfect infect.

Halibut or Holibut (Ichth.) from holy and Dutch but or bot, a flounder; i.e., holy flounder.

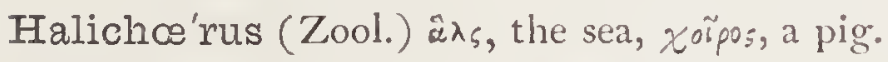

Halichon'dria (Lool.) ¿̈ $\lambda_{s}$, fea, $\chi^{\prime} \dot{s} \delta$ pos, cartilage; a genus of Sponges.

Hali'core (Zool.) ä $\lambda_{5}$, the fea, xópn, a maid.

Halico'ridæ (Zool.) halicore, fam. term. id $x$; a family of Mammalia.

Hali'drys, (Bot.) $\alpha \lambda ;$, the fea, $\delta \tilde{y}^{2} s$, an oak; a genus of marine Alga.

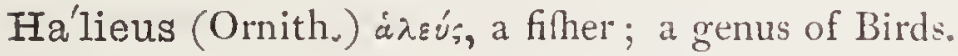

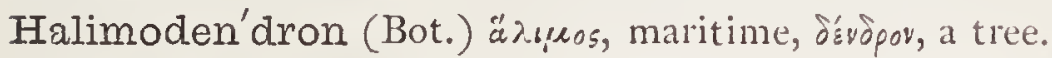

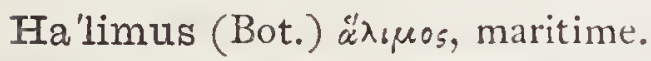

Hali'onyx (Bot.) ¿ ¿ $\lambda \xi$, the fea, ơv

Halio'tis (Zool.) $a \lambda a_{5}$, fea, ovs, wros, ear; the fea Ear-hell.

Ha'liphis (Ent.) $\dot{\alpha} \lambda i \pi^{\prime} \lambda$ os, failing on the fea.

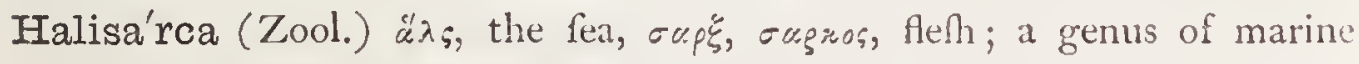
Sponges.

Hali'seris (Bot.) ä $\lambda_{5}$, the fea, Fépls, endive; it has membranous fronds; a genus of fucoid Algæ.

Halithæ'a (Zool, ) a' $\lambda_{s}$, the fea; a genus of marine Annelides.

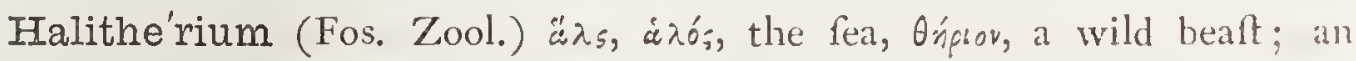
extinct cetacean of the tertiary.

Halle'ria (Bot.) P.N. in honour of Albert Haller, a diftinguilhed botanif, phyfiologift, and phyfician.

Halle'sus (Ent.) a genus of the Phryganidie.

Ha'llia (Bot.) P.N. from Berger. Martin Hall, a pupil of Linnacus. 
Halluca'tus (Zool.) hallex, a thumb or great toe.

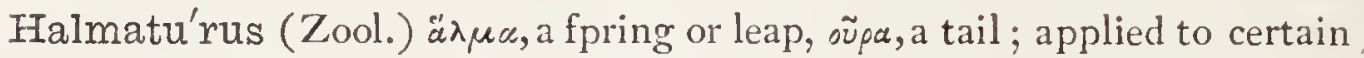
of the Kangaroos.

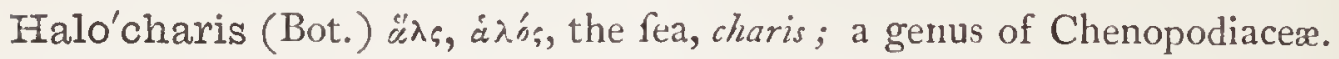

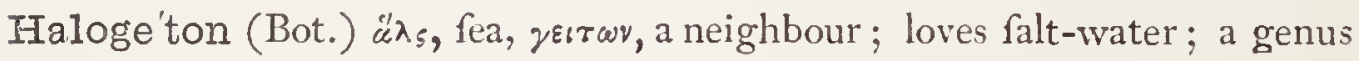
of Chenopodiacex.

Haloglos'sum (Bot.) «ँ $\lambda_{s}$, fea, $\gamma \lambda \tilde{\omega} \sigma \sigma a$, tongue; a genus of marine Algæ.

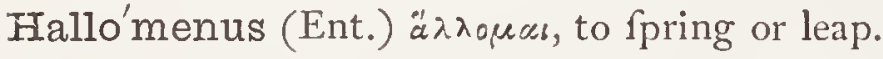

Fialo'nia (Fos. Bot.) dim. of halo, the luminous circle round the fun; a foffil genus intermediate between Lycopods and Conifers; alfo, a genus of Fungi.

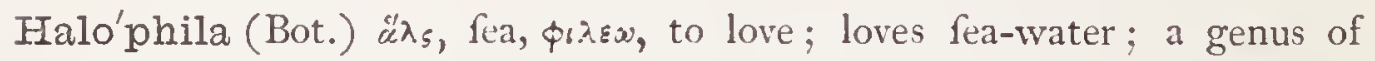
Podoftemacex.

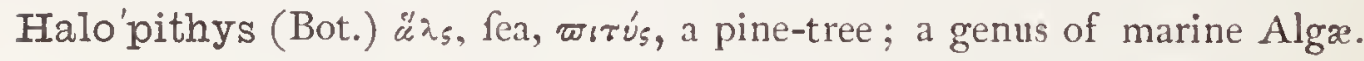
Halo'pteris (Bot.) « $\lambda_{s}$, fea, $\varpi \tau \varepsilon \iota_{s}$, a fern; a genus of marine Algæ.

Halora'gis (Bot.) ä $\lambda \varsigma$, the rea, $\mathfrak{p}^{\prime} \xi \xi$, a berry, especially a grape; typical genus of aquatic family Halorageacex.

Halorhiza (Bot.) «' $\lambda_{5}$, fea, $\dot{\rho} \zeta \kappa$, root; a genus of marine Algæ.

Halosa'ccion (Bot.) cü $\lambda_{s}$, fea, suxxiov, dim. of oxxisos, a fmall bag; a genus of marine Algx.

Haloschœ'nus (Bot.) "̈ $\lambda_{s}$, fea, Exỡvo, a rufh; "Sea-fide rufh"; a genus of Cyperacex.

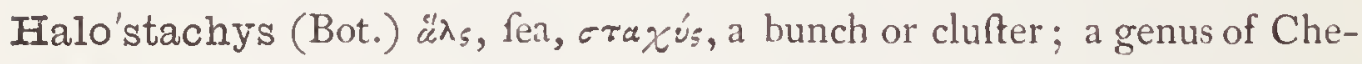
nopodiacex.

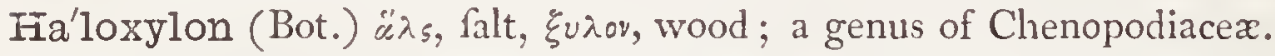

Halte'res (Ėnt.) Lat. balancers, from halter, a weight or dumb-bell; fome membranous appendages to certain Dipterous infects.

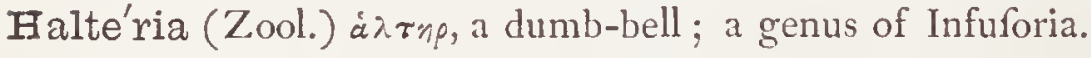

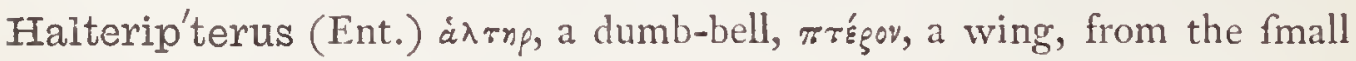
bodies on the top of the wings in fome Dipterous insects.

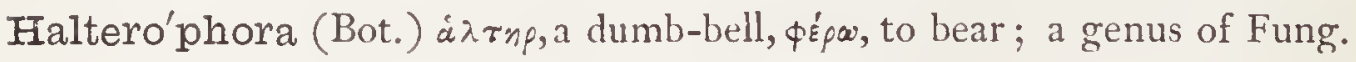
Ha'ltica (Ent.) ¿̇лix́s, good at leaping, active.

Haltiche'lla (Ent.) dim. of Haltica.

Halu'rus (Bot.) $x_{s}$, fea, oũpa, tail ; a genus of marine Algæ.

Halyme'nia (Bot.) å $\lambda \epsilon$, the fea, iuńv, a membrane; a genus of marine Algæ. Halysi'tes (Fos. Zool.) «̋vors, a chain; the chain-pore coral of the palæozoic Arata.

Hamadryas (Zool.) P.N., a nymph of the trees; a genus of Colubrine ophidians; and in Botany, a genus of Ranunculace $x$. 
Hamame'lis (Bot.) æ̋ $\mu \alpha$, together with, $\mu \tilde{n} \lambda \circ v$, an apple ;

Hame'lia (Bot.) P.N. from H. L. Du Hamel Du Monceau, a celebrated botanift, who died in 1782 .

Hamel'lus (Ent.) hamus, a hook.

Hamilto'nia (Bot.) P.N. from Mr. Hamilton, an American botanist.

Ha'mite (Fos. Zool.) hamus, a hook ; the Hook-lhell; a genus of Ammonites.

Ha'mites (Fos. Zool.) hames, a hook.

Hamo'des (Ent.) hamus, a hook, eidos, like.

Ha'mula (Ent.) dimin. of hamus, a hook.

Han'noa (Bot.) P. N., a genus of Simarubacex.

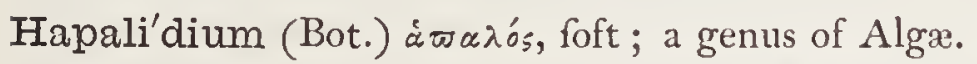

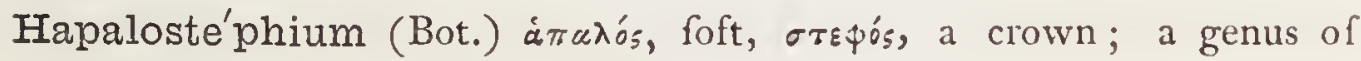
Compofitæ.

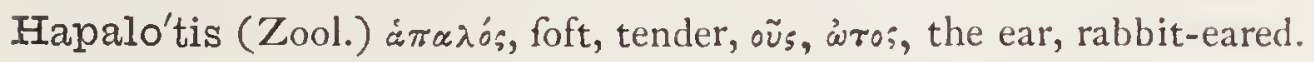

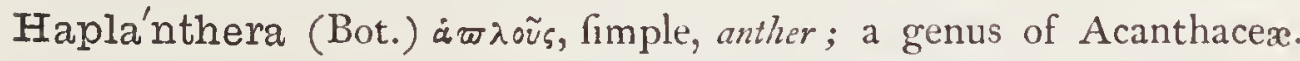

Hapla'ria (Bot.) ¿̇ø $\lambda$ oũ, fimple; a genus of Fungi.

Haploce'rcus (Zool.) a $\pi \lambda o_{s}$, plain, répros, a tail; a genus of Colubrine ophidians.

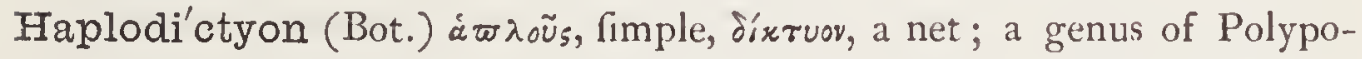
dioid Filices.

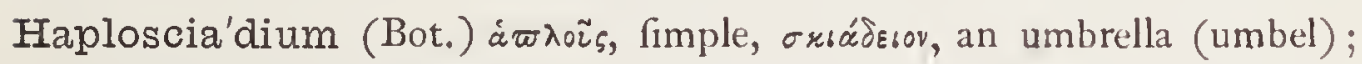
a genus of Umbelliferæ.

Ha'plota (Ent.) ȧт̇órns, plainness.

Hapsi'dophrys (Zool.) hapsus, a bandage, oppús, the eyebrow ; a genus of Colubrine ophidians.

Hardwi'ckia (Bot.) P.N. from Major Gen. Hardzvick, E.I.C. Artillery.

Hare (Zool.) Anglo-Sax. hara.

Hare'ngus (Ichth.) German, heer, an army; to exprefs the valt numbers in which the Herring occurs.

Hare'stail Cotton-grass (Bot.) Seems to be a tranflation of "Juncus alpinus cum caudâ Leporinâ," its name in J. Bauh. ii. 514 ; and Pluk. Almag., 201.

Hare'wort (Bot.) Anglo-Sax. hare-zuyrt.

Harla'ndia (Bot.) P. N., a genus of Cucurbitacex.

Haro'nga (Bot.) its name in Madagafcar.

Ha'rpa (Zool.) Lat. a harp; the Harp-shell.

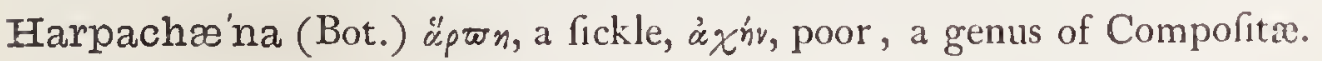

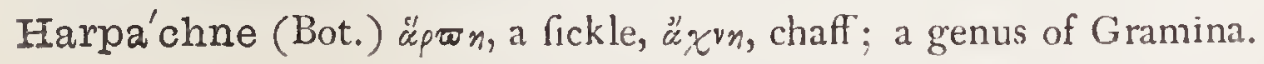




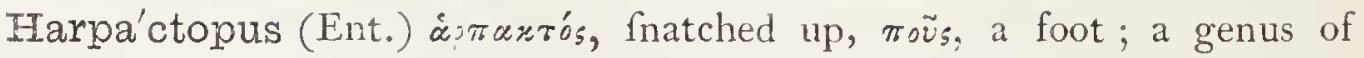
Hymenoptera.

Harpa'ctus (Ent.) áprantós, fnatched up; a genus of Hymenoptera.

Ha'rpagus (Ornith.) harpago, to rob or plunder.

Harpa'lidæ (Ent.) harpalus, fam. term. idœ.

IIa'rpalus (Ent.) ápta $a$ os, greedy; a genus of Coleoptera.

Harpa'lyce (Bot.) P N. from Harpalyce, daughter of Lycurgus, king of

'Thrace;

\section{"qualis equos 'Threîfla fatigat}

Harpalyce, volucremque fugâ præevertitur Hebrum."

VIRG. Æn. i. 320.

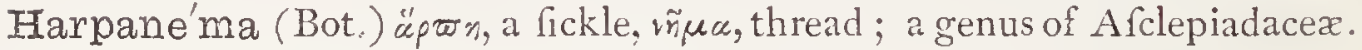

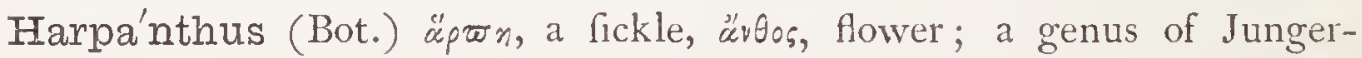
manniacex.

Harpel'la (Ent.) äprin, a fickle.

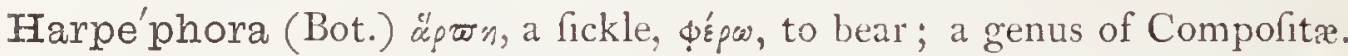
Harpoca'rpus (Bot.) äp๘n, a fickle, ráp๘os, fruit; a genus of Compofitæ.

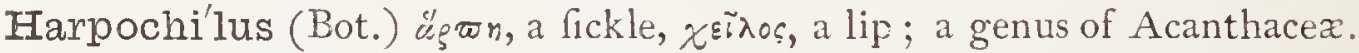
Harpo'chloa (Bot.) ๕̋ ๘n, a fickle, $\chi^{\lambda o ́} \alpha$, grafs; a genus of Gramina. Harpu'lia (Bot.) a genus of Sapindacex.

Harra'chia (Bot.) P. N., a genus of Acanthaceæ.

Harriers (Ornith.) fuppofed to allude to their mode of feeking their prey : they fly flowly along at a little diftance from the ground, apparently beating over every part of the furface, in the manner of a dog hunting for game.

Harriso'nia (Bot.) P.N. from Mrs. Harrifon, of Aigburgh, Liverpool.

Hart (Zool.) Anglo-Sax. heort.

Hartig'hsea (Bot.) P. N., a genus of Meliaceæ.

Harti'gia (Bot.) P. N., a genus of Melaftomacese.

Hartma'nnia (Bot.) P. N., a genus of Compofitæ.

Hartmannia'na (Ent.) P.N. in honour of P. E. Hartmann, Profellor at Frankfort-on-the-Oder, born in 1727 .

Harto'gia (Bot.) P. N. from J. Hartog, a Dutch traveller.

Hartwe'gia (Bot.) P. N. in honour of Theodore Hartreg, a fuccefsful collector of Mexican plants for the Horticultural Society, London, who difcovered this genus of Mexican Orchidaceæ.

Harve'ya (Bot.) P. N. in honour of Dr. Harrey, of Dublin; a genus of Scrophulariacea.

Ha'seltia (Bot.) P. N., a genus of 'Tiliaces. 
Ha'seltia (Bot.) P. N., a genus of Apocynacex.

Hassa'lia (Bot.) P. N. in honour of A. H. Haßall, M.D.; a genus of confervoid Algæ.

Hasselqui'stia (Bot.) P.N. from F. Haffelquif, M.D., its difcoverer, who died in $175^{2}$, he was a pupil of Linnæus, and a celebrated traveller in the Holy Land.

Hasska'rlia (Bot.) P. N., a genus of Pandanaceæ.

Hasta'ta (Ent.) hasta, a fpear; from the fpear-Ihaped markings.

Hasta'tus-a-um (Bot.) Lat., having arrow-fhaped leaves.

Hastia'na (Ent.) P. N. in honour of "Reinh. Haft, Fennus natus ad Infectorum historiam, et in flore ætatis periit egregius discipulus."

(LINNRUS.)

Hasti'ngia (Bot.) P. N., a genus of Byttneriacex.

Hautboy, or Hautbois (Bot.) this name of a ftrawberry is probably from the high-rvoods of its native Bohemia; in French, haut-bois.

Hau'ya (Bot.) P. N. in honour of René Juft Hauy, the celebrated Cryftallographer, died $18 \mathbf{2}$, aged 79 ; a genus of Onagracea.

Have'tia (Bot.) P. N., a genus of Clufiacea.

Hawk (Ornith) Anglo-Sax. hafoc.

Hawkera'na (Ent.) P.N. in honour of Rev. W. H. Hazuker, of Horndean,

Hants, who firft captured the fpecies in 1855 .

Hawo'rthia (Bot.) P.N. from A. H. Hazvorth, F.L.S., a diftinguifhed botanift.

Haworthia'ta (Ent.) P. N. from Adrian Hardy Hazvorth, author of "Lepidoptera Britannica."

Ha'wthorn (Bot.) Anglo-Sax. hag, a hedge, thorn, a thom.

Haxto'nia (Bot.) P. N., a genus of Compofitx.

Haylo'ckia (Bot.) P. N. in honour of Mattheze Maylock, Herbert's intelligent gardener; a genus of Brazilian Amaryllidaceæ.

Hay'nea (Bot.) P. N. ; a genus of Compolitx.

Hazel-nut (Bot.) Anglo-Sax. hasl-nutu, i.e. Head-drefs nut, becaufe of its peculiar involucrum.

Headleya'na (Ent.) firft captured in Headley Lane, near Mickleham : an infance of the want of an efficient fyftem of fcientific nomenclature.

Heath (Bot.) Anglo-Sax. hath.

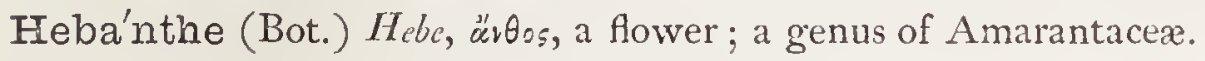

He'be (Bot.) P. N., the goddefs of youth; a genus of Scrophulari.. aceæ.

He'bea (Bot.) fame derivation; a genus of Iridacea. 
Hebea'ndra (Bot.) Hebe, ảvinp, ảvóós, a male (ftamen); i.e., having ftamens refembling thofe of that genus; a genus of Polygalaceæ.

Hebenstrei'tia (Bot.) P.N. from J. E. Hebenstreit, M.D., Profellor of Botany at Leipfic.

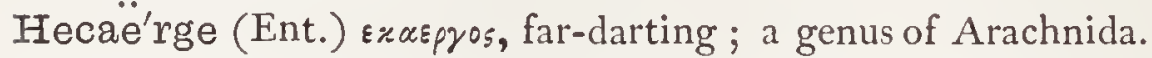

Hecate'ra (Ent.) P.N., from 'Exx'rn, the goddefs of the nether world.

Hectocoty'lus (Zool.) "̈xarov,, a hundred, xorún.n, a fucker.

Hecubæ'a (Bot.) P.N. from Hecuba, wife of Priam, king of Troy; a genus of Compofitæ.

Hedaro'ma (Bot.) ndús, fweet, aroma, fmell; a genus of Chamælauciaceæ. He'dera (Bot.) Lat. ivy, the word is thought by fome to be from the Celtic hedra, a cord. The true Hedera of the ancients is fuppofed to be a yellow-berried variety of $\mathrm{H}$. Helix, found in the Eaft Indies and occafionally in Italy.

Hedgehog (Zool.) perhaps from urchin-hog, or from its form and place of refort.

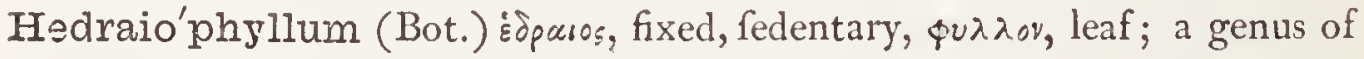
Compoliti.

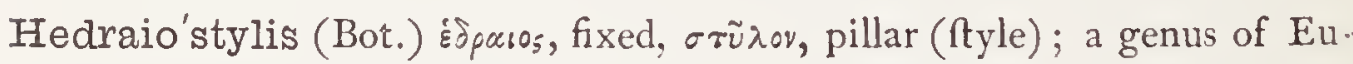
phorbiaceæ.

Hedwi'gia (Bot.) P. N. from Fohn Hedrvig, the great Bryologift, who died in 1799; a genus of Weft Indian Amyridacex; alfo a genus of Cryptogamia.

Hedwigi'dium (Bot.) P. N. in honour of Fohann Hedrvig, a diftinguihed German Botanift, born I730, died I799; a genus of Mufci.

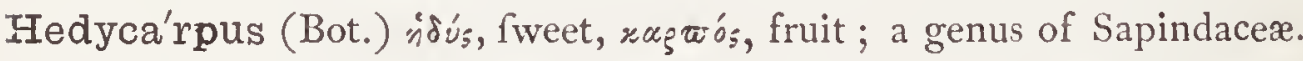

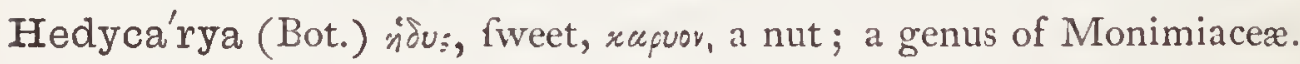

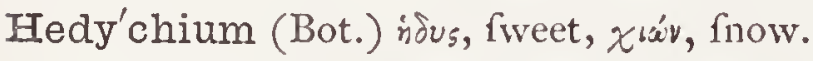

He'dycrum (Ent.) ídús, pleasant $\chi p^{\prime} \alpha$, colour; a genus of brilliantlycoloured Hymenopterous insects.

Hedyo'smum (Bot.) idós, fweet, $\delta \sigma \mu n$, a fmell : a genus of Chloranthacex. Hedyo'tis (Bot.) ídús, fweet, oùs, $\dot{\omega} \tau^{\prime} o_{s}$, an ear; it has leaves like ears. Hedy'pnois (Bot.) ridú, fweet, $\pi v^{\prime}=\omega$, to breathe; it fcents the breath.

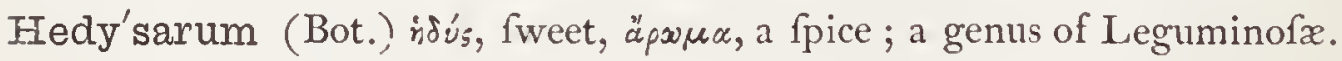
Heegeriel'la (Ent.) P.N. in honour of Herr Ernf Heeger, author of "Beiträje zur naturgefchichte der Phyfapoden."

He'eria (Bot.) P. N., a genus of Melaftomacer.

Hege'mone (Bot.) irgućs, a leader ; a genus of Ranunculacex.

Hegetschwel'lera (Bot.) P. N., a genus of Leguminofx. 
Heifer (Zool.) Anglo-Sax. heofre, a young cow.

Hei'mia (Bot.) P.N. from Dr. Heim, a celebrated Berlin phyfician.

He'insia (Bot.) P. N., a genus of Cinchonacex.

Heinze'lia (Bot.) P. N., a genus of Acanthaceæ.

Heinzelmánnia (Bot.) P. N., a genus of Scrophulariacex.

Hein'zia (Bot.) P. N., a genus of Leguminofx.

Heiste'ria (Bot.) P.N. from Lazurence Heifer, ProfefTor of Botany at Halltadt; died in $175^{8}$.

He'lamys (Zool.) ${ }^{E} \lambda n$, heat of the fun, $\mu \tilde{v} s$, a rat; the Jumping rat, found at the Cape of Good Hope.

Helarc'tos (Zool.) $\ddot{n} \lambda 60$, the fun, üprros, a bear; generic name of the Sun Bears.

Hele'nium (Bot.) P. N. from Helen, daughter of Jupiter and Leda, wife of Menelaus, and the caufe of the Trojan war; a genus of Compolitx.

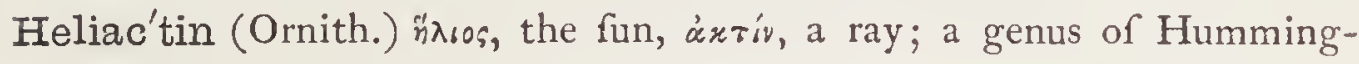
birds.

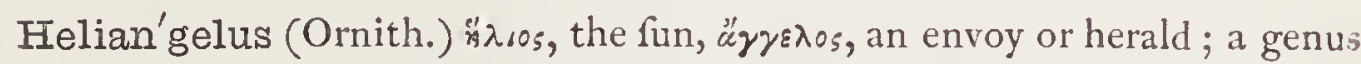
of Humming -birds.

Helian'thea (Ornith.) $\ddot{n} \wedge{ }_{10 s}$, the fun, $\ddot{u} v 0 s$, a flower; a genus of Humming-birds.

Helian'themum (Bot.) $\ddot{\eta} \lambda$ sos , the fun, $a^{\prime \prime} \theta \varepsilon \mu \circ v$, a flower; the Sun-rofe; a genus of Ciftacex.

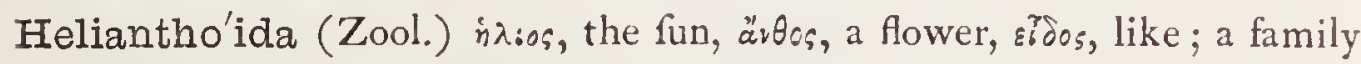
of Actiniform Zoophytes.

Helia'nthus (Bot.) $\ddot{n} \lambda เ \circ$, the fun, $\alpha^{\prime \prime} \forall \theta_{0 s}$, a flower; the Sun-flower; a genus of Compofitx.

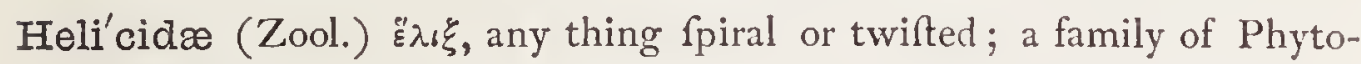
phagous gafteropods.

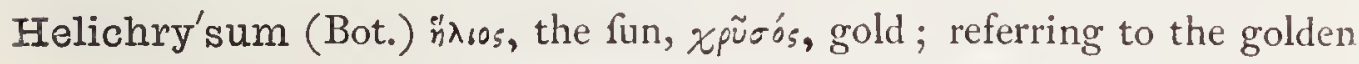
blofToms of the original fpecies; a genus of Compofitæ.

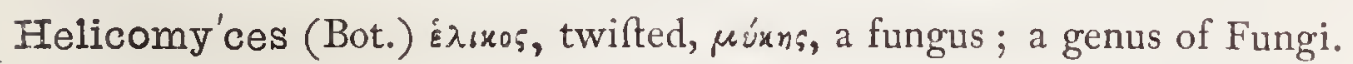

Helico'nia (Bot.) P. N. from Helicon, the mountain of the Mufes.

Helicoce'ras (Fos. Zool.) $\dot{\varepsilon} \lambda_{\iota x}$ s, fpiral, x'şus, a horn.

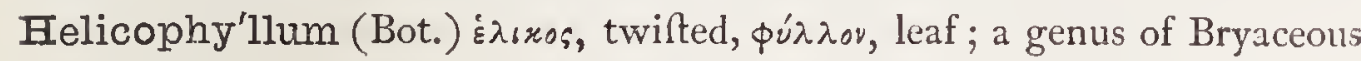
mofles.

He'licops (Zool.) $\dot{\varepsilon}$ ‘rros, twifted, $\ddot{\omega} \psi$, the eye; a genus of Ophidians.

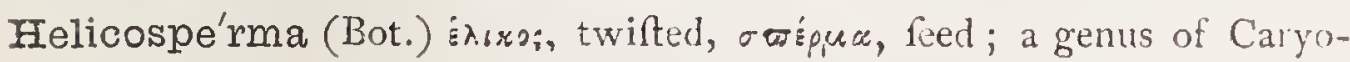
phyllaces. 


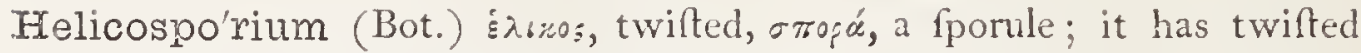
fporules; a genus of Hypomycetous Fungi.

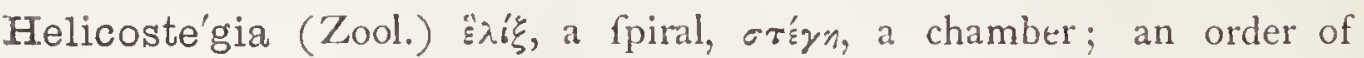
Foraminifera.

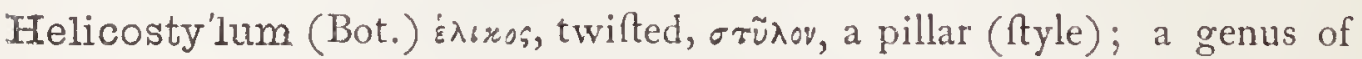
Fungi.

Helicotha'mnion (Bot.) $\sum_{\lambda เ \%}$, twifted, Oaprior, a fmall thrub; a genus of Algx.

Helico'trichum (Bot.) $\dot{\varepsilon} \lambda เ x \circ$, twilted, $\theta_{\rho} i_{\xi}, \tau \varphi^{\prime} x^{\prime}{ }^{\prime}$, hair; a genus of Fungi.

Helic'ta (Bot.) Ėı\%ros, twifted, wreathed; a genus of Compofitæ.

IIelic'teres (Bot.) helix, a fcrew; the carpels are twifted; the Screw-tree.

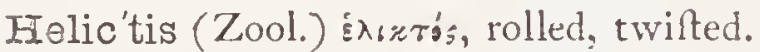

Ilelierella (Bot.) P. N., a genus of Algæ.

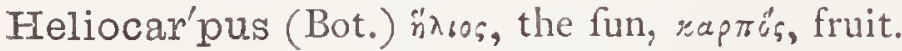

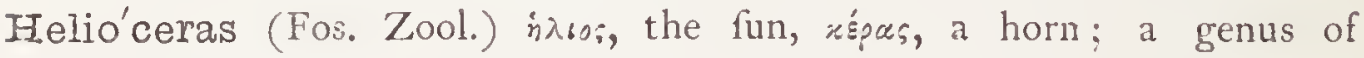
Ammonites.

Helioco'pris (Ent.) ${ }_{m}^{\prime \prime} \lambda เ 0_{5}$, the fun; the genus Copris.

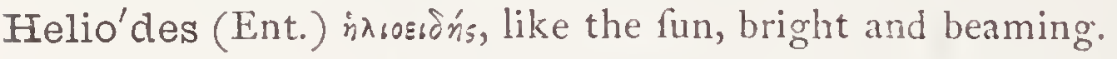

Heliodi'nes (Ent.) $n_{1}^{\prime} \lambda 60_{s}, \delta$ svrsıs, whirling in the fun.

Heliodo'xa (Ornith.) $\ddot{n}_{\wedge}{ }_{10}$, the fun, $\delta_{0} \xi \alpha$, glory; a genus of Hummingbirds.

Helioli'tes (Fos. Zool.) in $\lambda 105$, the fun, $\lambda \hat{i}_{0}$, a ftone; an extenfive genus of corves of the family of Milleporidx.

Helioma'ster (Ormith.) $\ddot{n}^{\prime} \lambda$ sss, the fun, árríp, a ftar.

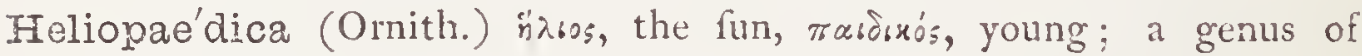
Humming-birds.

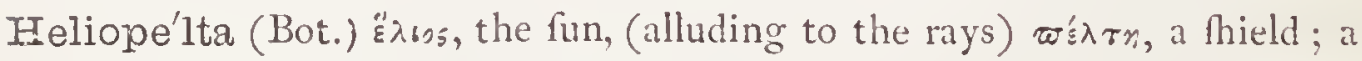
genus of Diatomacex.

Heliop'sis (Bot.) $\eta^{\prime} \lambda_{6 o s}$, the fun, ö $\psi_{5}$, appearance; referring to its flowers; a genus of Compolitx.

Helio'phila (Bot.) $\ddot{n} \lambda 605$, the fun, $\$ 6 \lambda^{\prime} \varepsilon \omega$, to lore; a pretty genus of Cruciferæ.

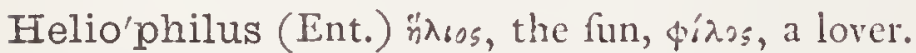

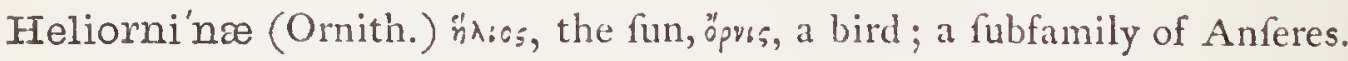

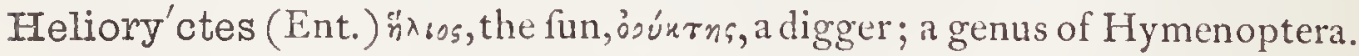

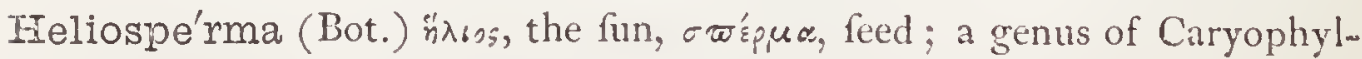
lacex.

Helio'thidre (Ent.) heliothis, fam. term. ids. 
Helio'this (Ent.) $i \lambda_{6} \omega \theta \theta_{i s}$, fcorched by the fun.

He'liothrix (Ornith.) $\tilde{\eta} \lambda$ ros, the fun, $\theta$ p $\xi \xi$, hair ; fometimes written Heliothrys; a genus of Humming-birds.

Heliotro'pium (Bot.) $\ddot{n} \lambda$ sos, the fun, tpotrn, a turning; alluding to its flowers; now applied to another plant, the well-known and fragrant Heliotrope of Peru; a genus of Ehretiacex.

Helio'trypha (Ornith.) $\ddot{n} \lambda$ เos, the fun, $\tau \rho u p \dot{n}$, luxury; a genus of Humming..birds.

Helip'terum (Bot.) $\tilde{y} \lambda_{o s}$, a bolt or nail, $\varpi \tau$ régov, a wing; a genus of Compolitic.

Helito'phyllum (Bot.) ì Proteacex.

Helixa'nthera (Bot.) $\varepsilon \lambda_{b} \xi$, a fpiral, anthera; a genus of Loranthacew.

Hella (Ent.) ¿̇ $\lambda \lambda \alpha$, inactivity, delay.

Hellebora'ster (Bot.) helleborus, afer, a ftar; a genus of Ranunculacex.

Hellebori'ne (Bot.) having fome refemblance to helleborus; Englith name of Epipactis; a genus of Orchidacex.

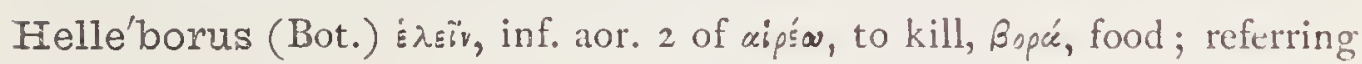
to its poifonous qualities; a celebrated genus of Ranunculacex. The Hellebore of the ancients was Helleborus orientalis.

Helle'nia (Bot.) P. N. from C. N. Hellenius, Profeflor at Aho.

Helle'ria (Bot.) P. N., a genus of Humiriacex.

Hellman'ni (Ent.) P. N. in honour of A. Hellmann, author of a treatific on the Anatomy of Snakes, publifhed at Gottingen, I817.

Hellwi'ngia (Bot.) P. N., a genus of Hacourtiacex.

Helmi'nthia (Bot.) É $\lambda \mu$ ívorov, a little worm; referring to its feeds; a genus of Umbelliferæ.

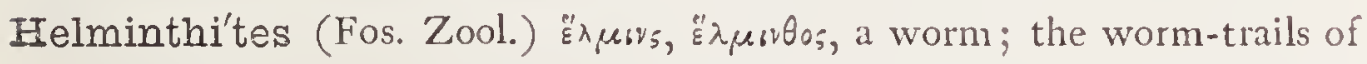
fandifone.

Helminthocho'rtus (Bot.) of Ceramian Algx

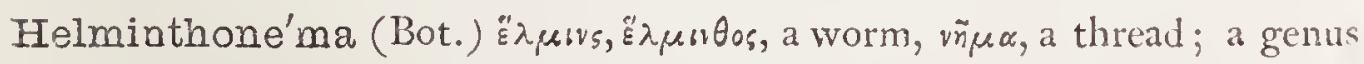
of $A \lg x$.

Helmin'thora (But.) $\varepsilon^{\prime \prime} \lambda \mu \omega \nu_{\xi}, \varepsilon^{\prime \prime} \lambda \mu \omega \theta_{05}$, a worm; a genus of Fungi.

Helminthospo'rium (Bot.) $\dot{\varepsilon}^{\prime} \lambda \mu \iota v s$, a worm, Spora; a genus of Hypomycetous Fungi.

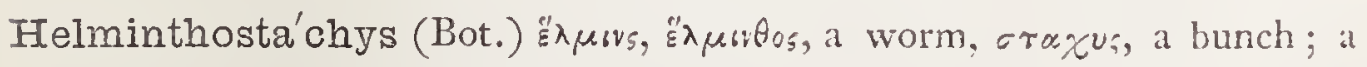
genus of Ophiogloftaceous Ferns.

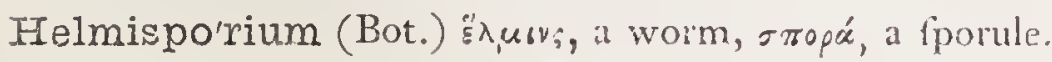




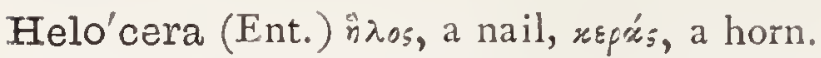

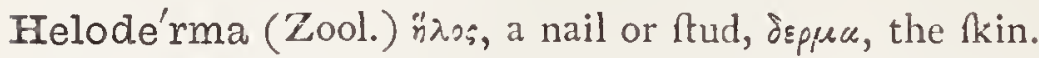

Helode'rmidæ (Zool.) heloderma, fam. term. ide; the Caltetepons of Heloderms.

He'lodes (Ent.) ทें ${ }_{05}$, a nail, sidos, like.

He'lodus (Fos. Ichth.) $\tilde{n} \lambda_{0 s}$, a nail or ftud, osoũs, a tooth ; "ftud-tooth ;" a genus of ceftraciant fifh-teeth of the carboniferous rocks.

Helo'gyne (Bot.) ñ் ${ }^{\Sigma}$, a bolt or nail, gu:n, female (piftil); a genus of Compolitx.

Helo'nias (Bot.) Ë̀os, a marh ; alluding to its habitation.

Helopho'ridæ (Ent.) a family of Coleoptera of which Helophorus is the type.

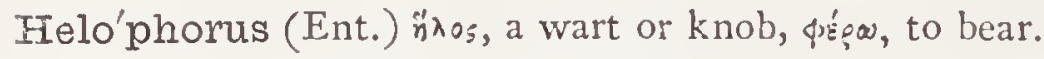

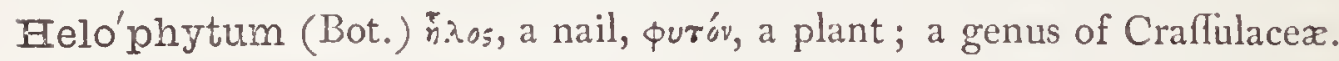
Helo'pidæ (Ent.) a family of Coleoptera of which Helops is the type.

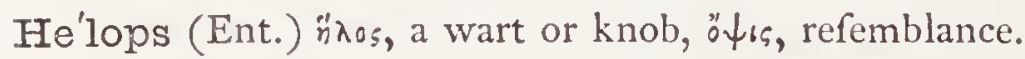

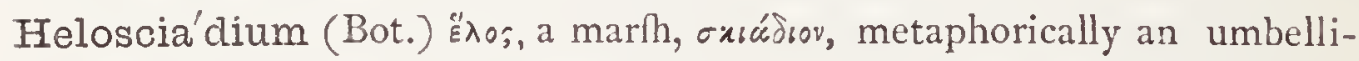
ferous plant, an aquatic genus of Umbelliferæ; vide Gymnofciadium.

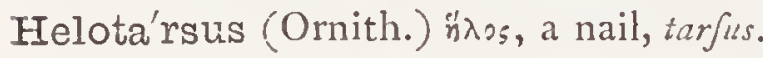

Helo'tium (Bot.) $\tilde{n} \lambda_{0 \circ}$, a nail; a genus of Fungi.

Helve'lla (Bot.) a name employed by Cicero for a fungus; fome think a fort of fmall cabbage; a genus of Fungi.

İelvetica'ria (Ent.) Helveticus, Swirs.

Hel'vola (Ent.) helvolus, pale yellow.

Hemerobiel'la (Ent.) dim. of in $\mu$ spóßıs, living for a day, or refembling a Hemerobius, a Neuropterous fly.

Eemero'bius (Ent.) ísspu, day, Brow, to live; a genus of Neuropterous infects.

Hemeroblem'ma (Ent.) ïuspos, tame, foft, $\beta \lambda \dot{\varepsilon} \mu \mu \alpha$, the look, vifage.

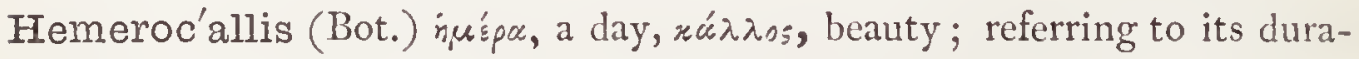
tion; a genus of Liliacex.

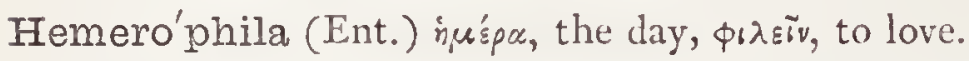

Hemiau'lus (Bot.) in

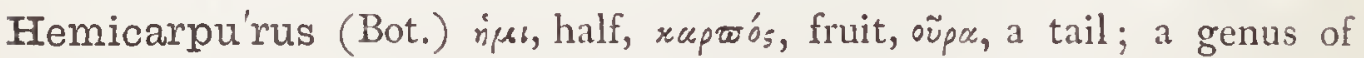
Araceæ.

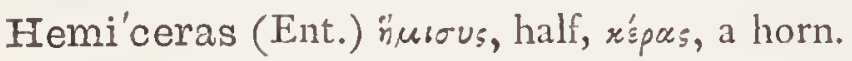

Hemice'ridæ (Ent.) a family of which Hemiceras is the type.

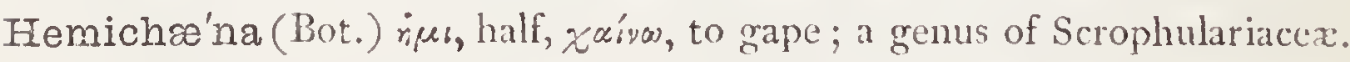

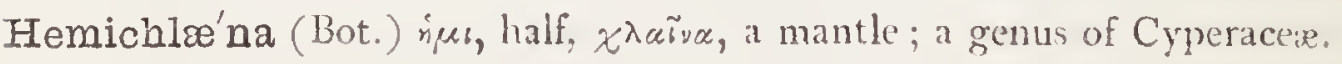




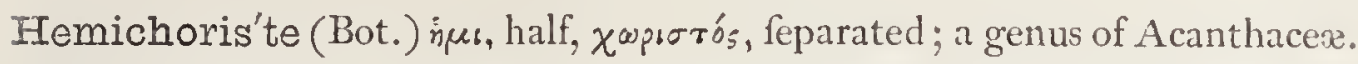
Hemi'chroa (Bot.) í $\mu$, half, $\chi \rho^{\circ} \alpha$, colour; a genus of Amarantacex.

Hemici'daris (Fos. Zool.) inct, half, cidaris, having large fpine-bearing tubercles on the lower part of the ambulacra.

Hemicir'cus (Ornith.) inus, half, xépros, a tail; it hould be Hemicercus

Hemicli'dia (Bot.) ís, half, $x \lambda \varepsilon^{\prime} i_{s}, x \lambda \varepsilon s \delta \delta_{s}$, a key; a genus of Proteacex.

Hemicosmittes (Fos. Zool.) in cyftidean genus of the lower Silurian rocks.

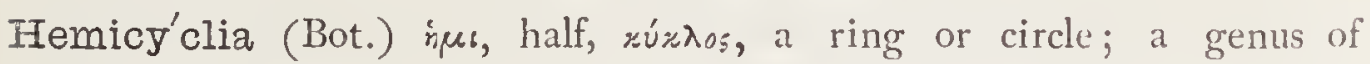
Euphorbiacex.

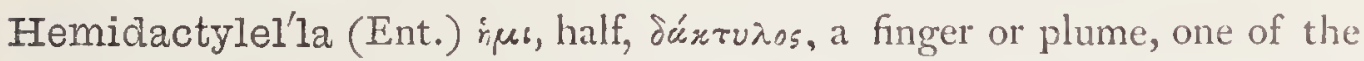
five divifions of the wings of a Pterophorus; the moth fomewhat refembling a plume in the narrownefs of its wings and the length of the fringes.

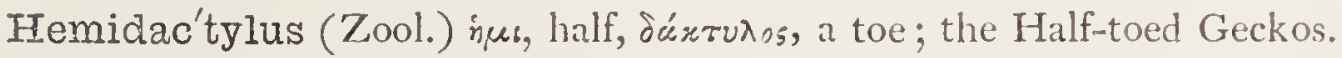

Hemide'smus (Bot.) in $\mu_{t}$, half, $\delta \varepsilon \sigma \mu o ́ s$, a band.

Hemidic'tyon (Bot.) ír, half, dirtvov, a net; a genus of Polypodioid Filices.

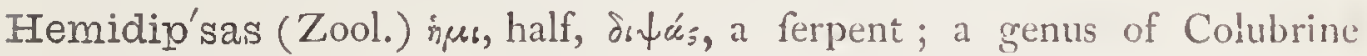
ophidians.

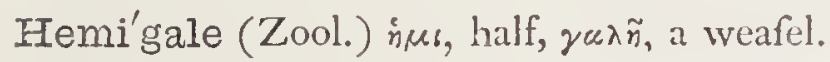

Hemigy'mnia (Bot.) inur, half, qurevó, naked; a genus of Verbenacex.

Hemigy'ne (Bot.) nं $\mu$, half, zurn, female (piftil); a genus of Myrfinactre.

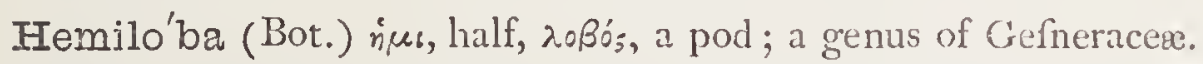

Hemi'meris (Bot.) in $\mu$, half, $\mu \varepsilon$ ṕrs, a part; a half-flower; a genus of Scrophulariacer.

Iemioni'tis (Bot.) nuíovos, a mule: it is fuppofed to be Rerile; a genus of Filices.

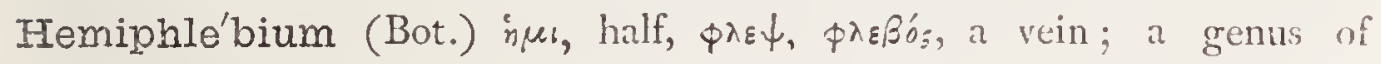
Polypodioid Filices.

Hemiphra'gma (Bot.) inu, half, ş̧е́yus, a fence or divifion; a genus of Scrophulariacex.

Hemipne'ustis (Fos. Zool.) inus, half, ๘veúrrns, one who blows; the forfil Spatangus.

Iemipo'dius (Ornith.) ins, half, $\pi \circ \tilde{u}_{s}$, wodos, a foot; from the total abfence of the hinder toe.

Hemipri'stis (Fos. Zool.) ine, half, wpiorks, the Saw-fifh; a genus of Sharktecth occurring in the chalk and tertiary formations. 
Femip'tera (Ent.) ine, half, $\pi$ repóv, a wing.

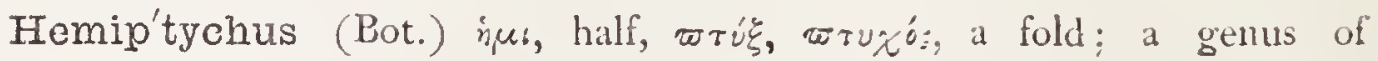
Diatomacex.

Hemiram'pbus (Ichth.) ris, half, pá $\mu ф o s$, a beak.

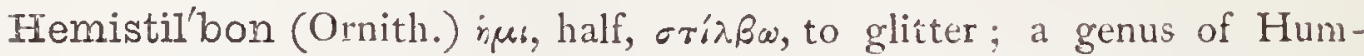
ming-birds.

Hemi'telites (Fos. Bot.) ri, oolitic ferns with abrupt pinnules.

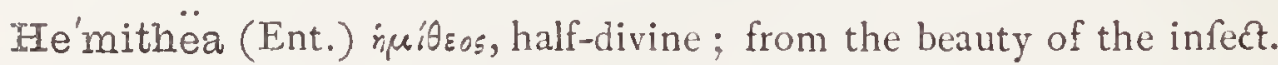

Femithy'laca (Ornith.) in birds.

Iemizo'ster (Fos. Zool.) inu, half, zyfter, a fea-hrub; a genus of Siliceous foffils.

Hemp (Bot.) Anglo-Sax. hanep.

Hen (Ornith.) Anglo-Sax. hen.

Henfreya (Bot.) P. N. in honour of the late Arthur Hinfrey, F.R.S., Profelfor of Botany at Cambridge.

Flenico'stoma (Ent.) Evirós, fingular, orórec, the mouth.

Flepara'na (Ent.) 范up, the liver; liver-coloured.

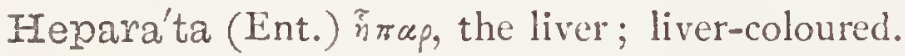

Hepa'tica (Ent.) irratırós, liver-coloured.

Hepa'tica (Bot.) ìtoctrós, relating to liver; it has lobed leaves; a well-

known and pretty fpecies of Anemone.

Hepial'idæ (Ent.) the family of which the genus Hepialus is the type.

Hepialus (Ent.) inianos, a fever; from the fitful alternating flight of thefe infects.

Hepoo'na (Zool.) intrén, to call out, to roar?

Hepsetoi'des (Ichth.) hepfetus, Eidos, iike.

Hepse'tus (Ichth.) ancient name of a fith which was eaten boiled, from

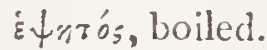

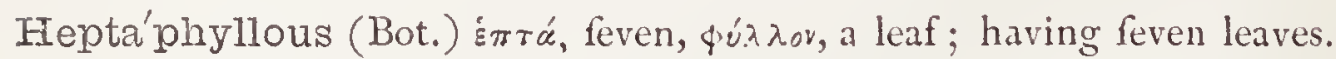

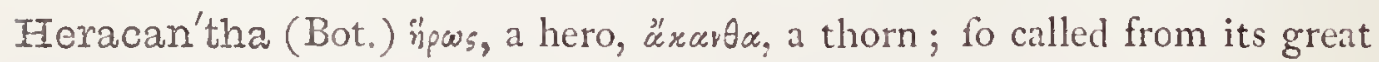
beauty.

IIeraclea'na (Ent.) feeds on the Cow Parfnip, (Meracleum Sphondylium.)

Hera'cleum (Bot.) 'Hpard'śs, Hercules; it was facred to him; a genus of Umbelliferæ.

Herba'na (Ent.) herba, grass.

Ierber'tia (Bot.) P. N. from the late IIon. and Rev. W. Herberi, Dean of

Manchefter, an afiduous botanit. 
Her'bida (Ent.) herbidus, grafly.

Her'bula (Ent.) herba, grafs, herbage; frequenting grafly fpots.

Hercothe'ce (Fos. Zool.) Ëpros, a fence or hedge, $\theta$ '́xn, a theath; a genus of Folfil Diatomacer.

Hercy'na (Ent.) P. N. from the Hercynian forent of Germany.

Hercynia'na (Ent.) P. N. from the Hercynian forent of ancient Germany, fituated in the modern Bohemia.

Hercy'nidæ (Ent.) the family of Lepidoptera of which Hercyna is the type. Heriti'era (Bot.) P. N. from G. L. l'Heritier de Brutelle, a French botanift; the Looking-glafs plant.

Herma'nnia (Bot.) P. N. from Paul Hermann, Profeflor of Botany at Leyden.

He'rmas (Bot.) the meaning is unknown.

Hermi'nia (Ent.) the Herminia gens was one of the ancient patrician houfes at Rome.

Hermini'idæ (Ent.) Herminia, fam. term. ide.

Hermi'nium (Bot.) P. N., a genus of terreftrial Orchidacex.

Hermino'des (Ent.) Herminia, દ̌ı̊os, refembling.

Herna'ndia (Bot.) P. N. from Francifco Hernandez, M.D., a Spanih botanift.

Hernia'ria (Bot.) hernia, rupture; alluding to its fuppofed medical qualities. Heron (Ornith.) French, héron.

Ierpes'tes (Zool.) Ė

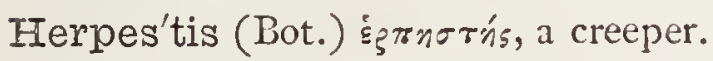

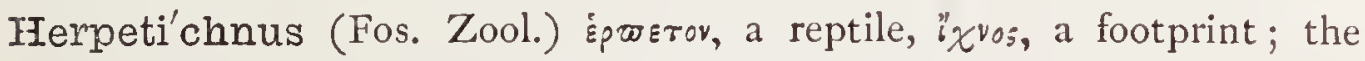

Lizard-like footsteps in the New Red fanditone.

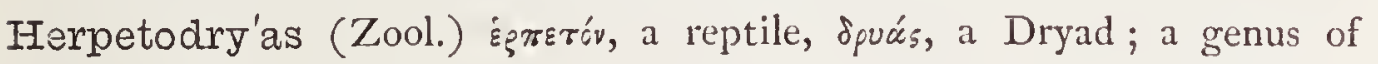
Colubrine ophidians.

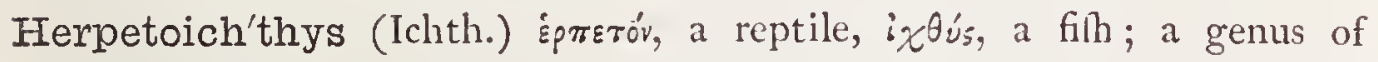
Ichthyology.

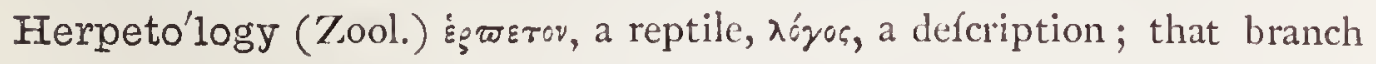
of Zoology which treats of Reptiles.

Herre'ria (Bot.) P. N. from C. A. de Herrera, a Spanifh agriculturif.

Herring (Ichth.) Pennant derives the word from the German heer, a hoft;

Moule derives it from hairang, an old French word for a troop or army.

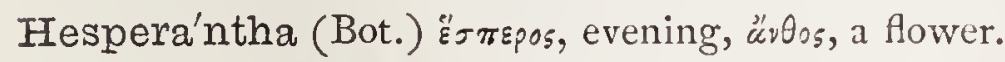

Hespe'ria (Ent.) P. N., an ancient name for Italy.

"Eft locus-Hefperiam Graii cognomine dicunt,

Terra antiqua, potens armis atque ubere glebæ."-VIRG, Fn, i. 530. 
Hesperi'idæ (Ent.) the family of which the genus Hepperia is the type.

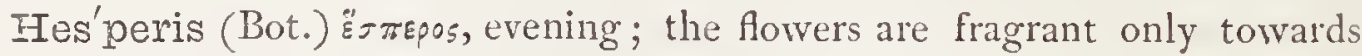
evening; the Night-fmelling ftock; a genus of Cruciferæ.

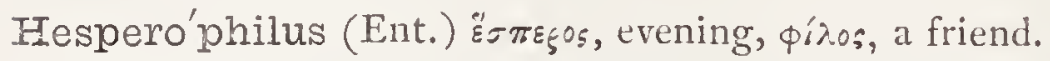

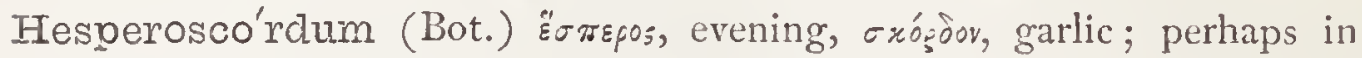
allufion to its finell.

Heteranthe'ra (Bot.) Ërepos, variable, ¿̇vtríp, an anther.

Heterocer'idæ (Ent.) the family of Coleoptera of which Heterocerus is the type.

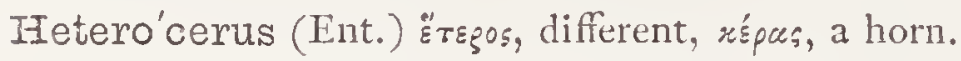

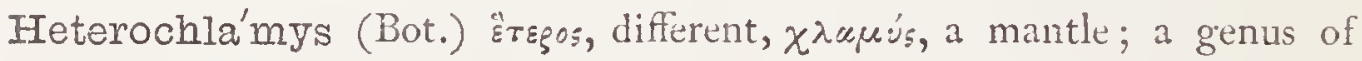
Euphorbiacex.

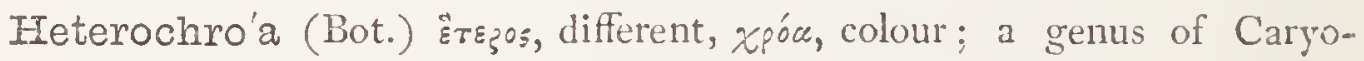
phyllacex.

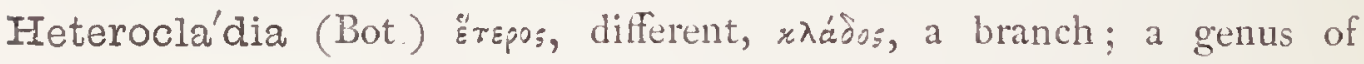
Ceramian Algæ.

Heteroco'ma (Bot.) Érepos, different, xóun, a tuft; a genus of Compofitæ.

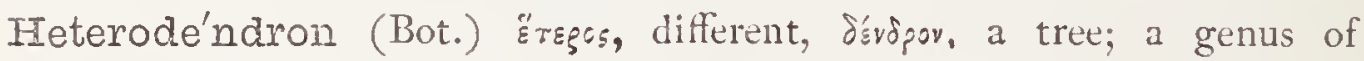
Rutaceæ.

He'terodon (Zool.) Ërepos, different, odoṽ:, odovrós, a tooth; a genus of Colubrine ophidians; and, in Bot., a genus of Bruniacez.

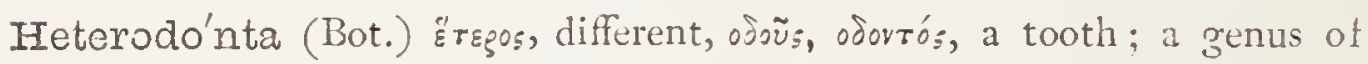
Compofitx.

Heteroge'nesis (Zool.) ع̈repos, different, y'śvers, birth; reproductive force acting through diffimilar cells.

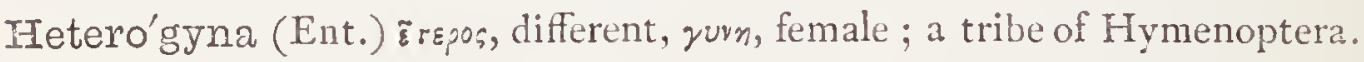

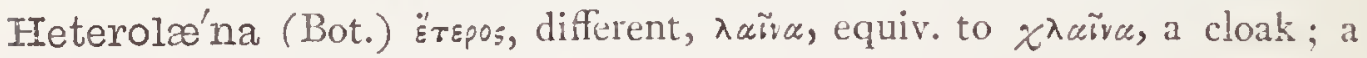
genus of 'Thymelacex.

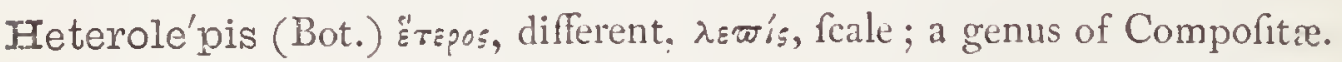

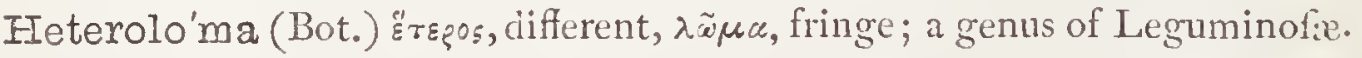

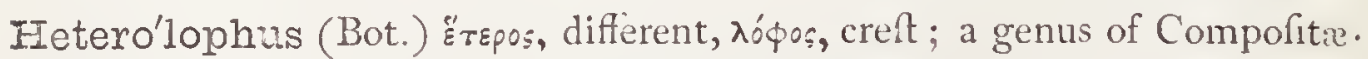

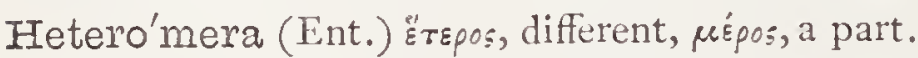

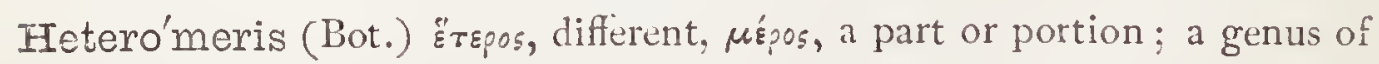
Ciftacex.

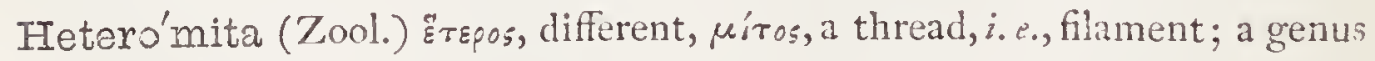
of Infuforia.

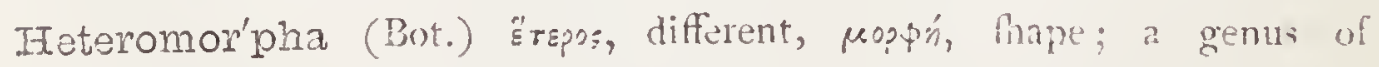
Umbellifern.

Io'teromys (Zool.) Érepos, the other, $\mu \tilde{v} \xi$, a moure. 


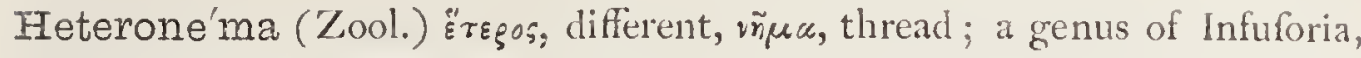
of the family Euglenia.

Heteropa'lpi (Ent.) having lefs than five palpi; a divifion of the Neuroptera.

Heteropa'ppus (Bot.) "̈tzpos, different, pappus, the down of plants; a genus of Compofita.

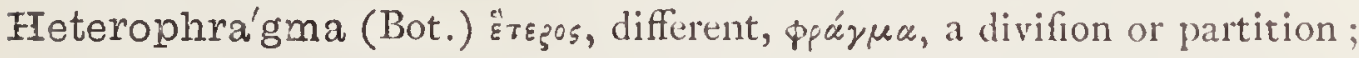
a genus of Bignoniacex.

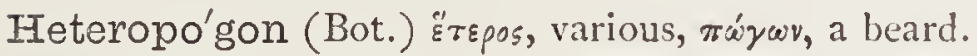

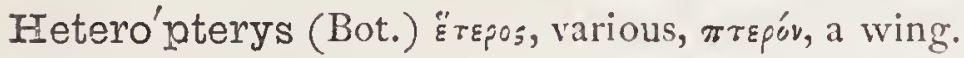

Heteropy'gas (Ent.) $\tilde{\varepsilon}_{\tau \xi \xi} \circ \xi$, of another kind, wúyn, the buttock or hinder part.

Heteroso'mata (Ichth.) Ërepos, other, different, $\sigma \tilde{w} \mu a$, body; having diverfe fides like the flat fimes, in which both eyes are on one fide.

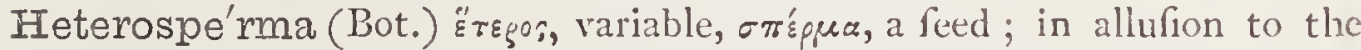
Thape.

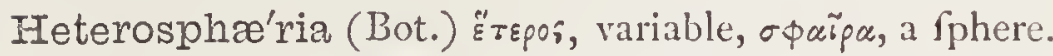

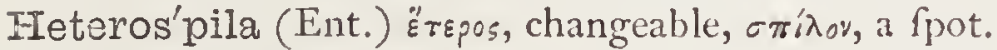

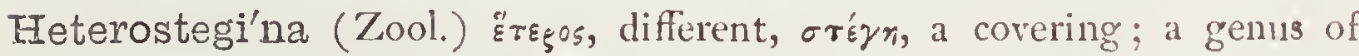
Foraminifera.

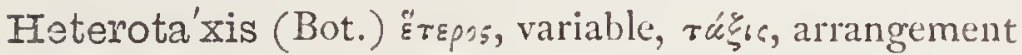

Heterotho'ps (Ent.) ह̈rદgos, another, $\theta \dot{w} \psi$, a fawner.

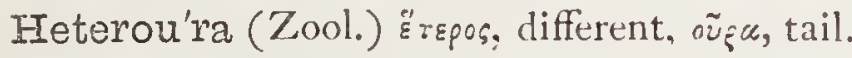

Heuche'ra (Bot.) P. N. from 7. H. Heucher, Profeflor of Medicine at

Wittenberg; a genus of Saxifragacex.

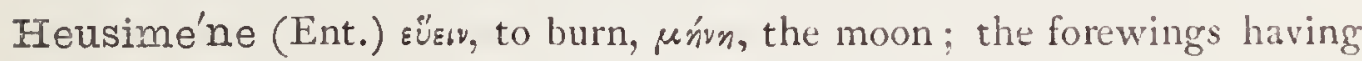
an afhy lunule on the inner margin.

Iexace'ntris (Bot.) $\varepsilon_{\xi}^{\mathrm{e}}$, fix, x'vrpov, a prickle; a fplendid genus of Scrophulariacer.

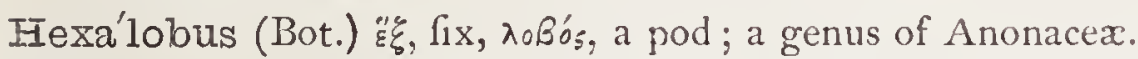

Hexa'mita (Zool.) ${ }^{\prime \prime} \xi$, fix, $\mu \iota \tau \circ_{\xi}$, a thread, having fix filaments; a genus of Infuforia.

Hexa'nthera (Bot.) $\ddot{\xi} \xi$, fix, anthera; a genus of Samydacex.

Hexa'nthus (Bot.) $\mathfrak{\xi} \xi, f_{1} x, a ̈ v \theta_{0 \hat{n}}$, a flower; a genus of Lauraceæ.

Fexapro'todon (Fos. Zool.) ${ }^{e} \xi$, fix, wpwrodoũs, a front tooth; having fix

front teeth; a large pachyderm of the Pliocene and Miocene.

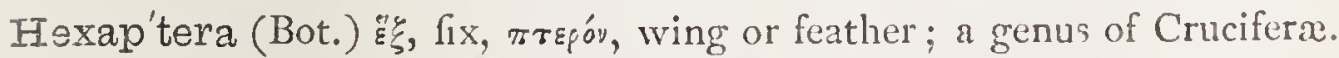

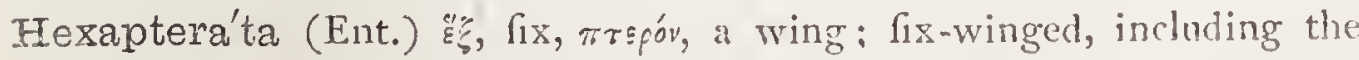
vinglets. 


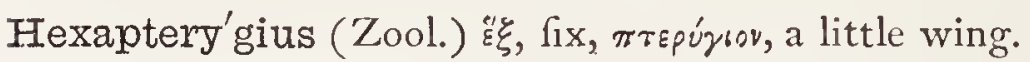

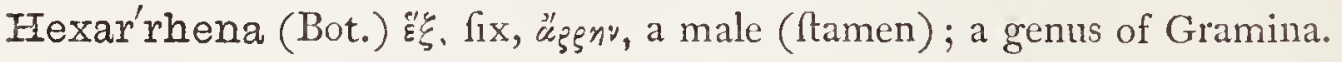

Hexase'palum (Bot.) $\varepsilon^{e ́} \xi$, fix, fepal; a genus of Cinchonacex.

Hexa'toma (Ent.) ${ }^{\varepsilon} \xi$, fix, rókn, a cutting; a genus of Diptera.

Fexops (Ent.) $\stackrel{\varepsilon}{\xi}$, fix, $\mathscr{\omega} \downarrow$, the eye ; fix-eyed.

Heylau'dia (Bot.) P. N. from $M$. Heylaud, an artift employed by Decandolle.

Iley'nea (Bot.) P. N. from Dr. B. Heyne, a German botanift.

Hiati'cula (Ornith.) hiatus, an aperture.

Hibbe'rtia (Bot.) P. N. from George Hibbert, a diftinguifhed collector of plants, a noble genus of Dilleniaceæ.

Hibi'scus (Bot.) the Greek name for Mallow, now applied to a fplendid tropical genus of Malvaceæ.

Filema'lis (Ent.) Lat. wintry, belonging to winter.

Hieraci'dea (Ornith.) fometimes written Feracidea, from 'śpa $\xi$, a hawk.

Hiera'cium (Bot.) iepá̧, a hawk; which is fupposed to tharpen its fight

with the juice of the plant; a genus of Compofitx.

Hiero'chloe (Bot.) isós, facred, $\chi^{\lambda o ́ n}$, grafs; a genus of Grafles.

IIieroglypha'lis (Ent.) having wing-marks resembling hieroglyphics.

Hierogly'phica (Ent.) hieroglyphic-like markings.

Hi'llia (Bot.) P. N. from Sir Fohn Hill, a voluminous botanical author.

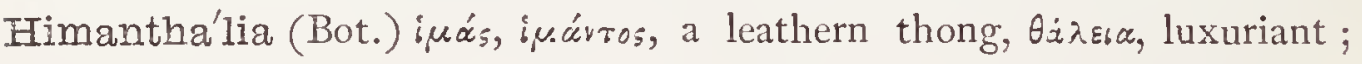
a genus of Algax.

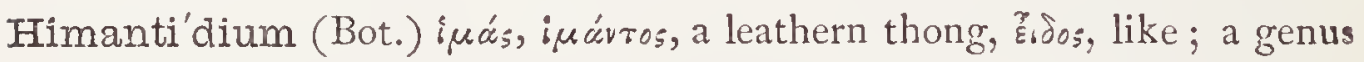
of Diatomacex.

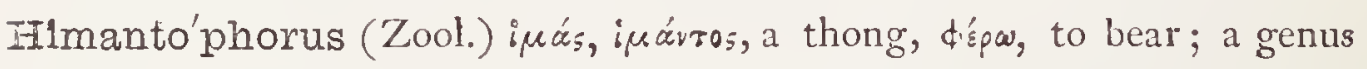
of Infuforia.

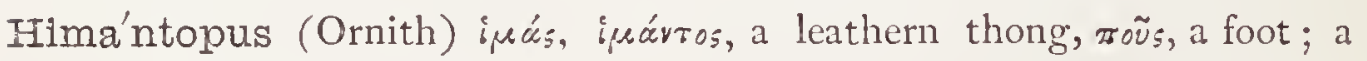
genus of Birds.

Hi'mera (Ent.) P.N., the name of an ancient city in Sicily.

Hi'ndsia (Bot.) P. N. in honour of R. B. Hinds, Esq., a zealous naturalift. Hipis'tes (Zool.) unexplained; a genus of Ophidians.

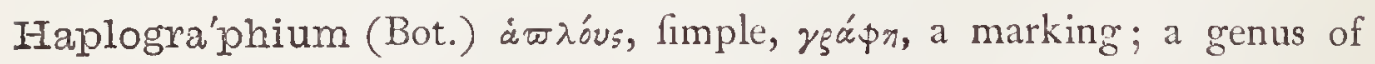
Fungi.

Hippa'rchia (Ent.) P.N.; a genus of $I$ ،epidopterous infects.

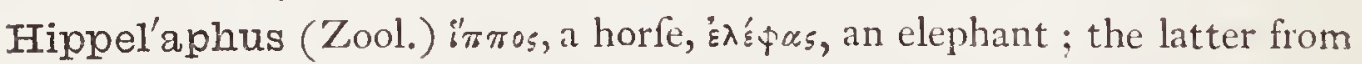
its ivory-like horns.

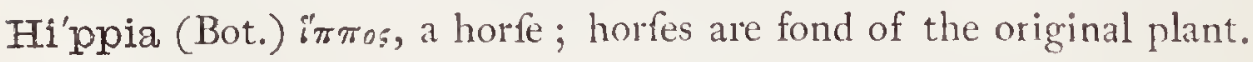
Hi'ppion (Bot.) immos, a horfe, br, a violet; horfe-riolet. 


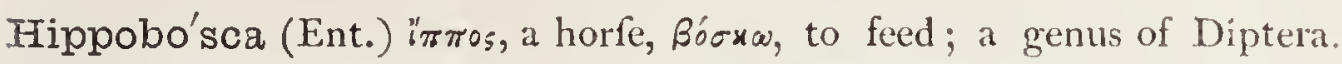
Hippoca'mpus (Ichth.) ' ${ }^{\prime} \pi \pi \circ s$, a horfe, $x \dot{x} \mu \pi n$, a bending; the head and neck contract after death forming fome refemblance to a horfe in miniature.

Fippocastana'ria (Ent.) named from the horfe-cheftnut, Fisculus Hippocastanum, on which, however, the larva is not known to feed.

Hippocrate'a (Bot.) P.N. from Hippocrates, the father of phyfic.

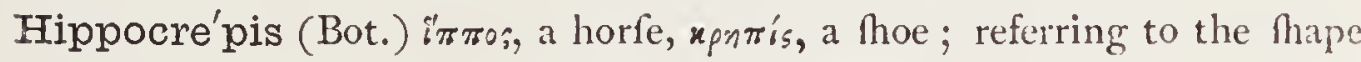
of the pod; a pretty genus of Leguminofa.

Hippodami'a (Ent.) P. N., an ancient mythological name.

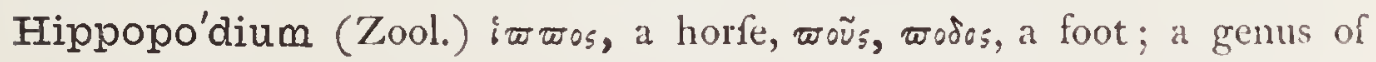
Molluf́ca.

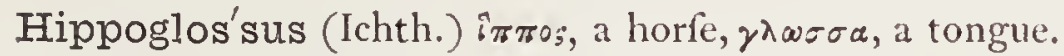

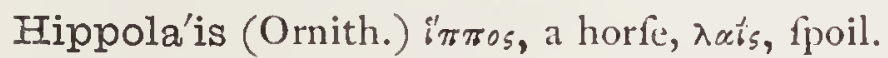

$\mathrm{Hi}^{\prime}$ ppolyte (Zool.) a genus of Cruftacea.

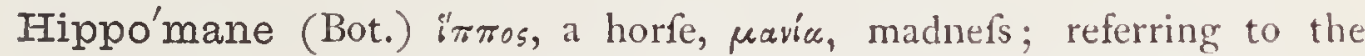
effects of the original plants upon horfes; the manchineel tree; Nat. Ord. Euphorbiaceæ.

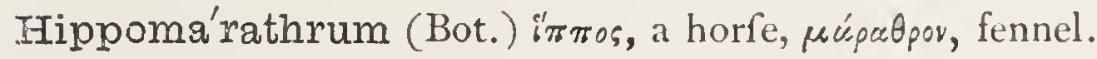

Hip'ponyx (Zool.) iтtos, a horfe, öv Mollunks.

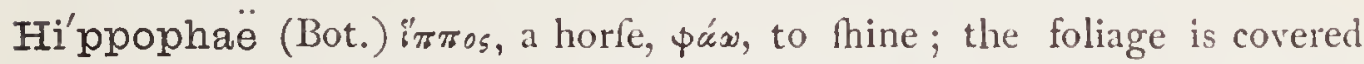
with glittering fcales; Nat. Ord. Elæagnacex.

Hippopotam'ina (Zool.) hippopotamus ; a fub-family of Mammalia.

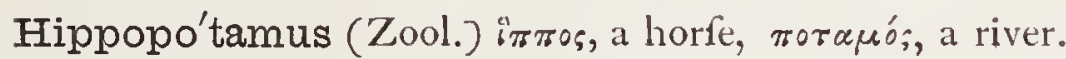

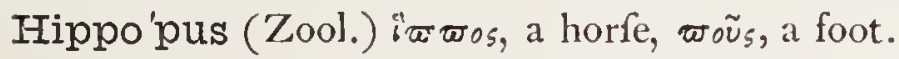

Hipposi'deros (Zool.) 'itros, a horfe, oídnøos, ftrength.

Hippotho'a (Zool.) P.N. from the name of a Nereid; a genus of Polyzoa

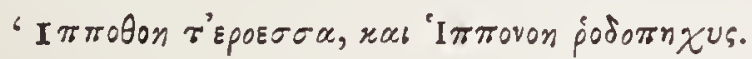

'The charming Hippothoa and rofy-armed Hipponoe.-Hesiod.

Hippu'ris (Bot.) "̈ros, a horfe, ougá, a tail ; the ftem refembles a horfe's tail ; Nat. Ord. Halorageacex.

\section{Hippu'rites}

Hippuri'tidæe (Zool.) imros, a horfe, oupa, a tail; the Horfe-tails.

Hipte'lia (Ent.) ü $\pi \tau$ เs, lying with the face upwards.

Hiræ'a (Bot.) P.N. in honour of $7 . N$. de la Hire, a French phyfician who died in 1727.

IIi'rcus (Zool.) Lat. a he-goat.

Hirta'lis (Ent.) hirtus, hairy. 
Iirta'rius (Ent.) hirtus, hairy.

'Firte'1la (Bot.) hirtus, hairy, alluding to the young branches.

Hi'rtus-a-um (Ichth., Bot.) Lat. Maggy, hairy.

Hiru ndo (Ornith.) Lat. a fwallow; a genus of Pafferes.

Hispaniole'nsis (Ornith.) Lat. relating to the inand of St. Domingo.

Hi'spidæ (Ent.) hifpidus, haggy.

Fispida'ria (Ent.) hispidus, fhaggy, rough.

Fi'spidus-a-um (Zool., Bot.) hifpidus, Thaggy, rough.

Hi'ster (Ent.) hiftrio, an actor; a genus of Coleoptera, remarkable for

feigning death when alarmed.

Histe' ridæ (Ent.) hiffer, fam. term. ida.

Fistrio'nica (Ornith.) hifrionicus, pertaining to an actor.

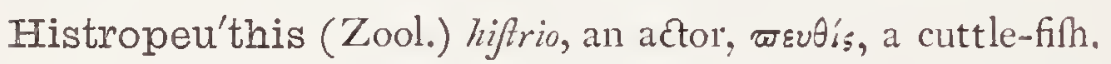

Hobby (Zool.) is defined by Sherwood in 1650 as "Cheval Irlandois" -

"Of fuch outlandifh horfes as are daily brought over unto us I speak not, as the genet of Spain, the courfer of Naples, the hobby of Ireland, the Flemifh roile, and the Spanih nag." - Harrison's Defcription of England. The name of Hobby is also given to one of the Falcons.

Iodgso'ni (Zool.) P. N. in honour of B. H. Hodgfon, Esq.

Hoffmanse'ggia (Bot.) P. N. from F. C. Hoffmansegg, a diftinguifhed naturalift.

Hog (Zool.) Weljb, hych.

Hohenwarthia'na (Ent.) P. N. from Von Hohezvarth, author (in conjunc-

tion with Reiner) of "Botanifche Reifen, u.s. $v$. (Ulm. I793.)"

Hoi'tzia (Bot.) hoitzit, its name in Mexico.

Ho'lcus (Bot.) $\varepsilon \lambda \kappa \omega$, to extract : the plant was fuppofed to extract thorns; a genus of Grafles.

Foldenel'1a (Ent.) P. N. from the oid family name Holden, of Holden, in Lancafhire

Holly (Bot.) Anglo-Sax. Holeyn.

Holmia'na (Ent.) named from the capital of Sweden (Holmia), Stockholm. Holmskio'1dia (Bot.) P. N. from Th. Holmskiold, a Danifh botanical author. Holoce'ntrum (Ichth.) o'ros, the whole, x'srpov, a point; a genus of Acanthopterygian fifhes.

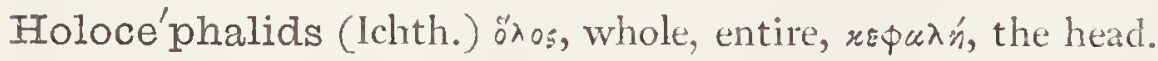

Holochi'lus (Zool.) ồos, whole, entire, $\chi x^{\prime} \lambda_{0}$ s, the finout.

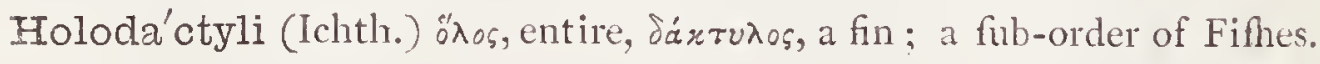

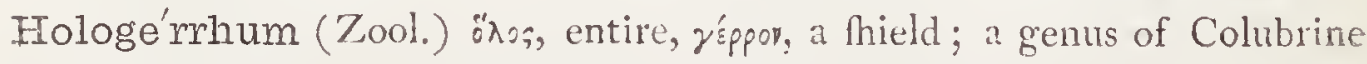
ophidians. 


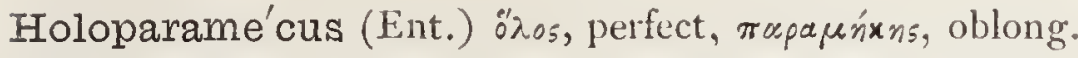

Holoserica'lis (Ent.) holofericeus, wholly filken.

Holoserica'ta (Ent.) ixorn̨ькós, all of filk, filky.

Holoseri'ceus-a-um (Zool., Bot.) Lat. wholly filken.

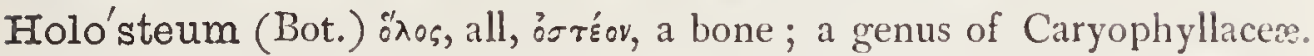

Holo'stomis (Ent.) "̈̀os, entire, orópa, mouth.

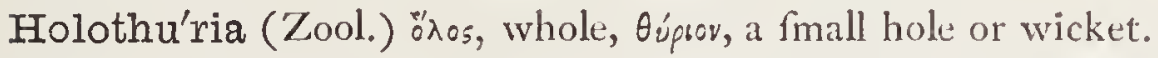

Holothuri'adæ (Zool.) Holothuria, and fam. term; a divifion of Echinodermata.

Holuroph'alis (Zool.) önos, entire, oũpa, tail; a genus of Colubrine ophidians.

Homalocra'nion (Znol.) ópcàós, fmooth, xpaviov, a $\mathrm{kull}$; a genus of Colubrine ophidians.

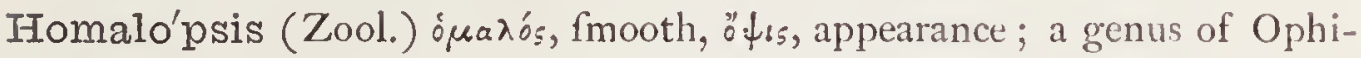
dians.

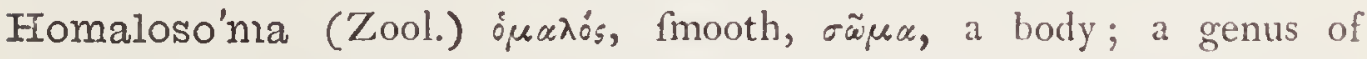
Colubrine ophidians.

Homalo'ta (Ent.) ¿ $\mu a \lambda s_{s}$, even, fmooth.

Ho'marus (Zool.) opapris, well-adjufted, agreeing well together; the Lobiter.

Hombergii (Ent.) P. $\mathrm{N}$ in honour of Homberg, a German naturalist.

Home'ria (Bot.) P. N. from Homer.

Homi'nidæ (Zool.) a family of Mammalia, of which Homo (man) is the sole genus and fpecies.

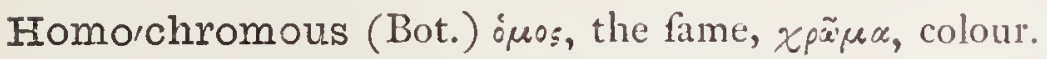

Ho'modes (Ent.) óros, like, equal, fimilar.

Homc'a (Ent.) örosos, fimilar, like, equal.

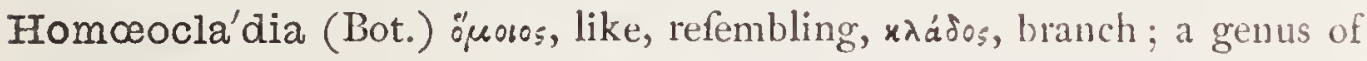
Cryptogamia.

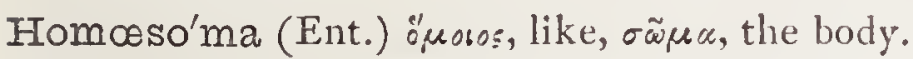

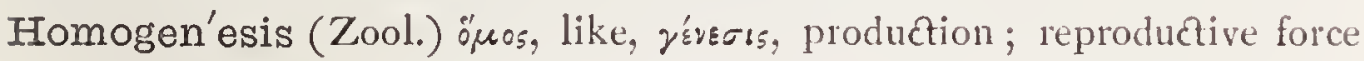
acting through fimilar cells.

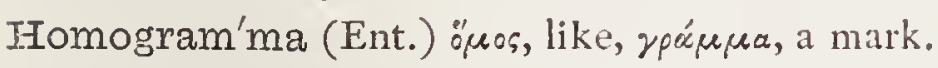

Homoiozo'ic (Fo3. Zool.) applied to parallel bands characterized by the

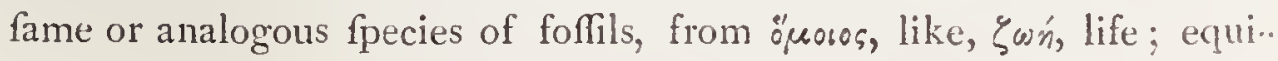
valent to Ifozoic.

Homomy'a (Zool.) ires, the fame, mya, a kind of muffel.

Homoph'ysa (Ent.) óros, like, $\phi \tilde{u} \tau \alpha$, a pair of bellows.

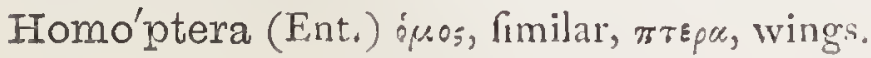


Homopte'ridæ (Ent.) fam. of which genus Homoptera is the type.

Hooke'ria (Bot.) P. N. in honour of Sir William Fackfon Hooker, LL.D., Director of Kew Gardens; a genus of Mufci.

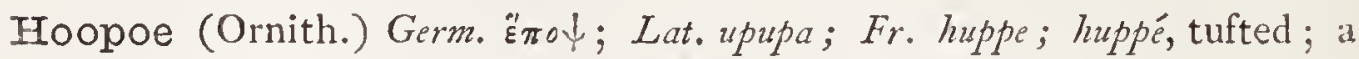
genus of $\mathrm{Pafleres}$.

Hop (Bot.) from the Anglo-Sax. hoppan, to climb.

Ho'pea (Bot.) \{ P. N., and

Hopea'na (Bot.) $\}$ P. N. in honour of Mrs. Thomas Hope, of Deepdene, to whom the Francifca Hopeana was firft fent by her brother, Marfhal Berefford.

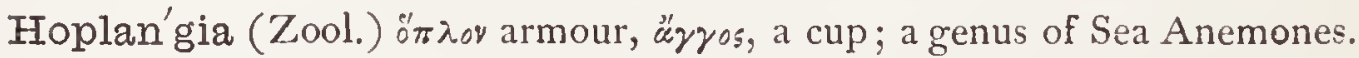
Ho'plia (Ent.) ö $\varpi \lambda_{\diamond v}$, armour.

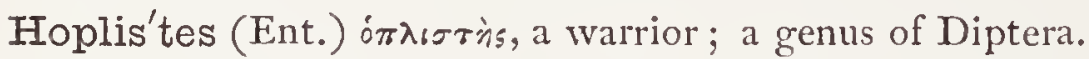

Hoploce'phalus (Zool.) ör $\lambda \circ$, armour, $\varkappa \varepsilon ф \alpha \lambda \dot{n}$, the head; a genus of Colubrine ophidians.

Hoplomy'tilus (Zool.) ö $\varpi$ ¿v, armour, mytilus; a genus of Mollufca.

Hoploste'thus (Ichth.) örnov, armour, $\sigma \tau \tilde{\tilde{n}} \theta_{0 s}$, the brealt; a genus of

Acanthopterygian fifhes.

Hopo'rina (Ent.) ömwprvos, autumnal.

Ho'rdeum (Bot.) Lat. barley ; a genus of Graftes:-

"Grandia fæpe quibus mandavimus hordea fulcis."-VIRG. Ecl. v. 36.

Horke'lia (Bot.) P. N. from Fohn Horkel, Profeflor of Phyfiology at Berlin. Horma'thia (Zool.) ópuatis, a necklace of pearls.

Hormi'num (Bot.) ippéa, to roufe, from its ftimulating qualities; a genus of Labiatx.

Hormo'ceras (Zool.) öpuos, a necklace or chain, x'şas, a horn.

Hormo'spora (Bot.) ópreos, a necklace, spora; a genus of Algæ.

Hornema'nnia (Bot.) P. N. from Profefor Hornemann of Copenhagen.

Hor'net (Ent.) Anglo-Sax. hyrnet.

Horse (Zool.) Anglo-Sax., Old Dutch, Old Germ., and Icel. hors.

Horsfieldii (Zool.) P. N. in honour of the late Dr. Horffield, who wrote on the Zoology of Java.

Hortel'la (Ent.) hortus, a garden.

Horte'nsia (Bot.) in honour of פueen Mortense; the Hydrangea Hortenfia is the common Hydrangea.

Horte'nsis (Ornith., Bot.) Lat. relating to a garden.

Horto'lus (Bot.) a little garden.

Hortuel'lus (Ent.) hortus, a garden.

Hortula'na (Ornith.) hortulanus, pertaining to a garden. 


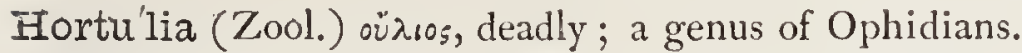

Hosack'ia (Bot.) P. N. from D. Hofack, M.D., F.R.S. of New York.

Hos'ta (Bot.) P. N. from N. T. IIof, a German botanift.

Hotto'nia (Bot.) P. N. from P. Hotton, a Profeffor in the Univerfity of

Leyden, who died in 1709 ; an aquatic genus of Primulaceæ.

Houbara (Ornith.) native name.

Houlle'tia (Bot.) P. N. in honour of $M$. Houlet, a French gardener.

Housto'nia (Bot.) in honour of $W$. Houfton, M.D., a Britifh botanift, who died in 1733 .

Houttu'ynia (Bot.) P. N. in honour of Dr. Houttuyn, a virtuofo of Amfterdam.

Ho'vea (Bot.) P. N. from A. P. Hove, a Polifh botanift and traveller in the Crimea and Perfia; a genus of Leguminofx.

Hove'nia (Bot.) P. N. from D. Hoven, a fenator of Amfterdam.

Howa'rdia (Bot.) P. N. in honour of $M r$. Hozvard, who wrote on the Cinchonas.

Ho'ya (Bot.) P. N. from Thomas Hoy, F.L.S. gardener at Syon Houfe, who died in I $82 \mathrm{I}$; the Wax-flower; a genus of Afclepiadaceæ.

Hub'neri (Ent.) P. N. in honour of Fakob Hübner, author of "Verzeichnifs bekaunter Schmetterlinge," I 8 I 7.

Hudso'nia (Bot.) P. N. from W. Hudfon, F.R.S., a botanical author, and compiler of one of the earlieft Englifh Floras.

Hudso'nius (Zool.) Lat. belonging to Hudfon's Bay.

Hue'rnia (Bot.) P. N. in honour of J. Huernius, an early collector of Cape plants.

Hugo'nia (Bot.) P. N. in honour of Dr. A. J. Hugo, Hanover, a friend of Haller.

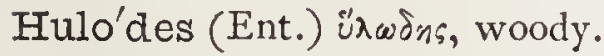

Hulo'didæ (Ent.) the fam. of which the genus Hulodes is the type.

Humbol'tii (Bot., Ichth.) P. N. in honour of Alexander von II lumboldt, the great German philofopher.

Hu'mea (Bot.) P. N. from Lady Hume, of Wormleybury; a curious genus of Compofitæ.

Humera'lis (Ent.) humerale, a cape or covering for the thoulder.

Humida'lis (Ent.) humidus, moift, damp.

Humidus-a-um (Zool., Bot.) Lat. moint, wet.

Hu'milis-e (Ent., Bot.) Lat. humble, low, flight.

Humora'lis (Ent.) humor, fluid, moifture.

Hum'phreyia (Zool.) P. N., a genus of Molluica: 
Hu'mulus (Bot.) humus, the ground; if not fupported it creeps along the ground. 'The common Hop; Nat. Order Cannabinacex.

Hunnema'nia (Bot.) P. N. from John Hunneman, a botanift.

Hun'tleya (Bot.) P. N. in honour of Rev. Mr. Huntley, a zealous cultivator of Orchidaceæ.

Hu'ra (Bot.) its South American name; the Sand-box tree.

Iutchin'sia (Bot.) P. N. from Mifs Hutchins, an Irifh cryptogamift; a pretty little genus of Cruciferæ.

Fiy'acinth (Bot.) P. N. from Hyacinthos, killed by Apollo. Profellor Martyn believed the Hyacinth of the ancients to have been the Tigerlily. It muft certainly have been a kind of turn-cap lily with a bulbous root.

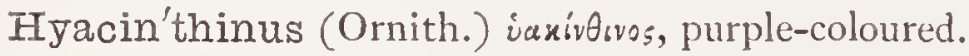

Hyacin'thus (Bot.) P. N., fee above.

Iyæ'na (Zool.) iaıva, ftrictly, a fow, but afterwards applied to a wild beaft having a mane like a hog, whence applied to the Hyæna.

Hyæni'na (Zool.) a fub-family of Mammalia.

Hy'ala (Zool.) ¿̇a ¿s $^{\prime}$ glafs; a genus of Mollufca.

Iya'lea (Ent.) P. N from Hyale, a nymph in the train of Diana.

Hyalina'lis (Ent.) iádıvos, glafs-green.

Hy'aline (Zool.) ïchos, tranfparent, glaffy.

Hyali'tis (Ent.) ขa vos, like glafs.

Hyalone'ma (Zool.) íàos, glafs, mñ a a thread.

Hyalone'midxe (Zool.) hyalonema, fam. term. ide ; the glafs-rope corals of Japan.

FIyber'nia (Ent.) hybermus, wintry; in allufion to the time of appearance of the infeets.

Hyberni'ida (Ent.) hybernict, fam. term. ida.

Hyblæ'a (Ent.) P. N. from Hybla, a mount in Sicily.

Hy'bodus (Fos. Zool.) iBós, a hump, ódós, a tooth; a genus of foffil fharklike Fifhes,

Hybrida'lis (Ent.) hybridus, mongrel.

Hybrida'na (Ent.) hybridus, a hybrid, mongrel.

Hy'brldus-a-um (Ornith., Bot.) Lat. mongrel, baftard.

Hyda'ticus (Ent.) idurıкs, watery, moint.

Fiyda'tina (Zool.) ídátwos, moilt, watery; a genus of Mollufca.

Hy'ảnum (Bot.) ¿jovor, a truffe; a Grcek name applied by Linnæus to a genus of Fungi. 
Hy'dra (Zool.) is $\delta \alpha$, a water-ferpent, a fabled monfter with many heads. Iydractínia (Zool.) a compound of hydra and actinia; a genus of Zoophytes.

Hydradeph'aga (Ent.) hydra, фáya, to eat.

Hydra'idæe (Zool.) hydra; a family of Zoophytes.

Hydra'lis (Ent.) Ujwp, water.

Hydra'ngea (Bot.) isap water, a'yzkĩov, a velfel; from the fhape of the corolla; the typical genus of Hydrangeacea.

Hydra'stis (Bot.) issup, water; it grows in humid places.

Hydre'la (Bot.) ispndós, watery.

Hydre'lia (Ent.) idpndós, watery; from its frequenting moift places.

Hy'dridæ (Zool.) :́spa, a water-ferpent, term ida; a family of Ophidians.

Hydril'la (Ent.) éswo, water; the only fpecimen taken in England was flying over a damp place.

Hydrillo'des (Ent.) hydrilla, हídos, refemblance.

Hydri'na (Zool.) hydra; a divifion of Zoophytes.

Hydro'bia (Zool.) is is $\omega_{\text {g }}$ water, Bıón, to live.

Hydro'bius (Ent.) U̇ंwp, water, Biów, to live.

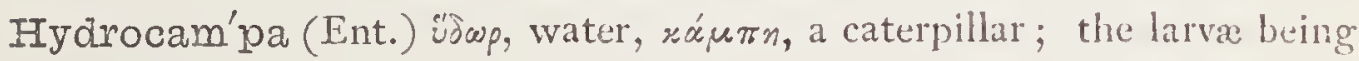
aquatic.

Hyörocampa'lis (Ent.) refembling hydrocumpa.

Hydroca'mpidæ (Ent.) the family of which hydrocumpa is type.

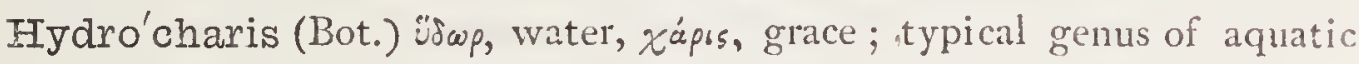
family Hydrocharidacex.

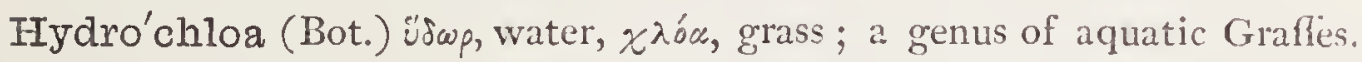
Hydrochœri'na (Zool.) hyárocharus; a sub-family of Mammalia.

Hiydrochce'rus (Zool.) is bup, water, xoõpos, a hog, fwine; the Water-hog; or Capybara.

Hydroco'tyle (Bot.) ¿̇owp, water, rorú.̉n, a cavity; Marth Penny-wort, an infignificant genus of Umbelliferr.

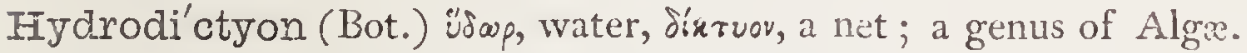

Iydro'chus (Ent.) Ü¿wp, water, oirnos, a habitation.

Hydrécia (Ent.) idsp, water, ơnos, a habitation.

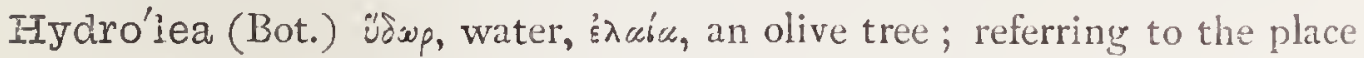
of its growth, and to the fact of its being oily; typical renus of Hydroleacæ.

Ifydromorina (Zool.) hydru, rópov, the mulberry, from the form of the fe aggregated monads. 


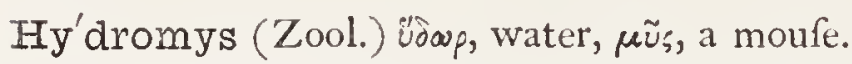

Iydropelti'der (Bot.) Inydropeltis, fam. term. ide; floating plants of

North and Central America.

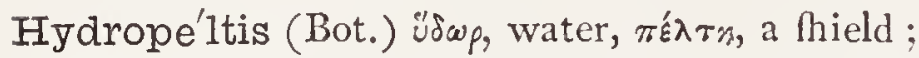

Hydrophi'lidæ (Ent.) hydrophilus, fam. term. ida.

Hydro'philus (Ent.) ijowp, water, фínos, fond of.

Hy'drophis (Zool.) údap, water, ópis, a snake; a genus of Ophidians.

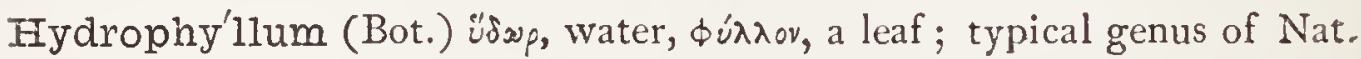

Ord. Hydrophyllacex.

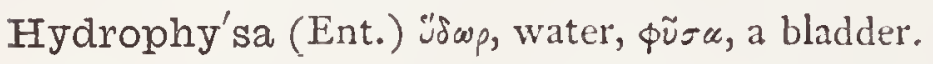

Hydropo'rus (E11t.) ujowp, water, porus, an outlet.

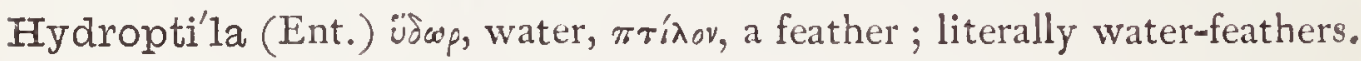
Hydropti'lides (Ent.) hydroptila, with fam. term.; a family of the Phryganidæ.

Hydrosau'rus (Zool.) ¿̇os, water, oúupos, a lizard; applied to the Lacelizard.

Hydrous (Ent.) unexplained.

Hy'drus (Zool.) Udoca, a water-ferpent; a genus of Ophidians.

Hyema'lis (Ornith., Bot.) hyems, winter; in botany, appearing in winter, as Eranthis hyemalis.

Hyema'na (Ent.) hyems, winter; the infect appearing at the beginning of the year.

IIygi'na (Zool.) igırıvos, wholesome; a genus of Ophidians.

Hygrocro'cis (Bot.) iypós, moift, xpoxis, a knot of wool; a genus of Cryptogamia.

Hygrómia (Zool.) íypós, moifture.

Hygro'noma (Ent.) iypós, moift, vou'́n, a pafture, from its habitat.

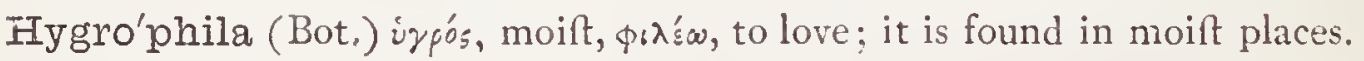
Hygro'tus (Ent.) iypot'́s, wetnefs, moifture.

Hylæosau'rus (Fos. Zool.) incä̃s, belonging to wood, cávpos, a lizard.

Hyle'sinus (Ent.) Ëi^ns,s, a warming in the fun?

Hylo'bates (Zool.) "'in, a wood or forest, faina, to go or traverse.

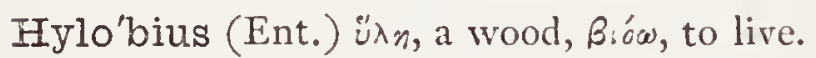

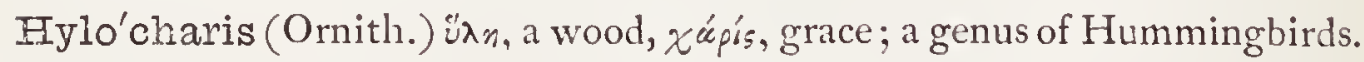

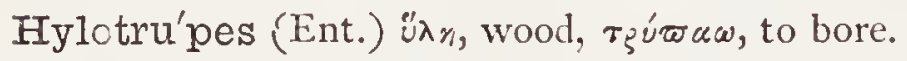

Hymenx'a (Bot.) Hymen, the god of marriage: the leaves are joined in pairs; a tropical genus of Leguminofie.

Hymenan'thera (Bot.) iuń, a membrane, óvanpa, an anther. Hymene'lla (Bot.) dim. of iuń, a membrane. 
Hyme'nium ?

Hyme'nius $\}$

(Bot.) iuńv, a fkin or membrane.

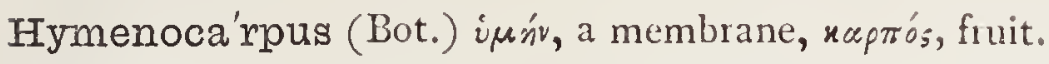

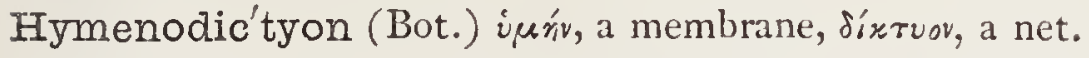

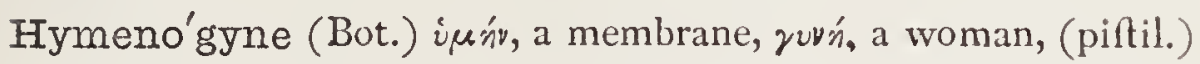

Hymenomy'cetous (Bot.) iunvi, a membrane, !rúrns, a fungus.

Hymenopa'ppus (Bot.) iunv, a membrane, $\pi \dot{\alpha} \pi \pi$ s, the down on the feeds of certain plants which ferves as wings for them.

Hymenophylla'cer (Bot.) a tribe of Ferns, of which the following is the typical genus.

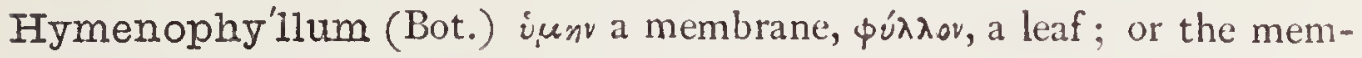
branous-leafed fern.

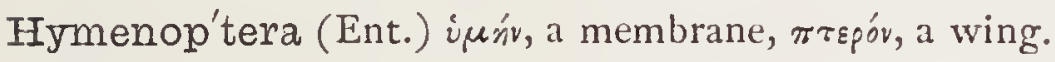

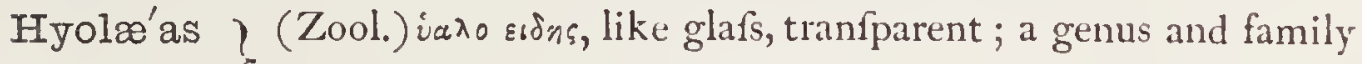
Hyolæ'idær of Mollufca.

Hyopo'tamus (Fos. Zool.) is, ios, a hog, woraros, a river; an extind genus of Mammalia.

Hyopro'rus (Ichth.) is, vós, a hog, wpwipa, the front.

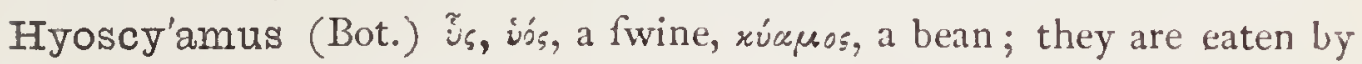

fwine, though poifonous to men: Henbane ; a genus of Solanacex.

Hyo'seris (Bot.) ĩs, vós, a fwine, ópş, endive or fuccory; a genus of

Compofitæ.

Hyp- or Hypo- (Zool., Bot.) üøo, below, underneath.

Hype'coum (Bot.) imn, $x^{\prime} \boldsymbol{c} \omega$, to found; alluding to the rattling of the feeds in the pods; a genus of Fumariace.

Hype'na (Ent.) irrinn, the chin, the beard; referring to the projecting,

fquamofe palpi.

Hypena'ria (Ent.) ix'inn, a beard or mouftache.

Hype'nidæ (Ent.) hypena, fam. term. ida.

Hypeno'des (Ent.) hypena, eibos, refembling hypena.

Hy'pera (Ent.) ïtrepa, a kind of caterpillar mentioned by Ariftotle.

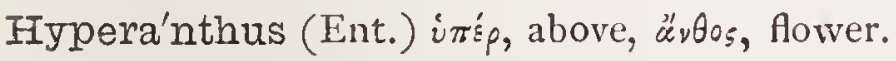

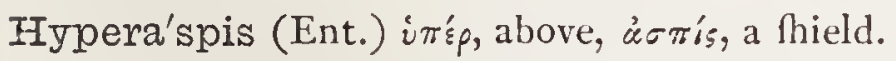

Hyperbo'reus-a-um (Ornith.,Bot.) Lat., northern, as Antennaria hyperbore.

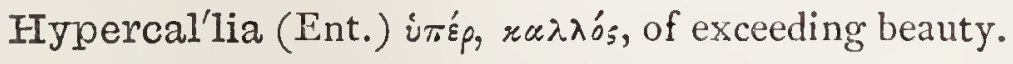

Fyperica'na (Ent.) feeds on St. John's wort (Hypericum)

Hype'ricum (Bot.) ixśp, above, fuperior, eixwón, an inage or fpectre, becaufe fuppofed to protect from evil fpirits.

Iyperme'cia (Ent.) imepuńixs, exceedingly long. 


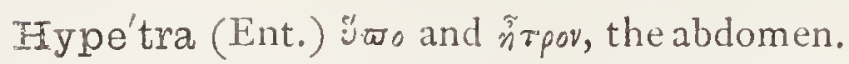

Hyphr'ne (Bot:) iquives to entwine, alluding to the fibres of the fruit; a genus of Palms.

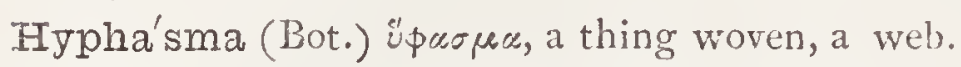

Hyphi'drus (Ent.) ípiopow, to perfpire lightly.

Hyphomy'cetous (Bot.) üpos, a web, rúxns, a fungus.

Hy'pnum (Bot.) î $\pi$ vov, a kind of mofs growing on trees; a genus of Mofles.

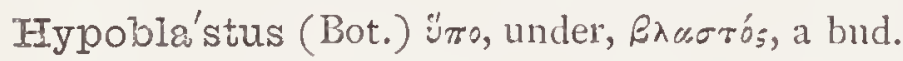

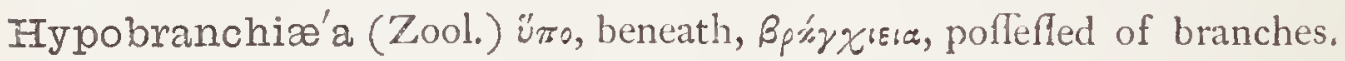

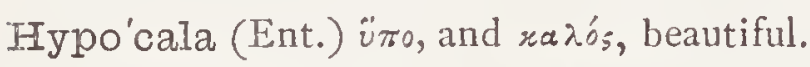

Iypoca'lidæ (Ent.) fam. of which genus Iypocala is the type.

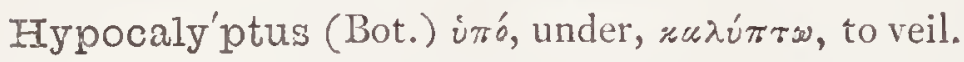

Hy'pochil (Bot.) referring to the flowers of Orchids, from inó, under, and xєinos, lip.

Hypochœ'ris (Bot.) iøó, for, xoípos, a pig; it is eaten by fwine; a genus of Compolite called Cat's-ear.

Hypocre'pia (Zool.) iwwos, a horfe, xpn ‘s, a fhoe; the circle of tentacula around the mouth is horfe-fhoe fhaped; an order of Polyzoa. The word fhould have been Hippocrepia.

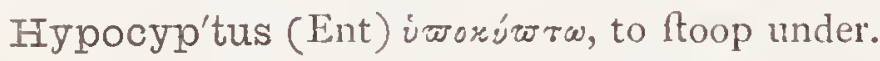

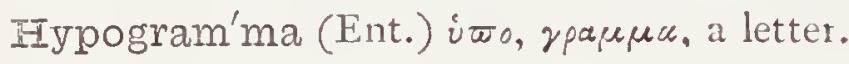

Hypogram'midre (Ent.) fam. of which genus Hypogramma is the type.

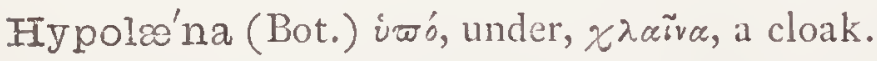

IIypola'is (Ornith.) iøodás, was a name ufed by Ariftotle for fome fmall bird, perhaps the tit-lark or the hedge-fparrow.

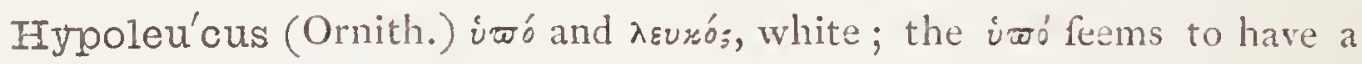
diminifhing effect, equivalent to "fomewhat white."

Hypo'lithus (Ent.) iøó, under, $\lambda_{6} \theta_{0}$, a ftone.

Iypoly'ssus (Bot.) iøó, under, lyfus; a genus of Fungi.

Hypo'lytrum (Bot.) iøó, under, Ěxvrpov, a cover.

Iyponomeu'ta (Ent.) iøovopsúerv, to undermine; to make underground parlages or mines.

Hypophlœ'us (Ent.) iøó, under, $\phi \lambda$ orś, bark.

Hypopy'ra (Ent.) iøó, beneath, wupá, a pyre or pile of wood

Hypopy'rida (Ent.) fam. of which the genus Hypopyra is the type.

Iypo'spila (Ent.) iøo and $\sigma$ triov, a fpot; alfo a genus in Botany.

Iypotri'x (Ent.) iwo and $\theta$ pi I $^{\prime}$, the hair.

IIjpo'xis (Bot.) ivo', beneath, 'ó' ', tharp.

Iypsilophus (Ent.) idinotos, with a high creft. 


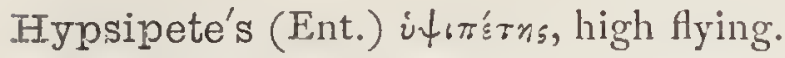

Hypsiprym'nus (Zool.) Üłos, height, wpupuós, the hind part; the Kangaroo rat.

Hypsirhi'na (Zool.) ¿ł $\psi_{0 s}$, height, $\rho$ or, the fnout; a genus of Ophidians.

Hypsirhyn'chus (Zool.) üłos, height, púxxos, the fnout; a genus of Colubrine ophidians.

Hypsopy'gia (Ent.) üłos, height, пvy'n, rump.

Hy'ptis (Bot.) ¿̇øros, laid on one's back; the limb of the corolla is

turned on its back.

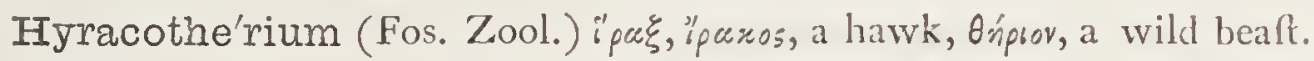

Hy'rax (Zool.) '"px

belonging to the Rhinocerina.

Hyr'iæ (Zool., Ent.) P. N., the name of a town in Bœotia.

Hy'ssia (Ent.) i $\sigma \sigma o s$, a dart or javelin.

Hy'ssop (Bot.) Latin, Hy/lopus ; Hebreav, Ezob.

Hyste'rium (Bot.) ior'sproเs, want, need; from the appearance of infefted trees; a genus of Fungi.

Iystri'cidæ (Zool.) a family of Mammalia of which Hyfrix is the type. Hy'strix (Zool.) $\tilde{H}^{\prime} \tau \rho \bullet \xi$, a porcupine.

Ia'ntha (Bot.) 'áv日rvos, violet-coloured; a genus of Orchidacex.

Ia'nthe (Bot.) iévervos, violet-coloured; a genus of Scrophulariacex.

Ian'thina (Zool., Ent.) íćvervos, violet-coloured.

Ibbetso'nia (Bot.) P. N., a genus of Leguminofx.

Iberide'lla (Bot.) dim. of iberis ; a genus of Crucifera.

Ibe'ris (Bot.) P. N. from the country called Iberic, now Spain; Candytuft; a genus of Cruciferæ.

I'bex (Zool.) Lat, a wild goat.

Ibi'dium (Bot.) the bird Ibis, and Eidos, refemblance; a genus of Orchidacer.

I'bis (Ornith.) the Greek name of that Egyptian bird to which divine honours were paid; the word is of Eaftern origin.

I'bla (Zool.) unexplained; a genus of Cirripedes.

Ica'cina (Bot.) Eixás, the number twenty; a genus of Olacacex.

Icaco'rea (Bot.) Eixús, twenty, zópns, a hioot,or fprout; a genus of Mirfinacex. 
Icara'nda (Bot.) Ei*ús, twenty, ùvńs, àvofós, a male (ftamen); a genus of Bignoniacer.

Ica'ria (Ent.) P. N. Icarus, an ancient Greek proper name; a genus of Hymenoptera.

I'carus (Zool.) P. N., the fon of Dxdalus; a genus of Mollufca, family Icaridx.

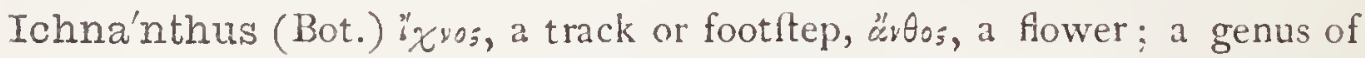
Gramina.

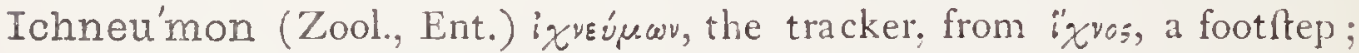
applied to a beaft and an infect.

Ichneumonifor'mis (Ent.) Ichneumon and forma, thape; refembles an Ichneumon Ay.

Iohni'tes (Fos. Zool.) ixyos, a footitep; a term applied to all folfil footprints.

Ichnoca'rpus (Bot.) '̌xvos, a veltige, rapтós, fruit.

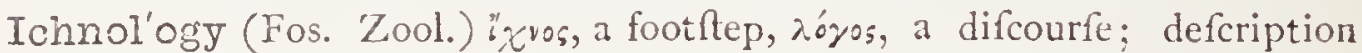
of forfil footprints.

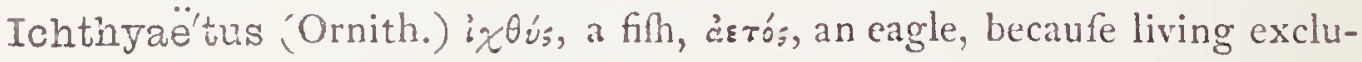
fively on filh.

Ichthy'apus (Ichth.) ' $\chi \chi^{\theta}$ '́, a filh, "̈wovs, without feet.

Ichthyd'ina (Zool.) ' $\chi^{\theta \dot{v}}$, a fith; a genus of Infuforia.

Ichthy'dium (Zool.) ' $\chi$ Aus, a fin, siōos, like; a genus of Infuforia.

Ichthyme'thia (Bot.) i $\chi^{\theta} \dot{v}_{s}$, a filh, $\mu \varepsilon \theta \dot{v} \omega$, to intoxicate; a genus of Leguminofie.

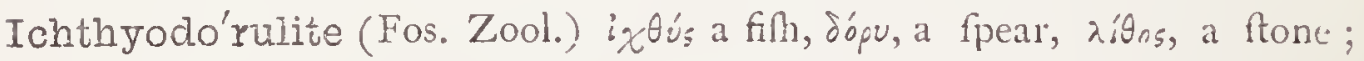
the foltil fin-fpines, or defences of fithes.

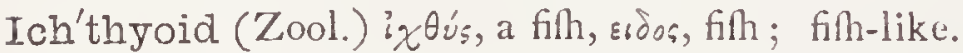

Ichthy'olite (Fos. Zool.) i $\chi \chi^{\theta} \dot{u}_{5}$, a fifh, $\lambda \hat{\theta}_{05}$, a ftone; a palxontological term for a foffil fifh, or any portion of a fin.

Ichthyo'logy (Ichth.) ixtés, a fifh, hóyos, a difcourfe.

Ichthyopa'toiites (Fos. Zool.) ixoús, a.fin, aarés, to walk or tread; filh-tracks, i.e., imprints of pectoral fin-rays.

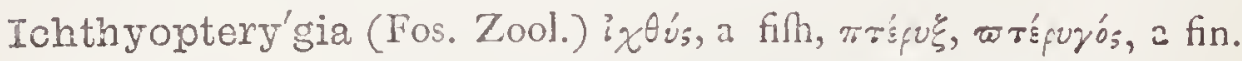

Ichthyosau'rus (Fos. Zool.) 'xtús, a filh, ocípos, a lizard.

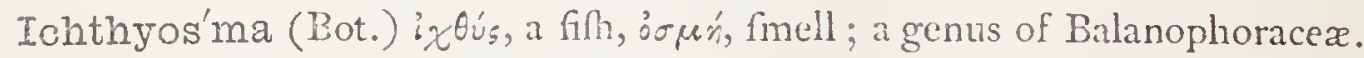

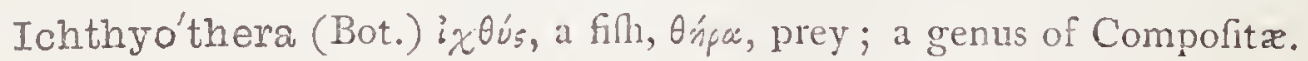
Ichthy'stoma (Zool.) ir, $\theta$ 's, a fin, oróno, mouth, from the conical pointed tentacles of the actinia, resembing the little frarp teeth of some filles. 
I'cica (Bot.) its name in Guiana; typical genus of Icicacez.

Ictera'na (Ent.) 'єrepos, a yellow bird; in allufion to the colour of the infect.

Icteri'na (Ornith.) "‘repos, a yellow bird, of the order Pafferes.

Icte'rus (Ornith.) '‘zrpos, a bird mentioned by Pliny, of a yellowin-green colour, now applied to a genus of Orioles.

Ic tis (Zool.) Lat. a weafel; a genus of Mollufca, family Leinapontiadx.

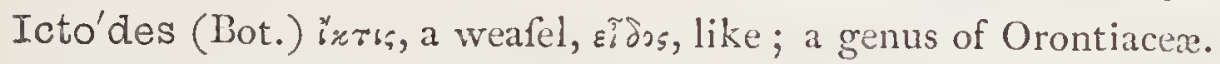

Idæ'us (Bot.) P. N., from mount Ida, in Crete; fpecific name of the rafpberry or Rubus Itceus; alfo a fpecies of Vaccinium called Vitis Idra.

Ida'lia (Zool.) P. N., one of the furnames of Venus; a genus of Mollufca.

Ida'lias (Zool.) Idalia was a furname of Venus; a genus of Goniodoridx, a divifion of the Mollurca.

Idar'nes (Ent.) zioup, fodder.

Idele'ria (Bot.) P.N., a genus of Gramina.

Idmo'nea ('Lool.) P. N. perhaps from Idmon, one of the Argonauts; ijuso,

knowing, fagacious; a genus of Polyzoa.

Ido'thea (Bot.) Eĩos, form, Aziov, divine; a genus of Liliacex.

I'floga (Bot.); a genus of Compolitæ.

Igna'lis (Ent.)

Ignea'lis (Ent.) $\}$ ignis, fire; being flame-coloured.

Igna'tia (Bot.) P. N. in honour of St. Ignatius, the former name of

Strychnos; a genus of Loganiacex.

Ignicapil'lus (Ornith.) ignis, fire, capillus, hair; red-haired.

Iguan'odon (Fos. Zool.) Igrana, a genus of Saurian reptiles, ooov;, odovт05, a tooth.

I'larus (Ent.) i iapós, cheerful; it Thould be Hilarus.

Ildefo'nsia (Bot.) P. N., a genus of Scropliulariacex.

I'lea (Bot.) zìzós, a lurking-place; a gerrus of Confervoid Algæ.

Ileosper'mum (Bot.) $i \lambda n$, or $\varepsilon i \lambda n$, a crowd, $\sigma \pi \dot{p} p \mu a$, feed; a genus of Menifpermaceæ.

Ilez (Bot.) the holm-oak or evergreen oak. Pliny mentions two, of which one was probably the holm-oak, the other the Quercus Ilex, Kermes-oak. Also, the generic name of the Holly.

Ili'acus (Ornith.) ilia, the flanks.

Ilicifol'ius-a-um (Ent., Bot.) Ilex, the holm-oak, folum a leaf; in Eıtomology, from the refemblance of the infect when at reft to the withered leaves of the oak and holm-oak refpectively; in Botany, from fimilarity of foliage to that of the holly.

Ilisin'ex (Bot.) the Nat. fam. which contains the Ilex or Holly. 


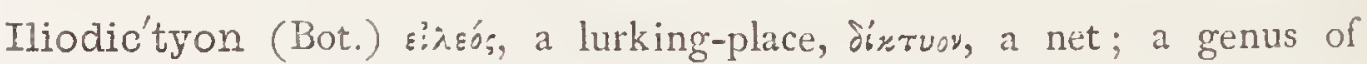
Fungi.

Ille'celorum (Bot.) Illecebra, of Pliny, from illicio, to allure ; typical genus of Illecebracex.

Illi'cium (Bot.) illicio, to allure, referring to its perfume; Star-anife, a genus of Dilleniacer.

Illi'gera (Bot.) P. N. in honour of Illiger; a genus of Combretacer. Inligerel'lus (Ent.) P. N. from C. Illiger, author of a fecond edition of the Vienna Catalogue.

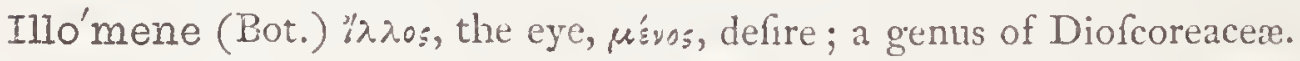

Illorica'tus-a-um (Zool.) Lat. fhell-lefs, from in, not, lorica, a corfelet.

Illospo'rium (Bot.) '̇ $\lambda \lambda \omega$, to envelope, $\sigma \tau$ ópos, a fporule.

Illuna'ria (Ent.) illunis, moonlefs; the lunule not occurring on the wings of this infect.

Illustra'ria (Ent.) illufris, remarkable, beautiful.

Iiluta'lis (Ent.) illutus, unwahed.

Iluan'thos (Zool.) ìís, mud, är0os, a flower; a genus of Zoophytes.

Ilus (Bot.) a brother of Ganymedes.

IIy'bius (Ent.) ìús, mud, Biów, to live.

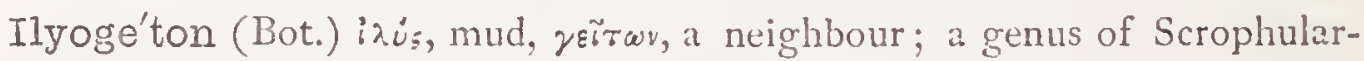
iacex.

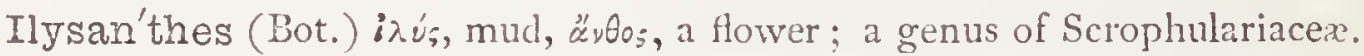

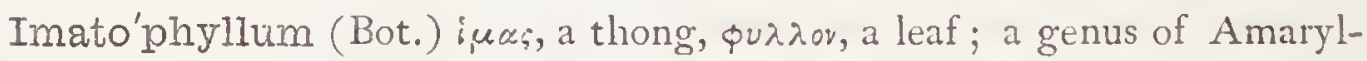
lidaceæ.

Imbrica'ria (Bot.) imbricus, rainy; a genus of Sapotacex.

Imbricária (Zool.) imbricatus; a genus of Mollufca.

Imbrica'rias (Zool.) imbricatus, covered with tiles; a genus of Mollufica, family Fafciolariadre.

Imbrica'tus-a-um (Bot.) Lat. having the appearance of tiles on a roof.

Imbuta'ta (Ent.) imbutus, dyed, tinged; leferring to the rofy tint on the forewings.

Imho'fa (Bot.) P. N. in honour of M. Imhof; a genus of Amaryllidaceæ.

Imita'ria (Ent.) imitare, to imitate.

Immacula'lis (Ent.) immaculatus, unfpotîed.

Immana'ta (Ent.) immanare, to flow into; from the variablenefs of the fpecies.

Immer'sus-a-um (Bot.) Lat. part. dipped.

Inmuta'ta (Enl.) immutatus, unchanged. 
Impa'tiens (Bot.) this name is given to it in confequence of the ovarium, from its extreme irritability, burfting from the bottom to the top on the flightert touch; the Touch-me-not; a genus of Balfaminacea.

Impe'nnis (Ornith.) Lat. winglefs.

Impera'ta (Bot.) imperare, to govern; the fpikes are like the plumes of a Cap of State.

Impera'tor (Zool.) Lat. a commander; applied to a Balanus, becaufe of its beautiful imperial purple colour.

Imperato'ria (Bot.) fo called from its reputed imperial virtues in medicine; a genus of Umbelliferr.

Imperia'lis (Ornith., Ent., Bot.) Lat. imperial, commanding.

Implica'lis (Ent.) implico, to entangle, to confufe.

Impluvia'ta (Ent.) impluviutus, Thaped like an impluvium, i. c., having a fquare border.

Improvi'sus (Zool.) Lat. unexpected.

Ina'chidæ (Zool.) the family of Decapod cruftaceans of which Inachus is the typical genus.

I'nachus (Zool.) P. N. from Inachus, firft king of Argos.

Incana'ria (Enț.) inconus, quite grey, hoary.

Incarvi'llea (Bot.) P. N., a genus of Bignoniaces.

Incerta'lis (Ent.) incertus, doubtful.

Incila'ria (Zool) incile, a gutter, with reference to the gutter-like chann-1 which divides the mantle from the foot.

Inclina'tus-a-um (Ent.) Lat. leaning out of the perpendicular.

Inclu'sus (Zool.) Lat. fhut in, confined.

Incolora'lis (Ent.) incolor, without colour.

Incoma'lis (Ent.) incomis, unpleafant.

Incompta'lis (Ent.) incomptus, unadorned.

Inconspi'cuus-a-um (Zool., Bot.) Lat. not remarkable.

Indica'lis (Ent.) indico, to point out, to declare.

Indica'tor (Ornith.) Lat. a guide; from the birds leading the Hottentors and others to the hives on which they feed, they are called Honey Guides. Indiga'ta (Ent.) indigens, poor, i.e., in appearance.

Indigo'fera (Bot.) indigr, a blue dye Iuff, fero, to bear; a genus of Leguminofa.

In'dris (Zool.) formed from the native word Indri, faid to mean " man of the woods."

Indu'sium (Bot.) Lat. a woman's under-garment; applied to the covering of the fori of ferns. 
Ine'ptus (Ornith.) Lat. unfuitable, abfurd; Ppecific name of the Dodo, from its fuppofed awkwardnefs. The Inepti of Illiger are equiralent to the Inertes of 'Temminck.

Infaus'tus-a-um (Ornith.) Lat. unlucky, unfortunate.

Inferobran'chia (Zool.) inferus, underneath, branchia, gills; a fub-order of the Gymnobranchiatæ divifion of the Mollufca,

Infima'lis (Ent.) infimus, inferior in quality.

Infla'tæ (Ent.) the larva feeds on the capfules of the Bladder Campion, (Silene inflata.)

Infla'tus-a-um (Bot.) Lat. bladder-like, as in the calyx of Silcne inflata.

Inflexa'lis (Ent.) inflexus, bent, curved.

Infundibula'ta (Zool.) infundibulum, a funnel; Zoophytes having the tentacles difpofed in a ring round the unarmed mouth.

Infusca'lis (Ent.) infufcus, duky, brown.

Infuso'ria (Zool.) procured from infufions, or watery folutions; a group of the Protozoa, characterized by the prefence of a mouth, whence the remaining orders are fometimes called aftomata.

In'ga (Bot.) a South American name adopted by Marcgraff.

Ingenhou'sia (Bot.) P. N., a genus of Leguminofæ.

Inglu'vies (Ornith.) Lat. the Crop of birds.

Ingrata'lis (Ent.) ingratus, unpleafant.

Innota'ta (Ent.) innotatus, marked.

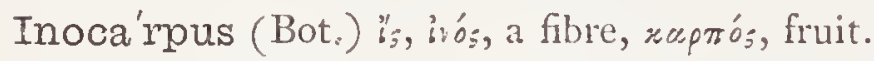

Inoce'ramus (Fos. Zool.) '̌s, ivós, fibre, xéparuos, a veflel.

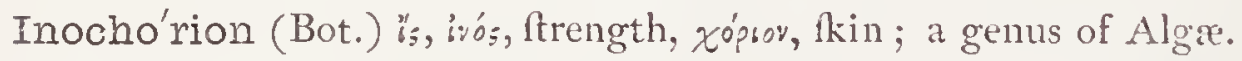

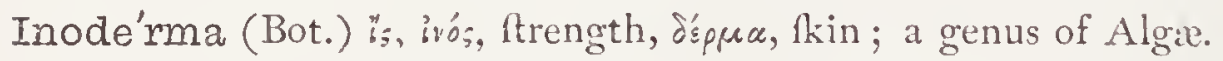

Inolo'ma (Bot.) '̌s, ivos, ftrength, $\lambda \tilde{\omega}^{\prime} \mu \alpha$, fringe; a genus of Fungi.

Inome'ria (Bot.) ':, ivós, ftrength, répos, a part; a genus of Algae.

Inopia'na (Ent.) inops, helplefs.

I'nops (Zool.) Lat. needy, helplefs.

I'nopus (Ent.) 䓅, ivós, ftrength, force, woṽs, a foot; a genus of Diptera.

Inorna'ta (Ent.) inornatus, unadorned.

Inquinata'lis (Ent.) inquinatıs, polluted, defiled.

Inscripta'lis (Ent.) infcriptus, unmarked.

Insecti'vora (Zool.) infecta, infects, voro, to devour.

Insesso'res (Ornith.) infideo, to fit upon, to perch; the Tree-perching birds.

Insignipennel'la (Ent.) inflgnis, marked, penna, a wing.

Insi'gnis-e (Ent., Bot.) Lat. beautiful, remarkable; e. g., Cypripediun inggrane. Insignita'lis (Ent.) in/ignatus, diftinguifhed. 
Insta'bilis (Ent.) Lat. changeable; from the great variation of the fpecies. Instita'le (Bot.) infita, a bandage or girth, referring to the appearance of the plants; a genus of Fungi.

Instita'lis (Ent.) inftita, a fringe.

Interita'lis (Ent.) interitus, deftruction.

Interjuncta'lis (Ent.) inter, within, junctus, united.

Intermedia'lis (Ent.) inter, between, medium, the middle.

Interme'dius-a-um (Bot.) Lat. intermediate, $i$, e., combining the characters of two fpecies.

Intermica'lis (Ent.) inter, within, mica, a crumb, a morfel.

Interna'lis (Ent.) internus, inward, internal.

Internita'lis (Ent.) inter, within, nitens, Mining.

Interoper'culum (Ichth.) inter, within, operculum, a cover or lid.

Interpuncta'lis (Ent.) inter, within, punctum, a fmall hole.

Intru'sae (Ent.) intrudo, to thruft in.

In'tsia (Bot.); a genus of Leguminofx.

Intybe'llia (Bot.) dim. of intyuus; a genus of Compofitx.

In'tybus (Bot.) the endive, and primary or Latinized form of the word;

a genus of Compofitr.

I'nula (Bot.) corrupted from Helenium; a genus of Compofitre.

Inula'ster (Bot.) inulus, and after; a genus of Compofitx.

Inun'guis (Zool.) Lat. without claws.

Invertebra'ta (Zool.) in, without, or neg. vertebratus, having vertebri.

Invisa'lis (Ent.) invifus, unfeen.

Involucra'ria (Bot.) involucrum, a wrapper; a genus of Cucurbitaceæ.

Involu'crum (Bot.) Lat. a wrapper; the outer calyx of the Mallows,

Dianthus, \&c.

I'o (Ent.) a Grecian heroine, famous for her beauty and her misfortunes-

Ovis, Met. i. 588 ; a fpecies of diurnal butterfly.

Io'des (Ent.) iẃdns, ruft-coloured, violet-coloured.

Io'des (Bot.) iásns, violet-coloured; a genus of Phytocrenacex.

Iodi'na (Bot.) iwóns, violet-like, dark-coloured; a genus of Olacacer.

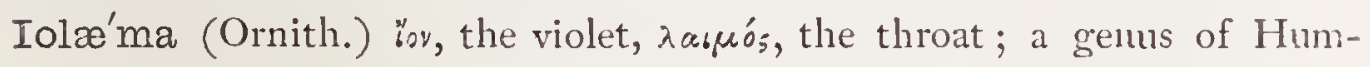
ming-birds.

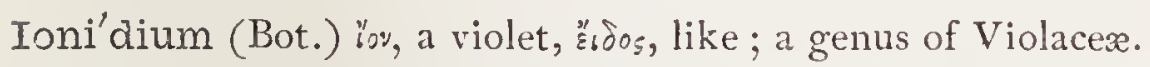

Ionopsi'dium (Bot.) isy, the violet, ö $\psi \varsigma$, refemblance; a genus of Cruciferæ.

Ionop'sis (Bot.) เov, a violet, "̋łı, appearance.

Io'thia (Zool) a genus of Mollufea.

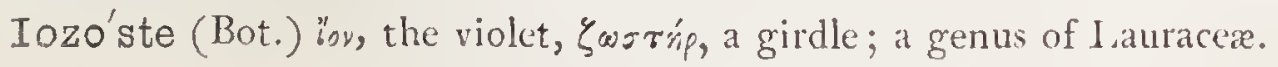


Ipecacua'nha (Bot.) ipe, a native word in Peru for root: cacuan, a native diftinction for that root.

Iphige'nia (Bot.) P. N., the daughter of Agamemnon and Clytemneftra: a genus of Liliacex.

Iphio'na (Bot.) '/申ros, ftrong, goodly; a genus of Compofitæ; "фuv», was the ancient name of an herb.

Ipome'ria (Bot.) i iów, to prefs down, $\mu^{\prime} \dot{s}$ pos, a part; a genus of Polemoniaceæ.

Ipomœ'a (Bot.) ' $\psi$, bindweed, "oreors, like; a genus of Convolvulacex.

Ipomo'psis (Bot.) imów, to ftrike forcibly, ơ:s, fight; refering to the dazzling flowers; a genus of Polemoniacer.

Ips (Ent.) : $\psi$, a worm that eats horn and wood, perhaps a cynips.

I'psea (Bot.) ' $\psi$, a cynips infect, from fancied refemblance; a genus of Orchidacex.

Iresi'ne (Bot.) Eipos, wool; alluding to the woolly appearance of the branches; a genus of Amarantacer.

Iriar'tea ) (Bot.) P. N. in honour of Iriarte, the celebrated Spanin Iriarte'lla\} botanif.

Iridæ'a (Bot.) coloured like the iris or rainbow; a genus of marine Algx. Iridi'na (Zonl.) Iris, the rainbow; a genus of Mollufca, family Iridinida. I'ris (Bot.) iris, the eye; alluding to the variety and brilliancy of its colours; typical genus of Iridacere.

Irpex (Bot.) Lat. a harrow or rake; a genus of Fungi.

Irradiel'la (Ent.) irradiare, to caft forth rays.

Irrecta'lis (Ent.) in, not, rectus, ftraight.

Irreti'tus (Zool.) irretire, to entangle in a net; from this bat being frequently arrefted in the ftrong web of two large fpiders.

Irrigua'ta (Ent.) irriguus, well-watered; the wings being traverfed by a feries of wavy fream-like lines.

Irri'guus-a-um (Bot.) Lat. well-watered, $i . e$, growing in marthes or marhy places, as Carex irrigua.

Irrora'tus-a-um (Zool.) irroro, to wet or moiften with dew.

Irrorel'la (Ent.) irrorare, to bedew, befprinkle; from the black dots which ftud the wings.

Isa'chne (Bot.) "ros, equal, “̈ærn, a glume.

Isa'nthera (Bot.) "ros, equal, anthera; a genus of Solanacex.

Isan'thus (Bot.) ڤ̆os, equal, äıos, a flower; alluding to the regulu: corolla.

Isa'ria (Bot.) 'Gos, equal; alluding to the filaments. 
Isar'thron (Ent.) "ซos, equal, äplpov, a joint.

Isatida'lis (Ent.) feeds on ifatis or woad.

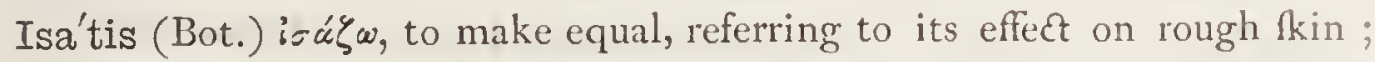
Woad; a genus of Cruciferæ.

Isau'xis (Bot.) 'ซos, equal, aй

Ischæ'mum (Bot.) " $\sigma \chi \omega$, to ftop, airua, blood; referring to its medical properties.

Ischa'rum (Bot.) 'r $\chi a$, to hold in check; a genus of Aracere.

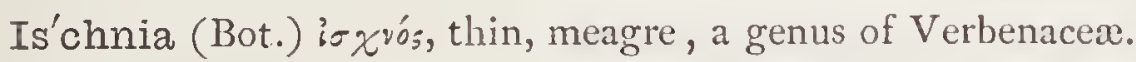

Ischnoga'ster (Ent.) io $\chi^{v^{\prime} \sigma_{j}}$, thin, meagre, yúrrnp, the belly; a genus of Hymenoptera.

Ischnogna'thus (Zool.) is zvos, thin, ricádos, the jaw; a genus of Colu. brine ophidians.

Ischnome'ra (Ent.) 'Exvós, thin, unpoi, the thighs.

Ischno'poda (Ent.) ir xvós, thin, moũs, wo

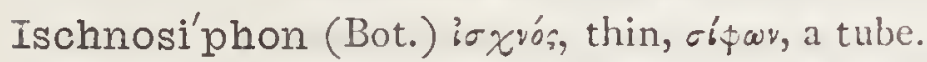

Ischy'odus (Fos. Zool.) is xús, ftrength, ódoús, a tooth.

Iser'tia (Bot.) P. N. from P. E. Ifert, a Dutch furgeon on the coaft of Guinea.

Isidio'ides (Bot.) refembling Ifidium.

Isi'dium (Bot.) 'Gos, equal; alluding to the fmall differences which exift

between the podetia; a genus of Cryptogamia.

I'sis (Zool., Bot.) P. N. of an ancient goddefs; a genus of Zoophytes; alfo a genus of Iridacex.

Isla'ndicus-a-um (Ornith., Bot.) Lat. relating to Iceland; $\iota . g$. Cetrariu Ifandica, or Iceland mors.

Isme'lia (Bot.) a genus of Compofitx.

Ismene (Bot.) P. N. from Ifmene, the daughter of Edipus and Jocafta.

Isme'nia (Zool.) P. N. from Ifmene, daughter of CEdipus and Jocafta, and fifter of Antigone; a genus of Mollufca, family 'Terebratulidie.

Isnar'dia (Bot.) P. N. in honour of A. T. D. d' Ifnard, a French botanift; a genus of Onagraceæ.

Isoa'rca (Zool.) 'Gos, equal, the genus arca; a genus of Mollufca, fanily Arcadx.

Isocar'dia (Zool.) \%ros, like, napdia, the heart; the Heart-cockle; a genus of recent and foffil thells of the family Cyprinidx.

Isoca'rpha (Bot.) ไoos, equal, xáppn, chaff.

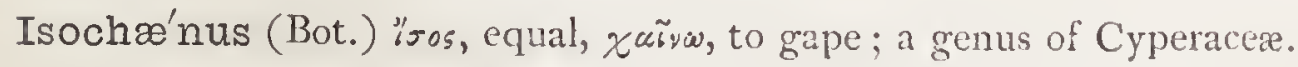

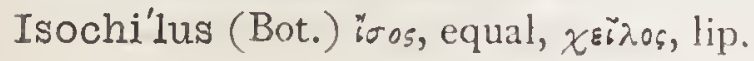


Isoco'ma (Bot.) :'cos, equal, ropeń, a tuft; a genus of Compofitæ.

Isocyr'tus (Ent.) "roos, equal, xuptós, curved.

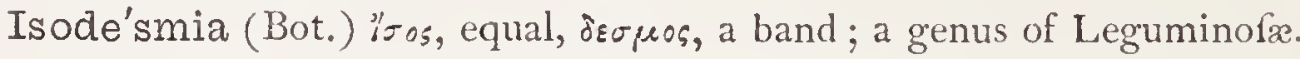

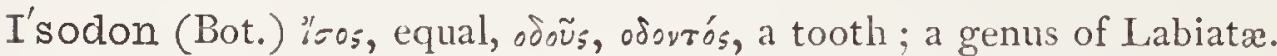

Iso'etes (Bot.) "ros, equal, हैros, the year; the plant being evergreen; a genus of Marfileacex.

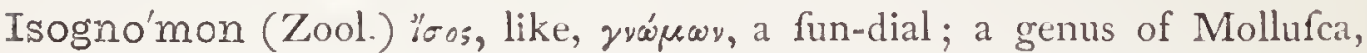
family Aviculidx.

Iso'gona (Ent.) 'ซos, equal, ravice, an angle.

Iso'lepis (Bot.) i'ros, equal, $\lambda \varepsilon \pi i s$, a fcale; a genus of Cyperaceæ.

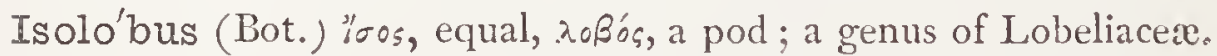

Isolo'ma (Bot.) " $\sigma^{\prime} s$, equal, $\lambda \tilde{\omega} \mu \alpha$, a fringe; a genus of Filices.

Isome'ria (Bot.) "ros, equal, $\mu$ śpos, a part; a genus of Compolitie.

Iso'meris (Bot.) fame derivation; a genus of Capparidacer.

Isomérium (Bot) fame derivation; a genus of Proteaceæ.

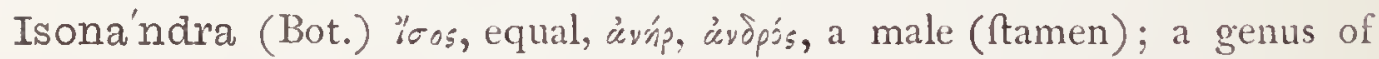

Sapotacex; the Gutta-percha tree belongs to this genus.

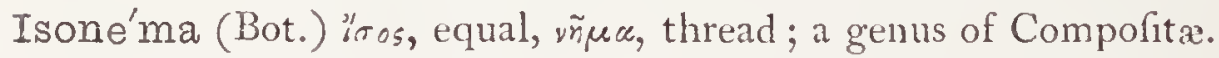

Isopap'pus (Bot.) 'sos, equal, $\pi \dot{\alpha} \pi$ os, pappus, the down on feeds; a genus of Compofitæ.

Isope'talum (Bot.) "ros, equal, petalım; a genus of Geraniacex.

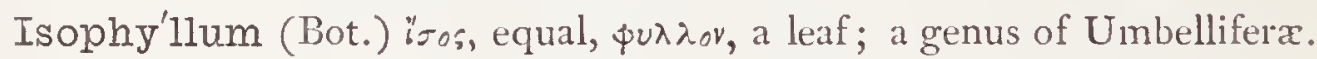

Isophy'toids (Bot.) "sos, equal, фuróv, a plant, eidos like.

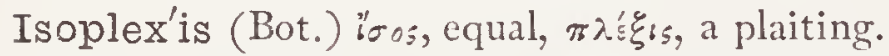

Isop'oda (Zool.) "Gos, equal, zoús, modós, a foot; an order of feffile-eyed Cruftacea.

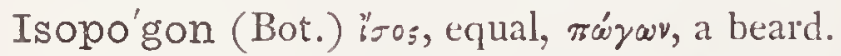

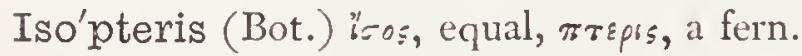

Iso'pteryx (Ent.) ‘'cos, equal, $\pi \tau \varepsilon f u \xi$, a wing.

Isopy'rum (Bot.) iros, equal, rupos, wheat; alluding to the tafte of the feeds.

Isoscela'lis (Ent.) "'

Iso'scelis (Zool.) fame derivation; a genus of Colubrine ophidians.

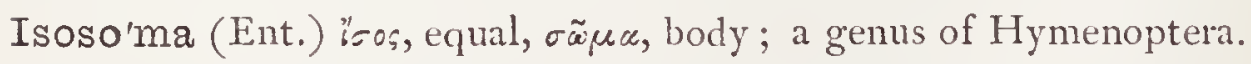

Isosti'gma (Bot.) isos, equal, figma; a genus of Compofitr.

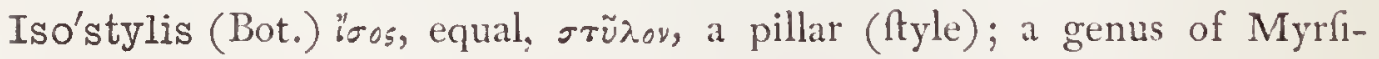
naceæ.

Isothe'cium (Bot.) 'ros, equal, Anxxn, a cheft or theath; a genus of Mufci. Iso'toma (Bot.) '̈ros, equal, rouń, a cutting: a genus of Lobeliaceæ. 


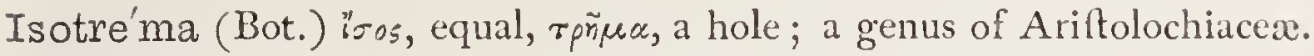

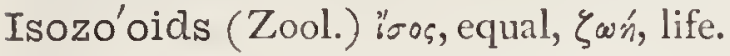

Isthmia (Bot.) i $\sigma \theta_{\mu}$ ov, a necklace; a genus of Diatoms.

Iswara (Ent.) a genus of Hymenoptera.

I'tea (Bot.) the Greek name of the Willow, ('Irø..)

Itha'ginis (Ornith.) 'Aayıv's, genuine, legitimate; a ${ }_{\star}$ genus of Indian Francolins.

Ito'nia (Ent.) P. N., a name of Athena.

I'va (Bot.) perhaps from yua, a name ufed by the older botanifts.

Ivy (Bot.) Anglo-Sax. ifg.

Ix'alus (Zool.) P. N., the name of a ruminant mentioned in the Iliad.

Ix'ia (Bot.) i $\xi^{\prime}$ c , birdlime; referring to the vifcid nature of the roots; a beautiful genus of Iridacer.

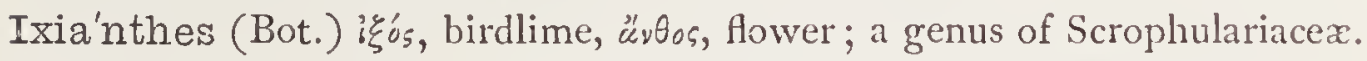

Ixia'nthus (Bot.) fame derivation; a genus of Gentianacex.

Ixiauche'nus (Bot.) ' ' $\xi_{5}^{\prime}$, glue, auxnv, the neck; a genus of Compofitr.

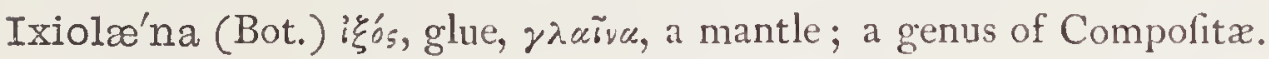

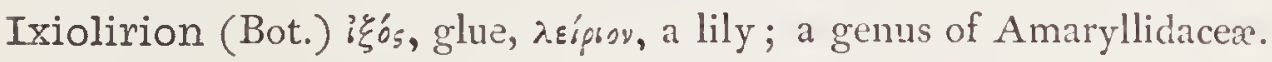

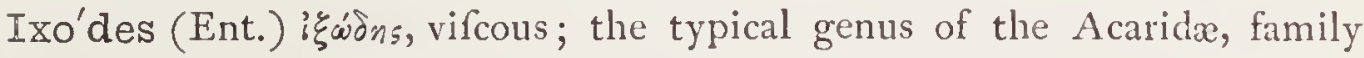
Ixodidx.

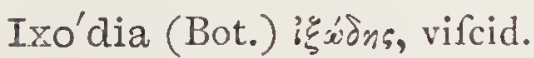

Ixo'ra (Bot) a Malabar idol, to which its flowers are offered; a fuperb tropical genus of Cinchonacex.

Jacara'nda (Bot.) its name in Brazil; Rofe.wood; Mimofa jacaranda.

Jack'al (Zool.) Arabian, tochakhal; Spanif, chacal; French, chacal.

Jackso'nia (Bot.) P. N. from G. Jackfon, librarian to A. B. Lambert; it genus of Leguminofre.

Jacobæ'æ (Ent.) feeds on Ragwort (Senecio Jacobra.)

Jacobæ'us-a-um (Bot.) native of the illand of St. Jacob; e. g., Lotus Facobcus; alfo the fpecific name of Ragwort.

Jacqui'nia (Bot.) P. N. from N. F. von Jacquin, Profeflor of Botany at Vienna.

Jaguar (Zool.) a native name.

Jambo'sa (Bot.) jambos, aboriginal name; a genus of Myrtacex.

Janel'la (Zool.) P. N., a genus of Leinacida (New Zealand grenus.) 
Jani'pha (Bot.) janipaba, its name in Brazil; the Caffava plant; a genus of Euphorbiacex.

Jani'ra (Zool.) a genus of Pectenidx.

Janthi'na (Zool.) iúv日svos, violet-blue; a genus of Molluks fo named on account of the beautiful violet colour of the thell.

Janthi'nea (Ent.) 'ávivvos, violet-blue.

Ja'nus (Zool.) P. N. from Roman mythology; a genus of Mollufca, family Proctonotidæ.

Japo'nicus-a-um (Ichth., Bot.) Lat. relating to, or native of, Japan; e.g., Camellia Faponica.

Jasio'ne (Bot.) applied by Pliny to wild potherb; a genus of Campanulacere.

Jasmi'num (Bot.) y fmyn, the Arabic name. The typical genus of Jafminacex.

Ja'tropha (Bot.) 'a $\tau_{5}^{\prime} o_{s}$, a phyfician, трофи́, food; referring to its qualities; a genus of Euphorbiaceæ.

Java'nicus-a-um ('Zool., Bot.) Lat. belonging to Java. Jay (Ornith.) French, geai, Span. gayo.

Jefferso'nia (Bot.) P. N. in honour of T. Fefferfon, Prefident of the United States.

Jeffre'ysia (Zool.) P. N. in honour of Mr. Gruynne Jeffreys, F.R.S., Jeffreysiadæ $\}$ author of a Manual of the Mollufa.

Jeny'nsii (Ent.) P. N. in honour of the Rev. Leonard Jernyns, M.A. Jerbo'idre (Zool.) a family of Mammalia of which Jerboa is the type. Jerusalem Artichoke (Bot.) This has nothing to do with Jerufalem, ancient or modern, but is the tuber of a fpecies of Sunflower, originally called by its proper defcriptive name. In Italian it is girafole (which turns to the fun), which is thus incorrectly anglicized into a geographical term.

Je'ssamine (Bot.) Arabic or Perfian y myyn, fweet odour.

Joba'phes (Bot.) ioßaфińs, violet-coloured.

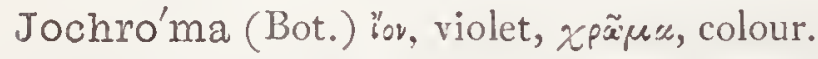

John Dory (Ichth.) from il janitore, the door-keeper; the fifh being called on the Italian coaft by the name of St. Peter, and he being fuppofed to be the door-keeper of heaven, our failors gave the name to the fifh. Jo'hnia (Bot.) P. N. in honour of the Rer. Dr. Johr, of 'Tranquebar. Jolli'fia (Bot.) P. N. in honour of Jollif, a friend of Bojer.

Jondra'ba (Bot.) \%r, the violet, and the genus Draba; a genus of Crucifere. 
Jone'sia (Bot.) P. N. in honour of Sir William Fones, the celebrated fcholar and botanift; a magnificent Eaft Indian genus of Leguminofie. Jonquil (Bot.) from juncus, a ruh, becaufe of its ruh-like leaves; the Narciffus Fonquilla.

Jonthla'spi (Bot.) bov, the violet, and the genus Thlaspi; a genus of Cruciferæ.

Jossínia (Bot.) derivation unknown.

Jouanne'tia (Zool.) P. N., a genus of Pholadidx, a family of Mollufca.

Ju'glans (Bot.) Fovis glans, the nut of Jove; the Walnut; a genus of Nat.

Order Amentacea.

Julia'na (Ent.) Julius, the month of July, in which the infect appears.

Julis (Ichth.) Lat. a name applied by Pliny to fome firh.

Julus (Zool.) Lat. a milleped; the Garden centipede.

Juncagina'cer (Bot.) juncus, a rufh; a Natural Order of inconfpicuous

Endogens, of which 'Triglochin is the type, formerly called Junago.

Juncicolel'la (Ent.) juncus, a rufh, colere, to frequent.

Junci'tes (Fos. Bot.) juncus, a ruh; follil Atems and leaves apparently related to ruhes.

Junctel'la (Ent.) junctus, joined, nnited.

Jun'cus (Bot.) jungo, to join: the firft ropes were made of ruthes; typical genus of the Ruh-family or Juncacea.

Jungerman'nia (Bot.) P. N. from Louis Fungermann, a German botanif, who died in 1653 ; typical genus of Jungermanniacere.

Junipera'ta (Ent.) feeds on the Funiper.

Juniperel'lus (Ent.) the larva forms webs on twigs of Funifer.

Juni'perus (Bot.) Celtic, Funeprus, rough, or rude; referring to the ftift fhrubs; a genus of Coniferæ, fub-order Cupreflineæ.

Jürge'nsia (Bot.) P. N., a genus of Byttneriacex.

Juri'nea (Bot.) P. N. in honour of $M$. Jurine; a genus of Compolitx.

Jussieu'a (Bot.) P. N. from the celebrated French botanical family $F_{u f-}$ feu; a genus of Onagracex.

Jussievia (Bot.) P. N. in honour of $M$. Fufieu; a genus of Euphorbiaceæ. Justi'cia (Bot.) P. N. in honour of 7 . Fufice, Efq., an eminent Scotch botanift, who publithed feveral works on gardening about $1754-6_{3}$; a fplendid tropical genus of Acanthacex.

Jute (Bot.) the fibre of an Eaft Indian Corchorus. 
Kadsu'ra (Bot.) a genus of Schizandracex.

Ka'dua (Bot.) a genus of Cinchonaceæ.

Iræmpfe'ria (Bot.) P. N. from E. Kempfer, a German naturalint, author of "Amœnitates Exotic $\rightsquigarrow$," who died in 1716 ; a curious tropical genus of Scitamineæ.

Kageneckia (Bot.) P. N, a genus of Rofacex.

IKahi'ria (Bot.) a genus of Compofitæ.

Iralancho'e (Bot.) the Chinefe name.

Kalbfu'ssia (Bot.) P. N. in honour of $M$. Kalbfufs; a genus of Com.. pofitx.

Kale (Bot.) Anglo-Sax. cal, carvl; a kind of cabbage; alfo applied to the Crambe maritima, or Sea-kale; Cruciferæ.

Irali (Bot.) Arabic, galy or âlgaly; fpecific name of a marine plant, from the alhes of which foda is obtained; the Saljola Kali, Nat. Ord. Chenopodiacex.

Ialifor'mia (Bot.) xarios, beautiful, forma, hape; a genus of Ceramian Alga.

Kal'lias (Bot.) ancient name of fome plant; a genus of Compofitæ. Kallströmia (Bot.) P. N., a genus of Zygophyilaceæ.

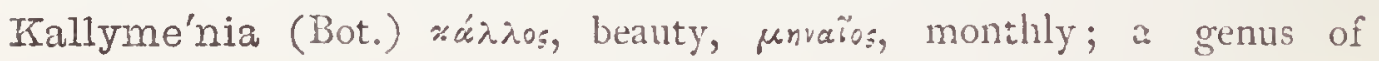
Alga.

Ka'lmia (Bot.) P. N. from P. Kalm, Profeftor at Abo in Sweden; a rery beautiful North American genus of Ericacex.

Kalong (Zool.) native name of a bat-Ptéropus.

Kalosa'nthes (Bot.) «àós, beautiful, «ँvos, a flower.

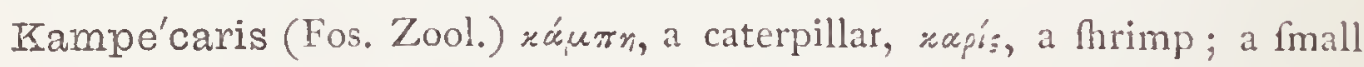
cruftacean, fo called from its appearance.

Irampma'nnia (Bot.) P. N., a genus of Xanthoxyiacer.

Kamptorliyn'chus (Ornith.) See Camptorhynchus.

Kam'ptzia (Bot.) P. N., a genus of Myrtaceæ.

IXan'garoo (Zool.) a native name.

Ka'tydid (Ent.) a fpecies of grafshopper, fo called from the found which it makes.

Kaulius'sia (Bot.) P. N. in honour of G. Fred. Kanlfuss, M. D., Profeftor of Botany, Halle; a pretty blue-flowered genus of Compofiti.

Iei'thia (Bot.) P.N., a genus of Labiatx.

Ire'llia (Zool.) P. N. in honour of Mr. O'Kelly of Dablin; a genus of Mollufca, family Kelliadæ. 
Kenne'dia (Bot.) P. N. from Mr. Kennedy, nurferyman, Hammerfmith; an elegant genus of Leguminore.

Ke'ntia (Bot) P. N., a genus of Palmr.

Ientra'nthus, fame as Centranthus, q.\%.

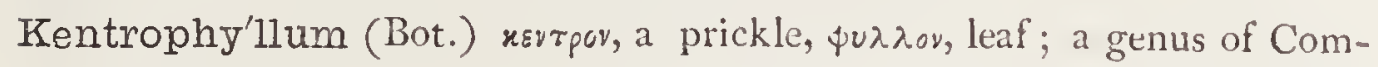
pofitix.

Ientro'phyta (Bot.) xevтpov, a prickle, фuтer, plant; a genus of Leguminofa.

Ke'ratophy'te (Zool.) x'́pas, a horn, фurov, that which grows; a name given by Cuvier to polypi of the genus Gorgonia, on account of the horny axis of the ftem.

Ke'ratose (Zool.) xépas, a horn; but the word is objectionable, fince of is not a proper termination for adjectives from the Greek, and analogy would require the $k$ in $x_{\varepsilon}^{\prime} \alpha_{5}$ to be exprefled by a $c$.

Keri'lia (Zool.) xnpos, a honey-comb, from the arrangement of the fcales; a genus of Ophidians.

Kerivoula ( $Z$ ool.) a native name.

Ke'rodon (Zool.) xñp, the heart, oboús, odorvos, a tooth; a genus of herbivorous rodents having molar teeth, of which the tranverfe fection is heart-fhaped.

Irerona (Zool.) xépas, a horn; a genus of minute Infuforia, having the body covered with hairs, fome of which are curved like horns; hence the name.

Ier'ria (Bot.) P. N. from W. Ker, a collector of plants for Kew gardens ; a genus of Japanefe Rofacex.

Kriggela'ria (Bot.) P. N. from Francis Kiggelar, a Dutch botanical author.

Kilmunel'la (Ent.) firft taken at Kilmun, N. B.

Kinge'na (Zool.) P. N., a genus of Mollufca, family Terebratulidx.

Kirgane'lia (Bot.) kirganeli, its Malabar name.

Kissos (Bot.) the Greek name for Ivy ; Sophocles calls it "wine-faced "-

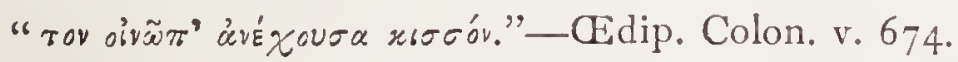

Kritaibe'lia (Bot.) P. N. from Paul Kitaibel, Profeflor of Botany at Pefth, Hungary.

Kite (Ornith.) Anglo-Sax. cyta.

Kleinho'fia (Bot.) P. N. from M. Kleinhof, formesly Director of the botanical gardens, Java.

Klei'nia (Bot.) P. N. from Fames Henry Klein, a German botanift; a genus of Compofiti. 
Inna'ppia (Bot.) P. N. from Mr. M. Knapp, who wrote on Britih Graf fes ; a genus of minute Gramina.

Innau'tia (Bot.) P. N. from C. Knaut, phyfician at Halle in Saxony, who died in 1694 ; a beautiful genus of Dipfacex.

Inni'ghtia (Bot.) P. N. from T. A. Knight, Efq., F.R.S., $\sigma_{c}$

Innipo'legus (Ornith.) it Mould be written Cnipolegus, $\mathrm{k}$ not being ufed in Latin.

Kno'rria (Fos. Bot.) a genus of coal-meafure plants, intermediate between Lycopods and Conifers.

Innot-grass (Bot.) a fpecies of Polygonum, fo called from its numerous joints.

Enowito'nia (Bot.) P. N. from T. Knowlton, curator of the Botanical Gardens, Eltham.

Inno'xia (Bot.) P. N. from Robert $K_{\text {nox }}$, an Englifh traveller of the $17^{\text {th }}$ century.

Kobre'sia (Bot.) P. N. from De Kobres, a German and great promoter of Botany; a genus of Cyperacex.

Ko'chia (Bot.) P. N. from M. Koch, a German botanift.

F́cle'ria (Bot.) P. N. from M. Kohler, Profeflor of Natural Hiftory at Mayence; a genus of Grafles.

Kœni'gia (Bot.) P. N. from Samuel Kanig, a Swifs mathematician.

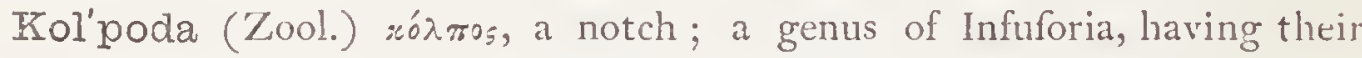
bodies notched laterally, their mouths being fituated at the bottom of the notch.

Iölreute'ria (Bot.) P. N. from F. G. Kolreuter, a celebrated German botanift and naturalift.

Ero'Ius (Zool.) *óroj, docked, curtailed.

Ko'niga (Bot.) P. N. from Charles Konig, F.R.S., Britifh Mufeum; a genus of Cruciferx.

Konin'ckia (Zool.) P. N. in honour of $M$. Konincke; a genus of Mollufeit, family Orthida.

Irame'ria (Bot.) P. N. from J. G. H. and W. H. Kramer, German botanifts.

Irau'ssia (Zool.) P. N., a genus of Mollufca, family Terebratulidæ. Krigia (Bot.) P. N. from Dr. David Krieg, a German botanin.

Iruhsea (Bot.) P. N. in honour of $\mathcal{F}$. Krufe.

Ku'hnia (Bot.) P. N. from Adam Küln, of Pennfylvania, a pupil of Linnous.

Kuichua (Zool.) native name of one of the Leopards. 
Kundo'o (Zool.) native African name; this word fhould have been Latinized into Cundu.

Irun'thia (Bot.) P. N. from C. S. Kunth, a French botanift.

Kurgo'sa (Zool.) Latinized form of the Kargofo.

Ky'dia (Bot.) P. N. from Col. Robert Kyd, firft director of the Calcutta

Botanic garden.

Irylli'ngia (Bot.) P. N. from P. Kylling, a Dutch botanift who died in I 6,6 .

Laba'tia (Bot.) P. N. in honour of the celebrated Spanifh naturalift, Labat; a genus of Aquifoliacex.

Labe'llum (Bot.) Lat. a little lip; applied to the pendulous petal of the Orchidaceæ.

Iuabia'tæ (Bot.) Labiate flowers; the natural order now called Lamiacex.

Labiatiflo'ræ (Bot.) Labiate-flowers; a fection of perigynous exogens, with lip-like flowers.

Labich'ea (Bot.) P. N., a genus of Leguminofie.

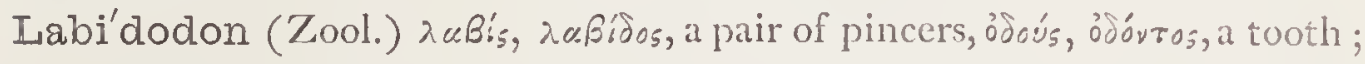
a genus of Infuforia.

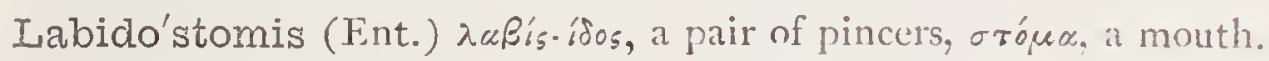

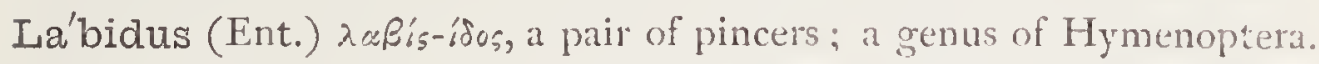

Labillardie'ra (Bot.) the fame as Billardiera, a New Hoiland genus of Pittofporacer.

Iabio'sus-a-um (Zool., Bot.) Lat. full-lipped.

Labi'sia (Bot.) P. N., a genus of Myrfinacese.

Ia'bium (Ent.) Lat. a lip.

La'blab (Bot.) the Arabic name of the convolvulus; now a fipecies of Dolichos; Nat. Ord. Leguminofic.

Labor'dia (Bot.) P. N., a genus of Loganiacer.

Labourdonnai'sia (Bot.) P. N., a genus of Sapotacer.

Labra'dia (Bot.) P. N. in honour of $M$. Labrade; a genus of Leguminosxe. Iabrax (Ichth.) a name ufed by Pliny for fome fin; now applied to the Baffe.

Labrel'la (Bot.) dim. of labrum. a lip; a genus of Fungi.

I $a^{\prime}$ 'bridæ (Ichth.) labrus, fam. term. ida; the family of the Wrafles, or Rock-filhes.

Labroids (Ichth.) Iabrus, sida;, like. 
Iabrum (Ent.) Lat. a lip.

La'brus (Ichth.) a name ufed by Pliny for a ravenous fin; the Wrafle. The name is derived from the extenfile lips of the members of this genus.

Labur'num (Bot.) at name ufed by Pliny: now the Latin fpecific name of the "Golden-rain," Cytifus Laburnum.

Labyrin'thodon (Fos. Zool.) iceßúpuvos, a labylinth, osoús, sjovros, a tooth; the teeth are of a peculiarly complicated ftructure; the name was given by Profeflor Owen.

Iaca'thea (Bot.) ruxágn was the ancient name of an unknown tret; a genus of Ternftrömiaceæ.

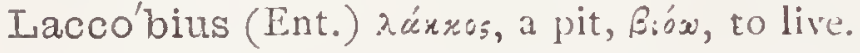

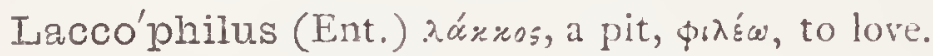

Iace'llia (Bot.) P. N., a genus of Compofita.

Lacepe'dea (Bot.) P. N. in honour of the celebrated Count de Lucépíde: a genus of Hippocrateacex.

Iacerna'tæ (Zool.) pl. of lacernatus, wearing a cloak; a family of Infuforia. Lace'rta ('Lool.) Lat. a lizard.

Lace'rticeps (Fos. Zool.) lacerta, a lizard, caput, head; lizard-headed.

Lace'rtidæ (Zool.) lacerta, fam. term. idhe.

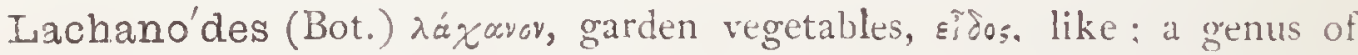
Compofitæ.

Isachena'lia (Bot.) P. N. in honour of $W$. de la Chenal, a writer on botany: a beautiful cape genus of Liliacer.

La'chesis (Zool.) P. N., one of the three Fates; a genus of Ophidians. Iachna'a (Bot.) $\lambda a x^{\prime} y$, down; alluding to the clothing of the corolla; a genus of 'Thymelacere.

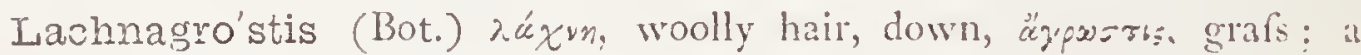
genus of Gramina.

Iachna'ia (Ent.) iaxväăs, hairy, downy.

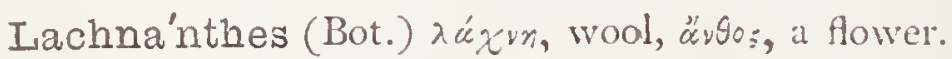

Lachne'lla (Bot.) diminutive of Lachnea; a genus of Fungi.

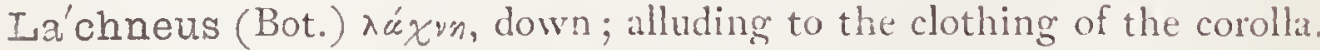

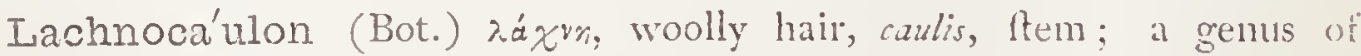
Eriocaulacer.

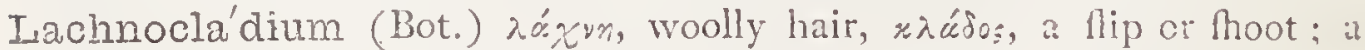
genus of Fungi.

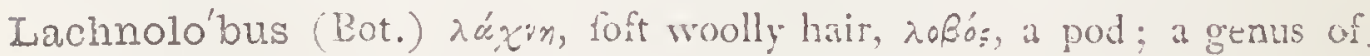
Fungi. 


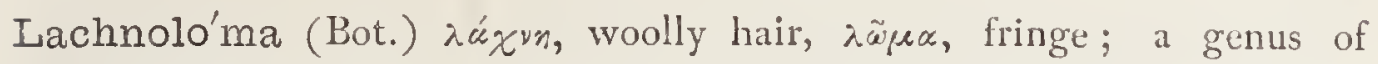
Crucifera.

Lachnope'talum (Bot.) $\lambda \dot{\alpha} \chi \nu n$, down, petalum; a genus of Sapindaceæ.

Lachnopo'dium (Bot.) $\lambda \dot{\alpha} \chi x$, woolly hair, $\pi \tilde{\nu}_{5}, \pi \circ \delta^{\prime} o_{5}$, foot; a genus of Melaftomacex.

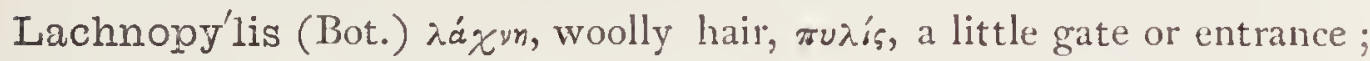
a genus of Scrophulariacex.

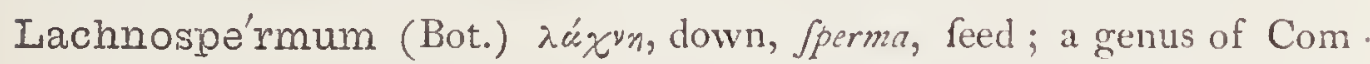
pofitx.

Lachnosta'chys (Bot.) $\lambda a^{\prime} \chi \nu n$, woolly hair, $\sigma \tau \alpha \chi^{i} ;$, a clufter; a genus of Amarantacex.

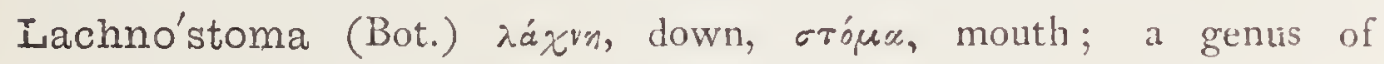
Cinchonacex; alfo a genus of Afclepiadacea.

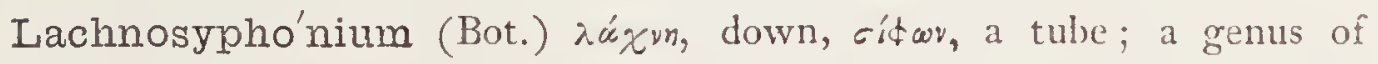
Cinchonaces.

La'chrymans (Ornith., Bot.) Lat. crying, caufing grief; as in Merulius lachrymans, the Dry-rot plant.

Lacinula'ria (Zool.) lacinia, a lappet or flap; a genus of Infuforia.

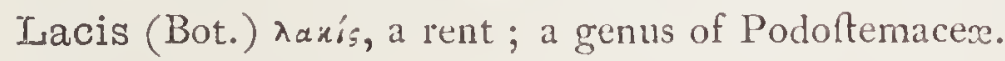

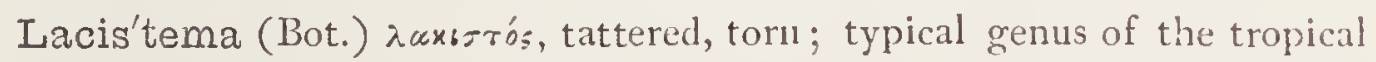
American order Laciftemaceæ.

Lacistema'ceæ (Bot.) the genus Laciftema; and fam. terminal.

Lacryma'ria (Zool.) lacryme, tears; a genus of Infuforia.

Lacta'rius (Bot.) Lat. milky; a genus of Fungi.

Lactea'ria (Ent.) lacteus, milk-white.

La'cteus (Zool., Bot.) Lat. cream-coloured; e.g., Crocus lacters.

Lactu'ca (Bot.) lac, milk; a milky juice exudes when it is broken; the

Lettuce; Nat. Ord. Compolitre.

Lacus'trine (Zool.) lacus, a lake.

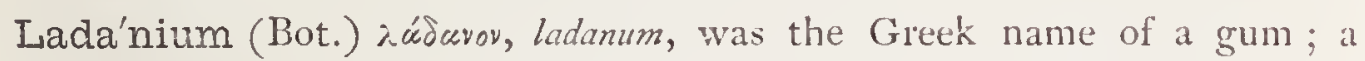
genus of Ciftacex.

Ladano'psis (Bot.) the genus Ladunim, and ö $\psi$ bs, like; a genus of Melaftomace:

Ladenbe'rgia (Bot.) P. N. in honour of $M$. Ladenberg; a genus of Cinchonacere.

Lady-smock (Bot.) probably from the white appearance which its blolfoms gave to the meadows where it abounds, refembling linen bleaching on the grafs; the Cardamine pratenfis.

Lælio'psis (Bot.) the genus Laclia, and of $\psi$ c, like; a genus of Orchidacex. 


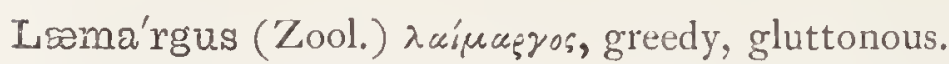

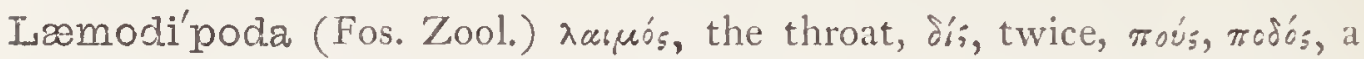
foot.

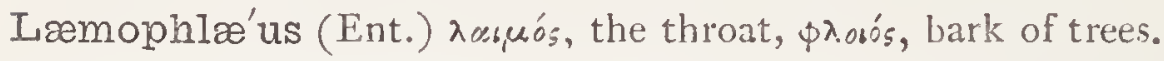

Lrenne'cia (Bot.) P. N. a genus of Compolitx.

Iae'tia (Bot.) P. N. in honour of $J$. de Laet, ot Antwerp, author of a hiftory of America.

Læva'ta (Bot.) levatus, lifted up.

Ireviga'tus-a-um (Bot.) Lat. Imoothed; e.g., Carex lavigata.

Læ'vis (Zool., Bot.) Lat. fmooth or soft ; e.g., Rivina levis.

Lafoe'nsia (Bot.) P. N., a genus of Lythracea.

Lafresna'ya (Ornith.) P. N. in honour of the venerable Baron de Lafrefnaye, a French naturalint.

Lafue'ntea (Bot.) P. N., a genus of Scrophulariaces.

Lagarosi'phon (Bot.) iayupós, hollow, cípwv, tube; a genus of Hydrocharidacex.

Laga'scea (Bot.) P. N. in honour of Don Mariana Lagafia, Profellor of Botany at Madirid.

Iragena'ndra (Bot.) lagenu, a Alak (hape), ärmp, üvdpós, a ftamen; a genus of Araceæ.

Lagena'ria (Bot.) lagena, a bottle; referring to the form of the fruit; the Bottle-gourd ; Nat. Ord. Cucurbitacese.

Lagene'lla ('Lool.) dim. of lagena, a Hak ; a genus of Infuforia.

Lage'nium (Bot.) גúznvos, Lat. lagena, a flak or flagon; a genus of Mufci.

Lagenoca'rpus (Bot.) lagenu, a flan, жaprós, fruit; a genus of Cyperaceæ.

Iageno'phora (Bot.) lagena, a flak, థrsw, to carry; a genus of Compofitx.

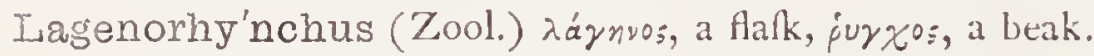

Lagerstrœ'mia (Bot.) P. N. in honour of Magnus Lagerftram, of Gotten -

burg, a friend of Linneus, and a director of the Swedifh Eaft India Company.

Laget'ta (Bot.) lagetto, its name in Jamaica; the Lace-bark tree; Nat. Ord.

Thymelacex.

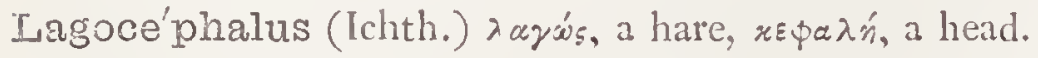

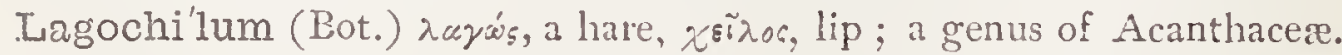

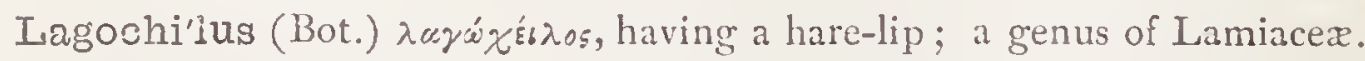

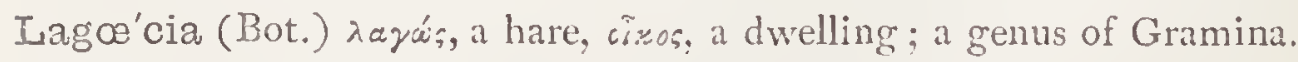

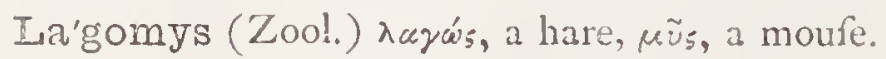

Lagony'chium (Bot.) rays', a hare, óvesov, a little nai?. 


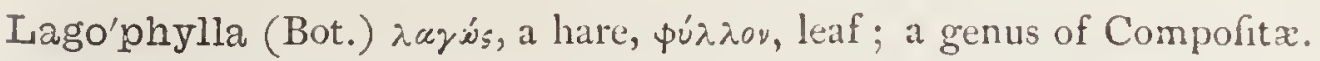

Lago'psis (Bot.) $\lambda \ltimes \gamma \omega_{s}$, a hare, ö $\psi$ s, like; a genus of Labiatr.

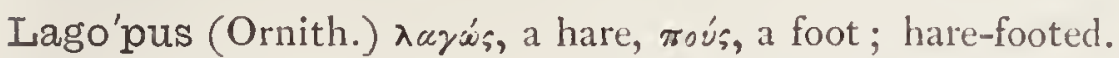

Lagorche'stes (Zool.) $\lambda a \gamma \omega_{s}$, a hare, opxnorns, a dancer; applied to the kangaroo hare.

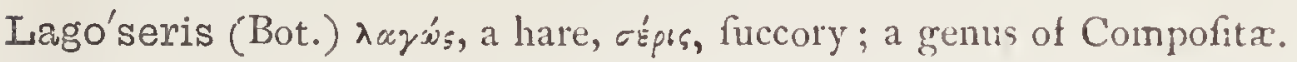

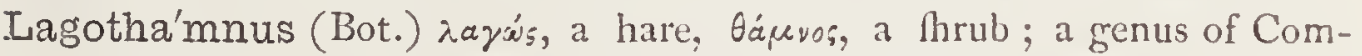

pofitx.

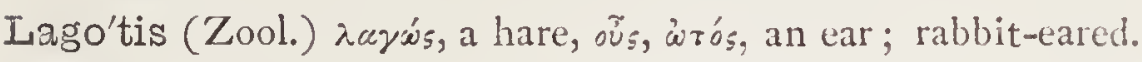

Lagre'zia (Bot.) P. N., a genus of Amarantacex.

Laguna'ria (Bot.) Ital. laguna, a marh ; a genus of Malvacex.

Laguncula'ria (Bot.) laguncula, a fmall flank or bottle; a genus of Combretacex.

Lagunc'zia (Bot.) P. N., a genus of Homaliacer.

Lagune'a (Bot.) P. N. in honour of Andreas Laguna, a Spanifh naturalift.

Lagura'nthera (Bot.) having anthers like thofe of the genus Lagurus : a genus of Compofitre.

Laguro'stemon (Bot.) the ftamins ( $\sigma r n \tilde{n} u$ w) refembling thofe of the genus

Lagurus; a genus of Compofitr.

Lagu'rus (Bot.) ^agós, a hare, ỏupú, a tail ; Hare's-tail grafs; a genus of Gramina.

Laha'ya (Bot.) P. N. in honour of $M$. Layhaye, a fcientific gardener.

La'lage (Bot.) P. N. in honour of Horace's lady; a genus of Leguminolx. Lallema'ntia (Bot.) P. N., a genus of Labiatæ.

Lama (Zool.) Latinized form of Llama.

La'mantin (Zool.) from the native name la manati; the Manatus or

Sea-cow; Cuvier fates that it was fo called from a fancied refemblance of its front feet to hands, or from a fuppofition that it had only fiont feet.

Lamarchea (Bot.) P. N., a genus of Myrtaceæ.

Lamar'ckia (Bot.) P. N., a genus of Celaftracex.

Lamb (Zool.) Anglo-Sax. lamb, Dutch, lam, Germ.lamm.

Lambdel'la (Ent.) from the Greek letter $\lambda$ marked on the wings.

Iamber'tia (Bot.) P. N. in honour of A. B. Lambert, Efq., F.R.S. Fi., a diftinguifhed botanift and writer upon the Coniferæ.

Lambs' Lettuce (Bot.) Anglicized from the old name, Lactuca agrina, of Ray and Gerarde; the Fedia olitoria; Nat. Ord. Valerianaceæ.

Lamella'ria (Zool.) lamella, a plate; a genus of Mollufca.

Lamellibranchia'ta (Zool.) lamella, a fmall plate, branchice, gills ; Blainville's term for the Conchiferæ. 
Lamellicor'nes (Ent.) lamella, a fmall plate, cornu, a horn; the antennx are compofed of nine or ten joints, the laft two or three of which are lamellated or plated.

La'mia (Ent.) P. N. of a fabulous monfter.

La'mia (Bot.) P. N., a genus of Portulacacex.

Lamia'cer (Bot.) the natural order of which Lamium is the typical genus. Ia'mina. (Bot.) Lat. a plate; the blade of a leaf.

Lamina'ria (Bot.) from the fori upon the lamince or fronds; a genus of marine Algie.

Laminarites (Fos. Bot) lamina, a plate; certain bıod-leaved foffil algæ of the upper rocks.

Iamina'strum (Bot.) lamina, plates, aftrum, a ftar; a genus of Fucoid Algx.

Lamiop'sis (Bot.) the genus Lamium, and ö $\psi b$, refemblance; a genus of Labiatie.

La'mium (Bot) dasmos, the throat, referring to the thape of the flower; a genus of Labiatx, and made the typical one in the equivalent term Lamiacex.

Lämmergeyer (Ornith.) Germ. lammergeir, from lammer, lambs, geir, a vulture.

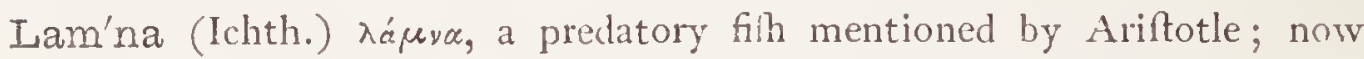
applied to a genus of Sharks.

Lamourou'xia (Bot.) P. N. in honour of $M$. Lamouraux; a genus of Algre.

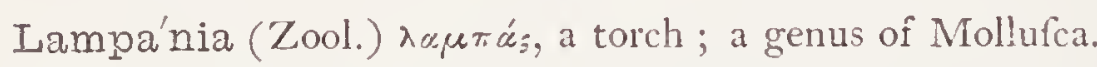

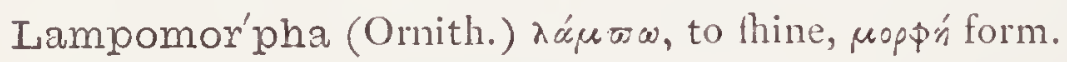

La'mpra (Ent.) $\lambda \propto \mu \varpi \rho^{\circ} ;$, brilliant.

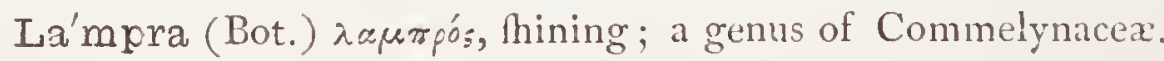

Lamprey (Ichth.) French, lamproie.

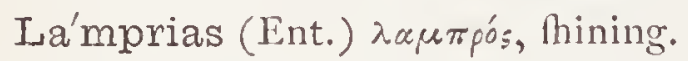

Lamproca'rpus (Bot.) fpecific name of the "Thining-fruited" whth or

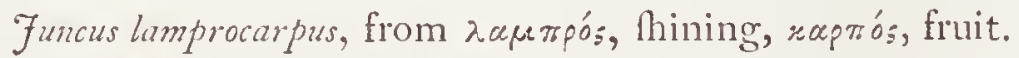

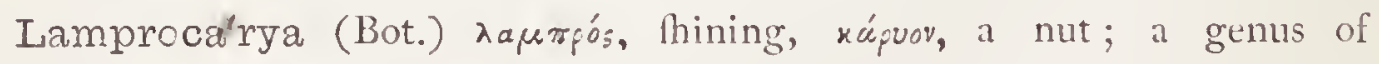
Cyperacex.

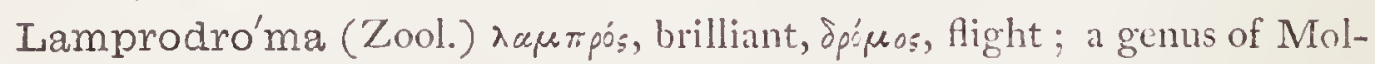
lufca.

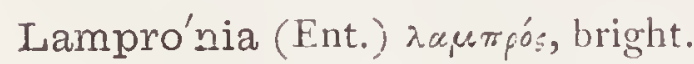

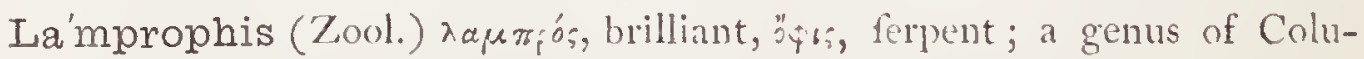
brine ophidians. 


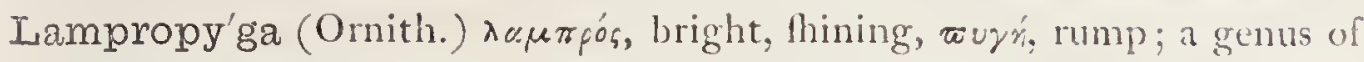
Humming-birds.

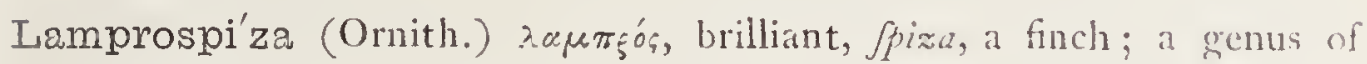
Tanagers.

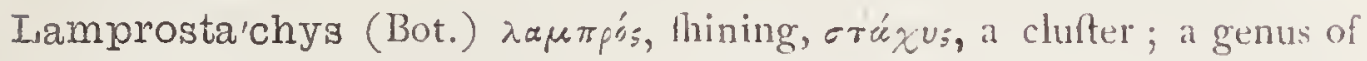
Labiatie.

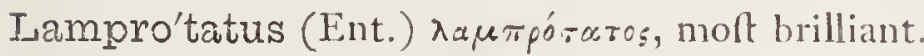

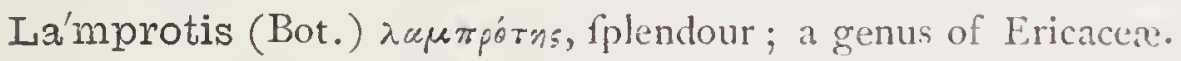

Lamproto'rnis (Ornith.) $\lambda a \mu \pi \rho \circ$, brilliant, ögvis, bird.

Lam'psana (Bot.) fime as Lapfana, ฯ.v.

La'mpsilis (Zool.) xá $\mu \psi \iota$, fplendour; a grenus of Molluica.

Lam'pyris (Ent.) $\lambda \dot{\alpha} \mu \pi \omega$, to thine, $\pi \tilde{v} p$, fire; the Glow-wom.

Lampy'riaze (Ent.) fam. of which Lampyris is the type.

Lamye'1la (Bot. P. N., a genus of Fungi.

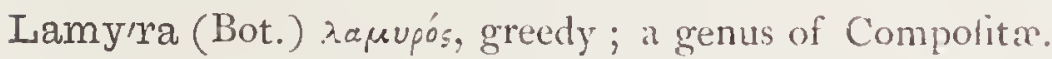

Lana'ria (Bot.) lanarius, woolly; a genus of Hæmodoracex.

Isana'rius (Ornith.) Lat. woolly.

Lancea'is (Ent.) lancea, a light fpear; the wings being narrow and huncolate.

Janceola'lis (Ent.) lanceola, a little lance.

Lanceola'ria (Bot) lanceola, a little lance; a genus of Cruciferx.

Lanceola'tus-a-um (Bot.) Thaped like a lancet, from lanceola, a little lance.

Lancina'lis (Ent.) lamino, to lacerate, from its torn appearance.

Lancre'tia (Bot.) P. N. in honour of $M$. Lancret; a genus of Elatinacex.

Lan'dia (Bot.) P. N., a genus of Cinchonacer.

Landolphia (Bot.) P. N., a genus of Apocynacea.

Lan'dtia (Bot.) P. N. in honour of M. Landt; a genus of Compolitx.

Lanes'tris (Ent.) lina, wool.

Langa'ha (Zool.) etymology unknown; a genus of Colubrine ophidians.

Langerma'nnia (Bot.) P. N. in honour of $M$. Langermann; a genus of Fungi.

Langevel'dia (Bot.) P. N., a genus of Urticacex.

La'ngia (Bot.) P. N. in honour of $M$. Lange; a genus of Amarantacer.

Juangiel'la (Ent.) P. N. in honour of H. G. Lang, a German author.

Langle'ia (Bot.) P. N. in honour of - Langley; a genus of Samydacer.

Langsdo'rfia (Bot.) P. N. in honour of $M$. Langfdorf; a genus of

Balanophoracere; alfo a genus of Compofita.

Lanianze (Ornith.) lanius, with term. for fub-family; the true Shrikes.

La'niger (Zool.) Tat. wool-bearing, Heecy. 
Lanigero'stemma (Bot.) laniger, wool-bearing, fleecy, ftemma; a genus of Hypericacex.

Lani'idæ (Ornith.) lanius, with fam. term.; the family of the Shrikes and Butcher-birds.

Lanipila (Bot.) lana, wool,pilus, a hair; a genus of Compolitx.

Lani'stes (Zool.) lanifta, a difturber; a genus of Mollufca.

La'nium (Bot.) lanius, an executioner; a genus of Orchidacex.

La'nius (Ornith.) Lat. a butcher; the Butcher-birds.

Lankester'ia (Bot.) P. N. in compliment to Dr. Edwin Lankefter, F.R.S., of London; a genus of Acanthacex.

La'nnea (Bot.) P. N., a genus of Anacardiacer.

Ianner (Ornith.) laniarius, a butcher; a fpecies of falcon.

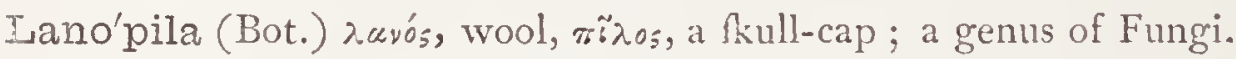

Iano'sa (Bot.) lanofirs, woolly; a genus of Fungi.

Lansbe'rgia (Bot.) P. N. in honour of $M$. Lanfberg; a genus of Iridace

La'nsium (Bot.) etymol. unknown; a genus of Meliacea.

Lanta'na (Bot.) fpecific name of Viburnum, from lento, to bend, on account of its ufe in tying articles; a genus of Verbenacer.

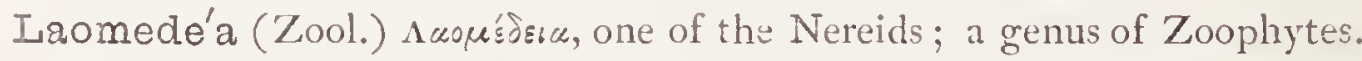
La'ophis (Fos. Zool.) $\lambda \tilde{a} \mu_{s}$, a rock, öфs, a ferpent; the Rock-fnake.

La'pachys (Bot.) $\lambda \alpha \pi \dot{c} \zeta \omega$, to evacuate; a genus of Compofitie.

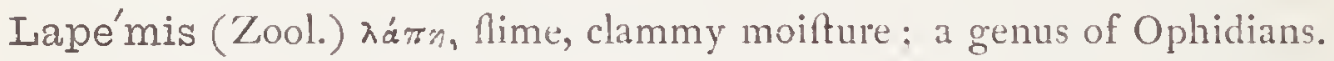

Lapeyrou'sia (Bot.) P. N. in honour of La Peyroufe, the French navigator.

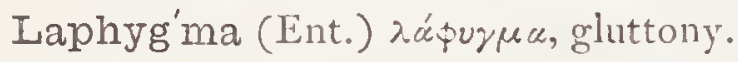

Lapida'ta (Ent.) lapis, a ftone; ftone-coloured.

Lapidico'lens (Ent.) lapis, a ftone, colens, part. inhabiting.

Lapla'cea (Bot.) P. N. in honour of the celebrated La Place; a genus of

Ternströmiacere.

Lapo'rtea (Bot.) in honour of $M$. Laporte; a genus of Urticacen.

Lappa (Bot.) Lat. a bur ; fpecific name of a curious Compofite plant, the Arctium Lappa, or Burdock.

Iappa'go (Bot.) dim. from lappa, the Burdock; having rough prickly flowers. Lappónicus-a-um (Ornith., Bot.) relating to Lapland.

Lappula (Bot.) diminutive of Luppa: a genus of 'Tiliacex.

Lap'sana (Bot.) $\lambda \iota \pi \dot{a} \zeta \omega$, to purge; alluding to its qualities.

Lap'wing (Ornith.) Anglo-Sax. kleapan, to leap, rvince, a wing; alluding probably to the rapidity with which it claps its wings.

Laquea'ria (Bot.) laquear, a panelled ceiling; a genus of Fungi. 
Lar, Lares ('Zool.) P. N. houfehold deities in mythology, fymbolized under the form of monkeys clothed with the Rins of dogs; applied to a Gibbon, Hylobates Lar.

Larbre'a (Bot.) P. N. in honour of the Abbé Larbré, a writer on botany : a genus of Caryophyllacer.

Larch (Bot.) from Lat. larix.

Lardizaba'la (Bot.) P. N., a curious South American genus, the typical one of Nat. Ord. Lardizabalacex.

Lare'ntia (Ent.) a name of Flora, or from Acca Larentia, the nurfe of Romulus and Remus.

Laridæ (Ornith.) larus, with fam. term.; the Gull family.

Lari'nus (Ent.) rapsvós, fat.

Larix (Bot.) Lat. the Larch-tree; Nat. Ord. Conifera.

Lark (Ornith.) Anglo-Sax. lafere, Dan. lerke.

Larkspur (Bot.) from fuppofed refemblance of the unexpanded flowers to the fpurs of larks; the genus Delphinium; Nat. Ord. Ranunculacex.

La'rnox (Bot.) the Greek word for a cheft or box; a genus of Solanacex. Laro'chea (Bot.) P. N. in honour of M. De la Roche, a writer on botany. Larra (Ent.) a name given by Dr. Leach, apparently without meaning; a genus of Hymenoptera.

Larrada (Ent.) formed from the genus Larra; a genus of Hymenoptera. Larraxena (Ent.) the genus Larra, and $\xi^{\prime}$ yos, Arange; a genus of Hymenoptera.

Iarrea (Bot.) P. N. in honour of $J . A . H$. de Larrea, a Spanilh botanilt. La'rridæ (Ent.) a family of Hymenoptera of which Larra is the type.

La'rus (Ornith.) Latin, a gull.

La'rva (Ent.) Lat. a ghoft or man.

Lasa'llia (Bot.) P. N., a genus of Lichenes.

Lasca'dium (Bot.) $\lambda \dot{\alpha} \sigma * \omega$, to ring or rattle; a genus of Euphorbiacer.

Laschia (Bot.) P. N., a genus of Fungi.

Laseguea (Bot.) P. N., a genus of Apocynacea.

Laserpi'tium (Bot.) lafer, the gum of the plant, pix, pitch, referring to

the fmell; a genus of Umbelliferæ.

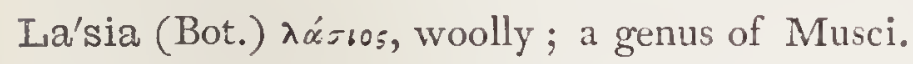

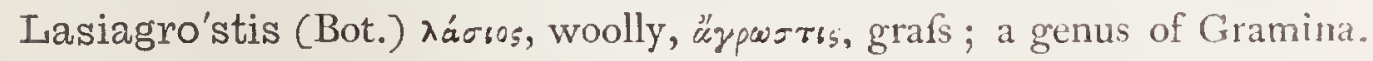

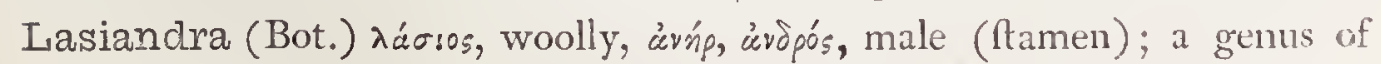
Melaftomaceæ.

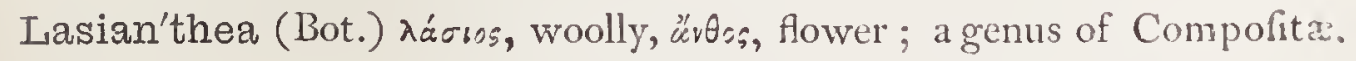
Iasianthera (Bot.) $\lambda \dot{\alpha}=60$, woolly, anthera; a genus of Vitacere. 


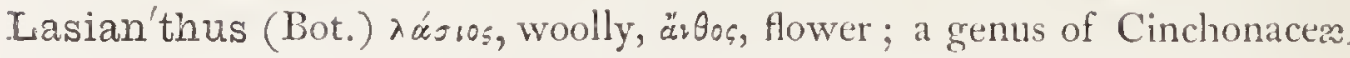
Lasiobot'rys (Bot.) $\lambda \dot{c}=60 s$, woolly, Bórfus, a bunch of grapes.

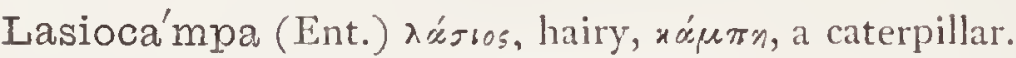

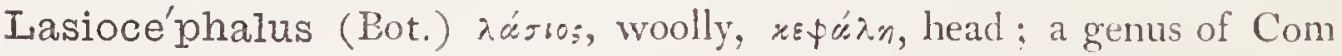
pofitie.

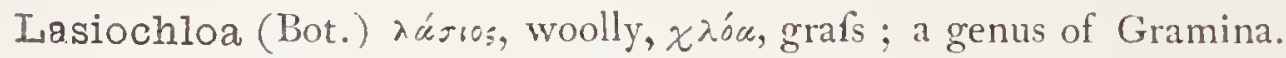

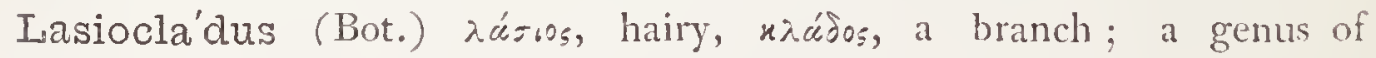
Acanthaceæ.

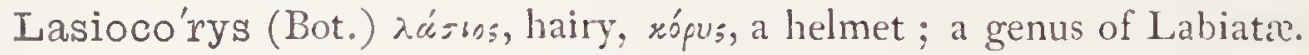

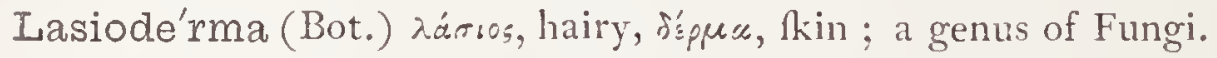

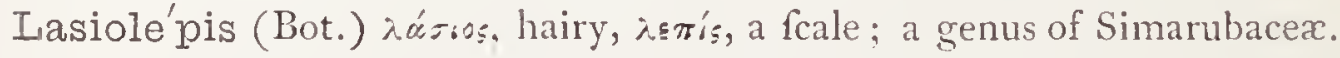

Lasione'ma (Bot.) $\lambda \dot{a}=r o s$, hairy, haggy, vńpece, a filament; a genus of

Cinchonacea.

Lasiópera (Bot.) $\lambda \dot{c}=$ sos, hairy, tźpus, an end or termination; a genus of Scrophulariaceæ.

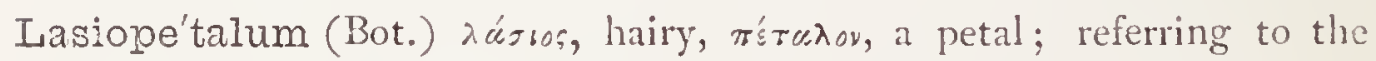
flower; a genus of Byttneriacex.

Lasiopo'gon (Bot.) $\lambda \alpha \alpha^{\prime}=6$, woolly, $\pi \dot{y}$ wav, a beard; a genus of Compofitie.

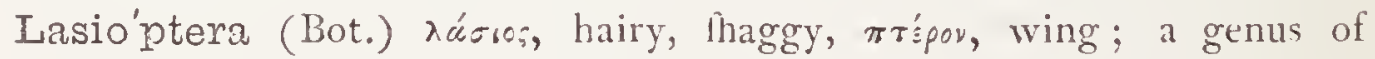
Crucifereæ.

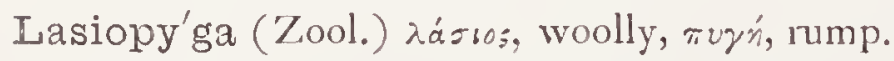

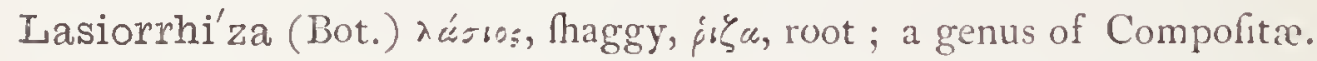

Lasiosi'phon (Bot.) $\lambda \dot{a}=b$, , haggy, $\sigma i \uparrow \omega v$, a tube ; a genus of Thymelacex.

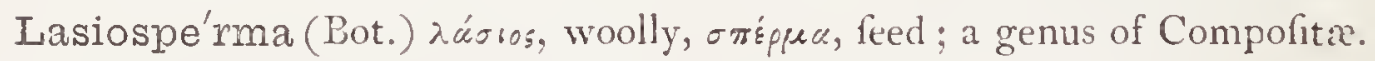

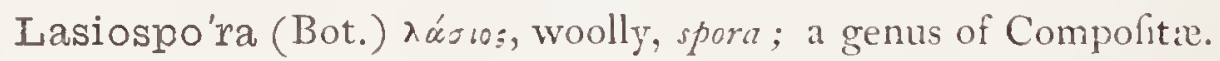

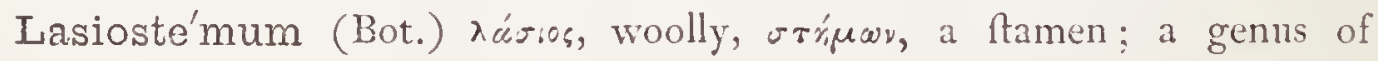
Rutaceæ.

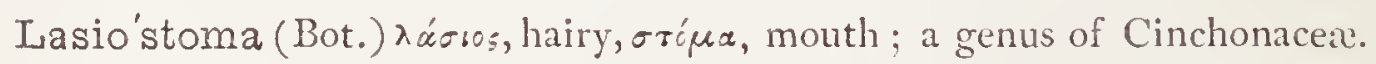

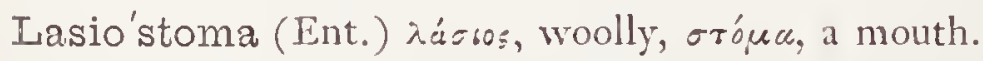

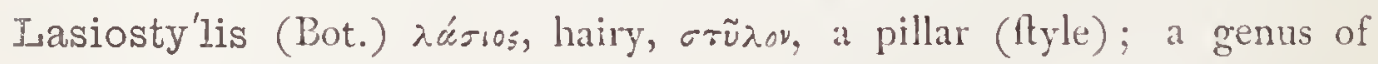
Euphorbiace

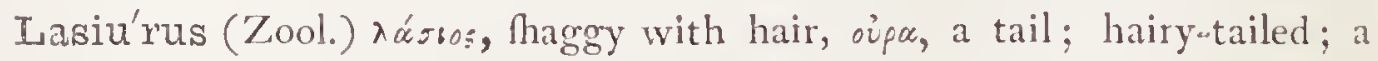
genus of Bats.

Lasthe'nla (Bot.) $\lambda \alpha=\theta \alpha i v \alpha$, to mock, insult ; a genus of Compofite.

Lastra'a (Bot.) P. N. in honour of the Abbé de Lastre, a French botanilt; a genus of well-known Ferns.

Lata'nia (Bot.) latanier, its name in the Ifle of Boubon.

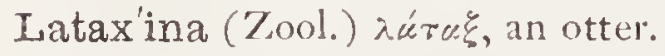

Isateritia'lis (Ent.) lateritius, brick-coloured. 
Lateri'tius-a-um (Bot.) Latin, brick-coloured, e.g. Loafa lateritia.

Late'rnea (Bot.) later, a brick, from its colour; a genus of Fungi.

Latha'mii (Ornith.) P. N. in honour of Dr. Fohn Latham, the eminent writer upon Ornithology, born 1740 , died 1837 , agred 97.

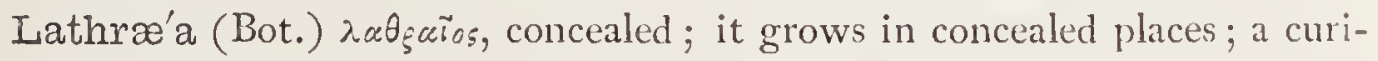
ous parafitic genus, Nat. Ord. Orobanchacex.

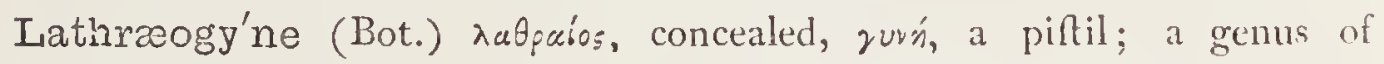
Leguminofx.

Lathræo'phila (Bot.) $\lambda \alpha \theta$ parios, concealed, and $\phi i \lambda_{s}^{\prime} \omega$, to love; a genus of Balanophoracer.

Lathro'bium (Ent.) $\lambda \dot{a} \theta \rho n$, fecretly, fíw, to live.

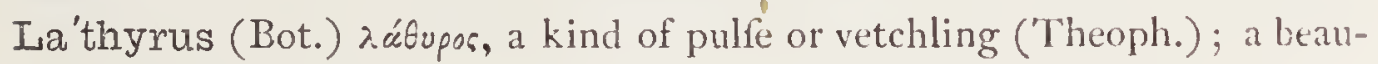
tiful genus of Leguminofie.

La'ticeps (Ichth.) latus, broad, caput, head; broad-headed.

Laticosta'lis (Ent.) latus, broad, cofta, the fide; broad-fided.

Latifascia'na (Ent.) latus, broad, fufcia, a band; broad-banded.

Latiro'stris (Ichth.) latus, broad, roftrum, a beak; broad-nofed.

Latistriel'lus (Ent.) latus, broad, fria, a ftreak.

Latitans (Ent.) part. of latito, to lie hid.

Latou'ria (Bot.) P. N. in honour of M. Latour; a genus of Orchidacea.

La'trans (Zool.) Lat. barking, roaring, applied to the Prairie-wolf.

Iatrei'llea (Bot.) P. N. in honour of Latrille; a genus of Compofitic.

Latreillel'la (Ent.) P. N. in honour of P. A. Latreille, Profeftor of Natural Hiftory at Paris, and a celebrated writer upon Entomology, died 1833 .

Latro'bea (Bot.) P. N. in honour of $M$. Latrobe, a French botanilt; a genus of Leguminofx.

Latro'num (Bot.) Lat. of thieves; this fpecific name of Rogues' acacia is faid by Burnett to be fo called from its forming fuch impenetrable thorny groves as to afford fecure retreats for thieves and lunaways.

Laube'rtia (Bot.) P. N. in honour of $M$. Laubert; a genus of Apocynacex. Lauge'ria (Bot.) P. N. in honour of $M$. Lauger ; a genus of Cinchonace. Lau'nea (Bot.) P. N., a genus of Compofitx.

Lau'nzea (Bot.) P. N., a genus of Anacardiacex

Laura'cer (Bot.) 'The Nat. Ord. of which the genus Laums is the type.

Laurel (Bot.) Englih modification of Lat. Laurus, through the French.

Laurembe'rgia (Bot.) P. N., a genus of Halorageacex.

Laure'ntia (Bot.) P. N. in honour of $M$ Antoine Laurent de Jufieu; a genus of Lobeliacex. 
Laure'ria (Bot.) from Fr. laurier; a genus of Solanacex.

Lauri'dia (Bot.) a genus of Celaftracex.

Lauroce'rasus (Bot.) from laurus and cerafus; fpecific name of the common laurel or Prunus Laurocerafus.

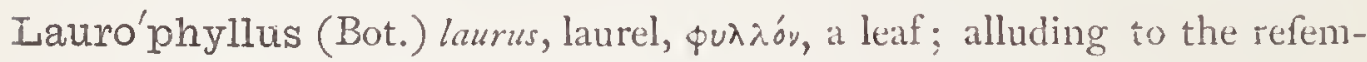
blance of the foliage.

Lau'rus (Bot.) Latin, the Bay-tree.

Isautel'la (Ent.) lautus, elegant.

Iuva'ndula (Bot.) lavo, to wa!h, becaufe ufed to perfume baths; Lavender: Nat. Ord. Labiat $x$.

Lava'nga (Bot.) a genus of Aurantiacex.

Lavate'ra (Bot.) P. N. in honour of the two Lavaters, friends of 'Tournefort; Nat. Ord. Malvacere.

Lavau'xia (Bot.) P. N., a genus of Onagracex.

La'vender (Bot.) lavo, to walh; fo called from being ufed in baths.

Lave'nia (Bot.) fuppofed to be of Cingalefe origin.

Laver'na (Ent.) P. N. the Roman godders of rogues and thieves.

Lavoisie'ra (Bot.) P. N. in honour of Lavoifer, the celebrated chemilt; a genus of Melaftomacex.

Lavra'dia (Bot.) P. N. in honour of Vaudelli, Marquis of Lavradio.

La'wia (Bot.) P. N. in honour of $M r$. Lawe; a genus of Podoftomacex.

Iawrence'lla (Bot.) P. N., a genus of Compofitie.

Lawre'ncia (Bot.) P. N., a genus of Malvaceæ.

Lawso'nia (Bot.) P. N. in honour of $\mathcal{F}$. Lazvon, M.D., author of a voy-

age to Carolina; the Lazugonia alba is fuppofed to be the Gopher-wood of Scripture.

Laxman'nia (Bot.) P. N. in honour of E. Laxmann, a Siberian traveller.

La'ya (Bot.) P. N., a genus of Compolita.

Layar'di (Zool.) P. N. in honour of Mr. Edgar Layard, who has written upon the natural hiftory of Ceylon.

I_a'yia (Bot.) P. N., a genus of Leguminofx.

Lazaro/lus(Bot.) P. N., a genus of Pomacex.

Leachii (Ichth.) P. N. in compliment to Dr. Liach, formerly Director of the Britifh Mufeum.

Leaf (Bot.) Anglo-Sax. leaf.

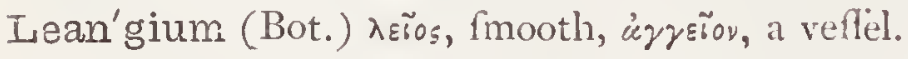

Lea'ntria (Bot.) $\lambda \varepsilon a v \tau$ ńp, one who polihes; a genus of Myrtacea.

Leathi'na (Bot.) P. N., a genus of Fucoid Algx. 
Leavenwo'rthia (Bot.) P. N., in honour of an American botanift; a genus of Cruciferæ.

Lebe'ckia (Bot.) P. N. in honour of Lebeck, an obfcure botanift; a genus of Leguminofx.

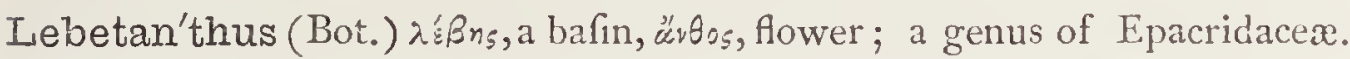

Lebe'tina (Bot.) dim. of $\lambda \varepsilon \beta \beta^{\prime} s$, a bafin; a genus of Compofitic.

Lebreto'nia (Bot.) P. N. in honour of Manuel le Breton, a French botanift.

Leca'ba (Bot.) P. N. in honour of $M$. Lecabe; a genus of Menifpermacex.

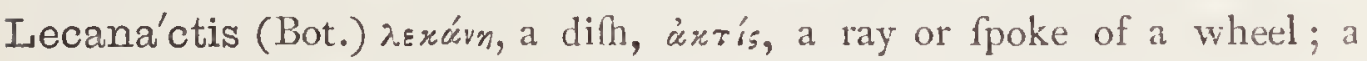
genus of Lichenes.

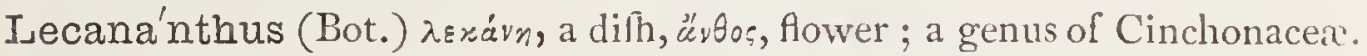

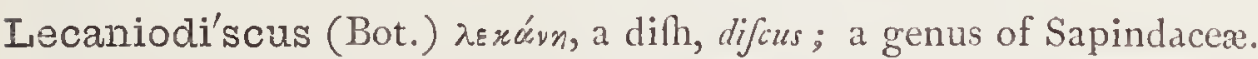

Lecan'ium (Bot.) $\lambda \varepsilon x a ́ v \%$, a difh; a genus of Polypodioid Filices.

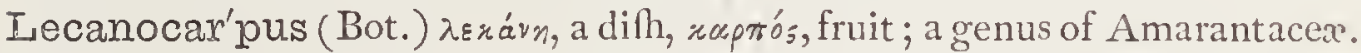

Lecanop'teris (Bot.) $\lambda \in x u^{\prime} v n$, a dih, $\pi \tau^{\prime} \varepsilon b s$, a fern ; a genus of Polypodioid Filices.

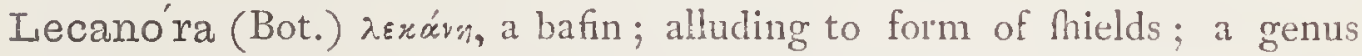
of Lichenes.

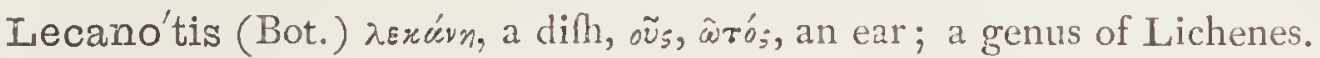

Le'chea (Bot.) P. N. in honour of G. Leche, a Swedilh botanift, died r 764 .

Lechenau'itia (Bot.) P. N. in honour of $M$. Lechenault, a French botanift and traveller.

Lechi'dium (Bot.) $\lambda \varepsilon \chi o s$, a couch or bed, $\varepsilon_{\delta}^{\tilde{\delta} \delta} \delta$ s, like; a genus of Ciftacez.

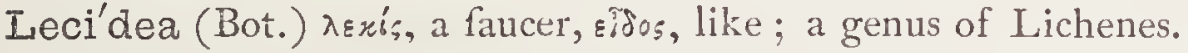

Leco'kia (Bot.) P. N. in honour of M. Le Cog; a genus of Umbelliferæ.

Lecon'tea (Bot.) P. N. in honour of $M$. Lecunte; a genus of Cinchonaceve.

Iecon'tia (Bot.) P. N., a genus of Araces.

Lecqueren'sia (Zool.) a genus of Infuforia.

Lecy'thea (Bot.) $\lambda \dot{n} x u \theta_{05}$, a flak ; referring to flape; a genus of Fungi.

Lecythida'cex (Bot.) an American order of plants, of which the genus

Lecythis is the type.

Le'cythis (Bot.) $\lambda \dot{n} x u f o s$, an oil jar; from refemblance of the feed-veflel;

the Monkey-pot, a noble American genas of Trees.

Lecytho'psis (Bot.) the genus Lecythis and " $\psi$ 's, refemblance; a genus of Lecythidacer.

I.erda (Bot.) P. N., a mythological perfonage; a genus of Confervoid Algæ.

Ledebu'ria (Bot.) P. N. in honour of M. Ledebour, a writer on botany; a genus of Umbelliferx. 
Iado'nia (Bot.) $\lambda$ ñdoy was the ancient name of a fhrub from which the gun called $\lambda$ ŕdavor was derived; a genus of Ciftacex.

La'dum (Bot.) $\lambda$ ñdov, Greek name of the Ciltus, now applied to a genus of Ericacex.

Lee'a (Bot.) P. N. in honour of $\mathcal{F}$. Lee, father, fon, and grandfon, botanifts near London.

Leek (Bot.) Anglo-Sax. leac.

Le'ersia (Bot.) P. N. in honour of . . D. Leers, a German botanift: a genus of Grafles.

Leeuwenhœ'ckia (Bot.) P. N. in honour of the celebrated Dutch micro.fcopint; a genus of Byttneriacex.

Lefeburia (Bot.) P. N., a genus of Umbelliferæ.

Lege'ndrea (Bot.) P. N., a genus of Convolvulacex.

Leguminosæ (Bot.) Legumen, a pod; the great family of which the pea is the type.

Lueguminosi'tes (Fos. Bot.) legumen, a pod; certain foffil feeds of the ter tiary ftrata.

Lehman'nia (Bot.) P. N., a genus of Solanacer.

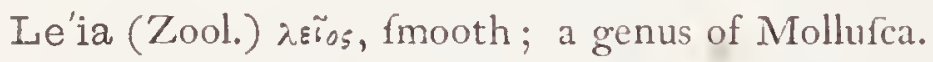

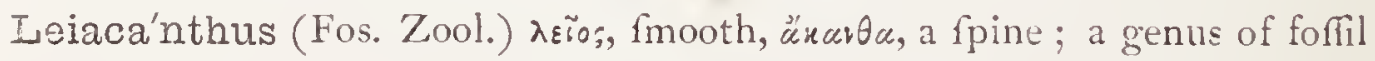
Fithes known only by their fpines.

Leianthoste'mon (Bot.) recirm, to fmooth or polin; a genus of Gentianaceæ.

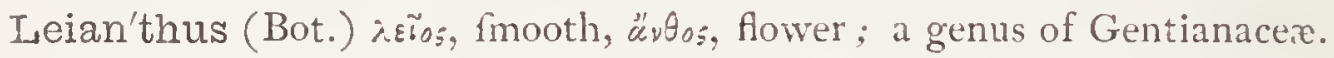

Laibnitzia (Bot.) P. N. in honour of the great German philofopher, Leib. uitz; a genus of Compofitx.

Leicha'rdtia (Bot.) P. N. in honour of - Leichardt, a German botanift; a genus of Afclepiadacex.

Lei'ghia (Bot.) P. N., a genus of Compofitie.

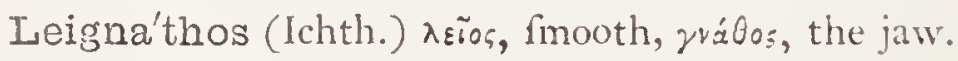

Iei'la (Zool.) P. N., a genus of Mollufa.

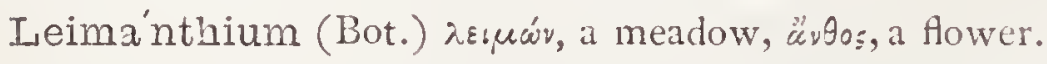

Leinke'ria (Bot.) P. N., a genus of Proteacex.

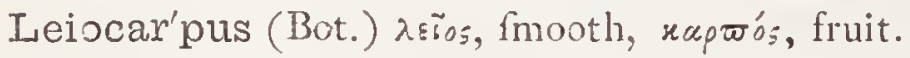

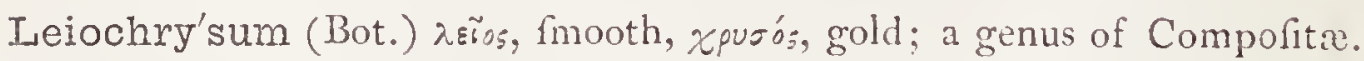

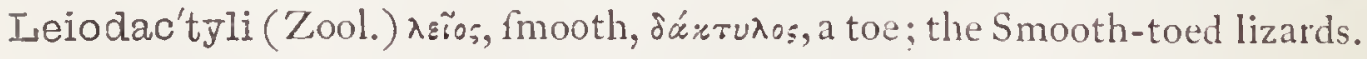

Leio'domus (Zool.) $\lambda \varepsilon_{\text {sos }}$, fmooth, domus, houfe; a genus of Mollufca.

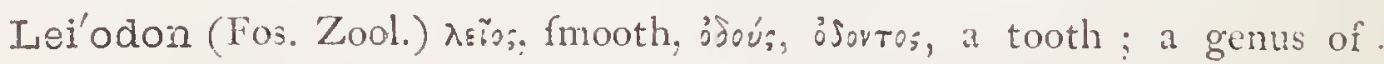
Saurians. 


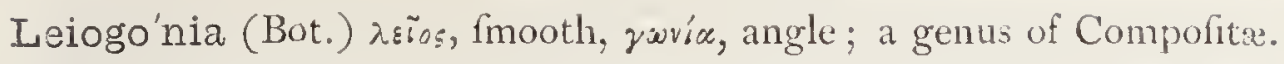

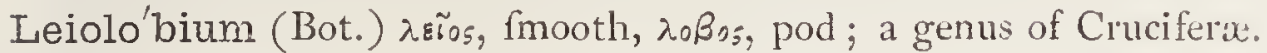

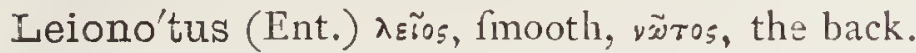

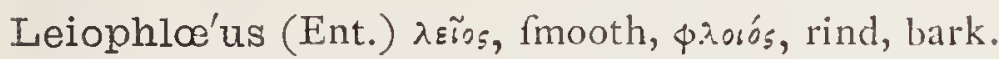

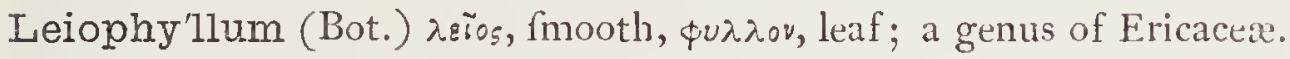

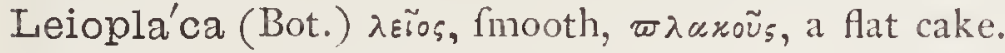

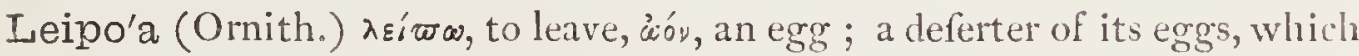
it leaves in a mound.

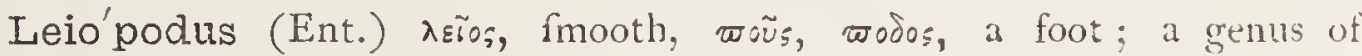
Hymenoptera.

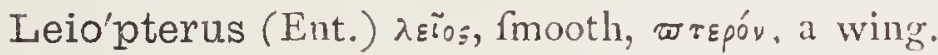

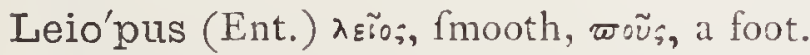

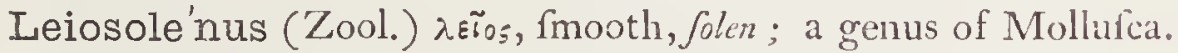

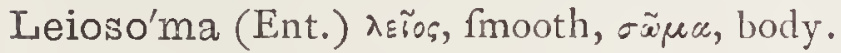

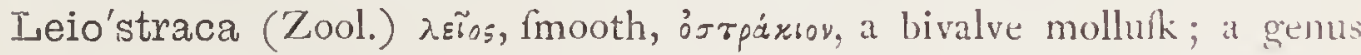
of Mollufca.

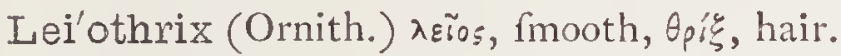

Leiotri'chonæ (Ornith.) leiothrix, with fub-family term.

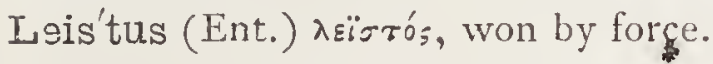

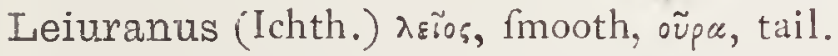

Lema'nea (Bot.) P. N. in honour of M. Lem.n, a French botanift ; it genus of Cryptogamia.

Lembo'sia (Bot.) $\lambda_{s}^{\prime} \mu \beta_{0}$, a fmall boat; a genus of Fungi.

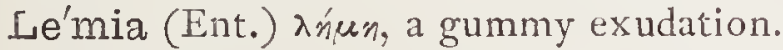

Lemio'des (Ent.) the genus Lemia, eidos, like.

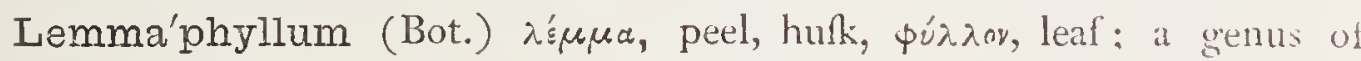
Polypodioid Ferns.

Lem'na (Bot.) a name ufed by Theophraftus for a water-plant; duck. weed ; typical genus of the aquatic family Lemnacer.

Lemna'lis (Ent.) feeds upon Lemna.

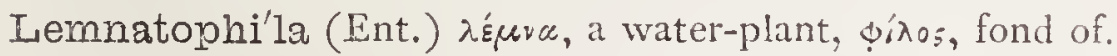

Lem'nopsis (Bot.) the genus Lemna, and ó $\psi$ s, like; a genus of Podoltemaceæ.

Isemon (Bot.) through Limonia, is from its original Indian name, Leemoo, or Neenoo; Arabic for the genus Citrus is Lymoun.

Lemonia (Bot.) P. N. given by Dr. Lindley in honour of Sir Charles Lemon, M.P.

Lemur (Zool.) Lat. a fprite, a night-walker; from the nocturnal habits of the animal. 
Lenorman'dia (Bot.) P. N. in honour of $M$. Lenormand, a French botanift; a genus of Ceramian Algr; alfo ufed as a fpecific name; e.g., Ranunculus I,enormandi.

Lentiginosel'Ia (Ent.) lentiginofirs, freckled.

Lsntiginosus-a-um (Bot.) Lat. freckled.

Leo (Zool.) Lat. a lion.

Leoca'rpus (Bot.) leo, a lion, xuprós, fruit; a genus of Fungi.

Leo'nia (Bot.) lio, a lion; a genus of Violacex.

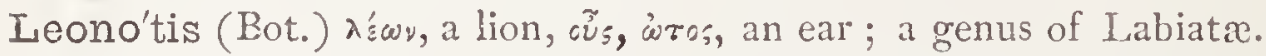

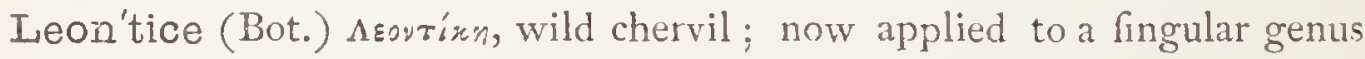
of herbaceous Berberidaceæ.

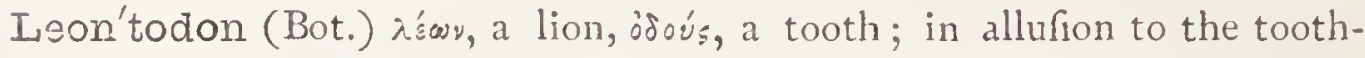

like divifions of the leaves; the Dandelion; Nat. Ord. Compofitx.

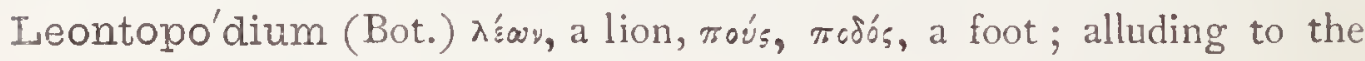
heads of the flowers; a genus of Compofitæ.

Leonu'rus (Bot.) $\lambda^{\prime} s \omega \nu$, a lion, cũ ṕs, a tail; a genus of Labiatie.

Leopard (Zool.) French, léopard, Low Lat. leopardus.

Leoparda'nthus (Bot.) literally "leopard-flower;" a genus of Orchidacez. Leopar'dus (Zool.) Lat. a leopard.; compounded of $\lambda_{\varepsilon}^{\prime} \omega v$, a lion, and $\varpi a ́ p \delta a \lambda$ s, a panther.

Leopoldi'na (Bot.) P. N. in honour of the late Emprefs of Brazil.

Leo'tia (Bot.) meaning unknown.

Lepa'didæ (Zool.) lepas; a family of Cirripedes.

Lepade'lla (Zool.) dim. from $\lambda \varepsilon \pi \dot{c}_{\vdots}$; a limpet; a genus of Infuforia.

Lepadi'tes (Fos. Zool.) $\lambda \_\pi \dot{u}_{5}$, a barnacle; a genus of foffil thells refembling barnacles.

Lepas (Zool.) Greek name for a limpet.

Isepechi'nia (Bot.) P. N. in honour of Fohn Lepechin, a Ruftan botanift.

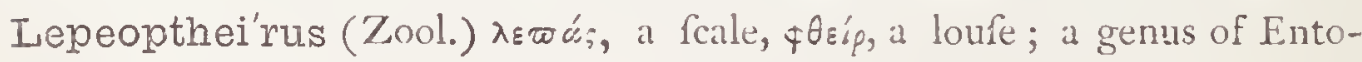
mostraca.

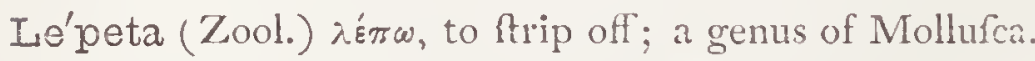

Iepidag'athis (Bot.) $\lambda \epsilon_{w} i_{5}-i_{005}$, a fcale, áratis, a ball.

Lepida'lis (Ent.) lepidus, neat, pretty.

Lepi'dium (Bot.) $\lambda \varepsilon x i s-i \delta o s$, a fcale; referring to the form of the silicles; a genus of Cruciferæ.

Lepidoca'ryum (Bot.) $\lambda \varepsilon \pi i_{5}-\hat{\delta}$ os, a fcale, xupvov, a nut; a genus of Palmæ.

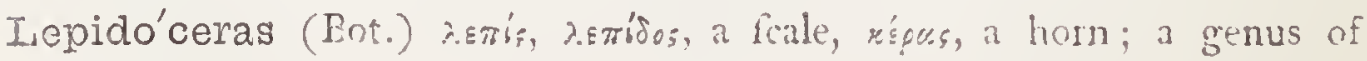
Vif́acex. 


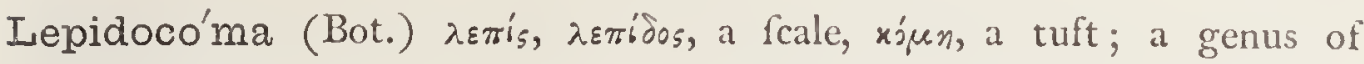
Leguminofa.

Lepido'dei (Fos. Zool.) $\lambda \varepsilon \pi i s, \lambda \varepsilon \pi i \delta o s$, a fcale; a family of gonoid Fines.

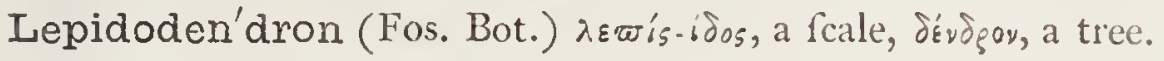

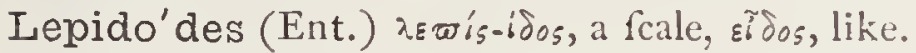

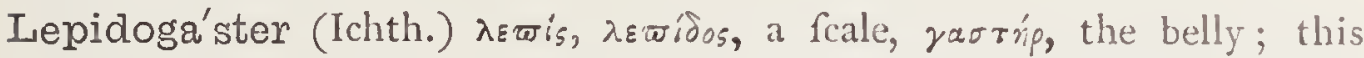
name appears to have been given on the lucus a ron lucendo principle, the filh being remarkable for the abfence of fcales.

Lepidola'rynx (Ornith.) $\lambda \varepsilon \pi ๘ s-i \delta s 5$, a fcale, larynx; a genus of Hummingbirds.

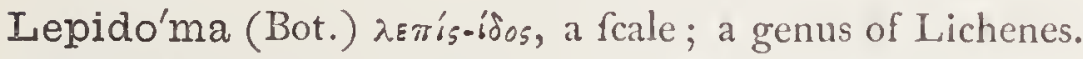

Lepi'domys (Ent.) $\lambda \varepsilon \varpi i_{s}$-ídos, a fcale, $\mu \tilde{u} s$, a moufe.

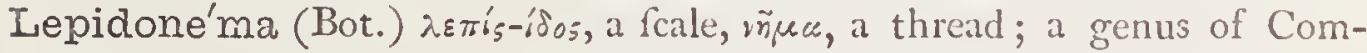
pofitæ.

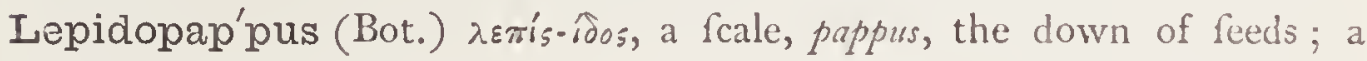
genus of Compofitæ.

Lepidope'talum (Bot.) $\lambda \varepsilon \pi i_{s}, \lambda \varepsilon \pi i \delta$ os, a fcale, petalum; a genus of Sapindaceæ.

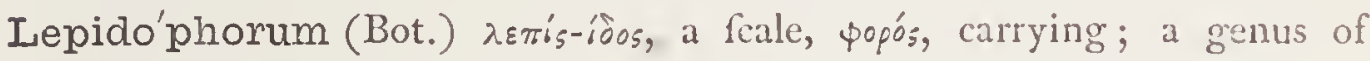
Compofitre.

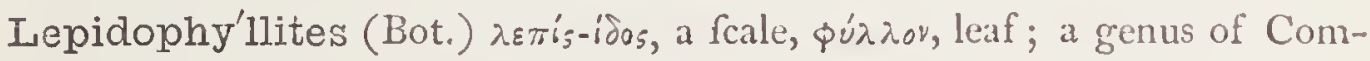
pofitæ.

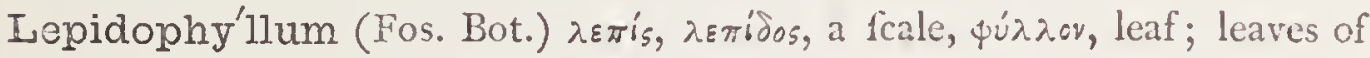
the coal-meafures.

Lepidoph'ytum (Bot.) $\lambda \varepsilon \pi i \xi, \lambda \varepsilon \pi i \delta o s$, a fcale, фutóv, a plant; a genus of Balanophoracex.

Lepidopi'lum (Bot.) $\lambda \varepsilon \pi i \xi-i \delta o s$, a fcale, $\pi i \tilde{\lambda} o v$, hair; a genus of Bryoid Mufci.

Lepidopleu'rus (Zool.) $\lambda \varepsilon \pi i_{5}^{\prime}, \lambda \varepsilon \pi \delta^{\prime} \delta_{05}$, a fcale, $\pi \lambda \varepsilon v$ por , the fide.

Lepidopo'gon (Bot.) $\lambda \varepsilon \pi i s-\hat{\delta} o s$, a fcale, $\pi \omega$ ywy, a beard; a genus of Compofiti.

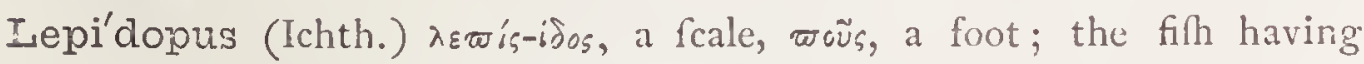
fcales only about the rent and ventral fins.

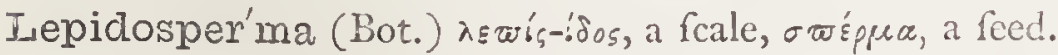

Lepidosta'chys (Bot.) $\lambda \varepsilon \pi i s-i \delta a s$, a fcale, $\sigma \tau \alpha \chi^{\nu}$, a fpike; a genus of Scepacer.

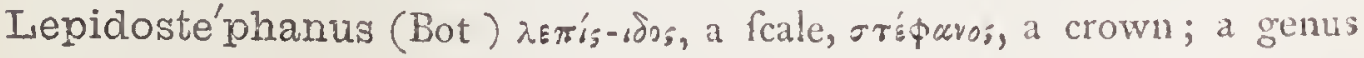
of Compolitaz. 


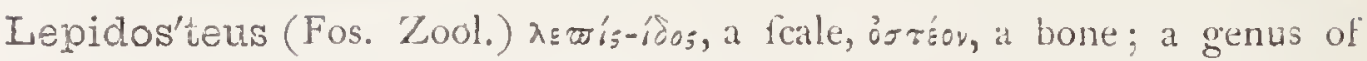
fithes covered with hard bony fcales.

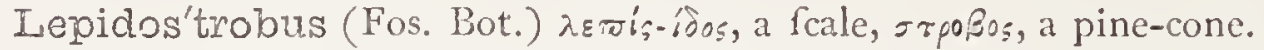

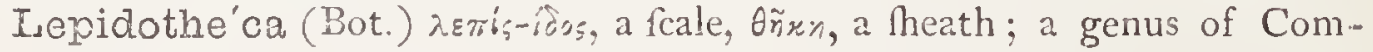
polita.

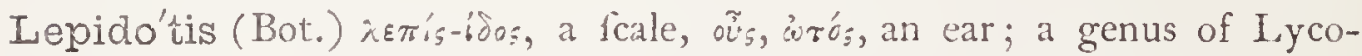
podiacex.

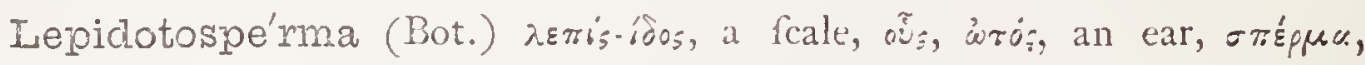
feed; a genus of Cyperacex.

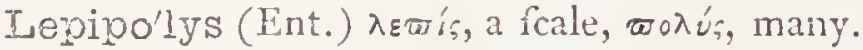

Lepi'stoma (Bot.) $\lambda \varepsilon \pi i_{5}$, a fcale, orópa, mouth; a genus of Afclepiadacex. Leplastriera'na (Eni.) P. N. in honour of Leplaftrier, formerly an active collector of infects at Dover and Ramfgate.

Isepori'des (Zool.) lepus, leporis, a hare, term. ides, refemblance.

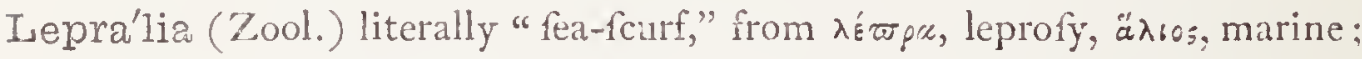

a genus of Polyzoa.

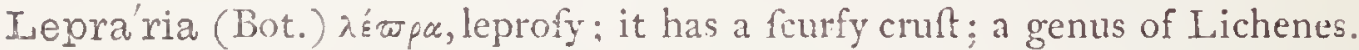

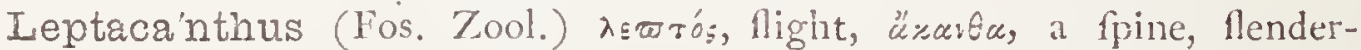
fpined; a genus of Fortil filhes, fo named by Agaffiz on account of their flender fin fpines.

Lepta'cinus (Ent.) $\lambda \varepsilon \varpi r u r$ rós, thin, delicate.

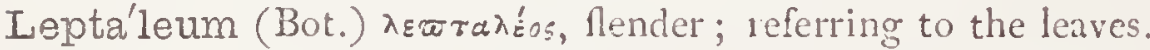

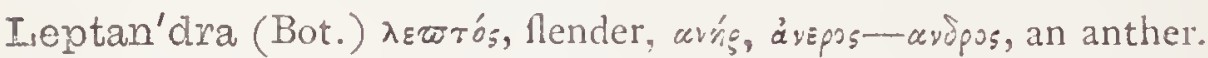

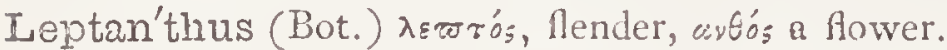

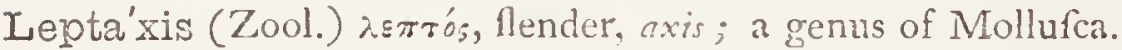

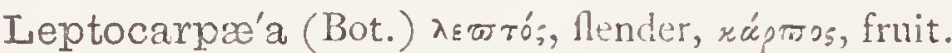

Leptocephal'idre (Ichth.) leptoceplalus, fam. term. ide; a family of Filhes

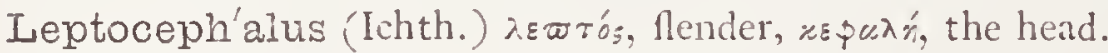

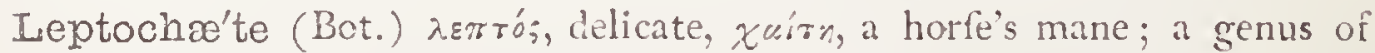
Fungi.

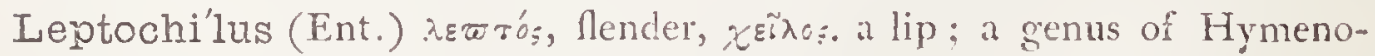
ptera.

Leptochi'ton (Zool.) $\lambda \varepsilon \pi \tau \delta_{s}$, delicate, clitors a coat of mail.

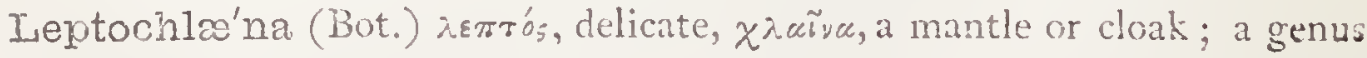
of Bryoid Mufci.

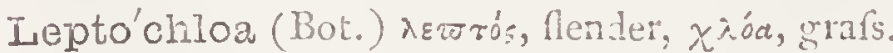

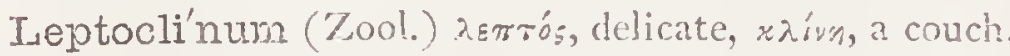

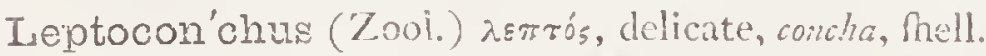

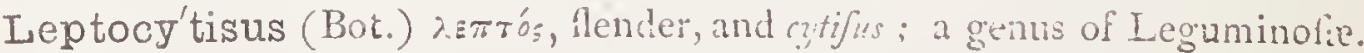




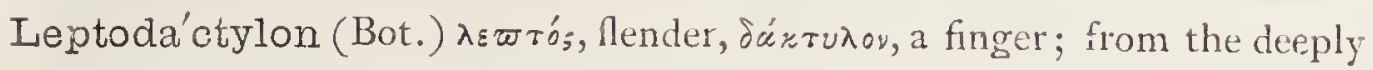
divided leaves and their very narrow fegments; a genus of Polemoniacex.

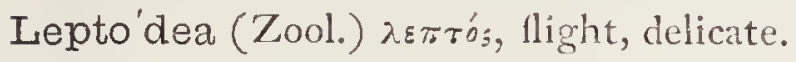

Leptodei'ra (Zool.) $\lambda \varepsilon \varpi \tau o_{z}$, llender, $\delta \varepsilon ı p n$, the neck; a genus of Colubrine ophidians.

Leptoglos'sa (Zool.) $\lambda \varepsilon \varpi r o s$, fiender, $\gamma \lambda \tilde{\omega} \sigma \sigma a$, a tongue; applied to the Slender-tongued lizards.

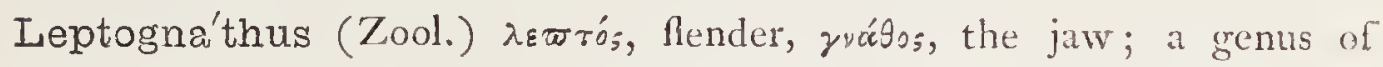
Colubrine ophidians.

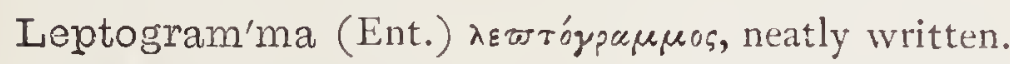

Lepto'lepis (Fos. Zool.) $\lambda \varepsilon \varpi \tau \tau^{\prime} \xi$, flender, $\lambda \varepsilon \varpi^{\prime} s$, a fale; a grenus of fmall Sauroid Fines.

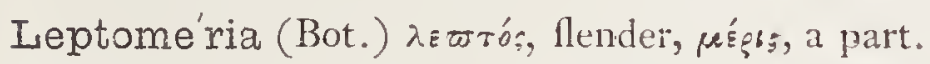

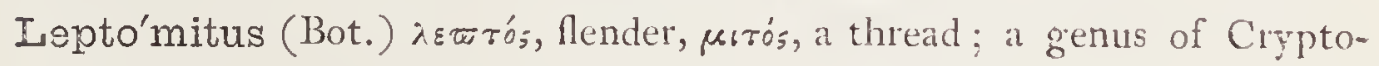
gamia.

Le'pton (Zool.) $\lambda \varepsilon \pi \tau^{\prime} o_{s}$, delicate.

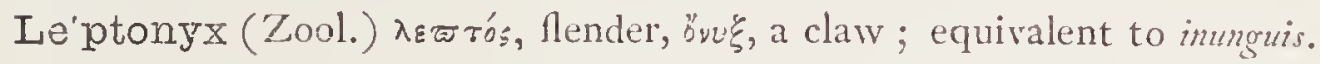

Leptophi'na (Zool.) $\lambda \varepsilon \varpi \tau \sigma_{s}$, flender, öpss, a ferpent; the Tree-ferpents.

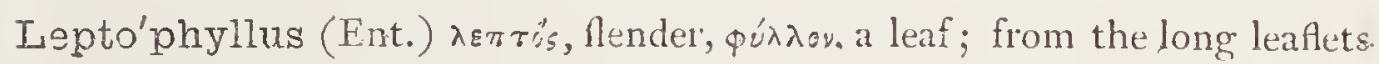

which compofe the antenne.

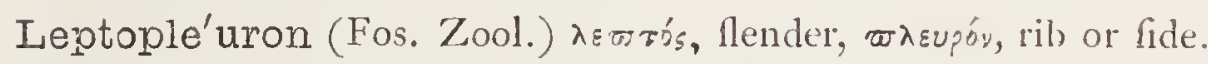

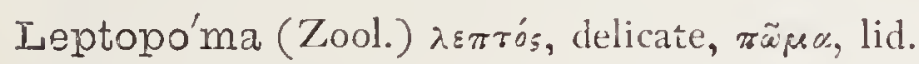

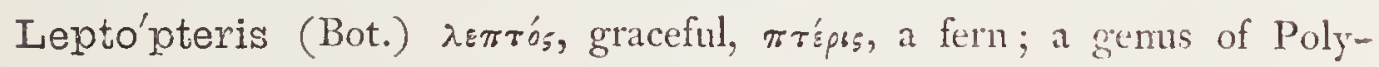
podioid Filices.

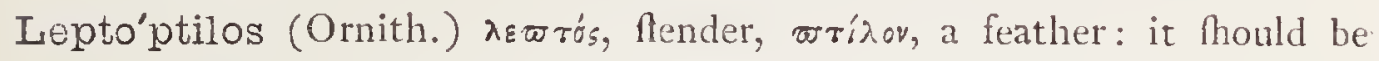
Leptoptilus, as the terminal os, in Greek, is always made us in correct Latin.

Le'ptopus (Bot.) $\lambda \varepsilon \pi r o ́ s$, flender, $\pi$ oũs, a foot; a genus of Euphorbiacex.

Leptorhi'nophis (Ichth.) $\lambda \varepsilon w$ rós, flender, ó:v, fnout, öprs, fnake.

Leptorhy'taon (Zool.) $\lambda \varepsilon \varpi$ rós, flender, jurós, that which is drawn along;

a genus of Colubrine ophidians.

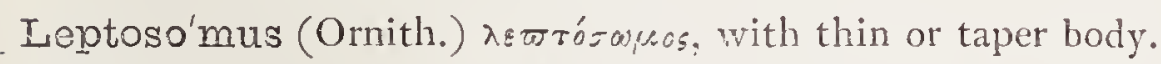

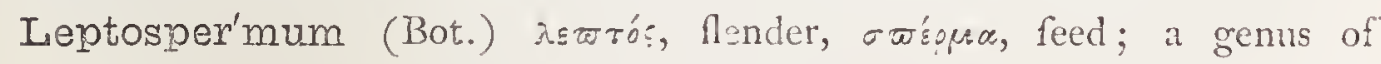
Auftralian Myrtacex.

Leptospo'ndylus (Fos. Zool.) $\lambda \varepsilon \pi \tau$ so, thin, delicate, fpondylus, a vertebra: a clars of Saurian vertebra.

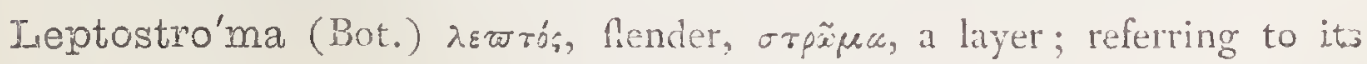
confiftence.

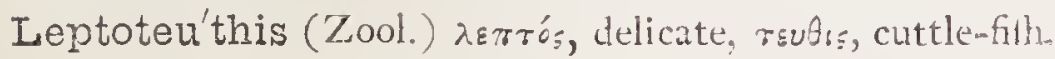


Lepti'ra (Ent.)

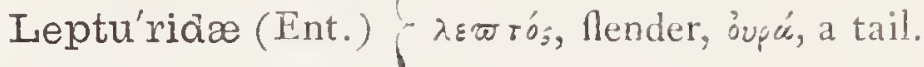

Leptu'rus (Ichth.)

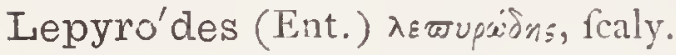

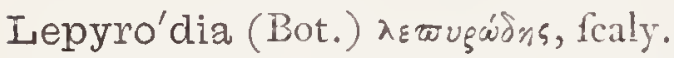

Lere'tia (Bot.) P. N., a genus of Olacacex.

Le'ria (Bot) P. N. probably in honour of Lari, a friend of De Candolle.

Lernæ'a (Zool.) Lerna, a marih in Argolis, which contained the Hydra

killed by Hercules; a fpecies of parafite.

Lernæ'adæ (Zool.) Lerna, with fam. term.

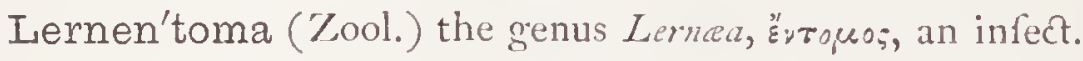

Lerneo'cera (Zool.) the genus Lernea, x'spas, a horn.

Lerneoce'radæ (Zool.) the genus Lernea, with fam. term.; a family of

Entomoftraca.

Lerneomy'zon (Zool.) the genus Lernea, and $\mu$ '́ $\zeta_{\omega} \omega$, to fuck.

Lerneone'ma (Zool.) the genus Lernea, and vĩ $\mu u$, a thread.

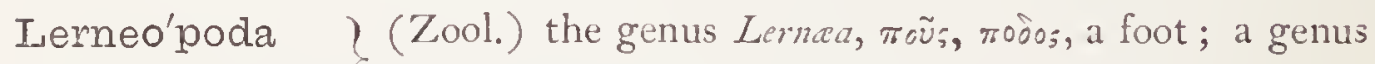
Lerneopo'dadæ $\}$ and family of Entomoftraca.

Leschenau'ltia (Bot.) P. N. in honour of $M$. Lefchenault, a French traveller and botanift.

Les'kea (Bot.) P. N. in honour of N. G. Lojke, Profeflor of Natural hiftory at Marburg; a genus of Mufci.

Lespede'za (Bot.) P. N. in compliment to Leepedez, Governor of Florida, a patron of the fience of botany.

Lesser'tia (Bot.) P. N. in compliment to Stephen Deleffert, a French patron of botany.

Le'stera (Ent.) etymology unknown ; a genus of Coleoptera.

Lestibode'sia (Bot.) P. N. in honour of J. F. Leffiboudois, a Flemith botanift.

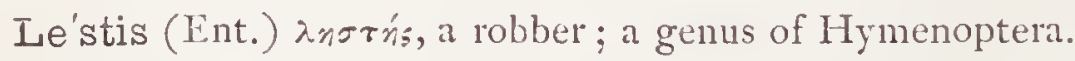

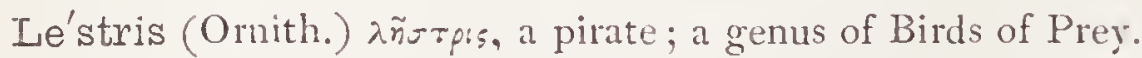

Lettso'mia (Bot.) P. N. in honour of J. Coakley Lettfon, M.D., an Englith phyfician and naturalift, born 1744 , died I 8 I 5 .

Lettuce (Bot.) from Latin, lactuca, the milky plant.

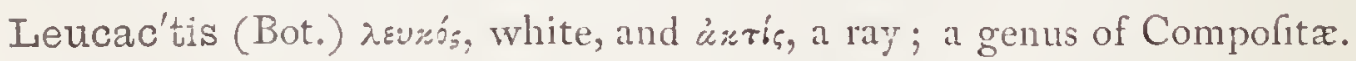

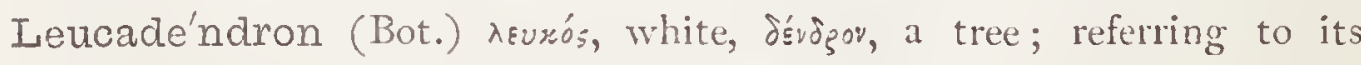

appearance. The Silver-tree; a Cape genus of Proteacea.

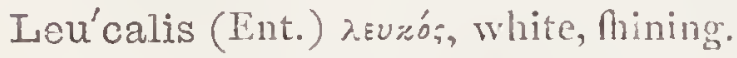

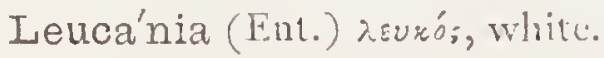


Leucánidæe (Ent.) leucania, fam. term. ida.

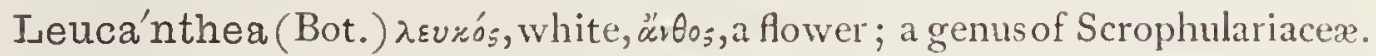

Leu'cas (Bot.) $\lambda \varepsilon u x^{\prime}$, white; referring to the downy whitenefs of the flowers; a genus of Labiata.

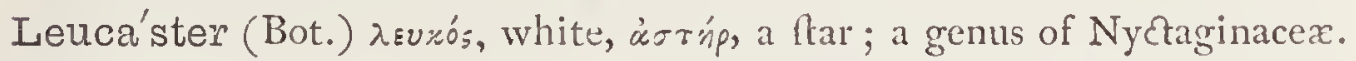

Leuchtenbe'rgia (Bot.) P. N. in honour of ——. Leuchtenberg, a German botanift; a genus of Cactacere.

Leucip'pus (Ornith.) P. N. : the word implies riding a white horfe; a genus of Humming-birds.

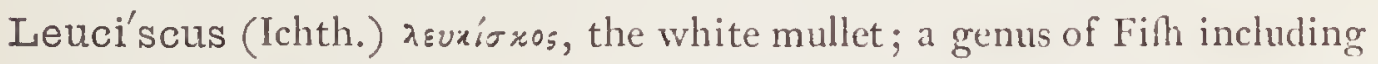
the dace and roach.

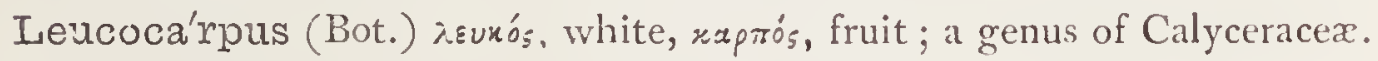

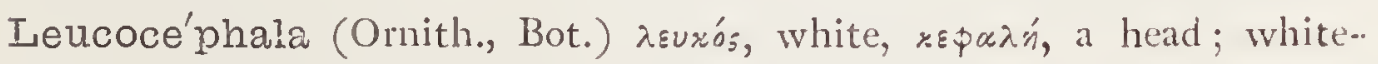
headed.

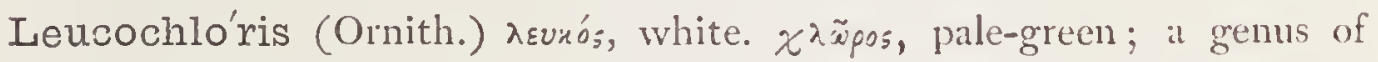
Humming-birds.

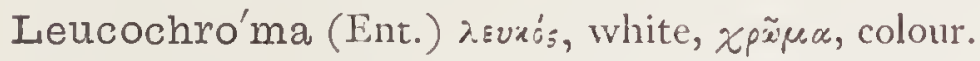

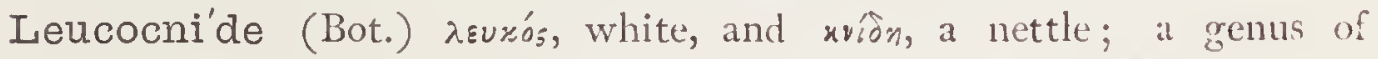
Urticaceæ.

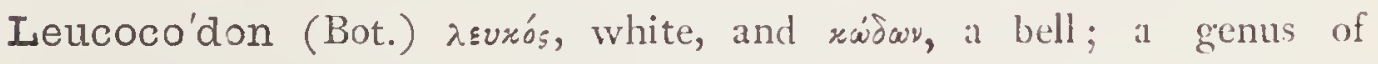
Cinchonacer.

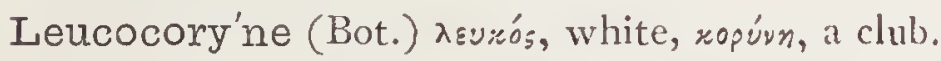

Leucodic'tyon (Bot.) $\lambda \varepsilon v x^{\prime} s$, white, $\delta$ '́xrvs\%, a net, a genus of Leguminofic.

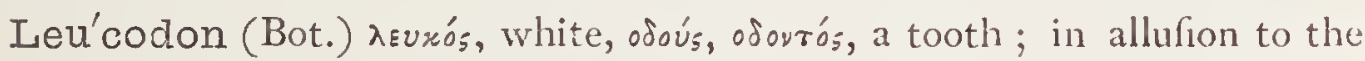
colour of the periftome; a genus of Mufci.

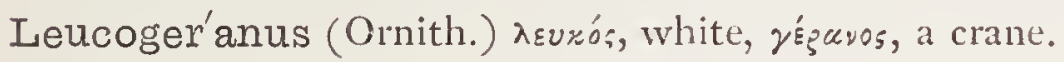

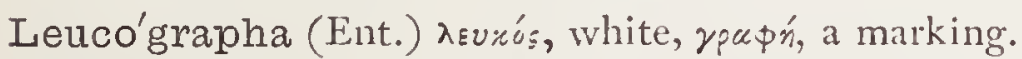

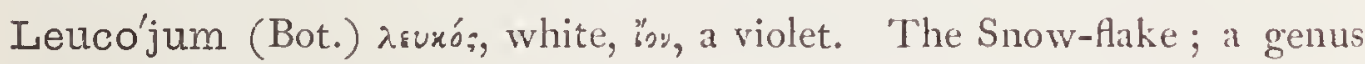
of Amaryllidacea.

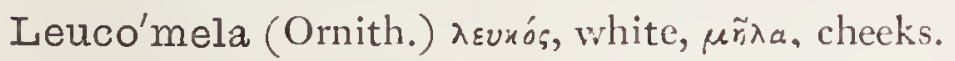

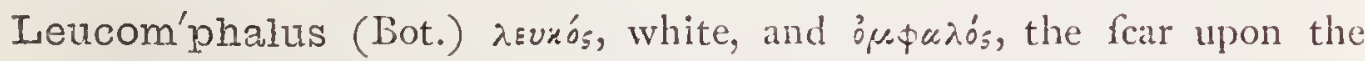
feed; a genus of Leguminofis.

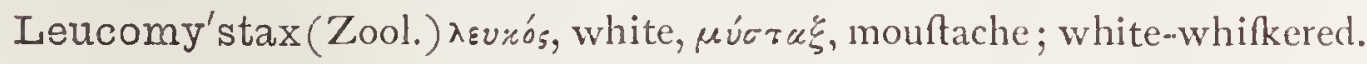

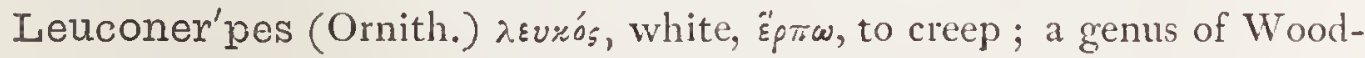
peckers.

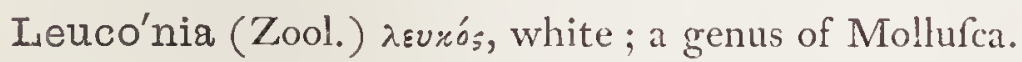

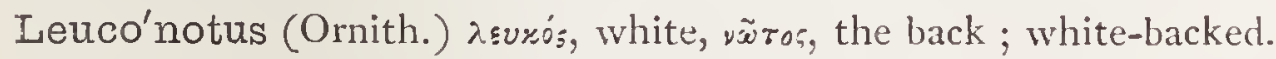

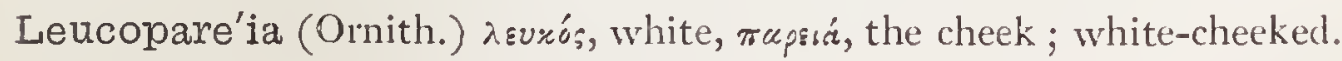

Leucophæa'ria (Ent.) .isvrópłaros, grey, afh-coloured. 


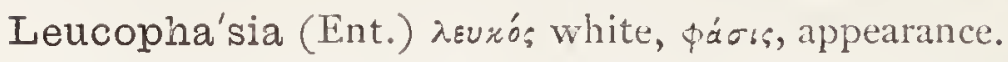

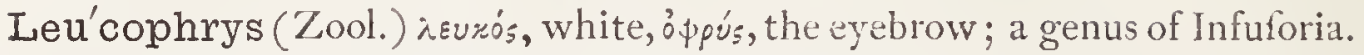

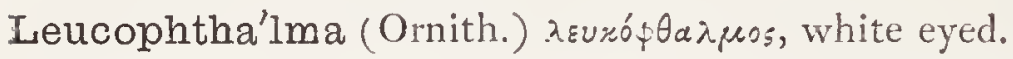

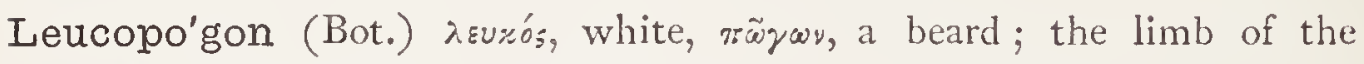
corolla being bearded with white.

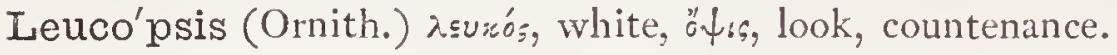

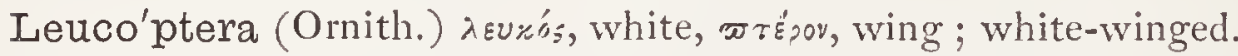

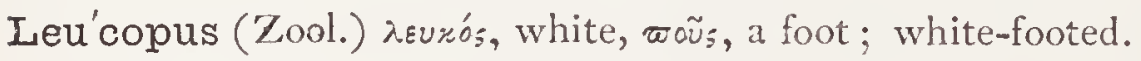

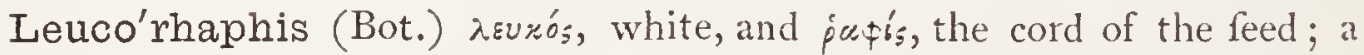
genus of Acanthaceæ.

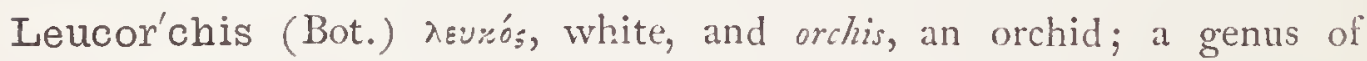
Orchidacea.

Leucoro'dia (Ornith.) $\lambda \varepsilon u r o ́ s$, white, fódov, a rofe; reddifh-white.

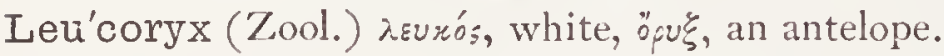

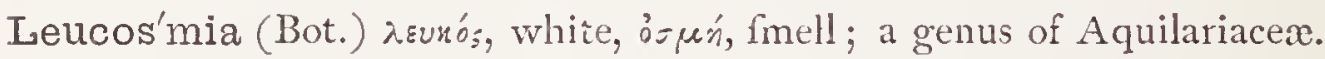

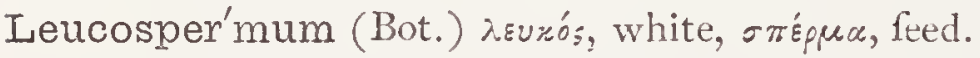

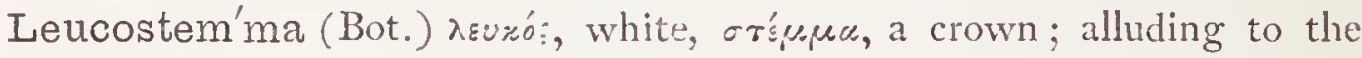
flowers.

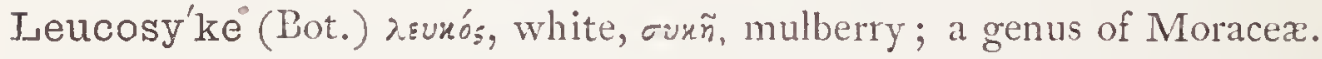

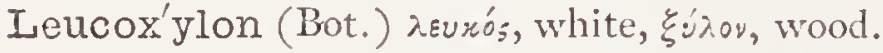

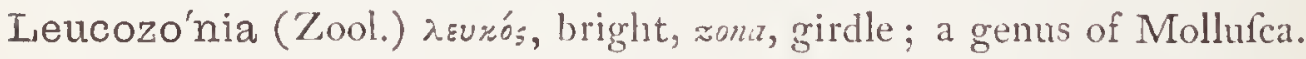

Leucu'rus ('Zool.) $\lambda \varepsilon v x_{o s}$, white, oũpu, a tail; white-tailed.

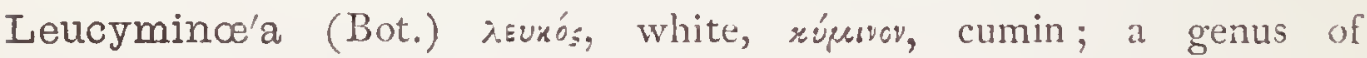
Melaftomaceæ.

Leu'zea (Bot.) P. N. in honour of De Leuze, a friend of De Candolle. Le'veillea (Bot.) P. N. in honour of M. Léveillé; a genus of Fungi.

Leveret (Zool.) French, lievre; a hare in the firft year of its age.

Levieu'xia (Bot.) P. N. in honour of _L Lervieux; a genus of Fungi.

Levis'ticum (Bot.) levo, to affuage; it relieves flatulency; a genus of Umbelliferx.

Lewenhoëkel'la (Ent.) P. N. in honour of Antony von Lercenhök, the famous Dutch naturalift and micrographer, author of "Arcana Nature," who died in 1723 .

Lewi'sia (Bot.) P. N. in honour of the American Captain M. Leavis, who accompanied Clarke to the Rocky Mountains.

Leyceste'ria (Bot.) P. N. in honour of W. Leycefer, Chief Judge at Bengal; a beautiful Eaft Indian genus of Caprifoliacex.

Leyse'ra (Bot.) P. N. in honour of Frederick W. Leyfer, a Gernan botanift. Li'asis ('/ool.) ג áçopat, to bend, to fwerve afide; a genus of Ophidians. 


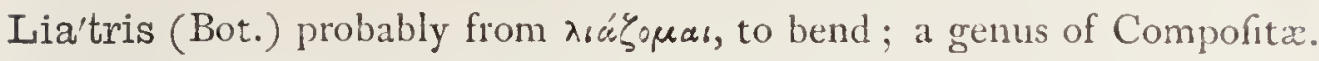

Liberia'nus (Zool.) Lat. relating to Liberia, Africa.

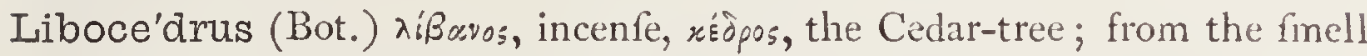
when burnt; a genus of Coniferæ.

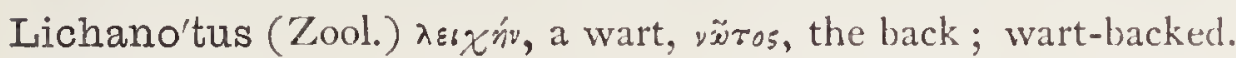

Lichen (Bot.) from its Greek name $\lambda \varepsilon \iota^{\prime} \chi^{\dot{\nu}}$, fignifying a wart.

Lichena'ria (Ent.) feeds on lichens.

Licheni'cola (Bot.) lichen, mofs, colo, to frequent.

Licheno'psis (Bot.) lichen, and ö $\psi$ 's, like; a genus of Fungi.

Lichi'na (Bot.) from its refemblance to lichen; a genus of Cryptogamia.

Lichtenstei'nia (Bot.) P. N. in honour of $M$. von Lichtenfein, a Prufian traveller.

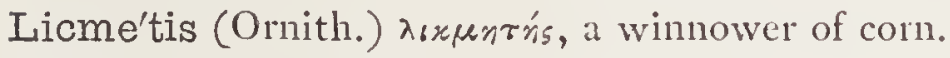

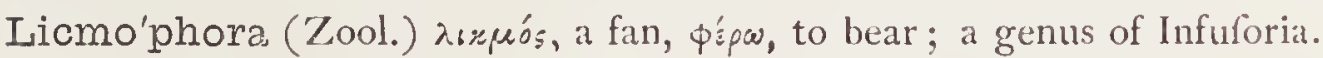

Licua'la (Bot.) its Macafiar name.

Iidbe'ckia (Bot.) P. N. in honour of E. G. Lidbeck, a Swedifh botanift.

Lienigiel'la (Ent.) P. N. in compliment to Madame Licnig, late Honorary

Member of the Entomological Society of Stettin, who died in 1856 .

Lig'dia (Ent.) P. N. from Ligdus, a Cretan, father of Iphis, for whofe ftory fee Ovid, Met. ix., 670.

Lightfoo'tia (Bot.) i'. N. in honour of the Rev. Fohn Lightfoot, author of the "Flora Scotica;" born 1735 , died 1788.

Lignipe'rda (Ent.) lignum, wood, perdere, to deftroy; the larva bores into the ftems of willow and other trees.

Ligulel'la (Ent.) ligula, a little Atrap; alluding to the flender white band acrofs the wings.

Ligu'sticum (Bot.) it grows in great abundance in Liguria; a genus of Umbelliferæ.

Ligu'strum (Bot.) ligure, to tie; alluding to its flexible branches; applied by Virgil to the large white Convolvulus or Convolvulus sepium.

Now given to the Privet; Nat. Ord. Oleaces.

Iilac (Bot.) from Perfan lilag, a flower ; $i$. e., the flower par excellence; the genus Syringa; Nat. Ord. Oleacez.

Iilium (Bot.) Celt. li, whitenefs; in reference to the flowers; the typical genus of the fplendid and favourite Nat. Ord. Liliacex.

Iily (Bot.) Lat. lilium, Greek, גeiprov. Pindar beautifully applies the name

of "Lily-flower of the ocean-dew," to coral:-

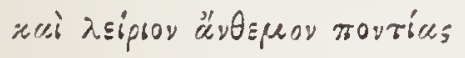

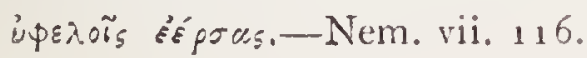


Lima (Zool.) Lat. a thle; a genus of Mollufca.

Lima'cia (Bot.) limaceus, muddy, nimy; a genus of Menifpermaceæ.

Lima'cina (Zool.) limacinus, fnail-like.

Lima'cium (Bot.) limaceus, muddy, flimy; a genus of Fungi.

Limaco'des (Ent.) $\lambda \varepsilon^{\prime} \mu_{\mu} \alpha \xi$, a fnail, eidos, form ; from the fnail-like appearance of the larvæ.

Limamuræ'na (Ichth.) lima, a file, murana, the lamprey.

Lima'nda (Ichth.) unexplained.

Limandoïdes (Ichth.) the genus limanda, sidos, refemblance.

Iimano'mia (Zool.) formed from the genera Lima and Anomia.

Limapo'ntia (Zool.) the genus Lima, and pons, pontis, a bridge; this having a1ched lateral ridges.

Limaitula (Zool.) dim. of lima.

Li'max (Zool.) Lat. a flug.

Limba'tæ (Ent.) limbatus, bordered.

Limbo'ria (Bot.) limbus, a border or fringe.

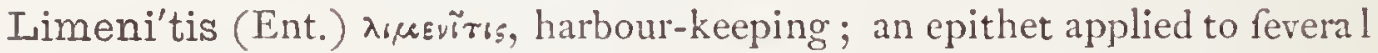
divinities.

Lime-tree (Bot.) properly Line-tree, as giving baft for cordage; the genus Tilia.

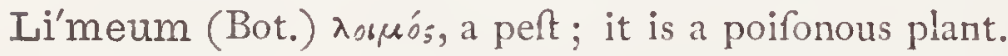

Limicola'ria (Zool.) limus, flime, colere, to dwell; a genus of Mollufca.

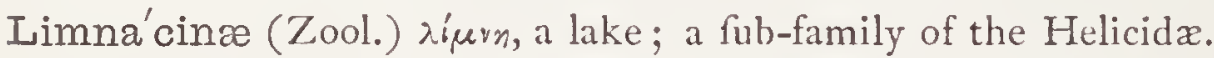

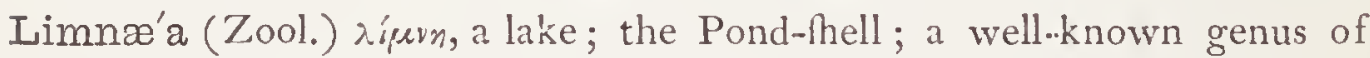
frefh-water Mollufca.

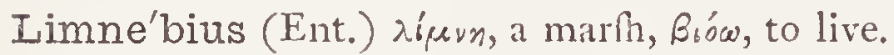

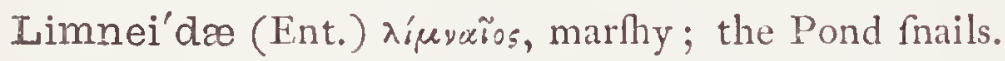

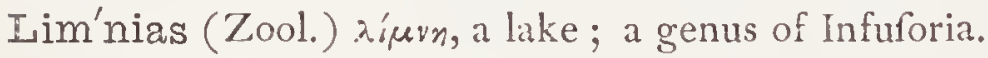

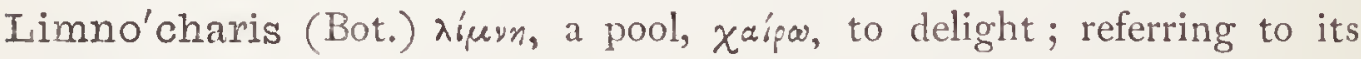
habitat.

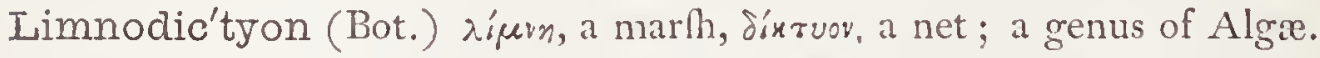

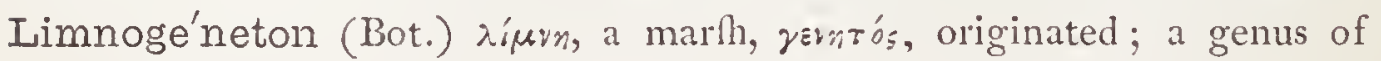
Compolitr.

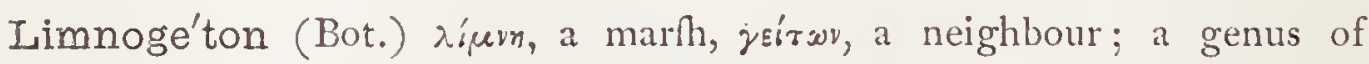
Juncaginacex.

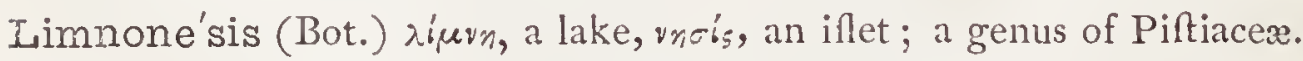

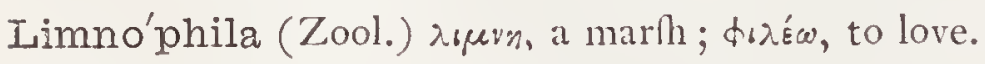

Limnophil'ides (Ent.) a fub-family of Phryganidx.

Limno'philus (Ent.) $\lambda_{i}^{\prime} \mu \nu n$, a pool of ftanding water, $\phi_{b} \lambda_{\varepsilon}^{\prime} \omega$, to love. 
Limno'psis (Zool.) the genus Limncea, and ö $\psi$.s, refemblance.

Limo'nia (Bot.) limoun, the Arabic name of the Citron.

Limo'sa (Ornith.) limofus, muddy.

Limose'1la (Bot.) limus, mud; alluding to its habitation; mudwort; Nat. Ord. Scrophulariacex.

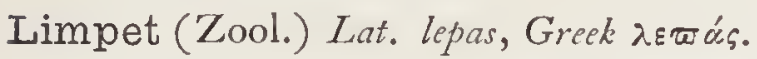

Lim'ulus (Zool.) dim. of limus, fideways; a genus of Cruftaceans.

Lina'ria (Bot.) Linum, flax, from the refemblance which fome of the fpecies, when out of flower, are thought to bear to that plant ; Nat. Ord. Scrophulariacex.

Linden (Bot.) equivalent to line-trec, becaufe it affords baft for cordage.

Linde'nia (Bot.) P. N., a genus of Nyctaginacer.

Linde'ra (Bot.) P. N., a genus of Lauraceæ.

Linde'rnia (Bot.) P. N. in honour of F. B. won Lindern, M.L., of Strafburg, a botanical author.

Lindhei'mera (Bot.) P. N., a genus of Compofitæ.

Lin'dia (Zool.) P. N., a genus of Infuforia.

Lindle'ya (Bot.) P. N. in honour of Dr. Fohn Lindley, the celebrated botanift; a genus of Rofacex; alfo applied to a genus of Samydacex, and another of Ternftrömiacex.

Lindsæ'a (Bot.) P. N. in honour of Lindfay, an Englifhman, who wrote on the germination of Mofles.

Li'nea (Ent.) fo called on account of the line on the forewings.

Linea'ris (Bot.) Lat. confifting of lines, linear ; e.g. Collomia linaris.

Iineo'des (Ent.) the genus Linea, êjoos, like.

Lineopa'lpa (Ent.) linea, a line, palpus, a feeler.

Ling (Bot.) the Englifh name of the Calluna vulgaris or heather.

Iing (Ichth.) Anglo-Sax. lang, long; a long flender fith of the Cod kind.

Inin'gula (Ichth.) Lat. a little tongue; fo called from the tongue-like form of their valves; a genus of Mollufa.

Lingula'tus-a-um (Bot.) Lat. tongue-Thaped; having leaves Thaped like a tongue; e.g., Saxifraga lingulata.

Iinnæ'a (Bot.) P. N. in honour of Linnous, the great naturalift; Nat. Ord. Caprifoliacer.

Linneel'la (Ent.) P. N. in honour of Linnaus.

Iinnet (Ornith.) perhaps fo called from its feeding on the feeds of linum, flax.

Linobla'dia (Bot.) P. N., a genus of Fungi.

Linoblo'mia (Bot.) P. N., a genus of Orchidacex. 
Iinochi'lus (Bot.) the genus Limm, and $\chi \in \overline{r \lambda .05}$, a lip; a genus of Compolitx.

Linocie'ra (Bot.) P. N. in honour of G. Linocier, a French phyfician.

Linschote'nia (Bot.) P. N., a genus of Goodeniacex.

Linseed (Bot.) linum-feed, or Aax-feed.

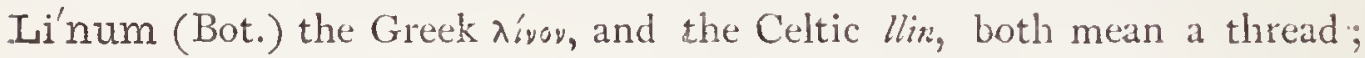
flax; typical gensis of Nat. Ord. Linaceæ.

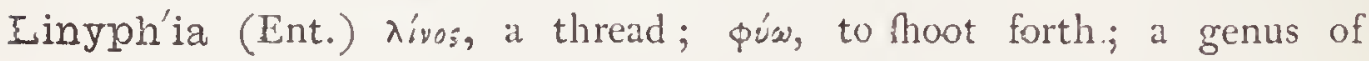
Arachnidx.

Linyphi'idæ (Ent.) a family of Arachnida, of which Limyphia is the type. Lioce'rcus (Zool.) this fpecific name thould be written Leiocercus, from

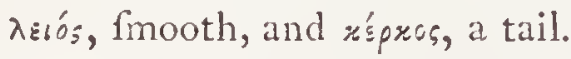

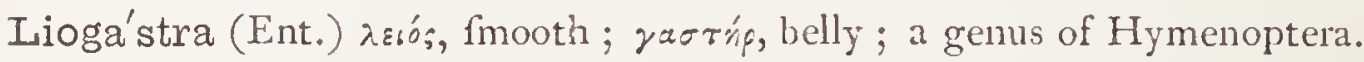
Lion (Zool.) $\lambda$ śwy, Lat. Leo, a lion; perhaps from $\lambda u^{\prime} w$, to fee, alluding to the fharpnefs of its fight.

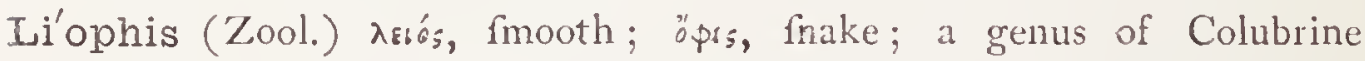
ophidians.

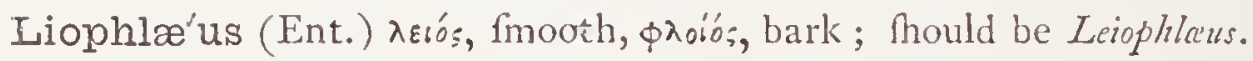

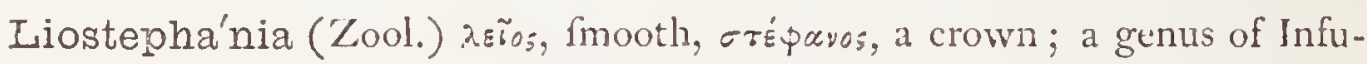
foria.

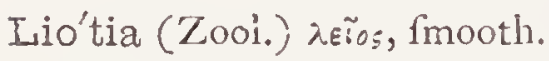

Lipara'lis (Ent.) $\lambda_{6 \varpi a \rho^{\prime}}$, brilliant.

Lipa'ria (Bot.) $\lambda$ เøupos, brilliant; alluding to the furface of the leaves.

Li'paris (Ichth., Bot.) $\lambda$ เ๘após, oily, Rining, brilliant.

Liparogy'ra (Zool.) $\lambda เ \pi \alpha \rho^{\prime} o_{s}$, oily, zupós, round; a genus of Infuforia.

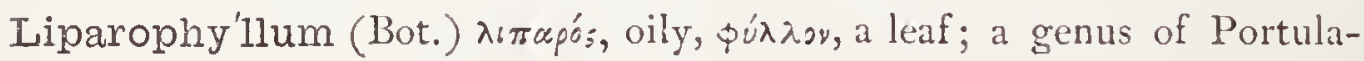
caceiz.

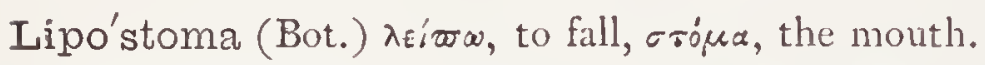

Lip'pia (Bot.) P. N. in honoul of Augufine Lippi, a French phyfician and traveller in Abyfinia.

Liquidam'bar (Bot.) liquidus, liquid, ambar, amber : it exudes gum.

Liquorice (Bot.) from $\gamma \lambda u x u p \rho p \zeta \zeta$, fweet root, through the Latin glycyrrhiza, and Italian liquirizia.

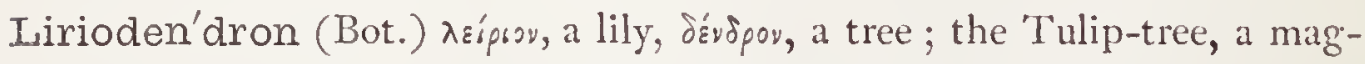
nificent North American fpecies of Magnoliacea.

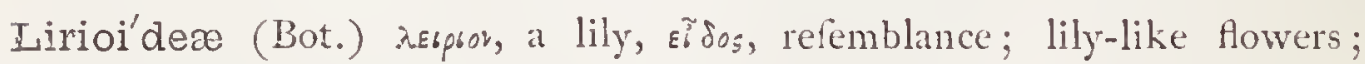
Brongniart's name for the Liliacex.

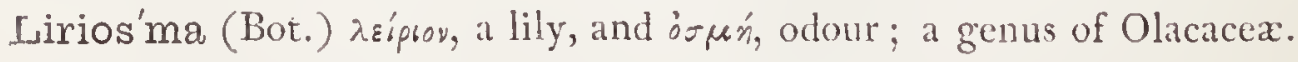

Lisia'nthus (Bot.) $\lambda i s$, fmooth; $\ddot{e} \nu \theta_{0}$, a flower. 


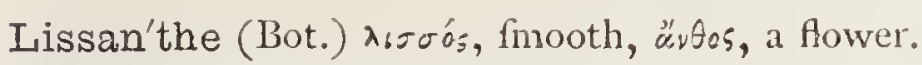

Lissochi'lus (Bot.) $\lambda_{6} \sigma \sigma^{\prime} o_{s}$, fmooth, $\chi \in \tilde{c} \lambda_{0} \sigma_{s}$, a lip.

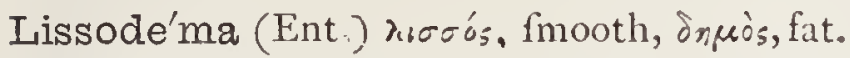

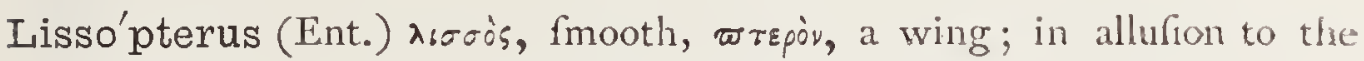
almoft total abfence of fculpturing on the elytra.

Liste'ra (Bot.) P. N. in honour of Martin Lifter, M.D., a celebrated Englifh naturalift; a curious genus of terrestrial Orchidaceæ.

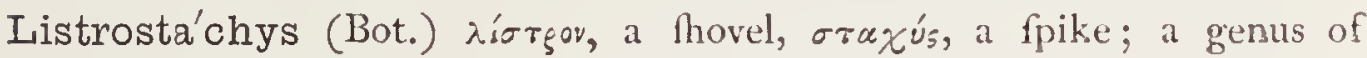
Orchidacex.

Litchi (Bot.) Chinefe native name for the celebrated fruit of the Dimocarpus Litchi.

Litera'lis (Ent.) litera, a letter; referring to the mark, refembling an Arabic character, in the middle of the wing.

Lithargy'ria (Ent.) $\lambda_{6} \theta$ áprupos, vitrified lead; from the general tinge of the wings.

Ii'thinus-a-um (Bot.) $\lambda^{\prime} \theta$ เvos, refembling ftone; ftorre-coloured.

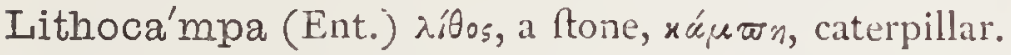

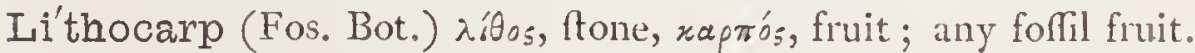

Lithoca'rpus (Bot.) $\lambda$ i $^{\prime}$ os, ftone, xapros, fruit, from the hardnefs of the fhell; a genus of Corylacex.

Lithoco'lletis (Ent.) $\lambda_{6} \theta_{0} x_{0} \lambda_{n} \tau_{0}$, inlaid work, mofaic.

Lithodac'tylus (Ent.) $\lambda \hat{i} \theta_{0 s}$, a ftone, $\delta \dot{\alpha} x \tau u \lambda_{0} ;$, a plume.

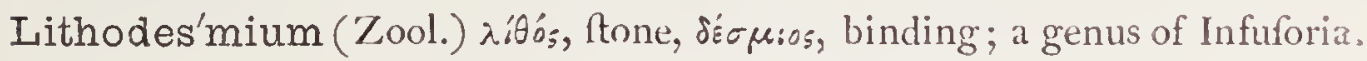
Litho'domi (Ichth.) $\lambda_{i}^{\prime} \theta_{0 s}$, a Itone, dános, a house; applied to Mollufcâ, which bore into solid rocks.

Lithogly'phus ('Zool.) $\lambda_{6}^{\prime} \theta_{05}$, ftone, riúps, to hollow out.

Lithone'ma (Bot.) $\lambda_{6} \theta_{0} ;$, a ftone, iñuce, a filament; from the calcareous incruftation; a genus of Alga.

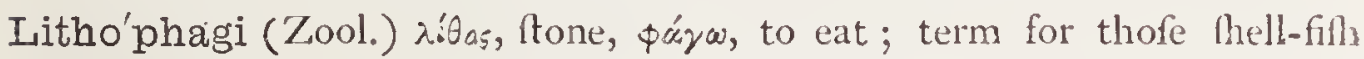
which bore holes and lodgments in ftone, coral, \&c.

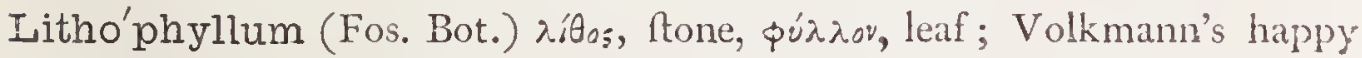
term for the Stigmaria.

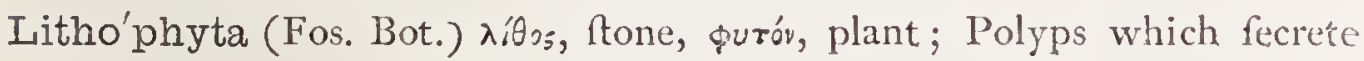
a ftony axis, as the corals, in contradiftinction to the Ceratoplayta.

Lithori'za (Ent.) $\lambda_{i}^{\prime} \theta_{0 s}$, a ftone, pi $\zeta \lll$, a root.

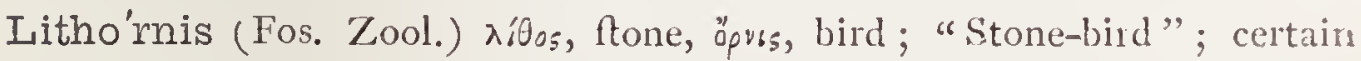
foffil birds of the Eocene clay.

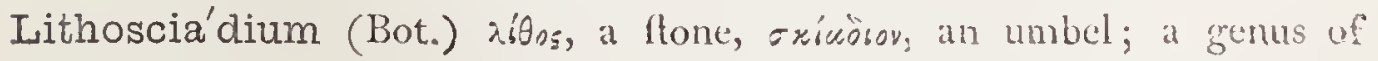
Umbelliferx. 
Lithosia'lis (Ent.) 入íos, a ftone; from the grey hue and ftony appearance of feveral of the fpecies.

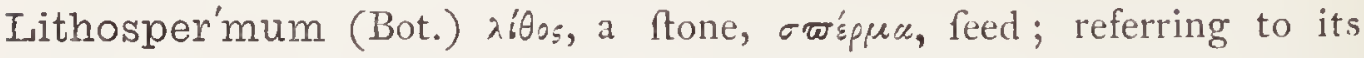
hardnefs: the pericarp of the feed contains nearly fixty per cent. of earthy matter; a genus of Boraginacex.

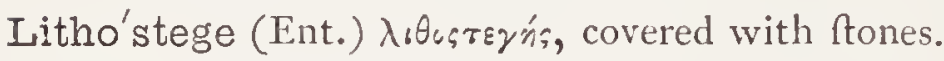

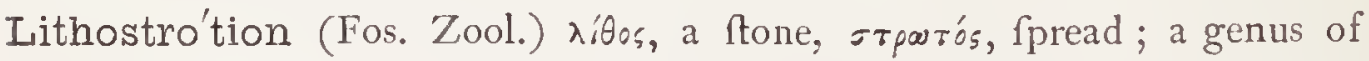
Foffil corals.

Lithothe'cia (Zool.) $\lambda . \theta_{0 \xi}$, ftone, $\theta_{n}$ xn, a theath; a genus of Infuforia.

Iithotry'a (Fos. Zool.) $\lambda{ }^{\prime} \theta_{0 s}$, frone, rpúw, to bore; a genus of Fofil Cirripecies.

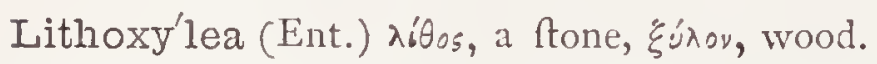

Litori'na (Zool.) litoreus, pertaining to the fhore.

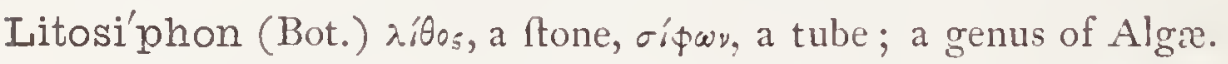

Littæa'a (Bot.) P. N. in compliment to the Duke of Lytta, near Milan.

Littora'lis (Bot.) Lat. pertaining to the fea-hhore.

Littorel'la (Bot.) littus, the More; alluding to its place of growth, which is, however, on the borders of lakes, rather than upon the margin of the fea; Nat. Ord. Plantaginaceæ.

Litui'tes (Fos. Zool.) liturs, a trumpet; a genus of chambered thells of the Silurian ftrata.

Lituoli'tes (Fos. Zool.) lituus, a trumpet, גios, ftone; a genus of Foraminifera found in the chalk.

Litura'lis (Ent.) litura, a blot or fmear.

Litura'ta (Ent.) lituratus, blotted or rubbed out.

Livia (Ornith.) P. N., a common Roman name.

Li'vidus-a-um (Zool., Ent.) Lat. of a bluifh colour, livid.

Llama ( 7 ,ool.) native Peruvian name.

Livisto'nia (Bot.) P. N. in honour of Patrick Murray, of Leviftone, near

Edinburgh; a genus of Palm-trees.

Ii'xus (Ent.) lix, athes, referring to colour.

Lizard (Zool.) lacerta, a lizand; fo called, perhaps, becaufe its limbs refemble the arm (lacertus) of a man.

Loa'sa (Bot.) unexplained; typical genus of the American Nat. Ord.Loafacex. Lo'bbia (Bot.) P. N. in honour of $M$. Lobb, a diftinguilhed Belgian botanift; a genus of Ariftolochiacex.

Lobe'lia (Bot.) P. N. from Mathere Lobel, author of various works, particularly of "Icones Plantarum." He was born at Lifle in 1538 , became Phyfician to James I., and died in London, I 616. 


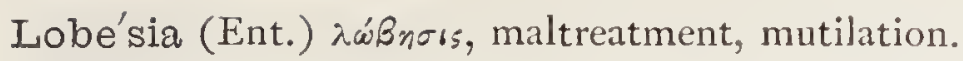

Lo'biger (Zool.) $\lambda$ óbos, a lobe or pod, gerere, to carry.

Lobi'pedes (Ornith.) lobus, a caruncle, pedes, feet; a family of Birds.

Lobivane'llus (Ornith.) lobus, a caruncle, vanellus, a lapwing.

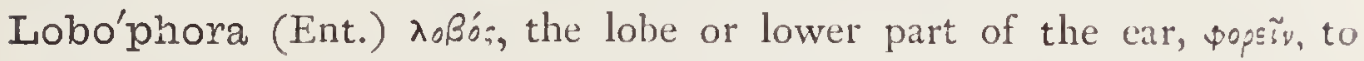
carry; in allufion to the lobe-haped winglets attached to the hind wings of the males.

Lobster (Zool.) Anglo-Sax. lopyftre; Homarus vulgaris.

Lobula'ta (Ent.) 2oBos, a lobe, or projection.

Lo'culi (Zool.) plural of loculus, a little receptacle or calket.

Locust (Ent.) Lat. locufta, which is faid to be from locus, a place, wro, whus, to burn.

Loddige'sia (Bot.) 1. N. in honour of Conrad Loddiges, nurferyman, Hackney.

Loddige'sia (Ornith.) P. N. in honour of George Loddiges, F.R.S., of Hackney; a genus of Humming-birds.

Lodoic'ea (Bot.) P. N. from Laodice, daughter of Priam and Hecuba; the double Coco-nut of the Seychelles; Nat. Ord. Palmæ.

Lœflin'gia (Bot., Ent.) P. N. from P. Laffing, a Swedifh botanift, born 1729 , died 1756 .

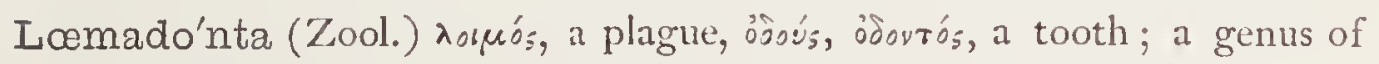
Mollufea.

Loewii (Ent.) P. N. from Dr. H. Loew, of Meferitz, late of Pofen; author of fome papers in " Linniea Entomologica."

Loganel'la (Ent.) P. N. from $M_{r} . R$. F. Logan, of Dudding ftone, near Edinburgh.

Loga'nia (Bot.) P. N. from J. Logan, a diftinguifhed botanift; typical genus of Nat. Ord. Loganiacex.

Loli'go (Zool.) Lat. a cuttle-fifh.

Lo'lium (Bot.) Lat. rye-grafs; L. temulentum is generally fuppofed to be the "Infelix lolium" of Virgil.-VIne alfo Ovid. Faftor. Lib. i. 692.

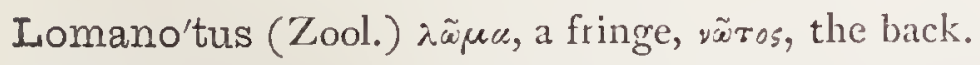

Loma'ria (Bot.) $\lambda \tilde{\omega} \mu \omega$, an edge; referring to the marginal pofition of indufia; a genus of Filices.

Lomarid'ium (Bot.) the genus Lomaria, and $\varepsilon_{i} \delta_{0}$, like; a genus of Polypodioid Ferns.

Loma'tia (Bot.) $\lambda \tilde{\omega} \mu \alpha$, a border; referring to the winged edge of the feeds. Iomentaceæ (Bot.) a fection of I.eguminofa, the pods of which are jointed or lomentofe. 
Lonchi'tis (Bot.) גoyxn, a lance; referring to the form of the fronds; a genus of Filices.

Lonchocar'pus (Bot.) $\lambda o_{\gamma} \times n$, a lance, xuprós, fruit.

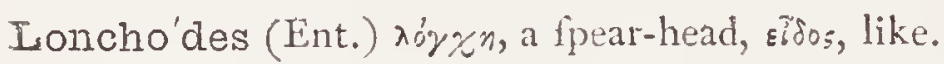

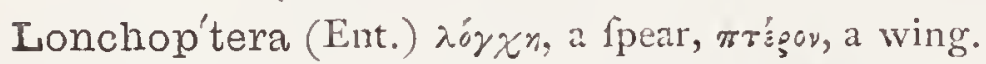

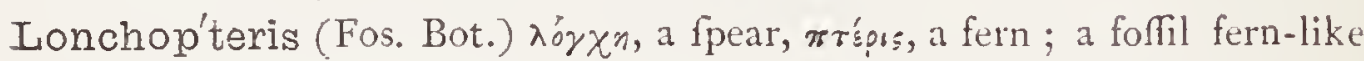
frond, fo called from its refemblance to the racent Lonchitis.

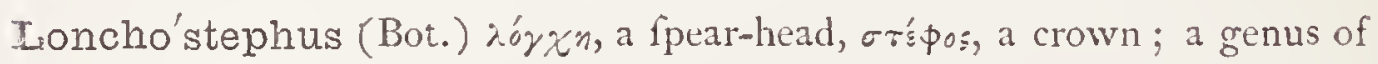
Podoftemacex.

Ioncho'stoma (Bot.) rórx\%, a fpear-head, rrókce, mouth; a genus of Bruniacex.

Lonchu'ra (Ornith.) róyxn, a lance, oüpe, tail.

Longcham psia (Bot.) P. N. from F. A. Loifeleur Defongchamps, RY.D., a French botaniR.

Longicau’da (Ornith.) longus, long, cauda, tail; long-tailed.

Iongicor'nes (Ent.) longus, long, cormt, horn; the Long-horned beetles.

Lon'gidens (Ent.) longus, long, dens, a tooth.

Iongim'ana (Zool.) longus, long, manus, hand; long-handed.

Longipa'1pis (Ent.) longrus, long, palpus, a feeler.

Longipin'nis-e (Ichth.) longus, long, pinna, a fin.

Loni'cera (Bot.) P. N. in honour of Adam Loniccr, a German botanift, who died in 1586 : the Honeyfuckle; Nat. Ord. Caprifoliaceæ.

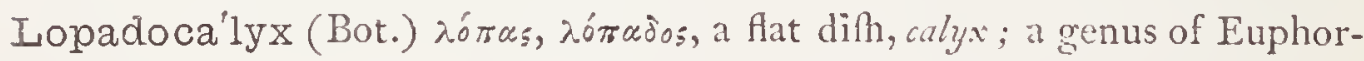
biacere.

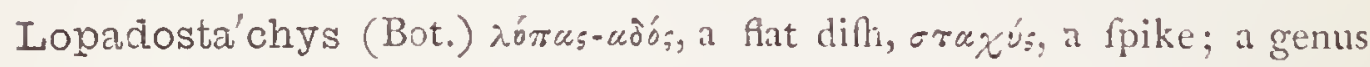
of Olacacex.

Lope'zia (Bot.) P. N. from T. Lopez, a Spanifh botanin; a pretty Amer. ican genus of Onagracex.

Lo'pha (Ent.) 入ópos, a plume or creft.

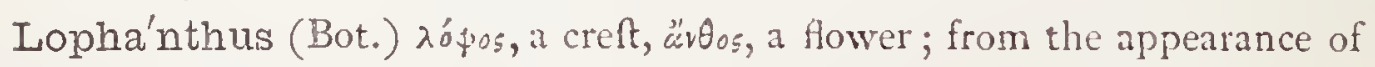
the flowers.

Lophi'odon (Fos. Zool.) xóprov, a fmall creft, ódoús, ódorros, a tooth; an extinct pachyderm fo called from certain points or eminences on its teeth.

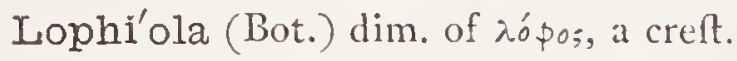

Lophi'ra (Bot.) $\lambda o ́ p o s$, a creit or plume.

Lo'phium (Bot.) גó

Lo'phius (Ichth.) ró

Lo'phobranchs (Ichth.) iósos, a tuft, Bpáy,x:x, gills: having tufted gills ; an order of Fifhes. 
Lopho'comus (Ent.) גópos, a tuft, ropen, hair.

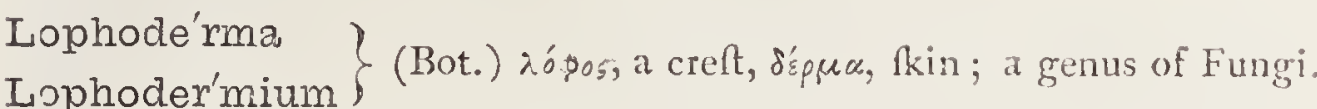

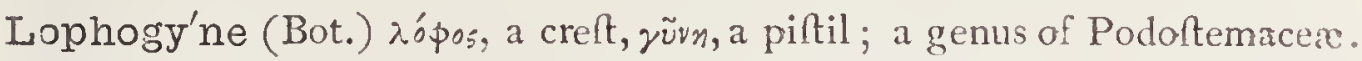

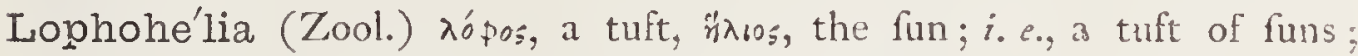
alluding to the radiating plates of the corallites.

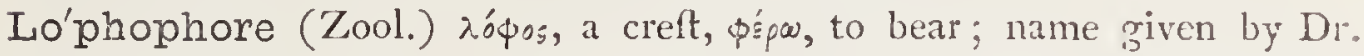
Allman to the din which bears the tentacles in fome marine animals.

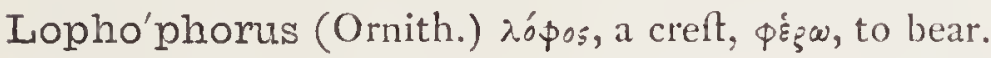

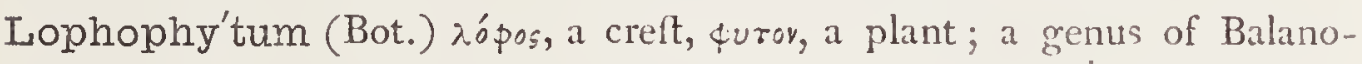
phoracex.

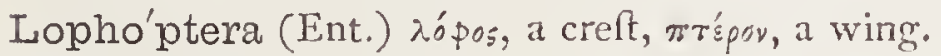

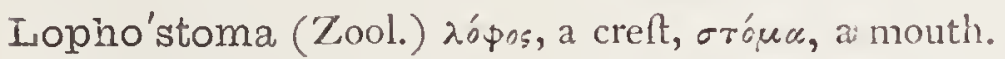

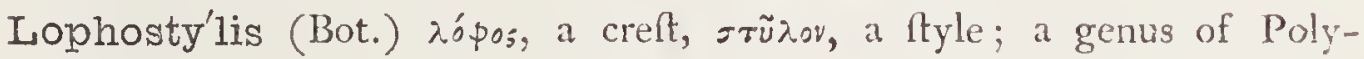
galacex.

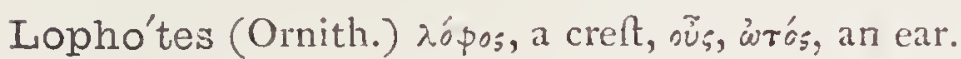

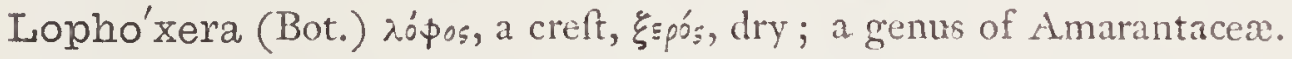

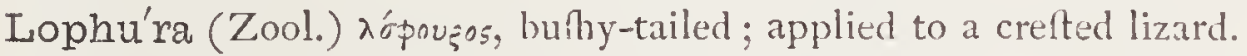

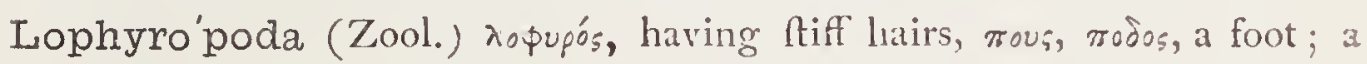
divifion of Entomoftraca.

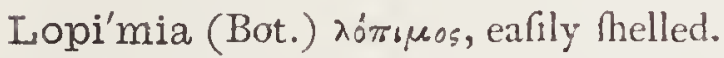

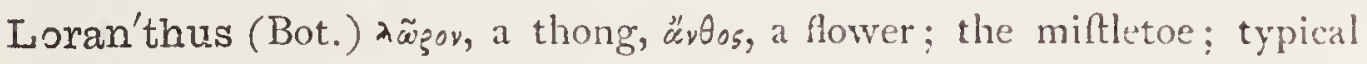
genus of Nat. Ord. Loranthacex.

Lorenza'nea (Bot.) P. N., a genus of Sapindacex.

Lo'rica (Zool.) Latin, a fence or inclofure; the diaphanous mombrane in the Infuforia.

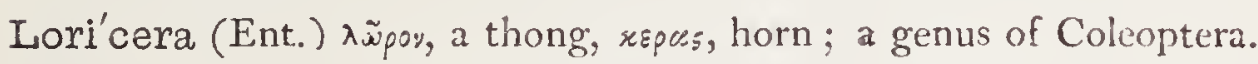

Lori'cula (Fos. Zool.) Lat. dim. of lorica, a coat of mail; a genus of Fofiil cirripedes.

Lorinse'ria (Bot.) P. N., a genus of Polypodioid Filices.

Lo'ripes (Zool.) Lat. crook-footed.

Lory (Ornith.) unexplained.

Lo'ta (Ichth.) lotus, neat; the Ling.

Lotono'nis (Bot.) Lotus and Oronis, combining the features of both genera; a genus of Leguminofie.

Lo'tor (Zool.) Lat. a walher; from its immerfing its food in water; fpecific name of the Racoon.

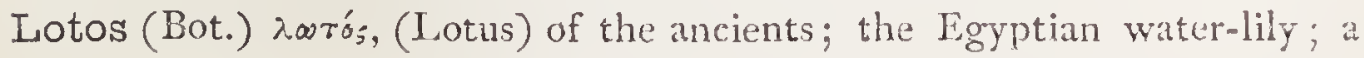
genus of Nymphæacex. 
Lo'tus (Bot.) intón, of the Greeks. There were three forts, of lotus diftinguifhed by the ancients, viz., their tree-lotus, which was our zizyphus lotus; the mark-lotus, which was our nymphaa lotus; and the herbaceous, now called nelumbium fpeciofum.

Loudo'nia (Bot.) P.N. in honour of the late eminent F. C. Loudon; a genus of Leguminofe; alfo applied by Lindley to a genus of Halorageacex.

Loure'ira (Bot.) P. N. from Father Fohn de Loureiro, a Portuguefe writer on botany.

Louse (Ent.) Anglo-Sax. lus.

Low'ea (Bot.) P. N., the fimple-leaved rofe, or Rofa berberifolia.

Lowei (Ichth.) P. N. in honour of the Rev. R. T. Lozve.

Loxan'thera (Bot.) $\lambda 0_{\xi}^{\prime} o_{s}$, flanting, anthera; a genus of Loranthacex.

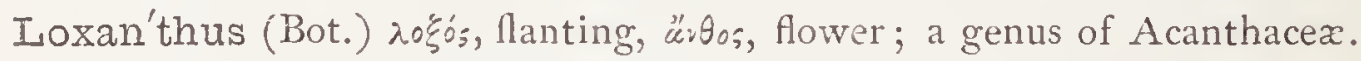

Io'xia (Ornith.) rołos, flanting, crofswife; the Crofsbill.

Loxi'nes (Bot.) Martius' name for the Monocotyledonous or Endogenous clafs of plants, from $\lambda .0_{\xi}^{\prime} \%$, crofs-wife.

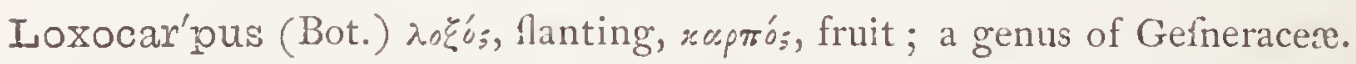

Loxoca'rya (Bot.) $\lambda_{0} \xi_{5} o_{\xi}$, flanting, xápuov, a nut; a genus of Reltiacex.

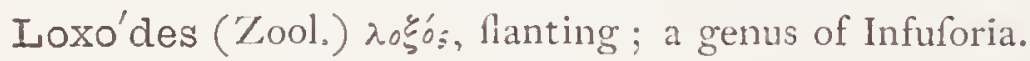

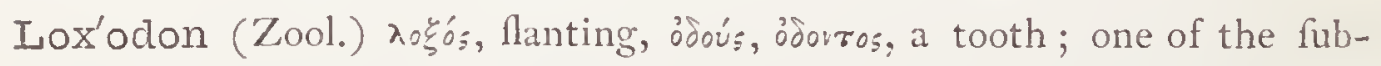
genera into which Dr. Falconer divides the elephant; referring to the rhomb-fhaped dinks of the worn molars.

Loxogram'ma (Bot.) ro $\xi_{5}^{\prime} o_{3}$, flanting, gramma, an infcription; a genus of Polypodioid Filices.

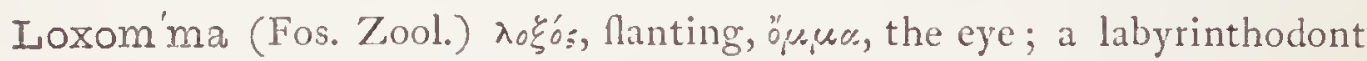
reptile from the Edinburgh coal-field.

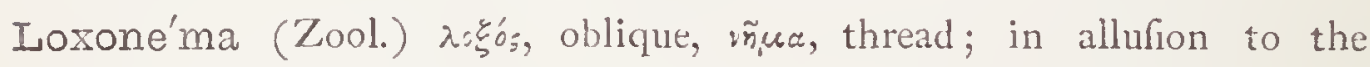
ftriated furface; a genus of Mollufca.

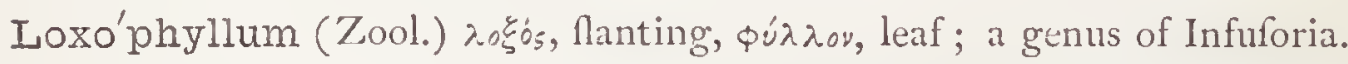

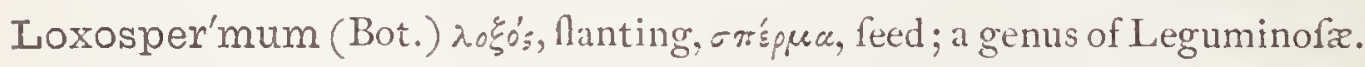
Lubínia (Bot.) P. N. from $M$. de St. Lubin, a French officer.

Lubrica'lis (Ent.) lubricus, llippery.

Iubri'cipes (Ent.) Lat. fwift-footed; from the activity of the larva.

Iuca'nidae (Ent.) lucanus, fam. term. ide.

Luca'nus (Ent.) Lat. pertaining to the light or morning.

Iu'cens (Bot.) Lat. Mining; e.g., Potanogeton lucens.

Iucern (Bot.) called, in Languedoc patois, lanferda; the Vielilotus; Nat.

Ord, l,eguminofie. 
Luce'rna (Zool.) Lat. a lamp.

Lucerna'ria

Iucernari'adæ $\}$ (Zool.) lucerna, a lamp; a genus and family of Zoophytes.

Lucer'nea (Ent.) lucerna, a lamp; "frequenter candelis involans."-Linnzus.

Lucida'lis (Ent.) lucidus, bright, clear.

Lu'cidus-a-um (Bot.) Lat. clear.

Luci'fugus (Ent.) lux, lucis, light, fugio, to avoid.

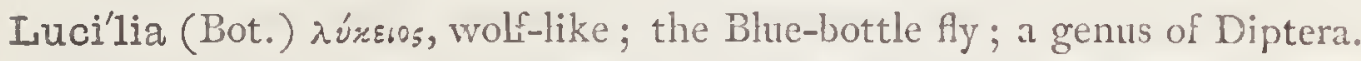

Luci'na (Ent.) P. N., the godders who aided women in childbirth.-VIRG. Ecl. iv. Io.

Luci'na (Zool.) P. N., a name of Juno; a genus of Mollufca.

Iucinop'sis (Zool.) the genus Lucina, o' $\psi$ s, refemblance; a genus of Mollufca.

Luci'ola (Bot.) fame etymology as Lulzul., q. v.; a genus of Jancacex.

Lu'cius (Ichth.) Lat. the Pike.

Luctuo'sa (Ornith.) Lat. forrowful, fad.

Isucule'lia (Ent.) luculus, a little grove.

Iucu'lia (Bot.) P. N. from Luculi Srva, of Nepal.

Iu'dia (Bot.) ludo, to fport.

Lu'dius (Ent.) Lat. a dancer.

Ludovicia'nus (Zool.) relating to Louifiana.

Ludwi'gia (Bot.) P. N. in honour of C. G. Ludzuig, Profeflor of Medicine at Leipfic.

Iu'ffa (Bot.) Arabic, louff; a genus of Cucurbitacex.

Iugu'bris-e (Ornith., Ent.) Lat. mournful.

Iui'dia (Zool.) etymology doubtful; a genus of Echinodermata.

Lumbrici'dia (Bot.) from the refemblince of the legumes to earthworms-lumbrici; a genus of Leguminofix.

Lumbricifo'rmis (Ichth.) lumbricus, an earth-worm, forma, thape.

Iumbri'cus (Zool.) Lat. an inteftinal worm.

Lumnit'zera (Bot.) P. N. from Stepken Lumritzer, a writer on botany.

Iunalis (Ent.) luna, the moon, from the crefentic wing-mark.

Iunar'ca (Zool.) luna, the moon, arca, a bow; from the fhape of the thell.

Luna'ria (Bot.) luna, the moon; referring to its broad filvery filicles; a genus of Cruciferæ. Alfo the fpecific name of a kind of Fern.

Iuna'tus (Zool.) Lat. horned, crefcentic.

Lunda'na (Ent.) P. N. in honour of Lund, a Norwegian entomologift of the laft century. 
Luni'gera (Ent.) lumb, the moon, gerere, to carry; from the lunule on the forewings.

Luno'sa (Ent.) luna, the moon ; from the lunule on the underfide.

Iunula'lis (Ent.) lusula, a ring or hoop.

Iunula'ria (Bot.) from the lunate form of the fronds; a genus of Marchantiacere.

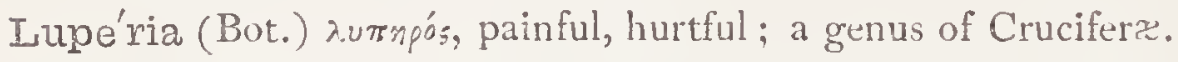

Lu'perus (Ent.) $\lambda v \pi n p_{0}$; troublefome; a genus of Coleoptera.

Lupinas'ter (Bot.) the genera Lupinus and After; a genus of Leguminofix. Lupi'nus (Bot.) lupus, a wolf; it is fuppofed to deftroy the fertility of the foil; the Lupine; a well-known genus of Leguminofx.

" 'Triftefque lupini

Suftuleris fragiles calamos."--VIrGiL.

Iupulina (Bot.) the little hop-trefoil, fo called from its "efemblance to Lupulus.

Lupulina'lis (Ent.) feeds on Luputus.

Lu'pulus (Bot.) fpec. name of the Hop, Humulus Lupulits; a corruption of its old name Lupus falizturius, fo called, according to Pliny, becaufe it grew among willows, and by twining and choking them, became as deftructive as a wolf to the flock.

Iurch'er (Zool.) Richarilfon says, "there can be no doubt that Lurk and Lurch are the fame word, varying a little in the application. It hats not been fatisfactorily traced to its origin." "The dog which more efpecially lurks or lies in wait for its prey, and is therefore moft ufed by poachers.

Lu'nidx (Ent.) luridus, pale, ghaftly : in Botany, the Linnxan name fur the Solanacer.

Euriaa'iis (Ent.) luridis, pale, ghafty.

Luscin'ia (Ornith.) Lat. the Nightingale; changed by the French into rofignol.

Iuscinoid'es (Ornith.) the genus Lufcinia, zidos!. like.

Iu'scus-a (Iclith.) Lat. blind of one eye, purblind.

Iussac'cia (Bot.) P. N., fame as Gayluffucia: a genus of Vacciniacer.

Lusus IJaturx (Zool.) Lat. a caprice or fport of nature.

Lutea'lis (Ent.) luteus, orange-yellow.

Iute'olus-a-um (Bot.) Lat. yellowifh; e.g. Refeda Luteolu.

Lu'teus-a-um (Zool. \& Bot.) Lat. yellow-coloured, orange-coloured; e.g. Refelul lutea.

Lu'thera (Bot.) P. N., a genus of Compofita. 
Luticomel'la (Ent.) luteus, faffion, coma, hair.

Lutlze'a (Bot.) P. N. in honour of $M$. Lutke; a genus of Celaftracex.

Luto'sus-a-um (Ent.) Lat. muddy, clay-coloured.

Lutra (Zool.) Lat. an otter.

Iutra'ria (Zool.) lutra, an otter; Otter.mell : a genus of Mollufca.

Lutule'ntus-a-um (Ent.) Lat. muddy.

Luxembu'rgia (Bot.) P. N., a genus of Sauvagefiacex.

Iuzel'la (Ent.) P. N. in honour of Herr Luz, a friend of Hübner.

Lu'zula (Bot.) gramen luzule, glow-worm grafs of Bauhin; becaufe it fhines; a genus of Juncacea.

Luzuria'ga (Bot.) P. N. from D. F. M. R. de Luzuriago, M.D., a Spanifh botanift.

Lyal'lia (Bot.) P. N., a genus of Portulacacex.

Ly'bicus-a-um (Zool.) Lat. Lybian.

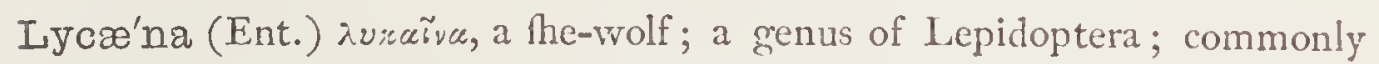
called Coppers.

IJcæ'nidx (Ent.) lycena, fam. term. idic.

Iyca'on (Zool.) P. N., Lycaon, who was turned by Jupiter into a wolf; applied to the Hunting-dog, Lycuon venaticus.

Iyca'ste (Bot.) P. N., of mythological origin; a genus of Orchidacex.

Iychnan'thus (Bot.) the genus Lychnis, ävos, flower; a genus of Caryophyllacer.

IJ'chnis (Bot.) rúxvo; a lamp; the down of the leaves is ufed for wicks; or from the brilliant colour of the flowers; a genus of Caryophyllacex.

Iychnoste'mon (Bot.) the genus Lychnis, and $\sigma \tau \operatorname{rn} \mu \omega v$, a famen; a genus of Diofcoreacex.

Ly'chnus (Zool.) $\lambda \dot{x} x^{r o s}$, a lamp.

Lyciople'sium (Bot.) the genus Lycium, and $\pi \lambda$ nsios, near allied to; a genus of Solanacex.

IJyciop'sis (Bot.) the genus Lycium and ö $\psi: 5$, like; a genus of Onagracex.

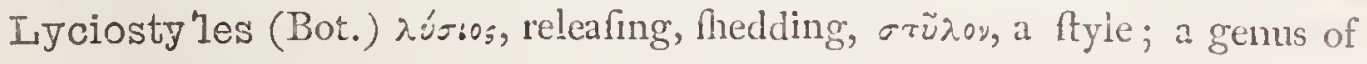
Convolvulace:e.

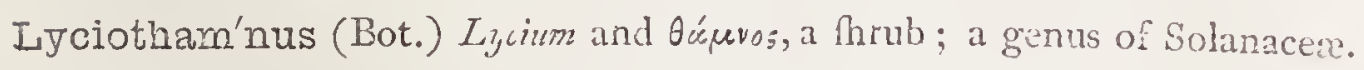
IrJ'cium (Bot.) from Lycia in Afia Minor, its native country. The Latin monks fay our Saviour's crown of thorns was made of the Lyciun: Spcciofum; a genus of Solanacex.

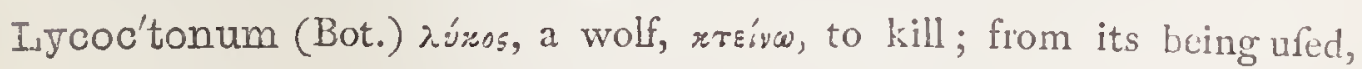
concealed in meat, as a bait to deftroy wolves; fpecific name of Yellow Wolf's-bane, or Aconitum Lycoctonum. 


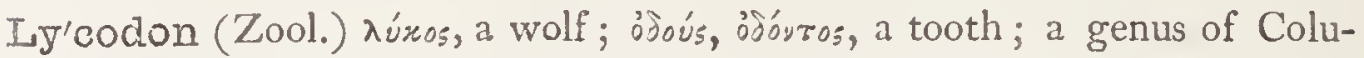
brine ophidians.

Iyoodon'tidæ (Zool.) lycodon, with fam. term. ide; a family of Colubrine ophidians.

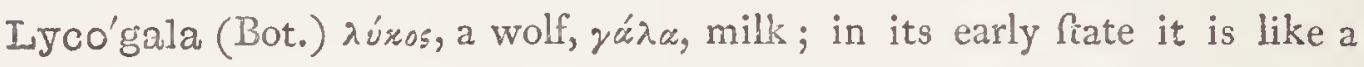
mafs of thick cream; a genus of Fungi.

Iyconor'mium (Bot.) גénos, a wolf, norma, hape; a genus of Orchidacex.

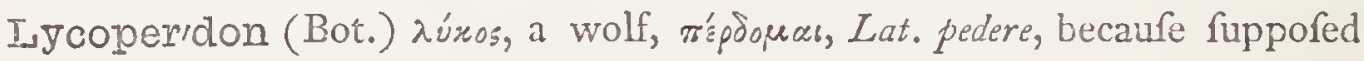
to proceed from wolf's dung; the Puff-ball; a genus of Fungi.

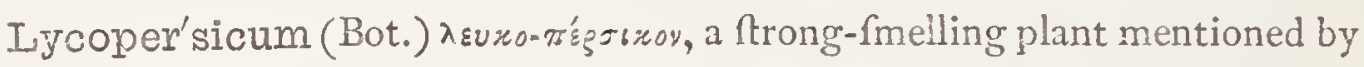

Galen; now ufed for the Love-apple or tomato; a genus of Solanacex.

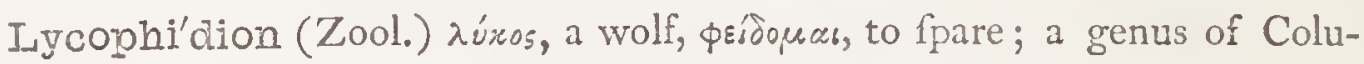
brine ophidians.

Iycopodites (Fos. Zool.) foffil plants allied to the exifting genus Lycepodium.

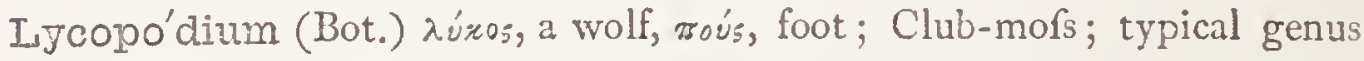
of the Lycopodiacer.

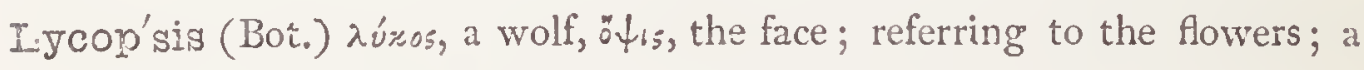
genus of Boraginaces.

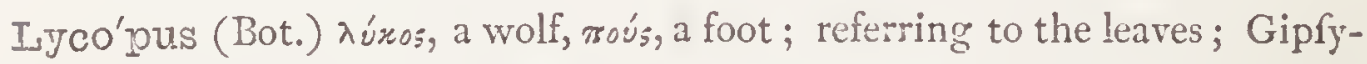
wort; a genus of Labiatæ.

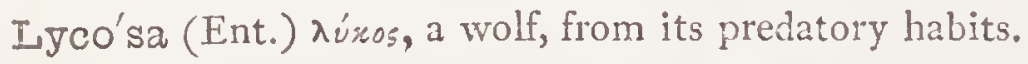

Iyco'sidæ (Ent.) family of Spiders of which $L_{y c o f a}$ is the type.

Iyco'sina (Ent.) adj., like a Lycofa.

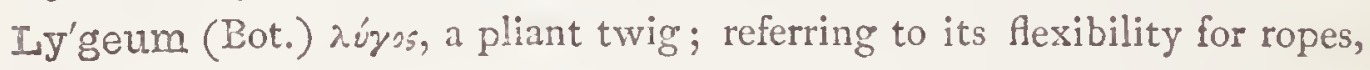
bafkets, \&c. ; Cord-grafs ; a genus of Gramina.

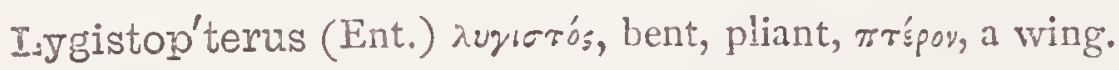

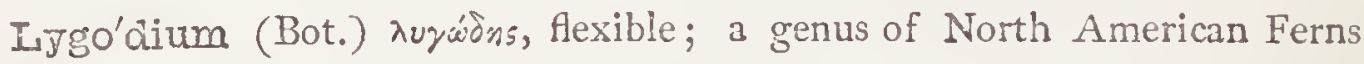
with twining ftems.

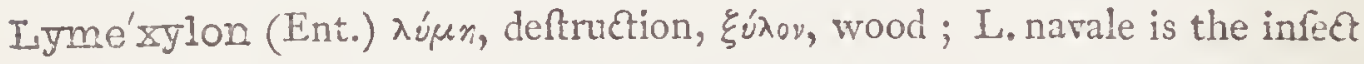
whofe ravages in the dock-yards of Sweden were checked by Linnzeus. Iymexylo'nidæe (Ent.) lymexylon, fam term. ida; a family of Coleoptera.

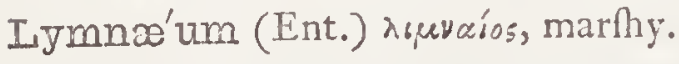

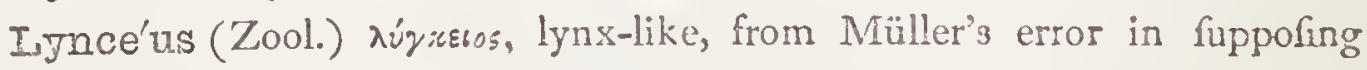
there was a fecond organ of fight; a genus of Entomofraca.

IJ'ingloya (Bot.) P. N. in honour of H. C. Lyngbye, a Danifh botanint; a genus of Fucoid Algæ.

Lyngbyel'la, (Bot.) dim. of Lyngbyea; a genus of Fucoid Algz. Lynx (Zool.) sing, a lynx; probably from $\lambda u x x$, light. 
Iyone'tia (Ent.) P. N. from Pierre Lyonet, author of "Defcriptions of Infects found at the Hague;" died $x 789$.

Lyo'nia (Bot.) P. N. in honour of $\mathcal{F}$. Lyon, an American collector of plants. Lyon'sia (Bot.) P. N. in honour of $\mathcal{F}$. Lyons, an Englifh botanift; alfo at genus of Mollufea.

Iypera'nthus (Bot.) $\lambda u ́ \pi n$, fadnefs, $\ddot{u}_{\nu} \theta_{0 s}$, a flower; referring to the hus of the flower.

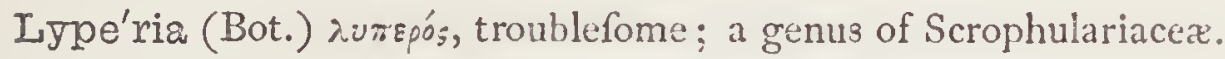

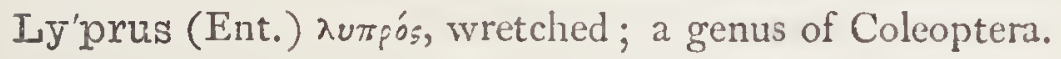

Ly'ra (Zool.) Lat. a lute.

Lyræ'a (Bot.) גúpo, lyra, a harp; a genus of Orchidacex.

Iyre-bird (Ornith.) applied to the menura, from the fhape of the tail.

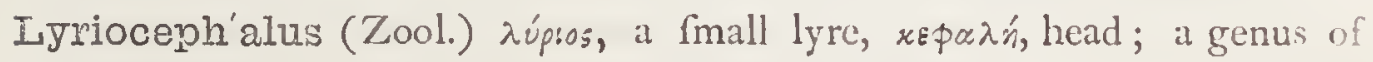
Saurians.

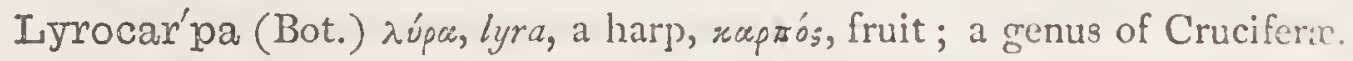
Iyrodes'ma (Zool.) lyra, a lute, f's $\sigma \mu \alpha$, a bond or fetter; from the radiating friated teeth; a genus of Mollufca.

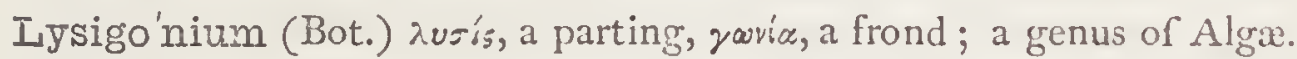

Lysilo'ma (Bot.) $\lambda v \sigma^{\prime} \xi$, a parting, $\lambda \tilde{\omega} \mu \alpha$, fringe; a genus of Leguminofie.

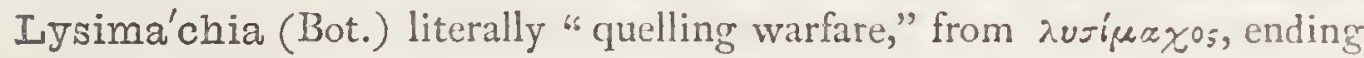
ftrife; Loofe-ftrife. See Ariftophanes "Lyfiftrata," 554. Some of the ancient authors attributed a very fingular property to this plant, no lefs than a power of taming ferocious or reconciling difcordant animals

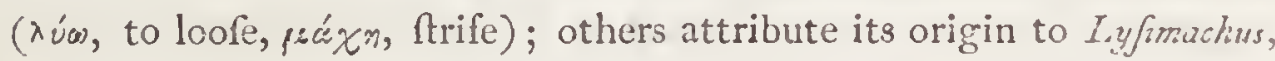
who, they say, was its firft difcoverer.

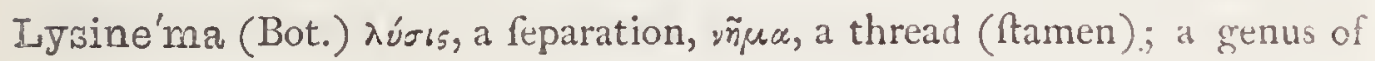
Epacridaceæ.

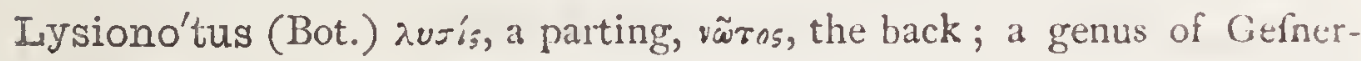
aces.

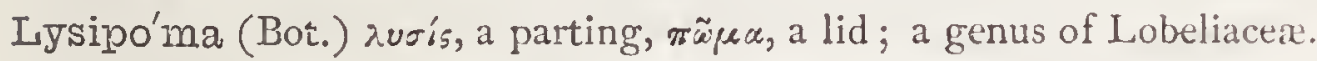

Iythra'ceæ (Bot.) the family of which the beautiful genus Lythrum is the type.

Iyy'thrum (Bot.) $\lambda$ úpov, black blood; alluding to the colour of the flower; the typical genus of Lythraceæ.

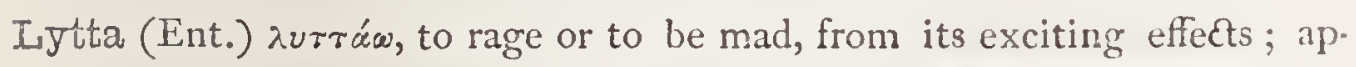
plied by Fabricius to the Bliftering fly, now called Cantharis resicatoria. 
Mabo'nia (Zool.) the name of this genus of Lizards is from the native American name Mabonya.

Maca'cus (Zool.) the word macaco is ufed by the natives of the coaft of Guinea for quadrumanous animals in general, but more particularly the monkey; the Macaques.

Macandrewa'nus (Zool.) P. N. in honour of $M_{r}$. Mc Andrezv, of Liverpool, an ardent labourer in Natural Hiftory.

Iraca'ria (Ent.) P. N., the daughter of Hercules and Dejanira.

Macca'na (Ent.) maccus, a buffoon.

Mase (Bot.) Grcek, $\mu a ́ x \varepsilon p ; ~ L a t$. and Fr. macis; Ital. mace; the reticulated nembrane which immediately covers the nutmeg, technically called the arillus.

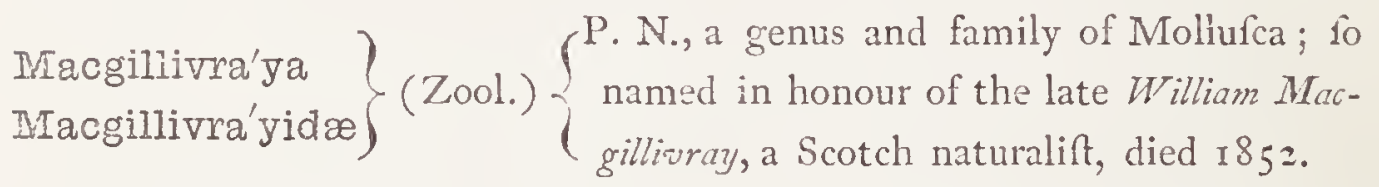
Machæ'ra (Zool.) púx xuspa, a fword or dagger; a genus of Mollufca.

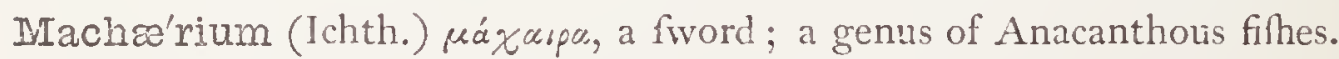

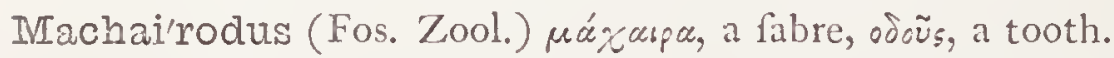

ITacha'on (Ent.) P. N., one of the fons of EEfculapius mentioned by Homer, Il. ii. 73I; fpecific name of a butterfly.

Ma'chetes (Ornith.) мaxyrn's, a fighter; formerly applied to the Ruff, now called Philomachus pugnax, implying the fame difpofition.

Mackerel (Ichth.) Fr. maquereau; Dutch, mackereel.

Maclea'ya (Bot.) P. N. in honour of A. Macleay, Secretary to the Linnxan Society.

Maclu'ra (Bot.) P. N. from William Maclure, a North American geologift; alfo a genus of foffil Shells.

Ma'coma (Zool.) rãros, length; a genus of Mollufea.

Macquarie'nsis (Ichth.) P. N. belonging to the Macquarie river; the Oligorus Macquarienfis is the "Murray cod" of Auftralia.

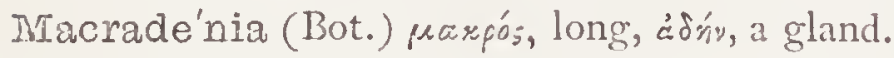

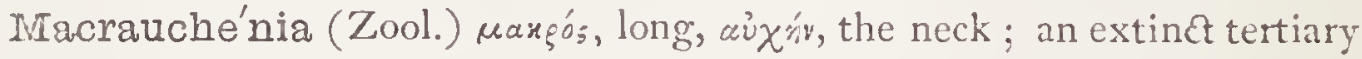
mammal of South America.

Macro-(Zool., Bot.) a frequent prefix, signifying “large," as Macrocephalus, large-headed.

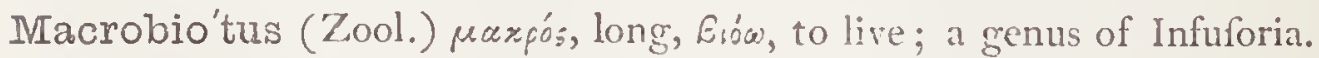

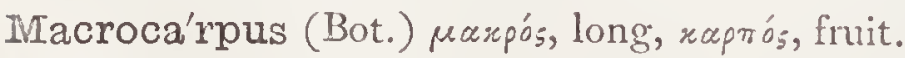

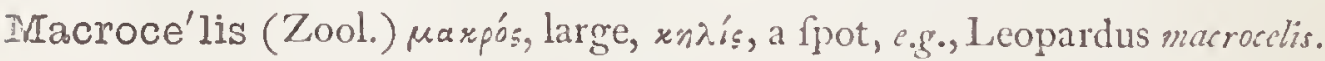

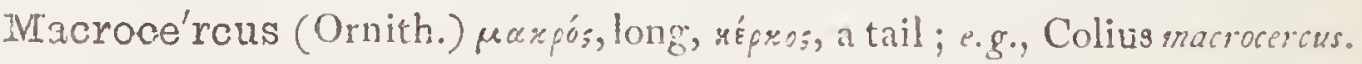




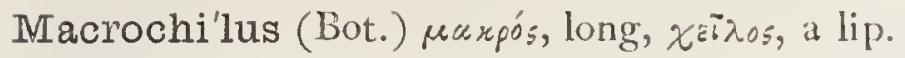

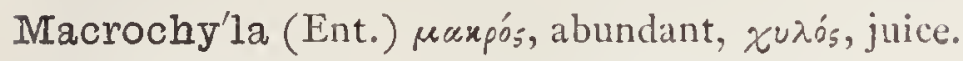

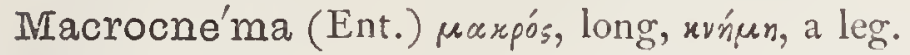

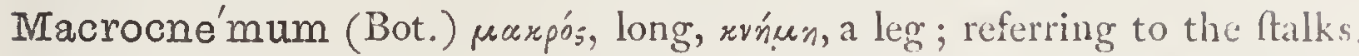

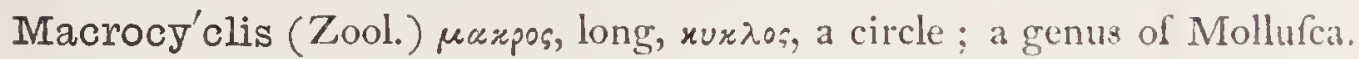

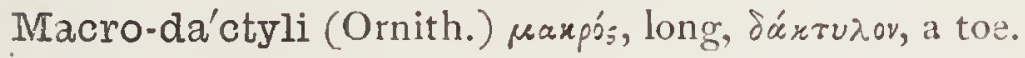

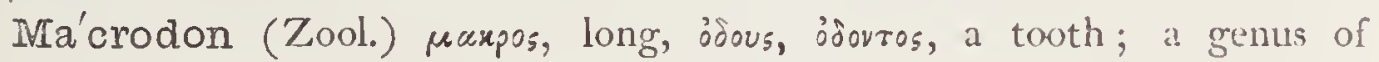
Mollufca.

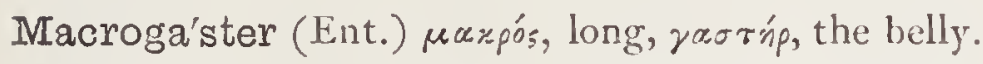

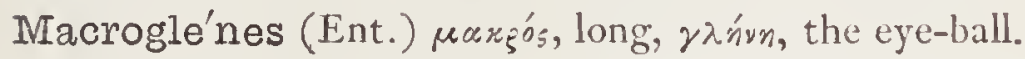

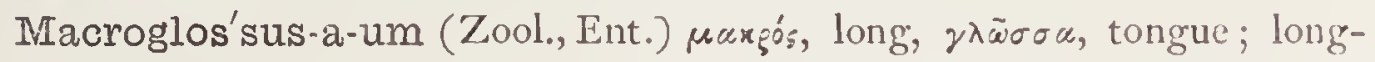
tongued.

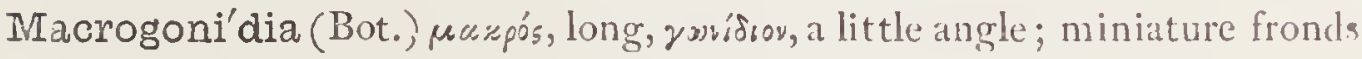
which efcape from the parent-cell in the Infuforia.

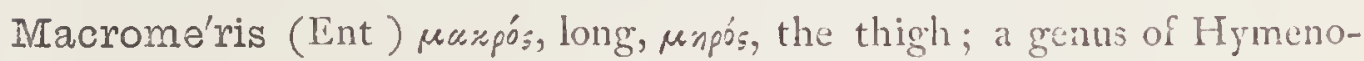
ptera.

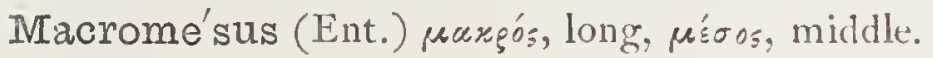

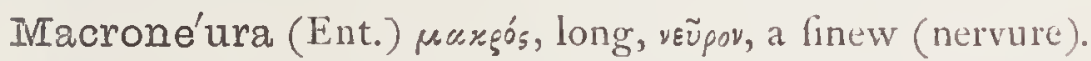

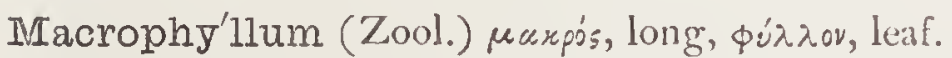

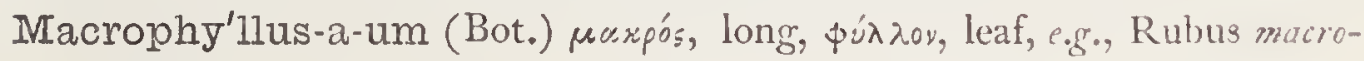
phyllus.

IMacro'pida (Zool.) a family of Mammalia, of which Macropus is the type.

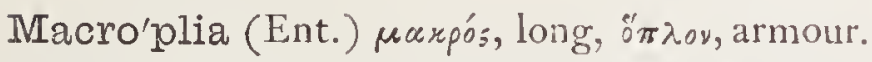

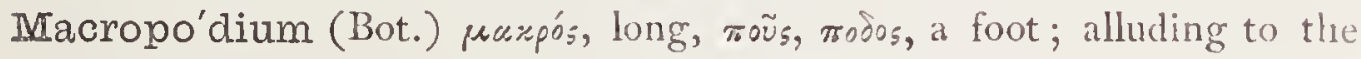
feed-veflel.

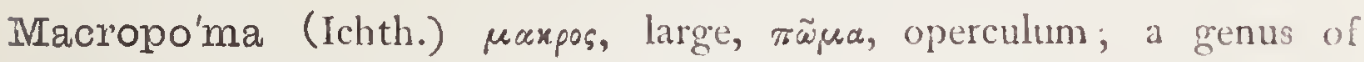
Sauroid fifhes of the chalk and wealden.

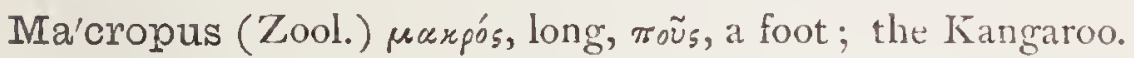

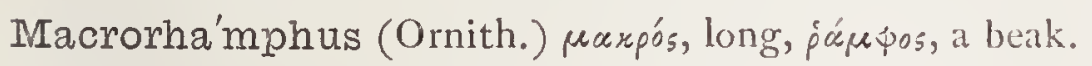

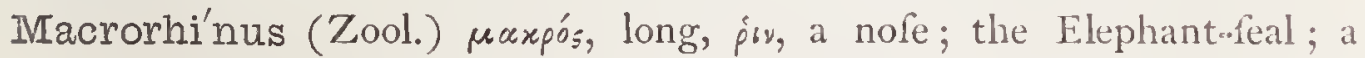
genus of Mammalia.

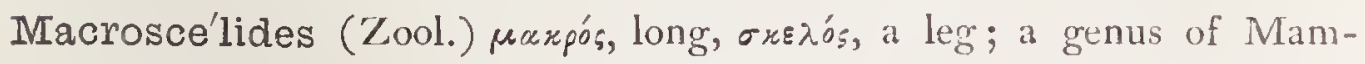
malia, called in Cape Colony, Elephant mice.

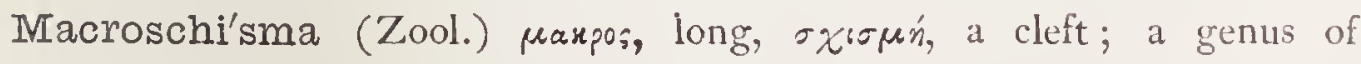
Mollufca.

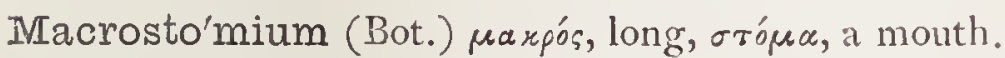

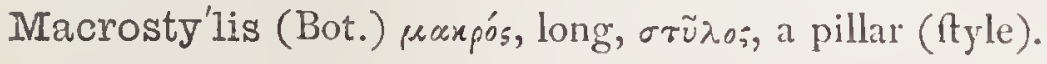

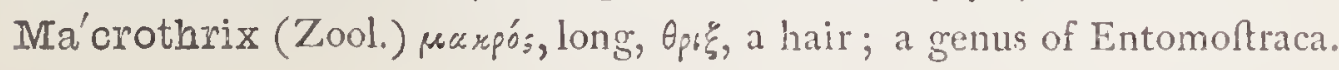


Macro'tis (Zool., Bot.) raxpós, long, oũs, 'wrós, the ear.

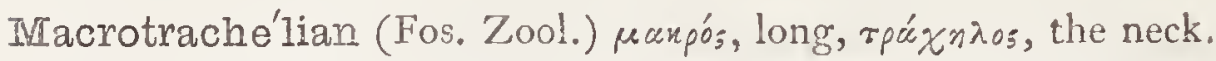

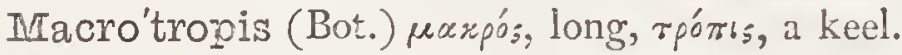

- Macrourra (Zool.) $\mu \alpha x p o ́ s$, long, oũpa, a tail ; Decapod Crufaceans of Macru'ra $\}$ the fecondary and tertiary ftrata.

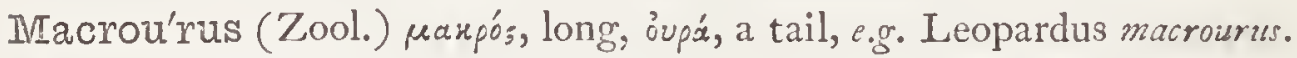

Ma'ctra (Zool.) Lat. a kneading-trough; a genus of Mollufca.

Mactre'lla (Zool.) dim. of Mactra; a genus of Mollufca.

Ma'ctridæ (Zool.) the family of Mollufca, of which Mactra is the type.

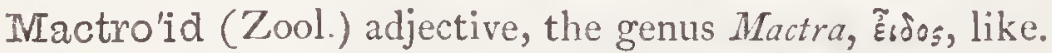

Iracula'lis (Ent.) masula, a fpot.

Macula'ris (Bot.) macula, a fpot.

Macula'rius (Ornith.) adjective, from macula, a fpot.

IVacula'tus-a-um (Ent., Bot.) Lat. maculatus, fpotted.

Madagascarien'sis-e (Zool.) Lat. relating to the Island of Madagafcar, e.g. Cheiromys Madagascarienfis.

Madder (Bot) Anglo-Sax. madre; Dutch, meed, which from meeden, to dye; the prepared root of the Rubia tinctorum.

Madefacta'lis (Ent.) madefacio, to make wet, to moiften.

Maderaspa'tanus-a-um (Zool.) Lat. relating to, or belonging in, Madras.

Ma'dia (Bot.) madi, its name in Chili ; a genus of Compofitæ.

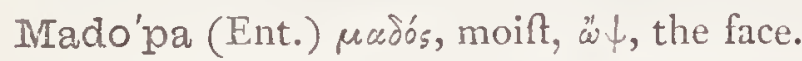

Madre'pora (Zool.) French, nadré, fpotted, pore: the Stony corals.

Ixadrepo'riform (Zool.) madrepora, and forma, Thape.

Madreporite (Fos. Zool.) the foffil Madrepore.

Irize'sa (Bot.) maas, its Arabian name.

IMagella'nicus-a-um (Zool) Lat. relating to the fraits of Magellan.

IVaggot (Ent.) Goth. and Anglo-Sax. matha; Weljh, macai; Dan. madike; a

Ay in its larva fate.

Nagnifica'lis (Ent.) magnificus, noble, diftinguifhed.

Magno'lia (Bot.) P. N. from Peter Magnol, M.D., Profeftor of Botany at Montpelier; typical genus of the fplendid Nat. Ord. Magnoliacex.

Magpie (Ornith.) pica, with prefix mag, as contracted from magnus, great? or perhaps from French, magot, a baboon, from its chattering. " Magot is the original name of the bird, being the familiar appellation given to pies, as we fay Robin to a red-breaft, Tom to a titmoufe, Philip to a fparrow," \&c.-Strevens.

Maher'nia (Bot.) an anagram of Hermannia; a genus of Byttneriacex. 
Mahog'any (Bot.) probably the refult of a confufion of names, in which the name of another tree, the "Mahagua," has been milapplied to this, the wood of the Swietenia Mahagoni.

Maho'nia (Bot.) P. N. from Bernard M'Mahon, of North America, a lover of botany; a genus of Berberidacex.

Ma'ia (Zool.) applied by Pliny to a kind of crab.

Mairadæ (Zool.) a family of Decapods, of which $M_{\text {aia }}$ is the type.

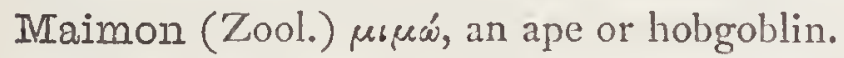

IVain.'nsis (Ichth.) Lat. relating to the ftate of Maine, U. S. of America. Major, Majus (Ornith.) Lat. adj. greater.

IVialaccen'sis (Zool.) belonging to Malacca.

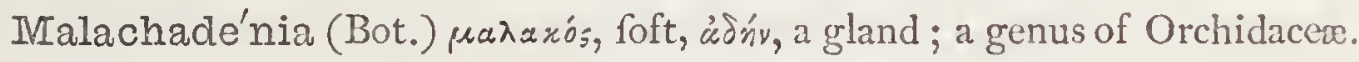

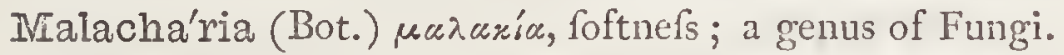

Ma'lache (Bot.) $\mu a \lambda a \alpha_{s}$, foft ; a genus of Malvacex.

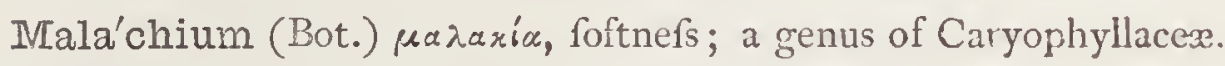

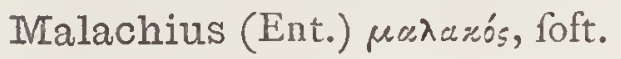

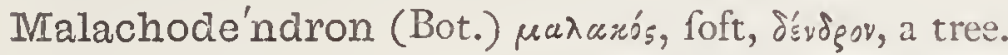

IMa'lachra (Bot.) $\mu \alpha \lambda \dot{x} \chi n$, a mallow; from the refemblance.

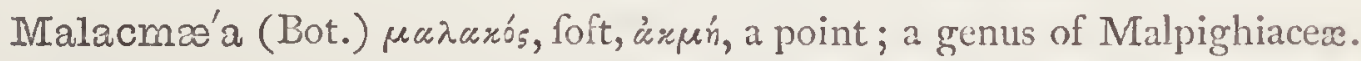

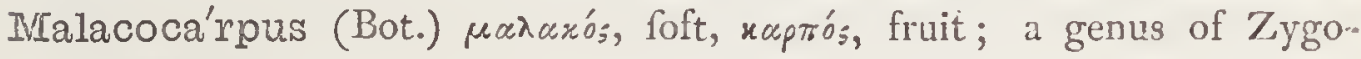
phyllacea.

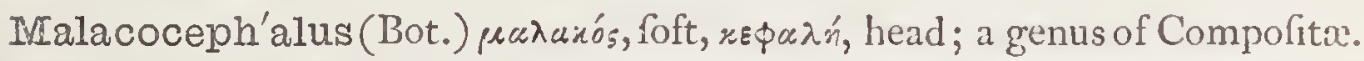

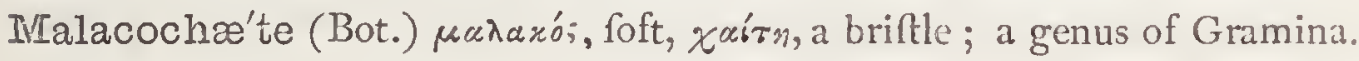

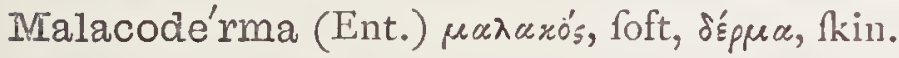

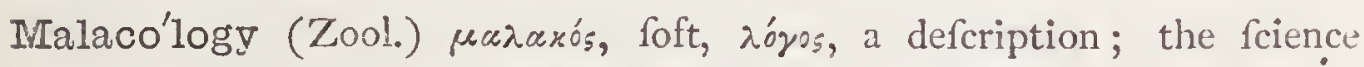
which treats of the Mollufca, or Soft-bodied animals.

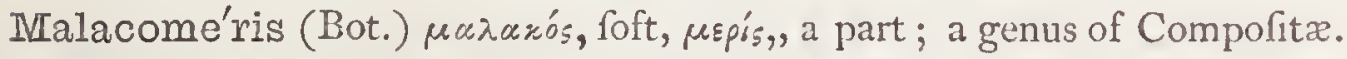

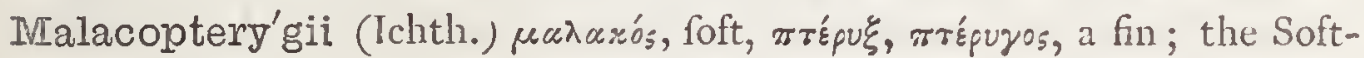
finned filhes.

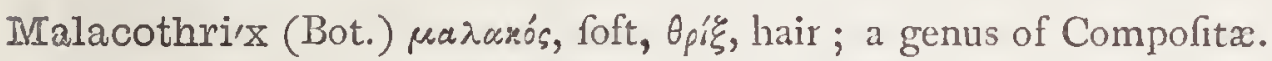

Mala'xis (Bot.) $\mu \alpha \lambda \alpha^{\prime} \xi{ }^{\prime}$, foftnefs; from its delicate texture; a genus of terreftrial Orchidacex.

Malco'mia (Bot.) P. N. from W. Malcolm, mentioned by Ray; a genus of Cruciferæ.

Mal'leus (Ichth.) malleus, a hammer; hammer-headed; alfo a genus of Mollufca.

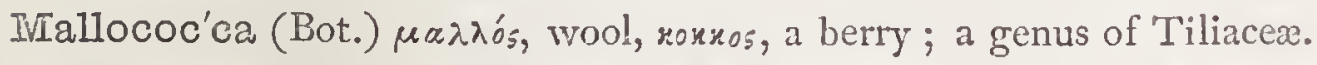

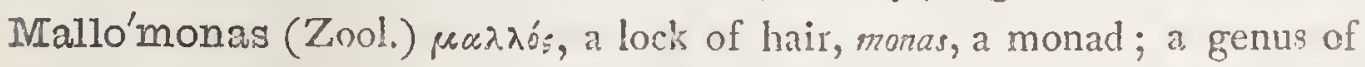
Infuforia. 


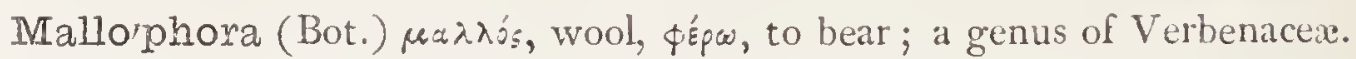
Mallo'tus (Bot.) $\mu a \lambda \lambda \omega \tau o$, fleecy, a genus of Euphorbiacex.

Iallo'tus (Ichth.) $\mu a \lambda \lambda o_{s}$, a lock of wool; alfo a foffil filh of the clay marl.

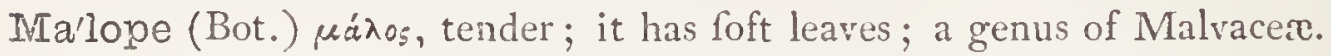

Malpi'ghia (Bot.) P. N. from M. Malpighi, Profeftor of Medicine at Bologna; typical genus of the fplendid Nat. Ord. Malpighiacex.

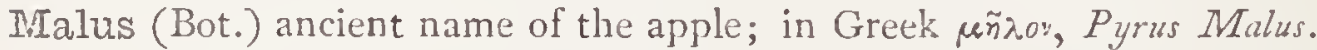

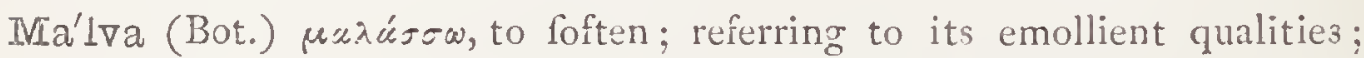
typical genus of the great Nat. Ord. Malvacex.

IMame'stra (Ent.) P. N., formerly the capital of Lefler Armenia.

Mamma'lia (Zool.) mamma, the breast; applied to thofe vertebrate animals which fuckle their young.

Mamme'a (Bot.) mamey, its American name: a genus of Sapotacer.

IMammi'feræ (Zool.) mamma, the brea凡, fero, to carry ; mammifers.

Mammilla'ria (Bot.) mammilla, a nipple; the plant is corered with teat-

like protuberances; a genus of Cactacer.

IrIa'mmoth (Zool.) faid to be of 'Tartar origin.

Mana'bea (Bot.) a genus of Verbenacex.

Mana'tidæ (Zool.) a family of Mammalia, of which Manatus is the type. Ma'natus (Zool.) having reftiges of nails on their fwimming paws: the name was given from the Spanilh mano, a hand.

Mangani'lla (Bot.) original native name of the Manchineel tree, Hippomane Mancinella.

Mandevilla (Bot.) P. N. in honour of Sir Fohn Mandeville, an early Englim traveller; a genus of Apocynacer.

Mandi'bula (Ent.) Latin, a jaw.

Mandio'cea (Bot.) from the native Brazilian name of the Caflava plant, Fatropha Manihot.

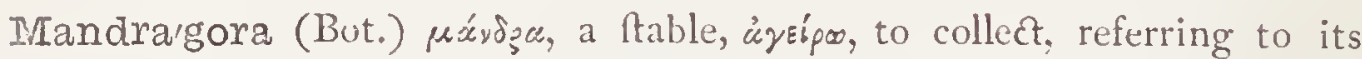
habitat; the celebrated Mandrake; a genus of Solanacex.

Mandrake (Bot.) corrupted from mandragora.

"And hrieks like mandrakes, torn out of the earth,

That living mortals, hearing them, go mad."-SHAKsPERE.

Mane'ttia (Bot.) P. N. from X. Manetti, Profefor of Botany at Florence. Manghas (Bot.) native Madagafcar name; the 'Tanghinia Manghas.

Mangi'fera (Bot.) mango, name of the fruit, fero, to bear.

Mangle'sia (Bot.) P. N. in honour of Captain Mangles; a genus of Myrtacex; also Rhodanthe Manglesii. 
Manglil'la (Bot.) its name in Peru.

Mango (Bot.) native name; fruit of the Mangifera Indica.

Mangosta'na (Bot.) native name of the fruit; the Mangofteen.

IMa'ngosteen (Bot.) native name; a fruit of the Garcinia Mangoftana.

Mangui'ba (Bot.) native name; a genus of Apocynacex.

Ma'nia (Ent.) ray, madnefs; figuratively, hobgoblin.

IManica'ria (Bot.) manica, a glove.

Mani'hot (Bot.) native name of the Jatropha Manihot.

Manis (Zool.) probably from manus, a hand; on account of the large foreciaws, which are employed in tearing down the nefts of the Termites or White ants.

Mann'ia (Bot.) P. N., a genus of Marchantiacex.

Mansue'tus-a-um (Ornith.) Lat. tame, gentle.

IVante'llia (Fos. Bot.) P. N. in honour of Dr. Mantell, the geologift; a genus of forfil Cycadeoida.

Iranti'sia (Bot.) the flowers refemble the infect mantis; a genus of Scitaminer.

Mantis'pa (Ent.) unexplained.

Manu'lea (Bot.) manus, the hand; from the five divifions of flowers.

Mara'nta (Bot.) P. N. from B. Maranti, a Venetian phyfician, who died in 1554 ; typical genus of the Nat. Ord. Marantaceæ.

Maras'mius (Bot.) rapaíw, to dry up; a genus of Fungi, fo called from their being of a lefs juicy nature than others, and more readily preferved by drying.

Marat'tia (Bot.) P. N. from F. F. Marati, of Vallombrofa, in Tufcany, who wrote on Ferns; a genus of Filices.

Inarcgra'via (Bot.) P. N. from G. Marcgraaf, author of a voyage to Brazil ; the typical genus of Marcgraaviacex.

Marchan'tia (Bot.) P. N. from Nicholas Marchant, a French botanift; the

typical genus of Marchantiacex.

Mare (Zool.) an Anglo-Saxon word.

Iva'reca (Ornith.) unexplained; the genus of Birds which includes the

Widgeon.

Marga'ceus-a-um (Bot.) refembling marl (marga).

Margari'ta (Zool.) Lat. a pearl; a genus of Mollufca.

IMargaritaceus-a-um (Bot.) Lat. pearly.

Margarita'na (Zool.) margarita, a pearl; a genus of Mollufca.

Margarito'phora (Zool.) margarita, a pearl, ф'spow, to bear; the Puat oyfter; a genus of Mollufca. 


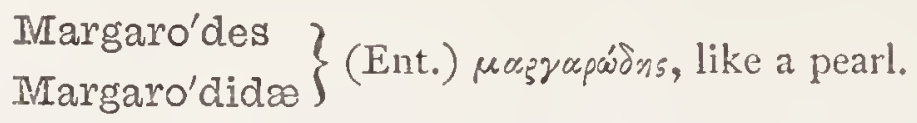

Margina'tus-a-um (Zool., Ichth., Bot.) Lat. bordered.

Marginel'la (Zool.) dim. of margo, a rim; a genus of Mollufca.

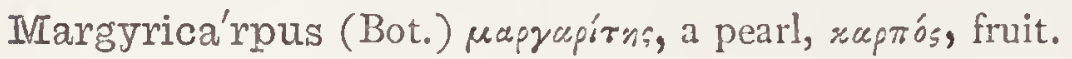

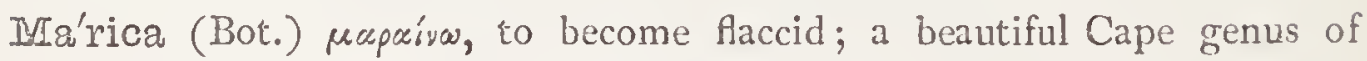
Iridacer.

Mariki'na (Zool.) native name of a monkey, Jacchus Rofalia.

Mari'la (Ornith.) paǵi $\lambda n$, charcoal.

Marimo'nda (Zool.) native name of a monkey from Central America. Ateles Belzebuth.

Mari'nus-a-um (Ornith., Bot.) Lat. pertaining to the fea, marine,

Ivarione'lla (Ent.) P. N., a name given by M. Guerin Meneville, to a fpecies of Hemerobius, after his youngeft daughter, Marion Frances.

Mari'sscus (Bot.) applied by Pliny to a kind of ruih; perhaps from Celtic mar, a marlh, in which it grows; fpecific name of the Cladium Marifcus. Maritimus-a-um (Ornith., Bot.) Lat. pertaining to the fea, maritime. Mar'joram (Bot.) Arabic, maryamych; Latin, majorana.

Ma'rkia (Ent.) P. N. in honour of Edward WV. MLark, Efq.; a genus of Orthoptera.

IVia'rlea (Bot.) from marliya, its Bengal name.

Marmora'tus-a-um (Ornith. Ent. Bot.) Lat. marbled.

Marmo'reus-a-um (Bot.) Lat. like marble; marbled.

IMa'rmoset (Zool.) dim. of French, marmot, a monkey; popular name of Jacchus vulgaris.

Miarmot (Zool.) French, marmot, a monkey; the Arctomys Marmotta. Marru'bium (Bot.) Heb. marrob, a bitter juice; Horehound; a genus of Labiatx.

Marsde'nia (Bot.) P. N. from W. Marsden, Efq., author of a "Hiftory of Sumatra."

Marshal'lia (Bot.) P. N. from Humphry Marfall, a writer on botany. Marsi'lea (Bot.) P. N. from Count L. F. Mar/ggli, founder of the Academy of Sciences, Bologna.

Marsi'pobranchs (Ichth.) pé́psıтоs, a bag or pouch, Bpáyxsa, gills ; having facculated gills.

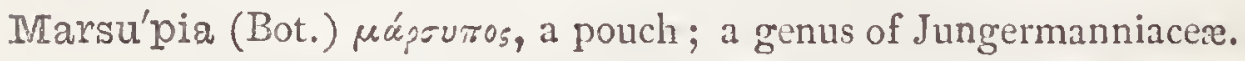

Marsupia'lia (Zool.) marfupium, a pouch or purfe.

Ma'rsupites (Fos. Zool.) marfupium, a pouch; a genus of Crinoidea of the chalk. 


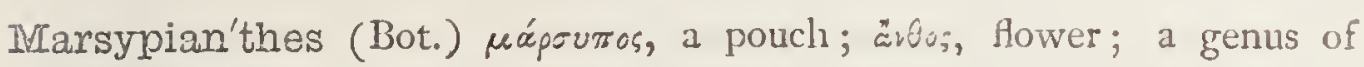
Labiatæ.

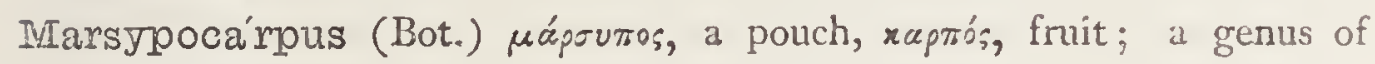
Crucifera.

Martagon (Bot.) French, martagon; the Turk's cap lily, Lilium Martagon. INarte'nsia (Bot.) P. N. in honour of _- Martens, the celebrated botanift; a genus of Ceramian Algx.

Martes (Zool.) Lat. a marten, or marten-cat.

Irartine'zia (Bot.) P. N., a genus of Palmx.

Ma'rtius (Ornith.) Lat. warlike, martial.

Marty'nia (Bot.) P. N. from Fohn Martyn, F.R.S., formerly Profeflor of Botany at Cambridge; a curious genus of Scrophulariacex.

Miarygold (Bot.) fo called because it is in flower at the times of all the Rominh feftivals of the Virgin Mary; the word gold having reference to its golden rays, compared to the rays of light around the head of the Virgin; the Calendula officinalis :-

"The marygold, that goes to bed with the sun,

And with him rises weeping."-SizAKsPere.

Masaris (Ent.) perhaps from $\mu \alpha_{\sigma} \alpha \alpha^{\prime} \mu \alpha$, to thoot out the lip; a genus of Hymenoptera.

Masca'gnia (Bot.) P. N. in honour of Paul Mafcagri, a celebrated Italian anatomift, born I752, died I8 I 5 ; a genus of Malpighiacer.

Masso nia (Bot.) P. N. from Mr. F. Muffon, author of Stapelix Norm.

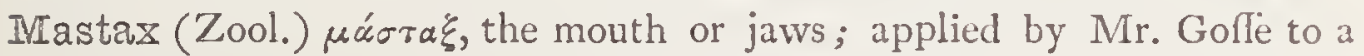
Róifer.

Mastichone'ma (Bot.) $\mu a \sigma r i x n$, refin, wñ $\mu a$, a filament; a genus of Algre.

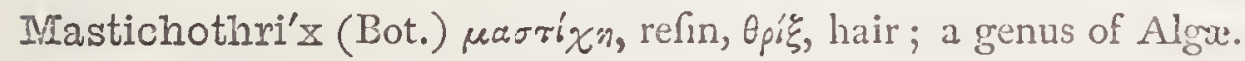

Mastiff (Zool.) French, mefif.

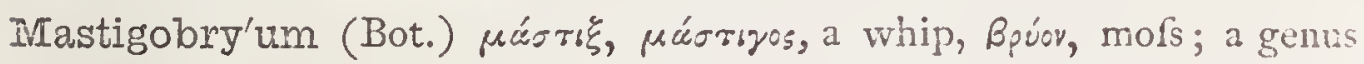
of Bryoid Mufci.

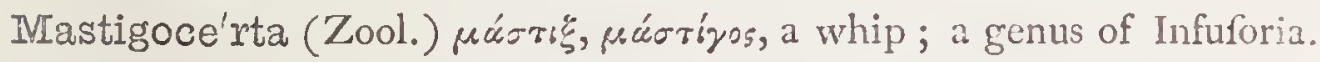

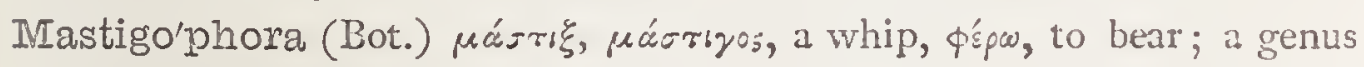
of Bryoid Mufci.

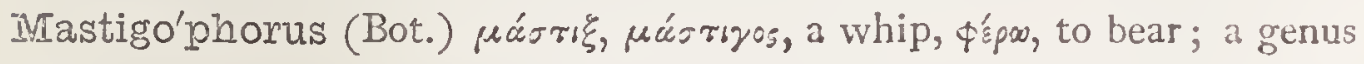
of Compolitx.

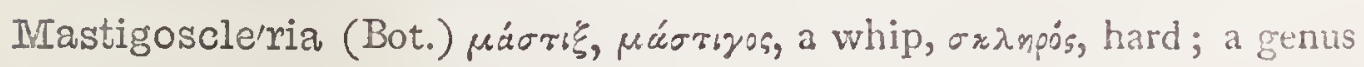
of Gramina.

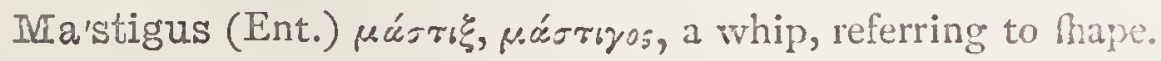

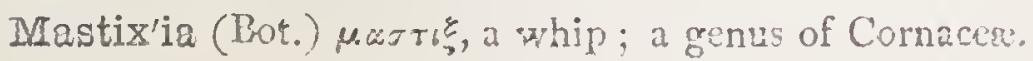




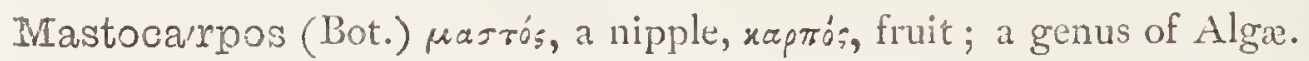
Mastodon (Fos. Zool.) Masros, a nipple, odous, ojovros, a tooth; the fummits of the ridges on the teeth having a refemblance to the teats of a cow.

Mastodonsau'rus (Fos. Zool.) having features in common with mafodon and faurus; a genus of foffil Saurians.

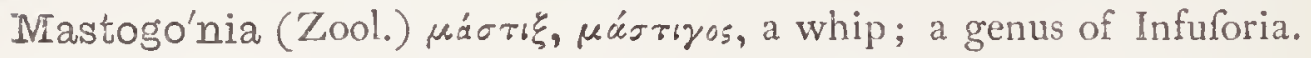

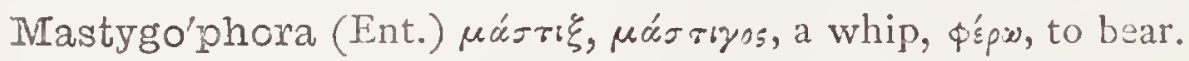

Mata'yba (Bot.) its vernacular name in French Guiana.

Matthi'ola (Bot.) P. N. from P. A. Matthioli, an Italian phyfician, who died in 1577 ; the Gilliflower; a genus of Cruciferæ.

Matrica'ria (Bot.) matrix, the womb, from its fuppofed medical effects; a genus of Compolitæ.

IMatrona'lis (Ent., Bot.) Lat. womanly, matronly; fpecific name of the Dame's rocket, or Hefperis matronalis.

Matutina'lis (Ent.) Lat. pertaining to the morning; from the time of appearing.

Maura'zdia (Bot.) P. N. in honour of Dr. Maurand, a Profeffor of Botany at Carthagena; a beautiful genus of Scrophulariaceæ.

Mauril'lus (Ent.) etymol. uncertain ; a genus of Hymenoptera.

Iviauritia (Bot.) P. N. from Prince Maurice, of Naflau, the patron of Riflo; a noble genus of Palms.

Maurus-a-um (Bot.) raṽps, black.

WIa'vis (Ornith.) French, mawvis; the Song-thrulh:-

"When to the mirthful merle the warbling mavis fings."-DRArtox.

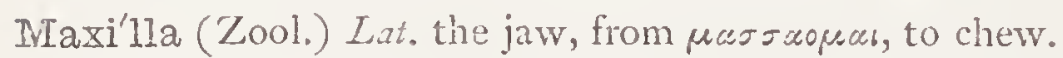

Maxilla'ria (Bot.) nams given becaure the labellum, when looked at fide. ways, refembles the maxillæ or jaws of fome infects; a genus of epiphytic Orchidacex.

Maxilla'tus (Zool.) maxilla, a jaw; applied to the Perna maxillat, on account of the hinge having many teeth.

Maxilli'ferus-a-um (Ent.) maxilla, the jaw, fero, to bear.

Maxillo'sus-a-um (Ent.) having large jaws (maxille) i. e. Staphylinus maxillofus.

Maximilia'na (Bot.) P. N. from Maximilian, Prince Weid-Neuweid.

Ina'ximus-a um (Ornith,, Bot.) Lat. greateft.

Mayduke (Bot.) this name, given to a kind of cherry, is from Mula in Burgundy.

Mra'zus (Bot.) wox $\zeta^{\prime} \dot{c}_{\xi}$, a teat. 
Me'adia (Bot.) P. N. in honour of the celebrated Dr. Mead; fpecific name of the Virginian cowflip, Dodecatheon Meadia.

Mea'dii (Ent.) P.N. in honour of R. H. Meade, Efq., of Bradford, Yorkfhire.

Meandri'na (Zool.) originally derived from Meander, a river in Phrygia, famous for its windings, and metaphorically applied to the convolutiony of the brain; Brain-coral; a genus of Madrepores.

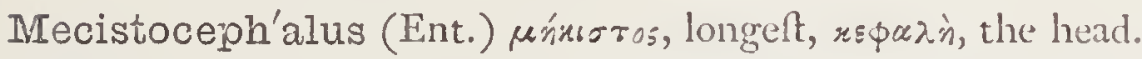

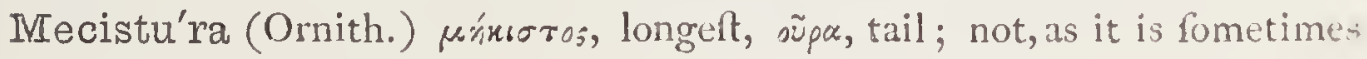
written, megifura.

Mecke'lia (Bot.) P. N., a genus of Malpighiacex.

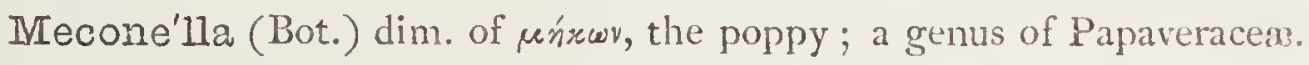

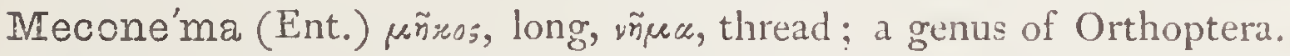

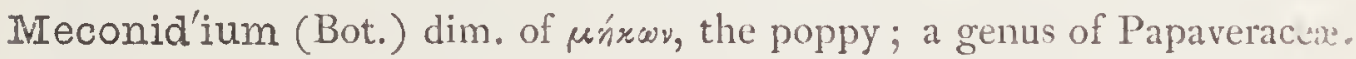
Meco'nium (Bot.) dim. of $\mu$ ńrov, the poppy; a genus of Papaveracex.

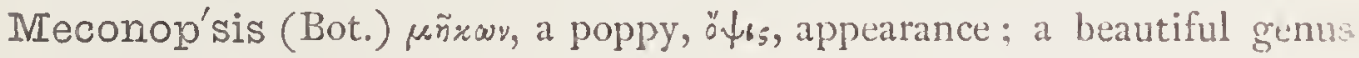
of Papaveracex.

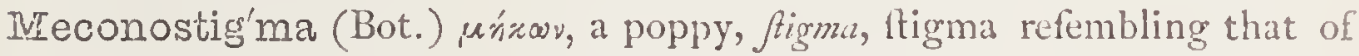
the poppy; a genus of Aracea.

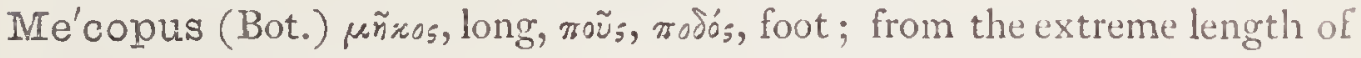
the ftipes of its pod.

Mecy'na (Ent.) «nxúvw, to lengthen, draw out.

Medéola (Bot.) P. N. from Medea.

Medica'go (Bot.) Mndเxìn, a term applied by Diofcorides to a Mediun grafs.

M. arborea is thought to be the Cytifus of Virgil, celebrated by him for caufing cows to yield abundance of milk, and as being particularly grateful to goats and bees; a genus of Leguminofx.

MIedioro'stris (Ichth.) medius, middle, roftrum, a beak or fnout.

Me'dius-a-um (Ornith., Bot.) Lat. of middle fize.

Mreesia (Bot.) P. N., a genus of Bryoid Mufci.

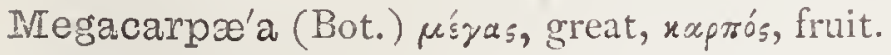

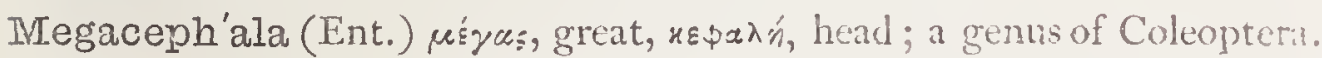

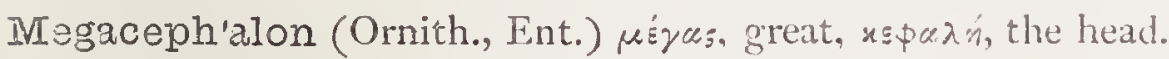

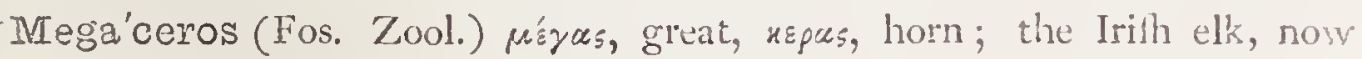
foffil or fub-foftil.

Megachi'le (Ent.) p'́zas, large, $\chi^{\varepsilon \tilde{b} \lambda o s, ~ l i p, ~ f r o m ~ t h e ~ f t o u t ~ m a n d i b l e s ; ~ t h e ~}$

Leaf-cutting Bee; a genus of Hymenoptera.

Megacli'nium (Bot.) $\mu^{\prime} \gamma_{\alpha}$, great, $x \lambda$ ím, to bend.

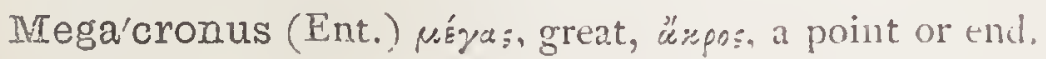

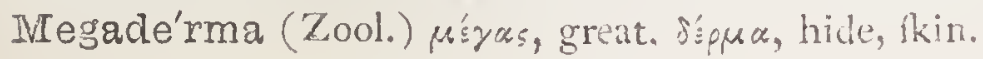


Megæ'ra (Zool., Ent.) P. N., one of the Furies.-VIRG. lEn. xii. 846; a genus of Ophidians.

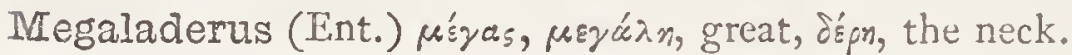

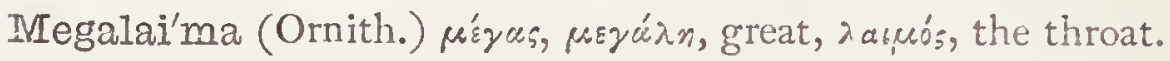

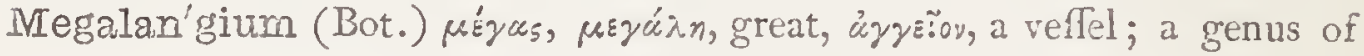
Bryoid Mufci.

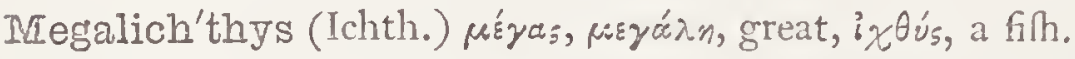

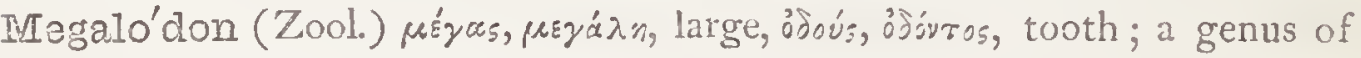
recent and forfil Mollufca.

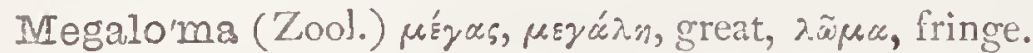

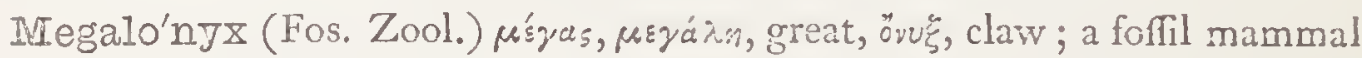
of the tertiary.

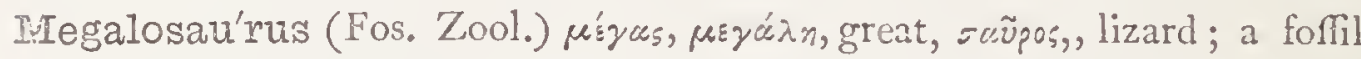
reptile of the chalk.

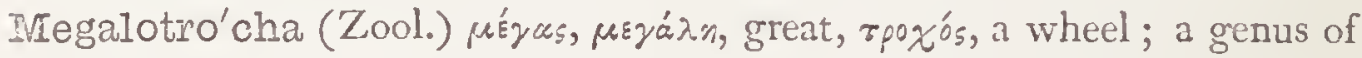
Infuforia.

Mega'nteris (Zool.) régus, great, ávтnpis, a prop; a genus of Mollufica.

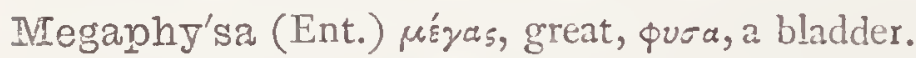

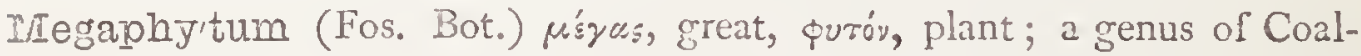
meafure foffil stems.

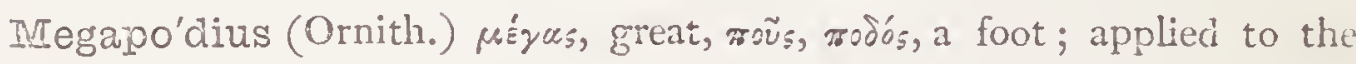
Jungle-fowl of Aufralia.

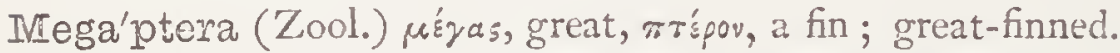

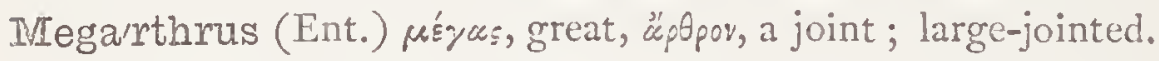

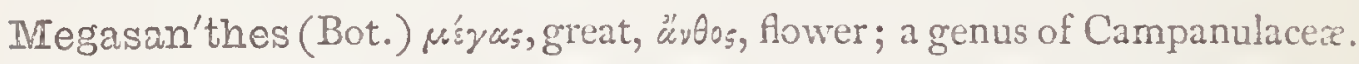

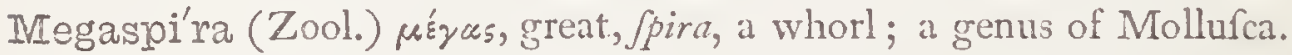

Megastach'ya (Bot.) rícyas, great, $\sigma \tau a ́ x v s$, a fpike; alluding to the flower. Iyegaste'gia (Bot.) $\mu^{\prime} y_{y} a_{5}$, great, $\sigma \tau^{\prime} \gamma n$, a covering; a genus of Leguminofx.

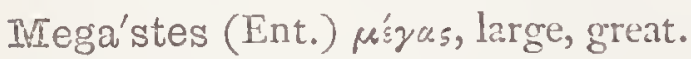

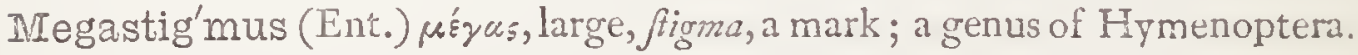

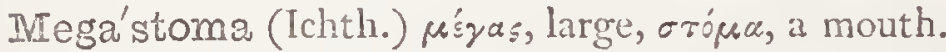

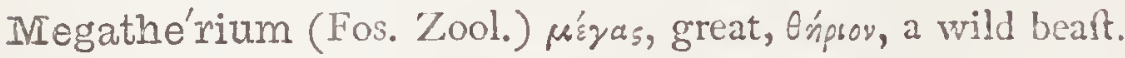

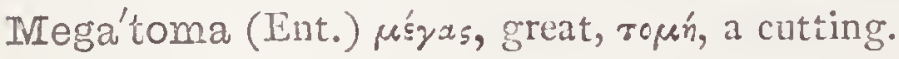

Meger'lia (Zool.) P. N., a genus of Mollufca.

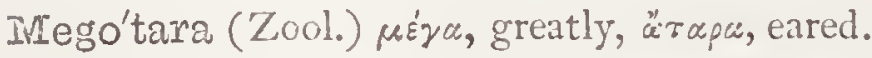

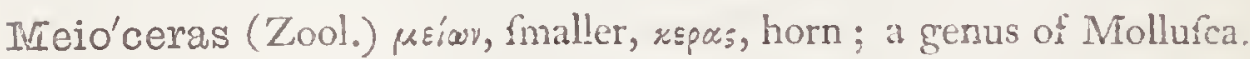

Meisne'ria (Bot.) P. N., a genus of Melaftomacer.

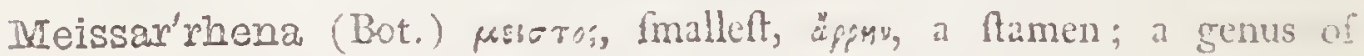

Acanthiccax. 


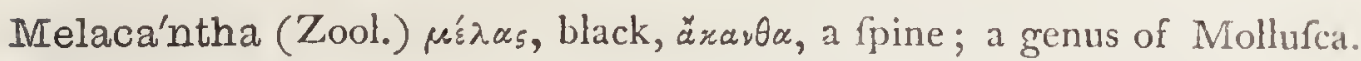

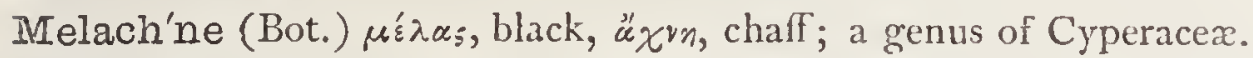

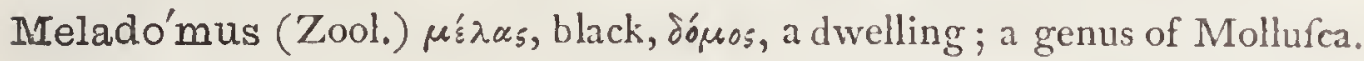

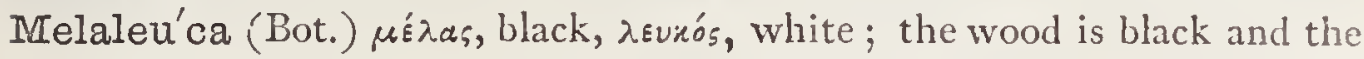
branches are white.

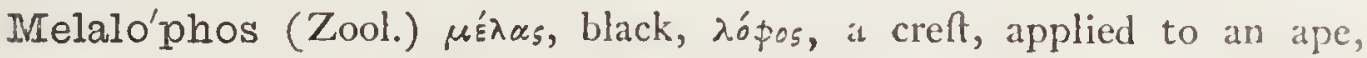
Prefbytes melalophos.

Melampo'dium (Bot.) faid, by Theophrafus, to be named after Melampus

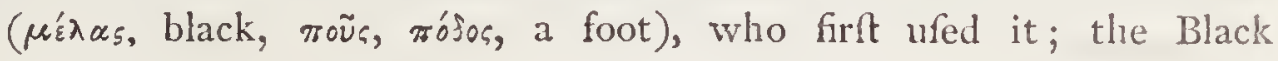
Hellebore.

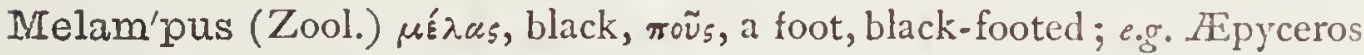
Melampus; alfo a genus of Mollufca.

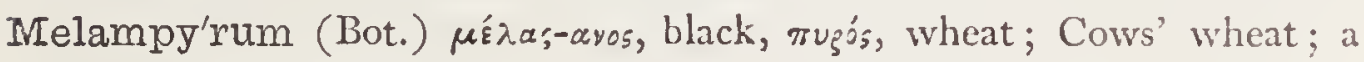
genus of Scrophulariacex.

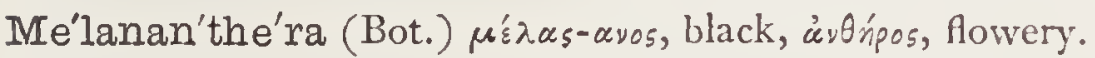

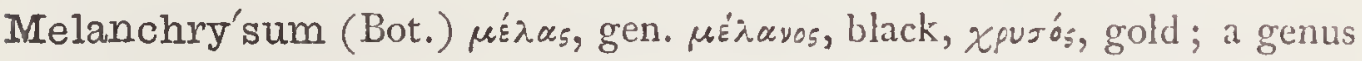
of Compofitæ.

Melanco'nium (Bot.) $\mu_{\varepsilon}^{\prime} \lambda \alpha_{5}-\alpha v o s$, black, xóybs, duft; in allufion to its appearance.

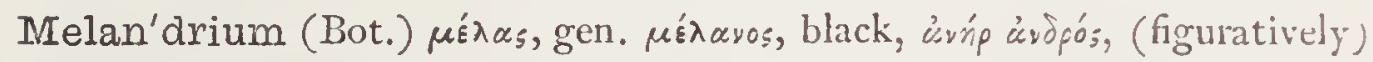
a ftamen; a genus of Caryophyllacex.

Melane'lla (Zool.) dim. of melania; a genus of Mollufca.

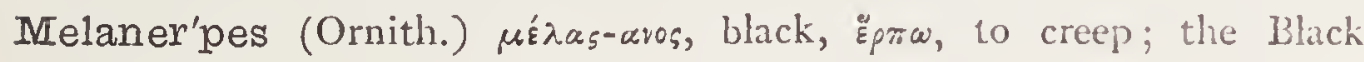
woodpeckers.

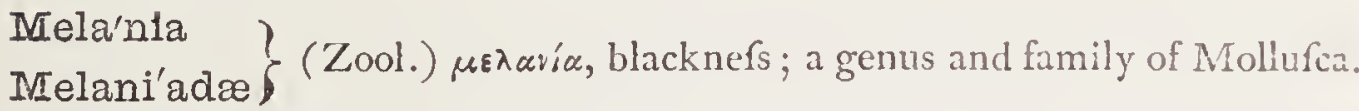

Irelanip'pe (Ent.) P. N., the daughter of Folus.

Mela'nium (Bot.) $\mu \varepsilon \lambda a$ ávov, the common violet, fo called in difinction to $\lambda$ Eurö́ov, literally "white-violet," fuppofed by fome to be the Stockgilliflower, by others the Wall-flower; a genus of Melaftomacex.

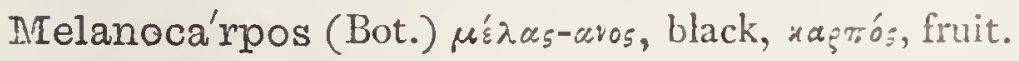

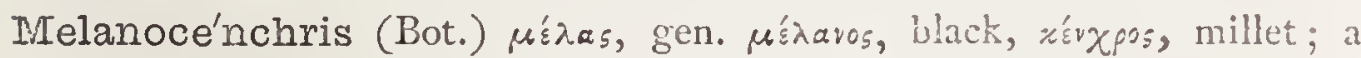
genus of Gramina.

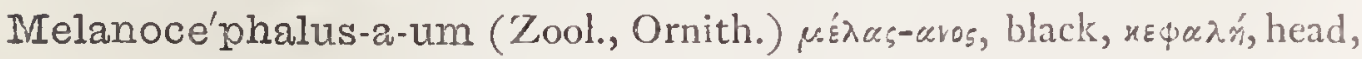
c. g. Pithecia Melanocéphala.

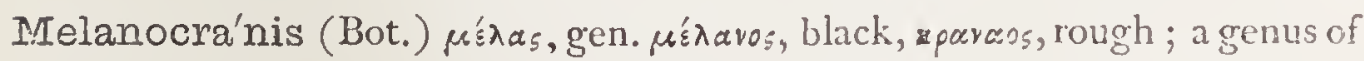
Gramina.

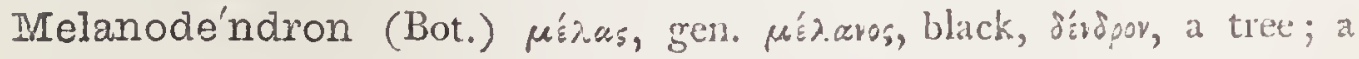
genus of Compolitx. 


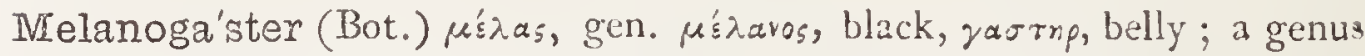
of Fungi; alfo in Ornithology.

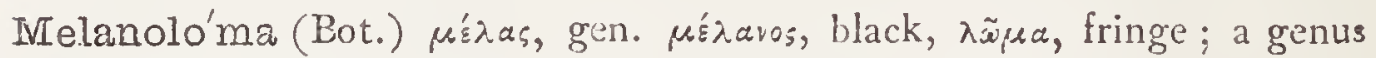
of Compofitæ.

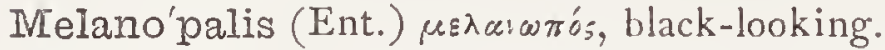

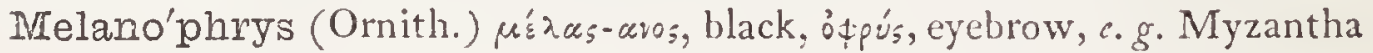
melanophrys.

Mielanopi'cus (Ornith.) $\mu \dot{\varepsilon} \lambda \alpha_{\xi}-\alpha 0_{\xi}$, black, picus; a Woodpecker.

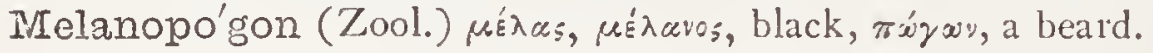

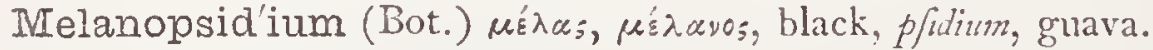

Melanop'sis (Zool.) the genus Melania, ö $\psi$ s, like; a genus of Mollufea.

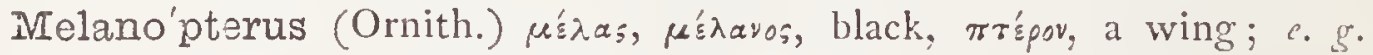
Elanus Melanopterus, the Black-winged Falcon.

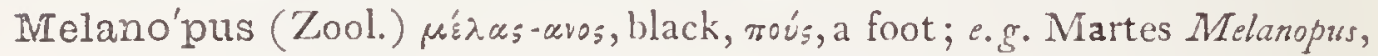
the Japanefe fable.

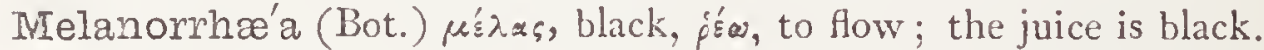

Melanoss'linum (Bot.) $\mu^{\prime} \lambda_{\lambda} \alpha_{s}$, black, $\sigma_{\varepsilon}^{\prime} \lambda_{\iota v o v}$, parlley; referring to its appearance.

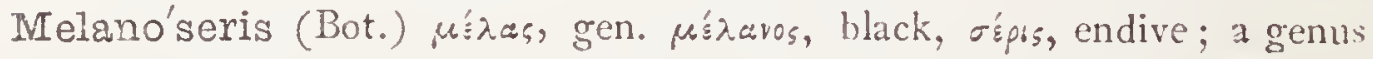
of Compofitr.

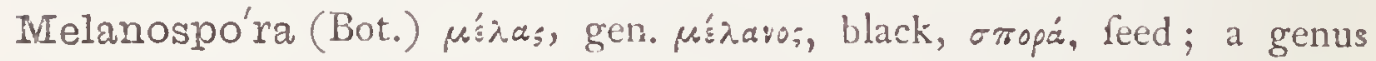
of Fungi.

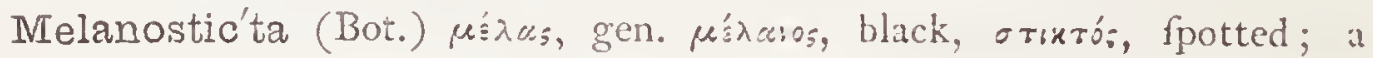
genus of Leguminofæ.

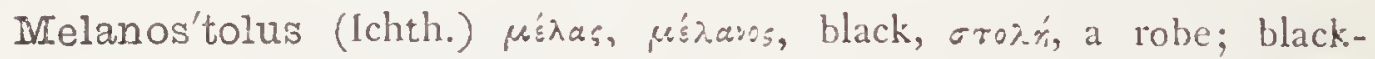
bodied.

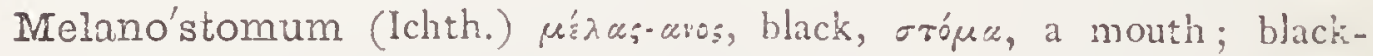
mouthed.

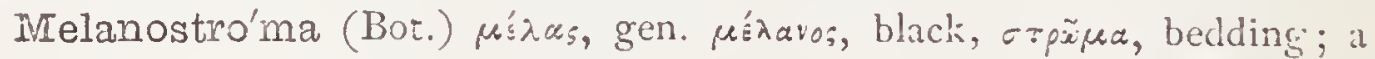
genus of Fungi.

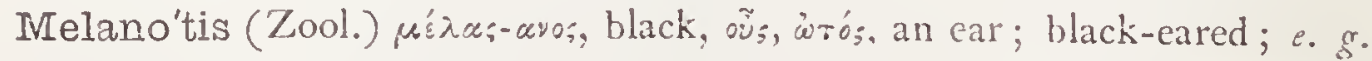
Caracal Melanotis.

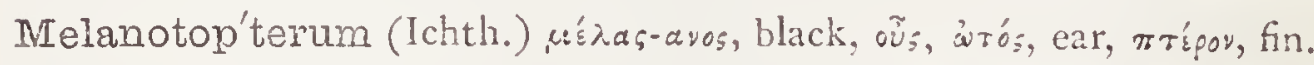

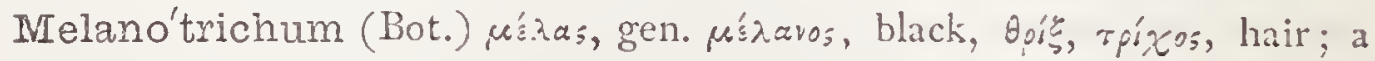
genus of Fungi.

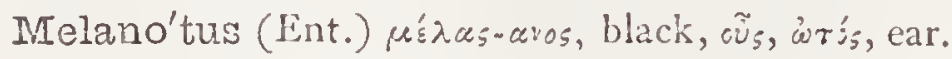

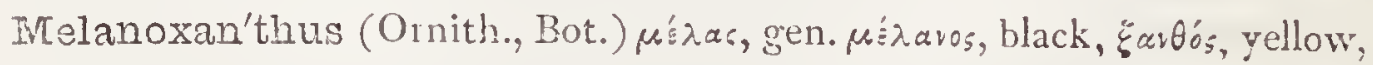
combining the two colouss; $e . g$. Coccothrauftes melanoxanthus; alfo.a genus of Fungi. 


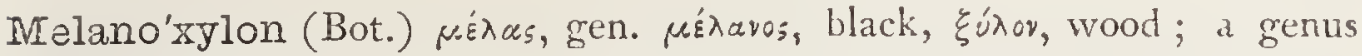
of Leguminofie.

Melantha'cere (Bot.) the Natural Order of which the Colchicum is the type, from the old name Melanthum, the fenmel flower.

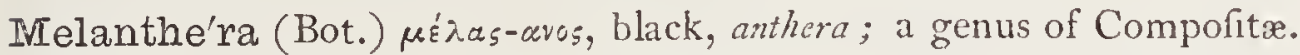

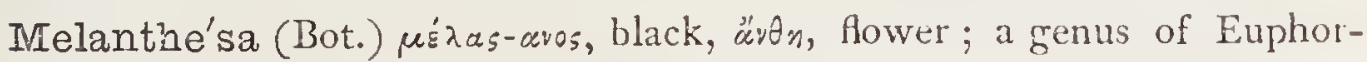
biaceæ.

Melan'thia (Ent.) $\mu \varepsilon \lambda a v \theta$ '́s, dark, fwarthy.

Melan'thium (Bot.) fame derivation.

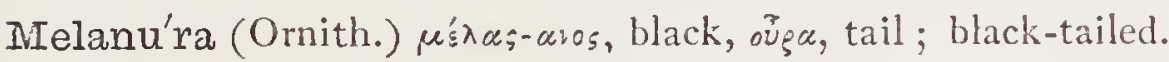

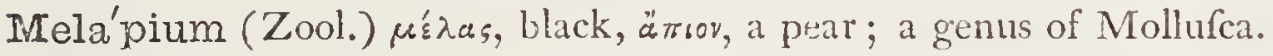

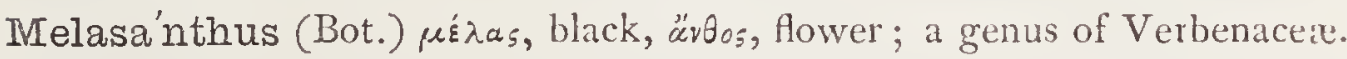

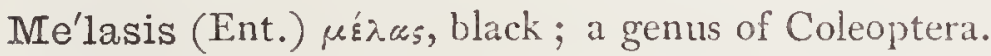

Mela'sma (Bot.) $\mu \varepsilon ́ \lambda \alpha \sigma \mu \alpha$, a black fpot; a genus of Scrophulariacea.

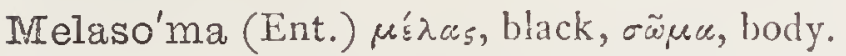

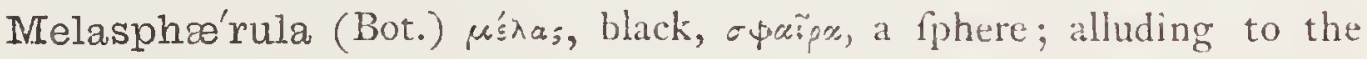
bulbs.

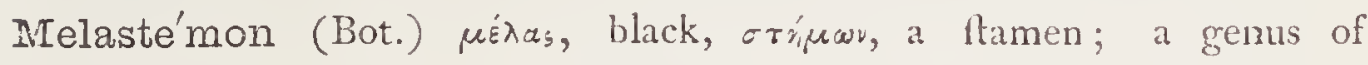
Ericacex.

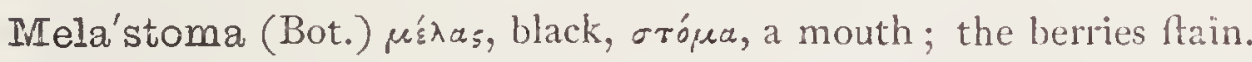

Melea'gris (Ornith., Bot.) the name given by the ancients to a fort of Guinea-fowl, from the hero Meleager. In Botany, the Chequered--lily, or Fritillaria Meleagris.

Nielec'ta (Ent.) mel, honey; a genus of Apida.

Melin'dres (Bot.) vernacular appellation of a fpecies of Vervain in Buenos Ayres; the Verbena Melindres.

Melha'ma (Bot.) P. N. from Mount Melhâm, in Arabia: it was firft found there.

IMe'lia (Bot.) $\mu \varepsilon \lambda i \alpha$, the Ah; typical genus of Meliacere.

Miel'ia (Ent.) $\mu^{\prime} \dot{\varepsilon} \lambda$ : honey; the larva feeds on the nefts of bees.

Melia'na (Ent.) P. N. from Melos, an ifland in the Aigean fea.

Melian'thus (Bot.) $\mu$ '́n, honey, üvos, a flower; the flower abounds in honey.

IMe'lica (Bot.) the name in Italy for the Great Millet; a genus of Grafles. Melice'rta (Zool.) P. N., a character in heathen mythology; a very beautiful genus of Infuforia.

Meli'chrus (Bot.) $\mu \varepsilon \lambda i_{\chi}$ poos, honey-coloured.

Melico'cca (Bot.) $\mu^{\prime} \lambda_{6}$, honey, xórzos, a berry; alluding to the flavcur.

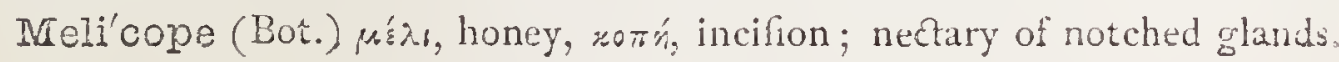




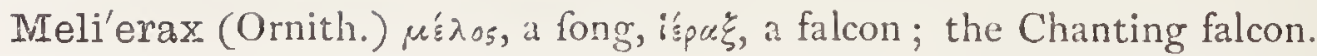

Melige'thes (Ent.) $\mu^{\prime} \lambda_{6}$, honey, $\gamma n \theta^{\prime} \xi^{\prime}$, to rejoice in; a genus of Coleoptera.

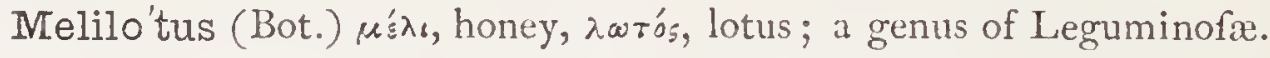

IVe'lina (Zool.) melina, mead; a genus of Mollufca; alfo a genus of Diptera and Coleoptera.

Melinaspa'rmum (Bot.) $\mu \varepsilon \lambda i v n$, millet; $\sigma \pi \varepsilon p \mu x$, seed; a genus of Leguminofx.

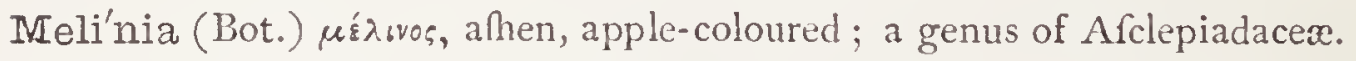

Meli'nis (Bot.) $\mu$ é

Meli'num (Bot.) $\mu \varepsilon \lambda_{i}^{\prime} n$, millet; a genus of Gramina.

Melipho'ra (Ent.) $\mu^{\prime} \lambda_{t}$, honey, $\phi^{w_{z}}$, a thief; the larva feeds on the honey in bee-hives.

Meli'pona (Ent.) $\mu^{\prime} \dot{\lambda} \iota$, honey, róv'sw, to toil; a genus of Hymenoptera.

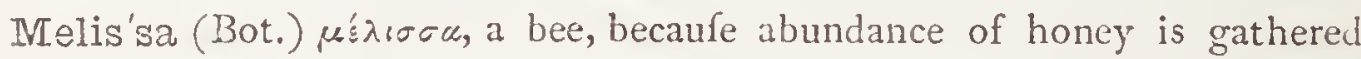
from it; Balm; a genus of Labiatæ.

Melis'sa (Ent.) $\mu$ ś $\lambda \iota \sigma \alpha$, a bee; a genus of Hymenoptera.

Melisso'des (Ent.) the genus Meliffa, and Eísos, like; a genus of Hymenoptera.

Melitæ'a (Ent.) P. N., a town in 'Therfaly.

Melit'tis (Bot.) $\mu \varepsilon \dot{\lambda} \iota \tau \tau \alpha$, a bee; bees gather honey from it ; Honey-balm; a genus of Labiatr.

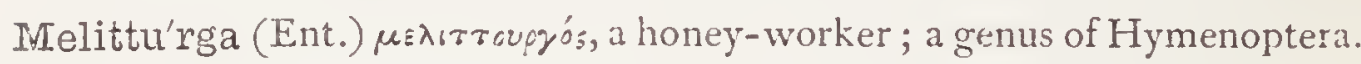
Melizo'philus (Ornith.) $\mu \dot{\varepsilon} \lambda_{\iota} \zeta \omega$, to fing, $\phi i \lambda^{\prime} \xi \omega$, to love.

Melli'fera (Ent.) mel, honey, fero, to carry; the Bees.

Irelli'ficus-a-um (Ent.) Lat. honey-making; Apis mellifica is the Honey. Bee.

Me'llinus (Ent.) mellinia, fweetnefs, from mel, honey; a genus of Hymenoptera.

Mellisu'ga (Ornith.) mel, honey, fugere, to fuck; Honeyfucker.

Melli'vora ('Zool.) mel, honey, voro, to devour; as in the Humming-bird; Florifuga mellivora.

Melo (Bot.) the ancient name, and now the fcientific one, of the Melor. Ifelo (Zool.) «ñ̀ ov, a melon, ain apple, from its fhape; a genus of Mollufca. Melobe'sia (Bot.) r'śnos, a limb, obefus, wafted away; a genus of Algx. Meloca'ctus (Bot.) melon, cactus, alluding to its Thape; a genus of Cac. tacex.

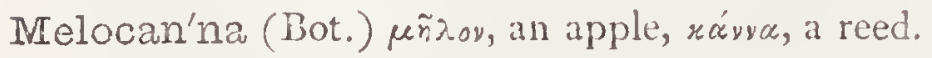

Irielo'chia (Bot.) melochich, its Arabic name.

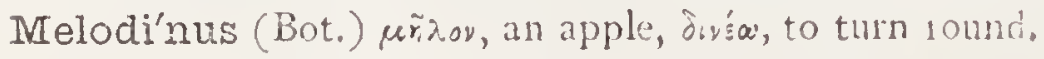


Meloë (Ent.) $\mu^{\prime} \lambda \alpha \varsigma$, black ; the Oil-beetle; a genus of Coleoptera.

Melolo'ntha (Ent.) $\mu n \lambda \Delta \lambda_{o} o v \theta$, a beetle or cock-chafer, from $\mu n \lambda o^{\circ} s$, to

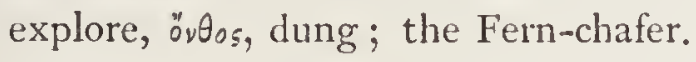

Melolon'thidæ(Ent.) a family of Coleoptera of which Melolontha is the type.

Melon (Bot.) Menage confiders the melon as a large apple, and derives it from $\mu \tilde{n} \lambda$ ov, an apple; the Cucumis Melo; Nat. Ord. Cucurbitacex.

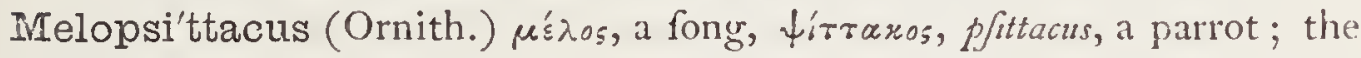
Warbling parroquet.

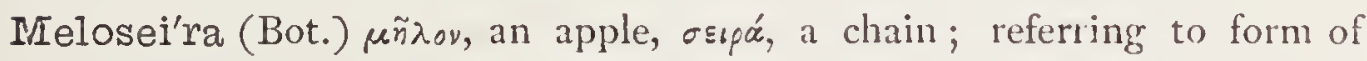
filaments; a genus of Cryptogamia.

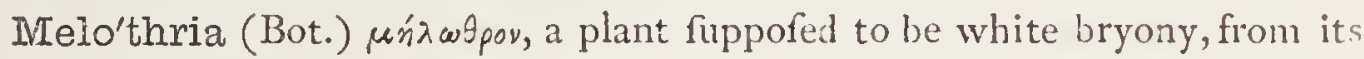
fimilarity.

Melu'rsus (Zool.) mel, honey, urfus, a bear; from eating bees' nelts; the Honey-bear.

Mely'ris (Ent.) a genus of Coleoptera.

Membrana'ceus-a-um (Zool) Lat. like a membrane or thin.

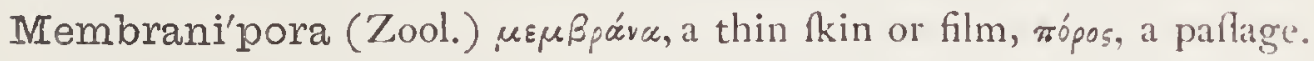

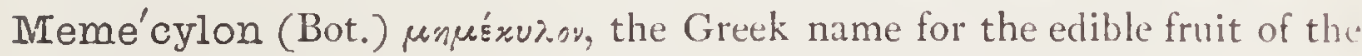
Arbutus.

Mendi'ca (Ent.) mendicus, a beggar; i.e. poor in appearance.

Mene'stho (Zool.) P. N. from a character in heathen mythology; a genus of Mollufed.

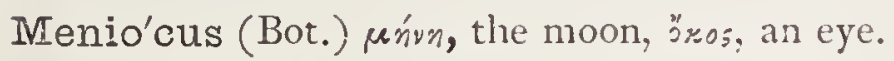

Menis'cium (Bot.) unvísros, a crefcent; from thape of fruetification.

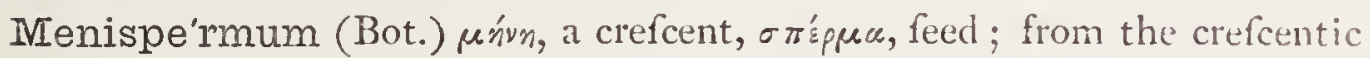
Thape of the feeds; typical genus of Menifpermacex.

Mie'nkea (Bot.) P. N. in honour of Menke, a German botanift; a genns of Crucifera.

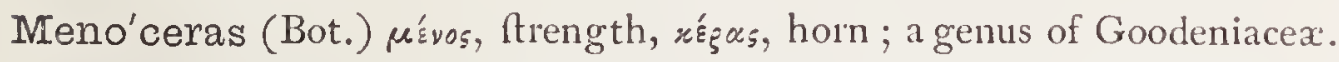

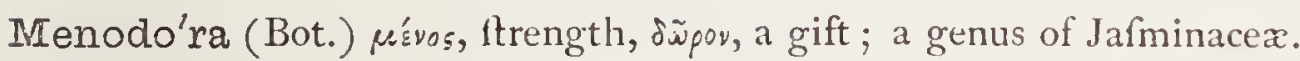

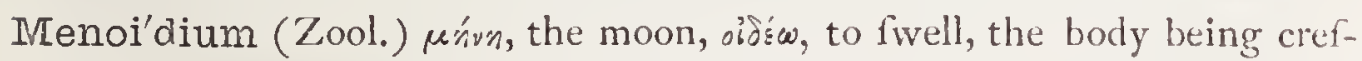
centic and thicker on the outer margin; a genus of Infuforia.

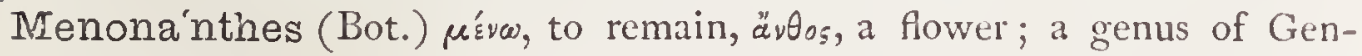
tianacex.

Menonvi'llea (Bot.) P. N, a genus of Crucifera.

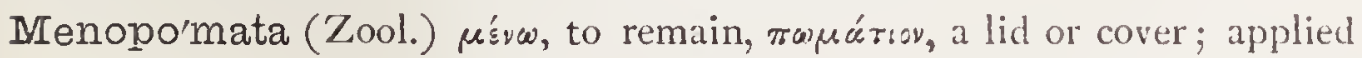
to the operculum of amphibious animals.

Me'ntha (Bot.) P. N. from Minthe, or Menthe, the daughter of Cocytus, who was changed into this plant; Mint; a genus of Labiatx. 
Menthras'trum (Bot.) dim. of mentha, mint; Wild mint.

Me'ntum (Ent.) Lat. the chin; applied to a part of the labium of infects. Mentze'lia (Bot.) P.N. from C. Mentzel, of Brandenburg, a writeron botany.

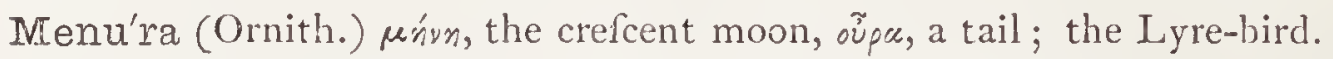

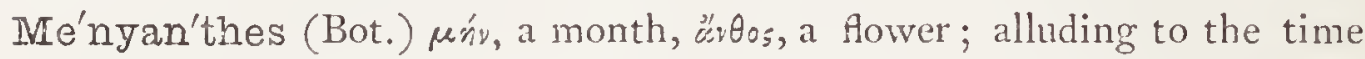
during which it is in bloffom; a beautiful genus of Gentianacex.

Menzie'sia (Bot.) P. N. from A. Menzies, F.L.S., an affiduous botanift; a genus of Ericacex.

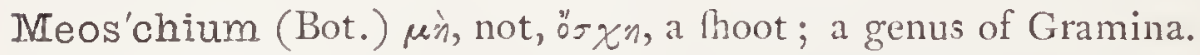

Mephiti'dia (Bot.) mephitis, a noxious exhalation, e'jos, likenefs; a genus of Cinchonacex.

Mephi'tis ('Zool.) Lat. a noxious exhalation, applied to the Skunk.

Inera'tia (Bot.) P. N. in honour of M. Merat; a genus of Compolitr.

Mercie'ra (Bot.) P.N. in honour of M. Mercier; a genus of Campanulacex.

Me'rclia (Bot.) P. N. in honour of Merke; a genus of Caryophyllaceæ.

Mercuria'lis (Ent.) from the refemblance of the ftigmata to the fymbo of the planet Mercury ( $\Varangle)$.

IV ercuria'lis (Bot.) Mercury firft difcovered the virtues of this plant; a genus of Euphorbiacer.

Merdel'la (Ent.) merda, dung.

Merende'ra (Bot.) a name given to the Colchicum by the Spaniards.

Merga'nser (Ornith.) popular name of the mergus, compounded of that word and anfer, a goofe.

Mer'gens (Zool.) Lat. diving or plunging: applied to the Duyker Bok, Cephálopus mergens; from its mode of efcaping in the bulh.

Me'rgulus (Ornith.) dim. of mergus.

Me'rgus (Ornith.) Lat. a diver or gull.

Meria'na (Bot.) P. N. from M. S. Merian, authorefs of a work on the infects of Surinam; born I647, died 1717.

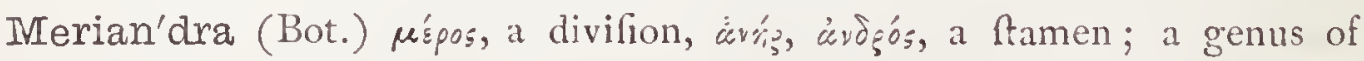
Labiati.

Meri'dion (Bot.) from its circular form; a genus of Defmidiacer.

Meridiona'lis (Ornith.) Lat. fouthern.

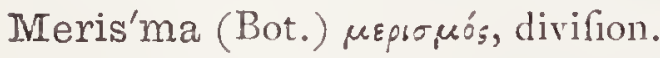

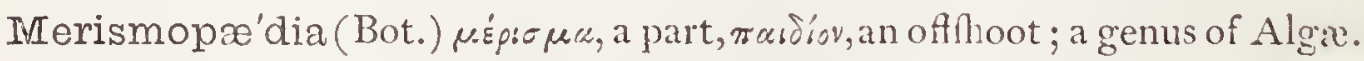

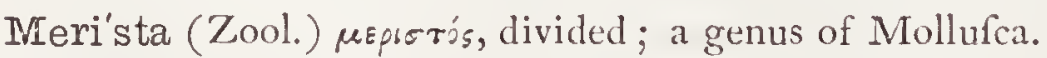

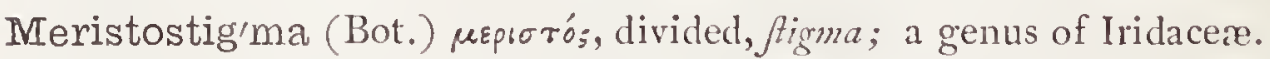

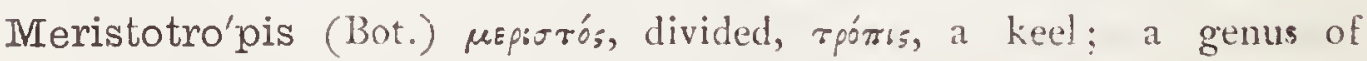
I.eguminofie. 


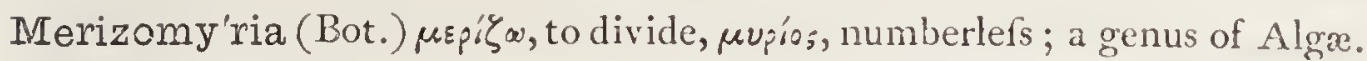
Merlan'gus (Ichth.) etymol. uncertain; the Coal-fifh is $M$. carbonarius; the Whiting, $\boldsymbol{M}$. vulgaris.

Merle (Ornith.) French, merle, a blackbird.

Merlu'cius (Ichth.) Fr.mer, fea, luce, pike; the Sea.pike; the Hake is M. vulgaris.

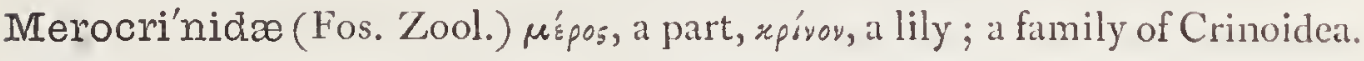
Meroe (Zool.) P. N., an ifland in the Nile; a genus of Mollufca; alfo in

Entomology, a genus of Neuroptera.

Mero'malus (Ent.) unpos, the thigh, oseanos, fmooth.

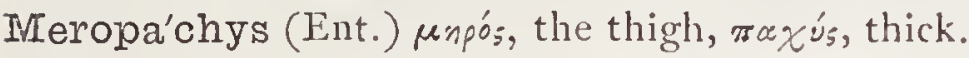

Merops (Ornith.) $\mu^{\prime}$ społ, Lat. merops, the Bee-eater.

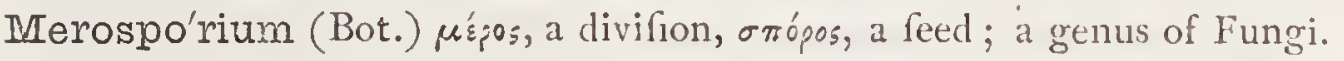

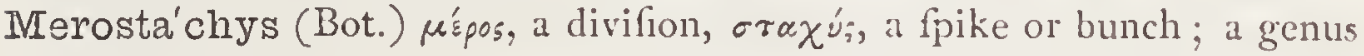
of Gramina.

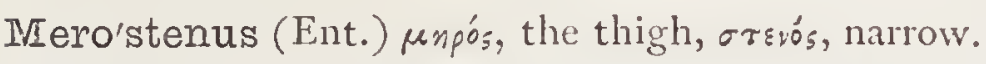

Merten'sia (Bot.) P. N. from Profeffor F. C. Mertens, of Bremen; a genus of Filices.

Me'rula (Ornith.) Lat. a black-bird; fpecific name of the Black-bird, Turdus Meruli.

Meruli'dæe (Ornith.) a family of Inceflores, containing the Black-bird.

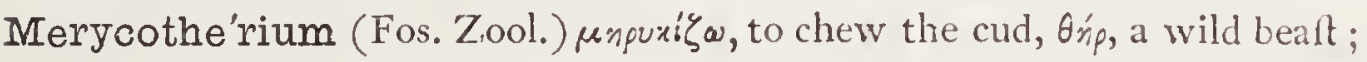
a foffil Ruminant of the drift.

Mesa'lia (Zool.) from Mefal, the African name of a Ahell-fifh; a genus of Mollufca.

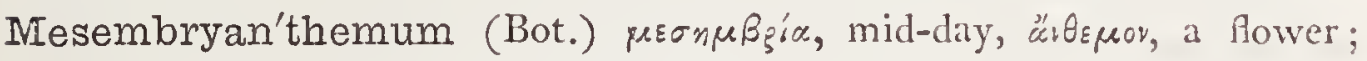
typical genus of the order Mefembryacex.

Mesembryan'themum (Zool.) an actinia fo named from refemblance to the plant: $q . v$.

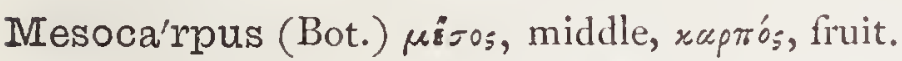

Mesoce'na (Zool.) p'ścos, middle, xevós, empty; a genus of Infuforia.

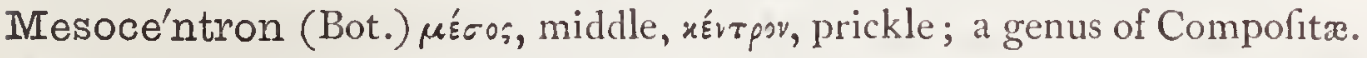

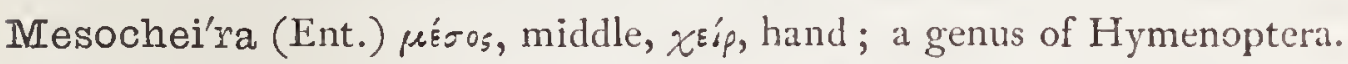

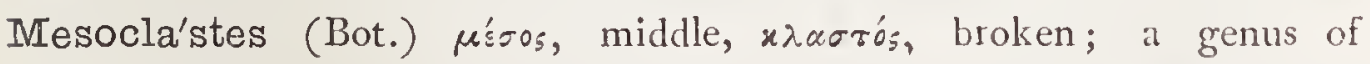
Orchidaceæ.

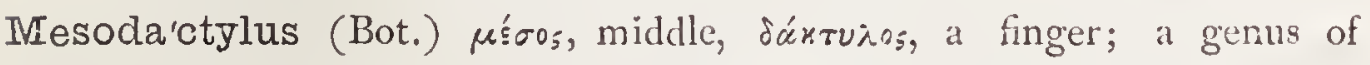
Apoltafiacex.

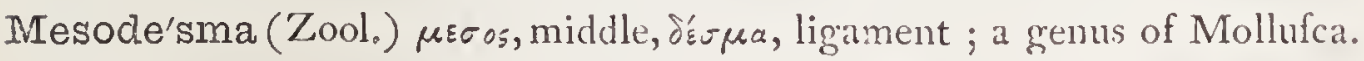

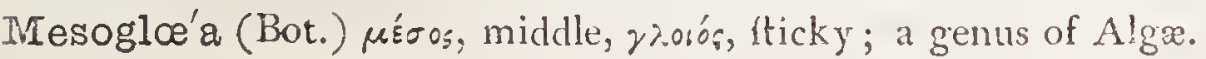




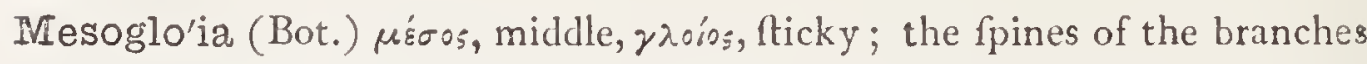
being a folid mafs.

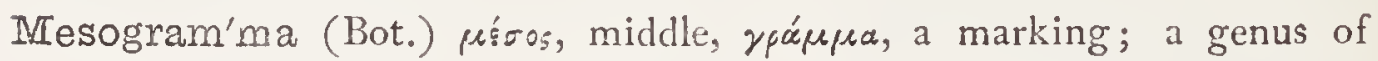
Compolitx.

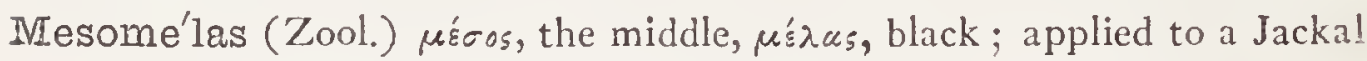
having a dark mottied band on its back.

Mesome'lla (Ent.) mefomelas, a white ftone with a black ftripe; a word ufed by Pliny.

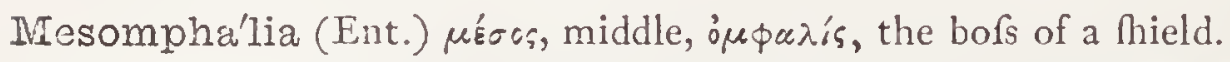

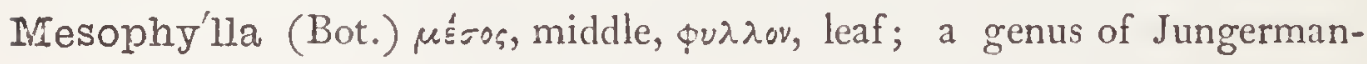
niacex.

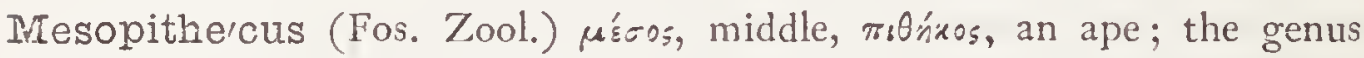
being regarded as tranfitional between Hylobates and Semnopithecus. Mesoreg'ma (Bot.) $\mu^{\prime} \sigma \sigma o s$, middle, $\rho^{\prime} \xi \mu \mu \alpha$, that which is dyed; a genus of Marchantiacex.

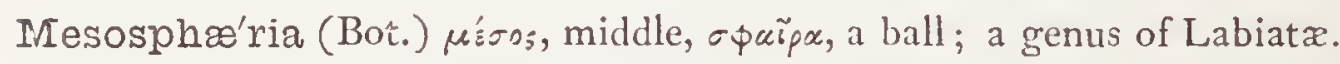

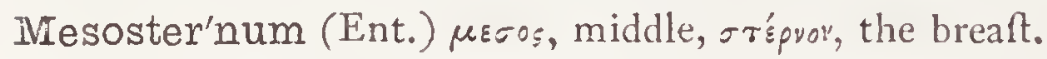

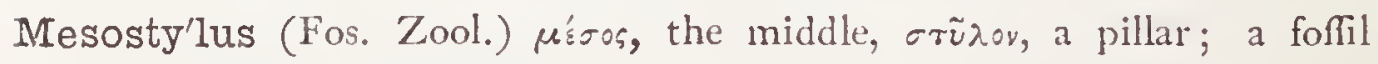
Cruftacean of the chalk.

Mespiloda'phne (Bot.) $\mu \varepsilon \sigma \pi i \lambda n$, mefpilus, the Medlar-tree, daphne; a genus of Lauracex.

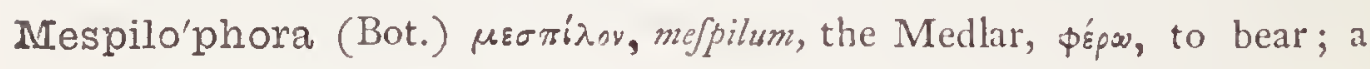
genus of Pomacer.

Me'spilus (Bot.) $\mu \varepsilon=\pi i \lambda_{n}$, Lat. mefpilus, the Medlar-tree; a genus of Nat. Ord. Pomiferæ.

Messaniel'la (Ent.) firf taken by Zeller near Meffina (the ancient Meflana), in Sicily.

Mitesserschmi'dia (Bot.) P. N. from D. Mefferfchmid. a German botanift.

Messingiel'la (Ent.) P. N. in honour of Herr Hof-und Stadt-Kantor Mefing, of Neuftrelitz, who firft found the fpecies.

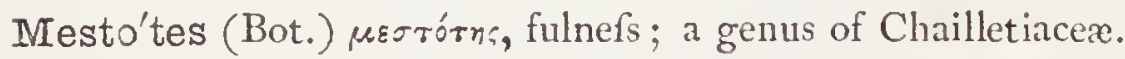

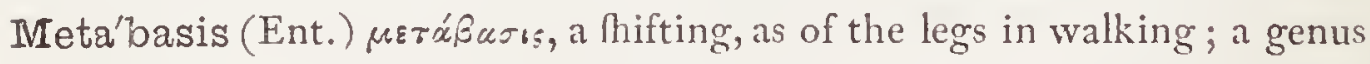
of Diptera.

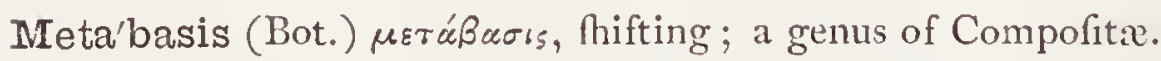

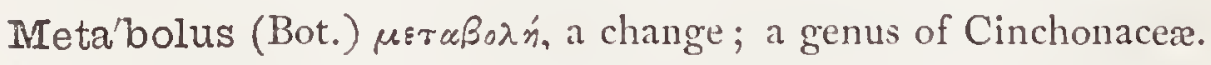

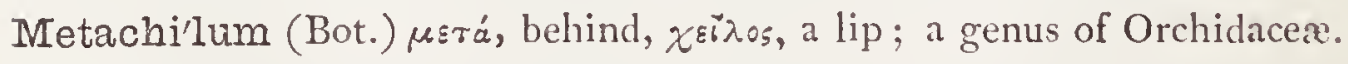

Metalli'tes,

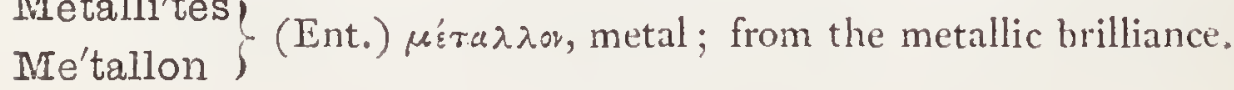




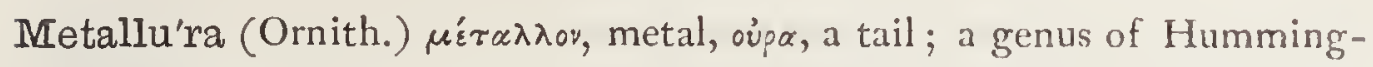
birds.

Metape'ima (Ent.) $\mu \varepsilon \tau \dot{\alpha}$, without, $\pi_{\varepsilon}^{\prime} \lambda \mu \alpha$, the fole of the foot.

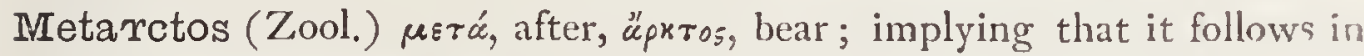
the feries after the bear.

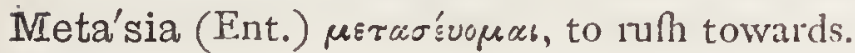

Metastel'ma (Bot.) $\mu \varepsilon \tau \alpha ́$, inftead of, $v \tau \varepsilon \lambda \mu \alpha$, a crown.

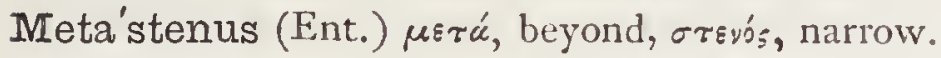

Methoca (Ent.) a genus of Hymenoptera.

Metho'rium (Bot.) $\mu \varepsilon \theta$ ópros, on the border, i. e. of difficult claflification;

a genus of Sterculiacex.

Meti'culosa'lis (Ent.) meticulosus, timorous; from its habit of quivering when the light is thrown on it.

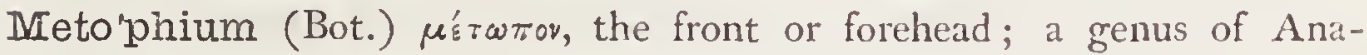
cardiaceæ.

Metopi'dia (Zool.) $\mu \varepsilon \tau \omega \pi i \delta$ sos, of the forehead; a genus of Infuforia.

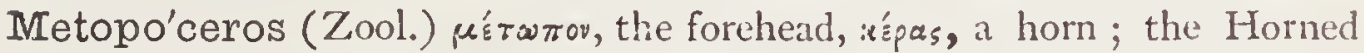
Iguana.

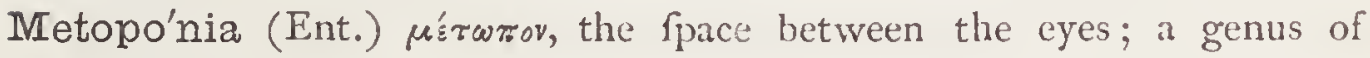
Diptera.

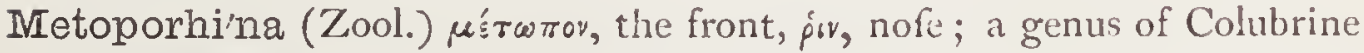
ophidians.

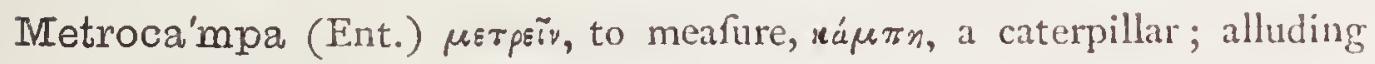
to the geometrical mode of progreffion of the larva.

Metroside'ros (Bot.) $\mu \varepsilon \tau \xi \alpha$, heart of a tree, oisnpos, iron; iron-wood; Nat. Ord. Myrtaceæ.

Metternich'ia (Bot.) P. N., a genus of Solanacex.

Metzber'ia (Bot.) P. N., a genus of Lobeliaceæ.

Metzge'ria (Bot.) P. N,. a genus of Jungermanniacex.

Metzneriel'la (Ent.) P. N. in honour of Herr Metzner, of Frankfort on the Oder.

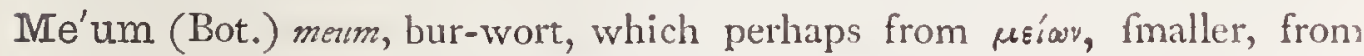
delicacy of leaves; a genus of Umbellifera.

Mexica'nus-a-um (Zool., Ornith., Bot.) relating to Mexico ; e. g., Trogon Mexicanus.

Meyenia (Bot.) P. N., a genus of Cinchonaceæ.

Meye'ra (Bot.) P. N. from Gottlieb Andreze Meyer, a German botanift.

Meye'ria (Bot.) P. N., a genus of Compofitx.

Meye'ria (Fos. Zool.) P. N., a foffil Cruftacean of the chalk. 
Mezerreon (Bot.) from Perlian madzaryoun.

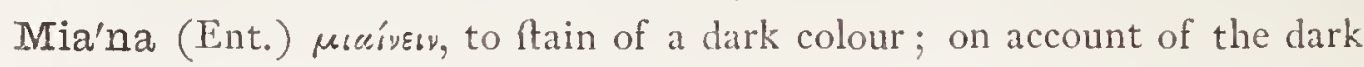
colour of feveral of the fpecies.

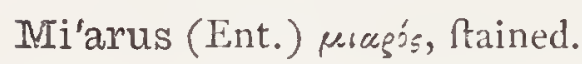

Mias (Zool.) the name ufed by the Dyaks for the Ourang.outang.

Mia'ta (Ent.) ucciverv, to ftain; the wings, originally of a rich green, foon' fade to a dirty yellort.

Mi'cans (Ent., Bot.) Lat. Thining, from mico, to glitter; e. g., Mefembry-anthemum micans.

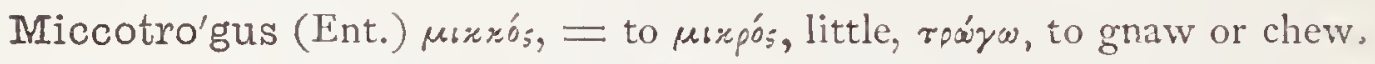
Michau'xia (Bot.) P. N. from A. Michaux, botanift to Louis XVI.

Miche'lia (Bot.) P. N. from P. A. Micheli, the great Florentine botanif: Nat. Ord. Magnoliacer.

Mico'nia (Bot.) P. N. from Dr. Micon, M.D., a Spanifh botanift. Mi'cra (Ent.) usufós, fmall.

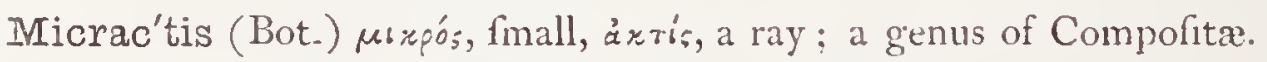

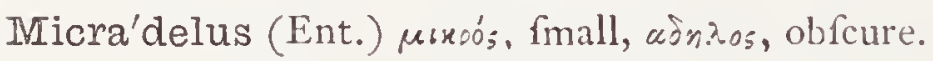

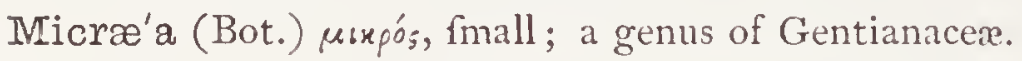

Micran'dra (Bot.) uskpos, fmall, àvrip, árópos, a ftamen; a genus of Sterculiacex.

Micran'dria (Bot.) fame derivation; a genus of Cinchonaceæ.

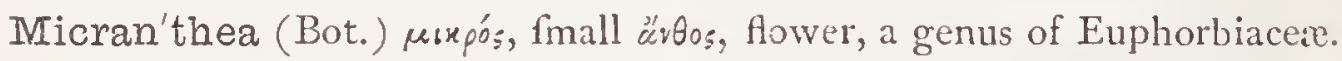

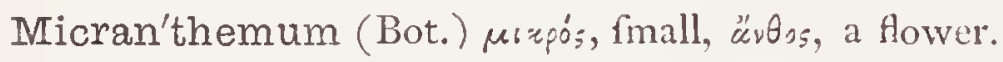

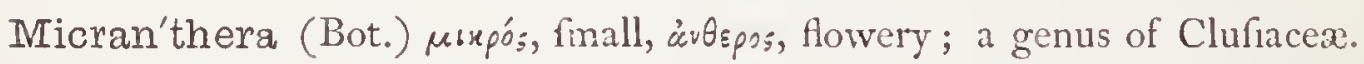

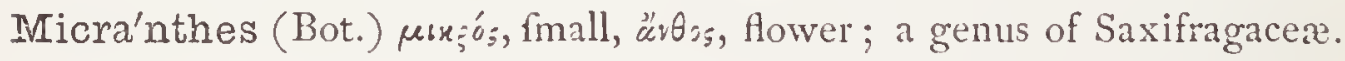

Micra'nthus (Bot.) fame derivation; a genus of Iridacer.

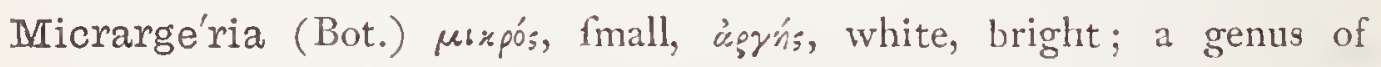
Scrophulariacer.

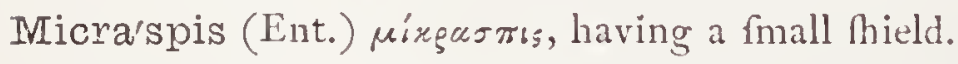

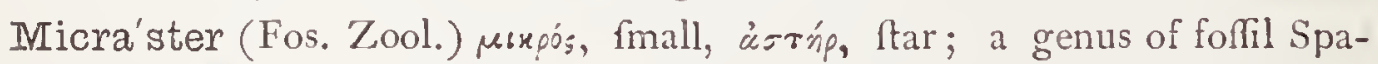
tangidre, very abundant in the chalk.

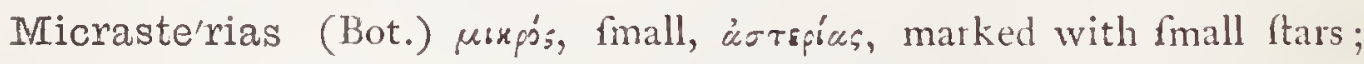
a genus of Algæ belonging to the Defmidiacex.

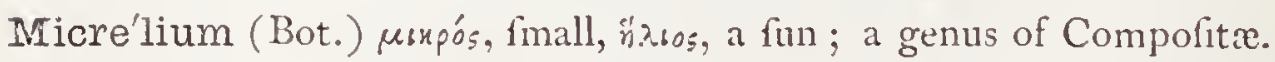

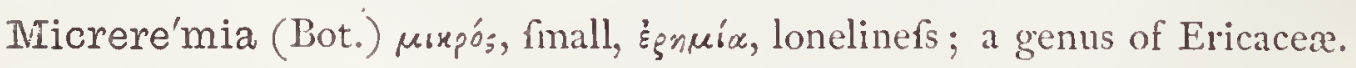

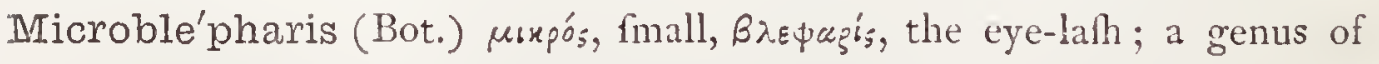
Papayacex.

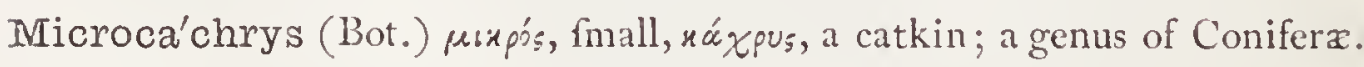

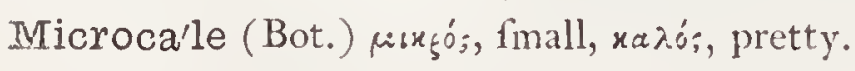




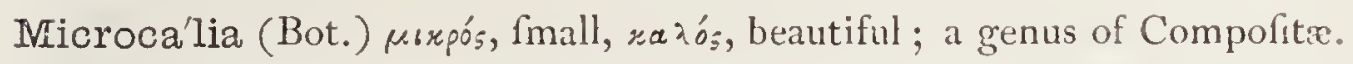

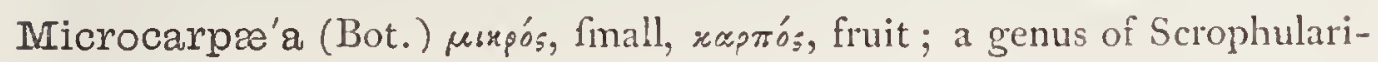
acex.

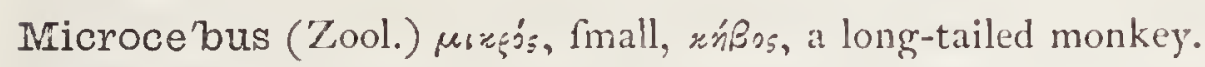

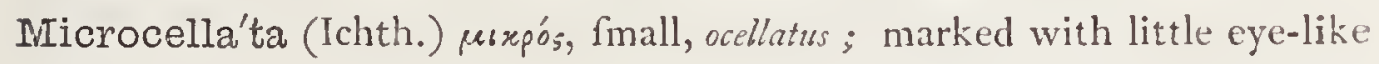
fpots.

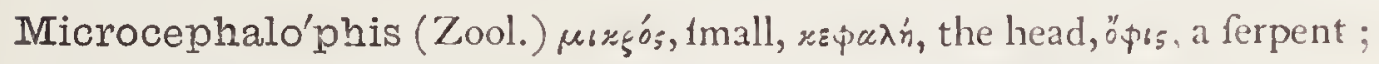
a genus of Ophidians.

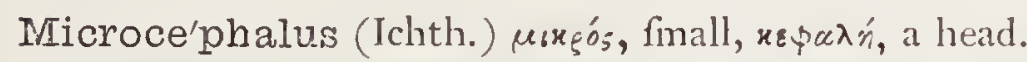

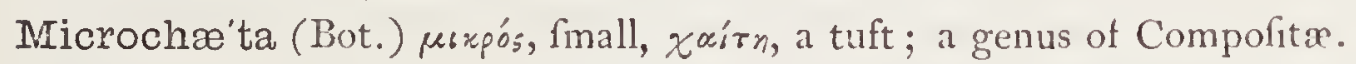

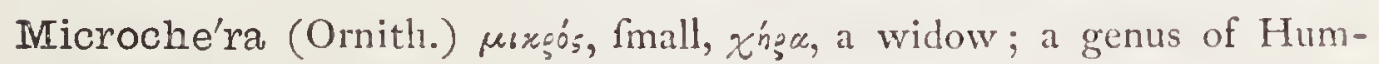
ming-birds.

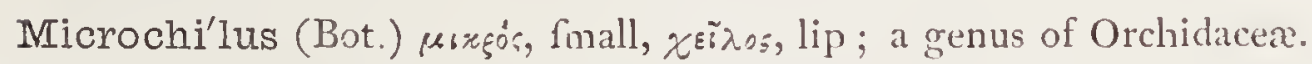

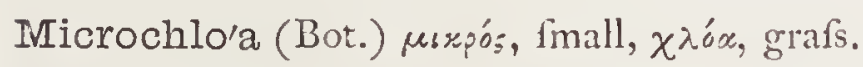

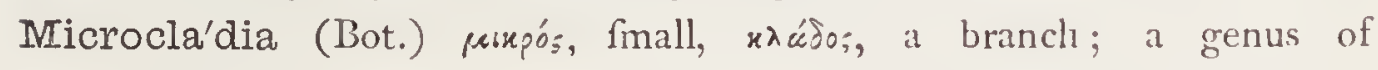
Cryptogamia.

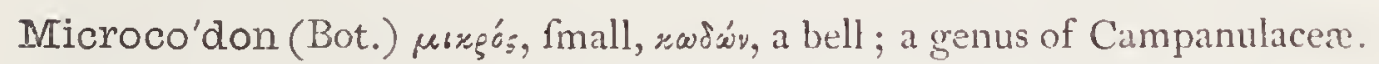

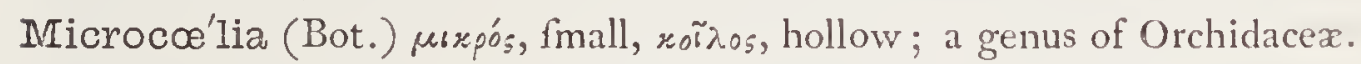

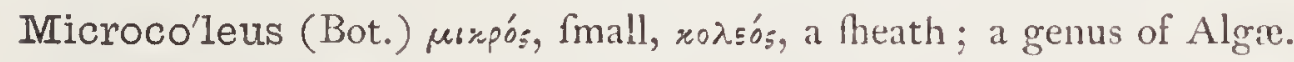

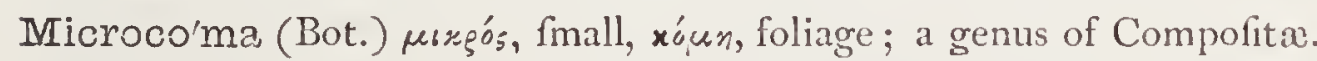

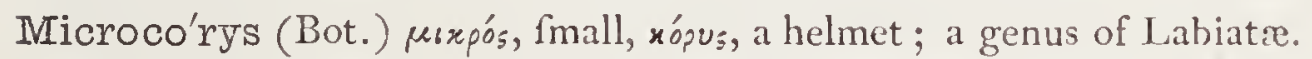

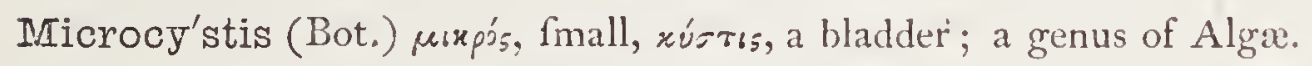

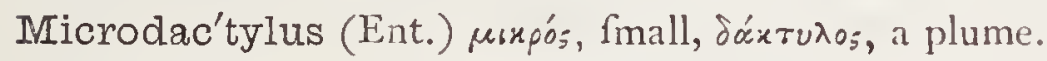

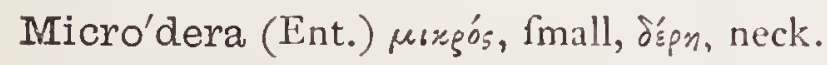

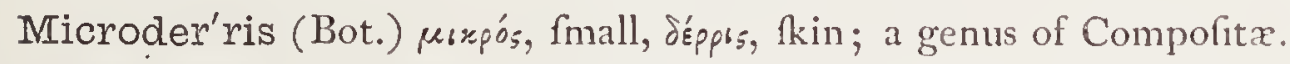

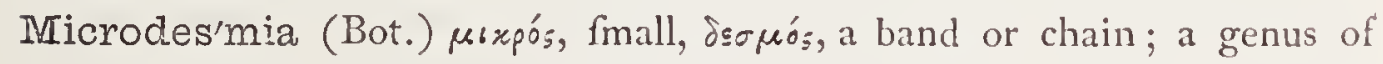
Chryfobalanacex.

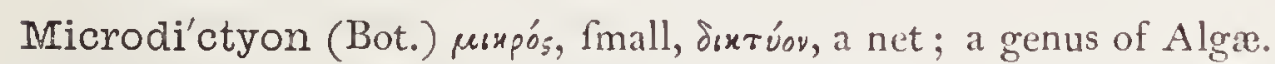

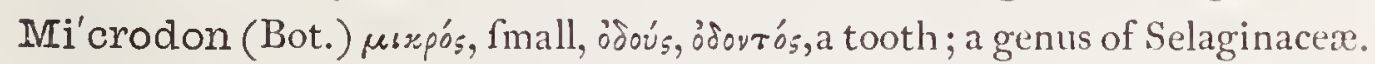

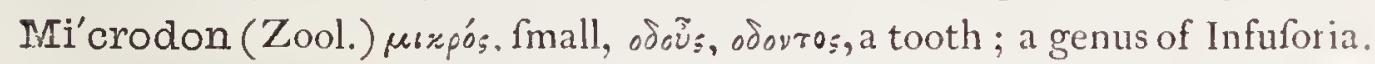

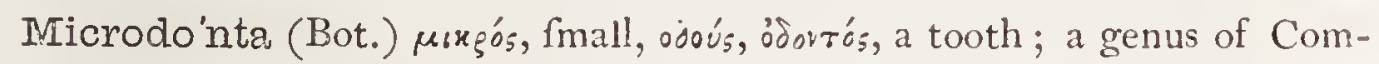
pofitæ.

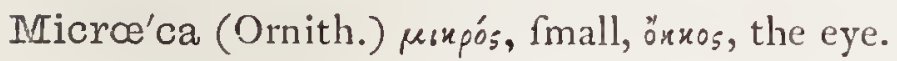

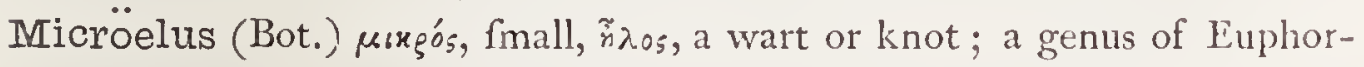
biacea.

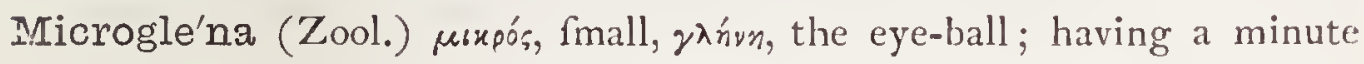
red eye-like fpeck at the anterior part of the body; a genus of Infuforia.

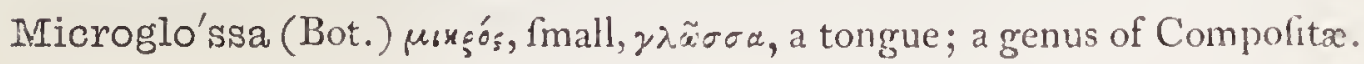




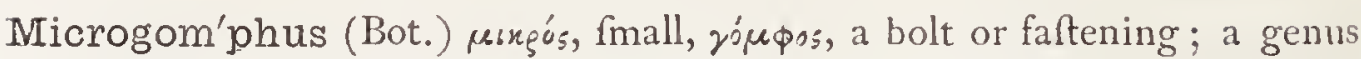
of Ericacex.

Microgoni'dia (Bot.) usxpós, fmall, yoursobov, dim. of ravice, angle; the fmalleft fronds which efcape from the parent cell in the Infuforia.

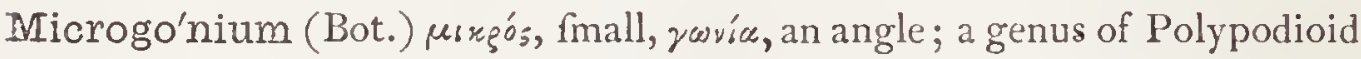
Filices.

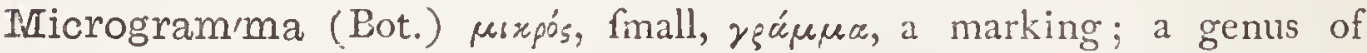
Polypodioid Filices.

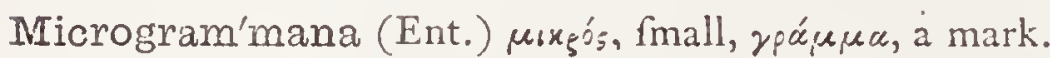

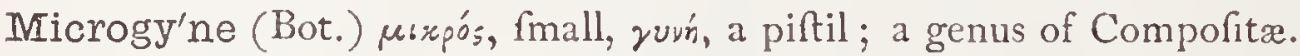

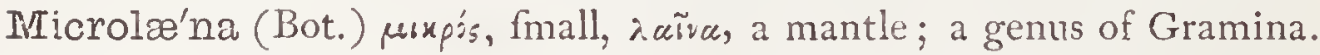

Microlépia (Bot.) usxpós, fmall, $\lambda \varepsilon \pi \xi_{\xi}$, a fcale; a genus of Polypodioid Filices.

Microle'pis (Bot.) fame derivation; a genus of Melaftomaceæ.

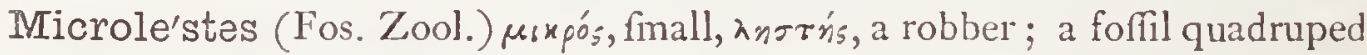
of the triaffic formation.

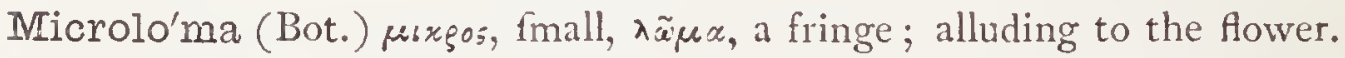

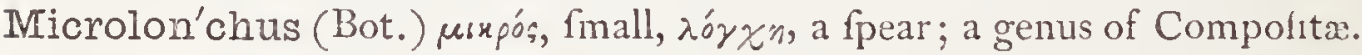

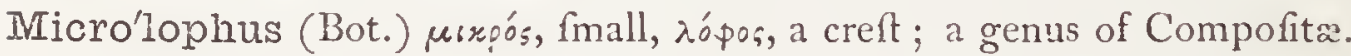

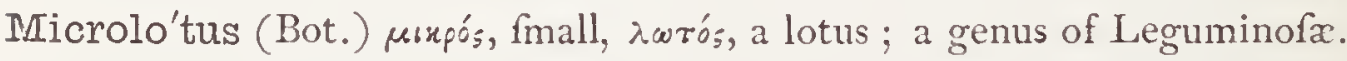

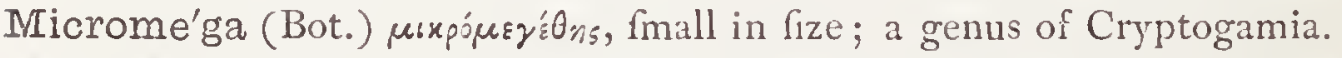

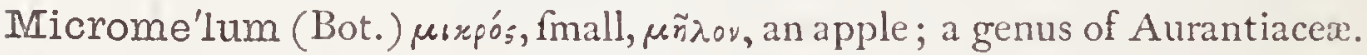

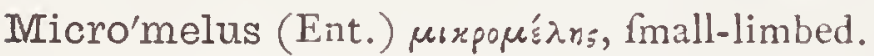

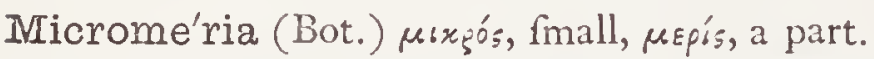

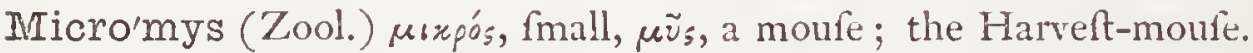

Micropel'tis (Bot.) $\mu \iota x \tilde{o ́}^{\prime}$, fmall, $\pi \varepsilon \dot{\lambda} \tau n$, a leather fhield; a genus of Fungi

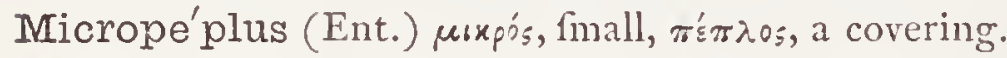

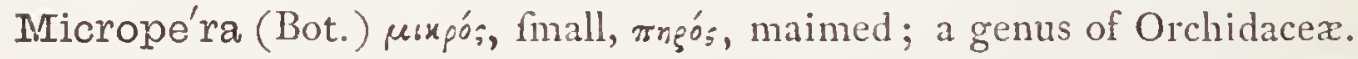

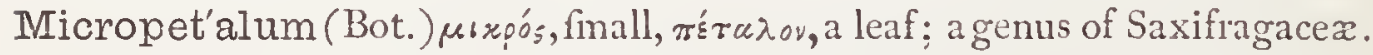

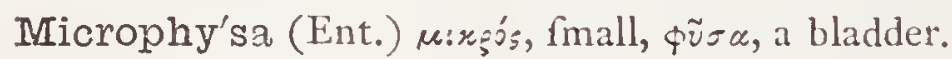

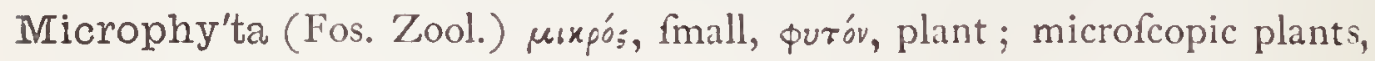
fuch as many Definids.

Micropi'per (Bot.) $\mu$ เxpos, fmall, piper, the pepper plant; a genus of Piperaceæ.

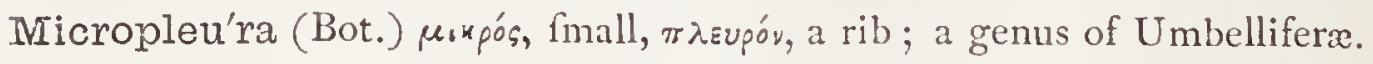

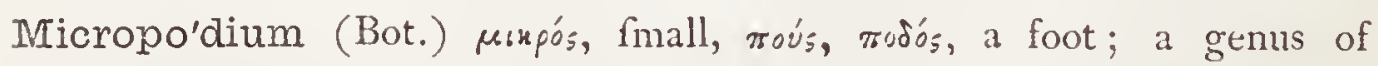
Cruciferæ.

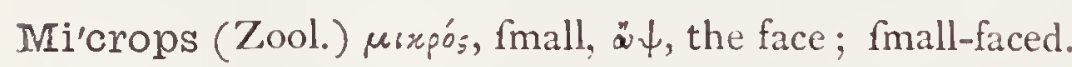

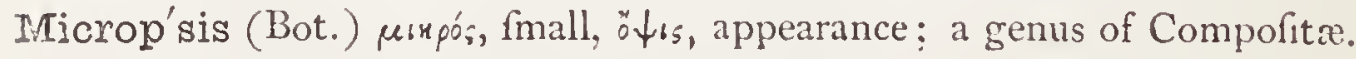




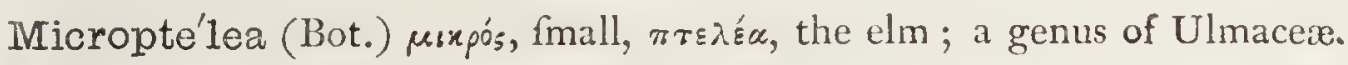

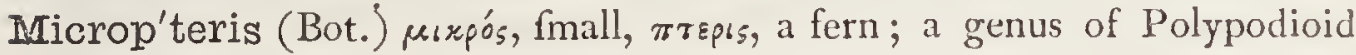
Filices.

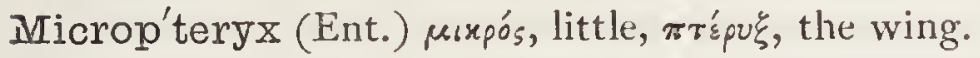

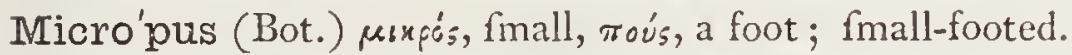

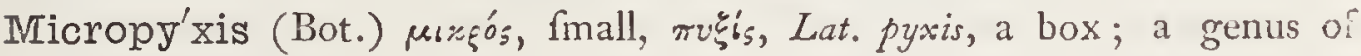
Primulace

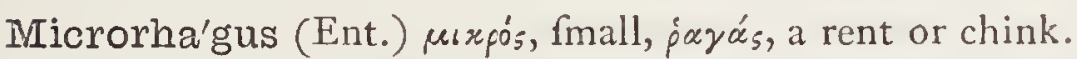

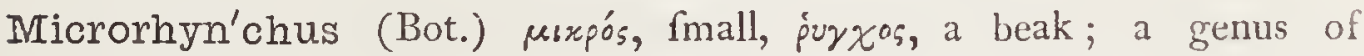
Compolitx.

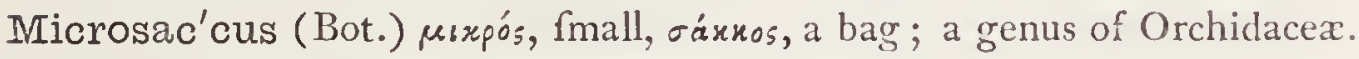

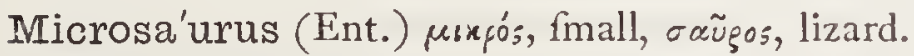

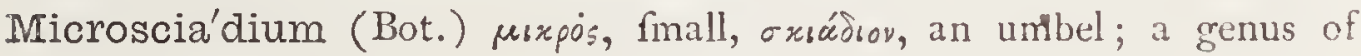
Umbelliferæ.

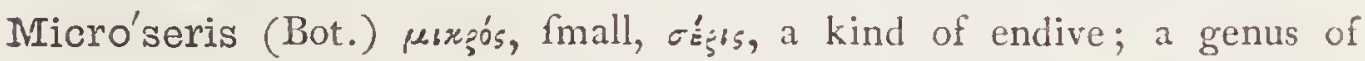
Compofitæ.

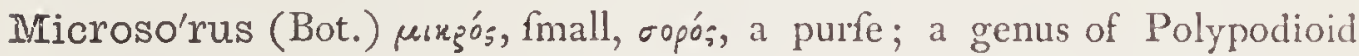
Filices.

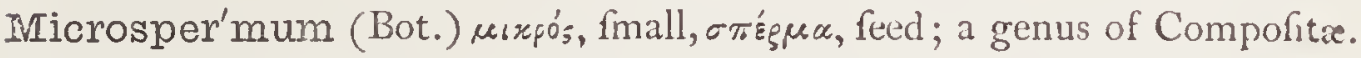

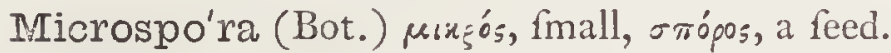

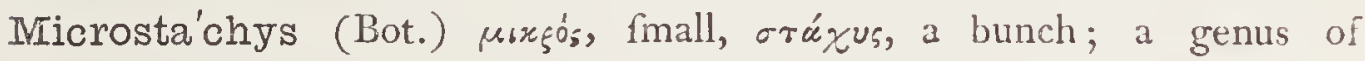
Euphorbiacex.

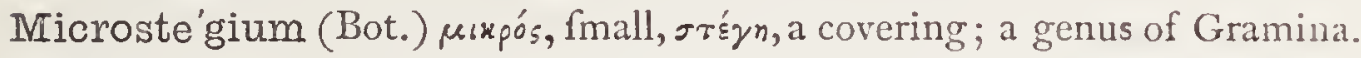

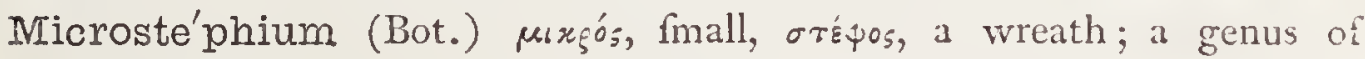
Compofitx.

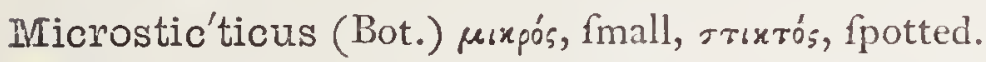

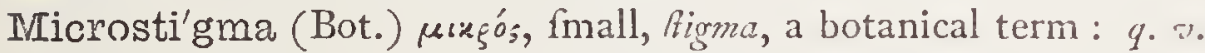

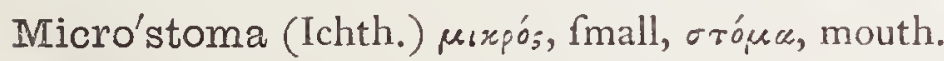

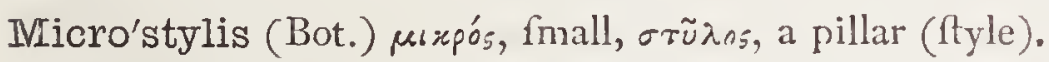

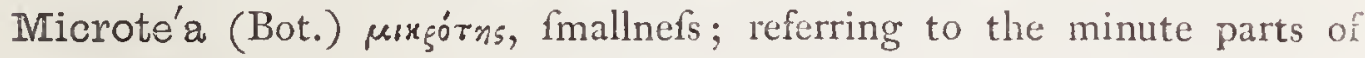
fructification.

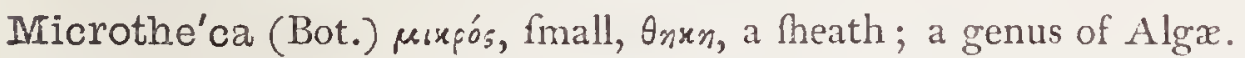

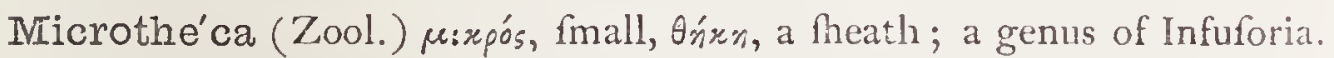

IVicrothe'cium (Bot.) fame derivation; a genus of Fungi.

Microtheriel'la (Ent.) $\mu \iota x$ ós, fmall, and dim. from Enpíov, a beaft.

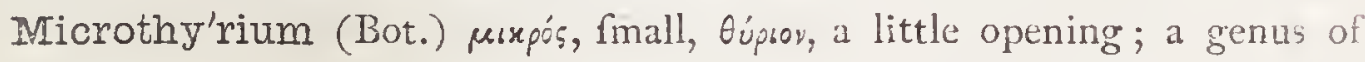
Fungi.

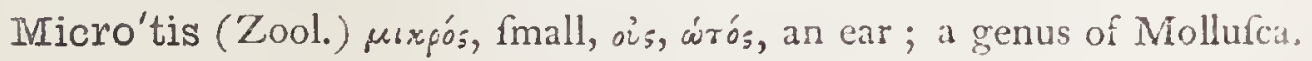
Micro'tis (Bot.) fame derivation; appendage to anther. 


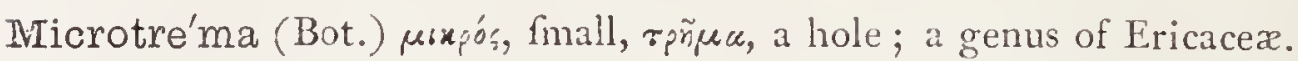

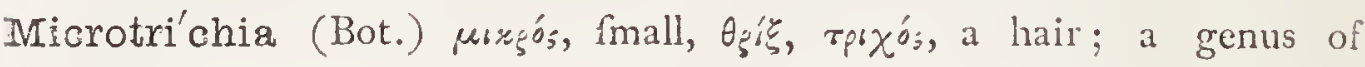
Compofita.

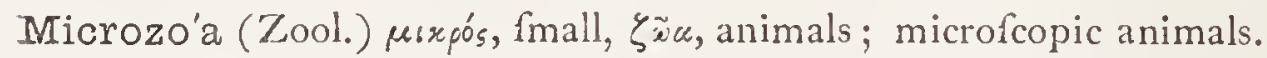

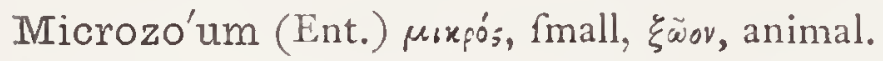

Middendor'fia (Bot.) P. N. given in honour of Baron Middendorff; an eminent Ruffian naturalift; a genus of Lythracea.

Miégia (Bot.) P. N., a genus of Compofitx.

Mielichofe'ria (Bot.) P. N., a genus of Bryoid Mufci.

Mie'ria (Bot.) usєpós, ftained; a genus of Compolitæ.

Mie'rsia (Bot.) P. N., a genus of Gilliefiacex.

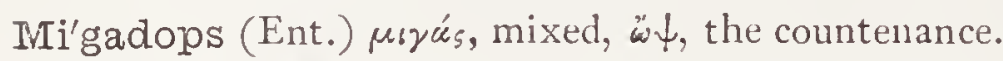

Irigrato'rius-a-um (Ornith.) Lat. wandering; e.g., Ectopiftes migratorius, the Paflenger pigeon.

Miza'nia (Bot.) P. N. from Jofeph Mickan, Profeflor of Botany at Prague. Milfoil (Bot.) contraction of millefolium; the Achillea Millefolium.

Miliaria (Ornith.) miliarius, pertaining to millet (Milium).

IMilia'ris (Zool., Ornith.) Lat. fed upon millet; e. g., Emberiza miliaris. Milia'rium (Bot.) milium, millet; a genus of Gramina.

Mili'ola (Zool.) dim. of milium, millet; a genus of minute Foraminifera ; alfo a genus of Infuforia.

Miitium (Bot.) Lat. millet; a genus of Gramina.

Mil'lea (Bot.) P. N. from Fulien Milla, chief gardener, Royal Gardens, Madrid.

Millegra'na (Bot.) mille, a thoufand, grain, grains; e. g., Radiola Millegrana.

Mille'pora (Fos. Zool.) mille, a thoufand, porus, an outlet; a genus of forfil Corals.

Millepori'dre (Fos. Zool.) Millepora, with fam. term. ; a family of Corals. Millepo'rum (Bot.) mille, a thoufand, porss, an opening; a genus of Hypericacex.

Nille'ria (Bot.) P.N. from Philip Miller, F.R.S., author of the "Gardener's Dictionary.

Mille'tia (Bot.) P. N. in honour of M. Millet; a genus of Leguminofie. Milliga'nia (Bot.) P. N. in honour of $\mathcal{F}$. Milligan; a genus of Araliacex. Millingto'nia (Bot.) P. N. from Sir T. Milington, Savilian Plofelfor at Oxford.

Millo'tia (Bot.) P. N., a genus of Compolitz.

Milne'a (Bot.) P. N., a genus of Meliacex. 
Miltit'zia (Bot.) P. N., a genus of Hydrophyllacer.

Miltomia (Bot.) P. N. given by Dr. Lindley in honour of Earl Fitzwilliam; a genus of Orchidacex.

Milva'go (Ornith.) dim. of milvus, a kite; a genus of Falconidx.

Milvulus (Ornith.) dim. of milvus, a kite; a genus of Mufcicapidæ or Fly-catchers.

Milvus (Ornith.) Lat. a kite.

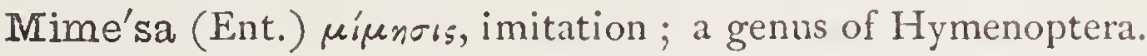

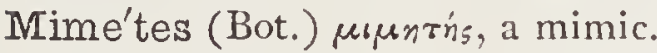

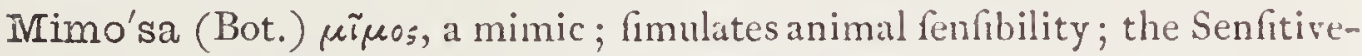
plant; a genus of Leguminofæ.

Mimosi'tes (Fos. Bot.) bearing fome refenblance to Mimofa; a genus of Foffil feed-pods.

Mi'mulus (Bot.) Lat. a little monkey, from its grotefque appearance; a genus of Scrophulariacex.

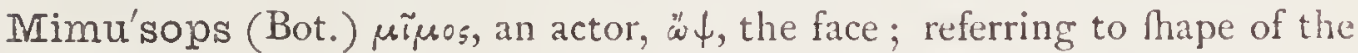
flowers.

Mi'na (Bot.) 'P. N. in honour of Don Francifco Xavier Mina, a Mexican Minifter of State.

Min'dium (Bot.) from the local name of a plant in Senegal, appropriated by Adanson, the great French Naturalift; a genus of Campanulacese, now included in Michauxia.

Minia'tus-a-um (Bot., Ent.) Lat. coloured red.

Min'imus-a-um (Zool., Ent., Bot.) Lat. leaft, e. g., Alaptus minimus, faid to be the fmallen Hymenopterous infect known.

Minio'sa (Ent.) minium, red lead.

Min'now (Ichth) French, menuife.

Mino'a (Ent.) P. N., a town of Paleftine (Gaza). It was, alfo the name of feveral towns in Greece and Sicily.

Mino'lia (Zool.) fo called by Mr. A. Adams, from Mino-Sima, a little ifland near Niphon; a genus of Mollufca.

Niinor (Zool., Bot.) Lat. lefs ; e.g., Galago minor.

Minos (Ent.) P. N., one of the Judges of departed fouls; from its gloumy afpect.

Mint (Bot.) Lat. mentha, French, menthe.

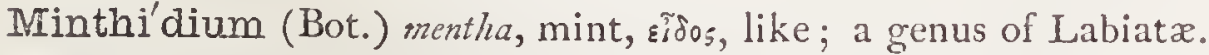

Minthosta'chys (Bot.) mentha, mint, $\sigma \tau \alpha \chi v_{s}$, a bunch; a genus of Labiatx. Minuar'tia (Bot.) P. N. from Mimart, a Spanifh apothecary.

Minu'tia (Bot.) minutus, fmall; a genus of Oleaces. 
Minutis'simus (Zool., Ent.) Lat. fmalleft; e.g. Halictus minutiffmus, the fmalleft bee found in this country.

Minu'tus-a-um (Ornith.) Lat. little, fmall ; e.g. Sterna minuta.

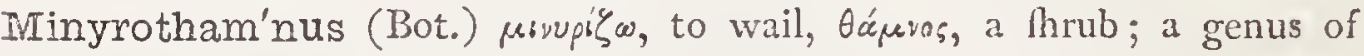
Compofitix.

Mioca'rpus (Bot.) «вíwv, fmaller, xщৎтós, fruit; a genus of Melaftomaceæ. Mique'lia (Bot.) P. N., a genus of Gramina.

Mira'bilis (Bot.) Lat. wonderful, alluding to the flowers; a beautiful genus of Nyctaginacer.

Mira'lia (Zool.) derivation uncertain; a genus of Ophidians.

Mirbe'lia (Bot.) P. N. from C. F. B. Mirbel, a celebrated French phyfiologint.

Irircooa (Bot.) etymology unknown; a genus of Lythraceæ.

Mi'rizi (Zool.) native name of a Brazilian monkey, Brachyteles hypoxanthus.

Mischoca'rpus (Bot.) rioxos, a ftalk, xagrós, fruit; a genus of Sapindacex.

Mischoca'ryon (Bot.) risxos, a ftalk, xá:vor, a nut; a genus of Proteacex.

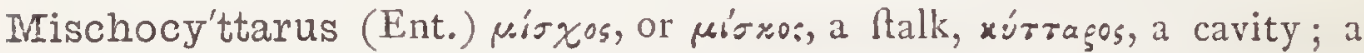
genus of Hymenoptera.

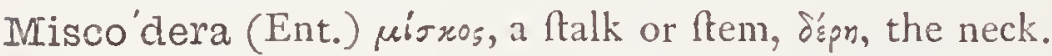

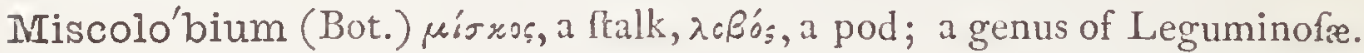

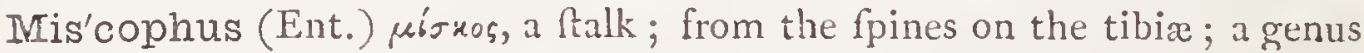
of Hymenoptera.

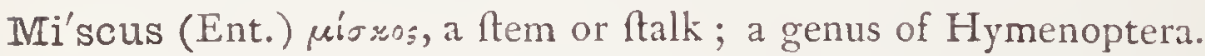

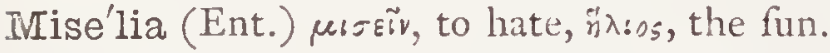

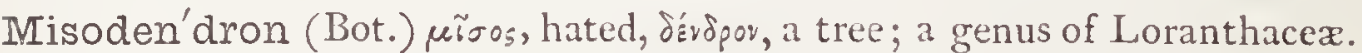

Misolam'pus (Ent.) $\mu \sigma^{\prime} \xi \omega$, to hate, $\lambda \propto \mu \pi \alpha_{s}^{\prime}$, a torch.

Mississippen'sis-e (Zool.) relating to the river Mififfppi; c.g. Iftinia Mififippenfis.

Misty'llus (Bot.) $\mu$ เ $\tau \lambda \lambda \lambda \omega$, to cut up; a genus of Leguminofx.

Mitchel'la (Bot.) P. N. from Mr Mitchell, an Englihman who travelled in Virginia.

Mitel'la (Bot.) Lat. a turban; referring to the capfule; a pretty genus of Saxifragacex.

Mitello'psis (Bot.) the genus Mitella, " $\downarrow$ is, afpect; a genus of Saxifragacer.

Ixitis-e (Zool) Lat. gentle, placid. 


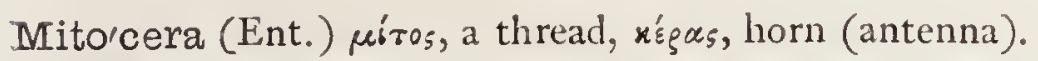

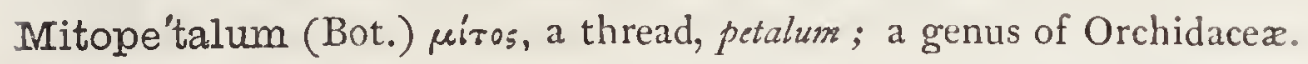

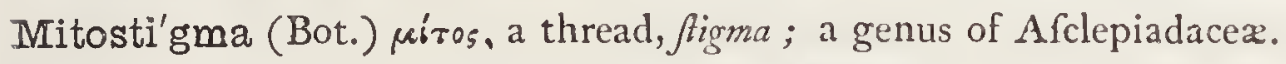

Mi'tra (Zool.) Lat. a turban; a genus of Mollufca.

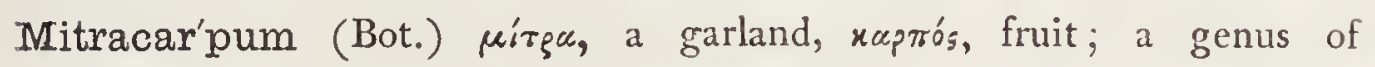

Cinchonacex.

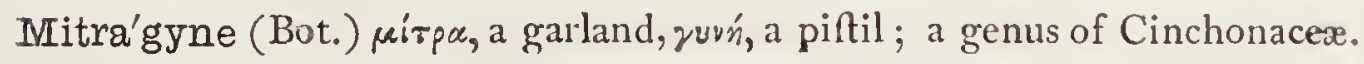

Mitra'lis (Zool.) mitra, a turban.

Mitra'ria (Bot.) rítpa, a mitre, from form of corolla; a genus of Gefneracex.

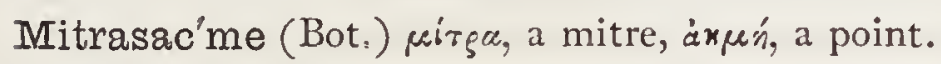

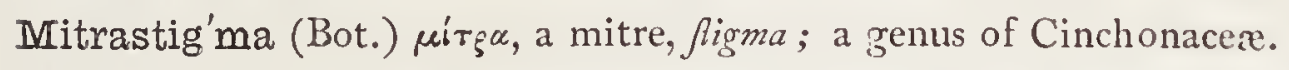

Mitra'tus-a-um (Zool.) mitra, a turban, a hood; e.g., Bafilifcus mitratus, the Hooded Bafilisk.

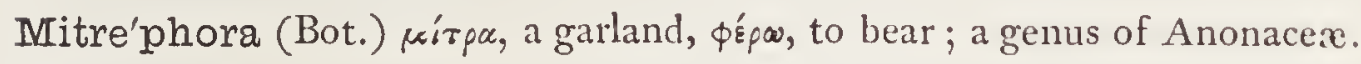

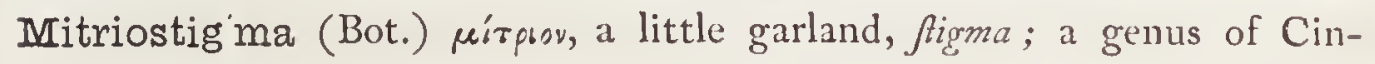
chonaceæ.

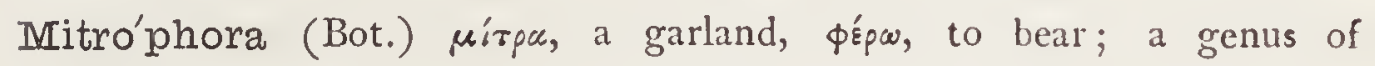
Valerianacex.

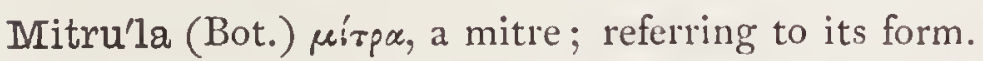

Mitterpacheria'na (Ent.) P. N. in honour of L. Mitterpacher, Profeftor of Natural Hiftory at Pefth; died 1814 .

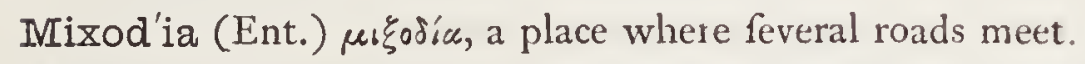

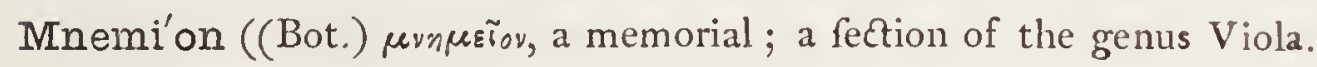

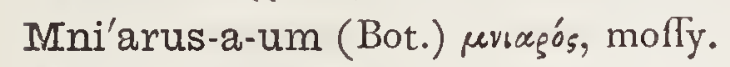

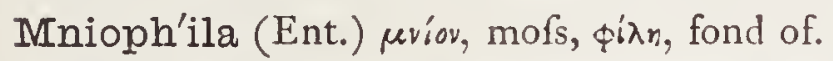

Mniop'sis (Bot.) the genus Mnium, ö , like; a genus of Podoftemaceæ.

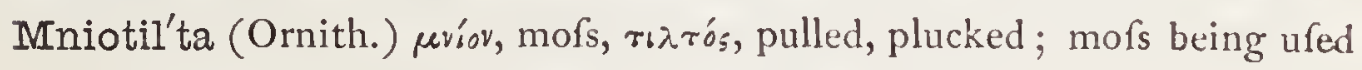
in making the neft; a genus of Warblers.

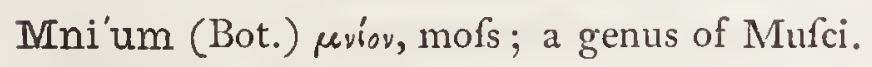

Mode'cca (Bot.) its Indian name.

Modee'ria (Zool.) P. N. in honour of Adolph Modeer, a Swede.

Modes'tus-a-um (Ornith.) Lat. mild, gentle, fhy.

Modi'ola (Zool.) modiolus, a fmall meafure, or drinking cup; the Horfemuffel; a genus of Bivalve thells, both living and foffil; in Botany applied to a genus of Malvacee.

Modiola'ria (Zool.) refembling modiola; a genus of Mollufca.

Modiolo'psis (Zool.) the genus modiola, ö $\psi_{\llcorner}$, like; a genus of Mollufa.

Modula'ris (Ornith.) modubor, to fing or play melodioully.

Modula'rius (Ornith.) fame derivation; c. g. Accentor modularius. 
Mod'ulus (Zool.) Lat., a fmall meafure; a genus of Mollufca.

Mœhrin'gia (Bot.) P. N. from P. H. G. Mohring, a celebrated German phyfician; a genus of Caryophyllacex.

Mcsta'lis (Ent.) mreftus, fad, gloomy.

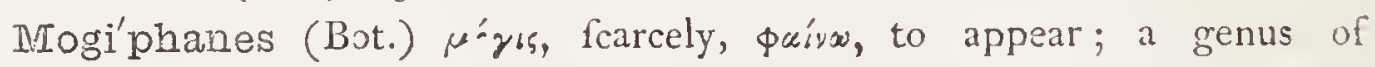
Amarantacere.

Mo'hria (Bot.) P. N., a genus of Polypodioid Filices.

Mo'la (Ichth.) Lat. a mill-ftone; the Sun-fin.

Moldenhawera (Bot.) P. N., a genus of Leguminori.

Mole (Zool.) of AnglomSax. etymology, fignifying the thrower-up of mowh or earth.

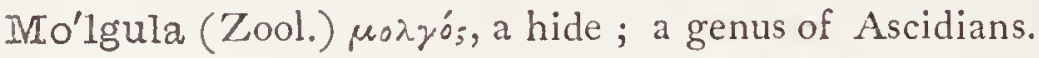

Moline'ria (Bot.) P. N. from Ignatio Molinerio, Director of the Botanical Gardens at Turin.

Molin'ia (Bot.) P. N. from G. 7. Molina, who wrote on the plants of Chili in $\mathrm{I}_{7} 82$; a genus of Gramina.

Mollipen'nes (Ent.) mollis, foft, penna, a wing; applied to certain beetles having foft elytra.

Mol'lis-e (Bot.) Lat. foft; e. g. Bromus mollis.

Ivollis'simus a-um (Zool., Ornith.) Lat. very foft; c. g. Somateria nollifina, the Eider-duck.

Mollu'go (Bot.) a name in Pliny, retained by Linnæus.

Mollu'sca (Zool.) mollis, foft, or mollities, foftners. Applied to the fubkingdom of animals, the members of which are deftitute of a bony Releton.

IMol'och (Zool.) a name given to an uncouth and horrid-.looking reptile from Weftern Auftralia, Moloch horridus.

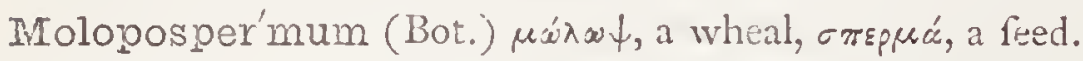

IMolos'sus (Zool.) derivation uncertain; the Thick-lipped bat.

Mo'lothrus (Ornith.) moлєiv, to tranfplant, from the habit of depofiting its eggs in the nefts of other birds; the Cow-pen bird is $M$. pecoris.

Molpa'dia (Bot.) P. N., a genus of Compofitæ; alfo, in Zoology, a genus of Echinodermata.

Mo'ltria (Bot.) P. N. a genus of Boraginacer.

Molucce'lla (Bot.) it was brought from the Moluccas; a genus of Labiata.

MT'ly (Bot.) $\mu \tilde{x} \lambda_{v}$, a kind of garlic; fpecific name of the Allium Moly of Linnæus.

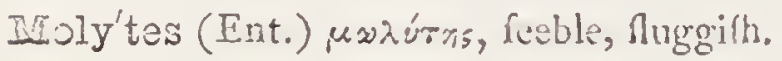


Momor'dica (Bot.) mordeo, to bite; the feeds feem bitten; a genus of Cucurbitaceæ.

Momo'tus (Ornith) Latinized form of the word Motmot, which is faid to be from the note of the bird.

Mo'na (Zool.) this is a fort of generic name for monkey in fome parts of the fouth of Europe, and was applied by Buffon to the Cercopithecus MIona.

IMo'nacha (Ent.) Lat. a nun, from its black and white wings.

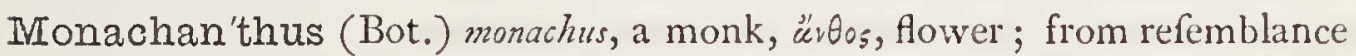
of labellum of the original fpecies to a monk's cowl.

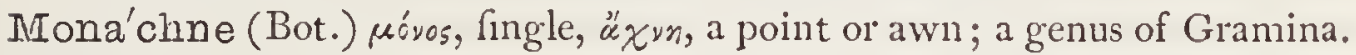

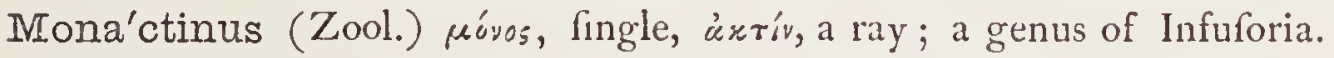
Monac'tis (Bot.) róvos, fingle, ảxris, a ray; a genus of Compolitx.

Monad (Zool.) revos, alone, fingle; becaufe never cluftering like other genera of Infuforia.

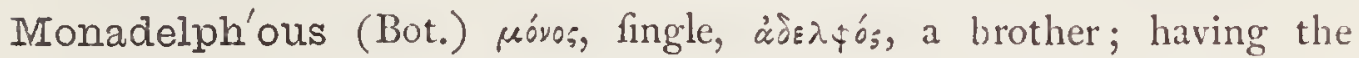
ftamens united into one bundle.

Monade'nia (Bot.) róvos, fingle, ảóny, a gland; a genus of Orchidacex. Monadi'na (Zool.) monas, with fam. term.; a family of Infuforia.

Mionan'dria (Bot.) róros, fingle, úvríp, àvjós, a man (fymbolically a ftamen), having a fingle ftamen.

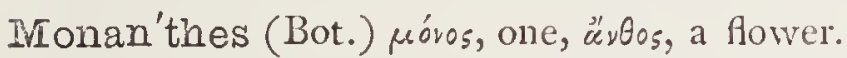
$\left.\begin{array}{l}\text { Monar'da } \\ \text { Monarde'lla }\end{array}\right\}$ (Bot.) $\left\{\begin{array}{r}\text { P. N. from N. Monardes, a phyfician of Seville, } \\ \text { in the i } 6 \text { th century ; genera of Labiatx. }\end{array}\right.$

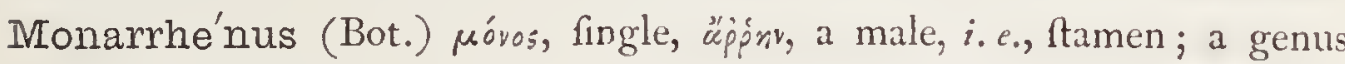
of Compofitx.

Mon'as (Zool.) explained under Monad.

Mon'ax (Zool.) rovák, fingly, alone; applied to Arctomys monax, the Maryland marmot, becaute it is faid to appoint fentinels.

Iviön'chia (Bot.) P. N. in honour of M. Wönth; a genus of Caryophyllacex.

Mone'chmia (Bot.) róros, fingle, Ěxuc, a holdfaft or ftay; a genus of Acanthace

Ironedula (Ornith.) Lat. a jackdaw, the feientific name of which is

Corvus Monedula:-

"Non plus aurum tibi quàm monedulx committebant."-Crc. Fl. 3 I. Mone'ma (Bot.) róvos, one, in $\mu \alpha$, a filament; alluding to its fimplicity. Irionen'sis (Ichth., Bot.) Lat. belonging to the ifle of Man-Mona; e. g. Braffica Monenfis.

Monen'teles (Bot.) Móros, fingle, $\tilde{\varepsilon} r \tau s \lambda \dot{r}$, complete; a genus of Compofitx. 


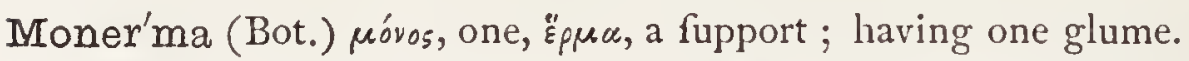

Mone'tia (Bot.) P. N. from Monet de la Marck, a celebrated French botanift.

Mongos (Zool.) Latinized form of the word Mongous.

Moni'lia (Zool., Bot.) monile, a necklace; the filaments are articulated; alfo a genus of Mollufca.

Monili'fera (Zool.) monile, a necklace, fero, to bear; alfo in Bot., a genus of Algx.

Monilifor'mia (Bot.) monile, a necklace, forma, Shape; a genus of Algæ.

Monili'na (Bot.) monile, a necklace; a genus of Algx.

Moni/mia (Bot.) róveros, ftedfaft; typical genus of Nat. Ord. Monimiaceæ.

Mon'itor (Zool.) Lat. one who gives warning; thefe reptiles being believed to give warning of the crocodile's approach.

Monito'ridae (Zool.) monitor, fam. term. ide ; a divifion of Reptilia.

Mon'key (Zool.) Dr. Johnion fays from monikin, a little man; Dr. Todd prefers monicchio, the old Italian for monkey.

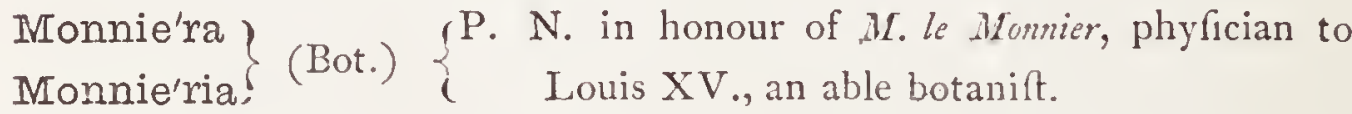

Mono'bia (Ent.) róvos, alone, fiow, to live; a genus of Hymenoptera.

Monoboth'rium (Bot.) póvos, fingle, Bótpos, a hole or pit; a genus of Gentianaceæ.

Monoca'ryum (Bot.) róvos, fingle, xx́pvov, a nut; a genus of Melanthacex.

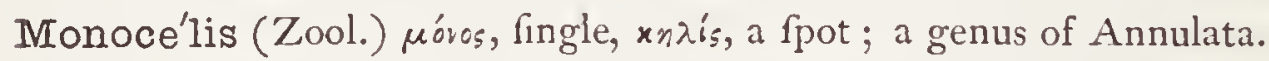

Monocen'tra (Bot.) Móros, fingle, révrpov, a prickle; a genus of Melastomacexe.

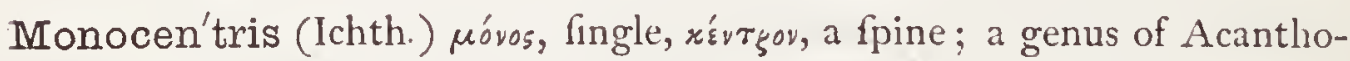
pterygian filhes.

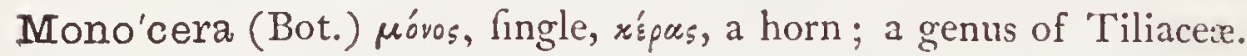

Mono'ceros (Zool.) róvos, fingle, x'spas, a horn; fpecific name of the Narwhal, Monodon Monoceros.

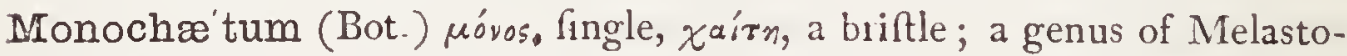
macer.

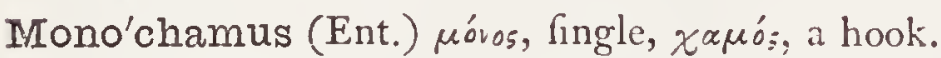

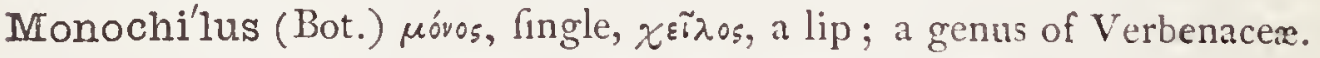

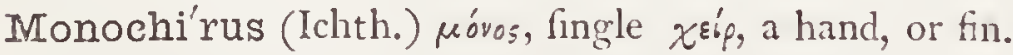

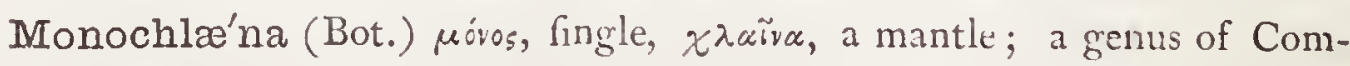
pofitæ.

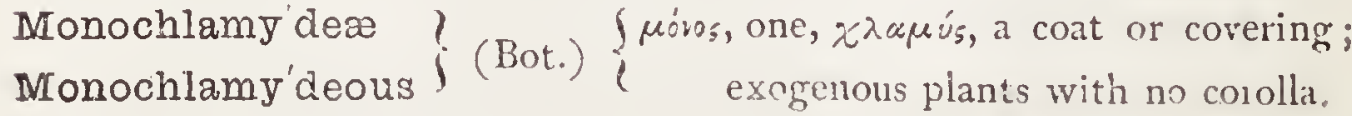




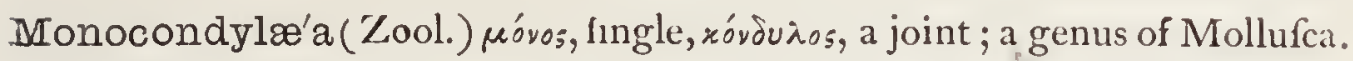

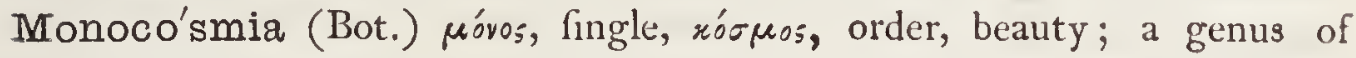
Portulacaces.

Monocotyle'dons (Bot.) póros, fingle, cotyledon, seed-leaf; equivalent to Endogens.

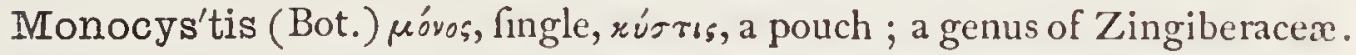

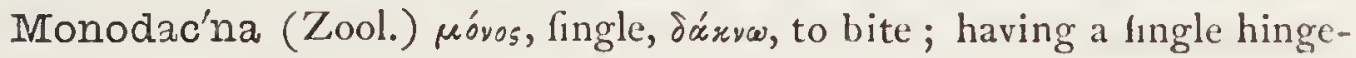
tooth.

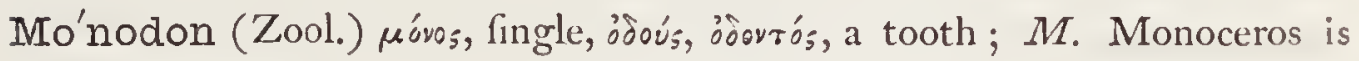
the Narwhal.

Monodo'nta (Zool.) róvos, one, ỏoús, ojóvros, a tooth; a genus of Mollufca.

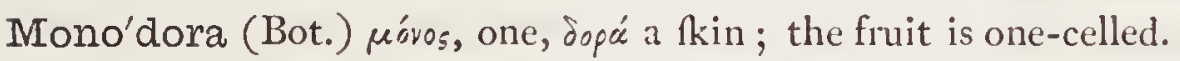

Monogo'nia (Bot.) póvos, fingle, rovía, an angle; a genus of Polypodioid Filices.

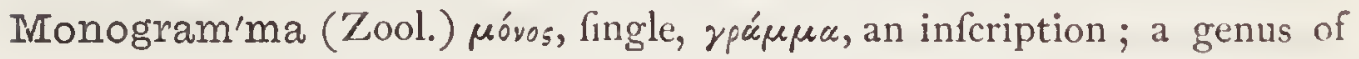
Infuforia: in Botany, a genus of Polypodioid Filices.

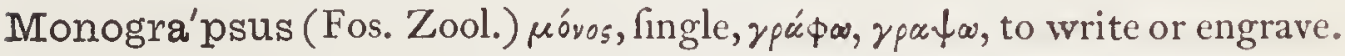
Monogy'nia (Bot.) róvos, fingle, zurn, a female (fymbolically a piftil).

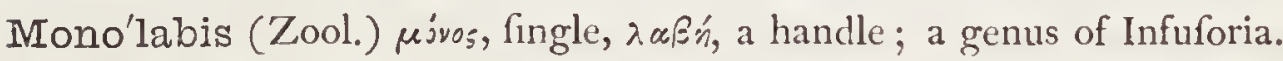

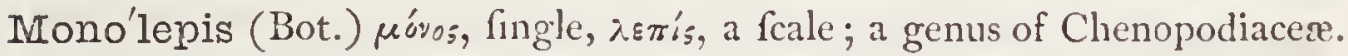
Monolo' cular (Bot.) róvos, fingle, loculus, a fmall cavity; one-celled.

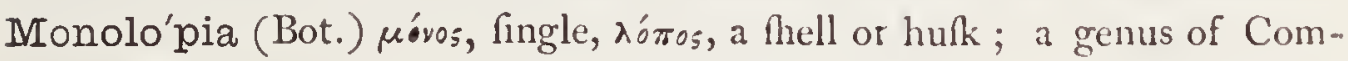
politæ.

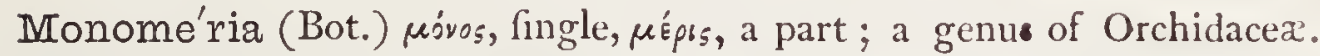

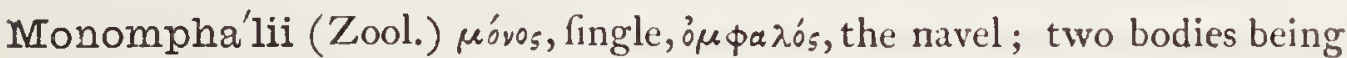
united by means of one umbilicus.

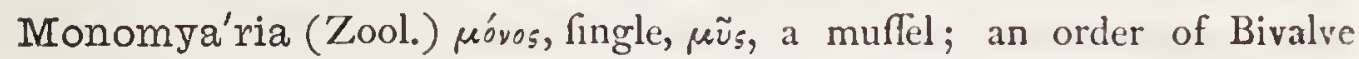
Thells, having only one mufcular depreffion on each valve.

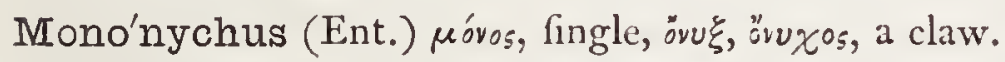

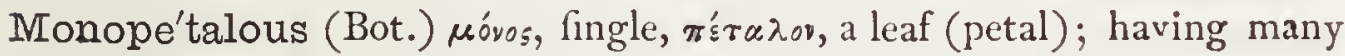
petals united together by their edges.

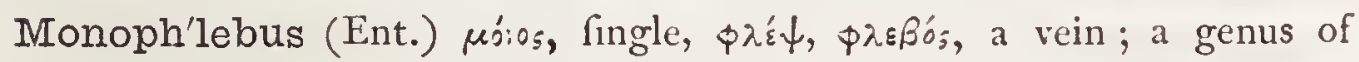
Hemiptera.

Monophyl'lus-a.-um (Zool., Bot.) róvos, fingle, having fimple leafiets; e.g. Kennedya monophylla.

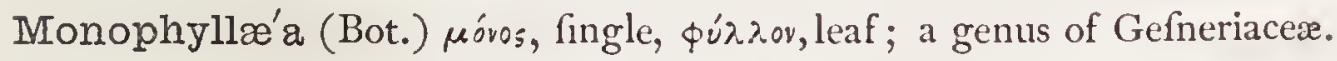
Monophy'odonts (Zool.) jóvos, once, фúw, to generate, joovis, odovros, a tooth; the term ufed by Profeflor Owen to exprefs thofe animals. having a fingle fet of unrenewable teeth. 
Mionopleu'ra (Zool.) póvos, fingle, $\pi \lambda \varepsilon$ epo:, a rib; a genus of Mollufca.

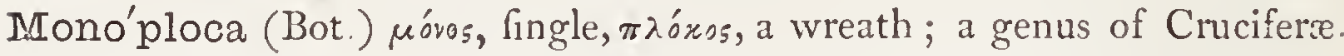

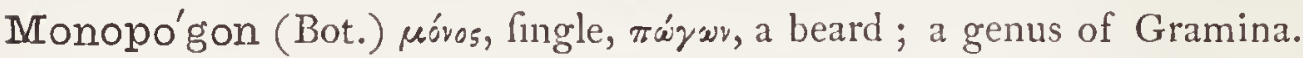

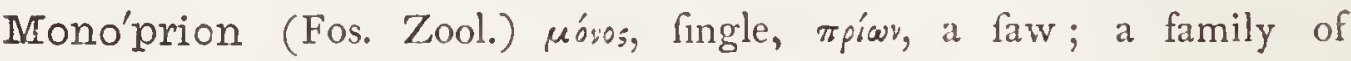
Graptolites.

Mono'psis (Bot.) róvos, one, ö $6_{5}$, appearance.

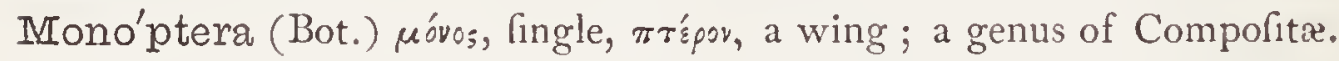

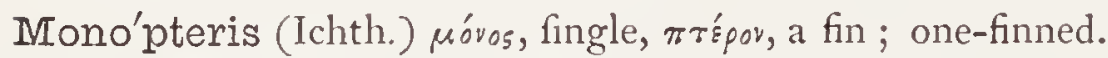

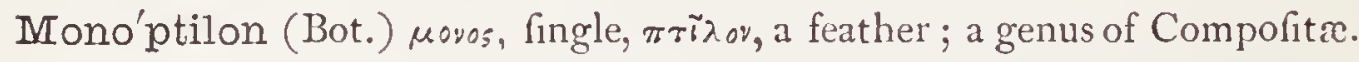

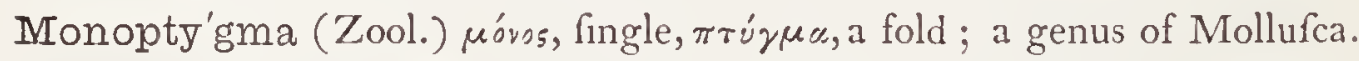

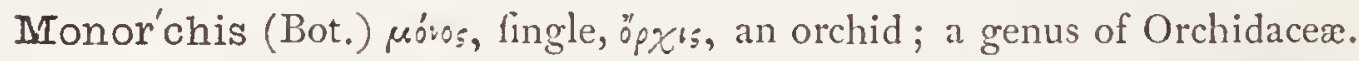

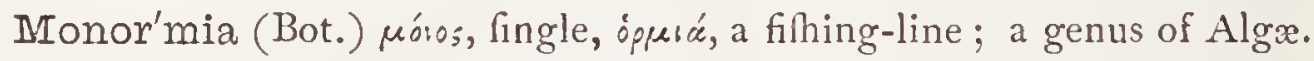

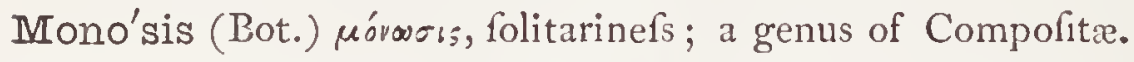

Monospo'ra (Bot.) róvos, fingle, eropè, a feed; a genus of Euphorbiacex.

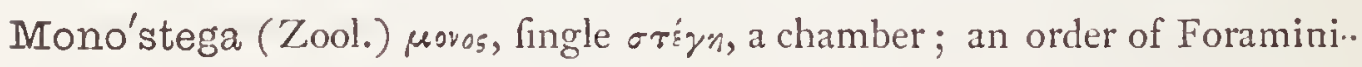
fera.

Monostic'tides (Bot.) róvos, fingle, erırós, fpotted; having one row of feeds attached to the feptum; a divifion of Bignoniacex.

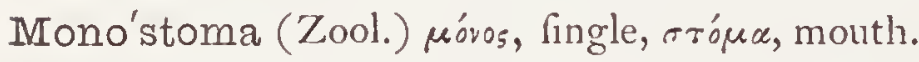

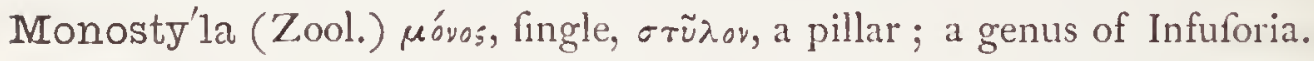

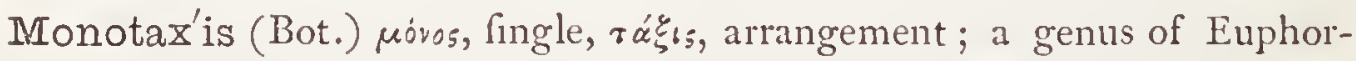
biace $\boldsymbol{x}$.

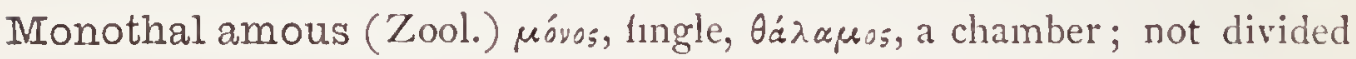
by partitions.

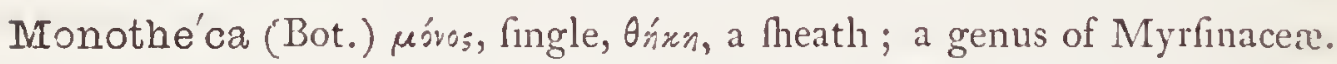
Monothe'cium (Bot.) fame derivation; a genus of Acanthacere.

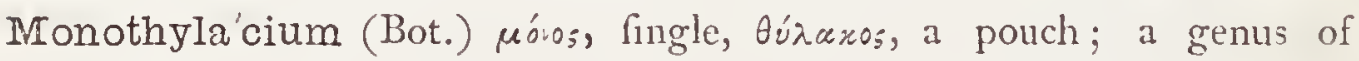
Asclepiadacex.

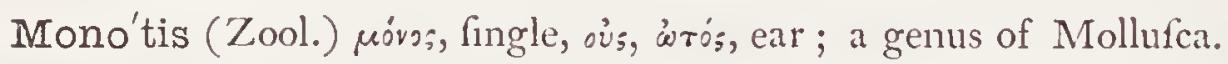

Mono'toca (Bot.) róvo;, one, róros, birth; the germen is one-feeded.

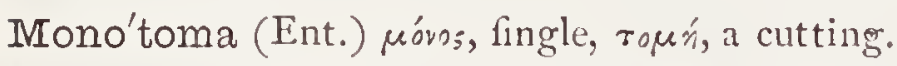

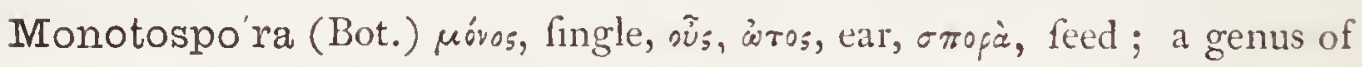
Fungi.

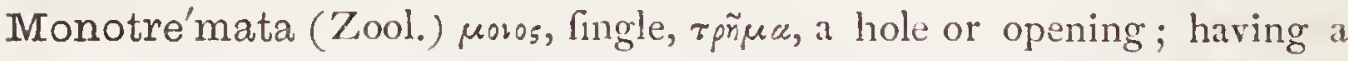
fingle excretory and generative outlet; a divifion of the Mammalia.

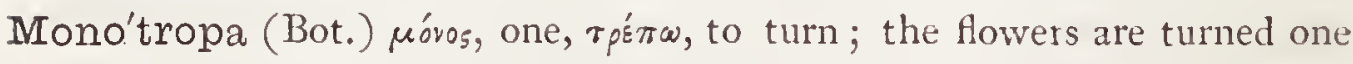
way; typical genus of Monotropacer.

Monotrop'sis (Bot.) the genus Monotropa, ö $\psi_{b \xi}$, likenefs; a genus of Monotropacex. 
Monso'nia (Bot) P. N. from Lady Anne Monfon, who was eminent as a botanift; a grenus of Geraniaceæ.

Montacu'ta (Zool.) P. N. in honour of Col. George Montagu, a diftinguithed early Englifh naturalint; a genus of Mollufca.

Montana'ta (Ent.) montanus, dwelling among mountains.

Montane'llus (Ornith.) dim. of montanus, dwelling among mountains.

Montano'a (Bot.) P. N. from Montano, a Mexican patriot.

Monta'nus-a-um (Ornith., Bot.) Lat. frequenting or growing upon mountains; e.g., Paffer montanzs.

Montezu'ma (Bot.) P. N. from Montezuma, the celebrated king of Mexico.

Mo'ntia (Bot.) P. N. from Fofeph Monti, Profelfor of Botany at Bologna; Nat. Ord. Portulacacex.

Monticola'na (Ent.) montes, mountains, colere, to frequent.

Montifringi'lla (Ornith.) mons, montis, a mountain, fringilla, a finch; the Mountain-finch.

Montínia (Bot.) P. N. from Laurence Montin, a Swedilh botanilt.

Mon'tium (Ornith.) gen. pl. of mons, a mountain; e.g., Linota montium, the mountain Linnet.

Monu'ra (Zool.) próvos, fingle, oupa, tail ; a genus of Infuforia.

Moo'nia (Bot.) P. N., a genus of Compofitæ.

Moorcrof'tia (Bot.) P. N., a genus of Convolvulacex.

Moqui'lea (Bot.) P. N., a genus of Chryfobalanacex.

Moqui'nia (Bot.) P. N., a genus of Compofitæ.

Moræ'a (Bot.) P. N. from R. Moore, a botanilt of Shrewlbury; a genus of Iridacea.

Morche'lla (Bot.) from morchel, the German name of the plant ; the Morel; a genus of Fungi.

Morchella'na (Zool.) from refemblance to the Fungus morchelk.

Morda'cia (Ichth.) mordax-acis, biting, Atinging.

IMorde'lla (Ent.) mordeo, to bite.

Morde'llidæ (Ent.) mordella, with fam. term.

More'lia (Zool.) etymology uncertain; a genus of Ophidians.

Moreno'a (Bot.) P. N. from P. Moreno, a Mexican patriot.

Morican'dia (Bot.) P. N. from Stephen Moricand, an Italian botanift.

Morie'ra (Bot.) P. N., a genus of Cruciferæ.

Morila'ndia (Bot.) P. N., a genus of Sanguiforbacex.

Mori'na (Bot.) P. N. from L. Morin, a l'rench botanift.

Morin'da (Bot.) reopsv, the mulberry "tree, Inda, Indian. 
Morine'llus (Ornith.) Lat. a little fool ; applied to the Dotterell, Charadrius morinellus, from its fuppofed ftupidity.

Morin'ga (Bot.) its name in Malabar; typical genus of Nat. Ord. Moringaceæ.

Mo'rio (Zool.) Ital. morione; Sp. and Fr. morion, a helmet; in Botany, from refemblance of flower to a little helmet; e.g., the Orchis morio.

Mori'sia (Bot.) P. N., a genus of Gramina.

Moriso'nia (Bot.) P. N. from R. Morifon, Profeffor of Botany at Oxford, who died in 1683.

Morit'zia (Bot.) P. N., a genus of Boraginacex.

Mormo'des (Bot.) roprú, a frightful-looking object; in allufion to the Prange appearance of the flowers; a genus of Orchidacex.

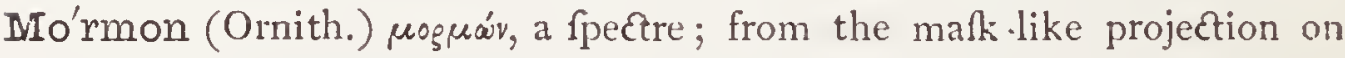
the beak; the Culterneb.

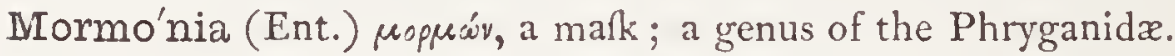

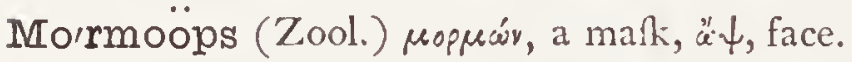

Mormy'rops (Ichth.) mormyrus, and $\ddot{\psi} \psi$, countenance.

Mormy'rus (Ichth.) «ogrúpos, a fea-filh mentioned by Ariftotle; a genus of malacopterous or foft-finned Fifhes.

Moroca'rpus (Bot.) rop's, the mulberry, sapró;, fruit; mulberry-fruited; a gemus of Chenopodiacer.

Mormheus (Ent.) P. N., the god of fleep.

Mo'rphidæ (Ent.) a family of Lepidoptera, of which morpho is the type.

Mo'rpho (Ent.) P. N., a name of Aphrodite; a genus of large diurna! Lepidoptera.

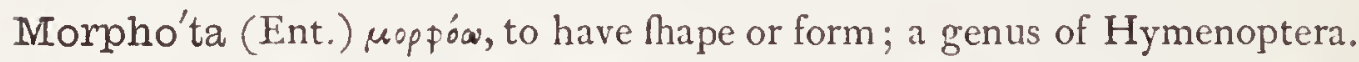
Mor'rhua (Ichth.) Lat. the Cod-filh; the common Cod is $M$. callarius; the Haddock, $M$. aglefinus.

Morri'sia (Zool.) P. N. in honour of _-Morris; a genus of Mollufca. Morse (Zool.) Rufian, morfs ; Lapponic, mork.

Mo'rsitans (Ent.) Lat. biting; e.g., Gloflina morfitans, the Tfe.tfe By of Africa.

Morun'ga (Zool.) etymology unknown; the Sea-elephant.

Mo'rus (Bot.) Celt. mor, black; alluding to the colour of the fruit; the Mulberry.

Morvi'llea (Zool.) P. N. ; a genus of Mollufca.

Moscha'ria (Bot.) nórxos, muRk; referring to the odour.

Mos'chatel (Bot.) common name of Adoxa mofchatellina, becaufe of its finell. Moscha'tus-a-um (Zool., Bot.) e.g., Ovibos mofichatus, the Mufk-ox. 
Moschi'ferus-a-um (Zool., Bot.) mofchus, mukk, fero, to bear; mukyielding.

Moschi'na (Zool.) a fub-family of Mammalia, which contains the Mufkdeer, Mofchus mofchiferus.

Moschi'tus (Ornith.) Lat. Imelling of murk; applied to a Humming bird; Chryfolampis mofchitus.

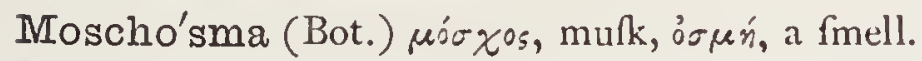

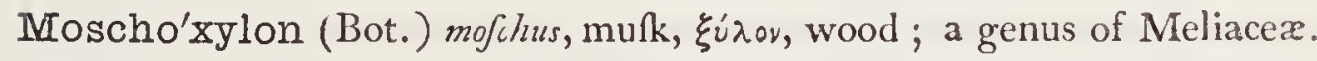

Mo'schus (Zool.) from the Arabic mofch, muk; the MuRk-deer family.

Moss (Bot.) from the Gallic mouffe, of fimilar meaning when applied to plants, but which alfo fignifies froth or lather, and is itfelf derived from mou, foft or loofe, like the foam of the fea or veficles of lather.

Moss-crop (Bot.) popular name of the Eriophorum or Cotton-grafs.

Mösslera (Bot.) P. N., a genus of Bruniacex.

Motaci'lla (Ornith.) Lat. a wagtail ; the meaning of the word is precifely

fimilar to our wagtail ; being, as Varro ftates, quòd femper movet caudam.

Motacilli'næ (Ornith.) a fub-family of Incellores, containing the genus Motacilla; the Wagtails.

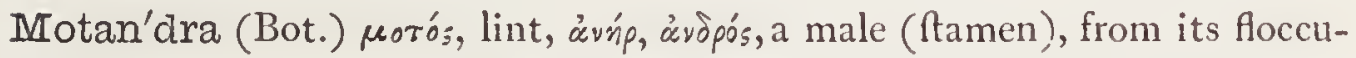
Moth (Ent.) Anglo-Sax. mogthe, mohthe, moth.

lent appea1ance; a genus of Apocynacex.

Mouffetel'ia (Ent.) P. N. in honour of Thomas Mouffet, a phyfician and naturalift of the i 7 th century.

Mougeo'tia (Bot.) P. N. from J. B. Mougeot, a Cryptogamic botanift; a genus of Algæ.

Mouri'ria (Bot.) from mouriri, its name in Guiana.

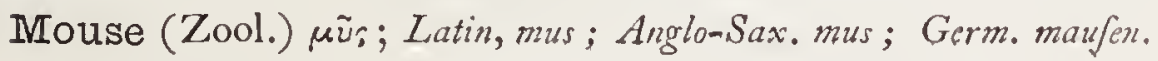

Moxo'stoma (Ichth.) a genus of Cyprinoid Finhes.

Mozin'na (Bot.) native name; a genus of Euphorbiacex.

Mo'zula (Bot.) unexplained; a genus of Lythraceæ.

Muce'dines (Bot.) mucedo, mucus; a family of Fungi.

Mucizo'nia (Bot) mucus, and ל̧árn, a belt; a genus of Craffulacex.

IMu'cor (Bot.) Lat. mould, from muceo, to be mufty; becaufe found on

mufty bread, vegetables, \&c.; a genus of Cryptogamia. $\left.\begin{array}{l}\text { Mucora'ceas } \\ \text { Mucori'ni }\end{array}\right\}$ (Bot.) $\left\{\begin{array}{c}\text { mucor, mould, with fam. term.; a division of } \\ \text { Fungi; Mucorini is more genelally ufed. }\end{array}\right.$

Iucrona'tus-a-um (Zool., Bot.) Lat. pointed, harp-pointed.

Mucro'nea (Bot.) mucro, a harp point; a genus of Polygonacex.

Mucronel'lus (Ent.) dim, of mucro, a tharp point. 
Mucu'na (Bot.) mucuna-guaca is the Brazilian name of M. urens; Cowitch; a genus of Leguminofæ.

Mugil (Ichth.) Lat. a mullet; Ital.muggine; Sp.mujol; Fr. muge; a genus of foft-finned Filhes.

Mugi'lidæ (Ichth.) the family of the Mullets.

Mugwort (Bot.) from Anglo-Sax. mucgruyrt; the common name of the Artemifia vulgaris.

Mühlenbec'kia (Bot.) P. N., a genus of Polygonaceæ.

Mulde'ra (Bot.) P. N., a genus of Piperaceæ.

Mulge'dium (Bot.) mulgeo, to milk; a genus of Compofitæ.

Mulle'ra (Bot.) P. N. from O.F. Muller, a Dane, one of the editors of the Flora Danica.

Mullus (Jchth.) Lat. a mullet; the Red mullet is $M$. furmuletus; the Bearded mullet, $M$. barbatus. The origin of this name is faid by Pliny to be mulleus, a fahionable red flipper; but Dr. Badham fuggefts that it mult have had a name before thefe were ufed, and favours the derivation from mollis, foft; from the extreme foftnefs of the Rin.

Multi'fidus-a-um (Bot.) Lat. many-clefts; divided into many hallow lobes. Multilinea'lis (Ent.) multi, many, linea, a line.

Multiparti'tus-a-um (Bot.) Lat. much-divided; divided into many deep Jobes.

Multiplica'lis (Ent.) multi, many, plica, a fold.

Multiscuta'ta ('Lool.) multus, much, foutum, a hield; many-ihielded.

Multistriga'ria (Ent.) multus, many, friga, a ftreak.

Münchhausia (Bot.) P. N., a genus of Lythracex.

Mu'nda (Ent.) Lat. neat, cleanly.

Munda'nus-a-um (Ent.) Lat. of the earth.

Mu'ndia (Bot.) mundus, neat ; referring to its appearance.

Munnic'kia (Bot.) P. N., a genus of Ariftolochiacex.

Munnic'ksia (Bot.) P. N., a genus of Pangiaceæ.

Munno'zia (Bot.) P. N., a genus of Compolitæ.

Muntin'gia (Bot.) P. N. from Abraham ILunting, Profellor of Botany at Groningen, who died in 1683 .

Muntja'cus (Zool.) Latinized form of the native name Muntjac.

Muræ'na (Ichth.) Lat. an eel; applied to the Murry.

Muræne'sox (Ichth.) compounded of murena, an cel, and cfox, a pike; applied to a genus of Congeroid fithes.

Muræ'nidæe (Ichth.) mursna, an eel; eel-lhaped Finhes. 
Murænoble'nna (Ichth.) murena, an eel, and blennius, the bienny.

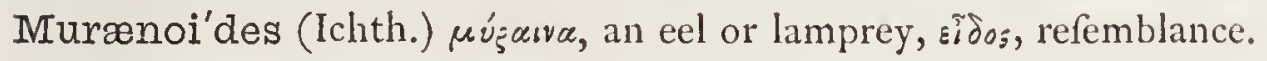

Murænop'sis (Ichth.) murana, ö $\downarrow$,, refemblance.

Mura'lis (Ent.) Lat. belonging to a wall; found fitting on walls.

Mural'tia (Bot.) P. N. from John von Muralt, a Swifs botanift; a genus of Polygalacex.

Mura'rius-a-um (Ornith.) murus, a wall; e.g., 'Tichódroma murarius, the Wall-creeper.

Murchiso'nia (Fos. Zool.) P. N. in honour of the diftinguilhed geologift, Sir Roderick Murchifon; a genus of Haliotidæ.

Mu'rex (Zool.) the ancient name of a univalve molluk, from which the

Tyrian dye was derived; a genus of Mollusca.

Murica'ria (Bot.) muricatus, pointed, prickly.

Murica'tus-a-um (Bot.) Lat. pointed; e.g. Pinus muricata.

Muri'cidæ (Zool.) a family of Mollufea, of which Dfurex is the type.

Murici'dea (Zool.) the genus Murex, and $\varepsilon^{\text {ro }} \delta_{0}$, refemblance ; a genus of Mollufca.

Muri'colus-a-um (Zool.) murus, a wall, colo, to frequent; applied to a bat which clings to walls, Vefpertilio muricola.

$\left.\begin{array}{l}\text { Mur'idæ) } \\ \text { Muri'na }\end{array}\right\}$ (Zool.) $\left\{\begin{array}{c}\text { a family and fub-family of Mammalia, containing } \\ \text { the genus Mus. }\end{array}\right.$ Miri'nus-a-um (Zool., Bot.) Lat. relating to mice, moufe-coloured, $\varepsilon_{\text {. g., }}$ Vespertilio murinus, the Moufe-coloured Bat.

Murra'ya (Bot.) P. N. from J. A. Murray, Profeffor of Botany at Gottingen.

Mus (Zool.) Lat. a moufe; Greek, $\mu$ ũs.

Mu'sa (Bot.) perhaps in honour of Antonius Mufa, phyfician to Auguffus;

the Plantain ; typical genus of Nat. Ord. Mufacex.

Mus'ca (Ent.) Lat. a fly.

Musca'ria (Bot.) mufcarium, a fly-trap; a genus of Saxifragaceæ.

Musci (Bot.) Lat. Mofles; the name is probably derived from rúrxoc, tender; a divifion of Acrogens.

IMusci'capa (Ornith.) mufca, a fly, capio, to catch; the Fly-catchers.

Musci'ferus-a-um (Bot.) mufca, a Ay, fero, to bear ; applied to the Fly-orchis.

Musci'tes (Fos. Bot.) mufcus, mofs; foffil plants refembling mors.

Muscula'na (Ent.) mufcula, a little fly, or mufculus, a little moufe, from the colour.

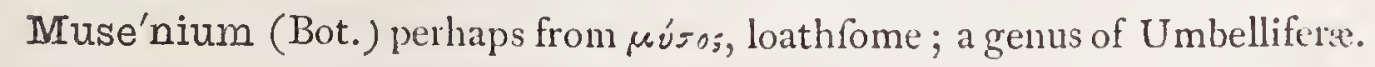

Mush'room (Bot.) French, monfferon. 
Mu'sicus-a-um (Ornith.) Lat. tuneful ; e.g. Meliërax mufucus, the Chanting-falcon; Turdus muficus, the Song-thrufh.

Muso'phaga (Ornith.) mufa, the Plantain-tree, $\phi \dot{\alpha} \gamma \omega$, to eat.

Mus'quash (Zool.) the Cree Indians' name for the Mufk-rat of Canada; Fiber zibeticus.

Mussæ'nda (Bot.) its name in Ceylon; a beautiful genus of Cinchonacex.

Mussehlia'na (Ent.) P. N. in honour of Herr Paftor Mufehl, of Kotalow, in Mecklenburg-Strelitz.

Mussel (Zool.) rũs, Lat. mufculus, ital. mufculo.

Mustard (Bot.) French, moutarde; muftum ardens, hot wine, the fweet muf of new wine being one of the ingredients of French table-muftard.

Muste'la (Zool.) Lat. a weafel ; alfo, in Ichthyology a name applied by Pliny to fome filh; now the Rockling.

Musteli'na (Zool.) muftela; a fub-family of Mammalia.

Muta'bilis-e (Bot.) Lat. changing colour ; e.g. Cheiranthus mutabilis.

Mu'ticus-a-um (Ornith.) Lat. curtailed, docked; e.g. Pavo muticus, the Japanefe peacock.

Mutilla (Ent.) perhaps a dim. of evĩa, a fly; a genus of Hymenoptera.

Mutilla'rius-a-um (Ent.) refembling the hymenopterous genus Mutilla;

e.g., 'Tillus mutillarius.

Muti'llidæ (Ent.) mutilla, with fam. term.; the Velvet-ants; a family of Hymenoptera.

Muti'sia (Bot.) P. N. from Geleftine Mutis, the difcoverer, a South American botanift; an extraordinary genus of Compofitæ, having tendrils. Mu'tus-a-um (Ornith.) Lat. dumb.

My'a (Zool.) $\mu \tilde{v} w$, to comprefs; form of fhell; a genus of Mollufca.

Myacites (Zool.) mya, a muffel; a genus of Mollufca.

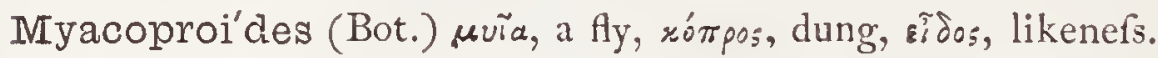

My'adæ (Zool.) mya, with fam. term.; a family of Conchiferous mollufea, both foffil and recent.

Myagro'psis (Bot.) myagrum, ö $\psi$ 's, likenefs; a genus of Algæ.

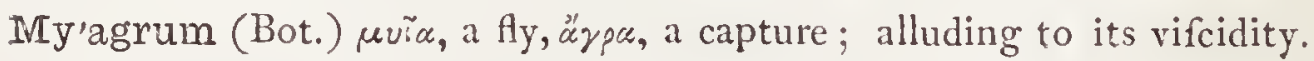

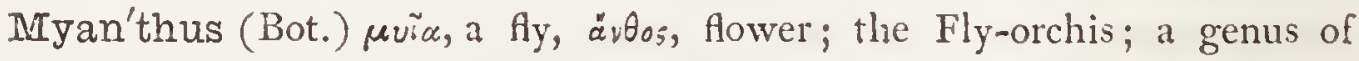

Orchidacex.

Myce'lium (Bot.)

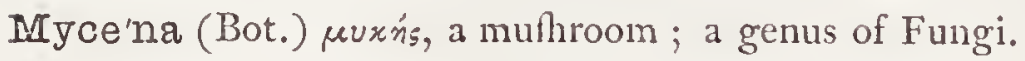

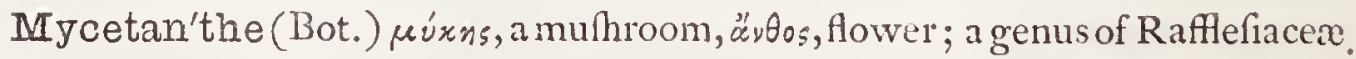
Myce'tes (Bot.) $\mu$ úxns, a fungusor muhroom; Splengel's name for the Fungi.

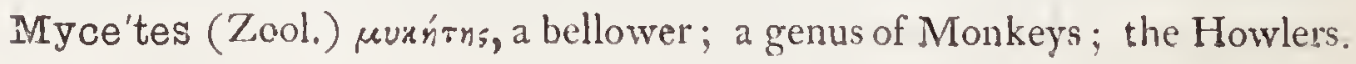


Myceto'bius (Ent.) kúnns, a mulhroom, Bióa, to live.

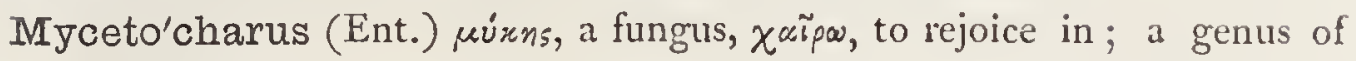
Coleoptera.

Myceto'logy (Bot.) múrns, a mufhroom, hóyos a difcourfe; a differtation on muhrooms; synonymous with mycology.

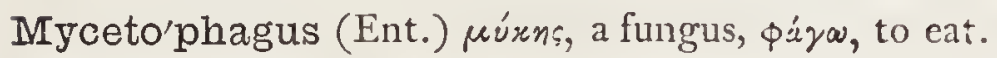

$\left.\begin{array}{l}\text { Myceto'pidæ } \\ \text { Myce'topus }\end{array}\right\}$ (Zool.) $\left\{\begin{array}{c}\mu u ́ x n s, ~ a ~ m u f h r o o m, \pi o \tilde{u}_{5}, \text { foot; a family and } \\ \text { genus of Mollufca. }\end{array}\right.$

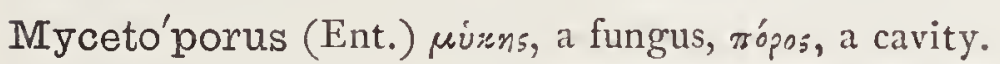

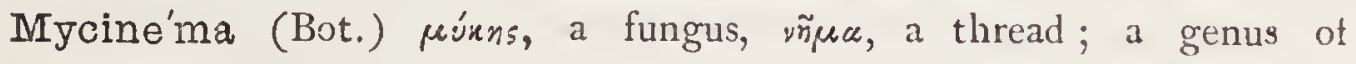

Cryptogamia.

Mycocœ'lium (Bot.) rúrns, a fungus, roìno;, hollow; a genus of Algx.

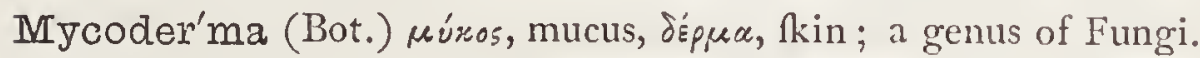

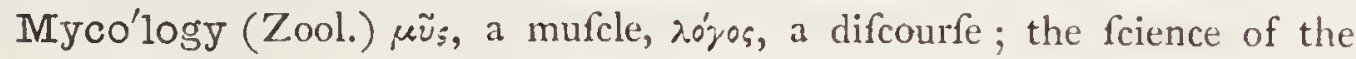
Fungi ; equivalent to Mycetology.

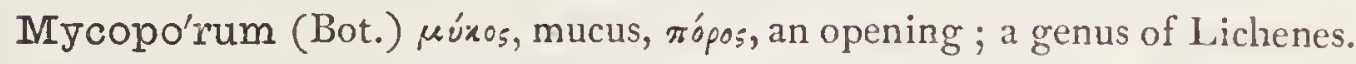

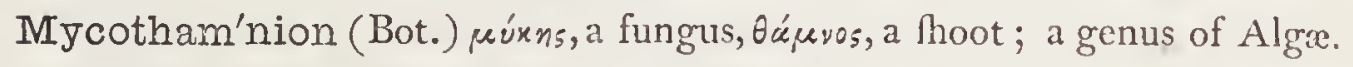

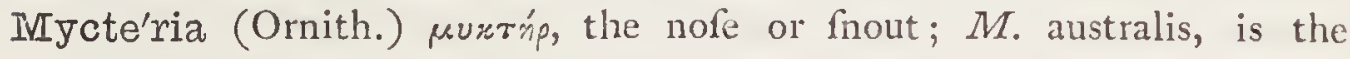
Australian Jabiru.

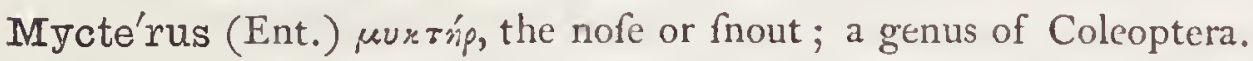

Mydaus (Zool.) $\mu u \delta \delta^{\prime}$, decay, alluding to the foetid fmell of the animal to which it is applied, the Stinkard or Teledu; a genus of Muftelidx.

Mydonospo'rium (Bot.) $\mu v \delta \alpha^{\prime} v$-ävos, fungus-like Aefh, $\approx \pi 0 \rho a ̀$ feed; a genus of Fungi.

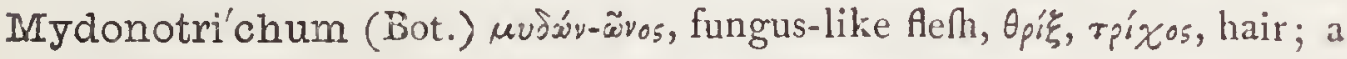
genus of Fungi.

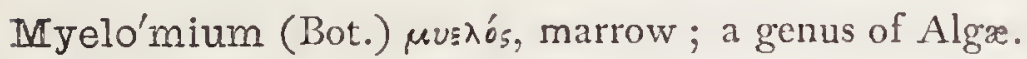

IIyeloph'ila (Ent.) $\mu v \varepsilon \lambda_{0}$ s, marrow, pith, фínos, loving; the larva lives in ftems of thifles, feeding on the pith.

My'gale (Ent.) $\mu u y a ́ \lambda n$, a field-moufe; a genus of hairy-bodied fpiders, fometimes called (but erroneoufly) Bird-catching Spiders.

Myga'lidæ (Ent.) a family of Arachnida, of which the genus Mygale is the type.

Mygalu'rus (Bot.) $\mu v \gamma \dot{a} \lambda n$, a field-moufe, àvpá, a tail; a genus of Gramina. Mygin'da (Bot.) P. N. from Couns. Mygind, of Vienna, a botanical amateur: a genus of Aquifoliacex.

Myiabei'llia (Ornith.) $\mu$ ĩa, a fly, Fr. abeille, a bee; a genus of Hummingbirds.

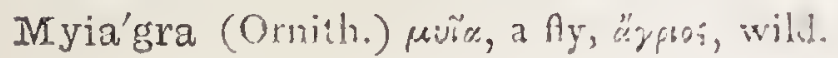




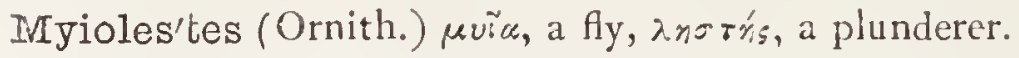

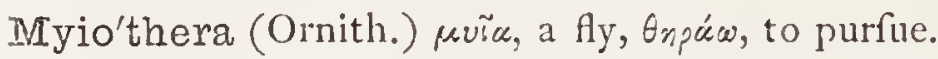

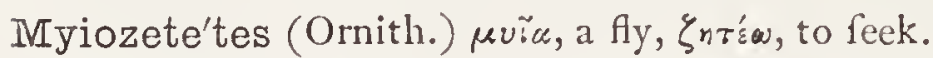

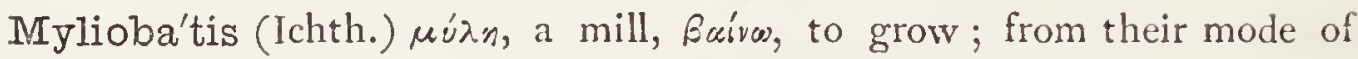
progreffion; the Eagle-rays.

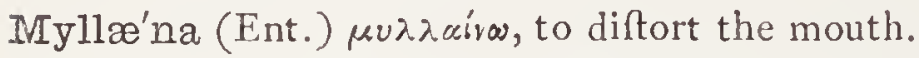

Mryloca'ryum (Bot.) $\mu \dot{x} \lambda n$, a mill, xúźvov, a nut; it has a four-winged feed.

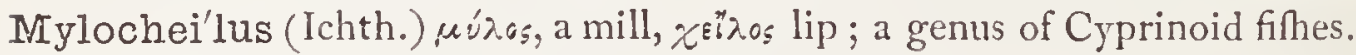

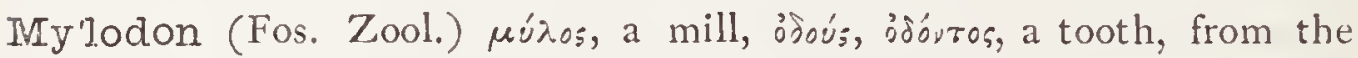
flat grinding furfaces of the molar teeth; a gigantic foffil animal of the upper 'Tertiary.

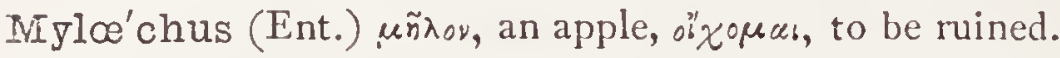

Miymar (Ent.) P. N., a name of Momus; a genus of Infects allied to the Ichneumonidx.

My'nomes (Zool.) $\mu u^{\prime}$, a moute, vouń, a pafture; applied to the Meadowmoufe. $\left.\begin{array}{l}\text { Myocha'ma } \\ \text { Myocha'midæe }\end{array}\right\}$ (Zool.) $\left\{\begin{array}{c}\text { compounded of the names of the genera mya } \\ \text { and chama; a genus and family of Mollufca. }\end{array}\right.$ Myoco'ncha (Zool.) mya, a mufiel, concha, a hell ; a genus of Mollufca. Iryo'des (Zool.) $\mu \tilde{\nu}_{5}$, moufe, sidos, likenefs; the Lemming.

Myo'graphy (Zool.) $\mu \tilde{v}_{5}$, a mufcle, ypí $\phi \omega$, to write.

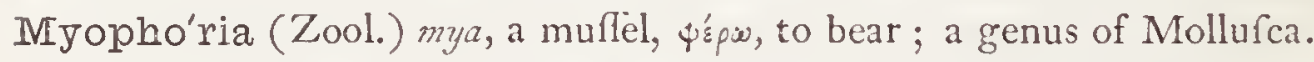

IMyo'porum (Bot.) $\mu \dot{\omega} \omega$, to fhut, rópos, a pore; alluding to the leares.

Myop'sia (Bot.) $\mu \tilde{\nu} s$, a moufe, ö $\psi$ s, like ; a genus of Lobeliaceæ.

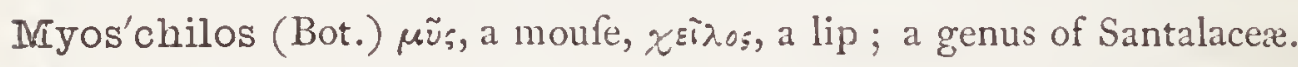

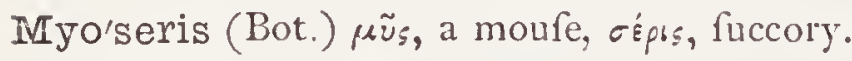

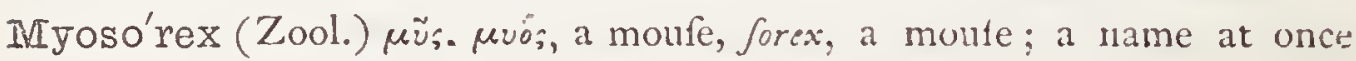
hybrid and tautological.

IMyosoti'dium (Bot.) myofotis, the Forget-me-not, E.dis, likenefs; the Arctic Forget-me-not.

Myoso'tis (Bot.) $\mu \tilde{v}_{s}$, a moufe, ḋrov, a little ear; the Forget-me-not; a genus of Boraginacer.

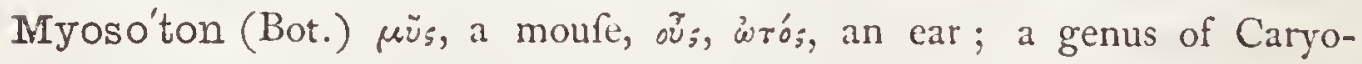
phyllaceæ.

Myosu'rus (Bot.) $\mu \tilde{u} s$, a moufe, ivpú, a tail ; the plant Moufetail, so called becaufe the feed is placed on a long receptacle like a moufe's tail; a genus of Ranunculacex.

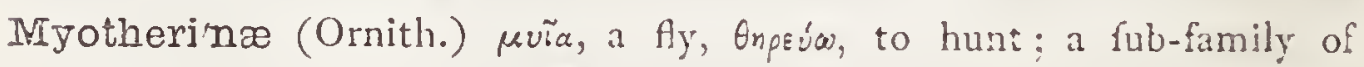
Inceliores; the Ant-catchers. 


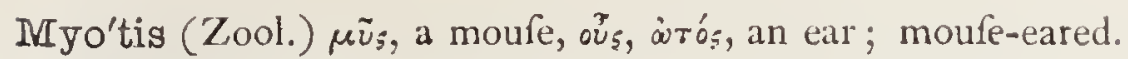

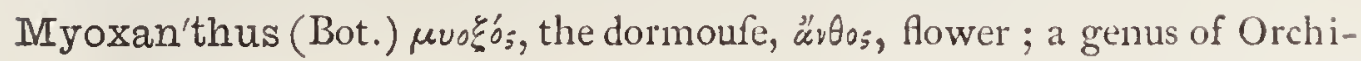
daceæ.

IMoxi'na (Zool.) myoxus; a fub-family of Mammalia.

IMyoxi'nus (Ent.) refembling the fnout of a dormoufe, myoxus, the antenniferous tubercles being prominent, and directed upwards; a genus of Coleoptera.

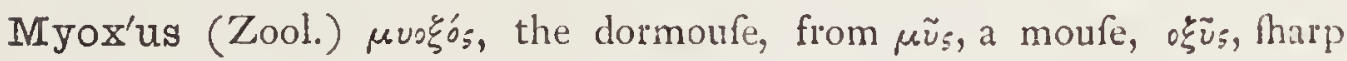
(fnout); the Dormoufe; a genus of rodent Mammals.

Myra'petra (Ent.) a fanciful word, compounded of the names of two ancient cities, one in Asia Minor, the other in Arabia, famous for rock caverns, applied to a honey-collecting wafp.

My'rcia (Bot.) a furname of Venus.

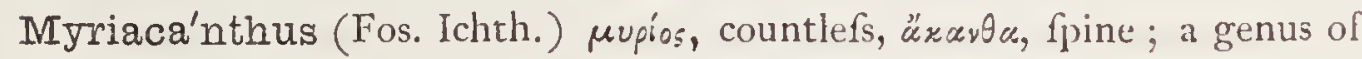
Foffil filhes.

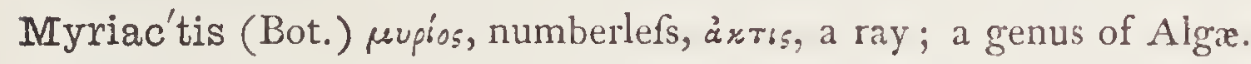

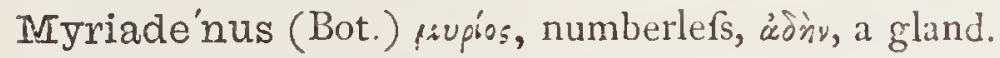

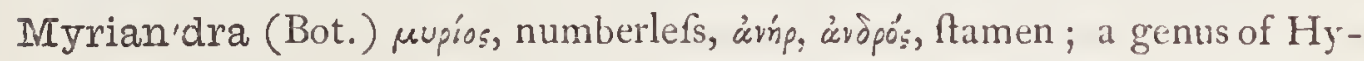
pericaceæ.

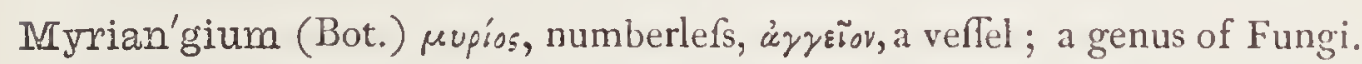

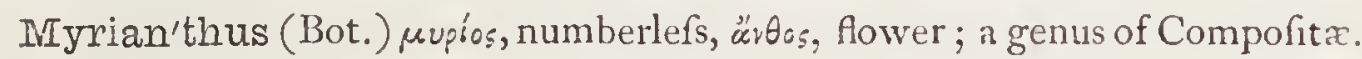

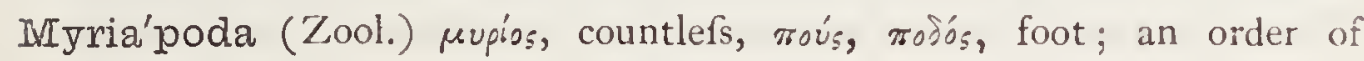
Articulata which contains the Centipedes.

Miyria'spora (Bot.) uupios, numberlefs, fpora; a genus of Melaftomacea.

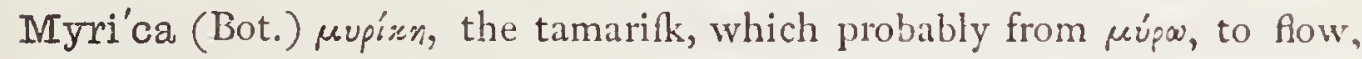
being found on the banks of rivers ; the typical genus of the aromatic

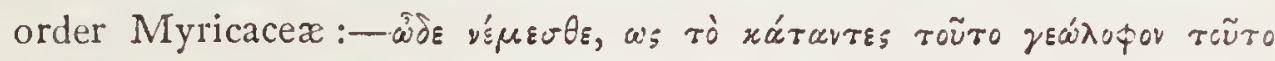

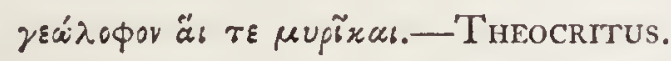

Myr'ina (Zool.) rúpsvos, a fea-filh (Ariftotle); a genus of Mollufca.

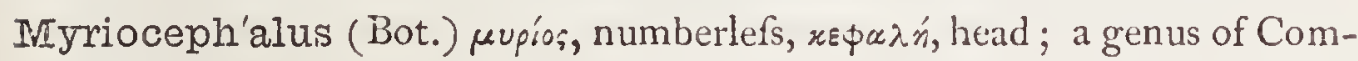
politx.

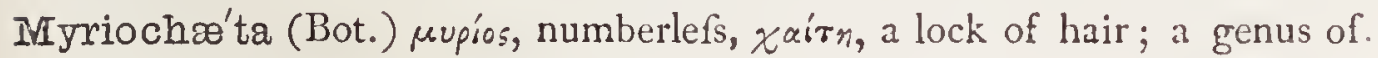
Tiliace $\mathbf{e}$.

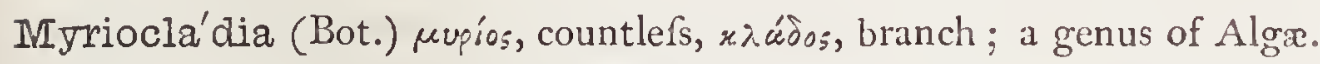

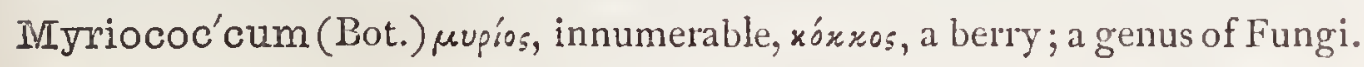

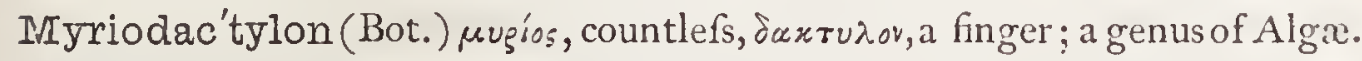

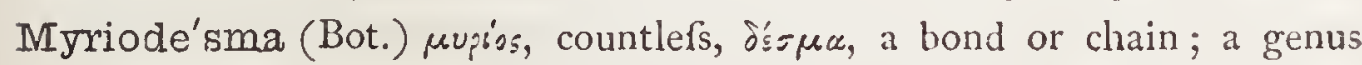
of Algx.

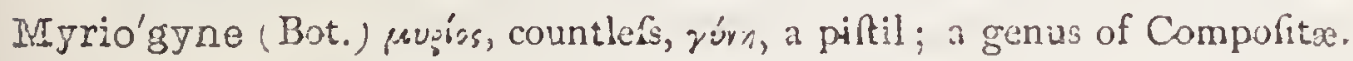


Myriome'les (Bot.) $\mu u_{5} i_{\circ} ;$, countlefs, $\mu \tilde{n} \lambda \circ \nu$, an apple; a genus of Pomaceæ.

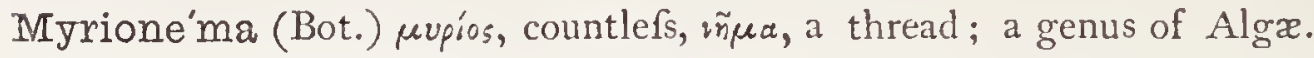

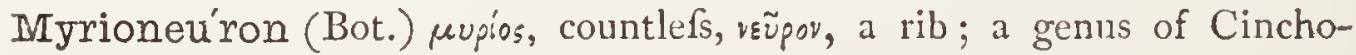
nacex.

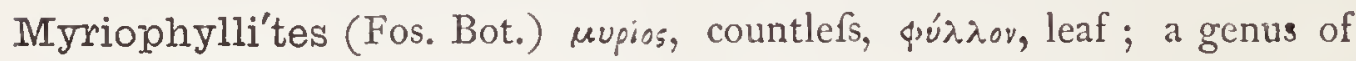
Foffil ftems.

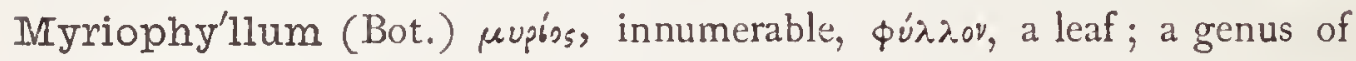
Halorageaceæ.

Myrio'pteron (Bot.) uupios, countlefs, arípov, a wing; a genus of Afclepiadacex.

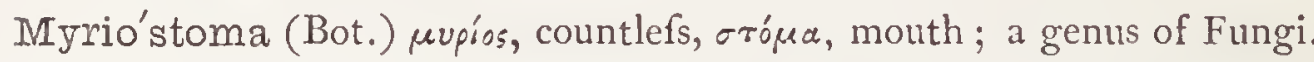

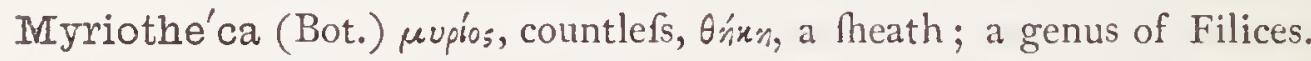

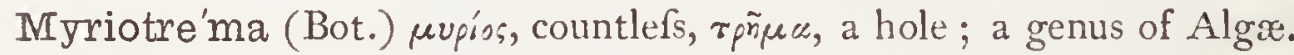

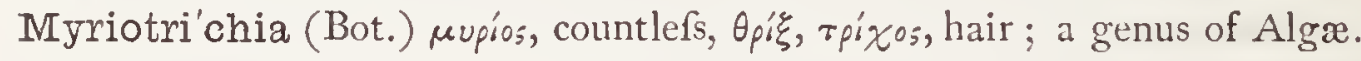

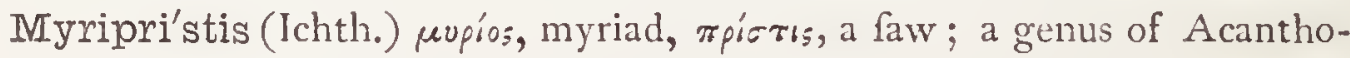
pterygian filhes.

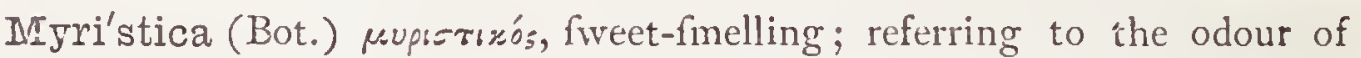
the fruit; the Nutmeg; typical genus of Nat. Ord. Myrifticaceæ.

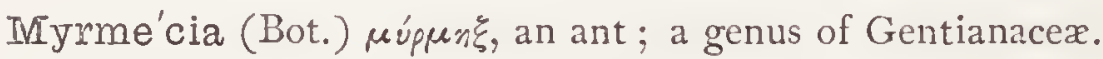

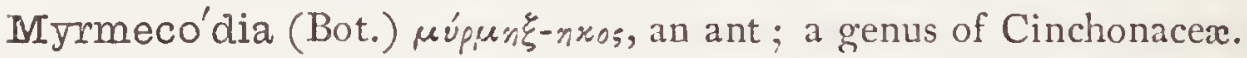

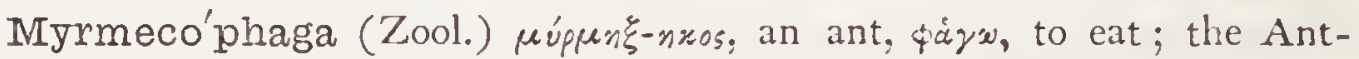
eater.

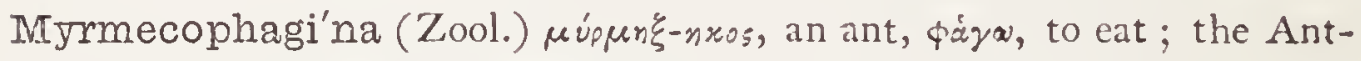
eater; a fub-family of Mammalia.

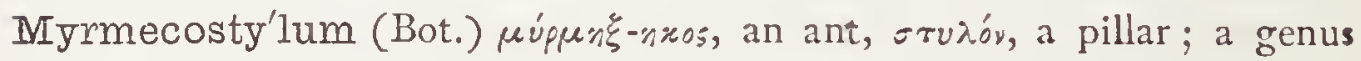
of Polypodioid Filices.

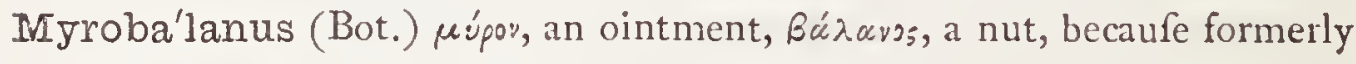
ufed in ointments; a genus of Compofitæ.

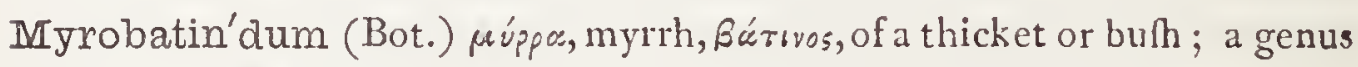
of Verbenacex.

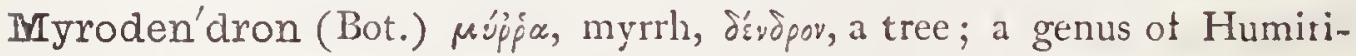
aceæ.

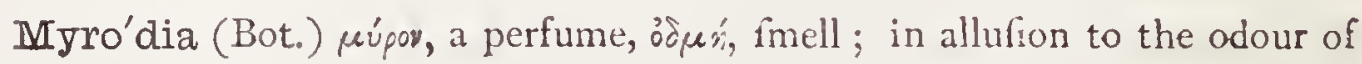
the plant.

Myron (Zool.) kúpov, a perfume; a genus of Ophidians.

My'rophis (Ichth.) $\mu \tilde{u}$ pos, a fea-eel, ö»s, a ferpent; a genus of Ophifuridx.

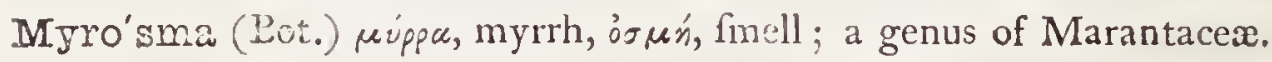

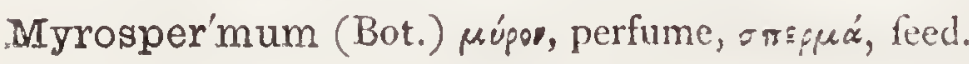




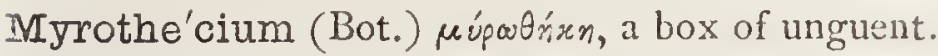

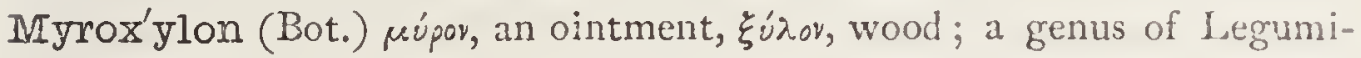
nofæ.

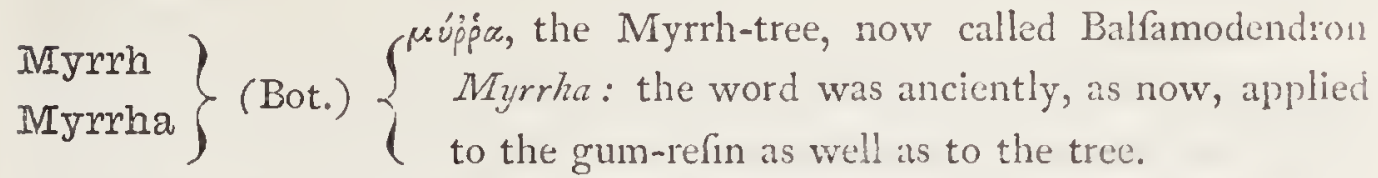

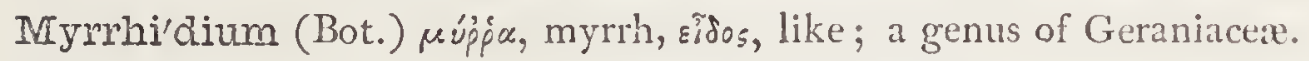

Myrrhi'nium (Bot.) rúppsvos, relating to myrtle; a genus of Melartomaceæ.

Myr'rhis (Bot.) a name ufed by Diofcorides; a genus of Umbellifer:e.

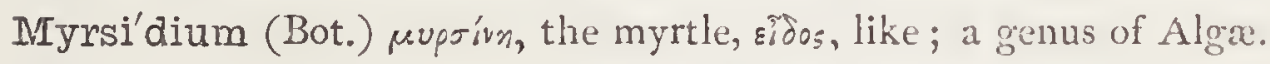

Myrsi'ne (Bot.) uuprivn, the myrtle; typical genus of Myrfinacea.

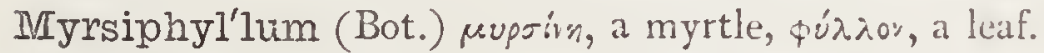

Myrtil'lus (Bot.) dim. of myrtus, the myrtle.

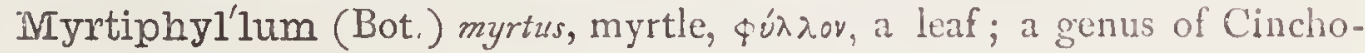
nacex.

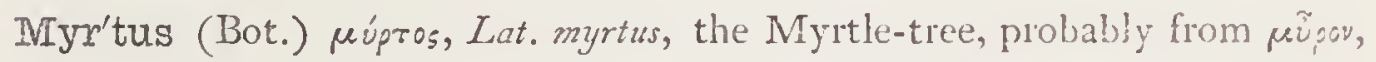
fweet perfume, referring to its fragrance; the Myrtle; typical genus of Nat. Ord. Myrtacese.

IMy'rus (Ichth.) rũpos, a rea-eel.

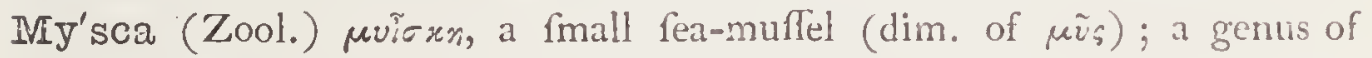
Mollufca.

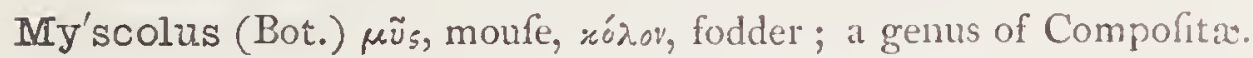

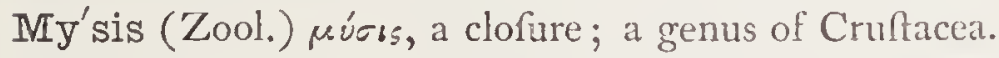

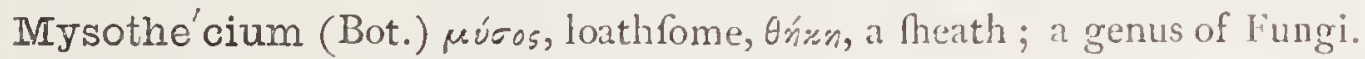

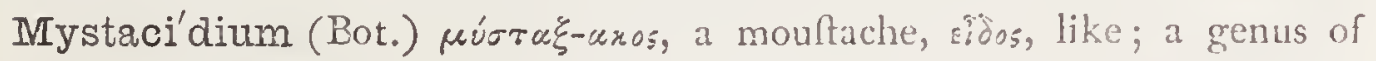

Orchidaceæ.

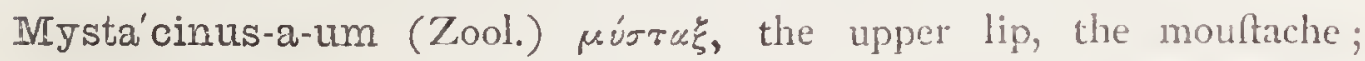
whifkered; c.g., Vefpertilio myftacina, which has coloured ftreaks like a mouftache on the upper lip.

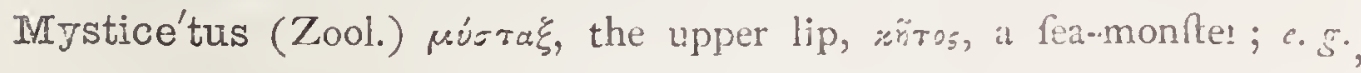
Balæna Myficetus, the Greenland whale.

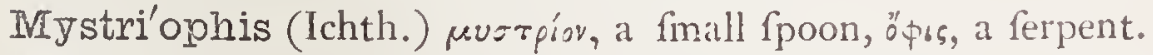

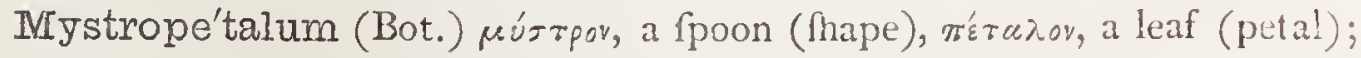

a genus of Balanophoraceac.

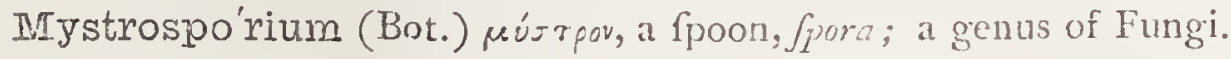

Mystro'xylon (Bot.) kúrtpov, a fpoon, ל̌ìov, wood: a genus of Celar. traces. 
Irytila'cea (Zool.) mytilus, a mufiel ; the Mufiel family.

Myti'lida (Zool.) the family of Mollufea, of which mytilus is the type.

Mytilime'ria (Zool.) Mytilus, a mullel, pepis, a bit or portion; a genus of

Molluf́ca.

MIy'tilus (Zool.) Lat. a fea-mulfel; a genus of Moliufca.

Myu'rus (Bot.) $\mu \tilde{v}_{;}$, moufe, oupú, tail ; the plant Moufe-tail.

My'xa (Bot.) $\mu \dot{y}$ o was a kind of plum; according to Sprengel, Cordia

myxa; a genus of Cordiacex.

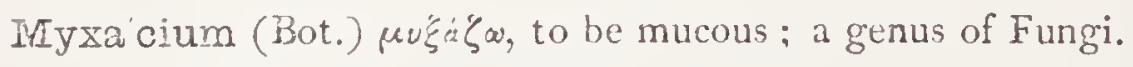

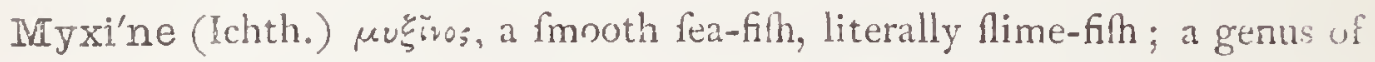

eel-haped fithes, of the family Petromyzidx, or Stone-fuckers.

My'xinoid (Ichth.) myxine, E⿱乛龰jo; likenefs.

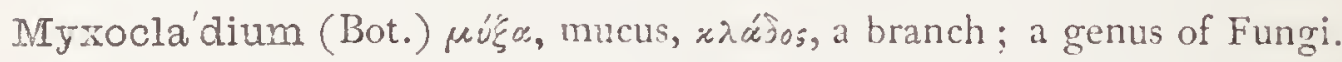

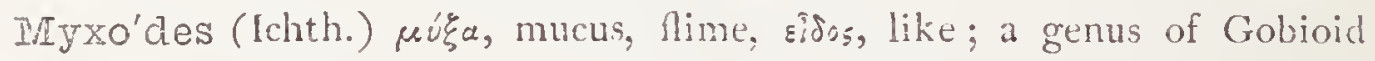
fintes.

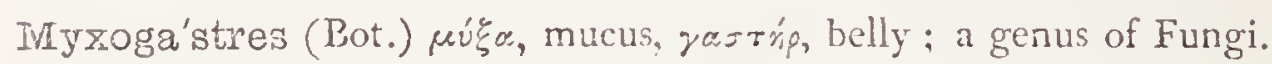

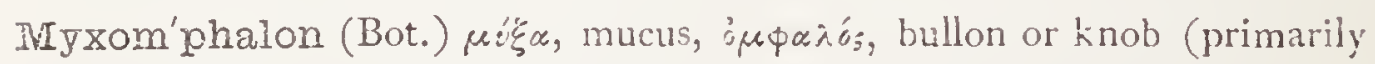

the navel); a genus of Fungi.

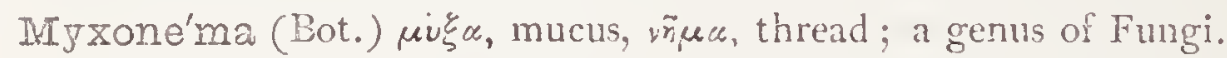

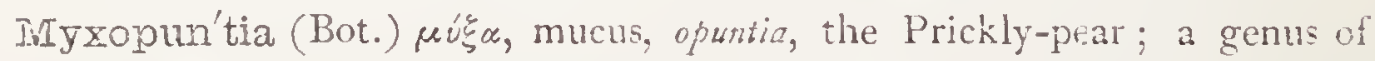

I.ichenes.

Myxospo'rium (Bot.) $\mu \dot{\xi} \alpha$, mucus, orópos, feed, a genus of Fungi.

Iryxo'trichum (Bot.) $\mu u_{\xi} \%$, mucus, $\theta_{p} \%$, rpixos, hair: a genus of Fungi.

My'zotrix (Bot.) fame derivation: a genus of Algx.

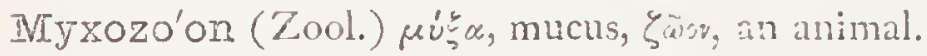

Myzan'tha (Ornith.) $\mu \nu \zeta \alpha_{\alpha} \infty$, to tiuck, äs9os, flower; the Honey-eater.

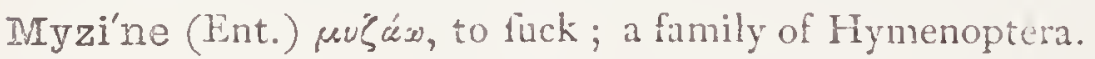

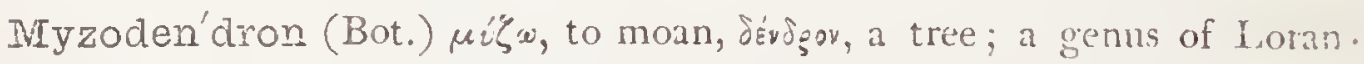
thacex.

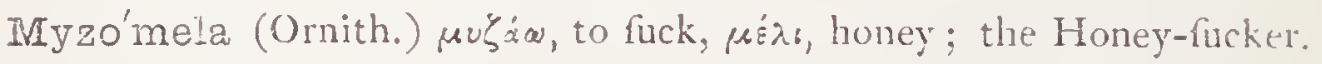

Nacca'ria, (Bot.) unexplained; a genus of Alga.

Nacel'la (Zool.) dim. from vúxn, a goat-fkin; a genus of Mollufca.

Nacerda (Ent.)

Naci'bea (Bot.) :árn, a woolly or hairy lkin; a genus of Cinchonacer.

Nac'reus-a-um (Zool.) French, nacre, mother of pearl; pearly. 
Næmas'pora (Bot.) vйua, a thread, $\sigma$ дора́, a fporule; from its refemblance. Næmate'lia (Bot.) varua, gelatine, $\Xi^{\prime \prime} \lambda \omega$, to collect; a genus of Fungi.

Næva'na (Ent.) narus, a mole or fpot.

Næ'vius-a-um (Ornith.) Lat. fpotted, tawny, e.g., Aquila nevia.

Nagassa'rium (Bot.) from the native word; a genus of Clufincex.

Nagei'a (Bot.) Nagi, its Japanefe name, fignifying catkin-bearing.

Näge'lia (Bot.) P. N., a genus of Pomaces.

Nahu'sia (Bot.) P. N., a genus of Onagracer.

Naiada'cer (Bot.) the Pondweed family of plants, of which Naias is a genus Nai'as (Zool., Bot.) P. N., a river-nymph; a genus of Unionida ; in botany, a genus of the Pondweed family.

Nais (Zool.) P. N., a water-nymph; a genus of freh-water Worms.

Naja or Naia (Zool.) its Indian name; a genus of Colubrine ophidians.

Na'jas (Bot.) Naïá, a water-nymph; from its habitation.

Na'ma (Bot.) vã $\mu x$, running water; from its habitat; a genus of Hyclrophyllaceze.

IJanan'thea (Bot.) vãv05, a dwarf, ävos, a Power; a genus of Compofitx. Nandi'na (Bot.) nandin, its name in Japan; a curious genus of Berberidacex. Nanel'la (Ent.) dim. of nanus, a dwarf.

Nano'dea (Bot.) vawwions, dwarfih; a genus of Santalacex.

Irano'des (Bot.) vavseidns, dwarfin ; a genus of Orchidace: ; alfo, in Zoology, a genus of Parrots.

Nanophy'tum (Bot.) vãvos, a dwarf, łurón, a plant; a gents of Cheno podiacex.

Nanotra'gus (Zool.) vãvos, a dwarf; тpórys, a he-goat; a genus of Antelopes.

Napre'a (Bot.) varains, of a wooded vale or dell; a genus of Malvacex. Napean'thus (Bot.) vámn, a glen, ävos, a flower; a genus of Gefneracex. Napel'lus (Bot.) dim. of napus, a turnip; from its bulbous root; fpecific name of Aconitum Napellus, Monkthood.

Napoleo'na (Bot.) P. N. in honour of Napoleon I.; typical genus of Nat. Ord. Belvifiaceæ.

Na'pus (Bot.) Lat. a turnip.

Narave'lia (Bot.) narazvel, its name in Ceylon.

Narcis'sus (Bot.) váprn, ftupor; from the effects of the fmell: it has been conjectured that Virgil's Narciflus was the Amaryllis lutea, the yellow autumnal lily; 


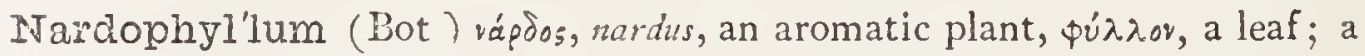
genus of Compofitæ.

Nardos'mia (Bot.) vápdos, nard, jouń, fmell; a genus of Compofitæ.

Nardo'stachys (Bot.) rápdos, a fweet-fcented hrub, oráxva, a fpike; a genus of Valerianaceæ.

Na'rdus (Bot.) vápdos, a peculiar perfurae ; a genus of Gramina.

Na'rica (Zool.) naris, a noftril, e.g., Nafua narica, one of the Apes, the muzzle being extended into a movable probofis. $\left.\begin{array}{l}\text { Nárica } \\ \text { Nari'cidæe }\end{array}\right\}$ Zool. $\left\{\begin{array}{c}\text { unexplained; a genus and family of Gafteropodous } \\ \text { Mollufca. }\end{array}\right.$

Nari'na (Ornith.) fpecific name of a Trogon, given by Le Vaillant, in remembrance of a young Hottentot girl.

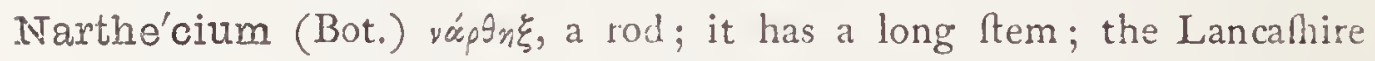
afphodel; a genus of Nat. Ord. Juncacex.

Nar'whal (Zool.) from a Gothic word fignifying "beaked-whale;" the Monodon monofceros or Unicorn whale.

Nasa'lis (Zool.) nafus, the nofe; a genus of Monkeys, containing only

$N$. larvatus, the Probofcis monkey.

Nas'cia (Ent.) P. N., the goddefs of birth.

Naseus (Ichth.) nafus, the nofe; a genus of Finhes, the front part of whore head is produced into a horn.

Nasmy'thia (Bot.) P. N., a genus of Eriocaulacex.

Nasomacula'ta (Zool.) nafus, the nore, maculatus, fpotted.

Naso'nia (Bot.) nafus, a nofe; from a remarkable protuberance; a genus of Orchidacex.

Na'ssa (Zool.) Lat. a baket ufed for catching filh; the Dog-whelk; a genus of Mollufca.

Nassa'ria (Zool.) fame derivation; a genus of Mollufca.

Nassa'via (Bot.) P.N. in honour of the houfe of Naflau; a genus of Compofitx.

Nas'sidæ (Zool.) a family of Mollufca, of which Naffa is the type.

Nasso'via (Bot.) P. N., fame derivation; a genus of Compofite.

ivas'sula (Zool.) dim. of naff $x$, a wheel, from the form of the circlet of teeth; a genus of Infuforia.

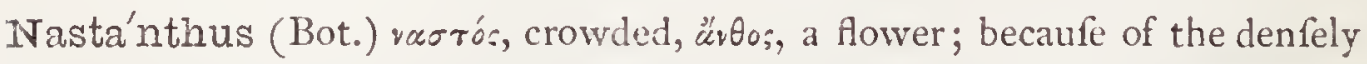
aggregated flowers and achenia in each of its capitula: a genus of Calyceracex.

Nastur'tium (Bot.) nafus, a noie, tortus, tormented, from its effects: the anglilh name of the Tropeolum majus, and the latin one of the common Mater-cres. 
INas'tus (Bot.) vartos, the Greek name for a kind of reed.

Na'sua (Zool.) from the great length of the nofe, nafo; the Coatis.

Nasu'tus-a-um (Zool.) Lat. large-nofed, e.g., 'Tockus nafutus.

Natalen'sis-e (Zool.) Lat. relating to Natal.

Nata'lia (Bot.) P. N. from Natal; a genus of Sapindacere.

Natato'res (Ornith.) plural of natator, a fwimmer ; the Swimming-birds.

Nathu'sia (Bot.) unexplained; a genus of Oleacex.

Na'tica (Zool.) unexplained; a genus of Gafteropodous Mollufca.

Naticel'la (Zool.) dim. of Natica; a genus of Mollufca.

Nati'cidæ (Zool.) the family of Mollufca, of which Natica is the type; the Sea-fnails.

Natri'cidæ (Zool.) a family of Colubrine ophidians, of which Natrix is the type.

Natrix (Zool.) Lat. a Water-fnake.

Nattere'ri (Zool.) P. N. in honour of - Natterer.

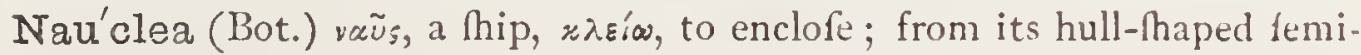
capfule.

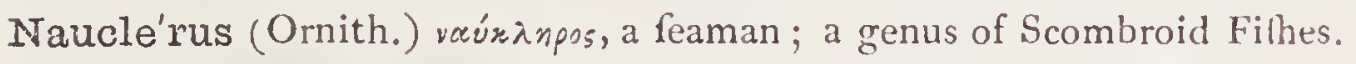

Nau'coris (Ent.) vavis, a hip, xóprs, a bug; a genus of Water-bugs.

Nau'crates (Ichth.) vauxpárns, commanding the fea; the Pilot-fill.

Nauember'gia (Bot.) P. N. in honour of Fohn Samuel Naumberg, a writer on botany.

Naune'ma (Zool.) veĩs, a Thip, vñ $\mu \alpha$, thread or cable; a genus of Infuforia.

Nautil'idæ (Zool.) a well-known family of Tetrabranch Cephalopods, of which nautilus is the type.

Nautili'tes (Fos. Zool.) foffil thells allied to the nautilus.

Nau'tilus (Zool.) dim. from var̃s, a hip; the pearly Nautilus is $N$. Pompilius; a genus of Mollufca, of the clafs Cephalopoda.

Nava'lis-e (Ent.) pertaining to hips, e.g., Lymexylon navale, a boring infeet.

Navicel'la (Zool.) Lat. a finall boat; a genus of Mollufca.

Navi'cula (Zool.) Lat. a fmall veftel.

Navicula'ria (Bot.) navicula, a fmall vellel; a genus of Gramina.

Navus-a-um (Ent.) bufy, induftrious.

$\left.\begin{array}{l}\text { Neba'lia } \\ \text { Nebali'adæe }\end{array}\right\}$ (Zool.) $\left\{\begin{array}{c}\text { unexplained; a genus and family of Entomor.. } \\ \text { tracous cruftaceans. }\end{array}\right.$

Ne'bria (Ent.) veßpicas, fawn-coloured.

Ne'bris (Ichth.) veBois, a fawn-Rkin; a genus of Ctenoid Fithes.

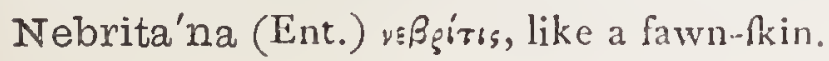


Nebulo'sus-a-um (Ornith.) Lat. cloudy, dark.

Necke'ra (Bot.) P. N. in honour of N. F. Necker, a German botanift; a genus of Murci.

Necro'bia (Ent.) vexpós, a dead body, Brów, to live; a genus of Coleoptera. Necro'des (Ent.) vexpóóns, corpfe-like; a genus of Coleoptera.

Necroph'aga (Ent.) vexpós, a dead body, payw, to eat; a genus of Coleoptera.

Necrophlœo'phagus (Ent.) verpòs, dead, $\phi \lambda$ obìn, bark, фáyw, to eat.

INecroph'orus (Ent.) vexpós, a dead body, фopós, a carrying; the Sextonbeetles; a genus of Coleoptera, of the family Silphidæ.

Nectan'dra (Bot.) vиято́, floating, àvńp, åvóśs, a male (Itamen); a genus of Lauracex.

Nec'tarine (Bot.) popular name of the fruit of the Amygdalus Nectarina. Nectari'nia (Ornith.) a name given by Jlliger to a genus of Birds which fuck the nectar of flowers.

Nectarinida (Ornith.) the Honey-fuckers.

Nectarobo'thrium (Bot.) nectarium, nectary or honey-cup, Botpiov, a little pit or hollow; a genus of Liliaceæ.

Nectaroscórdum (Bot.) nectarium, nectary, oxógovov, garlic; a genus of Liliaceæ.

Nec'tary (Bot.) v's:rap, nectar; applied originally, in Botany, to thofe parts of a flower which fecrete honey; fometimes called the honeycup.

Nectu'ra (Zool.) v'nxтn, a fwimmer, oũpe, a tail; a genus of Amphibia.

Necy'dalis (Ent.) vexífanos, the larva or nympha of the filk-worm; a genus of Coleoptera.

Nedy'us (Ent.) vnóu, a paunch; a genus of Coleoptera.

Needha'mia (Bot.) P. N., a genus of Epacridacex.

Nee sia (Bot.) P. N., a genus of Sterculiacere.

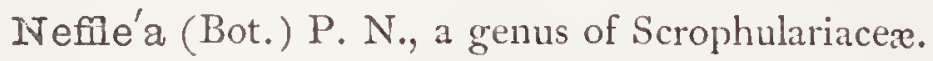

Neglec'ti (Ornith.) negligo, to neglect; applied by Scopoli to thore birds whofe fleth is not ufed by man.

Negre'tia (Bot.) a genus of Leguminof .

Negun'dium (Bot.) meaning unknown; a genus of Aceraceæ.

Nehemi'a (Bot.) P. N. in honour of Nehemiah Grew, vide Grezia; a genus of 'Tiliacen.

Neil'lia (Bot.) P. N., a genus of Rofacer.

Ne'ja (Bot.) without meaning.

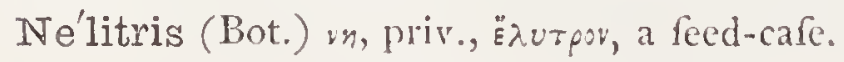


Nelso'nia (Bot.) P. N. in honour of $D$. Nolfon, a botanift, who accompanied Captain Cook.

Nelumbia'cer (Bot.) a Nat. Ord. of Dicotyledonous plants, of which the

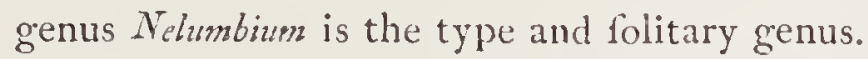

Nelum'bium (Bot.) from the Cingalefe Nelumbo. The Nelumbium fpeciofum was the plant which produced the Pythagorean o1- Sacred Indian bean; a genus of Nelumbiacex.

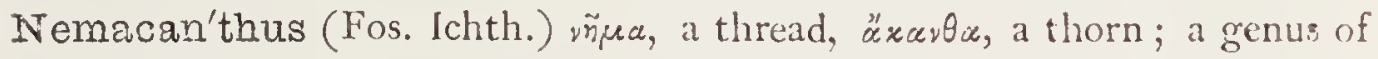
Oolitic Ichthyodorulites.

Nemaco'nia (Bot.) vñucs, a thread, xóvsos, dufty; a genus of Orchidaceŕe.

Nema'ctis (Zool.) iñuc, thread, $\dot{e} \times \tau i s$, a ray; a genus of Actinix.

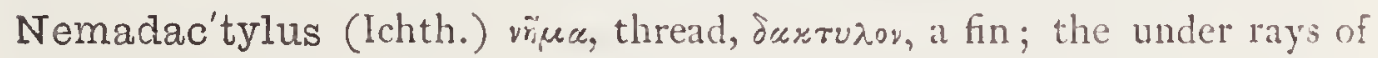
the pectorals being like hanging threads; a genus of Cerenoid acanthopterous Filhes.

Nema'lion (Bot.) dim. of vrijua, a thread; a genus of Cerainian Algæx.

Nema'spora (Bot.) vripce, a thread, onópcs, feed; a genus of Fungi.

Nemas'toma (Bot.) $\tilde{n} \mu x$, a thread, $\sigma \tau \tilde{c} \mu \mu$, a mouth; a genus of Algx.

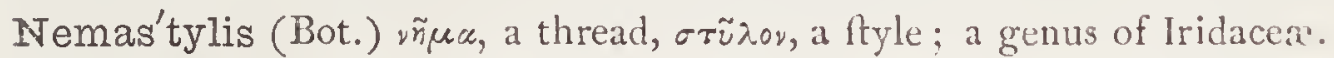

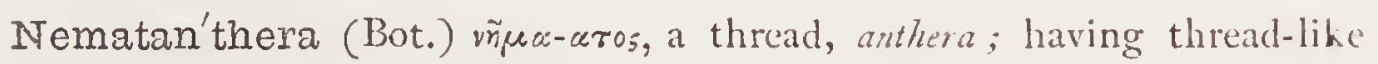
anthers.

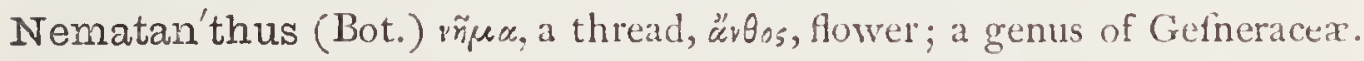

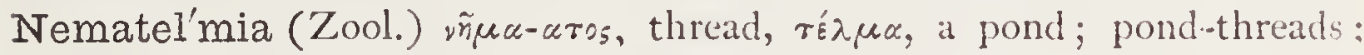
an order of Parafitic worms.

Ne'mathrix (Bot.) vñua, a thread, $\theta_{\varsigma}$ ' $\xi$, hair ; a genus of Alga.

Nematocos'cus (Bot.) rí.uce-aros, a thread, róxжos, a berry; a genus of Algx.

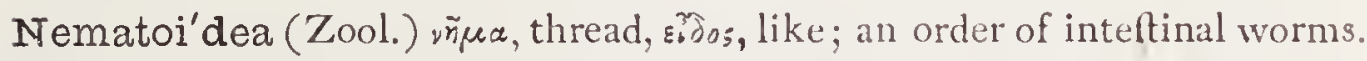

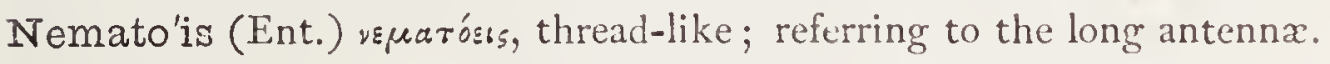

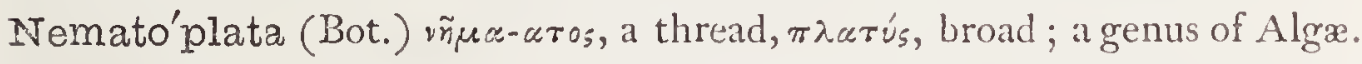
Nematopo'ma (Ichth.) vñ $s \%-\alpha \tau o s$, a thread, $\pi \tilde{\omega} \mu \alpha$, a lid; a genus of Malacopterous Fithes.

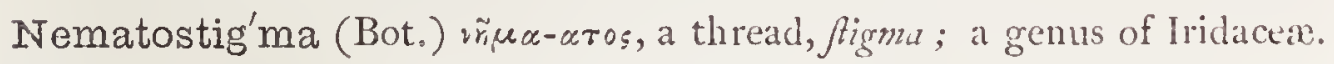

Nemau'chenes (Bot) in $\mu \alpha$, a thread, auxx'r, the neck; a genus of Compolitie.

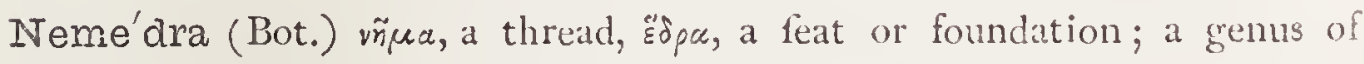
Meliacea.

Nemeo'bius (Ent.) véseos, a grove, B'os, life; living in woods.

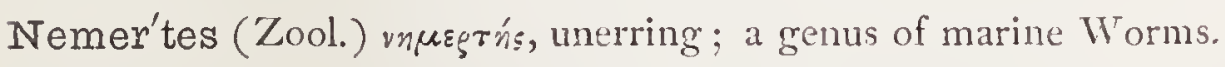

Neme'sia (Bot.) a name given by Diofcorides to a kind of Antimhinum; now applied to a genus of Scrophulariacea. 
Ne'mia (Bot.) nemus, a wood or grove; a genus of Scrophulariaceæ.

Nemich'thys (Ichth.) थñ

Nomoch'loa (Bot.) vñua, a thread, $\chi \lambda o ́ c e$, grafs; a genus of Gramina.

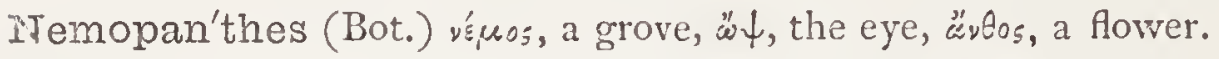

Nemoph'idx (Ichth.) a family of Filhes of which Nemophis is the type.

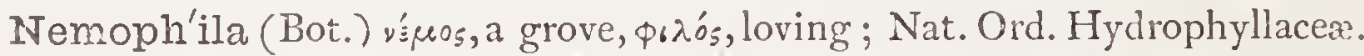

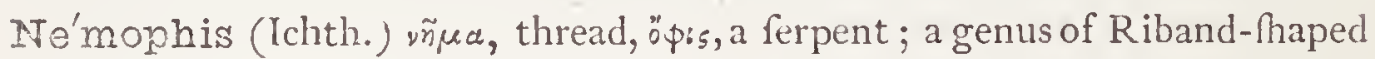

Filhes.

Iremora'lis-e (Zool., Bot.) Lat. belonging to groves or woods; e.g.

Helix nemoralis, Poa nemoralis.

Nemo'ria (Ent.) nemus, a grove.

Nemori-va'gus (Zool.) Lat. one that wanders in the woods.

Nemo'sia (Ornith.) v'́s:os, a wooded pafture.

Nemoso'ma (Ent.) ıñ $\mu \alpha$, thread, $\sigma \tilde{\omega} \mu \alpha$, body; a genus of Coleoptera.

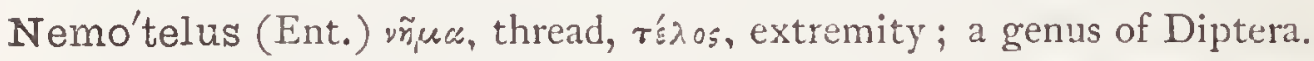

Nenu'phar (Bot.) v'sos, new, mphar, a water-lily; a genus of Nymphæacen.

Neo'phron (Ornith.) véspary, childifh in fpirit; applied to the Scavengervulture.

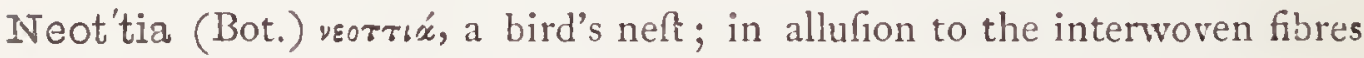
of the roots; a genus of terreftrial Orchidacer.

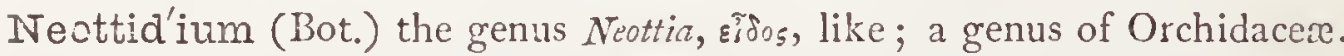

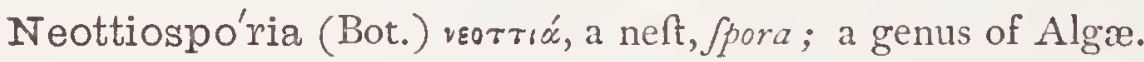

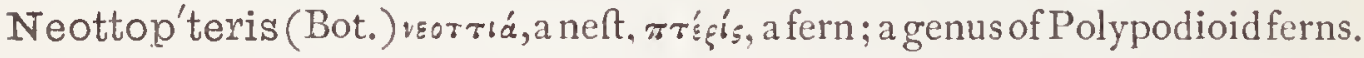

Nepentha'ceæ (Bot.) a family of Dicotyledonous plants, of which Nepenthes is the only fpecies.

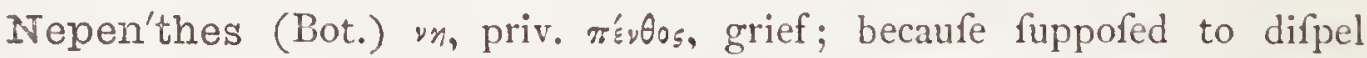
vexation; the Nepenthe of Homer is fuppofed to have been the poppy, or poffibly tobacco; typical genus of Nepenthacer; Eaft Indian Pitcher-plants.

Ne'peta (Bot.) It.al. nepitella, cat-mint; a genus of Labiatx.

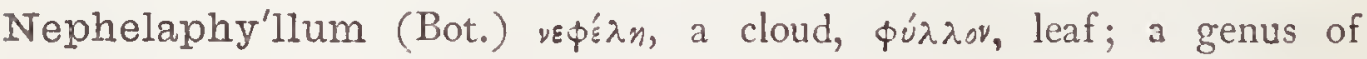
Orchidaceæ.

Ne'phelis (Ent.) $v \varepsilon \varphi^{\prime} \hat{\lambda} \lambda$, a cloud; a genus of Annelida.

Nephe'lium (Bot.) from dim. $v \varepsilon \notin \varepsilon \lambda \eta$, a little cloud; a genus of Sapindacex.

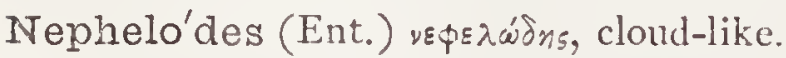

Nepho'bolus (Bot.) ข'́фos, a cloud, Bá $\lambda \lambda \omega$, to caft.

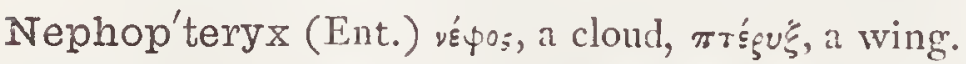

Nephrade'nia (Bot.) veśós, the kidney (referring to thape), ¿ínv, a gland;

a genus of Afclepiadacer. 


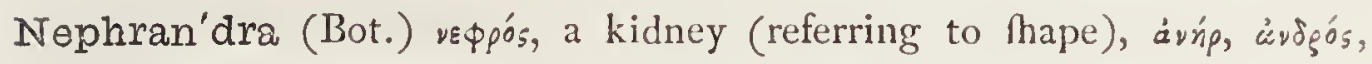
a male (ftamen); a genus of Verbenacex.

Nephran'thera (Bot.) vєфpó, a kidney, anthera; having kidney-(haped anthers; a genus of Orchidacex.

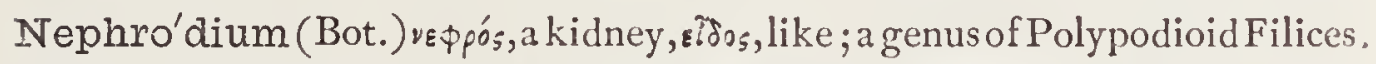
Nephroi'a (Bot.) v£\$pós, a kidney; a genus of Menifpermacex.

Nephro'lepis (Bot.) vзфpós, a kidney, $\lambda_{\imath} \pi i^{\prime}$, a fcale; a genus of Polypodioid Filices.

Nephro'ma (Bot.) veфpos, a kidney; from the form of the apothecia; a genus of Cryptogamia.

$\mathrm{Ne}^{\prime}$ phrops (Zool.) vєpós, kidney, $\ddot{\omega} \psi$, eye; a genus of Cruftacea.

Nephro'sis (Bot.) vєфpós, a kidney; a genus of Leguminofre.

Neph'thys (Zool.) unexplained; a genus of Annelida.

Nepti'cula, (Ent.) dim. of neptis.

Ne'ptis (Ent.) vท́ттй, fober, difcreet.

Neptisa'lis (Ent.) refembling the genus $N_{c p t i s .}$

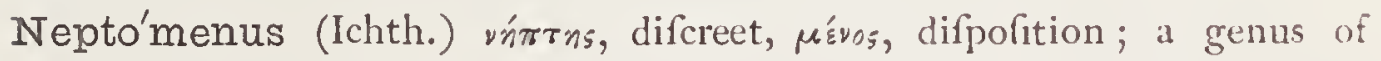
Scombroid Fifhes.

Neptu'nia (Bot.) P. N., well known in mythology; a curious aquatic genus of Leguminofx. $\left.\begin{array}{l}\text { Nere'idæ } \\ \text { Ne'rëis }\end{array}\right\}$ (Zool.) $\left\{\begin{array}{c}\text { P. N. from ancient mythology; a family and } \\ \text { genus of Annelida. }\end{array}\right.$

Nerei'dea (Bot.) refembling Nereis, a genus of Annelides; a genus of Alga.

Nerei'tes (Fos. Zool.) a family or genus of foffil Nereide, or Seacentipedes.

Nereocys'tis (Bot.) nereis, a worm, xú $\tau 6$, a bladder; a genus of Algæ.

Nereogra'psus (Fos. Zool.) a fection of the foffil nereites, having engraved markings ( $\left(\right.$ p $\alpha \pi \tau$ s. $_{\text {, }}$ written.)

Nerian'dra (Bot.) the genus Nerium, àvńp, dxvogés, a ftamen, i. e., implying refemblance; a genus of A pocynaceæ.

Ne'riene (Ent.) P. N., a wife of Mars; a genus of Araneidæ.

Nerinæ'a (Zool.) P. N., Nereis, a fea-nymph; a genus of Mollufca.

Neri'ta Zool. (vnpeírns, a fea-fhell; a genus and family of Mo!Neri'tidæ $\}$ Zool. $\{$ lufca.

Neriti'na (Zool.) dim. of Nerita; a genus of Mollufca.

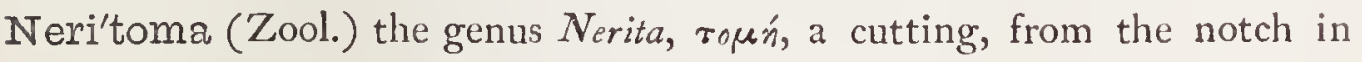
the middle of the outer lip; a genus of Mollufca.

Nerito'psis (Zool.) the genus Nerita, oł s, like; having a fhell fomewhat fimilar; a genus of Mollufca. 
Ne'rium (Bot.) vnpos, humid, referring to its habitation; the Oleander; a genus of Apocynaceæ.

Nervo'sa (Ent.) nervus, a finew, ftring.

Nesz'a (Bot.) P. N., one of the fea nymphs.

Nes'lia (Bot.) unexplained.

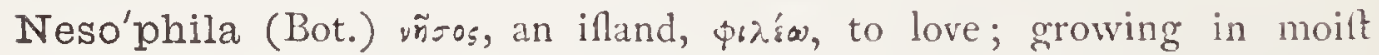
places; a genus of Campanulacex.

Nes'tis (Ichth.) iñatbs, an ancient name of a filh; a genus of Mugiloid Filhes.

Nes'tlera (Bot.) P. N., a genus of Compolitæ.

Nestor (Ornith.) P. N., a genus of Scanforial birds; family Pfittacidx.

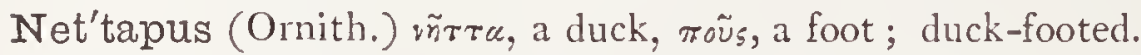

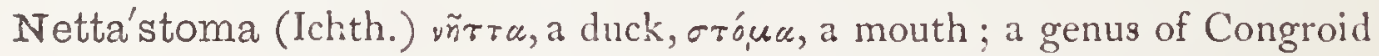
Filhes.

Nettle (Bot.) an alteration of needle, or at leaft both are of the fame AngloSaxon root, netel or nodl, and obviouly refers to the needle-like ftings, of the plant.

Neube'ria (Bot.) P. N., a genus of Iridacex.

Neudo'rfia (Bot.) P. N., a genus of Nolanacex.

Neuman'nia (Bot.) P. N., a genus of Bromeliacex.

Neuma'yera (Bot.) P. N., a genus of Caryophyllaceas.

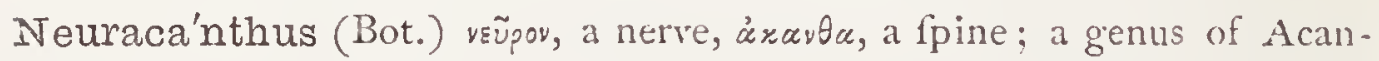
thaceæ.

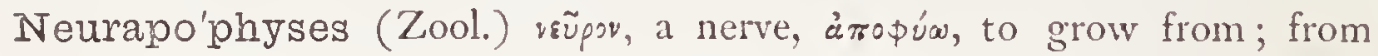
their being developed to protect the great nervous trunk.

Neu'ria (Ent.) reṽpor, a finew; on account of the pale nervures fo plainly vifible.

Neu'rica (Ent.) veupurós, finewy.

Neuroca'lyx (Bot.) veṽpov, a nerve, calyx.

Neurocarpæ'a (Bot.) veũpov, a nerve, raptros, fruit; a genus of Cinchonacer. Neurocar'pum (Bot.) veũpov, a nerve or tendon, xaptós, fruit.

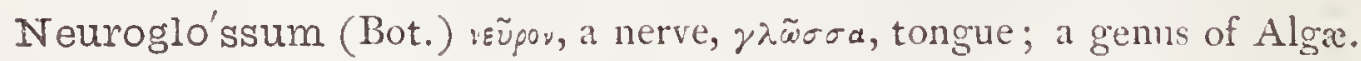

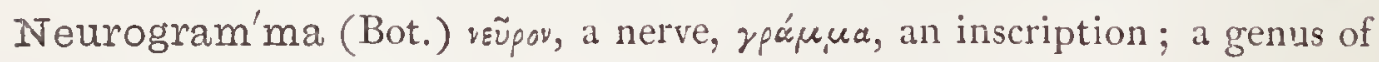
Polypodioid Filices.

Neurolæ'na (Bot.) ขย̃̃pov, a nerve or tendon, a aıv , a cloak.

Neurolo'ma (Bot.) veṽpov, a nerve or tendon, $\lambda \tilde{\omega} \mu a$, a fringe.

Neurónia (Bot.) reũpor, a nerre; a genus of Polypodioid Filices.

Neurope'1tis (Bot.) veũpov, a nerve, $\pi \varepsilon \lambda \tau n$, a thield; a genus of Conrolvulacex. 


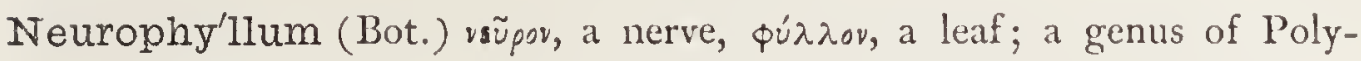
podioid Filices.

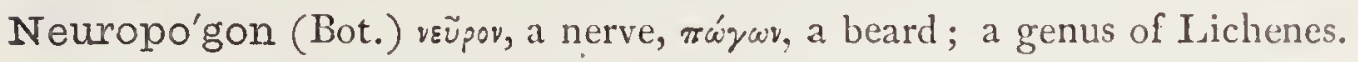

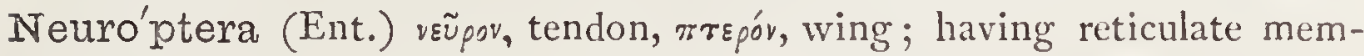
branous wings; an order of Infecta.

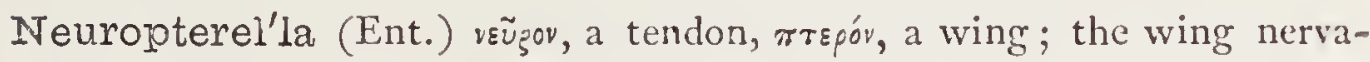
ture being diftinctly cinnamon brown.

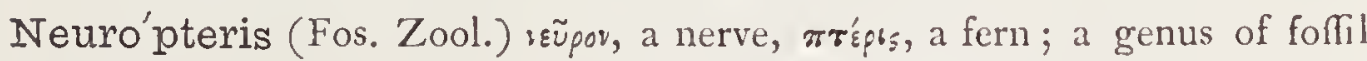
Ferns.

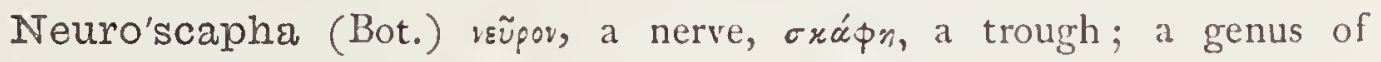
Leguminofx.

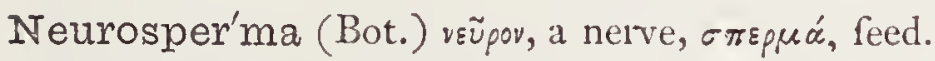

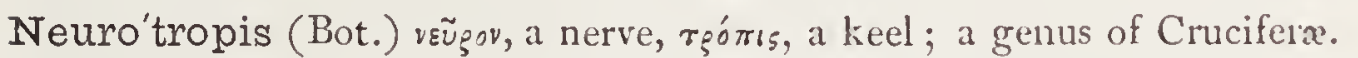
Neus'tria (Ent.) P. N., formerly applied to a portion of France, including Normandy, Brittany, and Anjou.

Neveri'ta (Zool.) P. N., a genus of Mollufca.

Newt (Zool.) corruption of evet, eft, a-n-eft $=$ a newt.

IJicel'lii (Ent.) P. N. in honour of Graf von Nicelli, a German entomologilt.

Nicholso'nia (Bot.) P. N., a genus of Leguminofie.

Nicoba'ricus-a-um (Ornith.) relating to the ifland of Nicobar; applied to a pigeon only found there; Calænas nicobarica.

Nicode'mia (Bot.) P. N., a genus of Scrophulariacex.

Nicolso'nia (Bot.) P. N. in honour of $M$. Nicolfon, a writer on the natural hiftory of St. Domingo.

Nicothoë (Zool.) P. N. from Nicothoë, one of the Harpies; a genus of Entomoltraca.

Nicotia'na (Bot.) P. N. in honour of $\mathcal{F}$. Nicot, of Nifmes, who firf brought it into Europe; the Tobacco-plant; a genus of Solanacer.

Nic'titans (Zool.) Lat. winking; e.g., Cercopithecus niczitans.

Nidula'ria (Bot.) nidus, a neft; the plants confift of cups containing egglike feeds; a genus of Fungi.

Niduli'tes (Fos. Zool.) nidus, a neft, $\lambda^{\prime} \theta_{0}$ s, ftone; foffil Silurian organifins, probably allied to the Bryozoa.

Niebu'hria (Bot.) P. N. in honour of Carlen Niebuhr, a traveller in Arabia.

Nierember'gia (Bot.) P. N., a genus of Solanacex.

Nige'lla (Bot.) dim. of niger, dark, black; the feeds are of that colour; a genus of Ranunculacea; alfo, in Entomology. 
Niger, Nigra, Nigrum (Zool., Ent., Bot.) Lat. black or dingy; e.g., Sciurus niger, Fritillaria nigra, Ribes nigrum.

Nightshade (Bot.) from their deadly qualities and gloomy afpect; the genus Solanum, alfo the Atropa Belladonna.

Nigra'lis (Ent.) niger, black.

Nigre'scens (Zool., Bot.) Lat. Rightly black.

Ni'griceps (Ornith.) niger, black, caput, head; black-headed.

Nigri'na (Bot.) nigro, to be black; a genus of Scrophulariaceæ.

Nigripunctel'la (Bot.) niger, black, punctum, a fpot; black-fpotted.

Nigrite'lla (Bot.) nigritia, black colour; a genus of Orchidaceæ.

Nigritel'lus-a-um (Bot.) dim. of niger, black; in allufion to the colour of the flowers; blackilh or duky, e. g., Juncus nigritellus.

Nigrogula'ris (Ornith.) niger, black, gula, throat; black-throated, e.g.. Craßticus nigrogularis.

Nigro-vitta'tus (Zool.) niger, black, vitta, a band; black-banded.

Nilo'ticus-a-um (Zool., Bot.) Lat. relating to the Nile.

Nilso'nia (Fos. Zool.) P. N., a genus of foffil Cycadaceous leaves of the lias and oolite.

Ni'ma (Bot.) unexplained; a genus of Simarubacex.

Nimbel'la (Ent.) dim. of nimbus, a cloud.

Niobæ'a (Bot.) P. N. from Niobe; a genus of Hypoxidaceæ.

Ni'obe (Bot.) P. N., a genus of Liliacex.

Ni'pa (Bot.) its name in the Moluccas; it yields Neepah fugar.

Nipadites (Fos. Zool.) nipa, a genus of Indian palms which produces neepah fugar; a genus of foffil Palm.nuts.

IJiphæ'a (Bot.) vфás, a fnow-flake; a genus of Gefneraceæ.

Nipho'bolus (But.) v'óßっдоs, covered with fnow; the indufra are like flakes of fnow; a genus of Filices; alfo, a genus of Simarubacex.

Ni'phon (Ichth.) this filh is only found in Japanefe feas, and takes its name from the principal illand, Niphon; a genus of the family Percidæ.

Nipho'na (Ent.) v'фás, fnow; a genus of Coleoptera.

Niphus (Bot.) vъфá; a fnow-flake; a genus of Ariftolochiaceæ.

Nip'plewort (Bot.) bitter juice applied by country mothers to nipples

before weaning; the Lapfana communis.

Ni'ptus (Ent.) vเттós. walhed; a genus of Coleoptera.

Nisa'na (Ent.) nifus, flight, from its rapid movements.

Niso (Zool.) unexplained; a genus of Mollufca. 
Nisso'lia (Bot.) P. N. in honour of Willian Niffolle, a French botanift; a genus of Leguminof: : alfo the fpecific name of a Lathyrus.

IJi'sus (Ornith.) Lat. flight; applied to the Sparrow-hawk, Accipiter Nijus, perhaps becaufe of its rapid flight.

Nite'la (Ent.) Lat. brightnefs, fplendour; a genus of Hymenoptera.

Nite'lium (Bot.) nitela, brightnefs; a genus of Compofitx.

Nitel'la (Bot.) nitco, to Rint; a genus of Characer, of which the ftems are fometimes tranfucent.

Nitide'lla (Zool.) dim. of nitidus, polifhed; a genus of Mollufca; alio, a genus of Infects.

$\left.\begin{array}{l}\text { Niti'dula } \\ \text { Nitidu'lidæ }\end{array}\right\}$ (Ent.) $\left\{\begin{array}{c}\text { dim. of nitidus, glittering; a genus and family of } \\ \text { Coleoptera. }\end{array}\right.$

Ni'tidus-a-um (Bot.) Phining.

Nitra'ria (Bot.) nitrum, nitre; it is found near the nitre-works in Siberia. Niva'lis-e (Ornith.) Lat. fnowy, e. g., Plectróphanes nivalis.

Niva'ria (Bot.) nivus, fnow; the Leusojum, or fnow.flake; a genus of Amaryllidaceæ.

Nivea'ria (Ent.) niveus, fnowy.

Niveicostel'la (Ent.) niveus, fnowy, cofta, the anterior margin of wing.

Nive'nia (Bot.) P. N. in honour of $\mathcal{F}$. Niven, a collektor of Cape plants.

Niv'eus-a-um (Ornith.) Lat. fnowy, e.g., Nyctea nivea, the Snowy Owl.

Nivive'nter (Zool.) niveus, fnowy, venter, belly; white-bellied.

No'cca (Bot.) P. N. in honour of Dominic Nocca, an Italian profeffor.

Noctilu'ca (Ent.) Lat. a candle; applied to the Glow-worm, Lampyris noctiluca.

Wocti'-vagus (Zool.) Lat.night-wandering; having noeturnal habits, e.g., Spalacopus noctivagus.

Noc'tuæ (Ent.) pl. of noctua, an owl; from their nocturnal habits, applied to the Night-moths.

Noctuli'nia (Zool.) the Noctule or Great Bat.

Noctuo-bomby'cidae (Ent.) having affinities with Nociuce and Bombyces. Noctuomor'pha (Ent.) having the form ( $\left.0_{5} \phi \phi^{\prime}\right)$ of the Noctuce.

Nodosa'lis (Ent.) nodofus, knotty.

Nodosa'ria (Fos. Zool.) nodofus, full of knots; a genus of folfil Foraminifera. Nodula'ria (Zool.) nodulus, a little knot; a genus of Mollufca.

Noeggerath'ia (Fos. Zool.) P. N., a genus of forfil Palm-like leaves.

Noëtia (Zool.) P. N., a genus of Mollufea.

Noise'ttia (Bot.) P. N. in honour of $L$. C. Noifette, a nurferyman at Paris; alfo applied to a clafs of Rofes. 
No'la (Ent.) P. N., a town in Campania in Italy.

Nola'na (Bot.) nola, a little bell; in reference to the corolla; the typical genus of Nolanaceæ.

Nolin'a (Bor.) P. N. from P. C. Nolin, an American botanift.

Noma'da (Ent.) Nomades, wandering people; the Wafp-bees; a genus of Hymenoptera.

Nonag'ria (Ent.) P. N., an inland in the Aggean fea, faid by Pliny to have been the earlier name of Andros.

Non'nea (Bot.) P. N. from 7. P. Nonne, a German botanift.

Nonioni'na (Fos. Zool.) a genus of foflil Nautiloid organifms.

Noran'tea (Bot.) from Gonoro-Antegri, its name in Guiana.

Nordmannia'ruus (Zool., Bot.) P. N. from Alexander von Nordinann, an eminent Prufian naturalift; $e_{.} g .$, Pinus Nordmanniana.

IYorfolcen'sis-e (Zool.) Lat. belonging to Norfolk Inand.

Nor'thia (Zool.) P. N., a genus of Mollurea.

INos'toc (Bot.) unexplained; a genus of terreftrial Algæ.

Nostoca'cex (Bot.) a family of convervoid Algr, of which Noftoc is the type.

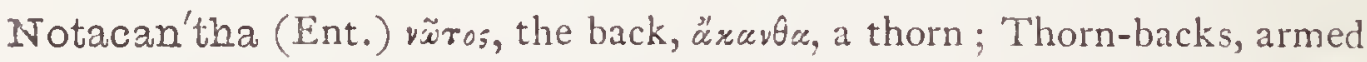
fies

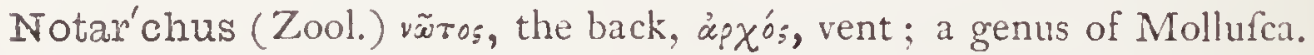

Nota'tus-a-um (Ent.) Lat. marked.

Notelæ'a (Bot.) vótos, the fouth, '̇raía, the olive.

Iutero'plila (Bot.) vorepós, wet, moilt, $\phi i \lambda \hat{s} \omega$, to love; a genus of Melaftomacex.

Noth'ium (Bot.) v:0,s, fpurious; a genus of Orchidaceæ.

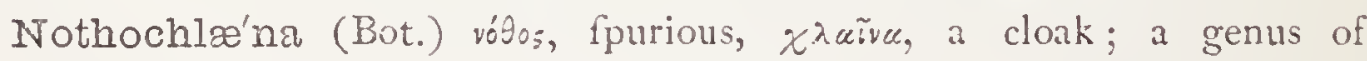
Filices.

Nothoge'nia (Bot.) velo. ývvnros, of fpurious origin; a genus of Ceramian Algx.

INotho'nia (Bot.) vósos, fpurious; a genus of Compofitæ.

IJothosau'rus (Fos. Zool.) vósos, fpurious, oũ̃pos, a lizard.

Nothoscor'dum (Bot.) síbos, fpurious, oxópsov, garlic; a genus of Liliacex.

No'thria (Bot.) vatgós, Auggih ; a fection of the genus Frankenia.

IJo'thris (Ent.) valpós, nuggih.

No'thus (Ent.) vólos, fpurious; a genus of Coleoptera.

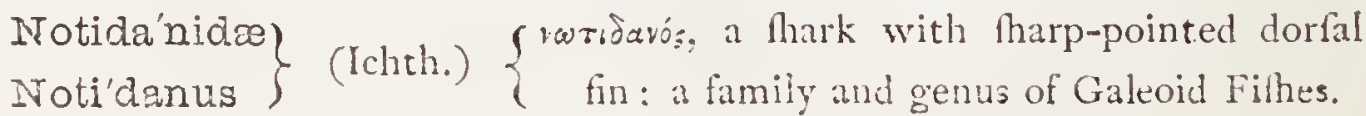


Notid'anus (Fos. Zool.) vẽros, a ridge, idavós, comely; a genus of forlil Shark-teeth.

Notido'bia (Ent.) vinros, the back, B.ow, to live; a genus of the Phryganida.

Notiomi'mus (Ent.) vótros, fouthern rinos, an imitator; a genus of Coleoptera.

Notióphilus (Ent.) vótro5, damp, фiגów, to love; a genus of Coleoptera.

Noto'ceras (Bot.) vĩros, the back, x'spos, a horn; alluding to the back of the pod.

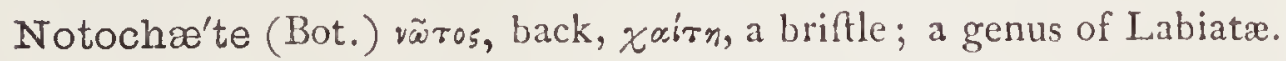

No'tochord (Ichth.) vĩros, the back, chorda; an elaftic gelatinous chord enclofing the myelon in fome filhes.

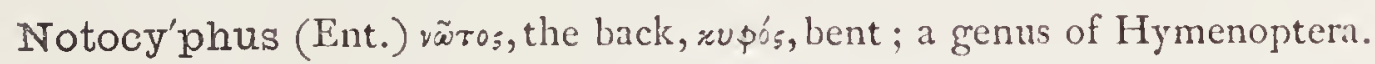
INotode'lphys (Zool.) vî̀ros, the back, $\delta \varepsilon \lambda \phi \dot{v}$, the matrix or womb; a genus of Entomoftraca.

Notodo'nta (Ent.) vĩros, the back, ojov́s, ofovros a tooth; from the toothlike projections on the inner edge of the fore-wings, which meet over the back.

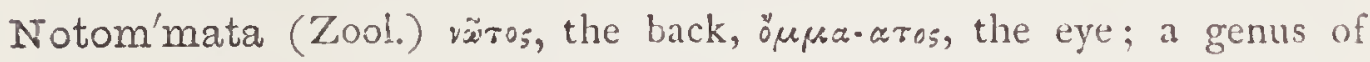
Infuforia.

Notonec'ta (Ent.) väros, the back, v'xxтns, a fwimmer; the Boat-fly.

Notopocory'stes (Fos. Zool.) vãros, a ridge, coryfes, a genus of Cruftacea; a genus of foffil Corals of the Chalk.

No'tops (Zool.) vĩros, the back, $\ddot{\omega} \psi$, the eye.

INoto'pterus (Ichth.) vĩros, the back, rrépov, a fin; a genus of Herringpikes.

Notorhi'zeæ (Bot.) vĩros, the back, $\mathfrak{p}^{\prime} \zeta \alpha$, root; having the cotyledons Aat, and the radicle iffuing from the back; a fection of Nat. Ord. Crucifera.

Notor'nis (Ornith.) vóros, the fouth, öprss, a bird, i. e., the "Southern bird;" a fub-fofil and recent bird of New Zealand.

Notothe'rium (Fos. Zool.) róros, fouth, and Onģov, a wild animal; the fouthern animal; a fornl genus of Aurtralian Quadrupeds.

$\left.\begin{array}{l}\text { Noto'xiaæ } \\ \text { Noto'xus }\end{array}\right\}$ (Ent.) $\left\{\begin{array}{l}v \tilde{\omega} \tau 05, \text { the back, }{ }^{\circ} \xi v_{s} \text {, fharp; the thorax being pro- } \\ \text { duced in front, over the head; is genus and } \\ \text { family of Heteromerous Coleoptera. }\end{array}\right.$

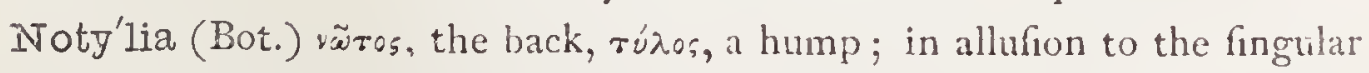
callofity on the ftigma.

Novaculi'na (Zool.) novacula, a razor; a genus of Mollufea.

Noveboracen'sis-e (Ichth.) the Latin adj. for what appertains to New York, North America. 
Nubeculo'sus-a-um (Ent.) Lat. covered with little clouds.

INucifra'ga (Ornith.) nuces, nuts, frangro, to break; the Nut-crackers. 'The Greek equivalent is Caryocatactes.

Nucleoli'tes (Fos. Zool.) nuclezs, a little nut, and $\lambda$ íos, a ftone; a foffil genus of Clypeidx.

Núcleus (Zool.) Lat. a little nut, a kernel.

INu'cula (Zool.) dim. of nux, a nut; a genus of bivalve fhells of the family Arcadx.

$\left.\begin{array}{l}\text { Nucu'lia } \\ \text { Nucu'iidæe }\end{array}\right\}$ (Zool.) nucula, a fmall nut; a genus and family of Mollufca.

Nucunel'ia (Zool.) dim. of nucula; a genus of Mollufca.

Nuda'ria (Ent.) nudus, naked; the wings being only flightly clothed with fcales.

Nudibranchia'ta (Zool.) nudus, naked, branchice, gills; an order of gafteropod Mollufca ; equivalent to Gymnobranchiata.

Nu'dipes (Ornith.) nudus, naked, pes, the foot; naked-footed.

Nudive'nter (Zool.) nudus, naked, venter, the belly; naked-footed.

Nu'dus-a-um (Zool., Bot.) Lat. bare or leaflefs.

Nulli'pora (Zool.) nullus, none, porus, a paflage; applied to corallines having no apparent pores on the furface.

Nume'nius (Ornith.) derivation unknown to me; a genus of Scolopacidie.

$N$. phæopus, and $N$. arquata, are the Whimbrel and Curlew.

Nume'ria (Ent.) P. N., the goddefs of numbers.

Nu'mida (Ornith.) P. N., the Guinea-Fowl is named Numida from Numidiu in Africa, whence it came.

Nummula'ria (Bot.) nummus, money; from the fimilarity of its round leaves to money. Hence alfo Moneywort, Herb-truopence, and Truopenny grafs.

Nummuli'na) nummus, a coin or piece of money; a genus of minute Summuli'tes Animalcules.

Nummuli'tes (Fos. Zool.) nummus, a coin, $\lambda \hat{6}$ Oos, ftone; a large clars of forfil Foraminifera.

Nu'piar (Bot.) Arab. Neufar, the name for Nymphas; a genus of Nymphracex.

Nut (Bot.) Anglc-Sax. Inut; Dan. noot; Srved. noet; Fr. noix.

Nuthe'tes (Fos. Zool.) róvernти́s, a monitor; a genus of fofil Lizards. Nutmeg (Bot.) formerly called normmuge; from Tabl. noce mofazar, muk nut. 
Nuttal'lia (Bot.) P. N. in honour of Thonas Nuttall, formerly Profefior of Mineralogy at Cambridge, New England, who died in 1858 ; a genus of Malvacex.

Nuy'tsia (Bot.) P. N., the celebrated "Fire-tree" of Auftralia; a genuss of Loranthacer.

Nyctage'1la (Bot.) dim. of Nyctago; a fection of the genus Nicotiana.

isyctagina'cer (Bot.) an order of plants of which Nyctugo is the type.

Nycta'go (Bot.) dim. of w⿳, vuxrós, night; the plant called Marvel-ofPeru.

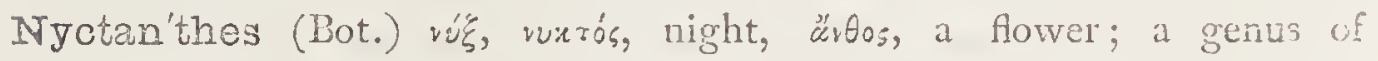
Jarninaceæ.

Nyc'tea (Ornith.) v'̌́s, vurrós, night; $N$. nivea is the Snowy Owl.

Nycte'gretes (Ent.) vurnyp's-ns, watching by night; from the nocturnal fight of the moth.

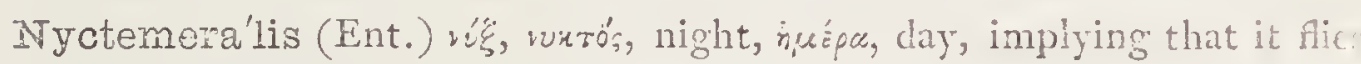
at both periods.

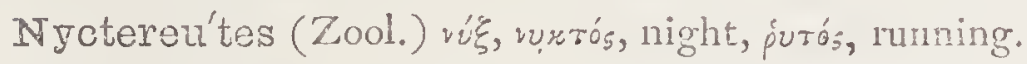

Nycteri'bia (Ent.) vurriṕs, a night-bird, fić; life; a genus of wringleis infects parafitic on the Cheiroptera.

IJgcterinia (Bot.) vúxrepos, nocturnal; fragrant only after dark; a gunus of Scrophulariacer.

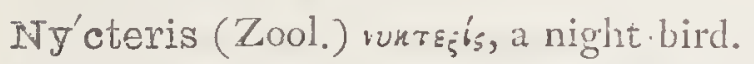

Nycterisition (Bot.) wurep's, a bat, estiov, food; referring to the flower. Nycte'rium (Bot.) vúrsepos, nocturnal; alludirg to the time of Alwering. Nycthe'merus (Ornith.) vís, vuró; night, ipuśpa, day, e.g., Phafianus Nycthemerus, the Silver Pheafant.

Nyctíbius (Ornith.) v'̌, vurós, night, ếos, life; a ggenus of Goatfuckers. Nyctice'bus (Zool.) víz, vustós, night, sйßus, an ape.

INyctico'raz (Ornith.) )

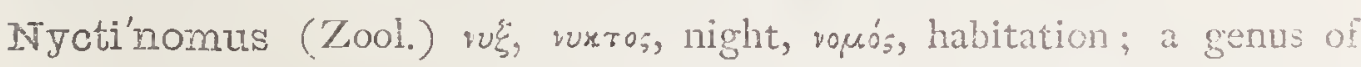

Night-prowling mammalia.

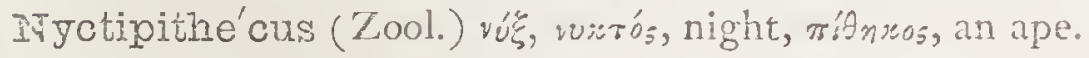

IJyctisau'ra (Zool.) vúg, wxrós, night, oxüpos, a lizard; the Nociurnal lizards.

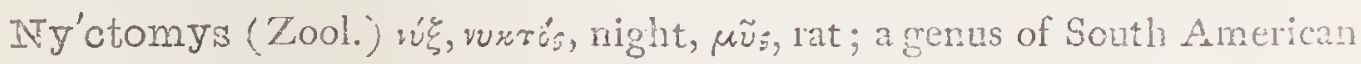
Miammalia.

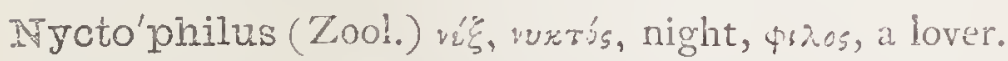

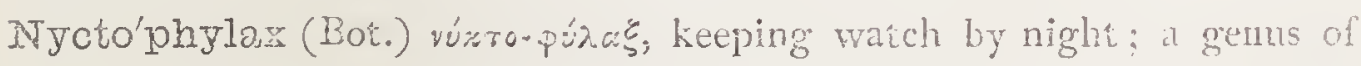
Zingiberacex. 
Ifyland'tia (Bot.) P. N., the fame as the genus Mundit.

Nylghau (Zoo!.) a Perfran word, meaning Blue Ox.

Ny'mpha (Ent.) vís a a chryfalis or pupa.

Nympha'a (Bot.) vús $\$ n$, a Water-nymph; referring to its habitation.

The $N_{y m p h a a}$ Lotus was the Egyptian lotus of the ancients; the typical genus of the fplendid aquatic order Nymphæacer.

Nymphrea'ceæ (Bot.) an order of Dicotyledonous plants, of which Nymphas is the type.

Iymphx'anthe (Bot.) vúrфn, a nymph, ävoos, a flower; the fame as Villarfia ; a beautiful aquatic genus of Gentianaceæ.

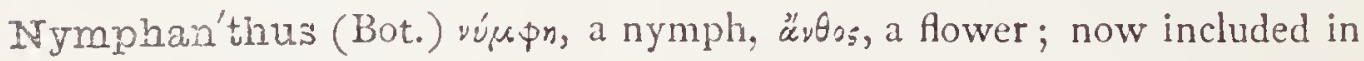
the genus Phyllanthus.

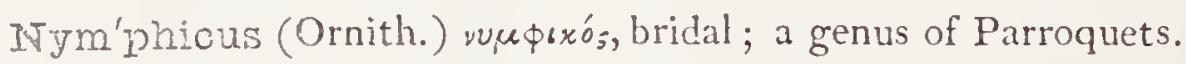

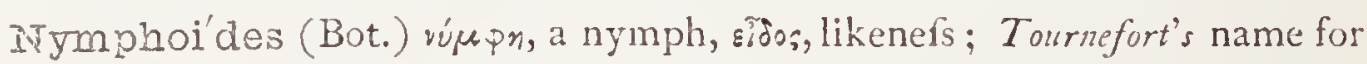
the Limnanthemum.

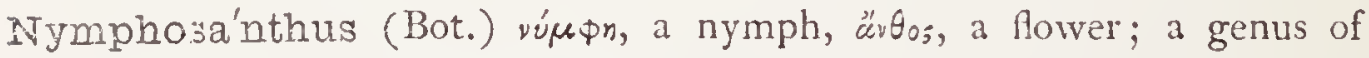

Nymphracex, now included in Nuphar.

Ny'pa (Bot.) P. N., the name of a nymph; the Tupelo; a genus of Alangiacen.

Nys'sa (Bot.) probably the name of a Water-nympli; alluding to its

habitation; the Tupelo.

Nys'sia (Ent.) P. N, flom Nyfa, the birthplace of Bacchus; or from v'́zรเv, to pierce or prick, as its briftly thorax might do.

INys'son (Ent.) vic=a;, to prick or pierce; a genus of Hymenoptera.

Nysson'icic (Ent.) a family of foforial Hymenoptera, of which Nyfon is the type.

Nysta'lea (Ent.) wขว taג'os, drowfy.

Oak (Bot.) Anclo-Sax. ac, ac; query, connected with oculus.?

Obelis ca (Ent.) obeliscus, a fmall fpit; from the mark ( $i$ ) on the forewings.

Obelisca'ria (Bot.) oßzдirrss, a pointed pillar, from the conical form of the receptacie; a genus of Compolitx.

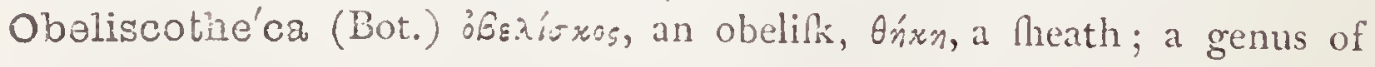
Compolitr.

Obero'nia (Bot.) P. I. from fairy mythology; a genus of Orchidacex. Obe'sia (Bot.) obefus, fat, in allufion to the flowers. 
Obe'sus-a-um (Zool., Bot.) Lat. fat, plump.

Obi'one (Bot.) P. N., a genus of Chenopodiacex.

Obla'tus-a-um (Zool.) Lat. broader than long.

Obliqua'ria (Ent.) obliquas, oblique; referring to the oblique dark brown bar acrofs the wings.

Oblonngus-a-um (Zool., Bot.) Lat. rather long, longer than broad; e. g., Succinea oblonga.

Obola'ria (Bot.) obslus, an ancient coin; a genus of Orobanchacex.

Obova'tus-a-um (Bot.) Lat. egg-hhaped, as to outline.

O'brium (Ent.) öß pra, the young of animals; a genus of Coleoptera, family Cerambycidx.

Obscu'rus-a um (Zool.) Lat. indiftinct, obfcure, ufed with reference to colour, form, or relations; e.g., Bulimus objcurus.

Obsole'tus-a-um (Zool. Bot.) Lat. worn out, poor.

Obtusilin'gues (Ent.) obtufus, blunt, lingua, tongue; a fub-family of Hymenoptera, fo called by Weftwood from the bluntnefs of their tongues.

Obtu'sus-a-um (Zool., Bot.) Lat. blunt, dull, rounded off.

Obvolu'tus-a-um (Zool. Bot.) Lat. folded, tied about; e.g., Helix obvoluta.

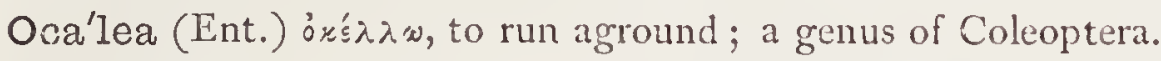

Occidenta'lis-e (Zool., Bot.) Lat. weftern, relating to the welt, with particular reference to America.

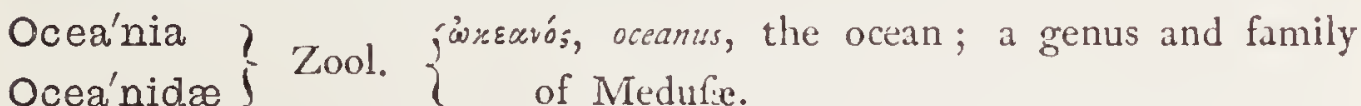
Ocella'ria (Fos. Zool.) ocelliss, a little eye; a foffil Zoophyte of the chalk.

Oce'anus (Zool.) fame derivation; a genus of Nautilidr.

Ocella'tus-a-um (Zool., Ent.) Lat. covered with eye-like fpots.

Ocellura'ria (Bot.) ocellis, a little eye; a genus of Lichenes.

O'celot (Zool.) ocellus, a little eye, from the beautiful eye-like markings of the fur.

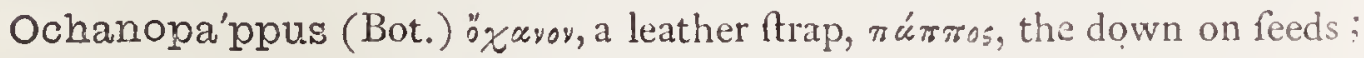
a genus of Compofitre.

Ocheto'phila (Bot.) oxzros, a ditch or canal, $\phi \lambda^{\prime} \leqslant a$, to love; a genus of Rhamnaceæ.

Och'na (Bot.) Greek name of the wild pear, to which it has fome refemblance. 'The typical genus of Ochnacer.

Ochna'cere (Bot.) the Button-flower family of plants, of which Ochna is the type. 
Ochra'ceus-a-um (Ornith., Bot.) ̋̋xpós, pale-yellow, e.g. Campephaga ochiracea.

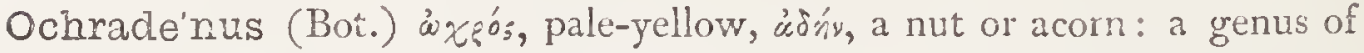
Refedacex.

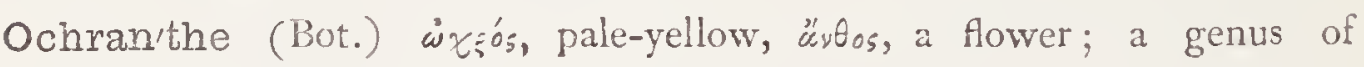
Cunoniacer.

Ochrea'ta (Ent.) ochreus, ochre-yellow.

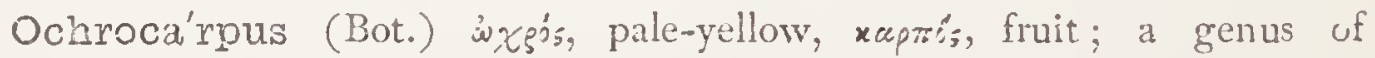
Clusiacex.

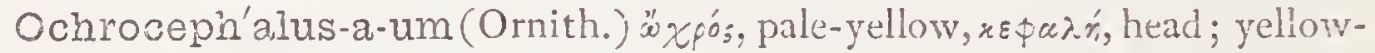
headed, $e \cdot g$. Mufcicapa ochrocephala.

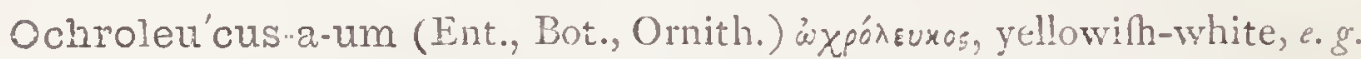
Sylvia ochroleuca.

Ochro'ma (Bot.) ¿̇xfós, fallow; a genus of Sterculiace:e.

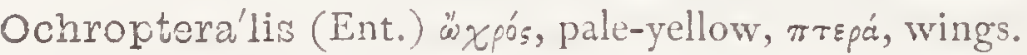

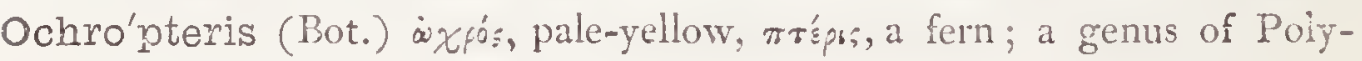
podioid Filices.

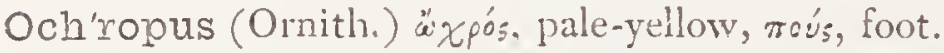

Ochrosan'thus (Bot.) a'xvós, pale-yellow, $\alpha^{2} \theta_{0,5}$, a lower; a feetion of the genus Gooderia.

Ochro'sia (Bot.) پ’x,ós, pale-yellow.

Ochro'stoma (Bố.) ̈̈xfós, pale, rtórec, a mouth.

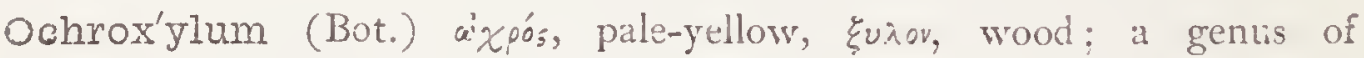
Xanthoxylacex, now included in Xanthoxylon.

O'chrus (Bot.) $\ddot{\omega} x$ fós, pale; referring to its pale muddy-coloured flowere.

Ochsenheime'ria (Ent.) P. N. in honour of Ferdinand Ochfenkeimer, who died in 1822 .

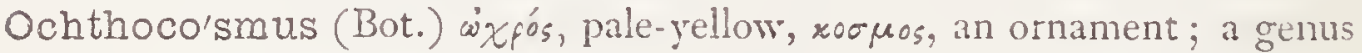
of 'Ternftrömiacere.

O'cimum (Bot.) fame as Ocymum, q. v.

Ocke'nia (Bot.) P. N. in honour of the celebrated Oken; a genus of Rutacex, now included in Adenandra.

Ocnero'stoma (Ent.) oxympos, ufelefs, oróua, the mouth.

Or'nus (Zool.) oxios, hefitation, flugginness.

O'crea. (Bot.) Lat. oura, a boot; the name applied to the united ftipules which form a theath round the ltem in the family Polygonacex.

Octac'bis (Zool.) oxtá, cight, árís, a ray.

Octade'nia (Bot.) crtú, eight, àdry, a gland or acorn; a genus of Crucifcre.

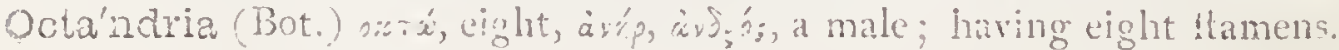


Octarillum (Bot.) on rá, eight, arilhs, a feed-covering; a genus of Santalacex.

Octa'via (Bot.) P. N., a genus of Cinchonacere.

Octavia'na (Bot.) P. N., a genus of Fungi.

Octhe'bius (Ent.) ox日n, a bank or Thore, frow, to live; a genus of Coleoptera.

Cctho'dium (Bot.) ' $\chi^{\vartheta \omega}$ 's ns, warted; referring to the furface of filicles

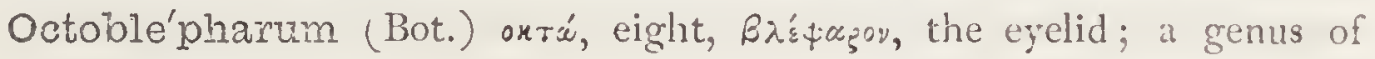
Bryoid mufci.

Octobo'thrium (Zool.) 'ser ́́, eight, fóspos, a pit, having four cup-Ahapad depreffions on each fide of the hody; a genus of Entozoa.

Octọdi'ceras (Bot.) ortẃ, eight, díxepus, a double-horn; a genus of Bryoid murci.

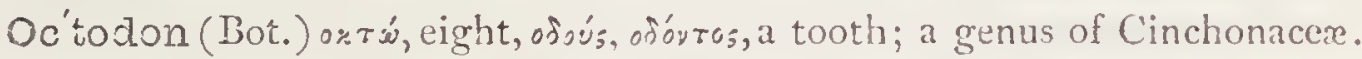
Oc'todon (Zool.) óntú, eight, ódvus, ófovt'ss. a tooth; a genus of Rodent animals.

Octogy'nia (Bot.) orrẃ, eight, yuv́n, a female; having eight piftils.

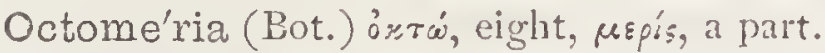

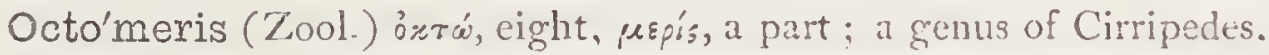

Octonoculi'na (Zool.) octo, eight, oculıs, an eye; a tribe of Spiders.

Octo'pera (Bot.) ortẃ, eight, $\pi s_{p} \alpha s$, an extremity'; a fection of the genus Eriva.

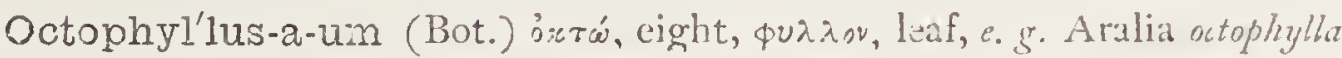
Octoplica'tus-a-um (Zool, ) Lut. eight-folded.

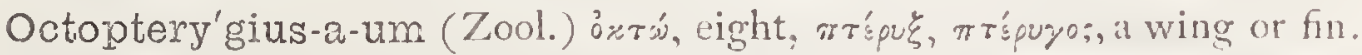

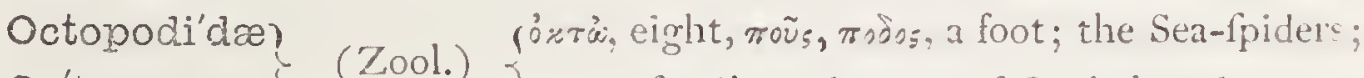
oc'topus $\}$ (Zool.) $\{$ a family and genus of Cephalopods.

Ocula'tus-a-um (Zool.) Lat. having eyres, or eye-like fpots, e. g. Cellepora oculata.

Ocu'lea (Ent.) oculis, an cye; on account of the confpicuous figma.

Oculi'ferus-a-um (Zool.) oculus, an eye, fero, to bear; e.g. Emysoculifera.

Oculina (Zool.) oculus, an eye; a genus of Corals: 0 . virginea is the common White-branched coral.

Oculi'nus-a-um (Zool.) Lat. full of eyes, or cye-like fpots.

Ocy'alus (Ornith.) wrúcגos, fwift.

Ocy'dromus (Zool.) '́rìs, quick, Spónos, flight, efcape; applied to the Kangaroo.

O'cymum (Bot.) $\omega^{\prime} \omega$, to fmell, it has a poiverful fcent; Bafil; a gentis of fragrant Labiatix.

O'cyphaps (Ornith.) ouśs, fwift, tót, a wild pigeon. 


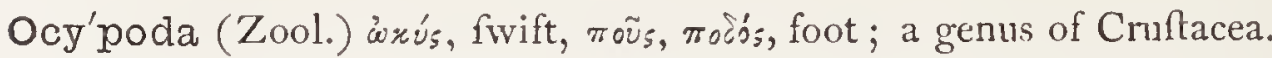

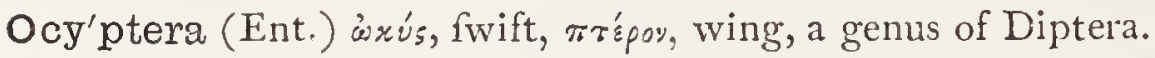

Ocy'pterus (Ornith.) fame derivation; a genus of the Laniad:e.

O'cypus (Ent.) ́xú́, fwift, тo $\widetilde{v}_{5}$, foot; a genus of Coleoptera.

O'cys (Ent.) Wxú;, fwift; a genus of Coleoptera.

Ocythö (Zool.) P. N. in Mythology; a genus of Mollufca.

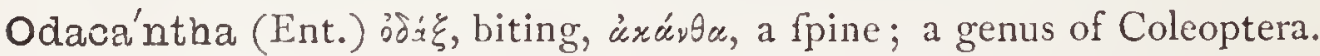

Odax (Ichth.) ósá, biting.

Odone'ctis (Bot.) isó, a path, vия

Odones'tis (Ent.) according to Agaffiz, ơdoús, a tooth, ขñorเs, hunger; perhaps from its voracity.

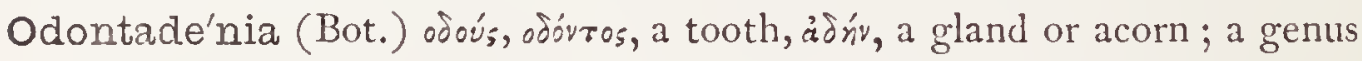
of Apocynacex.

Odontanthe'ra (Bot.) odoús, odórros, a tooth; anthera; a genus of Afclepiadacex.

Odontarrhe'na (Bot.) odoús, ofórros, a tooth, äpprr, a male (ftamen); having toothed ftamens; a genus of Cruciferæ.

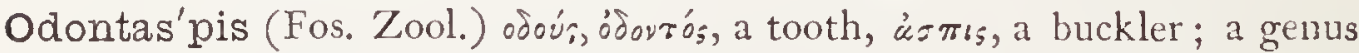
of Shark-like Fithes, fo termed from the buckler-like afpect of their teeth, the only portions yet known.

Odonte'lla (Bot.) odoús, odorros, a tooth, with diminutive terminal; a genus of Algre.

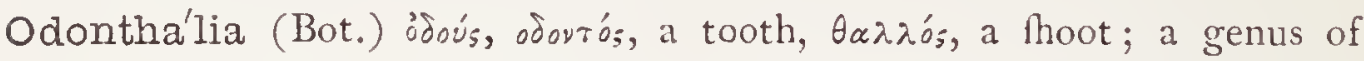
Cryptogamia.

Odonti'dium (Zool.) odoús, odovtós, a tooth, Eidos, likenefs; a genus of Infuforia.

Odo'ntia (Ent.) ofoús, sonvos, a tooth; from the toothed ftreaks and marks upon the wings.

Odo'ntia (Bot.) odoús, odorros, a tooth; a genus of Fungi.

Odon'tida (Ent.) the family of which Odontia is the type.

Odonti'tes (Bot.) odoús, odovtoi, a tooth; fpecific name of a fpecies of Bartfia.

Odontoca'rya (Bot.) odoús, ojovros, a tooth, záfuov, a nut, i. e., having indented nuts; a genus of Menifpermaceæ.

Odontocy'clus (Bot.) odoús, ofórros, a tooth, xúrnos, a circle; a genus of Cruciferæ.

Odonto'des (Ent.) the genus Odontia, zidss, likenefs.

Odontodis'cus (Zool.) josós, ojovros, a tooth, disxoj, a round plate; a genus of Infuforia. 


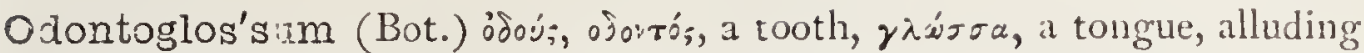
probably to the cre?t of the labellum.

Odontogna'tia (Bot.) ódoús, odórros, a tooth, grátos, a mouth; a genus of Compolita.

Odontogna'thus (Ichth.) ojoús, odóvtós, a tooth, yvádos, a mouth; a genus of Clupeoid Filhes.

Odontolépis (Bot.) jooús, ofóvros, a tooth, $\lambda \varepsilon \pi i s$, a fcale; a genus of Compolitæ.

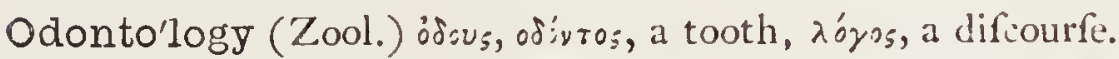

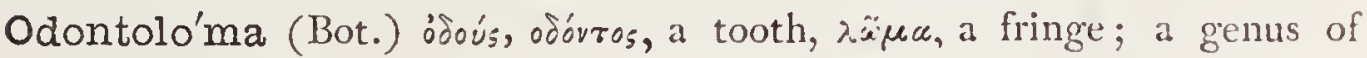
Compolitix.

Odontolo'phus (Bot.) ódoú, odovros, a tooth, rópos, a cre?t; a gellus of Compolitæ.

Odon'tomus (Zool.) ódoús, joórrós, a tooth, róun, a cutting; a genus of Colubrine ophidians.

Odontone'ma (Bot.) ofoús, ofórtos, a tooth, iñec, thread; a genus of Acanthacex.

Odon'tonyz (Ent.) ojoú;, s'ószos, a tooth, ovuk, a claw.

Odonto'pera (Ent.) odoús, obovros, a tooth, mépas, an end, a boundary; the margin of the wings being toothed.

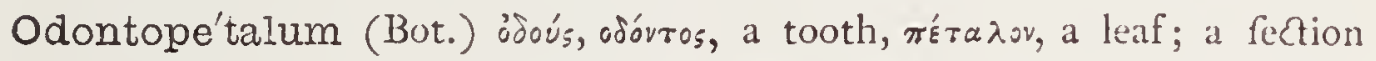
of the genus Monfonia, Nat. Ord. Geraniacese.

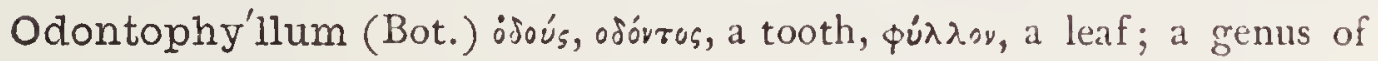
Compolitæ.

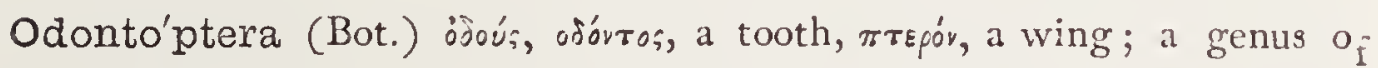
Compolitæ.

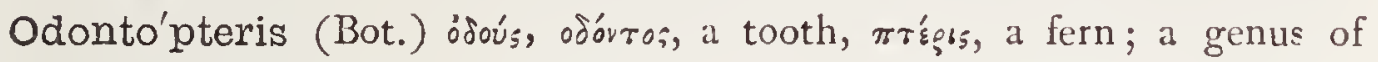
Polypodioid Filices; alfo applied to a genus of foffil Ferns, from the blunt tooth-like lobes of their leaflets.

Odontoschi'sma (Bot.) idoús, odórros, a tooth, $\sigma$ xi $\sigma \mu \alpha$, a divifion; a genus of Jungermanniaceie.

Odontoso'ria (Bot.) ódoús, ofóyros, a tooth, rapós, a heap, i. e. the fori; a genus of Polypodioid Filices.

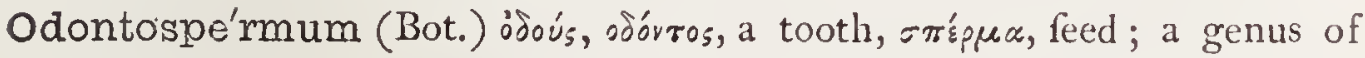
Compofitæ.

Odontostem'ma (Bot.) ódoú, ofóvros, a tooth, $\sigma \tau \varepsilon \mu \mu \alpha$, a wreath; a genus of Caryophyllacex.

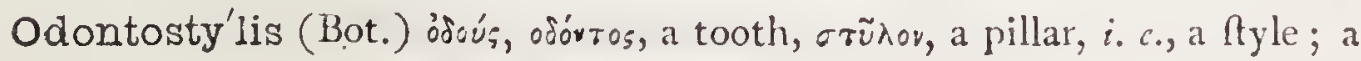
genus of Orchidacer. 
Odonto'trichum (Bot.) odoús, odórros, a tooth, $\theta_{\rho \circ} \xi$, róizos, hair; a genus of Compofitx.

Odosto'mia (Zool.) odoús, a tooth, бróra, a mouth; a genus of Molluf́a.

Ody'nerus (Ent.) ooviefós, painful, alluding to the fting; a genus of Plymenoptera.

Gern'thus (Ent.) oiros, a house, $\ddot{u} \nu \theta_{0}$, a flower; from the circumfance of this American fpecies of cricket living among flowers and not upon the ground.

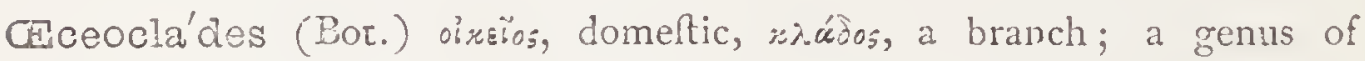
Orchidacea.

CGchmea (Bot.) fame as Fichmea, which latter is the cornect fpelling.

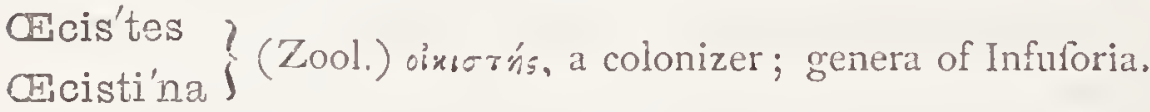

Geo'doma (Ent.) oirodónos, a houfe-builder; a genus of Ants.

ceoge'nia (Ent.) oixryev's, born in the houfe; the moth occurs in houfes.

CEco'phora (Ent.) oinos, a houle, фopäru, to carry; the Cafe-bearers.

AEda (Ent.) oidoc, a fwelling: a genus of Homoptera.

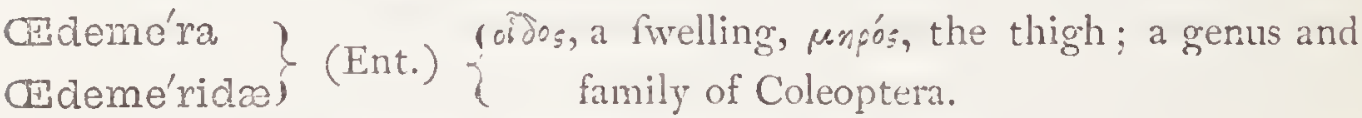

G Je'mium (Bot.) o’onuc, a tumour; a genus of Fungi.

Gde'ra (Bot) P. N. in honour of George Eder. a Dane, Profeffor of Botany

at Copenhagen; a genus of Compofita.

Ede'ria (Bot.) sids'w, to fwell; a genus of Compofitie.

CEdicne'mus (Ornith.) obdsew, to fwell, жvnun, the leg: the 'Thick-knee.

G dipa'chne (Bot.) ç̃os,a fwelling, üxrn, chafi (awn); a genus of

Gramina.

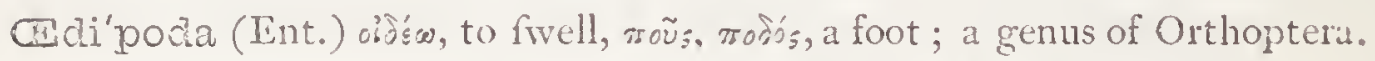

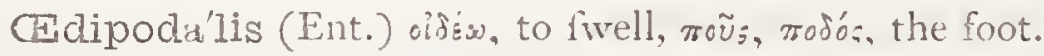

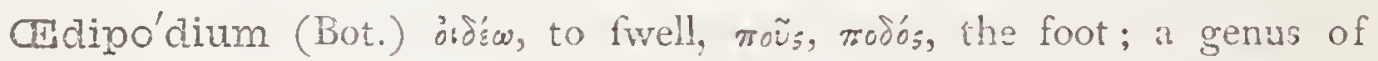
Cryptogamia.

Chlmanniel'la (Ent.) P. N. in honour of CElmann, an Entomologift of Leipfic, the difcoverer of the fpecies.

G Enan'the (Bot.) orros, wine, üros, flower ; alluding to the odour; a genus of Umbellifera. The oiveren of Theophraftus and Diofcorides was probably Ginanthe pimpinelloides.

G'nas (Ornith.) the Greek name of a wild pigeon, of the colour of ripening grapes, from sivvos, wine; now ufed as the fpacific name of the Stock-doves. 
Gesnec'tra (Ent.) öun, the vine, śxтpißssu, to defiroy.

Ginocar'pus (Bot.) oivos, wine, xaptós, fruit; a genus of South American Palms.

Gnoph'ila (Ent.) oivos, wine, síros, loving; found in wine-cellars, the larva feeding on the corks of the bottles.

Enothe'ra (Bot) oĩvos, wine, Aripa, a catching; the Evening Prinurofe; fonamed becaufe the roots are faid to fmell like wine; and the ancients fuppofed that, when mixed with drink, they poflefled the power of calming the mof ferocious animals. Our CEnothera is not the genus to which 'Theophraftus applied the name, being wholly American.

CEsirus (Ent.) ois rpos, the Gad-Aly or Breeze-fly; a grenus of Diptera.

G'thra (Zool.) etymology obfcure; a genus of Cruftacea.

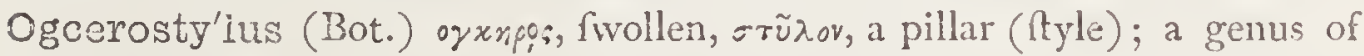

Compofitie.

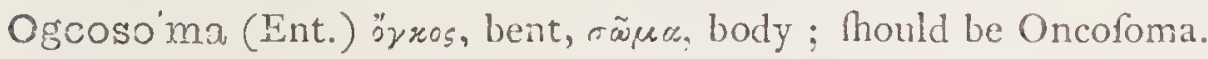

Ogie'ra (Bot.) P. N., a genus of Compofitie.

O'gilfa (Bot.) P. N., a genus of Compofitie.

Ogy'gia (Fos. Zool.) P. N. from Ogyges, the Greek monarch; a genus of

Silurian trilobites.

Ohlendor'fia (Bot.) P. N., a genus of Scrophulariacer.

Oiceopto'ma (Ent) Dirsios, domeftic, $\pi$ rōer calamity.

Oide'mia (Ornith.) ob́snuce, a fwelling; it fhould be CElemiar; a genus of Ducks.

Oídium (Bot.) oiféa, to fivell ; from its wonderful power of rapid growth :

a genus of parafitic Fungi.

Oiosper'mum (Bot.) oio, alone, stéprea. fed; a genus of Compofitæ.

O'lax (Bot.) $\tilde{\omega} \lambda \alpha$, a furrow, referring to the flowers; typical genus of Olacacex.

Oldenbur'gia (Bot.) P. N., a genus of Compofitr.

Oldenla'ndia (Bot.) P. N., given by Linneus in honour of $H$. $B$. Oldenland, a Dutch Naturalin, who travelled in Africa.

Oldha'mia (Fos. Zool.) P. N. in honour of Profefior Oldham, of Dublin; a genus of Silurian zoophytes or polyzoa.

O'lea (Bot.) Exacia, the Olive-tree, which was facred to Athena; the typical genus of Nat. Ord. Oleacex.

Olea'cez (Bot.) the natural family of plants of which Olea is the type.

Olea'ster (Bot.) Lat. the Wild Olive-tree; the Elcagnus.

Olera'ceus-a.um (Bot.) Lat. refembling herbs (from olus, cabbage, colewort): Areca oleracca, the cabbage-paim of the Went Indies has 
acquired its name from the practice of cutting off the young buds and cooking them like coleworts.

Olfe'rsia (Bot.) P. N., a genus of Polypodioid Filices.

Oliga'crion (Bot.) oגíyos, few, äxooc, a filmmit; a genus of Compofitæ.

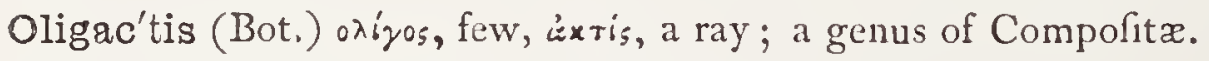

Oligac'tis (Zool.) òiryos, few, àrrís, a ray.

Oligan'dra (Bot.) oxígos, few, ávńp, ávóós, a male (Itamen); a genus of Compolitx.

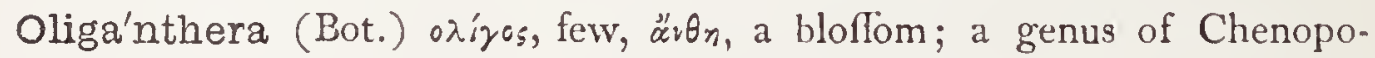
diacex.

Oliga'nthes (Bot.) oxíros, few, àvos, a flower; a genus of Compofitæ.

Oligarrbe'na (Bot.) oגíros, few, üp’p̀v, a male (ftamen); a genus of Epacridaceæ.

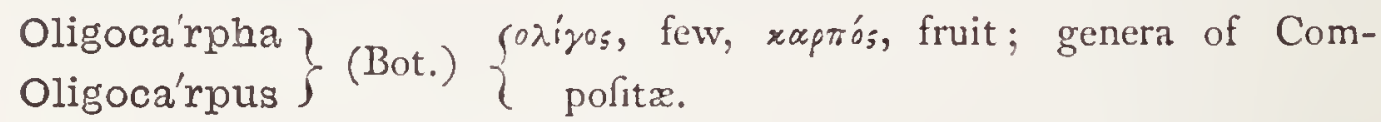
Oli'gocene (Fos. Zool.) òirgos, fmall, xasvos, recent; applied by M. Beyrich to certain beds a little more recent than Eocene.

Oligochre'ta (Bot.) ỏíros, few, xairn, a lock of hair; metaphorically, foliage: a genus of Compofitæ.

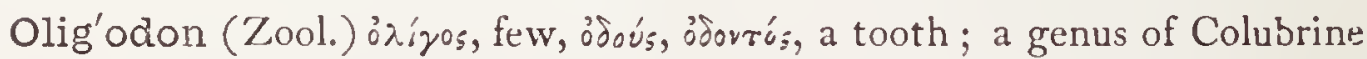
ophidians.

Oligodo'ra (Bot.) òíros, few, düpor, a gift; a genus of Compofitx. Oligogy'ne (Bot.) ỏíros, few, guin, a female (piftil); a genus of Compolita.

Oligo'lepis (Bot.) ỏ $\lambda_{i}^{\prime}{ }_{5}$, few, $\lambda \varepsilon \pi i_{5}$, a fcale; a genus of Compofitæ.

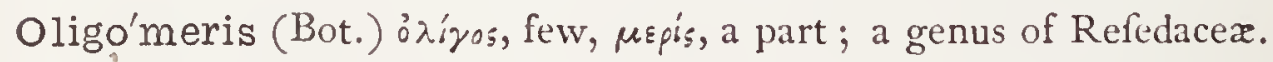

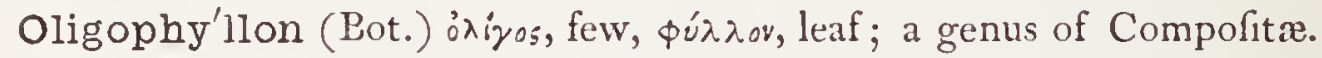
Oligo'rus (Ichth.) o $\lambda$ เrapśa, to efteem lightly; Dr. Günther's name for 2 genus of Ctenoid Acanthopterous fithes.

Oligosporus (Bot.) òíros, few, orópos, feed; a genus of Compofitx. Oligostig'ma (Ent.) o’íros, fmall, $\sigma \tau i$ 're $\alpha$, a mark.

Oli'gota (Ent.) ỏíros, fmall.

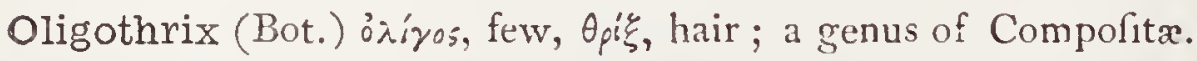

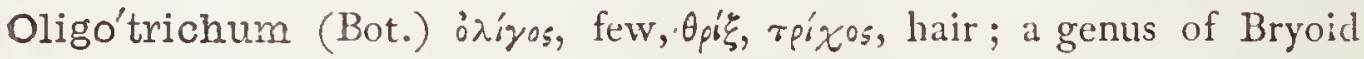
Mufci.

Olin'dia (Ent.) P. N., a town of South America, near Pernambuco. Olistophus (Ent.) ö $\lambda_{s} \sigma \theta_{n s}$, fmoothnefs; a genus of Coleoptera.

Oli'va (Zool., Bot.) Lat. the olive; in Zoology, a genns of Mollufca, popularly called the Olive-flell; in Botany, the Olive-plant. 
Oliva'ceus-a-um (Bot.) Lat. olive-coloured; e.g., Mufcicapa olivacea, a fy-catcher.

Olive (Bot.) Lat. oliva, an olive-plant.

Olive'ria (Bot.) P. N. in honour of G. A. Olivier, a French botanift.

Oliveto'rum (Ornith.) gen. pl. of olivetum, an olive-yard, that being the bird's frequent refort.

Oli'via (Bot.) P. N., a genus of Fucoid Algx.

Olme'dia (Bot.) uncertain derivation; a genus of Artocarpaceæ.

O'Iophrum (Ent.) ónoфuńs, confifting all of one piece; a genus of Coleoptera.

Olusa'trum (Bot.) olus, a pot-herb, ater, black, alluding to the colour of the fruit; specific name of the Smyrnium Olufatrum, or "Alexanders ;" a genus of Nat. Ord. Umbellifer $x$.

Oly'mpia (Bot.) P. N., a genus of Hypericacex.

Olyn'thia (Bot.) ò $\lambda u r \theta_{0}$, an unripe fig.

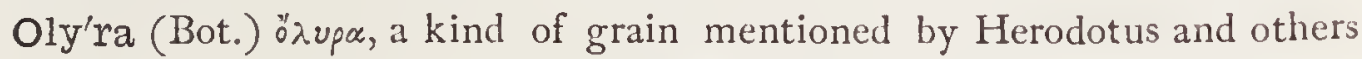
as food for horfes, along with barley.

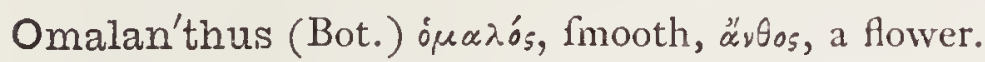

Omala'xis (Zool.) o $\mu a \lambda_{o}$, fmooth, axis; a genus of Mollufca.

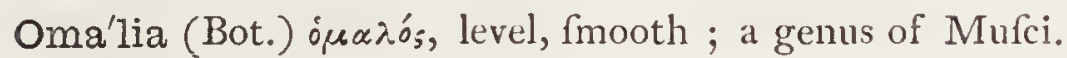

$\left.\begin{array}{l}\text { Omali'iðæx } \\ \text { Oma'lium }\end{array}\right\}$ (Ent.) $\left\{\begin{array}{c}\text { ósás, level, fmooth; a family and genus of } \\ \text { Coleoptera. }\end{array}\right.$

Oma'lipus (Ent.) ojacios, fmooth, тог̌s, foot; a genus of Coleoptera.

Omali'sus (Ent.) a genus of Coleoptera.

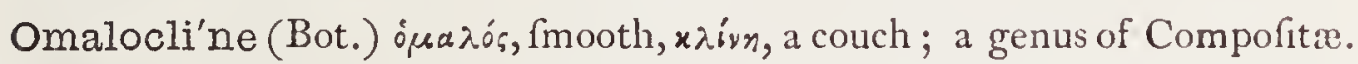

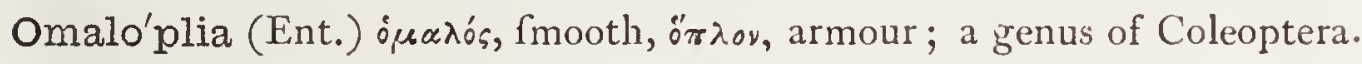

Omalothe'ca (Bot.) iscanos, fmooth, $\theta \dot{n} x n$, a theath; a genus of Compofita.

Oma'seus (Ent.) or ás, the whole?

Om'bria (Fos. Zool.) opßpos, a thower of rain; a name formerly applied to foffil Sea-urchins, fuppofed to have fallen from heaven in howers.

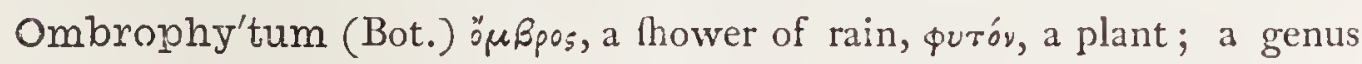
of Balanophoracex.

Omi'a (Ent.) '̇u'cu, a projection as of a wing or fhoulder.

Omi'as (Ent.) Wuras, broad-fhouldered; a genus of Coleoptera.

Omicrona'ria (Ent.) o $\mu$ sжóv, the little o; the wings are marked with an o-like circle.

Omio'des (Ent.) refembling the genus Omia.

Ommastre'phes (Zool.) örfec, the eye, srpśpw, to turn; a genus of Cephalopods 


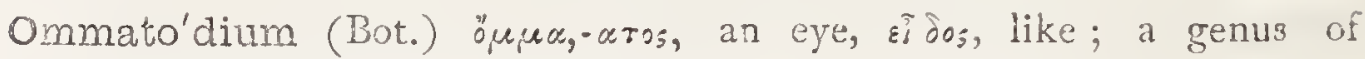
Orchidacex.

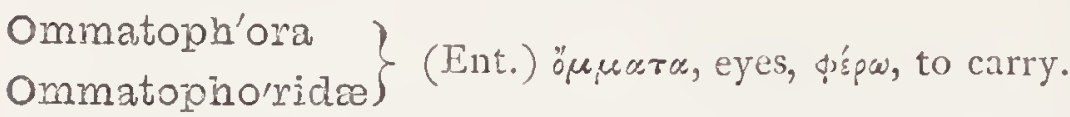

Omce'a (Bot.) öruobs, refembling; a genus of Orchidacex.

Omo'phius (Ent.) órópлasos, bark-like; a genus of Coleoptera.

Omophro'nides (Ent.) ócúłpary, agreeing, united; a genus of Coleoptera.

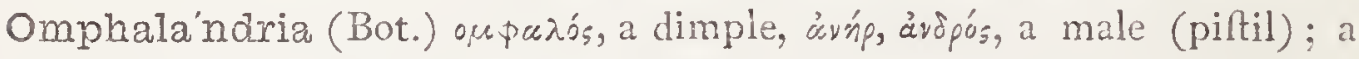

genus of Euphorbiacere.

Ompha'lea (Bot.) ókparos, the navel; having umbilicated anthers.

Ompha'lia (Bot.) ouparó;, a navel, from the depreffion in the centre of pileus; a genus of Fungi.

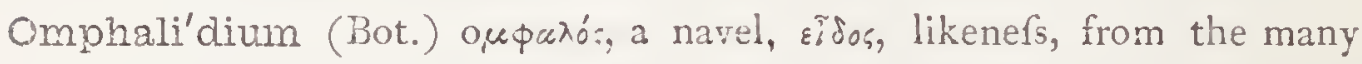
cavities; a genus of Lichenes.

Ompha'lium (Bot.) ouфaxos, a navel; from the form of the fruit; a genus

of Bornginacer.

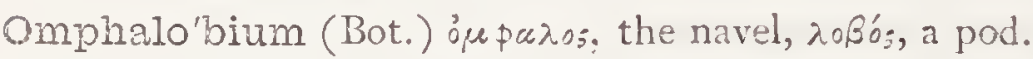

Omphaloca'rpum (Bot.) ouфaiós, a navel, жúprós, fruit; a grenus of Sapotacex.

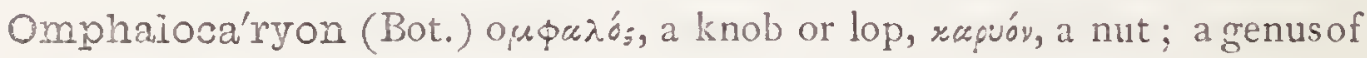
Ericacex.

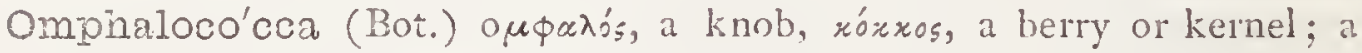
genus of Verbenactex.

Omphalo'des (Bot.) ós ụanos, a navel, sidos, like, referring to the feeds; a genus of Boraginacex.

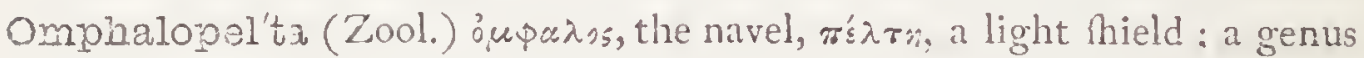
of Infuforia.

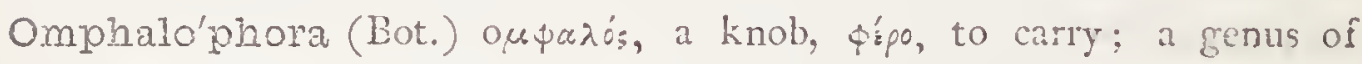
Mufci.

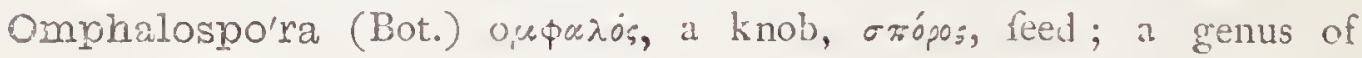
Scrophulariacex.

Omphalostig'ma (Bot.) oupanós, al knob, origua, a mark or fpot (Aigma); a genus of Gentianacex.

O'nagra (Bot.) named from the wild afs (ว̆yos äypros) probably because it was thonght to feed on the plant; a genus now included in Enothera.

Onagra'ceæ (Bot.) the natural family of plants of which Onagra is (or rather was) the type; the Fuchfra family.

On'chus (Fos. Zool.) orro;, bent or hooked; applied by Agaffiz to a genus of foffil Filhes. 
Oncid'ium (Bot.) öyrobsv, a little tubercle: plants belonging to this genus have warts, tumours, or other excrefcences at the bafe of the labellum; a genus of Orchidacex.

Oncine'ma (Bot.) oy:oos, a hook, vripsa, a flament; a genus of Asclepiadace:2.

On'cinus (Bot.) oyxivos, a hook; a genus of Myrsinacex.

Oncoby'rsa (Bot) oyros, a hook, Búpra, a hide, a theath; a genus of Algæ.

Onco'cera (Ent.) öyros, a mafs, xispas, a horn; the males have a mafs of fcales at the bafe of the antenna.

Oncoga'sira (Bot.) oy*os, a hook, yasríp, belly; a genus of Gefneracex. Oncome'ra (Ent.) orros, a turcour, $\mu n$ pos, the thigh; a genus of Coleoptera.

Onco'phorus (Bot.) oyros, a hook, $\phi^{\prime}$ fpew, to carry; a genus of Mufci.

Oncorhi'nus (Ent.) "ryos, a tumour, pov, the fnout; a genus of Hymenoptera.

Oncorhy'nchus (Bot.) oyxos, a hook, jryxós, a beak; a grenus of Scrophulariacex.

Oncosperma (Bot.) cyros, a hook, ortepux, feed; a genus of Palmx.

Oncosphe'nia (Zool.) öyros, a hook, opńn, a wedge; a genus of Infuforia.

Oncospo'rum (Bot.) cyros, a hock, ortóps, feed; a genus of Pittofporacex.

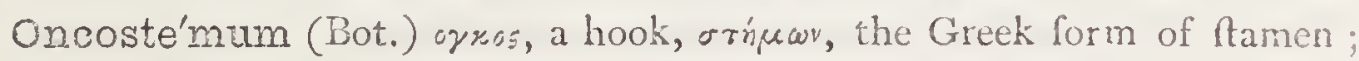
a genus of Myrfinacex.

Oncosty'lis (Bot.) cyros, a hook, $\sigma \tau \tilde{\nu} \lambda c v$, a pillar (ftyle); a genus of Cyperacex.

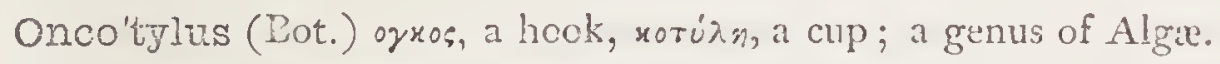

On'cus (Bot.) oy:os, a hook; a genus of Liliacex.

Onei'liia (Bot.) P. N. in honour of $M r$. O'Neill; a genus of Alga.

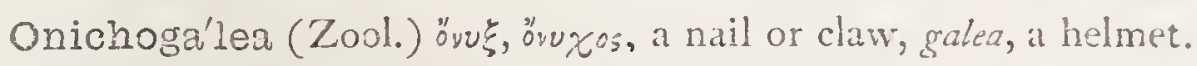

Onion (Bot.) from Fr. oignon, which perhaps from unis, one, the root having no offsets.

Onis'cus (Zool.) byiszos, the wood-loufe.

Onobro'ma (Bot.) òvos, an afs, Bpĩuse, food; affies are fond of it.

Onobry'chis (Bot.) 'oros, an afs, Bpúxw, to gnaw; in allufion to the fond-. nefs of cattle for the plants; Saint-foin; a genus of Leguminofid.

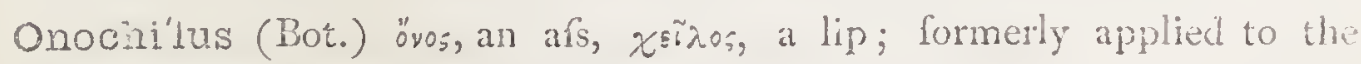
Alkanet.

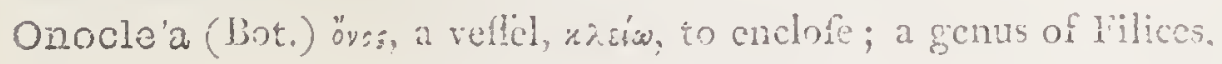


Onocro'talus (Ornith.) övos, an afs, xpóranov, a creaking; applied by Pliny to a marfh. bird, which was thought to bray like an afs, perhaps the Bittern.

Ono'nis (Bot.) övos, an afs, ovínus, to delight; Reft-harrow; a genus of Leguminofix.

O'nopix (Bot.) ovóru⿳亠s was the name of fome unknown plant mentioned by Theophraftus; a genus of Compofitx.

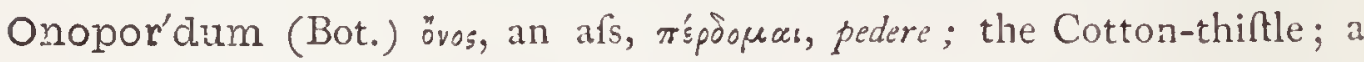
genus of Compofitx.

Ono'pteris (Bot.) literally "afles'-fern," from ovos, an afs, $\pi \tau^{\prime}$ és;, fern; a genus of Polypodioid Filices.

Onos'ma (Bot.) orros, an afs, or $\mu^{\prime}$, fmell, from the fuppofition that thefe plants are grateful to that animal; a genus of Boraginacex.

Onosmo'dium (Bot.) the genus Onofma, عídos, likenefs.

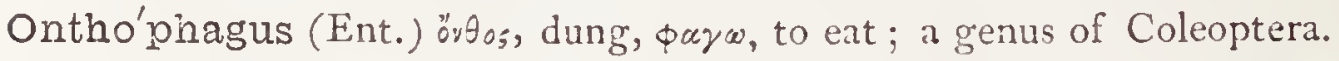

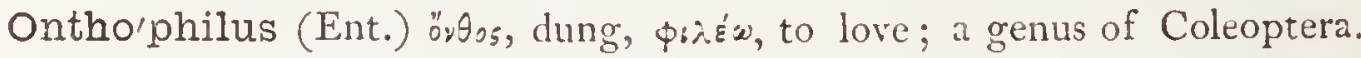
Ony'chium (Bot.) ovv६-uxos, a claw; a genus of Polypodioid Filices.

Ony'chius-a-um (Zool.) Lat. Thaped like a little claw.

Onychogna'thus (Ornith.) ơv

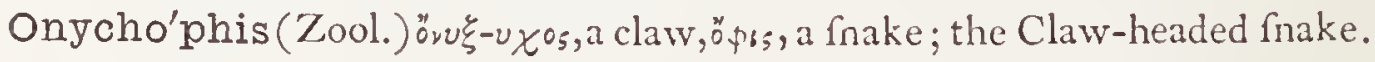

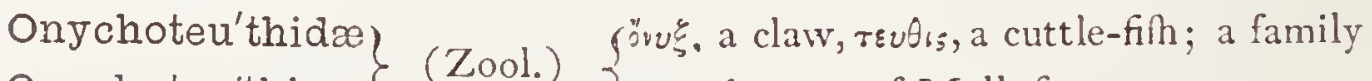

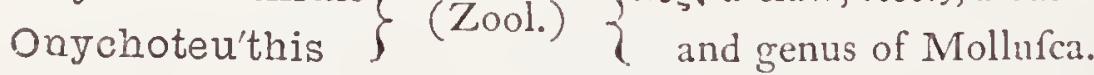

Onychothe'rium (Fos. Zool.) ovr of foffil Mammalia.

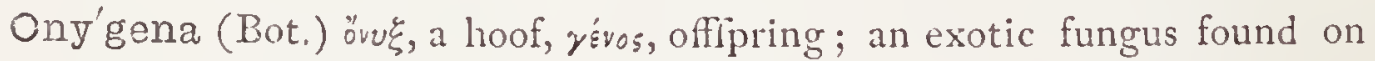
buffaloes' horns.

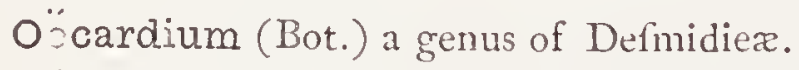

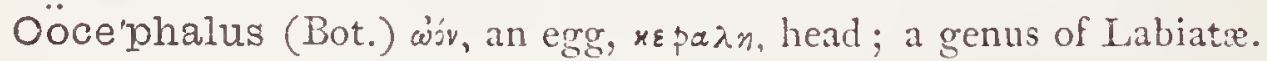

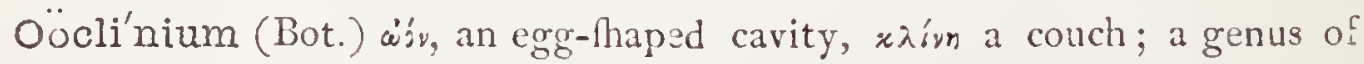
Compofitie.

Öоso'cca (Bot.) wón, an egg (Thape) xoxros, a berry; a genus of Sapindacex. Oödes (Ent.) wivins, egg-like, oval; a genus of Coleoptera.

Cöli'tes (Fos. Zool.) wov, an eggr, $\lambda^{\prime} \theta_{0}$ s, a ftone; forfil eggs.

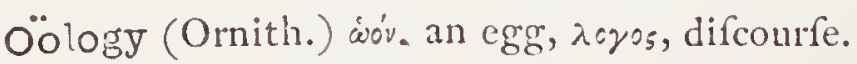

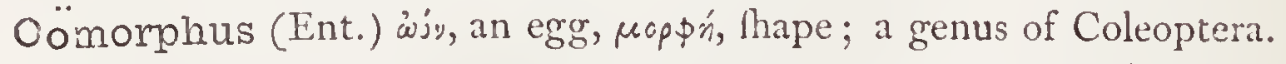

Conops (Ent.) üov, an egg, $\ddot{\omega} \psi$, the face.

Opa'dia (Ent.) öraঠos, an attendant; always flying with other fpecies.

$\left.\begin{array}{l}\text { Opala'lis } \\ \text { Opaliza'lis }\end{array}\right\}$ (Ent.) $\left\{\begin{array}{c}\text { opalus, the opal, a gen ; from the various thades } \\ \text { of colour on the wings. }\end{array}\right.$ 
Ope'grapha (Bot.) ónń, a chink, rpápw, to write; a genus of Lichenes.

Opercula'ria (Bot.) operculum, a lid, in allufion to the calyx; alfo a genus of Infuforia.

Opercula'ris-e (Zool.) furnithed with an opercular bone, from operculum, a lid.

Operculi'na (Bot.) operculum, a lid; a genus of Convolvulacex.

Oper'culum (Zool., Bot.) Lat. a cover or lid. In Zoology, applied to the calcareous or horny mouth-covering of fome mollufca; in Botany, chiefly applied to the lid covering the theca of mofies.

Ope'ticla (Bot.) oли́rıv, a little awl; a genus of Cyperacer.

Opetiorhy'nchus ('/ool.) órńr6ov, an awl, jurx05, a fnout.

Ophe'lia (Bot.) P. N., a genus of Gentianacex.

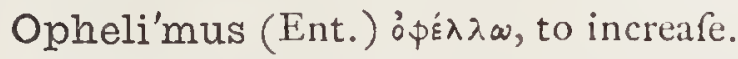

O'phelus (Bot.) $ф \phi \varepsilon \lambda_{\circ} o_{\text {, }}$, helpful; a genus of Sterculiacex.

Ophi'ala (Bot.) dim. from oф:s, a ferpent; a genus of Ophiogloffacea.

Ophi'deres ?

Ophide'ridæ $\}$

(Ent.) öps. a ferpent, $\delta \xi_{\xi}^{\prime} n$, the neck.

Ophi'dia (Zool.) öp:5, a ferpent, Ei⿱宀os, form or hape; an order of Reptiles. Ophidi'na (Ichth.) öp:s, a ferpent, with fam. term.; a family of elongated Filhes.

Ophi'dioids (Ichth.) öpss, a ferpent, eĩos, likenefs; the Snake-like Finhes.

Ophi'dion (Ichth.) ö pódเov, a little fnake; one of the Pipe-filhes.

Ophi'dium (Ichth.) öprs, a ferpent, eîjos, likeners; a genus of Snake-like Filhes.

Ophioca'ryon (Bot.) oфьr, a fnake, xápuor, a nut; a genus of Sapindacex. Ophioco'ma (Zool.) joss, a ferpent, ión, hair; the Brittle-ftars.

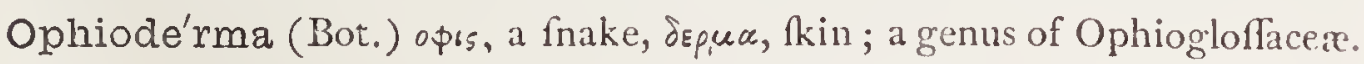
Ophio'des (Ent.) o" \$s, a ferpent, Ei⿱jos, appearance.

Ophioglossa'ceæ (Bot.) the natural order of plants of which opliogloffum is the type; the Adder's-tongue family.

Ophioglos sum (Bot.) ő $\$ \varsigma ;$, a ferpent, $\gamma \lambda \tilde{\omega} \sigma \sigma \alpha$, a tongue; Adder's-tongue; a genus of Filices.

Ophiogram'ma (Ent.) öprs, a fnake, rpasuśr, a line.

Ophio'logy (Zool.) öpss, a ferpent, גóyos, a difcourfe; equivalent to Herpetology.

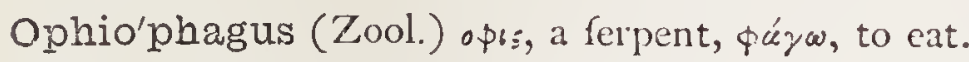

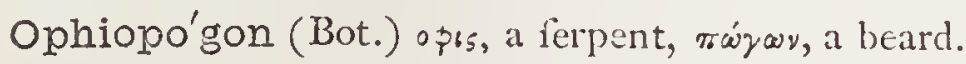

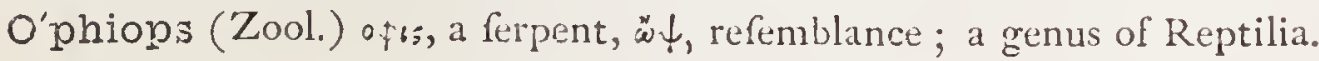


Ophio'pteris (Bot.) ops, fnake, tźpors, fern; a genus of Polypodioid Filices.

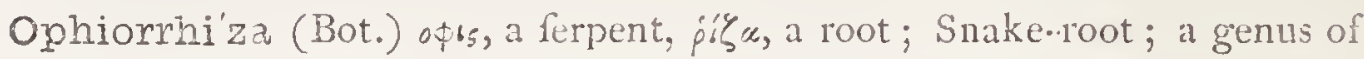
Cinchonacex.

Ophioscor'odon (Bot.) opro- rúspodov, or Wild garlic of Diofcorides.

Ophiospe'rma (Bot.) ołs, fnake, otśpse, feed; a genus of Myrfinaceid. Ophiosta'chys (Bot.) oprs, a fnake, oruxvs, a bunch (fpike); a genus of Melanthacer.

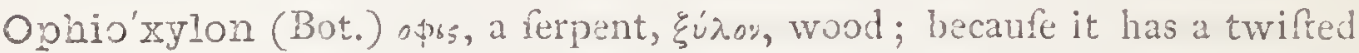
root and ftems; or, as fome think, becaufe fuppofed to be an antidote to ferpents' bites; a genus of Apocynaces.

Ophisau'rus (Zool.) opø, a ferpent, =uи̃pos, a lizard; the Glafs-fnake; a genus of Reptilia.

Ophispe'rmum (Bot.) opıs, a fnake, oréprea, feed; a genus of Aquilariacede.

Ophister'non (Ichth.) opis, a ferpent, orépvov, the breaft; a genus of Serpentiform Fifhes.

Ophisu'raphis (Ichth.) opts, a ferpent, cups, tail, papis, a needle-fhaped Sea-filh. Ophisu'ricta, (Ichth.) $\left\{\begin{array}{c}\text { a family and fub-family of Ee!-like Filhes, of } \\ \text { Ophisurinas }\end{array}\right\}$ which Ophifurus is the type.

Ophisu'rus (Ichth.) opb; a ferpent, oupa, a tail; a genus of Serpentiform Apodal Finhes.

Ophi'tes (Zool.) ỏsirns, like a ferpent; a genus of Colubrine ophidians.

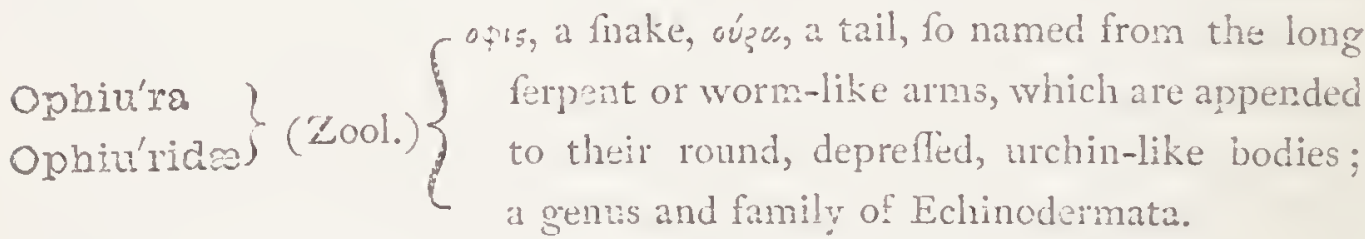
Ophiu'rus (Bot.) osts, a ferpent, eũpe a tail; a genus of Gramina. Ophingoscléria (Bot.) ớpús, a margin, $\sigma x \lambda$ pros, hard; a grenus of Cyperacex.

Ophryospo'ms (Bot.) oфpús, a margin, бrópo;, feed; a genus of Compolitix.

Oph'rys (Bot.) ółpés, an eyebrow; referring to fringe of inner fepals; a genus of terreftrial Orchidacex, inciuding the Bee and the Fiy orchis. ophthalmidium (Bot.) o $40 \lambda \mu$ cos, an eye, gidos, likenefs: from the eyclike frubtifation; a genus of Lichenes.

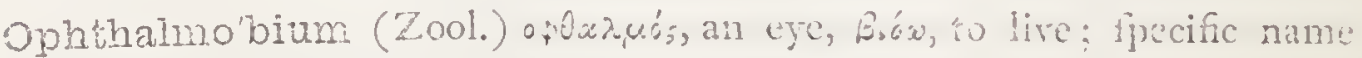
of a parafite rond in the capfule of the eye. 
O'pilus (Ent.) etymology unknown; a genus of Coleoptera.

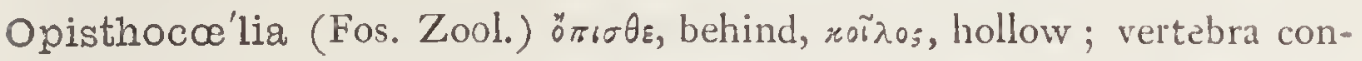
cave behind, convex or flat in front.

Opistho'comus (Ornith.) ö $\pi เ \sigma \theta \varepsilon$, behind, ró $\mu n$, a lock of hair; having certain elongated feathers forming a creft which bends backwards.

Opisthoglo'ssa (Zool.) ö $\pi \iota \sigma \theta \varepsilon$, behind, $\gamma \lambda \tilde{\omega} \sigma \sigma \alpha$, tongue; applied to certain Batrachians with a tongue adherent in front and more or lefs free behind.

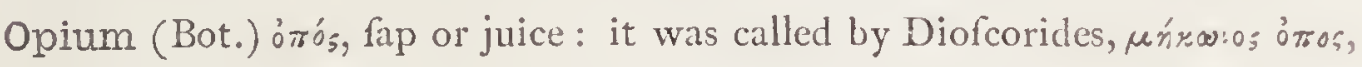
juice of the Poppy.

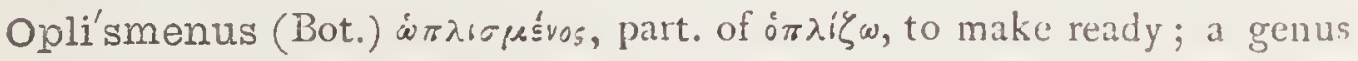
of Gramina.

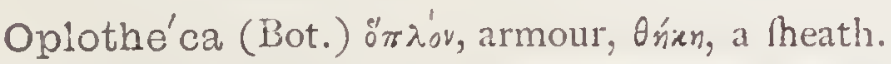

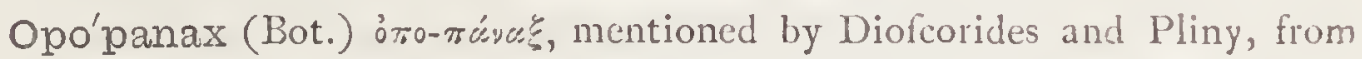
ömos, juice, panax, the plant yielding it; a genus of Unbelliferæ.

Opora'bia (Ent.) órógce, autumn, Brós, life; a genus of Lepidoptera.

Oporan'thus (Bot.) ótrápz, autumn, avdos, flower; a genus of A maryllidaces.

Opo'rina (Ent.) ómẃpa, the autumn, from the time of its appearance; a genus of Lepidoptera.

Oporínia (Bot.) ómwssvós, autumnal; alluding to its time of flowering; a genus of Compofitx.

Opospe'rmum (Bot.) ỏrós, juice, orepua, feed; a genus of Algæ.

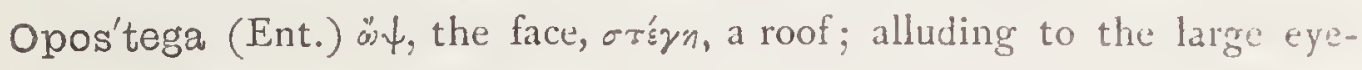
caps ; a genus of Lepidoptera.

Opsa'rion (Ichth.) ó భáprov, a little fifh.

Opsian'thus (Bot.) $\ddot{\omega} \psi$, the eye, $\omega_{\nu} \theta_{2}$, llower'; a genus of Onagraceie.

O'pulus (Bot.) derivation doubtful; fpecific name of the Guelder-role, Viburnum Opulus.

Opun'tia (Bot.) it was plentiful near Opus (gen. Opuntis), a city of Locris; now applied to a genus of Cactacex.

Opuntia'cer (Bot.) the family of plants of which Opuntic is (or rather was) the type; the Indian-fig family.

Or (Ent.) from the letters or, fuppofed to be legible on the forevings.

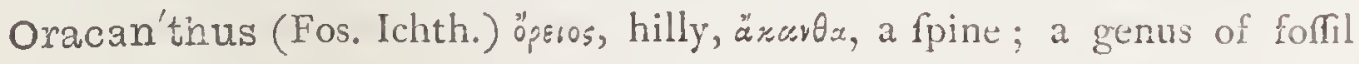
Fin-fpines.

Orange (Bot.) altered from Latin aurantium, which is from aurum, gold, in reference to its colour.

Ora'ng-outan (Zool.) the Malay name for the Simia Satyrus, meaning "Man of the woods." 
Or'bea (Bot.) orbis, an orb; alluding to the flowers.

Orbi'cula (Zool.) Lat. a little orb; a genus of Mollufca.

Orbicula'ris e (Zool.) Lat. of rounded form.

Orbiculi'na (Zool.) orbiculus, a fmall orb or difk; a genus of living and foffil Foraminifera.

$\left.\begin{array}{l}\text { Orbig'nya (Bot.) } \\ \text { Orbignya'nus (Zool.) } \\ \text { Orbigny'ia (Zool.) }\end{array}\right\} \begin{gathered}\text { P. N. in honour of the late celebrated French } \\ \text { naturalift, M. D'Orbigny; in Bot. a genus of } \\ \text { Palma. }\end{gathered}$

Orbo'na (Ent.) P. N., the godders of parents who had loft their children.

Or'chesis (Ent.) ópxnobs, dancing; a genus of Coleoptera.

Orche'stes (Ent.) ópxnsrns, a dancer; a genus of Coleoptera.

Orchida'cex (Bot.) the Orchis family of plants.

Orchi'dium (Bot.) opxidroy, dim. of 'opxbs, teftis; a genus of Orchidacex.

Orchidoca'rpum (Bot.) orchis, and saptós, fruit ; orchis-fruited; a genus of Anonacex.

Orchidofu'nizia (Bot.) compounded of Orchis and Funkia (a beautiful genus of Liliacex,) because it resembles both; a genus of Orchidacex. Orchipe'da (Bot.) orchis; pes, pelis, a foot; a genus of Apocynaceæ.

Orchipe'dum (Bot.) fame derivation; a genus of Orchidacex.

Or'chis (Bot.) ópx's,teftis; from the thape in fome roots of terreftrial fpecies; typical genus of Jat. Ord. Orchidacex.

Oréades (Bct.) P. N., a peculiar tribe of nymphs in Grecian mythology: fpecific name of a fungus, Agaricus Oreates; from its habit of growing in regular rings, popularly confidered fairy rings.

Orea'ruthes (Bot.) literally "oreas-flowtred;" a genus of Vacciniacex.

O'reas (Bot.) P. N., an Oread, or Mountain-nymph; a genus of Cruciferr; alfo. in Zoology, a genus of Mammalia.

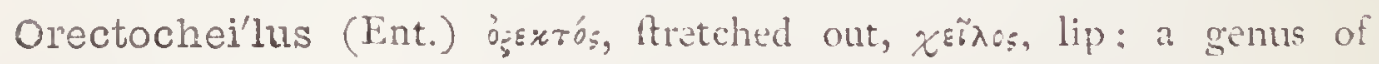

Coleoptera.

Oregura (Bot.) opsyw, to ftretch ont, oujá, tail; a genus of Orchidacere.

Oreo'bolus (Bot.) literally "mountain-fpread," from ofos, mountain, and

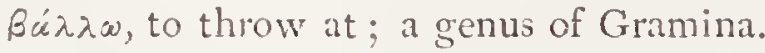

Oreoca'llis (Bot.) literally "mountain-beauty," from 0:05. mountain, rx́ $\lambda \lambda_{0}$, beaucy; a genus of Proteacex.

Oreo'charis (Bot.) opos, mountain. X́ąts, grace or beauty; a genus of Boraginacea.

Oreochlóa (Bot.) j,os, mountain, xiós, grafs : Nountair-grafs; a gems of Gramina. 
Oreoda'phne (Bot.) literally "mountain-laurel," from jops, a mountain, dáprn, a laurel; a genus of Lauracex.

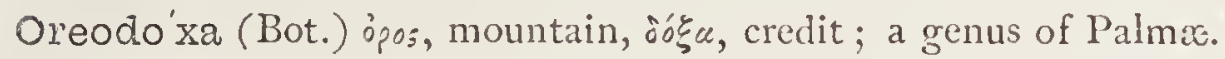

Oreoge'um (Bot.) ópos, mountain, and Geum; a genus of Rofacex.

Oreoica (Ornith.) "sos, a chain of hills, obx's, to inhabit.

Oreomyr'rhis (Bot.) opos, mountain, and Myrrhis, a genus of Umbelliferæ.

Oreo'phila (Bot.) ópos, mountain, фi $\lambda \dot{\varepsilon} \omega$, to love; a genus of Compofitx.

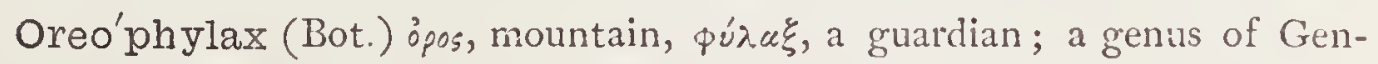
tianacea.

Oreo'pteris (Bot.) öpos, a mountain, $\pi \tau^{\varepsilon}$ pss, a fern; Sweet mountain-fern, or "Oreads" fern;" fpecific name of the Afpidium Oreopteris.

Oreopy'ra (Ornith.) opos, a mountain, mũp, fire; a genus of Humming-birds.

Oreoscia'dium (Bot.) ópos, mountain, бxú́se:ov, an umbrella or parafol, metaphorically an umbel; a genus of Umbelliferx.

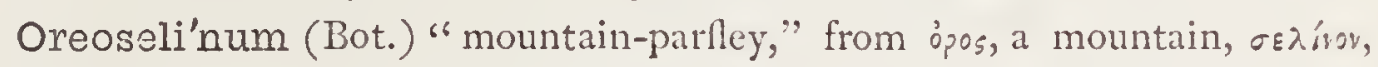
parfley; a genus of Umbelliferx.

Oreose'ris (Bot.) ósos, mountain, s'śpss, endive; a genus of Compofitax.

Oreosple'nium (Bot.) ópos, mountain, $\sigma \pi \lambda n_{\text {nv }}$ ov, fpleenwort; a genus of Saxifragacex.

Oreothrau'pis (Ornith.) öpos, a mountain, Opautis, a little bird like the goldfinch; a genus of Tanagers.

Oreotra'gus (Zool.) opos, a mountain, tp'syos, a he-goat.

Oreotro'chilus (Ornith.) opos, a mountain, trochilus, a humming-bird; Mountain Humming-bird.

Orga'nica (Ornith.) this name was given by Mr. Gould from the refemblance of the bird's note to "the founds of a hand-organ out of tune."

Or'ganum (Zool,) arranged like the pipes of an organ.

Orgyi'a (Ent.) óprvia, the outfretched arm; from the infect's habit of extending the fole feet; a genus of Lepidoptera.

Oriba'tidæ (Zool.) öpos, a paling, Búros, walking; a family of Arachnida : the Wood-mites.

Orig'azum (Bot.) öpos, a mountain, ycévos, delight, referring to its habitation and odour; Marjoram; a genus of aromatic Labiatz.

Orioli'nas (Ornith.) a fub-family of Inceflores, of which oriolus is the typical genus.

Ori'olus (Ornith.) Latinized form of Oriole, which was probably given in imitation of the bird's cry.

Ori'on (Ent.) P. N., the handfomeft hunter of his race. (Hom. Odyft, v. 121. feg.): fpecific name of a butterfy. 
Orithy'ia (Zool.) P. N., daughter of Erechtheus; a genus of Cruftacea.

Or'ium (Bot.) öprov, a little hill, where it is chiefly found; a genus of Cruciferæ.

Or'menis (Bot.) öprevos, a ftem or ftalk; a genus of Compofitæ.

Ormi'scus (Bot.) óppiozos, a fmall necklace; a genus of Cruciferæ.

Ormocar'pus (Bot.) öpros, a necklace; ruptoó, fruit.

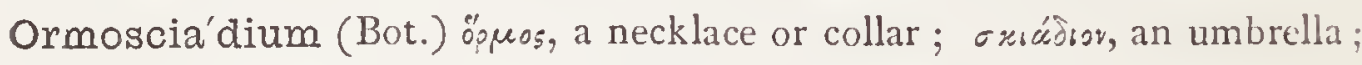
(metaphorically) an umbel; a genus of Umbelliferæ.

Ormo'sia (Bot.) öpros, a necklace, feeds were worn in necklaces; a genus of tropical Leguminofæ.

Ormosole'nia (Bot.) literally a "grooved necklace," from ópres, a necklace, $\sigma \omega \lambda \dot{r v}$, a channel; a genus of Umbelliferæ.

Ornata'lis (Ent.) ornatus, part. of orno, to adorn.

Ornatis'simus-a-um (Zool.) Lat. fuperl. very much adorned.

Orna'tus-a-um (Ent., Bot.) Lat. adorned; e.g., Lupinus ornatus.

Ornithich'nites (Fos. Ichth.) öprs-ítos, a bird, and "'xvos, a foot-print; folfil Bird-foot-prints.

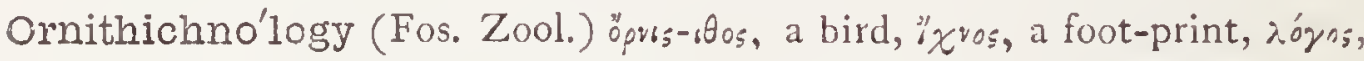
a difcourfe; the fcience of foffil footmarks of Birds.

Ornithid'ium (Bot.) oporss-s005, a bird, eidos, likenefs; the upper lip of the ftigma is beak-like.

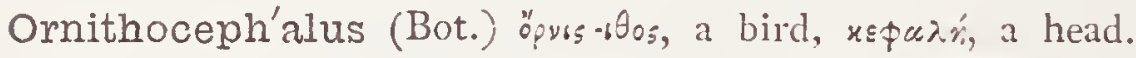

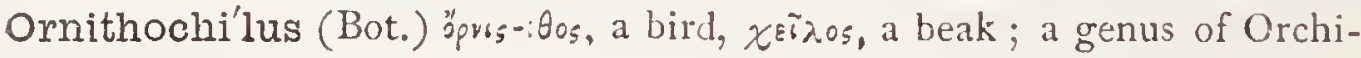
daceæ.

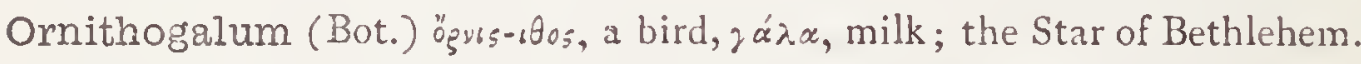
Ornithoglos'suin (Bot.) öpyıs-ı0os, a bird, $\gamma \lambda \bar{i} \sigma \sigma a$, a tongue.

Ornithoi'des (Zool.) ópys-ıtos, a bird, erós, likeners.

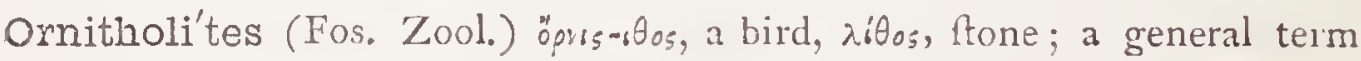
applied to foffil Birds.

Ornitho'logy (Ornith.) óprs-190s, a bird, גoovos, a difcourfe; the Science of Birds,

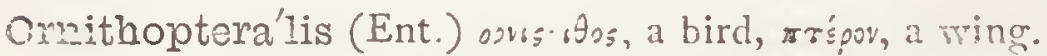

Omi'thopus (Bot.) opvs 'Acs, a bird, rov̀, a foot; claw-like pods; a genus of Leguminof $x$.

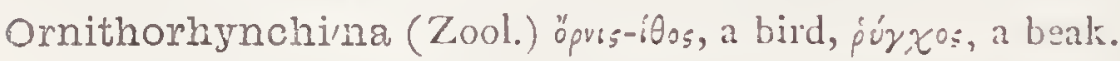

Ornithorhyn'cus-a-um (Bot.) opvss-r605, a bird, puyecss, a beak; having the form of a bird's beak; the Duck-billed Platypus.

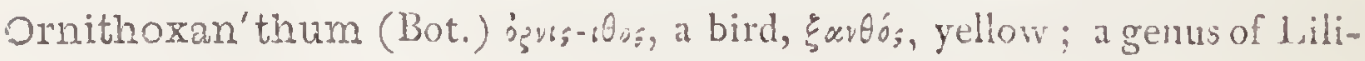
acex. 
Or'nix (Ent.) öpv6s, a bird; a genus of Lepidoptera.

Or'nus (Bot.) Lat. the Alh-tree; the Manna-alh; a genus of Nat. Ord. Oleacer.

Orobancha'cez (Bot.) the family of plants of which Orobanche is the type; the Broom-rape family.

Oroban'che (Bot.) öpoßos, a kind of vetch, äyxw, to ftrangle, becaufe it chokes or ftrangles the Orobus; the Broom-rape; typical genus of the parafitic order Orobanchacex.

Orobi'tis (Ent.) feeding on the vetch (Orobus); a genus of Coleoptera.

O'robus (Bot.) opoßos, the bitter vetch; O. tuberofus is fuppofed to be the Chara mentioned in Cæar's Commentaries, on which, mixed with milk, the foldiers of Valerius' army fubfifted during a fcarcity of bread. O'rodus (Fos. Ornith.) áparos, beantiful, ódoús, a tooth; a beautiful genus of folfil Fifh-teeth.

Orontia'cer (Bot.) the Sweet-flag family, of which Orontium is the type. Oron'tium (Bot.) a Greek name adopted by Linnæus; typical genus of the Nat. Ord. Orontiace

Orope'tium (Bot.) opps, mountain, peto, to travel to; a genus of Gramina. Oro'phanes (Bot.) öpos, mountain, фavós, brightnefs; a genus of Ericacex. Oro'phea (Bot.) óop̣̂́n, a roof-tree; a gonus of Anonacere.

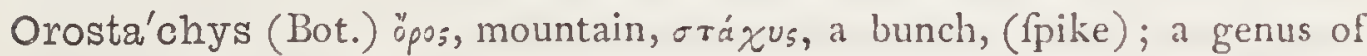
Craffulacex.

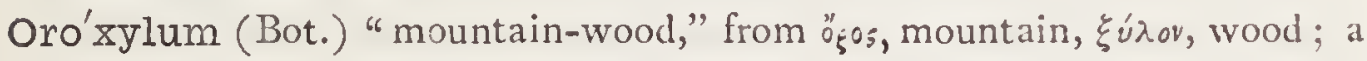
genus of Bignoniacex.

Or'ris-root (Bot.) i. e. Iris-root, (Iris Florentina.)

Orsoda'cna (Ent.) óprofáxvn, a name ufed by Ariftotle for an infeét which eats the buds of plants; a genus of Coleoptera.

Orte'gia (Bot.) P. N. in honour of C. G. de Ortega, a Spanith botanift. Orthagoris'cus (Ichth.) iptayopir ros, a fucking.pig; the Sun-fifh.

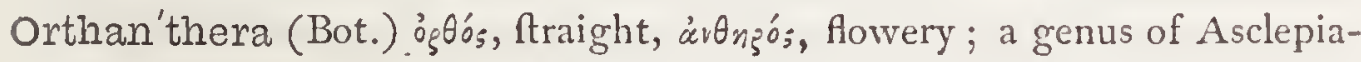
daceæ.

Or'this $\}$ (Fos. Zool.) \{óp $\theta_{5}$, Atraight; genera of foffll Bivalves, occurOrthisi'na (Fos. Zool.) $\{$ ring only in palicozoic ftrata.

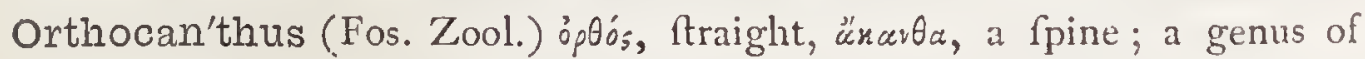
folil Fin-fpines.

Orthocarpæa (Bot.) óplós, ftraight, xąrós, fruit; a genus of Sterculiacea. Orthoca'rpus (Bot.) fame derivation; a genus of Scrophulariaceæ.

Orthoce'ntrum (Bot.) äg日os, ftraight; s'śrpov, a prickle; a genus of Compofitie. 
Ortho'ceras (Bot.) óplós, fraight, répus, a horn.

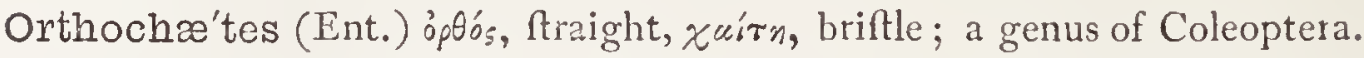
Ortho'clada (Bot.) ip $\theta$ śs, ftraight, $x \lambda \alpha \delta \delta s$, a hoot or young branch; a genus of Gramina.

Ortho'danum (Bot.) $o_{j}^{\prime} G_{o}^{\prime}$, ftraight, davó, dry, parched; a genus of Leguminofx.

Or'thodon (Bot.) opgós, Araight, ofovs, ofsvros, tooth; a genus of Bryoid Mufci.

Orthodo'ntium (Bot.) fame derivation; a genus of Bryoid Mufci.

Ortho'genys (Ornith.) op os, ftraight, $\gamma^{\prime}$ rvos $_{s}$, the jaw ; a genus of Tanagers.

Orthognat'tus (Zool.) up $\theta_{o_{5}}$, upright, quácos, the jaw.

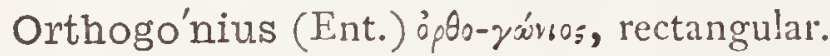

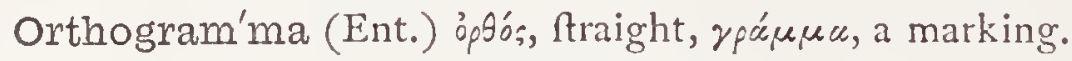

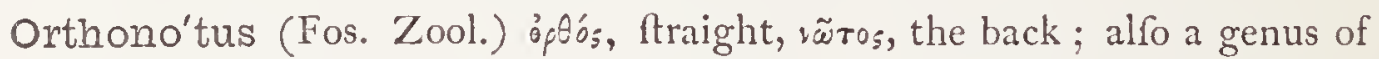
Mollufca.

Ortho'perus (Ent.) óptós, ftraight, $\pi^{\prime} \varepsilon p a s$, an extremity; a genus of Coleoptera.

Orthoplo' cere (Bot.) opós, ftraight, $\pi \lambda c x^{\prime}$, a web; the cotyledons conduplicate, or longitudinally folded; a fection of the Cruciferæ.

Orthopo'gon (Bot.) óptón, fraight, $\pi \tilde{x}$ wav, a beard.

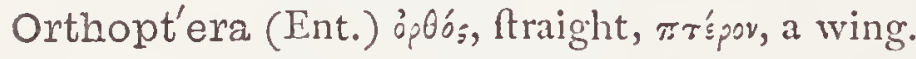

Orthopy'xis (Bot.) aptós, ftraight, $\pi u \xi \xi$, a box; a genus of Bryoid Mufci.

Orthora'phium (Bot.) ojpós, ftraight, páśav, dim. of paśs, a needle; a genus of Gramina.

Orthorhyn'cus (Ornith.) optó, ftraight, jurxos, a beak; a genus of Humming-birds.

Ortho'sia (Bot.) ỏplwors, ftraightness; a genus of Afclepiadacex. $\left.\begin{array}{l}\text { Ortho'sia } \\ \text { Orthosi'idæ }\end{array}\right\}$ (Ent.) $\left\{\begin{array}{c}\text { P. N., a surname of Diana. Prnd. Olymp: iii. } \\ 54 . ; \text { a genus and family or Lepidoptera. }\end{array}\right.$

Orthosi'phon (Bot.) óp $\theta_{s}^{\prime}$, ftraight, $\sigma i p w \nu$, a tube; a genus of Labiatæ.

Orthospo'rum (Bot.) óplós, ftraight, oró:os, feed; a genus of Chenopodiacex.

Orthoste'mon (Bot) óplós, ftraight, srńpar, a fpindle (ftamen); a genus of Gentianacex.

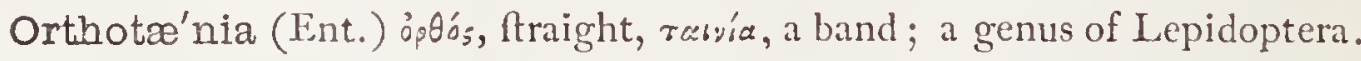

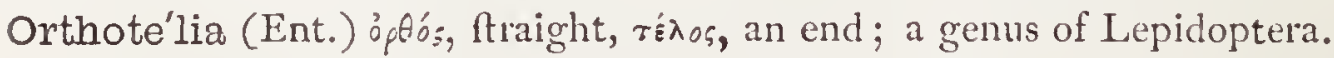
Orthothe'ca (Bot.) ópós, ftraight, Oŕnx, a fheath; a genus of Bryoid Mufci. Orthothe'cium (Bot.) fame derivation; a gemus of Sterculiacex.

Ortho'tomus (Ornith.) opios, ftraight, rouń, a cutting; the Tailor-bird. 
Ortho'trichum (But.) óplós, Atraight, $\theta_{p} b_{\xi}$, rpixns, hair; a genus of Mufci. Ortho'tropis (Bot.) $o_{5}^{\prime} G_{0}^{\prime}$, ftraight, т $\rho^{\prime} \pi \omega$, to turn; a genus of Leguminofa.

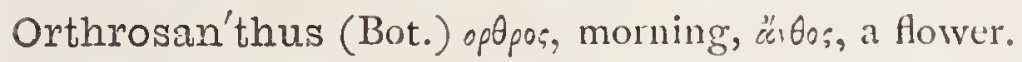

Or'tolan (Ornith.) Fr. ortolan; Ital. ortulano; from hortulams, reliting to gasdens, which it frequents; common name of the Emberiza hortulant.

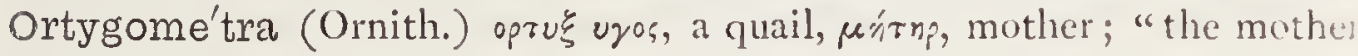
of the quails," applied by Arifotle, Aldrovandus and others to the Corn-crake.

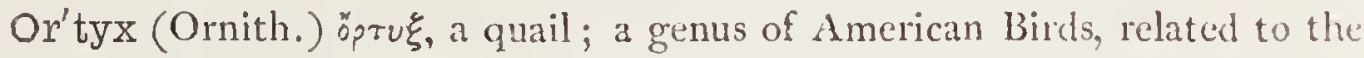
partridge; the Colins.

Orva'la (Bot.) French, orvale, the herb Clary; fpecific name of a fjecies of Dead-nettle, Lamium Orvala.

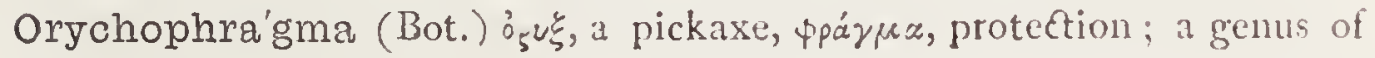
Cruciferx.

Orycter'opus (Zool.) ófuxтrip, a digger, тог̃s, a foot; antelope-footed: a genus of Mammalia.

Ory'cterothe'rium (Fos. Zool.) ópuxzós, dug up, Anpioy, a healt.

Oryc'terus (Zool.) ỏuxińp, a digger ; a genus of Rats.

Ory'ctes (Ent.) ogúxrns, a digger; a genus of Coleoptera.

Ory'ctis (Ent.) opúxтns, a digger; a genus of Coleoptera.

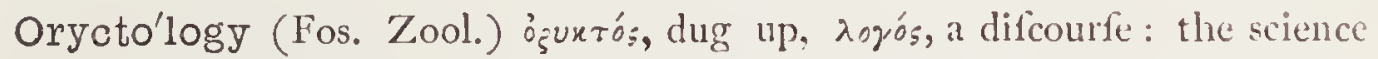
of Extinct animals; almolt difplaced by Palacontology, q. $\vartheta$

Orycto'phaga (Ent.) i. e. eater, ( $\$ a ́ y \omega$, to eat) of the beetle Oryctes; fpec. name of Scolia oryclophaga, a foflorial hymenopterous infect.

Ory'gia (Bot.) ỏ̧urn, a digging; a genus of Mefembryacex.

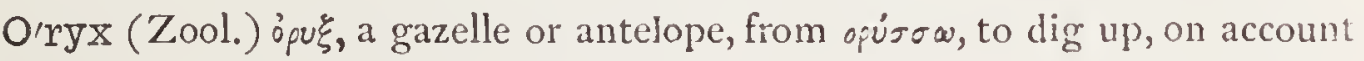
of its pointed horns.

Ory'za (Bot.) Lat. rice; Arab. Oruz; Greek, oguל̧ ; the rice plant; it genus of Cereal gialles.

Oryzi'vorus-a-um (Ornith.) Lat. rice-eating, e.g. Dolichonyx oryzivorus. Oryzop'sis (Bot.) oryza, rice, o $\psi 65$, appearance; ricc-like.

Oryzor'nis (Omith.) öpu $\%$, the rice plant, (which from Arab. oruz) opvsi, bird; the Rice-bird; a genus of Pafferes.

Osibe'clia (Bot.) P. N. in honour of P. Obeck, a Swedifh clergyman and naturalif ; a genus of Melaftomacer.

Oscilla'ria (Bot.) ofcillum, a fwing; a genus of Algax.

Oscillato'ria (Bot.) plants having an ofillatory or fwinging motion; a genus of Algm.

oscu'lifer (Zool.) Lat. having a lirtle month. 
Osi'ris (Ent.) P. N., an Egyptian divinity; a genus of Hymenoptera.

Osmade'nia (Bot.) óruń, fragrance, ảón,y, a gland; a genus of Compolitr.

Osma'nthus (Bot.) ösu'r, fragrance, ür6os, a flower; a genus of Oleaceæ.

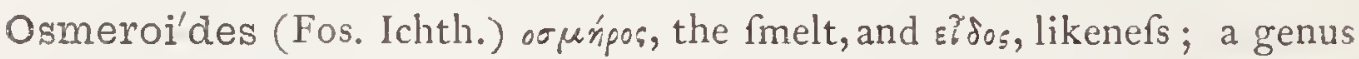
of foflil Filhes of the chalk, fo named from their refemblance to the fmelt.

Osme'rus (Ichth.) orknisns, fweet-fmelling; the Smelt.

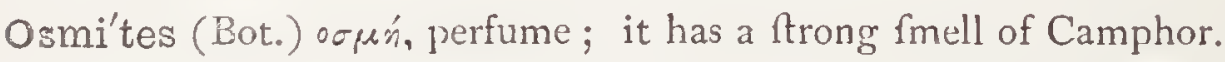

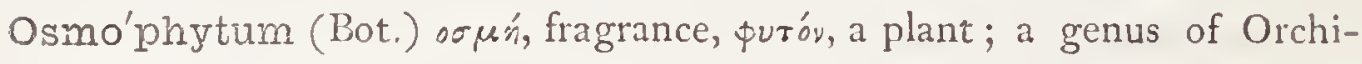
dacex.

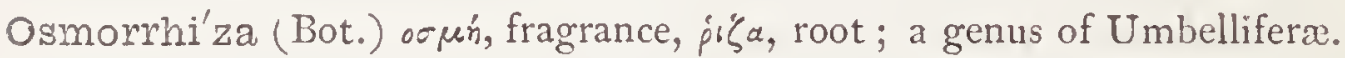

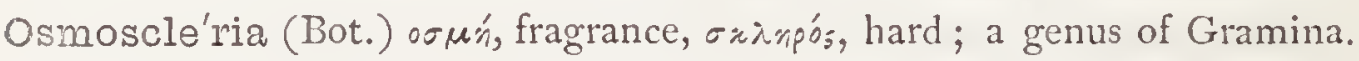

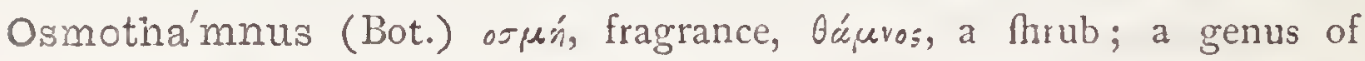
Ericacer.

$\left.\begin{array}{l}\text { Osmun'da } \\ \text { Osmunda'ceæ }\end{array}\right\}$ (Bot.) $\left\{\begin{array}{c}\left(S_{a x}\right) \text { Ofmund, Atrength; a genus and family } \\ \text { of Filices. }\end{array}\right.$ Osmunda'ria (Bot.) having fome refemblance to the Flowering-fern or Ofmunda; a genus of Algæ.

Osmu'ndia (Bot.) fame derivation; a genus of Algæ.

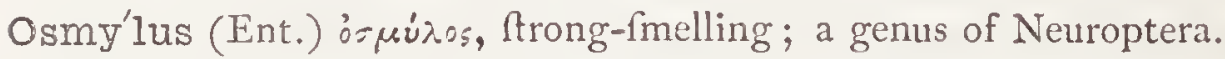

Osphran'ter (Zool.) or фopuvsinpros, able to fmell, Marp-fmelling.

Osphro'menus (Ichth.) os क;ócssvos, tracking by fmell; the Gourami.

Ospriospo'rium (Bot.) östrprov, pulfe (Thaped), otógos, feed; a genus of Fungi.

O'sseus-a-um (Zool.) Lat. bony ; compofed of, or armed with, bone.

Osteole'pis (Fos. Zool.) orrśov, a bone, $\lambda є \pi i s$, a fcale; a genus of Ganoid Finhes, fo called from the enamelled bony character of its fcales.

Osteo'logy (Zool.) or réov, a bone, tóyos, a difcourfe; that which treats of the bony ftructures of the animals.

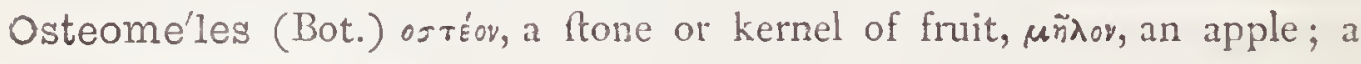
genus of Pomacer.

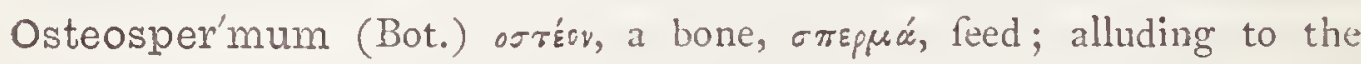
hardnefs of the feed.

Osterdy'ckia (Bot.) P. N., a genus of Cunoniacex.

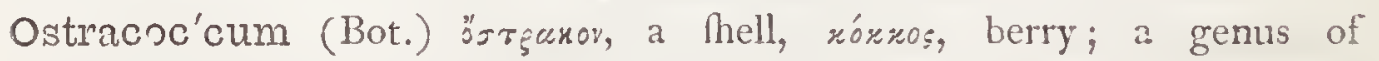
Fungi.

Ostrac'oda (Zool.) östparov, a Mell ; an order of Entomoltraca.

Ostracode'rma (Bot.) örtpaxoy, a fhell, óppuce, fkin; a genus of Fungi. 
Ostra'legus (Ornith.) oftrea, an oyfter, lego, to collect; e.g., Hæmatopus of ralegus, the Oyfter-catcher.

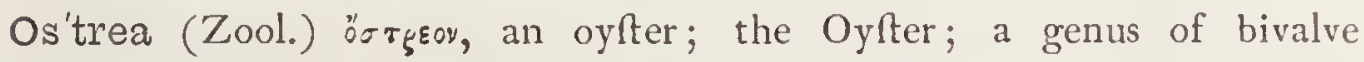
Mollufca.

Ostreæfo'rmis-e (Zool.) oftrea, an oyfter, formis, fhape; oyfter-thaped.

Os'trich (Ornith.) French, auf ruche; Latin, fruthio.

Ostro'pa (Bot.) etymology unknown; a genus of Fungi.

O'strya (Bot.) or $\tau_{\text {gé }}$ of Theophraftus, a tree with very hard wood; the Hop-hornbeam; a genus of Corylacex.

Ostryo'dium (Bot.) the genus Oftrya, Eidos, likenefs; a genus of Leguminofx.

Oswa'lda (Bot.) P. N., a genus of Compofitx.

Osyri'cera (Bot.) the genus Ofyris, and cera, wax; a genus of Orchidacex.

Osy'ris (Bot.) öovpss of Diofcorides, a fhrub with dark tough branches; Poets' Caffia; a genus of Santalaceæ.

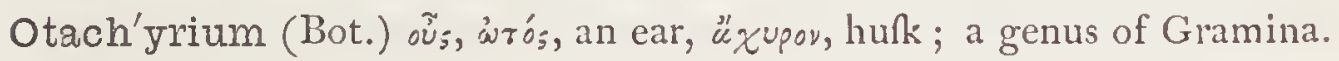

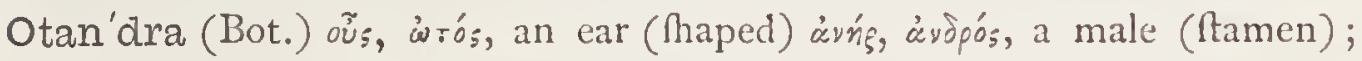

a genus of Orchidacex.

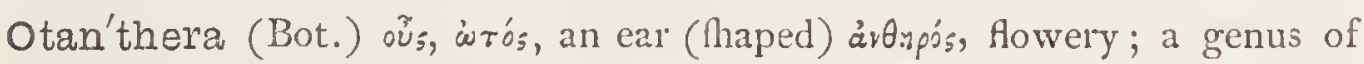
Melaftomacea.

Otan'thus (Bot.) oũs, wrós, an ear, äv $\theta_{0 s}$, a flower; a genus of Compofitx. Ota'ria (Zool.) wrapós, large-eared; a genus of Seals with external ears.

Othon'na (Bot.) ctoon, linen; alluding to the downy clothing of the original plant; a genus of Compofitæ.

$\left.\begin{array}{l}\text { Otina } \\ \text { Otini'næ }\end{array}\right\}$ (Zool.) $\left\{\begin{array}{c}\text { ovs, cंrós, an ear; a genus and fub-family of } \\ \text { Mollufca. }\end{array}\right.$ Oti'næ (Ornith.) a fub-family of Birds, of which Otis is the type; the Buftards.

Otiorhyn'chus (Ent.) 'wriov, a little ear; juyxos, a beak; a genus of Coleoptera.

O'tis (Ornith.) oris, a buftard; a genus of Birds.

Otoco'ris (Ornith.) cưs, ìtón, the ear, *ópos, a fprout; the bird has, above the forehead, on each fide, a few elongated feathers, which it has the power of raifing in the form of a pair of pointed ears.

Oto'cyon (Zool.) oũs, Wros, the ear, *úvy, a dog; the Eared-dog.

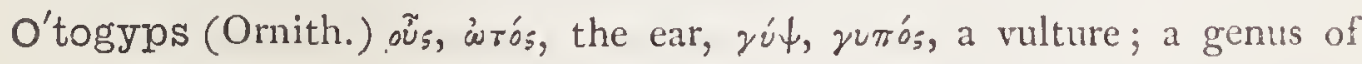
Vultures.

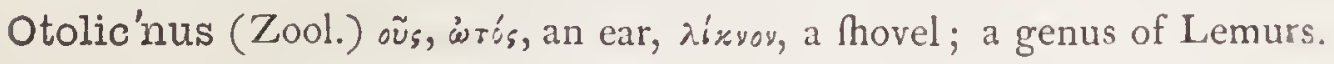




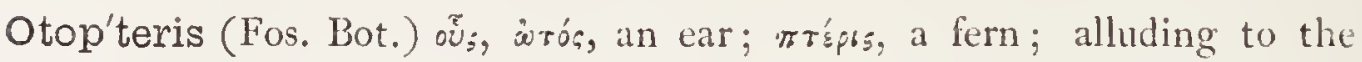
ear-lhaped projection with which the bafes of their leaflets are furnilhed.

Ot'ter (Zool.) Anglo-Sax. oter; Dutch and Ger. otter; common name of Lutra vulgaris.

O'tus (Ornith.) o $\tilde{i}_{s}$, 'wrós, an ear; the Long-eared Bat.

Oude'nodion (Fos. Zool.) oidz'y, none, odous, a tooth; the upper as well as lower jaws being quite or nearly without teeth.

Ounce (Zool.) common name of the Felis uncia; Portug. onça; Ital. lonza; Sp. onza; Fr. once; this laft was formerly written lonce, and is evidently from $\lambda \dot{v} v \xi$, Lat. lynx.

Ou'tea (Bot.) a Carib name.

Ouviran dra (Bot) literally, "water-yam;" in the Malagafy and Polynefian languages, ouvi means yam, and rano, in the former, fignifies water.-Rev. W. Ellis. - The Lattice-leaf plant.

Ova'lis-e (Zool. Bot.) Lat. egg-(haped, oval; e.g., Sphœrium ovale.

Ova'tus-a-um (Zool. Bot.) Lat. ovate, egg-lhaped; e.g., Limnaa ovata.

O'vibos (Zool.) ovis, a theep, bos, a bull, an ox.

Ovifo'rmis-e (Zool. Bot.) Lat. egg-lhaped.

O'vis (Zool.) Lat. a theep.

Ovoï dea (Zool.) ovum, an egg, sidos, likenefs; egg-like.

O'vula (Zool.) Lat. a little egg; a genus of Mollufca.

Ovula'lis (Ent.) dim. of ovum, an egg.

O'weni (Zool.) P N. in honour of the celebrated anatomift and naturalift Profellor Richard Ozven, F.R.S.

Owl (Ornith.) Lat., ulula, the fcreech-owl, from ululo, to howl or fhriek; orvl and how t are eflentially the fame words, the young of the owl being termed hozulets, as remarked by Dr. Trench.

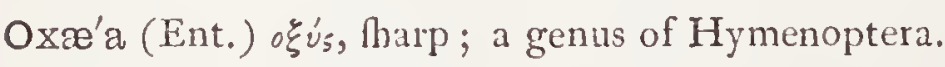

Ox'alis (Bot.) o $u^{\prime}$, harp or four, alluding to its qualities, Wood forrel; typical genus of Oxalidacer.

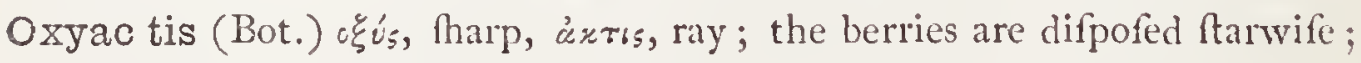

the Star or Litter-pepper of China.

Oxyan'thus (Bot.) o $\xi^{\prime} \dot{u}_{\text {, f }}$ (harp, äv0os, a flower.

Oxybaph'us (Bot.) ó̌́s, fharp, Baф̧ń, dye.

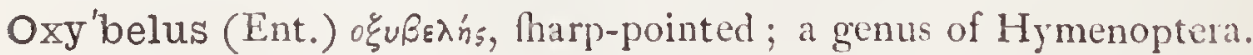

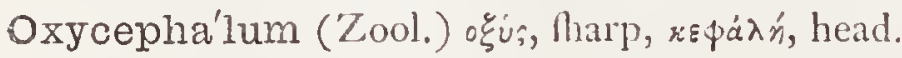

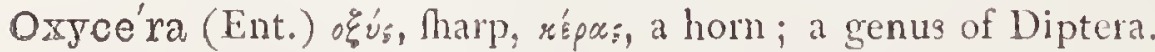


Oxycoc'cus (Bot.) ołús, harp, acid, roxros, a berry, from the tharp, acid tafte of the berries; the Cranberry; a genus of Vacciniaces.

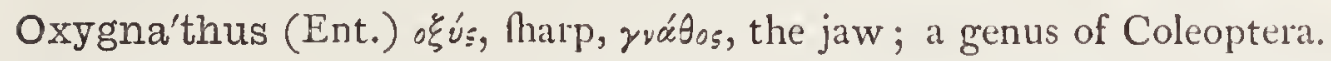
Oxylo'bium (Bot.) o sús, fharp, noßós, a legume or pod; a genus of Leguminoræ.

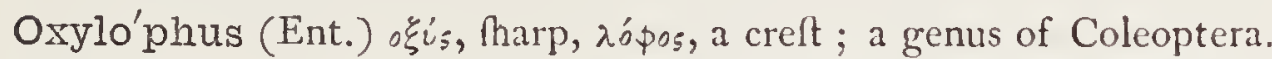

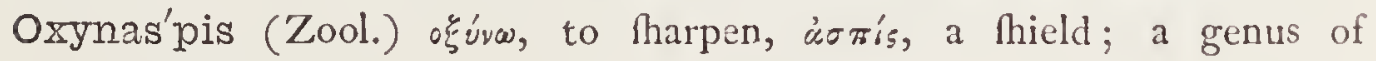
Cirripedes.

Oxyno'pterus (Ent.) ołúva, to Tharpen, $\pi \tau \varepsilon$ pòv, a feather (antenna).

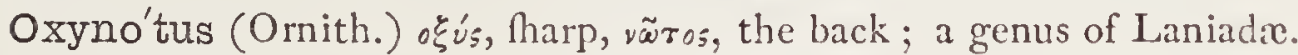

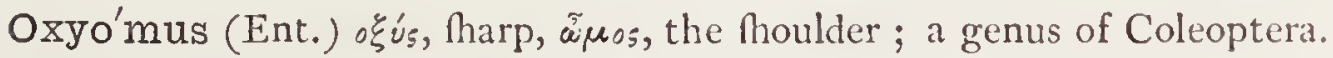

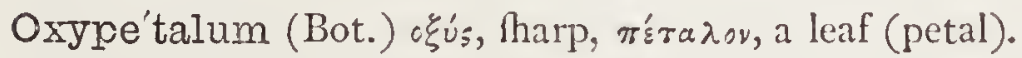

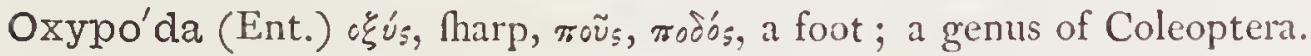

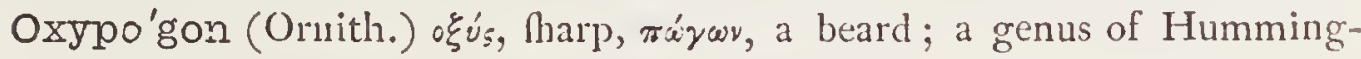
birds.

Oxypo'rus (Ent.) o ̌́s, fharp, tópos, an opening; a genus of Coleoptera. Oxyrho'pus (Zool.) ołúp-potros, eafily turned; a genus of Colubrine Ophidians.

Oxyrhyn'ca (Zool.) oḱs, fharp, ṕúy xos, beak; a divifion of Cruftacea. Oxyrhyn'cus (Ornith.) oł́ús, tharp, púyxos, a beak; a genus of Picidx. Oxyrhyn'cus-a-um (Ichth.) ołús, harp, fóvxos, a fnout, e.g., Mormyrus Oxyrhyncus.

Oxy'ria (Bot.) o $u^{\prime}$, Tharp; a genus of Polygonacer; O. reniformis is the Mountain-forrel.

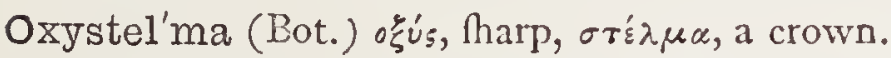

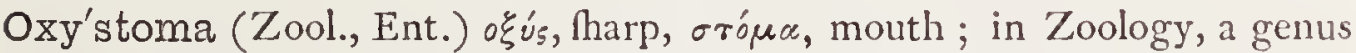
of Cruftacea ; in Entomology, a genus of Coleoptera.

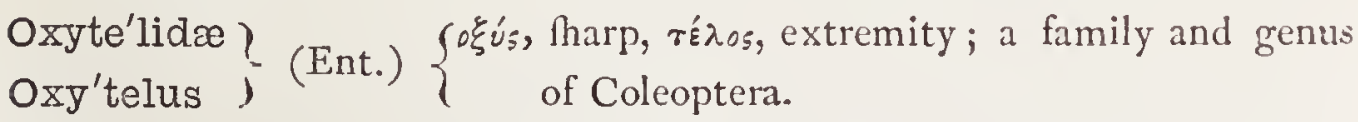
Oxy'tropis (Bot.) ớus, fharp, pointed, rpómbs, a keel; a genus of Leguminofe.

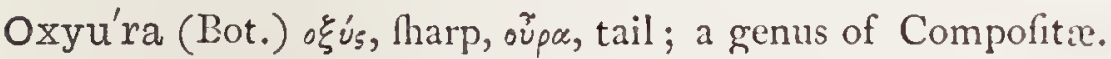
Oxyu'ris (Ent.) o óv́s, Tharp, oũpa, tail ; a genus of Entozoa. Oyster (Zool.) Anglo-Sax. oftra; Latin, oftrea; Greek, örrpecv Ozo'nium (Bot.) 'o $\zeta_{0,}$, a branch; having branched filaments.

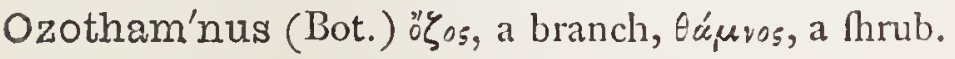


Pache'tra (Ent.) $\pi \alpha \chi u$ s, thick, $\tilde{n} r$ pov, the abdomen; a genus of Lepidoptera.

Pachi'ria (Bot.) etymology uncertain; a genus of Sterculiacex.

Pachi'tes (Bot.) $\pi \alpha \chi x_{\text {ś }}$, thick; a genus of Orchidaceæ.

Pachno'bia (Ent.) $\pi u^{\prime} \chi$ nn, froft, Bís, life; a genus of Lepidoptera.

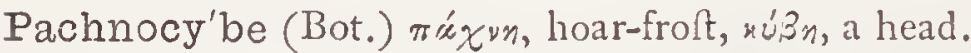

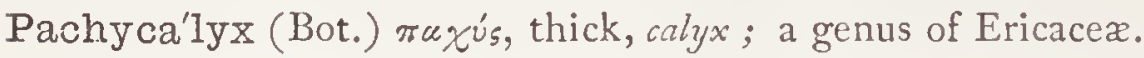

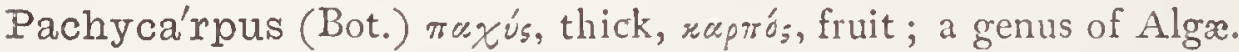

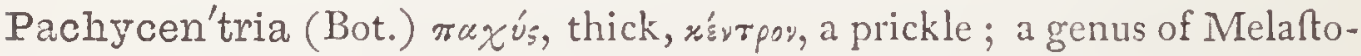
macer.

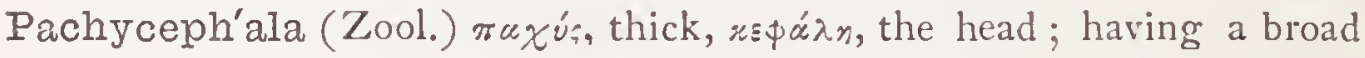
and fhield-fhaped head; a tribe of Entomoftracous Cruftaceans.

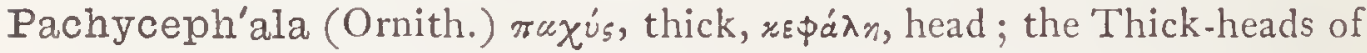
Auftralia.

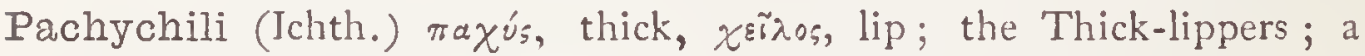
divifion of Cyprinoid Fithes.

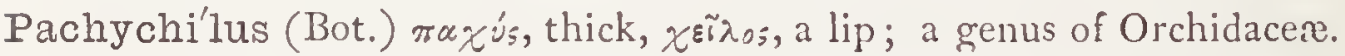

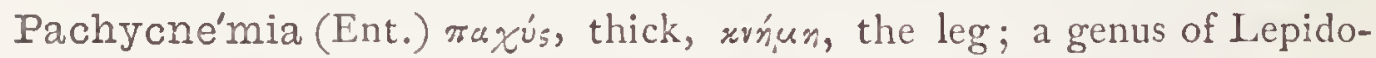
ptera.

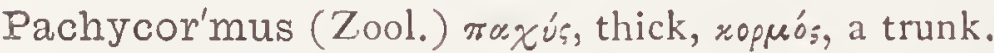

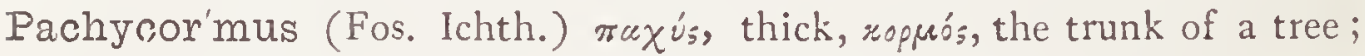
a genus of forfil Ganoid Finhes.

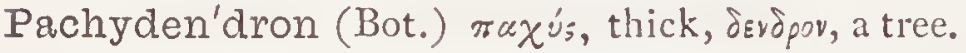

Pa'chyderm, Pachyder'mata (Zool.) rax'́, thick, d'spus, the $\mathrm{k}$ in ; an order of Mammalia.

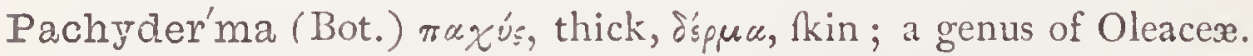

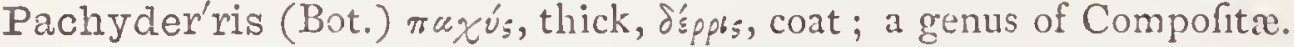

Pachy'dium (Bot.) $\pi \alpha^{\prime} \dot{u}_{;}$, thick; a genus of Onagraceæ.

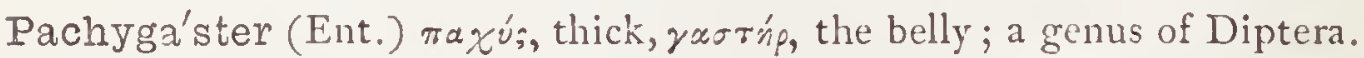

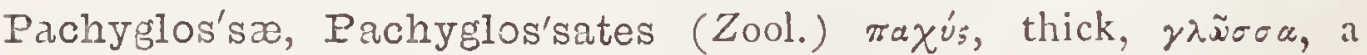
tongue.

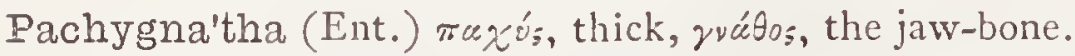

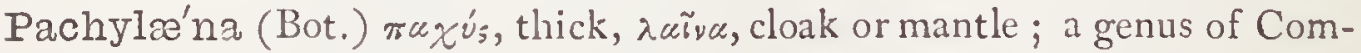
politæ.

Pachylar'thrus (Ent.) $\pi \alpha \chi_{i} \dot{\nu}_{i}$ thick, $\ddot{\alpha}_{p} \theta_{p}$ ov, a joint.

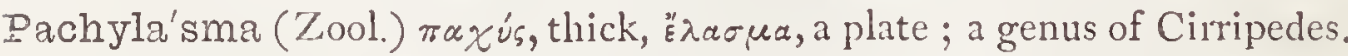

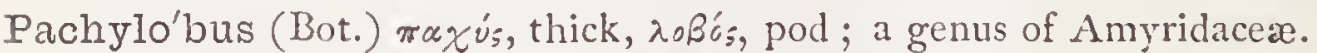
Pachyle'pis (Bot.) $\pi \alpha \chi u_{s}$, thick, $\lambda \varepsilon \pi i s$, fcale; a genus of Compolitr. Pachylo'ma (Bot.) $\pi \alpha, x_{\bar{s}}$, thick, $\lambda \tilde{\omega} \mu \alpha$, fringe; a genus of Melaftomacer. 


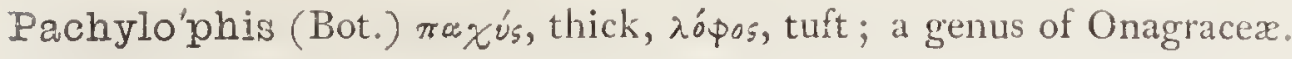

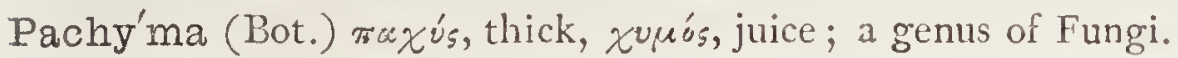

Pachy'menes (Ent.) $\pi \alpha \chi^{\nu_{5}}$, thick, $\mu^{\prime}$ vos $_{5}$, ftrength of body; a genus of Hymenoptera.

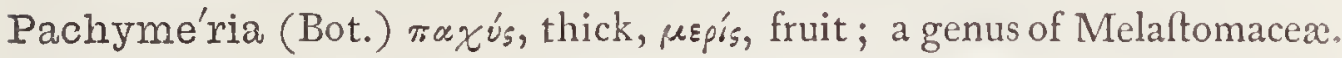
Pachy'na (Bot.) muxúvos, to thicken; a genus of Orchidacez.

Pachyne'ma (Bot.) $\pi \propto x$ v́s, thick, viñ

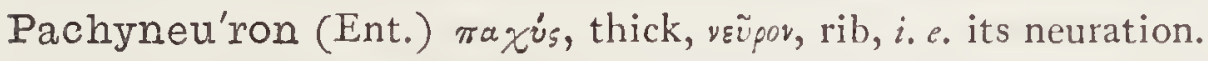

Pachyneu'rum (Bot.) $\pi \alpha \chi^{\nu}$ s, thick, veṽpov, a rib (neuration); a genus of Cruciferæ.

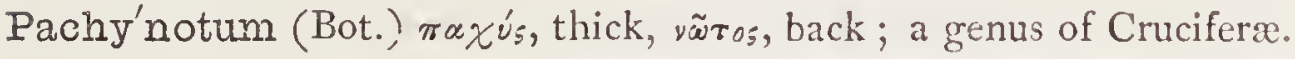

Pachyphlæ'us (Bot.) $\pi \alpha_{\chi} \chi_{\xi}$, thick, $\phi \lambda_{\text {o }} o_{5}$, bark, rind; a genus of Fungi.

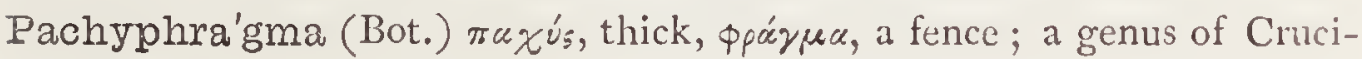
feræ.

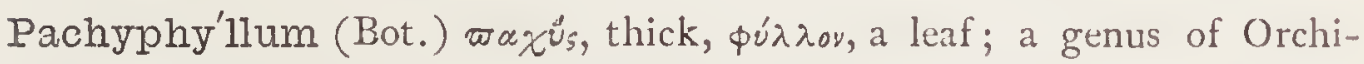
daceæ.

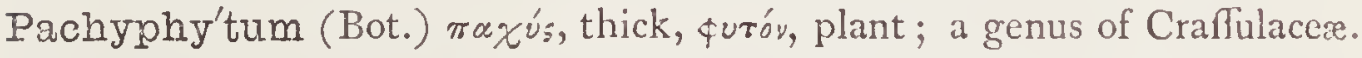
Pachypleu'ria (Bot.) $\pi \alpha \chi u ́ s$, thick, $\pi \lambda \varepsilon v$ póv, rib; a genus of Polypodioid Filices.

Pachypleu'rum (Bot.) fame etymology ; a genus of Umbelliferæ.

Pachypo'dium (Bot.) ruxús, thick ródoov, a little foot (peduncle); having thick footitalks.

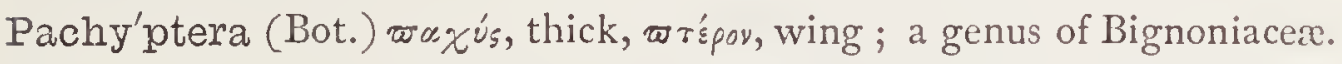

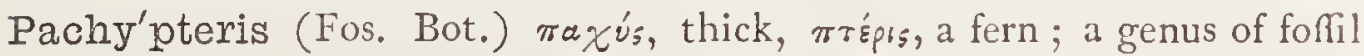
Ferns.

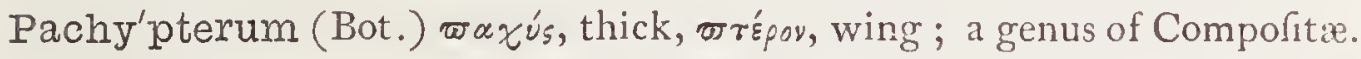
Pachyptery'gium (Bot.) $\pi \alpha \chi u_{5}$, thick, $\pi$ repúyrov, a little wing; a genus of Cruciferse.

Pachy'ptila (Ornith.) $\pi a x u ́ s$, denfe, $\pi$ rínov, a feather; a genus of Birds.

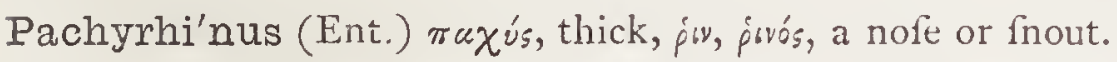

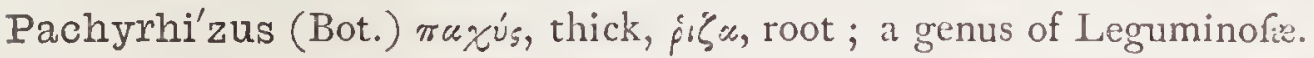

Pachyrhy'nous (Bot.) ruxús, thick, ṕryxos, beak; a genus of Compolitx. Pachyrhyn'cus (Ent.) $\pi \alpha_{\chi u_{s}}$, thick, jór xos, a fnout or beak.

Pachy'sa (Bot.) ruxús, thick; a genus of Ericacea.

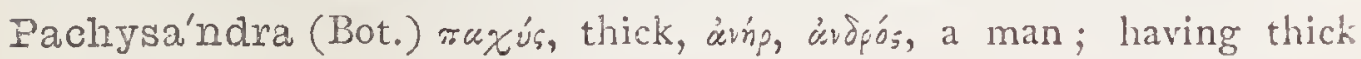

ftamens; a genus of Euphorbiacex.

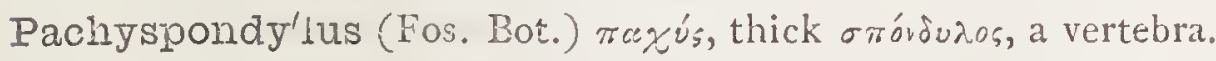

Pachyste'mon (Bot.) wuxis, thick, orńswy, a fpindle (ftyle); a genus of

Euphorbiacciv. 


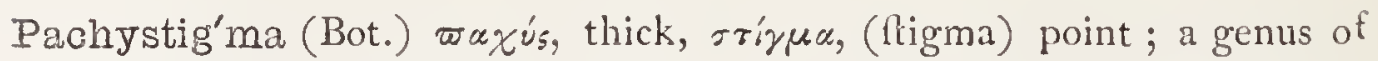
Rutacex.

Pachy'stoma (Zool.) $\pi \propto x \dot{u}$, thick, oróra, mouth ; from the inner edge of the mouth of the thell being thickened to support the operculum ; a genus of Mollufca.

Pachy'ta (Ent.) raxúrn;, thicknefs, fatnefs.

Pachythe'rium (Fos. Zool.) raxús, thick, Anpiov, an animal; a genus of foffil Mammalia.

Pa'cos (Zool.) a Peruvian wood; the fpecific name of the Llama.

Pastola'lis (Ent.) $\pi$ artos, compact.

Pade'llus (Ent.) feeding on the Bird-cherry, Prunus Padus.

Padifolie'lla (Ent.) Padus, the Bird-cherry, folium, a leaf.

Padi'na (Bot.) đúsıเvs, like the Eird-cherry, "Peacock-weed"; a genus of Marine Alga.

Padine'lla (Bot.) dim. of Padina; a genus of Algæ.

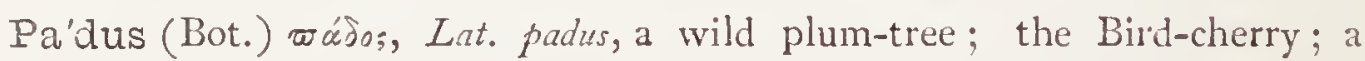
genus of Amygdalaceæ.

Padero'ta (Bot.) a name applied by the ancients to a fpecies of Acantlius.

Pæiderus (Ent.) feeding on Paderia, $q . v$.

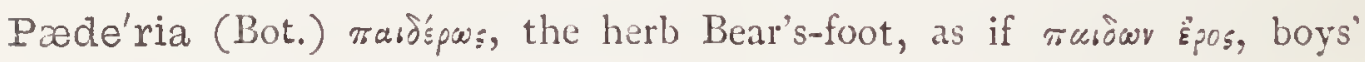
love.

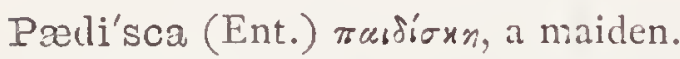

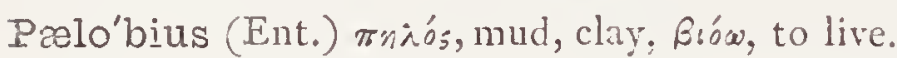

Pro'nia (Bot.) P. N. from an ancient Phyfician, Pren; or perhaps, as fuggefted by Dr. Dou, from Pconia, a mountainous country of Macedonia; a fplendid genus of Ranunculacer.

Paga'patæ (Bot.) wáyı, rock, wurśw, to traverfe; a genus of Myrtacex.

Page'llus (Ichth.) Lat. dim. of pargina, a leaf, alluding to its flatnefs. Pa'gina (Bot.) pagina, a page or leaf; referring to flatnefs.

Pago'phila (Ornith.) $\pi \dot{\alpha}$ yos, a pointed rock, $\Phi \measuredangle \lambda \dot{\varepsilon} \omega$, to love.

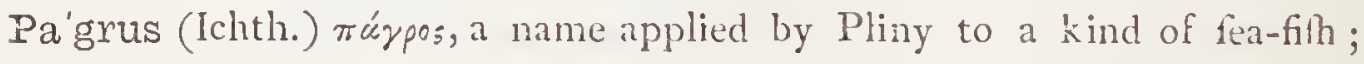

the Braize or Becker; P. unicolor is the "fchnapper" of Aufralia.

Pagu'ma (Zool.) rúugos, a rock or cliff. (?)

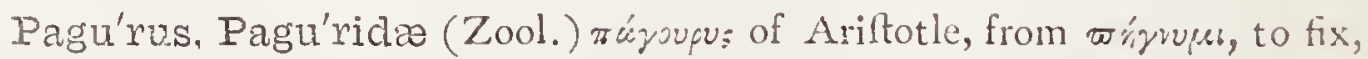
oupá, a tail; the Hermit-crab.

Pa'jeros (Zool.) fpecific name of the Pampas cat, Leopardus Pajeros. 


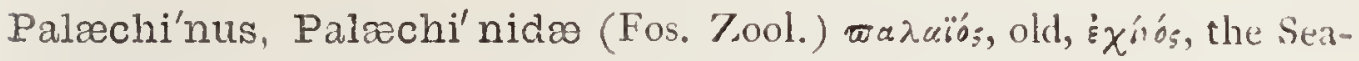
urchin.

Palæmo'nidæ (Zool.) P. N. from Palæmon, a fea.god; a genus of decapod Cruftaceans.

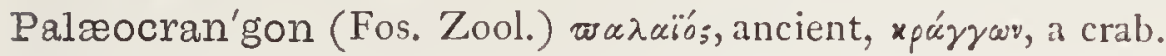

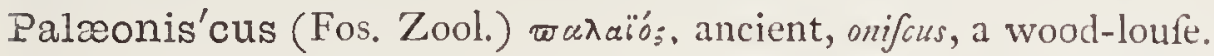

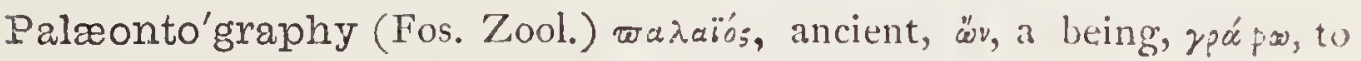
write.

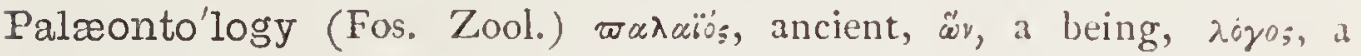
difcourfe.

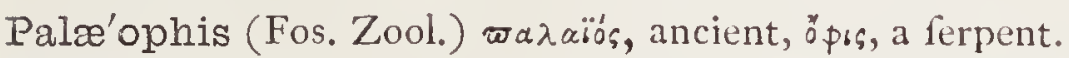

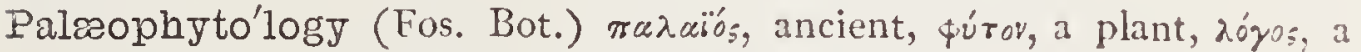
difcourfe; a defcription of Foffil plants.

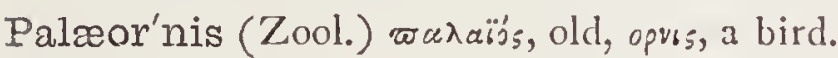

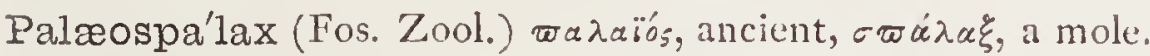

Palæothe'rium (Fos. Zool.) $\varpi \varkappa_{a i o s}$, ancient, Onfior, an animal ; a genus of extinct Pachyderms.

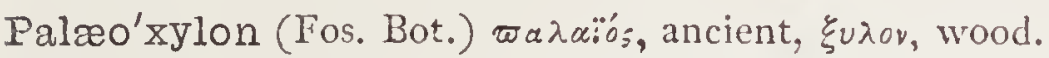

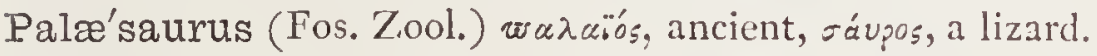

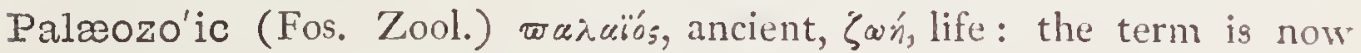
reftricted to the lower fecondary rocks.

Palæoza'mia (Fos. Bot.) wanäós, ancient, zamia, a genus of Cycadaceous plants ; a genus of folfil Cycadeous plants.

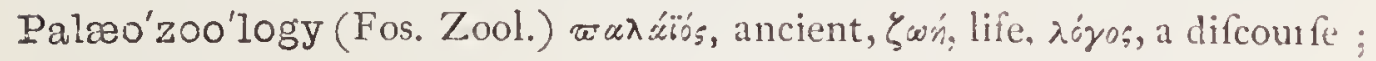
a difcourfe or treatife on extinct animals.

Palafo xia (Bot.) P. N. in honour of General Palafox.

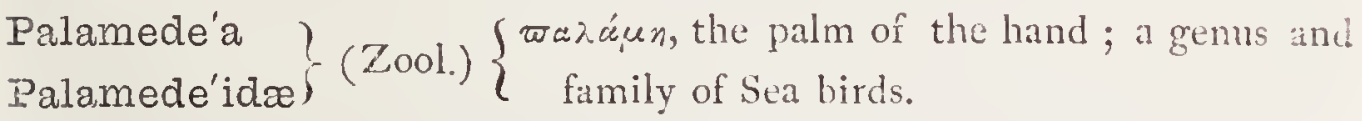

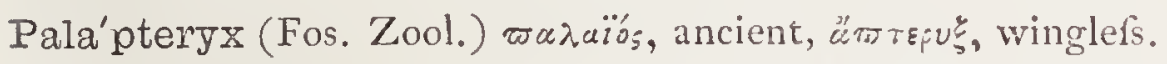

Pala'quium (Bot.) altered from the native American name: the Butter-

tree, or Baffia; a genus of Sapotacer.

Pal'arus (Ent,) $\pi \dot{u} \lambda n$, fight, battle; a genus of Hymenoptera.

Pala'va (Bot.) P. N., a genus of Malvacex.

Pala'via (Bot.) P. N. in honour of Paluz y Verdera, formerly a Profufios

at Madrid; a genus of Malvacex.

Pa'lea (Bot.) Lat. chaff, from $\pi \dot{e} \lambda \lambda \omega$, to vibrate.

Palea'ceus-a-um (Bot.) Lat. chaff-like.

Palea'lis-e (Ent.) Lat. pertaining to chaff; fraw-coloured.

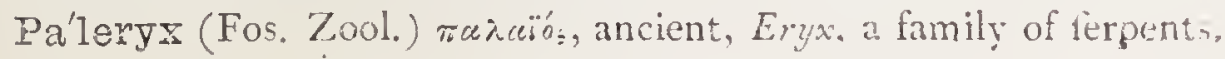




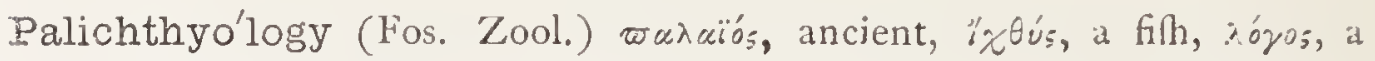
difcourfe; the fcience of forfil Fifhes.

Palicu'ria (Bot.) called Ise Pulicour, in Guiana.

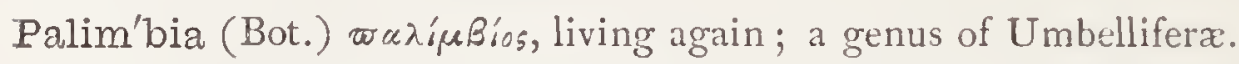

$\left.\begin{array}{l}\text { Palin'dia } \\ \text { Palin'dida }\end{array}\right\}$ (Ent.) $\left\{\begin{array}{l}\text { etymology uncertain; a genus and family of Lepi- } \\ \text { doptera. }\end{array}\right.$

Paliso'ta (Bot.) P. N. in honour of Palifot de Beawrais, a celebrated French writer upon Grafles; a genus of Commelynaceæ.

Paliu'rus (Bot.) a Greek name adopted from Diofcorides. Our Saviour's crown of thorns is faid to have been formed from the pliant branches of the $P$. aculeatus.

Palla'sii (Bot.) P. N. in honour of Peter Simon Pallas, an eminent German botanift and traveller in Ruffia; born in Berlin $174 \mathrm{I}$, died $18 \mathrm{Ir}$.

Palla'via (Bot.) P. N., a genus of Nyctaginaceæ.

Pallens (Ent.) Lat. pale.

Palle'scens (Bot.) pallefere, to grow pale, e. g., Carex pallefcens.

Pallescente'1la (Ent.) Lat. pallefcere, to grow pale.

Palliate'lla (Ent.) Lat. palliatus, cloaked; referring to peculiarities of the pupa-cafe.

Pallidula'lis (Ent.) pallidulus, palifh.

Paillidus-a-um (Bot.) Lat. pale-coloured.

Palliobranchia'ta (Zool.) pallium, a mantle, brancince, gills.

Pal'lium (Zool.) Lat. a mantle; applied to the mantle of bivalve Mollufa. which forms the depreffion on the internal furface of the Mell, called the "pallial" impreffion.

Pallore'lla (Ent.) Lat. palior, palenefs.

Palm (Bot.) Lat. palma, Fr. paume, Ital. palmo

Palma (Bot.) doubtlefs from palma, the hand, to the digits of which the fruit of the Date-palm was compared, and whence alfo it obtained the name of Dactylifera.

Palma'cer (Bot.) the Nat. Ord. of which the l'alm-tree is the type.

This name thould be written fimply Palmce.

Palmaci'tes (Fos. Bot.) palma, the palm-tree; palm-like forfils.

Palma'les (Bot.) palma, the palm-tree; the great alliance of which the

Palme are the principal reprefentatives.

Palma'ria (Bot.) palma, palm of the hand; a genus of Algr.

Palma'ris-e (Bot.) Lat. a palm's-breadth or fpan; alfo, palm-like.

Palmatus-a-um (Zool., Bot.) Lat. palm-haped, e. g., Viola palmata.

Palmel'la (Bot.) warı́s, a thaking or quivering; a genus of Algæ. 
Palmico'rnis (Ichth.) palma, a palm, cornu, a horn; the Crefted Blenny.

Palmifo'lius-a-um (Bot.) Lat. palm-leaved.

Pal'mipes, pl. Palmi'pedes, (Ornith.) Lat. palm-footed.

Palmoglce a (Bot.) palma, a palm, zrorós, fticky; a genus of Alga.

Pa'lmon (Ent.) $\pi \alpha \lambda \mu \sigma_{s}$, a quivering.

Dalpa'lis (Ent.) palpus, a teeler.

Pal'pebræ (Zool.) Lat. eye-lids.

Palpe'lla (Ent.) from peculiarities of the palpi.

Pal'pi (Ent.) palpus, a feeler.

Palpi'na (Ent.) from the large palpi.

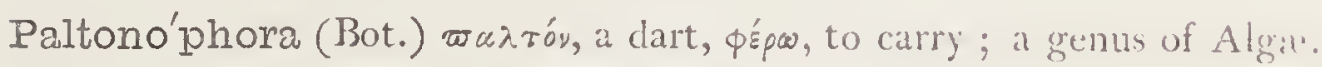

Palto'ria (Bot.) a genus of Aquifoliacex.

Paluda'na (Bot.) palus-udis, a marfh; a genus of \%ingiberacex.

Palude'lla (Bot.) dim. from palus-udis, a marfh; a genus of Bryacea.

Palude'llus (Ent.) dim. from palus-uais, a marth.

$\left.\begin{array}{l}\text { Paludicel'la } \\ \text { Paludicella'idæe }\end{array}\right\}$ (Zool.) $\left\{\begin{array}{r}\text { palus-udis, a marfh, celle, a cell; a senu; } \\ \text { and family of Polyzoa. }\end{array}\right.$

$\left.\begin{array}{l}\text { Paludina } \\ \text { Paludinidæ }\end{array}\right\}$ (Zool.) $\left\{\begin{array}{l}\text { palus, a marth; the Pond Snail; a genus and } \\ \text { family of Mollufea. }\end{array}\right.$

Paludo'sus-a-um (Bot.) Lat. mariny, e.g. Carex paludofa.

Palu'dum (Ent.) gen. pl. of palus, a marn ; i. e. "of the marfhes."

Palumba'ria )

Palumbe'lla $\int$ (Ent.) palumba, a dove; i. e., dove-coloured.

Palu'mbus (Ornith.) Lat. a wood pigeon.

Palustra'lis

$\left.\begin{array}{l}\text { Palustra'na } \\ \text { Palustre'lla }\end{array}\right\}$ (Ent.) palufler, marny.

Palustris-tre (Ent., Bot.) Lat. marhy.

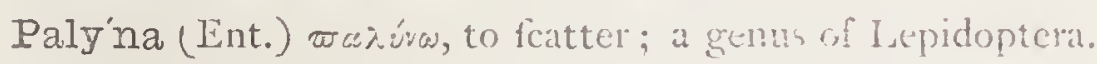

Pampas-grass (Bot.) popular name of the Gynerium argenteun, from

South America.

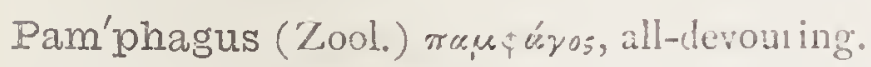

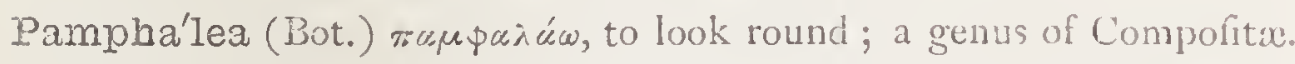

Pamphília (Bot.) đáuфiros, beloved of all; a genus of Styracacex.

Pam'philus (Ent.) P. N., a Roman furname.

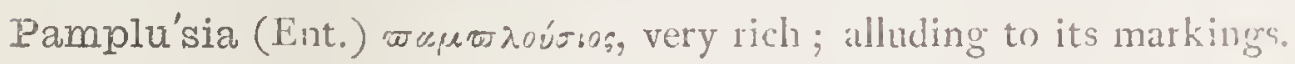

Panagæ'us (Ent.) wuvarńs, lacred.

Pana'gra (Ent.) waváypros, quite wild; a genus of Leepidoptera. 
Pa'nax (Bot.) wévu the Grinfeng; a genus of Araliacew.

Panæ'olus (Bot.) wav́odos, variegated, fparkling; a genus of Algr.

Panæ'tia (Bot.) apparently from wavairıs, caufe of all; a genus of Com pofitx.

Panca'lia (Ent.) øarúras, very beautiful; a genus of Lepidoptera.

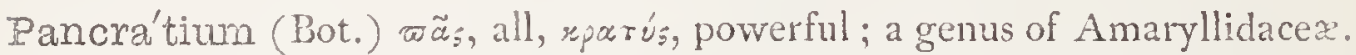
Pancra'tium (Bot.) räy, all, xparús, potent, in allufion to medical qualities. Panda'lis (Ent.) P. N. from Pan'a, a Roman godders.

Pandana'cea (Bot.) the Screw-pines, of which Pandanus is the type. Paindanophy'llum (Bot) "Pandanus-leaved"; a genus of Cyperacese. Panda'nus (Bot.) from MTalayan, pandang, to behold, in allufion to it; being confpicuous: the Screw-pine; typical genus of Pandanacer.

Panda'ridæ (Zool.) a family of Entomoltraca, of which the following is the type.

Pa'ndarus (Zool.) P. N. from Pandarus, a famous archer; a genus of Entomoftraca.

Pande'sma (Ent.) ๘ã Pandion (Zool.) P. N. of a king of Athens; applied to the Ofprey, or Fim-hawk.

Pando'ra (Zool.) P. N., Pantora, a mythological perfonage; a genus of Mollufca.

Pandura'tus-a-um (Bot.) pandira, a mufical inftrument; fiddle-lipped; e. o., Mefembryanthemum panduratum.

Pandu'riforrn (Bot.) pandura, a fiddle, forma, Thape; fiddle-fhaped.

Ianetos (Bot.) probaisly altered from the native South American name:

a genus of Cinchonacex.

Iangia'ces (Bot.) the Nat. Ord, of which Pandin is the typical genti. Pan'gium (Bot.) from an Indian name; a genus of Indian poifonous plants, typical of Pangiacers.

Pango'nia (Ent.) räs, wär, all, yovic, an angle; a genus of Diptera. Ran'gus (Ent.) etymology doubtful; is genus of Coleoptera.

Pani'ceus-a-am (Bot.) Lat. like bread; e.g., Carex panicer. Pánicle (Bot.) panicula, a tuft.

Panicula'ria (Bot.) panicula, a tuft; a genus of Polypodioid Filices.

Panicula'tus (Bot.) pirisula, a tuft.

Panic'ulus (Zool.) paricuia, a tuft.

Pa'nicum (Bot.) panis, bread, fome fpecies having been ufed for bread; Millet; a genus of Cramina. 
Panis'cus (Zool.) wavišos, dim. of way, a little pan.

Panno'nicus-a-um (Bot.) Lat. Hungarian.

Panno'sus-a-um (Bot.) Lat. ragged; ragged-leaved.

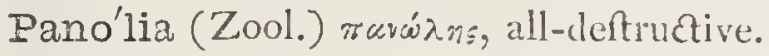

Panopæáa (Zool.) P. N. of a Sea-nymph; a genus of recent and foffil Mollufca.

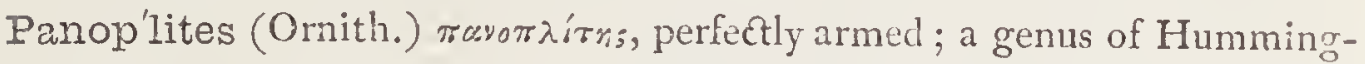
birds.

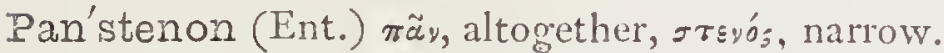

Pansy (Bot.) Fr. penfée; emblem of thought, in the language of flowers:

(see Shakfpere :) the Hearts-eafe, or Viola tricolor.

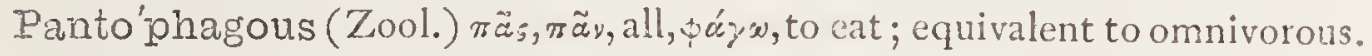

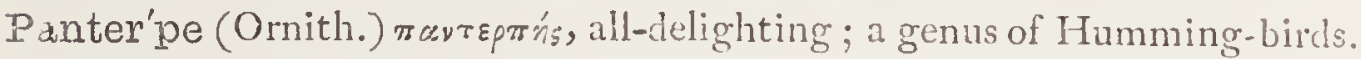

Pantheri'na (Zool.) referring to certain coloured fpots refembling thofe of a panther.

\section{Panur'gidæ)}

Panur'gus

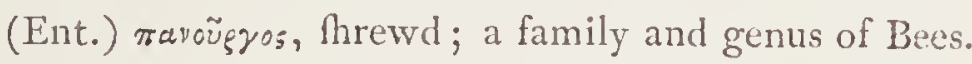

Pa'nus (Ent.) panus, a ball of wool; a genus of Coleoptera.

Pa'nus (Bot.) ஐãvos, a web of cloth; a genus of Fungi.

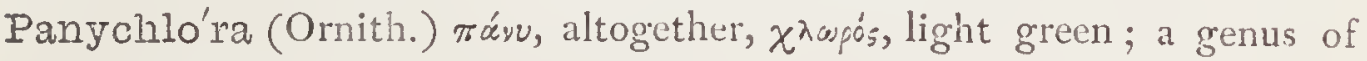

Humming-birds.

Panzerel'la (P. N. from Panzer, a German entomologift.

Panze'ria (Bot.) P. N. in honour of Panzer, a German botanift; a genus of Labiatie.

Papa'ver (Bot.) papa, pap, Celtic ; formerly ufed in children's food as a

fedative; the Poppy; typical genus of Nat. Ord. Papaveracca.

Papavera'cese (Bot.) papaver; the order of plants of which Papaver is the type.

Paparya (Bot.) native name in tropical America; the Papaw--tree, Carica Pupaya.

Papara'ccez (Bot.) the Nat. Ord. of plants of which Carica Paipaya is

the typical genus.

P.x'phia (Ent.) P. N. from Venus of Paphos.

Papilio (Ent.) Lat. a butterfly; a genus of diumal Iopidoptera.

Papiliona'cez (Bot.) papilio, a butterfly f from the form of the corolla in

a large fection of Leguminofie.

Papilio'nica (Ent.) a family of day-fying Lepidoptera, of which Pafilio

is the type.

Papil'la (Ent.) papilla, a nipple.

Papilla'tus-a-um (Zool.) papilla, a nipple or protuberance. 
Papillo'sus-a-um (Zool., Bot.) Lat. puftular or veficular, from papilla, a nipule.

Pa'pio (Zool.) etymology uncertain; a genus of Baboons.

Pappochro'ma (Bot.) pappus, the down of feeds, and xpẽua, colour; a genus of Compolitæ.

Pappopho'reæ (Bot.) pappus, down of feeds, థop'sw, to carry; a tribe of Grafles remarkable for their pappus.

Pappo'phorum (Bot.) fame fignification; a genus of Gramina.

Pap'pus (Bot.) ๘úøus, down, like the feeds of the dandelion.

Papula'ria (Bot.) papula, a pimple; a genus of Fungi.

Papyra'ceus-a-um (Bot.) Lat. paper-like, e. g. Betula papyracea.

Papy'rius (Bot.) Lamarck's name for the Paper-mulberry tree, Brouffoneti. papyrifera.

Papy'rus (Bot.) papyrus, the paper-reed, anciently ufed as a writing material; from Syriac babeer.

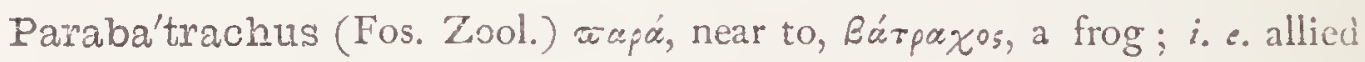
to the frogs.

Paracoro'lla (Bot.) wapá, befide, corolla.

Paracy'athus (Zool.) wapó, near, allied to the genus Cyathus.

Parácyon (Zool.) øupá, near to, xúw, a dog; a genus of Mammalia.

Paradis'ea (Ornith.)

Paradisiaca (Bot.) fpec. name given from a fanciful belief that the

Plantain was the forbidden fruit of Eden; e.g. Mufa paradifuca.

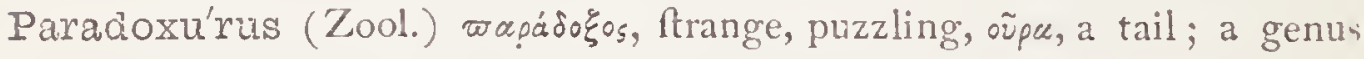
of Mammalia.

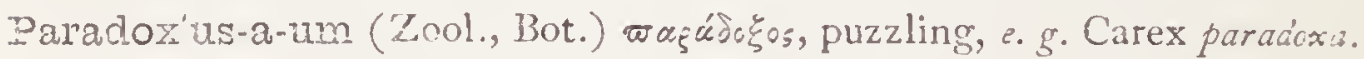

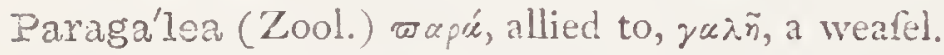

Para'gia (Ent.) тupáysıs, flying near the earth; a genus of Hymenoptera. Pera'gnathis (Bot.) wapazvatis, the cheek-jiece of a helmet; a genus of

Orchidacer.

Para'lis (Ent.) par, a pair.

Paraméciun (Zool.) apauńxns, oblong; a genus of infuforia.

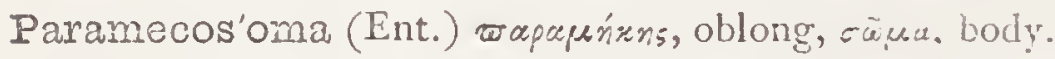

Parapo'mpilus (Ent.) rapú, near to, and the gerus Pompilas : a genus of Hymenoptera.

Para'ponyz (Ent.) wagé, near to, like, övy the oryx, a reined flone: it genus of Lepidoptera.

Para'pterum (Uinith., Ent.) wré, near, wrs.sv, a wing.

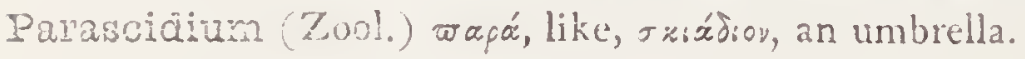


Para'sia (Ent.) either a mythological name, or perhaps from Parrhafua, a town of Arcadia; a genus of Lepidoptera.

Parasite, Parasitical (Zool., Bot.) wupáritcs, one who lives on another. Parasitel'la (Ent.) dim. of wapírıtros, a parafite.

Parasit'icus (Ornith., Ent., Bot.) ๘apáortos, a parafite, one who lives at another's expenfe.

Pa'rastohex (Ent.) ๘apá, near to, and the genus Sphex.

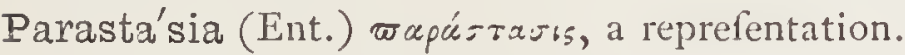

Paratar'sium (Ornith.) ఐapò, near, túgøos, the tarfus.

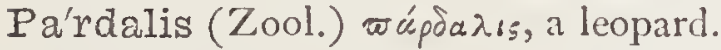

Pardalo'tus (Ornith.) $\pi \alpha \rho \delta \alpha \lambda \omega r o s$, fpotted like the pard; a genus of Ampellidx.

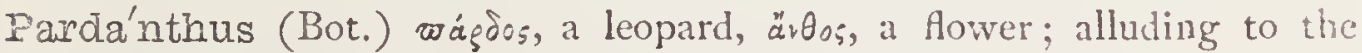
fpotted Howers.

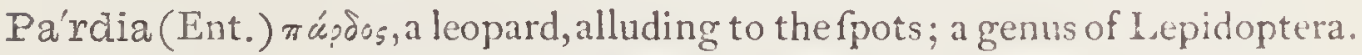
Pardi'color (Zool.) pardus, a leopard; color, colour; party-coloured.

Pardi'nus-a-um (Zool.) pardus, a leopard; panther-like.

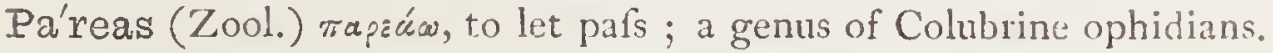

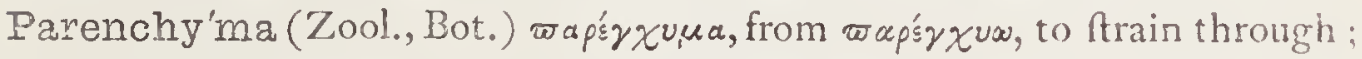
applied by botanifts to fome forms of cellular tiflue.

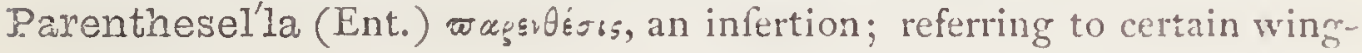
marks.

Paria'næ (Ornith.) parus, a titmoufe; a fub-family of Incefloits.

Parieta'ria (Bot.) paries, a wall, from its habitat; Pellitory: a crenus of

Urticacex.

Parina'rium (Bot.) Parinari, the Guiana name of the fpecies.

Paripennel'la (Ent.) par, paris, equal, penna, a feather.

Pa'ris (Bot.) par, paris, equal; from the regularity of its leaves and flow-

ers; a curious genus of Trilliacex.

Pa'rkia (Bot.) P. N. in honour of the famous African traveller, Muno Park; a genus of Leguminofe.

Parkinso'nia (Bot.) P. N. in honour of Fohn Parkinfon, a celebrated bctanift, author of the "Theatre of Plants," who died in 1650.

$\left.\begin{array}{l}\text { Parmace'lla } \\ \text { Parmace'llidær }\end{array}\right\}$ (Zool.) $\left\{\begin{array}{c}\text { máppen, a fmall hield; a genus and family of } \\ \text { Pulmoniferous Mollufca. }\end{array}\right.$ Parma'phorus (Zool.) $\pi$ áqun, a hield, sépw, to bear ; a genus of Mollufea.

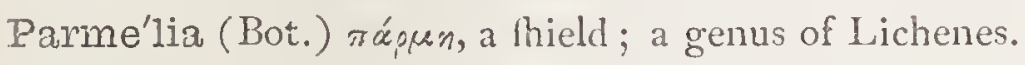

Parnas'sia (Bot.) P. N. from Mount Parnafus ; a beautiful genus of Saxifragacex. 
Par'nidæe (Ent.) a family of Coleoptera of which Parnus is the type.

Par'nus (Ent.) etymology unknown; a genus of Coleoptera.

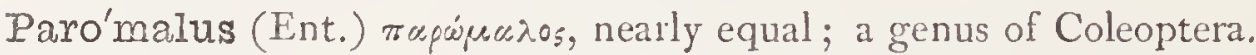

Paronychia'cez (Bot.) paronychia, a medical term for a difeafe of the nail; the Knot-worts; the family is now generally called Illecebracer. Paro'tia (Ornith.) wapú, befide, ous, the ear; the female having two ear..

like tufts on the head.

Par'ra (Ornith.) parra, a bird of ill-omen; a genus of Rallidæ.

Parrot (Ornith.) contraction of French, parroquet.

Parsley (Bot.) fome fay a corruption of Petrofelinum, q. \%. but probably becaufe an herb to be chopped, alluding to its ufe in fauces, \&c., ley being only another fpelling of lea, grafs, as in the fong-

"Over the water and over the lea,"

but in Parfey it is ufed for herb, as Virgil, on the contiary, ufes herba for grafs: In molli confedimus herba.-Buc. iii. 55 .

Parsnep (Bot.) the nep, which, from its fize, requires to be chopped up or divided into fmall portions before it can be eaten, as fchool-boys are faid to parfe their leflons, when they divide them grammatically.

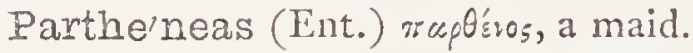

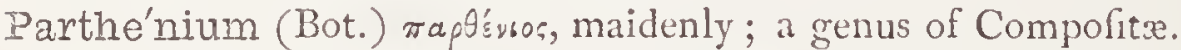

Partheno'des (Ent.) the genus Parthenos, हidos, likenefs; a genus of Lepidoptera.

Par'thenos (Ent.) mup $\theta_{\varepsilon}^{\prime} y^{\prime}$, a virgin; a genus of Lepidoptera.

Parti'tus-a-um (Bot.) Lat. divided.

Partridge (Ornith.) properly partrich, like oltrich, from French, perdrix; Lat. perdix ; Greek, w'śpdı.

Pa'rus (Ornith.) Lat. a titmoufe.

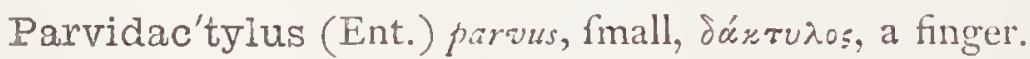

Pa'rvidens (Ichth.) parwus, fmall, dens, a tooth.

Parviflo'rus-a-um (Bot.) parvus, fmall, flos, foris, a flower.

Par'vulus (Zool.) Lat. very fmall.

Pasca lia (Bot.) P. N. in honour of Pafal, the celebrated French moralitt and epiftolift; a genus of Compofitæ.

Pascuel'lus (Ent.) frafcum, a meadow.

Pasi'tes (Ent.) $\varpi \tilde{a} z\llcorner$, poflefion; a genus of Hymenoptera.

Pasithe'a (Ent.) one of the Graces; a genus of Spiders.

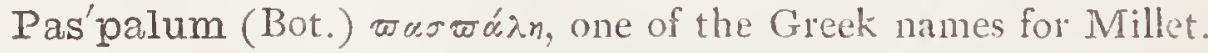

Pasque-flower (Bot.) i. c. paifu', or Eafter-flower (French); becaufe it blofloms about Eafter. 


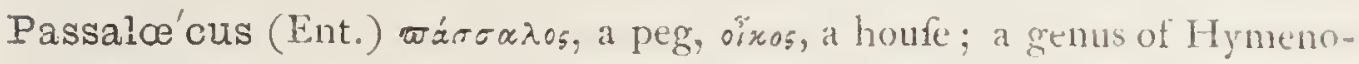
ptera.

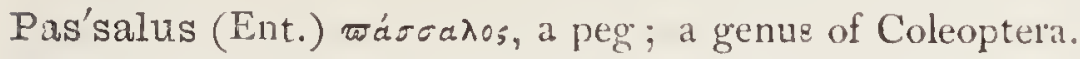

Pas'ser (Ornith.) Lat. a fparrow.

Pas'seres (Ornith.) plural of passer, a fparrow.

Passeri'na (Bot.) paffer, a fparrow, from having beaked feeds; a gemus of Thymelacex.

Passerita (Zool.) derivation unknown; a genus of Colubrine ophidian.

Passiflo'ra (Bot.) this name (conftructed from Flos paffionis) with its equir. Paffion-flower, is faid to have been given to the genus from a fuppofition of fome of the older botanifts that the appendages of the flowe' reprefent the paffion of our Saviour; their fertile imagination having led them to compare the five ftamens to the five wounds, the three ftyles to the Trinity, the column which fupports the germ to the crofs, and the filamentous rays to the crown of thorns.

Passion-flower (Bot.) ride Paffflora.

Pastina'ca (Bot.) Lat. a parfnip, probably from paftinum, a forked planting tool, from its refemblance; the Parfilip: a genus of Nat. Ord. Umbelliferæ.

Pastinace'lla (Ent.) feeding on the Wild-parfnip, Paftinaca fativa.

Pas'tor (Ornith.) Lat. a Thepherd or herdfman, becaufe frequently feen in company with theep or cattle; fpecific name of a tern.

Patacho'nicus-a-um (Zool.) Lat. Patagonian.

Patro'cus (Ichth.) from warabroi, the name given to certain inages of Phonician gods, from fancied refemblance.

Patel'la, Patel'lidæ (Zool.) patella, a fmall pan or dilh; a genus and family of Mollufca.

Patellifor'mis (Bot.) patella, forma. Thape; dith-thaped.

Pa'tens (Bot.) Lat. fpreading, e.g., Salvia patens.

Paterso'nia (Bot.) P. N.; a genus of Iridacex.

Patien'tia (Bot.) "Several fpecies of this genus, (Rumex), have from time to time been ufed in medicine, but, on account of their general inertnefs, they are now difcarded. Indeed, R. patientia feems to have been wittily named from the length of time it took to cure difieafes, and the exemplary patience required in thofe who recovered under its adminiftration." -BURNeTT.

Patricia'lis (Ent.) patricius, a noble.

Datrínia (Bot.) P. N. from M. Patrin, a Siberian traveller; a genus of Valerianacex. 
Patro'bus (Ent.) 1'. N., an ancient furname; a genus of Coleoptera.

Pat'ula (Ent.) patulus, wide-open; a genus of Lepidoptera.

Pat'ulus-a-um (Bot.) Lat. pateo, to fand open; fpreading, ftanding open : e.g. Atriplex patula.

Pauciflo'rus-a-um (Bot.) pauci, few, flos, a flower.

Paucispi'rus-a-um (Bot.) pauci, few, Spira, a whorl.

Paulow'nia (Bot.) P. N. in honour of Her Imperial and Royal Highnefs the hereditary Princefs of the Netherlands; a genus of Scrophulariacer.

Paupe'lla (Ent.) pauper, poor.

Paupera'na (Ent.) pauper, poor.

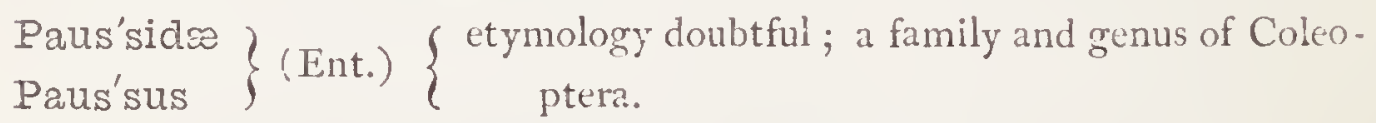
Pave'tta (Bot.) a Malabar name; a genus of Cinchonacex.

Pa'via (Bot.) P. N. from Pierre Pazw, Profeftor of Botany at Leyden: the Scarlet Horfe-chefnut.

Pavo (Zool.) Lat. a peacock.

Pavona'ria (Zool.) paro, a peacock; a genus of Zoophytes.

Pavo'nia (Bot.) P. N. in honour of Don Fofeph Paron, M.D. of Madrid, a traveller in Peru, and one of the authors of "Flora Peruviana."

Favo'nius-a-um (Zool., Bot.) paronimus, coloured like a peacock's tail, e. $g$., Corallina paronia.

Paxi'llus (Zool.) Lat. a peg.

Paxto'nia (Bot.) P. Nं, a genus of Orchidaceous plants named in honour of Sir Fofeph Paxton, Kt.

Paykullia'na (Ent.) P. N. from G. de Paykull, a Swedifh entomologift.

Peach'ia (Zool.) P. N. in honour of Charles W. Peach, an intelligent and active naturalift; a genus of Zoophytes.

Pec'cary (Zool.) common name of a pachydermatous quadruped, Dicotyles Tajaçu.

Peco'pteris (Fos. Bot.) $\pi \xi x \omega$, to comb, $\pi \tau^{\prime} \varepsilon$ ps, a fern; the Comb-fern. Pec'ten (Zool.) Lat. a comb; a genus of Mollufca.

Pec'ten-Ven'eris (Bot.) "Venus'comb;" a fpecies of Scandix, with fruit like the tecth of a comb.

Pectina'lis (Ent) pectn, a comb.

Pectina'tus-a-um (Bot.) Lat. Moped two ways like a comb, toothed: comb-leaved.

$\left.\begin{array}{l}\text { Pectina'ria } \\ \text { Pectinea }\end{array}\right\}$ (Ent.) prfen, a comb. 
Pectinibrancinia'ta ('Zool.) pecten, a comb, branchia, gills; a divifion of Gafteropodous Mollufca, having combed or plumed gills.

Pectinicorna'lis (Ent.) pecten, a comb, cornu, a horn.

Pecti'nidæ (Zool.) the family of Mollufea of which pecten is the type.

Pectinifor'mis-e (Bot.) pecten, a comb, forma, Thape.

Pe'ctis (Bot.) an ancient name of fome plant.

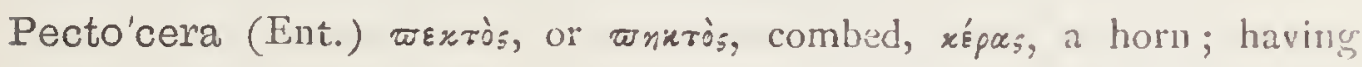
comb-horned antennæ.

Pectora'lis (Ornith.) Lat. belonging to the breaft.

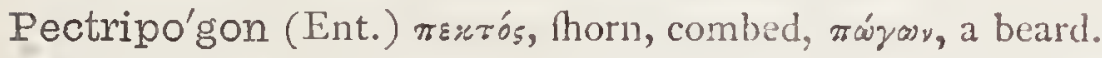

Pectun'culus (Zool.) Lat. a fmall comb; a genus of Mollufca.

Pedalia'cer (Bot.) the natural family of plants of which Pedalium is the type.

Peda'lium (Bot.) $\pi$ ró $\lambda$ เov, a rudder; from the dilated angles of the fruit. Pe'date (Bot.) pes, pedis, a foot; applied to foot-lhaped leaves.

Pede'lla (Ent.) pes, pedis, a foot; from the pofition of the infect's foot.

Pedesti'na (Zool.) pedefter, a walker; the Jumping Hare; a rodent animal of the Jerboa family.

$\left.\begin{array}{l}\text { Pedia'strea } \\ \text { Pedia'strum }\end{array}\right\}$ (Bot.) $\left\{\begin{array}{c}\text { pes, pedis, a foot, aftrum, a ftar; a fub-family and } \\ \text { genus of Defmidiex. }\end{array}\right.$

Pedicellatus-a-um (Zool.) pediculus, a little foot.

Pedicelli'na (Zool.) dim. of pes, pedis, a foot; a genus of Polyzor.

Pedicula'ris (Bot.) pediculus, a loufe; formerly fuppofed to bring on difeate

in Theep; Red-Rattle; a genus of Scrophulariacex.

Pedicula'tus-a-um (Zool., Bot.) pediculus, a little foot.

$\left.\begin{array}{l}\text { Pediculidæ } \\ \text { Pedi'culus }\end{array}\right\}$ (Ent.) $\left\{\begin{array}{c}\text { pediculus, a loufe; the Loufe-family and its typical } \\ \text { genus. }\end{array}\right.$

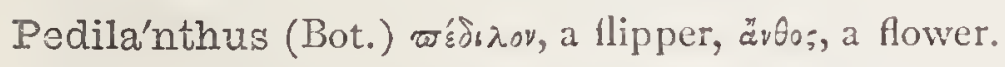

Dedima'ni (Zool.) pes, pedis, a foot, manus, a hand.

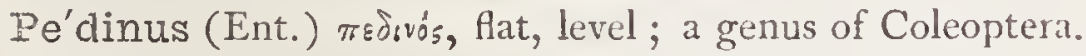

Pe'dipes (Zool.) apparently from a duplication of pes, a foot, on account

of its divifion into two parts, feparated by a tranfverfe groove.

Pedipila lis (Ent.) pes, pedis, a foot, pilus, a hair ; hairy-footed.

Pedriolel'lus (Ent.) P. N., found at Pedriole, on Monte Rola.

Peduncula'tus-a-um (Bot.) Lat. falked; e.g., Atriplex pedunculata.

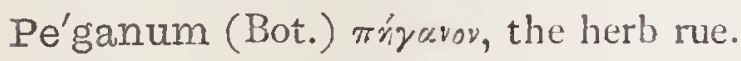

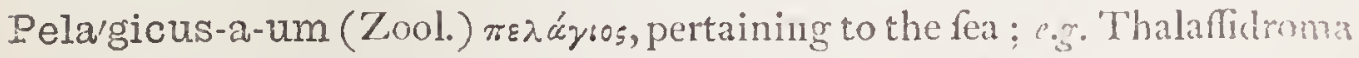

pelagica, the Stormy Petrel.

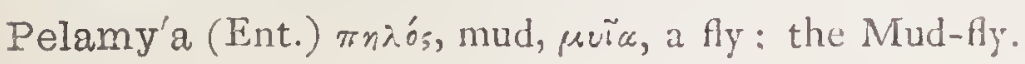


Pe'lamis ('Zool.) $\pi n \lambda_{o}$; mud, clay; a genus of amphibious Ophidians.

Pe'lamys (Ichth.) $\pi n \lambda a \mu \dot{v}_{5}$, a name applied by Pliny to the young Tunnyfilh, from $\pi n \lambda_{o_{5}}$, mud; $P$. farda is the Bonito.

Pelargona'tus (Zool.) rexuprós, a ftork.

Pelargo'nium (Bot.) $\pi \varepsilon \lambda u p \gamma^{\prime}$, a ftork; from fome fancied refemblance of the fruit; a genus of Geraniacex.

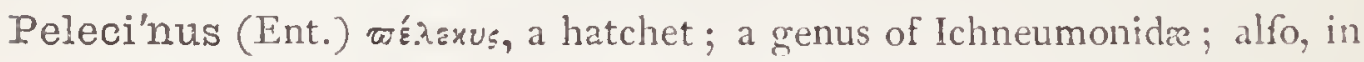
Botany the Hatchet-vetch.

Pe'lias (Zool.) P. N. from Pelias, an ancient King; a genus of Ophidians.

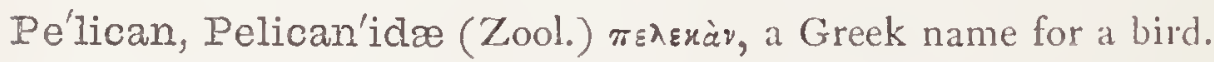

Peli'dna (Ornith.) $\pi \varepsilon \lambda$ เòós, livid.

Pelie'lla (Ent.) dim. of $\pi n \lambda o ́ s$, mud, or clay.

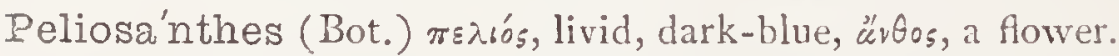

Pelisseria'na (Bot.) P. N. in honour of $M$. Peliffer; fpecific name of a fpecies of Linaria: Nat. Ord. Scrophulariacex.

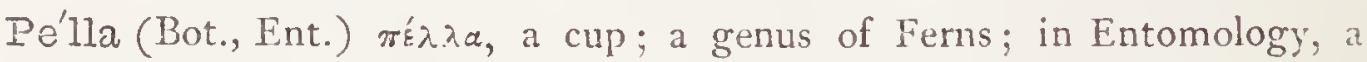
genus of Coleoptera.

Pe'llicle (Zool., Bot.) pellicula, a thin Rin.

Pellione'lla (Ent.) pellis, a kin or hide; the larva feeding on feathers.

Pellu'cidus-a-um (Bot.) Lat. tranfparent; e.g. Tetraphis pellucidu.

Pelo'bates (Zool.) $\pi$ \%ó;, mud, Baivw, to go ; a mud-walker; a genus of Batrachians.

Pelody'乞es (Zool.) $\pi \pi_{1} \lambda_{j}$, mud, dúrns, a burrower or diver; a genus of Batrachians.

Pelopx'us (Ent.) literally, "the Plafterer," becaufe it forms cells with loft mud ( $\left.\pi \eta \lambda o_{s}\right)$; a genus of Hymenoptera.

Pelo'phila (Ent.) $\pi \lambda_{i o s}$, mud, $\phi\left\llcorner\lambda s^{\prime} \omega\right.$, to love.

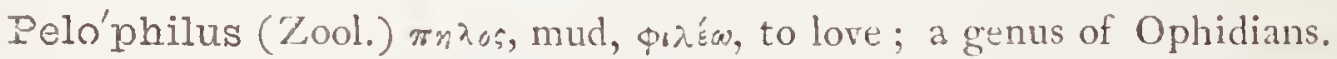

Pelo'ria (Bot.) $\pi \varepsilon \lambda \omega \omega$ pros, monftrous; from its having an unufual number of fpurs, e.g. Linaria vulgaris, B. Peloria.

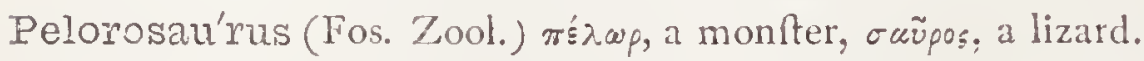

Pelta'lis (Ent.) $\pi \dot{\varepsilon} \lambda \tau$, at thield; Thield- Thaped.

Pelta'ria (Bot.) $\pi \dot{\varepsilon} \lambda \tau n$, a inall thield; in allufion to the form of the fruit;

a genus of Crucifere.

Pelti'dea (Bot.) $\tau^{\prime} \varepsilon \tau \tau$, a thield; a genus of Lichenes.

Pelti'gera (Ent.) $x^{\prime} \lambda r \%$, pelta, a light thield, gerere, to bear.

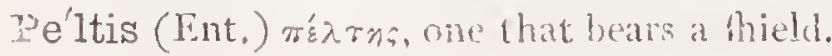

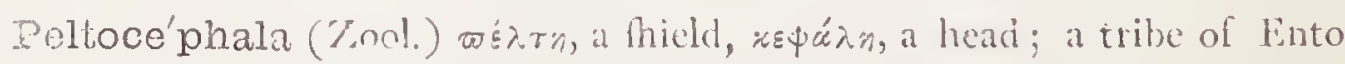
moltraca. 
Pelu'rga (Ent.) $\pi \eta \lambda$ cuprós, a worker in clay; having clay-coloured wings;

a genus of Lepidoptera.

Pempe'lia (Ent.) $\pi \varepsilon^{\prime} \mu \pi \varepsilon \lambda$ s, an old perfon; a genus of Lepidoptera.

Pem'pheris (Ichth.) $\pi \varepsilon \mu \phi n p i s$, a name applied anciently to a firh.

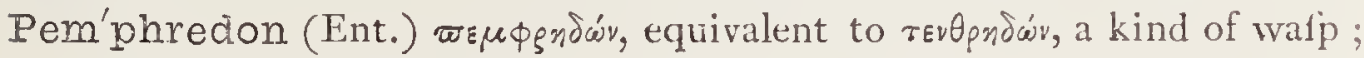

a genus of Hymenoptera.

Penæ'a (Bot.) P. N. in honour of M. Pena, conjoint author with Lobel, of Adverfaria Botanica, 1570.

Penæa'ceæ (Bot.) a natural family of Plants of which Penar is the type.

Pendula'ria (Ent.) pendulus, hanging.

Penduli'nus (Ornith.) pendulus, hanging.

Pene'lope (Zool., Ornith.) P. N. from the wife of Ulyfles; in Ornithology, a genus of Cracidx.

Pen'golin (Zool.) the Malay name of the fcaly Ant-eater, implying "rolling: itfelf up " into a compact ball.

Penichro'a (Ent.) ז'́y'xpos, poor, deftitute; a genus of Coleoptera.

Penicilla'lis (Ent.) penicillum, a pencil, a brufh.

Penicilla'ria (Bot.) penicillum, a brufh.

Pe'nium (Bot.) fo called from its refemblance to the quill (nnviov) on which the bobbin is wound in weaving; a genus of Defmidiacex.

Penkleria'na (Ent.) P. N. in honour of Baron Penkler, a German Entomologift.

Penna'ntii (Ichth.) P. N. in honour of Thomas Pennant, a Britih Na. turalift, who died 1798 .

Penna'ria (Ent.) penna, a feather.

$\left.\begin{array}{l}\text { Penna'tula } \\ \text { Pennatu'lidæe }\end{array}\right\}$ (Zool.) $\left\{\begin{array}{c}\text { dim. of penna, a quill; a genus and family of } \\ \text { Zoophytes. }\end{array}\right.$ Penna'tus-a-um (Ornith., Bot.) Lat. feathered, winged.

Pennicil'liform (Bot.) pennicillum, a pencil or bruth, forma, a thape.

Pennise'tum (Bot.) penna, a feather, feta, a briftle.

Penta'ceros (Zool.) $\pi \varepsilon v \tau \varepsilon$, five, «épas, a horn; a genus of Echinodermatu.

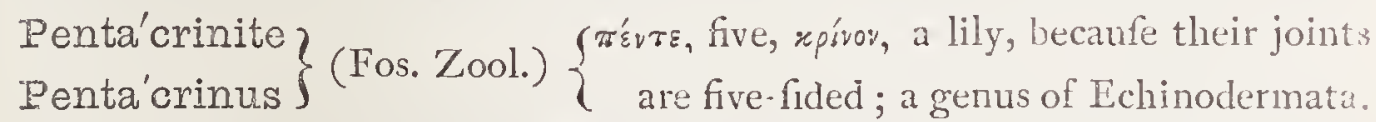
Pentac'tæ (Zool.) $\pi \dot{\varepsilon} v \tau \varepsilon$, five, $\dot{\alpha} x \tau^{\prime}$, an edge, from the five parallel row of ambulacra; a fub-family of Echinodermata.

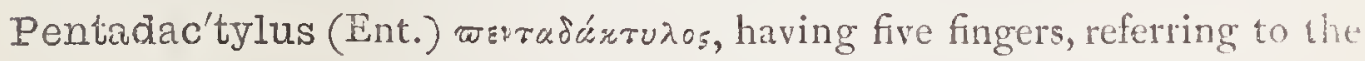
five plumes; a genus of Pluma moths.

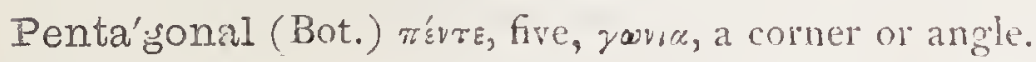

Pentagy'nia (Bot.) rí̀re, five, yusń, a female; $i$.e., having five piftils. 


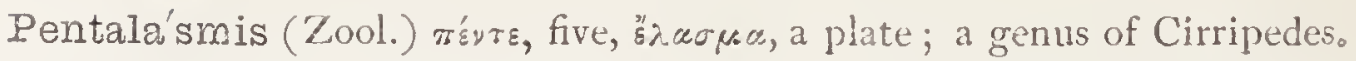

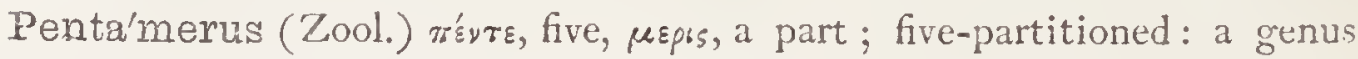
of Mollufca.

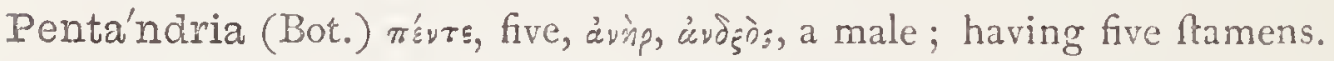
Pentangula'tus (Zool.) $\pi \dot{\varepsilon} v \tau \varepsilon$, five, angulatus cornered.

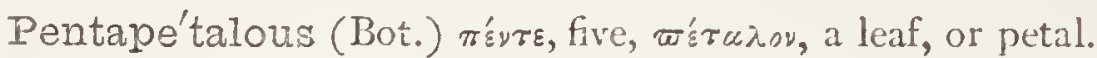

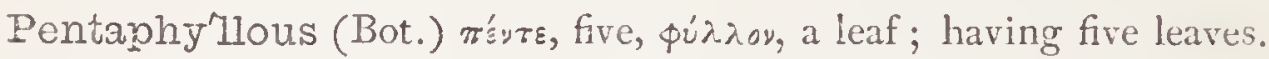

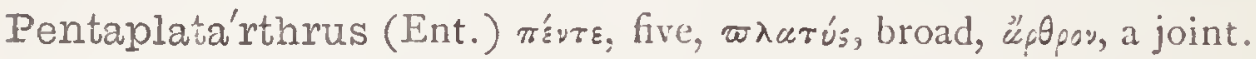

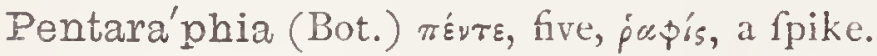

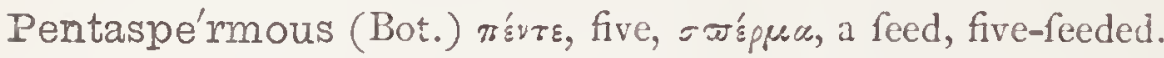

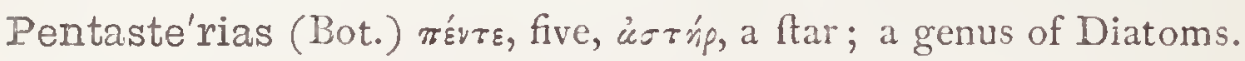

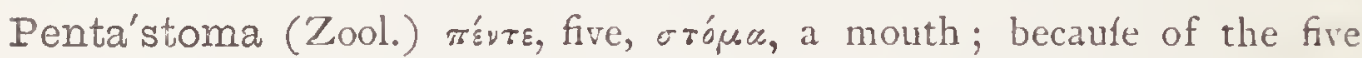
openings on the under furface of the head; a genus of Entozoa.

Penta'stomus-a-um (Zool.) fame derivation; five-mouthed.

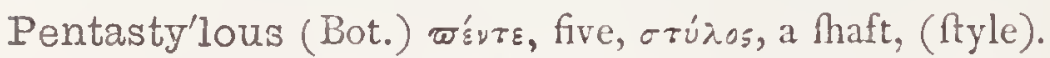

Pen'thina $\left\{\right.$ (Ent.) $\left\{\begin{array}{l}\pi^{\prime} \text { svos, forrow, mourning, from the black and } \\ \text { white markings of the wings; a genus and } \\ \text { family of Lepidoptera. }\end{array}\right.$

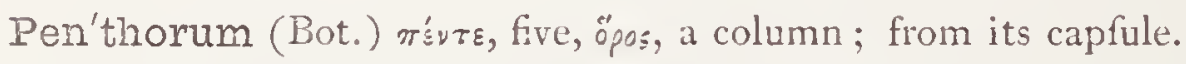

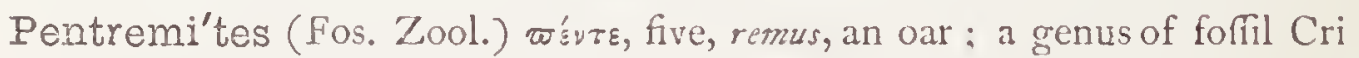
noids.

Pentste'mon (Bot.) $\pi$ śrre, five, orńusur, a fpindle (ftamen); in allufion to the additional or fifth fterile ftamen, the ufual number in Scrophulariacex being four.

Pe'ntz a (Bot.) P. N. from Charles John Pentz, a pupil of Thunberg.

Peo'sina (Ent.) $\pi x^{\prime} o_{s}$, a kinfman.

Pep'lis (Bot.) an ancient name of a plant; a genus of Lythraceæ; alfo a fpecies of Euphorbia.

Pe'plus (Bot.) Lat. a robe; fpecific name of a fpecies of Euphorbia, (as well as Peplis).

Pe'po (Bot.) $\pi$ 'swav, a gourd or melon; the Pumpkin: Nat. Ord. Cucus bitacex.

Pepper (Bot.) alteration of Latin Piper.

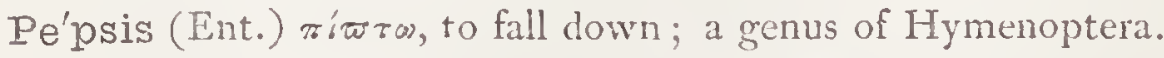

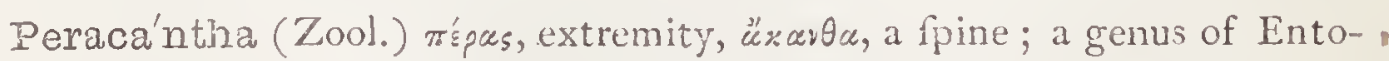
motiraca.

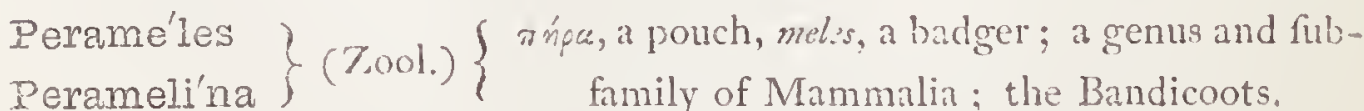
Perarma'tus-a-um ('Zool.) Lat. well-armed. 
Pe'rca (Ichth.) w'sæn, Lat. perca, a petch.

Percari'na (Ichth.) perca; a genus of the family Percida.

Pe'rcidre (Ichth.) perca, a perch, term.ide ; a family of Acanthopterygiai fithes.

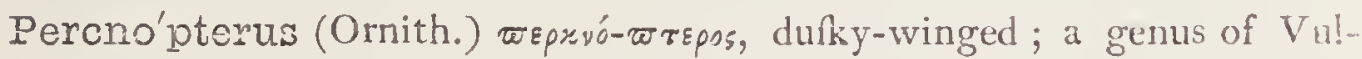
tures.

Percursa'ria (Bot.) percurfor, one who runs through; a genus of Algix.

Perdi'cidæe (Ornith.) perdix, a partridge, with fam. term.

Per'dix (Ornith.) $\pi \varepsilon \rho \delta \xi$, Lat perdix, a partridge.

Pere'bea (Bot.) probably the native American name; a genus of Artocarpacea.

Peregri'nus-a-um (Zool., Bot.) Lat. foreign, wandering, e.g., Scrophularia peregrina.

Perei'ria (Bot.) P. N. in honour of the celebrated writer on Materia Medica, Dr. Pereira, who died in 1853 ; a genus of Menifpermacex.

Peren'nial (Bot.) per, through, annus, a year; living more than one or (wo) years, and thus oppofed to annual and bi-annual.

Pere'skia (Bot,) P. N. from N.F. Peirefkius, of Provence; a genus of Cactacex.

Pere'zia (Bot.) P. N. in honour of M. Perez; a genus of Compolitit.

Per'fidus-a-um (Zool., Ent.) Lat. treacherous.

Perfila'tus-a-um (Bot.) Lat. threaded.

Perfolia'tus-a-um (Bot.) when the ftem appears to pass through the leaf, owing to certain adhefions of the latter, $c . g$. Chlora perfoliata.

Perfora'tus-a-um (Zool., Bot.) Lat. pierced.

Pergula'ria (Bot.) pergula, trellis-work, being fit for arbours; a genus of Afclepiadacer.

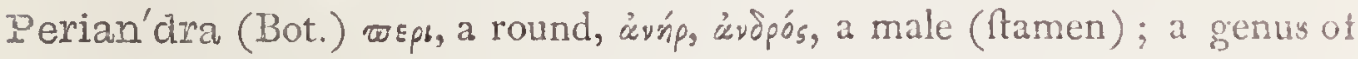
Caryophyllaceæ.

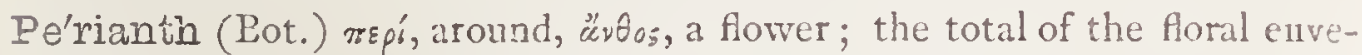
lopes, comprifing both calyx and corolli, when both are prefent, and equivalent to "calyx" when there are no petals.

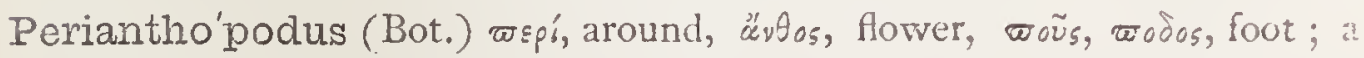
genus of Cucurbitacea.

Periba'a (Bot.) øepıßaivw, to go round; a genus of Liliacex.

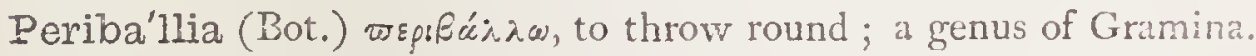

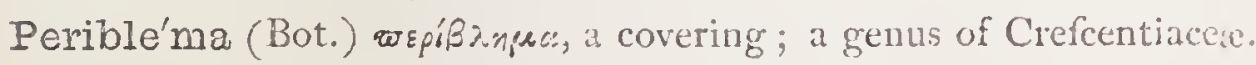

Peribo'tryon (Bố.) weṕ, around, Bórpus, à clufter; a genus of Fungi. 


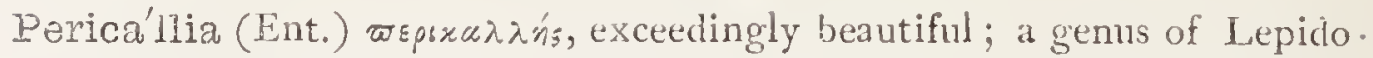
ptera.

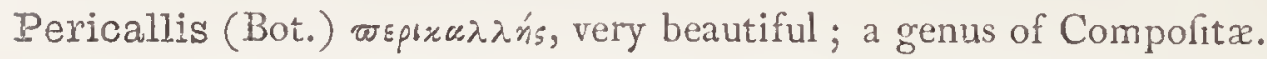

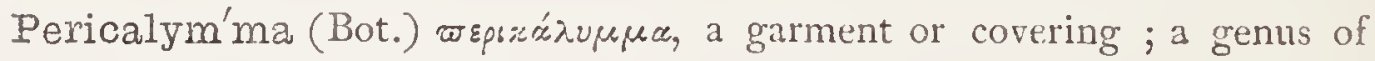
Myrtacex.

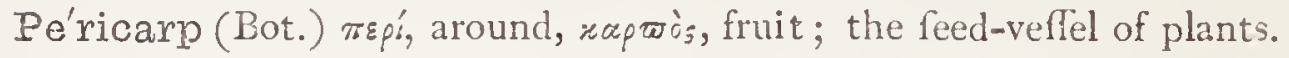

Perichæ'na (Bot.) ఐeprxuiva, to gape; a genus of Fungi.

Perichæ'tium (Bot.) $\pi$ ep', around, $x$ airn, a hair or briftle; applied to the fcaly theath round the bafe of the foot-ftalk in fome molles.

Pericli'nium (Bot) $\pi \varepsilon \rho$ ', around, $x \lambda$ irn, a bed; applied to the mass of bracteæ which furrounds the flowers in certain plants.

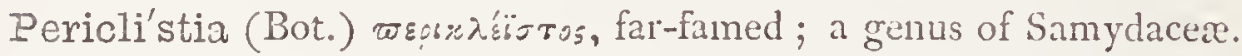

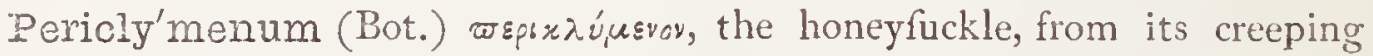
habit; the wild honeyfuckle is Lonicera Periclymenum; Nat. Ord. Caprifoliacex.

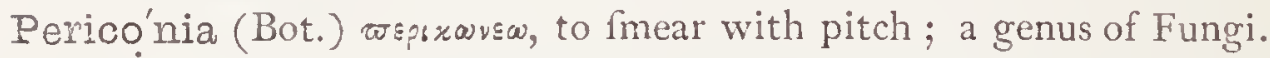

Pericroco'tus (Ornith.) repí, around, xfóros, faffron; from its orangecoloured plumage.

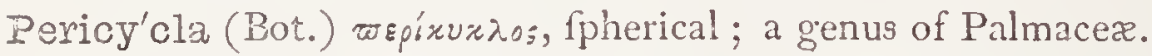

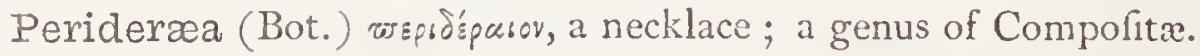

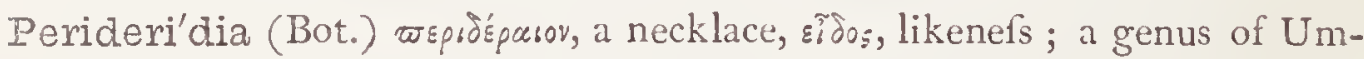
belliferæ.

Pe'riderm (Bot.) $\pi \approx \rho^{\prime}$, around, $\delta \varepsilon^{\prime} \rho \mu \alpha$, $\mathrm{kin}$; applied to the outer layer of bark.

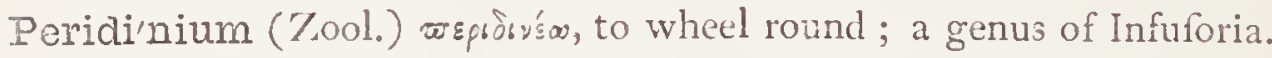

Peri'dium (Bot.) wnpisıov, dim. of sinpa, a leathern ponch; applied to the dry feed-cafe of fome mulhrooms; alfo ufed for the envelope of fome fruits.

Periechocri'nites (Fos. Zool.) weptśza, to furround, zpovov, a lily.

Perige'a (Ent.) ซspiresos, about or upon the earth.

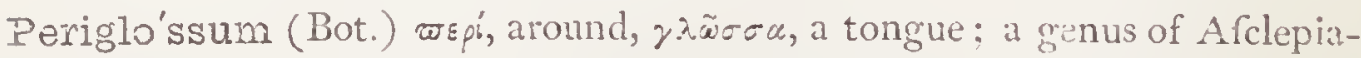
dacex.

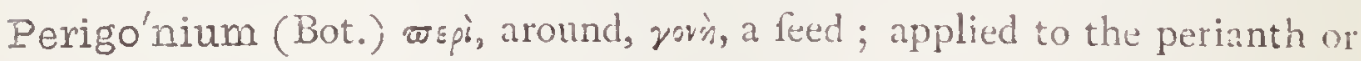
corolla.

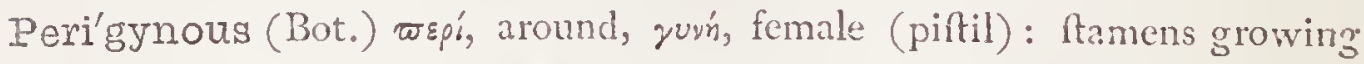
upon the calyx or corolla are fo termed.

Perila'mpus (Ent.) wsp. $\lambda \dot{\mu} \mu w \omega$, to thine around.

Perillila (Bot.) etymology uncertain; a genus of Labiatx.

Periola (Bot.) dim. of $\pi$ ripor, a leathern pouch : a genus of Fungi. 


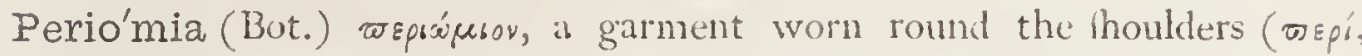
क) $\mu$ s) ; a genus of Labiatx.

Periphra'gmos (Bot.) $\pi \varepsilon p^{\prime}$, around, фpayuó, a fence or hedge ; a genus of Polemoniacea.

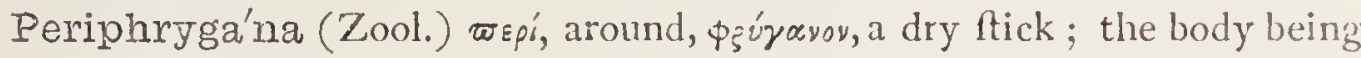
furrounded with fetaceous tentacles; a genus of Infuforia.

Peri'ploca (Bot.) ๘epi

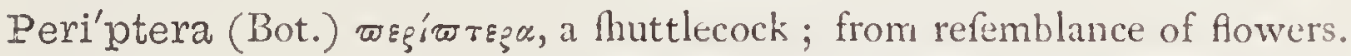

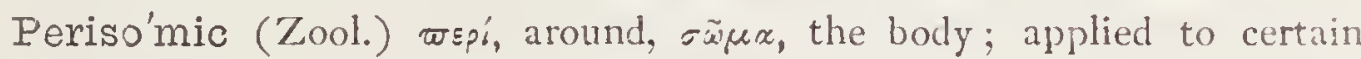
plates which furround the body.

Pe'risperm (Bot.) ๘epí, around, $\sigma \varpi \varepsilon \dot{p} \mu \alpha$, a feed; the albumen of albuminous feeds.

Perisphæiricus-a-um (Bot.) wspí, around, sqaipa, a fjhere or globe.

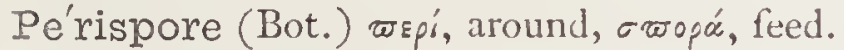

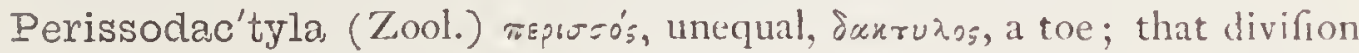
of the Ungulata having an odd number of toes.

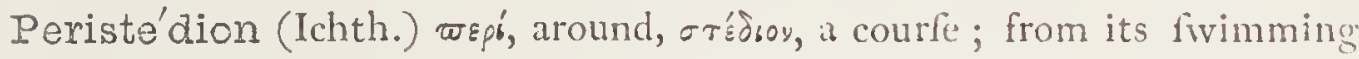
in circles.

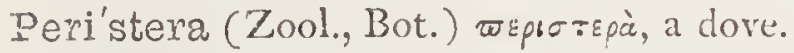

Pexiste'thus (Ichth.) $\pi \varsigma_{\rho}$ i, around, $\sigma \tau \tilde{n} 00$ s, the breaft; the Mailed Gumard. Pe'ristome (Bot.) wepi, around, orók a a mouth; the fringe round the theca of many molies.

Peri'toma (Bot.) reprtou'n, a cutting round about; from bafe of calyx.

Períttia (Ent.) ๘epitrós, uncommon; a genus of Lepidoptera.

Periwinkle (Bot.) French, purvenche; Latin, vinca; Lowu Latin, pervin.

The old fpelling was pervinkë:

"There fprang the violet al newe

And freih pervinkë, rich of hewe."-Ciraucre.

Pev'la (Ent.) Lat. a pearl; a genus of acquatic infects.

Perlel'lus (Ent.) dim. of perk, a pearl.

Perlepida'na ?

Perlepide'lla $\}$ (Ent.) perlepidus, very pretty.

- Perlucida'lis (Ent.) perlucidus, very tranfparent.

Permuta'na (Ent.) permuiare, to change.

Per'na (Zool.) an ancient name for a Thell-fin, which took its name from

its refemblance to a gammon of bacon (perna); a genus of Mollufea.

Per'nis (Ornith.)' wépyns, the name of a bird of prey; the Buzzard.

Per'niz (Ent.) Lat. fwift.

Pernota'ta (Ent.) pernotatus, well-marked. 


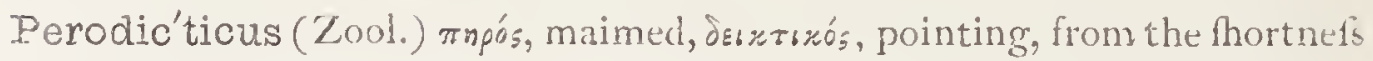
of the index of the anterior hands; a gemus of Lemuride.

Perogna'thus (Zool.) wnpós, maimed, yvútos, the jaw; a genus of Mammalia.

Perone'a (Ent.) $\pi \varepsilon_{\text {piun }}$ a buckle or button; one of the Button-moths.

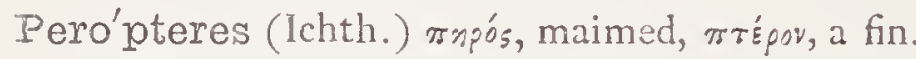

Pe'rotis (Bot.) wnpós, deficient; i. e., the flower.

Perpendicula'lis (Ent.) perpendiculum, a plumb-line.

Perplexa'lis ?

Perpleze'lla $\}$

(Ent.) perplexus, confufed, obfcure.

Perpusil'lus (Bot.) Lat. very diminutive, e. g. Ornithopus perpuffllus.

Pe'rsea (Bot.) ufed by Theophrantus for an Egyptian tree.

Pe'rsica (Bot.)P. N. from Perfia, whence the fruit came; the Peach and Nectarine are refpectively Perfica vulgaris, and $P$. lavis.

Persica'ria (Bot.) the leares refemble thofe of the peach-tree (Perfica); a genus of Polygonaces.

Persicifolius-a-um (Bot.) Lat. Peach-tree-leared; $c$. g. Campanula perficifolia.

Persis'tent (Bot.) perfigo, to continue ftanding: a calyx or corolla remaining till the fruit is ripe, is to called.

Persona'tus-a-um (Bot.) perfona, a malk; applied to corollas that refemble a creature's mizzle.

Persoon'ia (Bot.) P. N in honour of the great Botanilt Perfoon.

Perspecilla'tus-a-um (Otnith.) perfpecilli, fpectacles, e. g. Anas perfpecillata. Perspecta'lis (Ent.) perspectus, well-known.

- Perspica'lis (Ent.) perfpicax, Marp-fighted.

Pe'rtinax (Ent.) Lut. obfinate; applied to a beerle. Anobiun persinax.

from its pertinacious limulation of death.

Pertusa'lis (Ent.) pertufus, part. pertundo, to perforate, to bore through.

Pertusa'ria (Bot.) pertufis, full of holes; a genus of Cryptogamia.

Pertu'sus-a-um (Bot.) Lat. perforated, full of holes.

Per'ula (Bot.) peruhi, a little fatchel.

Perversa'lis (Ent.) perversus, turned the wrong way.

Pe'ryphus (Ent.) weprývew, to cling to, to go round.

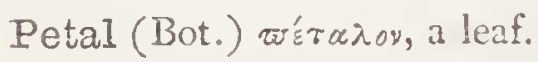

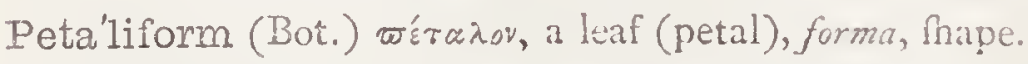

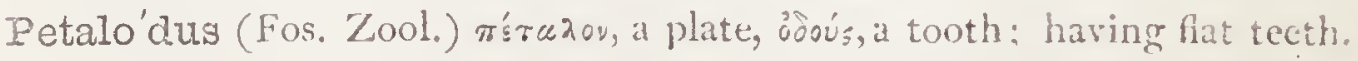

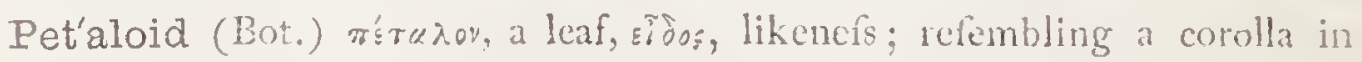
texture anc crlour. 
Petalo'ma (Bot.) $\pi \dot{\varepsilon} \tau \alpha \lambda o v$, a petal, $\lambda \tilde{\omega} \mu \alpha$, fringe; petals in calyx-teeth.

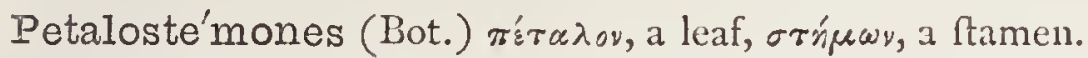

Peta'sia (Ent.) $\pi \varepsilon \tau \dot{\alpha} \sigma \omega$, or $\pi \varepsilon \tau$ ćmvuse, to fpread out, to fprawl; a genus of Lepidoptera.

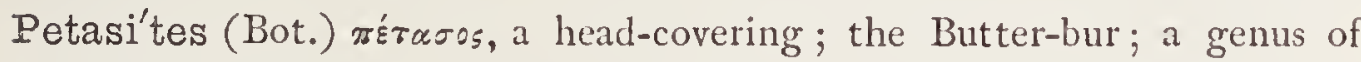
Compofitæ.

Petasi'tis (Ent.) feeds on the Butter-bur, Petafites vulgaris.

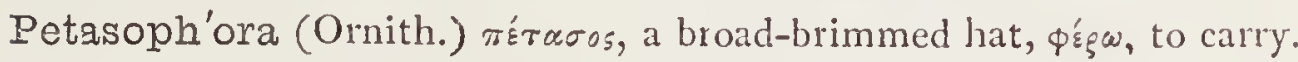

Petau'rus (Zool.) réraupoy, a perch to rooft upon; applied to fome of the fquirrels.

Petiola tus-a-um)

Pe'tiole (Bot.) petiolus, a leaf-ntalk.

Petivera'na (Ent.) P. N. in honour of Fames Petiver, F.R.S.

Petive'ria (Bot.) P.N., named by Linnæus in honour of F. Petiver, F.R.S.,

a London apothecary; typical genus of Petiveriacex.

Petræ'a (Bot.) P. N. in honour of Lord Petre; a fplendid climbing genus of Apocynacere.

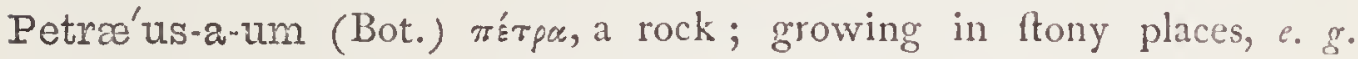
Hutchinfia petraca.

Petrária (Ent.) $\pi \dot{\varepsilon} \tau p \alpha$, a lock or crag.

Petre'a (Bot.) P. N. in honour of Robert Fames, Lord Pctre, a great patron of botany, who died in 1742 .

Petri'cola (Zool.) petra, a rock, colo, to inhabit; a genus of Mollufca.

Petrifica'ta (Ent.) petrificatus, turned to ftone, from its habit of counterfeiting death.

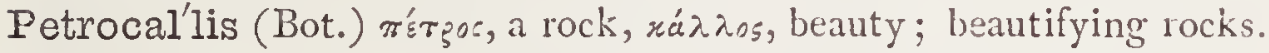

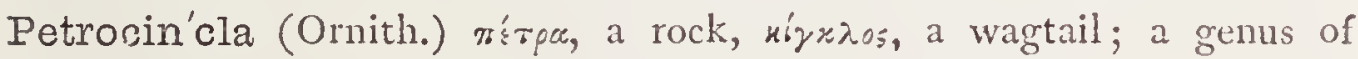
Merulidæ.

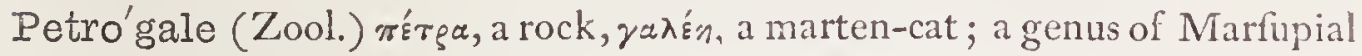
animals, fome of which are called Rock Kangaroos.

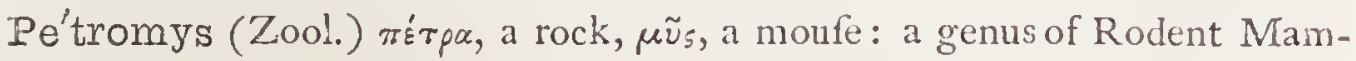
mals.

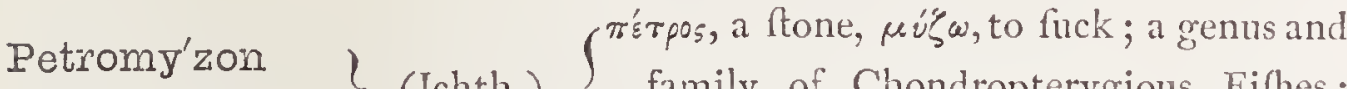
$\left.\begin{array}{l}\text { Petromyzon } \\ \text { Petromyzo'nidæ }\end{array}\right\}$ (Ichth.) $\left\{\begin{array}{l}\text { family of Chondropterygious Fifhes; } \\ \text { the Lampreys. }\end{array}\right.$

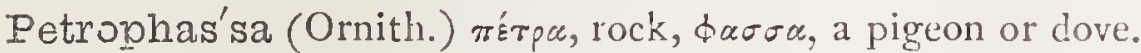

Petro'phila (Ornith., Bot.) $\pi \dot{\varepsilon} r \rho a s$, a ftone, $\phi i \lambda \varepsilon \omega$, to love.

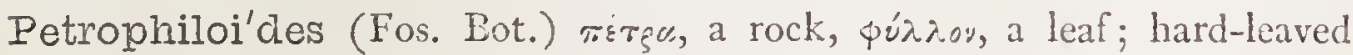
forfil cones, allied to the Nat. Ord, Proteacer. 


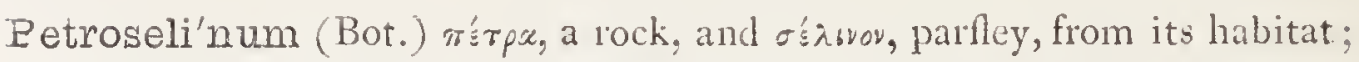
common Parfley: a genus of Nat. Ord. Ümbellifera.

Petro'sus-a-um (Zool., Ornith.) Lat. rocky.

Petu'nia (Bot.) the name for tobacco in Brazil is Petun; a genus of Solanaceæ.

Peuce'danum (Bot.) revrśsavov of Theophraftus and Diofcorides, from твír, a pine, on account of the refinous fmell of the plant; Hog'sfennel; a genus of Umbelliferx.

Peuci'tes (Fos. Bot.) $\pi \varepsilon u$ iń, the fil-tree; foffil coniferous wrood.

Pezi'za (Bot.) $\pi \varepsilon^{\prime} \zeta: 5$, a fungus without a ftalk; now applied to a genus of Hymenornycetous Fungi.

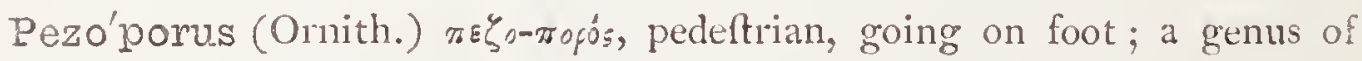
Scanforial birds.

Pfeiffere'1la (Ent.) (Ent.) P. N., named after Carl Pfeiffer, a German Naturalin.

Pha'ca (Bot.) థarós, a lentil; a genus of Leguminofæ.

Phacelo'monas ('Lool.) థáonnos, a fkiff, monus; a genus of Infuforia.

Phacídium (Bot.) ф̧arós, a lentil, Eidos, likenefs; a genus of Fungi.

Phacocápnos (Bot.) фaxió, lentil, xátrvos, Fumitory; a genus of Fumariaceæ.

Phacochce'rus (Zool.) фaxós, a wart, xoípos, a hog; the Wart-hog.

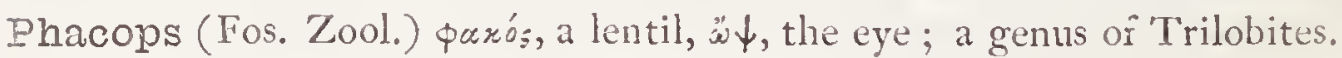

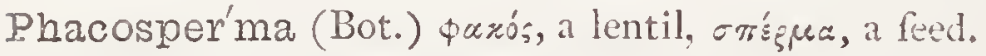

Phæa'lis (Ent.) фars, duky.

Phr'don (Ent.) P. N., a difcipie of Socrates and friend of Placo.

Phadranas'sa (Bot.) фasdpós, lhowy, ävarra, a queen, from the bealitiful appearance of the flowers; a genus of Liliacex.

Phænicu'ra (Zool.) фaiva, to difplay, cúsã, a tail.

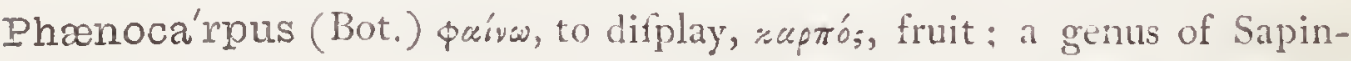
dacer.

Phæno'coma (Bot.) paivw, to fhine, xónn, a tuft; a beautiful Cape genus of "Everlaftings"; Nat. Ord. Compofitre.

Phzeno'gamous (Bot.) Quiva to difplay, rapss, marriage; equivalent to Phanerogamous.

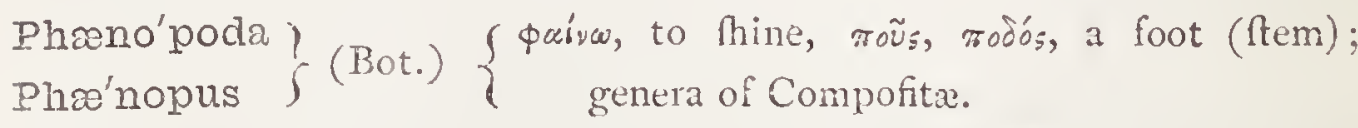

Phæochro'a (Ornith.) థasós, duky, Xpóa, colour; a genus of Humming-birds. Phæocordy'lis (Bot.) qaios, duky, nopdínn, a tuber; a genus of Balanophoracer. 
Phæocy'ma (Ent.) фaís, dußky, rũfe, a wave, i.e., on the wings; a genus of Lepidoptera.

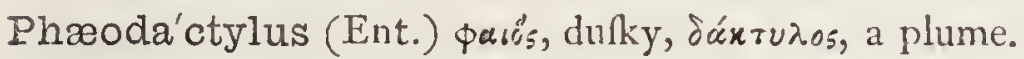

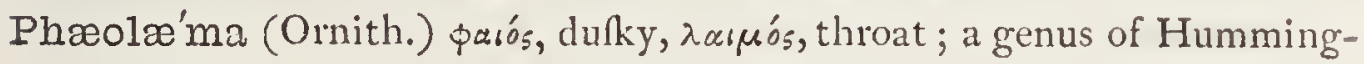
birds.

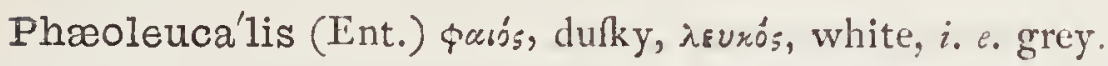

Phæone'ma (Bot.) фa.ós, dufky, vrimuce, thread; a genus of Algæ.

Phropap'pus (Bot.) фa:ós, dufky, pappus, the down of feeds; a genus of Compofita.

Phæoptera'lis (Ent.) çaı́c, dufky, ๘rśpor, a wing.

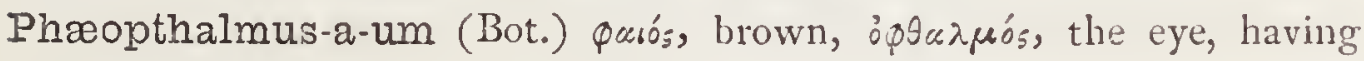
eye-like fpots.

Phæo'ptila (Ornith.) paiós, dukky, obfcure, ørĩ Humming-birds.

Phæ'opus (Onith.) paiós, dufky, woĩ;, a foot; dark-footed.

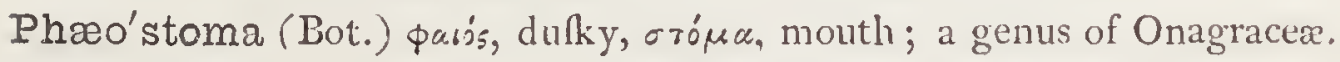

Phætho'rnis \} (Ornith.) (the proper name Plicïton, öprs, a bird; a

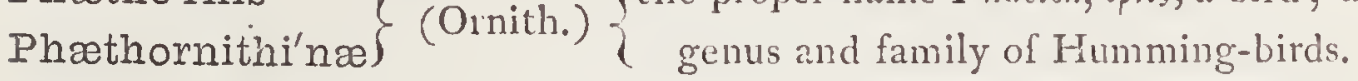

Phaëton (Zool., Omith.) P. N., an epithet of the Sun ; applied in ornithology to the Tropic-bird.

Phaetu'sa (Bot.) P. N., one of the daughters of the Sun; a genus of Compolitæ.

Phæus-a-um (Bot.) paiós, dukiy; e.g. Geranium pharum.

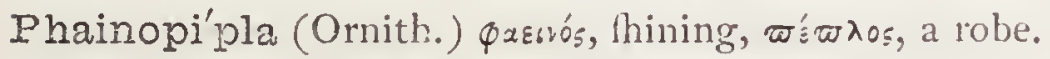

Phai'us (Bot.) pais, brown, the firt difcovered fpecies being of that colour; a genus of Orchidacex.

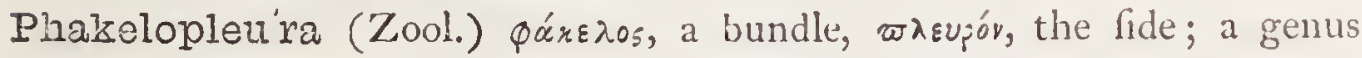
of Chitons.

Phakelu'ra (Ent.) фúrв

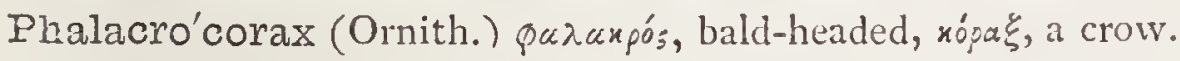

Pina'lacrus (Ent.) фàax̧ós, bald-headed.

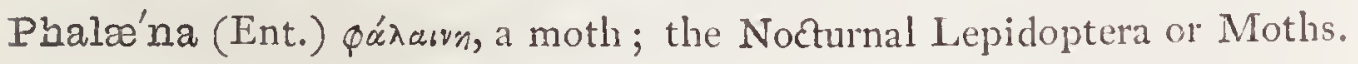

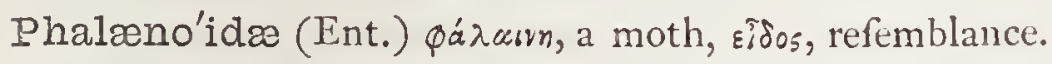

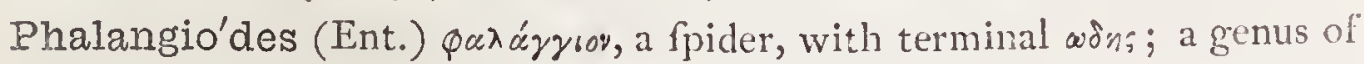
Lepidoptera; alfo fpecific name of a fpider, Pholcus phalangiodes.

Phalangi'sta $)$ (Zool.) $\left\{\begin{array}{l}\text { from the curious manner in which two of } \\ \text { the toes are joined together as far as the } \\ \text { laft phalanx: a genus and family of Kan- } \\ \text { garons. }\end{array}\right.$ 
Phalanx, pl. Phalan'ges (Zool.) pán ay z, a fmall bone of the fingers or toes, fo named from the military term for a column or line of battle. Pha'laris (Bot.) Qúx os, fhining, canary-feed being very glofly; a genus of Gramina.

Phalar'opus (Ornith.) parapós, white, wcũs, a foot.

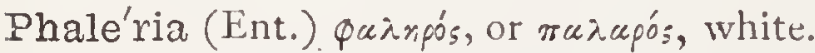

Phal'lus (Bot.) the $\phi a \lambda \lambda o^{\prime}$ of the Greeks; a genus of Fungi.

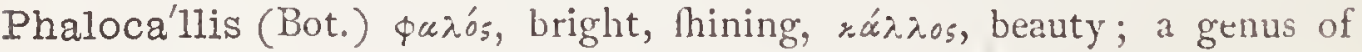
Iridacese.

Phal'oë (Bot.) Quגós, bright, hhining; a genus of Caryophyllacex.

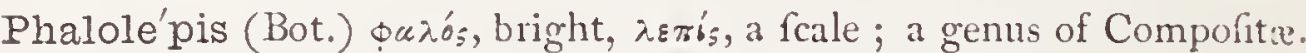

Pha'nera (Bot.) фагєрós, vilible ; a genus of Leguminofr.

Phaneroca'rpus-a-um (Bot.) paveós, confpicuous, xapæós, fruit.

Phanerocotyledo'neæ (Bot.) "vifible feed-leares," Agardh's name for

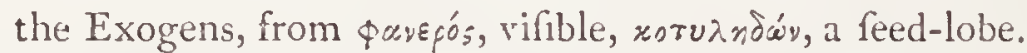

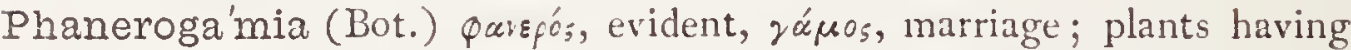
vifible flowers and feeds, in contradiftinction to Cryptogamia.

Phaneromy'cteres (Ichth.) pavéós, confpicuous, $\mu$ uxr и́, noftril; a fection of Malacopterous filhes.

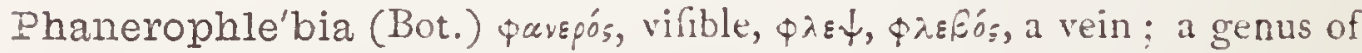
Polypodioid Filices.

Phan'tapus (Zool.) privouar, to appear, øcĩs, a foot

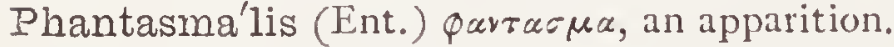

Pharbi'tis (Bot.) etymology doubtful; a fplendid genus of Convolvulacea, including the well-known "Convolvulus major."

Pha'rium (Bot.) dim. from $₫$ ãpos, a cloak or mantle; a genus of Liliacere.

Pharna'ceum (Bot.) P. N. from Pharnaces, King of Pontus, who firft ufed it; a genus of Illecebraceæ.

Pha'rus (Bot.) pãpos, a covering, the leaves being ufed for packing; is genus of Graffes.

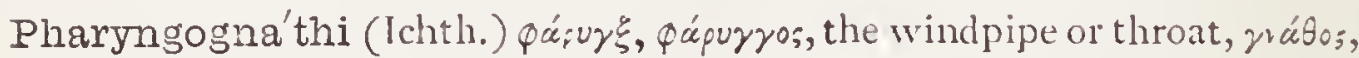
the jaw; from the union of the lower pharyngeals into a fingle bone.

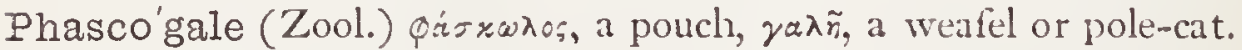

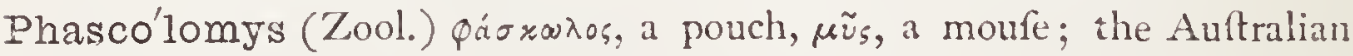
Wombat.

Phascolother'ium (Fos. 'Zool.) Gins $x^{\prime} \lambda_{05}$, a pouch, Orpion, a wild beaft; a Marfupial Mammal.

Fha'scum (Bot.) $\phi \alpha ́ z x$, a kind of lichen mentioned by 'Theophraftus; a genus of Muci. 
Phaseoli'tes (Fos. Bot.) qúonros, the kidney-bean; a genus of foffil Leguminous plants.

Phase'olus (Bot.) qúzndos, Lat. phafelus, or phafeolus, the kidney-bean; a genus of Leguminofx.

Phasianel'la (Zool.) phafianis, a pheafant ; from the beautiful pheafantlike arrangement of the colours on the hell; a genus of Mollufca.

Phasia'nidæ) (Ornith.) $\left\{\begin{array}{l}\text { from the bird having been brought from the } \\ \text { banks of the river Phafis, in Colchis: the } \\ \text { common pheafant is the } P \text {. Colchicus. }\end{array}\right.$

Phasianipenne'lla (Ent.) phafianus, a pheafant, penna, a feather.

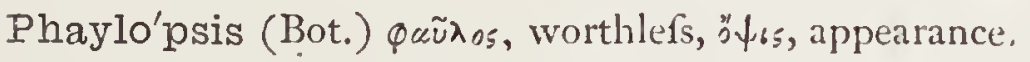

Pheba'lium (Bot.) фıßád $\varepsilon_{n}$, a myrtle, from Phibalis, in Attica.

Phebo'lithis (Bot.) ф́́n, like as, Rón.rvos, cow-dung; a genus of Sapindacex.

Phego'pteris (Bot.) Qnyós, the oak, but fometimes ufed for the beech, ๘s'pss, a fern, the Beech-fern; from the refemblance of the outline of the frond; e. g. Polypodium phegopteris.

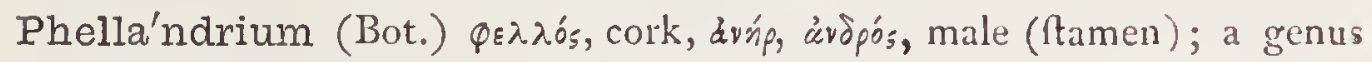
of Umbelliferæ.

Phe'llia (Zool.) $\varphi \varepsilon \lambda \lambda$ ós, the Cork-tree, from the rough appearance of the epidermis.

Phenicea'lis (Ent.) Qovvireos, purple-red.

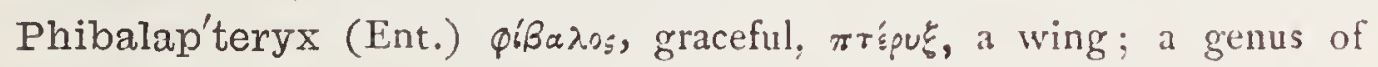
Lepidoptera.

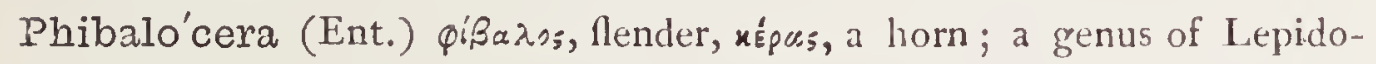
ptera.

Phibalu'ra (Ornith.) фiß $\alpha \lambda_{\text {os }}$, graceful, oũ $\alpha$, a tail.

Phiga'lia (Ent.) P. N. from a town of Arcadia; a genus of Lepidoptera. Philadel'phicus-a-um (Bot.) Lat. Philadelphian.

Philadel'phus (Bot.) ufed by Athenæus for a tree now unknown; now applied to the typical genus of Nat. Ord. Philadelphaces.

Phila'nder (Zool.) фinavojpos, conjugal; a genus of Marfupial animals.

Phila'nthus (Ent.) $\varphi\left(\lambda \dot{\varepsilon} \omega\right.$, to love, äv $\theta_{0 s}$, a flower; a genus of Hymenoptera.

Phile'don (Ornith.) $\phi \iota \lambda \hat{\delta} \delta$ ovos, given to pleafure.

Philenope'tra (Bot.) $\phi \iota \lambda^{\prime} \varepsilon \omega$, to love, $\pi_{\varepsilon}^{\prime} \tau p \alpha$, a rock ; a genus of Leguminof $x$. Philere'mus (Ent.) $\varphi\left(\lambda_{\varepsilon}^{\prime} \omega\right.$, to love, ipprn $\mu_{s}$, a defolate place; a genus of Hymenoptera.

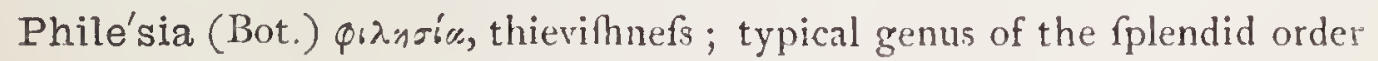
Philefiacex. 
Philesia'cer (Bot.) the family of plants of which Philefia is the type.

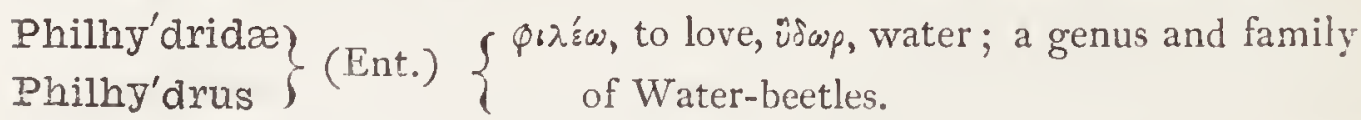
Philip'pia (Bot.) P. N., a genus of Ericaceæ.

Philippoden'dron (Bot.) arborefcent ( $\delta$ śvopov, a tree), and refembles Philippia; a genus of Byttneriacex.

Philly'rea (Bot.) P. N. from Philyra, the mother of Chiron, who was changed into a tree; a genus of Oleacex.

Philocre'na (Bot.) фı $\lambda \dot{\varepsilon} w$, to love, $x$ ṕńn, a fpring; a genus of Podoftemaceæ.

Philoc'thus (Ent.) $\phi\left(\lambda \dot{\varepsilon} \omega\right.$, to love, $\ddot{0} \chi \theta_{05}$, a bank of a river.

Philoden'dron (Bot.) $\varphi \iota \lambda o_{\delta} \delta$ vdpos, fond of trees; a very curious genus of Aroidex.

Philo'dice (Bot.) P. N., a genus of Eriocaulacex.

Philo'dromus (Ent.) фi $\lambda_{0} \delta_{5} 0_{\mu 05}$, loring the courfe, fond of running.

Philodry'as (Zoo1.) $\varphi_{1} \lambda \varepsilon^{\prime} \omega$, to love, $\Delta$ puxiss, wood-nymphs, which is from opĩs, an oak; a genus of Serpents.

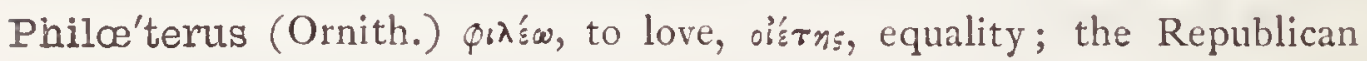
Grofbeaks.

Philo'machus (Zool.) фiróka Xos, a lover of battles; the Ruff.

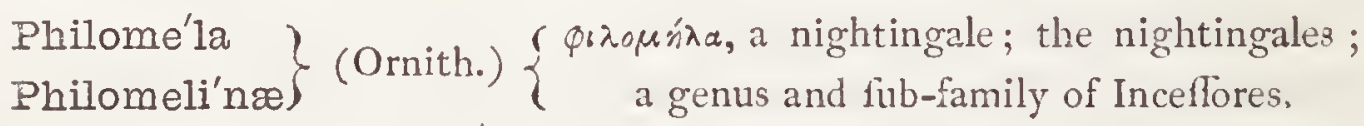

$\left.\begin{array}{l}\text { Philomyce'nidæ) } \\ \text { Philomy'cus }\end{array}\right\}$ (Zool.) $\left\{\begin{array}{c}\phi \iota \lambda^{\prime} \omega, \text { to love, } \mu \text { ũxos, flime; a family and } \\ \text { genus of Pulmoniferous Mollufca. }\end{array}\right.$

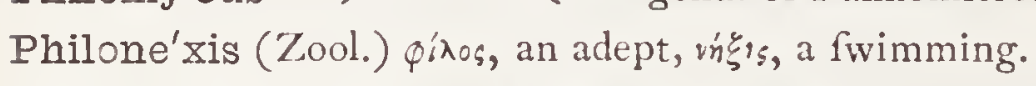

Philon'thus (Ent.) $\varphi 6 \lambda_{\varepsilon}^{\prime} \omega$, to love, övoss, dung.

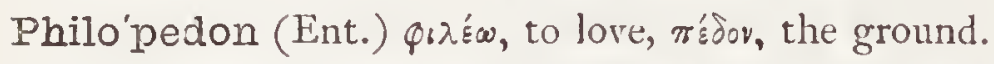

Philopj'ra (Ent.) $\phi$ ‘ $\lambda_{\varepsilon}^{\prime} \boldsymbol{w}$, to love, $\pi \tilde{u}$, fire; a genus of Lepidoptera.

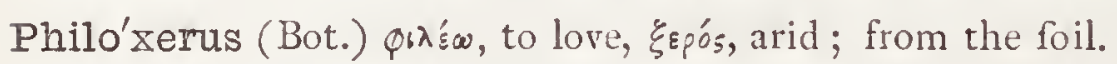

Phily'drum (Bot.) фínos, a lover, ü wp, water.

Phlæ'as (Ent.) P. N., a furname of Venus.

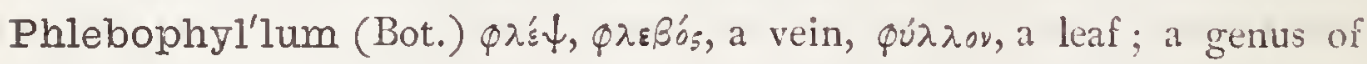
Acanthaceæ.

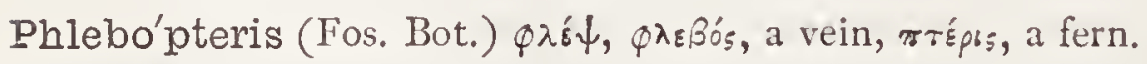

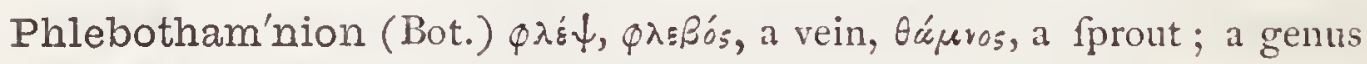
of Algx.

Phlegeto'nia (Ent.) Q $\lambda \dot{\varepsilon}$ yos, to fcorch, róvos, a finew or tendon; a genus of Lepidoptera.

Phlegma'cium (Bot.) $\varphi \lambda^{\prime} \gamma \mu \alpha$, Alame; a genus of Fungi. 
Phle'um (Bot.) $\varphi \lambda_{\varepsilon} o_{s}$, or $\varphi \lambda_{c} \tilde{u}_{s}$, a Greek name for fome unknown plant; now applied to a genus of Graffes.

Phlœo'des (Ent.) фrowódms, refembling the bark of trees; a genus of Lepidoptera.

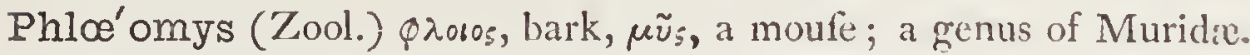

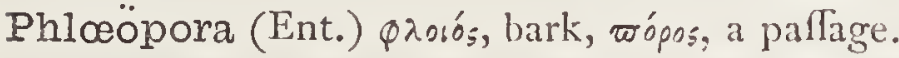

Phlœ'othrips (Ent.) quorós, bark; the genus Thrips; a genus of 'I'hyfanoptera.

Phlogacan'thus (Bot.) próyzos, flaming, red, acanthus ; a genus of Acanthacex.

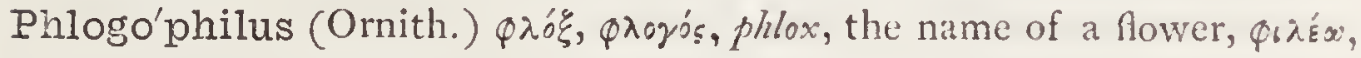
to love; a genus of Humming-birds.

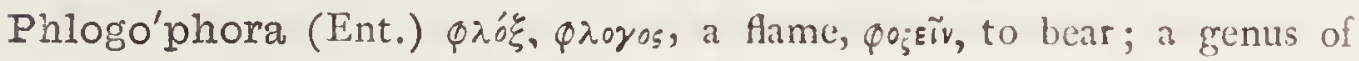
Lepidoptera.

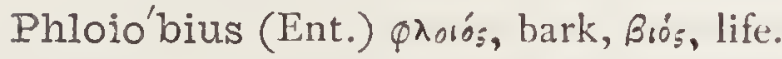

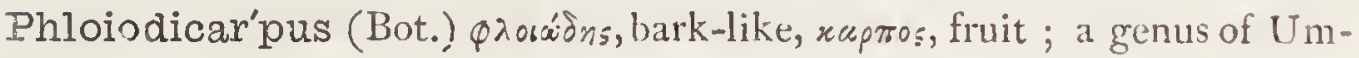
belliferæ.

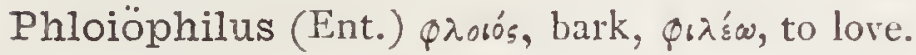

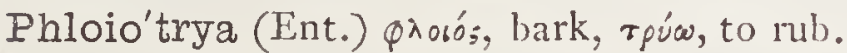

Phlomido'psis (Bot.) the genus Phlomis, and ö $\psi s$, refemblance, $i . c$. to that genus; a genus of Labiatie.

Phlomis (Bot.) Q $\lambda_{0 \mu} i_{5}$, the Greek name for mullein; a genus of Labiatic. Phlomoi'des (Bot.) Phlomis, Eidos, hape, refemblance; mullein-leaved.

Phlox (Bot.) $\varphi \lambda o ́ \xi$, a plant fo called, the word fignifying a flame; a beautiful North American genus of Polemoniacere.

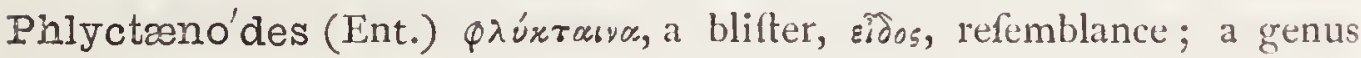
of Lepidoptera.

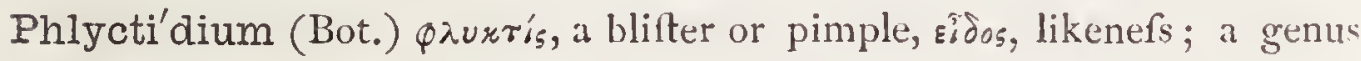
of Fungi.

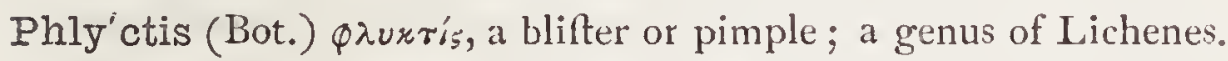

Pho'beros (Bot.) фoßspó ${ }_{3}$, formidable ; a genus of Flacourtiacex.

Phoca (Zool.) Lat. a feal, from фúxn.

Phocaena (Zool.) фúraıva, a porpoife.

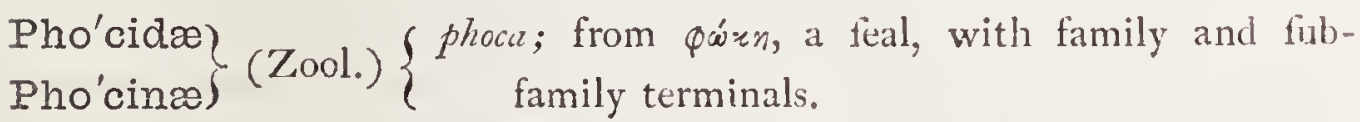

Phœbe (Bot.) P. N., a genus of Lauraces.

Phœnica'lis (Ent.) фoivirsos, purple, red.

Phœnican'themum (Boi.) posv'ros, crimfon, àvrkewv, blooming, from the colour of the flowers; a genus of Loranthacex. 
Phœnicau'lis (Bot.) థorvšśs, crimfon, caulis, a ftem; a genus of Cruciferæe.

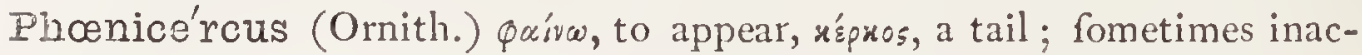
curately written Phonicircus.

Phœniceus-a-um (Bot.) 申oเv'szes, purple, cinnabar-colour.

Phonicites (Fos. Bot.) from Phenix dactylifera, the Date-Palm; a kind of forfil palm-leaves.

Phœnicoce'rcus (Ornith.) Qowíreos, purple-red, x'śpos, tail ; having crimfon tail feathers.

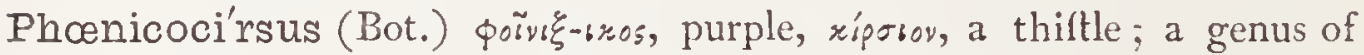
Bignoniacex.

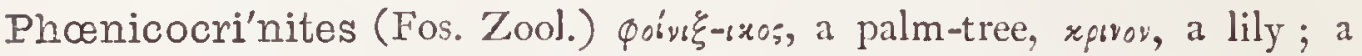
genus of Crinoidea.

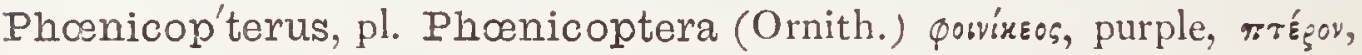
a wing.

Pho'nix (Bot.) 申oir. ï, its Greek name; the Date-palm.

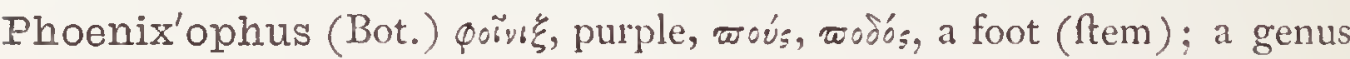
of Compn!itx.

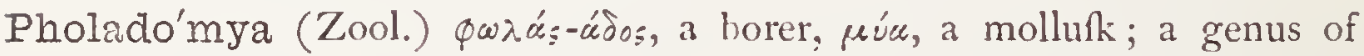
Mollufca.

Pholas (7ool.) from $\varphi \omega \lambda^{\varepsilon} \omega$, to bore; a name applied to a mollufcous animal which makes holes in ftones; a genus of Mollufca.

Phol'cus (Zool.) Q

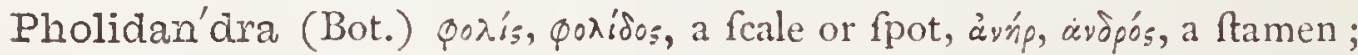
a genus of Rutaceæ.

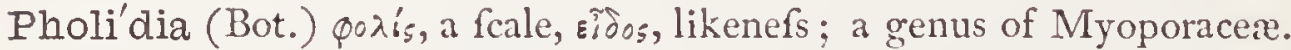

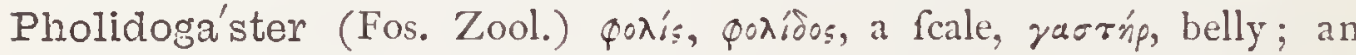
ichthyoïd labyrinthodont.

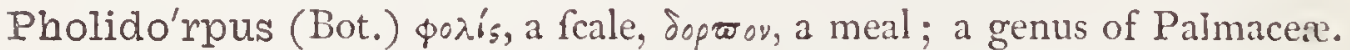
Pholis (Ichth.) $\varphi \omega \lambda \bar{s}^{\prime} \omega$, to lie in a hole ; alluding to the habits of the filh. Pholi sma (Bot.) фoגis, a fale; a North American genus of Monotropacex.

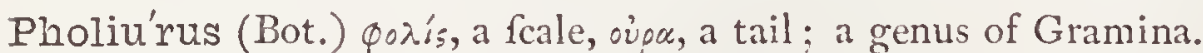

Pholoë (Zool.) P. N. a Nereid:-

"As Pholoë, moft that rules the monfters of the main."-Drarton.

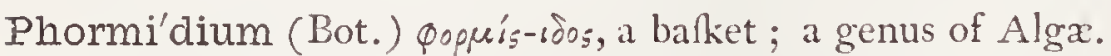

Phor'mium (Bot.) Qopuós, a baket, from its ufe in New Holland: Phormium tenax produces the New Zealand Aax.

Phoro'cera (Ent.) Qopós, bearing, xésas, a horn; a genus of Lepidoptera.

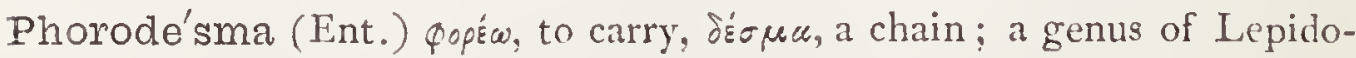
ptera. 
Phorolo'bus (Bot.) popós, bearing, גóßos, a lobe or pod; a genus of Polypodioid Filices.

Phos (Zool.) $\phi \tilde{x}_{s}$, light ; a genus of Mollufca.

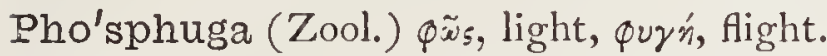

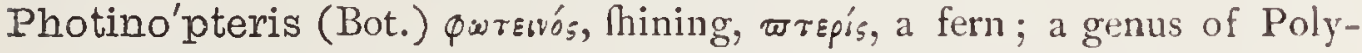
podioid Filices.

Phoxichili'dium (Zool.) $\varphi_{0 \xi}{ }^{\circ}$ s, pointed, $\chi \varepsilon \tilde{\lambda} \lambda \Delta s$, lip.

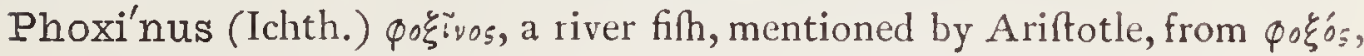
pointed; the Minnow.

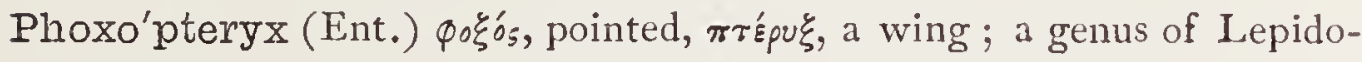
ptera.

Phragmite'lla (Ent.) phragmites, a reed, on which it feeds.

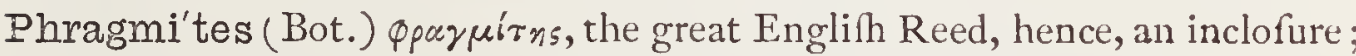
thefe reeds being thus employed; a genus of Gramina.

Phragmi'tidis (Ent.) gen. of the above; feeding on the Reed, Arundo Phragmites.

Phragmito'phis (Zool.) literally " the reed -fnake," from phragmites, a reed, and $" \phi \varphi s$, a fnake.

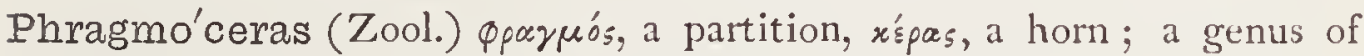
Mollufca.

Phra'tara (Ent.) probably from 申párnp, a kinfman.

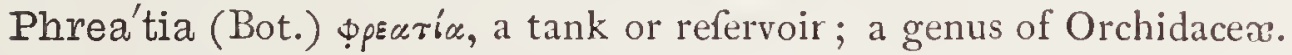

Phrissotric'hia (Bot.) $\phi \rho i \sigma \sigma \omega$, to be rough, $\theta_{\rho}^{\prime} \dot{\xi}, \tau \rho \chi^{\prime}{ }^{\prime}$, a hair or briftle:

a genus of Bryoid Mufci.

Phryga'nea (Ent.) 申púgavov, a faggot; a genus of Neuroptera.

Phryganel'la (Ent.) 申púgavov, a faggot; from the fimilarity of the larvacafe.

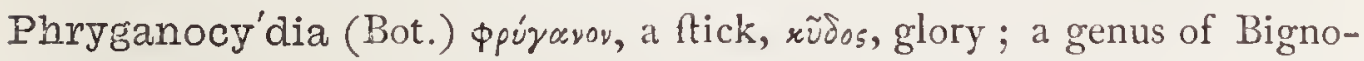
niaceæ.

Phrygano'des (Ent.) థoúravov, a faggot; a genus of Lepidoptera; perhaps given from fome fancied refemblance to the order of infects, Phry.. ganide.

Phry'nium (Bot.) 申púrn, a toad; a plant growing in marthes.

Phrynoso'ma (Zool.) фpúvn, a toad, $\sigma \tilde{\omega} \mu \alpha$, body.

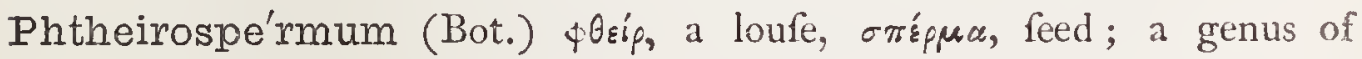
Scrophulariacex.

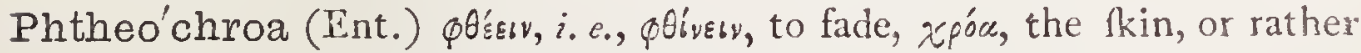
complexion; a genus of Lepidoptera.

Phthiru'sa (Bot.) фөeip, a loufe; a genus of I.oranthaces. 
Phu (Bot.) the $\$ \tilde{v}$ of Diofcorides; a fpecies of Valeriana.

Phu'rys (Ent.) Qúpw, to mix or confound; a genus of Lepidoptera.

Phyce'lla (Bot.) dim. of фũ̃ss, red alkanet, from its colour.

Phy'cidæ (Ent.) a family of Lepidoptera, of which Phycis is the type.

Phy'cis (Ichth., Ent.) Quxis, a coloured filh living in fea-weed; in Ento-

mology a genus of Lepidoptera, becaufe fome of the fpecies are red.

Phycobo'trys (Bot.) фũ ros, fea-weed, Bórpus, a clufter ; a genus of Algr.

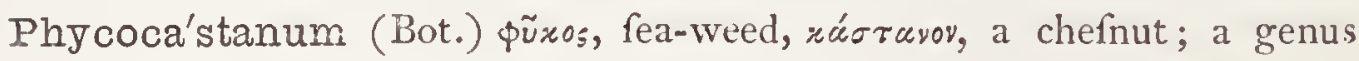

of Algx.

Phyco'des (Ent.) Qũxos, Lat. fucus; a genus of Lepidoptera.

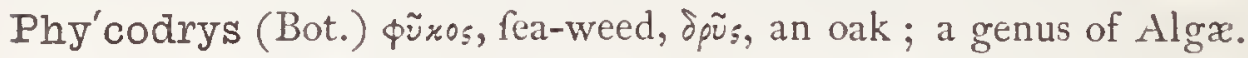

Phycolapa'thum (Bot.) фüros, fea-weed, $\lambda \dot{u} \pi \alpha \theta_{o v}$, forrel; a genus of Algæ.

Phycomy'ces (Bot.) фũros, fea-weed, rúxns, a fungus; a genus of Fungi.

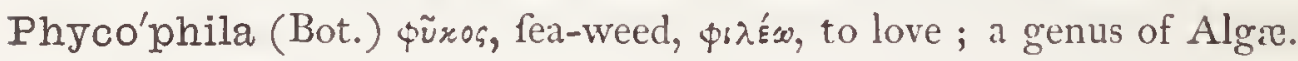

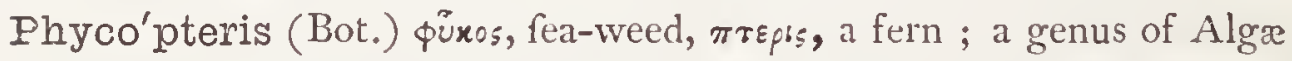
Phycose'ris (Bot.) фũxos, fea-weed, r'sps, endive; a genus of Algæ.

Phy'cus (Ent.) фॄüros, fea-weed; a genus of Diptera.

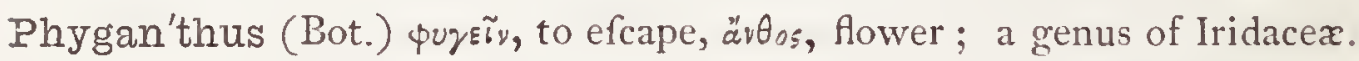
Phyge'lius (Bot.) qurń, flight, fhunning, or efchewing; in confequence of having fo long efcaped the researches of botanifts; a genus of Scrophulariacere.

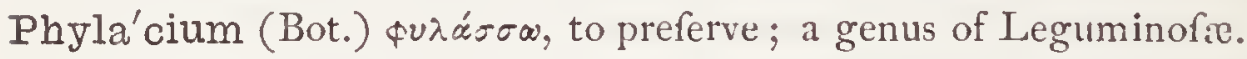

Phy'lica (Bot.) фuגıxós, leafy, from its copious evergreen foliage; a grenus of Rhamnacex.

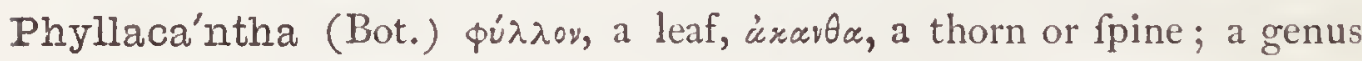
of Algæ.

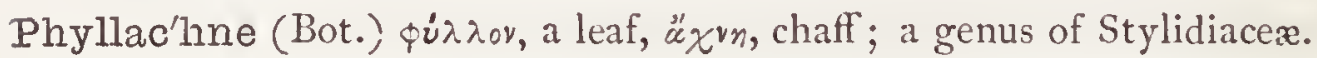
Phyllacti'dium(Bot.) the genus Pluyllactis, हidos, likenefs; a genus of Algx.

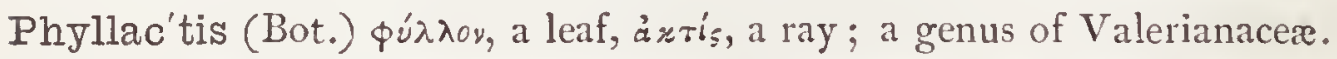

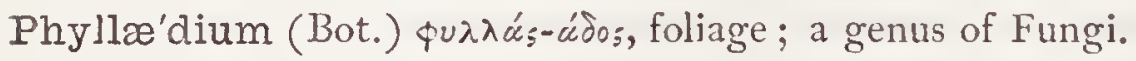

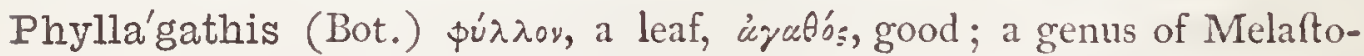
maceæ.

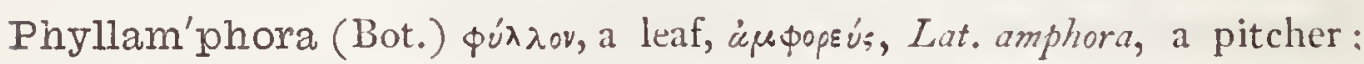
the original generic, and now the fpecific name of a Pitcher-plant, Nepenthes Phyllamphora.

Phyllan'ther (Bot.) a fection of Euphorbiacer, reprefented in Phyllanthus.

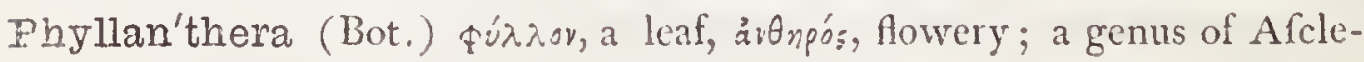
piadacer. 


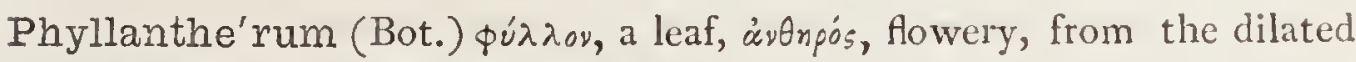
filaments; a genus of Trilliacex.

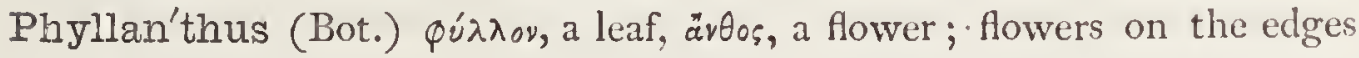
of the leaves; a genus of Cactacex.

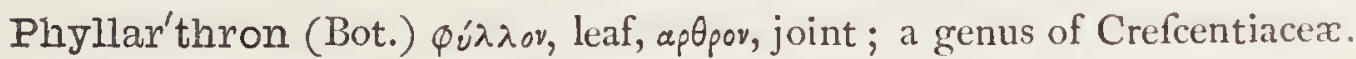

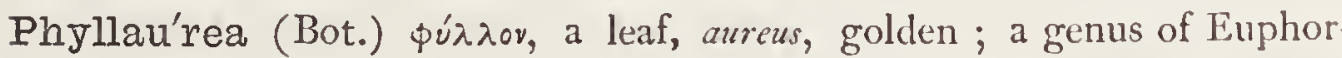
biacex.

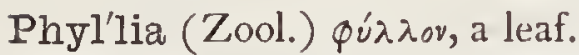

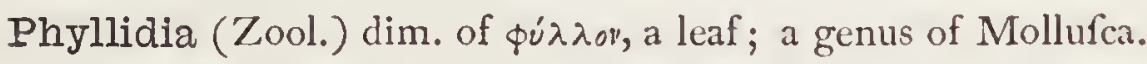

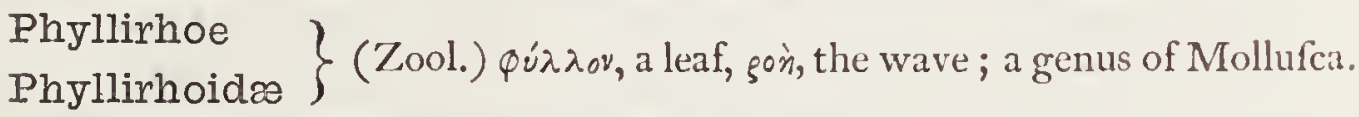

Phy'llis (Bot.) P. N., one of Virgil's nymphs.

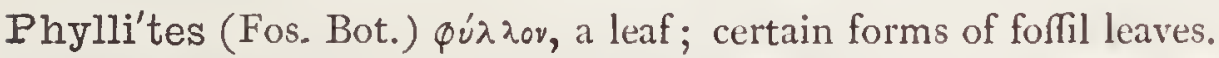

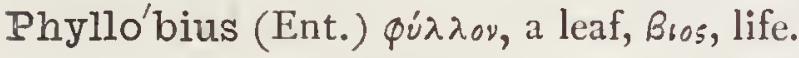

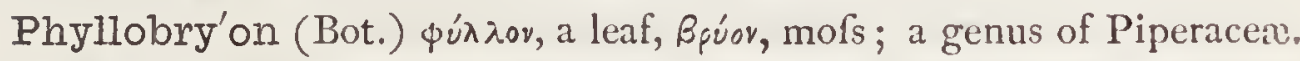

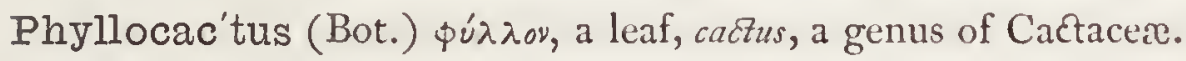

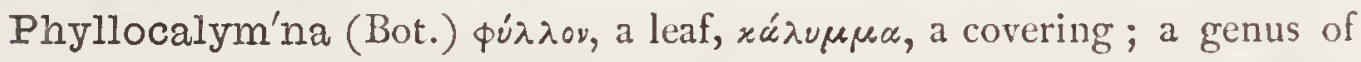
Compofitæ.

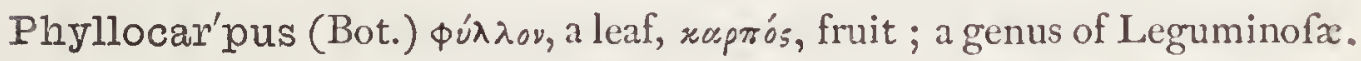

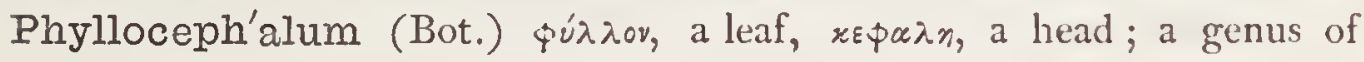
Compolita.

Phyllocla'dus (Bot.) фú $\lambda \lambda \circ v$, leaf, $x \lambda a \delta \circ$, branch, having leaf-like branchlets; a genus of Taxacex.

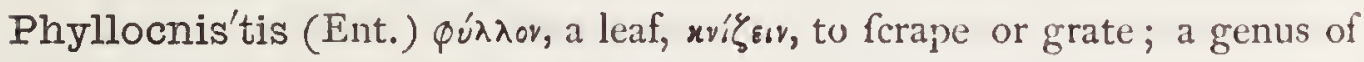
Lepidoptera.

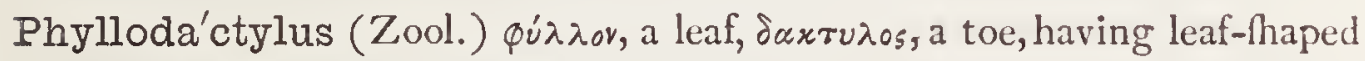
toes; a genus of Saurians.

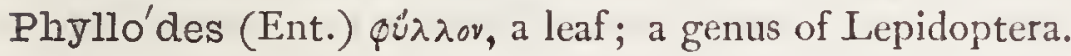

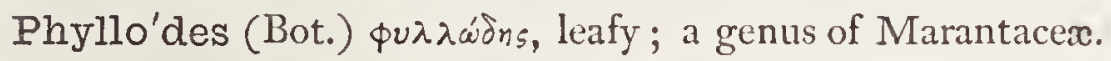

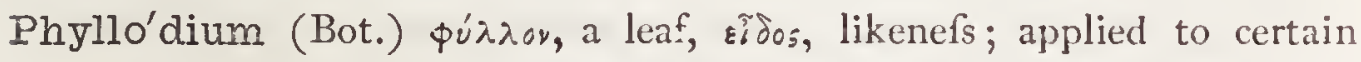
organs (wattles) of the Aufralian Acacias or Wattle-trees; the wattles are enlarged petioles.

Phy'lladoce (Zool.) P. N., the name of a fea-nymph; in Botany, a genus of Ericacex.

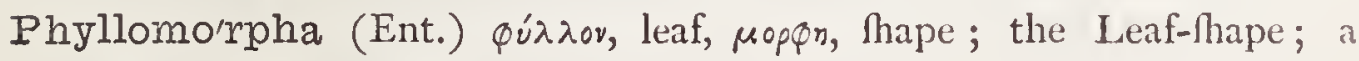
genus of Hemiptera.

Pinyllope'rtha (Ent.) $\varphi \dot{u} \lambda \lambda \circ v$, a leaf, $\pi_{\xi}^{\prime} \xi \omega$, , to deftroy.

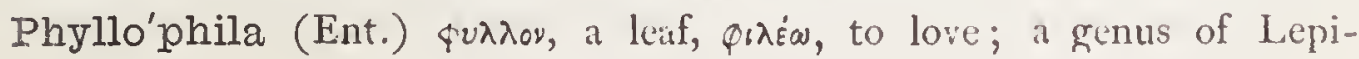
doptera. 


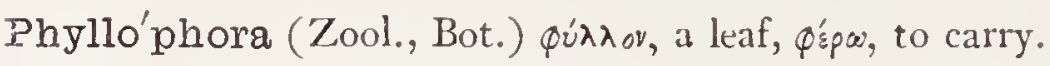

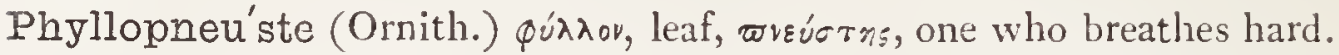

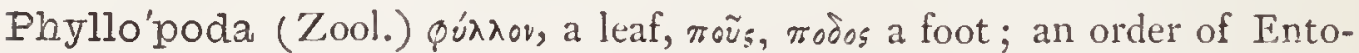
moftracous Cruftacea.

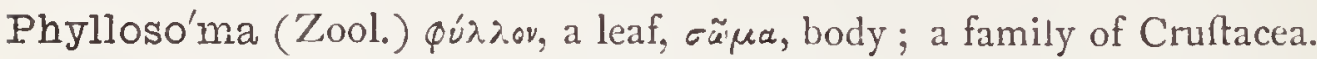

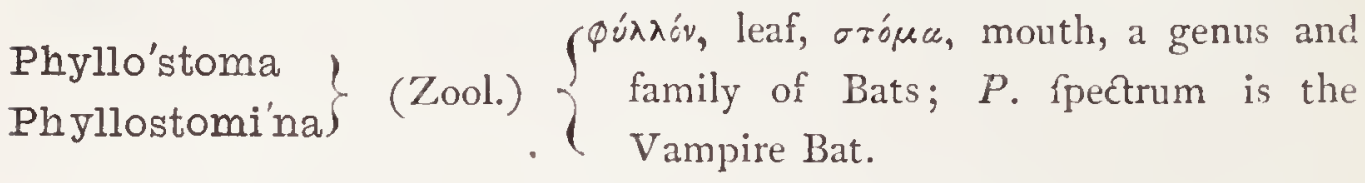

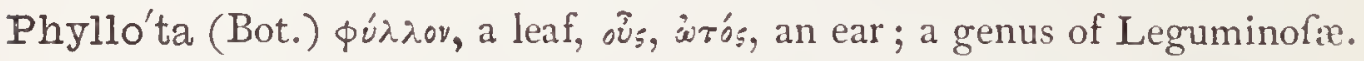

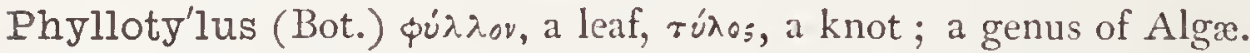

Phymac'tis (Zool.) фúpú, a wave, ảxr ‘́, a ray; a genus of Actiniæ.

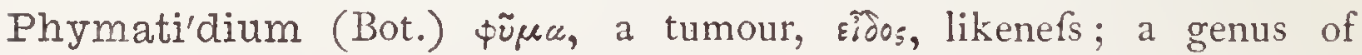
Orchidacex.

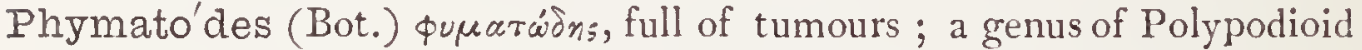

Filices; alfo fpecific name of a celebrated Lichen.

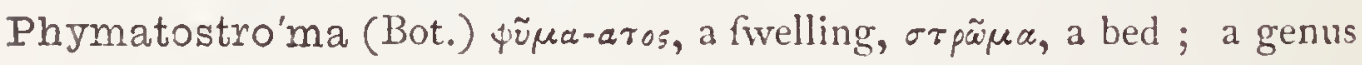
of Fungi.

Phymo'sia (Bot.) фrúcs, to conftrict; a genus of Malvacere.

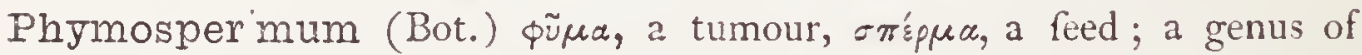

Compolitie.

Phy'sa (Bot.) фũ $\sigma \alpha$, a pouch; a genus of Mefembryaceæ.

Phy'sa (Zool.) фĩ $\approx a$, a pouch; a genus of Mollufca.

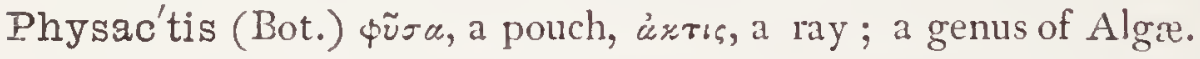

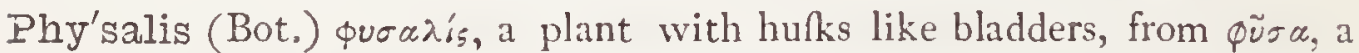

bladder, from refemblance of calyx; the Winter-cherry; an admired genus of Solanacex.

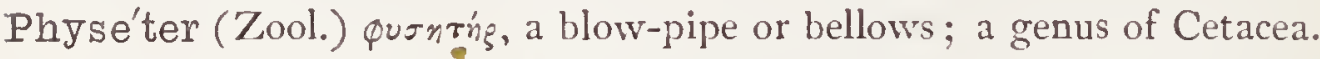

Physio'tium (Bot.) $4 \tilde{u} \sigma \alpha$, a pouch, wrเov, a little ear ; a genus of Jungermanniacea.

Physiph'ora (Bot.) $\phi \tilde{u} z \alpha$, a pouch or bladder, $\phi^{\prime} p x$, to carry, from the inflated capfules; a genus of Violacex.

Physocaly'cium (Bot.) 申usáw, to fwell, calyx, from the inflated calyx ; a genus of Craflulacex.

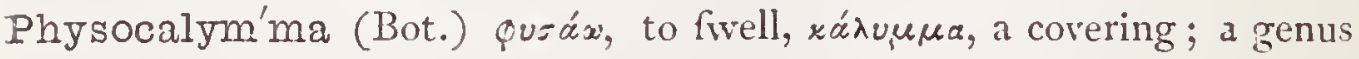
of Lythraceæ.

Physoc'alyx (Bot.) fame meaning as Phyfocalycium; a genus of Scrophulariaceæ.

Physocarpi'dium (Bot.) фusáw, to inflate, xapлós, fruit, from the infiated follicles: a genus of Ranunculacex. 
Physocar'pus (Bot.) quráw, to inflate, rapґós, fruit; a genus of Rofacex. Physocau'lon (Bot.) puráw, to inflate, raùós, a ftem; a genus of Algre. Physochlæ'na (Bot.) Queáw, to inflate, xraiva, a mantle, from the inflated calyx; a genus of Solanacer.

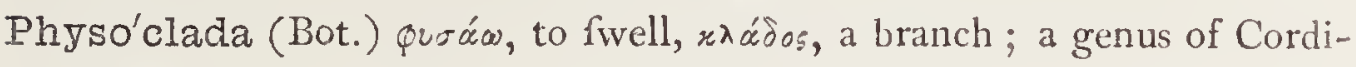
acex.

Physoder'ma (Bot.) quráw, to fwell, d'spra, the cuticle; a genus of Fungi. Physódes (Bot.) quowions, full of wind; fpecific name of a fpecies of Lichenes, Parmelia Phyjodes.

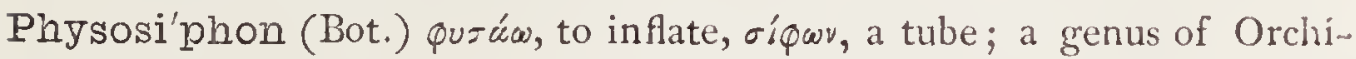
daceæ.

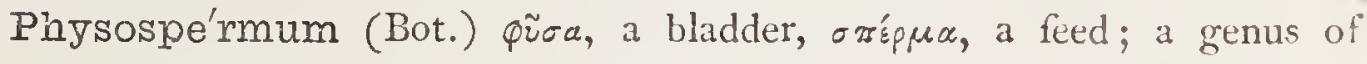
Umbelliferæ.

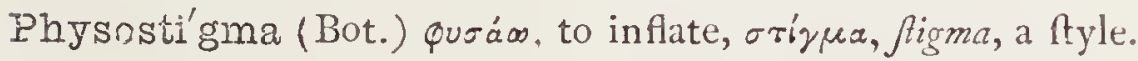

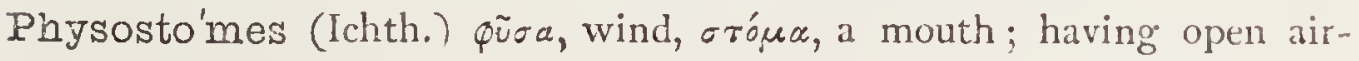
bladders.

Phy'sula (Ent.) puraגís, a bubble? a genus of I.epidoptera.

Phytel'ephas (Bot.) фuróv, a plant, 'sz'́qas, ivory; the Ivory-bearing plant.

Phyteu'ma (Bot.) a name adopted from Diofcorides; the Rampion; a genus of Campanulaceæ.

Phyteumo'psis (Bot.) the genus Phyteuma, and ö $\psi^{\prime} \xi$, refemblance; a genus of Compofitr.

Phyto'conis (Bot.) quróv, a plant, xóvss, dilft; a genus of Algæ.

Phytocre'ne (Bot.) Quróv, a plant, rprivr, a fpring; the celebrated watervine of Martaban; a genus of Artocarpacex.

Phytce'cia (Ent.) Qut's, a plant, o'nos, an abode.

Phytogeo'graphy (Bot.) фuróv, a plant, ýn, the earth, ypa $\varphi_{x}$, to defcribe; the fience of the diftribution of trees and plants.

Phyto'graphy (Bot.) puróv, a plant, zpápar, to write; defcriptive botany. Phytolac'ca (Bot.) Qurov, a plant, lacca, lac; having crimfon fruit; typical genus of Phytolaccacex.

Phytolacca'cer (Bot.) Nat. Ord. of which Phytolacca is the type.

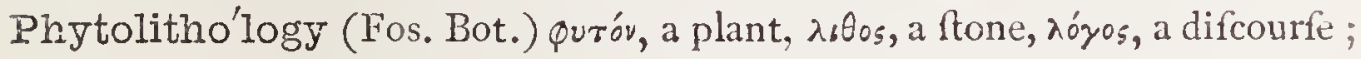

the fcience of foffil plants.

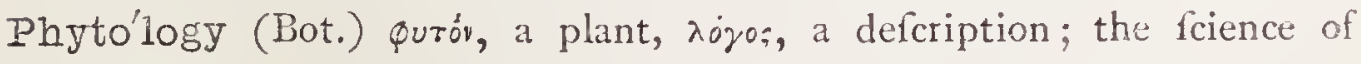
botany.

Phytolop'sis (Zool,) puróv, a plant, öł:; appearance; a genus of Ophidians, 


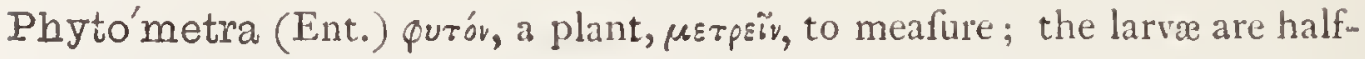
loopers.

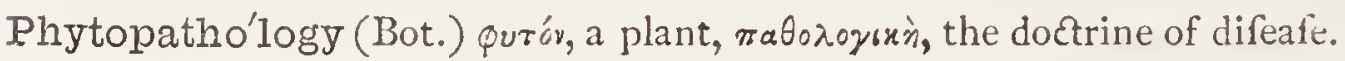
Phyto'phagous (Zool.) фurór, a plant, фúr $\omega$, to eat ; plant-eating.

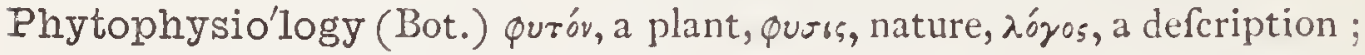

the fcience of the nature of plants.

Phyto'sus (Ent.) Quróv, a plant.

Phyto'toma (Ornith.) Qurór, a plant, rouś, a cut; a plant-cutter; the

Tailor-bird.

Phyto'tomy (Bot.) Qurór, a plant, rour, a cut or incifion; the fcience of diflection of plants.

Phyto'xys (Bot.) Quróv, a plant, ơ̌́s, Marp or pointed; a genus of Labiatæ.

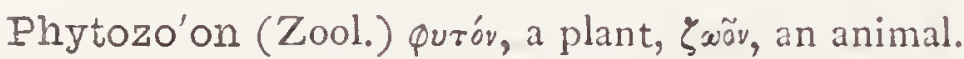

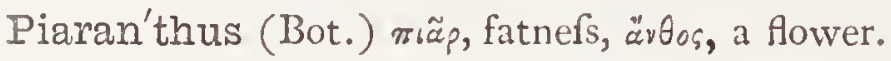

Pi'ca (Ornith.) Lat. a pie or magpie.

Pica'ta (Ent.) pica, a magpie; from the contraft of colours.

Picatha'rtes (Ornith.) pica, a pie or crow, uataigs, to clear; the baldheaded Crow of Weftern Africa.

Picea (Bot.) Lat. the Silver-fir; a genus of Conifer:e.

Pícidæ (Zool.) a family of Scanforial birds called the Woodpeckers, of which picus is the type.

Pi'cinus-a-um (Ent.) Lat. pitch-black.

Pi'cipes (Ent.) pix, pitch, pes, a foot; black-footed.

Pickerin'gia (Bot.) P. N. in honour of Jofeph Pickering; a genus of Leguminofe.

Pico'tia (Bot.) P. N. in honour of $M$. Picot; a genus of Boraginacex.

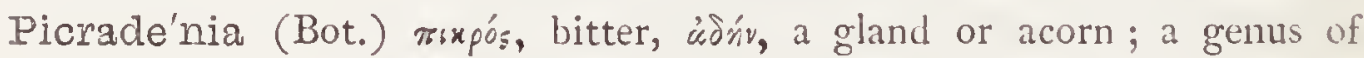
Compofitæ.

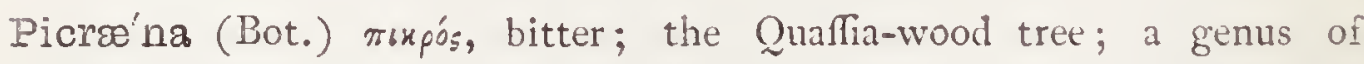
Simarubaceæ.

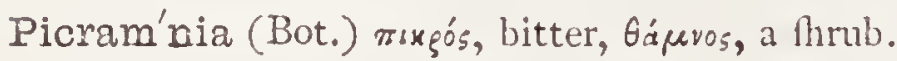

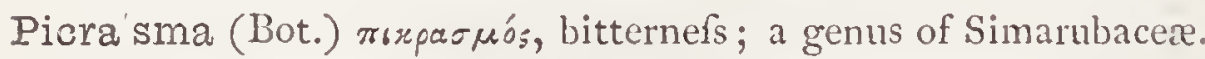

Pi'cria (Bot.) тькрic, bitternefs; a genus of Gefneracex.

Picri'dium (Bot.) the genus Picris, عidos, likeners.

Pi'cris (Bot.) mixpis, a bitter herb; a genus of Compofitz.

Pi'crium (Bot.) fame derivation; a genus of Gentianacex.

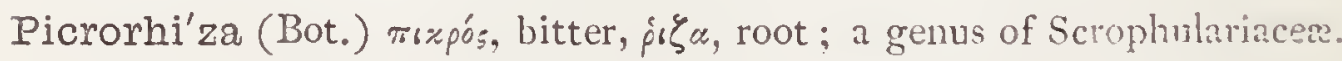

Picro'sia (Bot.) mikpó, bitter: a genus of Compolita. 
Picrotham'nus (Bot.) mเxpós, bitter, $\theta$ ákrós, a flurub; a genus of Compofitx.

Picta'ria

Pictel'la $\}$ (Ent.) pictus, painted.

Picte'tia (Bot.) P. N. in honour of the celebrated M. Pictet, of Geneva;

a genus of Leguminofr.

Pic'tus-a-um (Zool., Bot.) Lat. painted.

Pi'cus (Ornith.) Lat. a woodpecker.

Picum'nus (Ornith.) dim. form of picus, to meet the popular term Piculets; a genus of minute Woodpeckers.

Piddington'ia (Bot.) P. N., a genus of Lobeliacer.

Pieran'dia (Bot.) P. N., a genus of Sapindacex.

Pie'ridæ (Ent.) P. N., a family of diurnal Lepidoptera, of which Pieris is the type.

Pi'eris (Ent.) P. N., one of the Mufes; a genus of Lepidoptera; alfo ufed in Botany.

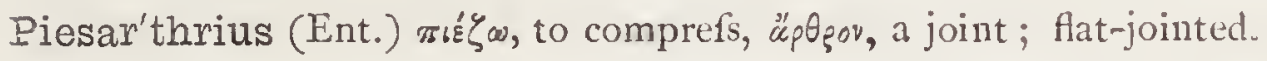

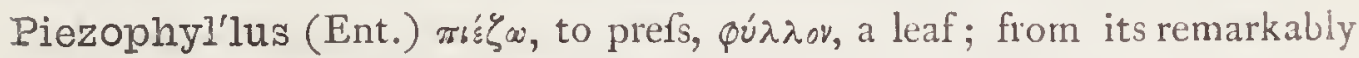
compreffed antenna.

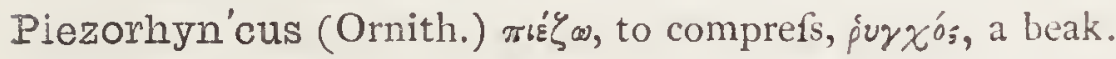

Pig (Zool.) Dutch, bigghic, big.

Pigeon (Ornith.) French, pigeon; Ital. piccione.

Pike (Ichth.) becaufe the head is peaked or pointed; the fcientific name is Efox.

Pila'ris (Zool., Ornith.) Lat. like a ball.

Pil'chard (Ichth.) this word is probably from Anglo-Sax. pylce, the cover-

ing of a faddle; in allufion to the foftnefs of the integuments.

Pi'lea (Bot.) pileus, a cap; a genus of Urticacex.

Pile'olus (Zool.) Lat. a little cap; a genus of Mollufca.

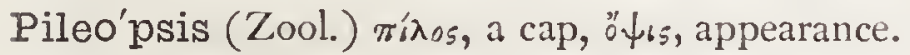

Pi'leus (Bot.) Lat. a cap; applied to the cap-like expanfion of a mufhroom.

Pile-wort (Bot.) the popular name of Ficaria verna, becaufe its tubers remind the furgeon of hæmorrhoidal facs.

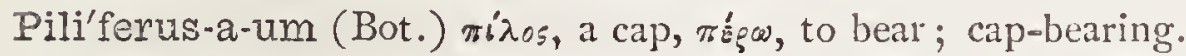

Pilleria'na (Ent.) P. N. in honour of Piller, a German entomologift.

Pilosa'lis (Ent.) pilofus, hairy.

Pilosa'ria (Ent.) pilojus, hairy.

Pilosel'la (Ent.) feeding on Hawk-weed, Hieracium Pilafella.

Pilo'sus-a-um (Bot.) Lat. hairy. 
Pilula'ria (Bot.) pilula, a little pill; from the fhape of its feed-vefiels; a genus of Marfileacex.

Pimele'a (Bot.) $\pi \iota \mu \varepsilon \lambda \dot{n}$, fat ; a genus of 'Thymelaceæ.

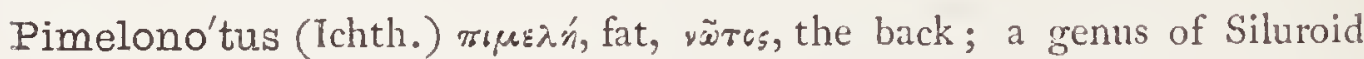
Finhes.

Pimen'ta (Bot.) from the Spanilh pimento, the name for Indian pepper.

Pim'pernel (Bot.) French, pimprenelle; Latin, pimpinella.

Pimpine'lla (Bot.) altered from bi-pinella, twice pinnated, from the doubly pinnate leaves ; Pimpinel; a genus of Umbelliferx.

Pimpinella'ta (Ent.) feeding on the Burnet-faxifrage, Pimpinella Saxifraga. Pina'ceæ (Bot.) Lindley's name for the Coniferæ, of which Pinus, the Firtree, is the type.

Pina'nga (Bot) native Indian name of a genus of Afratic palms.

Pina'ria (Bot.) rıvapós, habby, fqualid; a genus of Crucifera.

Pinaropa'ppus (Bot.) $\pi$ rvapos, Thabby, pappus, the down of plants; a genus of Compolitæ.

Pincenecti'tia (Bot.) Profeflor Scheidweiler of Ghent fays that about the year I 836 , Galeotti fent to Van der Maelen fome plants whofe half illegible ticket appeared to be Freycinetia. The gardener to whofe care they were configned changed the word to Pincenectitia, and fo it has remained ever fince.

Pinckne'ya (Bot.) P. N. in honour of M. Pinckney, an American botanift. Pi'ndalus (Ornith.) ancient Greek name for an unknown bird.

Pinel'lia (Bot.) P. N., a genus of Araceæ.

Pineta'ria (Ent.) pinetum, a pine-grove.

Pinete'llus (Ent.) pinetum, a fir-wood, which it frequents.

Pine-tree $\}$ (Bot.) $\{\pi i \tau u s$, Latin, Pinus, apparently connected with Celtic Pinus $\}$ (Bot.) $\{$ Ben, a mountain, as in Ben Lomond, Apernines.

Pinguedine'lla (Ent.) pinguedo, fatnefs.

Pingui'cula (Bot.) pinguis, fat; the leaves are greafy to the touch; a genus of Lentibulariacex.

Pinguicula'tus (Ent.) pinguiculus, fomewhat fat.

Pinguina'lis (Ent.) pinguis, fat, from its greafy appearance.

Pinia'ria (Ent.) from feeding on the fir-tree, Pinus Abies, and fylveftris. Piniarie'lla (Ent.) feeding on the Pinus.

Pini'cola (Ornith.) pinus, a pine-forelt, colo, to inhabit; the Pine Grofbeak. Pinicola'na ? Pinicole'lla (Ent.) pinns, a frr-tree, colere, to frequent.

Pinites (Fos. Bot.) prime, the fri-tree; foffil rood allied to the Conifere. 
Pinivora'nus-a-um (Ent.) finus, a fir, vorare, to devour, c. g. Retinia Pinivorana.

Pinna (Zool.) Lat. a fin or wing; a genus of Mollufca.

Pinnati'fidus-a-um (Bot.) pinna, a feather or leaflet, findo, to cleave; pinnatifid; applied to leaves irregularly cut towards the mid-rib.

Pinna'tus-a-um (Bot.) Lat. feathered; pinnate.

Pinnothe'res (Zool.) rivvorńpns, a name which occurs in Ariltotle, means " pinna-guard," from mirvo, the fhell pinna, rnpśw, to guard, and was applied to a fmall crab inhabiting the fhell ; the Pea-crabs; a genus of Brachyurous Cruftacea.

Pin'nula (Bot.) dim. of pinna, a reather or leaflet.

Pinnula'ria (Fos. Bot.) pinnula, a little feather; a genus of fofil coal-meafure plants.

Pinta'do (Ornith.) Spanißn, pintado, painted ; another name for the Guinea Fowl.

Pi'nus (Bot.) Lat. the Pine-tree; a genus of Conifere.

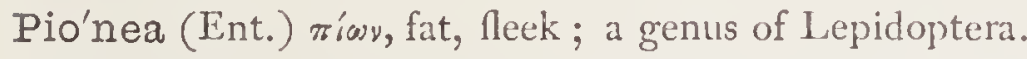

Pi'per (Bot.) $\pi \varepsilon \xi \varepsilon \rho$, pepper, from $\pi \varepsilon \pi \tau \omega$, to digelt; but perhäp, as ftated

by Galen, from an Indian word.

Pipera'cer (Bot.) the family of plants of which Piper is the type.

Piperi'tus-a-um (Bot.) of or belonging to pifer, pepper; pepper-like, i.e., having the fmell or biting tafte of pepper.

Pi'piens (Zool.) Lat. piping, chirping.

Pip'it (Ornith.) popular fynonyme for the Titlark, Anthus pratenfis.

Pip'pin (Bot.) this word is derived by Dr. Jolinfon from the Dutch pupp.

pyngke, but it is furely more reafonable to fuppofe it from Pepin, the king of the country from which the fruit was derived.

$\left.\begin{array}{l}\text { Pi'pra } \\ \text { Pi'prioze }\end{array}\right\}$ (Ornith.) $\left\{\begin{array}{r}\pi i \pi p \mu, \text { the name of a bird in Arifotle; a genus } \\ \text { and family of Pafleres; the Manakins. }\end{array}\right.$ Piproi'dea (Ornith.) the genus Pipra, eidos, likenefs.

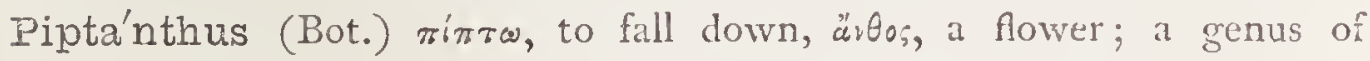
Leguminofre

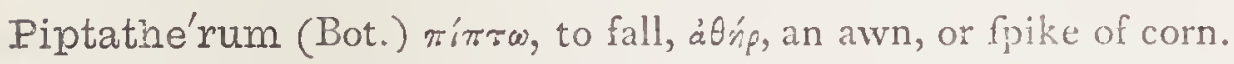

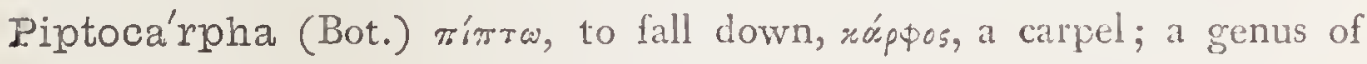
Compolitio.

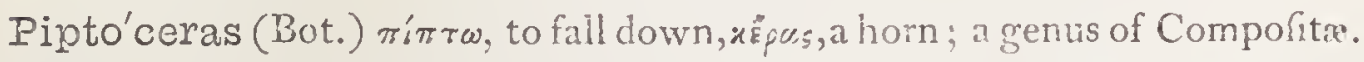
Piptochæ'tium (Bot.) rirro, to fill bown, zuiti, al brifle (awn); a genus of Gramina. 


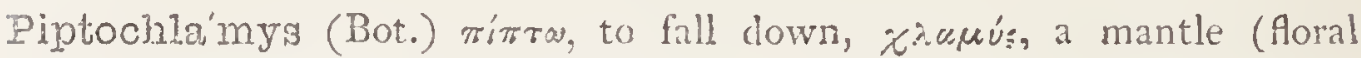
envelope); a genus of 'Thymelacex.

Pipto'coma (Bot.) ritrtw, to fall down, xácen, a tufi ; a genus of Compofitx.

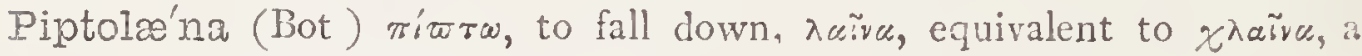
mantle; a genus of Apocynacex.

Pipto'lepis (Bot.) $\pi i \varpi \tau \omega$, to fall down, $\lambda \varepsilon \pi i s$, a fcale.

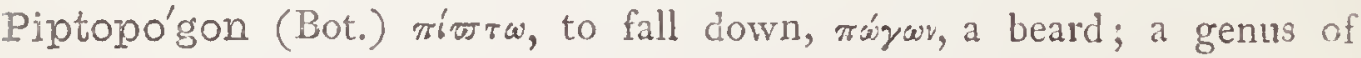
Compofita.

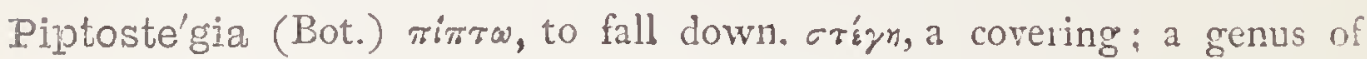
Convolvulaceæ.

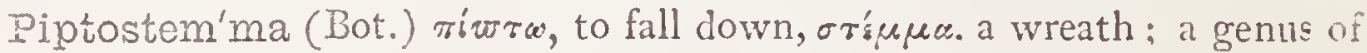
Compofitæ.

Piquéria (Bot.) P. N. in honour of Andreas Piquerio, a Spanilh botanirt. Pisa'na (Zool.) pifum, a pea, referring to thape.

Pisa'nia (Zool.) P. N. from Pifa, in Italy; a genus of Mollufca.

Piscato'rius-a-um (Ichth.) Lat. relating to fifhermen; $\bullet . g$. the Filhing Frog, Loplicus Pifatorizs.

Pisces (ichth.) pl. of pifis, a fin ; the great divifion of vertebrata called Fifhes. Pisciculus (Ichth.) dim. of pifis, a filh; a little filh.

Pisci'cia (Bot.) pifits, a fih, cado, to kill: parts of the plant being ufed to ftupify fih: a genus of Leguminolip.

Piscinalis-e (Zool.) i.ot pertaining to a bath, $i . \varepsilon$. found in bath-rooms. $\because$ S. Vairata pifinalis.

Piscivorus-a-um (Zool.) pifis. a lin, soro, to devour; fill-eating: equivalent to Ichthyophagus.

Pisifor'mis-e (Zool.) pifum, a pea, formis, thape; pea-fhaped.

Pisinire (Ent.) popular name of the Formica rufa.

Pisodono'phis (Ichth.) ríros, pea, odous, ôdorrós, tooth, öpss, a ferpent: a genus of Snake-like filhes.

Piso'nia (Bot.) P. IN. in honour of M. Pifo. an eminent Italian phyfician:

a genus of Nyctaginacen.

Pisso'des (Ent.) ricsu, pitch, Eijos, likenefs: a grenus of Coleoptera, family

Curculionide.

Pista'cia (Bot.) faid to be altered from foufurg, its Arabic name; the Tere-

binth-tree; a renus of finacariliacte.

Pistacinus-a-zm (Ent.) being the colour of the Pifachic-tree.

Pi'stia (Rot.) clymology unknowii : typical genus of the following family.

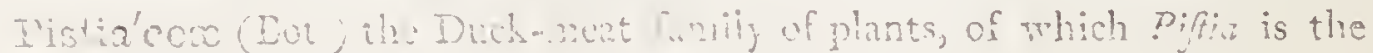


Pistilli'dium (Bot.) dim. of piffillum, a piftil; applied to the equivalent of the piftil in mofles and liverworts.

Pistilli'ferus-a-un (Bot.) piffillum, a piftil, fero, to bear.

Pistil'lum (Bot.) Lat. a peftle (piftil).

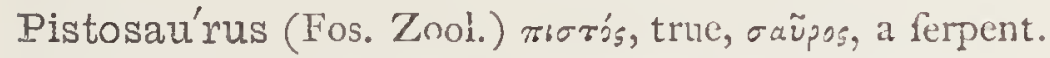

Pi'sum (Bot.) Lat. a pea; a genus of Leguminofx.

Pitan'gus (Ornith.) etymology unknown; a genus of 'Thrufhes.

Pitcair'nia (Bot.) P. N. in honour of Dr. Pitcairn, an eminent phyfician; a genus of Bromeliacex.

Pithe'cia (Zool.) rînros, an ape; a genus of quadrumanous animals o the family Cebidx.

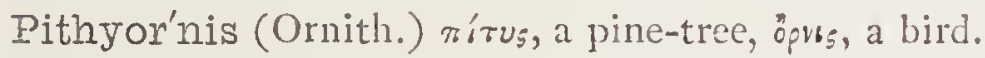

Pit'ta (Ornith.) mistu, pitch, referring to colour; the Ant-thrufhes.

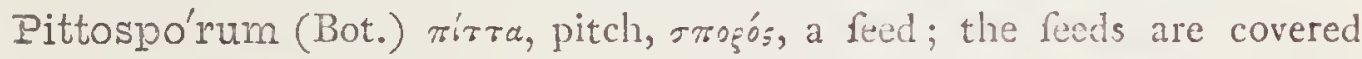
with a black refinous pulp; typical genus of Pittofporacer.

Pituo'phis (Zool.) ritus, the pine-tree, oै ôss, a fnake; a genus of Colubrine ophidians.

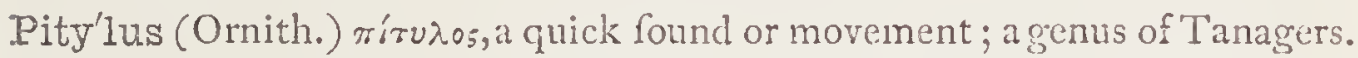

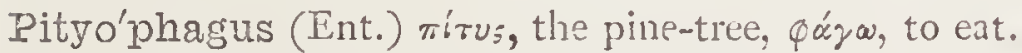

Pityopsit'tacus (Ornith.) mirv;, the pine-tree, firrus.s, a parrot: the Parrot Cróltuill.

Placen'ta (Zool., Bot.) zraroü, a flat cake.

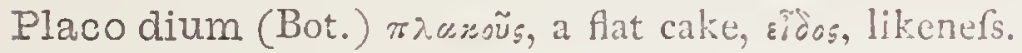

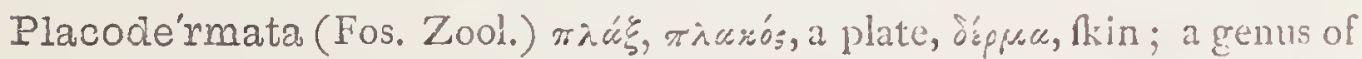
extinct Fihes.

Placo'des (Ent.) $\pi$ ruxśons, Alat.

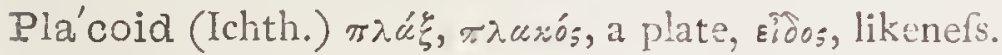

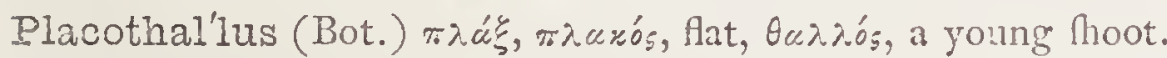

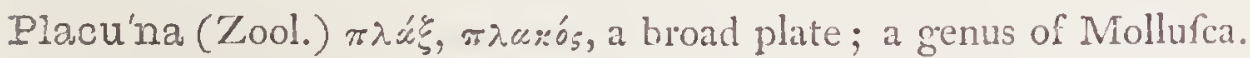

Placu'sa (Ent.) $\pi \lambda \alpha \% o \tilde{u}$, a flat cake.

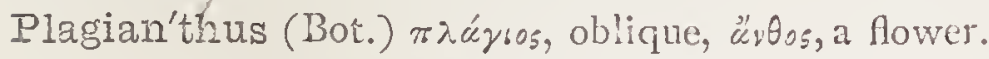

Plagia'ta (Ent.) plara, a zone, from the pattern of the wings.

Plagiau'lax (Fos. Zool.) abbreviation of Plagianlacodon, from ricíybs.

oblique, ainás, a groove, ṡoves, a tooth; having refurence to the diagonal grooving of the premolar tooth.

Plagicole'lla (Ent.) plagia, an open ground, colere, to frequent.

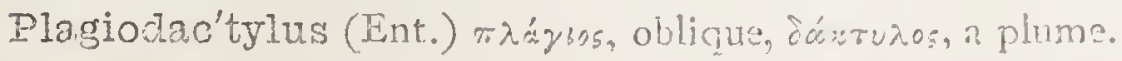

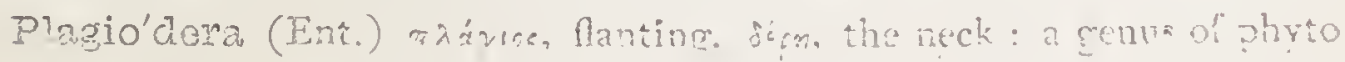
hagous Bectles 


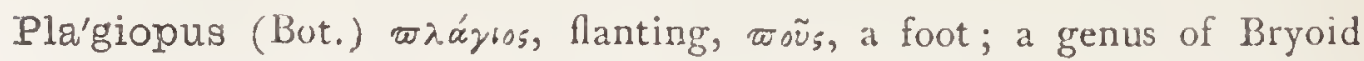
Mufci.

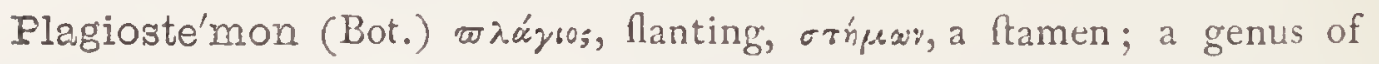
Ericacex.

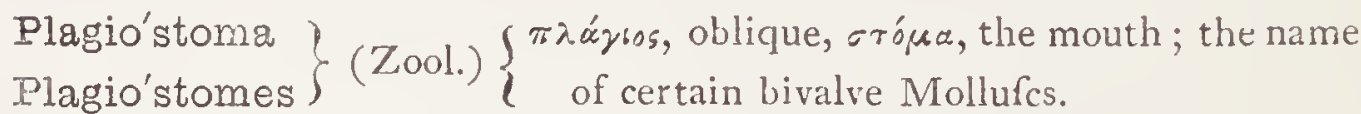

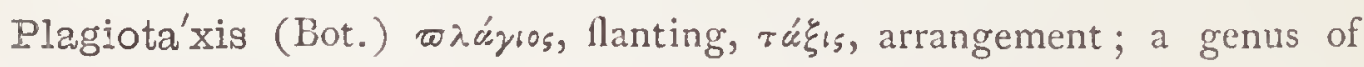
Cedrelacex.

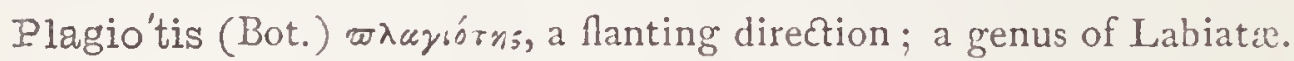

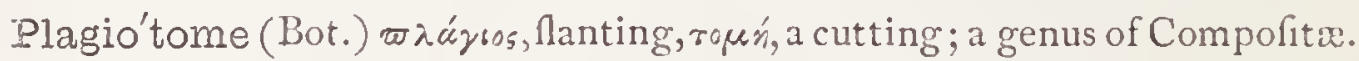

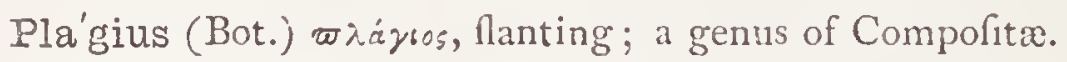

Plana'ria (Zool., Bot.) planus, Aat; in Zoology, a genus of Annelids; in Botany, a genus of Leguminofx.

Planax'is (Zool.) planus, flat, axis ; a genus of Mollufca.

Plane'ra (Bor.) P. N. in honour of $\mathcal{F}$. Planer, a German Botanift.

Plane-tree (Bot.) abbreviated from Platunus.

Pla'niceps (Ent.) " Aat-headed," from planus, flat, caput, head; a genus of Hymenoptera.

Planicosta'tus-a-um (Zool.) planus, Itraight, flat, cofta, a rib.

Planicul'mis-e (Bot.) planus, flat, culmus, a ftem; flat-ftalked.

Planipen'nes (Ent.) planus, Aat, pema, a feather, i.e. having flat antennæ; one of Latreille's three fections of the Neuroptera.

Planius'culus (Bot.) Lat. a little flattened.

Planor'bis (Zool.) planus, Aat, orbis, a diRk; a genus of Mollufca.

Plantagíneus-a-um (Bot,) Lat. plantain-leaved.

Planta'go (Bot.) planta, the fole of the foot, from the fhape of the leares; the Plantain.

Plan'tia (Bot.) P. N., a genus of Iridacex.

Plantigra'da (Zool.) planta, the fole of the foot, gradior, to walk; applied to an order of carnivorous animals which place the whole of the fole of the foot upon the ground, as the bears, etc.

Plantigra'dus-a-um (Zool.) fame derivation; flat-footed.

Plappértia (Bot.) P. N., a genus of Chailletiacex.

Plata'1ea (Ornith.) Lat. a fpoonbili.

Platana'cere (Bot.) 1plentid Nat. Ord. of plants compofed of the genus Platinus, or Plaile-trees.

Platanoca'rpum (Bot.) "platanis-fruited;" from platanis, and ráparos, fruit; a gerus of Cinchonacex.

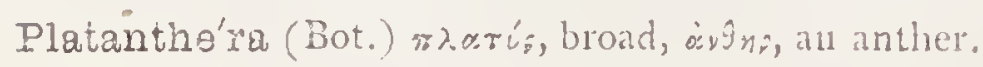


Pla'tanus (Bot.) $\pi \lambda \alpha \tau \dot{u}_{5}$, fpreading, in allufion to the branches and foliage; the Plane-tree.

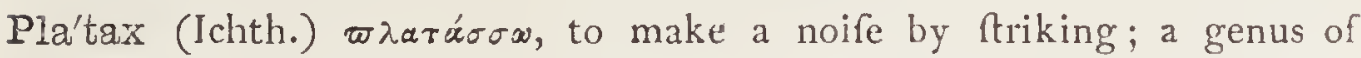
Chatodont Filhes.

Pla'tea (Bot.) $\varpi \lambda a \tau u ́ s$, broad; a genus of Olacacex.

Plates'sa (Ichth.) Lat. a flat-filh ; the Plaice.

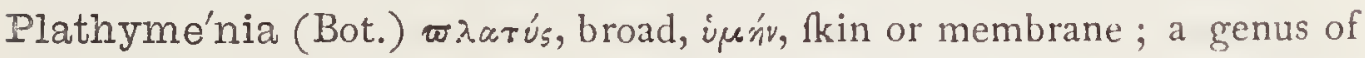
Leguminofr.

Platis'ma (Bot.) $\varpi \lambda \alpha \tau \dot{v}_{\varsigma}$, broad; a genus of Lichenes.

Plato'nia (Bot.) P. N. in honour of Plato; a genus of Gramina.

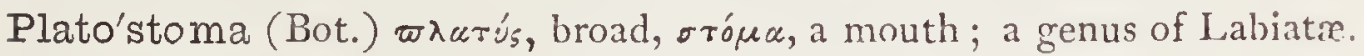
Platu'nium (Bot.) $\varpi \lambda \alpha \tau$ v́va, to widen; a genus of Labiatæ.

Platycap'nos (Bot.) $\varpi \lambda \mu \tau \dot{s}_{s}$, broad, rawvós, fumitory; a genus of Fumariacer.

Platyca'ra (Ichth.) $\pi \lambda \alpha \tau \dot{u}_{5}$, broad, xápa, the head; a genus of Cyprinoid Fifhes.

Platycar'pha (Bot.) $\varpi \lambda \alpha \tau \dot{s}$, broad, rápфos, a ftalk; a genus of Compofitx. Platycar'pos (Bot.) $\pi \lambda_{\alpha} \alpha u_{\xi}$, broad, rapmós, fruit; flat-podded.

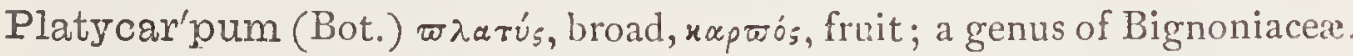

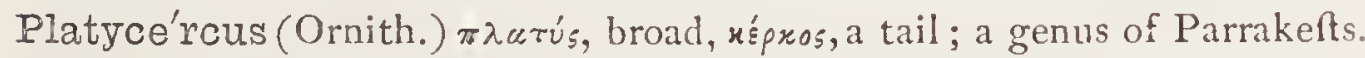

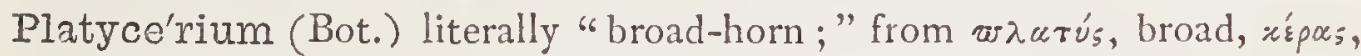
horn; a magnificent Auftralian genus of Polypodioid Ferns, including the "Stag's horn," and the "Elk's horn."

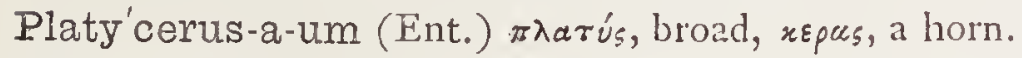

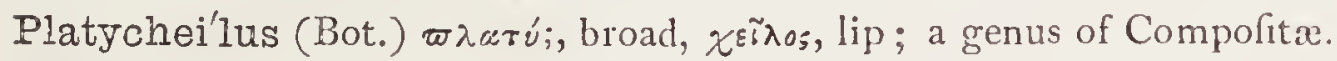

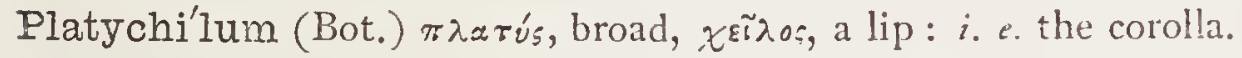

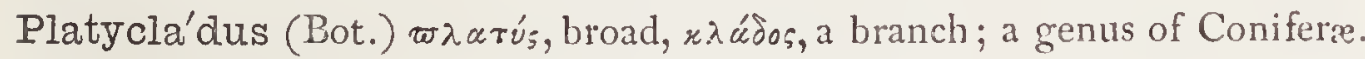

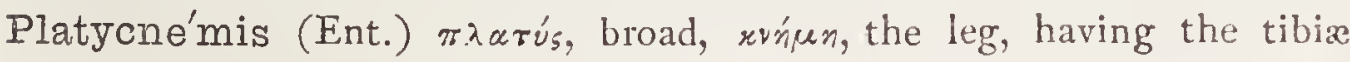
much dilated; a genus of Neuroptera.

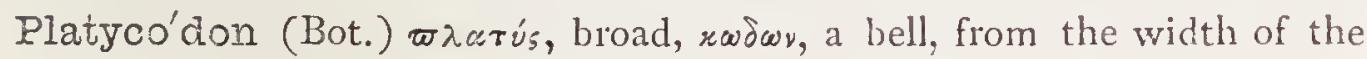
corolla; a genus of Campanulacex.

Platycra'ter (Bot.) geaceæ.

Platycri'nus (Fos. Zool.) $\pi \lambda \alpha \tau u ́ s$, broad, xpivór, a lily; a genus of Encrinites.

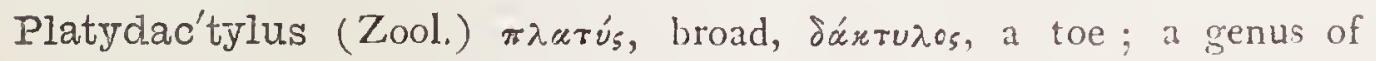
Saurians.

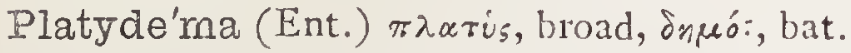

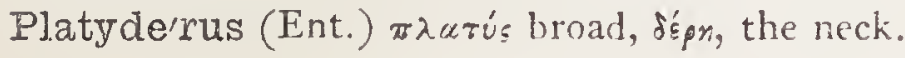


$\left.\begin{array}{l}\text { Platy'dic } \\ \text { Platy'didxe }\end{array}\right\}$ (Ent.) $\left\{\begin{array}{c}\pi \dot{\lambda} \alpha \tau \dot{s}, \text { broad; a genus and family of Lepido- } \\ \text { ptera. }\end{array}\right.$

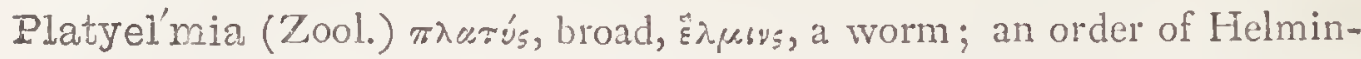
thia or parafitic worms.

Platygramima (Bot.) genus of Lichenes.

Platygy'na (Bot.) ๒raris, broad, yurí, a female (piftil); a genus of Euphorbiaces.

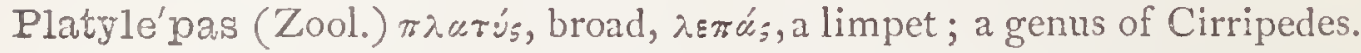

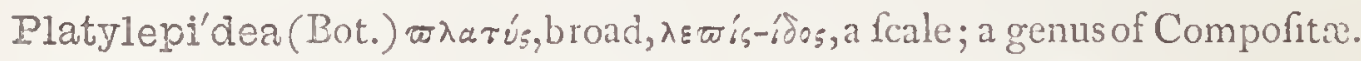
Platyle'pis (Bot.) fame derivation; a genus of Compofitæ.

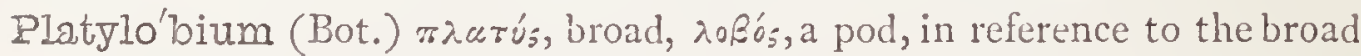
legumes.

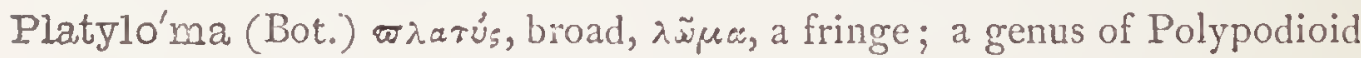
Filices.

Platylo'phus (Bot.) wharés, broad, $\lambda$ ópos, a creft; a genus of Compofita.

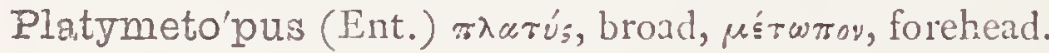

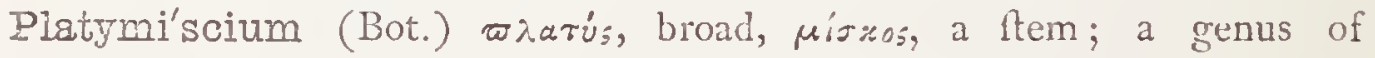
Leguminofx.

Platy'na (Ent.) $\pi \lambda \alpha t u ́ v a$, to make broad; a genus of Diptera.

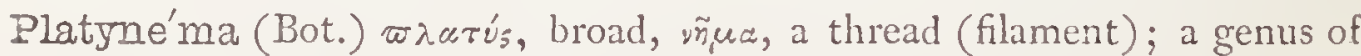
Malpighiacex.

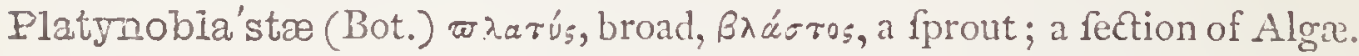

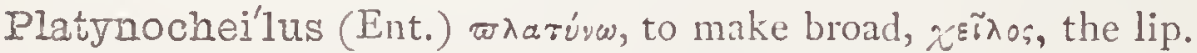

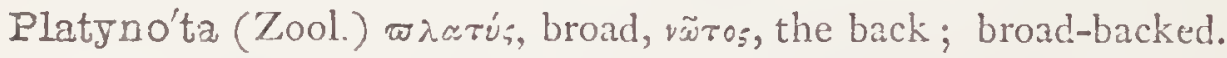

Platy'nus (Ent.)

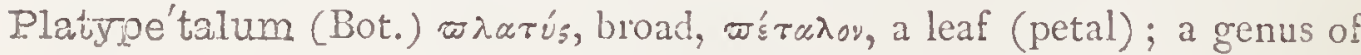

Crucifera.

Platyphyl'ium (Bot.) $\nsim \lambda a \tau u_{s}$, broad, $\phi u \lambda \lambda . \nu$, a leaf; a genus of Lichenes.

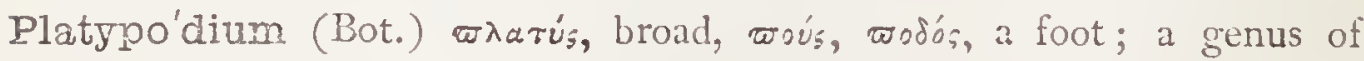

Leguminofa.

Platy pteris (Bot.) $\varpi \lambda \alpha \tau \dot{u}_{s}$, broad, wrépov, a wing, from margin of feeds.

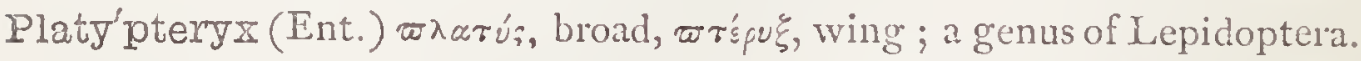
pla'typus (Zool.,Ent.) $\pi \lambda \alpha \tau \dot{u}_{5}$, broad, $\varpi \tilde{\nu}_{z}$, a foot; in Zoology; a fynonyme of Ornithorhynchus.

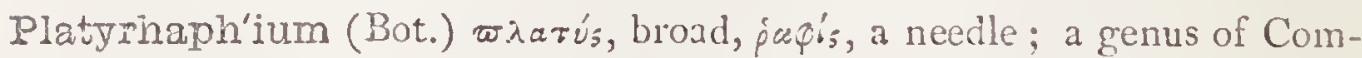
pofitx.

Platyrhinos (Zool.), Platyrhi'nus (Ent.) $\}$ waarí, broad, $\dot{p}$ เข, the nofe; broad-nofed. 


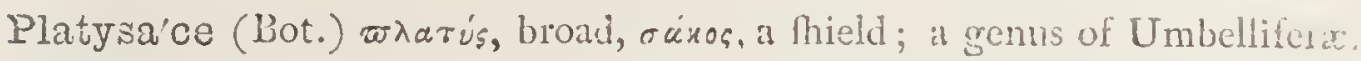

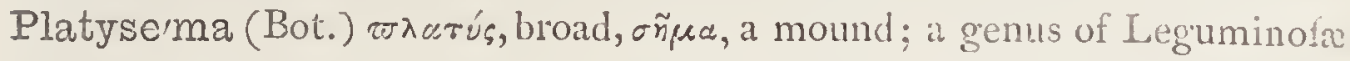

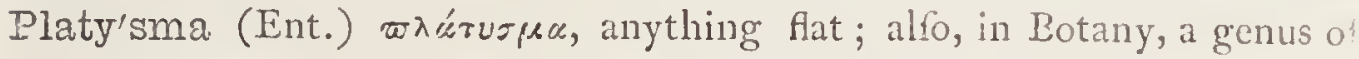

Orchidacex.

Platyso'ma (Ent.)

Platyso'mus (Fos. Zool.) fane derivation; a genus of Ganoid Fithes.

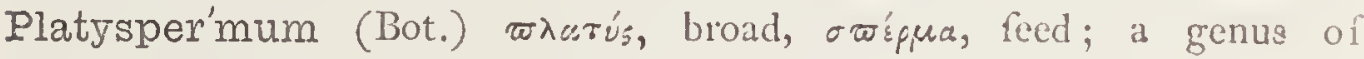

Umbellifer:

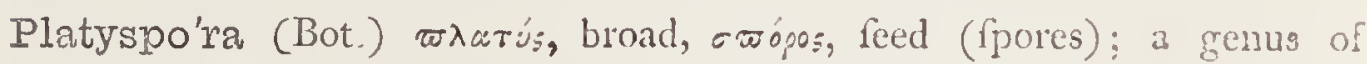
Ericacex.

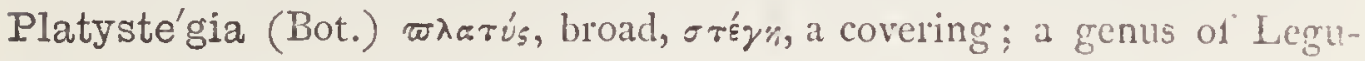
minofa.

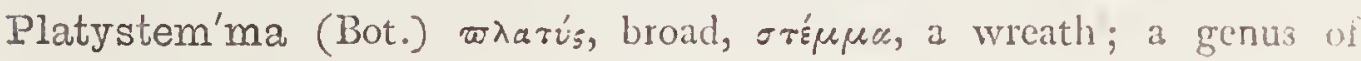
Gefneracex.

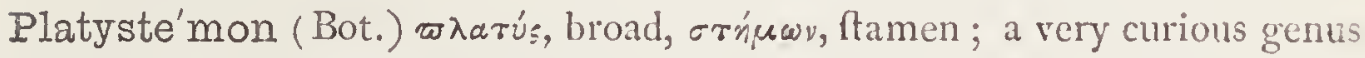
of Californian Papaveracex.

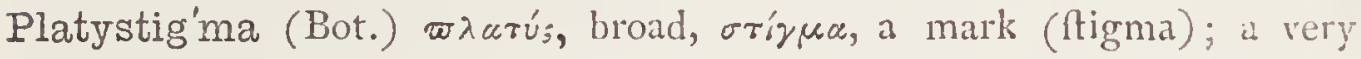
curious genus of Californian Papaveracex.

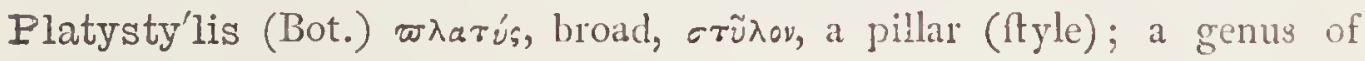
Orchidacee.

Platy'tes (Ent.) ๘лarúrns, breadth; a genus of Lepidoptera.

Platytha'lia (Bot.)

Platythe'ca (Bot.) $\pi \lambda a \tau$ ús, broad, $\theta \dot{n} \times n$, a theath; a genus of Tremandracex.

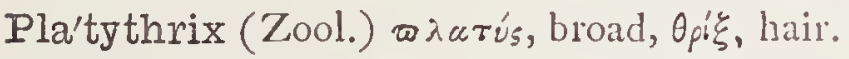

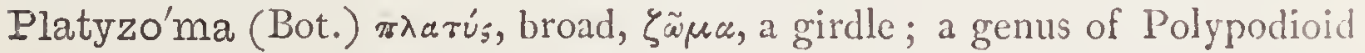
Filices.

Plat'zia (Bot.) P. N., a genus of Compofitre.

Pla'xia (Ent.) ॠá̧́, anything flat.

Plazerrium (Bot.) $\pi \lambda a^{\prime} \zeta \omega$, to wander; a genus of Gramina.

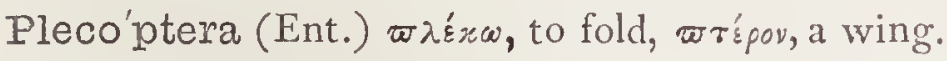

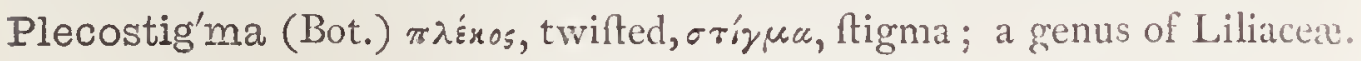

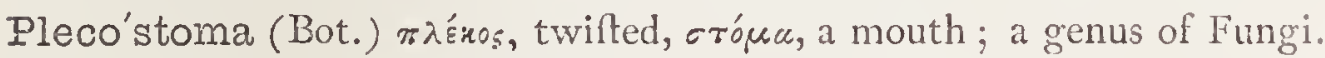
Plecotre'ma (Zool.) $\varpi \lambda^{\prime} \varepsilon \omega$, to fold, rprinuce an opening.

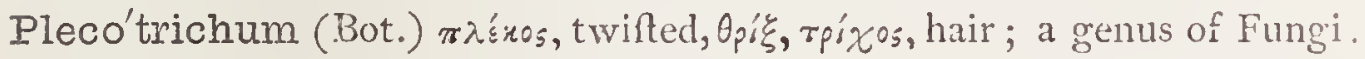

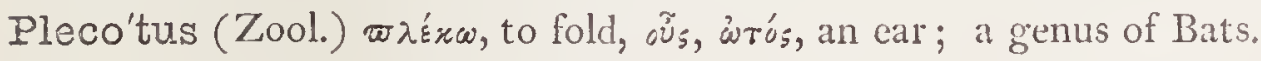

Plecta (Ent.)

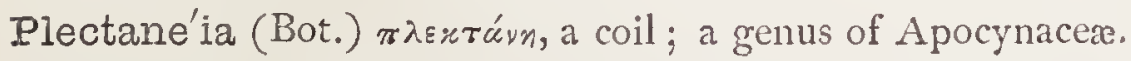

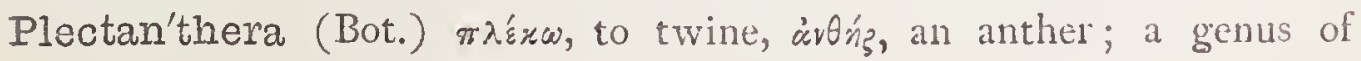
Sauvagefiacex. 


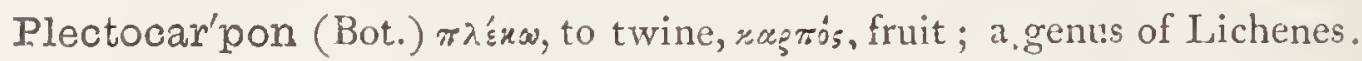

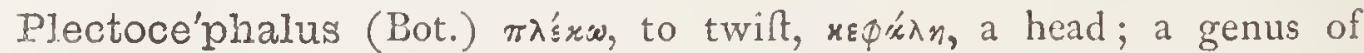
Compofitæ.

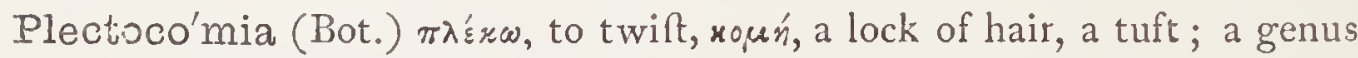
of Palmx.

Plectode'ra (Ent.) $\varpi \lambda \varepsilon r r^{\circ}$; , twifted, $\delta^{\prime} \rho^{\prime} n$, the neck; a genus of Coleoptera. Plectogna'tbi (Ichth.) $\pi \lambda \varepsilon \% \tau^{\prime}$ s, twifted, yvátos, the jaw, from the union by indented future of the right and left halves of the upper jaw and mandible.

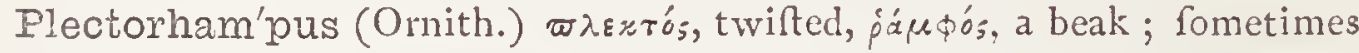
written Plectoramphus. N. B.-Naturalifts feem too often to forget that the initial $\rho$ in Greek being afpirated, all words of Greek derivation which commence with $\dot{\rho}$ muft be followed by $h$, which they retain in compolition.

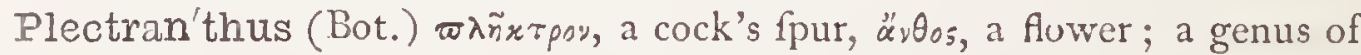
Labiatæ.

Plectrocar'pa (Bot.) $\pi \lambda \tilde{n} x \tau$ ¡ov, a cock's-fpur, xaptós, fruit, alluding to ihape; a genus of Zygophyllacex.

Plectroma'ntis (Zool.) $\varpi \lambda \tilde{n}$ is pov, a fpul, $\mu$ avrเs, a frog; a genus of Treefrogs.

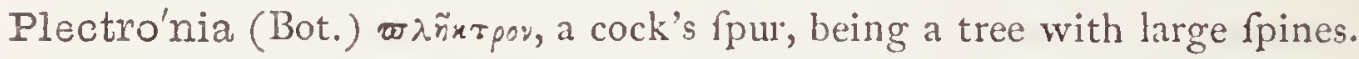

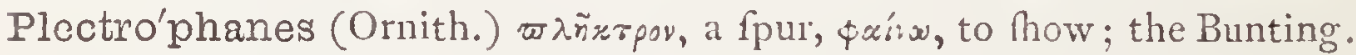
Plectro'tropis (Bot.) $\pi \lambda \tilde{n}$ is pov, a cock's-fpur, $\pi \rho \xi \xi \omega$, to turn; a genus of Leguminofie.

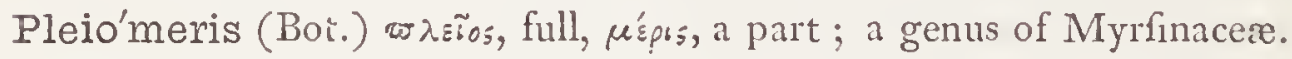

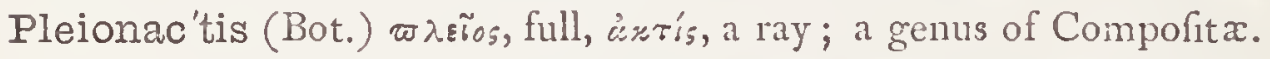

Ple'ione (Bot.) P. N., the daughter of Oceanus and mother of the Pleiades; a genus of Orchidacex.

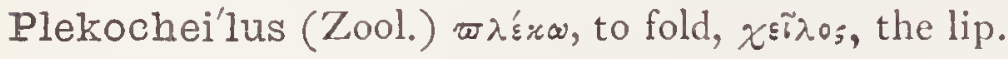

Plen'ckia (Bot.) P. N. in honour of F. F. Plenck; a genus of Mefembryacer.

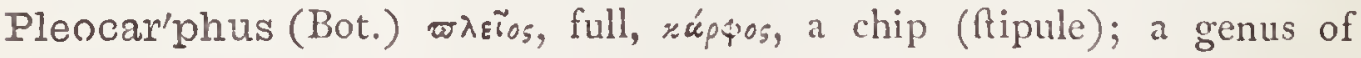
Comporitr.

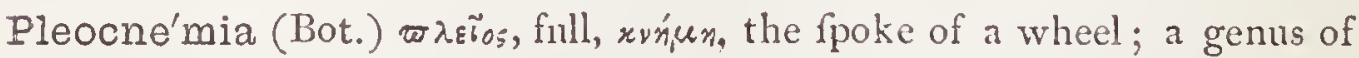
Polypodioid Filices.

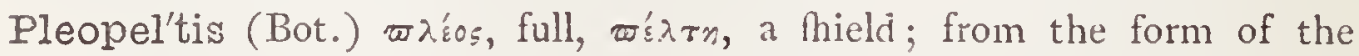
indufium.

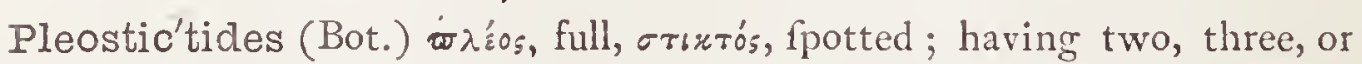
four rows of teeds attached to the feptum; a divifion of Bignoniacex.

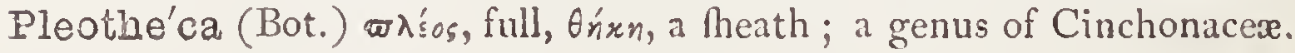


Plero'ma (Bot.) $\varpi \lambda \operatorname{rips}_{1} \alpha$, fulness, in allufion to the cells of the capfules ; a genus of Melaftomaceæ.

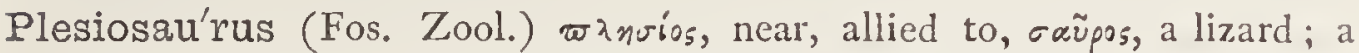
genus of foffil marine Reptiles.

Plestiödon (Zool.) Lizards.

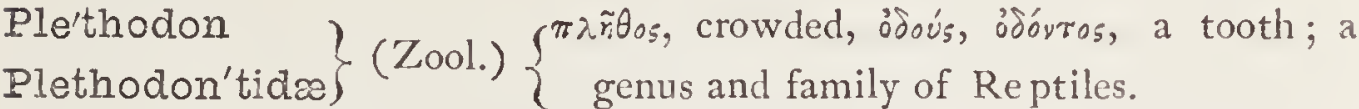

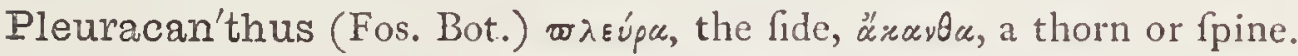

Pleuran'dra (Bot.)

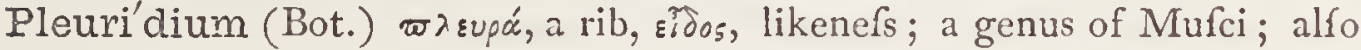
one of Polypodioid Filices.

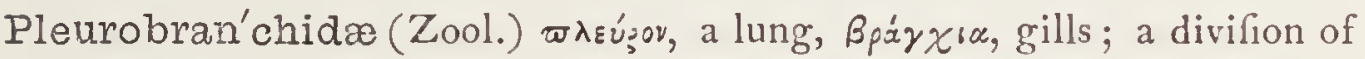
Mollufca.

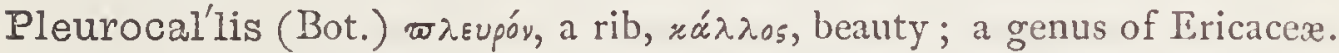
Pleuroceph'alum (Bot.)

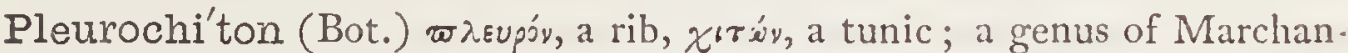
tiacex.

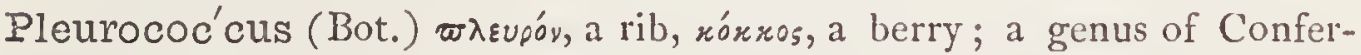
void Algx.

Pleurode'les (Zool.) piercing the 1 kin ; a genus of Batrachians.

Pleurodes'mia (Bot.) $\lambda \varepsilon u \rho^{\prime} y$, a rib, $\delta \varepsilon \sigma \mu o_{\xi}^{\prime}$, a band or chain; a genus of Dilleniaceæ.

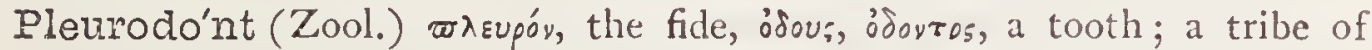
Saurians, whofe teeth are anchylofed to the bottom of an alveolar groove, and supported by its fide.

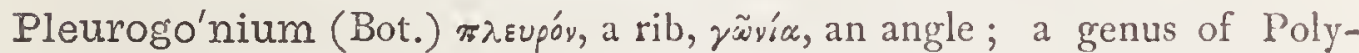
podioid Filices.

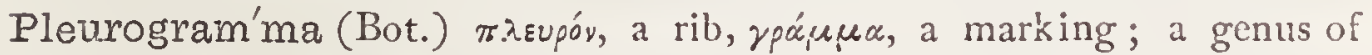
Polypodioid Filices.

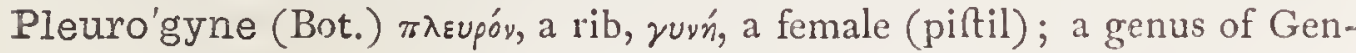
tianaceæ.

Pleurogyra'tæ (Bot.) $\pi \lambda \varepsilon u p o ́ n$, a rib, yupoo, to bend; a fection of Polypodioid Filices.

Pleuromo'nas (Zool.) $\varpi \lambda \varepsilon u p$ ', the fide, monas, a monad; the filament extending from the concave fide of the body; a genus of Infuforia.

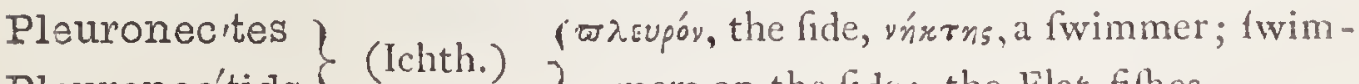
Pleuronec'tids $\}$ (Ichth.) $\{$ mers on the fide; the Flat-fithes. 


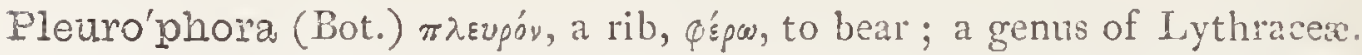

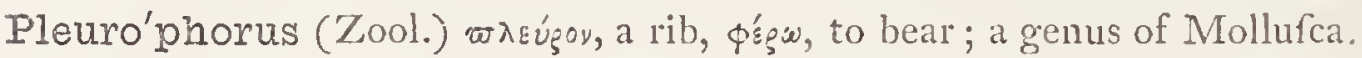
Fleurophyl'lum (Bot.) $\pi \lambda \varepsilon u p^{\prime} y$, a rib, $\varphi^{\prime} \lambda \lambda \sigma^{\prime}$, a leaf; a gellus of Compofitic.

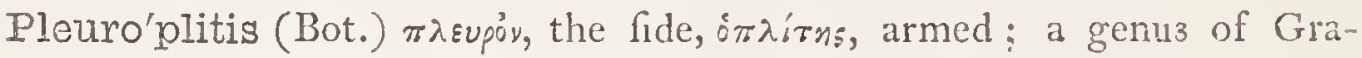
mina.

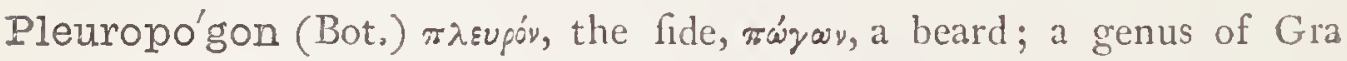
mina.

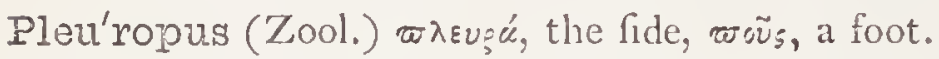

Pleuropy'xis (Bot.) $\pi \lambda \varepsilon u p o ́ n$, a rib, $\pi v_{\xi}^{\xi} \hbar_{\xi}$, a box; a genus of Fungi.

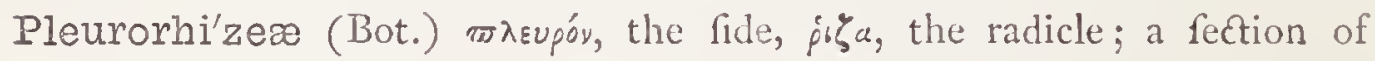
Cruciferæ.

Pleuroschis'ma (Bot.) $\pi \lambda \varepsilon u$ porv, the fide, $\sigma x^{\prime} \sigma \mu c$, a llit; a genus of Jungermanniacex.

Pleuroschismaty'pus (Bot.) the genus Pleurofhifma, тย́nos, a type or pattern; a genus of Jungermanniacex.

Pleurosper'mum (Bot.) $\pi \lambda \varepsilon u p^{\prime} y$, a rib, $\sigma \pi^{\prime} \rho p u c$, feed; a genus of Umbelliferre.

Pleurosta'chys (Bot.) $\pi \lambda \varepsilon u$ por, the fide, oraxu's, a clufter; a genus of Cyperaceæ.

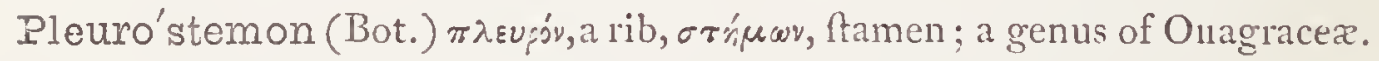

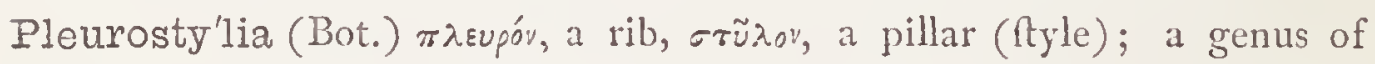
Celattracex.

Pleuro'ta (Ent.) $\varpi \lambda$ supov, a rib, referring to the rib-like fripes on the wings; a genus of Lepidoptera.

Pleurothal'lis (Bot.) $w \lambda \varepsilon u p o v$, the fide, $\theta a \lambda \lambda^{\prime} \sigma_{5}$, a branch; from the onefided arrangement of the flowers; a genus of Orchidacex.

Pleuro'toma (Zool.) $\varpi \lambda \varepsilon u p o ́ v$, the fide, rónn, a lit; a genus of Mollufca. Pleurotoma'ria (Fos. Zool.) refembling the genus Pleurotoma; a genus of foffil Mollufks.

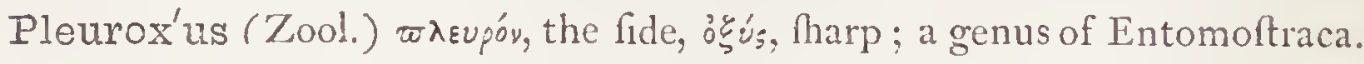
Plica'tula (Zool.) plicatus, folded, plaited; a genus of Mollufea. Plica'tus-a-um (Zool., Bot.) Lat. folded.

Plicipen'nis (Ent.) plico, to fold, pema, a wing; one of Latreille's three fections of the Neuroptera, equivalent to Trichoptera of other writers. Pli'nia (Bot.) P. N. in honour of the celebrated Roman naturalift; a genus of Myrtacex.

Plin'thine (Bot.) $\pi$ iślıss, refembling brick-work; a genus of Caryophyllacex. 
Plin'thus (Ent.) $\varpi \lambda_{\imath} v_{0}$ s, a brick; brick-lhaped.

Pli'ocene (Fos. Zool.) $\varpi \lambda \varepsilon i ́ \omega v$, more, xusvós, recent ; applied by Sir Charles

Lyell to the Upper Tertiary ftrata, becaufe containing more recent teflacea than the Miocene or Eocene.

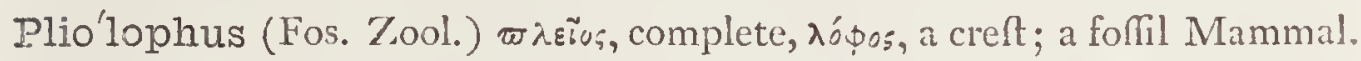
Pliopithe'cus (Fos. Zool.) ape from the Miocene depofits.

Pliosau'rus (Fos. Zool.) $\varpi \lambda \varepsilon \tilde{o s}$, complete, oaũpos, a lizard; a marine reptile from the Upper Oolite.

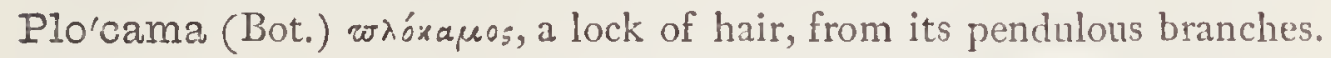

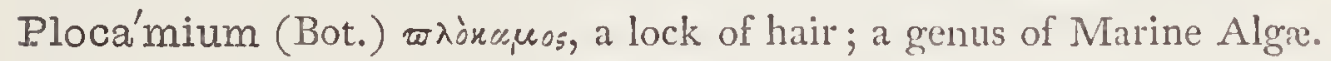

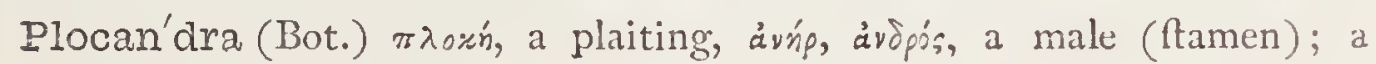
genus of Gentianacex.

Ploca'ria (Bot.) $\pi$ ro\% ń, a plaiting; a genus of Algx.

Ploce'us (Ornith.) $\varpi \lambda_{0}: x^{\prime}$, a web, from the fkill with which they build their nefts; the Weavers.

Plocoglot'tis (Bot.) $\pi \lambda \circ x^{\prime}$, a twifting, $2 \lambda \tilde{\omega} \tau \tau a$, a tongue; a genus of Orchidacex.

Ploe'sslea (Bot.) P. N., a genus of Amyridacer.

Ploia'rium (Bot.) $\pi \lambda$ sićpsov, a little kiff or boat; a genus of Ternftrömiacex.

PIösslea (Bot.) P. N., a genus of Sapindacex.

Plo'tia (Bot.) P. N., a genus of Myrfinacex.

Plo'tus (Ornith.) $\varpi \lambda \omega$ wrns, a fwinmer; the Darters.

Plo'ver (Ornith.) Fr. phwvier, equiv. to "rain-foreteller," becaufe the bird is moft active in rainy weather.-" MudIE's Feathered Tribes, Vol. II." Junius fays: aere pluvio; Skinner, quia pluviâ gaudet.

Plu'chea (Bot.) P. N., a genus of Compofitæ.

Plukene'tia (Bot.) P. N. in honour of Leonard Plukenet, an Englifh botanift. Plum (Bot.) Anglo-Sax. plume.

Pluma'ria (Ent.) pluma, a feather.

$\left.\begin{array}{l}\text { PlumateI'la } \\ \text { Plumatel'lidæ }\end{array}\right\}$ (Zool.) $\left\{\begin{array}{c}\text { dim. of plumata, feathered; a genus and } \\ \text { family of Polyzoa. }\end{array}\right.$ Plumbagina'ceis
Plumba'go (Bot.) $\left\{\begin{array}{l}\text { probably from a reference made by Pliny to } \\ \text { plants ufed to cure an eye-complaint called } \\ \text { Plumbum. }\end{array}\right.$

Plumbcl'lus (Ent.) plumbum, lead; lead-coloured.

Plu'mbeola'tus-a-um (Ent.) plumbeus, lead-coloured.

Plum'beus-a-um (Bot.) Lat. lead-coloured. 
Plumie'ria (Bot.) P. N. in honour of C. Plumier, a celebrated French butanilt.

Plumi'gerus-a-um (Ent.) pluma, a feather, gerere, to carry.

Plumo'sus-a-um ('Zool.) Lat. feathered.

Plu'mula (Bot) Lat. a little feather; the plumule is that part of a feed which forms the ftem, in oppofition to the radicle.

Plumulária (Zool.) plumula, dim. of pluma, a feather; a genus of Zoophytes.

Plu'ridens (Bot.) plures, many, dens, a tooth; teeth of calyx like Bidens; a genus of Compofitæ.

Plurimam'mis (Zool.) plures, many, mamma, a nipple.

$\left.\begin{array}{l}\text { Plu'sia } \\ \text { Plusi'idæ }\end{array}\right\}$ (Ent.) $\left\{\begin{array}{c}\text { ॠoúrเo5, rich, i. e. in colour; a genus and family of } \\ \text { Lepidoptera. }\end{array}\right.$

Plutel'la $\}$ (Ent.) \{wiuros, wahed, from the fmeared markings of the Plutel'lidæ $\}$ (Ent.) $\{$ wings; a genus of Lepidoptera.

Pluvia'lis-e (Ornith., Bot.) Lat. pertaining to rain, rainy.

Pluvia'nus (Ornith.) pluvius, rainy.

Plyctol'ophus (Ornith.) $\pi \lambda^{\prime} \varepsilon \omega$, to fold, $\lambda \dot{o} \varphi \circ \sigma^{\prime}$, a creft; a genus of Pfittacida.

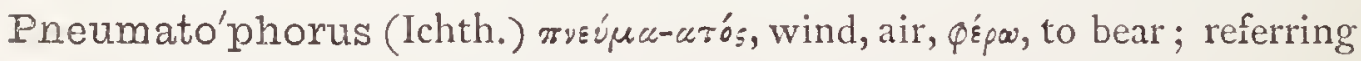
to the fwimming bladder.

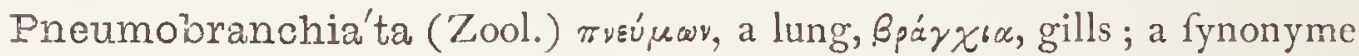
of Pulmonifera.

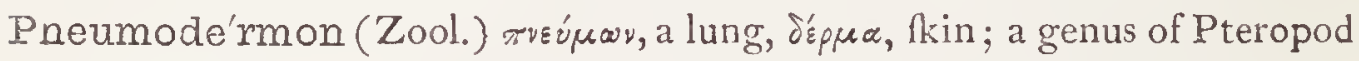
Mollufca.

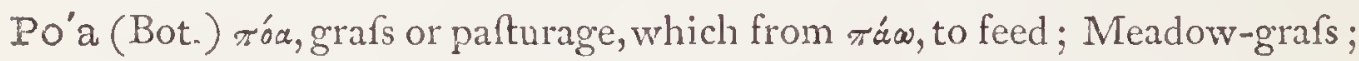

a genus of Gramina.

Poaci'tes (Fos. Bot.) poa, the Meadow-grafs; certain forfil Monocotyledonous leaves. $\left.\begin{array}{l}\text { Poa'phila } \\ \text { Poaphil'idxe }\end{array}\right\}$ (Ent.) $\left\{\begin{array}{l}\pi^{\circ}{ }^{\prime}, \text { grafs, } \varphi \triangleleft \lambda_{\varepsilon}^{\prime} \omega, \text { to love; a genus and family of } \\ \text { Lepidoptera. }\end{array}\right.$

Pocillopo'ra (Zool.) pocillum, a little cup, porus, an opening; a genus of́

Zoophytes.

Poda'brus (Ent.) rodaßpós, fmooth-footed.

Podali'ria (Ent., Bot.) P. N. from Podalirius, fon of AEfculapius :-

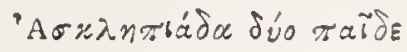

iท

(The two fons of FEfculapius, Rilled in leech-craft, Podalirius and Machaon.)

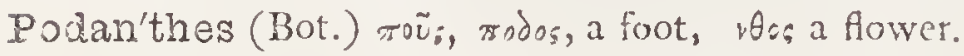


Podar'cis (Zool.) rodaprns, fwift-footed; applied to fome of the Lizards.

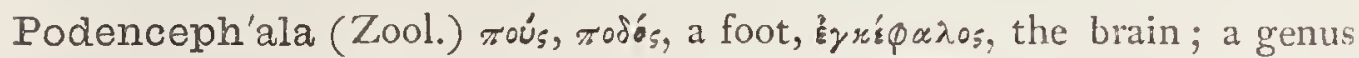
of monfter's in which the brain hangs by a pedicle.

Pode'tium (Bot.) roús, rodos, a foot; applied to the footftalk of the tubercles in the Cup-lichens.

Pordiceps (Ornith.) podex, the rump, pes, a foot; the legs being thrown far back; the Grebes.

Podicepsi'næ (Ornith.) the family of Birds of which Podiceps is the type; it hould be Podicipince.

Po'dium (Ent.) rós rov, a little foot; a genus of Hymenoptera.

Podo'a (Ornith.) rov́s, rodós, a foot, äa, a fringe; a genus of Pelecanidæ.

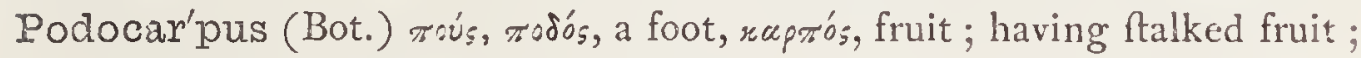
a genus of Тахасеæ.

Podo'lepis (Bot.) toús, a foot, $\lambda \varepsilon \pi i s$, a fcale; the flower-ftalks being covered with them; a genus of Compolite.

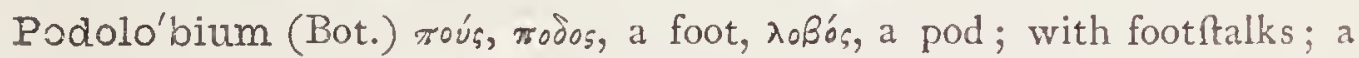
genus of Leguminofx.

Podophyl'lum (Bot.) "abridged from Anapodophyllum, a word fignifying a duck's foot; the leaves bear fome refemblance to that, whence the Englih name Duck's-foot."-PAxton.

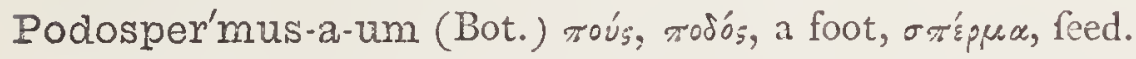

Podosphe'nia (Fos. Bot.) тоús, rodós, a foot, $\sigma \varphi$ rr, a wedge; a genus of microfcopic foffil plants.

Podu'ra (Ent.) roús, rodos, a foot, oũgo, a tail; the Spring-tails; a genus of apterous infects of the order Thyfanura.

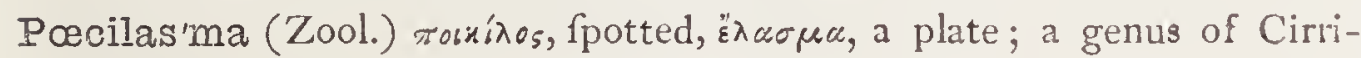
pedes.

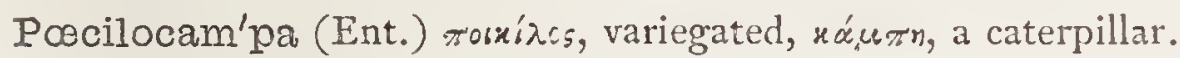

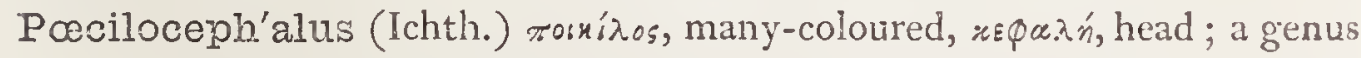
of Serpentiform Fifhes.

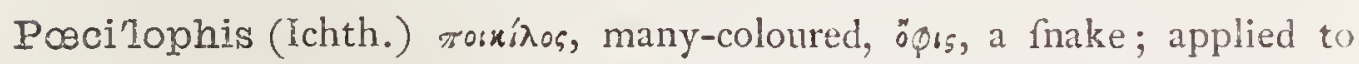
the Pipiro, a ferpentiform filh.

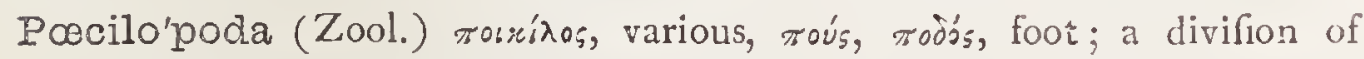
Entomoftracous Cruftacea.

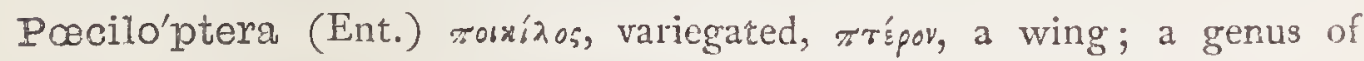
Homoptera.

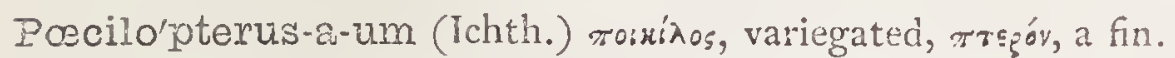

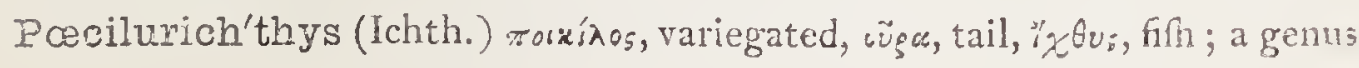
of Weft Indian Fimes. 
Pœ'cilus-a-um (Zool., Ent.) тоr ríros, fpotted, many-coloured.

Poen'sis-e (Zool.) Lat. relating to Fernando Po.

Poë'phagus-a-um (Zool.) mon, grafs, фúgw, to eat; e.g. Bos poëphagus, the Pö̈'philus-a-um (Ornith.) т'́n, grafs, $\varphi^{\prime} \lambda \varepsilon \omega$ to love.

Yak or Grunting $\mathrm{Ox}$.

Pogo'nia (Bot.) rẃyw, a beard; from the fringed lip of the flowers.

Pogo'nias (Ornith., Ichth.) rwyavic.s, bearded.

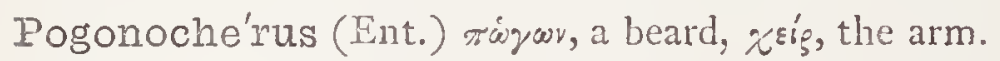

Pogo'nus (Ent.) rórwy, a beard.

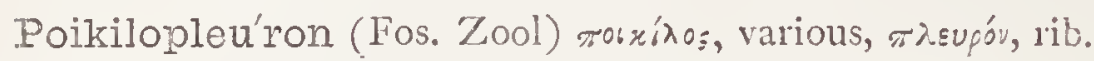

Poincia'na (Bot.) P. N. from M. de Poinci, governor of the Antilles; a genus of Leguminofa.

Poinset'tia (Bot.) P. N. in honour of $M$. Poinfette, who difcovered the plant in Mexico; a genus of Euphorbiacex.

Poin'ter (Zool.) becaufe this fporting dog is trained to ftop and point towards the game.

Pola'chius (Ichth.) Latinized form of Pollach.

Polani'sia (Bot.) тодv́, very much, ävros, unequal; ftamens?

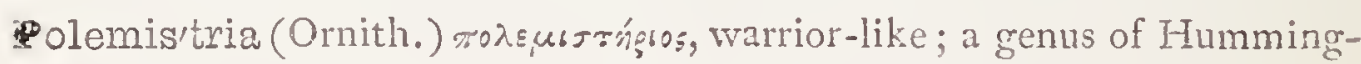
birds.

Pulemo'nium (Bot.) róx.s.us, a battle; from a legend which ftates that î caufed a war between two kinģs.

Po'lia (Ent.) roג'ó: grey.

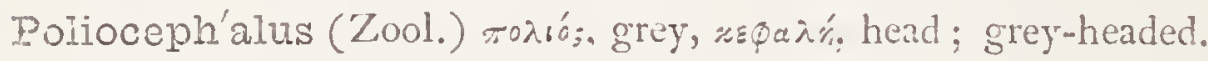

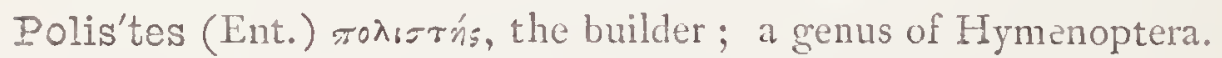

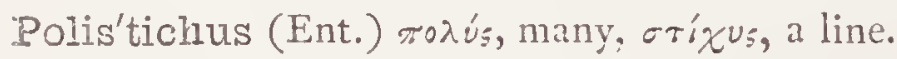

Polita'na (Ent.) politus, polifhed.

Pollen (Bot.) Lat. fine flour, applied to the farina contained in the anthers of Alowers.

Pollex (Zool.) Lat. the laft joint of the thumb.

Pollic'thia (Bot.) P. N. in honour of Goln Adam I'ollich, a German botanift.

Polli'cipes (Fos. Zool.) pollex, a thumb, pes, a foot; a genus of foffil Cirripedes.

Pollin'ium, pl. Pollinia (Bot.) applied to the pollen-mafles in Orchidaceous and other plants.

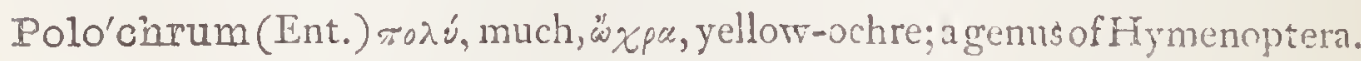
Polo'nicus-a-um (Bot.) Lat. Polih.

Polyachy'rus (Bot.) roגés, many, axupov, chaff.

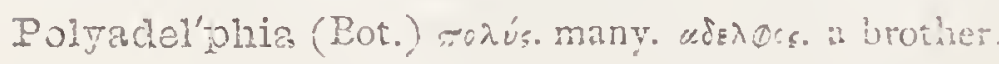


Polyan'dria (Bot.) rodús, many, árnp, ¿vopos, a male (ftamen); having many famens.

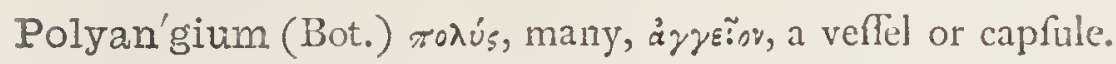

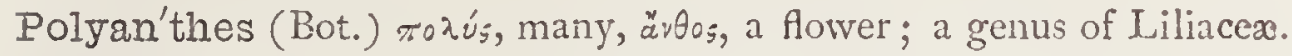

Polyan'thus (Bot.) fame derivation; a name applied to certain varieties of Primula.

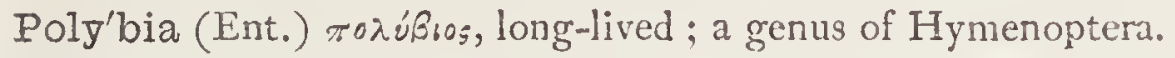

Poly'borus (Ornith.) ) $0 \lambda u$ ßógos, much-devouring; a genus of Falconidx.

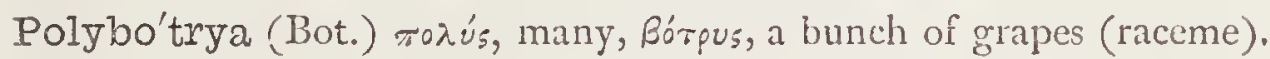

Polycar'pon (Bot.) roגús, many, raptós, fruit; a genus of Illecebracer.

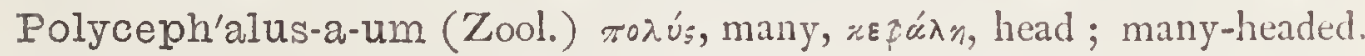

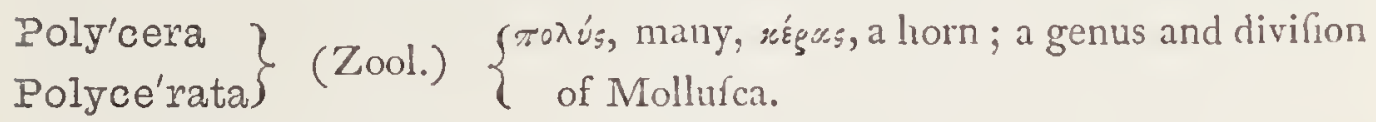

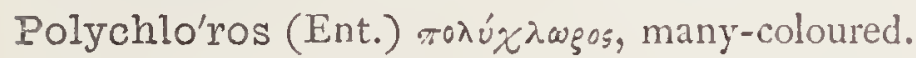

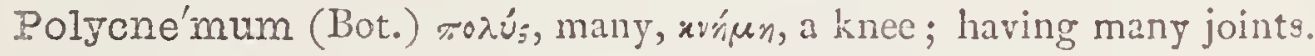

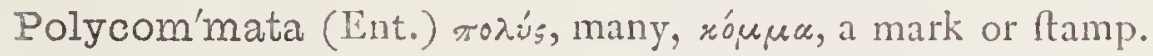

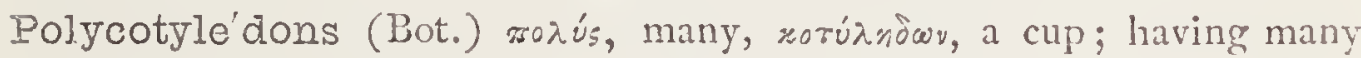
leed-veltels.

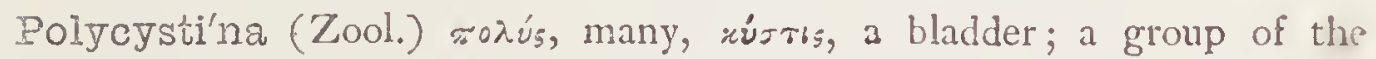
Rhizopods.

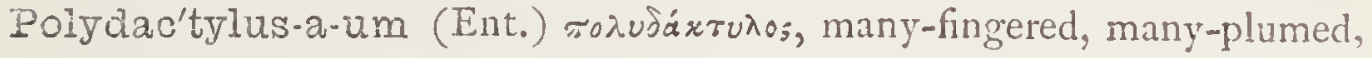
e. g. Alucitina polydactyla.

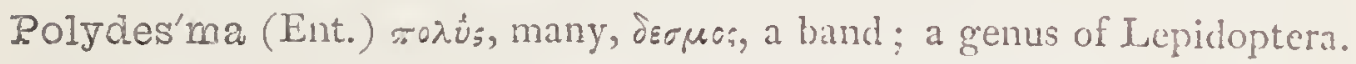

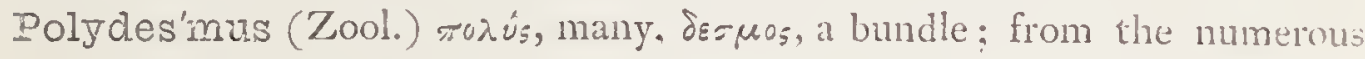
groups of limbs arranged along the body; a genus of Myriapoda.

Poly'drusus (Ent.) толúdporos, very moint.

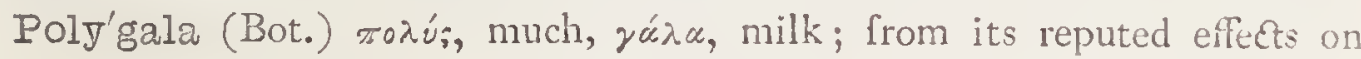
milch cattle.

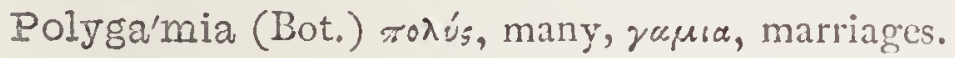

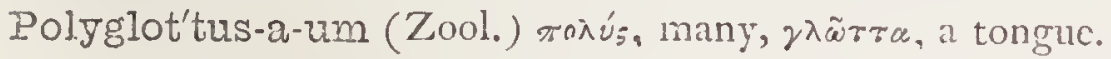

Poly'gonal (Bot.) \{roxús, many, rovin, an angle or corner: manyPolygona'lis $\}$ (Ent.) $\{$ cornered.

Polygona'tum (Bot.) roxús, many, róve, a knee, in allufion to ftem; Solomon's Seal; a genus of Liliacer.

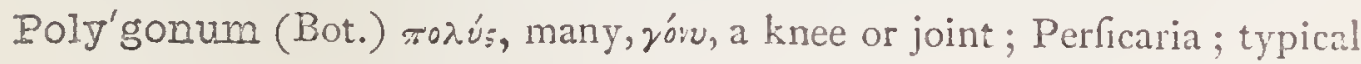
genus of Polygonacex.

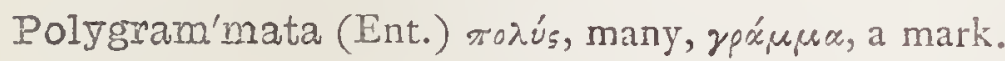

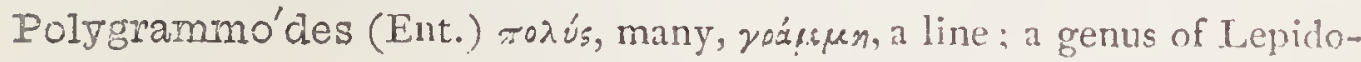
ptera. 
Poly'graphus (Ent.) roגís, many, yọ̣́, a drawing; alluding to its markings.

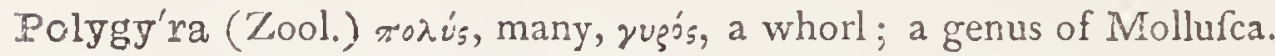

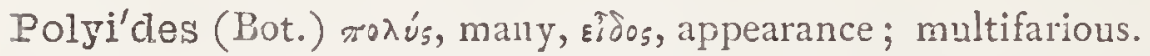

Polymixia (Ichth.) $\pi 0 \lambda v \mu$ iłice, a mingling of many characteriftics; a genus of Acanthopterygian Fifhes.

Polym'nia (Bot.) P. N., Polymnia was the name of one of the Mufes.

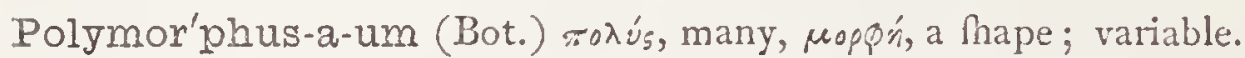

Polyne'mus (Ichth.) rodés, many, in $\mu a c$, a thread; alluding to the free thread-like appendages below the pectoral fin; the Mango-firh.

Polyn'ö (Zool.) P. N., one of the Nereids.

Polyo'don (Ichth., Ent.) roגús, many, ósurv, a tooth; in Entomology, from markings on the wings.

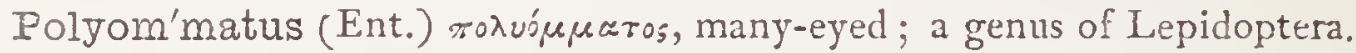

Poiyöum (Zool.) roגن́s, many, wor, an egg; a fpecific name of a Polyzoon; from the numerous round granules on its body.

Po'lypary (Zool.) the ftructure which forms the habitation of Polypi.

Po'lype (Zool.) roגuroũs, many-footed.

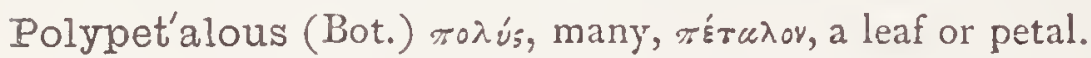

Poly'phagus-a-um ('Zool.) roגís, much or many, $\varphi \dot{y}$ wa, to eat.

Polyphe'midæ) (Zool) $\{$ P. N. from Polyphemus; referring to the large Polyphe'mus $\}$ (Lool) $\{$ eye; a genus and family of Entomoftraca.

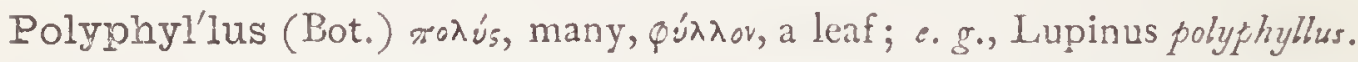
Polypi'de (Zool.) a name given by Dr. Allman, in place of the word Polypary.

Poly'pidom (Zool.) polypus, the polyp, domus, a houfe.

Polyplectron (Ornith.) $\pi \circ \lambda_{\text {ú }}$, many, $\pi \lambda \dot{n} x$ rpov, a fpur; having two fpurs on each tarfus; a genus of Gallina.

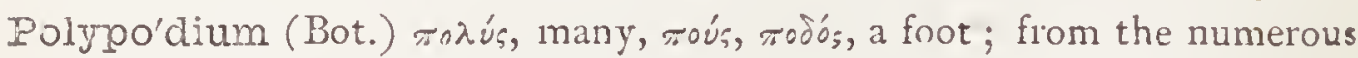
fegments of its leaves, fome fay of its roots; a genus of Filices.

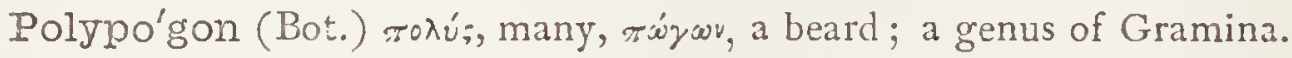

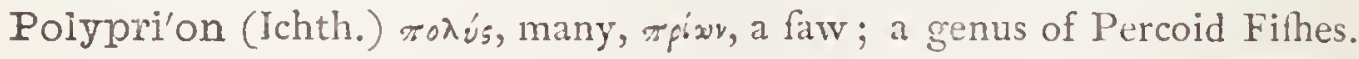

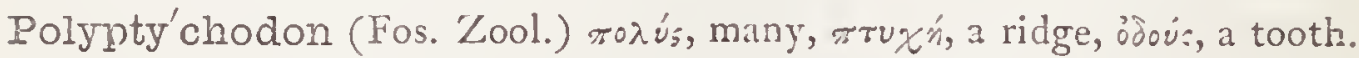

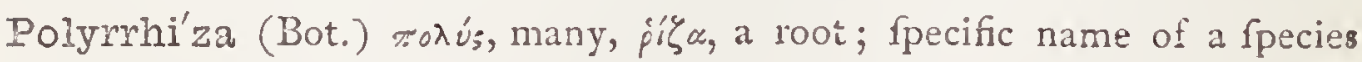
of Lemna.

Polysipho'nia (Bot.) roxús, many, cị́ar, a tube; a genus of marine Algze.

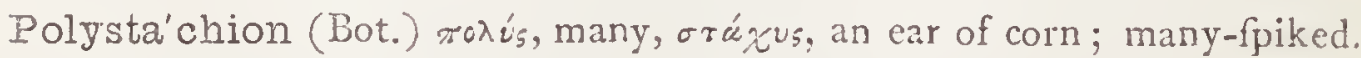
Polystic'ta (Ent.) roxú, much, orixtó, fpotted.

Poly'stoma (Ent.) rodés, many, oróka, a muuth. 
Poly'tela (Ent.) $\pi \circ \lambda \cup \tau \varepsilon \lambda n_{s}$, magnificent; a genus of Lepidoptera.

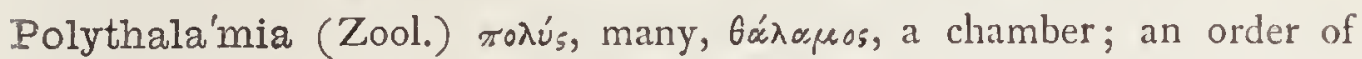
Polyzoa.

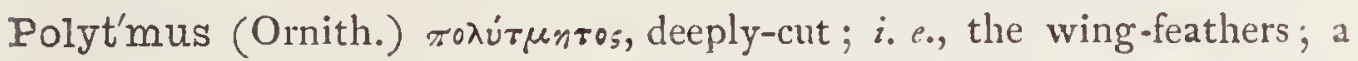
genus of Humming-birds.

Polyto'ca (Bot.) толutóros, bringing forth many young ones, prolific; a genus of Gramina.

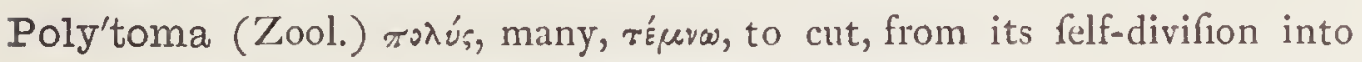
many fections; a genus of Infuforia.

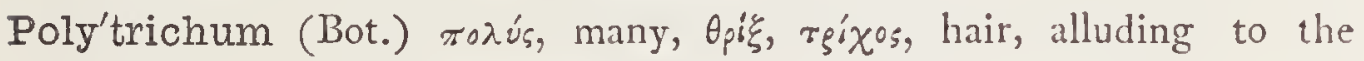
calyptra; a genus of Mufci.

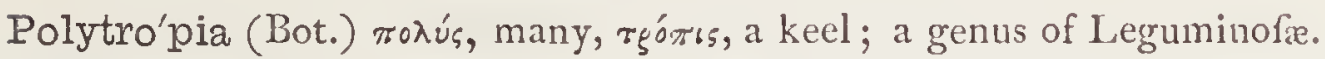

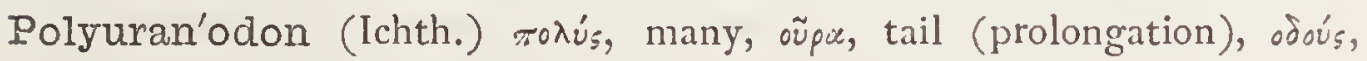
odsvrós, a tooth.

Poly'xena (Bot.) P. N. from mythology; a genus of Liliacer.

Poly'xenus (Zool.) $\pi 0 \lambda \dot{y} \xi_{\varepsilon v \sigma_{5}}$, very hofpitable; a genus of Myriapoda.

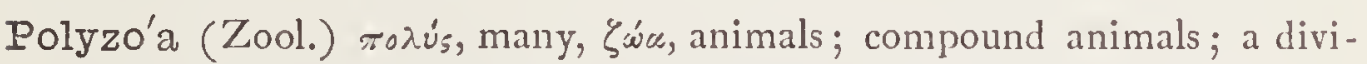

fion of mollufcan Zoophytes, fometimes called Bryozoa.

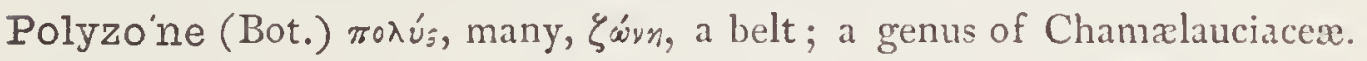

Polyzo'nia (Bot.) fame derivation; a genus of Ceramian Algix.

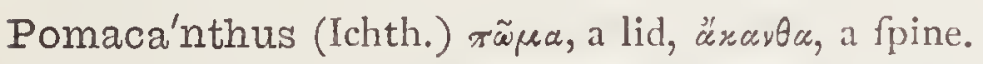

Poma'ceæ (Bot.) the Nat. Ord. of plants, of which Pomum is the type; the Apple and Pear family.

Pomader'ris (Bot.) $\pi \tilde{x} \mu \alpha$, a lid, S'spss, a Rkin, in allufion to the berries; a genus of Rhamnaceæ.

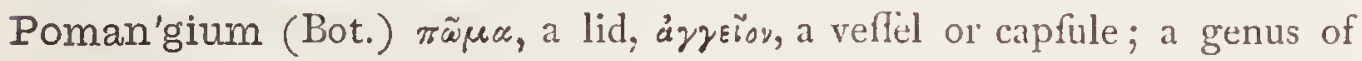
Cinchonacex.

Poma'ria (Bot.) $\pi \tilde{\omega} \mu \alpha$, a lid; a genus of Leguminofx.

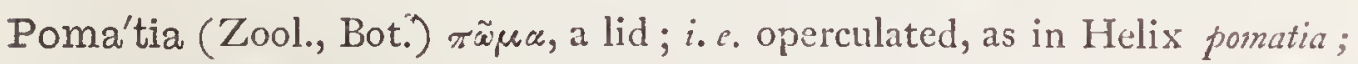
in Botany a genus of Lauraceæ.

Pomatoder'ris (Bot.) fame etymology as Pomaderris; a genus of Rhamnacex.

Po'max (Bot.) $\pi \omega \mu \alpha ́ \zeta \omega$, to cover with a lid; a genus of Cinchonacex.

Pomba'lia (Bot.) P. N. in honour of the Marquis de Pombal, a Portuguefe ftatefman ; a genus of Violaceæ.

Pomegran'ate (Bot.) from pomum granatum, the grained apple, once applied to it; now called Punica granatum. The fruit was formerly called Mala Punica.

Pomereul'la (Bot.) P. N., a genus of Gramina. 
Pomeri'dian (Bot.) poft, after, meridies, mid-day.

Pomi'ferus-a-um (Bot.) Lat. apple-bearing.

Pompadou'ra (Bot.) P. N. in compliment to the celebrated Madame Pompadour; a genus of Calycanthacex.

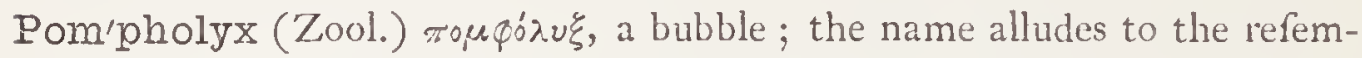
blance of the Lorica to a round flat fmelling-bottle; a genus of Infuforia.

Pompi'lidæ (Ent.) a family of Hymenoptera, of which Pompilus is the type.

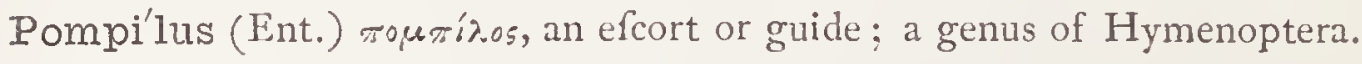
Po'mum (Bot.) Lat. an apple; the Apple-tree.

Ponæ'a (Bot.) P. N., a genus of Sapindaceæ.

Poncele'tia (Bot.) P. N., a genus of Epacridaceæ.

Ponga'mia (Bot.) from the Malabar name Pongam.

Pontede'ra (Bot.) P. N. in honour of Julio Pontedera, an Italian botanift;

a curious genus of aquatics, typical of Pontederacex.

Ponthie'va (Bot.) P. N. in honour of $M$. de Ponthieu, a French merchant; a genus of Orchidacea.

Pontoppida'na (Bot.) P. N., a genus of Lecythidaceæ.

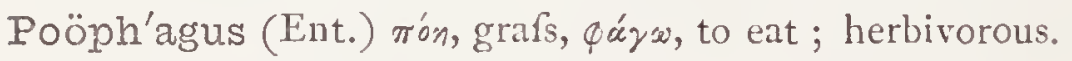

Poo'tia (Bot.) P. N., a genus of Gentianacex.

Pop'lar (Bot.) from Lat. Populus.

Pöppi'gia (Bot.) P. N., a genus of Verbenacex.

Poppou'ria (Bot.) P. N., a genus of Anonacex.

Pop'py (Bot.) Lat. papaver, Ital. papavero, Fr. pavot.

Popula'ta (Ent.) feeding on the Poplar, Populus.

Popule'ti $\}$ Ent. $\{$ gen.fingular and plural of populetum, a poplar-grove, Populeto'rum $\}$ Ent. $\{$ implying that the infects frequent thefe groves. Pop'ulus (Bot.) Lat. the Poplar-tree, probably from $\pi \alpha \iota \pi \alpha \lambda \lambda \omega$, to Make :

i.e. by the wind; a genus of Salicacex.

Pora'na (Bố.) ropeća, to travel, from its fpreading branches.

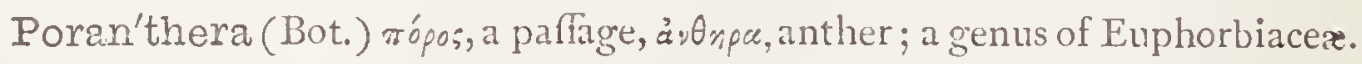

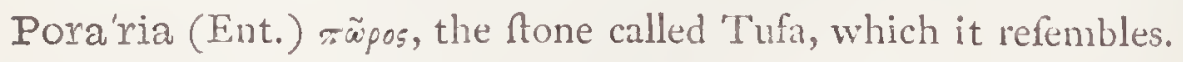

Porca'tus-a-um (Zool.) porcus, a fwine; frine-like.

Porce'lia (Bot.) P. N., a genus of Anonacer.

Porcella'na (Zool.) fo called, becaufe their thells are fmooth like porce-

lain; the Porcelain-Crab : a genus of Crultacea.

Porcell'io (Ent.) Lat. a little hog; the Wood-loufe.

Pcrcell'us (Ent.) Lat. a little hog; fpecific name of a fphinx moth,

Chorrocampa Porcellus.

Pori'ferus-a-um (Zool.) pori, pores or openings, fero, to bear. 
Po'rina (Bot.) $\pi \tilde{x} \rho$ svos, crumbling away, from $\pi \tilde{\omega}$ pos, the 'Tufa-ftone.

Porlie'ra (Bot.) P. N., a genus of Zygophyllacex.

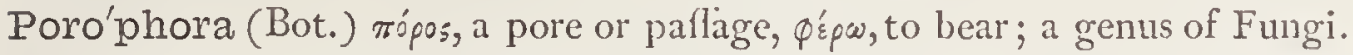

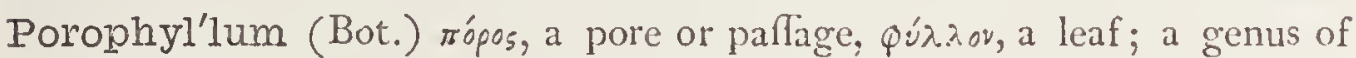
Saxifragaceæ.

Poropter'ides (Bot.) tópos, a paftage or pore, $\pi$ rśpss, a fern; a fection of Filices.

Poro'stema (Bot.) זópo:, a paffage, $\sigma$ rś $\mu \mu \alpha$, a wreath; a genus of Lauracer. Porothe'leum (Bot.) rópos, a paflage, $\theta n \lambda \dot{n}$, a nipple; a genus of Fungi.

Porothe'lium (Bot.) fame derivation; a genus of Lichenes.

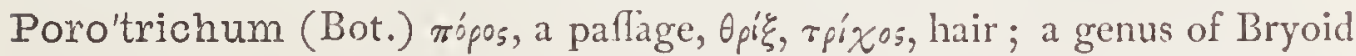
Mufci.

Porphy'ra (Bot.) торфú, $\alpha$, purple, a genus of marine Algæ.

Porphyra'lis (Ent.) \%opфúpa, purple; from the prevailing colour.

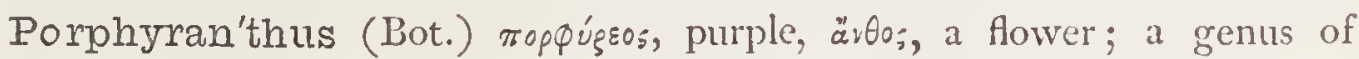

Goodeniacex.

Porphy'rea (Ent.) торфúpєos, purple.

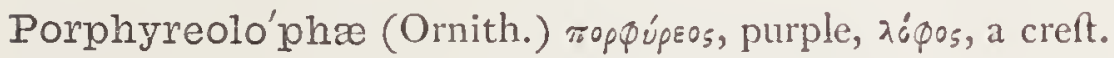

Porphy'res (Ornith.) торфúpeos, purple.

Porphy'rion (Bot.) $\pi 0_{\xi} ₫ \dot{p} p \varepsilon r o \xi$, purple; a genus of Saxifragacex.

Porphyri'tica (Zool.) roppúpa, purple; from the colour of the body; applied to one of the Salamanders.

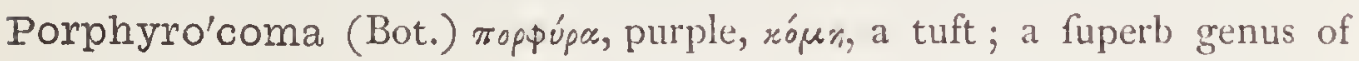
Acanthaceæ.

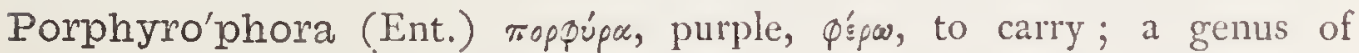
cochineal-bearing infects.

Por'poise (Ichth.) French, porc-poifon, hog. filh; fometimes written Porpeffe; popular name of the Phocana communis.

Porrecte'lla (Ent.) Lat. porrectus, out-ftretched.

Porrec'tus-a-um (Ent.) Lat. fretched out, extended.

Por'rigens (Bot) Lat. fpreading, e g., Achyranthes porrigens.

Por'rum (Bot.) Lat. a leek; the common leek is Allium porrum; a genus of Liliacex.

Portale'sia (Bot.) P. N., a genus of Compofitx.

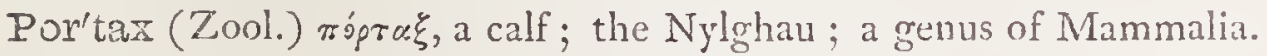

Portenschla'gia (Bot.) P. N., a genus of Celaftracex.

Porte'sia (Bot.) P. N., a genus of Meliacex.

Portla'ndia (Zool. Bot.) P. N. in honour of the Duchess of Portland; applied to a genus of Cinchonacex; in Zoology, a genus of Mollufca. 
$\left.\begin{array}{l}\text { Portula'ca } \\ \text { Portulaca'ceæ }\end{array}\right\}$ Bot. $\left\{\begin{array}{l}\text { porto, to carry, lac, milk, from the juicy nature } \\ \text { of the plants; but fome fay from portula, a } \\ \text { little gate, from refemblance of the leaves; } \\ \text { the Purflane genus and family. }\end{array}\right.$

Po'ruli (Bot.) porules; dim. of $\pi \tilde{\omega} p$ os, a paffage or pore.

Po'rus, pl. Po'ri (Zool., Bot.) rŵpos, a paffage; pores.

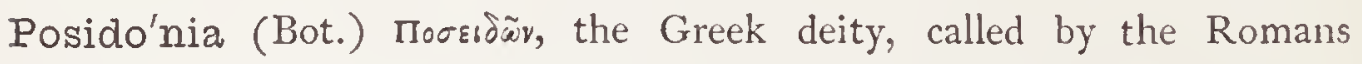

Neptune; from its marine habitat; a genus of Zofteraceæ.

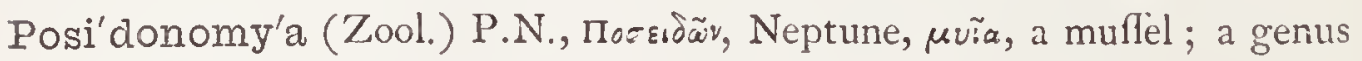
of Mollufca.

Posoque'ria (Bot.) P. N., a genus of Cinchonacex.

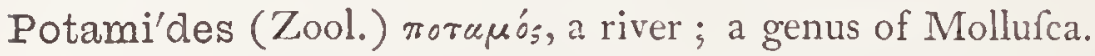

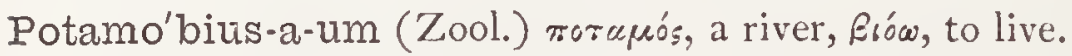

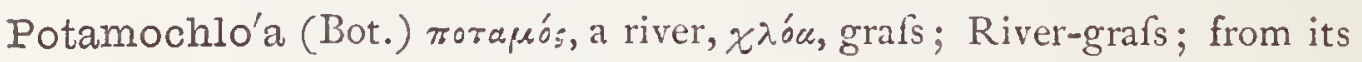
aquatic habitat; a genus of Gramina.

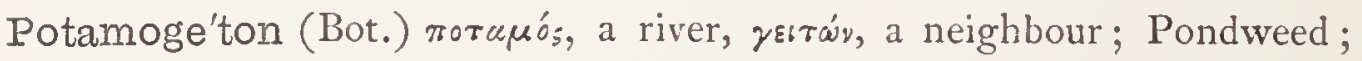
a genus of Fluviales.

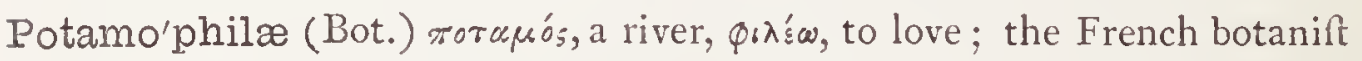

Richard's name for the Naidacea.

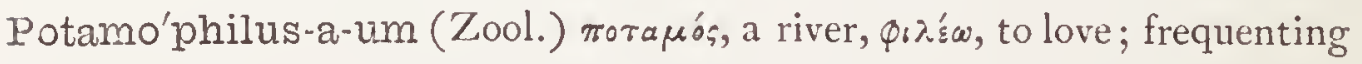
Areams.

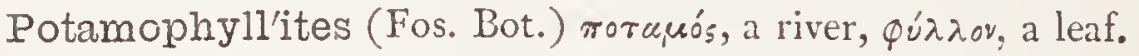

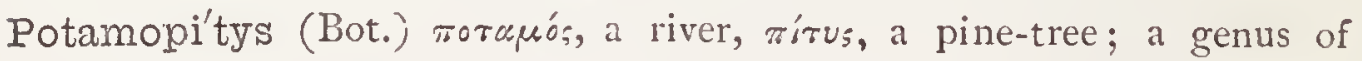
Elatinacex.

Pota'to (Bot.) from the fimilarity of its tubers to thofe of the Convolvulus Batatas.

Potato'ria (Ent.) potator, a drinker.

Potato'rum (Bot.) Lat. of drinkers; the fpecific name of a Strychnos, which is ufed in India for clearing muddy water.

Potentil'la (Bot.) potens, powerful, from the aftringency of the root; a genus of Rofacer.

Poteran'thera (Bot.) rotńs, a drinking cup, àvonpa, anther; a genus of

Melaftomacex.

Pote'rii (Ent.) feeding on the Salad Burnet, Poterium Sanguiforba.

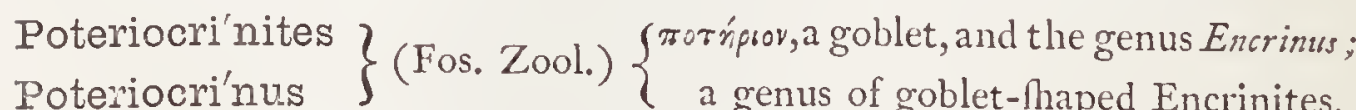
Pote'rium (Bot.) poterium, a drinking-cup; formerly ufed in the "cool tankard;" the Salad-Burnet; a genus of Sanguiforbacex. 
Pothomor'phe (Bot.) the genus Pothos, $\mu o p \phi n$, refemblance, i. e., to that plant; a genus of Piperacex.

Po'thos (Bot.) from Potha, the common appellation given to thefe plants in Ceylon; a genus of Orontiacer.

Po'tia (Ichth.) etymology obfcure; a genus of Cyprinoid Fifhes.

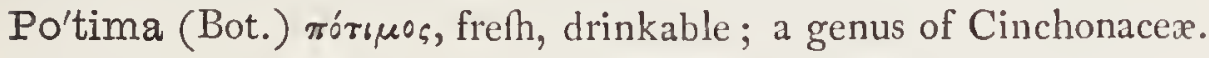

Po'toroo (Zool.) native Aufralian name of the Kangaroo Rat.

Pot'tia (Bot.) P. N., a genus of Bryoid Mufci.

Pot'to (Zool.) native African name of the lemurine mammal, Perodicticus Potto.

Pot'tsia (Bot.) P. N., a genus of Apocynaceæ.

Pouche'tia (Bot.) P. N., a genus of Cinchonacex.

Poupartia (Bot.) P. N., a genus of Anacardiacex.

Pourou'ma (Bot.) probably the vernacular name in Guiana; a genus of Artocarpaceæ.

Pourre'tia (Bot.) P. N. in honour of $M$. Pourrett, of Touloufe; a genus of Bromeliacer.

Poute'ria (Bot.) P. N., a genus of Sapotacer.

Pouzol'zia (Bot.) P. N., a genus of Urticacer.

Pozo'a (Bot.) P. N., a genus of Umbellifera.

Præal'tus-a-um (Bot.) Lat. very high.

Præangu'sta (Ent.) praanguftus, very narrow (wings).

Præcocel'la (Ent.) dim. of pracox, early; $i . e$ appearance in fpring.

Præ'cox (Ent., Bot.) Lat. precocious, early.

Prælatel'la (Ent.) prelatus, chofen, preferred.

Prælonga'na (Ent.) pralongus, very long.

Præmor'sus-a-um (Bot.) Lat. bitten off; terminating abruptly; applied to fuch roots as thofe of the Scabiofa fuccifa.

Præ'nitens (Bot.) Lat. very glittering; e.g., Primula pranitens.

Pran'gos (Bot.) a native Tartar name; a genus of Umbelliferæ.

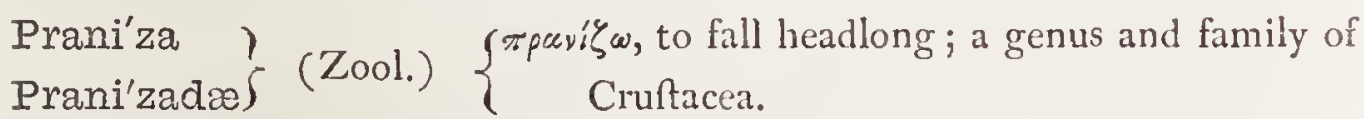

Prasina'na (Ent.) трús,vos, leek-green.

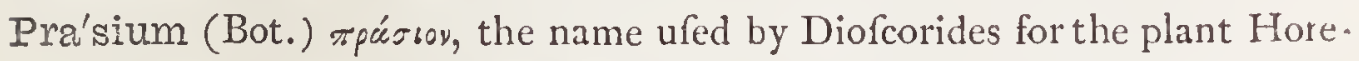
hound; a genus of Lamiaceæ.

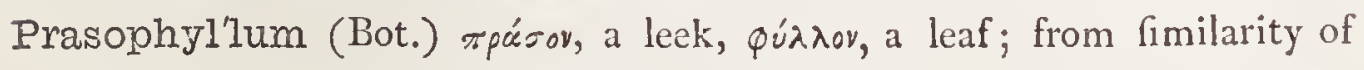
form; a genus of Orchidacer.

$\left.\begin{array}{l}\text { Prata'na } \\ \text { Pratel'lus }\end{array}\right\}$ (Ent.) pratum, a meadow. 
Praten'sis-e (Bot.) Lat. growing in meadows; e. g., Alopecurus pratenfis. Prawn (Zool.) popular name of Cruftaceans of the genus Pandalus.

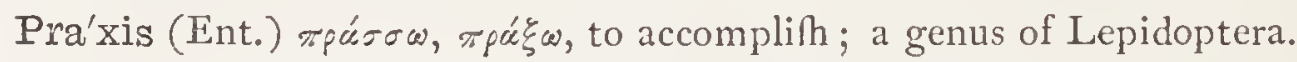

Pra'ys (Ent.) זpás, gentle, delicate; a genus of Lepidoptera.

Precato'rius (Bot.) precator, one who prays; becaufe the feeds are ufed to make rofaries; $e . g .$, Abrus precatorius.

Prehen'sile (Zool.) prehendo, to take hold of.

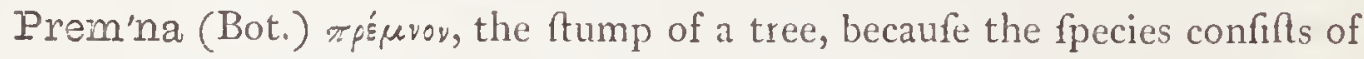
Mrubs and fmall trees; a genus of Verbenaceæ.

Prenan'thes (Bot.) rprùrs, drooping, äv0s, a flower; a genus of Compofitx. Preonan'thes (Bot.) rpnáv, a projection, ü»sos, a flower; a genus of Ranunculacex.

Preoper'culum (Ichth.) pre, before, operculum, a lid or gill-cover; applied to one of the four parts of the operculum of fifhes.

Prepu'sa (Bot.) from an anatomical term, and referring to the inflated calyx; a beautiful genus of Gentianacex.

Pres'byter (Ichth.) rṕs Bos, blind; fpecific name of the Land-fmelt.

Presbyteroi'des (Ichth.) the genus Prefbyter, हidos, likenefs.

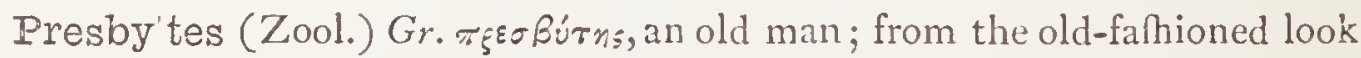
of this Ape; the Capped apes; a genus of Simiidx.

Pres'lia (Bot.) P. N. in honour of the celebrated German writer upon Ferns; a genus of Labiatæ.

Presto'nia (Bot.) P. N., a genus of Apocynacere.

Pretio'sus-a-um (Zool.) Lat. valuable.

Prevos'tea (Bot.) P. N. in honour of M. Prevof, of Geneva; a genus of Convolvulacea.

Pria'pulus (Zool.) from Priapus, a mythological name; a genus of Echinodermata.

Priestley'a (Bot.) P. N. in honour of Dr. Priefley, the celebrated chemift; a genus of Leguminofie.

Prieur'ea (Bot.) P. N., a genus of Onagracex.

Primæ'vus-a-um (Zool.) Lat. of the firtt age.

Prima'tes (Zool.) primus, firft Linnæus's firft great divifion of Mammalia, which includes Man.

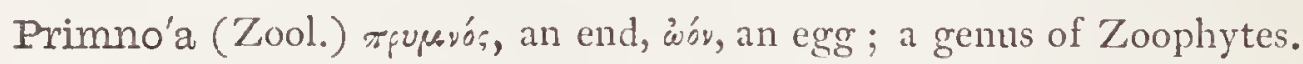
Pri'mula (Bot.) primıs, firt, from its early flowering; the Primrofe. Primula'cer (Bot.) the Primrofe family, of which Primula is the type. Prino'psis (Bot.) the genus Prinos, ö $\psi$ 's, refemblance; a genus of Compofitx. 
Print'zia (Bot.) P. N., a genus of Compofitx.

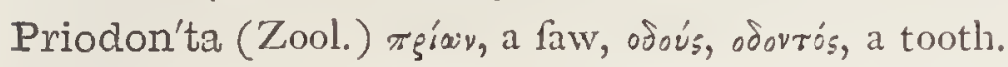

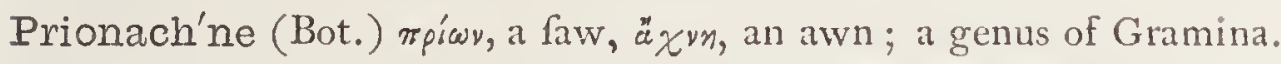

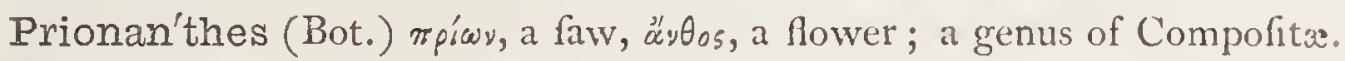

Prion'idæ (Ent.) a genus of beetles, of which Prionus is the type.

Prioni'tes (Ornith.) rpíw, a faw, from the ferrated mandibles; Illiger's name for the Motmots.

Prioni'tis (Bot.) $\pi p^{\prime}(w v$, a faw; a genus of Umbelliferæ.

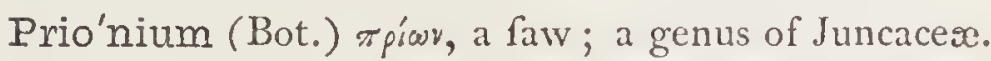

Prionochi'lus (Ornith.) $\pi$ piwv, a faw, $\chi^{\text {sĩ } \lambda 05, ~ a ~ l i p . ~}$

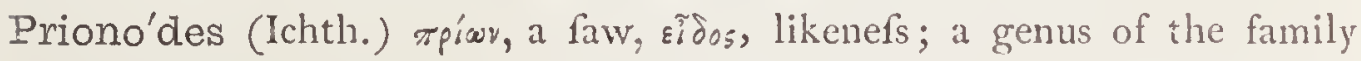
Percidx.

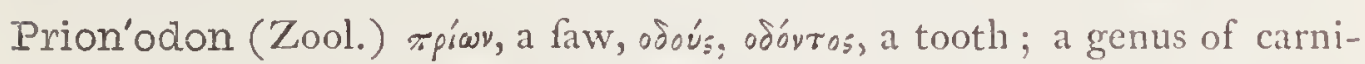
vorous animals of the family Felidx.

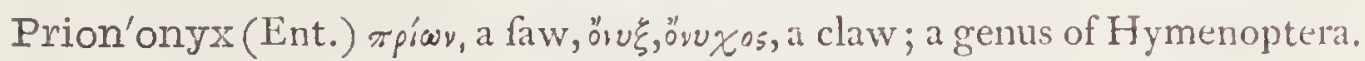

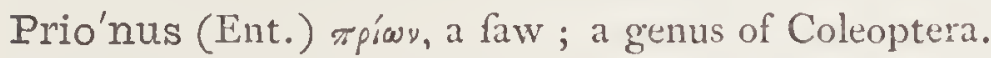

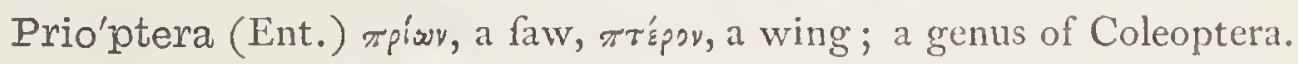

Priosce'lis (Ent.) $\pi p^{\prime} i^{\prime} \omega$, a faw, $x n \lambda i_{5}$, a fpot.

Prisma'ticus-a-um (Zool., Bot.) Lat. reflecting the prifmatic colours, or angular like a prifm.

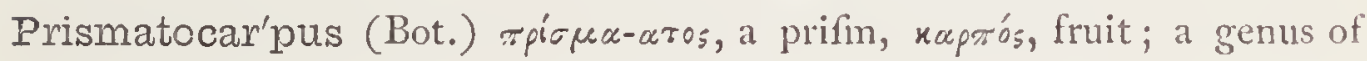
Campanulacex.

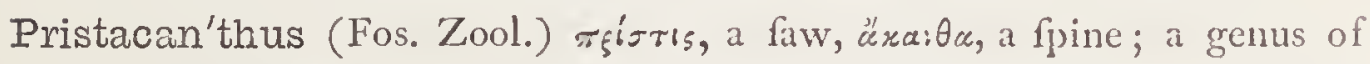
extinêt Fines.

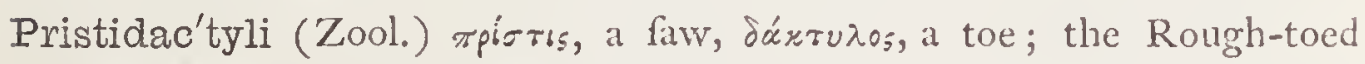
lizards.

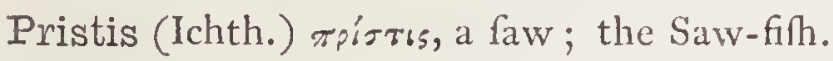

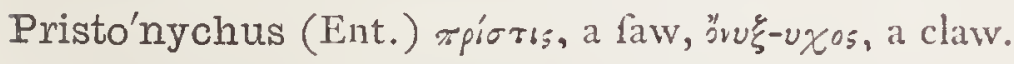

Proboscida'lis (Ent.) probofis, a trunk or finout.

Probosci'dea (Ent., Bot.) probofics, a trunk or fnout; a fub-clafs of Diptera; alfo in Botany, as Martynia probofcidea.

Proboscidi'fera (Zool.) probofcis, a trunk or fnout, fero, to carry; a group of Mammalia.

Probosci'diform (Zool.) probofcis, a trunk or fnout, forma, thape.

Probo'scis (Zool.) Lat. a trunk or frout.

Procella'ria

$\left.\begin{array}{l}\text { Procellar'idæ } \\ \text { Procellari'næ }\end{array}\right\}$ (Ornith.) $\left\{\begin{array}{c}\text { procella, a ftorm, i. e. the Storm-birds; the } \\ \text { Petrels. }\end{array}\right.$

Procella'ta (Ent.)procella, a ftorm; from fome cloudy markings on the wings. 


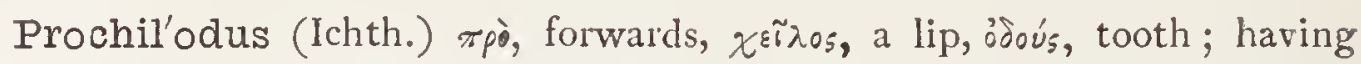
remarkable thick lips fringed with teeth as flender as hairs; a genus of South American Fithes.

Proc'nias (Ornith.) derivation uncertain; the Swallow Chatterer.

Procœ'lia (Fos. Zool.) rpós, front, xoĩ 05 , hollow; having vertebræ with the cup at the fore part and the ball behind.

$\left.\begin{array}{l}\text { Pro'cridæ } \\ \text { Pro'cris }\end{array}\right\}$ (Ent.) $\left\{\begin{array}{r}\text { P. N. from Procris, a daughter of the king of } \\ \text { Athens; a family and genus of Lepidoptera. }\end{array}\right.$ Procru'stes (Ent.) a mythological name; a genus of Coleoptera.

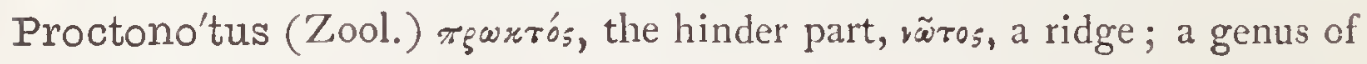
Mollufca.

Procum'bens (Bot.) Lat. leaning forward, or proftrate on the ground; e.g., Azalea procumbens.

Pro'cyon (Zool.) т gorvér, one who fnarls like a dog; the Racoon.

Procyonoi'des (Zool.) procyon, a racoon, Eíjos, likenefs.

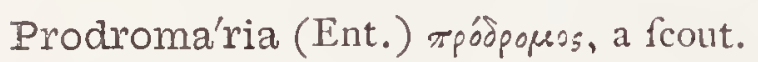

Produc'ta (Zool.) Lat. drawn out; a genus of Brachiopodous Mollufca.

Profugel'la (Ent.) profugus, a fugitive.

Profunda'na (Ent.) profundus, deep.

Progemma'ria (Ent.) progemmans, budding forth.

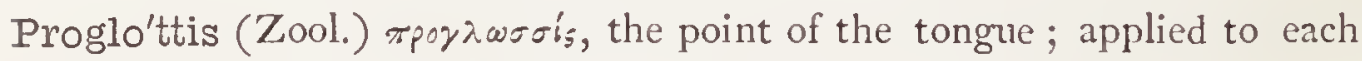

fegment of the tapeworm.

Progna'thic (Zool.) mpò, forwards, yvágos, the jaw.

Proli'ferus-a-um (Zool., Bot.) proles, offspring, fero, to bear; e.g. Hynum proliferum.

$\left.\begin{array}{l}\text { Promero'pidæ } \\ \text { Pro'merops }\end{array}\right\}$ (Ornith.) $\left\{\begin{array}{c}\text { allied to Merops; a family and genus of } \\ \text { incelforial Birds, family Upupidie. }\end{array}\right.$ $\left.\begin{array}{l}\text { Pronate } \\ \text { Prone }\end{array}\right\}$ (Zool., Bot.) pronus, leaning forward.

Pro'nuba (Ent.) pronuba, a bridefmaid.

Pronubel'la (Ent.) dim. of promba, a bridefmaid.

Propinquel'la (Ent.) dim. of propinquus, refembling.

Propithe'cus (Zool.) prope, near, allied to, pithecus, an ape; to exprefs its relations.

Propugna'ta (Ent.) propugnatus, fought for, defended.

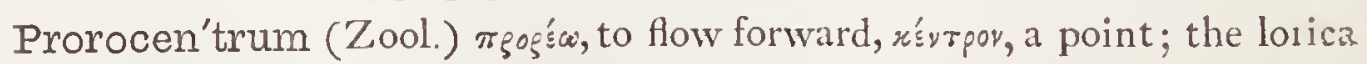

being pointed anteriorly; a genus of Infuforia.

Proscarabæ'us (Ent.) having a refemblance to Scarabceus.

Proserpina'ca (Bot.) proferpo, to creep; a genus of Haloragacex. 
Pro'sobranchia'ta (Zool.) r gós, in front of, Bpóyxos, the windpipe.

Proso'des (Ent.) rpoowions, ftinking.

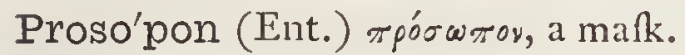

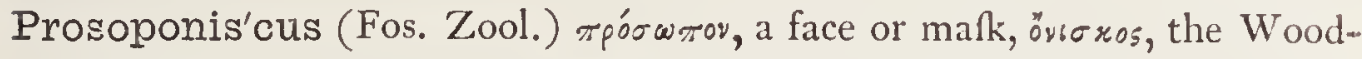
loufe; the name has been given inftead of Palæocrangon.

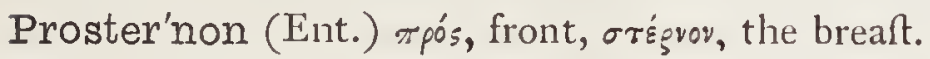

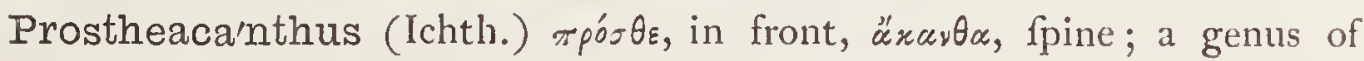
Fufiform Filhes.

Prostra'tus-a-um (Bot.) Lat. trailing.

Prosym'na (Zool.) unexplained; a genus of Ophidians.

Pro'tea (Ent., Bot.) P. N. from Proteus, the changeable god.

Pro'teles (Zool.) $\pi \rho^{\prime}$, in front, $\tau$ 's $\lambda \circ$ s, extremity, from the extended fnout ; the Aard Wolf; a genus of Mammalia.

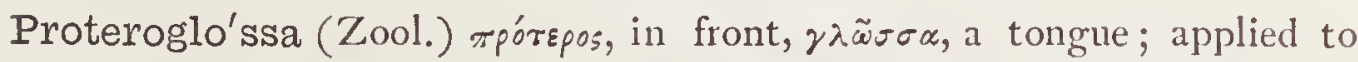
certain Batrachians, with a tongue free in front and adherent behind.

Pro'teus (Zool.) P. N., a fea-god; a genus of Amphibia.

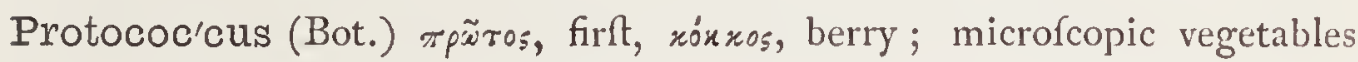
of the fimple?t poffible fructure.

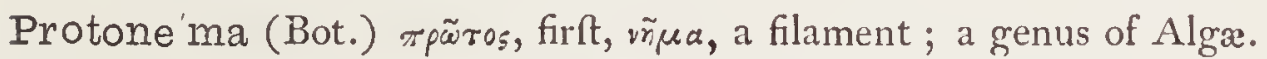

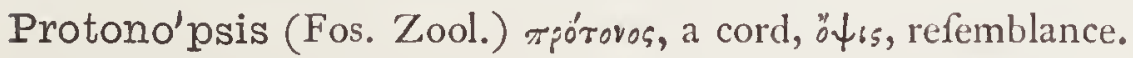

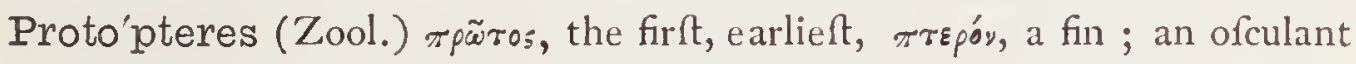
form between Fifhes and Reptiles.

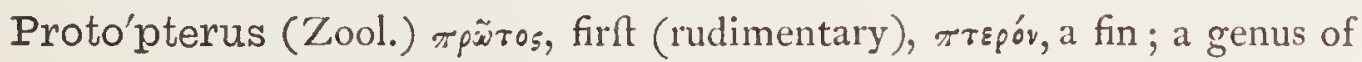
Amphibia.

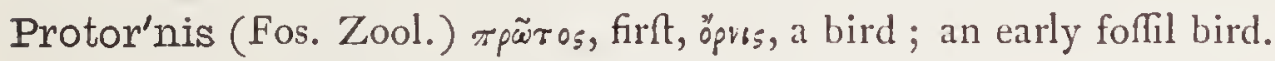

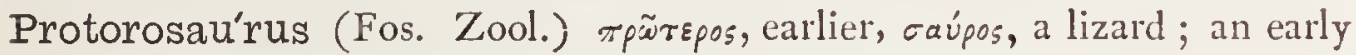
foffil reptile, known as the foffil Monitor of Thuringia.

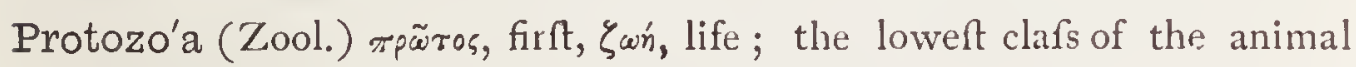
kingdom, correfponding to the true Infuforia.

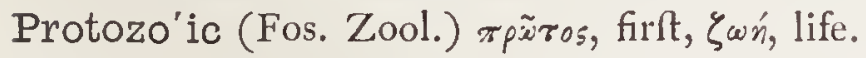

Pro'tula (Zool.) трó, before, rúr.os, a knob; a genus of Annelids.

Prui'na(Bot.)Lat. hoar-froft ; a mealy fubftance on the furface of fome plants.

Pruino'sus-a-um (Bot.) Lat., hoary-frofted.

Pruna'ta (Ent.) from feeding on Blackthorn, Prunzs fpinofa.

Prunel'la (Bot.) from the Germ. Die Breaune, a name given to an affection of the fauces for which it was ufed; or perhaps from pruna, a burning coal, being ufed to cure burns ; Self-heal ; a genus of Labiatx.

Pruneto'rum (Ent.) gen. pl. of prunetum, a loe thicket; fuch being the refort of the infeet. 
Prunia'na (Ent.) feeding on various fpecies of Prunus.

Pru'nus (Bot.) Lat. a plum-tree; a genus of Drupaceæ.

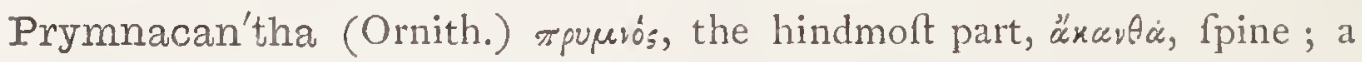
genus of Humming-birds.

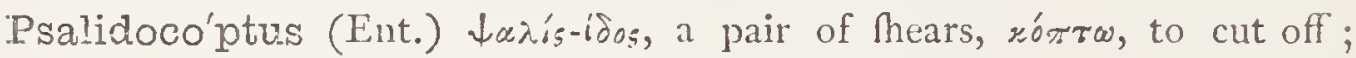
alluding to the elytra being cut with a delicate outline and incifures; a genus of Coleoptera.

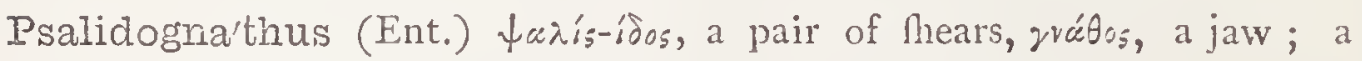
genus of Coleoptera.

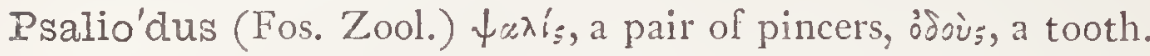

Psalu'rus (Ornith.) $\psi_{a \lambda}{ }_{i}^{\prime}$, a vault, oũpa, a tail ; fpecific name applied to birds which have the tail much arched.

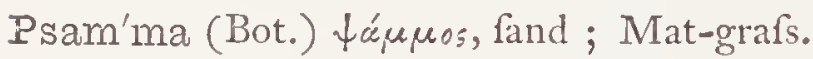

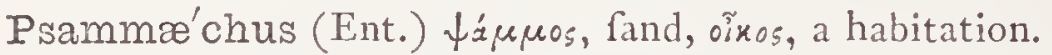

Psammi'sia (Bot.) P. N. from Pfammis, a King of Egypt.

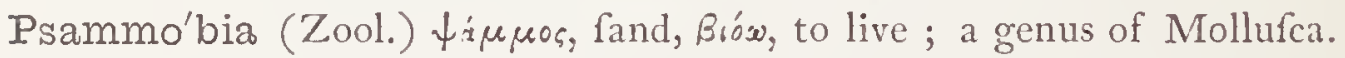

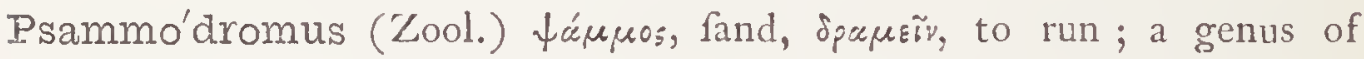
Reptilia.

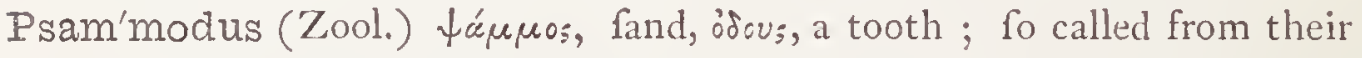
rough upper furfaces.

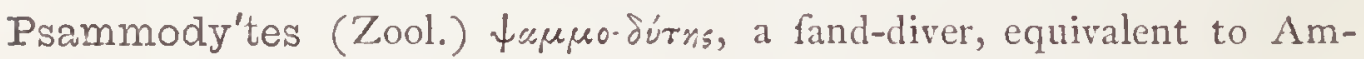
modytes.

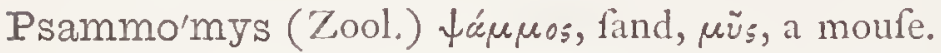

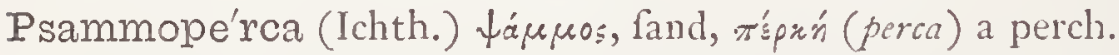

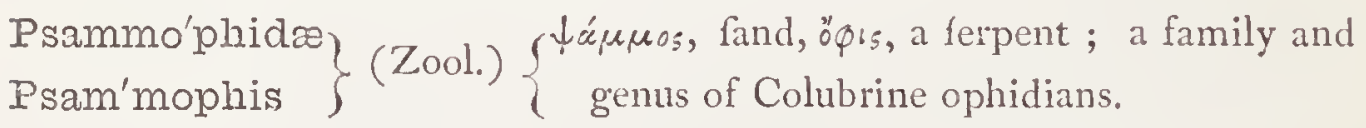

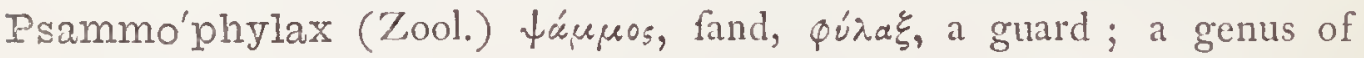
Colubrine ophidians.

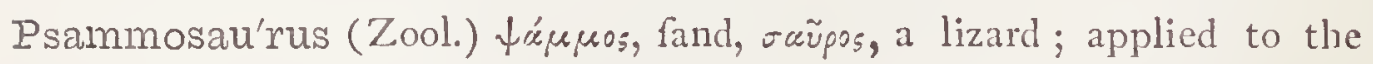
Land Monitor.

Psaroli'tes or Psaroni'tes (Fos. Bot.) భupos, fpeckled, $\lambda_{i} \theta_{0} ;$, a ftone ; applied to certain foffl tree-ftems.

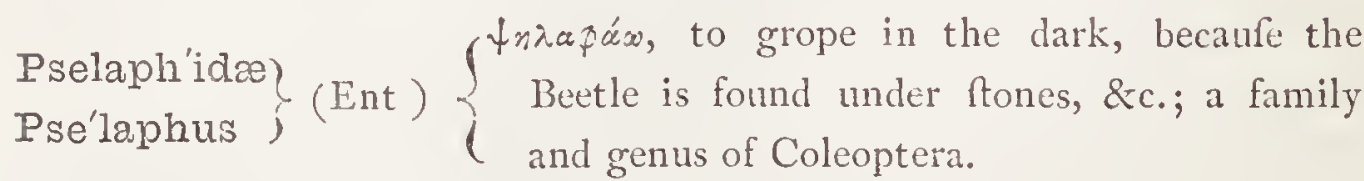

Psen (Ent.) friv, the gall infect, Lat. Cynips; a genus of Hymenoptera.

Pse'phis (Ent.) 恼as, darknefs, obfcurity; a genus of Lepidoptera.

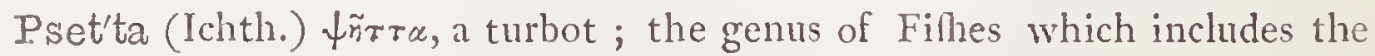

'Turbot and Brill. 
Pset'tus (Ichth.) $\psi \tilde{n} \tau \tau \alpha$, a turbot; a genus of chatodont (briftle.toothed) Fifhes.

Pseudec'henëis (Ichth.) $\downarrow \varepsilon v \delta n^{\prime}$, falfe, Exzevnis, the filh remora; a genus of Siluroid Fighes.

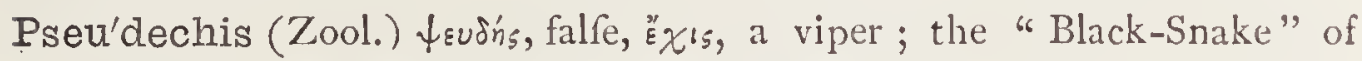
Autralia ; a genus of Colubrine ophidians.

Pseudína (Ent.) $\downarrow \varepsilon u \delta n_{s}$, falfe; a grenus of Lepidoptera.

Pseudo (Zool., Bot.) łevińs, falfe; a prefix ufed to imply fome light refemblance, or imperfect analogy.

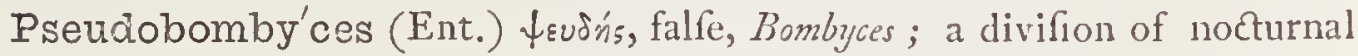
Lepidoptera.

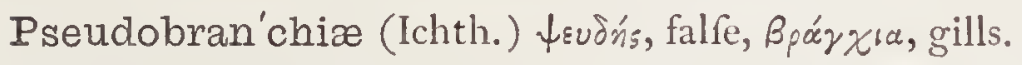

Pseudocer'vus (Zool.) ఫevớns, falfe, cervus, a ftag.

Pseudocordy'lus (Zool.) the falfe Cordylus; a genus of African Lizards.

Pseudo-deltoi'dæ (Ent.) $\downarrow \varepsilon u \delta \tilde{n}_{s}$, falfe, $\delta^{\prime} \lambda \tau \tau_{05}$, a writing tablet; which refembled the letter Delta $(\Delta)$, in confequence of the moths fitting at reft with wings folded fomewhat in that fhape.

Pseudola'rix (Bot.) భevón's, falfe, larix, the larch ; the Chinefe Larch.

Pseudoli'va (Zool.) łevońs, falfe, oliva, a kind of thell; a genus of Mollufca.

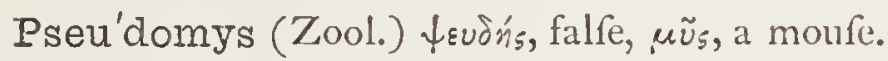

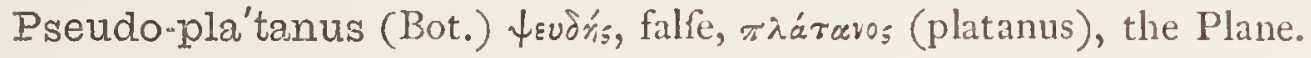

Pseudo'psis (Ent.) $\psi \leqslant v \delta \delta^{\prime}$, falfe, ö $\psi_{15}$, appearance.

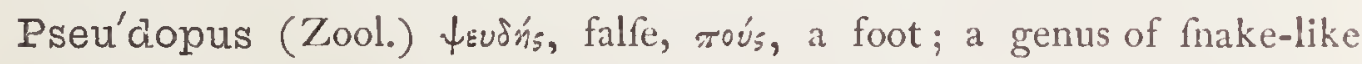

Lizards.

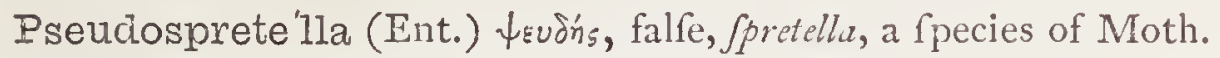

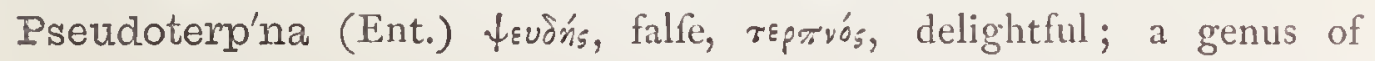
Lepidoptera.

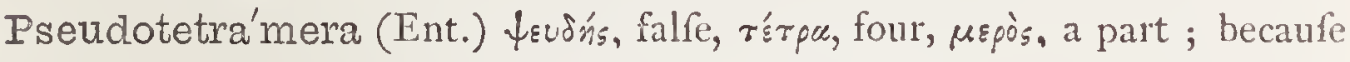

having really five, though apparently only four, joints of the tarfus ; a divifion of Coleoptera.

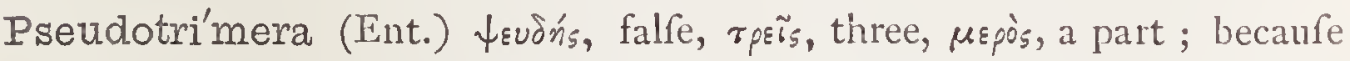
thefe beetles have really four, though apparently only three, joints of the tarfus ; a divifion of Coleoptera.

Psi (Ent.) from the Greek letter $\psi$, with which it is marked.

Psi'dium (Bot.) 恬 a $_{5}$, the Greek name of the Pomegranate; now applied to the Guava.

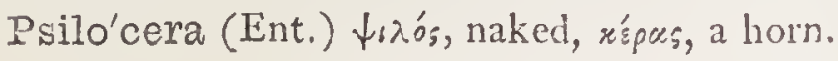




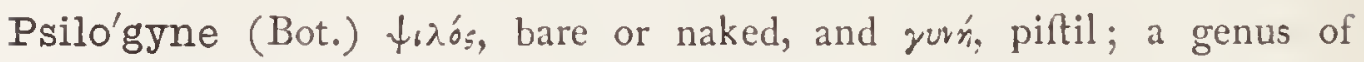
Verbenacex.

Psilone'ma (Bot.) భьлós, bare or naked, and $\nu \tilde{n} \mu a$, filament; a genus of Cruciferæ.

Psilo'nia (Bot.) $\psi_{i \lambda o s}$, bare or naked; a genus of Fungi.

Psilono'tus (Ent.) $\psi_{1} \lambda_{o s}$, bare, rãros, the back; from their appearance.

Psilopi'lum (Bot.) $\psi_{6} \lambda_{0}^{\prime}$ s, naked, $\pi \tilde{i} \lambda_{0}$, wool; a genus of Bryoid Mufci.

Psilorhyn'chus (Ornith.) $\psi_{6 \lambda} e_{s}$, thin, juyxos, a beak or fnout.

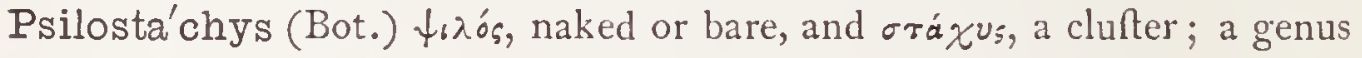
of Euphorbiacea.

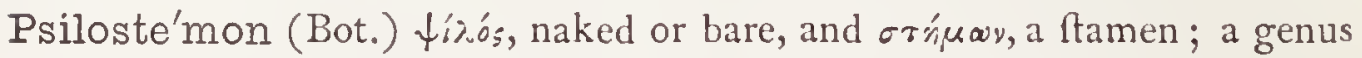
of Boraginacex.

Psilos'toma (Bot.) $\psi_{6} \lambda^{\prime} o_{s}$, naked or bare, and $\sigma \tau{ }^{\prime} \mu \alpha$, orifice; a genus of Cinchonacer.

Psilosty'lis (Bot.) $\psi_{6} \lambda_{o}{ }_{5}$, naked or bare, $\sigma \tau \tilde{u} \lambda_{0}$, a pillar (ftyle); a genus of Crucifer'a.

Psilosty'lum (Bot.) fame derivation; a genus of Cruciferæ.

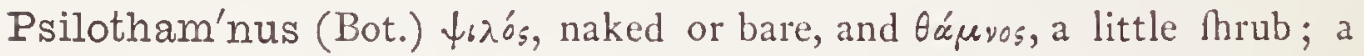
genus of Compolita.

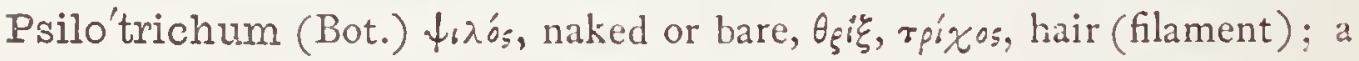
genus of Amarantacex.

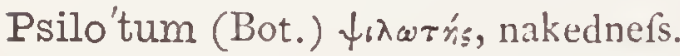

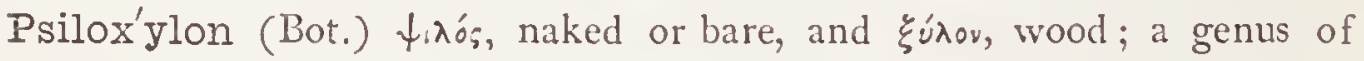
Scrophulariaceæ.

Psilu'rus (Bot.) $\psi_{0} \lambda_{0_{5}}$, naked or bare, and oúpo, a tail; a genus of Gramina.

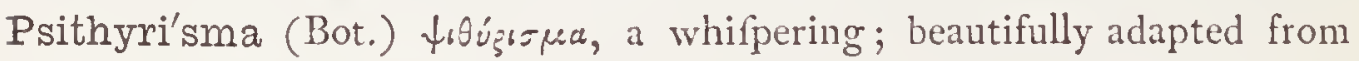
the celebrated line of Theocritus :-

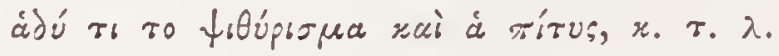

(Sweet is the whifper of the wind among the fir-trees!)

Psittaca'ta (Ent.) psittacus, a parrot, from a refemblance in colour.

Psitta'cidæ (Ornith., Zool.) the Parrot family, of which Pfittacus is the type. Psittacoglos'sum (Bot.) 屯irraros, a parrot, and $y^{\lambda} \tilde{\omega} \sigma s a$, a tongue, from the form of labellum; a grenus of Orchidacea.

Psitta'cula (Ornith.) dim. of pfittacus, a parrot.

Psit'tacus (Ornith.) 廿ír «ros, a parrot; a genus of scanforial Birds.

Psittiro'stra (Ornith.) pjattacus, a parrot, rof rum, a beak.

Pso'cus (Ent.) Wwiw, to rub or grind, becaufe the infect is fuppofed to make a llight noife like the ticking of a clock; the Book-loure ; a genus of Neuroptera. 
Pso'dos (Ent.) భódos, equivalent to $\sigma \pi o_{\delta} \sigma_{0 s}$, alh-coloured.

Psoli'nus (Zool.) భónos, fmoke; a genus of Echinodermata.

Pso'lus (Zool.) łóros, foot, fmoke; a genus of Echinodermata.

Psoph'ia (Ornith.) łópos, a Thrill found; applied to the genus of Cranes which contains the Trumpeter.

Psophocar'pus (Bot.) łópos, founding, raptós, fruit; a genus of Leguminofx.

Pso'ra (Bot.) భwós, warty, rough; a genus of Bryoid Mufci.

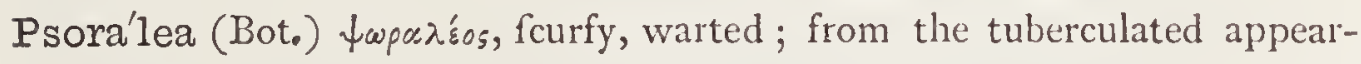
ance of calyx; the Wart-vetch; a genus of Leguminofx.

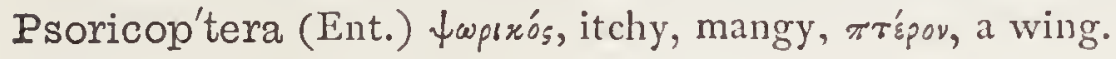

Psorophy'tum (Bot.) łwós, warty, Quróv, a plant; a genus of Hypericaceæ.

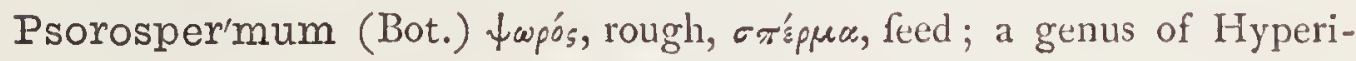
cacex.

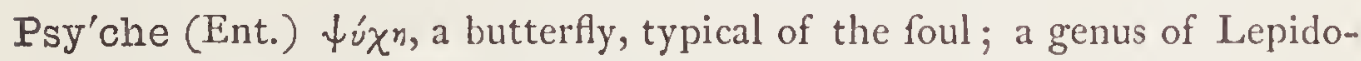
ptera; alfo, a genus of Mollufca.

Psy'chidæ (Ent.) a family of Moths, of which Pfyche is the type.

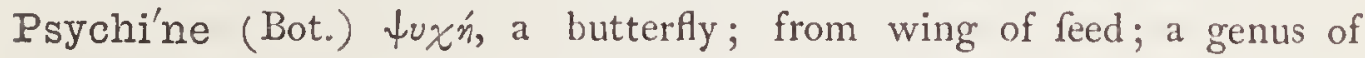

Cinchonaceæ.

Psychoi'des (Ent.) refembling Psyche (E⿱丷idos, likenefs).

Psycho'tria (Bot.) łuxń, life, iarpsice, healing; from its medicinal qualities; a genus of Cinchonacex.

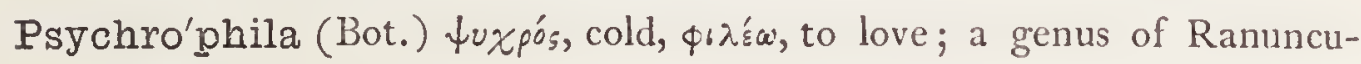
laceæ.

Psy'drax (Bot.) $\downarrow$ vóp $\alpha_{\xi}$, a blifter or pimple; a genus of Cinchonacex.

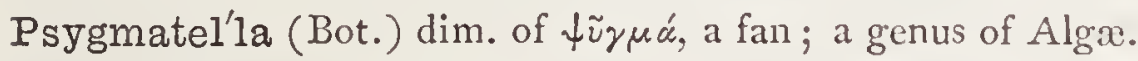

Psyg'mium (Bot.) $\psi \tilde{u} \gamma \mu \omega$, a fan; a genus of Polypodioid Filices.

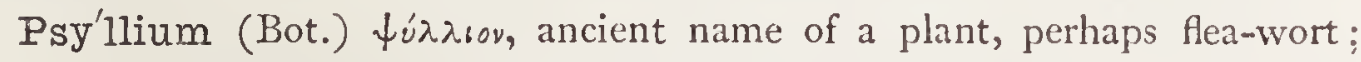

fpecific name of the Flea-plantain, Plantago PJyllium.

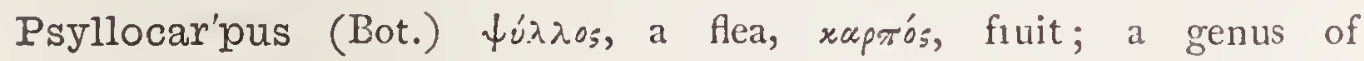

Cinchonacex.

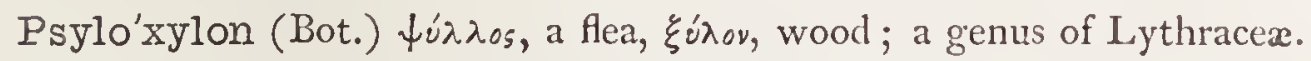

Ptar'mica (Bot.) тrapurrós, that caufes fneezing; fpecific name of a fpecies of Aclillea.

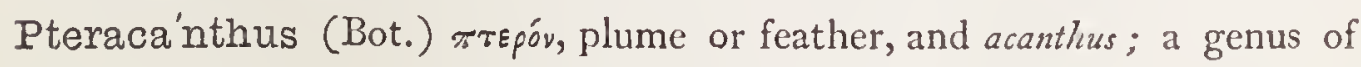
Acanthaceæ.

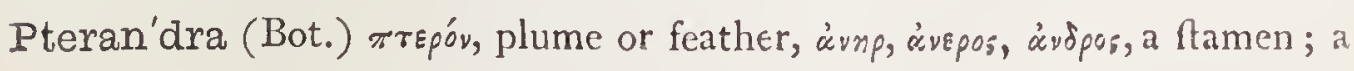
genus of Malpighiaceæ. 


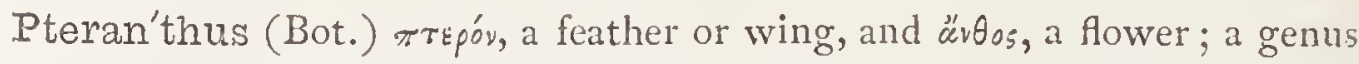
of Illecebracea.

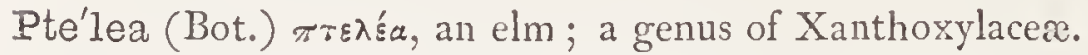

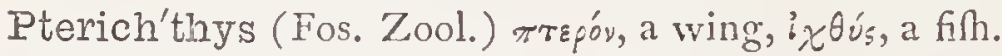

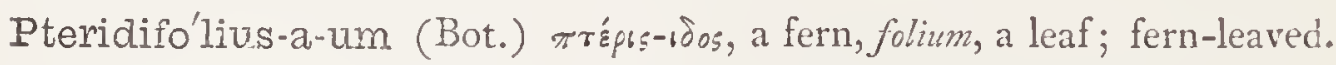

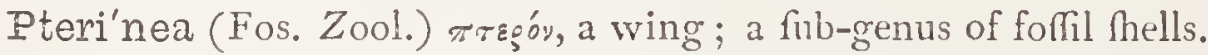

Pte'ris (Bot.) $\pi \tau \varepsilon \varepsilon_{\tilde{r}}$, a fern; the Brake; a genus of Filices.

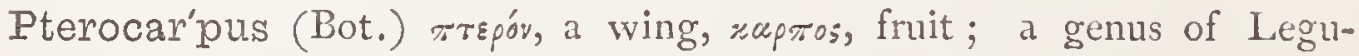
minofæ.

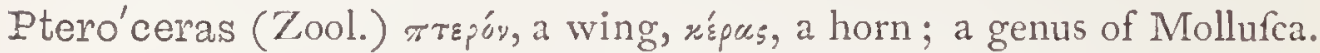

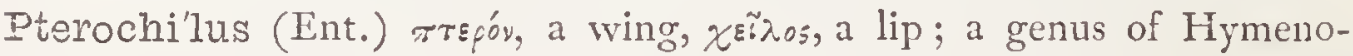
ptera.

Pte'rocles $\}$ (Ornith.) $\{\pi \tau$ sór, a wing, $x \lambda \varepsilon i s$, a hook, from the two or Ptero'clidas $\}$ (Ornith.) $\{$ three long tail feathers; the Sand Groufe.

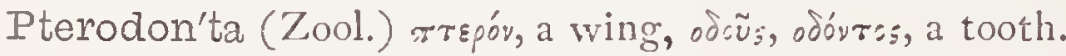

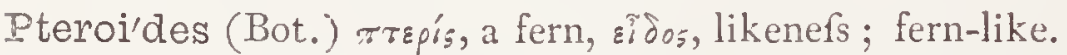

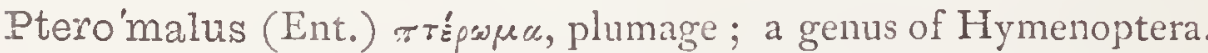

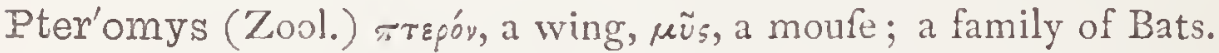

Ptero'nia (Bot.) rrepóv, a wing; from the feathery fcales of the receptacle. Ptero'phanes (Ornith.) rrepóv, a wing, Quíva, to hine; a genus of Humming-birds.

Pterophori'na (Ent.) a family of Plume-moths, of which Pterophoris is the type.

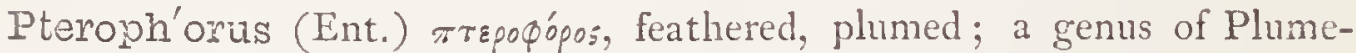
moths.

Ptero'poda (Zoo!.) rrepón, a wing, roús, rocós, a foot.

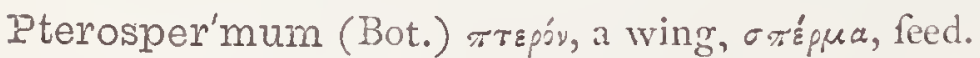

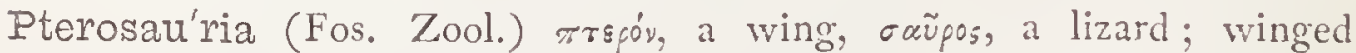
Saurians.

Ptero'stichus (Ent.) rtepor, a wing, crixos, a row or line.

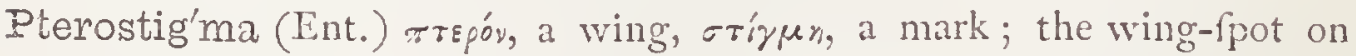
infects.

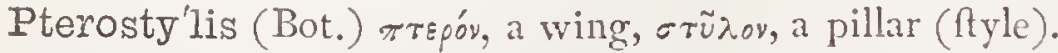

Pterothe'ca (Zool.) rrapóv, a wing, 6ńxn, a fheath.

Pter'uthrus (Ornith.) rréóy, a wing, épuopós, red. "To be confiftent with etymology, it thould be written Ptererythrus, but fhould it be thought that this is taking too great a liberty with the original name, we may, at leaft, venture to write it Pterythrius."--STRICKLAND.

Pterygo'dium (Bot.) тrepuýdon, wing-like; i.e. the fepals. 


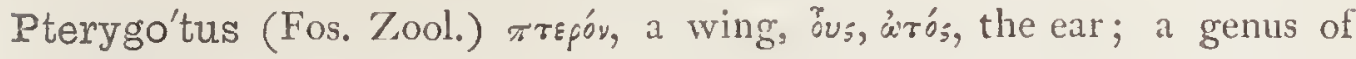
foffil Cruftaceans.

Ptilodic'tyon (Fos. Zool.) жrírov, a feather, dirtuov, a net; a genus of Silurian Polyzoans.

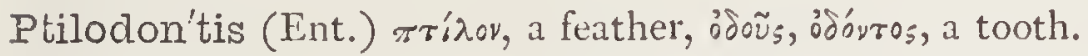

Ptilo'phora (Ent.) $\pi \tau i \dot{\lambda} s v$, a feather, pop'sos, to carry; alluding to the antennæ.

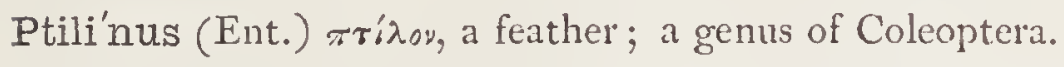

$\left.\begin{array}{l}\text { Pti'nidæ } \\ \text { Pti'nus }\end{array}\right\}$ (Ent.) unexplained; a family and genus of Coleoptera.

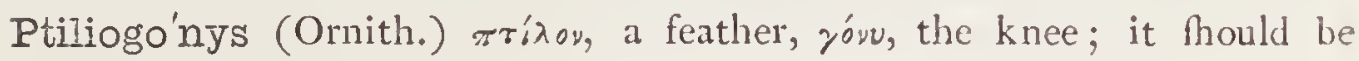
written Ptilogonys.

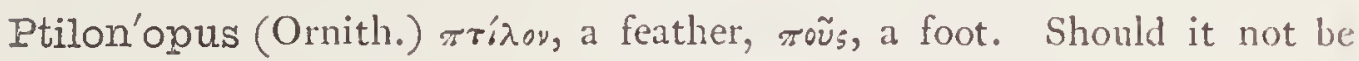
Ptilopus?

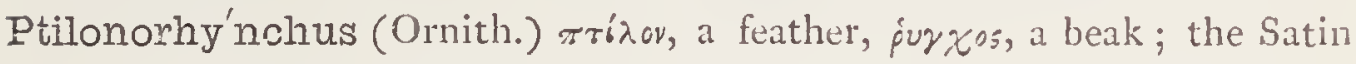
Bower-bird of Auftralia.

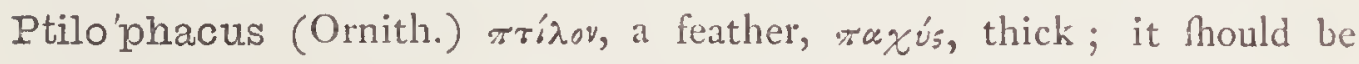
Pilopachys.

Ptilo'ta (Bot.) $\pi$ rínón, a feather ; a genus of marine Alga.

Ptoma'phagus (Ent.) rrĩuc, that which is fallen or killed, púgw, to eat.

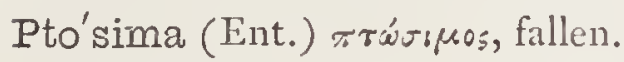

$\left.\begin{array}{l}\text { Ptycho'ceras } \\ \text { Ptychoce'ratite }\end{array}\right\}$ (Fos. Zool.) $\left\{\begin{array}{c}\pi \tau \chi^{\prime} \text {, a fold, x'spar, a horn; a genus } \\ \text { of foffil Shells. }\end{array}\right.$

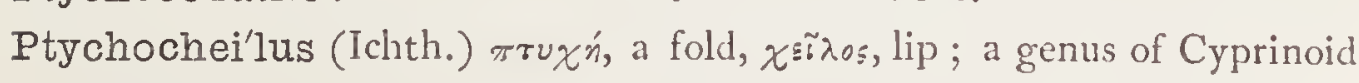
Filhes.

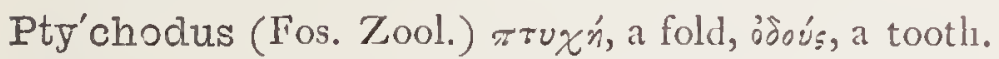

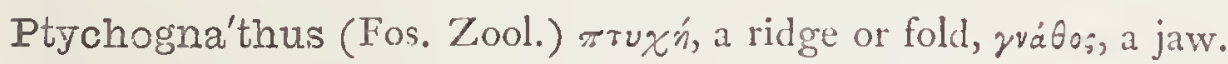

Ptycho'lepis (Fos. Zool.) $\pi \tau u x^{\prime}$, a fold or wrinkle, $\lambda \varepsilon \pi^{\prime} i_{3}$, a fcale; a genus of Sauroid Fifbes.

Ptycholo'ma (Ent.) $\pi \tau \dot{u} \xi, \pi \tau \chi^{\circ} \sigma_{5}$ a fold, $\lambda \tilde{a} \mu c_{*}$, the edge; the edge of the wing folding over.

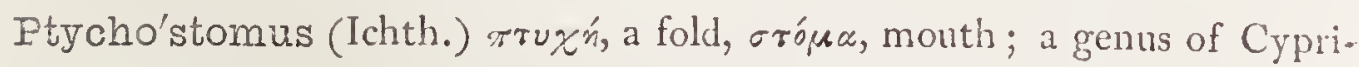
noid Filhes.

Ptychozo'on (Zool.) жruxń, a fold, '̌wov, an animal; a genus of Geckos.

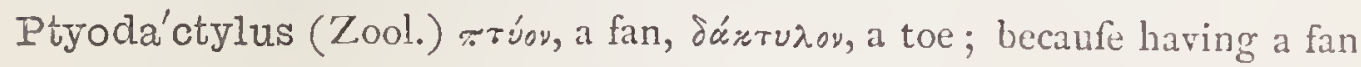
foot; a genus of thick-tongued Lizards.

Pu'berum (Bot.) puber, downy.

Pube'scens (Bot.) pubefco, to grow hairy.

Pubicornel'la (Ent.) pubes, hair, down, cornu, a horn, from its antennx. 
Pudibun'da (Ent.) pudibundiss, modert.

Pudori'na (Ent.) pudor, modefty; from the bluh-like colour of wings.

Puffinus (Ornith.) P. brevicaudus is the "Mutton bird" of Bafs's Straits. Pu'gio (Zool.) Lat. a digger; e.g. Unio pugio.

Pug'nax (Zool.) pugnax, quarrelfome; e.g. Machetes pugnax, the Ruff.

Pulchella'ta (Ent.) pulcher, beautiful.

Pulchel'lus-a-um (Zool., Bot.) Lat. beautiful, little; e. g. Clarkia pulchella.

Pulcherimel'la (Ent.) pulcherrimus, very pretty.

Pule'gium (Bot.) Lat. pennyroyal; Penny-royal or Mentha Pulegium.

Pu'lex (Ent.) pulex, a fiea; a genus of Aphaniptera.

Puli'cidæ (Zool., Ent.) the family of which Pulex is the typical genus; the Flea family.

Pullel'la (Ent.) pullus, dark-coloured.

Pul'lus-a-um (Bot.) Lat. duky, dark-coloured; fpecific name of a fpecies of Carex.

Pul'mo (Zool.) Lat. a lung; plural pulmones, lungs.

Pulmona'ria (Bot.) pulmo, the lung; from its former ufe in pulmonary complaints; a genus of Boraginaceæ.

Pulmona'ria (Bot.) pulmo, the lung; Lung-wort; a genus of Boraginaceæ. Pulmoni'fera (Zcol.) pulmo, a lung, fero, to bear.

Pulpa

Pulpa'ceus-a-um $\}$ (Bot.) pulpa, flefh.

Pulpo'sus-a-um (Bot) Lat. pulpy, Alefhy.

Pultenæ'a (Bot.) P. N. in honour of Dr. Pulteney, who wrote a Life of Linnæus: a genus of Leguminof $x$.

Pulvera'ceus-a-um (Bot.) pulvis, duft.

Pulverosel'la (Ent.) pulverofus, covered with dult.

Pulverulen'tus-a-um (Bot.) Lat. covered with duft, dufty.

Pumila'ta (Ent.) pumilus, dwarfilh.

Pu'milus-a-um (Zool., Bot.) Lat. dwarfih ; e.g. Agroltis pumila.

Puncta'ria (Ent.) punctum, a dot.

Puncticosta'na (Ent.) punctum, a fpot, cofta, the front margin of the wings. Punctidac'tylus (Ent.) prnctum, a dot, dactylus, a finger; from refemblance. Punctifor'mis (Bot.) punctum, a point, formis, thape; pointed.

Punctula'ria (Ent.) punctulum, a little dot.

Punctula'tus-a-um (Zool.) Lat. dotted, pointed.

Puncturel'1a (Zool.) punctim, a fmall hole.

Pungi'tius (Ichth.) pungo, to prick or Iting; fpecific name of the tenfpined ftickleback, Gafterofcus pungitius. 
'Pu'nica (Bot.) Punicus, Carthaginian, becaufe brought from Africa; the Pomegranate-tree; a genus of Myrtacex.

Punicea'lis (Ent.) puniceus, red, purple.

Puni'ceus-a-um (Bot.) Lat. carmine-1ed; e.g. Clianthus punicets.

Puntaz'zo (Ornith.) Ital. puntazzo, a promontory.

Pu'pa (Zool.) pupa, a doll; applied to chryfalides, from a refemblance to a fwathed child or mummy.

Pupilla'na (Ent.) pupilla, the pupil of the eye; from its wing-fpots.

Pupína (Zool.) pupa, a doll.

Pur'pura (Zool.) roppupa, Lat.purpura, the Purple.filh (mollukk); a genus of Mollufca.

\section{Purpura'lis}

Purpura'na

Purpuras'cens (Bot.) dim. part, from purpura; becoming purple.

Purpurel'la (Ent.) purpureus, purple.

Purpu'reo-cceru'leus (Bot.) Lat. violet-coloured; $\iota_{. g}$., Lithofpermum purpureo-cceruleum.

Pusa'ria (Ent.) pufa, a little maiden.

Puschki'nia (Bot.) P. N. in honour of the celebrated Polith botanif; a genus of Liliacex.

$\left.\begin{array}{l}\text { Pusici'la } \\ \text { Pusilla'ta }\end{array}\right\}$ (Ent.) pufillus, fmall, puny.

Pusil'lus-a-um (Zool., Bot.) Lat. fmall, puny; e.g. Geranium pufllum.

Pustula'tus-a-um (Bot.) Lat. bliftered.

Pustulo'pora (Fos. Zool.) having the pores placed on pufules.

Pu'ta (Ent.) from putus, clear, diftind.

Puto'rius (Zool.) putor, a ftench; fpecific name of the Foumart, Murtela putorius.

Pu'tris (Bot.) puter, rotten; from a refemblance to rotten wood.

Pycnan'themum (Bot.) rv*vós, thick, ảvesris, chamomile (?); a genus of Labiatie.

$\left.\begin{array}{l}\text { Pycnodon'tidae } \\ \text { Pyc'nodonts }\end{array}\right\}$ (Fos. Zcol.) $\left\{\begin{array}{c}\text { Türós, thick, ojoús, oodoryos, a tooth; a } \\ \text { family of folfil Filhes. }\end{array}\right.$ Pycnogon'idæe (Zool.) тuxiós, thick, yovo, knee; the fea-fpiders; an order of Cruftacex.

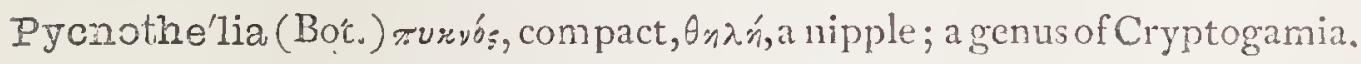
Pygæe'ridæ (Ent.) muyn, the rump, apesv, to raife; from the attitude of the infects. 
Pyge'rythrus-a-um (Zool.) тvgn, the rump, éputpós, red.

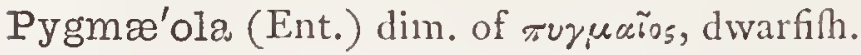

Pygmea'na)

Pygmea'ta $\}$ (Ent.) тugucios, pigmy, dwarfilh.

Pygobran'chia (Zool.) equivalent to Anthro-branchiata of Adanfon; a group of Nudibranchiate Mollufca.

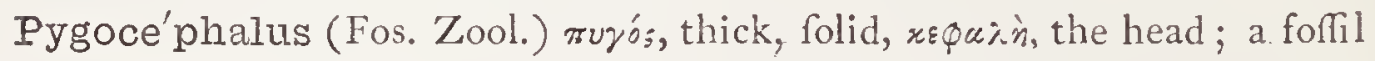
Cruftacean.

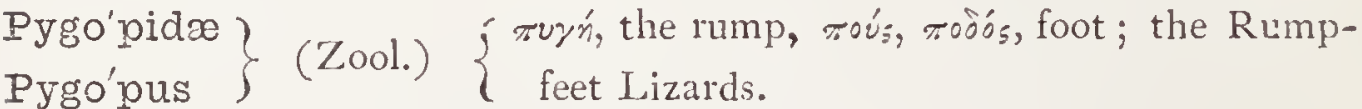

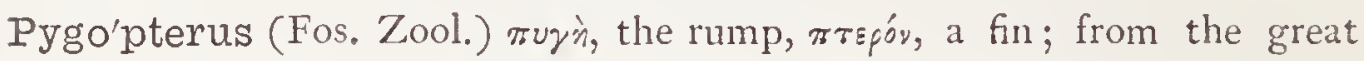
development of caudal fins; a genus of folfil Filhes.

Pylog'nathus (Ichth.) rírn, a gate, yućtos, the jaw.

Pyralia'ta (Ent.) pyralis, an infeet formerly fuppofed to live in the fire; having flame-coloured wings.

Pyraloi'didæ (Ent.) Pyralides, a family of Moths, eidos, refemblance.

Pyramida lis-e (Bot.) pyramid-fhaped, conical; e.g. Orchis pyramidalis.

Pyramide'a (Ent.) muparis, a pyramid, عioos, likenefs; alfo a genus of Mollufca.

Pyramidel'la ) (a diminutive to exprefs the fpiral, turretPyramidel'lidæ) (Zool.) $\left\{\begin{array}{l}\text { ed, and pyramid thape of the thell; a } \\ \text { (a) }\end{array}\right.$ Pyra'nga (Ornith.) mĩ , fire; a genus of Tanagers, confilting chiefly of fcarlet-coloured birds.

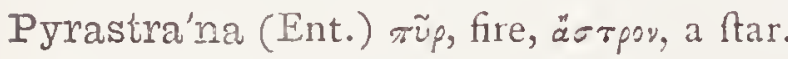

Pyraus'ta (Ent.) pyraufi, a name expreffive of a love for hot fun-fhine; from $\pi \tilde{\imath} \rho$, fire.

Pyra'zus (Zool.) rupá̧̧ Pyrel'la (Ent.) feeding on the pear, Pyrus.

Pyrena'icus-a-um (Bot.) Lat. Pyrenean, e.g. Valeriana Pyrenaica.

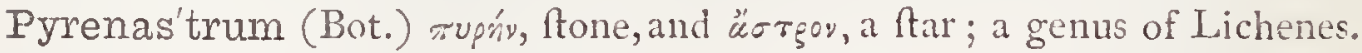
Pyre'nium (Bot.) тupŕv, a ftone; a genus of Fungi.

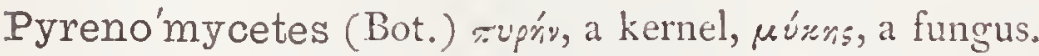

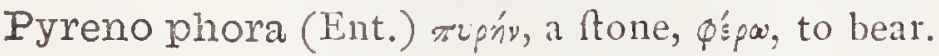

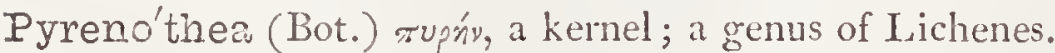

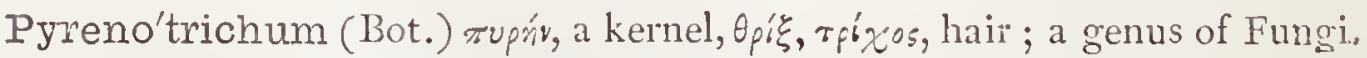
Pyre'nula (Bot.) dim. of rupŕv, a ftone; a genus of Lichenes.

Pyre'thrum (Bot.) ríg日por, an ancient Greek name of a plant, fo called from its hot tafte; Pellitory: a genus of Compofitre. 
Pyrgitz (Onith.) mupgirn; was applied by Gulen to the houfe-fparrow, from rúpros, a towel.

Pyrgo'ma (Zool.) mípyouce, that which is furnifhed with towers; a genus of Cirripedes.

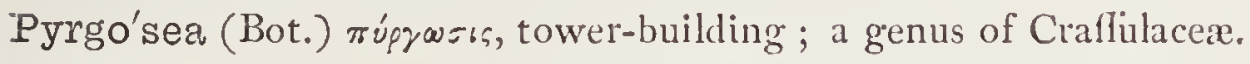

Pyirgula (Zool.) rúpros, a tower, the fhell being turreted; a genus of Molluf́ca.

Pyr'gus (Bot.) rúgros, a tower; a genus of Myrfinacea.

Py'riform (Bot.) pyrus, a pear, forma, thape ; pear-lhaped.

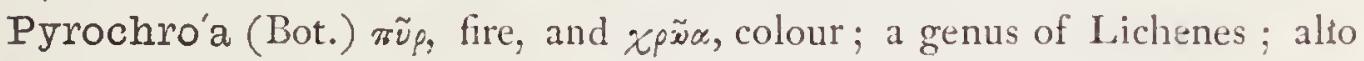
ufed in Entomology.

Pyro'des (Ent.) rupúdns, fiery.

Py'rola (Bot.) dim. of Pyrus, pear-tree, having fimilar leaves; WinterGreen; the typical genus of Pyrolacex.

Pyroli'rion (Bot.) "Fire-lily" ( $\pi \tilde{u}$ and $\lambda$ sipro:), from colour of flowers; a genus of Amaryllidacex.

Pyro'palis (Ent.) $\pi \tilde{u} \rho$, fire, $\dot{\omega} \psi$, the eye

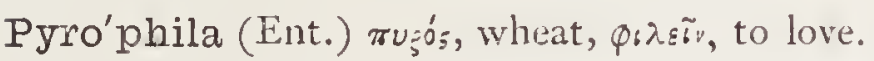

Pyro'phorum (But.) pyrus, a pear, $\phi^{\prime}$, s $\omega$, to bear; a genus of Pomacex.

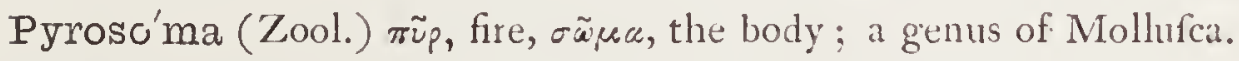

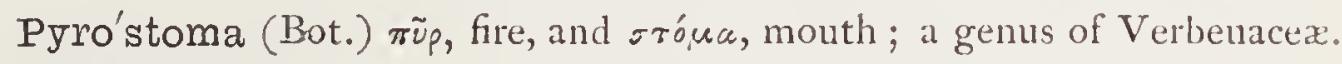

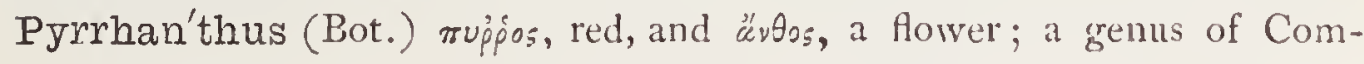
bretacex.

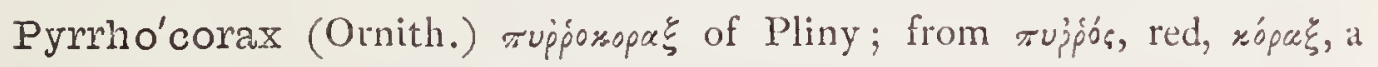
crow; the feet and beak being flame-coloured.

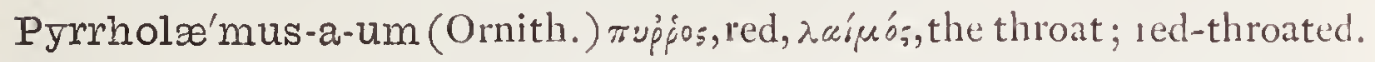
Pyrrhopap'pus (Bot.) rup’pos, red, and $\pi x_{\pi}$;os, feed-down; a genus of Compolitx.

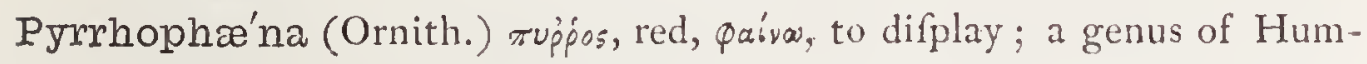
mingabirds.

Pyrrho'sia (Bot.) สuṕpos, red; a genus of Polypodioid Filices.

Pyrrhotho'rax (Ornith.) ruppos, red, thorax, the breaft.

Pyrrhotri'chia (Bot.) rupópos, red, and $\theta p i \xi$, rp'́xos, hairy furface; a genus of Leguminofie.

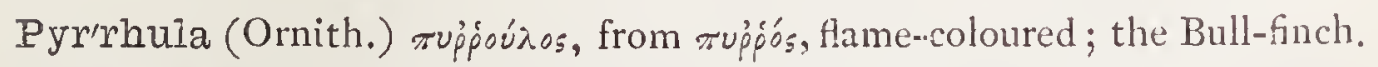

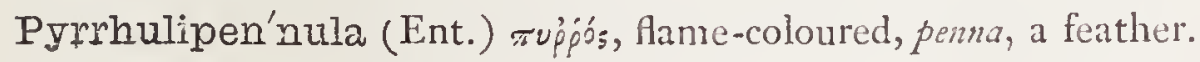

Pyrrócoma (Bot.) tuppos, red, xóun, tuft; a genus of Compofitie.

Py'rula (Zool) pyrus, a pear, from the thape of the thell; a genus of Mollufca. 
Pyrula'ria (Bot.) pyrus, a pear (Thape of fruit); a genus of Santalaceæ.

Py'rus (Bot.) Lat. a pea:-tree, perhaps from Peren, Celtic; the Apple and Pear ; Nat. Ord. Pomiferæ.

Pythagore'a (Bot.) P.N. in honour of the celebrated ancient philofopher; a genus of Lythracex

Py'thion (Bot.) $\pi \theta^{\prime} \theta_{\text {iav }}$, an ancient Greek name for a bulbous plant; a genus of Aracew.

Py'thon (Zool.) P. N., a mythological name; a genus of Ophidians.

Pytho'nium (Bot.) жúbw, to rot; a genus of Aracex.

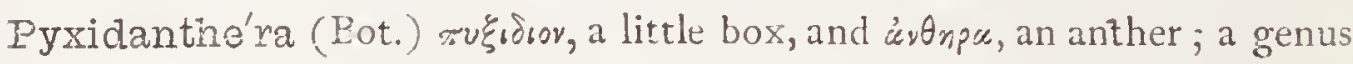
of Diapenfiacei.

Pyxida'tus-a-um (Bot.) $\pi v \xi \xi_{s}$, a box; jointed; e.g. Scyphophorus pyxidatus. Pyxidic'ulum (Fos. Bot.) Lat. a fmall box.

Pyxi dium (Bot.) $\pi u_{5}^{5}$ s, a box, eisos, likeners; a capfule fuch as that of the Anagallis.

Quad'racus (Ichth.) quatuor, four, acus, a gar-pike.

Quadra'ta (Ent.) Lat. four-cornered.

Quadre'lla (Bot.) quatuor, four; a genus of Capparidaceæ.

Quad'ria (Bot.) P. N. in honour of Antoine de la Quadra, a Spanifh cultirator;

a genus of Proteacer.

Quadri'fidæ (Ent.) quadrifidus, cleft into four parts.

Quadrimacula'lis (Ent.) quatuor, four, maculu, a fpot.

Quadrinota'tus (Ent.) quatuor, four, notatus, diftinguifhed; in allufion to the male fex having four of the joints of the anterior tarfi diftinctly dilated. Quadripuncta'lis (Ent.) quatuor, four, punctum, a fpot or dot. Quadripuncta'tus-a-um (Ent.) quatuor, four, purctatus, fpotted.

Quadriscrip'tus (Zool.) quatuor, four, foriptus, marked; applied to a

Paradoxurus having four black ftripes along the back.

Quadristigma'lis (Ent.) quatuor, four, figma, a mark.

Quadrival'vis (Zool., Bot.) quatuor, four, valwa, valve or fold.

Quadrivitta'tus (Zool.) quatuor, four, vitta, a chaplet; having four longitudinal grey bands.

Quadru'mana (Zcol.) quatuor, four, manus, a hand; a divifion of Mammalia. Quadru'peda (Zool.) quatuor, four, pes, a foot; a general term for four. footed mammals.

Qua'ring-grass (Bot.) popular name of Briza.

Qua'lea (Bot.) uncertain; a genus of Vochyacex. 
Qua'moclit (Bot.) native Indian name fignifying " dwarf bean;" a genus of Convolvulacex.

Quapo'ya (Bot.) native name; a genus of Clusiace:e

Quarti'nia (Bot.) P. N.; a genus of Lythraceæ.

Quas'sia (Bot.) P. N. in honour of Quafy, a negro flave of Surinam who

firft ufed it medicinally; a genus of Simarubacex.

Quel'tia (Bot.) P. N. in honour of Nicholas Le Quelt.

Quer'citron (Bot.) quercus, the oak, citron ; equivalent to "oak-citron;" a

fpecies of oak.

Quer'cus (Bot.) Irat. an oak; a celebrated genus of Corylacex.

Que'ria (Bot.) P. N. in honour of Don J. Duer y Martines, a Spanifh furgeon.

Querque'dula (Ornith.) Lat. a kind of duck, a teal.

Quille'sia (Bot.) P. N. ; a genus of Olacaceæ.

Quina'ria (Bot.) quinarius, containing five; a genus of Aurantiacex.

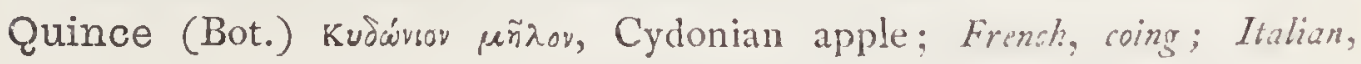
cotogna; the fruit of Cydonia vulgaris.

Quine'tia (Bot.) P. N.; a genus of Afteracere.

Quinque-carina'tus (Ichth.) quinque, five, carinatis, keel-lhaped; applied to a Cray-filh, Aftacoides quinque-carinatis.

Quinquecirra'ta (Ichth.) quinque, five, cirrus, a curl.

Quinque'fidus-a-um (Bot.) quinque, five, findo, to flit.

Quinquefo'lius-a-um (Bot) quinque, five, folium, a leaf: quinquefolium.

Quinti'llia (Bot.) P. N.; a genus of Gefneracex.

Quintínia (Bot.) P. N.; a genus of Efcalloniacea.

Quis'calus (Ornith.) etymology uncertain; the Grakle: a genus of Birds called boat-tails.

Quisqua'lis (Bot.) quis, who, qualis, what kind; from the uncertainty; a beautiful Indian genus of Combretacex.

Quivi'sia (Bot.) from Bois de Quivi, name in the lile of France.

Raca'ria (Bot.) uncertain; a genus of Sapindacex.

Ira'ceme (Bot.) racemus, a bunch of grapes; an inflorefcence like that of the currant.

Pacemo'sus-a-um (Bot.) e.g. Paffiflora racemofa.

Rachi'cerus (Ent.) ṕúxis, a ridge, répos, a horn (antennæ); a genus of Diptera. 
Rachiodon'tidæe (Zool.) fáx's, a ridge, odoús, odovrós, a tooth; the fpinetoothed Serpents; a family of Colubrine ophidians.

Ra'chis (Zool., Bot.) $\dot{\rho} \dot{\alpha}_{\chi}$ s $^{\prime}$, the back-bone or ridge; in botany the main ftalk of a fern-leaf or rather frond.

Racli'tia ('Zool.) derivation unknown; a genus of Ophidians.

Raco'dium (Bot.) pános, a torn garment; from the appearance of the plants.

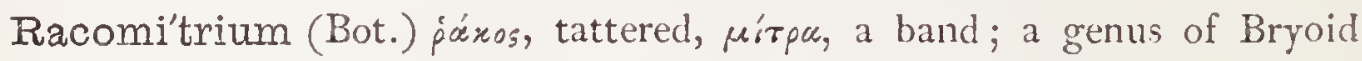
Musci.

Racoon' (Zool.) common (native) name of Procyon lotor,

Racopillum (Bot.) paros, tattered, тĩnos, a cap; a genus of Bryoid Mufci.

Racou'bia (Bot.) P. N. a genus of Homaliaceæ.

Radamæ'a (Bot.) P. N., named after Radama, Queen of Madagafcar; a genus of Scrophulariacex.

Rad'dia (Bot.) P. N.; a genus of Gramina.

Raddi'sia (Bot.) P. N.; a genus of Hippocrataceæ.

Radema'chia (Bot.) P. N. ; a genus of Artocarpacex.

Ra'dia (Bot.) júd́sos, eafy of accefs; a genus of Hxmodoracex.

Radia'ria (Zool.) the Rayed animals, properly so called.

Radia'ta (Zool.) radius, the fpoke of a wheel; having the organs of fenfe and motion difpofed circularly around a centre or axis

Ra'dicle Bot.) radiculum, a little root; the rudimentary root in the embryo.

Radi'cula (Bot.) dim. of radix, a root; a genus of Cruciferæ.

Radi'ola (Bot.) radiolus, a little ray; from the radiated capfule; a genus of Linacer.

Radioli'tes (Fos. Zool.) so called from "the radiated ftructure of the outer layer of their opercular-looking upper valves;" a genus of Cretaceous bivalves.

Rad'ish (Bot.) Latin, radix.

Radiu'sia (Bot.) a genus of Leguminofre.

Rad'ula (Bot.) Lat. a fcraper'; a genus of Jungermanniacex.

Radulo'typus (Bot.) the genus Radula, typus, an image; a genus of Jungermanniacere.

$\left.\begin{array}{l}\text { Raffle'sia } \\ \text { Rafflesia'ceæ }\end{array}\right\}$ (Bot.) in compliment to Sir Thomas Stamford Raffles.

Rafine'squia (Bot.) P. N. in honour of the celebrated Rafmefque; a genus of Compofitis. 
Raf"nia (Bot.) P. N. in honour of $C$. G. Rafn, of Copenhagen, a writer on botany; a genus of Leguminofie.

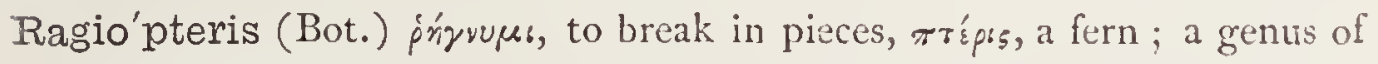
Polypodioid Filices.

Rag'wort (Bot.) common name of Senecio Jacobæa.

Ra'ia (Ichth.) Lat. a ray or kate.

Rai'idæ (Ichth.) the family of the Rays.

Raja'nia (Bot.) P. N. in honour of Joln Ray, a difinguithed Englifh naturalift.

Ralei'ghia (Bot.) P. N.; a genus of Cunoniacex.

Ralf'sia (Bot.) P. N. in honour of Fohn Ralfs, of Penzance; a genus of Algx.

Pullius (Ornith.) Latinized form of rail, which is formed from the found made by the bird; a genus of Gralla.

Ram (Zool.) Anglo-Sax. and Dutch, ram; German, ramm.

Ramali'na (Bot.) ramale, a withered branch; from its habitat; a genus of Lichenes.

Ramen'ta (Bot.) Lat. chips, havings; applied to the foft chaff-like lairs growing upon the petiole of ferns.

Ramon'da (Bot.) P. N. in honour of M. L. Ramond, a French botanift; a genus of Solanacex.

Ramphas'tidæ)

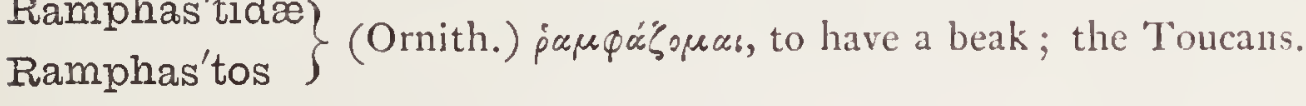

Ram'phia (Ent.) fócupos, a beak.

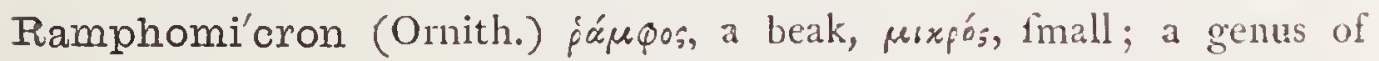
Humming-birds.

Ramphorhyn'chus (Fos. Zool.) pár фos, a beak, f́úy zos, a fnout.

Ram'phus (Ent.) pós фos, a beak.

Ram'sons (Bot.) common name of Allium urfinum; from Anglo-Sax. Hramfa.

Ramilila (Bot.) ram-tilla; an Indian name for the oil procured from the feeds; a genus of Compofitix.

Ramula'ria (Bot.) ramus, a branch; a genus of Algæ.

Ramu'sia (Bot.) a genus of Acanthacere.

Ra'na (Zool.) Lat. a frog; the common frog is Rana temporaria.

Puana'les (Bot.) the great alliance reprefented by the Ranunculacex.

Fanda'lia (Bot.) P. N. ; a genus of Eriocaulacex.

Ran'dia (Bot.) P. N. in honour of 7 . Rand, F.R.S., a London botanift; it genus of Cinchonacex. 
Rane'lla (Zool.) dim. of rana, a frog; the Frog-hhell; a genus of Mollufca. Ran'gifer (Zool.) rang-bearing or ring-bearing; fpecific name of the Reindeer.

Rangiferi'nus-a-um (Bot.) rangifer, the reindeer; reindeer-mofs; e. g. Lichen rangiferinus.

Ranhy'la (Zool.) rana, a flog, and the genus Hyla; the "green-frog" of Auftralia.

Ra'niceps (Ichth.) Lat. frog-headed (rana and caput.)

IRani'vorus-a-um (Zool., Ornith.) rana, a frog, voro, to devour; e. r. Circus ranivoris.

Ranmzuı'ssa (Bot.) P. N.; a genus of Capparidaceæ.

Ran'tus (Ent.) pavtós, fpotted, fpeckled; a genus of Coleoptera.

Ranuncula'cer (Bot.) the Crow-foot family of plants, of which Ranunculus is the type.

Ranunoula'strum (Bot.) literally, the "Star-ranunculus;" a genus of Ranunculacex.

Ranun'culus (Bot.) rana, a frog; it inhabits humid places: Crow-foot ; typical genus of Ranunculacer.

Ra'pa (Bot.) Lat. the turnip plant; a genus of Cruciferix.

Rapa'na (Zool.) rapa, a turnip; a gemus of Mollufca.

Rape (Bot.) rapa, turuip.

Raphanis'trum (Bot.) formed from the genus Raphumus; a genus of Cruciferæ.

Raph'anus (Bot.) ṕaparos, a radilh; probably from $\dot{\rho} \alpha$, quickly, $\phi$ aiva, to appear; from its rapid germination. 'The Radith; Nac. Ord. Crucifera. Raph'ia (Bot.) jaṕn, a feam; a genus of Gramina.

Raphides (Bot.) jap's, a needle; applied to acicular or other cryftals feattered among vegetable tiflie.

Rarhi'dia (Ent.) pasis, a needle; a genus and family of Neuropterat. Raphidi'idæe)

Raphiglos'sa (Ent.) japis, a needle, $\gamma \lambda \hat{i} \tau=x$, a tongue; a genus of Hymenoptera.

Raphigna'thus (Zool.) prapis, a needle, yráscs, the jaw or mouth; a genus of Arachnida.

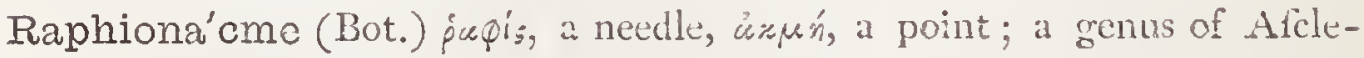
piadacex.

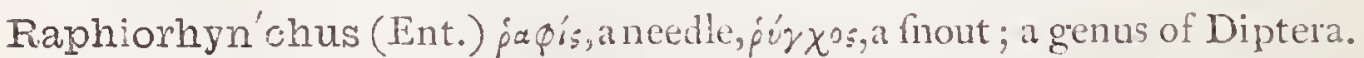

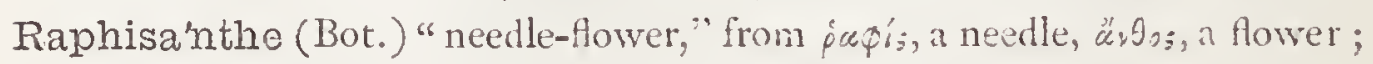
al genus of J onafacer. 
Raphis'toma (Zool.) juфis, a needle, otóma, mouth; a genus of Mollufca. Raphy'rus (Zool.) a genus of Sponges.

Rapicau'dus-a-um (Zool.) rapa, a turnip, cauda, a tail; e. g. Thecadactylus rapicauda, the turnip-tailed Gecko.

Rapi'nia (Bot.) P. N.; a genus of Campanulaceix.

Rapis'trum (Bot.) rapum, a turnip; from its having fimilar leaves; a genus of Cruciferx.

Rapto'res (Onith.) raptor, a feizer or fnatcher; an order of Birds fo called from their habit of feizing and retaining their prey with their powerful talons.

Rapun'culus (Bot.) dim. of Rapa; from refemblance of root; a genus of Campanulacex.

Rapun'tium (Bot.) from Rapa; from refemblance of root; a genus or Campanulace

Raso'res (Ornith.) Lat, "feratchers" or "fcrapers;" an order of Birds which fcrape up the foil with their feet.

Raspailia (Bot.) P. N. in honour of the celebrated French chemift; a genus of Bruniacex.

Rastri'tes (Fos. Zool.) rafer, a rake or hoe; the Silurian Sea-pens, which have tubercular projections along the axis or ftem.

Rat (Zool.) Anglo-Sax. rat; loot of Latin rodo, to gnaw.

Rath'kea (Bot.) P. N.; a genus of Leguminofx.

Ratzebu'rgia (Bot.) P. N. ; a genus of Gramina.

Ratzeburgia'na (Ent.) P. N. in honour of Ratzeburg, the author of

"Forft-Infekten," (I 840) and other works.

Rauwol'fia (Bot.) P. N. in honour of M. Raurvolf, a phyfician of Aligfourg; a genus of Apocynacea.

Rava'lis (Ent.) ravus, greyilh.

Ra'ven (Ornith.) Anglo-Sax. lirefen.

Ravena'la (Bot.) one of Adanfon's names, molt likely without meaning;

a genus of Mufaceæ.

Ra'vidus-a-um (Ent.) Lat. grey, or dark-coloured.

Ray-grass (Bot.) corrupted from the Er. ivraie, which word is in the

French New Teftament employed for tares; the Lolium perenne.

Reaumu'ria (Bot.) P. N. in honour of Reiné A. F. de Reaumur, an Entomologint.

Recc'hia (Bot.) P. N.; a genus of Dilleniaceie.

Reclu'sa (Ent.) Lat. a reclufe.

Reclu'zia (Zool.) P. N. ; a genus of Mollufia. 
Recta'lis (Ent.) rectus, ftraight.

Rectangula'ta (Ent.) rectus, right, angulus, an angle; referring to the fquare fpots on the apical part of the wing.

Rectri'ces (Ornith.) rector, a ruler, governor; applied to the tail-feathers of a bird, acting fomewhat as rudders to guide its flight.

Recurva'lis (Ent.) Lat, recurvus, bent backwards.

$\left.\begin{array}{l}\text { Recurviro'stra } \\ \text { Recurviro'stres }\end{array}\right\}$ (Ornith.) recurvus, bent backwards, roftrum, the bill.

Recur'vus-a-um (Bot.) curved downwards, e.g. Carex recurva.

Redimita'na (Ent.) Lat. redimitus, crowned, wreathed.

Redoute'a (Bot.) P. N. in honour of P. J. Redouté, a celebrated French botanical draughtsman; a genus of Malvacex.

Redow'skia (Bot.) P. N.; a genus of Cruciferæ.

Reducta'lis (Ent.) Lat. reductis, drawn back.

Reaun'cus-a-um (Zool.) Lat. crooked, bent back.

Reed (Bot.) Anglo-Sax. hreod; fcientific name, Arundo.

Reeve'sia (Bot.) P. N. in honour of John Reeves, of Canton; a genus of Sterculiaceæ.

Rega'lis (Zool, Bot, and Ent.) Lat. royal, e.g. Ofmunda regalis.

Regina'lis (Ent.) Lat. regina, a queen.

Regnosau'rus (Fos. Zool.) "royal Saurian," a foffil from the Wealden.

Regu'lecus (Ichth.) rex, king, halecus, herring ; i. e. king of the Herrings; the Deal-fifh.

Re'gulus (Ornith.) Lat. a fmall bird, perhaps a wren; now applied to the genus which contains the wrens.

Reicha'rdi (Bot.) P. N., fpecific name of a Geranium, in honour of $M$.

Reichard, a French gentleman who difcovered it in Minorca.

Reiche'lia (Bot.) P. N. ; a genus of Hydrophyllaceæ.

Reichenba'chia (Bot.) P. N. ; a genus of Nyctaginacex.

Rein-deer (Zool.) this word ought certainly to be Rane-deer; the animal was formerly called fimply the Rane, a word of Danilh origin, anfwering to the Saxon hrana, or hranaf.

Rei'throdon (Zool.) perïpov, a river or ftrean, ödovis, ofórros, tooth.

Rejecta'ria (Ent.) rejectus, part. from rejicio, to throw away.

Rejou'ia (Bot.) P. N.; a genus of Apocynacex.

Relha'nia (Bot.) P. N. in honour of Rev. Richard Relhan, a writer on Botany; a genus of Compolita.

Re'miges (Ornith) romex, romigis, a rower; applied to the quills of a bird's wings, ferving for propulfion. 
Remi'gia ,

Remi'gidæ⿸厂 (Ent.) remigo, to low.

Remi'jia (Bot.) P. N. ; a genus of Cinchonacer.

Re'mipes (Ent.) remus, an oar, pes, foot; oar-footed; a genus of Cruftaceæ.

Remi'rea $\left(\mathrm{Bo}^{+}\right.$.) its native name in ${ }^{\mathrm{*}} \mathrm{Guiana}$; a genus of Cyperacex.

Remo'ra (Ichth.) Lat. a hindrance; applied by Pliny to a filh which the ancients thought could ftop a Mip by adhering to the rudder; the Sucking-finh.

Re/mus (Ent.) Lat. an oar.

Remusa'tia (Bot.) P. N.; a genus of Araceæ.

Remuta'tus-a-um (Ent.) Lat. changed.

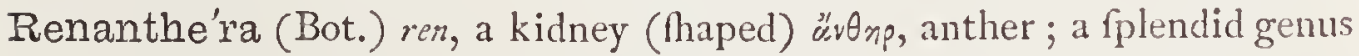
of Orchidacex.

Reneal'mia (Bot.) P. N. in honour of $P$. $\xi M$. L. Renealme, the firnt a French Phyfician, the other a Botanift; a fplendid genus of Scitaminer.

Renegge'ria (Bot.) P. N.; a genus of Clufiacex.

Rengiffa (Bot.) P. N.; a genus of Clufiacex.

Renifor'mis-e (Bot.) Lat kidney-haped; e.g. Oxyria reniformis.

Ren'nett (Bot.) the name of this Apple is from la Reinette, or the Little Queen.

Rensslæ'ria (Bot.) P. N.; a genus of Araceæ.

Repanda'lis (Ent.) repandus, bent backward, turned up.

Repa'ndra (Bot.) repandus, bent back; a genus of Orchidacer.

Repan'dus a-um (Bot.) Lat. fpread out; applied to a fungus, Hydnum

repandum, it refers to the irregular form which the pileus often afliumes.

Peptil'ia (Zool.) repto, to creep or crawl.

Repto'nia (Bot.) P. N.; a genus of Myrfinacex.

Requie'nia (Zool., Bot.) P. N. in honour of $M$. Requien of Avignon, a French botanift; alfo a genus of Molhufca.

Rese'da (Bot.) refedo, to calm, to appeafe; from its medical qualities;

typical genus of Nat. Ord. Refedacex, or Mignonette family.

Reseda'ceæ (Bot.) the Mignonette-family, from the typical Refedit.

Resede'lla (Bot.) dim. of Refeda; a genus of Refedacex.

Rest-harrow (Bot.) common name of Ono'nis.

Restia'cer (Bot.) the family of plants of which Reftio is" the type.

Res'tio (Bot.) Lat. a rope-maker, from its ufe at the Cape of Good Hope;

typical genus of Nat. Ord. Reftiaccie.

Retanil'la (Bot.) its name in Peru; a genus of Rhamnacex. 
Rete'pora ('Zool.) rete, a net, porus, an opening; i. e. a porous net-work; a genus of Polyzoa.

Reticularia (Bot.) reticulum, $\mathrm{a}^{-}$net, fiom its appearance; a genus of Fungi.

Reticula'tus-a-um (Zool., Ent., Bot.) Lat. net-like, reticulated; e.g. Crocus reticulatus.

Reticulospi'ra (Fos. Zool.) reticulum, a little net, Spira, a coil; from the reticulation of the extreme fpines of the whorl.

Retina'ria (Bot.) prrivn, refin, gum; a genus of Rhamnacex.

Reti'nia (Ent.) rete, a net, from the net-like markings of the wings; a genus of Lepicloptera.

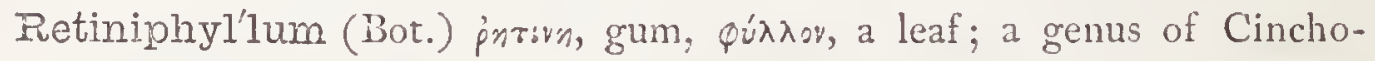
naceæ.

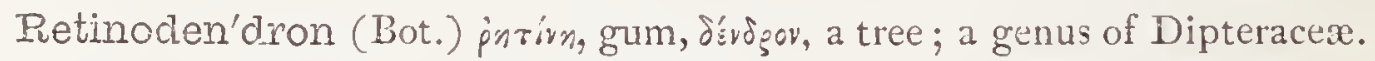
Retinospo'ra (Bot.) prrın, refin, fpora, feeds; the feeds being coated with refin.

Retrospi'nis (Ichth.) retro, backwards, Spina, prickle, fpint.

Rettber'gia (Bot.) P. N. ; a genus of Gramina.

Retu'sus-a-um (Ent., Bot.) Lat. blunted; e.g. Schizanthus retufus.

Ret'zia (Zool., Bot.) P. N. in honour of A. J. Retzius, Profeftor of

Natural Hiftory in Sweden; alfo a genus of Mollufca.

Revaya'na (Ent.) P. N. in honour of the Naturalin Revay.

Rhabarba'rum (Bot.) the original na!ne of Rlubarb, from $R h a$, root, and Lat. barbarum, of the barbarians.

Puhab'dia (Bot.) pásdos, a wand; a genus of Ehretiacex.

Rhab'dion (Zool.) jußsiov, a little rod; a genus of Colubrine ophidians. Phab'dium (Bot.) paßjos, a wand; a genus of Algx.

Rhabdoch'loa (Bot.) ṕáßoos, a twig, $\chi \lambda .0$, grafs.

Ruabdoci'daris (Fos. Zool.) ṕxßsos, a wand, cidaris; the ambulacral pores being widely separated.

Rhabdoco'la (Zool.) jébsos, a wvand or rod, uob̃nos, hollow; a tribe of Turbellaria.

Rhalodociinum (Bot.) páßso:, a Thaft, xpsrov, a liIy; a genus of Liliacex. Rhabdoi'dea (Zool.) júảsos, a rod, ¿dsú, form ; rod-like; ftriped-looking. Rhabdomo'nas ('Lool.) ṕáżos, a wand, monas; a gonus of Infuforia.

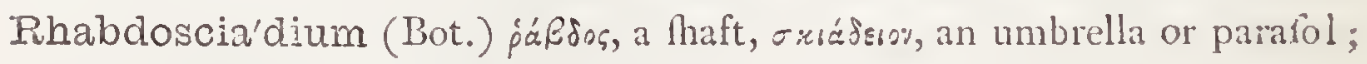
a genas of Umbellifera.

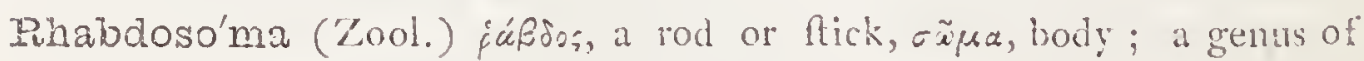
Colubrine ophidians. 


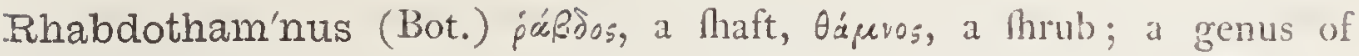
Gefneraceæ.

Rhabdothe'ca (Bot.) paBdos, a haft, $\theta_{n x} x^{\prime}$, a theath; a genus of Compolita. Rhadoca'lyx (Bot.) jußjos, a fhaft, calyx; a genus of Cardiaceæ.

Rhagadi'olus (Bot.) a dim. formed from jayas, a nit, from the divifion of calyx; a genus of Compofitæ.

Rhagiga'ster (Ent.) jaykus, a llit, rusrńp, belly; a genus of Hymenoptera.

Rhago'dia (Bot.) juyẃdns, like berries or grapes; its principal diftinction;

a genus of Chenopodiacex.

Rhagro'stis (Bot.) po, root, agrofis, wild; a genus of Chenopodiaceæ.

Rhamna'cer (Bot.) the Buckthorn family of plants, from the typical genus Rhamnus.

Rham'nophis (Zool.) jásvos, a prickly fhrub, bै prs, a frake; a genus of Ophidians.

Rhamno'psis (Bot.) the genus Rhamms, and of fs, refemblance; a genus of Flacourtiacer.

Ruham'nus (Bot.) pásvos, Lat. rhammus, was applied by the ancients to a prickly fhrub; Buckthorn; typical genus of Nat. Ord. Rhamnacea.

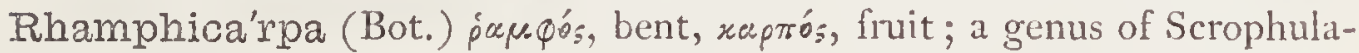
riaceæ.

Rhamphicin'thys (Ichth.) pós $\varphi_{0 s}$, a crooked beak, 'xtous, a filh.

Rhamphocæ'nus (Ornith.) fometimes written ramphocenus, from pós $\mu$ os, a crooked beak, ห⿻ьsós, Atrange.

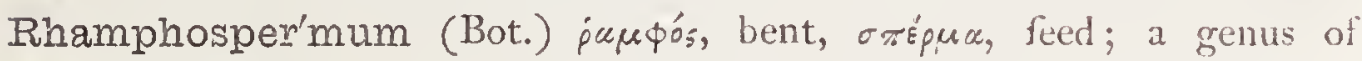
Cruciferæ.

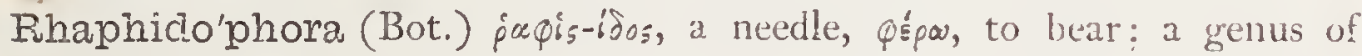
Orontiaceæ.

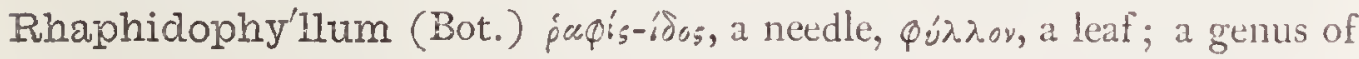
Scrophulariacer.

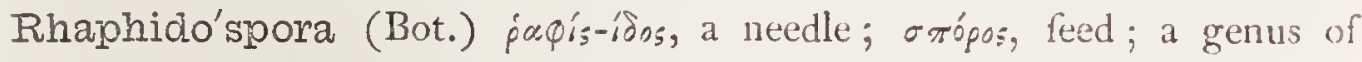
Acanthacex.

Rhaphio'cera (Ent.) jậ́, a needle, xépas, horn (antennie); a genus of Diptera.

Rhaphi'odon (Bot.) papiśs, a needle, idoves, dósros, a tooth; a gurus of Labiatx.

Rhaphio'lepis (Bot.) japis, a needle, $\lambda \varepsilon \pi i_{5}$, a fale; a genus of Pomacex. Rhaphispe'rmum (Bot.) pupis, a needle, stśpra, feed; a geisus of Scror. phulariacex.

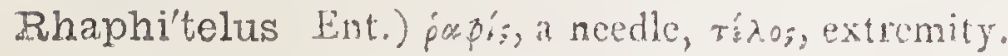


Rha'pis (Bot.) pupís, a needle; from the acute awns of the Corolla; a genus of Fan palms.

Rhapon'ticus-a-um (Bot.) rha, root, Ponticus, of Pontus, near the Euxine ; fpecific name of rhubarb, becaufe it grows near the river $R h a, i . e$. the Volga.

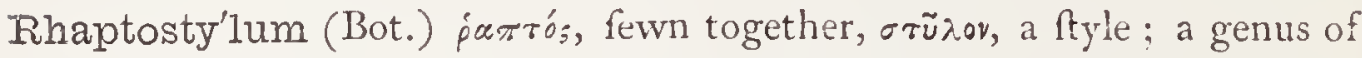
Aquifoliacex.

Rhee'dia (Bot., Ent.) P. N. in honour of Henr. van Rheede van Draakenfein, a patron of botanifts.

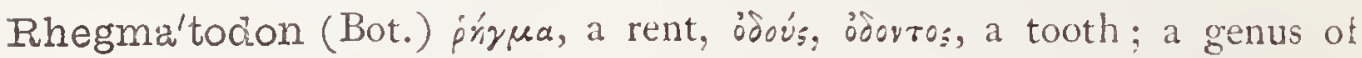
Bryoid Mufci.

Rhego'stoma (Zool.) ṕryvus, to bear away, soóuc, mouth; a genus of Mollufca.

Rhe'um (Bot.) the f'ov, of Diofcorides, faid to be derived from the river Rha, in Rufira, now the Volga ; the Rhubarb plant; a genus of Polygonacer.

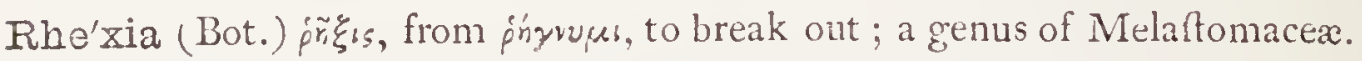
Rhi'na (Ichth.) pirv, a fnout; a genus of Rays or Skates.

Rhinacan'thus (Bot.) ṕrn, a inont, äuava, a thorn or prickle; a genus of Acanthaceæ.

Rhinac'tina (Bot.) fim, a file, èr ז́r, a ray; a genus of Compofita.

Rhinantha'cex (Bot.) the fection of Scrophulariacex reprefented in Rhinanthus, \&c.

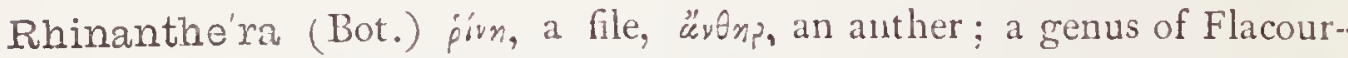
tiace:

Rhinan'thus (Bot.) fív, a fnout, ävos, flower: Yellow-rattle; a genus or Scrophulariacex.

Rhine'chis (Zool.) f̊́v, a fnout, $\chi^{\prime \prime} ;$, a viper; a genus of Colubrine ophidians.

Rhinoba'tidx (Ichth.) a genus of Fines, of which Rhinobatus is the type. Rhino'batus (Ichth.) $\dot{\rho}$ wó-ßaros, ancient name of a fith.

Rhinoboin'ryum ('Lool.) fir, nofe, $\varepsilon_{0} \theta_{5}{ }^{\circ}$, a hole or pit; a genus of Colubrine ophidians.

Rhinoca'rpus (Bot.) pir, a fnout, жupros, fruit; a genus of Anacardiaceæ. Rhinoceri'na (Zool.) rlinoceros; a fub-family of Mammalia.

Rhino'ceros (Zool.) ṕrvoxépas of the Greeks, from pir, ṕrós, the nofe, x'şas, a horn.

Rhino'des (Ent.) jowsins, fnout-like,

Rhinolo'bium (Bot.) fir, a fnout, $\lambda_{0} \hat{S}_{0}$, , a pod; a genus of Afclepiadacer. 


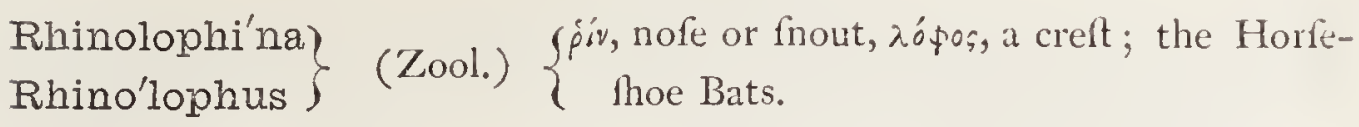

Rhinomy'za (Ent.) povós, a hide, $\mu v^{\prime} \zeta \omega$, to fuck in ; a genus of Diptera.

Rhinon'chus (Ent.) fív, a fnout, öyros, a curve.

Rhinope'talum (Bot.) ṕsvos, a hide, $\pi \dot{\varepsilon} \tau \alpha \lambda \alpha^{\prime}$, leaf; a genus of Liliaceæ.

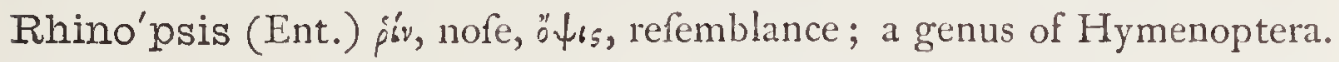

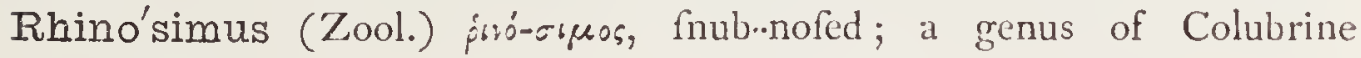
ophidians.

Rhinoste'gia (Bot.) p̈in, a fnout, $\tau \tau^{\prime} \gamma n$, a covering; a genus of Santalacex.

Rhino'stoma (Zool.) fiv, nofe, oróre, the face; a genus of Colubrine ophidians.

Rhino'trichum (Bot.) piv, a fnout, $\theta \rho_{b} \xi$, rp'xos, hair; a genus of Fungi.

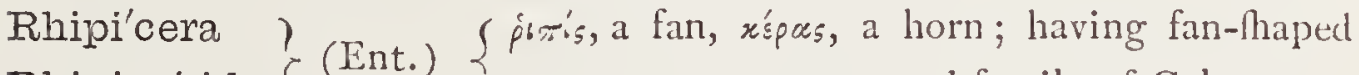

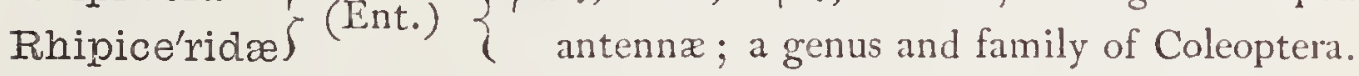

Rhipidium (Bot.) dim. of $\dot{\rho} 6 \pi_{5}$, a fan; a genus of Polypodioid Filices.

Rhipidoden'dron (Bot.) ṕr is-ídos, a fan, disvoov, a tree.

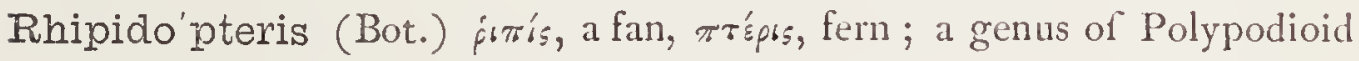
Filices.

Rhipidos'iphon (Bot.) pisis, a fan, riфar, a tube; a genus of Algx.

Rhipidu'ra (Ornith.) firts, a fan, ov́pe, a tail; the Fan-tail; a genus of Pafferes.

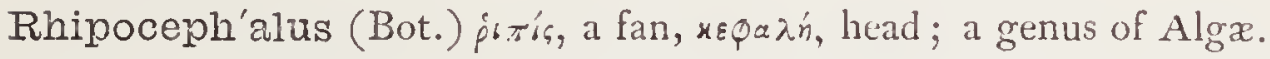

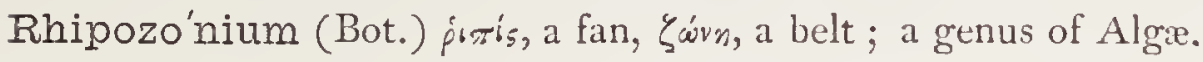

Rhip'salis (Bot.) ṕs $\psi$, a willow branch; referring to its flexible branches;

a fingular genus of Cactacex, with cord-like ftems.

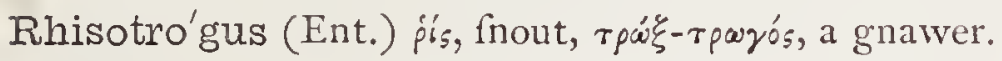

Rhizobola'cere (Bot.) the Natural Order of plants of which the following is the typical genus:-

Rhizo'bolus (Bot.) posso-Bóros, throwing out roots; the same genus as Caryocar; the Souari-nut tree.

Rhizobo'trya (Bot. ( $\rho^{\prime} \xi \alpha$, root, Rórpus, a bunch; a genus of Cruciferie.

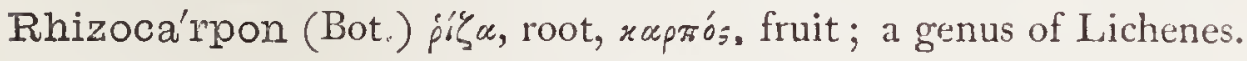

Rhizoceph'ala (Zool.) pisa, a root, xєфaiń, head; becaufe the head of thefe apparent worms, which is inferted into the body of its hoft, emits roots iike thofe of plants; a genus of parafitic Cruftacea.

Rhizochi'lus (Zool.) $\rho_{\imath} \zeta \alpha$, root, $\chi \varepsilon \tilde{i} \lambda$ os, lip; a genus of Mollufca.

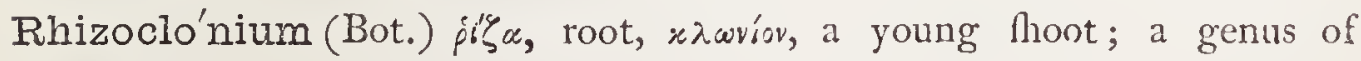
Algæ.

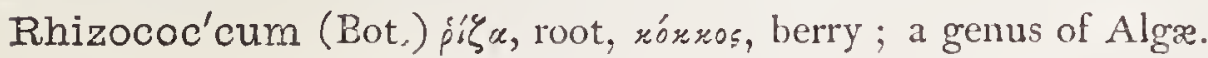


Rhizocto'nia (Bot.) $\mathfrak{p}^{\prime} \xi_{\zeta} \leftrightarrow$, a root, $x \tau \varepsilon i v \omega$, to deftroy; it deftroys the roots it grows on; a genus of Fungi.

Rhi'zogens (Bot.) fí̧ c, root, ysuréw, to produce; Lindley's name for the great tribe reprefented in the Rhizanthacex, \&c.

Rinizo'litha (Ent.) 's'sce, a root, $\lambda_{i}^{\prime} \theta_{\text {ss }}$, a ftone.

Rhizo'ma (Bot.) $\dot{p} b \%$, a root; applied to a fubterranean creeping titem like that of Iris.

Rhizomor'pha (Bot.) pis" $a$, a root, $\mu$ opeń, Mape; from refemblance to the roots of trees; a name given to abnormal conditions of Fungi when developed in the dark; not a fcientific genus.

Rhi'zomys (Zool.) pisca, a root, $\mu \tilde{u} s$, a moufe; ufed for the Bamboo rat. Rhizo'nium (Bot.) pi' $\alpha$, root; a genus of Bryoid Mufci.

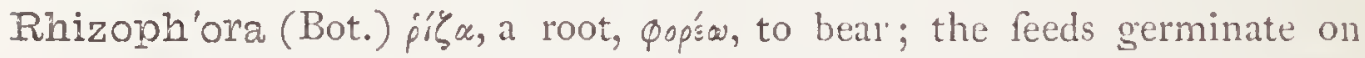
the branches; the Mangrove-tree; typical genus of the Nat. Ord. Rhizophoracez.

Rhizophora'cere (Bot.) the Mangroves.

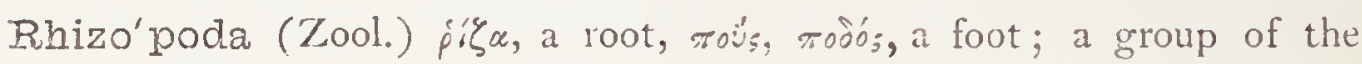
Protozoa.

Rhizopo'gon (Bot.) ficu, a root, tújary, a beard; a genus of Fungi.

Rhi'zopus (Bot.) pisc, root, mov́s, mojoos, foot; a genus of Fungi.

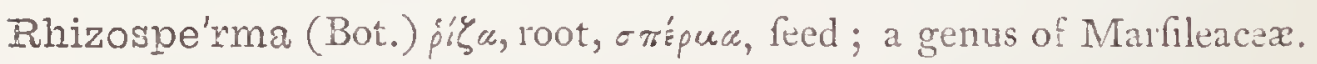

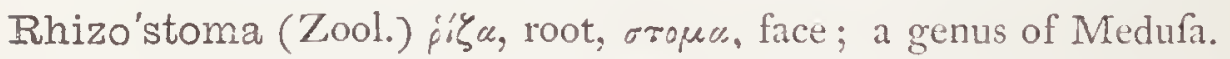

Rhoda'mina (Bot.) jéśsuvs, a young fhoot; a genus of Myrtacex.

Rhoda'nthe (Bot.) posov, a rofe, "̈vvos, a flower; in allufion to the colour of the flower-heads; a genus of Authalian Everlaftings.

Rhodaria (Ent.) fósov a rofe; from its rofy colour; a genus of Lepidoptea. Phodax (Bot.) pósck, a dwarf rofe; a genus of Cintacex.

Rho'clea (Bot.) pisov, a rofe; a genus of Liliacer.

Rhodi'ola (Bot.) pódsr, a rofe; its roots fmell like rofes; Rofe-root; a genus of Craflulacere.

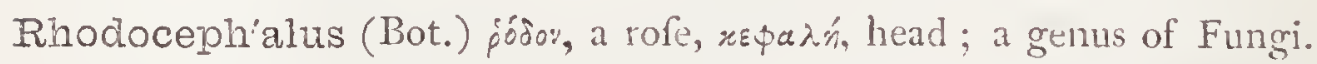
Rhodocer'idx (Ent.) fódov, a rofe, xśpas, a horn; from the rofy-tipped antennæ; a family of Lepidoptera.

Rhodochi'ton (Bot.) póoov, a rofe, xairn, foliage; a genus of Scrophulariacex.

Rhodoci'stus (Bot.) fódo\%, a roie, жiбros, a fhrub : a genus of Ciltacex. Rhodocoma (Bot.) fósov, a rofe, róur, a tufí; a genus of Reltiacen.

Rhodocrírus (Fos. Zoo!.) poodn, rofe, xpivov, lily, equivalent to "Roflencrinite;" a gems of l'alxozoic encrinites. 
Rhododac'tylus-a-um (Ent.) posov, the rofe (referring to the colour),

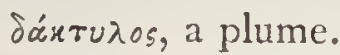

Rhododen'dron (Bot.) pódov, a rofe, dévopor, a tree; a magnificent and well-known genus of Ericaceæ.

Rhododer'mis (Bot.) fósov, a rofe, sépreu, kin; a genus of Algr.

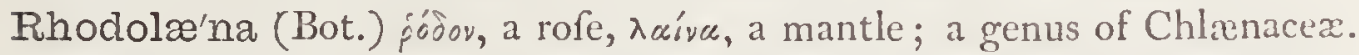

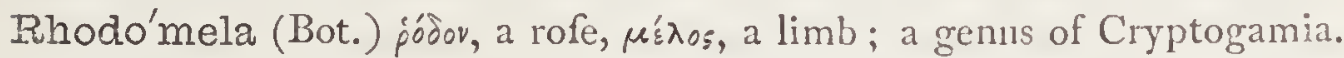

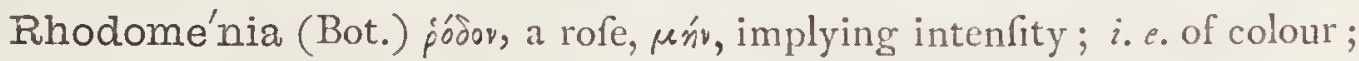
a genus of Marine Algr.

Rhodomyr'tus (Bot.) pódov, a rofe, myrtus, myrtle; a genus of Myrtacex. $\left.\begin{array}{l}\text { Rhodo'na } \\ \text { Rhodo'nidæ }\end{array}\right\}$ (Lool.) $\left\{\begin{array}{c}\text { poośr, a bed of rofes; a genus and family of } \\ \text { flender-tongued Saurians. }\end{array}\right.$

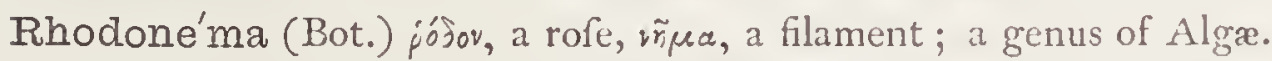

Rhod'ope (Zool.) P. N. ; from claffic geography; a genus of Mollufca.

Rhodophæ'a (Ent.) pósov, a rofe, pusós, dull, duky; rofy-grey; a genus of Lepidoptera.

Rhodoph'ora (Ent.) fóoov, a rofe, Qop'sw, to carry.

Rhodophy'cere (Bot.) jodov, a rofe, фũros, Lat. fucus, fea-weed; a family of Algre, equivalent to the Rhodofpermex of Dr. Harvey.

Rhodo'psis (Bot.) jodov, a rofe, öłı, refemblance; a grenus of Portulacaceæ.

Rhodo'ra (Bot.) foriov, a rofe; alluding to the colour of the flowers; a genus of Ericacere.

Rhodora'ceæ (Bot.) a fub-family of Ericacex, with Rhodora for the type.

Rhociorhíza (Bot.) jodov, a rofe, $\dot{\rho}$ ' $\zeta$ a, root; a genus of Convolvulacex.

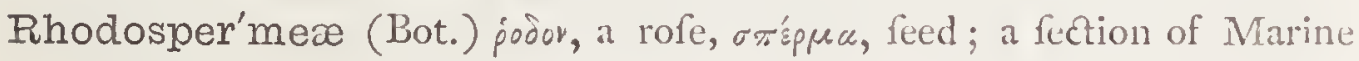
Algre.

Rhodo'stoma (Bot.) podov, a rofe, orópa, mouth; a genus of Cinchonacex. Rinodotham'nus (Bot.) jofov, a rofe, 6 ćuvos, a thrub; a genus of Ericacex. Rhodoty'pus (Bot.) jofov, a rofe, tútos, a model or pattern; a genus of Roface

Rhœ'as (Bot.) f́śa, to flow; fpecific name of a fpecies of Poppy.

Rho'gmus (Ent.) fwymń, a cleft; a genus of Hymenoptera.

$\left.\begin{array}{l}\text { Rhomba'lis-e } \\ \text { Rhom'bicus-a-um }\end{array}\right\}$ (Ent.) vhombus, a four-fided figure; a Thomb.

Rhomboida'ria (Ent.) jop Bosións, rhombus-fhaped, lozenge-fhaped; from the form of the markings.

Rhom'bus (Ichth.) Lat. a turbot; the 'Tubot. 
Rhopa'la (Bot.) roupala, its aboriginal name in Guiana; a fplendid genus of Proteacex.

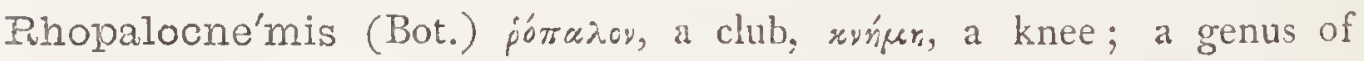
Balanophoraceæ.

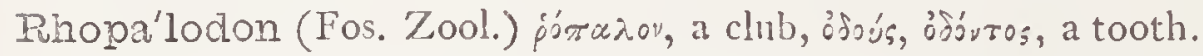

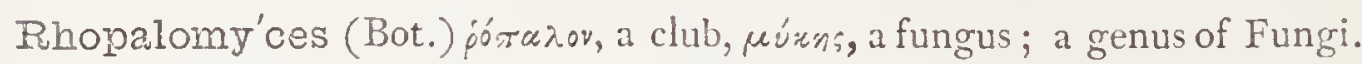
Rhus (Bot.) joũs, Lat. rhus, a fmall tree ufed in tanning; the Sumachtree; Nat. Ord. Anacardiaces.

Rhyaco'phila (Bot.) ṕúç aros, a mountain-ftream, $\phi \iota \lambda \varepsilon \omega$, to love ; a genus of Lythracex.

Rhy'ma (Bot.) pũ $\mu \alpha$, a bow-Thaft ; a genus of Clufiacex.

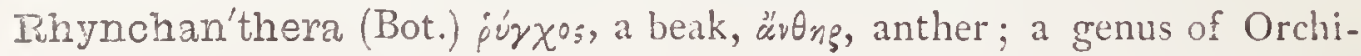
dacex.

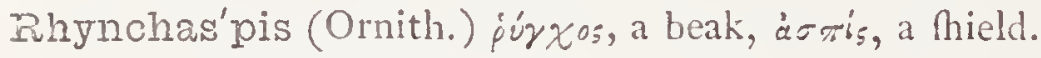

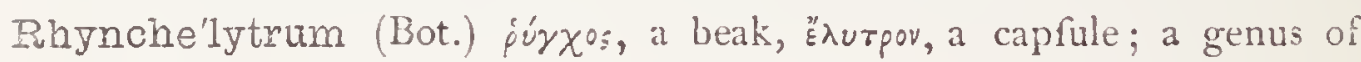
Gramina.

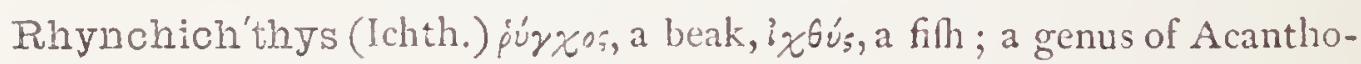
pterygian filhes.

Rhynchi'na (Ent.) púyxos, a beak or fnout.

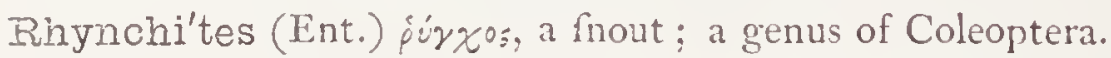

Rhyn'chium (Ent.) p'śr $\chi_{5}^{5}$, a finout: a genus of Hymenoptera.

Rhynchoca'rpa (Bot.) púyxos, a beak, xuprós, fruit; a genus of Cucurbitacex.

Rhynchoca'rpus (Bot.) fame derivation; a genus of Compofita.

Rhynchoco'ccus (Bot.) jóryos, a beak, жóxжos, a berry; a genus of Algxe. Rhynchoco'rys (Bot.) púrxos, a beak, xópus, a helmet; a genus of

Scrophulariacex.

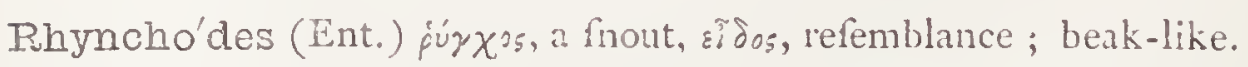

Rhynchoglos'sum (Bot.) fúyxos, a beak, $\gamma^{\lambda} \tilde{\omega}=\sigma a$, tongue; a genus of Gerneracer.

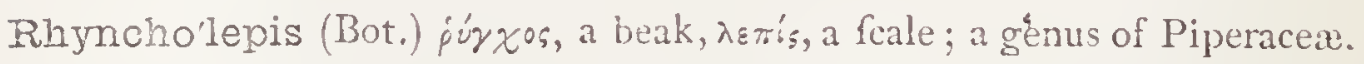
Ilhynchone'ma (Bot.) fúrxos, a beak, irena, a thread; a genus of Algx.

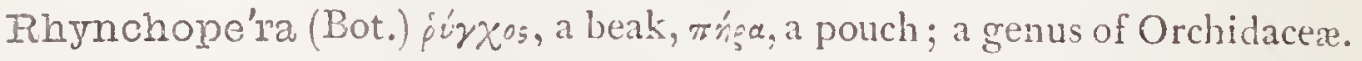

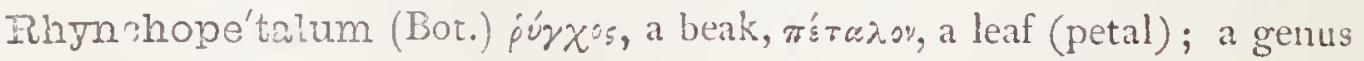
of Lobeliacere.

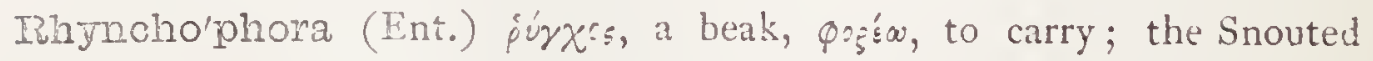
Beetles; a divifion of Coleoptera.

Ehjncho'phorus-a-un (7ool,) fame derixtion; fnout-bearing; having a proboricis. 
Rhynchopsi'dium (Bot.) puryos, a beak, and the genus Pfidium, the Guava; a genus of Compofitr.

Rhynchosau'rus (Fos. Zool.) ṕúyøos, a beak, cãupos, a lizard.

Rhyncho'sia (Bot.) púrxos, a beak; a genus of Leguminofie.

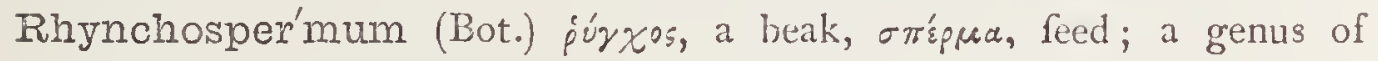
Chinefe Apocynacea.

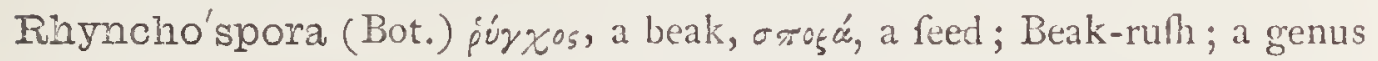
of Cyperacex.

Rhynchosporel'la (Ent.) firft taken at Kilmun, N. B., hovering over and fettling on the Rhynchofpora, (Acc. Lift of Brit. Lepid.)

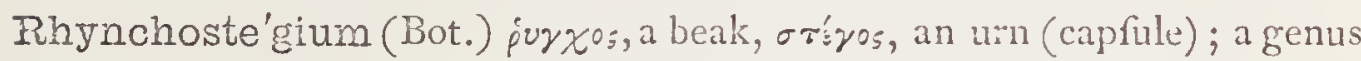
of Molles.

Rhynchosty'lis (Bot.) púrxos, a beak, crĩnov, a pillar (ftyle); a genus of Orchidaceæ.

Rhynchothe'ca (Bot.) fúrzos, a beak, orikn, a fheath; a genus of Oxalidacex.

Rhyncho'tus-a-um (Zool., Ent.) having a frout or probofcis (pérzos).

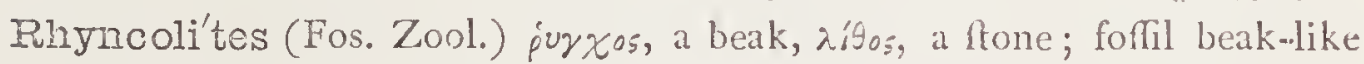
mandibles of Cephalopods.

Rhyncone'lla (Zool.) dim. of jurxos, a beak; a genus of Niollufia.

Rhyn'cops (Ornith.) púrxos, beak, $\ddot{\omega} \psi$, fice; the Skimmer or Scifor-3ill ;

a genus of web-footed Birds.

Rhyncoteu'tris (Zool.) púyðos, a beak, revfis, a cuttle-fith or fquid.

Rhy'nea (Bot.) P. N., a genus of Compolitr.

Rhypo'des (Zool.) furwíns, dirty, fmeared.

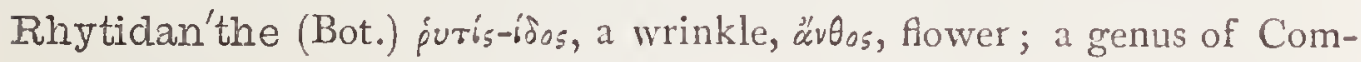
politx.

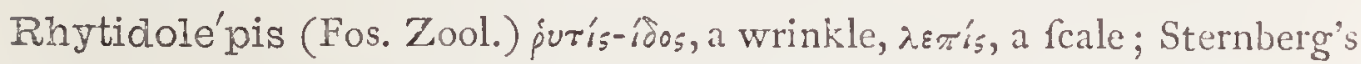
excellent name for the Sigillaria, referring to its corrugated bark.

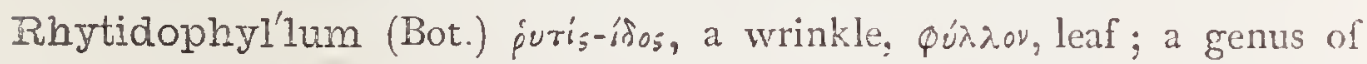
Gefneracese.

Rlyytiglos'sa (Bot.) puris, a wrinkle, $\gamma \lambda \tilde{\omega} \sigma \sigma a$, tongue; a genus of Acanthacex.

Rhytirhi'nus (Ent.) jurís, a wrinkle, pór, a nofe or fnout; a genus of Coleoptera.

Phy'tis (Bot.) puris, a wrinkle; a genus of Euphorbiacex.

Rhytis'ma (Bot.) puris, a wrinkle; referring to the appearance of the plants to which they are attached; a genus of parafitic Fungi. 
Rhytisper'mum (Bot.) puris, a wrinkle, or̊ģua, feed; a genus of Boraginaceæ.

Ri'bes (Bot.) this generic name originated in the fuppofition that our currant and goofeberry plants were thofe to which the A rabian phyficians of the eleventh and twelfth centuries gave the name of ribas, but which have fince been difcovered to be a kind of rhubarb, Rheum Ribas.-Paxton. A genus of Groflulariacer.

Ribesia'cere (Bot.) the Nat. Ord. of plants better known as Grofulariacer; having the above as its typical genus.

Rib-grass (Bot.) thofe plants which have been obferred to be eaten by cattle have often obtained the name of grafs, though differing in every other refpect from real graffes. This one is the Plantagro lanceolata.

Ric'cia (Bot.) P. N. in honour of Pietro Francifco Ricci, a Florentine botanift; typical genus of Ricciacer ; a divinion of the Cryptogamia. Riccie'lla (Bot.) dim. of Riccia; a genus of Ricciacere.

Ricciocar'pus (Bot.) the genus Riccia, and zagtos, fruit; a genus of Ricciacex.

Richæ'ia (Bot.) P. N. in honour of Mr. Riclice, a traveller who died at Tripoli in 1820 ; a genus of Loganiacex.

Rice (Bot.) Lat. oryza; Gr. öpuל̌ ; Arabic, eruz.

Richar'dia (Bot.) P. N. in honour of Louis Ciaude-Marie Richard, an eminent French botanift, who died in $\mathrm{I} \delta 21$; a fplendid genus of Orontiacex, often called the Ethiopian lily.

Richardso'nia (Bot.) P. N. in honour of Richard Richardfon, an Englih botanift; a genus of Cinchonacer.

Richardso'nii (Zool.) P. N. in honour of Sir Fokn Richardfon, M.D.

Ri'chea (Bot.) P. N. in honour of M. Riche, a French naturalift who accompanied D'Entrecafteaux, and being loft three days on the coaft of New Holland, lived upon the berries of an allied genus; a genus of Epacridacer.

Riche'ria (Rot.) P. N., a genus of Euphorbiacex.

Richte'ria (Bot.) P. N., a genus of Compofitix.

Ricinocar'pus (Bot.) the genus Ricinus, and raprós, fruit; a genus of Euphorbiaceæ.

Eici'nula (Zool.) dim. of Ricinus, the Caftor-oil plant, the berries of which the fhell refembles; a genus of Miollufca.

Ri'cinus (Bot.) Lat. a tick; from the refemblance of the feed ; the Caftor. oil plant; a genus of Nat. Ord. Euphorbiaceac.

Rico'tia (Bot.) P. N., a genus of Crucifer: 
Riddel'lia (Bot.) P. N., a genus of Compofitx.

Ridibun'dus-a-um (Ornith.) Lat. laughing.

Ridol'fia (Bot.) P. N., a genus of Umbelliferx.

Riedle'ia (Bot.) P. N. in honour of $M$. Riedle, who accompanied Captain

Baudin round the world; a genus of Byttneriacex.

Riencour'tia (Bot.) a genus of Compolita.

Riesenbac'hia (Bot.) P. N., a genus of Onagracex.

Ri'gens (Bot.) rigeo, to ftiffen; e.g. Gazania rigens.

Rigidel'la (Bot.) rigidus, rigid, in reference to the ftiffness of the peduncles,

when fupporting the feed-veffels.

Ri'gidus-a-um (Bot.) Lat. Atiff, hard; e.g. Carex rigida.

Rimo'sus-a-um (Bot.) Lat. full of clefts.

Ri'mula (Zool.) dim. of rima, a fillure; a genus of Mollufca.

Rinde'ra (Bot.) P. N. in honour of Rinder, Dean of Medicine in Mofcow;

a genus of Boraginacex.

Rin'gens (Zool., Bot.) Lat. gaping, e.g., Melicerta ringens.

Ringi'cula (Zool.) dim. of ringens, grimning; a genus of Mollufca.

Rino'rea (Bot.) P. N., a genus of Violacex.

Ripa'rius-a-um (Ornith., Bot.) Lat. frequenting rivers, growing on river banks; e.g. Carex riparia.

Ripidium (Bot.) ṕrı sov, a little fan; the application is not evident; a genus of Gramina.

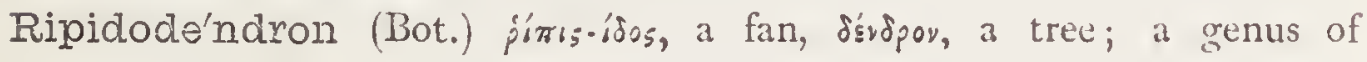
Liliaceæ.

Ripiph'orus (Ent.) ṕrtis, a fan, popśco, to carry; a genus of Coleoptera.

Ripi'dius (Ent.) pirsis-i\$os, a fan; a grenus of Coleoptera.

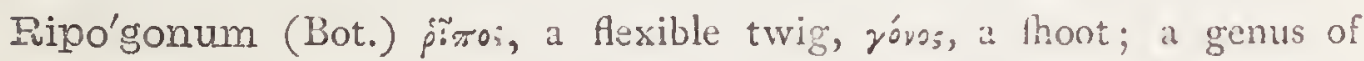
Smilaceæ.

Risso'a (Zool., Bot.) P. N. in honour of Riffo, a French zoologift; a genus of Mollufca; in Botany, a genus of Aurantiacex.

Riva'ta (Ent.) rivus, a rivulet ; from the wave-like markings.

Ri'vea (Bot.) P. N, a genus of Convolvulacer.

Rive'ria (Bot.) P. N., a genus of Leguminofa.

Rivi'na (Bot.) P. N. in honour of A. Q. Rivinus, a botanift of Saxony, who

died in 1722 ; a genus of Phytolaccaces, bearing racemes of red berries. Ri'vula (Ent.) rivulus, a little brook; a genus of Lepidoptera.

Rivula'lis (Ent.) rivulus, a rivulet.

Rivula'ria (Bot.) rivulus, a ftream becaufe it grows in rivers; a genus of Frefh-water Algx. 
Rivula'ris-e (Bot.) rivulus, a brook; growing in brooks; e. o. Saxifraga rivularis.

Roach (Ichth.) Anolo-Sax, reokche; Dutch, roch; Germ. roche; common name of Lencifcus rutilus.

Ro'bbia (Bot) P. N., a genus of Apocynacex.

Rober'gia (Bot.) P. N. from Laurent Roberg, Profeflor of Medicine at Upfal; a genus of Connaracex.

Rober'tia (Dot.) P. N. in honour of M. Robert, a Corfican botanift; a genus of Taxacex; alfo a genus of Ranunculacex.

Rober'tsia (Bot.) P. N, a genus of Compofitre; alfo a genus of Sapotacex.

Robertso'nia (Bot.) P. N., a genus of Saxifragacex.

Robique'tia (Bot.) P. N., a genus of Orchidacex.

Rob'in (Ornith.) Lat. rubecula, from rubeo, to be red.

Robin'ia (Bot.) P. N. in honour of Jean Robin, a French botanift, who died in 1597 ; the falf Acacia; a fuperb genus of Leguminous trees.

Robso'nia (Bot.) P. N , a genus of Groffulariacex.

Fuobusta'lis (Ent.) robuftus, ftout, ftrong.

Roc'ambole (Bot.) common name of Allium Scorodoprafum.

Roccel'la (Bot.) Port. rocha, a rock; from its place of growth; Orchil, a genus of Lichenes.

Rock'et(Bot.) French, roquette; Italian, ruchetta ; corrupted from Latin, Eruca. Roden'tia (Zool.) rodo, to gnaw; the Rodents; fo called from their habit of gnawing or nibbling their food.

Rodi'gia (Bot.) P. N. in honour of Rodio, a friend of Sprengel's; a genus of Compolitx.

Rodo'pis (Ornith.) podov, a rofe, $\ddot{\omega} \psi$, refemblance; a genus of Hummingbirds.

Rodrigue'zia (Bot) P. N. in honour of Emanuel Rodriguta, a Spanith phyfician and botanift; a genus of epiphytic Orchidacex.

Rodschie'dia (Bot.) P. N., a genus of Cruciferæ.

Roe (Zool.) Anglo-Sax. raa, rali; the Capreolus Dorcas.

Roëa (Bot.) P. N., a genus of Leguminofie.

Roel'la (Bot.) P. N. in honour of G. Roelbe, Profelior of Anatomy at AmRerdam.

Rcesel'ia (Ent.) P. N. in honour of A. F. Röfel, a painter and entomologift, who died in $1759 .-$ (Acc. List Brit. Lepid.)

Ro'hdea (Bot.) P. N. in honour of Michael Rohde, of Bremen in Germany. 
Röhlin'gia (Bot.) P. N., a genıs of Dilleniacex.

Ro'hria (Bot.) P. N., a genus of Compolita.

Rolan'dra (Bot.) P. N. in honour of Danid Rolander, a pupil of Linnæus, who vifited Surinam; a genus of Compofita.

Rolda'na (Bot.) P. N., a genus of Compofitx.

Rolfin'kia (Bot.) P. N., a genus of Compofita.

Rollan'dia (Bot.) P. N., a genus of Lobcliacex.

Rolli'nia (Bot.) P. N., a genus of Anonacex.

Rolo'fa (Bot.) P. N., a genus of Mefembryaces.

Romanzorvia (Bot.) P. N., a genus of Hydrophyllaceæ.

Röme'ria (Bot.) P. N. in honour of 7 . F. Römer, Profellor of Botany at

Landhut, who died in I 820 ; a genus of Papaveracex.

Romne'ya (Bot.) P. N., a genus of Papaveracer.

Romu'lea (Bot.) uncertain; a genus of Iridacex.

Rona'bea (Bot.) P. N., a grenus of Cinchonacex.

Rondele'tia (Bot.) P. N. given by Linnæus in honour of Rondelet, a cele-

brated phyfician of the I 6th century; a genus of Cinchonacer.

Rore'lla (Bot.) dim. of ros, roris, dew ; a genus of Droferacex.

Rorel'lus (Ent.) dim. of ros, dew.

Ror'qual (Zool.) from a Norwegian word fignifying "whliale with folds."

Rosa (Bot.) Lat. a rofe: the podoy of the Greeks was not a rofe, but probably the pomegranate-flower.

Rosa'ceus-a-um (Zool., Bot.) Lat. rofy, rofe-like; arranged like rofuleaves; c.g., Mufa rofacea.

Rosæcola'na (Ent.) rofa, a rofe, colere, to frequent.

Rosali'na (Zool.) rofa, a rofe; a genus of Foraminifera, the chambers of which are difpofed in a rofe like manner.

Rosa'ria (Bot.) rofarius, rofe-like; a genus of Cryptogamia.

Roscö'ea (Bot.) P. N. in honour of $W$. Rofcoe, the hiftorian of the Medici, who died in $18{ }_{3} \mathrm{I}$; a genus of Zingiberacex.

Ro'seus-a-um (Ornith., Bot.) Lat. rofy, rofe-coloured; arranged like rofe-leaves; $\iota . g .$, Bryum rofeum.

Roslerstam'mia (Ent.) P. N. in honour of Fifcher von Roferfamm, a writer on Entomology: a genus of Lepidoptera.

Rosmari'nus (Bot.) ros, dev, marinus, belonging to the fea ; it might be tranflated "fea-fpray;" Rofemary; a genus of Labiatæ.

Ros'marus (Zool.) the Norwegian word Rofmar latinized.

Ros'sia (Zool.) P. N. in honour of Sir Fohn Ross; a fub-genus of Cephalopods. 
Rostella'ria (Zool.) roftellum, a little beak; a genus of Strombidæ or Wing-thells.

Rostella'tus-a-um (Bot.) roftellum, a little beak; from fancied refemblance. Rostel'lum (Bot.) Lat. a little beak.

Rostra'lis (Ent.) roftrun, a beak.

Rostra'ria (Bot.) roftrum, a beak; a genus of Gramina.

Rostra'tus-a-um (Bot.) roftrum, a beak; beaked, e.g., Mnium roftratum.

Rosula'tus-a-um (Bot.) rofa, a rofe; having the leaves arranged in little rofe-like clufters.

Rote'1la (Zool.) dim. of rota, a wheel; a genus of Mollufica.

Rot'hia (Bot.) P. N. in honour of $A$. $W$. Roth, of Bremen, a German botanift; a genus of Compolitx; alfo a genus of Leguminofa.

Rottböl'lia (Bot.) P. N. in honour of C.F. Rotbüll, a Danilh botanift, who died in 1797 ; a genus of Gramina.

Rottle'ra (Bot.) P. N. in honour of Rev. Dr. Rottler, a Danilh mifínary; a genus of Euphorbiacex.

Rotunda'ria (Ent.) rotundus, round; from the rounded form of the wings.

Roxa'na (Ent.) P. N. in honour of Roxana, wife of Alexander the Great ; a genus of Lepidoptera.

Roxburg'hia (Bot.) P. N. in honour of W. Roxburgh, M.D., director of the Botanical gardens at Calcutta, who died in 1815 ; typical genus of Roxburghiacea.

Royd'sia (Bot.) P. N. in honour of Sir F. Royds; a genus of Capparidacex. Roye'na (Bot.) P. N. in honour of Adrian von Royen, Profellor of Botany at Leyden, who died in 1779 ; a genus of Ebenacer.

Roy'lea (Bot.) P. N. in honour of Dr. Fohn Forbes Royle, F.R.S. formerly fuperintendent of the Botanical gardens at Saharunpoor, who died in I 358 ; a genus of Labiata.

Puyston Crow (Ornith.) common Englim name of the Hooded-crow; Corvus Cornix.

Rube'cula (Ornith.) rubeo, to become red; fpecific name of the Red-breaft. Rubel'lus-a-um (Ent., Bot.) Lat. reddilh ; e.g. Arenaria rubella.

Ru'bens (Zool, Ent., Bot.) Lat. red, reddifh ; e.g. Trifolium rubens. Ru'ber, ru'bra, ru’brum, (Ornith., Bot.) Lat. red.

Ru'betra (Ornith.) ruber, red, reddifh; fpecific name of the Whinchat, Saxicola rubetra.

Ru'bia (Bot.) ruber, red; the roots are ufed as a dye; Madder; a genus of Nat. Ord. Galiacex. 
Rubi'cola (Ornith.) rubus, the bramble, colo, to frequent ; fpecific name of the Stonechat, Saxicola rubicola.

Rubicun'dus-a-um (Zool., Ent.) Lat. red, ruddy.

Rubida'lis (Ent.) rubidus, red.

Ru'bidus-a-um (Zool.) Lat. red, reddifh.

Rubiga'lis, Rubigina'lis (Ent.) rubigo, ruft; nuft-coloured.

Rubigino'sus-a-um (Bot.) Lat. ruft-coloured; alfo glandular; e. g. Rofa rubiginofa, fweet-brier.

Rubrica'lis (Ent.) having the colour of rubrica, red earth, red ochre.

Rubricol'lis (Ent.) ruber, red, collum, the neck; from the red collar.

Rubricol'lus-a-um (Ornith.) fame derivation.

$\mathrm{Ru}^{\prime}$ bripes (Ent.) ruber, red, pes, the foot.

Rubrocinc'tus (Ichth.) ruber, red, cinctus, banded; red-banded.

Rubrotibiel'la (Ent.) ruber, red, tibia, the fhank.

Ru'bus (Bot.) Lat. a brambie; a genus of Nat. Ord. Rofacex.

Rudbe'ckia (Bot.) P. N. in honour of Olof Rudbeck, Profeflor of Botany at Upfal, who died in I 702 ; and of his fon, who died in 1740 ; a genus of Compolitx.

Rudd (Ichth.) the Leucifcus erythrophthalmus or Red reye.

Ru'dis-e (Bot.) Lat. rough; e.g. Rubus rudis.

Rudol'phia (Bot.) P. N. in honour of $W . J . H$. Rudolph, a botanift of Jena; a genus of Leguminofa.

Rue (Bot.) Lat. ruta.

Ruel'lia (Bot.) P. N. in honour of Fohn Ruelle, of Soiflons, a botanift and phyfician to Francis I.; a genus of Scrophulariacex.

Ruficilia'na (Ent.) rufus, red, cilium, a fringe.

Ruficincta'tus-a-um (Ent.) rufus, red, cinctus, girt about.

Rufi'na (Ornith.) rufus, red.

Ru'fipes (Ornith., Ent.) rufus, red, pes, a foot.

Rufoguala'ris (Ornith.) rufus, red, gula, the throat.

Rufo-vire'scens (Bot.) rufus, red, virefcens, greenith.

Ru'fulus-a-um (Ornith.) Lat. dim. rather red, ruffet.

Ru'fus-a-um (Zool., Ornith., Bot.) Lat. red.

Rugi'lus (Ent.) rugo, to be wrinkled or crumpled.

Rugo'sus-a-um (Bot.) wrinkled, corrugated.

Ruiz'ia (Bot.) P. N. in honour of Don Hippolito Ruiz, one of the authors of "Flora Peruviana"; a genus of Byttneriacex.

Rulin'gia (Bot.) P. N. in honour of J. P. Ruling, author of " Ellay on Natural Orders;" a genus of Byttneriacex. 
Ru'mex (Bot.) Lat. a fpear, referring to the Thape of the leaves; the Dock; a genus of Nat. Ord. Polygonaceæ.

Ru'mia (Ent.) P. N., the goddefs who prefided over fuckling; a genus of Lepidoptera.

Ruminan'tia (Zool.) ruminare, to chew the cud; the Ruminants.

Runci'na (Zool.) Lat. a plane; a genus of Mollufca.

Rupes'tris-e (Eot.) Lat. growing upon rocks, e. g. Draba rupeftris.

Rupicapra'ria(Ent.) rupicapra, a mountain goat, a chamois; from the colour. Rupi'cola, (Ornith.) rupes, rocks, colere, to frequent; equiv. to the popular name, Cock of the Rock.

Rupicola'lis (Ent.) rupes, rocks, colere, to frequent.

Rup'pia (Bot.) P. N. in honour of H. B. Ruppi, a German botanift; a genus of Juncaginacer.

Rus'cus (Bot.) rufcum was applied by Pliny to the Butchers' broom; a fuffruticofe genus of Liliacex.

Rush (Bot.) Anglo-Saxon, rics, rifc, a ruh; Latin, rufcum, butchers'-broom ; applied to the genus Juncus.

Rusi'na (Ent.) the fame as Rurina, the goddefs of the Country (Rus).

Russa'tus-aum (Ornith.) Lat. clothed in red.

Russe'lia (Bot.) P. N. in honour of A. RuJell, M.D., F.R.S., author of

"Natural Hiftory of Aleppo"; a genus of Scrophulariaceæ.

Rus'sula (Bot.) rufulus, reddifh; a genus of Fungi.

Pus'sulus-a-um (Ent.) Lat. reddith.

Rusti'colus-a-um (Ornith.) rus, the country, colo, to frequent; living in fields or meadows; e.g. Scolopax ruficola, the Woodcock.

Rus'ticus-a-um (Ornith.) Lat. rural, ruftic;e.g. Hirundo ruffica, the Swallow.

Ru'ta (Bot.) jurńn, rue; it is nearly the fame in moft languages; Rue; typical genus of Nat. Ord, Rutacex.

Rute'la
Rute'lidæe (Ent.) etymol. uncertain; a genus and family of Coleoptera. Ruticil'la (Ornith.) rutilus, red, cillo, to ftir or agitate; the Redftart.

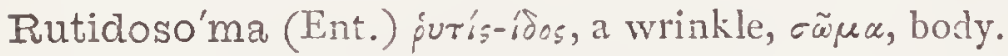

Ru'tilans (Bot.) Lat. red, glowing; e. g. Thyrfacanthus rutilans. Rutilus-a-um (Ornith.) Lat. red, inclining to golden yellow.

Ru'yschia (Bot.) P. N. in honour of F. Ruyfch, M.D., a celebrated Dutch anatomift, boin 1638 , died $173 \mathrm{I}$; a genus of Marcgraviacex.

Puya'nea (Bot.) P. N. in honour of John Ryan, M.D., F.R.S., a correfpondent of Vahl's; a genus of Pafifloracex. 
Rypoph'aga (Ent.) puros, dirt, filth, páyw, to eat; a genus of Coleoptera. Rytidocar'pus-a-um (Bot.) puris, a wrinkle, xugrós, fruit ; c.g. Hedyfarum rytidocarpum.

Rytiphlœ'a (Bot.) putí, a wrinkle, фroós, bark; a genus of Algæ.

Rytirhynchus-a-um (Ornith.) purís, a wrinkle, pírxos, a beak; e.g.

Rallus rytirhynchus.

Sa'bal (Bot.) a name given by Adanfon, meaning unknown; a genus of Palmæ.

Sabba'tia (Bot.) P. N. in honour of L. Sabbati, a celebrated Italian botanift; a genus of Gentianacere.

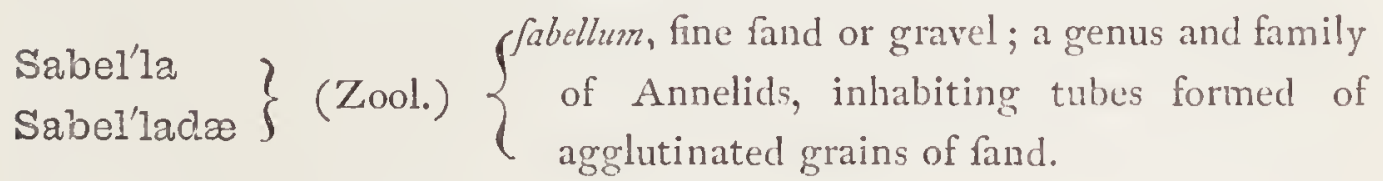

Sabulo'sus-a-um (Ent.) Lat. fandy, gravelly.

Saburra'lis (Ent.) Lat. fandy ; fand-coloured.

Sacca'tus-a-um (Ent., Bot.) faccus, a fack or bag; in Ent. applied to a

fpider, from the bag of eggs it carries fixed to its fpinnerets.

Sacchari'na (Bot.) faccharum, fugar; from its fweet talte; a genus of Marine Algæ.

Saccharoph'orum (Bot.) faccharum, fugar, fero, to bear; a genus of Gramina.

Sac'charum (Bot.) Lat. fugar, from the Sanfcrit farkara, Greek oáxxap, oúr xupov; the Sugar-cane; a genus of Gramina.

Sacci'dium (Bot.) dim. of cúxros, a bag, sîjos, likenefs; from the form of labellum; a genus of Orchidacex.

Saccochi'lus (Bot.) oúzxos, a bag, $\chi \varepsilon \tilde{i} \lambda \circ 5$, a lip; from the form of the labellum; a genus of Orchidacex.

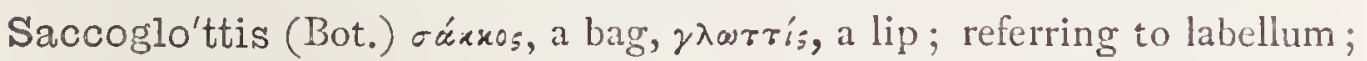

a genus of Humiriacex.

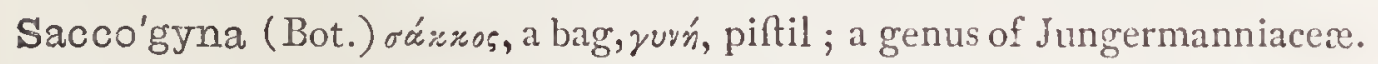

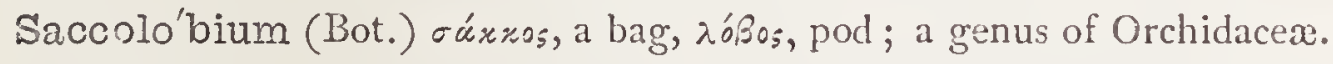

Saccolo'ma (Bot.) бáxнos, a bag, $\lambda \tilde{\omega} \mu a$, fringe; a genus of Polypodioid Filices.

Sa'ccomys (Zool.) бáz\%os, a bag, $\mu \tilde{u}_{s}$, a moufe, from the great fize of the cheek-pouches; the Pouched-rat; a genus of Mammalia.

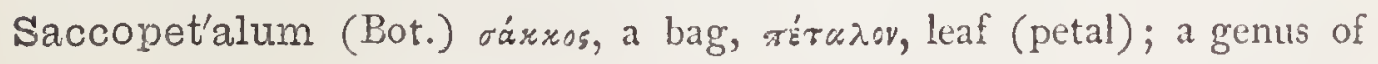
Anonacex. 
Saccoph'orus-a-um (Zool.) oúxuos, a fmall bag or pouch, popía, to bear. Sacra'ria (Ent.) facrarius, a facriftan.

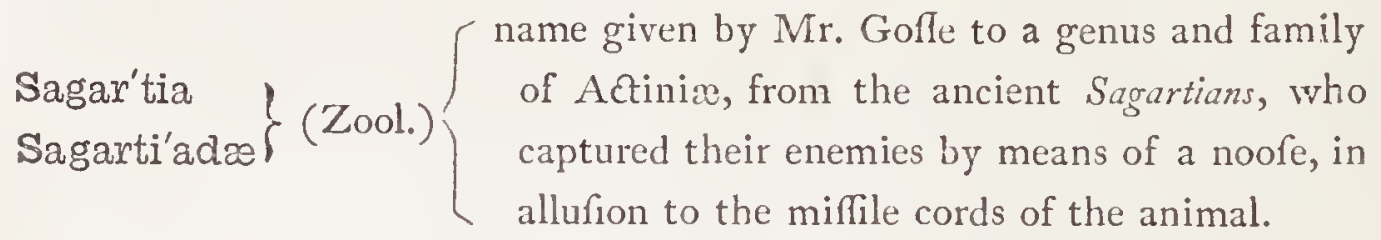

Sag'da (Zool.) a precious ftone mentioned by Pliny of a leek-green colour;

a genus of Mollufca.

Sagenocri'nites (Fos. Zool.) бayйyn, a filhing-net, xpivoy, a lily; a genus of Crinoidea, or Stone-lilies.

Sagi'na (Bot.) Lat. fomething nourihing; heep-food; now applied to an infignificant genus of Caryophyllaces.

Sagitta'ria (Bot.) faritta, an arrow, alluding to the form of the leaves of fome fpecies; a beautiful aquatic genus of Alifmacex.

Sagitta'tus-a-um (Ent.) fagitta, an alrow; having arrow-head marks on the wings.

Sagittilin'gues (Ornith.) fagitta, an arrow, lingua, a tongue.

Sa'go $\{$ fagu, Malay name of various plants; the Sago-palm; Sa'gus $\}$ (Bot.) $\left\{\begin{array}{l}\text { Nat. Ord. Palmx: Sago is prepared from the pith } \\ \text { of thefe palms. }\end{array}\right.$

Salaccen'sis-e (Bot.) P. N. relating to Mount Salak, in Java.

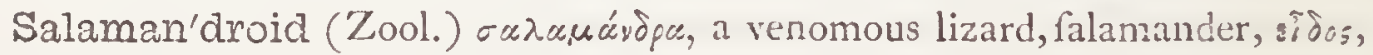
refemblance; Salamander-like.

Salar (Ichth.) Lat. a falmon.

Salep (Bot.) Arabic, Salleb; this name is applied to a farina procured from the dried roots of a fpecies of Orchis.

Salicallis (Ent.) feeds on Sallows and Ofiers (Salix Capres and viminalis.) Salica'rius-a-um (Ornith., Bot.) Jalix, a willow; willow..like; in Bot. from refemblance of leaves; e.g., Lythrum Salicaria.

Salice'tum (Bot.) Lat. a collection or plantation of fpecies of willow.

Sal'icis (Ent.) feeds on the willow (Salix.)

Salicor'nia (Bot.) fal, falt, corm, a ho:n; Glaflwort or Saltwort; a genus of Chenopodiacere.

Salisbu'ria (Bot.) P. N. in honour of R. A. Salisbury, F.R.S., a distinguifhed botanift; a remarkable Japanefe genus of Taxacex.

Sa'lius (Ent.) Lat. a leaper or jumper ; a genus of Hymenoptera.

Sarix (Bot.) Lat. a willow-tree; the Willow; typical genus of Salicacer. Sal'mea (Bot.) P. N. in honour of Prince Charles of Salm Dyke, in Holland; a genus of Compofitx. 
Sal'mo (Ichth.) Lat. a salmon.

Salmon (Ichth.) French, faumon; Lat. falmo.

Salmo'nidre (Ichth.) falmo, the falmon; the family of the Salmon and Trout. Sa'mulus (Ichth.) dim. of falmo, the salmon; the Samlet.

Salopiel'la (Ent.) was firft captured in the county of Salop; fpecific name of a moth.

Salpiglo'ssis (Bot.) $\sigma \alpha \dot{\lambda} \pi \cdot \gamma \xi$, a tube, $\gamma \lambda \tilde{\omega} \sigma \sigma a$, a tongue, in reference to the tongue- Phaped fyle in the tube of the corolla; a genus of Scrophulariaceæ.

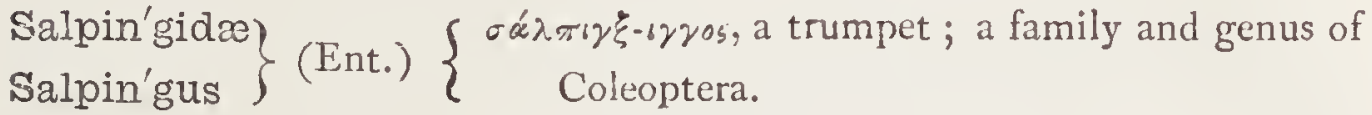
Sa'lsafy (Bot.) name given to the efculent roots of 'Tragopogon porrifolius ; corrupted from fol-fequens, following the fun, which the flowers do.

Salso'la (Bot.) falfus, falt, from its faline properties; Saltwort; a genus of Chenopodiacex.

Saltici'dæ (Ent.) fam. of Spiders, of which the genus Salticus is the type.

Sal'ticus (Ent.) Lat. dancing, jumping; a genus of Arachnidx.

Sal'via (Bot.) falveo, to be in good health, in reference to its healing qualities; how highly these were efteemed by the ancients may be gathered from the verfe:- "Cur moriatur homo cui Salvia crefcit in horto?"-a genus of Labiatæ.

Salvin'ia (Bot.) P. N. in honour of Antonio Maria Salvini, Greek Profeffor at Florence, who died in I729; a genus of Marfileacea.

Sambuca'lis (Ent.) feeds on the Elder, (Sambucus nigra and Ebulus.)

Sambu'cus (Bot.) faid to have been fo called from oupeíxn, an ancient mufical inftrument, perhaps the dulcimer, which was made of its wood; the Elder; a genus of Caprifoliacer.

Samo'lus (Bot.) Celtic, fan, falutary, mos, a pig; the plant originally fo-. called was pigs' food; Brook-wveed; a genus of Primulaceæ.

Sam'phire (Bot.) from the French St. Pierre_" Galli enim et Itali Herbam Sancti Petri vocant."-Ray., Syn. Stirp. Brit. p. xı. The true Samphire is Crithmum maritimum.

Samy'da (Bot.) Greek name of the birch; a genus of tropical plarts.

Sa'nctuary (Bot.) corruption of centaury, (Erythraa Centaurium.)

Sando'ricum (Bot.) fantoor, the aboriginal name; a genus of Meliacex.

Sanguina'lis (Bot.) fanguis, blood; fpec. name of a Digitaria : this is not taken from its colour, but from an idle trick which the boys in Germany have of pricking their noftrils with the fpiculæ till they draw blood.-Curtis. 
Sanguina'ria (Bot.) fanguis, blood, from the blood-coloured juice of the root; Blood-root; a genus of Papaveracex.

Sanguisor'ba (Bot.) fanguis, blood, forbeo, to abforb ; Burnet; typical genus of Sanguiforbacez.

Sani'cula (Bot.) fano, to heal, from its fuppofed healing qualities; a genus of Umbellifer æ.

Sansevie'ra (Bot.) P. N. in honour of Sanfevier, a Swedifh botanift; a genus of Liliacei.

San'talum (Bot.) fundul-fufed, its Perfian name; Sandal-wood; typical genius of Santalace

Santoli'na (Bot.) fantus, holy, linum, flax, from its reputed medicinal qualities; a genus of Compofitie.

Sanvita'lia (Bot.) P N, a genus of Compolitæ.

Saphe'nia (Zool.) caфvrris, clear, diftinct.

Sapin'dus (Bot.) Sapo Indus, Indian foap; the fruit gives a lather to water which cleanfes linen; typical genus of the fplendid arborefcent order Sapindaces.

Sapium (Bot.) fapo, foap, which is perhaps from Celt. Sap, fat; from the fatty exudation from the wounded trunk; a genus of Euphorbiacex.

Sapona'ria (Bot.) fapo, foap ; from its fap giving a lather like that of foap ; a genus of Caryophyllacex.

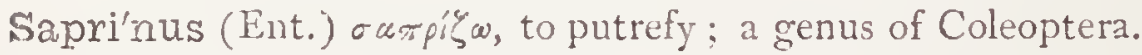

Sa'racha (Bot.) P. N. in honour of 7. Saraclia, a Spanilh botanif ; a genus of Solanacem.

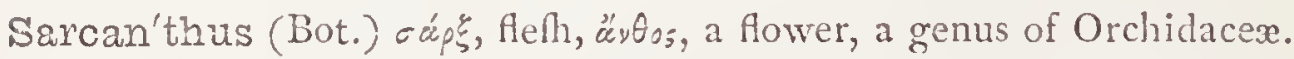

Sarcio'phorus-a-um (Ornith.) eupriov, a caruncle, фopáw, to bear; having wattles.

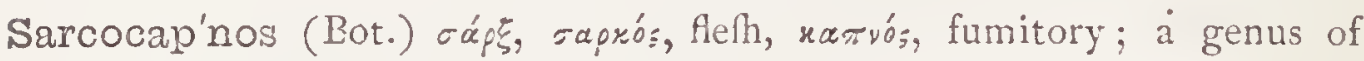
Fumariacese.

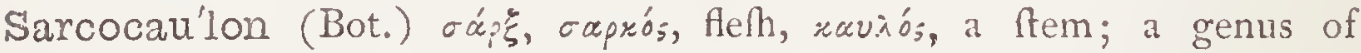
Geraniacex

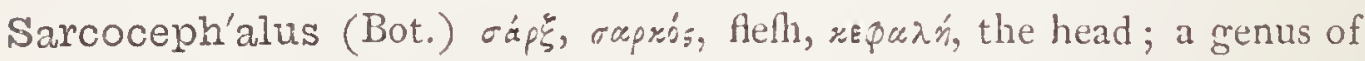
Cinchonacex.

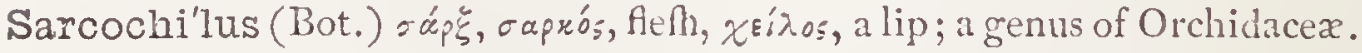

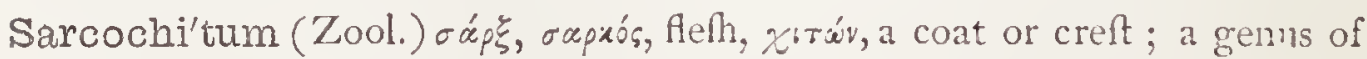
Polyzoa.

Sarcococ'ca (Bot.) capł, oxprós, flefh, rórros, a berry; a genus of Euphorbiacere.

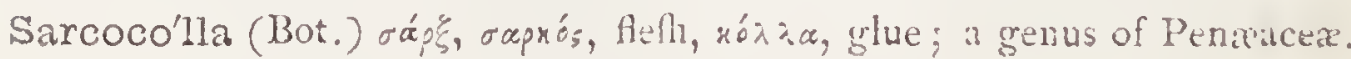




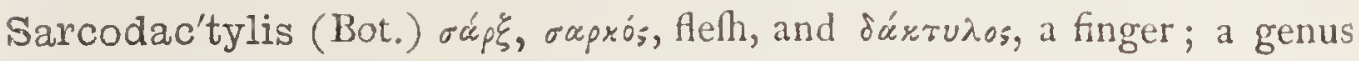
of Aurantiacex.

Sarco'de (Zool.) oxprwions, flefhy; applied to the gelatinous and femitranfparent fubftance found in the fimpleft forms of living creatures.

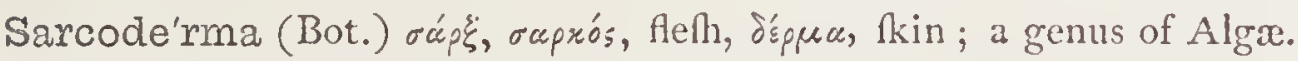

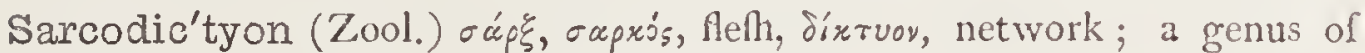
Zoophytes.

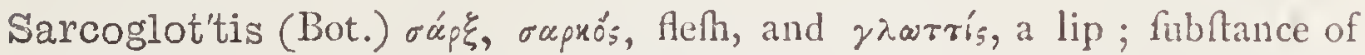
labellum; a genus of Orchidacex.

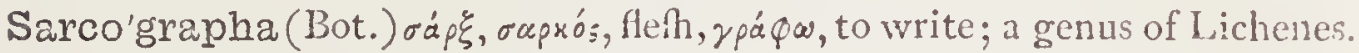

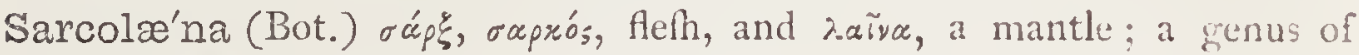
Chlænaceæ.

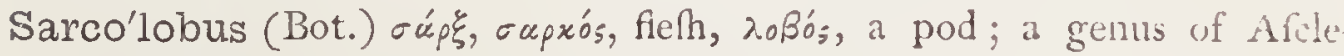
piadacex.

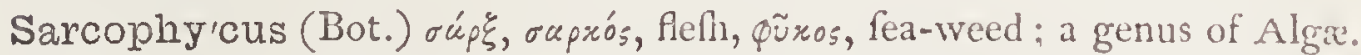

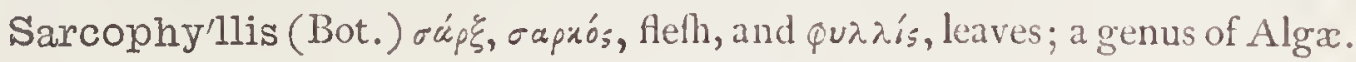

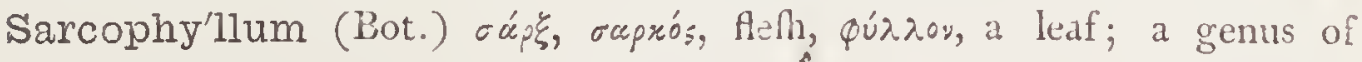
Leguminofæ.

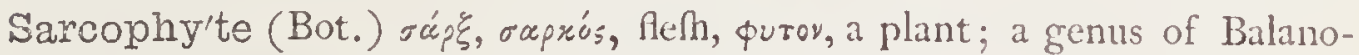
phoracere.

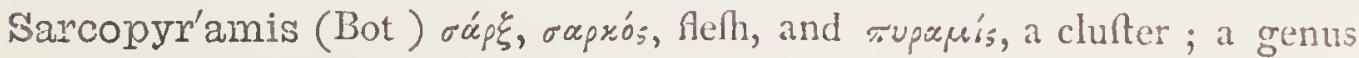
of Melaftomaceæ.

Sarcorham'phus (Ornith.) eáp乡, oxprós, flefh, fáupos, the crooked beak of birds of prey; the Condors.

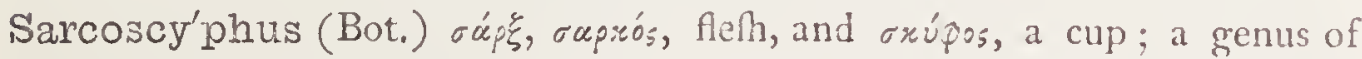
Jungermanniaceæ.

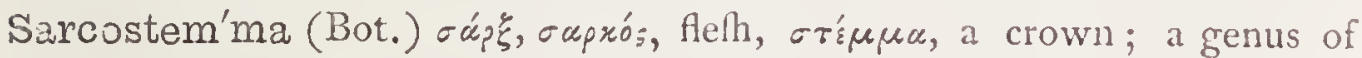
Afclepiadacex.

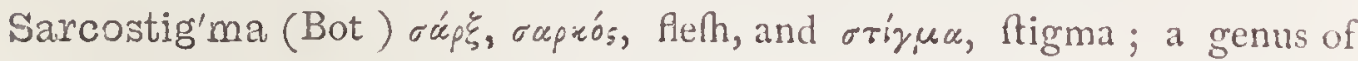
Thymelacex.

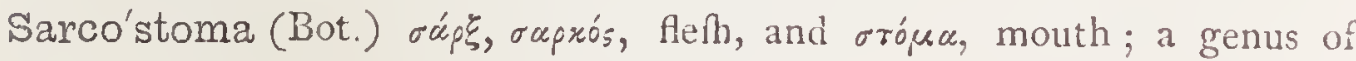
Orchidacex.

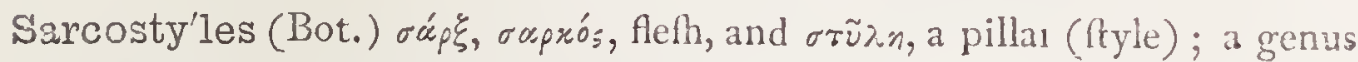
of Hydrangeacex.

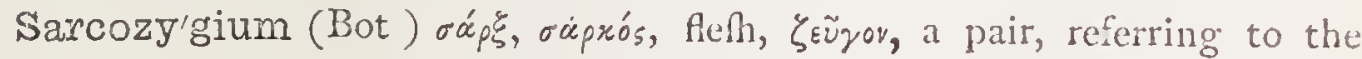
oppolite leaves; a genus of Zygophyllaceæ.

Sargas'sum (Bot.) Spanij, fargazo, fea-rveed; Gulf-weed; a genus of Marine Algre.

Sarma'ticus-a-um (Zool., Bot.) Lat. belonging to Poland. 
Sarmenta'ceæ (Bot.) farmentum, a long hoot or twig; Ventenat's excellent name for the Vitacee.

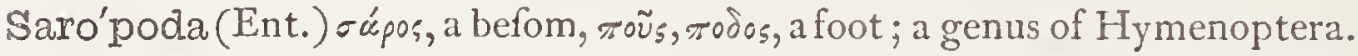
Sarosan'thera (Bot.) oúpos, a befom, àv $\theta$ npa, anther; a genus of Ternftrömiacex.

Saro'tes (Bot.) rapúrns, a fweeper; a genus of Byttneriacex.

Sarotham'nus (Bot.) oúpos, a broom, $\theta x_{\iota} u v_{s}$, a hrub; a genus of Legu. minofx.

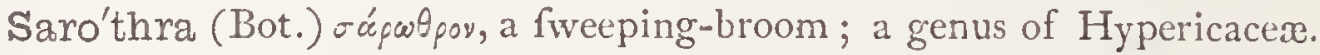

Saro'thripus (Ent.) cúpwipor, a fiveeping-broom, $\pi \approx \tilde{\nu}$, the foot ; from "the brufhes of hair which are attached to the fore-legs."-Curtis.

Sarothrosta'chys (Bot.) the genus Sarothra, and oráxvs, a fpike; a genus of Euphorbiacex.

Sarpedo'nia (Bot.) P. N. in mythology; a genus of Ranunculaceæ.

Sarrace'nia (Bot.) P. N. in honour of Dr Sarrazin, a French phyfician;

typical genus of North American Order Sarraceniacex; the Waterpitcher or Side-faddle-flower family.

Sarsapari'lla (Bot.) literally " thorny vine," from Spanif, zarza, a bramble, parilla, a vine; a genus of Smilacex.

Sa'rsia (Zool.) P. N. in honour of M. Sars, a learned zoologitt ; a genus of Medufie.

Sasan'qua (Bot.) the Japanefe name; a beautiful fpecies of Camellia.

Sas'safras (Bot.) formed, through the Italian, from Lat. faxum, a rock, frango, to break; Span. Salfafras; Fr. fafafras; a genus of Lauraceæ. Saturatel'lus-a-um (Ent.) faturatus, full, rich (of colour).

Sature'ja (Bot.) Jätter, the Arabic name for all labiate plants ; Sarory; a genus of Labiatie.

Satur'nia (Bot.) P. N. of Mythology; a genus of Liliacex; alfo the "Hen and Chickens" Daify,

Satyri'dium (Bot.) the genus Satyrium, Eidos, likenefs; a genus of Orchidacex.

Saty'rium (Bot.) fatyrus, a fatyr, from its ftrange figure; a genus of terreftrial Orchidacez.

Sat'yrus (Zool., Ent.) sárupos, a fatyr, a fabled animal and companion of Bacchus, reprefented with pointed ears and a goat's tail and legs; applied both to a Monkey and a Butterfly.

Saucia'nus-a-um (Ent.) faucius, wounded, injured.

Saurauja (Bot.) P. N. in honour of Sabraujo, a Spanilh botanift(?);

a genus of Dilleniacir. 


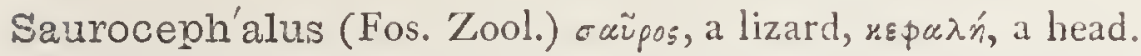

Sauroglos'sum (Bot.) $\sigma \alpha \tilde{\nu} p o s$, a lizard, and $\gamma^{\lambda \tilde{\omega} \sigma \sigma \alpha, ~ a ~ t o n g u e: ~ a ~ g e n u s ~ o t ~}$ Orchidaceæ.

Sau'roids (Ichth.) oaũpos, a lizard, sî̀os, likenefs; Lizard-fifhes.

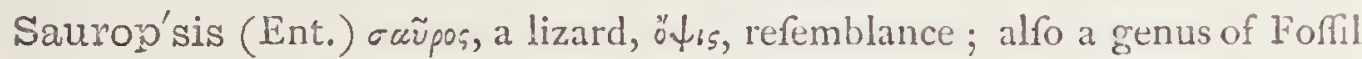
Filhes.

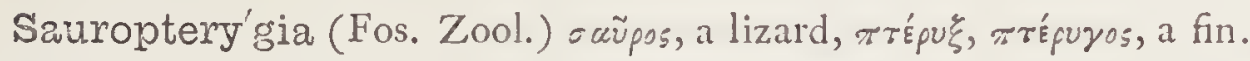

Sau'ropus (Bot.) caũpos, a lizard, $\pi$ ov's, a foot ; a genus of Euphorbiaceæ. Saurothe'ra (Ornith.) cavpwrńp, a fpike, from its long fraight bill.

Sauru'rus (Bố.) ocūpss, a lizard, ỏvá, a tail ; typical genus of Saururactx.

Saussu'rea (Bot.) P. N. in honour of Horace Benedict de Saufure, a Swifs

philofopher and botanin, who died in 1799 ; a gerus of Compofitxe.

Sautéria (Bot.) P. N., a genus of Marchantiacex.

Sautie'ra (Bot.) P. N., a genus of Acanthacex.

Sauvage'sia (Bot.) P. N. in honour of F. L' de Sanvages, a French phy-

fician, who died in 1767 ; typical genus of Sauvagesiaceit.

Savasta'nia (Bot.) P. N., a genus of Melaftomacea.

Sa'via (Bot.) P. N., a genus of Leguminofie.

Savig'nia (Ent.) P. N. in honour of Savigny, a French naturalint.

Savignya (Bot.) 1. N., a genus of Cruciferx.

Savinio'nia (Bot.) P. N., a genus of Malvaceie.

Saxa'tilis-e (Ornith., Ent, Bot.) Lat. that dwells among ftones, cs.

Veronica faxatilis.

Saxe-Go'thæa (Bot.) P. N., named in compliment to his late Royal Highnefs Prince Albert.

$\left.\begin{array}{l}\text { Saxi'cola } \\ \text { Saxicoli'næ }\end{array}\right\}$ (Ornith.) $\left\{\begin{array}{l}\text { saxum, a rock, colo, to inhabit; the Wheatear } \\ \text { genus and family. }\end{array}\right.$ Sixi'fraga (Bot.) fuxum, a ftone, frango, to break; from its repured medical qualities in calculus; typical genus of Saxifragacex.

Sca'ber-bra-brum (Zool., Bot.) Lat. rough, furfy.

Scabéria (Bot.) P. N., a genus of Algæ.

Scabio'sa (Bot.) fcabies, leprofy ; from its medicinal qualities; the Scabious ;

a genus of Dipfacacex.

Scabio'sus-a-um (Bot.) Lat. rough, feurfy, e. g. Centaurea fabiofa.

Scabra'lis (Ent.) fcaber, rough; alluding to the raifed fcales on the forewings,

Scabrita (Bot.) fcaber, rough, furfy ; a genus of Jafminacex.

Sca'voia (Bot.) fcera, that ufes the left hand; a genus of Goodeniacex. 


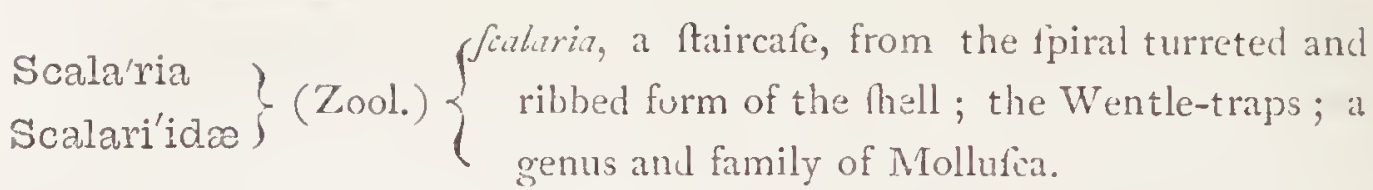

Scala'ris (Ent.) Lat. of or belonging to a ladder.

Scale-mosses (Rot.) popular name of Jungermanniacex.

Sca'lia (Bot.) P. N., a genus of Compofitre.

Scali'gera (Bot.) P. N., a genus of Leguminofx.

Scalige'ria (Bot.) P. N., a genus of Umbelliferse.

Scalio'ps ss (Bot.) the genus Scalicl, and of $\psi^{\prime} ;$, refemblance; a genus of Compofitxe.

Sca'lops (Zool.) oid $\lambda_{0}$. , a mole; the Shrew mole.

Scalpel'lum (Zool.) Lat. a lancet; a genus of Cirripedes.

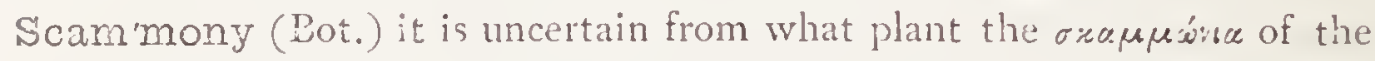

Greeks "was derived; the name is now given to purgative refins derived from Convolvulacex and Afclepiadacer.

Scan'diz (Bot.) รxx́sb's, a kind of wild pot-herb; a genus of Umbelliferx.

Scapa'nia (Bot.) $\sigma * a \pi u_{i}$, it a hoe; a genus of Jungermanniacex.

Ścaphidi'idx) (Ent.) dim. of oxapi;, a bowl; a family and genus of Scaphídium 5 Colcoptera.

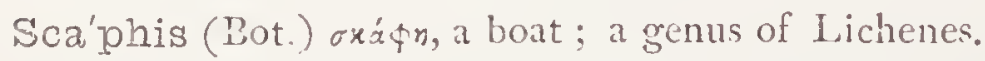

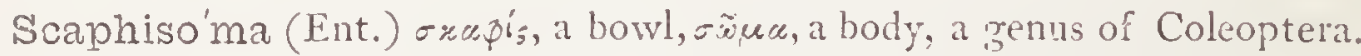

Sca'phium (Bot.) $\sigma \% \alpha \dot{p} n$, a boat or Riff; a genus of Sterculiacere.

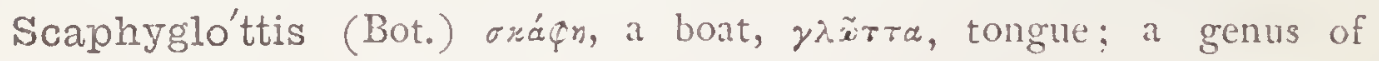
Orchidace:

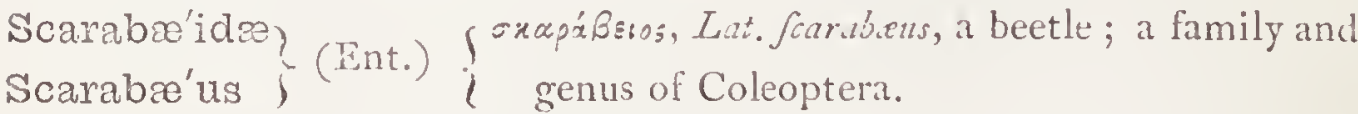

Sca'rabus (Zool.) applied to a genus of land-fhells, probably from a refemblance to the beetle, jarabius.

Scarede'deris (Bot.) etymology uncertain ; a genus of Orchidacer. Scari'ola (Bot) doubtful ; fpecific name of a fpecies of wild Lettuce. Scari'tes ; (Ent.) $\left\{\begin{array}{r}\text { Lat. a kind of precious ftone of the colour of the } \\ \text { firh Scarus; a genus and family of Coleoptera. }\end{array}\right.$ Sca'su (Ichth.) Lat. a very delicate kind of fin mentioned by Pliny, of which \{ange tales were told; a genus of Labridx.

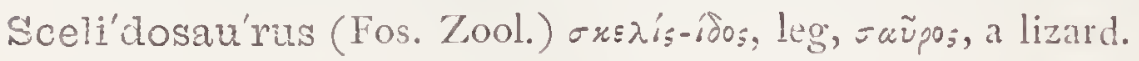

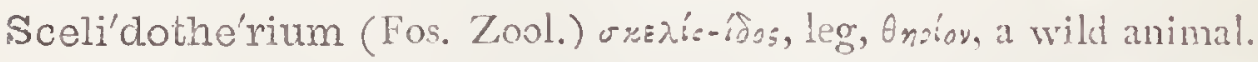

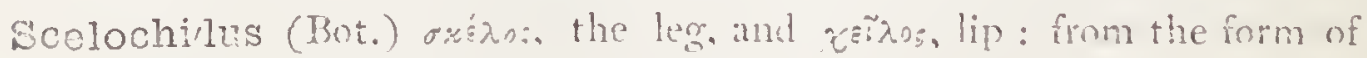
labellum in this Epiphyte a gems of Orchidaces. 


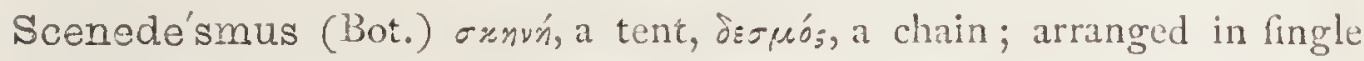
linear feries, fide by lide; a genus of Defmidiex.

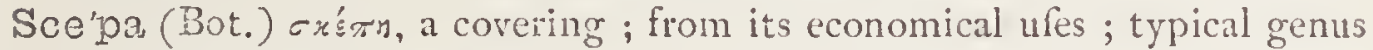
of Nat. Ord. Scepacex.

Scepas'ma (Bot) รx'́r $\alpha \sigma \mu x$, covering, ihelter; a genus of Euphorbiacer.

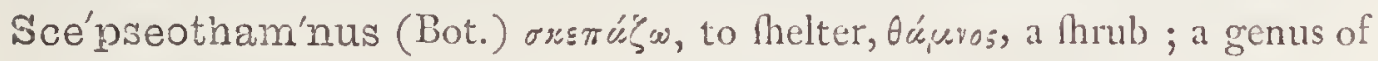
Cinchonacex.

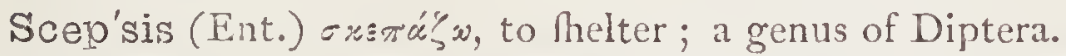

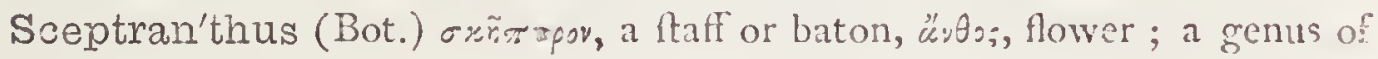
Amaryllidacer.

Sceptromy'ces (Bot) orñ Fungi.

Schaeffe'ria (Bot.) P. N. in honour of F.mmes Chriflizn Schaefer, a German naturalift and writer upon Fungi; a genus of Rhamnacere

Schænlei'nia (Bot.) P. N.; a genus of Cinchonacex.

Schalleria'na (Ent.) P. N. in honour of Schaller, a member of the fcientific focieties of Berlin, Halle, and Jena, who publifhed feveral works between 1735 and 1805 .

Schangi'nia (Bot.) P. N., a genus of Chenopodiacex.

Schasma'ria (Bot.) P. N., a genus of Lichenes.

Schau'era (Bot.) P. N., a genus of Lauracex.

Sohaue'ria (Bot.) P. N., a genus of Labiatr.

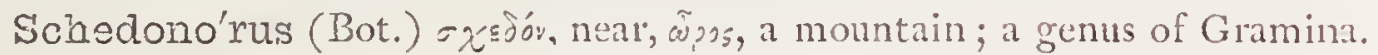
Sche'fflera (Bot.) P. N., a genus of Araliaceæ.

Schelham'mera (Bot.) P. N. in honour of C. C. Schellammer, Profeflor at Jena; a genus of Melanthacex.

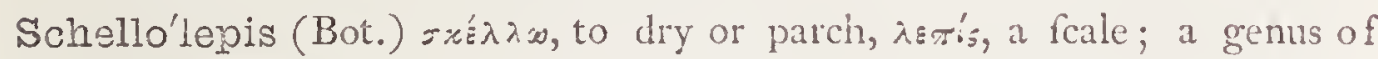
Polypodiaceæ.

Schelve'ria (Bot.) P. N., a genus of Scrophulariacer.

Scheppe'ria (Bot.) P. N., a genus of Capparidacea.

Scheuchze'ria (Bot.) P. N. in honour of Folin and fames Scheuchaer, German botanifts; a genus of Juncaginacer.

Schie'kria (Bot.) P. N., a genus of Liliacere.

Schil'lera (Bot.) P. N. in honour of the illuntrious German poet and dramatift; a genus of Byttneriacex.

Schille'ria (Bot.) P. N. in honour of the fame; a genus of Piperace:e.

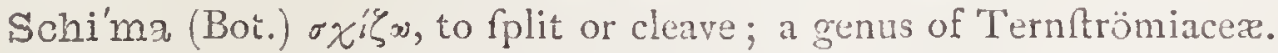

Schim'pera (Bot.) P. N. in hono.r of the diftinguifhed bryologit?; a genus of Cruciferie. 
Schi'nus (Bot.) = xivos, the Greek name for Piftacia Lentifcus, the Maftictree; a genus of Terebintacex.

Schin'za (Bot.) P. iv., a genus of Euphoribiacer.

Schis'ma (Bot.) oxiל̧, to fplit; a genus of Jungermanniacex.

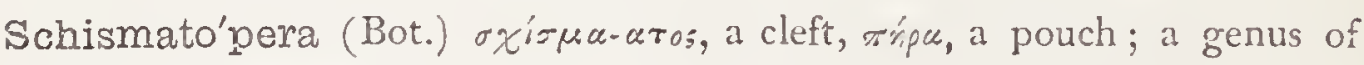
Euphorbiacer.

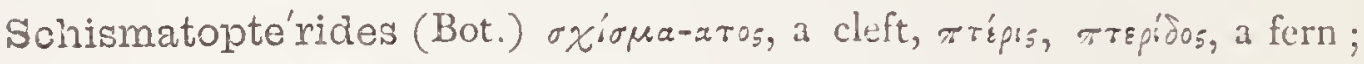
a fection of Polypodioid Filices.

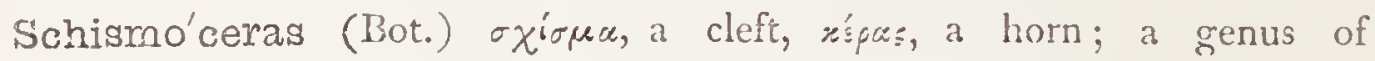
Orchidacex.

Sohis'mus (Bot.) $\sigma \chi^{i} \sigma \mu \alpha$, a cleft; a genus of Gramina.

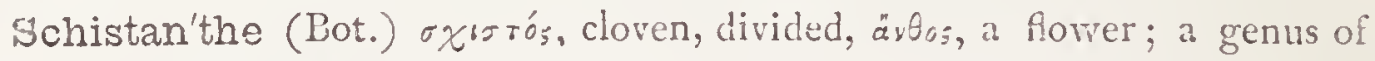
Scrophulariacer.

Schi'stas (Ornith.) $\sigma \chi^{\prime}$ 's $\omega$, to divide; in allufion to the forked tail; a genus of Humming-birds.

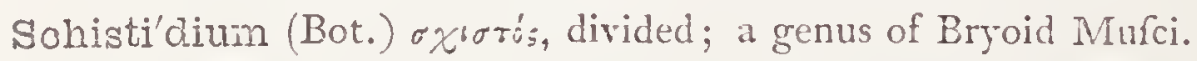

Sohistocar'pha (Bot.) oxroró, divided, xúppos, a carpel (literally; huR:); a genus of Compclite.

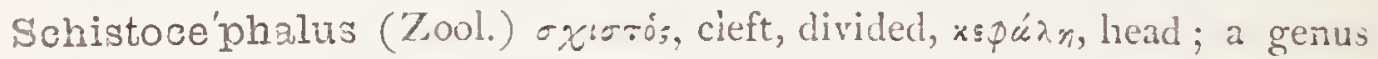
of Entozoa, or inteftinal worms.

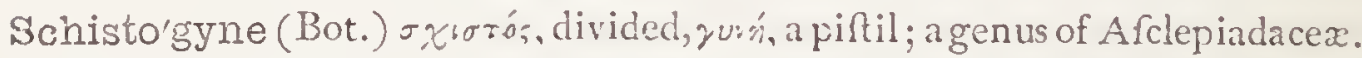

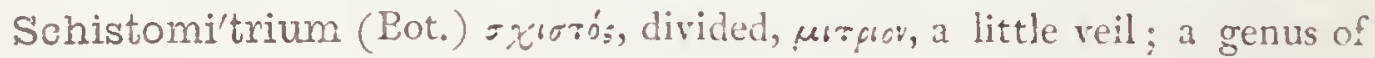
Mofles.

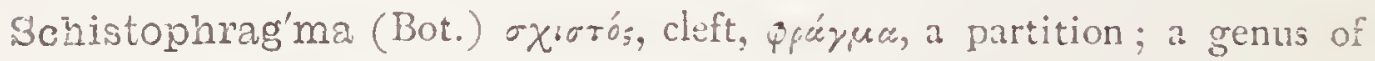
Scrophulariacex.

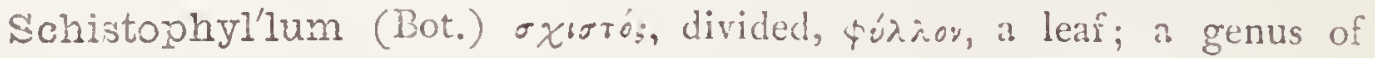
Bryoid Mufci.

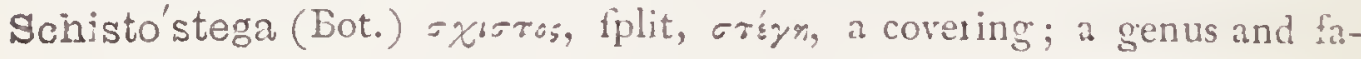
mily of Mufci.

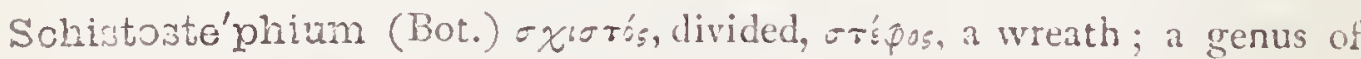
Compofitr.

Sohiwere'ckia (Bot.) P. N. in honour of Andreal Schivereck, a Rufitian botanift; a genus of Cruciferre.

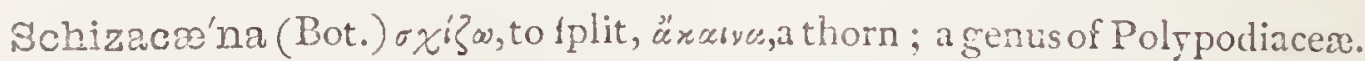

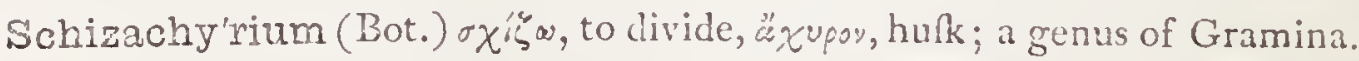
Schiza'a (Bot.) $=x$ ' like fpikes; a genus of Polypodiaces.

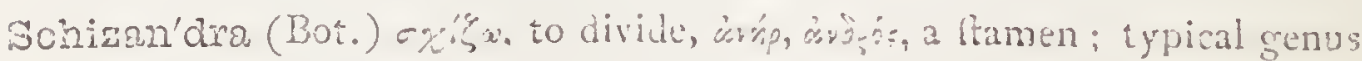
of Schizandractiv. 
Sohizan'gium (Bot.) $\sigma \chi^{\prime \zeta \zeta} \omega$, to divide, áyzriov, a veflel (feed-vedlel or capfule); a genus of Cinchonacer.

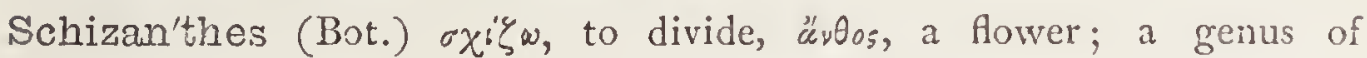
Amaryllidaceæ.

Schizan'thus (Bot.) $\sigma \chi \zeta \zeta \omega$, to cut, $\ddot{\alpha} \nu \theta_{0}$, a fower; a genus of Scrophu.. lariacex.

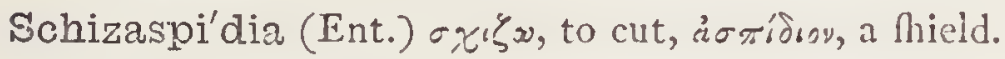

Schizocar'pis (Bot.) $\sigma x^{i} \zeta \omega$, to fplit, rapros, fruit; a divifion of Mufci.

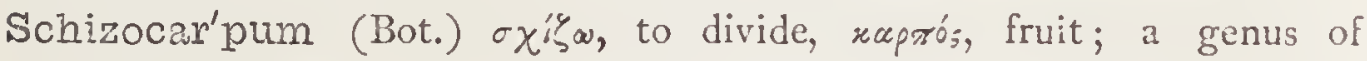
Cucurbitaceæ.

Schizoca'rya (Bot.) $\sigma \chi^{\prime \zeta}(x$, to divide, xáprov, a nut; a genus of Onagracex.

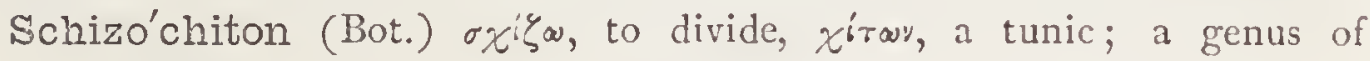
Lichenes.

Schizorhla'na (Bot.) $\odot \chi^{i \zeta} \omega$, to divide, $\chi^{\lambda u r v a, ~ a ~ m a n t l e: ~ a ~ g e n u s ~ o f ~}$ Polypodioid Filices.

Schizochla'mys (Bot.) $\sigma \chi^{\prime} \zeta \omega$, to fplit, $\chi \lambda \alpha \mu \dot{u}^{\prime}$, a mantle; a genus of Algx. Schizoco'don (Bot.) $\sigma \chi^{\prime \zeta \zeta \omega, ~ t o ~ d i v i d e, ~ x w i s w, ~ a ~ b e l l, ~ f r o m ~ t h e ~ d e e p l y ~ c l e f t ~}$ corolla; a genus of Polemoniacex.

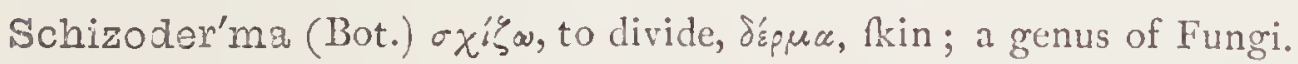

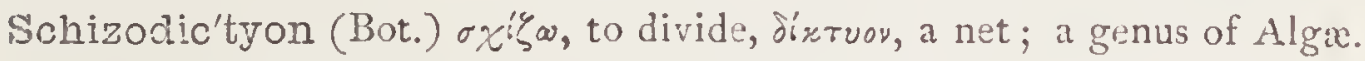

Schizo'dium (Bot.) $\sigma \chi \zeta, \omega$, to divide; a genus of Orchidacex.

Schizodon (Bot.) $\sigma \chi^{\prime} \zeta^{\omega}$, to divide, ódós, ojoorrós, a tooth; a genus of Bryoid Mufci.

Schi'zodon (Zool.) $\sigma \chi \chi^{\prime} \zeta$, to divide, odoú;-odovrós, a tooth.

Schizoglos'sum (Bot.) $\sigma \chi^{\prime \zeta} \omega$, to cleave, $\gamma \lambda \tilde{\omega} \sigma \sigma u$, a tongue; a genus of Algre.

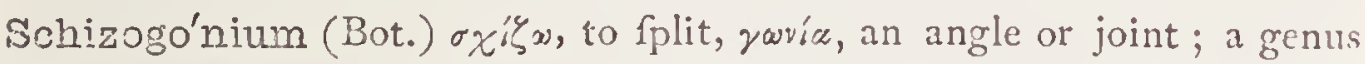
of Algæ.

Schizo'gyne (Bot.) $\sigma x^{i} \zeta \omega$, to divide, yurn, a piltil; from the deeply cleft ftigma; a genus of Compofitre.

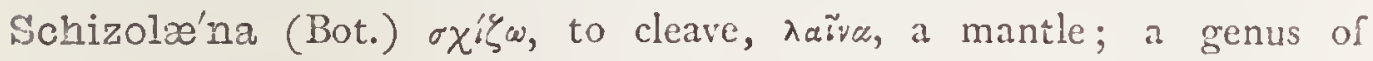
Chlænacex.

Schizo'lepis (Bot.) $\sigma \chi^{i} \xi_{5} \omega$, to divide, $\lambda \varepsilon \pi i_{5}$, a fcale; a genus of Gramina.

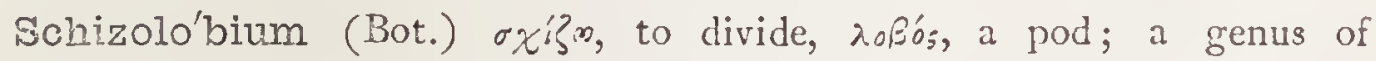
Leguminofx.

Schizolo'ma (Bot.) $\sigma \chi^{\prime} \zeta \omega$, to divide, $\lambda \tilde{\omega} \mu \alpha$, fringe or edge, alluding to the fronds; a genus of Polypodioid Filices.

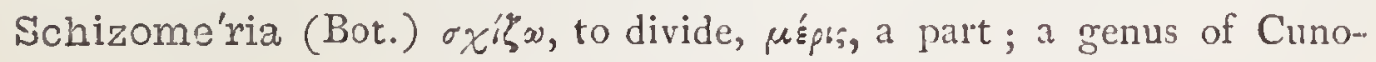
niacex. 
Schizo'meris (Bot.) fame derivation; a genus of Alga.

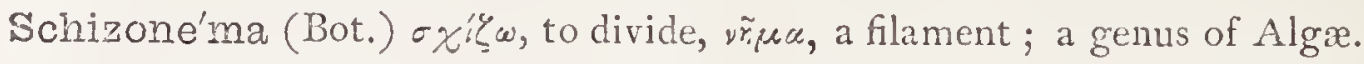

Schizono'tus (Bot.) $\sigma x^{\prime} \zeta^{\omega} \omega$, to divide, $v \tilde{\omega} \tau 0 s$, a ridge or back; a genus of Rofacex.

Schizope'talon (Bot.) $\odot \chi^{\prime} \zeta \omega$, to divide, $\tau^{\prime} \varepsilon \alpha \lambda . \%$, a leaf; from the laciniated petals; a genus of Cruciferæ.

Schizophrag'ma (Bot.) $\sigma \chi^{\prime \zeta} \omega$, to divide, Qpázuce, a partition; a genus of Hydrangeacer.

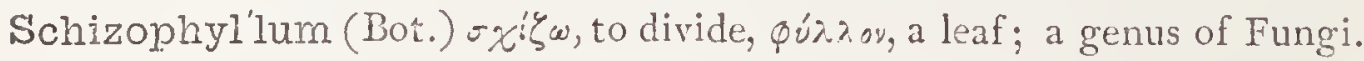
Schizopleu'ra (Bot.) $\sigma x^{\prime \prime} \omega$, to divide, $\pi \lambda_{\text {supor }}$, the fide; a genus of Myrtacere.

Schizop'teris (Fos. Bot.) $\sigma \chi^{\prime} \zeta^{\prime} \omega$, a cleft, $\pi \tau^{\prime} \operatorname{sps}_{\text {s }}$, a fern; foffil ferns fo called from their deeply cleft leaflets.

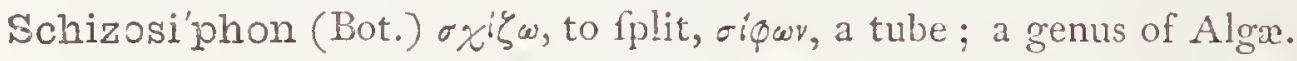

Schizosta'chyum (Bot.) $\sigma \chi^{\prime \zeta} \omega$, to divide, $\sigma \tau a ́ x v 5$, a clufter; a genus of Gramina.

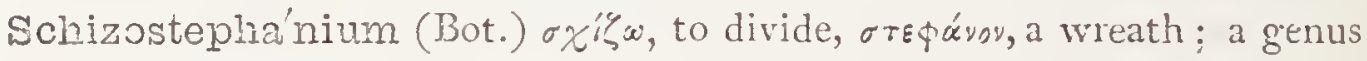
of Amaryllidaces.

Schizostig'ma (Bot.) $\sigma^{1} \boldsymbol{x}_{s} \omega$, to divide, criguce, a mark; a genus of Cucurbitacea.

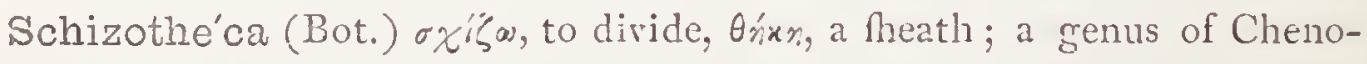
podiacer.

Schizothe'cium (Bot.) fame derivation; a genus of Fungi.

Schi'zothrix (Bot.) $\sigma x^{\prime} \zeta \omega$, to divide, $\theta_{5} \xi \xi$, hair or tuft; a genus of Algx.

Schizy'lon (Bot.) $\sigma \chi^{\prime} \zeta^{\omega} \omega$, to divide, $\xi u$ ìov, wood; a genus of Fungi.

Schku'hria (Bot.) P. N. in honour of Chrifian Schkuhr, a German botanift; a genus of Compofita.

Schlege'lia (Bot.) P. N. in honour of the eminent German metaphyfician; a genus of Crefcentiacea.

Schleiche'ra (Bot.) P. N. in honour of a Swifs botanift; a genus of Sapindacex.

Schleide'nia (Bot.) P. N. in honour of the eminent German author of "The Plant;" a genus of Ehretiacex.

Schler'odus (Fos. Zool.) $\sigma x \lambda n_{g} o_{s}$, rough, òous, a tooth; foffil fifhes fo called from the minute pufules on the furface of their teeth. The jaws and teeth are the only portions yet found.

Schlothei'mia (Bot.) P. N., a genus of Murci.

Schmide'lia (Bot.) P. N. in honour of C. C. Schmidel, formerly Profeftor of Botany, Academy of Erlangen; a genus of Sapindacex. 
Schmid'tia (Bot.) P. N.in honour of Schmidt, a German botanift; a grenus of Compolita.

Schobe'ria (Bot.) P. N., a genus of Chenopodiacex.

Schœnefel' dia (Bot.) l'. N., a genus of Gramina.

Schceni'culus (Ornith.) dim. of $\sigma$ xoivos, a reed; fpecific name of the Reed Bunting; Emberiza Schceniculus.

Schœni'dium (Bot.) oxorvos, Lat. fcherus, a rufh, eisos, refenblance; it genus of Gramina.

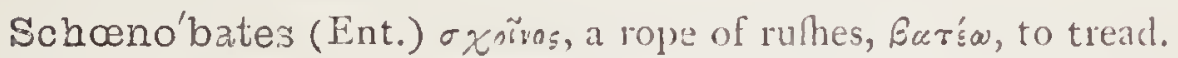

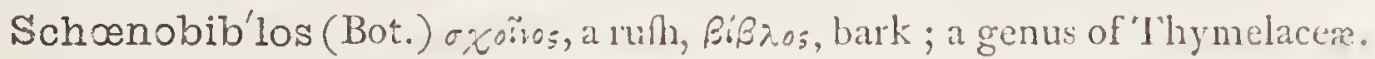

Schœno'bius (Ent.) oxoinvs, a rufh, Brów, to live; it is found among rufhes. Schœnobry'um (Bot.) oxoirvos, a rufh, Bpusv, bryım, a mofs; a genus of Mufci.

Schœnocau'lon (Bot.) oxorvos, a rulh, xavaós, Lat. caulis, al ftem; a genus of Melanthacex.

Schcnopra'sum (Bot.) oxoivon, a rith, roúzov, a leek; fpecific name of it fpecies of garlick.

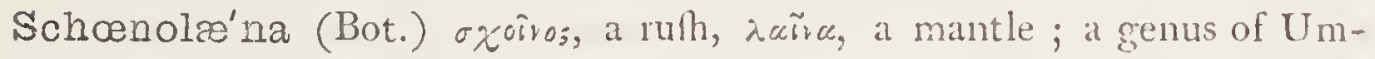
belliferie

Schœno'psis (Bot.) the genus Schanus, ö $\downarrow$ เ5, refemblance; a genus of Cyperacex.

Schœnor'chis (Bot.) oxoivos, a rufh, öpuss, an orchid; a genus of Orchidacere.

Schœnoxy'phium (Bot.) oxorvos, Lut. Schenus, a rulh, «upós, bent; a genus of Gramina.

Schc'nus (Bot.) oxoivos, a cord; it is made into cordage; a genus of Cyperacea.

Schœpfia (Bot.) P. N. in honour of John Schöpf, a German botanif; i genus of Olacacex.

Scho'llera (Bot.) P. N., a genus of Vacciniacere.

Schombur'ghia (Bot.) P. N., in honour of Sir Robert Schomburgh, a celebrated traveller in Demerala, and difcoverer of the Victoria Regia; a genus of Orchidacex.

Scho'nia (Bot.) P. N., a gentis of Compolitie.

Schori'geram (Bot.) one of Adanton's unmeaning names; a genus of Euphorbiacex.

Scho'tia (Bot.) P.N. in honour of R. van der Schot, Jacquin's fellowtraveller in America; a genus of Leguminofix.

Schousbra (Bot.) P. N., a genus of Compofitre. 
Schouten'sia (Bot.) P. N., a genus of Meliaceæ.

Schou'wia (Bot.) P. N. in honour of F. F. Schouw, a celebrated Danih botanift; a genus of Cruciferæ.

Schrädera (Bot.) P. N. in honour of Her. A. D. Schräder, a German hotanift and Profeflor at Göttingen; a genus of Cinchonacex.

Schran'kia (Bot., Ent.) P. N. in honour of Francis Paulo de Schrank, a German naturalift; a genus of Leguminofi.

Schre'bera (Bot.) P. N. in honour of an eminent German botanift and Profefior at Erlangen; a genus of Celaftracex.

Schraberia'na (Ent.) P. N. in honour of Fohann Chrifian Daniel von Schreber, author of "Novr Infectorum Species," \&c.

Schreiber'sia (Bot.) P. N., a genus of Cinchonacex.

Schrenkia (Bot.) P. N., a genus of Umbelliferæ.

Schuber'tia (Bot.) P. N. in honour of M. Schubert, a Polifh botanift; a grenus of Coniferx.

Schüchia (Bot.) P. N., a genus of Vochyaceæ.

Schu'fia (Bot.) P. N., a genus of Onagracer.

Schultes'ia (Bot.) P. N. in honour of an eminent German botanift; a genus of Gramina.

Schult'zia (Bot.) P. N. in honour of Carl Heinrich Schultz, a celebrated German botanif: a genus of Umbelliferæ.

Schumache'ria (Bot.) P. N., a genus of Dilleniacex.

Schwa'bea (Bot.) P. N., a genus of Acanthacer.

Schwägriche'nia (Bot.) 1. N. in honour of Frederick Schwägricken, a

Profeflor at Leipzig; a genus of Amyridacen.

Schwal'bea (Bot.) P. N., a genus of Scrophulariacex.

Schwan'nia (Bot.) P. N., a genus of Malpighiacex.

Schwarz'ia (Bot.) P. N. in honour of C. Schrvarz, a writer on Entomo$\operatorname{logy}$; a genus of Miarcgraaviacere.

Schwarziel'la (Ent.) P. N., fame derivation.

Schweig'gera (Bot.) P. N. in honour of Profeflor Schweigger, one of the authors of a Flora of Erlangen; a genus of Chufiacex.

Schweigge'ria (Bot.) P. N. fame derivation; a genus of Violaceæ.

Schweinit'zia (Bot.) P. N. in honour of M. Schreeinitz; a genus of Monotropacere.

Schwenkfeld'ia (Bot.) P. N., a genus of Cinchonacer.

Schwen'kia (Bot.) P. N. in honour of J. T. Schavenk, Profeflor of Medicine at Jena; a genus of Scrophulariaces.

Schweyckher'ta (Bot.) P. N., a genus of Gentianacex. 
Schychows'kya (Bot.) P. N., a genus of Urticacex.

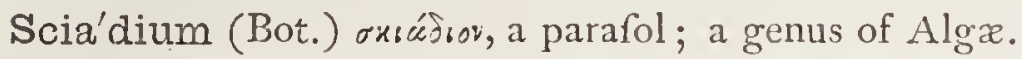

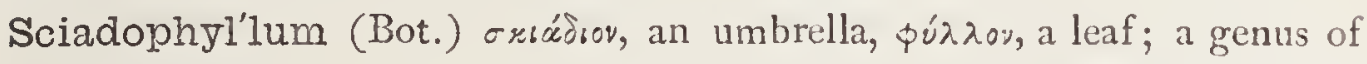
Araliaceæ.

Sciadophy'sium (Bot.) oxśx́sıv, an umbrella, $\varphi v \sigma^{\prime} \dot{\omega} \omega$, to inflate; a genus of Bryoid Mufci.

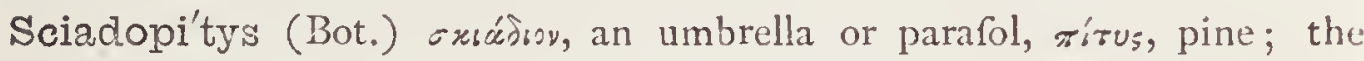
Umbrella pine; a Japanefe genus of Coniferx.

Sciæ'na (Ichth.) oxiasva, a fea-fifh; the Maigre.

Sciæ'nidæ (Ichth.) the family of the Maigre filhes, of which Sciand is the type.

Sciæ'noids (Ichth.) refembling (Eidos) the genus S'ciana.

Scia'phila (Bot.) Fxi $\omega$, thade, $\varphi \iota \lambda^{\prime} \omega$, to love; a genus of Artocarpacex.

Sciaph'ilus (Ent.) exice, thade, $\varphi \iota \lambda \varepsilon \tilde{v}$, to love; a genus of Coleoptera.

Scil'la (Bot.) $\sigma x u ́ \lambda \lambda \omega$, to injure; the roots are poifonous; Squill; a genus of Liliacex.

Scincoi'dians (Zool.) the genus Scincus, हi

$\left.\begin{array}{l}\text { Scin'cidæ) } \\ \text { Scin'cus }\end{array}\right\}$ (Zool.) $\left\{\begin{array}{l}\sigma x i y \gamma o s, \text { or oxiyros, the land crocodile or newt } \\ \text { about the Nile, mentioned by Pliny; a genus } \\ \text { and family of Reptilia; the Skinks. }\end{array}\right.$

Scindap'sus (Bot.) oxเvox tós of the Greeks was an ivy-like tree; a genus of Orontiacex.

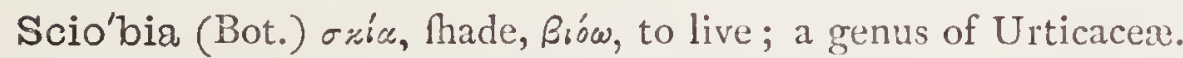

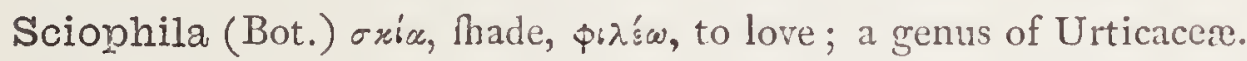

Sciotham'nus (Bot.) oríc, fhade, $\theta$ ćs $\mu$ s, a thrub; a genus of Umbelliferse.

Scipio'num (Bot.) the Calamus Scipionum yields the walking-canes, and bears this name in common with the noble Roman, P. Cornelizs, upon whom his father when blind leaned as on a ftaff, and who was called Scipio by his fellow-citizens.

Scirpid'ium (Bot.) dim. of Scirpus, an allied genus; a genus of Cyperaceas. Scir'pus (Bot.) Lat. a ruth; a genus of Cyperaceæ.

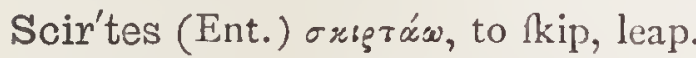
$\left.\begin{array}{l}\text { Scissurel'la } \\ \text { Scissurel'lidæ }\end{array}\right\}$ (Zool.) $\left\{\begin{array}{c}\text { dim, of fciflura, a rent or cleft; the Little lip- } \\ \text { mells; a genus and family of Mollufca. }\end{array}\right.$

Scitami'neæ (Bot.) Jcitamenta, dainties; the fplendid Nat. Ord. of plants reprefented by the Ginger-plant, \&c.

Sciuri'na (Zool.) ficurus; a fub-family of Mammalia. Sciuro'pterus (Zool.) foiurus, a fquirrel, $\pi \tau$ repóy, a wing.

Sciu'rus (Zool.) Lat. a fquirrel. 
Sclare'a (Bot.) Latinized from the word Clary, a well-known fpecies of Sage.

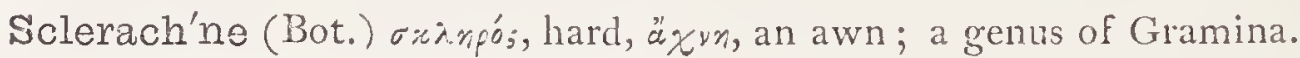

Scleran'thus (Bot.) $\sigma x \lambda n p^{\prime} \xi$, hard, $\ddot{\alpha}_{y} \theta_{0 \xi}$, a flower; from the dry, juicelets calyx ; typical genus of Scieranthacex.

Scle'ria (Bot.) $\sigma \times \lambda n$ gó , hard; a genus of Gramina.

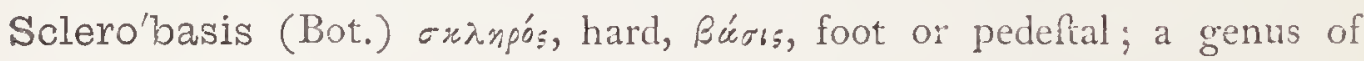
Compolitie.

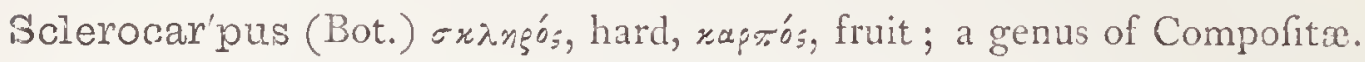

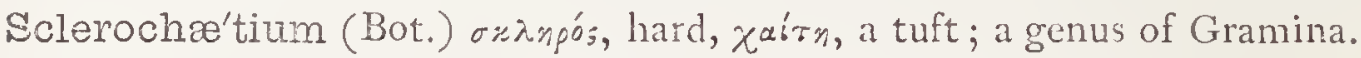

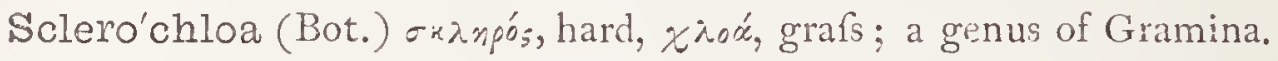

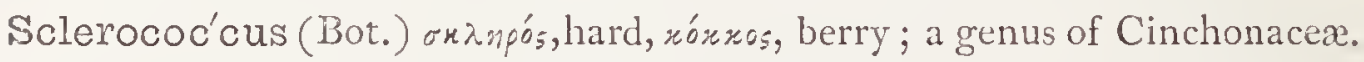

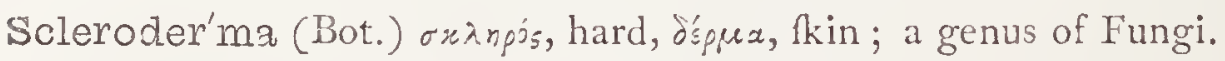

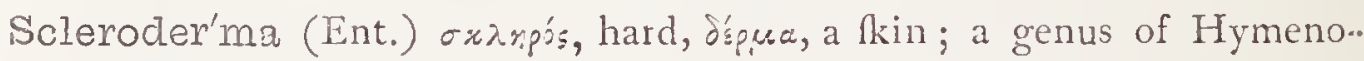
ptera.

Sclerodon'tium (Bot.) $\sigma \times \lambda$ nós, hard, joov;, joovtos, a tooth; a genus of Bryoid Molles.

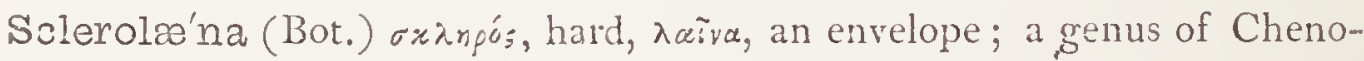
podiacer.

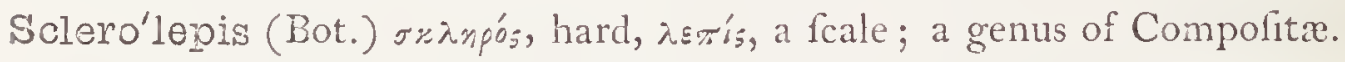

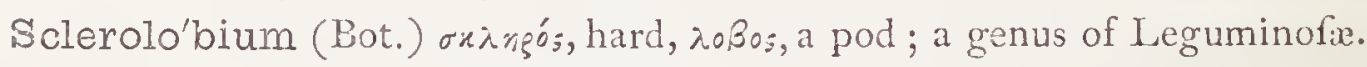

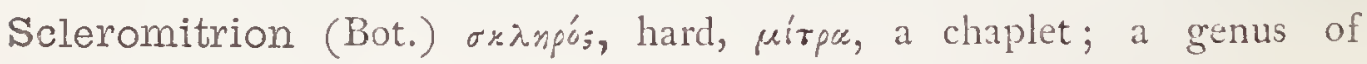
Cinchonacex.

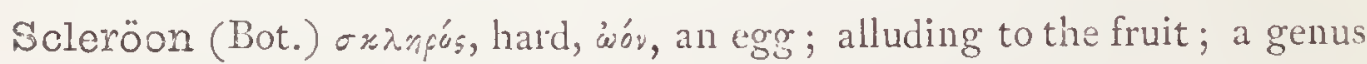
of Verbenacea.

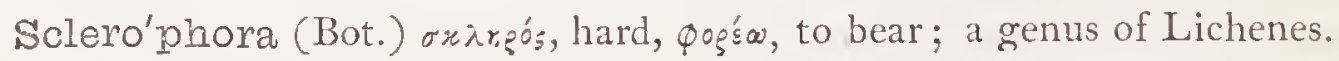

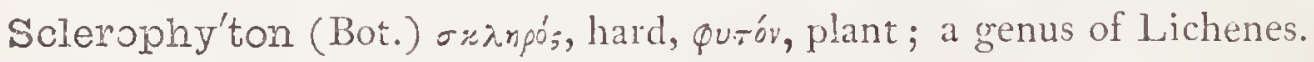

Scle'rops (Zool.) oxinpo's, hard, ${ }^{\prime} \psi$, the eye; e.g., Jacare fclerops, the fpectacled Yacure.

Sclerop'teris (Bot.) ๘xinpó; hard, $\pi \tau \varepsilon \rho^{\prime}=$, a fern; a genus of Orchidacea.

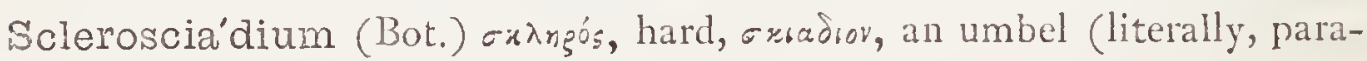
fol); a genus of Umbellifera.

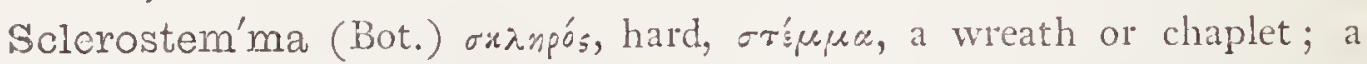
genus of Dipfacacex.

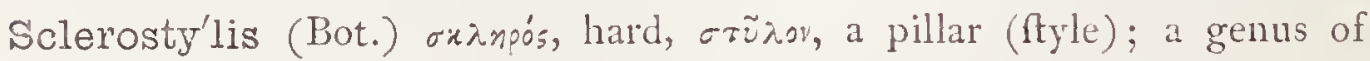
Aurantiacez.

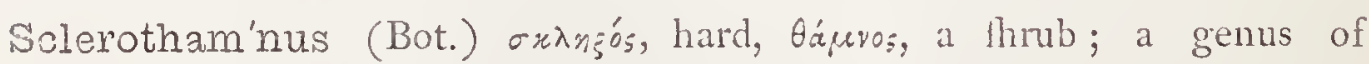
Leguminofx.

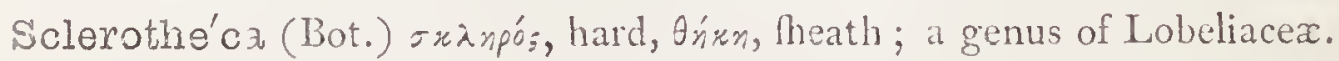




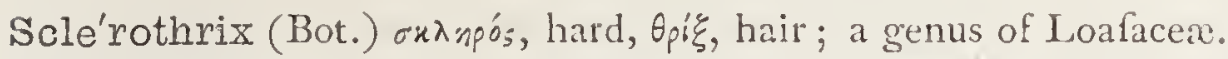

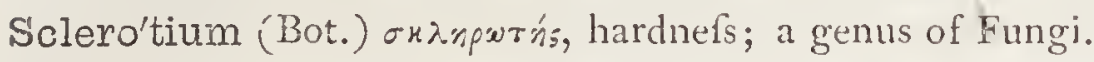

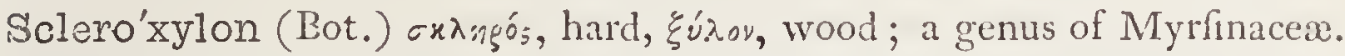

Sco'biform (Bot.) fcobis, powder or duft produced by fawing; like fine faw-dunt.

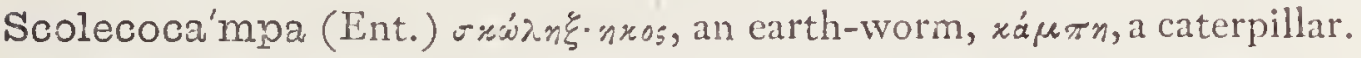

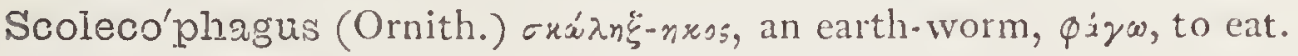

Scoleco'trichum (Bot.) "hairy-worm," from $\sigma x^{\prime} \lambda^{2} \xi_{\xi}-n x o s$, worm, $\theta_{\xi}$ ' $\tau p^{i} \chi \circ$ s, hair; a genus of Fungi.

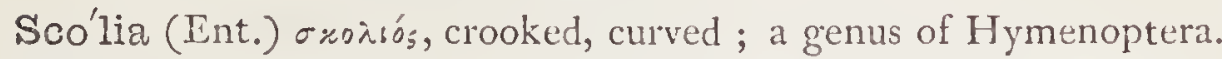

Scoli'adæ (Ent.) a family of Hymenoptera of which Scolia is the typical genus.

Scol'obus (Bot.) a genus of Leguminofx.

Scoloch'loa (Bot.) $\leftarrow x \tilde{x} \lambda_{.0}$, a prickle, $\chi x^{\circ} a$, grafs; a genus of Gramina.

Scolopacina (Ent.) fcolopax, a woodcock; from a refemblance to the plumage of this bird.

Sco'lopax (Ornith.) Lat. a woodcock.

Scolope'ndra (Zool.) Lat. a centipede.

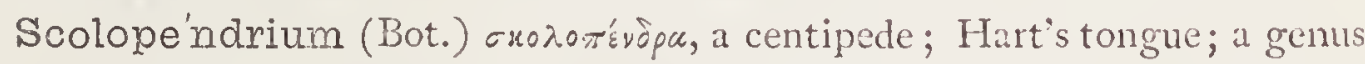
of Polypodioid Filices.

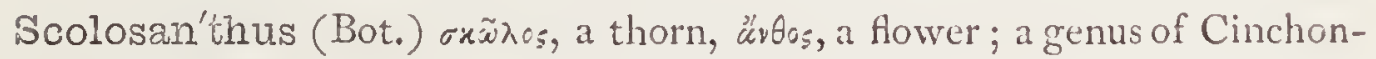
acex.

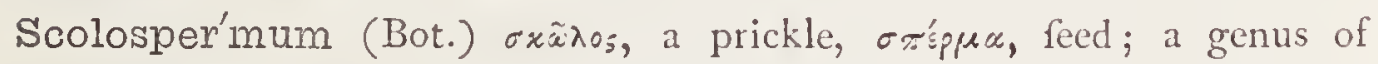
Compofitx.

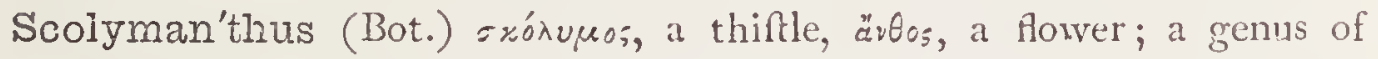
Compofitre.

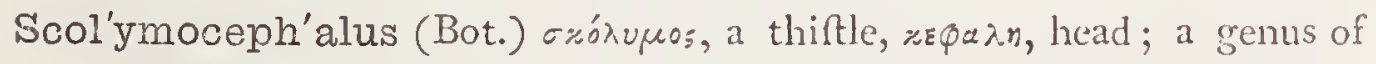
Proteacea.

Sco'lymus (Bot.) cxóros, a thorn; the plants are fpiny; a genus of Compofitx.

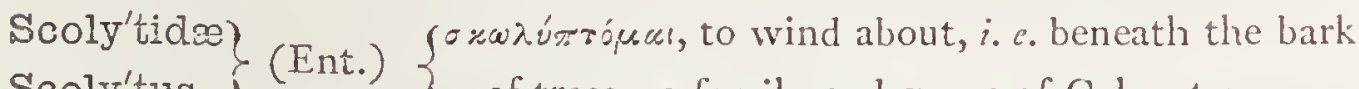
Scoly'tus $\}$ (Ent.) $\{$ of trees; a family and genus of Coleoptera.

Sco'mber (Ichth.) Lat. a mackerel; typical genus of the family Scomberidx.

Scomber'esox (Ichth.) fcomber, a mackerel, efox, an old name of a fint; the Gar-pike or Skipper.

Scom'beroid (Ichth.) fcomber, a mackerel, sidos, refemblance.

Scopa'ria (Bot.) fcoparius, a fweeper; a genus of Scrophulariacex.

Scopa'ria (Ent.) fopre, a broom or befom; alluding to its appearance. 
Scopa'rium (Bot.) foope, a broom; fpecific name of Spartium, the Broom ; from the ufe made of the twigs.

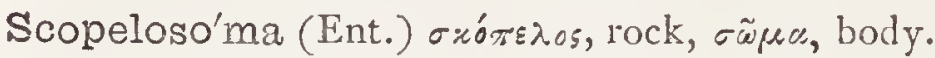

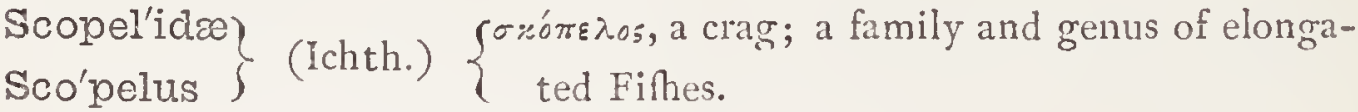

Scopo'lia (Bot., Ent.) P. N. in honour of G. A. Scopoli, a celebrated

Profeflor of Botany, who died in 1789 ; in Bot. a genus of Solanacex.

Scopoli'na (Bot.) P. N. in honour of J. A. Scopoli, a celebrated Profeflor

at Pavia, who died in 1787 ; a genus of Solanacex.

Sco'ps (Ornith.) oxw' $\psi$, an owl; a genus of the Crane family.

Sco'pula (Ent.) Lat. a little broom, a bruh.

Scopula'ria (Bot.) fcopulu, a little broom; a genus of Orchidacex.

Scopuli'na (Bot.) fiopulus, a rock; a genus of Jungermanniaceæ.

Scopulip'edes (Ent.) Scopula, a bruh, pes, pedis, a foot; a genus of Hymenoptera.

Sco'pus (Ornith.) oxstós, a fentinel, an obferver; a genus of Birds.

Sco'rdium (Bot.) oxóprov, a plant fmelling like garlic; now the fpecific name of the Marh Germander, a fpecies of Teucrium; a genus of Labiatx.

Scoria'iis (Ent.) $\sigma * \omega_{\xi}$ 'ú, the drofs of metal.

Sco'rias (Bot.) oxceipic, Lat. fcoria, fcum, drofs; a genus of Fungi.

Scorodo'nia (Bot.) oxósodov, garlic; fpecific name of the Wood-fage, or

Hedgerow Germander; a fpecies of Labiatr.

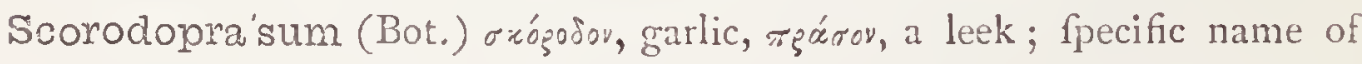
a pecies of Garlic.

Scorpa'na
Scorpæ'nida) (Ichth.) $\left\{\begin{array}{l}\text { rxópresus, fcorpion-like; from its fuppofed } \\ \text { power of inflikting incurable wounds; a } \\ \text { genus and family of Bull-headed Fifhes. }\end{array}\right.$

Scor'pio $\}$ (Zool.) $\{$ axoptiśr, Lat. Scorpio, a fcorpion; a genus Scorpio'nidze $\}$ (Zool.) $\left\{\begin{array}{l}\text { and family of Annulofe animals; clafs } \\ \text { Arachnida. }\end{array}\right.$

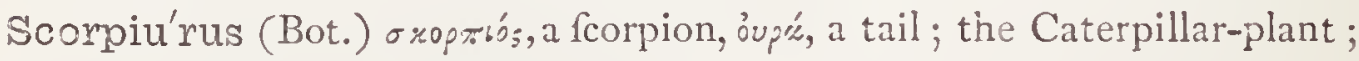
a genus of Leguminofie.

Scorzonel'ia (Bot.) dim. of Scorzonera; a genus of Compoliti.

Scorzone'ra (Bot.) the Spanilh name for a well-known pot-herb; a genus of Compofitx.

Sco'ticus-a-um (Ornith., Bot.) Lat. Scottihl, e. g. Ligufticum Scoticum.

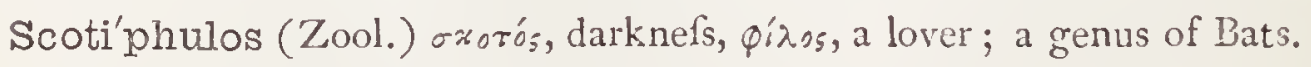
Scoto'sia (Ent.) бuorós, darknefs. 
Scott'ia (Bot.) P. N. in honour of Robert Scott, M.D., Lrofellor of Botany at Dublin ; a genus of Leguminofx.

Scriptura'lis (Ent.) foriptura, a marking.

Scrofula'ria or Scrophularria (Bot.) it has tubercles on the roots like fcrofulous tumouis; Figwort; typical genus of Scrophulariacex.

Scrupo'sus-a-um (Bot.) Lat. rough.

Scuta'tus-a-um (Zool., Bot.) Lat. Mielded, Mield-Rhaped; e.g. Rumex futatus.

Scutella'ria (Bot.) foutella, a falver; Rull-cap; alluding to the figure of the calyx; a genus of Labiati.

Scu'tia (Bot.) fautum, a fhield, from the form of the dink; a genus of Rhamnacere.

Scutica'ria (Bot.) foutica, a whip; in allufion to the form of the leaves; a genus of Orchidacex.

Scuto'sus-a-um (Ent.) foutum, a fhield.

Scutula'tus-a-um (Ent.) fcutula, a lozenge-fhaped figure; diamond-Thaped.

Scu'tum (Zool.) Lat. a Mield.

Scydmæ'nidæ (Ent.) the family of Coleoptera of which Scydmenus is the typical genus.

Scydmæinus (Ent.) exvouaiva, to be angry; to be of a forrowful countenance; a genus of Coleoptera.

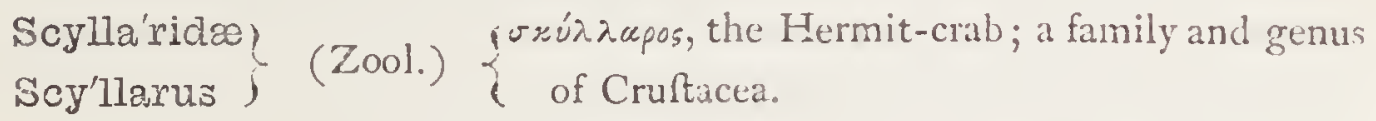

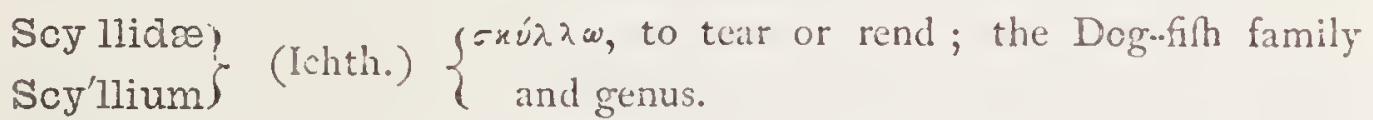

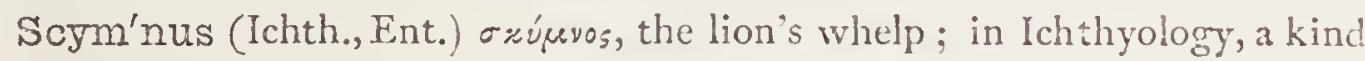
of Thark; in Entomology, a genus of Colcoptera.

Scyphan'thus (Bot.) =xúp̧os, a cup, äy Scy'phia (Zool.) exúpos, a drinking-bowl.

Soyphophiorus (Bot.) oxýpos, a drinking-bowl, Q'fpw, to bear; the Cup Lichens, a genus of Lichenes.

Scy'taia (Bô.) oxurú $\lambda$, a fick or cudgel; a genus of Compofitx.

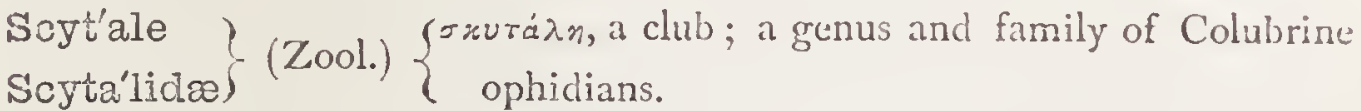
Scyta'lia (Bot.) fame derivation; a genus of Sapindacex. Scy'talis (Bot.) fame derivation; a genus of Leguminofie.

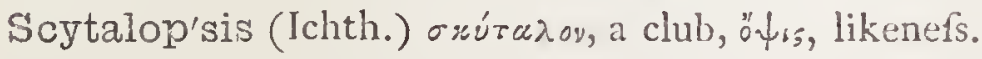

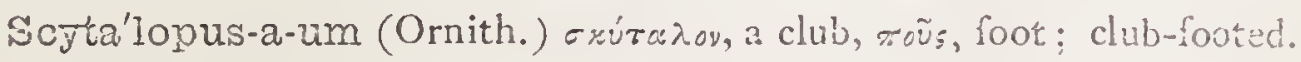
Scytan'thus (Bot.) zxuró, leathery, ür9os, flower; a genus of Afclepiadacen. 


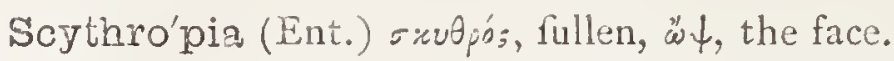

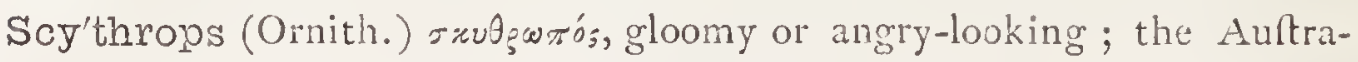
lian Rain-fowl.

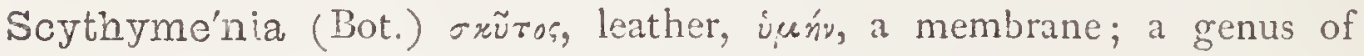
Cryptogamia.

Ścytordes (Ent.) r\%ursós, like leather.

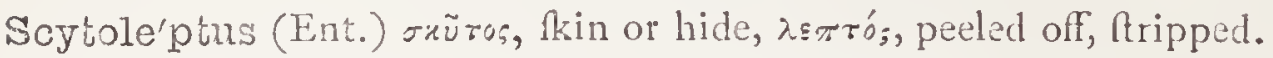

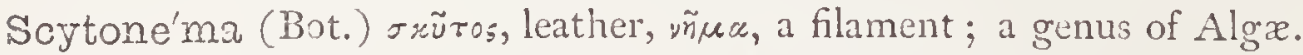

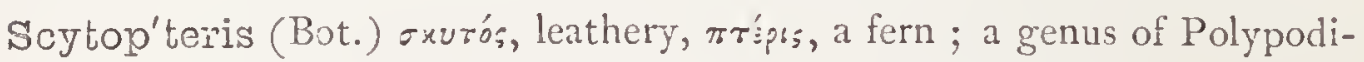
oid Filices.

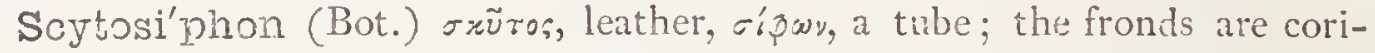
aceous and tubular; a genus of Algre.

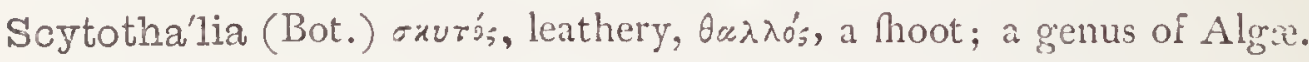

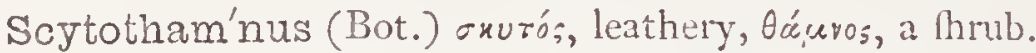

Sea-ioear (Zool.) the Aretocephalus urfinus.

$\left.\begin{array}{l}\text { Sea-calf } \\ \text { Sea-cow }\end{array}\right\}$ (Zool.) applied to certain fpecies of Phocida.

Sea-devil (Ichth.) applied to the genus Lophias.

Sea-ear (Zool.) the thell of Haliotis.

Sea-eggs (Zool.) the different kinds of Echinus.

Sea"fan (Zool.) certain fpecies of Polypifera have this name.

Seaforth'ia (Bot.) P. N. in honour of Franis, Lord Seaforth-" Botanices periti cultoris et fautoris;" a genus of Palmx.

Sea-fox (Ichth.) applied to a fpecies of the genus Squalis.

Sez-heath (Bot.) the fpecies of Frankenia.

Sea-holly (Bot.) the Eryngium maritimum.

Sea-Irale (Bot.) the Crambe maritima.

Seal (Ichth.) Anglo-Sax. fele or fol; the common Seal is Calocephalus vitulinus.

Sea-lavander (Bot.) the Statice Limonium.

Sea-leopard (Zool.) the Stennorhynchus Wedellii.

Sea-lion (Zool.) the Otaria jubata.

Sea-mouse (Zool.) common name of Aphrodita aculeata.

Sea-needle (Ichth.) a name for the Garfilh, Efox.

Sea-nettles (Zool.) common name of the Acalepha.

Sea-pens (Zool.) applied to the Anthozoa.

Sea-pike (Ichth.) a name of Belone vulgaris.

Sea-pink (Bot.) a fynonym for Thrift, Armeria maritima.

Sea-rocket (Bot.) the Cakile maritima. 
Sea-snipe (Ichth.) popular name of Centrifcus fcolopax, which has a long tubular fnout.

Sebæ'a (Bot.) P. N. in honour of $A$. Seba, an apothecary of Amfterdam.

Seba'stes (Ichth.) $\sigma \varepsilon \beta a \sigma r o ́ s$, imperial; a genus of Fifhes, family Scorpanidax.

Sebastian'a (Bot.) P. N. in honour of Sebaftian Vaillant, a French botanin; a genus of Compofitx.

Sebi'fera (Bot.) febun, taliow, fero, to bear; a genus of Lauracer; alfo ufed adjectively.

Sebo'phora (Bot.) "wax-bearer," from febum, wax, fero, to bear ; a genus of Myrifticacer.

Səca'le (Bot.) an ancient name derived from feco, to cut; Frgot of Rya; a genus of Gramina.

Secamo'ne (Bot.) Arab. Squamouna; a genus of Afclepiadacer.

Sechella'rum (Bot.) gen. pl.; of, or belonging to the Sechelles archipelago, e. g. Lodoicea Sechellarum.

Se'chium (Bot.) =nxisy w, to fatten; it is given to hogs; a genus of Cucurbitacex.

Sec'ondaries (Ornith) applied to thofe quills which arife from the fecont bone of the wings.

Seconda'tia (Bot.) P. N., a genus of A pocynacer.

Seco'tium (Bot.) onró, a hollow trunk of a tree; a genus of Fungi.

Securida'ca (Bot.) fecuris, a hatchet; alluding to the form of the end of pod; a genus of Polygalaces; alfo ufed as a fpecific name for the Hatchet-vetch, Coronilla fecuridaca.

Securi'fera (Zool.) Securis, a hatchet, fero, to carry; a family of Hymenoptera.

Securi'gera (Bot.) fecuris, a hatchet, gero, to carry; a genus of Leguminofx. Secuxi'nega (Bot.) fecuris, a hatchet, nero, to refufe; it is extremely hard;

a genus of Euphorbiacex.

Sea'dera (Bot.) P. N., a genus of Convolvulaceæ.

Sedge (Bot.) the genus Carex; Nat. Ord. Cyperacex.

Se'dum (Bot.) Jedere, to fit; from the manner of its growth; Stonecrop; a genus of Crafiulacer.

Seetze'nia (Bot.) P. N. in honour of $M$. Seetzen, a Dutch botanilt; a genus of Zygophyllacea.

Segestrella (Bot.) Segfofre, a covering.

Sego'stria (Ent.) Jegefrum, a packing cloth or garment madeof animals' Rins. Seztatis (Ent.) feres, corn land; the larva feeding on the roots of various grafies. 
Se'getum (Ornith., Bot.) gen. pl. of feges, corn land, e.g., Chryfanthemum fegetum.

Segi'strium (Ent.) Jegeftrum, a packing cloth or garment made of animals' Rkins; a genns of Spiders.

Segui'era (Bot.) P. N., a genus of Petiveriaceæ.

Sehi'ma (Bot.) etymology unknown; a genus of Gramina.

Seid'lia (Bot.) P. N., a genus of Dipteraceæ.

Seimatospo'rium (Bot.) oñuc:, a mark, oropá, feed (fpore); a genus of Fungi.

Seiridium (Bot) osspa, a cord, हidos, refemblance; a gerus of Fungi.

Seisu'ra (Ornith.) $\sigma^{\prime} i \omega$, to thake, ovpa, tail, from the tails being always in motion; it ought to be Sifura; a genus of Birds, of which S. volitans is the Dilhwaher of the colonifts of New South W'ales.

Sela'chians (Ichth.) ósceros, was applied by Hippocrates and Ariftotle to a tribe of Fithes with cartilages inftead of bones; the term is equivalent to that of Plagioftomes.

Se'lachus (Ichth.) $\sigma^{\prime} \lambda_{a z} \alpha_{5}$ of the Greeks, from $\sigma^{\prime} \lambda_{2} \alpha_{5}$, brightnefs; the Bafking Shark, or Sun-fifh.

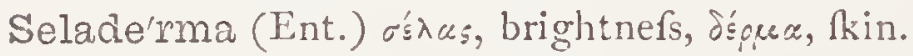

Sela'go (Bot.) Lat, a plant refembling the Savin-tree; typical genus of Selaginacex.

Selasel'1us (Ent.) dim. from $\sigma \dot{\varepsilon} \lambda \alpha_{5}$, brightnês.

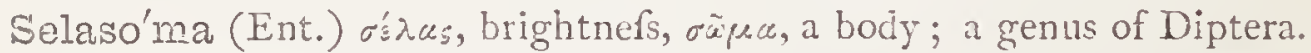

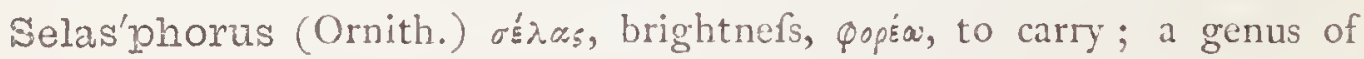
Humming-birds.

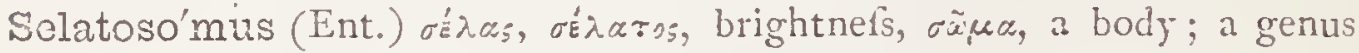
of Coleoptera.

Sele'ne (Ent.) the Greek name for Luna, the Moon; fpecific name of a butterfly, Argynnis Selere.

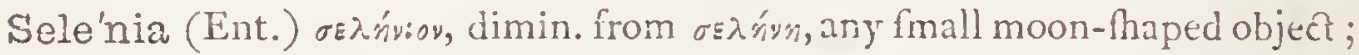
alluding to the crefcent .haped mark upon the wings of feveral fpecies; a genus of Lopidoptera.

Sele'nis (Ent.) $\sigma: \lambda$ nvís, a crefcent.

Selidose'ma (Ent.) $\sigma \varepsilon \lambda i s-i \delta o s$, the page of a book, oñua, a mark, charac ter, or boundary; a genus of Lepidoptera.

Solige'ria (Bot.) P. N. in honour of a celebrated German cryptogamilt; a genus of Mufci.

Eeli'sum (Bot.) cshivs, the moon; from the fhape of the fruit; a genus of Umbellifera. 
Sella'lis (Ent.) fella, a feat.

Sel'loa (Bot.) P. N. in honour of Frederick Sello, a German botanilt in Brazil ; a genus of Compofitæ.

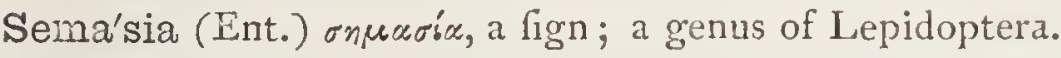

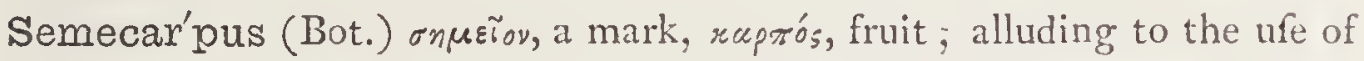
the juice in marking cotton-cloths; a genus of Anacardiacex.

Sem'ele (Ent.) P. N., the mother of Bacchus-Prnd. Ol. ii. 48 ; fpecific name of a butterfly, Satyrus Semele.

Semiarma'tus (Ichth.) Jenis, half, armatus, armed.

Semicinc'tus-a-um (Zool.) femis, half, cinczus, bound; having bands extending half way round.

Semilorica'tus (Ichth.) femis, half, loricatus, harnefled, having a lorica.

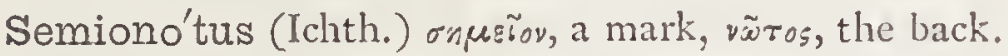

Semipalma'tus (Ornith.) finis, half, p.lmatus, palmed, webbed.

Semirufel'la (Ent.) Jemis, half, rufus, red.

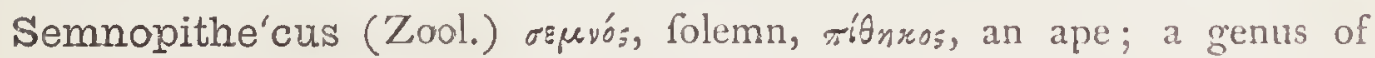
Monkeys.

Sempervi'vum (Bot.) Sempervivo, to live for ever; alluding to its tenacity of life ; a genus of Cratiulacex.

Sendtnerra (Bot.) P. N. in honour of O. Sendtner, a Profeflor at Munich; a genus of Hepaticæ.

Senebie'ra (Bot.) P. N. in honour of ' $F$. de Sencbier, of Geneva; a genus of Cruciferæ.

Senecil'lis (Bot.) perhaps dimin. of fenecio; a genus of Compolitx.

Sene'cio (Bot.) fenex, an old man; naked receptacle like a bald head;

Groundfel; a genus of Compofit:e.

Senerínia (Bot.) P. N., a genus of Aurantiacen.

Se'nex (Ent.) Lat. old, from the wrinkled appearance of the wings.

Sen'na (Bot.) Arabic, fenna, acute, from its tharp-pointed leaves: the fenna of commerce is derived from various fpecies of Caflia.

$\left.\begin{array}{l}\text { Senocula'ta } \\ \text { Senoculína }\end{array}\right\}$ (Ent.) $\left\{\begin{array}{c}\text { feni, fix, oculus, an eye; having fix eyes or eye- } \\ \text { like fpots. }\end{array}\right.$ Sen'sitive-plant (Bot.) applied to fome fpecies of Mimola, particularly M. Senfitiva.

Sen'ta (Ent.) P. N., a place on the coafe of Dalmatia, mentioned by Pliny ; a genus of Lepidoptera.

Se'pedon (Zool.) onted'́y, putrifaction; a genus of Ophidians.

Sepedo'nium (Bot.) $\sigma n \pi s \delta \delta$, putrefcence; it grows on putrid fubltances; a genus of Fungi. 


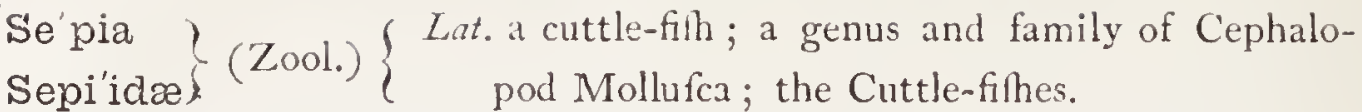

Sepi'ola (Zool.) dim. of Jepia, a cuttle-finh; a genus of Cephalopods, family Teuthidx.

Sepioteu'this (Zool.) from the genera Sepia, and Teuthis; a genus of Cephalopods.

Seppel'la (Ent.) P. N. in honour of Jan Chriftian Sepp, a Dutch entomologilt.

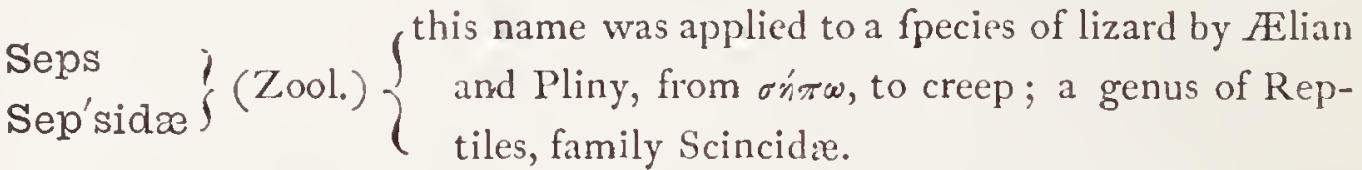

Septa'ria (Zool.) Septum, a divifion, the cavity of the mell being divided by a feptum into two equal tubes; a genus of Mollufca.

Sep'tas (Bot.) feptem, feven; all parts of flower divided into feven : a genus of Craftulacer.

Septemcinc'tus (Zool.) Jeptem, feven times, cinctus, girded.

Septentriona'lis-e (Ornith.) Lat. northern.

Septifo'rmis-e (Bot.) Jeptum, a partition, forma, fhape; partition-like.

Septo'ria (Bot.) Septum, a divifion; a genus of Fungi.

Sep'tum (Zool., Bot.) Lat., a partition.

Sera'pias (Bot.) P. N. from Serapis, an Egyptian divinity; a genus of Orchidaceæ.

Ser'apis (Ent.) P. N., an Egyptian divinity; a genus of Hymenoptera. Seriala'ria (Zool.) feriala, dım. from feries, a row; a genus of Polyzoa.

Ser'ica (Ent.) fericus, filken; a gerus of Coleoptera.

Sericea'lis)

Seri'cia $\}$ (Ent.) fericeus, filky.

Seri'ceus-a-um (Oınith., Bot.) Lat. filken, filky ; e.g. Hypnum fericeum. Sericocar'pus (Bot.) onģrós, filken, rapтós, fruit; a genus of Compofitr. Serico'derus (Ent.) onprrós, filky, d'spos, the Rin; a genus of Coleoptera.

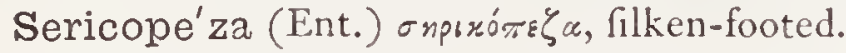

Serico'phorus (Ent.) onprxóv, filk, $\varphi^{\prime} e_{p} \omega$, to bear; a genus of Hymenoptera. Seri'coris (Ent.) onšb́ó, fllky; a genus of Lepidoptera.

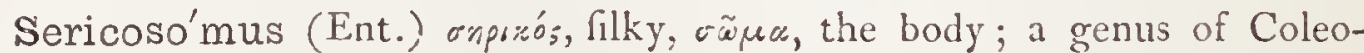
ptera.

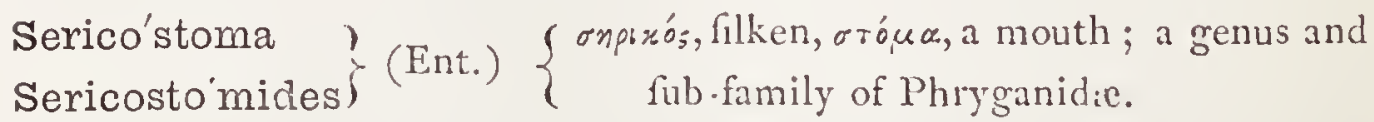

Serin'gia (Bot.) P. N. in honour of Nicholas Charles Seringe, a Swifs botanilt; a genus of Byttneriaces. 
Seri'ola (Bot.) feris, fuccory or endive, from fome fuppofed refemblance; a genus of Compolitæ.

Seriphi'dium (Bot.) the genus Seriphium, عi $\delta_{\text {ss, }}$, refemblance; a genus of Compofitie.

Seri'phium (Bot.) oepiprov, a kind of wormwood; a genus of Compofitæ. Se'ris (Bot.) $\sigma_{\varepsilon p b s}^{\prime}$ a kind of endive; a genus of Compofitæ.

Seris'sa (Bot.) a name given by Commerfon, meaning unknown; a genus of Cinchonacex.

Serja'nia (Bot.) P. N. in honour of Philip Serjeant, a French friar and botanift; a genus of Sapindacex.

Sero'tinus-a-um (Zool., Bot) Lat. that brings forth or happens late; e.g., Crocus ferotinus.

Serpent (Zool.) Latin, ferpens, creeping, Sanfcrit, farpa.

Serpenta'ria (Bot.) ferpens, a ferpent; being thought a cure for ferpent-

bites ; Snake-root; a genus of Ariftolochiaceæ.

Serpenta'rius (Ornith.) the generic name of the Serpent-eaters, but par-

ticularly applied to the Secretary-bird.

Serpentina'ria (Bot.) ferpentinus, ferpent-like; a genus of Algr.

Serpícula (Bot.) dim. from ferpo, to creep; from its habit and fize; a genus of Haloragacer.

Ser'pula (Zool.) Lat. a little fnake; fiom the form; a genus of Annelids. Serra'a (Bot.) P. N. in honour of a Spanifh botanif, Corre. de Sirra; a genus of Malvacez.

Serra'nus (Ichth.) Serra, a faw; a genus of Percoid Fifhes.

Serrasa'lmo (Ichth.) ferra, a faw, falmo, salmon; a genus of Fithes of the family Characinidæ.

Serra'ria (Bot.) ferra, a faw; from the edges of the leaves; a genus of Proteacex.

Serra'tor (Ornith.) Lat. a fawyer.

Serra'tula (Bot.) diminutive of ferra, a faw; the leaves are edged with cutting teeth; a genus of Compofitx.

Serricor'nes (Ent.) Jerra, a faw, cornu, a horı; the antennx being much ferrated towards the apex; a group of Coleoptera.

Serro'des (Ent.) Jerra, a faw, عidos, likenefs.

Serrónia (Bot.) P. N., a genus of Piperaceæ.

Serru'ria (Bot.) P. N. in honour of Dr. J. Serrurier, Profeflor of Botany at Utrecht; a genus of Proteacex.

Sersali'sia (Bot.) P. N. in honour of J. B. Serfalis, a Neapolitan ecclefiaftic; a genus of Sapotacex. 
$\left.\begin{array}{l}\text { Sertula'ria } \\ \text { Sertulari'idæ }\end{array}\right\}$ (Zool.) $\left\{\begin{array}{c}\text { fertula, dim. of ferta, a gariand: a genus and } \\ \text { family of Zoophytes. }\end{array}\right.$ Sertur'nera (Bot.) P. N., a genus of Amarantacex.

Servilla'na (Ent.) P. N. in honour of Audinet Serville, author of "Infectes Coléoptères," (I83I) \&xc.; fpecific name of a Lepidopterous infect.

Sesamo'pteris (Bot.) Sefume, the principal genus, r réprs, a fern; a genus of Pedaliacer.

Se'samum (Bot.) Jemfem, its Arabic name; fefame of Arabian Nights; the feeds of $S$. Orientale have been ufed as food in Egypt and the Ealt from the moft remote antiquity, and the oil expreffed from them is fubftituted for olive oil ; a genus of Pedaliacex.

Sesba'nia (Bot.) Jefban, Arabic name of one of the fpecies; a genus of Leguminofx.

Se'seli (Bot.) feycelyous, the Arabic name of a related plant; $\sigma \varepsilon \varepsilon \varepsilon \lambda$ of the Greeks; a genus of Umbelliferæ.

$\left.\begin{array}{l}\text { Se'sia } \\ \text { Sesi'idæe }\end{array}\right\}$ (Ent.) $\sigma n_{s}$, a moth; a genus and family of Lepidoptera.

Sesle'ria (Bot.) P. N. in honour of Sefer, a phyfician and botanift of the eighteenth century; a genus of Gramina.

Ses'silis-e (Bot.) Jedeo, to fit; feffile, having no ftem or ftalk.

Sestínia (Bot.) P. N., a genus of Labiatx.

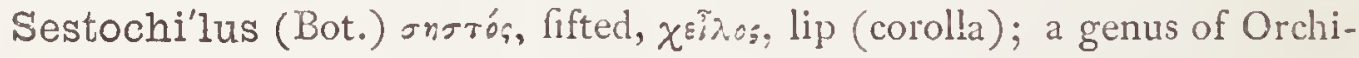
dacea.

Sesu'vium (Bot.) not explained; a genus of Tetragoniacex.

Se'ta, pl. Se'tæe (Ent., Bot.) Lat. a briftle; in cryptogamic plants the Atalk which carries the fporangium.

Seta'ria (Bot.) Seta, a briftle, the involucrum being brifty; a genus of Gramina.

Seta'rius-a-um (Ornith.) feta, a briftle; briftle-bearing.

Se'thia (Bot.) P. N. in honour of S. Sethi, author of a work on culinary vegetables; a genus of Erythroxylace

Se'tifer (Zool.) feta, a briftle, fero, to bear; fame as Setiger.

Setiformis-e (Zool., Bot.) feta, a brifle, forma, lhape; fetiform; brifte-like.

Seti'na (Ent.) P. N. from Setia, a town of Latium; a genus of Lepidoptera. Seuber'tia (Bot.) P. N., a genus of Compolitx.

Seute'ra (Bot.) P. N., a genus of Áclepiadace:.

Sezcinc'tus-a-um (Z,ool) fax, frx times, inchr, girded; $\because$. Dafypus fexcincius. 
Sex'ual Sys'tem (Bot.) Jexus, sex ; Linnæus' claffification of plants, bafed upon the number and arrangement of the famens and piftils.

Seyme'ria (Bot.) P. N. in honour of Henry Seymer, an Englifh naturalift;

a genus of Scrophulariacew.

Shad (Ichth.) popular name of the Alaufa vulgaris and communis; a fpecies of Clupeoid filhes.

Shad'dock (Bot.) faid to be a Malay word; fruit of the Citrus decumana. Shal'lot (Bot.) Fr. echallotte; Germ. fchalotte; Dutch, Jjalot; the Allium afcalonicum.

Sham'rock (Bot.) Irif, fcamrog or ßommrog; the true hamrock of the Irith is fuppofed to be Oxalis Acetofella, though fome fay Trifolium repens.

Shark (Ichth.) corruption of Latin carcharias, which from Greek xapxa६os, fharp.

Shefileldia (Bot.) P. N., a genus of Primulacex.

Shepherda'na (Ent) P. N. in honour of Mr. Edwin Shepherd, Secretary of the Entomological Society of London, who firf met with the fpecies; fpecific name of a moth.

Shepher'dia (Bot.) P. N. in honour of $W$. Shapherd, curator of the botanical gardens, Liverpool; a genus of Elxagnacex.

Sherar'dia (Bot.) P. N. in honour of $W$. Sherard, a celebrated Britih botanift; a genus of Rubiacer.

Sho'rea (Bot.) P. N. in honour of Sir F. Shore, afterwards Lord Teignmouth, Governor-general of Bengal; a genus of Dipteraceæ.

Shor'tia (Bot.) P. N., a genus of Pyrolaceæ.

Shrimp (Zool.) of Anglo-Saxon origin; the Crangon vulgaris.

Shrike (Ornith.) applied to members of the family Laniida,

Shute'ria (Bot.) P. N., a genus of Convolvulacer.

Shuttlewor'thia (Bot.) P. N., a genus of Myoporacer.

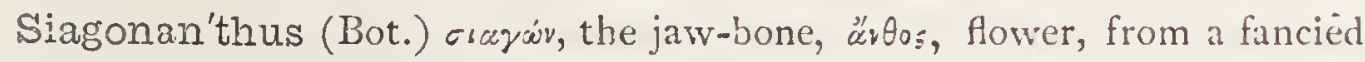
refemblance; a genus of Orchidacex.

Siagonar'rhen (Bot.) osayóv, the jaw-bone, äp’p’nv, a male (Aamen); a genus of Labiatx.

Siago'nium (Ent.) a a a áv, the jaw-bone; a genus of Coleoptera. Sialo'des (Bot.) $\sigma: a \lambda \omega^{\prime} n_{s}$, fatty; a genus of Tetragoniaceæ.

Sibbal'dia (Bot.) P. N. in honour of Sir Robert Sibbald, Profeftor of Phyfic, Edinburgh ; a genus of Rofacex.

Sibila'trix (Ornith.) Lat. hiffing, whifling.

Sibir'icus-a-um (Ornith., Bot.) Lat. Siberian, e. g. Delphinium sibiricum. Siboura'tia (Bot.) P. N., a genus of Myrfinacer. 
Sibthor'pia (Bot.) P. N. in honour of H. Sibthorp, M. D., Profeltor of Botany at Oxford; a genus of Scrophulariacex.

Sibyl'la (Ent.) Lat. a Sibyl.

Sicca'lis (Ent.) ficcus, dry.

Siccifo'lia (Ent.) ficcus, dry, folium, a leaf; from the peculiar larva cafe.

Sice'æ (Bot.) a fection of Cucurbitaceæ, named from Sicyos, the principal genus.

Sicula'lis (Ent.) ficula, diminutive of fica, a dagger.

Sickin'gia (Bot.) P. N., a genus of Cinchonaceæ.

Sicy'dium (Ichth.) oъxúc, a cylindrical gourd; a genus of Fifhes, family Gobiidæ; in Botany, refembling the genus Sicyos.

Sic'yos (Bot') oเxúa, the Greek name for a fruit like the cucumber; a genus of Cucurbitaceæ.

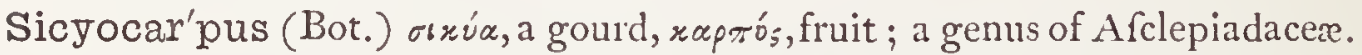
$\mathrm{Si}^{\prime} \mathrm{da}$ (Bot.) a name ufed by Theophraftus; a genus of Malvaceæ; alfo in Zoology a genus of Entomoftraca.

Si'dera (Ichth.) fínpo;, iron; a genus of Fithes.

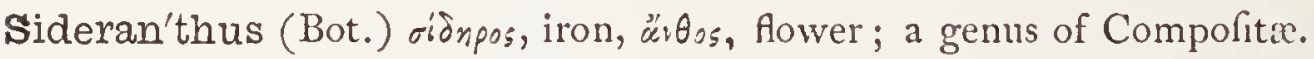

Side'ria (Ent.) бî́npos, iron; a genus of Lepidoptera.

Sideri'tis (Bot.) ríonpos, iron; fuppofed to cure wounds by iron weapons; a genus of Labiatæ.

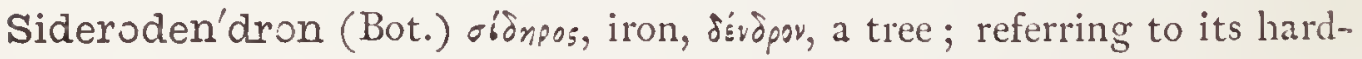
ners; a genus of Cinchonaceæ.

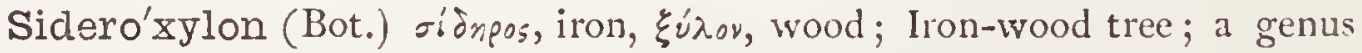
of Sapotaceæ.

Siebe'ra (Bot.) P. N., a genus of Compofitæ.

Siegesbe'ckia (Bot.) P. N. in honour of 7 . George Siegefbeck, M.D., a

German botanift; a genus of Compofitx.

Sieglin'gia (Bot.) P. N, a genus of Gramina.

Siemsse'nia (Bot.) P. N., a genus of Compofitie.

Sieve'rsia (Bot.) P. N. in honour of $M$. Sievers, a Ruffian botanift and traveller ; a genus of Rofacer.

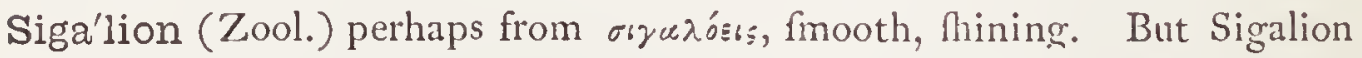
is a name of Harpocrates, the companion of Efculapius and Hygeia, by whom phyficians were obliged to fwear that they would obferve a religious filence in their profeffion; applied to a genus of Annelids. Sigilla'ria (Fos. Bot.) Lat. fgillum, a feal; applied to a genus of Foril treeftems with feal-like depreffions. 
Sig'modon (Zool.) having crefcent-fhaped or figma--Shaped (s) teeth.

Signa'tus-a-um (Ent.) Lat. marked.

Sila'us (Bot.) a name ufed by Pliny; a genus of Umbelliferæ.

Silenan'the (Bot.) the genus Silene, ävos, flower; a genus of Caryophyllaceæ.

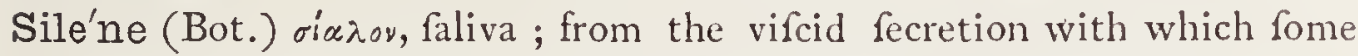
of the fpecies are frequently covered; a genus of Caryophyllacex.

Sile'nus (Zool.) P. N., applied to a monkey; from a refemblance to the white beard and whinkers of the tutor of Bacchus.

Siller (Bot.) salio, to thoot up, referring to its quick growth; a genus of Umbellifera.

Siliculo'sa (Bot.) a divifion of the Crucifera.

Siliculo'sus-a-um (Bot.) filiqua, a pod; bearing filicles.

Si'liqua (Bot.) Lat. a pod.

Siliqua'riz (Bot.) filiqua, a pod; a genus of Capparidacex.

Siliquo'sa (Bot.) filiqua, a pod; one of the Orders in the Linnaan fyftem.

Siliquo:sus-a-um (Bot.) filiqua, a pod; bearing pods.

Silk-worm (Ent.) the Bombyx mori is the infect fo called, though filk is procured from fome other fpecies.

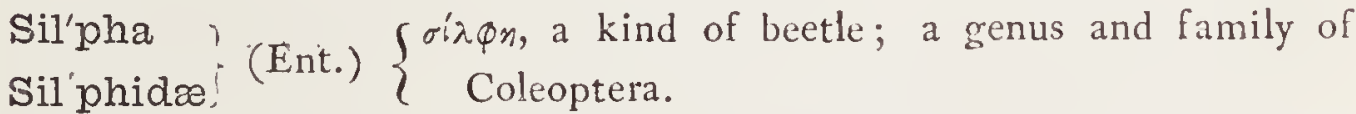

Silphiaspe'rma (Bot.) having filphium-like feed; a genus of Compofitie. Sil'phium (Bot.) Arab. Zalaph, Gr. obiфıv; a name given to the Afafotida plant; a genus of Compofitæ.

Silu'ridæe (Ichth.) \{rinoupos, probably the Shad; now applied to a Silu'rus $\}$ (Ichth.) $\{$ family and genus of foft-finned Filhes.

Silva'nus (Ent.) filva, a wood, foreft; a genus of Coleoptera.

Silvi'cola (Ent.) filva, a wood, colo, to inhabit.

Sil'vius (Ent.) filva, a wood; a genus of Diptera.

Si'lybum (Bot.) ufed by the Greek writers for a plant not now known ;

a genus of Compofitix.

Silybu'ra (Zool.) osíw, to thake, oúpo, a tail; a genus of Snakes.

Sima'ba (Bot,) its name in Guiana; a genus of Simarubacex.

Simaru'ka (Bot.) Simarouba, its name in Guiana; the Quaffia-tree.

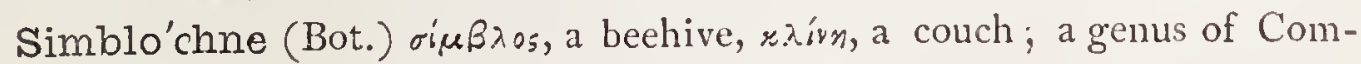
pofitx.

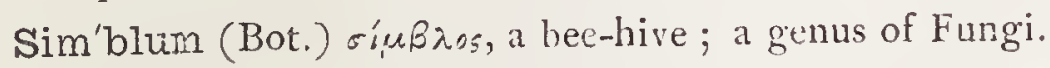

Simbule'ta (Bot.) doubtful; a genus of Scrophulariacex. 
Sime'this (Bot.) unknown; a genus of Liliacex.

Si'mia (Zool.) ovrós, flat-nofed; a genus of Apes.

Si'milis-e (Ent.) Lat. like.

Simi'ra (Bot.) unknown; a genus of Cinchonaceæ.

Simmond'sia (Bot.) P. N. in honour of an American botanift; a genus of Euphorbiacex.

Simoceph'alus (Zool.) erés, bent upwards, xєфá $\lambda$. head; a genus of Colubrine ophidians.

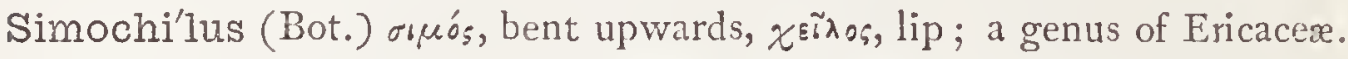

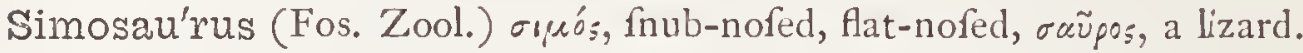

Si'motes (Zool.) eьpórns, flatnefs of nofe; a genus of Colubrine ophidians.

Sim'plex (Bot.) Lat. fimple, unbranched; e. g. Sparganium simplex.

Simpliteg'mia (Bot.) fimplex, fingle, tegmen, a covering; one of the divifions in Dumortier's Nat. arrangement.

Sim'sia (Bot.) P. N. in honour of Foln Sims, M.D., F R.S., F.L.S., one of the early Editors of the "Botanical Magazine;" a genus of Compolitre, alfo of Proteacex.

Si'myra (Ent.) P. N., a town near Tripolis; a genus of Lepidoptera.

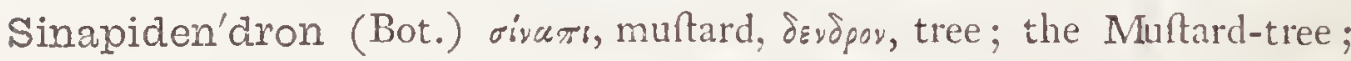

a genus of Cruciferæ.

Sina'pis (Bot.) the Gr. oivari, and Lat. Jmapi, are fuppofed to be derived from oivw, to hurt, $\ddot{\omega} \psi$, the eye, from its effects ; the Muftard-plant; a genus of Crucifere.

Sinclai'ria (Bot.) P. N., a genus of Compofitæ.

Singa'na (Bot.) from its name in Guiana, fingafinga; a gerus of Capparidacere.

Sinnin'gia (Bot.) P. N. in honour of $W$. Sinning, Garderer to the

Univerfity of Bonn; a genus of Gefneraces.

Sinoden'dron (Ent.) oivw, to injure, Jiśdpov, a tree; a gents of Coleoptera.

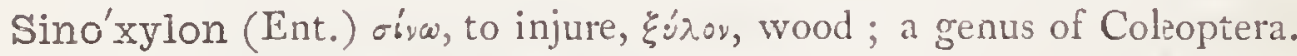
Sinuel'la (Ent.) Jinus, a curve.

$\left.\begin{array}{l}\text { Sio'na } \\ \text { Sio'nidæ }\end{array}\right\}$ (Ent.) $\left\{\begin{array}{l}\text { P. N. from Mount Sion ; on account of "its barren- } \\ \text { nefs of markings."-STrphens. A genus and } \\ \text { family of Lepidoptera. }\end{array}\right.$

Sio'pelus (Ent.) sıw\% $n \lambda_{5}$, taciturn, in allufion to the fmallnefs of the ligula. Siphanthe'ra (Bot.) oipwr, a tube, àvonpá, an anther; a genus of Melaftomacea. 
Siphi'sia (Bot.) sipwr, a tube; from the long tube of the corolla ; a genus of Ariftolochiaceæ.

Si'pho (Bot.) oipwy, a reed or tube; a genus of Ariftolochiacex.

Siphoca'lyx (Bot.) oípwy, a tube, calyx; a genus of Groffulariacex.

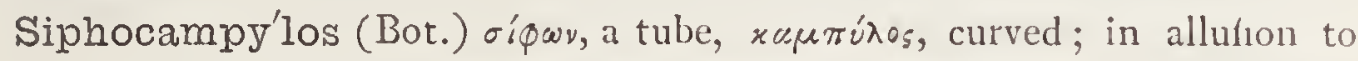
the curved tube of the corolla; a genus of Lobeliacex.

Siphoder'ma (Bot.) cí $\phi \omega v$, a tube, $\delta \varepsilon p \mu a$, kin; a genus of Algx.

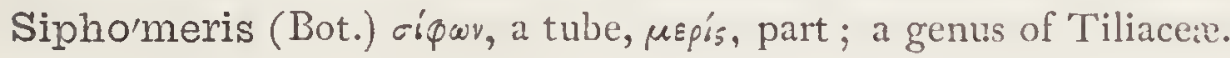

Siphonan'thus (Bot.) cipwr, a tube, ürtos, flower; a genus of Verbenacex.

Sipho'nia (Bot.) cípw, a pipe; one of the India-rubber trees.

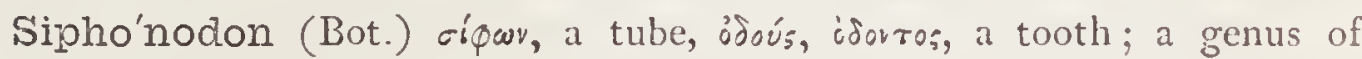
Aquifoliacex.

Siphonomor'pha (Bot.) ríwv, a tube, $\mu_{\xi} \phi n$, thape; a genus of Caryophyllacex.

Siphonoste'gia (Bot.) =ipwv, a tube, otínn, a chamber; a genus of Scrophulariaces

Siphono'stoma (Zool.) rípw, a tube, cróma, a moutli; an order of Entomoftraca.

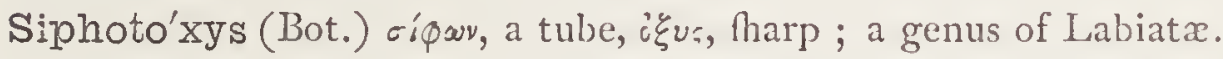

Siphun'cula (Zool.) dim. of $\sigma$ ípwr, a tube or fiphon ; fiphuncle.

$\left.\begin{array}{l}\text { Siphuncul'idæ } \\ \text { Siphun'culus }\end{array}\right\}$ (Zool.) $\left\{\begin{array}{c}\text { fiphrnoulus, a little watering-pot; a family and } \\ \text { genus of Echinodermata. }\end{array}\right.$

Sircomel'la (Ent.) P. N. in honour of Mr. Sircom, late of Briftol, who

firft took this fpecies; fpecific name of a moth.

Sirococ'cus (Bot.) orgós, a pit, roxros, berry; a genus of Algx.

Sirogo'nium (Bot.) otgós, a pit, rovń, feed; a genus of Algx.

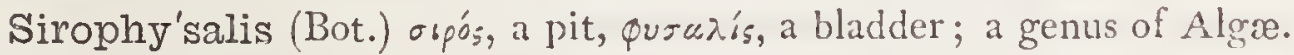

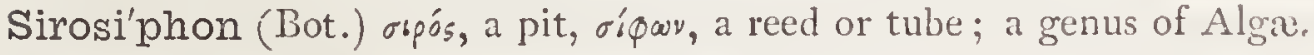

Sis'arum (Bot.) oiragov, an edible plant; Skirrets; a culinary genus of

Umbelliferæ.

Sis'kin (Ornith.) popular name of Chryfomitris fpinus.

Si'son (Bot.) Celt. fizun, a running ftream; a genus of Umbelliferæ.

Sistotre'ma (Bot.) fifto, to place, $\tau \rho^{\tilde{r}} \tilde{\mu} \boldsymbol{\alpha}$, an orifice; a genus of Fungi.

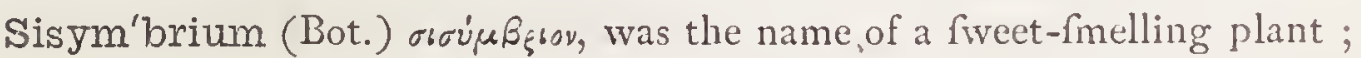
a genus of Cruciferæ.

Si'syphum (Ent.) P. N. from Sifyphus, "Homer's Iliad, vi. 154," perhaps in allufion to the difproportionate fize of the abdomen, which would infallibly roll the fpider down again directly it got to the top. 


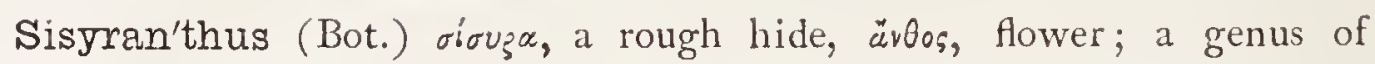
Afclepiadace .

Sisyrin'chium (Bot.) $\tilde{u}_{5}$, a pig, $\dot{\rho} v_{\gamma} \chi^{\circ}$, a fnout; a genus of Iridaceæ.

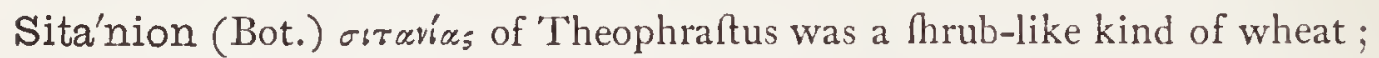
a genus of Gramina.

Si'taris (Ent.) ซiros, corn (?) a genus of Coleoptera.

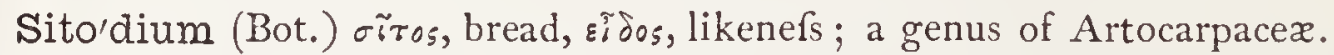

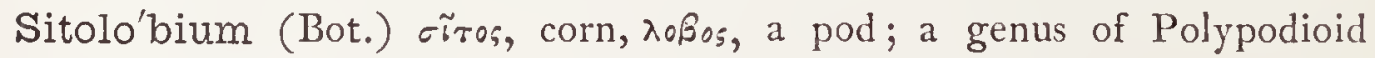
Filices.

Si'tona (Ent.) $\sigma r \tau \dot{y}$, a corn-field; a genus of Coleoptera.

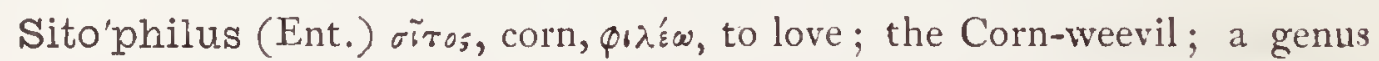
of Coleoptera.

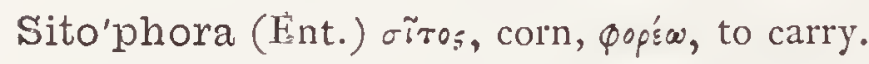

Si'tta (Ornith.) Lat. from oirrn, a wood-pecker; the Nut-hatch; a genus of Birds.

Si'um (Bot.) oioy was a marfh or meadow-plant; Water-parfnep; a genus of Umbelliferæ.

Skate (Ichth.) applied to the different fpecies of Raiæ.

Skim'mia (Bot.) from the native Japanefe name; a genus of Aurantiacex.

Skin'nera (Bot.) P. N. an honour of Captain Thomas Skinner, a diftinguilhed botanift; a genus of Convolvulacea.

Skip'per (Ichth.) the Scomberefox camperi.

Skirroph'orus (Bot.) oxspós, a tumour or fivelling, popés, to bear; a genus of Compofitæ.

Slkull-cap (Bot.) common name of the Scutellaria.

Skytan'thus (Bot.) $\sigma \varkappa \tilde{\tau} \tau о s$, leather, äv0os, flower; a genus of Apocynace

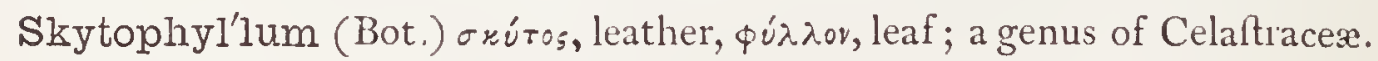
Slate'ria (Bot.) P. N., a genus of Liliacex.

Slevog'tia (Bot.) P. N., a genus of Gentianacex.

Sloa'nea (Bot.) P. N. in honour of Sir Hans Sloane, principal founder of the Britilh Mufeum.

Sloe (Bot.) the fruit of the Prunus Spinofa, the Wild plum.

Slow-worm (Zool.) Anglo-Sax. Slazv-zurm; another name for the Blindworm, Anguis fragilis.

Slug (Zool.) Daniß, slok; whence are derived the words flack and fluggard; the genus Limax.

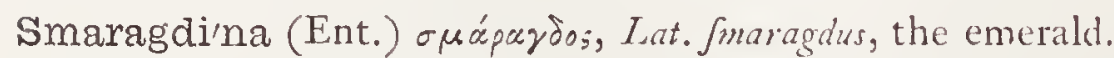

Smaragdoch'rysis (Ornith.) rúapajos, an emerald, zepüros, gold; a genus of Humming-birds. 
Smarag’dulus-a-um (Bot.) ouápaydos, an emerald; emerald-coloured.

Smarag'dulus (Ent.) orápayjos, an emerald; referring to colour.

Smeathman'nia (Bot. and Ent.) P. N. in honour of H. Smeathmann, an African traveller, who inveftigated the infects of Sierra Leone; in Botany a genus of Paffifloraceæ.

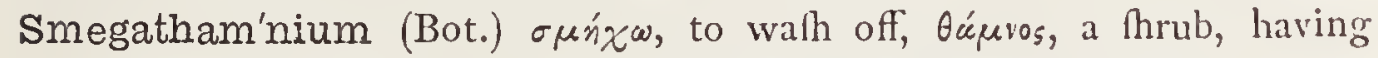
faponaceous properties; a genus of Caryophyllacex.

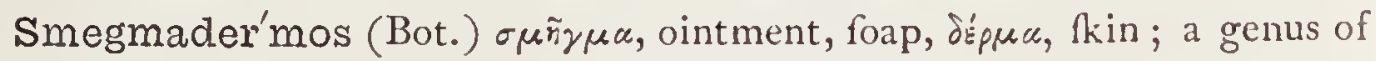
Roface .

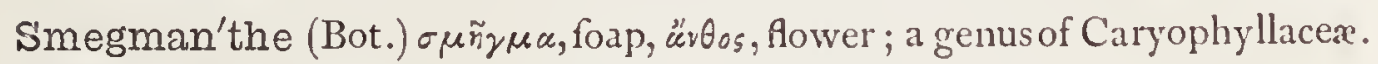
Smelows'kia (Bot.) P. N., a genus of Cruciferæ.

Smelt (Ichth.) the Ofmerus eperlanus, of the family Salmonidx.

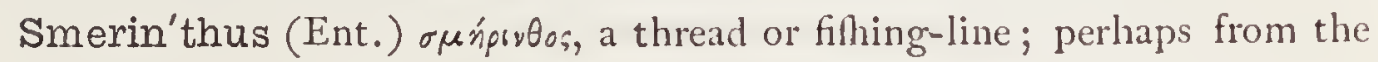
lateral Atripes on the larve; a genus of Lepidoptera.

Smilaci'na (Bot.) dim. of fmilax, from fimilar roughnefs.

Smi'lax (Bot.) an ancient name of a plant, perhaps from $\sigma \mu i \lambda \eta$, a fcraper, the ftems being rough with prickles; the Sarfaparilla plant ; typical genus of Smilacer.

Smi'thia (Ent.) P. N. in honour of Frederick Smith, Efq., of the Britifl Mufeum; a genus of Hymenoptera,

Smi'thia (Bot.) P. N. in honour of Sir Fames E. Smith, F.R.S., founder of the Linnæan Society, who died in 1828 ; a genus of Leguminofie.

Smut (Bot.) this difeafe in wheat is produced by a minute parafite, Uledo fegetum.

Smyrniop'sis (Bot.) the genus Smyrnium, o' ${ }^{\prime 5}$, likenefs; a genus of Umbelliferæ.

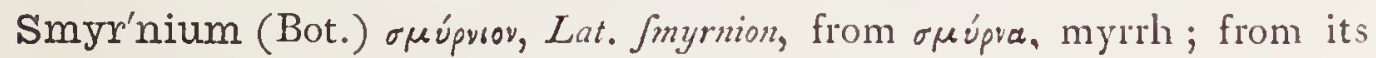
fimilar qualities; Alexanders; a genus of Umbellifer $x$.

Snail (Zool.) Anglo-Sax. Jnagel ; the genus Helix.

Sneeze-wnrt (Bot.) the Achillea ptarmica.

Snipe (Ornith.) Dan. fnip, allied to nib, from its bill; the Scolopax galinago.

Snow-berry (Bot.) the Symphoria racemofa.

Snow-bunting (Ornith.) the Plectrophanes nivalis.

Snow-drop (Bot.) the Galanthus nivalis.

Snowdrop-tree (Bot.) the Halefia tetraptera.

Soap-berry (Bot.) the Sapindus faponaria.

Soap-wort (Bot.) the Saponaria officinalis.

Sobolew'skia (Bot.) P. N. in honour of G. Soboleru'ki, a Rufian botanift; a genus of Crucifera. 
Sobra'lia (Bot.) P. N. in honour of Don Francifco Martin Sobral, a Spanifh botanift; a genus of Orchidacex.

Sobry'a (Bot.) P. N., a genus of Compofitæ.

Soccus (Bot.) etymology uncertain ; a geuus of Artocarpaceæ.

Sodada (Bot.) etymology uncertain; a genus of Capparidacex.

Soft-grass (Bot.) applied to the fpecies of the genus Holcus.

Sogalgi'na (Bot.) P. N., a genus of Compofitre.

Sogalig'na (Bot.) P. N., a genus of Compolitæ.

So'ja (Bot.) Jooja, its name in Japan; a genus of Leguminofr.

Sola'ndra (But.) P. N. in honour of Dr. Solander, a celebrated botanift;

a genus of Solanacex, alfo a genus of Compofitx.

Sola'num (Bot.) Lat. nighthade ; probably from folor, to comfort, as it foothes by fupefying; typical genus of Solanacex.

Sola'ster (Zool.) fol, the fun, after, a ftar; i. e. funs in the fyftem of feaftars.

Soldane'lla (Bot.) dim. of folidus, a Rilling, Loudon; others fay from folido, to make firm; a genus of Primulaceæ.

Soldevil'la (Bot.) P. N. in honour of Soldevilla, a friend of Lagafca; a genus of Compofitæ.

Sole (Ichth.) Anglo-Sax. fol.

Solea (Ichth.) Lat. the fole of a hoe, in reference to its flatnefs; the common Sole-filh.

Solea (Bot.) P. N. in honour of $W$. Sole, author of an ellay on the genus "Mentha;" a genus of Violacer.

Solecu'rtus (Zool.) the genus Solen, and curtus, hort; a genus of Mollufca. Soleiro'lia (Bot.) P. N.; a genus of Urticacex.

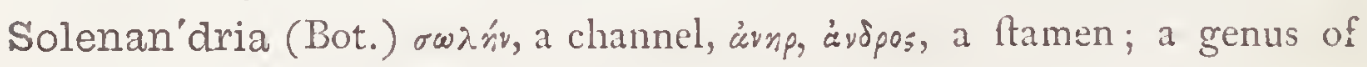
Pyrolacex.

Solen (Zool.) $\sigma \omega \lambda \dot{n}$, a tube; refemblance when the thells are clofed.

Solenan'tha (Bot.) $\sigma \omega \lambda \dot{n}$, a channel, üvor, flower; a genus of Rhamnacex.

Solenan'this (Bot.) fame derivation; a genus of Lobeliacer.

Solenan'thus (Bot.) fame derivation; a genus of Boraginaceæ.

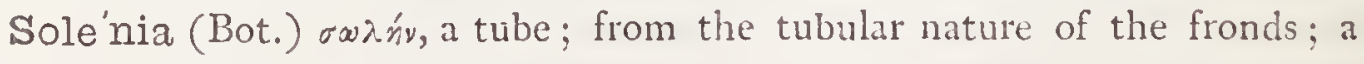
genus of Algæ.

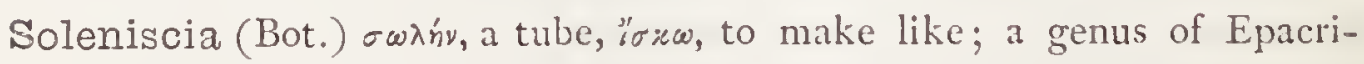
dacere.

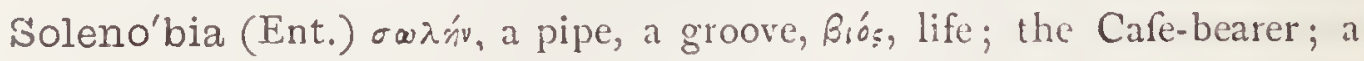
genus of Lepidoptera. 
Solenoca'rpus (Bot.) $\sigma \omega \lambda n^{\prime}$, a reed or tube, xsp $\pi^{\prime} o_{5}$, fruit; a genus of Anacardiaceæ.

Sole'nodon (Zool.) $\sigma \omega \lambda \dot{n} v$, a pipe, odóv, a tooth; a genus of Mammalia.

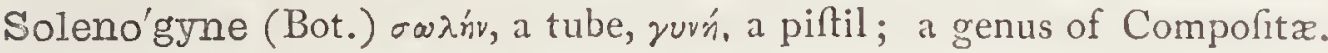

Soleno'melus (Bot.) $\sigma \omega \lambda \dot{n} v$, a tube, $\mu \varepsilon \dot{\lambda} \circ s$, a limb; a genus of Iridacer.

Soleno'phora (Bot.) $\sigma \omega \lambda \dot{n} \nu$, a tube, $\varphi \circ \rho^{\prime} \omega \omega$, to bear; a genus of Gefneraceie.

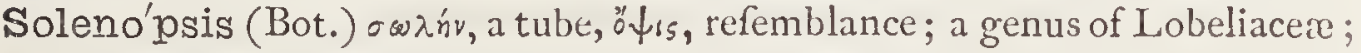
alfo ufed in Entomology.

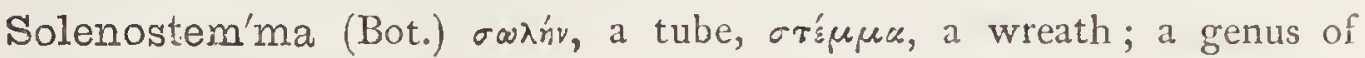
Afclepiadacea.

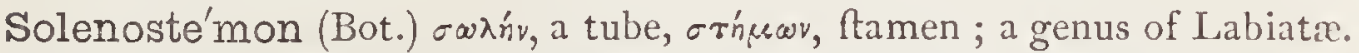

Solenostig'ma (Bot.) $\sigma \omega \lambda \dot{n} v$, a tube, $\sigma \tau i \gamma \mu \alpha$, ftigma; a genus of Ulmacex.

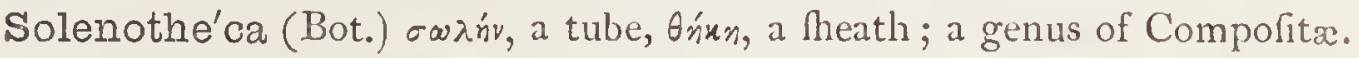

So'lers (Ent.) Lat. adroit, Rilful.

Solida'go (Bot.) folido, to unite; from being fuppofed to heal wounds; a genus of Comporiti.

Soliere'lla (Ent.) etymology doubtful; a genus of Hymenoptera.

Solie'ria (Bot.) P. N., a genus of Alga.

Soligra'nia (Bot.) folus, fingle, granum, a feed; one of the fub-clafles of Dumortier's Nat. arrangement.

Solitariel'la (Ent.) folitarius, folitary ; originally defcribed by Teller from

a fingle Specimen; fpecific name of a moth.

Soliteg'mia (Bot.) Jolus, fingle, tegmen, a covering; one of the clafles in Dumortier's Nat. Sylt.

Soli'va (Bot.) P. N. in honour of Salvator Soliva, a Spanifh phyfician and botanift; a genus of Compolitæ.

Solivæ'a (Bot.) P. N., a genus of Compofitæ.

Solly'a (Bot.) P. N., a genus of Pittofporacex.

Solomon's-seal (Bot.) common name of different fpecies of Polygonatum. Solori'na. (Bot.) rónos, a folid mafs, ṕrón, lkin; from the texture of the fronds; a genus of Cryptogamia.

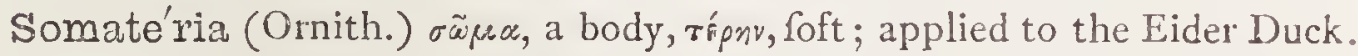

Somme'a (Bot.) P. N., a genus of Calyceracer.

Somme'ra (Bot.) P. N., a genus of Cinchonacex.

Sommerau'era (Bot.) P. N., a genus of Caryophyllacex.

Sommerfel'tia (Bot.) P. N., a genus of Compofitæ.

Sommerin'gia (Bot.) P. N., a genus of Leguminofe.

Son'chus (Bot.) ooyxos, Lat. foncins, the herb fow-thiflle; the Sow thifle; a genus of Compofita. 
Son'corus (Bot.) etymol. uncertain; a genus of Zingiberaceæ.

Son'dera (Bot.) P. N., a genus of Droferacex.

Sonnera'tia (Bot.) P. N., a genus of Myrtacex.

Sonni'nia (Bot.) P. N. in honour of C. N. S. Sonnini, a celebrated naturalift and traveller, who died in $18 \mathrm{I}$ I; a genus of Afclepiadacex.

Sophi'a (Bot.) Eopica chirurgorum, "the wifdom of furgeons," being ufed by them in hæmorrhage; the Sifymbrium Sophia.

Sopho'ra (Bot.) from the Arabic name (Jophara) of one of the fpecies; a genus of Leguminor

Sophro'nia (Ent.) P. N., the goddefs of fober-mindednefs; a genus of Lepidoptera.

Sophronitis (Bot.) o'sppwy, modeft; referring to its appearance; a genus of Orchidaceæ.

Soran'the (Bot.) oopos, an urn, üvbos, flower; a genus of Proteacex.

Soran'thera (Bot.) ropo;, an urn, ávinpa, anther; a genus of Alga.

Soran'thus (Bot.) ropós, an urn, ül, os, flower; a genus of Umbelliferæ.

Soras'trum (Bot.) copós, an urn, ácríp, a ftar; having a globular frond;

a genus of Defmidiex.

Sorba'ria (Bot.) forbus, the Mountain-ash; a genus of Rofacex.

Sorbia'na (Ent.) named from the Service-tree (Sorbus); but the larva feeds, according to Röfel, upon cherry leaves.-Acc. Lift. Brit. Lepid.

Sor'bus (Bot.) Pliny's name for the Mountain-ash, from forbeo, to fuck ; the genus of Rofacex which contains the mountain-ah or rowantree.

Soredospo'rium (Bot.) owprióv, by heaps, orópos, reed; a genus of Fungi.

So'rex (Zool.) Lat. a moufe.

Sor'ghum (Bot.) Jorghi, its Indian name according to Bauhin; Millet; a genus of Gramina.

Sorindei'a (Bot.) meaning unknown; a genus of Anacardiacer.

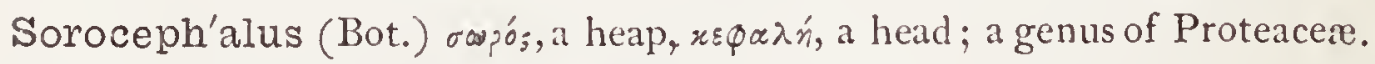
Soroid'ea (Zool.) ropós, an irregular-haped vellel, idéc form.

Sor'rel (Bot.) Meadow.forrel or Green-fauce is Rumex Acetofa; Sheep'sorrel is Rumex Acetofella.

Sorrel-tree (Bot.) the Andromeda arborea.

So'rus (Bot.) $\sigma \omega_{;} o_{;}$, a heap; applied to the mafs of fporangia in the Filices, which are called fori.

Soulan'gia (Bot.) P. N. in honour of Sor!ıny. Bodin, a nurferyman near Paris; a genus of Rhamnacer. 
Southby'a (Bot.) P. N. in honour of Dr. Southby; a genus of Hepatica.

South'ernwood (Bot.) is corrupted from fudden-rvood, and that name arofe from the rapidity with which llips of this plant became fuffruticofe; the Artemifia Abrotanum.

Sowerbæ'a (Bot.) P. N. in honour of Fames Sorverby, F.L.S. F' H.S., an eminent botanical artift; a genus of Liliaceæ.

Sow'thistle (Bot.) applied to the varieties of Sonchus.

Spadi'ceus-a-um (Ornith.) Lat, nut-brown, cheftnut-coloured.

Spa'dix (Bot.) a form of inflorefcence, as in arum, enveloped by the fpathe; taken from $\sigma \pi \alpha \dot{\delta} \delta \xi$, a palm-tree, becaufe found there.

Spado'nia (Bot.) бradóv, a tear or rent; a genus of Compofitx.

Spadosty'les (Bot.) $\sigma \pi \alpha \delta \omega^{\prime}$, a rent, $\sigma \tau \tilde{u} \nu_{j}$, pillar (ftyle); a genus of Leguminofie.

Spætalu'meæ (Bot.) formed from Spatum, a North American Indian name; a fynonym of Mefembryacex with the American botanifts.

Spalacothe'rium (Fos. Zool.) $\sigma \pi \alpha \dot{\alpha} \alpha \varepsilon_{\xi}^{\xi}-\alpha x_{05}$, a mole, onpiov, an animal.

Spala'copus (Zool.) literally "mole-footed," from $\sigma \pi a ́ \lambda a^{\xi}$, and toús; a genus of Mammalia.

$\left.\begin{array}{l}\text { Spalan'gia } \\ \text { Spalangi'idæ }\end{array}\right\}$ etymol. uncertain; a genus and family of Hymenoptera.

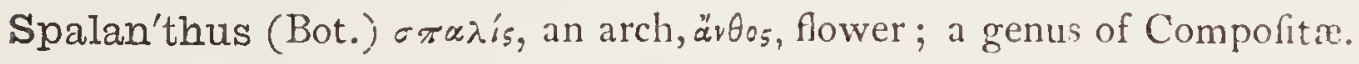

Spa'lax (Zool.) $\sigma \pi a ́ \lambda \alpha \xi$, a mole; a genus of rodent Mammals.

Spallanzarnia (Zool.) P. N., a genus of Barringtoniacex.

Spanan'the (Bot.) orcuós, 1are, ävos, a flower; a genus of Umbelliferce.

Span'iel (Zool.) Old French, espaneul.

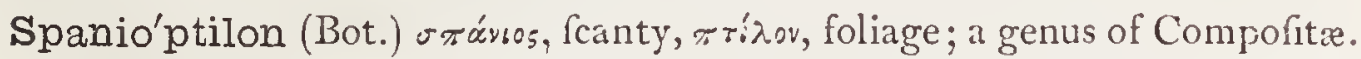
Spanish-Ches'nut (Bot.) the Caftanea vefca, belonging to the Corylacex.

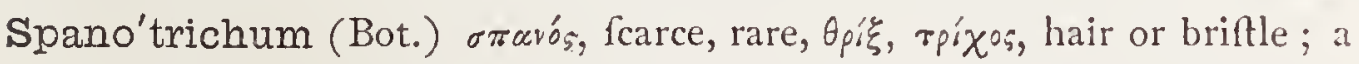
genus of Compofitæ.

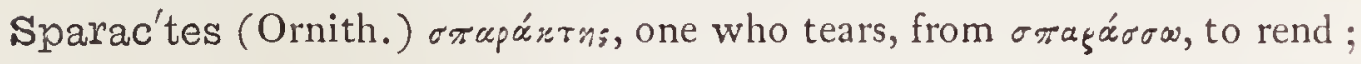

a genus of Birds.

Sparag'mia (Ent.) $=\pi \alpha p \alpha y$ sos $_{3}$ a tearing or mangling.

Sparas'sis (Bot.) (Jparafjis) $\sigma \pi \alpha \rho a \sigma \sigma \omega$, to tear or mangle; a genus of Fungi. Sparas'sus (Ent.) $\sigma \pi \alpha_{\xi} \alpha ́ \sigma \sigma \omega$, to tear or lacerate.

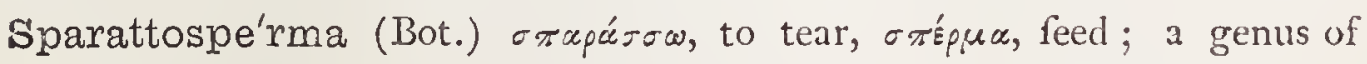
Bignoniacex.

Sparax'is (Bot.) $\sigma \pi \alpha \alpha^{\prime} \sigma 5 \omega$, to tear or lacerate; from the lacerated fpathes; a genus of Iridacese. 
Spargan'ium (Bot.) รtápravov, a band; it has riband-like leaves; a genus of 'Typhaceæ.

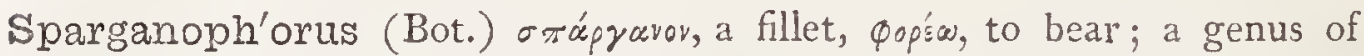
Compofitæ.

Spa'ridæ (Ichth.) the family of marine Bream of which Sparus is the type. Sparman'nia (Bot., Ent.) P. N. in honour of $A$. Sparmann, a traveller in China, who died in 1820 ; a genus of Tiliaceæ.

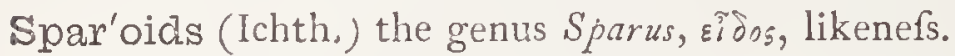

Spar'row (Ornith.) Anglo-Sax. Spearra; the Pafler domeftica.

Jpartian'thus (Bot.) the genus Spartium, üv日os, flower; having broom.

like flowers; a genus of Leguminofæ.

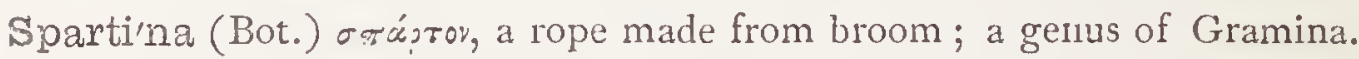
Spar'tium (Bot.) orapriov, Lat. Jpartium: the ancient name of the fhrub was probably derived from $\sigma \pi u ́ p r o v$, a rope made of broom; alluding to its ufe in early times; Broom; a genus of Leguminofat.

Sparto'phila (Ent.) the plant $\int p a r t i u m, \varphi: \lambda_{\varepsilon}^{\prime} \omega$, to love; a genus of Coleoptera.

Spartotham'nus (Bot.) oráprov, Lat. Spartium, cordage, 6áuros, fhrub, from its ufes; a genus of Myoporacex.

Spa'rus (Ichth.) Lat. ancient name of a filh.

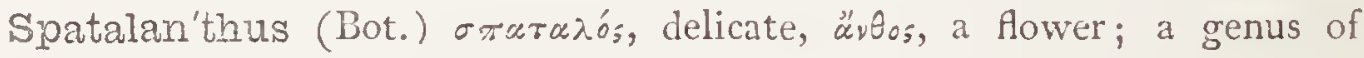
Iridaceæ.

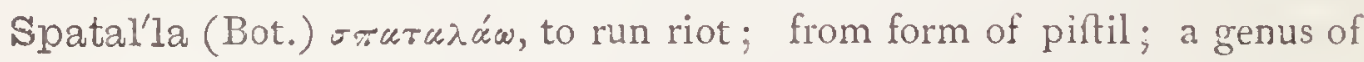

Proteacere.

Spatan'gus (Zool.) бтuтúryns, a fea-urchin; a genus of Echinodermata. Spa'tha (Bot.) $\sigma \pi \alpha \dot{\theta} \theta$, a broad blade or fpatula; the term fpathe is applied

to the theathing involucrum of certain plants, particularly the Palms.

Spatha'ceæ (Bot.) $\sigma \pi c \dot{\theta} n$, a fpatula, botanically a fpathe; a fection of liliaceous endogens.

Spathan'dra (Bot.) crátn, a fpatula, àrp, áropos, a ftamen; a genus of Melartomacexe.

Spathan'thus (Bot.) бrádn, a fpatula, äbos, a flower; a genus of Xyridacex.

Spathica'rpa (Bot.) $\sigma \pi \dot{\theta} \theta n$, a fpindle, xuprós, fruit; a genus of Aracex.

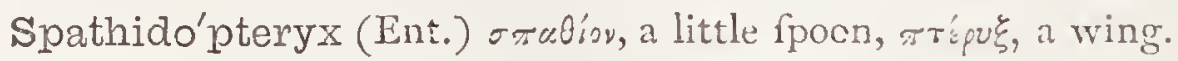

Spathio'stemon (Bot.) $\sigma \pi \alpha \dot{\theta} n$, a paddle (Thape), ormuar, Ramen; a genus of Euphorbiacex.

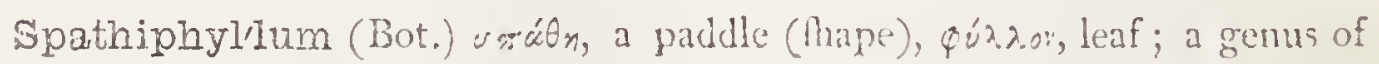
Orontiacea. 
Spa'thium (Bot.) $\sigma \pi \alpha^{\prime} \theta$, a fpathe; a genus of Orchidacex.

Spatho'dea (Bot.) $\sigma \pi \alpha^{\prime} \theta n$, a paddle or fpindle; a genus of Bignoniacex.

Spathoglot'tis (Bot.) $\sigma \pi \alpha \dot{\theta} n$, a fpathe, $\gamma \lambda \tilde{\omega} \tau \tau a$, tongue; a genus of Oíchidacex.

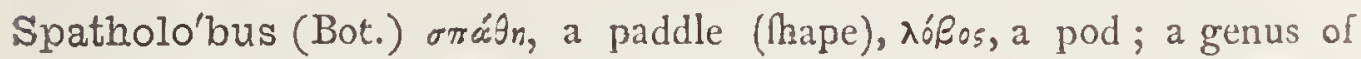
Leguminofa.

Spathula'ria (Bot.) $\sigma \pi \dot{\alpha} \theta n$, a fpindle; a genus of Celaftraceæ.

Spathula'tus-a-um (Bot.) Lat. fpindle-rhaped, e. g., Statice Spathulata.

Spathu'lea (Bot.) Spatula, a broad knife, or fpatula, from the form of the plant; a genus of Fungi.

Spathu'ra (Ornith.) $\sigma \pi \dot{c}^{\prime} n$, a paddle, oũpà, a tail ; a genus of Hummingbirds.

Spear-mint (Bot.) the Mentha viridis.

Specta'bilis-e (Ornith., Bot.) Lat. remarkable, admirable; e. g., Dielytra Spectabilis.

Spelæ'us-a-um (Zool.) $\sigma \pi n ́ \lambda \varepsilon เ o v$, a cavern ; frequenting caves, e.g. Urfus speleus.

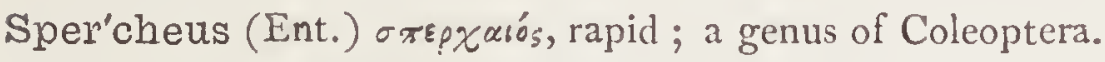

Sper'gula (Bot.) Spargo, to fcatter, it is very prolific of feeds; Spurrey:

a genus of Caryophyllacex.

Spergula'strum (Bot.) the genus Spergula, and «̋orpoy, a ftar; from its fimilarity.

Spermaco'ce (Bot.) $\sigma \pi^{\prime} \dot{\rho} \rho \mu \alpha$, a feed, $\dot{\alpha} \varkappa s x \dot{n}$, a point; a genus of Cinchonacex.

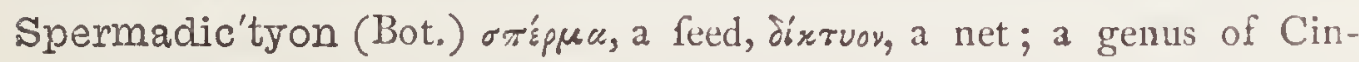
chonaceæ.

Spermago'nium, pl. Spermago'nia (Bot.) бтв́pua, feed, rov', fruit; Spermagonia, Spermogonia, or $\int p e r m a t o g o n i a$ are organs containing the male elements in Lichens.

Sperma'tium, pl. Sperma'tia, (Bot.) dim. of orśpuc, feed; fpermatia are

fmall feed-like bodies contained in the fpermagonia of cryptogamic plants.

Sper'matocysti'dium (Bot.) a name applied by Hedwig to the male

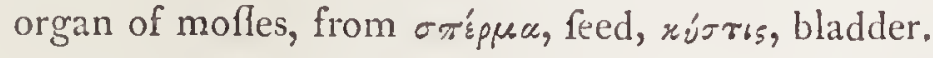

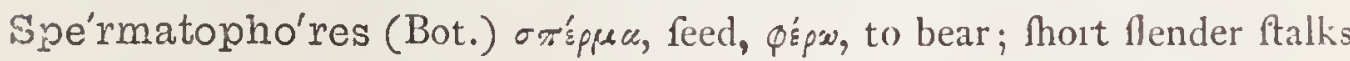
which carry the fpermatia in the Lichens; equivalent to ftylofpores.

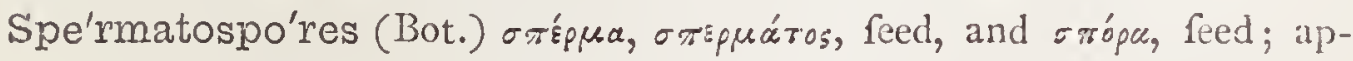

plied to certain Cryptogamic fèed-cafes.

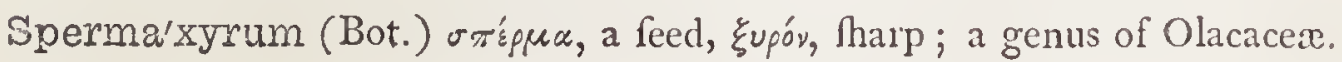




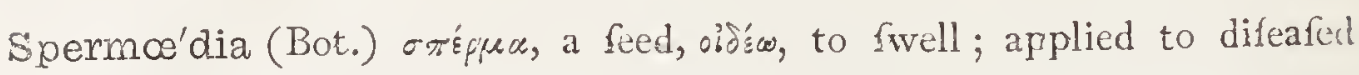
feeas, the fame as Ergot.

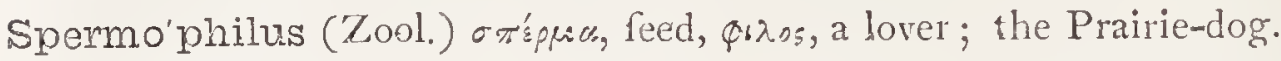

Sphacela'ria (Bot.) $\sigma \varphi_{\alpha} \alpha \varepsilon \lambda_{\Delta s}$, gangrene; from the appearance of the truncate extremity of the frond; a genus of marine Algre.

Spha'cele (Bot.) opárıs, Greek name for Sage; a genus of Labiatx.

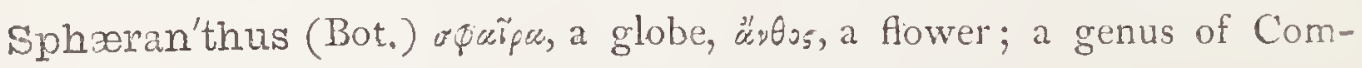
politie.

Sphæratele (Bot.) $\sigma \varphi \propto \tilde{\rho} \propto$, a globe, $\tau \varepsilon \lambda \xi \omega$, to terminate; a genus of Anaryllidacex.

Sphære'ila (Bot.) dim. of $\sigma$ peípx, a ball ; a genus of Algæ.

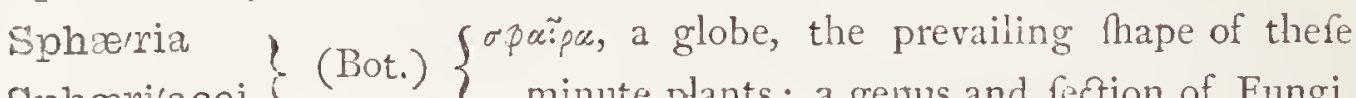

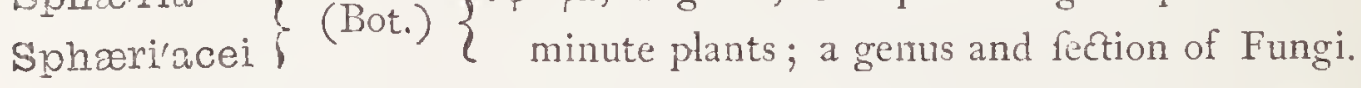

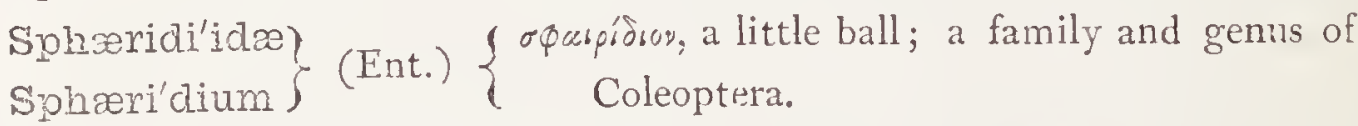

Sphzeridio'phorum (Bot.) opaspisıo", a little ball, popśw, to carry; a genus of Leguminore.

Sphreri'ne (Bot.) eథ̣ĩpa, a ball; a genus of Amaryllidacer.

Sphzeri'tes (Ent.) бpaspirns, globular; a genus of Coleoptera.

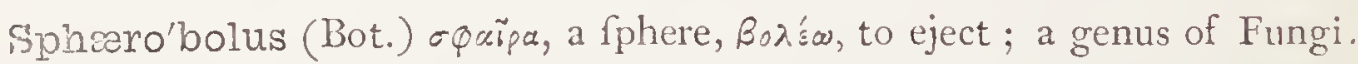

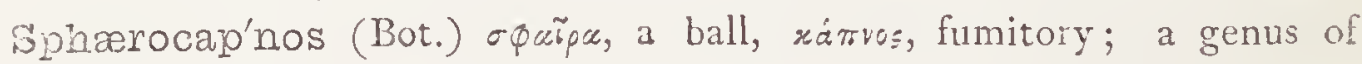

Fumariaceæ.

Sphrerocanpze'a (Bot.) opuĩou, a globe, zaprós, fruit; a genus of Gentianacex.

Sphæroca'rpus (Bot.) бфат̈ра, a fphere, жкрто́, fruit; a genus of Ricciaceæ.

Spharoca'rya (Bot.) oparipu, a ball, xúpuov, a nut; a genus of Santalaces.

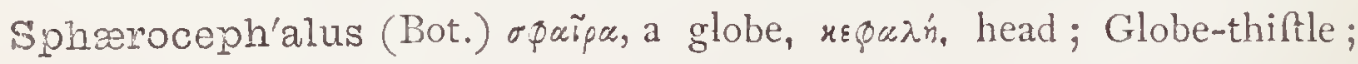
a genus of Compofitx.

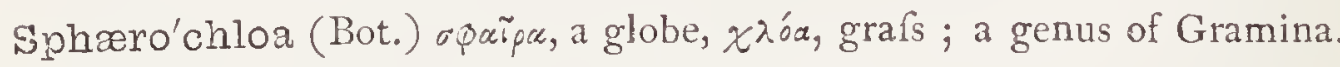
Sphæroco'ccus (Bot.) opaipa, a fphere, rórxos, a berry; a genus of Cryptogamia.

Sphærocyo'nium (Bot.) opas̃pa, a globe, xúw, to contain; a genus of Polypodioid Filices.

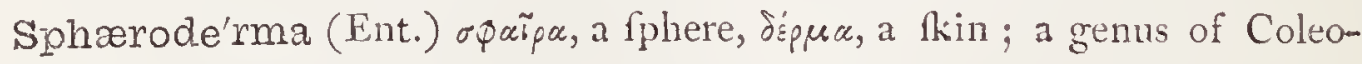
ptera.

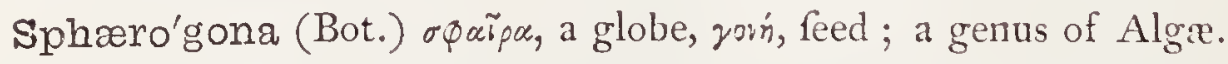

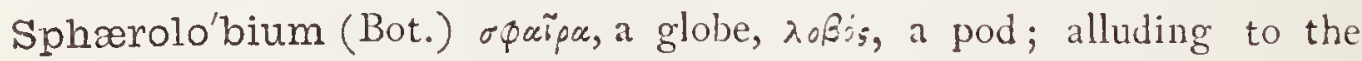
Shape; a genus of Leguminofie. 
Sphæro'ma (Bot.) opaipase any thing globular; a genus of Malvacex. $\left.\begin{array}{l}\text { Sphæro'ma } \\ \text { Sphæro'madæe }\end{array}\right\}$ (Zool.) $\left\{\begin{array}{c}\text { fame etymology; a genus and family of } \\ \text { Cruftacea. }\end{array}\right.$

Sphærone'ma (Bot.) apaĩpo, a globe, vaifec, gelatine; a genus of Fungi.

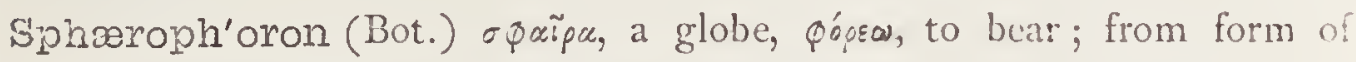
fructification; a genus of Lichenes.

Sphærophy'sa (Bot.) epaipa, a globe, $\phi \tilde{v} \sigma x$, a bladder; referring to the pods; a genus of Leguminofx.

Sphæro'pteris (Bot.) opaĩpa, a globe, $\pi \tau^{\prime} \varepsilon$ dioid Filices.

Sphærosac'me (Bot.) oфaípu, a globe, üxки́, an edge; a genus of Meliacex.

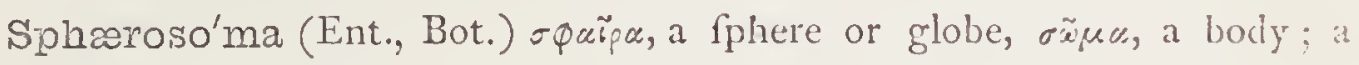
genus of Fungi; in entomology, a genus of Coleoptera.

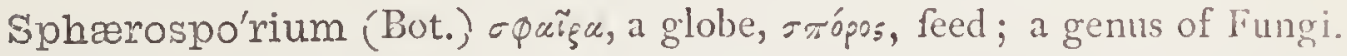

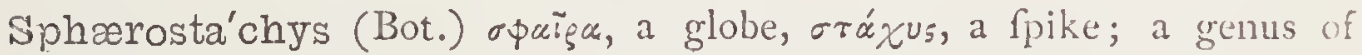
Piperacex.

SE phæro'stema (Bot.) $\sigma \phi \alpha \tilde{i} \alpha$, a globe, $\sigma \tau \tilde{x} \mu \omega \nu$, ftamen ; a genus of Scluizan-. dracex.

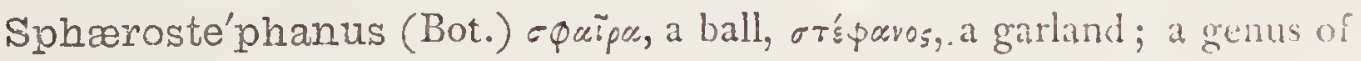
Polypodioid Filices.

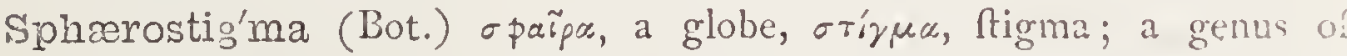
Onagracex.

Sphærothal'lia (Bot.) $\sigma \phi \alpha i p \alpha$, a globe, $\theta \alpha \lambda \lambda a_{s}$, a hoot or fprout; a gelius of Lichenes.

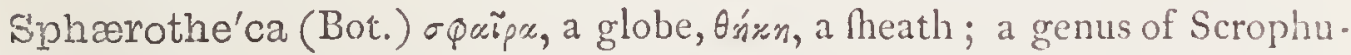
lariaceæ.

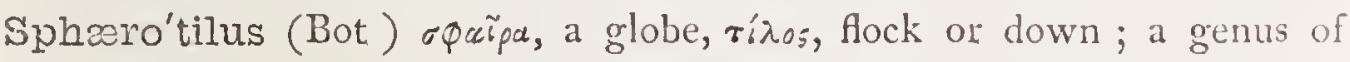
Algæ.

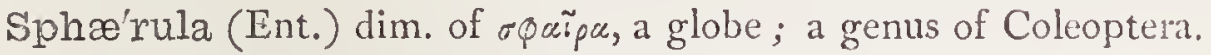

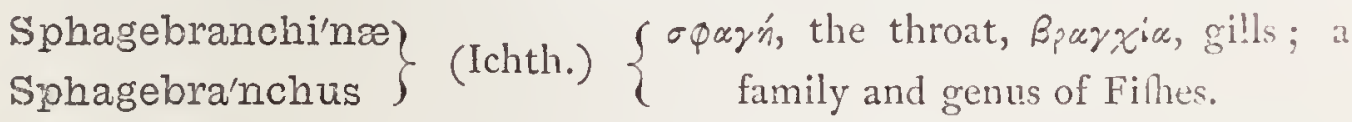

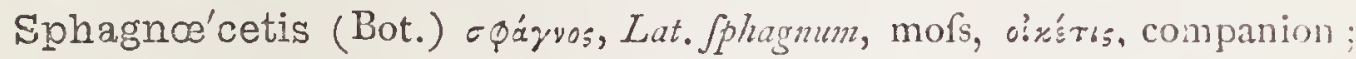
being found among Jphagnum; a genus of Jungermanniacea.

Sphag'num (Bot.) a name ufed by Pliny to defignate fome kind of mois, adapted from the Greek equáyos; Bog mofs; a genus of Mufci.

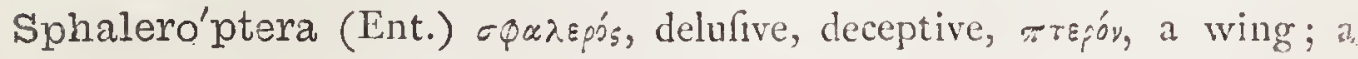
genus of Lepidoptera. 
Sphallerocar'pus (Bot.) $\sigma \phi \alpha^{\prime} \lambda \lambda \omega$, to totter or fagger, *aptós, fruit; a genus of Umbelliferæ.

Sphe'cida (Ent.) the family of Hymenoptera of which Sphex is the type; the Wafp family.

Spheco'philus-a-um (Bot.) $\sigma \varphi^{\prime} \xi \xi$, a wafp, fungus found upon a dead hornet, Ifaria $\int p h e c o p h i l a$.

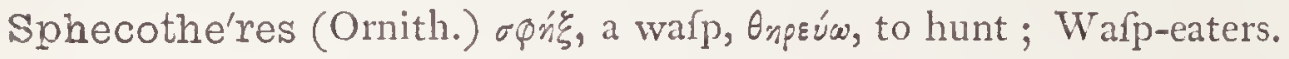
Sphe'gidæe (Ent.) equiv. to Sphecida.

Sphegiga'ster (Ent.) Sphex, a wafp, gafter, belly; wafp-hhaped.

Sphenan'dra (Bot.) $\sigma \phi^{\prime \prime} \nu$, a wedge, àvíp, àvdpós, a ftamen; a genus of Scrophulariaces.

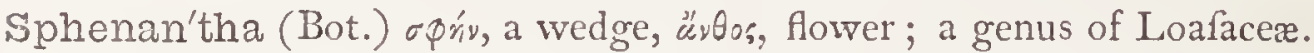
Sphenis'cus (Ornith.) dim. of $\sigma \varphi^{\prime}$ v, a wedge ; a genus of Penguins.

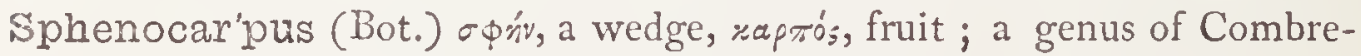
tacex.

Sphenœ'acus (Ornith.) $\sigma \phi \dot{n}$, a wedge, ők

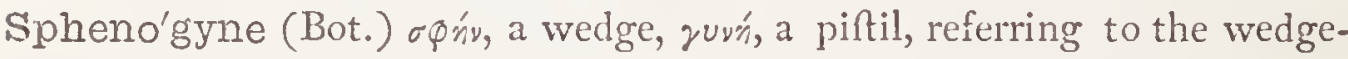

Thaped apex of the Ryles; a genus of Compofitie.

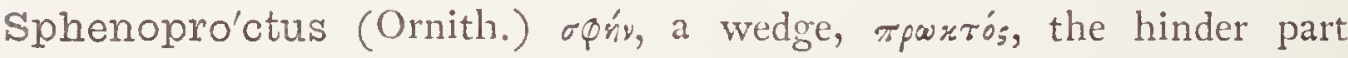
(anus); a genus of Humming-birds.

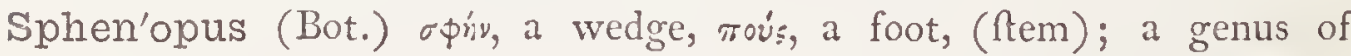
Gramina.

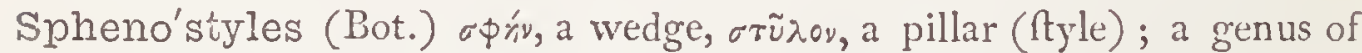
Leguminofæ.

Spheno'toma (Bot.) $\sigma \varphi y^{\prime}$, a wedge, rópros, a flice or fection; a genus of Epacridaceæ.

Sphenotrochus (Zool.) op'riv, a wedge, rpoxós, a fpinning-top, in allufion

to the form of the corallum.

Sphenu'rus-a-um (Ornith.) $\sigma \varphi^{\prime}{ }^{\prime}$, a wedge, oũpa, a tail ; wedge-tailed, e. $g$. Heliaftur Jphenurus.

Sphex (Ent.) Lat. from $\sigma \varphi \hat{\prime} \xi$, a wafp ; the Wapp; a genus of Hymenoptera.

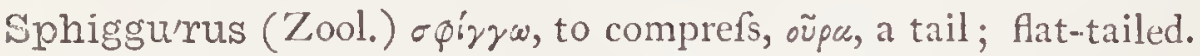

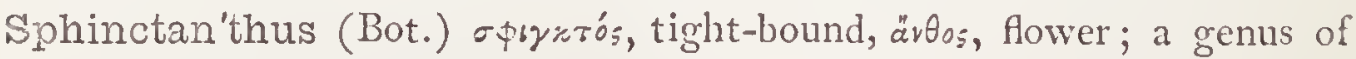
Cinchonacex.

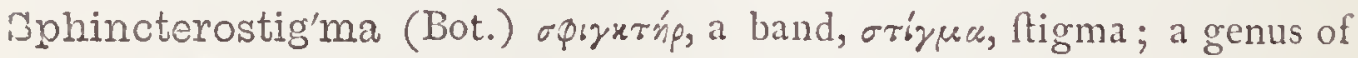
Aracer.

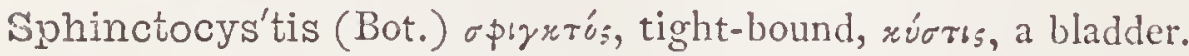

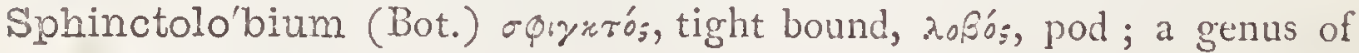
Leguminof 


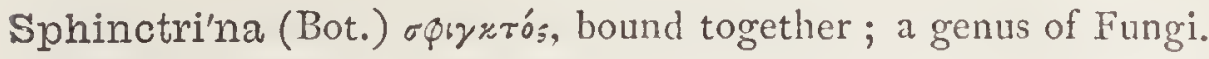

Sphin'gidæe (Ent.) the family of night-flying Moths, of which fphinx is the typical genus.

Sphin'gium (Bot.) $\sigma \phi$ øry

Sphinx (Zool., Ent.) P. N. applied to the Thoth Baboon, Cynocephalus

Sphins from the circumftance of its being fo often found fculptured on Egyptian hieroglyphics; alfo a genus of Moths.

Spho'drus (Ent.) opodfós, active, frong; a genus of Coleoptera.

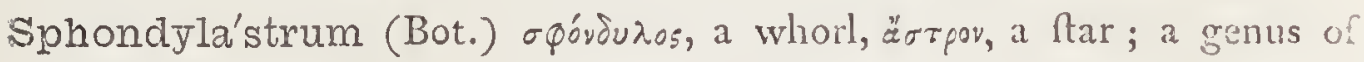

Halorageacer.

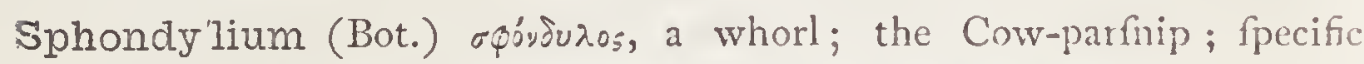
name of a fpecies of Heracleum, Nat. Ord. Umbellifera.

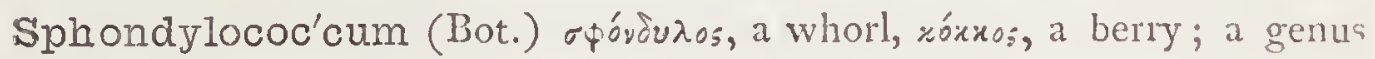
of Verbenaceæ.

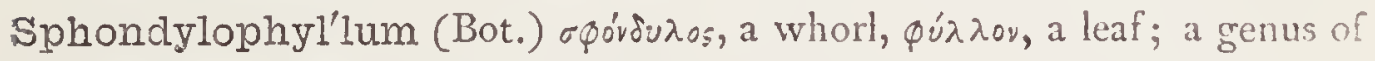
Halorageaceæ.

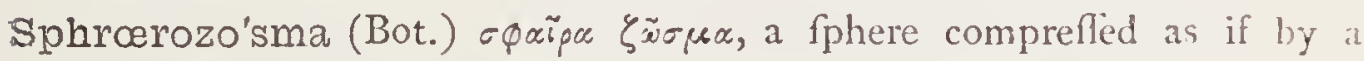
girdle; a genus of Algre belonging to the Defmidiacex.

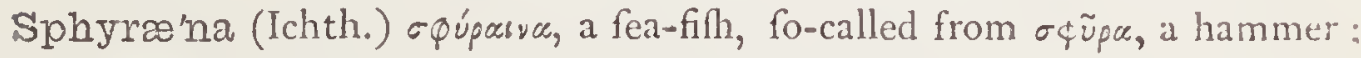

a genus of Filhes called Barracuda Sea-pikes.

Sphyri'dium (Bot.) эфüpa, a hammer, عijos, likenefs; a genus of Bryoid Mufci.

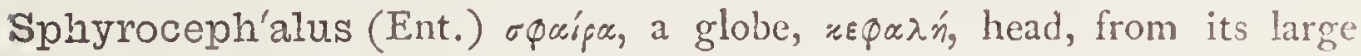
and oblong head.

Sphyrode'ta (Zool.) oфupods'srs, an ancle-band; from the lint round the tentacle-foot.

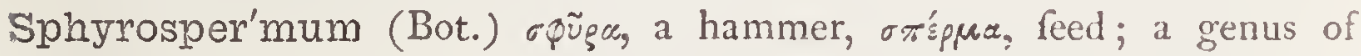
Vacciniacez.

Spica'ria (Bot.) Spica, a tuft; a genus of Labiatre.

Spiculæ'a (Bot.) Jpicula, a fpikelet; a genus of Orchidaceæ.

Spicu'liform (Zool.) Spiculum, a tharp point or fing, forma, thape, thornmaped.

Spider (Zool.) i. e. the fpinder or fpinner; from Anglo-Sax. Spinan, to weave.

Dan. Speyder: the fpiders, which are not fcientifically confidered infects, belong to the Areneidx, a family of the Arachnida.

Spi'der-wort (Bot.) from refemblance of the ftamens to the hairy legs of a fpider; the Tradefcantia Virginica.

Spielmannia (Bot.) P. N. in honour of $7 . R$. Spielmann, Profeffor of Medicine and Botany at Straburg; a genus of Verbenacex. 
Spie'sia (Bot.) P. N. in honour of a well-known Botanift; a genus of Leguminofie.

Spige'lia (Bot.) P. N. in honour of $A$. Spigelius, Profellor at Padua, who died in 1625 ; a genus of Loganiacex.

Spike'nard (Bot.) nardi fpica-" the head of Nardus fpreadeth into certain fpikes or eares."-Holcand's Plinie; the Spikenard of the ancients was moft probably Nardoftachys Jatamanfi, a plant of the Nat. Ord. Valerianacese.

Spila'cron (Bot) $v \pi i x^{2} \xi$, a rock, "̈upov, the top; a genus of Compolitx.

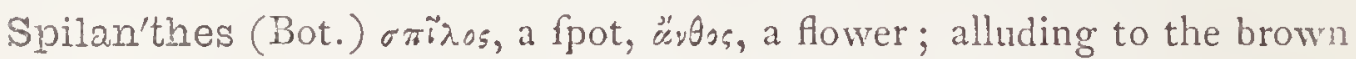
difk of fowers; a genus of Compofitie.

Śpilocr'a (Bot.) $\sigma \pi \iota \lambda a_{s}$, a rock ; a genus of Fungi.

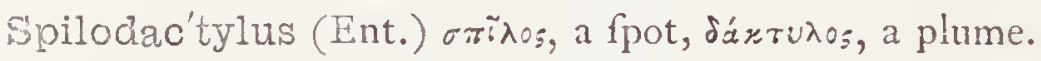

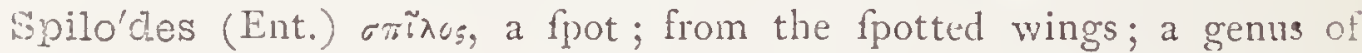
Lepidoptera.

Spilo'ma (Bot.) $\sigma \pi i \omega_{\mu} \mu$, a fpot; from the appearance of the fructifica. tion; a genus of Cryptogamia.

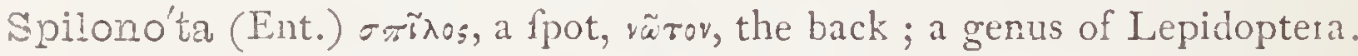

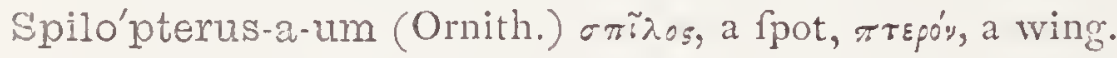

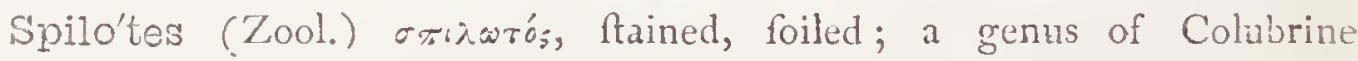
Ophidians.

Spinach or Spin'age (Bot.) Lat. Spinacia. Ital. Spinace, Span. efpinaca, Fr. epinurd the Spinacia oleracea.

Spinach'ia (Ichth.) Jpina, a thorn, áx'r, a point or edge; the body being covered laterally with fpiny plates,

Spina'cia (Bot.) Spina, a thorn; from the prickly integument of the fruit; Spinach; a genus of Chenopodiacer.

Spi'nax (Ichth.) Jpina, a thorn; the Dog-fin.

Spindle-tree (Bot.) the hard white wood was formerly ufed for making Spindles; the Euonymus Europæus.

Spini'fea (Bot.) Spina, a thorn; a genus of Gramina.

Spini'ferus-a-um (Zool., Bot.) Spina, a thorn, fero, to carry, e. y. Productus Spiniforus.

Spinima'na (Ent.) Spina, a prickle, manus, a hand; in allufion to fome characteriftic rows of briftles on the upper fide only of the fore-legs, quafi hands of the fpider.

Spinolel'la (Ent.) P. N. in honour of the Marquis Maximilian Spinola, a s. writer on Entomology. 
Spino'sus-a-um (Ornith,, Bot.) Lat. thorny ; e.g. Acanthus Jpinofus.

Spinulo'sus-a-um (Ichth., Bot.) Spina/us, prickly, thorny ; c. g. Laftraz spinulofa.

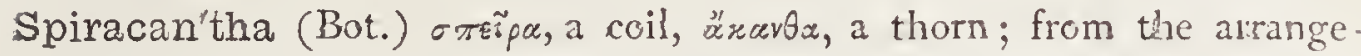
ment of fpines of involucrum; a genus of Compofitæ.

Spira cles (Ent.) Spiraculum, a breathing-hole, or air hole; applied to the external orifices of the trachex of infects and Spiders; equivalent to Stigmata.

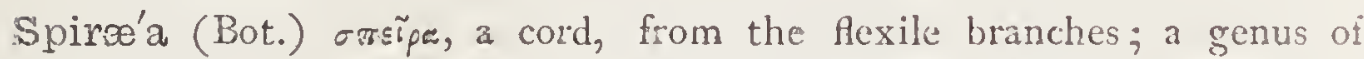
Rofacex.

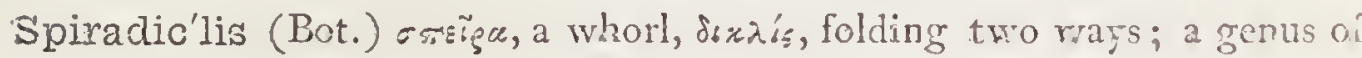
Cinchonacex.

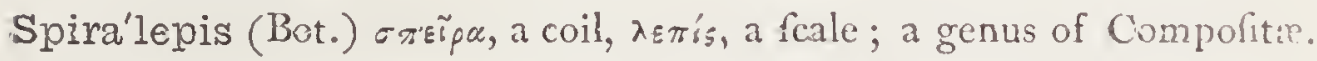

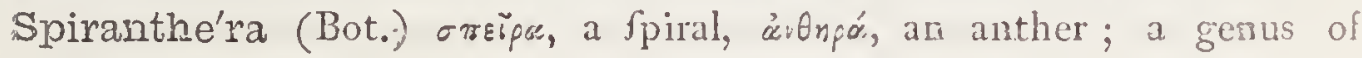
Rutaceæ.

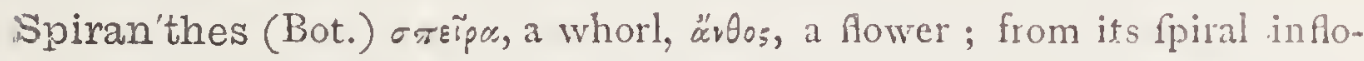
refcence; "Ladies' Trefles;" a genus of terreftrial Orchidacex.

Spirasti'gma (Bot.) бrsipo, a coil, бrípux, ftigma ; a genus of Bromeliacex.

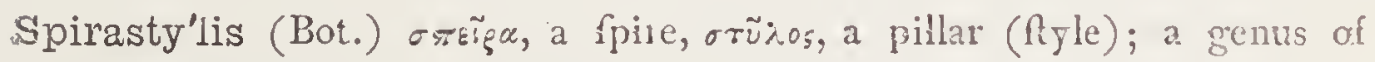
Loranthacex.

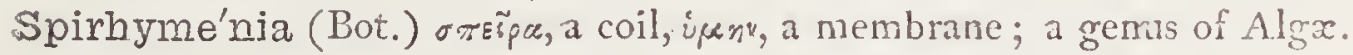

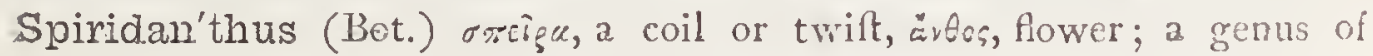
Compofita.

Spi'ridens (Bot.) Jpiras a coil, dene, a tooth; i.e. of the periftome; a. genus of Bryoid Mufci.

Spi'rifer (Zool.) Jpira, a wholl, fero, to carry ; a genus of Mollufica.

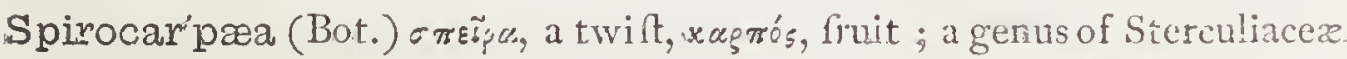

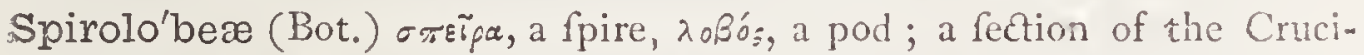
feræ, in which the cctyledons are fpirally or rather circinnately swifted.

Spirodela (Bot.) $\sigma \pi \varepsilon \tilde{g} \alpha \alpha$, a whorl, $\delta n \lambda \hat{\sigma}_{s}$, manifeft ; a genus of Piftiacen.

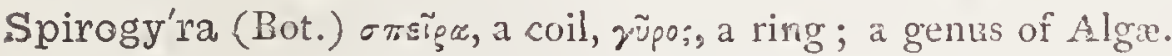

Spiro'monas (Zool.) Spira, a coil or fold, monas; a genus of Infuforia, the body of which is rolled fpirally on itfelf longitudinally.

Spirone'ma (Bot.) $\sigma \pi \varepsilon \tilde{p} \alpha$, a fpiral, Spirosper'mum (Bot.) oreípa, a coil, orépuce, feed.

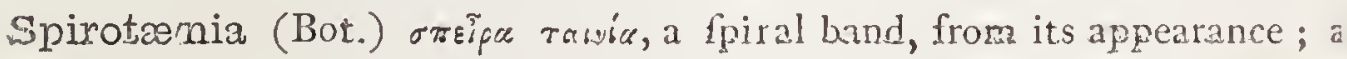
genus of Defmidiacem. 


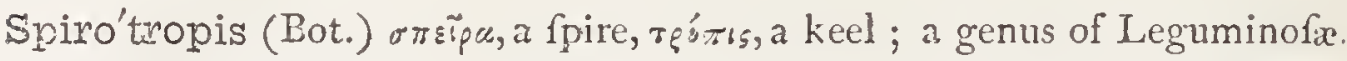
$\left.\begin{array}{l}\text { Spi'rula } \\ \text { Spiru'lidæe }\end{array}\right\}$ (Zool.) Y Spirula, a fmall whorl; a genus and family of

Spirulina (Bot.) Jpirula, a fmall fpire; a gुenus of Algre.

Spitze'lia (Bot.) P. N., a genus of Compolıtre.

Spiz'ia (Bot.) P. N. in honour of $M$. Spix, a celebrated Brazilian tra. veiler and companion of Martius; a genus of Compofitre.

Spi'za (Ornith.) ori' «, a finch, equivalerst to the Lat. fringilli.

Spizaetus (Ornith.) $\sigma \pi \zeta_{\zeta} \omega$, to pipe or cry loudly, a'stós, an eagle; th Piping-eagles; a genus of Eagles.

Splachni'dium (Bot.) the genus Splanchnu, sidos, likenefs; a genus o: Algæ.

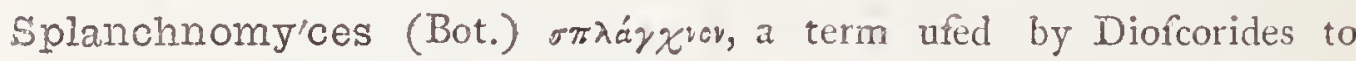
include Lichens and Molfes, and $\mu$ úrss, a fungus; a fection of Fungi.

Splanchnone'ma (Bot.) the genus Splanchrum, vĩuc, filament; a genus of Fingi.

Splan'chnum (Bot.) borrowed from the exגáyxury of Diofcorides, which was originally ufed for fome lichen or cryptogamic plant; Collarmofs; a genus of Mufci.

Spleenwort (Bot.) takes its origin in a curious flory, that in Cerito there is a river, the Ceterach growing abundantly on one fide of the ftream and not on the other. On the fide where this fern grows the pigs are faid to have no fpleen, but on the other fide no fuch deficiency is recorded, hence the name, Spleenwort, or Afplenon.

Splitger'bera (Bot.) P. N., a genus of Urticacer.

Split-mosses (Bot.) applied to the Andræacer, becaufe the fporangiurn splits vertically into four valves connected at the fummit.

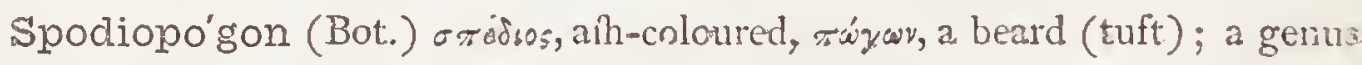
of Gramina.

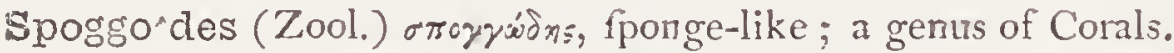

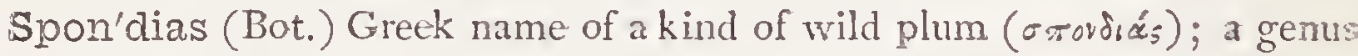
of Anacardiacex.

Spondy'lis (Ent.) orovdúdn, an infect that lives in the ground, and gnaws the roots of trees; a genus of Coleoptera.

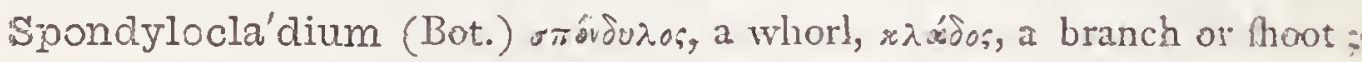
a genus of Fungi.

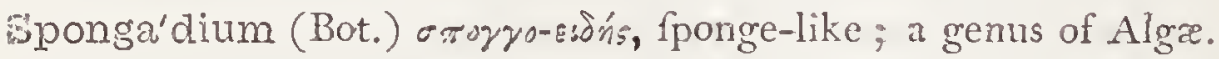
Sponge (Zool.) sroyric, Lat. Spongia, Fr. esponge; the sponge of com* merce belongs to the genus Spongia, of the clafs Porifesa. 
Spongi'cola (Zool.) Jpongia, fponge, colo, to inhabit.

Spo'ngidæ (Zool.) Spongia, (Jroy zia) fponge; the Sponges; a group of the Protozoa.

Spongil'la (Zool.) dim. of Spongia; a genus of frefh-water Sponges.

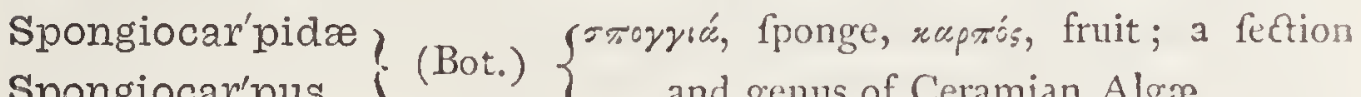
Spongiocar'pus $\}$ (Bot.) $\{$ and genus of Ceramian Algæ.

Spongi'tes (Bot.) oroyzı́, fporige; a genus of Algx.

Spongocar'pus (Bot.) бróyros, fponge, raprós, fruit; a genus of Algx.

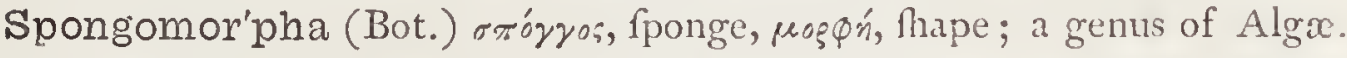

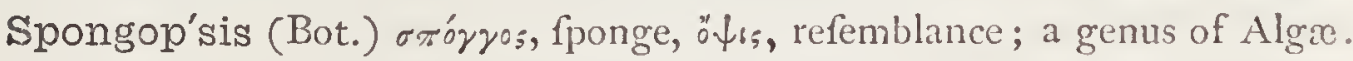

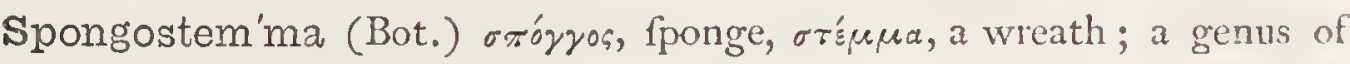

Dipfacaceæ.

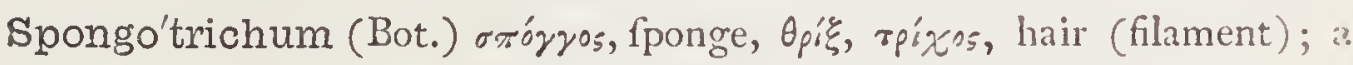
genus of Compofitix.

Spo'nia (Bot.) uncertain ; a genus of Ulmacer.

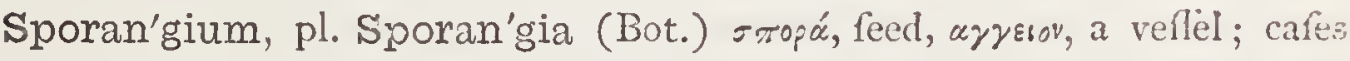
containing fpores in cryptogamic plants, commonly called the Urns; equivalent to these, afci, and cyfidia.

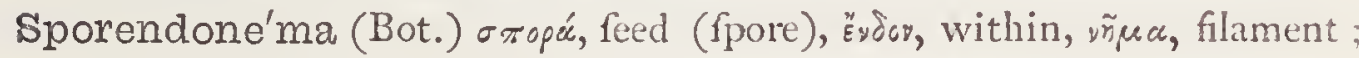
a genus of Fungi.

Sporides'mium (Bot.) $\sigma \pi \circ \rho_{\alpha}$, a feed, $\delta \varepsilon \sigma \mu^{\prime} \sigma_{s}$, a band; a genus of Fungi. Spori'đium, pl. Spori'dia (Bot.) $\sigma \pi$ opó, feed, हions, likenefs; thefe bodieare equivalent to the feeds of flowering plants.

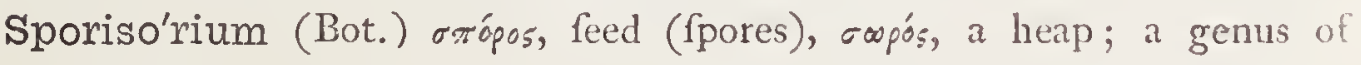
Fungi.

Sporle'dera (Bot., Zool.) P. N. in honour of Sporleder, of Vernigerode; a genus of Yedaliacex; alfo a genus of Mollufca.

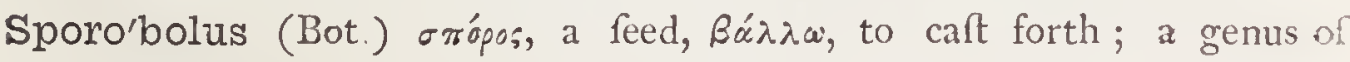
Gramina.

Sporochna'ceæ (Bot.) an order of Algx, of which the following is the typical genus.

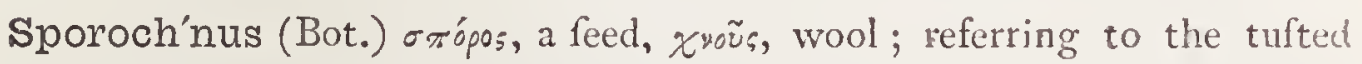
reproductive organs; a genus of Alga.

Sporocy'be (Bot.) $\sigma$ tópos, feed, xuf́n, head; a genus of Fungi.

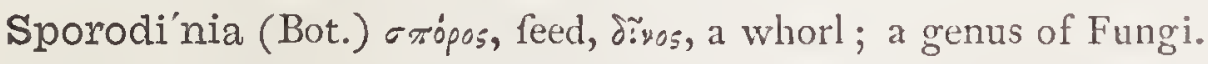

Spo'rodum (Bot.) бrópos, feed; a genus of Fungi.

Sporo'mega (Bot.) $\sigma$ tópos, feed, $\mu$ śya, large; a genus of Fungi.

Sporophle'um (Bot.) =rópos, feed, $\phi \lambda_{0} s^{\prime} \sigma_{3}$, bark: a genus of Fungi.

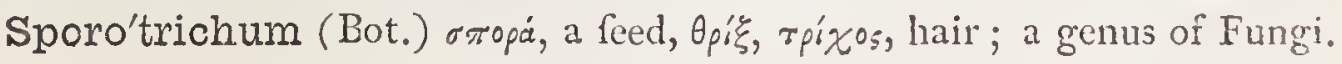


Sprat (Ichth.) Dutch, Sprot; Germ. Sprotte; probably from Jprotten, to Eprout, as if the fprout of the herring; the Herengula Sprattus.

Sprat'tus (Ichth.) Latinized form of fprat.

Sprenge'lia (Bot.) P. N. in honour of C. C. Sprengel, of Spandau in

Brandenbirgh; a genus of Epacridacex.

Spuma'ria (Bot.) Spuma, froth; a genus of Fungi.

Spurge (Bot.) Fr. espurge, probably from jpargo, to fcatter, the reeds

being abundantly difperfed; the genus Euphorbia.

Spyridia (Bot.) бтupísıv, a little filh-bafket; a genus of Algæ.

$\left.\begin{array}{l}\text { Squa'lidæ } \\ \text { Squa'lus }\end{array}\right\}$ (Ichth.) $\left\{\begin{array}{c}\text { fqualus, a kind of fea-fifh; the family and } \\ \text { typical genus of the Sharks. }\end{array}\right.$ Squama'ria (Bot.) fquama, a fcale; a genus of Fungi : alfo the fpecific name of the Toothwort, Lathræa fquamaria.

Squama'ta (Zool.) Squama, a fcale; the firt order of reptiles in Dr. Gray's arrangement.

Squama'tus-a-um (Zool.) fquama, a fcale ; fcaly or fcale-like,

Squamopeda'lis (Ent.) fquama, a fcale, pes, pedis, a foot.

Squamo'sus-a-um (Zool., Ent., Bot.) Lat.fcaly ; e. g. Anona fquamofa.

Squamulo'sus-a-um (Bot.) fquamula, a little fcale; covered with fmall fcales.

Squarro'sus-a-um (Bot.) ․ g. Melaleuca fquarrofa, Aconitum fquarrofum. Squa'tina (Ichth.) Lat. a Rate.

Squill (Bot.) Lat. Scilla; Arabic, afqyl.

Squinancy-wort (Bot.) corrupted from Alperula Cynanclia, which is

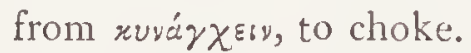

squirrel (Zool.) from fciurichus, dim. of fciurus; Fr. écureuil ; the common fquirrel is Sciurus vulgaris.

Staz'via (Bot.) P. N. in honour of Martin Stazf, a correfpondent of Linnæus ; a genus of Bruniacex.

Staberoha, (Bot.) P. N., a genus of Reftiacer.

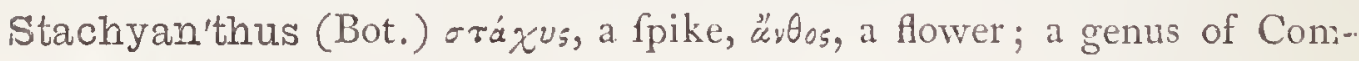
pofitx.

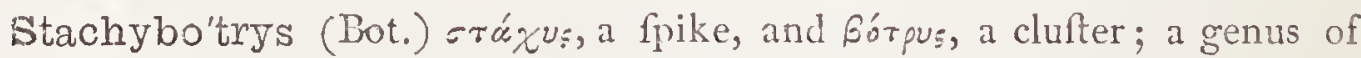
Fungi.

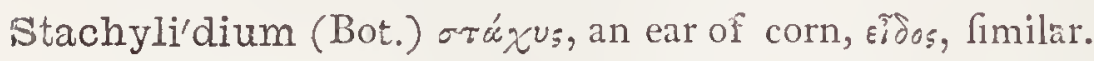

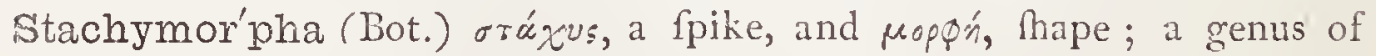
Caryophyllacex.

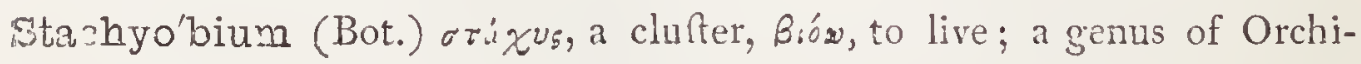
dacex. 
Sta'chys (Bot.) oráxvs, a fpike; flowers in fpikes; a genus of Labiatx.

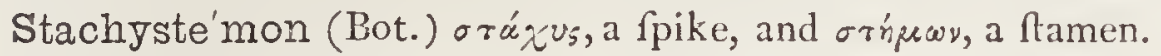

Stachyta'rpheta (Bot.) бráxus, a fpike, rupфвı́s, denfe; a genus of Verbenacex.

Stachyu'rus (Bot.) srázus, a fpike, and ó́pa, a tail; a genus of Pittofporacer.

Stackhou'sia (Bot.) P. N. in honour of M. Stackhoufe, a Britifh botanifl; typical genus of Nat. Ord. Stackhoufiaceæ.

Stadman'nia (Bot.) P. N. in honour of $M$. Stadmam, a botanical traveller; a genus of Sapindacex.

Stæ'chas (Bot.) a geographical name ; the name of a fpecies of Lavandua and of a fpecies of Gnaphalium.

Stæchasper'mum (Bot.) the Lavandula Strechas, and otsépucs, feed; from refemblance of plant to the fruit of the former; a genus of Alga.

Stæheli'na (Bot.) P. N. in honour of Benedict Stahelin, a Swifs botanift; a genus of Compofitæ.

Stag (Zool.) of Anglo-Sax. origin ; the Red Deer or ftag is Cervus Elephas, the Fallow Deer is Dama Vulgaris.

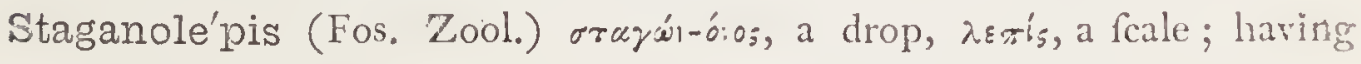
pitted fcales.

Stag-beetle (Ent.) fo called from their powerful mandibles refembling ftag's horns; the Lucanus cervus.

Sta'getus (Ent.) бrayeris, a drup; a genus of Colcoptera, family Anobiadie.

Stagna'lis-e (Ent., Bot.) ftagnum, a pool or fwamp; living among poods. Stagna'tilis-e (Ornith.) Lat. pertaining to ponds or pools.

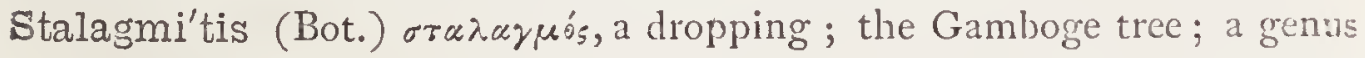
of Clufiacer.

Stal'ion (Zool.) Anglo-Sax. fall.

Sta'men, pl. Stam'ina (Bot.) ornf:ar, a fpindle, or the warp in the ancient upright loom; applied to the male organs of flowering plants, con. fifting of the filament and anther.

Stanho'pea (Bot.) P. N. in honour of Earl Stanhope, a diftinguifhed patron of Botany; a genus of Orchidacere.

Stanley'a (Bot.) P. N. in honour of Edrvard Lord Stanley, F.R.S., after-

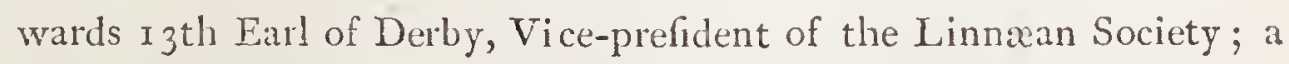
genus of Cruciferæ.

Stanneël'lum (Ent.) fanneus, made of frannum, an alloy of filver and lead; from the colour of the wings which are "fhining pale bronzy grey." 
Stape'lia (Bot.) P. N. in honour of Dr. F. B. à Stapel, Dutch editor of "Theophraftus;" a genus of South African Afclepiadacex.

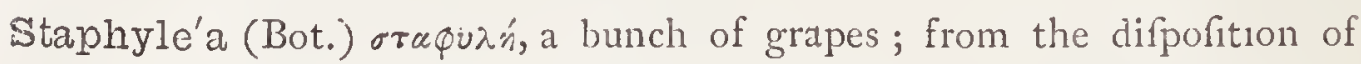
the fructification; Bladder-nut; typical genus of Staphylacex.

$\left.\begin{array}{l}\text { Staphylinidæ) } \\ \text { Staphyli'nus }\end{array}\right\}$ (Ent.) $\left\{\begin{array}{c}\sigma \tau a \varphi v \lambda n ́, \text { a bunch of grapes; a family and } \\ \text { genus of Coleoptera. }\end{array}\right.$

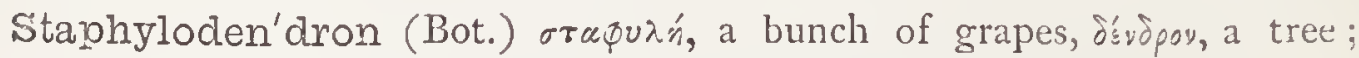
from the form of the inflorefcence; a genus of Staphyleacex.

Staphisa'gria (Bot.) Latinized form of "Stavefacre;" a genus of Ranunculaceæ.

Starlse'a (Bot,) P. N. in honour of Rev. M. Starke, of Gros Tfchirna, Silefra; a genus of Compofiti.

Star'ling (Ornith.) Anglo-Sax.fare; Germ. ftahr; the Sturnus vulgaris.

Star'wort (Bot.) from the form of flower; the genus After; a genus of Compofitx.

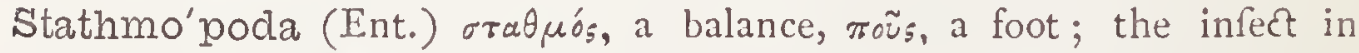
repofe extends its hind legs in a horizontal polition; a genus of Lepidoptera.

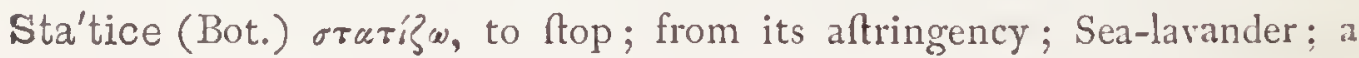
genus of Plumbaginacex.

Staunto'nia (Bot.) P. N. in honour of Sir George Staunton; a genus of Lardizabalaceæ.

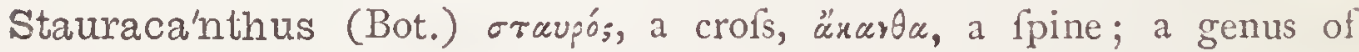
Leguminof:

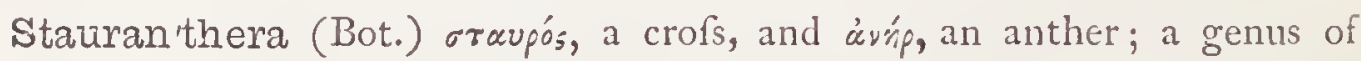
Gefneraceæ.

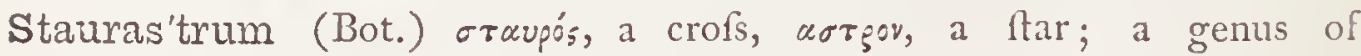
Algx.

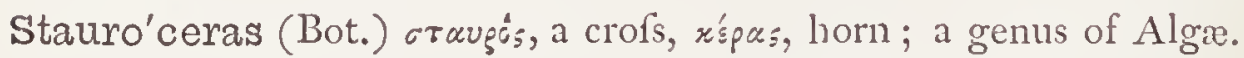

Stauroglot'tis (Bot.) $\sigma \tau a v_{\xi} o_{s}$, a crors, and $\gamma \lambda \omega \tau \tau \xi_{5}$, a lip or labellum; a genus of Orchidacere.

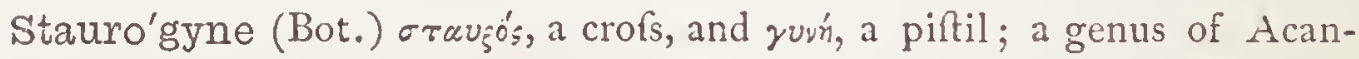
thaceæ.

Stauro'neis (Bot.) rravęó, a crofs; a genus of Algre.

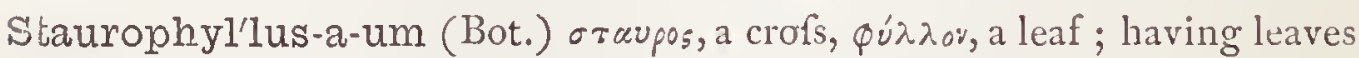
arranged croll-ivife, e.g. Podolobium ftaurophyllum.

Staurop'tera (Bot.) rruvsós, a crofs, trepor, a feather; a genus of Algx.

Staurop'terus-a-um (Bot.) fame etymol.; having crofles on the wings. 


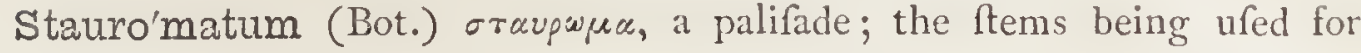
making them; a genus of Aracex.

Staurophal'lus (Bot.) oravpos a crofs, and $\phi a \lambda \lambda_{0} o_{s}$, a fungus.

Staurophra'gma (Bot.) oruupós, a crofs, фpú $\gamma \mu a$, a divifion or palifade; a genus of Scrophulariacex.

Stau'ropus (Ent.) craĩpos, a crofs, $\pi \tilde{u}_{5}$, a foot; from the form of the forelegs of the larva; a genus of Lepidoptera.

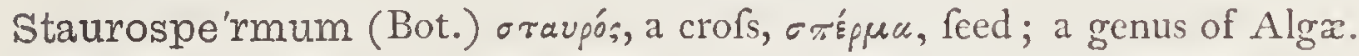
Sta'vesacre (Bot.) Anglo-Sax. Jtafes-acre; the Delphinium Staphifagria.

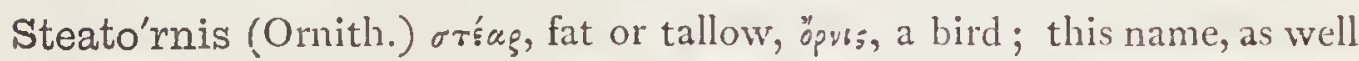
as the popular one of Oil bird, is taken from the fact that the natives largely employ the oil contained in their bodies; the Guacharo bird. Stechman'nia (Bot.) P. N., a genus of Compolitæ.

Steenhamma'ria (Bot.) P. N. in honour of a celebrated German botanift; a genus of Boraginacer.

Steenstru'pia (Zool.) P. N. in honour of - Steenftrup, a Danifh naturalift.

Steer (Zool.) Anglo-Sax. fteor; a young bullock or young ox.

Stee'tzia (Bot.) P. N. in honour of a celebrated Cryptogamia botanift ; a genus of Hepatica.

Steffen'sia (Bot.) P. N. in honour of Heinrich Steffens, a diftinguifhed German naturalift, who died in 1848 ; a genus of Piperaceæ.

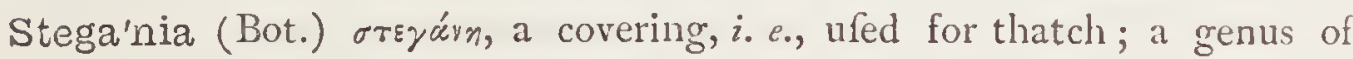
Polypodioid Filices.

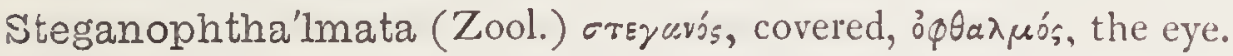

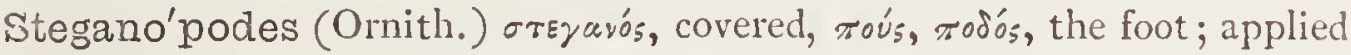

to fwimming birds having all the toes enclofed in the fame membrane.

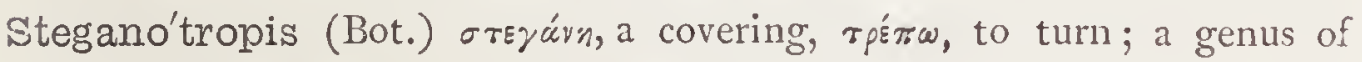
Leguminofx.

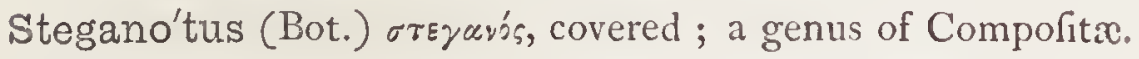

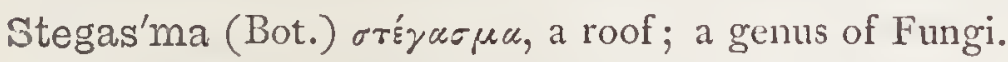

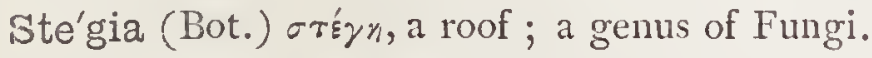

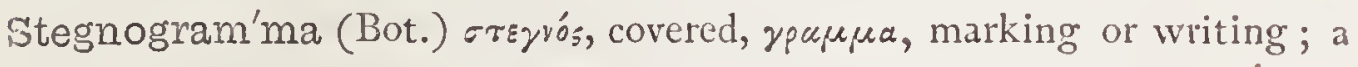
genus of Polypodioid Filices.

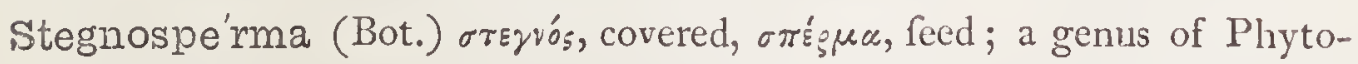
laccacex.

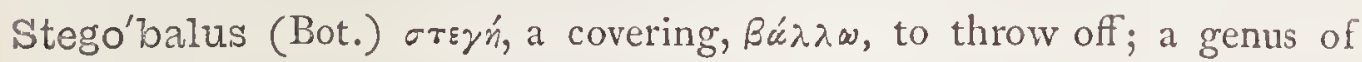
Fungi.

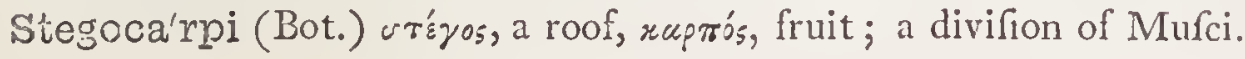




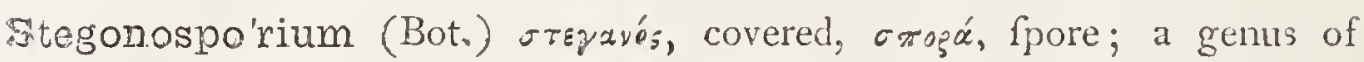
Fungi.

Stego'sia (Bot.) $\sigma \tau$ ryw, to cover (with thatch); a genus of Gramina. S.teinhellia (Bot.) P. N., a genus of Afclepiadacex.

Steinkellneriel'la (Ent.) P. N. in honour of Steinkellner, one of the

Therefian Profeffors at Vienna.

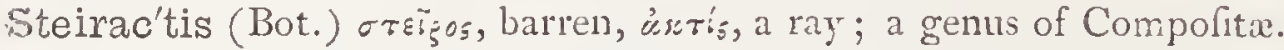

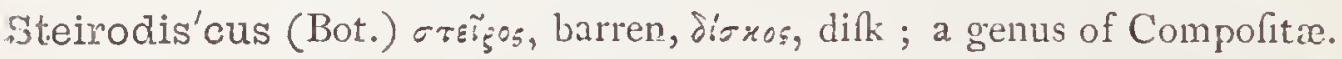

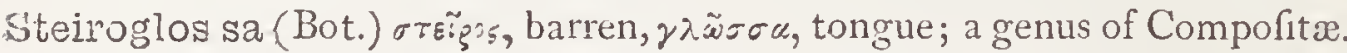

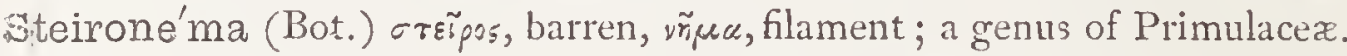

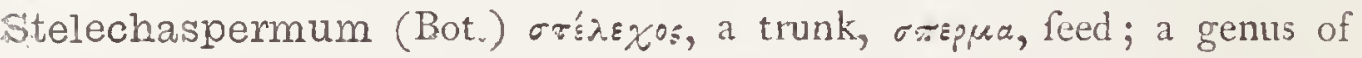
Clusiacer.

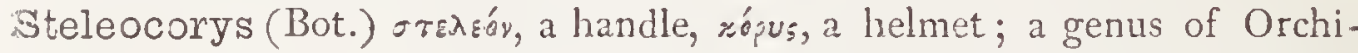
dacex.

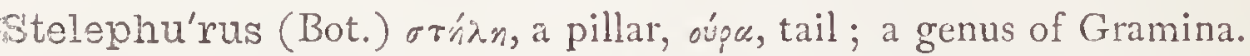

Ste'lis (Bot.) $\sigma \tau \varepsilon \lambda i_{s}$, the Greek name of fome parafitical plant, perhaps the miftletoe; a genus of Orchidacer.

Ste'lis (Ent.) $\sigma \tau n_{\lambda}^{\prime} n$, a poft; a genus of Hymenoptera.

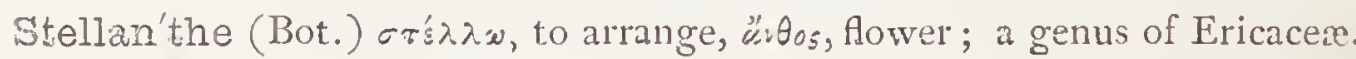
¿3tella'ra (Bot.) fellaris, ftarry; a genus of Orobanchaceæ.

Stella'ria (Bot.) filla, a ftar; from its ftar.like frowers; a genus of Caryophyllacex.

Stella'xis (Bot.) Lat. Atary; in botany, a genus of Liliacex.

Stella'ris-e (Ornith., Bot.) Lat. ftarry, e. g., Saxifraga ftellaris.

Stella'tae (Bot.) fellatus, ftar-fhaped; the order, formed by Ray, which comprifes the Galiums and other ftellate-leaved plants.

Stella'tus-a-um (Zool., Bot.) Lat. e.g. Teftudo fellata.

Stelle'ra (Bot.) P. N. in honour of G. W. Steller, a celebrated botanical collector, who died in 1746 ; a genus of Gentianacex.

Ste'llio (Zool.) Lat. a lizard; the Gecko, which has ftar-like fpots on its back; a genus of Reptilia.

Stel'lula (Ornith.) dim. of fella, a ftar; a genus of Humming-birds.

Stellul'iria (Bot.) ftellula, a little ftar; a genus of Confervacex.

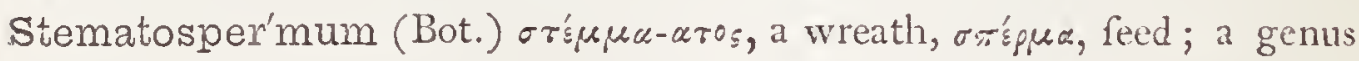
of Gramina.

Stemmacantha (Bot.) $\tau \tau^{\prime} \xi \mu \mu \alpha$, a wreath, $\dot{\alpha} \alpha \nu \theta \alpha$, a prickle; a genus of Compolitx.

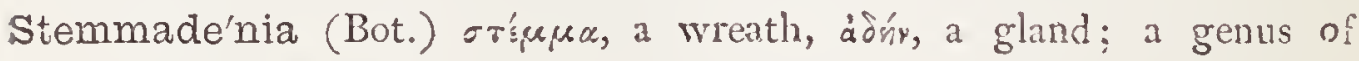
Apocynacex. 


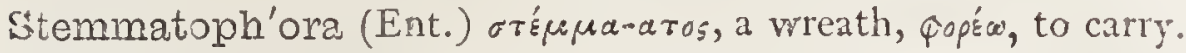

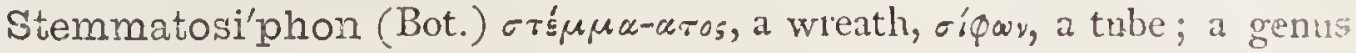
of Styracacere.

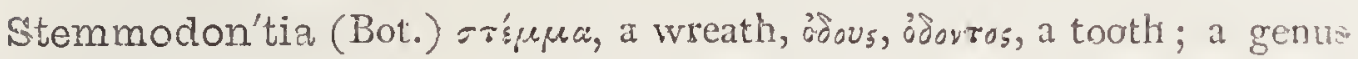
of Compofitæ.

Stemo'dia (Bot.) stíkcov, a ftamen, Jis, double; having two-anthered filanıents; a gerus of Scrophulariacex.

Stemoni'tis (Bot.) orriswr, a fpindle; alluding to the form of fome fpecies; a genus of Fungi.

Stemphy'lium (Bot.) orésфuдov, oil-cake; which it refembles; $i$ genus of Fungi.

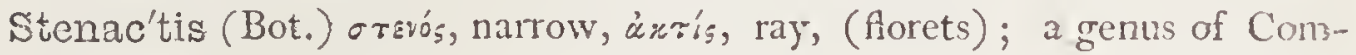
pofitx.

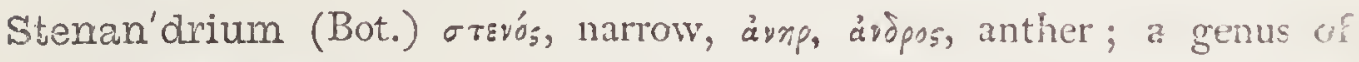
Acanthacex.

Stenan'thera (Bot.) orevó, narrow, sivenpo, an anther; a genus of Epacridaceæ.

Stenan'thium (Bot.) orevós, narrow, ä: $\theta_{05}$, flower ; a gelius of Melan-. thacex.

Ste'ne (Ent.) бrevós, natrow; a genus of Coleoptera.

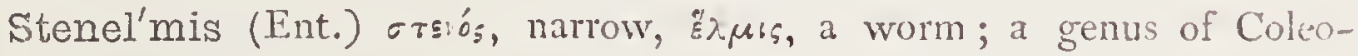
ptera.

Ste’nia (Ent., Bot.) oreı́s, narrow; a genus of Orchidacex ; alfo a genus of Lepidoptera.

Ste'nida (Ent.) the family of Coleoptera of which Stenus is the typica! genus.

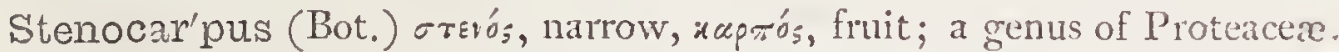

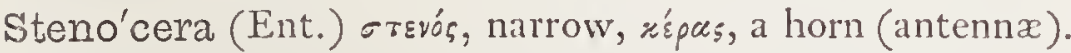

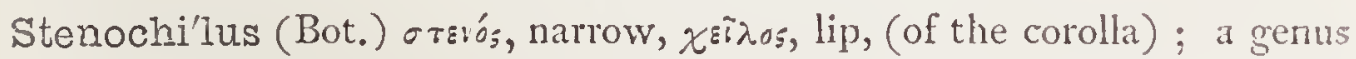
of Myoporaceæ.

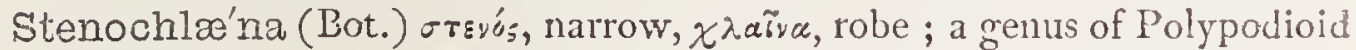
Filices.

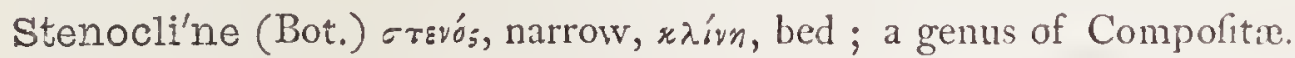

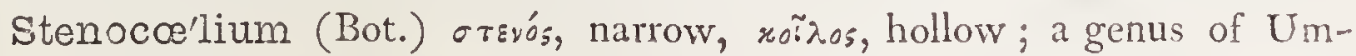
belliferæ.

Stenocory'ne (Bot.) rsะvós, narrow, ropúrn, a club or mace ; a genus of Orchidaceæ.

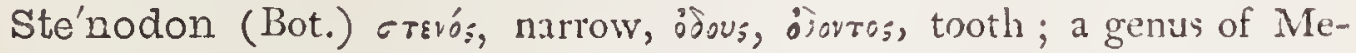
laftomacex. 


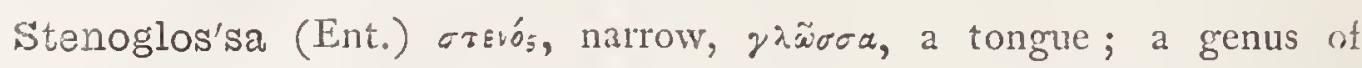
Hymenoptera.

Stenoglos'sum (Bot.) fame derivation; a genus of Orchidaceæ.

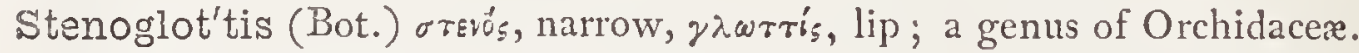

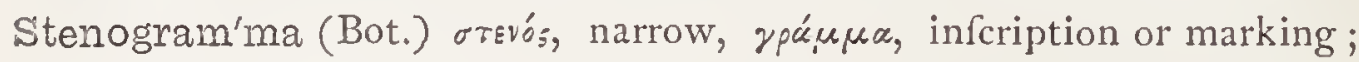
a genus of Algæ.

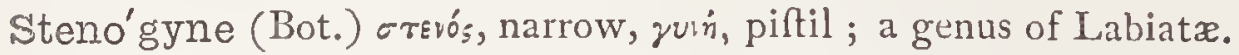

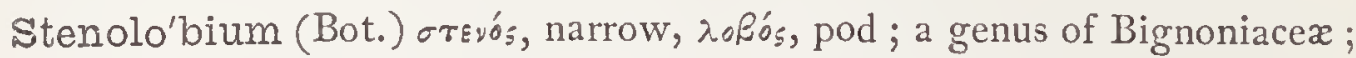
alfo a genus of Leguminofx.

Stenolo'bus (Bot.) fame derivation; a genus of Polypodioid Filices.

Steno'lophus (Bot.) orєvós, narrow, גópos, a creft; a genus of Compofitx.

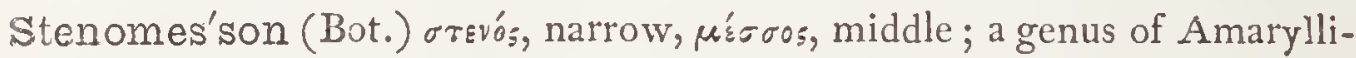
daceæ.

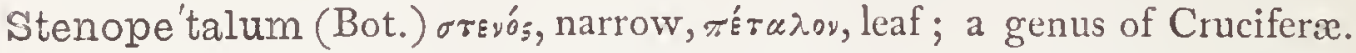

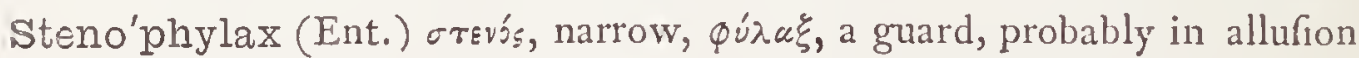
to the antennæ.

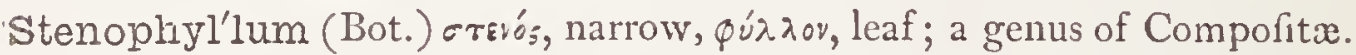

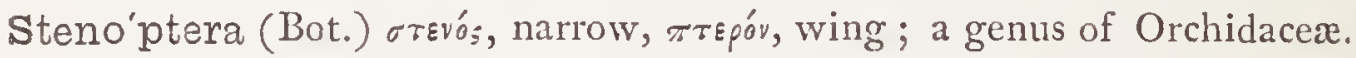
Stenop'terus (Ent.) fame derivation; a genus of Coleoptera.

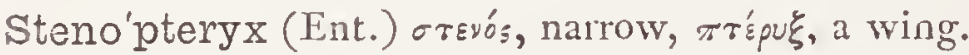

Stenorhi'na (Zool.) orevós, narrow, p̊ív, nofe.

Stenorhynchi'na (Zool.) orkvós, narrow, ṕúzxos, a beak; a fub-family of Mammalia.

Stenorhyn'chus (Bot., Zool.) orevós, narrow, fúyxos, a beak ; a genus of Orchidacex; in zoology, a genus of Decapod Cruftacea and of Phocidx.

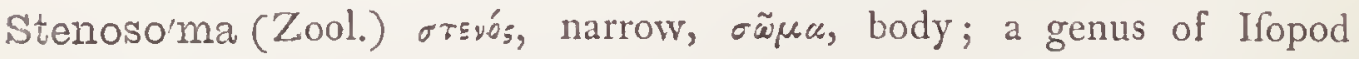
Cruftacea.

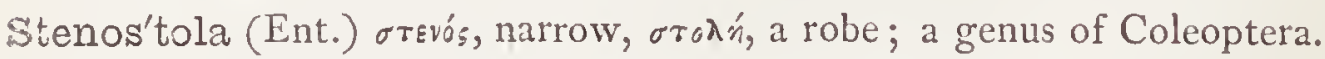

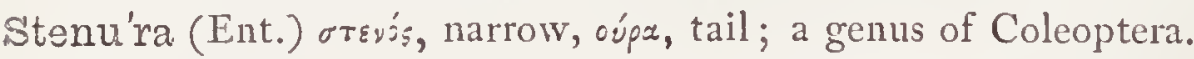

Ste'nus (Ent.) ฮrevós, narrow, referring to its attenuated form; a genus of Coleoptera.

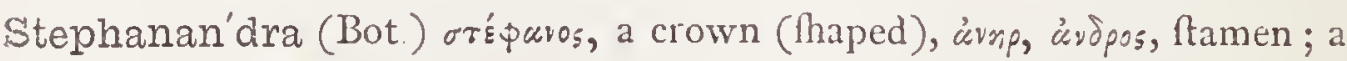
genus of Rofacer.

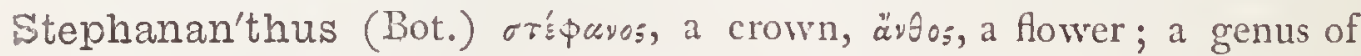
Compofitio.

Stepha'nia (Bot.) P. N. in honour of F. Stephan, a Profeftor at Mofcow ; a genus of Menifpermaceæ.

Stepha'nium (Bot.) rré申uros, a crown; a genus of Cinchonaceæ. 
Stephanoca'rpus (Bot.) $\sigma \tau^{\prime}$ paros, a crown, and xaprós, fruit; a genus of Ciftaceæ.

Stephano'coma (Bot.) otépavos, a crown; xócun, a tuft or head; a genus of Compofitx.

Steph'anohy'dra (Zool.) or'şavos, a wreath or coronet, ¿́opa, a waterferpent; a genus of Ophidians.

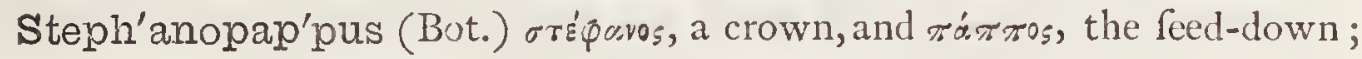

a genus of Compofitæ.

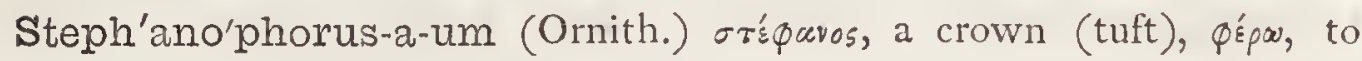
bear ; tuft-bearing.

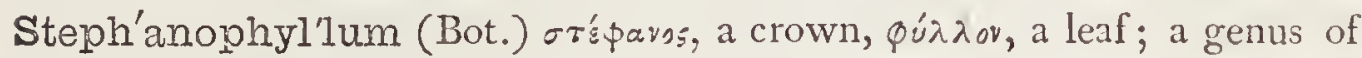
Eriocaulaceæ.

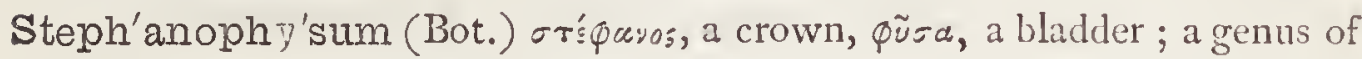
Acanthaceæ.

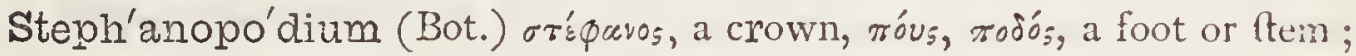
a genus of Chailletiacex.

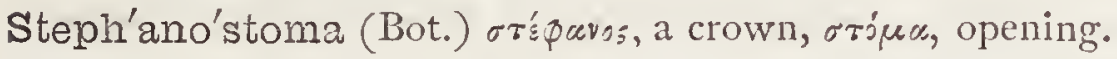

Stephano'tis (Bot.) oréqavos, a crown; from its natural adaptednefs for chaplets; a magnificent genus of Af́clepiadacea.

Stephen'sia (Ent.) P. N. in honour of Fames Francis Stephens, author of "Illuftrations of Britifh Entomology," \&c., who died in I 85 I ; a genus of Lepidoptera.

Sterbec'kia (Bot.) P. N., a genus of Capparidacex.

Stercora'rius (Ornith.) fercus, ordure; the Skua; a genus of Sea-gulls.

Stercu'lia (Bot.) fercus, ordure ; fome 1pecies are fetid; typical genus of Sterculiaceæ.

Ste'rcus musca'rum (Ichth.) Lat. the dung of fies; from a longitudinal feries of black dots on the prix-operculum and fides.

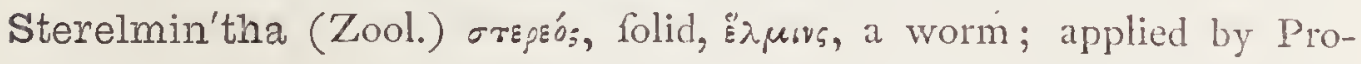
feflor Owen to inteftinal worms having no difcoverable vifcera.

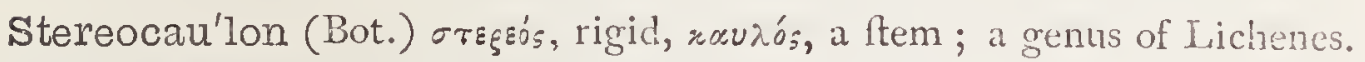

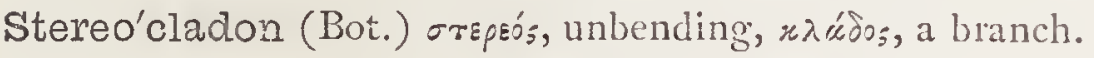

Stereococ'cus (Bot.) бтврво;, hard, zóx жs;, berry or feed; a gentis of Algæ.

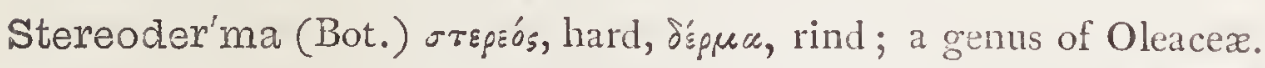

Ste'reodon (Bot.) бтврвós, ftiff, ojown, tooth (of the periltome); a grenus of Mufci.

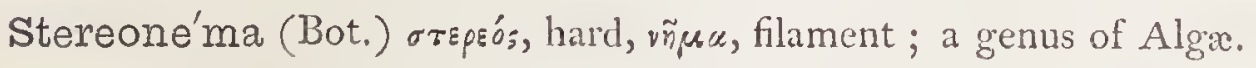




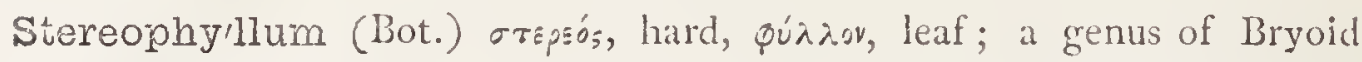
Mufci.

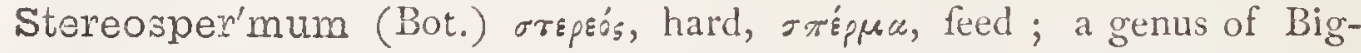
noniacex.

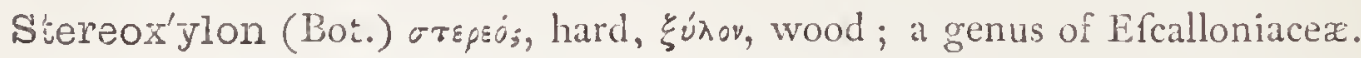

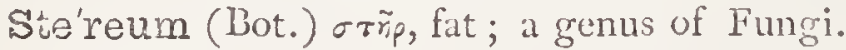

Sterig'ma (Bot.) ornpiyse, a prop; the ftamens are joined at the bafe; a genus of Cruciferæ.

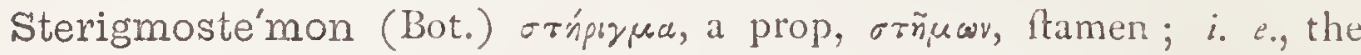
ftamen being bifurcated at the top ; a genus of Cruciferæ.

Ster'ilis-e (Bot.) Lat. barren, ufelefo; $e$.g. Bromus fterilis.

Ste'ripha (Bot.) orépsфos, tough ; a genus of Convolvulacer.

Steripho'ma (Bot.) otéprpos, tough; a genus of Capparidacex.

Ste'ris (Bot.) oтñp, greafe; a genus of Hydrophyllacer.

Ste'rna (Ornith.) Lat. a tern; typical genus of Sternida, the Terns or Sea-fwallows.

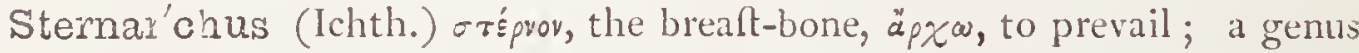
of Gymnotid Fithes.

Sternber'gia (Bot.) P. N. in honour of Count Gapper Sternberg, a celebrated botanilt; a genus of Liliacex.

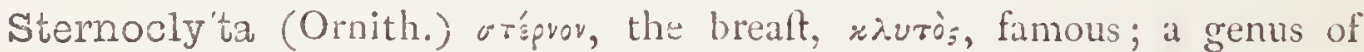
Humming-bircis.

Sterno'xi (Ent.) orśpvor, the breaft, oysus, harp; a divifion of Coleoptera.

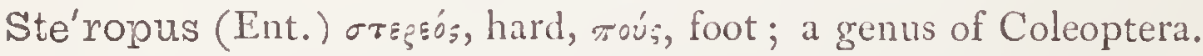

Ster'rha (Ent.) oтвppó, hard, ftrong; a genus of Lepidoptera.

Stethorec'tus (Ent.) orngos, the brealt, refiss, ftraight; a grenus of Hymenoptera.

Stettinen'sis-e (Ent.) belonging to Stettin, Pomerania.

Steude'lia (Bot.) P. N. in honour of the celebrated auchor of the "Nomenclator;" a genus of Erythroxylace:e.

Stevar'tia (Bot.) P. N., a genus of Malvacere.

Steve'na ( Bot.) $\rho$ P. N., in honour of C. Steven, a Rufian botanift; Steve'nia) ( generu of Cruciferie.

Steven'sia (Bot.) P. N., a genus of Cinchonacei.

Ste'via (Bot.) P. N. in honour of Peter Fames Efeve, M.D., Profellor of Botany at Valencia; a genus of Compofite.

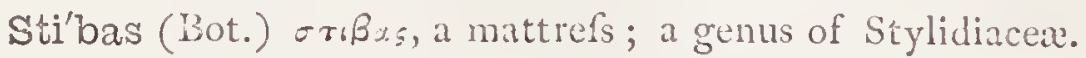

Stibi'sta (Zool.) from fibium, a preparation of antimony ufed for faining the eyelids; from having two narrow black bars acrofs the foot. 
Sti'cherus (Bot.) бríxoi, a row or line; a genus of Polypodioid Filices.

Stichocar'pus (Bot.) бríxos, a row or line, zuprós, fruit; a genus of Alga.

Stichoco'ccus (Bot.) orixos, a row or feries, wóros, berry or feed; a genus of Algie.

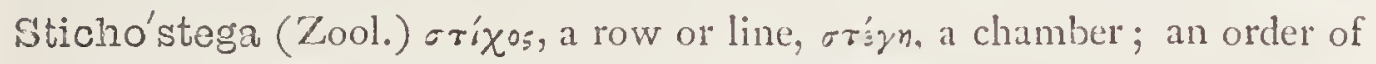
Foraminifera, having a linear feries of chambers.

Stick'leback (Ichth., Bot.) Goman, fickling; Dutch, fleckelbarar ; French, épinoche; the Gafterofteus aculeatus; in Botany, the Galium Aparine. Stic'ta (Bot.) orberó;, fpotted, fiom the under furface of the fronds; a genus of Lichenes.

Stictica'lis (Ent.) orikrós, marked, fpotted.

Stic'tis (Bot.) orıxós, fpotted; from the dot-like appearance of many fpecies; a genus of Fungi.

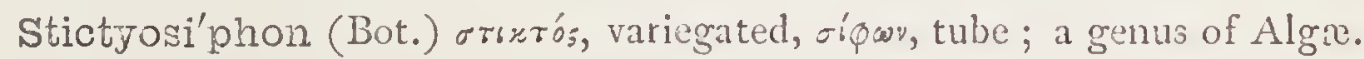
Stiff'tia (Bot.) P. N., a genus of Compofitix.

Stigeoclo'nium (Bot.) $\sigma \tau i \zeta ̧ \omega$, to fpot or mark, $* \lambda \omega v$ sov, a young ihoot; a genus of Algx.

Stigone'ma (Bot.) ori̧̧, to mark or pit, injku, filament; a genus of Algæ, fection Ofcillatoriacex.

Stig'ma, plural Stig'mata (Ent., Bot.) Lut. a mark or fpot; the figmat. are the air-nits of infects, equivalent to fpiracles; in Botany, that part of the piftil upon which the pollen relts.

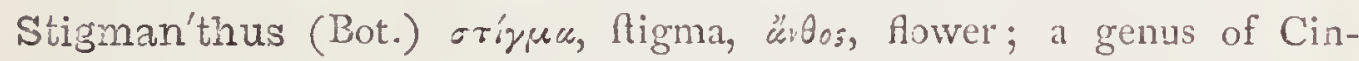
chonacex.

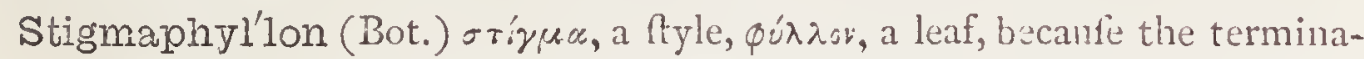
tion of the ftyle becomes expanded into the form of a leaf; a genus of Malpighiaceæ.

Stigmatotine'ca (Bot.) origree, ftigma, Ár n, a theath; a genus of Compofitis.

Stig'mea (Bot.) oriyuce, a point; a genus of Fungi.

Stigmode'ra (Ent.) srírua, a fpot, d'sgn, the neck.

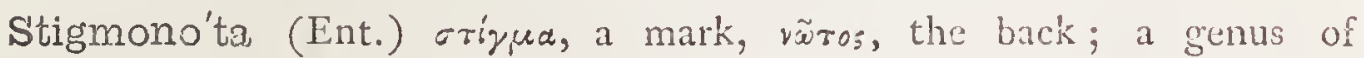
Lepidoptera.

Stig'mus (Ent.) origua, a fpot; a genus of (iymenoptera

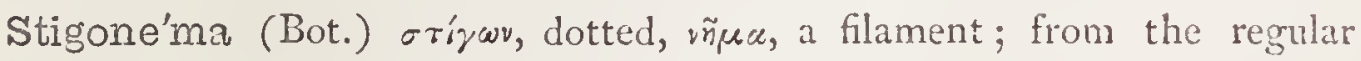
annular dots of the filaments; a genus of Confervaces.

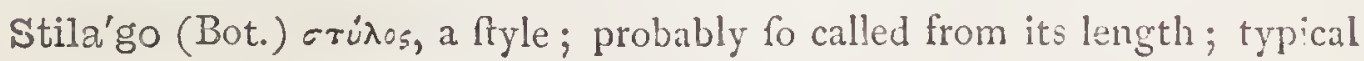
genus of Stilaginacere. 


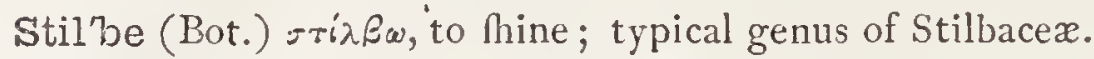

$\left.\begin{array}{l}\text { Stil'bia } \\ \text { Stilbi'idæ }\end{array}\right\}$ (Ent.) $\left\{\begin{array}{c}\sigma \tau i \lambda \beta \omega, \text { to glitter; a genus and family of Lepido- } \\ \text { ptera. }\end{array}\right.$

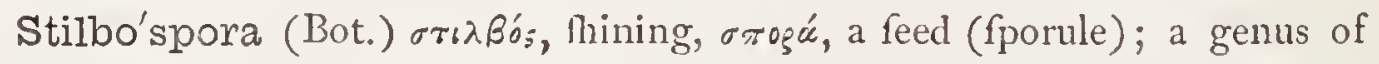
Fungi.

Stil'bum (Bot.) $\sigma \tau \iota \lambda$ bós, fhining; the plants are at firft watery and gelatinous; a genus of Fungi.

Stillingfleet'ia (Bot.) P. N. in honour of Benjamin Stillingfleet, grandfon of the bifhop, who died in I77I; a genus of Euphorbiacex.

Stillin'gia (Bot.) P. N. in honour of the fame eminent Englin botanift; the $S$. febifera is the Tallow tree of China; a genus of Euphorbiacex.

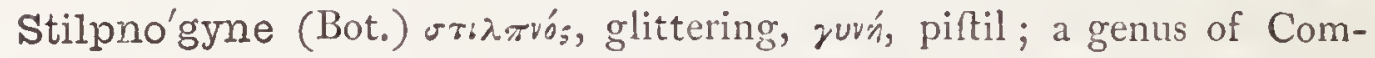
politæ.

Stilpnopap'pus (Bot.) $\sigma \tau \iota \lambda \pi v o$, glittering; $\pi \dot{a} \pi \pi 0 ;$, the down of plants ; a genus of Compolita.

Stilpnophy'tum (Bot.) $\sigma \tau \iota \lambda \pi$ 'ós, glittering, Quróy, a plant; a genus of Compofitx.

Sting-fish (Ichth.) the Trachinus vipera; called alfo the Little Weever.

Stink-horn (Bot.) the Pliallus impudicus.

Sti'pa (Bot.) бrúmn, hemp; Feather-grafs; a genus of Gramina.

Stipagros'tis (Bot.) the genus Stipa, and agroftis, wild; a genus of Gramina.

Stipitu'rus (Ornith.) fipes, a club, ośpa, tail ; a genus of Wren-like Birds.

Stipocau'lon (Bot.) ftipo, to comprefs, caulis, a ftem; a genus of Algie.

Stipopo'dium (Bot.) fiipo, to comprefs, $\pi \circ \dot{v}_{\Sigma}, \pi 0 \delta_{s}$, ltem; a genus of Algæ.

Stipula'ria (Bot.) Stipula, a ftraw (Itipule); a genus of Illecebraceæ.

Sti'pulze (Bot.) Ripula, a ftraw; Ripules, the little leaf-like appendages adjoined to the bafe of the leaf; in hepatica and molles they are called amphigattrid.

Stit'chmort (Bot.) the varieties of Stellaria.

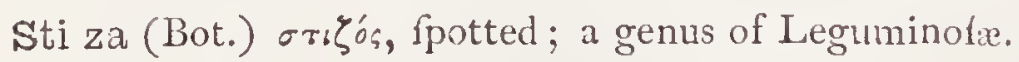

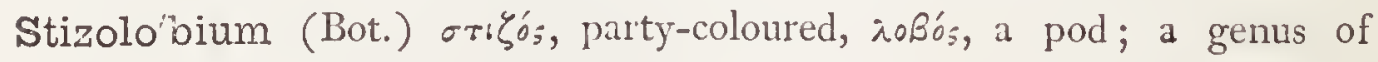
Leguminofie.

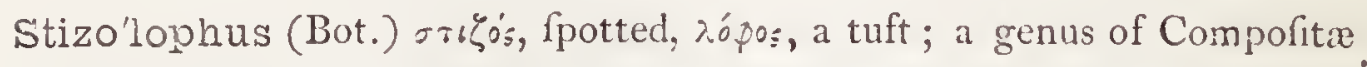
Sti'zus (Ent.) $\sigma \tau \iota^{\prime}{ }^{\prime}{ }^{\prime}$, party-coloured; a genus of Hymenoptera.

Stoat (Zool.) the Muftela erminea.

Stobx'a (Bot.) P. N. in honour of Dr. Stobeus, of Lund, one of Linnaus's first patrons; a genus of Compofitie. 
Stock (Bot.) various fpecies of the genus Matthiola.

Stock-dove (Ornith.) " becaufe it builds in the ftocks of trees, particularly fuch as have been headed down, and have become in confequence rugged and buthy at the top."-YArrell. The Columba CEnas.

Stco'be (Bot.) oroßßn, a cufhion or pad, becaufe the original plant was ufed for bedding; a genus of Compofitx.

Stoke'sia (Bot.) P. N. in honuur of Jonathan Stokes, M.D., coadjutor of Withering; a genus of Compofitæ.

Sto'lidus-a-um (Ornith.) Lat.dull, fupid; e.g., Anöus folidus, the Noddy. Stolon (Bot.) Lat. folo, folonis, a fucker, which from $\sigma \tau^{\xi} \lambda \lambda \omega$, to put forth ; French, folon; applied to a branch given off above the furface of the ground which defcends thereto, and from which arife freth lhoots.

Stoman'dra (Bot.) бrópce, an opening, àviń, àvóós, ftamen; a genus of Loganiacex.

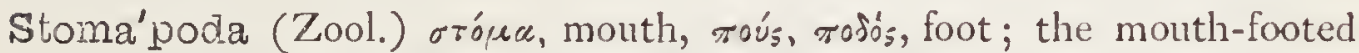
Cruttaceans; an order of Podophthalma.

Stomar'rhena (Bot.) oróua, opening, üp’p̧r, flamen; a genus of Epacridacese.

Sto'mata, or Sto'mates (But.) orósce, opening or mouth; the fmall longitudinal openings in the epidermis of plants.

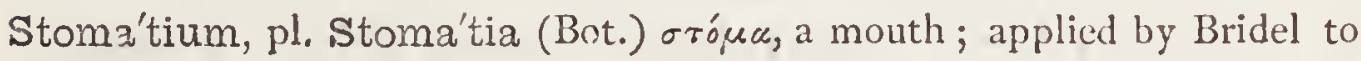
the epiphragm of moffes.

Sto'mias (Ichth.) rróma, the mouth; having the mouth deeply cleft; a genus of Pike-like Fithes.

Sto'mis (Ent.) otócus, hard-mouthed; a genus of Coleoptera.

Stomobra'chium (Zool.) eróka, a mouth, Bpxx'wr, the arm; a genus of Medufx.

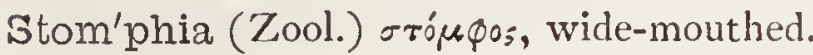

Stone-crop (Bot.) the common ftone-crop is Sedum acre.

Sto'rax (Bot.) a gum which is the produce of Styrax officinale.

Stork (Ornith.) Anglo-Sax. Store, Girm. Storch; the common ftork is Ciconia alba.

Stor'zia (Bot.) P. N., a genus of Liliacex.

Stot (Zool.) Anglo-Sax.ftod-hors; applied, like fteer, to a young bullock or ox. Strabo'nia (Bot.) P. N. in honour of the ancient celebrated geographer; a genus of Compofitx.

Stramenta'lis (Ent.) framen, ftraw; ftraw-coloured.

Stramina'lis (Ent.) framineus, ftraw-coloured; from the colour of the wings. 
Strami'neus-a-um (Zool., Bot.) Lat. ftraw-coloured.

Stramo'nium (Bot.) faid to be from ftramen, a ftraw, from its fibrous roots; Thorn-apple; a genus of Solanacex.

Stranga'lia (Ent.) $\sigma \tau \xi a \gamma r a \lambda \iota x$, a knot; a genus of Coleoptera.

Strangwe'ia (Bot.) P. N., a genus of Liliacex.

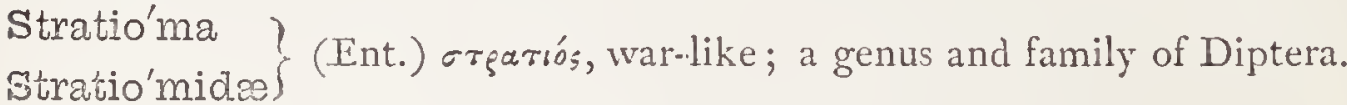

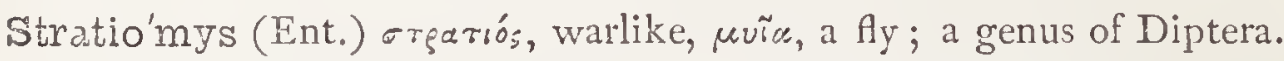

Stratiota'lis (Ent.) feeds on Stratiotes aloides, the common Water Soldier. Stratio'tes (Bot.) orparı́xтns, a foldier, from its fword-like leaves; the

Water Soldier ; a genus of Hydrocharidaceæ.

Straus'sia (Bot.) P. N., a genus of Cinchonacer.

Stranvæ'sia (Bot.) P. N. in honour of the Hon. W. T. H. Fox Strangeways; a genus of Rofacere.

Strava'dia (Bot.) P. N., a genus of Barringtoniaceæ.

Strava'dium (Bot.) from Tjeria Samfravadi, its Malabar name; a genus of Myrtacex.

Straw'berry (Bot.) the berry that grows upon a plant prone to fray, by runners, from its centre of attachment; properly Strayberry; plant and fruit of the genus Fragaria, order Rofacea.

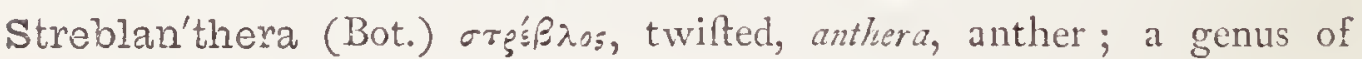
Boraginacex.

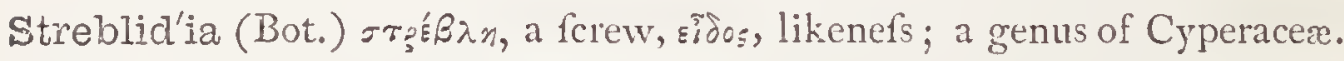

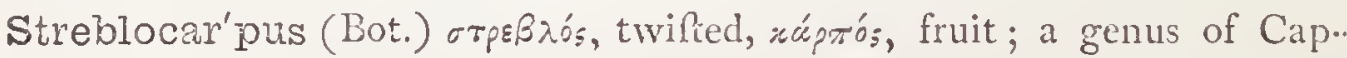
paridacex.

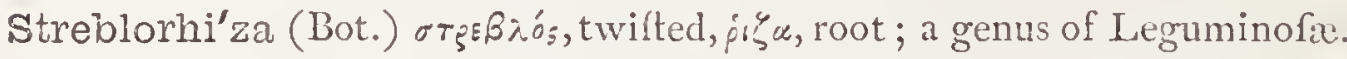

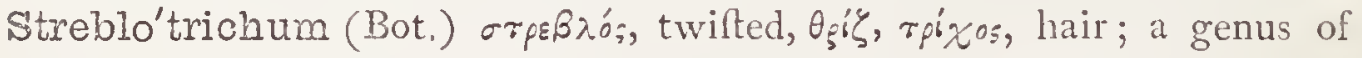
Bryoid Mufci.

Stre'blus (Bot.) $\sigma \tau_{5} \varepsilon \beta \lambda \dot{o}_{s}$, twifted; a genus of Artocarpacex.

Streck'era (Bot.) P. N., a genus of Compolitx.

Strelit'zia (Bot.) P. N. in honour of the houfe of Mecklenburg Strelitio, of which Queen Charlotte was a member; a genus of Mufaceæ.

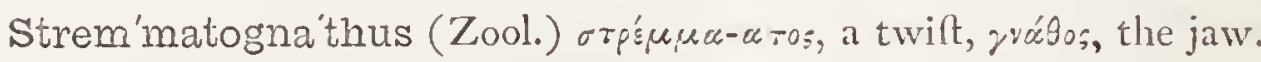

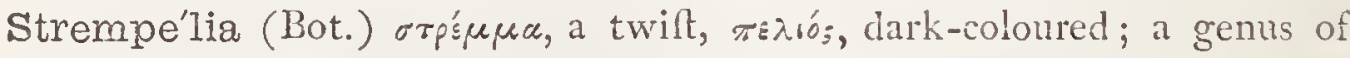
Cinchonacex.

Stre'nia (Ent.) P. N. the goddefs who prefided over new year's gifts. Stre'pera (Ornith.) frepo, to make a noife; from its loud and ringing note; the Shrike.

Strephe'dium (Bot.) eтp'spos, a fpiral; a genus of Bryoid Mufci. 


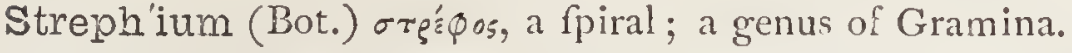

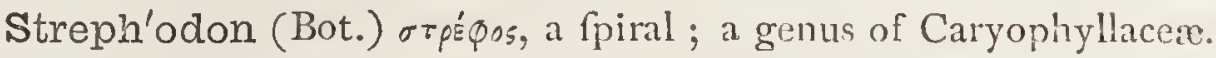

Strep'selas (Ornith.) $\sigma \tau \rho^{\prime} \psi^{\prime} s \nu$, to turn, $\lambda \tilde{a}_{s}$, a ftone; Illiger's name for the Turn-ftones.

Strep'sia (Bot.) $\sigma \tau p^{s} \psi$ ss, a turning round; a genus of Bromeliacex.

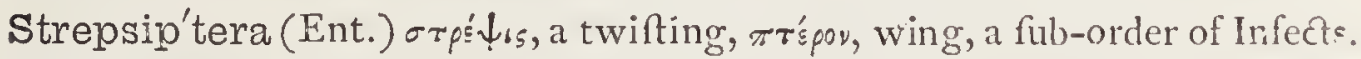

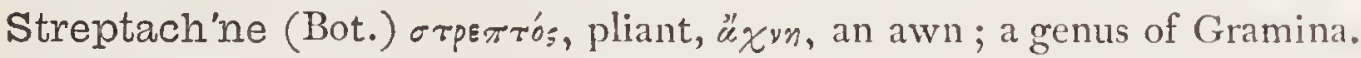

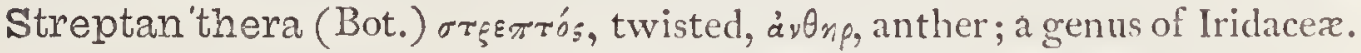

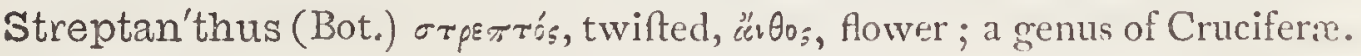

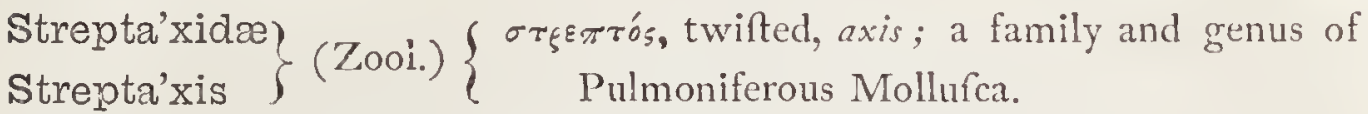

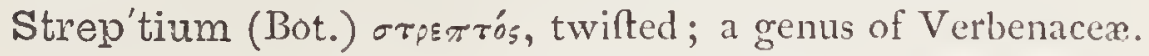

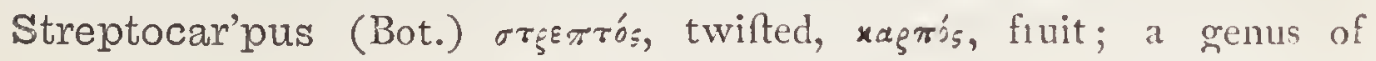
Gefneraces.

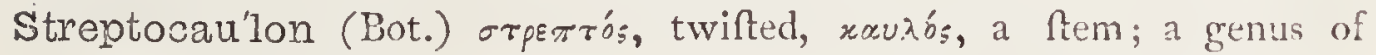
Afclepiadacer.

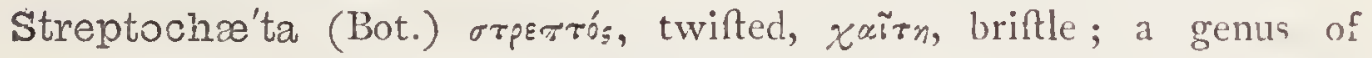
Gramina.

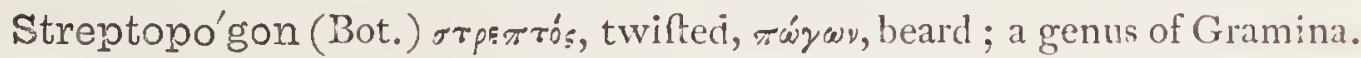

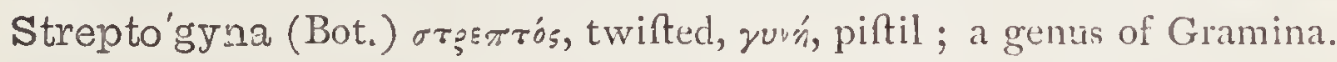

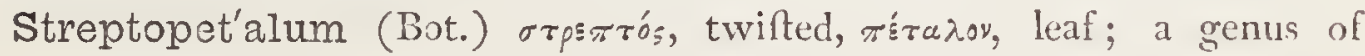

Frankeniacex.

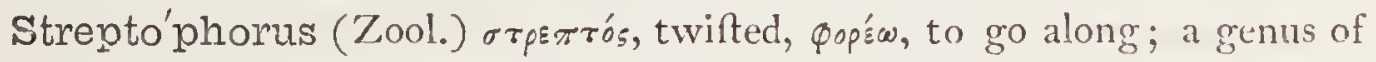
Colubrine ophidians.

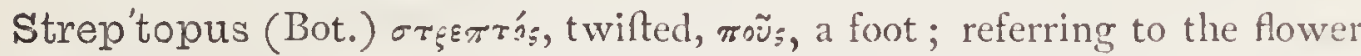
ftalks; a genus of Melanthacex.

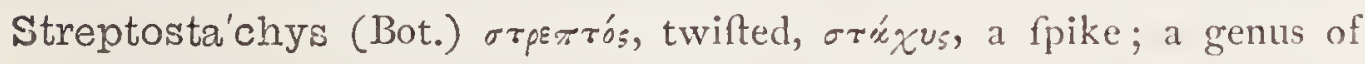
Gramina.

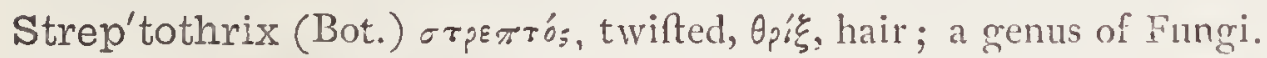

Stria'ria (Bot.) fria, a groove; the fronds are marked with grooves; a genus of Fuci.

Striatel'la (Bot.) dim. of frim, a groove; the fruftules are longitudinally ftriated; a genus of Diatoms.

Stria'tula (Bot.) dim. of fria, a groove; a fmall groove.

Stria'tus-a-um (Zool., Bot.) Lat. furrowed, fluted, grooved.

Stri'ga (Bot.) Jtriga, a furrow; a genus of Scrophulariacere.

Stri'gia (Bot.) ftrigia, a furrow; a genus of Compolite.

Stri'gidze (Ornith.) Arix, an owl; the Owls; a family of Birds of the order Raptores. 
Strigidor'sus-a-um (Zool.) friga, a furrow, dorfum, the back; e.g. applied to a muftela (weafel) having a yellowifh-white dorfal and ventral ftripe; e.g. Muftela frigidorfa.

Strigila'ta (Ent.) Jrigilis, a ftrigil or fcraper ufed by bathers, the form of which is fuppofed to be reprefented by the marks on the wings.

Strigil'ia (Bot.) ftrigilis, a fcraper; a genus of Styracacex.

Strigi'næ (Ornith.) a fub-family of birds, of the order Accipitres, of which Strix is the typical genus.

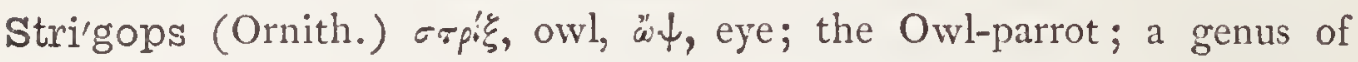
Pfittacidr.

Strigo'sus-a-um (Bot.) friga, a fwathe; having brifle-like hairs.

Stri'gulus-a-um (Bot., Ent.) friga, a fwathe, a line or ftreak; implying markings like furrows in a field.

Strix (Ornith.) $\sigma \tau p^{\prime} \xi$, Lat. frix, an owl.

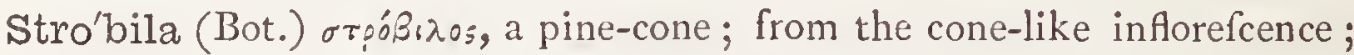
a genus of Boraginacex.

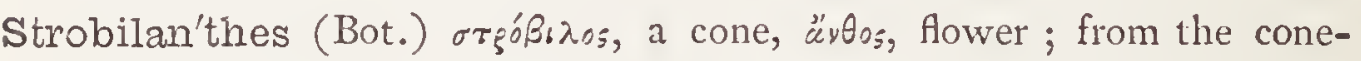
like inflorefcence; a genus of Acanthaceæ.

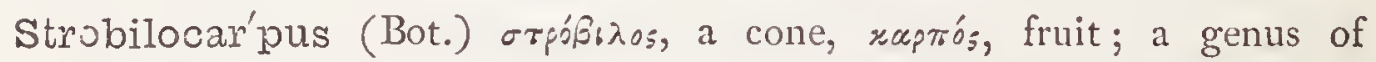
Bruniacex.

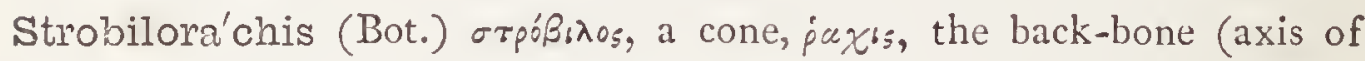
inflorefcence); a genus of Acanthacex.

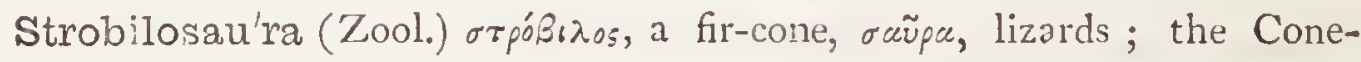
tailed Lizards.

Stro'bilus (Bot.) Lat. a cone; an imbricated fcaly inflorefcence.

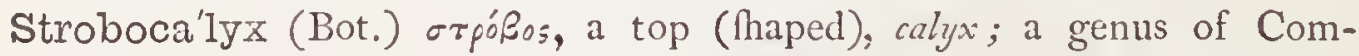
polita.

Strogano'via (Bot.) P. N. in honour of Strogonoff, a Ruflian botanift; a genus of Cruciferæ.

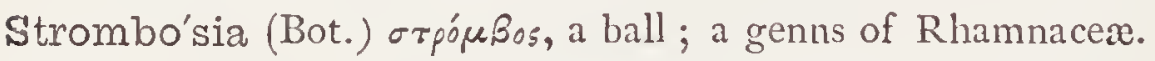

Strömia (Bot.) P. N., a genus of Capparidacex.

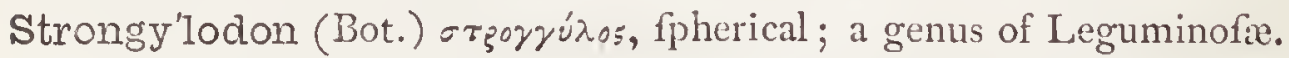

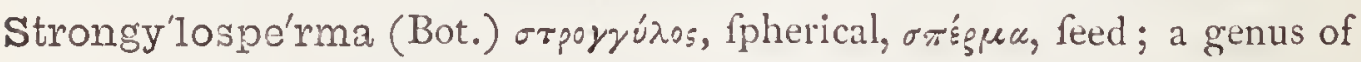
Compolitie.

Stro'ngylus (Zool., Ent.) orporyínos, round, fpherical; in entomology, a genus of Coleoptera.

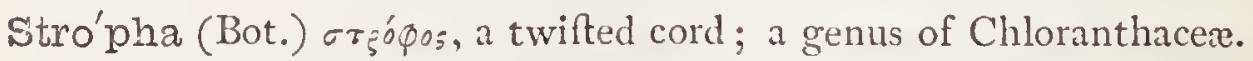

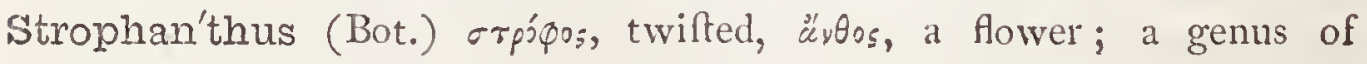
A pocynacex. 


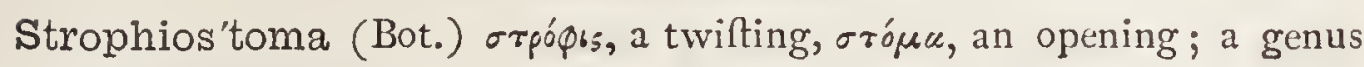
of Boraginacex.

Strophopap'pus (Bot.) erpópos, a twift, $\pi \dot{a} \pi \pi$ s, the down of plants; a genus of Compofitie.

Strophoso'mus (Ent.) oтpópos, a twift, $\sigma \tilde{a} \mu \alpha$, body; a genus of Coleoptera.

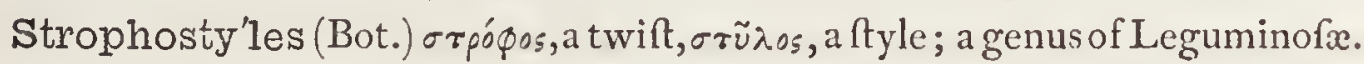

Strucke'ria (Bot.) P. N., a genus of Vochyacex.

Struma'ria (Bot.) ftruma, a tubercle; from the bafe of the ftyle; a genus of Amaryllidacex.

Strump'fia (Bot.) P. N., a genus of Cinchonacex.

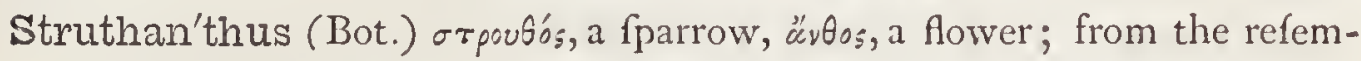
blance of its flowers to an unfledged bird; a genus of Loranthacex.

Stru'thio (Ornith.) orpoutiav, an oftrich, i. e., the great orpoutós, which latter word was ufed for a fmall bird; the Oftrich.

Struthi'ola (Bot.) stpoutós, a little bird; the feeds are beak-like; a genus of 'Thymelacex.

Struthiola'ria (Zool.) fruthio, an oftrich; the Oftrich's-foot fhell; a genus of Mollufea.

Struthio'pteris (Bot.) otpoufiwv, an oftrich, $\pi \tau^{\prime}$ spos, fern; the fronds are like feathers; a genus of Filices.

Stru'thium (Bot.) erpougióv, ancient name of a plant; a genus of Caryophyllacex.

Stru'vea (Bot.) P. N. in honour of Struve, the aftronomer.

Stry'chnos (Bot.) rrpúxvos, the Greek name of the Solanum; a genus of Loganiacex.

Strychnodaph'ne (Bot.) the genus Strychnos, daphne, laurel; a genus of Laurace:e.

Stryphnoden'dron (Bot.) orpupvós, rough, aftringent; a genus of Leguminofe.

Stuar'tia (Bot.) P. N. in honour of Foln Stuart, Marquis: of Bute, a diftinguifhed patron of botany; a genus of Ternftrömiaceæ.

Stubendor'fia (Bot.) P. N., a genus of Cruciferæ.

Stul'tus (Zool.) Lat. a fool.

Stur'geon (Ichth.) Gothic, Jtur, latinizẹd into Jturio; Ital. Sturione, Fr. efturgeon; from the laft of thefe we derive the word.

Stu'rio (Ichth.) Lozv Lat., a fturgeon.

Sturion'idæ (Ichth.) Jturio, with family term.; the Sturgeon family.

Stur'mia (Bot.) P. N. in honour of Facob Sturm, a German botanift; a genus of Orchidacex. 
Sturnel'la (Ornith.) dim. of fíurnus, a ftarling.

Stur'nidæ (Ornith.) fturnus, fam. term. idx; the Starling family.

Stur'nus (Ornith.) Lat. a ftarling.

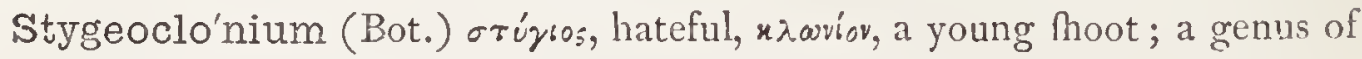
Algx.

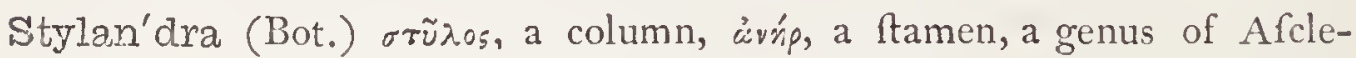
piadacer.

Styla'tus-a-um (E.nt. Bot.) Styhus, a pointed thaft; having an elongated or pointed body, e.g. Afilus ftylatus, Erodium ftylatum.

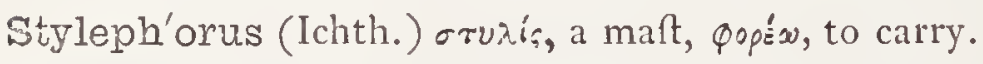

Style'sia (Bot.) P. N., a genus of Compofitx.

Stylidia'ceæ (Bot.) the Styleworts, of which the following is the typical genus.

Stgli'dium (Bot.) $\sigma \tau \tilde{u} \lambda \curvearrowright s$, pillar, from the remarkable irritability of the column formed by the union of the filaments and ftyle; Stylewort; a typical genus of Stylidiaceæ.

Sty'lis (Bot.) $\sigma \tau \tilde{u} \lambda$ s $^{\prime}$, a pillar; a genus of Alangiaceæ.

Stylis'ma (Bot.) oтuגis, a maft or fpar; a genus of Convolvulacex.

Stylo'ba'sis (Bot.) $\sigma \tau \tilde{\nu} \lambda_{\circ}$ s, pillar, bafis; a genus of Algæ.

Styloba'sium (Bot.) fame derivation; a genus of Chryfobalanacex.

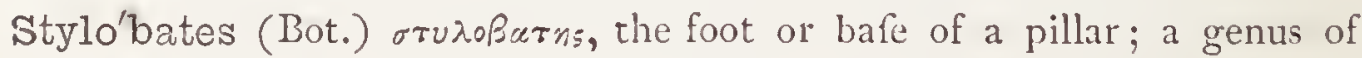
Fungi.

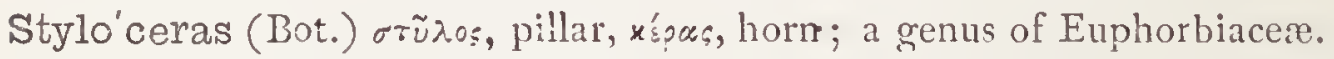

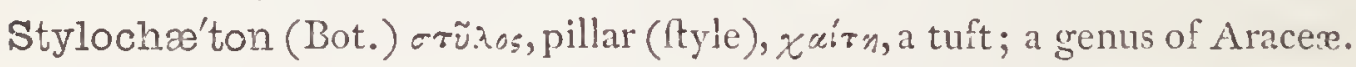
Stylocli'ne (Bot.) $\sigma \tau \tilde{\nu} \lambda$ os, pillar (ftyle), $\lambda^{\prime}$ inn, a bed; a genus of Compofitæ.

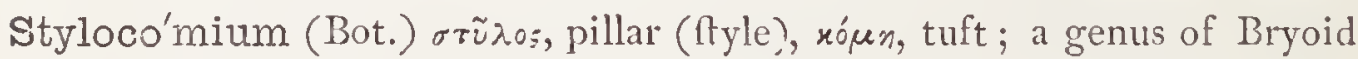
Mufci.

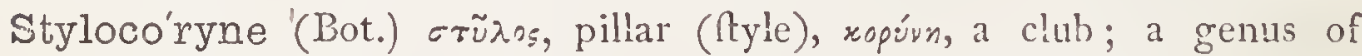
Cinchonacer.

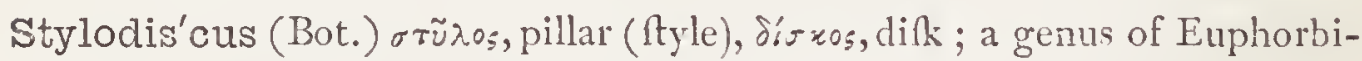
acer.

Styloglos'sum (Bot.) $\sigma \tau \tilde{\nu} \lambda \circ$, pillar, $\gamma \lambda \tilde{x} \sigma \sigma \alpha$, tongue; a genus "of Orchidacer.

Stylo'gyne (Bot.) $\sigma \tau \tilde{\nu} \lambda o s$, pillar (ftyle), yvýn, piftil ; a genus of Myrfmacex. Stylo'lepis (Bot.) $\tau \tau \tilde{i} \lambda \circ$ s, a ftyle, $\lambda \varepsilon \pi \sigma_{\xi}^{\prime}$, a fale ; alluding to the form; a genus of Compofitr.

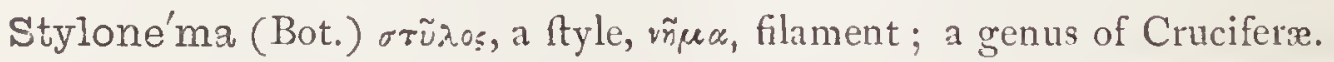
Stylopap'pus (Bot.) $\sigma \tau \tilde{\nu} \lambda \circ$, a Atyle, $\pi \dot{\alpha} \pi \pi$ s, the down of plants; a genus of Compofitx. 


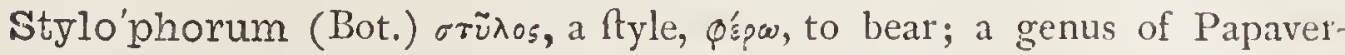
acex.

Sty'lops (Ent.) $\sigma \tau \tilde{\nu} \lambda_{\circ s}$, the writing-ftyle of the ancients, ö $\psi_{15}$, likenefs; a genus of Strepfiptera.

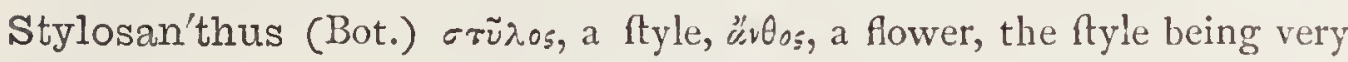
long; a genus of Leguminofæ.

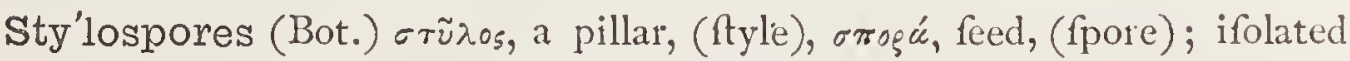
fpores of certain Fungi borne upon thort fimple ftalks.

Styloste'gium (Bot.) $\sigma \tau \tilde{\nu} \lambda \sigma^{\prime}$, ftem (columella), $\sigma \tau^{\prime} \gamma \eta$, lid.

Stylu'rus (Bot.) $\sigma \tau \tilde{\nu} \lambda_{0 s}$, a pillar, oúp, a tail; from the long tails of the feeds. Sty'lus (Bot.) Lat. a fhaft or column; the ftyle is that portion of the piffil which feparates the ftigma from the germen; alfo, in entomology applied to the Baft of the poifer of the Diptera.

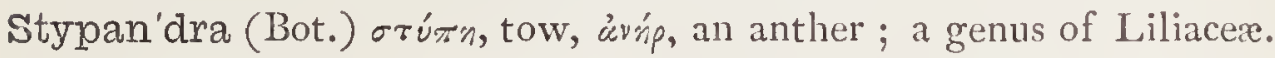

Styphe'lia (Bot.) $\sigma \tau \cup \emptyset \varepsilon \lambda_{0}^{\prime}$, rigid; a genus of Epacridacex.

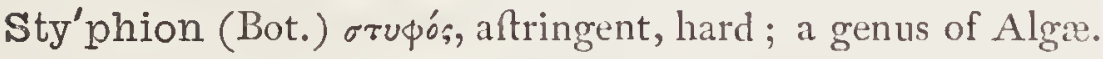

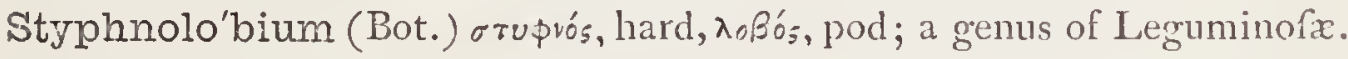

Stypho'nia (Bot.) бтuфós, rugged; a genus of Anacardiacex.

Sty'rax (Bot.) altered from afthirak, the Arabic name; typical genus of Styracacex.

Sty'sanus (Bot.) etymology unknown; a genus of Fungi.

Suæ'da (Bot.) cuwisns, fwine-like, becaufe they feed on it; Sea-blite; a genus of Chenopodiacex.

Suar'dia (Bot.) P. N., a genus of Gramina.

Suavel'la (Ent.) fuavis, pleafant, agreeable.

Sua'veolens (Bot.) Lat. fweet-fcented, e. g. Tulipa fuaveolens.

Subal'bicans (Bot.) Lat. fomewhat white.

Subarqua'tus-a-um (Ornith.) Lat. fomewhat arched.

Subbu'teo (Ornith.) implying fome refemblance to the buzzard, Buteo.

Subcilia'ta (Ent.) fub, hightly, ciliatus, fringed ; the antennæ being ciliated in the male.

Subcinc'tus (Zool.) Lat. flightly girdled; having bands very faint or nearly obfolete

Su'ber (Bot.) Lat. the cork-tree, fcientifically Quercus Suber.

Subflaviven'tris (Zool.)fubflavus, fomewhat yellowin, venter, the belly.

Subgutturo'sa (Zool.) Lat. fomewhat wide-throated.

Subli'mia (Bot.) Jublimis, lofty; a genus of Palmx.

Submer'sus-a-um (Bot.) Jubmergo, to fink, to fubmerge, e.g. Ceratophyllum fubmerfum; becaufe it lives in water. 
Suboper'culum (Ichth.) fub, under, operculum, a cover or lid.

Subro'seus-a-um (Ent.) Lat. flightly rofy.

Subsericea'tus-a-um (Ent.) fub, flightly, fericeus, flky.

Sub'ula (Ent.) Lat. an awl; a genus of Diptera.

Subula'lis (Ent.) "awl..like," from fubula, an awl.

Subula'ria (Bot.) fubula, an awl, from the form of the leaves; a genus of Cruciferæ.

Succenturia'tus-a-um (Ent.) Lat. taken as a recruit, a fubstitute.

Succi'sus-a-um (Bot.) Lat. lopped, from the appearance of the roots;

e. g. Scabiofa Sucifa.

Succo'wia (Bot.) P. N. in honour of Prof. Suckorv, a botanilt of Heidelberg; a genus of Cruciferæ.

Suchtele'nia (Bot.) P. N., a genus of Boraginacex.

Sucker (Bot.) applied to a branch arifing from the ftem below the furface of the earth, which ultimately rifes and forms a feparate plant.

Suécicus-a-um (Ornith., Bot.) Lat. Swifs, e.g. Cornus Suecica.

Suffre'nia (Bot.) P. N., a genus of Lythracex.

Su'hria (Bot.) P. N., a genus of Algæ.

Suil'lus (Bot.) Lat. pertaining to fwine; applied by Pliny to a black hogmulhroom; a genus of Fungi.

Suil'lus-a-um (Zool.) Lat. fwine-like, pig-nofed.

Sulca'tus-a-um (Ent., Bot.) Lat. furrowed, e.g. Scorpiurus fulcatus.

Suli'pa (Bot.) etymology doubtful; a genus of Cinchonacer.

Sullivan'tia (Bot.) P. N., a genus of Saxifragaceæ.

Sulphura'lis·e (Ent.) Lat. fulphur-coloured.

Sulphu'reus-a-um (Ornith., Bot.) Lat. fulphur-coloured, e.g. Motacilla fulphurea, the Yellow Wagtail.

Sulze'ria (Bot.) P. N., a genus of Loganiacex.

Sulzeriel'la (Ent.) P. N. in honour of $\mathcal{F}$. H. Sulzer, a Swifs, and Profeflor at Berlin, who died in 1779.

Su'mach (Bot.) Arabic, fimaq; the genus Rhus.

Sumatra'nus-a-um (Zool.) appertaining to the Island of Sumatra.

Sun-dew (Bot.) common name of the Drofera.

Sun-fish (Ichth.) popular name of one or two kinds of Orthagorifcus.

Su'nius (Ent.) etymology doûbtful; a genus of Coleoptera.

Supe'rbus-a-um (Ornith., Bot.) Lat.fplendid, magnificent, e.g. Paradifea fuperba.

Supercilio'sus (Ornith.) fupercilium, an eye-brow; e.g. Pomatorhinus fuperciliofus, the White Eye-browed Thruh. 
Su'rculus (Bot.) Lat. a young thoot.

Sur'nia (Ornith.) etymology doubtful; a genus of Strigidæ.

Sus (Zool.) Lat. a boar or fow.

Sutherlan'dia (Bot.) P. N. in honour of F. Sutherland, author of botanical catalogue; a genus of Leguminof $x$.

Su'tor (Ichth.) Lat, a fhoemaker; ufed as a fpecific name of the "Thoemaker" of Martinique, Blepharis futor.

Swainso'nia (Bot.) P. N. in honour of Ifaac Szvainfon, F.R.S. E L.S., a great cultivator of plants about the end of the laft century; a genus of Leguminofie.

Swallow (Ornith.) Anglo-Sax. frualezve; the common fivallow is Hirundo ruftica.

Swammerdammel'la (Ent.) P. N. in honour of Fohn Szuammerdamm, the difcoverer of the true metamorphofes of infects, who died in 1680.

Swan (Ornith.) unchanged from the Anglo-Saxon; common name for Anas cygnus.

Swa'rtzia (Bot.) P. N. in honour of Olof Szvartz, a celebrated Swedifh botanift; a genus of Leguminofie.

Swederel'la (Ent.) P. N. in honour of N. S. Szeder, anthor of various papers pubiifhed in the "Stockholm Tranfactions" at the close of the laft century. (Acc. Lift of Brit. Lepid.)

Swee'tia (Bot.) P. N. in honour of Robert Sweet, F.L.S., promoter and editor of feveral botanical periodicals; a genus of Leguminofie.

Sweet-brier (Bot.) popular name of the Rofa rubiginofa.

Sweet-Ciceley (Bot) the Myrrhis odorata.

Swer'tia (Bot.) P. N. in honour of E. Szert, a celebrated cultivaton in Holland; a genus of Gentianaces.

Swiete'nia (Bot.) P. N. in honour of Baron Gerard van Szvieten, a celebrated

Dutch phyfician and botanitt; the Mahogany-tree; a genus of Cedrelacex.

Swift (Ornith.) popular name of the Cypfelus.

Sword-iish (Ichth.) the Xiphias gladius.

Sy'agrus (Bot.) P. N., the firft who wrote the Trojan war in verfe; a genus of Palmacex.

Sy'baris (Ent.) P. N. in mythology; a genus of Coleoptera.

Sy'calis (Ornith.) ourad's, the fig-pecker; a genus of Finches.

Sychi'nium (Bot.) ourivos, fig-like; a genus of Moracex.

Sycko'rea (Bot.) P. N., a genus of Jungermanniaceæ.

Sycocri'nites (Fos. Zool,) oĩxov, a fig, xp'́vov, a lily; a genus of Crinoidea. 


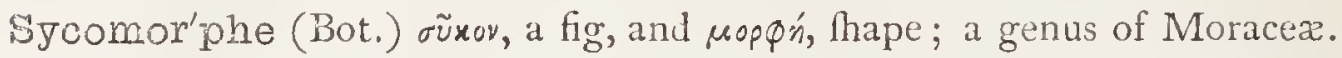
Sye'na (Bot.) ounvós, fwinith, i. e. only fit for fwine's food; a genus of Mayaceæ.

Syze'sia (Bot.) P. N., a genus of Loganiacex.

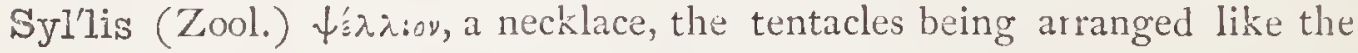
beads of a mecklace; a genus of Annulata, family Nereides.

Sylva'nus-a-um (Ent.) Lat. found in woods.

Sylva'ticus-a-um (Bot.) Lat. belonging to woods; e. o. ., Carex fylvatica. Sy'lvia (Ornith.) Lat. a warbler.

Sylvi'idæe (Ornith.) Jylvia, with fam. term.; a family of Inceflores.

Sylvinze (Ornith.) Jylvia, a warbler; the Warblers; a fub-family of Palferes.

Symæ'this (Ent.) the name of a Nymph, mentioned by Ovid, Met. xiii. 50.

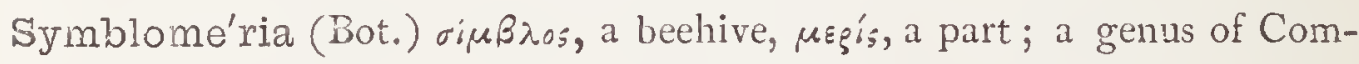
politæ.

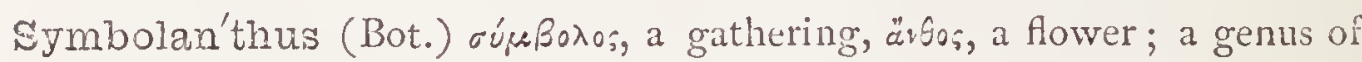
Gentianacex.

$\left.\begin{array}{l}\text { Symbran'chidre } \\ \text { Symbran'chus }\end{array}\right\}$ (Ichth.) $\left\{\begin{array}{l}\sigma u ́ v, \text { together, Bparxice, gills; from the two } \\ \text { outlets of the gills forming a fingle ex- } \\ \text { ternal orifice; a genus of Malacopterous } \\ \text { Filhes. }\end{array}\right.$

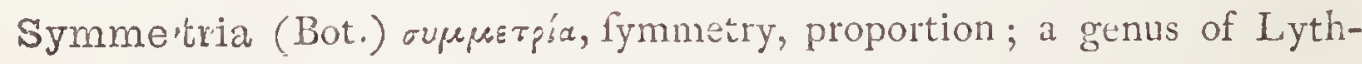
race:e.

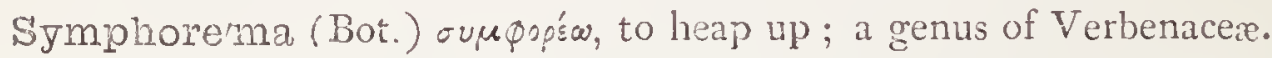

Sympho'ria (Bot.) ourpopśs, to colledt together; a genus of Caprifoliacex.

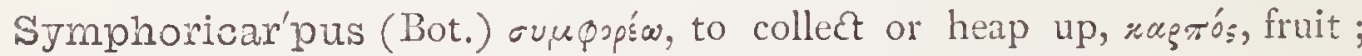

the Snow-berry buhn; a grenus of Caprifoliacex.

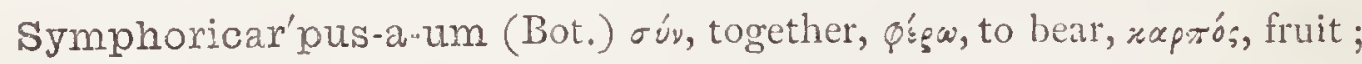
bearing fruit cluftered together.

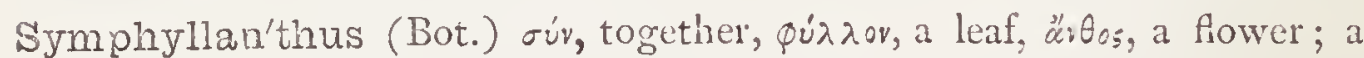
genus of Chailletiaceæ.

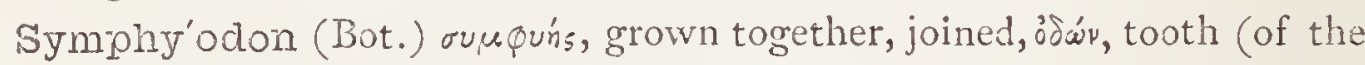
periftome); a genus of Bryoid Mufci.

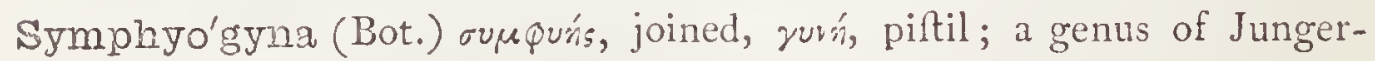
manniacex.

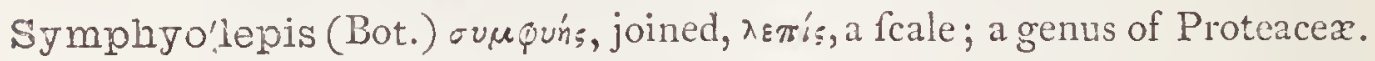
Symphyolo'ma (Bot.) ovupuns, joined, $\lambda \tilde{x} \mu$ ce, fringe; a genus of Umbelliferæ.

Sjmphyomy'rtus (Bot.) ruupurs, united, myrtus; a genus of Myrtacex. 


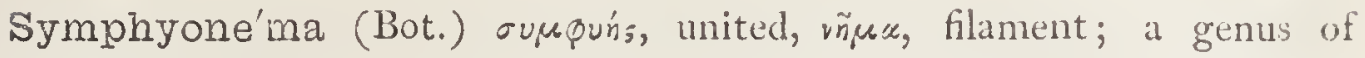
Proteacer.

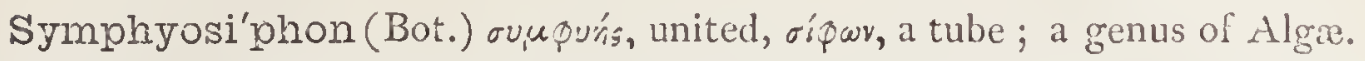

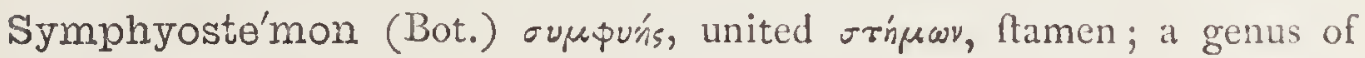
Iridacex.

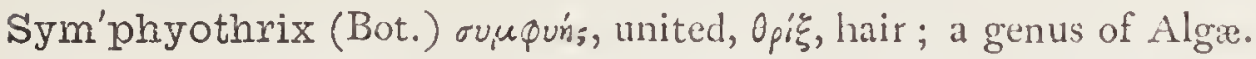
Sym'phyotrichum (Bot.) fame derivation; a genus of Compofitie.

Symphy'sia (Bot.) oúupusı, a natural joining; a genus of Vacciniacex.

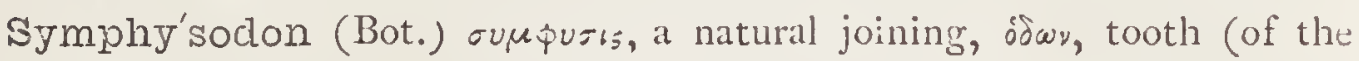
perifome); a genus of Bryoid Mufci.

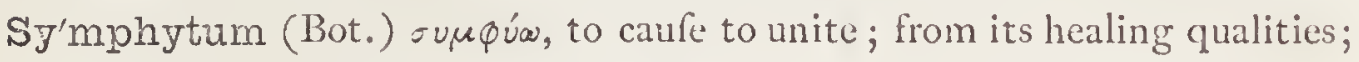
Comfrey; a genus of Boraginacex.

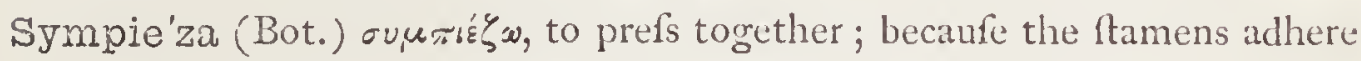
to the tube of the corolla; a genus of Ericacer.

Sy'mploca (Bot.) бúkr

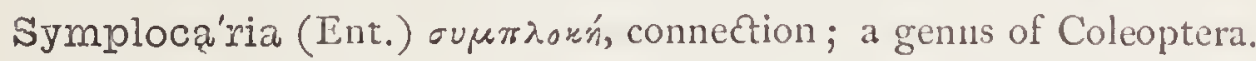

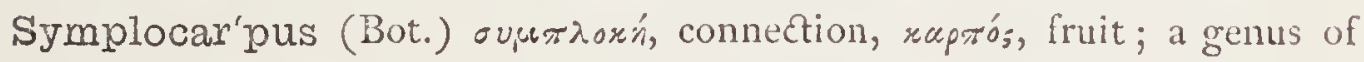
Orontiacer.

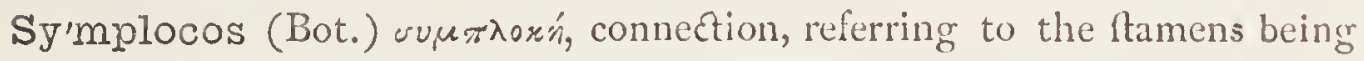
united at the bafe; a genus of Styracacex.

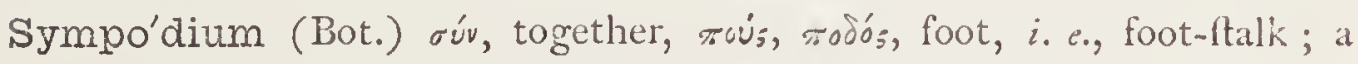
genus of Umbelliferæ.

Synæ'drys (Bot.) $\sigma u ́ v$, implying relation to, $\delta \rho \tilde{u}_{\bar{\sigma}}$, the oak; a genus of Corylaces.

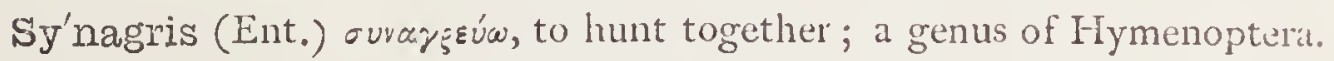

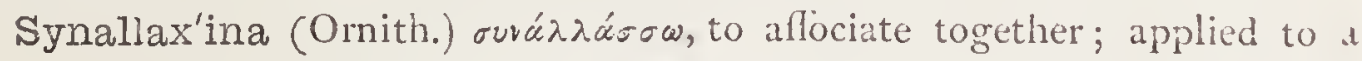
group of birds, family Certhide ; typical genus, Synallaxis.

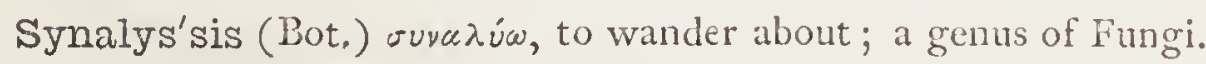

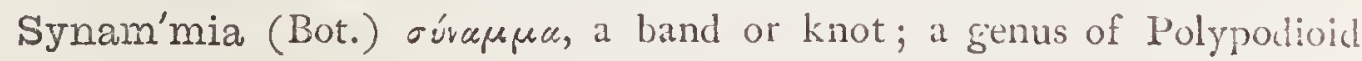
Filices.

Synan'dra (Bot.) Fúv, together, ảińp, ávópó, anther; a genus of Acanthacex.

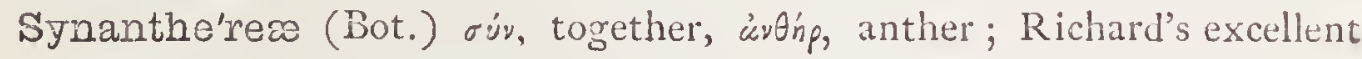
name for the Compolitæ.

Synan'therus-a-um (Bot.) oúv, together, avonp, anther; the anthers united into a tube; equivalent to fyngenefious.

Sy'naphe (Ent.) ourap'n, a junction.

Syna'phea (Bot.) ouvuşs, united, from the fingular union of the barren flament with the figma; a genus of Proteacex. 


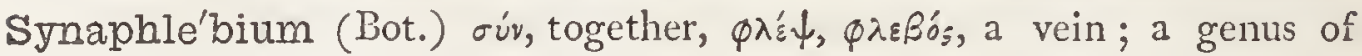
Polypodioid Filices.

Syna'ptæ (Zool.) euvaric, to lay hold of; a family of Echinodermata. Synarrhe'na (Bot.) $\sigma u ́ r$, together, äpjprnv, a ftamen; a genus of Sapotaceæ. Synar'thrum (Bot.) $\sigma u ́ v$, together, äpopov, a joint; a genus of Compofitie.

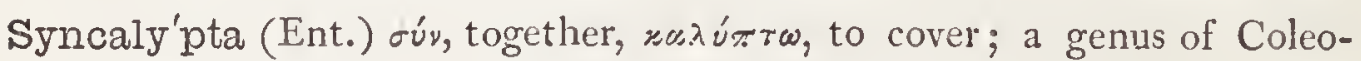
ptera.

Syncar'pha (Bot.) oúv, together, xúpфos, a chip (ftipule); a genus of Compofitæ.

Syncar'pia (Bot.) oúv, together, zupтós, fruit ; a genus of Myrtaceæ.

Syncephalan'tha (Bor.) oúv, together, $x \notin ф a ́ \lambda n$, head, ảv $\theta_{o s}$, flower; a genus of Compolitæ.

Synceph'alum (Bot.) oúv, together, $x \notin \varphi u^{\prime} \lambda$, head; a genus of Compolitio. Synchi'ta (Ent.) oúv, together, xirár, a cafe or covering; a genus of Coleoptera.

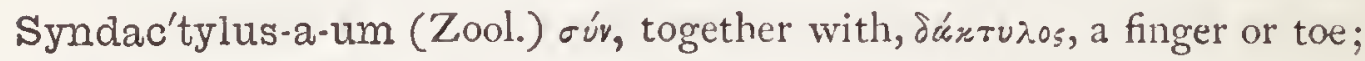
having united toes.

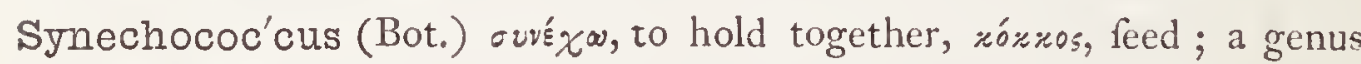
of Algx.

Syne'dra (Bot.) ourefoíc, affembly; a genus of Algæ.

Syngene'sia (Bot.) oúv, together, $\gamma^{\prime} v \varepsilon=$ s, birth; the anthers united into a tube; a Linncean clafs of plants.

Syngene'sius-a-um (Bot.) fame derivation and meaning; having united anthers.

$\left.\begin{array}{l}\text { Syn'gnathus } \\ \text { Syngna'thidx }\end{array}\right\}$ (Ichth.) $\left\{\begin{array}{l}\sigma^{2} v, \text { together, rvá6os, a jaw; a family } \\ \text { and genus of Pipe-filhes, group Lopho- } \\ \text { branchia. }\end{array}\right.$

Synno'tia (Bot.) P. N. in honour of $W$. Synnot, who collected many plants at the Cape; a genus of Iridacex.

Synor'gana (Bot.) oúv, together, opparvy, organ; name propofed by Schultz for the Endogens.

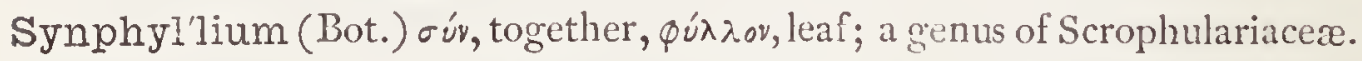
Synspo'rea (Bot.) oúv, together, oropú, feed (fpore); a fection of Algæ. Syntheris'ma (Bot.) ouvenpés, to find together; a genus of Gramina. Synthy'ris (Bot.) oúv, together, Oupis, an opening (cell); a genus of Scrophulariace $x$.

Synto'mium (Ent.) surrśsuw, to cut Thort; a genus of Coleoptera.

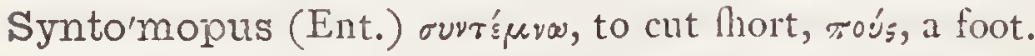

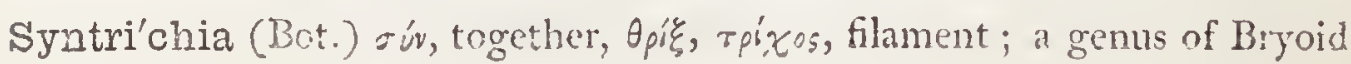
Mufici. 


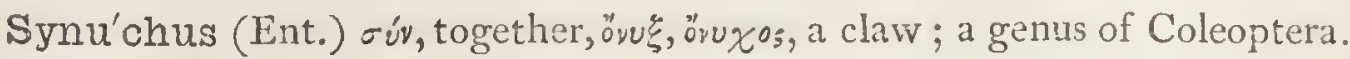

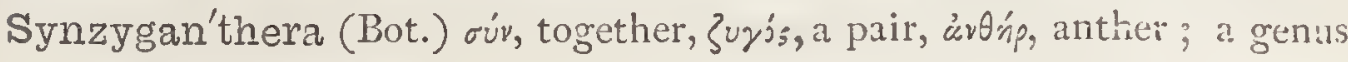
of Laciftemaceis.

Syorhyn'chium (Bot.) oṽ , fwine, jurøos, beak; Pig's fnout Iris ; a genus of Iridaceæ.

Syre'nia (Bot.) a geographical name; a genus of Cruciferie.

Syr'nium (Ornith.) etymology doubtful ; a fub-genus of Sirrigide.

Syreno'psis (Bot.) the"genus Syrenia, öł: s, likenefs; a genus of Cruciferæ.

Syriacus-a-um (Ornith., Bot.) Lat. Syrian, e.g. Hibifcus Syriacus.

Syrich'thus (Ent.) perhaps from $\sigma \tilde{u}$ p $(y \xi$, a pipe; alluding to the markings, which, in fome fpecimens, refemble a Pan's"pipe; or (as fuggented by

M. Guénée), from s-upırtńs, a piper.

Syrin'ga (Bot.) from $\sigma \tilde{u} \xi \iota \xi \xi$, a pipe or tube; becaufe formerly ufed for making Turkilh pipes; the Lilac; a genus of Oleacex.

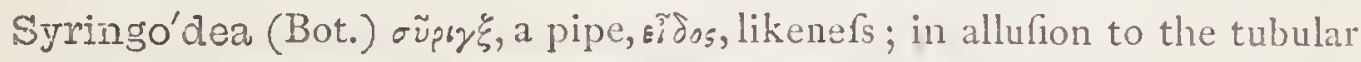
form of the flowers; a genus of Elicacex.

Syringo'sma (Bot.) the genus Syringa, (lilac), orun, fmell; a genus of Apocynaceæ.

Sy'rinx (Zool.) $\sigma \tilde{e} \varrho \gamma^{\prime} \xi$, a tube or pipe; a genus of Echinodermata.

Syrma'tium (Bot.) oúpua-aros, that which is trailed along; a genus of

Leguminofx.

$\left.\begin{array}{l}\text { Sy'rphidx, } \\ \text { Sy'rphus }\end{array}\right\}$ (Ent.) $\left\{\begin{array}{c}\sigma^{\prime} \text { spos, a fmall-winged infect; a family and renus } \\ \text { of Diptera. }\end{array}\right.$

Syrrha'ptes (Ornith.) oup’parr

of the toes; Pallas' Sand-groufe; a genus of Gallinx.

Syrrhopo'don (Bot.) ópposts, confluent (connivent), ösór, a tootin; the

teeth being nearly hoirontal; a genus of Bryoid Mufci.

Sys'pone (Bot.) $\sigma v \sigma \pi u^{\prime} r$, to fqueze together ; a genus of Leguminofi.

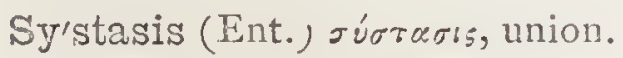

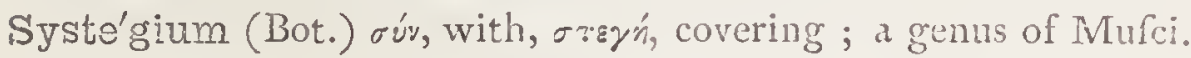

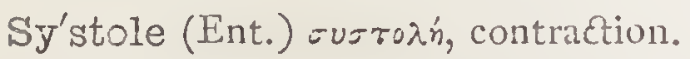

Systyllium (Bot.) ớrtunor, arranged like columns; a genus of Bryoid Mufci.

Syu'rus (Bot.) =ũs, fwine, oúpa, tail ; Pig's-tail grafs; a genus of Gramina. Syzigi'tes (Bot.) oujuris, union; a genus of Fungi.

Syzy'gium (Bot.) súsuys, coupled; the branches and leaves are united together in pairs; a genus of Myrtacex.

Szovit'sia (Bot.) P. N. in honour of M. Szovitz, a Hungarian botanift; a genus of Umbelliferx. 
Ta'bacum (Bot.) this name has been varioully accounted for"; fome derive it from the illand of Tobago, others from Tabafca, in New Spain; the moft probable explanation is that from tabac, an inftrument ufed by the natives of America in fmoking this herb; fpecific name of the Tobacco-plant, Nicotiana Tabacum.

Taban'idæ) (Ent.) \{tabanus, a gad-Ay; Ital. tafano; Span. tabano; the Taba'nus $\}$ (Ent.) $\{$ Breeze-flies; a family and genus of Diptera. Tabella'ria (Bot.) tabella, a tablet; a genus of Diatomacex.

Tabe'rnæmonta'na (Bot.) P. N. in honour of $\mathcal{F} . T$. Taberncmontanus, a celebrated botanilt; a genus of Apocynaceæ.

Tac'ca (Bot.) the Malay name of one fpecies; typical genus of Taccacere.

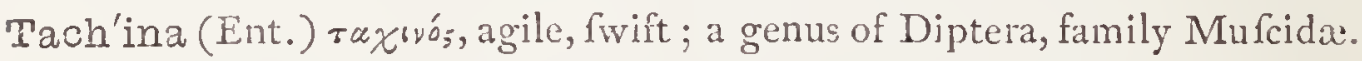

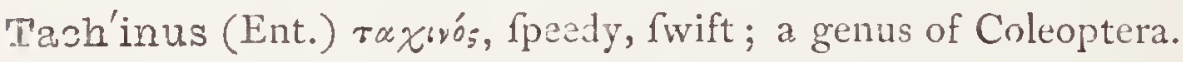

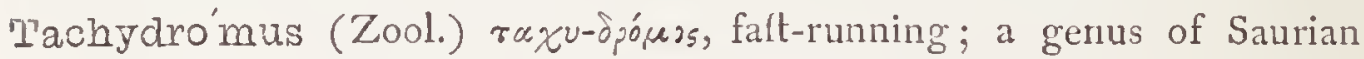
reptiles.

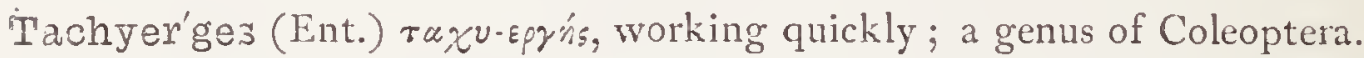
Tashygga'lia (Bot.) Tachygali, its name in Guiana; a genus of Leguminofx. Tachyme'nis (Zool.) raxú unvs, fwift to anger; a genus of Colubrine ophidians.

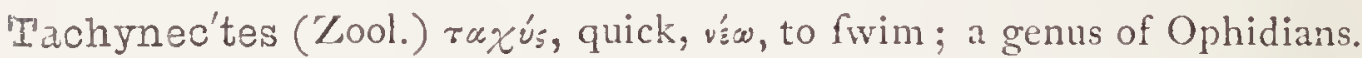
Tachype'tes (Ornith.) $\tau \alpha \chi v-\pi \dot{s} \tau s$, Aying faft; a genus of the family

Pelecanidx, which contains the Frigate-bird.

Tachypho'nus (Ornith.) $\tau \alpha \chi u_{5}$, fivift, 申óvos, naughter; a genus of Tanagers.

Tashypo'ridæ (Ent.) a family of Coleoptera, of which Tachyporus is the type.

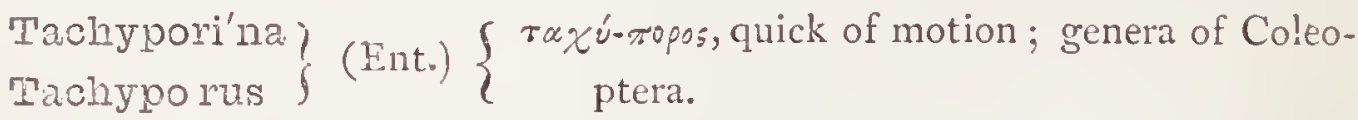

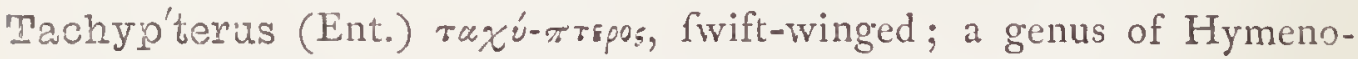
ptera.

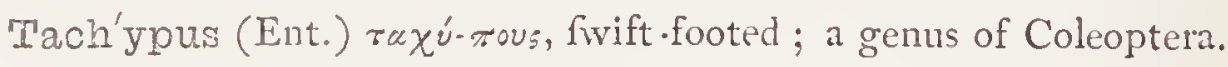

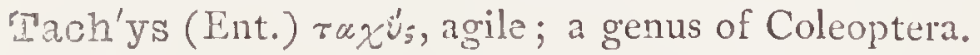

Pachysau'rus (Zool.) taxú, fwift, ouĩpos, a lizard; a genus of Saurian reptiles.

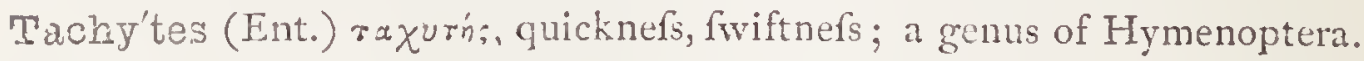

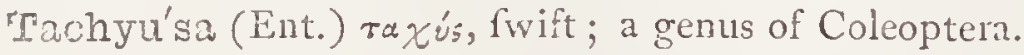

Tazso'nia (Bot.) tacfo, its name in Peru; a genus of Pafliforacea.

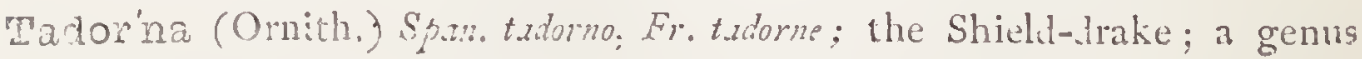
of Anatidix. 
Tad'pole (Zool.) Anglow Sax. tade, toad, fole, (Lat. pullus) a foal or colt; the young of the frog in their firft ftate from the fpawn.

Taeda'na (Ent.) taeda, a pine, fir-tree, on which it feeds.

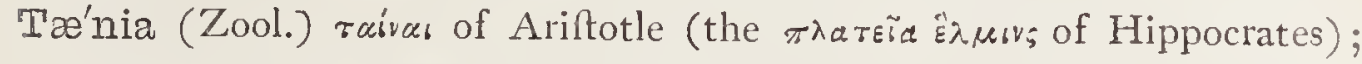
the Tape-worm; a genus of Entozoa.

Tænia'tus-a-um (Ent.) tania, a band; having ftripes of colour.

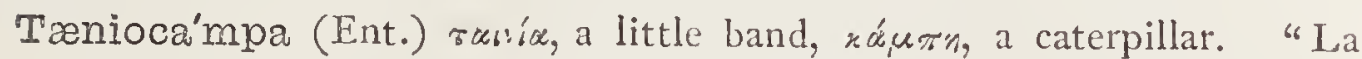
netteté de léurs lignes c'eft ce qui m’a décidé à en tirer le nom générique." (Guénée.) A genus of Lepidoptera.

Tæniocar'pum (Bot.) ratvia, a riband, xapros, fruit; a genus of Legu. minofa.

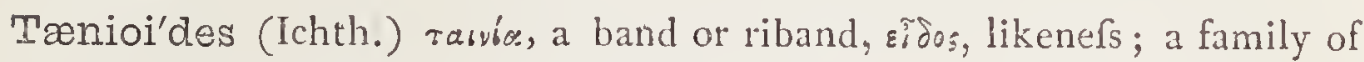
Finhes nearly allied to the Mackerels.

Troniola'lis (Ent:) tenia, a band; alluding to the ftraight whitifh band acrofs the wings.

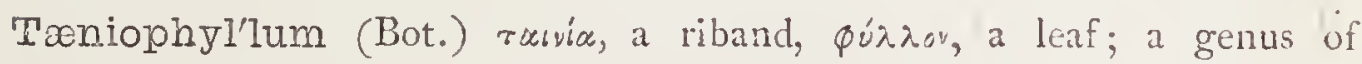
Orchidacex.

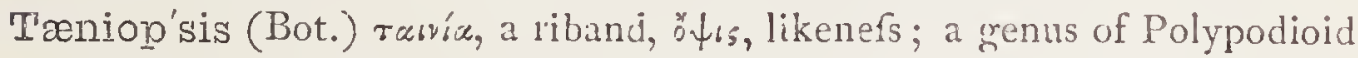
Filices. Taniopteri'nso $\}$ and tribe of Birds, family Mufcicapidx.

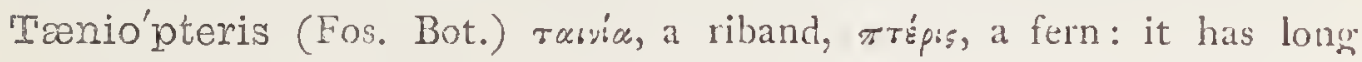
riband-like leares.

Tani'tis (Bot.) raı'ia, a fillet, from the long narrow frond; a genus of Polypodiaceæ.

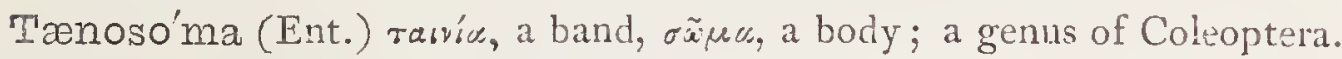
Tage'tes (Bot.) P. N. from Tages, a Tufcan divinity; a genus of Compolitix.

Talæpo'ria (Ent.) raגairwpos, wretched; i. e. in appearance.

Talau'ma (Bot.) remacular name of the South American fpecies; a genus of Magnoliacex.

Talegal'la (Ornith.) Fr. taleve, the name of an allied fpecies, and gallis, the domeftic fowl; a genus of Birds of the family Palamedeidx?.

Talgue'nea (Bot.) after its vernacular name, talguin; a gunus of Rhamnaceæ.

Talie'ra (Bot.) its aboriginal name; a genus of Palmæ.

Talínum (Bot.) probably from baxí, bloom; a genus of Portulacacex.

Ta'lipat-paIm (Bot.) Fr. tallipot; the Corypha umbraculifera of Ceylon.

Tali'sia (Bot.) from toulichi, its name in Guiana; a genus of Sapindacea. 
Talitrus (Zool.) talitrun, a rap or fillip with a finger; the Sand-flea; a genus of Cruftacea.

Tal'pa (Zool.) Lat. a mole; Fr. la taupe; Span. topo; a genus of infectivorous Maminals.

Tal'pidæ (Zool.) talpa, a mole; the Moles; a family of Infectivora.

Taman'dua (Zool.) from the native name; a genus of Ant-eaters.

Tamarin'dus (Bot.) the Latinized form of Arabic Tamar Indi, Indian date or palm; the 'Tamarind-tree; a genus of Leguminofx.

Tam'arix (Bot.) Fr. and Span. tamaris; Ital. tamarifo; by fome faid to be derived from $H_{c} b$. tamarik, cleanfing; but by others from the river Tamaris, now Tambro, near the Pyrenees, the people of which neighbourhood were called Tamarifci; the Tamarik; typical genus of Tamaricaceæ.

Tama'tias (Ornith.) etymology uncertain; the Puff.bird; a genus of Pafferes.

Ta'mias (Zool.) rau'as, a ftorekeeper; from pollefing cheek-pouches; a genus of Mammalia, family Sciuridæ.

Tamo'nea (Bot.) from tumone, its name in Guiana; a genus of Verbenaceæ.

Tamus (Bot.) name of Columella for a plant refembling a vine: Tamus communis is the mifcalled "Black bryony;" a genus of Diofcoreaceic.

Tanace'tum (Bot.) Latinized from Tanyy, q. v.; a genus of Compolitæ.

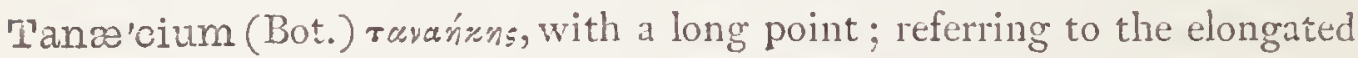
ften ; a genus of Crefcentiacex.

Tan'agra (Ornith.) a genus of Birds of the family Fringillidx.

Tranagri'nee (Ornith.) a tribe of Birds belonging to the family Fringillidx; the Tanagers.

Tan'ais (Zcol.) raváos, outftretched, long; a genus of Cruftacea.

Tanghi'nia (Bot.) the native Madagafcar name of the ordeal-tree, Tanghin;

a genus of Apocynacex.

Tankervil'lia (Bot.) P. N. in honour of the Earl of Tankerville; a genus of Orchidacex.

Tan'sy (Bot.) faid to be a corruption of citavarva, immortality; from its durable flowers; Fr. tanaifie, Itat. tanacéto; the Tanacetum vulgare.

Tan'talus (Ornith.) P. N., a genus of Birds of the family Scolopacidxe.

Tanyme'cus (Ent.) ra:ucurres, flim, long-ftretched.

Tanysi'ptera (Ornith.) ravíw, to extend, $\pi \tau^{\prime}$ spor, a wing; a genus of tropical Kingfiners. 


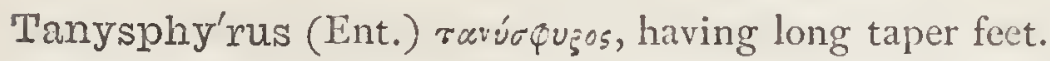

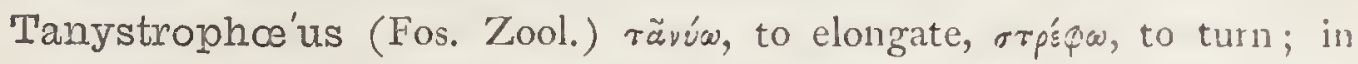
allufion to the peculiar proportion of the Vertebræ.

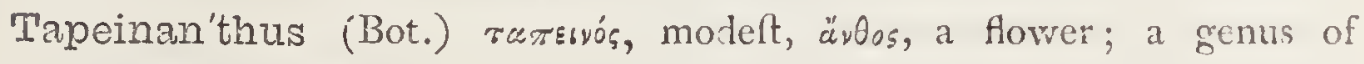
Amaryllidacer.

Tapetiel'la (Ent.) tapetia, carpets, tapeftry.

Ta'phozous (Zool.) rúpos, a tomb, ל’ow, to live; applied by M. Geoffroy to a vampire which he found in the catacombs of Egypt.

Taphrode'res (Ent.) rúppos, a channel, J'sn, the neck ; a genus of Coleoptera.

Taphrosper’mum (Bot.) тáppos, a trench, $\sigma \pi^{\prime}$ spua, feed; a genus of Cruciferæ.

Tapio'ca (Bot.) no doubt from the native Brazilian name; the prepared meal of the Jatropha Manihot.

Tapiri'na) (Zool.) adapted from the native word; the 'Tapir; a fubTapi'rus ; family and genus of Mammalia.

Tarac'tes (Ichth.) rxpáxrns, a difturber; a genus of tropical Filhes.

Taran'dus (Zool.) Lat. a quadruped in Scythia, mentioned by Pliny, of the fize of an ox, with pointed horns and a head like a ftag, probably the reindeer; the Remdeer.

Taran'tula (Zool.) from Tarentum, in Italy, where, as well as in the South of France, this fpecies of fpider is very common; it is thought to require mufic for the cure of its bite.

Tarax'acum (Bot.) rupúrow, to change; from its fuppofed effects on the blood; formerly a generic name, now the fpecific name of the Dandelion, Leontodon Taraxacum.

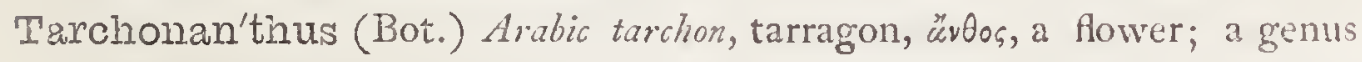
of Compolitæ.

Tardi'gracia (7ool.) tardus, now, gradus, a ftep; applied by Cuvier to a family of Mammals; alfo ufed for a family of Arachnida.

Tardi'gradus-a-um (Ent.) fame etymology; flow-paced.

'Tar'dus-a-um (Ornith.) Lat. flow.

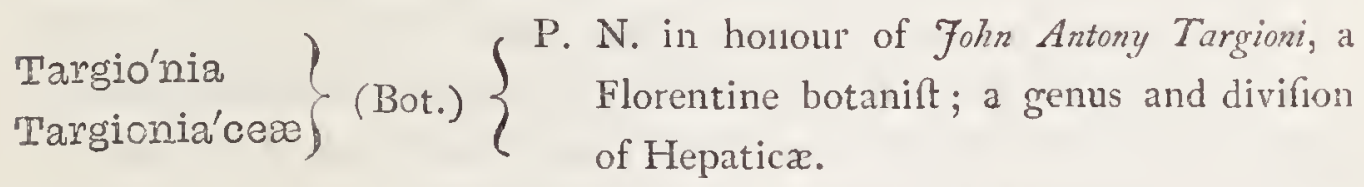

Tar'ragon (Bot.) corruption of Arabic tarchon, which is the Artemifia Dracunculus.

Tarsicrina'lis (Ent.) tarfus, the extremity of the leg, crinalis, like hair. 
Tarsicrista'lis (Ent.) tarfus, the extremity of the leg, criftalis, like a plume. Tarsipenna'lis (Ent.) tarfus, the extremity of the leg, perna, a feather; alfo referring to the bruth or fan upon the forefoot of the male.

Tar'sipes (Zool.) tarfus and pes, the foot.

T'arsipluma'lis (Ent.) tarfus, the extremity of the leg, phumalis, like down. Tar'sius (Zool.) tarfus, the inftep; from a peculiar elongation of the bones; a genus of Mammalia, order Quadrumana.

'Tartar'icus-a-um (Ornith., Bot.) Lat. belonging to Tartary; Tartarian, e.g., Lonicera Tartarica.

Tarrus (Ent.) rúpos, fivift; a genus of Coleoptera.

Tas'gius (Ent.) etymology unknown; a genus of Coleoptera.

Tata'o (Ornith.) fipecific name of the feven-coloured Tanager; doubtlefs from the idea of its being tatoo-ed.

Tatu'sio, (Zool.) Latinized form of the native word tatou; applied to an Armadillo.

Tau'rec or Teu'rec (Zool.) the Centetes ecaudatus.

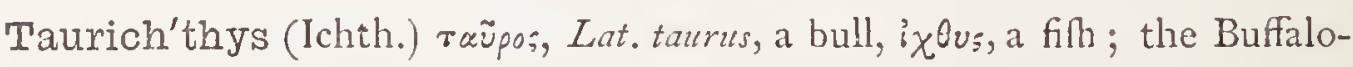
firh; a genus of Fithes, family Chætodontidie.

Tauro'ma (Ent.) raũpos, Lat. taurus, a bull, ڤ̇uos, the fhoulder.

Tausche'ria (Bot.) P. N. in honour of Ignatizs F. Taufich, Profeflor of botany at Prague; a genus of Cruciferx.

Tavernie'ra (Bot.) P. N. in honour of Jean Baptife Tavernier, an Eaftern traveller who died at Mofcow in 1689 ; a genus of Leguminof

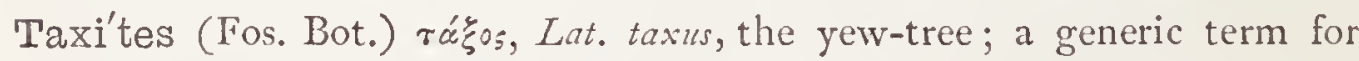
fuch coniferous remains as are evidently allied to the yew-tree.

Taxocri'nus (Fos. Zool.) тúłos, a yew (form), x ģivov, lily (encrinite); a genus of foffil Echinodermata.

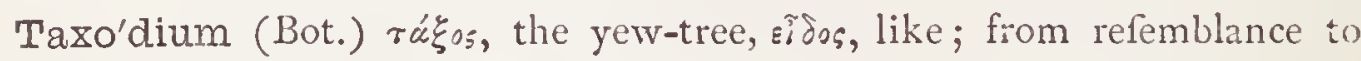
the common yew; a genus of Coniferæ.

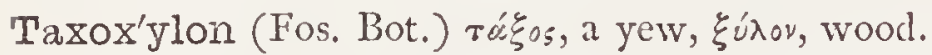

Tax'us (Bot.) Lat. the Yew-tree ( $\tau \alpha^{\prime} \xi_{05}$ ); either from $\tau a \xi: 5$, arrangement, from the leaves being placed on the branchlets like the teeth of a comb; or from rósov, a bow, the wood being much ufed for that purpofe. $T$. baccata is the fmilax of Diofcorides, and the $\mu$ in ${ }_{0}$ s of Theophraftus. Taylo'ria (Bot.) P. N. in honour of Dr Thomas Taylor, one of the authors of the Mufcologia Britannica ; a genus of Mufci.

Teal (Ornith.) Dutch, teeligh, from teelen, to procreate ; the Anas Crecca. Tearlia (Zool.) P. N. in honour of Thomas Pridgen Teale, the eminent furgeon of Leeds; a genus of Zoophytes. 
Teasel or Teazle (Bot.) Anglo-Sax. taf ; the Fullers' Teafel is the Dipfacus Fullonum.

'Te'coma from tecomaxochitl, the Mexican name, which meals Tecoma'ria $\left\{\right.$ (Bot.) $\left\{\begin{array}{l}\text { a flower (xochitl) refembling a certain earthen- } \\ \text { ware veflel (tecomatl); genera of Bignoniacex. }\end{array}\right.$

Tec'tona (Bot.) tekk, its name in Malabar; the Teak-tree; a genus of Verbenacex.

Tec'trix, pl. Tec'trices, (Ornith.) tego, to cover; the "coverts" or clothing feathers of birds, divided into primæ, fecundæ, and tertiæ.

Tee'dia (Bot.) unexplained; a genus of Scrophulariacex.

Teesda'lia (Bot.) P. N. in honour of Robert Teefdale, an Englifh botanical author; a genus of Cruciferæ.

Tes-tee or Titi (Zool.) native name of a monkey, Callithrix Sciureus.

Tegena'ria (Ent.) teges, covering; a genus of Arachnida.

Tego:stoma (Ent.) réyos, a roof, orópes, a mouth.

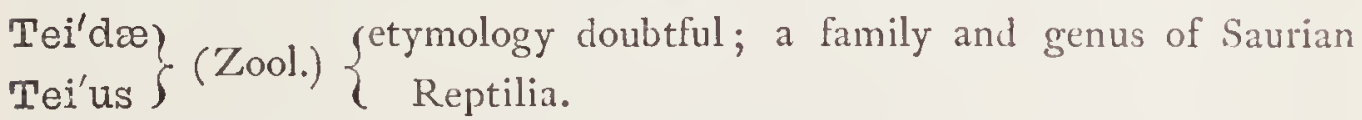

Tela'rius-a-um (Ent.) tela, a web; webbed.

Teledu (Zool.) its name in Java; the Stinkard; Mydaus meliceps.

Tele'kia (Bot.) unexplained; a grenus of Compolitr.

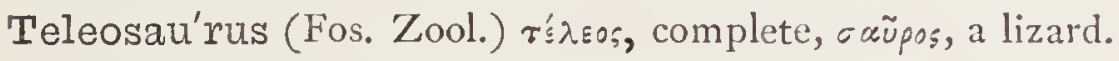

Tele'phium (Bot.) fuppofed to heal old ulcers like that of Telephus; fpecific name of a celebrated fpecies of Sedum.

Telephor'idæ)

Teleph'orus $\}$ (Ent.) a family and genus of Coleoptera.

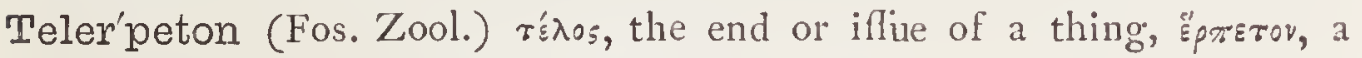
reptile; $i_{.} e_{.}$, the lant of reptiles.

Tel'lima (Bot.) anagram of Mitella; feparated from that genus by $R$. Brozun; a genus of Saxifragacere.

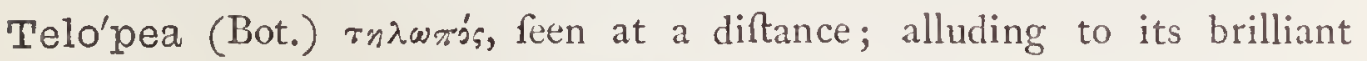
blofloms; a genus of Proteacex.

Telopho'nus (Ornith.) $\tau \tilde{n} \lambda n$, far off, $\varphi \% n$, a loud clear voice; a genus of Laniadx.

Temnopleu'rus (Zool.) $\tau_{\varepsilon}^{\prime} \mu r \omega$, to cut off, $\pi \lambda$ हugór, the fide; a genus of Echinodermata.

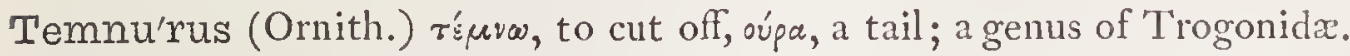
Temo'ra (Zool.) P. N., Temora, the palace of the ancient kings of Ireland. Templeto'nia (Bot.) P. N. in honour of 7 . Templeton, an excellent Irih botanift; a genus of Leguminofr. 
Tench (Ichth.) Anglo-Sax. tince; the Tinca vulgaris.

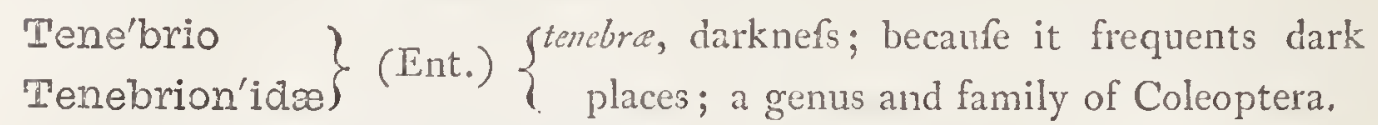

Tenel'lus-a-um (Bot.) Lat. delicate, tender, e.g., Anagallis tenella.

Teniæfor'mis-e (Bot.) tania, a tape-worm, forma, thape, riband-like.

reno'ria (Bot.) P. N. in honour of M. Tenore, Profeflor of Botany at

Naples, and author of the "Flora Roinana;" a genus of Umbelliferx.

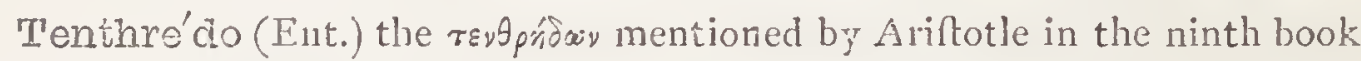

of his Hiftory of Animals, is evidently fome fying vefpiform infect;

the Saw-ny; a genus of Hymenoptera.

Tenuicor'nis-e (Ent.) tenuis, nender, comi, a horn; laving fender antennx. Tenuiros'tris (Ornith.) tenuis, flender, rofirum, a beak; the Tenuirofires form a finily of Birds of the order Palleres.

Ten'uis-e (Zool. Bot.) Lat. thiu, Alender; e.g., Lotus tenuis.

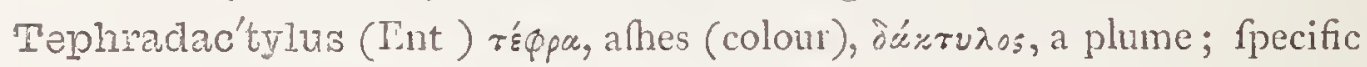
name of a moth.

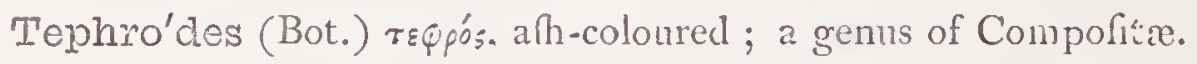

Tephrodor'nis (Ornith.) reppos, aft-coloured, opvss, a bird; the Grey

Shrike of India; a genus of Laniadæ.

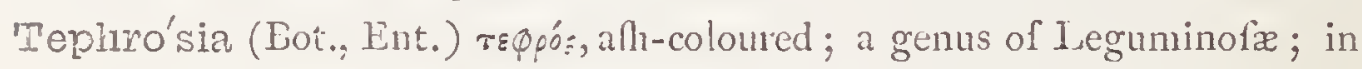

Entomology a genus of l.cpidopiera.

Tepidario'rum (Lnt.) gen. pl. of tepidarius, relating to warm baths; from

the circumfance of the only known habitat of the fpider, in England

and on the continent, being in gieen and hot houfes.

Teram'inus (Bot.) répapvos, foft; from the delicate pod; a genus of Legumin@ßx.

Te'ras (Ent.) rípos, a wonder; a genus of Lepidoptera.

Tera'stia (Ent.) repúatros, ftrange, wonderful; a genus of Lepidoptera.

Terebratel'la (Zool.) dim. of terebra, a borer or gimlet; a genus of Brachiopod Mollufca.

Terato'cera (Ent.) r'śpus-aros, a wonder, xípus, a horn.

Terato'logy (Zool., Bot.) r'spas-aros, a monftrofity; dógos, a treatife; the

fcience of abnormal forms.

Terebin'thus (Bot.) the rspşı⿻日s of Theophraftus and Diofcorides. Te'rebra (Zool.) Lat. a borer or gimlet; the Auger-fhell; a genus of Gafteropod Mollufca.

$\left.\begin{array}{l}\text { Terebra'tula } \\ \text { Terebratu'lidx }\end{array}\right\}$ (Zool.) $\left\{\begin{array}{l}\text { dim. formed from terebra, a borer; the Lamp- } \\ \text { ihells; a genus and family of Brachiopod } \\ \text { Mollufea. }\end{array}\right.$ 
Terebra'tus-a-um (Zool.) Lat. bored, pierced.

Tere'do (Zool.) Lat. a wood-worm, from $\tau \varepsilon \rho^{\prime} s \omega$, to bore; well known to the ancients :-

"Eftur ut occulta vitiata teredine navis ;

IEquorei fiopulos ut cavat unda falis."

Ovid. Epist : Lib. i., Ep. r.

Tere'cus (Ent.) repró̀ं\%, a wood-worm; a genus of Coleoptera.

Terel'lus-a-mm (Jnt.) terra, ihe earth; earth-coloured.

Tere'irius (Eni.) tores, plimp, well-haped; a genus of Coleoptera.

Ter'gum (7.ool.) Lat. the back; that which covers the back.

Terminal'ia (Eot.) terminus, end; the leaves are in bunches at the end of

the branches; a genus of Conbreticex.

Termina'lis (Eot.) Dracæna terminalis derives its fpecific name becaufe it is planted as a landıark in India and China, to divide eftates, and to denote the bounds of territorial property.

$\left.\begin{array}{l}\text { Termi'tes } \\ \text { Termi'tidæ }\end{array}\right\}$ (Ent.) $\left\{\begin{array}{c}\text { etymol. doubtful; the White Ants; a family of } \\ \text { Neuroptera. }\end{array}\right.$

Ter'mo (Zool.) this fpecific name was given from having been luppofed

to be the limit of animal organization; one of the Monads.

Terrea'lis (Eni.) terrot:s, earthy.

Ternströmia(Bot) P. N. in honour of $M$. Ternström, a Swedish naturalist; typical genus of Ternströniacex.

Terres'tiris-e (Bot.) Lal. that remains on the ground; e.g., Nafturtium terref: $: \cdot$.

Terri'colze (Ent.) terra, the earth, colo, to inhabit; the Crane-flies; a divifion of Diptera, fanily Tipulæ.

Terricula'lis (Ent.) teriviula, that which frightens, a bugbear.

Tersa'tus-a-um (Ent.) torfies, clean, neat.

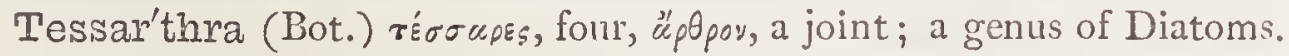

Tessel'la (Bot.) Lat. a fmall fquare or quadrangular piece of ftone for pavements \&c.; a genus of Diatoms.

Tessella'tus-a-um ('Zool., Bot.) Lat. tellelated, checkered ; e.g., Actinocrinus teffelatus.

Tessera'nus-a.um (Ent.) teffera, a fquare tablet or chequer; 1 eferring to the wing-markings.

Testacea'lis (Ent.) teftaceus, having the colour of an earthen veflel.

Testacel'la ) (Zool.) dim. of tefta, a thell; a genus and family of PulTestacell'adæS moniferous Mollufca.

Testa'lis (Ent.) tefa, a brick; from the colour. 
Testudina'ria (Bot.) tifudo, a tortoife; from the refemblance of the outfide of the rhizome; an extraordinary genus of Diofcoreaceæ.

Testu'do (Zool.Ent.) Lat. a tortoife; in entomology, from the larvæ having no perceptible legs.

Tes'tula (Bot.) Lat. a piece of broken pot; a term of Ehrenberg's, the equivalent of fruftule; applied to the individual Diatom.

Testula'lis (Ent.) tefula, a brick-bat, referring to colour.

Te'thea (Ent.) a kind of fungus mentioned by Pliny; a genus of Lepidoptera.

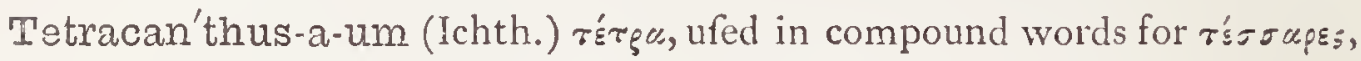
four, $\ddot{\varkappa} \approx \alpha \theta \alpha$, a fpine; four..finned.

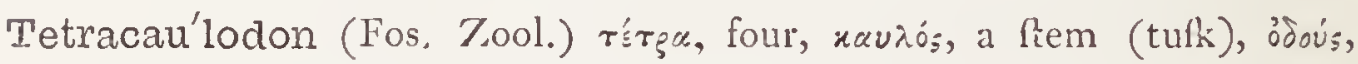
odovros, a tooth; applied to a Maftodon.

Tetra'cerus-a-um (Zool.) rśspa, four, x'spas, a horn; four-horned; applied to a genus of Antelopes.

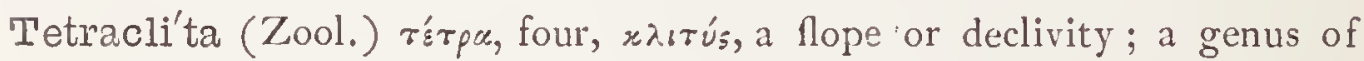
Cirripedes.

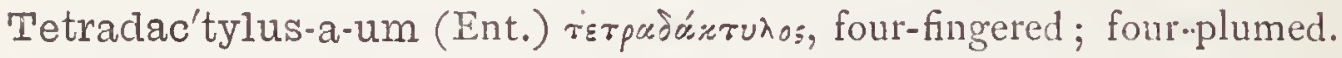

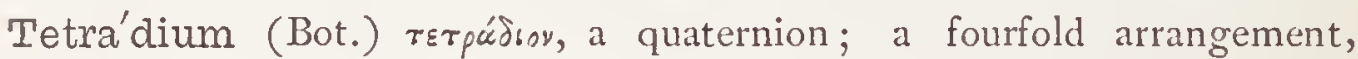
referring to the fructification; a genus of Xanthoxylacex.

Tetrady'namia (Bot.) r'spa, four, dúyaus, preponderance; the Linnæan class of plants having fix Itamens, two of which are fhorter than the others.

Tetraglo'chin (Bot) $\tau^{\prime} \tau_{\xi} \alpha$, four, $\gamma \lambda \omega \chi^{i v}$, a point; a genus of Sangui.. forbace:e.

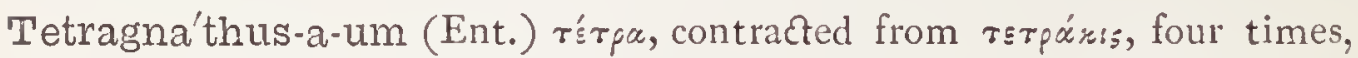
rvá日 os, the jaw or cheek.

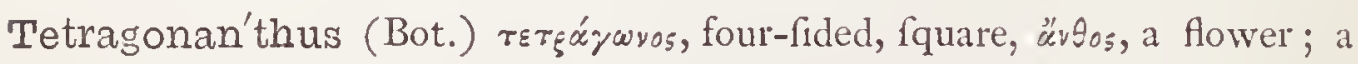
genus of Gentianacex.

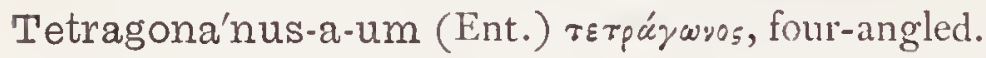

Tetrago'nia (Bot.) r'śr $\alpha$, four, gwoía, an angle; in allufion to the fruit; typical genus of Tetragoniacer; T. expanfa is the celebrated New Zealand Spinach.

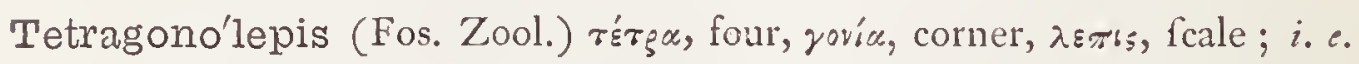
having, four-cornered fcales.

'Tetragono'lobus (Bot.) rérpo, four, yavía, angle, noßós, a pod; a genus of Leguminof

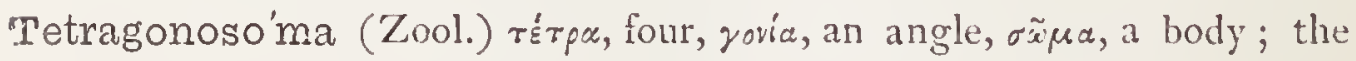
body being quadrangular; a genus of Colubrine ophidians. 


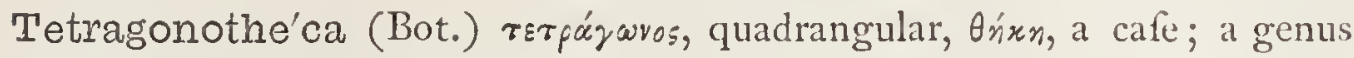
of Compolita.

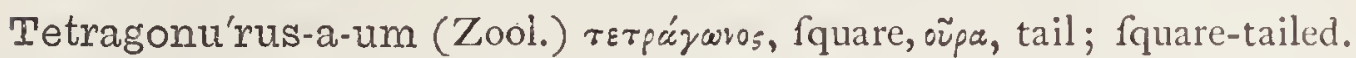
Tetragy'nia (Bot.) r's $\tau^{\prime} \alpha$, four, ruvn, piftil.

retra'hit (Bot.) r'́spu, four, from the four-angled Atem; fpecific name of the common hemp-nettle, Galeopfis Tetrahit.

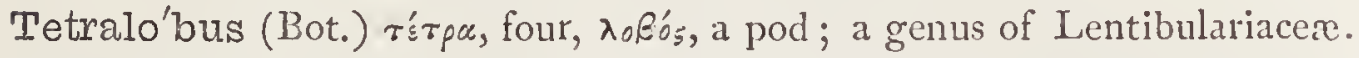

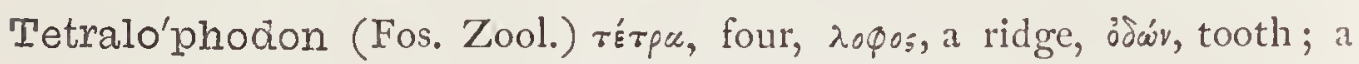
fub-genus of Maftodons having four-ridged molar teeth.

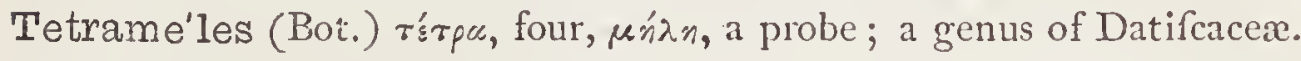

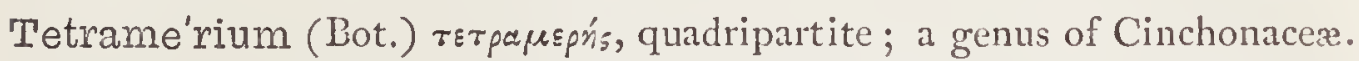

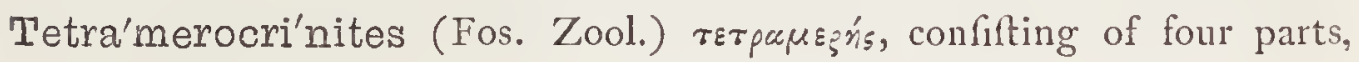
x ģivor, a lily.

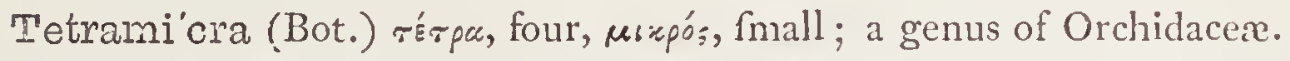

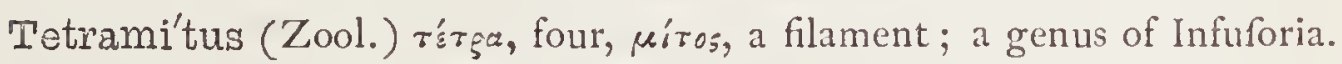

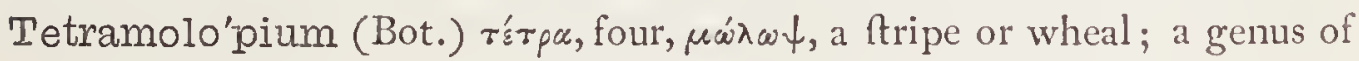
Compofitre.

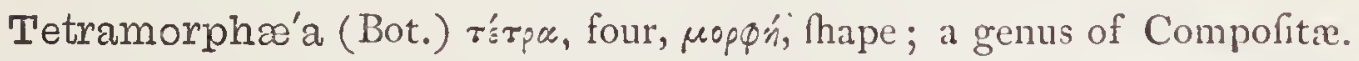

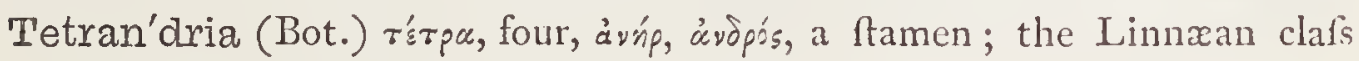
which contains plants with four ftamens.

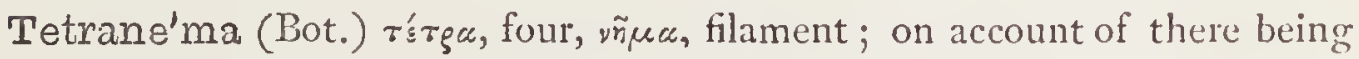
but four filaments in this genus, whilft the neighbouring genus, Pentftemon, has five; a genus of Scrophulariacex.

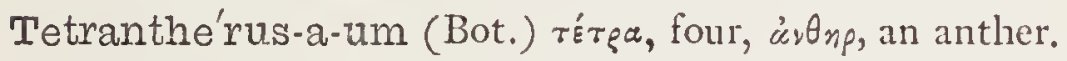

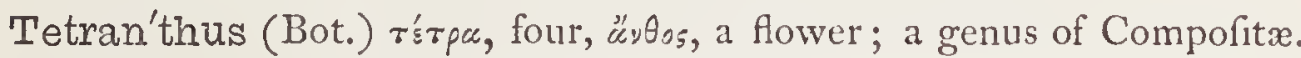
$\left.\begin{array}{l}\text { Tetra'o } \\ \text { Tetrao'nidæe }\end{array}\right\}$ (Ornith) $\left\{\begin{array}{l}\text { Lat. a black-cock or groufe; a genus and family } \\ \text { of Gallinæ. }\end{array}\right.$

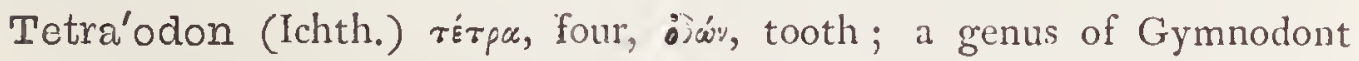
Fines.

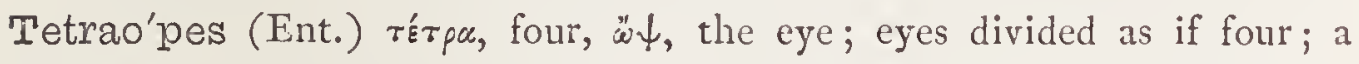
genus of Coleoptera.

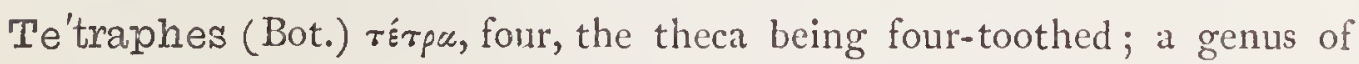
Mufci.

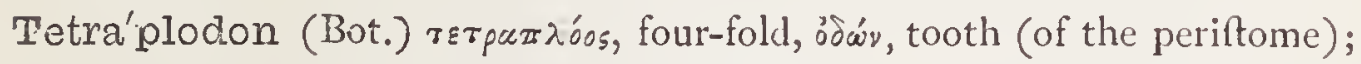
a genus of Mufci.

Tetra'poda (Zool.) rsтpersóns, four-footed; one of Ariftotle's great divifions of the Animal kingdom.

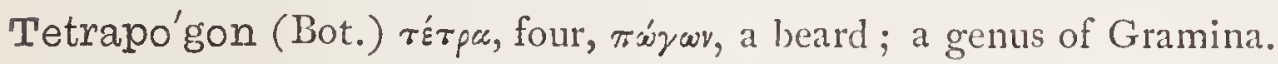

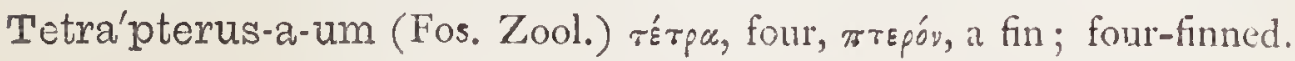




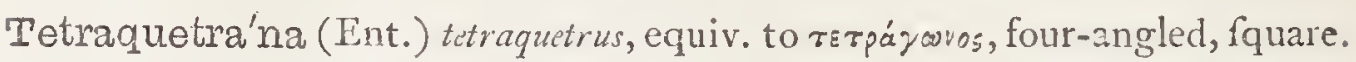
Tetrarhy'nchus (Zool.) r'spa, four, pryxos, beak; the head polfefling four uncinate or hook-like probofcides; a genus of parafitic Worms.

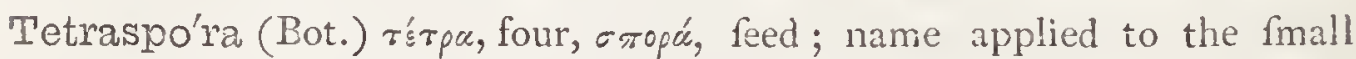
buds formed by the quaternary divifion of the protoplafms of certain cells in Cryptogamic plants.

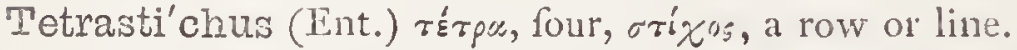

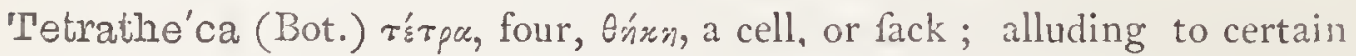
forms of anthers; equiv. to quadrilocular.

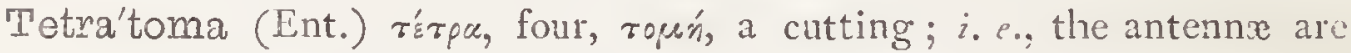
divided into four points; a genus of Coleoptera.

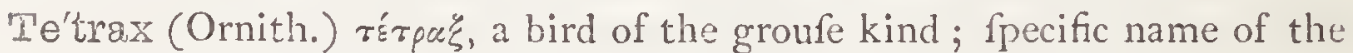
Little Buftard, Otis tetrax.

Te'trix (Ornith.) rérpı fpecific name of the Black Cock, or Black Groufe ; Tetrao tetrix.

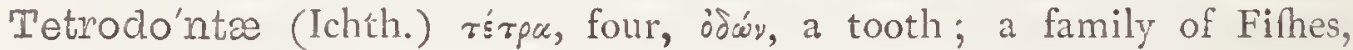
equiv, to the genus 'Teträodon of Linnæus and Cuvier.

Te'trops (Ent.) ville Tetraopes; a genus of Coleopiera.

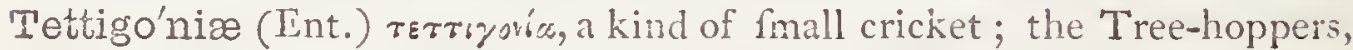
a kind of locufts.

Teu'crium (Bot.) тยúxprov, a kind of germander; a genus of Iabiatæ.

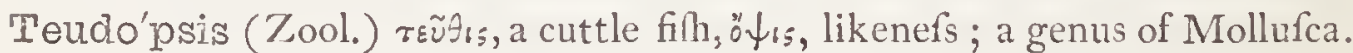
Textila'ria (Zool.) textilis, woven, plaited; a genus of Foraminifera.

Pex'trix (Zool., Ornith.) Lat. a female weaver; a genus of Arachnida; alfo fpecific name of one of the Tailor-birds, Drymoica textrix.

Textura'ius-a-um (Zool.) textura, a web; reticulate, web-like.

Thalamiflo'ra (Bot.) thalamus, a bed or receptacle, flos, a flower; the ftamens are inferted below the piftil.

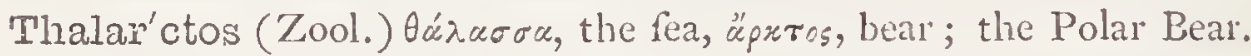

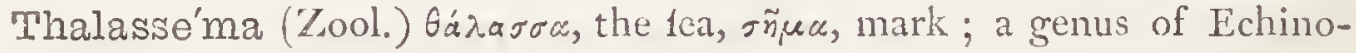
dermata.

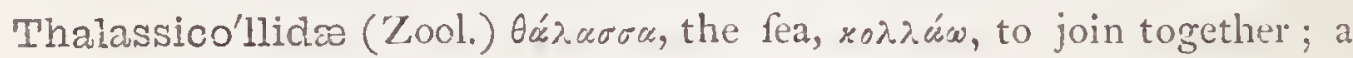
group of the Protozoa.

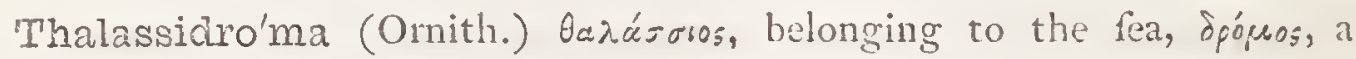
flight ; the Storny Petrel, a genus of Sea-birds.

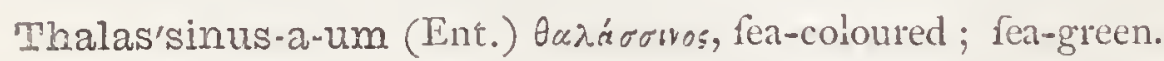

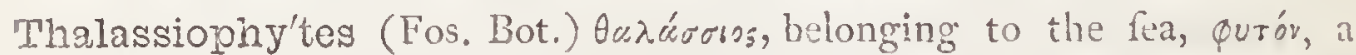
plant. 
Tha'lia (Bot.) P. N. in honou of $\mathcal{F}$. Thalius, a German phyfician, who died in 1588 ; a genus of Marantacer.

Thalic'trum (Bot.) Aú $\lambda \lambda \omega$, to grow green; alluding to the young thoots; a genus of Ranunculacex.

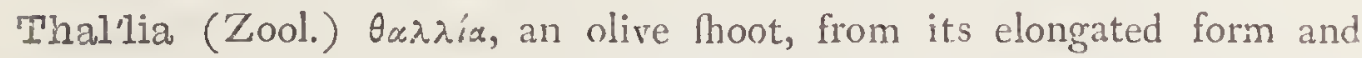
glaucous colour ; a genus of Actinix.

Thal'logens (Bot.) $\theta \omega \lambda \lambda_{0}^{\circ}$, a fhoot, ysvrúw, to bring forth; applied to the lower Cryptogamia, in which the ftems and leaves are indiftinguifhable.

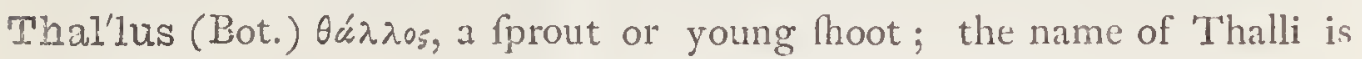
given to the broad foliaceous expansions of the cells of the lower Cryptogamic plants.

Thalura'nia (Ornith.) $\theta \dot{\alpha} \lambda \lambda \omega$, to be luxuriant, ovecevros, hearenly; a genus of Humming-birds.

Thamni'dium (Bot.) Oisuvos, a twig; from the appearance of the plants under the microfcope.

Thamnocho'rtus (Bot.) Oáuvos, a Mrub, xópros, grafs; a genus of Reftiacer.

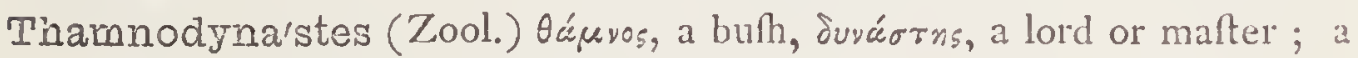
genus of Colubrine Ophidians.

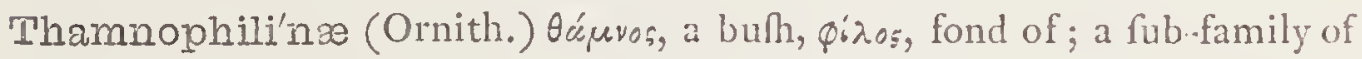
the Inceflores ; the Bu?h-Shrikes.

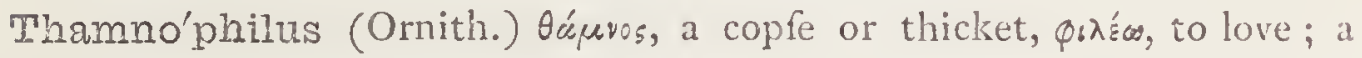
genus of Birds, family Laniidæ.

Than'aos (Ent.) perhaps a typographical error for táveros, death, in allufion to the dark colour of the fpecies (Acc. Lift Brit. Lepid.); a genus of Lepidoptera.

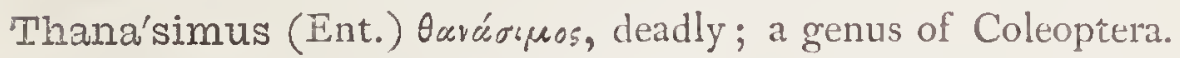

Thanato'philus (Ent.) Oáveros, death, pínos, fond of, i. e., given to fimu-

lating death; a genus of Coleoptera.

Thap'sia (Bot.) firft difcovered in 'Thapfus; a genus of Umbelliferæ.

Thap'sus (Bot.) the ancient name of fome poifonous Arub; now applied to a fpecies of Verbafcum.

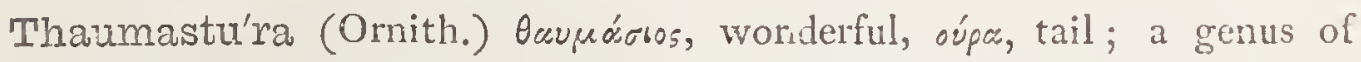
Humming--birds.

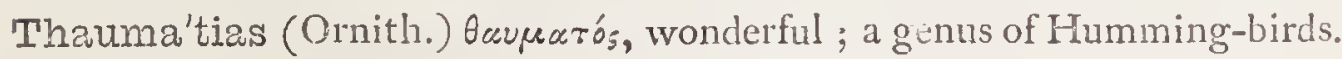
The'a (Bot.) tcha, the Chinefe name for tea; Fr. du thé; Ital. dol te; the

Tea-plant; a genus of Ternfrömiaceæ.

The'ca (Zool., Bot.) Arixn, Lat. theca, a Theath or receptacle; in zoology

a genus of Mollufca ; in botany, the receptacle or urn of Mofles. 
Theca'cera (Zool.) O'nxn, a fheath, répas, horn; the tentacles being retracted within the fheaths; a genus of Mollufea.

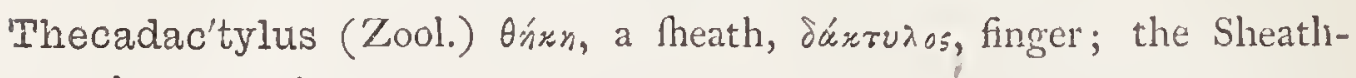
clawed Geckos.

Theci'dium (Zool.) dim. of Ónxn, a fheath; a divilion of Brachiopods.

Thec'la (Ent.) P. N. in honour of Thecla, virgin and martyr; fee Butler's

"Lives of the Saints," ix. 286 ; a genus of Lepidoptera.

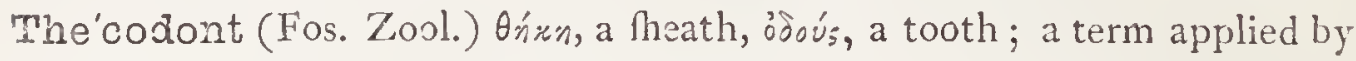

Profelfor Owen to thofe inferior Saurians which have the teeth implanted in fockets.

The'codontosau'rus (Fos. Zool.) Ginkn, a Theath, ojovis, ojovros, a tooth,

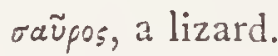

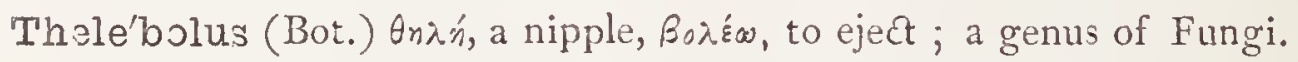

'Thele'phora (Bot.) Enגй, a nipple, фopés, to bear; a genus of Fungi.

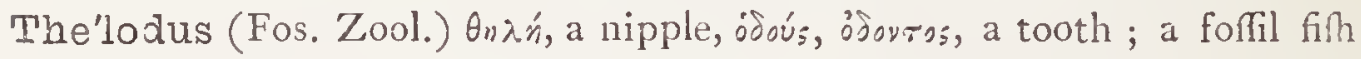

fo called from its peculiar mammilated teeth.

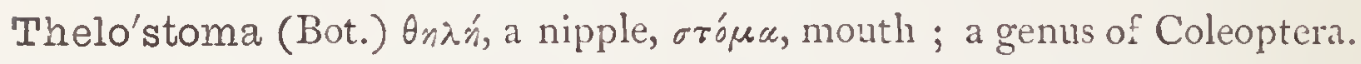
Thelo'stomus (But.) fame derivation; a genus of Coleoptera.

Thelotre'ma (Bot.) $\theta_{n} \lambda \dot{n}$, a nipple, трй $\mu \alpha$, an orifice; from the pierced protuberances of the cruft; a genus of Lichenes.

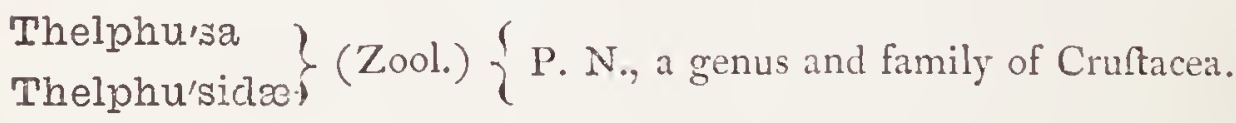

Thelygo'num (Bot.) Paxton ftates that this genus is named from Gñas, a woman, your, the knee, from a fancied refemblance of the joints; but may it not more probably be from onduróvos, begetting females, on account of the fpecies being moftly unifexual; a genus of Chenopodiaceæ.

Theiymi'tra (Bot.) $\theta \tilde{n} \lambda \nu_{5}$, a woman, $\mu$ it $\rho \alpha$, a cap; referring to the hooded fructification ; a genus of Orchidacex.

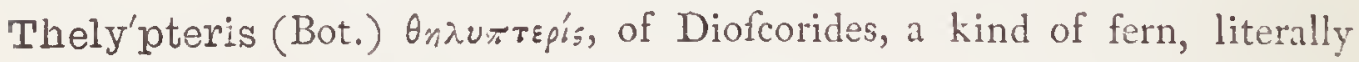
"female fern;" now applied to a fpecies of Afpidium, Afpidiun Thelypteris.

Thenar'dia (Bot.) P. N. in honour of M. Thenard, a diftinguifhed French chemint; a genus of Apocynaceæ.

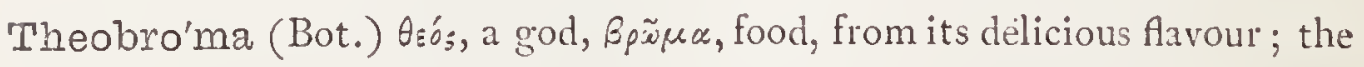
Cacao tree; a genus of Byttneriacez.

Theophras'ta (Bot.) P. N. in honour of Theophraftus, the father of natural hiftory ; a genus of Myrfinacex.

The'ra (Ent.) the name of an illand near Crete; a genus of Lepidopteria. 
Thera'tes (Ent.) Enpáw, to hunt, or purfue eagerly ; a genus of Coleoptera.

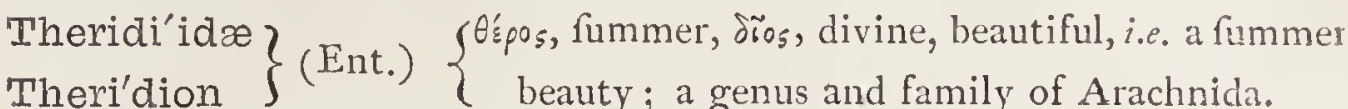
Therine'lla.(Ent.) dim. from Eepsvós, belonging to fummer.

Theris'tis (Ent.) Eéproros, harveft-time; a genus of Lepidoptera.

Thermop'sis (Bot.) Eśspos, the lupine, ö $\downarrow$ s, refemblance; a genus of Leguminofie.

The'sium (Bot.) Ońn, a labouring fervant; from its mean habitat-PAxton; a genus of Santalaceæ.

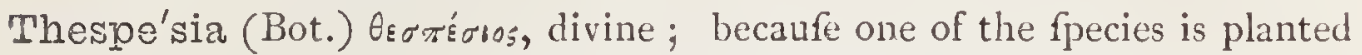
about the churches in tropical countries; a genus of Malvacex.

Thino'corus (Ornith,) eiv, $\theta_{6}$ ós $^{\prime}$, the fhore, rópsw, to fweep ; from inhabiting littoral diftricts.

Thlas'pi (Bot.) $0 \lambda \dot{u} 5 \pi b$, a plant of the crefs kind; a genus of Cruciferx.

'Thoma'sia (Bot.) P. N. in honour of M. Thomas, a collector of Swifs plants; a genus of Byttneriacex.

$\left.\begin{array}{l}\text { Thomi'sidæ } \\ \text { Tho'misus }\end{array}\right\}$ (Ent.) $\left\{\begin{array}{c}\theta \text { opic } \omega, \text { to bind with a cord; a family and } \\ \text { genus of Arachnida. }\end{array}\right.$

Thora'cicus-a-um (Ent.) Lat. relating to the breast-bone or thorax. $\left.\begin{array}{l}\text { Thoric'tidæ } \\ \text { Thoric'tus }\end{array}\right\}$ (Ent.) $\left\{\begin{array}{c}\theta \text { wprirn's, armed with a breast.plate; a family } \\ \text { and genus of Coleoptera. }\end{array}\right.$

Thoroughwax (Bot.) popular name of the Bupleurum rotundifolium; the old Englith word waxa, means to grow, and thorough is through, becaufe the ftem feems to grow through the leaf; Gerarde calls it Thorowewaxe or 'Thorowe leaf.

Thoui'nia (Bot.) P. N. in honour of And. Thouin, of the Jardin des Plantes, Paris ; a genus of Sapindacere.

Thrasaëtus (Ornith.) Opúsos, courage, boldnefs, ázrós, an eagle; a genus of Falconide.

I'hrasonel'la (Ent.) P. N. from Thraso, a bragging foldier in Terence's "Eunuchus."

Threlke'ldia (Bot.) P. N. in honour of the Rev. L. E. Threlkeld, miffionary in New South Wales; a genus of Chenopodiacex.

Threne'tes (Ornith.) Opnvins, a nourner, from the fombre plumage; a genus of Humming birds.

Threno'des (Ent.) Eprvíon:, mournful.

Thresher (Ichth.) applied to a fin (Alopecias vulpes), which uses its tail in combat as a threher would ufe a flail; is is alfo called the Foyfhark. 
Thri'nax (Bot.) Opirceg, a fan, from the form of the leaves; a genus of Palmx.

Thrin'cia (Bot.) Apryrós, a fence; a genus of Compofita.

Thrips (Ent.) Apí

'Thrissono'tus (Fos. Zool.) $\theta$ p $\xi \xi$, a briftle, $\nu \tilde{\omega} \tau o s$, the back.

Thris'sops (Fos. Zool.) $\theta \rho \cdot \xi$, a brifte, ö $\psi$ เs, appearance; one of Agalliz' genera of Foffl fithes, fo named from the long briftle like character of their fin rays.

Throm'bium (Bot.) Өpópßos, a lump; a genus of Lichenes.

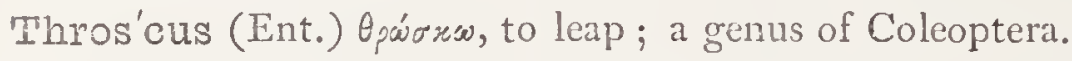

Throstle (Ornith.) Anglo-Saxon throftle; Germ. and Dan.droflel; a fynonym for thrufs.

Thrush (Ornith.) Anglo-Saxon thrix; the Turdus muficus.

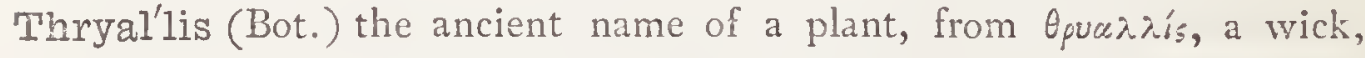
becaufe ufed for making wicks; now applied to a genus of Malpighiaceæ.

Thu'ia (Zool.) Euts, a cedar; a genus of Zoophytes.

Thuia'ria (Zool.) refembling Thuia; a genus of Zoophytes.

Phu'ja (Bot.) Avov, facrifice; the wood when burnt giving out an agreeable perfume like incenfe, and was ufed in facrifices. Plin. Hist., lib. xxiij., in prormio; a genus of Cupreffiner.

Thujop'sis (Bot.) the genus Thuja, ö $\psi^{\prime}$, like; a genus of Cupreflinex.

Thunbergel'la (Ent.) P. N. in honour of K. P. Thunberg, who fucceeded the younger Linnieus as Profefor of Botany at Upfala, author of "Infecta Suecica," \&c., died in 1828 .

Thunber'gia (Bot.) P. N. in honour of the fame celebrated botanift and traveller; a genus of Acanthaceæ.

Thy'amis (Ent.) uncertain; a genus of Coleoptera.

Thyati'ra (Ent.) P. N., a city in Afia Minor; a genus of Lepidoptera.

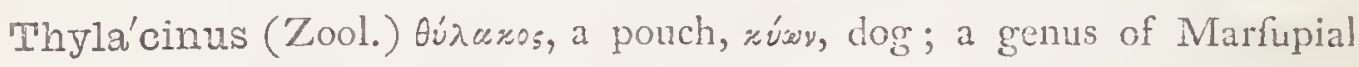
anima!s.

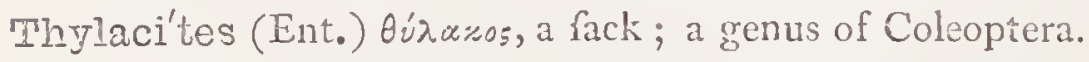

Thy'lacoléo (Fos. Zool.) Gúdaros, a pouch, leo, a lion; a mammal fo called from "the trenchant dentition of its frull, which rivals that of the lion in fize."-PAGE.

Thylacothe'rium (Fos. Zool.) Eúrcuros, a pouch, enpíry, a wild beaft; a genus of foffil Marfupial animals.

- Thy'lamys (Zool.) Oúraros, a fack, pẽs, a inoufe. 


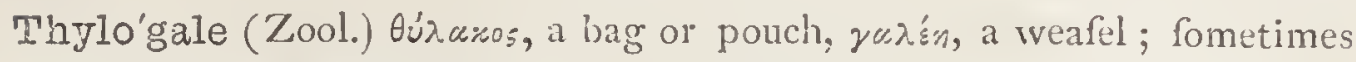
applied to the Kangaroo.

Thymal'lus (Ichth.) Lat. an ancient name of a fin fmelling of thyme when newly taken; $T$. vulgaris is the Grayling; a genus of Salmonidr.

Thy'malus (Ent.) Qúrov, thyme; from the pleafant odour of the beetle; a genus of Coleoptera.

Thym'bra (Bot.) a name given by the ancients to a plant like thyme ; a genus of Labiatæ.

Thy'mus (Bot.) Lat. thyme; Thyme ; a genus of Labiatx.

Thyn'nu.s (Ichth.) Lat. the tunny-fifh; a genus of Scomberidre.

Thy'one (Zool.) P. N., according to Cicero the mother of the 4th Bacchus; Ovid and Horace confider her to be Semele; a genus of Echino. dermata.

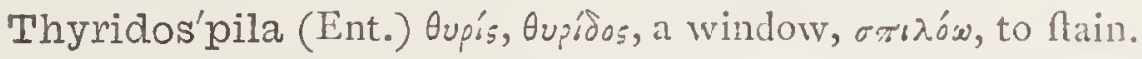

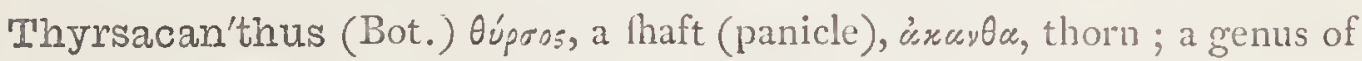
Acanthaceæ.

Thyrsites (Ichth.) Eupoimv, Lat. thyrfiro, an ancient name of a filh; Thyrfites atun is the "Baracoota" of Auftralia.

Thyrsus (Bot.) Lat. a ftaff, twined with ivy and vine-lhoots; a panicle with (hort oppofite branches, as in privet.

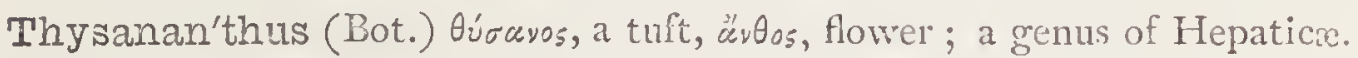
Thy'sanothe'cium (Bot.) túsavos, a fringe, tńxn, capfule; a genus of Lichenes.

Thysano'ptera (Ent.) Oúcavol, fringes, $\pi \tau \varepsilon p o ́ v$, a wing; an order of Infects.

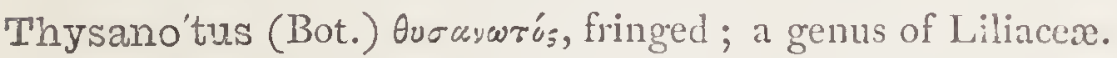

- Thysanu'ra (Ent.) Oíravoi, fringes, oúpa, tail; the Fringe-tails; an order of Infects.

Thyse'linum (Bot.) O'v́, to facrifice, oślıvov, parley; a genus of Umbelliferæ.

Tiarel'la (Bot.) dim. of $\tau$ เápa, a Perfian diadem, from its mitred capfule;

a genus of Saxifragaceæ.

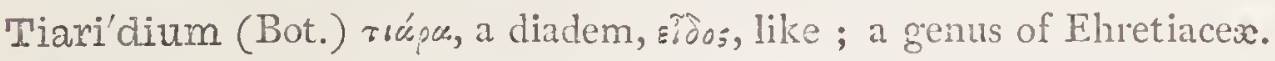

Tibialis-e (Ent.) Lat. of or pertaining to the fhin bone.

Tibi'cinis (Bot.) gen. fing. of tibicen, a flute-player; Epidendrum tibicinis, becaufe the fhoots, three yards long, cylindrical and hollow, are ufed as trumpets by the native children.

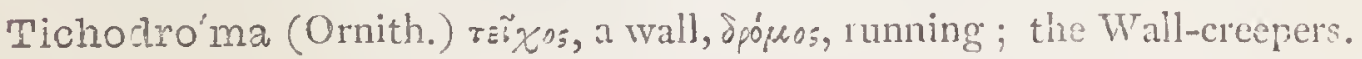




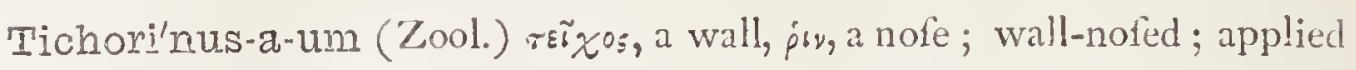
to the Rhinoceros tichorimes becaufe of a vertical pattition which fus.. tains the nafal vault.

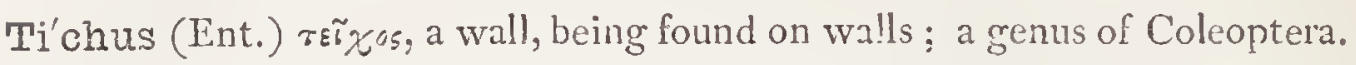
Ti'gellary (Bot.) French, tige, a ftem or ftalk; applied by Gaudichaud where the theathing or ftipulary portion of a leai-ftalk is incorporated with a ftem.

Ti'griceps (Fos. Zool.) tigris, a tiger, caput, head ; liger-headed.

Tigni'dia (Bot.) tigris, a tiger, es sos, like; from its fpotted flowers; a genus of Iridacex.

Ti'gris (Zool.) Lat. a tiger; a genus of Mammalia, family Felidx.

Ti lia (Bot.) Lat. the linden, or lime-tree; typical genus of Tiiliacex.

Tiliaco'ra (Bot.) tilickora, its name in Bengal; a genus of Menifpermacex.

Tillæ'a (Bot.) P. N. in honour of M. A. Tille, an Italian botanift, who died in 1740 ; a genus of Craftulacex.

Tillan'dsia (Bot.) P. N. in honour of Eriar Tillards, Piofeffor of Phyfic at Abo in Finland; Linnaus gives the following curious acconnt:"Tillandfix cannot bear water, and therefore I have given this name to a genus from a Profeftor at Abo, who in his youlh having an unpropitious paflige from Stockholm to that place, no jooner fet his foot on hore than he vowed never again to venture himfelf npon the fea. He changed his original name to Tillands, which means on or by land; and when he had fubfeculunt!y occarion to remm to Swede!, he preferred a circuitous journey of 200 Swedith miles through Lapland, to avoid going eight miles by fea; " a gुenus of Bromeliacex.

Tillidre (Ent.) a family of Coleoptera of which Tillus is the type.

Tilloida (Ent.) the genus Tillus, sidos, likenefs; a genus of Coleoptera.

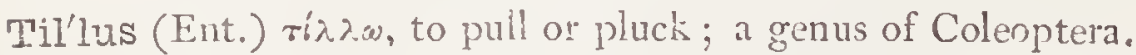

'Tilu'rus (Ichth.) rór ov, a feather, ópo, tail; a genus of Hair-tailed Finhes. Timan'dra (Ent.) P. N. the daughter of 'Tyndareus and Leda, and mother of Evandrus; a genus of Lepidoptera.

Timar'cha (Ent.) rıма弓xice, honour, refpect; a genus of Coleoptera.

Ti'midus-a-um Lat. timid, fearful; e. g. Lepus timidus, the common hare. Tim'mia (Bot.) P. N. in honour of F. G. Timm, a German botanical author; a genus of Mufci.

Timothy-grass (Bot.) common name of the Phleum pratenfe. 'Tinag'ma (Ent.) rivagra, a thake or jerk; from the Tharp jerking motions of the infect; a genus of I epidoptera. 

$\left.\begin{array}{l}\text { Tinami'dæ } \\ \text { Tin'amus }\end{array}\right\}$ (Ornith.) $\left\{\begin{array}{c}\text { Latinized form of the native word; the Tina- } \\ \text { mou; a family and genus of Gallinx. }\end{array}\right.$

Tinamo'tis (Ornith.) the gerrus Tinamus, otis, a buftard, from a fancied refcmblance; the crefted 'Tinamou; a genus of Gallinæ.

Ti'nca (Ichth.) Lut. the Tench; a genus of Cyprinoid fihes.

Tinctel'lus-a-um (Ent.) dim of tinalus, dyed.

Tinctórum (Bot.) e. g., Rubia tinctorum; Dyers' Mauder.

Tinëa (Ent.) Lat. a muth or worm, in cluthes, books, Ec.; 'T. mellonella was well known to the ancients as an encmy of bees-dirum tinex genus: VırGil. Georg. iv. 246 ; a genus of Lepidoptera.

Tinëi'are (Ent.) the family of nocarnal Lepidoptera, of which Tinea is the type.

Tineo'des (Eut.) the genus Tinea, हiòn, likcnefs.

Tinnunculoi'des (Ornith.) the genus Tirmuncul's, દ'sos, like; keftrel-like. Tinnun'culus (Ornith.) Lai. a kind of hawk or keftrel montioned by Pliny; a genus of Falconide which includes the keft rel, ' $l$ '. alaudarius. Ti'nhia (Ent.) rip̣n, a bah.ehoufe becile; a genus of Hymenoptera. Típula Tipu'lidæ) (Ent.) \{tipur. a midge; a genus and family of Diptera. Tipulæfor'mis-e (Ent.) tifula, a midge, forma, fhape.

Tire'sias (Ent.) P. N. a cclobrated foothrayer of 'Thebes in Bocotia; a genus of Coleoptcra.

Tische'ria (Ent.) P. N. in honour of Cuit won Tifichr, of Drefden, born in 1777, author of feverul works on infeets; a genus of Lcpidoptera.

Titho'nia (Bot.) P. N. fion Tititum, favourite of Aurora; the flower is conleur d'aurore; a genus of Compoitie.

Tittman'nia (Bot.) P. N. in honour of Titmann, a German botanift; a genus of Bruniacex.

Tityrel'la (Ent.) the infeet feeds on the becch, and the name alludes to the line-" Tilyre; tu patule recubans fub tegmine fagi."

Toco'ca (Bot.) tococo, its name in Guiana; a genus of Melantomacex.

Tocoye'na (Bot.) its name in Guiana; a genus of Cinchonacex.

Todda'lia (Bot.) toddali, the Malabar name of one of the fpecics; a genus of Xanthoxylicux.

To'dea (Bot.) P. N. in honour of Henry Fulius Tok', of Mecklenburg, an experienced mycologift; a genus of Polypodiacer.

To'dus (Ornith.) Latinized from the popular ndme of this Bird; the Tody; a genus of fifiroftral Pafleres. 
Tofiel'dia (Bot.) P. N. in honour of $M r$ Tofield, a friend of Hudfon, the botanift; a genus of Melanthacex.

Toga'tus-a-um (Ent.) Lat. wearing a cloak, robed.

Tol'pis (Bot.) one of Adanfon's names, probably without meaning; a genus of Compofitx.

Tomenie'llus-a-um (Bot.) tomentum, a flock of wool ; woolly, e. g. Polylepis tomentella.

Tomento'sus-a-um (Bot.) fame derivation ; downy, hairy.

To'micus (Ent.) ropเ\%ó, cutting; the tibix are ferrated; a genus of Coleoptera.

Tom'odon (Zocl.) ropess, Marp, ossóv, a tooth; a genus of Colubrine ophidians.

Tomoga'ster (Zool.) res's, tharp, yasrinp, the belly; a genus of Ophidians. Topa'za (Ornith.) having colours refembling topaz ; a genus of Hummingbirds.

Tordy'lium (Bot.) an ancient Greek name (ropóvissv), of unknown meaning ; Hart-wort; a genus of Umbellifere.

Tore'nia (Bot.) P. N. in honour of Rer. Olof Toren, a Swedifh botanift; a genus of Scrophulariacer.

Tori'lis (Bot.) ropeviw, to carve, from the leaves being much cut ; Hedgeparfley; a genus of Umbelliferæ.

Tormentil'la (Bot.) tormentum, pain; from its fuppofed efficacy in pain of the teeth and bowels; a genus of Rofacer.

Torpe'do (Ichth.) Lat, the torpedo or cramp-fili, a fpecies of Ray.

Torquatel'la (Ent.) torquatus, adorned with a collar or necklace.

Torqua'tus-a-um (Ornith.) Lat. adorned with a collar, e.g. Melanopicus torquatus, the Collared Woodpecker.

Torquil'lus-a-um (Ornith.) torqueo, to twift; e.g. Yunx torquilia, the Wryneck.

Turre'ya (Bot.) P. N. in honour of Dr. Torrey, an American botanint, and one of the authors of the "North American Flora;" a genus of Taxacex.

Tor'tilis-e (Bot.) tortus, twifed; it has reference to the twifted fate of the repals and petals, e. g., Trichopilia tortilis.

Tortrico'des (Ent.) the genus Tortrix, with term. of fimilarity, $i, e$. like one of that genus; a genus of Lepidoptera.

Tor'trix, pl. Tortri'ces (Ent., Zool.) fem. of tortor, one who twints; the larve twift and contort the leaves of the food-plant; a genus of Iepidoptera ; alfo a genus of Ophidians. 
Tor'tula (Bot.) tortus, twifted; the teeth of the periftome being twifted round the apex of the columelia; a genus of Mufci.

Tor'ula (Bot.) diminutive of torus, a twifted cord; from the appearance of the filaments; a genus of microfcopic Fungi.

To'rus (Bot.) Lat. a knot or protuberance; in botany the word is ufed to exprefs the expanded apex of the floral axis, and is equivalent to receptacle or thalamus.

Torymi'dæ (Ent.) a family of Hymenoptera of which Torymus is the type. 'Tor'ymus (Ent.) etymol. doubtful; a genus of Hymenoptera.

Totani'næ) (Ornith.) $\left\{\begin{array}{l}\text { etymol. doubtful; a fub-family and genus of } \\ \text { Scolopacidæ, containing the Red-shanks and } \\ \text { Sand-pipers. }\end{array}\right.$

Totipa'lmes (Ornith, totus, entire, palma, fole of the foot; Cuvier's name for the birds whofe hind toe is united with the others by one continuous membrane.

Tournefo'rtia (Bot.) P. N. in honour of $\mathcal{F}$. P. de Tournefort, the celebrated French botanift, who died in 1708 ; a genus of Boraginaceæ.

Tourret'tia (Bot.) P. N. in honour of $M$. A. de la Tourrette, a friend of Roufteau; a genus of Bignoniacex.

Toza'ster (Fos. Zool.) rókov, a bow, üsrpov, a ftar; a genus of foflil Seaurchins, characterized by a fomewhat femicircular contour.

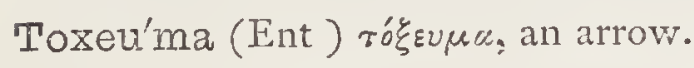

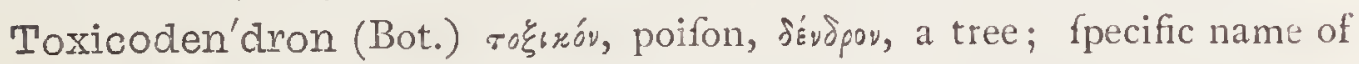
the Trailing Poifon-oak, Rhus toxicodendron.

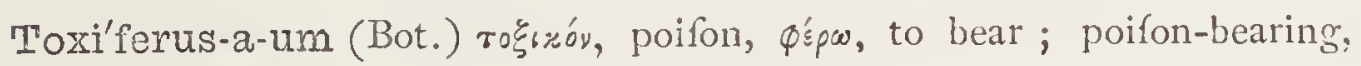
e. g. Amyris toxifera.

$\left.\begin{array}{l}\text { Toxoca'mpa } \\ \text { Toxoca'mpidæe }\end{array}\right\}$ (Ent.) $\left\{\begin{array}{l}\text { rósov, a bow, xáx } x \text {, a caterpillar; from the } \\ \text { arched mode of progreffion; a genus and } \\ \text { family of Lepidoptera. }\end{array}\right.$ Toxo'ceras (Fos. Zool.) rógov, a bow, résus, a horn; a genus of the Ammonite family.

Tox'odon (Fos. Zool.) rósov, a bow, ỏśóv, a toothi a large quadruped, fo named by Profeflor Owen, from the fingularly curved form of its two outer incifors.

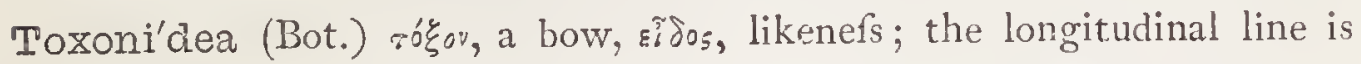
curved fo as to refemble a bow; a genus of Diatomacex.

Tox'otes (Ichth.) ro $\xi_{0}^{\prime} r n s$, an archer; the Archers; a genus of tropical Fifhes, which have the power to expel water to a diffance. 
Tox'otus (Ent.) roło-ns, an archer; the laft joint of the palpi is arched, or hatchet-fhaped; a genus of Colcoptera.

Trache'a (Ent.) трахи́, lough; a genns of I.epidoniera.

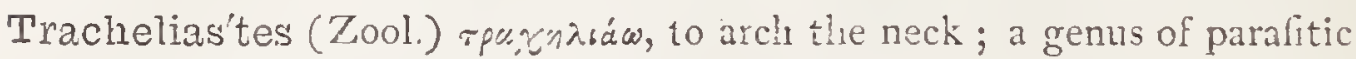
Entomoliac:

Tracine'lium (Boto) rqu, yrios, the throat; from its suppofed medicinal virtues in thront affections; a genns of Campanularex.

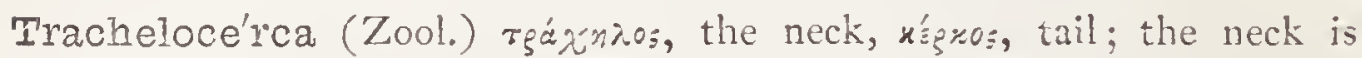
long, and the moveable and dilated end contains the ciliated mouth; a genus of Infuforia.

Tracheloxa'chys (Ent.) rpáxinos, a neck, paxbs, a fpine.

Trachenciny'ma (Bot.) rpasss, rough, zús, tillie; applied to thore fpiral vellels in the iillue of plauts in which the fpiral fibre is elalic, and may be unrolled.

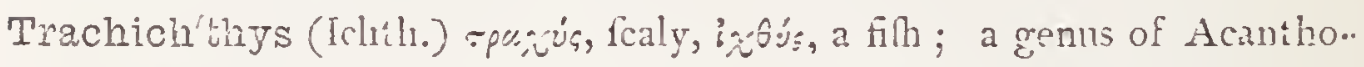
pterggian tifhes.

Tra'chinus (Ichth.) fiom I'a!. Trafina, a corruption of Dracena, a dragon : the Weere: filh.

Trachis'chium (Zool.) roc:xis, rough, izxiov, the hip-joint; a genus of Colubrine ophidians.

Tracizu'rus (Tch九̂.) rou,ús, rugged, ỏpú, a tail; a genus of Scombroidi Finies.

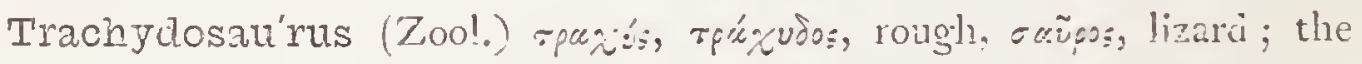
fump-tail Lizard.

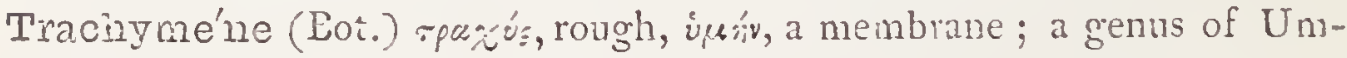
belliferæ.

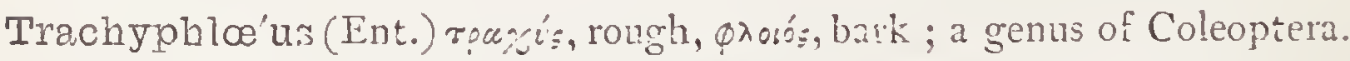

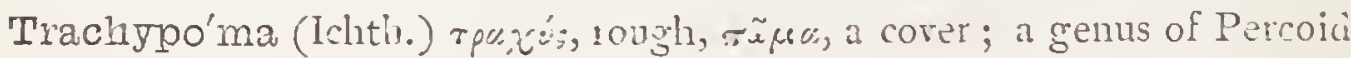
Finhes.

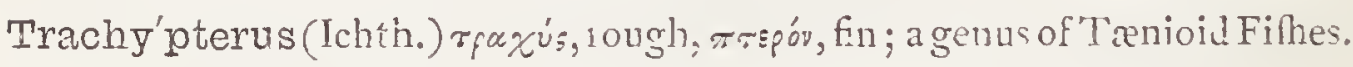
Tra'chypus (Bot.) rpax's, rough, rás: Rem; a gents of Mufci.

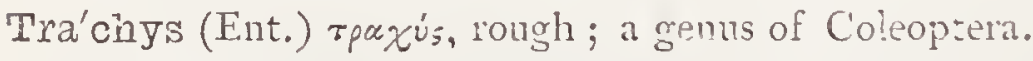

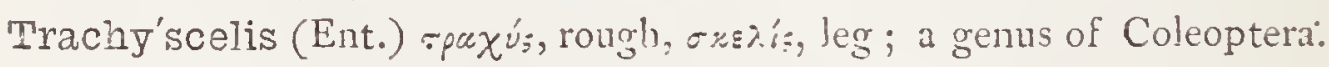

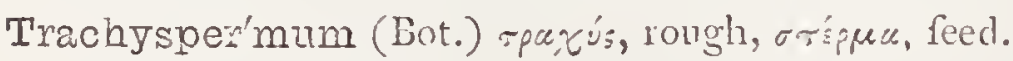

Trachytel'la (Bot.) rpaxírns, roughnefs, refurring to the leares; a genus of Dilleniacex.

Tradesca'ntia (Bot.) P. N. in honom of Forr Tradefant, a diftinguifhed traveller and naturalift in the reign of Charles 1. : a genus of Commelynaceæ. 
Trage'laphus (Zool.) тpuýxaфos, goat-ltag ; was applied by the Greeks to a fabulous aninal; now ufied for the Bolch-Bok, an African ante! one.

rea'gia (Bot.) P. N. in lionour of Jerome Eock, a German botanift, commonly called Trejes; a genus of Euphorbiacex.

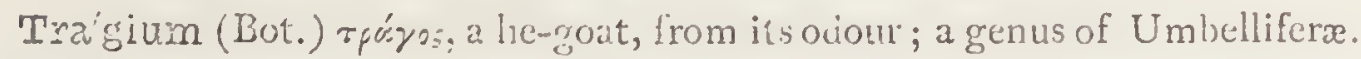

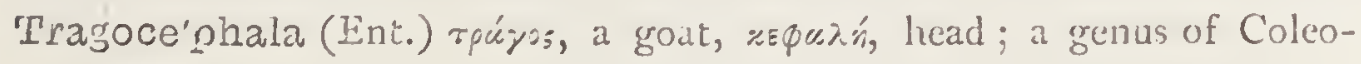
ptera.

Twagopo'gon (Bot.) rpayos, a he-goat, réyar, a beard; in allufion to the feeds; Goats'-bcari; a genus of Compofitic.

Tragopy'rum (Bot.) rpúyos, a goat, zupos, wheat; Goats--wheat: a genus of Poljgonacex.

Tiag'vilus ('/ool.) ciim. of rpáys,a he-goat ; laving the hinder edge of the metataius nearly balu and flightly callous; the Pigmy MuR.

Tra'pa (Bot.) "abricloed from Calcilrapa, the Latin name of an inftrument called Calirops, furuifued with fous fpines, formeriy ufed in war to imperte the progrefi of cavalry: the fruit of fome of the fpecies is furnished with four fpines."-PAxrov. Water-Caltrops: a genus of Unigracex.

Trapeziio'mis-e (Bot.) trapezium, a four-fided figure, forma, fhape, e.g. Adiantum tropazijorms.

I'iapezi'na (Ent.) jo called on accout of the trapezoid mark on the fore wijess.

Tre'chus (Ent.) rp'zal, to run faft; a genus of Colcoptera.

Ireitscintiel'la (Ent.) P. N. in honour of Friedrich Trcilfchke, author of the latter part of "Die Schmetterlinge von Europa," begun in I 807 by Ocilenheimer, and concluded in 1835 - - (Acc. Lift Brit. Lepidopt.)

Tremato'da (Zool.) rpñus, an opening or foramen; a divifion of Entozoa. Tremaio'don (Dot.) rpripu, a hole, ifsvs, osovro; a tooth; the teeth of the periftome being pierced; a genus of Mufci.

Trecoato'pnei (Ichth.) rpripu, a hole piesced through any thing, $\pi$ 's $\omega$, to breathe.

Tremel'la (Bot.) tremo, to tremble, the plants being of a gelatinous, tender, tremulous fubftance; a genus of Fungi.

T:emez (Ent.) tremo, to quiver; a gcnus of Hymenoptera, family Siricidæ. Trem'ulus-a-um (Bot.) Lat. trembling, Thal:ing, e. g. Populus tremula, the trembling Poplat or Afpen.

Trentepo'hlia (Rot.) P. N. in honour of Trentepohl, an obfcure German botanift; a genus of Algr. 
Trepang (Zool.) Fr. beche-de-mer, Enc. fea-lug; commercial name for feveral fpecies of Holothurix, ufed by the Chinefe in their foups.

Trepida'rius-a-um (Ent.) trepidus, trembling, reftless.

Trepo'monas ('Zool.) r f́́rsw, to turn, monas, from having a whirling and jerking movement; a genus of Infuforia.

Treron (Ornith.) rpípwr, timorous, hy; a genus of Tree Pigeons.

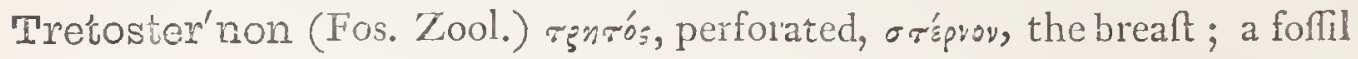
genus of Mielded Reptiles, order Chelonia.

Trevira'na (Bot.) P. N. in honour of Dr. Treviranus, a German botanift;

a genus of Geineracew.

Tre'wia (Bot.) P. N. in honour of Chriftoplzer James Trezu, of Nuremberg, a writer on botany; a genus of Euphorbiaceæ.

Triangula'ris-e (Zool., Ent.) Lat. three-cornered.

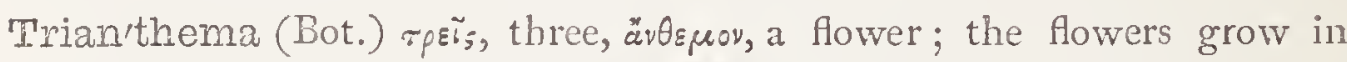
threes in the axels of the leaves; a genus of Tetragoniacex.

'Triatom'ea (Ent.) ter, thrice, atomis, a fpeck.

Tribo'lium (Ent.) тpißsios, three-pointed, three-pronged; a genus of Coleoptera.

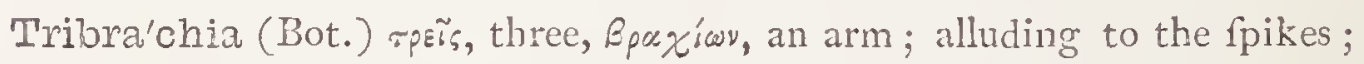
a genus of Orchidacere.

Tri'bulus (Bot.) rpíBonos, three-fpiked or pointed, $i . e$. the fruit-capfule is armed with prickles; a genus of Rutacere.

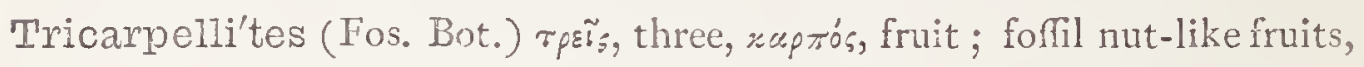
fo-called from their confinting of three carpels or feed-cells.

Trichæ'ta (Bot.) трвís, three, xairn, a briftle; a genus of Gramina.

Trich'ecus (Zool.) $\theta$ pís, rpixos, hair; from the long wiry hair of the muzzle; the Wolrus.

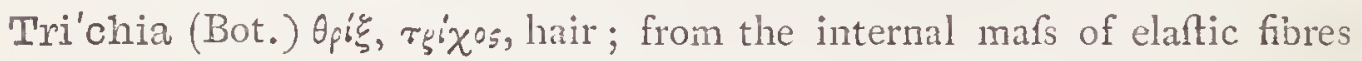
expanding after the head burts; a genus of Fungi.

Trichi'lia (Bot.) rpix , ternary; the capfule is three-celled and threevalved; a genus of Meliacer.

Tri'china (Zool.) rpixtvos, made of hair; a genus of Hair-like Worms.

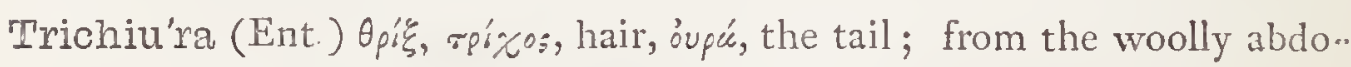
men of the female; a genus of Lepidoptera.

Trichiu'rus (Ichth.) fame derivation and meaning; the Hair-tail; a genus of Tanioid Filhes.

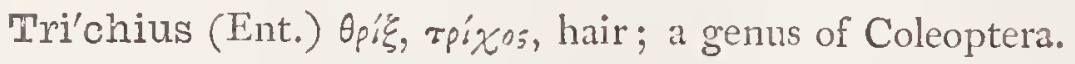

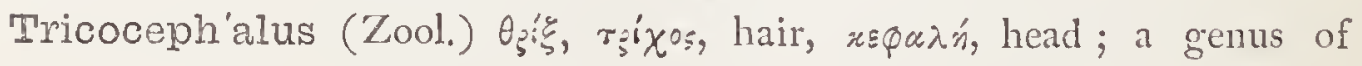
Entozoa. 


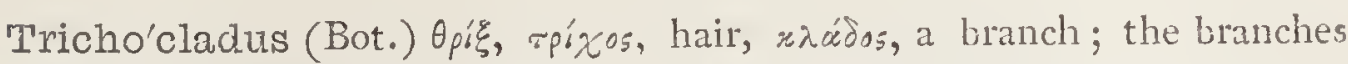
are clothed with ftellate hairs; a genus of Hamamelidacex.

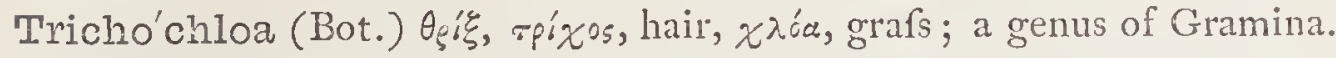

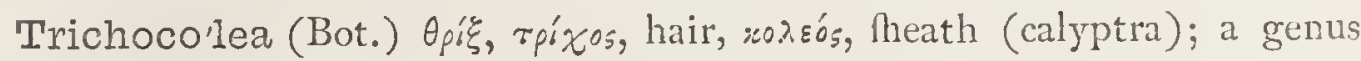
of Hepaticr.

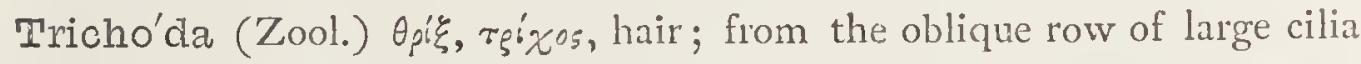
at the mouth; a genus of Infuforia.

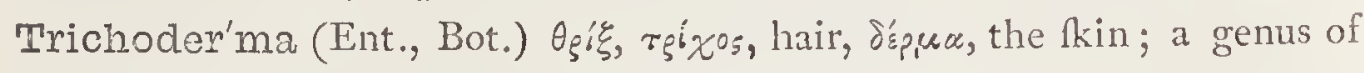
Coleoptera; alfo a genus of Fungi.

Tricho-des'ma (Bot.) $\theta \rho^{\prime} \xi$, тp'xos, hair, $\delta^{\prime} \sigma \mu \alpha$, bonds; a genus of Boraginaceæ.

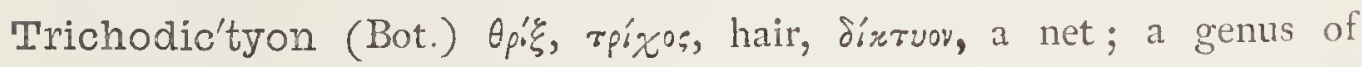
Hepaticæ.

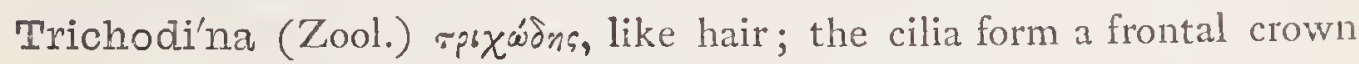
or tuft; a genus of Infuforia.

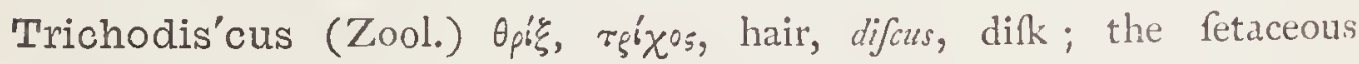
tentacles form a row upon the margin of the body; a genus of Infuforia.

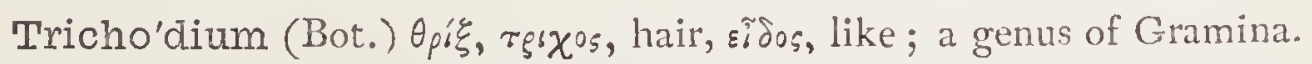

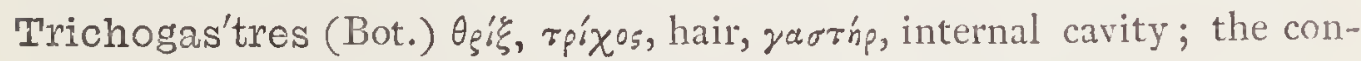
tents of the leathery peridium break, when mature, into powdery fpores and filaments; the Puff balls; a family of Fungi.

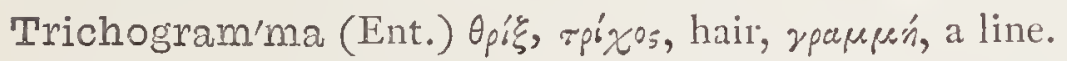

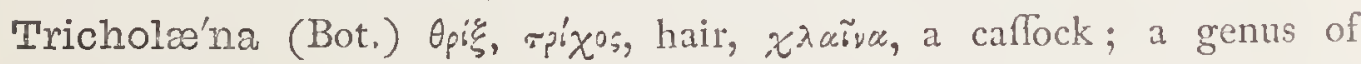
Gramina.

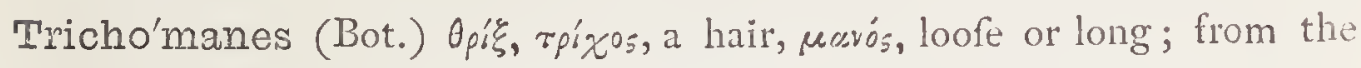
fhining ftems appearing like fine hair; a genus of Filices.

Trichomano'ida (Bot.) refembling Trichomanes; a divifion of Hepaticx.

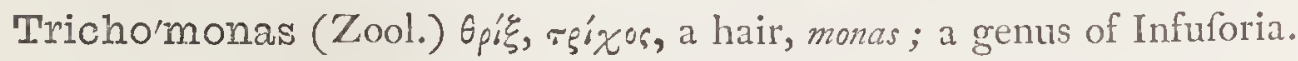

Trichone'ma (Bot.) $\theta_{\xi} i \xi, \tau \varphi^{\prime} \chi^{\circ} s$, hair, $\nu \tilde{n} \mu \alpha$, a filament; the filaments are hairy; a genus of Iridaceæ.

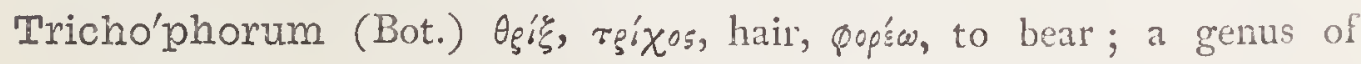
Gramina.

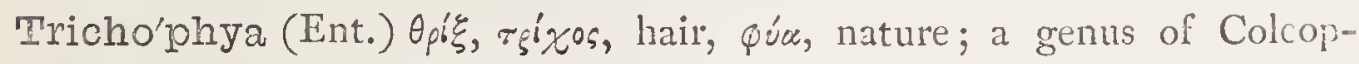
tera.

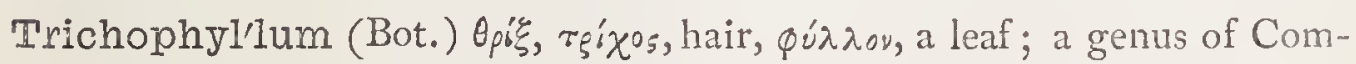
politæ.

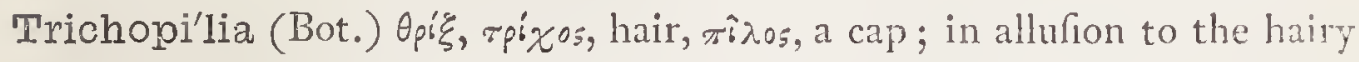
appearance of the clinandrium; a genus of Orchidace 


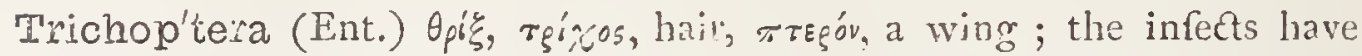
four hairy membranous wings; the ozder which contains the Phryganex, or Cadis-worm fiies.

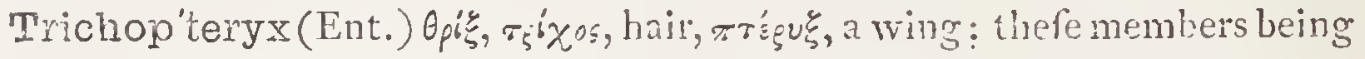
furnifhed with a fafcicle of hairs at the apes: a genus of C'olerptera.

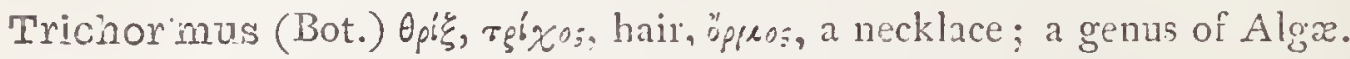

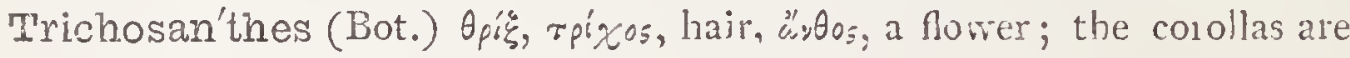
ciliated; a genus of Cucurbitace

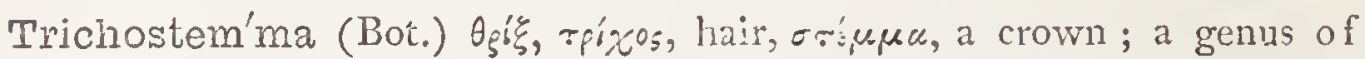
Compofitx.

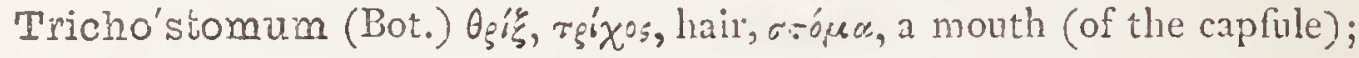
in allufion to the flende: teeth; a genus of $\mathrm{Mn}$ f $\cdot$ i.

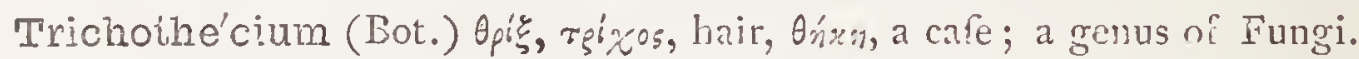

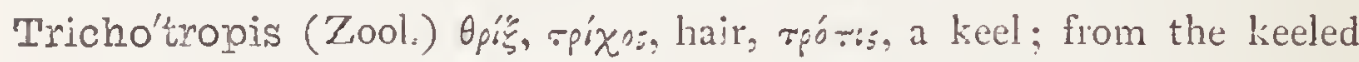
whorls, fringed with a horny finge; a genus of Mollinica.

Tricinc'ta (Zool.) tris, three, cinçus, girded; threz-bundel.

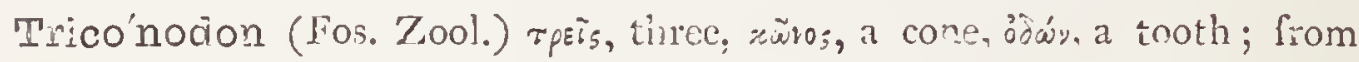
the crowns of the molar teeth of the lower jaw having three nearly equal cones.

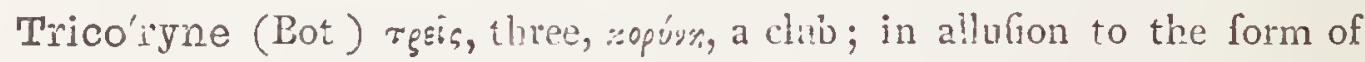
the capfinles; a genus of Iiliacex.

Tricuspida'lus a um (Bot.) ires, thre, cufpis, a point; three-pointed; c.g. Matthida tricusfiriata.

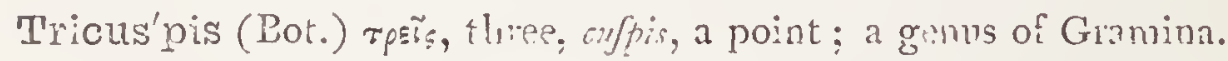

Tridac'na (Zool.) the 'Tridacna of Pliny was a hell-fifh which could be eaten in three bites, from $\tau p \varepsilon \tilde{s}$, three, òd $x \nu \omega$, to bite; it could not be the animal now fo called, which atiajns a large fize; a genus of Conchiliferouss Mollufica.

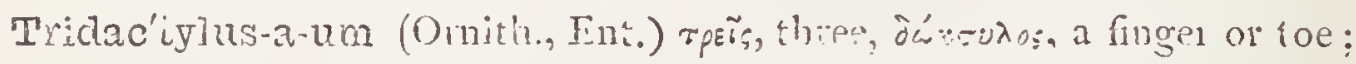

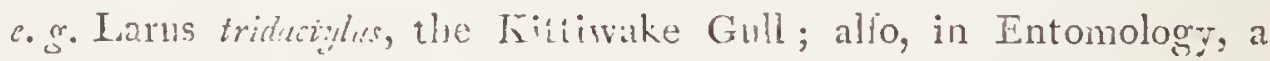
genus of Oithopiera, family Gryllidx.

Tri'dax (Bot.) rpiónevos, thrice-bitten; the rays of the fower are diviciei into three; a gems of Compolit $x$.

Tridens (r.ool., Bot.) tris, three, dens, a tooth; three-tooihed, tridentate; in Botany, a genus of Gramina.

Trienta'lis (Bot.) iriens, one thitd; probably in alluiton to the humble ftature of the fpecies: a gemus of Primulacex.

Trifascia'lus-a-um (Zool.) Iat. tres, three, fafciatus, banded; threebanded, three-ftriped. 
Tri'fią (Ent.) trifidus, cleft into three pars; three-forked.

Trifo'lium (Bot.) tres, three, jolium: a leaf; laving three ledflets on a ftalk;

Treíoil; a gुenus of Legruminore.

Trifurca'tus-a.um (Tcinth.) trifierchs, having three foths or prongs.

Trisur'cula (Ent.) t, : furcus, three pronred; lie median vein of the wings

being trifil; a geilus ol L,epidoptera.

Trigemina'ta (Ent.) triremians, ihree together; referring to the three fubconfuent blackith fpois on the fore wings.

Tixig'la (Ichth.) r

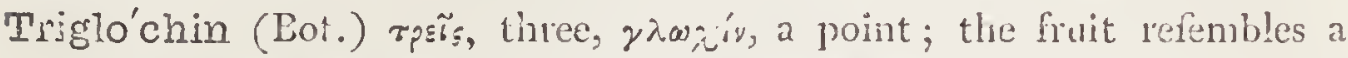
three-barbed arrow; a genus of Juncaginaceie.

Trigona (Zool., Ent.) tpirwros, triangular; a gems of Mollufca; alfo a genus of Hymenoptera.

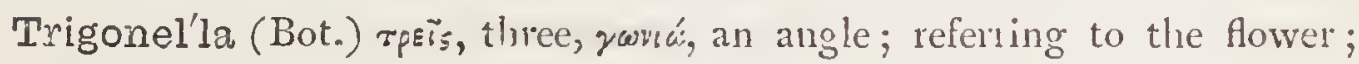
Fenugreek; a genus of Lrgininofx.

Trigo'nia (But.) rpíguvos, triangular; the fruit is thec-angled, three. valved, and three-celled; a genus of Celafuacer. In Zoology, a genus of Conchiferous Mollufica.

Trigonocaripon (Fos. Bot.) тṕrwvos, threc-colnercel, xucrós, fruit; a genus of thick-thelled fruits, fo called from the three projeding corners which mark the furface of the Thell.

Trigonoce'phali (Zool.) rgigaro:, three-cornered, xeфusin, the head; a divifion of Ophidians, fanily Crotalidæ.

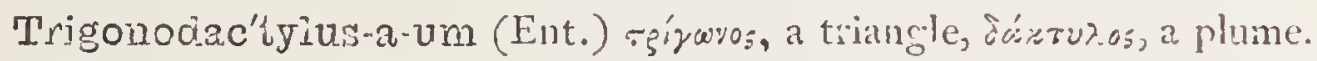

Trigono'ciexus-a-um (Ent.) -g'ywyos, tiangular, ösn, the neck.

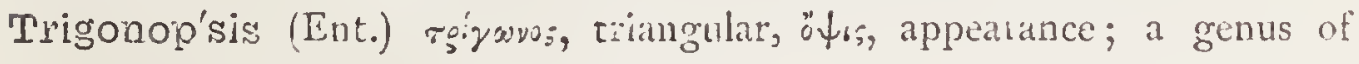
Hymenoptera.

Trigo'nus-a-um (Zool.) tpigaves, triangular.

Tiriguttel'ius-a-um (.Ent.) lar, thrice, gitia, a fpot; three-fpotied.

Trilinea'tus-a-vm (Tnt.) tren, three, lincaiss, lined or ftreaked.

Tril'lium (Bot.) trim, a tiflie of three threats; "the calyx has three repals, the corolla three peitils, the pinil three Ayles, and the ftem three leaves."-PAxron. 'J'ypical gcuus of 'Triliacer.

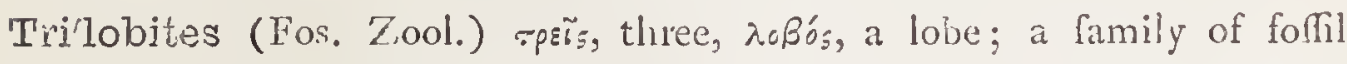
Cinfacea, fo called from the three-lobed appearance of their bocies.

Trilo'phodon (Fos. Zool.) rpers, three, $\lambda \dot{0} \phi 0 s$, a ridge, ojowy, a tooth; the grinders having three ridges.

Triloculi'na (Zool.) tres, three, loculus, a cell; a genus of Foraminifera. Tri'lophus-a-um (Ent.) rpidoфos, with three crefts or humps. 
Trimacula'nus-a-im (Ent.) ter, thrice, macula, a fpot; three-fpotted.

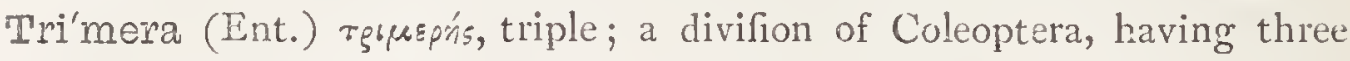
joints to all the tarfi.

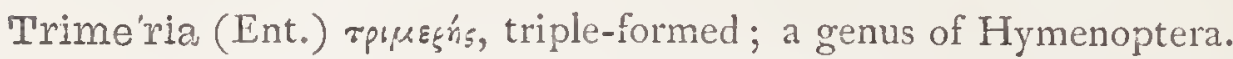
Tri'merus-2.-um (Ent.) fame derivation; having three parts, trifid.

Trimesu'rus (Zool.) триявṕns, three-fold, oúpo, a tail; a genus of Ophidians.

Tri'mium (Ent.) rgißw, to grind down, to rub away; a genus of Colenptera.

Trimor'phus-a-um (Zool.) rpisspфos, triple-formed; having three parts. Trimor'phus (Ent.) fame derivation; a genus of Colenptera.

Irimucrona'tus-a-um (Zool.) tres, three, mucronatus, pointed.

Trin'ga (Ornith.) Lat. a ruff; the Sandpipers; a genus of Scolopacidæ.

Tri'nia (Bot.) P. N. in honour of Dr. C. B. Trinius, a Ruffian botanift; a genus of Umbelliferæ.

Trino'des (Ent.) rpic, three, عỉos, likenefs; a genus of Coleoptera.

Trio'dia (Bot.) rpice, three, osov's, a tooth (point); referring to the palea; a genus of Gramina.

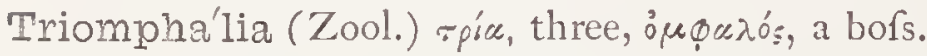

Triony'cida (Zool.) the Soft Tortoifes, of which the following is the typical genus.

Trionyx (Zool.) rpice, three, öv Soft Tortoifes, becaufe, although they have five toes on each foot, only the three inner toes are armed with claws.

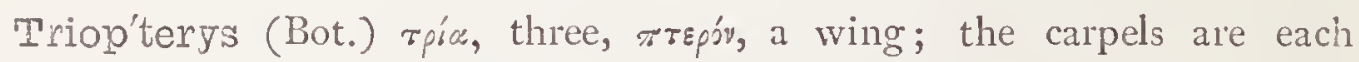
furnithed with three wings; a genus of Malpighiace».

Triomitho'phora (Bot.) rpia, three, opvrs, opprstos, a bird; from the form of the flowers, which prefent the fanciful appearance of three little birds feated in the fpur; fpecific name of a Linaria.

Trios'teum (Bot.) rpice, three, ortsov, a bone; in allufion to the three bony ends in each berry; a genus of Caprifoliaceæ.

Triparel'la (Ent.) tp's, three, par, a pair; on the difc of the wing are three pairs of black fpots.

Tripha'sia (Bot.) тpьpús,os, triple; the calyx is three-cleft, and there are three petals; a genus of Aurantiacex.

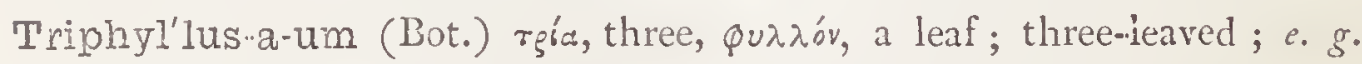
Arum triphyllum.

Trip'laris (Bot.) triplex, triple; the parts of fructification are arranged in threes; a genus of Polygonacex. 
Triplas'ia (Ent.) $\tau p \sigma \pi \lambda \dot{\alpha} \sigma 6 \sigma_{5}$, three-fold.

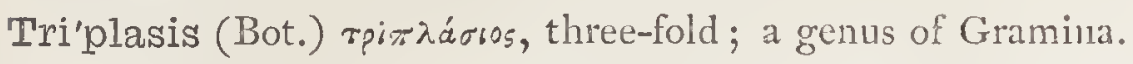

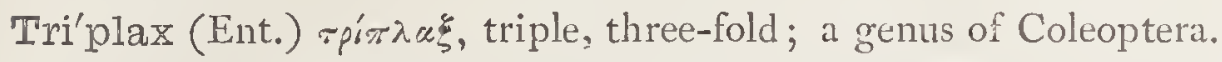

Trip'sacum (Bot.) rpïtrs, a grinding; flour is made from the grains; a genus of Gramina.

Tripti'lion (Bot.) rpia, three, $\pi \tau^{2} \lambda a v$, a feather; alluding to the three divifions of the pappus or feed-down; a genus of Compofitre.

Tripu'dians (Zool.) Lat. dancing; applied to the fnake, Naja tripudians, which is taught by the natives to dance.

Triquetrel'la (Ent.) triquetrus, triangular.

Trique'trus-a-um (Bot.) e.g. Allium triquetrum.

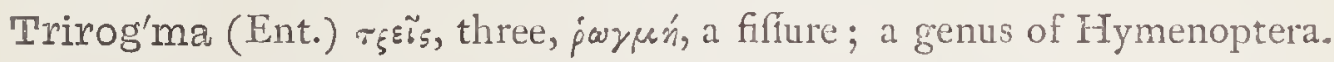

Triseriatel'la (Ent.) ter, thrice, feries, a row; the wings having three rozus of black fcales on the difc.

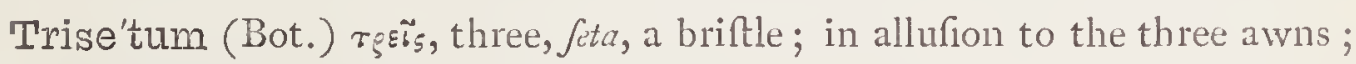
Oat-grafs; a genus of Gramina.

Trista'nia (Bot.) P. N. in honour of M. Triftan, a French botanift; a genus of Myrtaceæ.

Trista'ta (Ent.) triffis, forrowful ; the black and white wings appear to be in mourning.

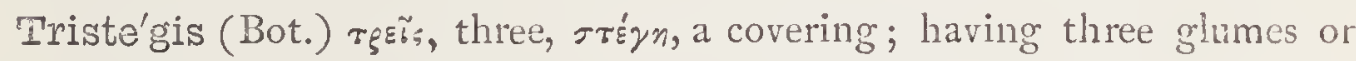
valves of the calyx; a genus of Gramina.

Tristis-te (Zool., Bot.) Lat. harfh, gloomy, e. g. Hefperis triftis.

Tristrigel'?a (Ent.) ter, thrice, friga, a ftreak.

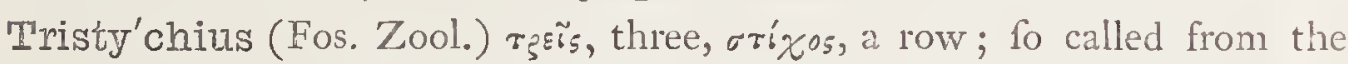
triple row of barbs with which they are armed; applied to the remains of certain foffil thark-like fifhes.

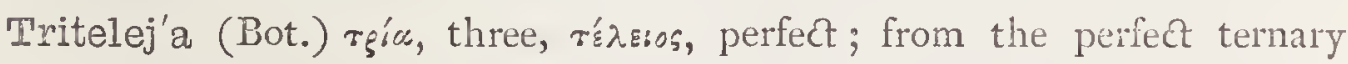
arrangement of the parts; a genus of Liliacex.

Tri'ticum (Bot.) Lat. wheat; from tritus, which comes from tero, to grind, becaufe ground into flour; Wheat; a genus of Cereal Gramina.

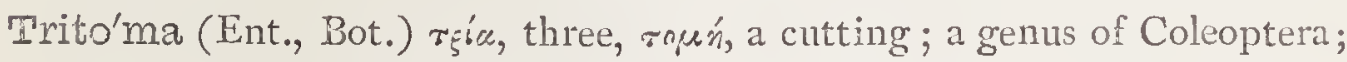
in botany, a genus of Liliacex.

Tritoma'crus (Ent.) reiros, the third, pangós, long, i. e. the third joint of the antennæ; a genus of Coleoptera.

Tri'ton (Zool.) Lat. a water-newt; a genus of Reptilia.

Trito'nia (Bot.) triton, a weather-cock; in allufion to the varied direction of the Ramens; a genus of Iridacex. 
Trito'nia (Zool.) P. N. from Triton, a lea-god; a genus of Nudibranchiate Mollistica.

Trlumfectsa (Bot.) P. N. in honour of G. B. Triumfelti, of Bologna, a celebrated wsiter on botany; a genus of 'Tiliaccie.

Triu'ris (Boi.) rpés, three, oúpe, ‘ail; threc-celled triangular cap'ule; 'Tailworts.

Triverga'tus-a-vm (Zool.) tres, three, virraius, friped; having three bancis or firipsos.

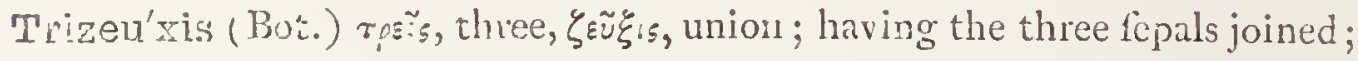
a germs of ()rchidacese.

Trochi'lidae (Ornith.) the Humming-birds, of which the following is the type.

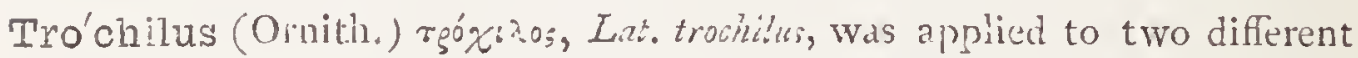
kinds of fam!l birds; now ufed for the Humming -birkls ; typical genus of Trochilidx.

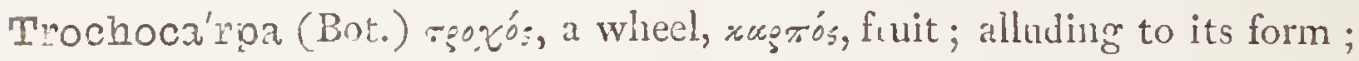
a genus of Epacridacex.

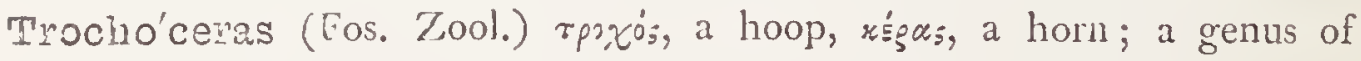
Nautilites.

Trochocrínus (Fos. Zool.) rรoxos, a hoop, rpivov, lily (encrinite); a genus of Fonil Erhinociema!

Tro'chus (7.ool.) Lat. a boy's hoop (Greek, rpo xos); from refemblance

in fome of the frocies; a gemus of Mollufia, fumily 'Turbinidx.

Tro'sida (Ent.) rgẃyw. to guaw; a fimily of Lamellicorn Coleoptera, of which Trox is the typical genus.

Trog'lodytes (Zool., Unith.) rpwyiósúrns, one who hides in caverns; in

Zoology the genus of Murnmalia to which belong the Gorilla and

Chimpanzee; in Ornilio'ogy, the Wren.

Trogon (Onnith.) a genus of Incellorial Birds.

Trogonline'rium (Fos. Zool.) tpúgw, to gnaw, Anpior, a wild beaft; a genus of exitinct Rodents.

Trogophlz'us (Ent.) rá̧y

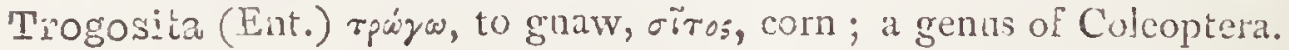
'Trol'lius (Bot.) Germ. trou, a globe; allnding to the thape of tive flowers; a genus of Ranunculacex, popularly called the Globe-flower.

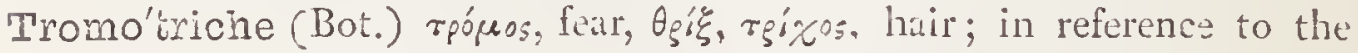
cilia of the corolla being tremulous; a genus of Afclepiadacer.

Tropa'olum (Bot.) rpótasov, a trophy; "The common garden nåturtium is the Tropæolum majus, the generic name referring to the fhield- 
Thaped leaves, prefented full frout, and dark enlanguined flowers, which together fo aptly image the blood-ftained 'trophy; helmets, a:monr, and weapons, of the ancient battle-field."-Grisdon's "Britifh and Garden Botany," p. I $5 \hat{3}$. 'The Indian Ciefs; typical genus of Tiopreolicex.

Troph'is (But.) répos, fodder; cittile eat it in time of fcarcity; a genus of Al zocarpacer.

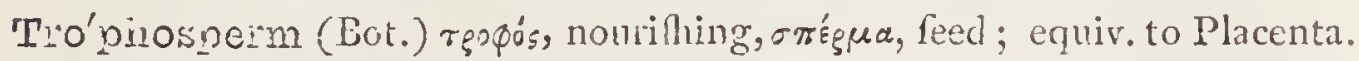

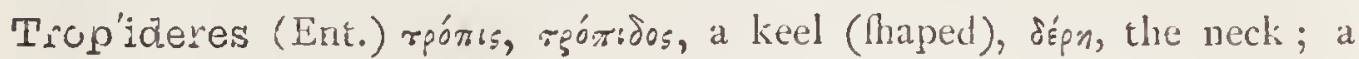
genus of Coleoplera.

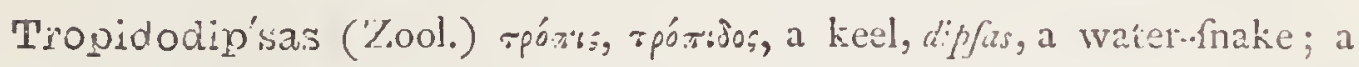
genus of (ulubrine ophilians.

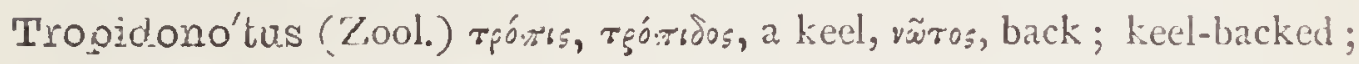
applied to a genus of fipents from the fhape of the back fcales.

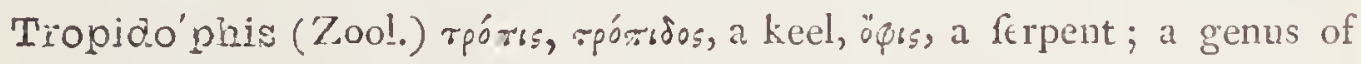
Oplidians.

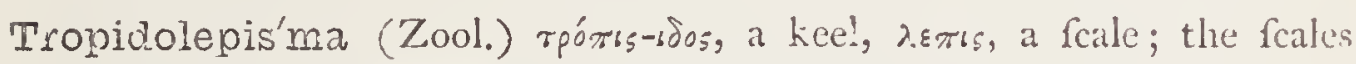
being three o: five keeled; a gems of Scincida.

Tropidorify'nchus (Zool.) rpuzts, rpórtoos, a ridge or keel, púrzos, a finout; a genus of Meliphagidie or Honey-fichers.

Tropidoazu'rus (Zool.) ró́trı, a keel, raüpos, lizard.

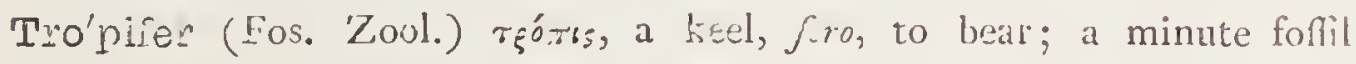
Cruftacean, fo callod from its keeled caraplec.

Trout (Iclith.) Anoro-Sax. iruht; the common tiout is Salmo fario: the Salmon trout, Salmo trate:..

Troz (Ent.) три́̆, a gnawer; a genus of Coleoptera, family Trogidax.

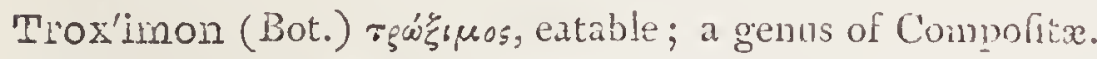

Trumpet-tree (Bot.) ihe Cecropia peltata is fo called becaute its ftens are hollow, with paritions, and correpponding exterior rings; thefe being removed, they are ufed as wind infruments.

$\left.\begin{array}{l}\text { Truncatel'la } \\ \text { Truncatellidre }\end{array}\right\}$ (Zool.) $\left\{\begin{array}{c}\text { truncatus, notched; a genus and division of } \\ \text { Mollufca. }\end{array}\right.$ Truncatipen'nes (Ent.) truncatus, notehed, pennes, wings; one of Latreille's divifions of Coleoptera; from the elytra being truncated or notched at the end.

Truncatuli'na (Zool.) dim. of truncatus, notched; a genus of Foffil Foraminifera.

Truncatus-a-um (Zool., Bot.) Lat. truncate, bottle-nofed, notched; e.g. Epiphyllum truncatum. 
Truncicola'lis (Ent.) truncus, the trunk of a tree, colere, to frequent; found on the trunks of fir-trees.

Tru'x (Ent.) Lat. fiery, favage.

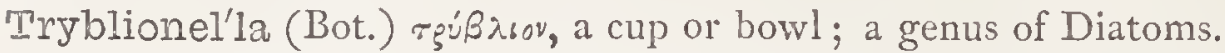

Tryche'ris (Ent.) rpu хnpó, ragged, tattered; a genus of Lepidoptera.

Try'ma (Bot.) rpúrn, a hole; fometimes applied to the form of endocarp,

as in the walnut, where there are prolongations which enter the interior, and caufe a remarkable divifion in the feed.

Tryphre'na (Ornith., Ent.) P. N. T ǵvousve, the name of a lady mentioned in the New Teftament, (Rom. xvi., I2) ; a genus of Humming-birds; alfo a genus of Lepidoptera.

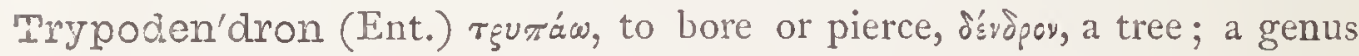
of Coleoptera.

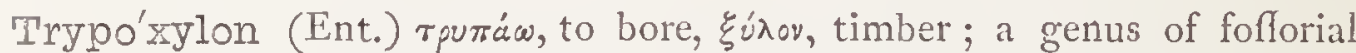
Hymenoptera.

Tse-tse (Ent.) the African infect, Glofina morfitans, fo well defcribed by Dr. Living ftone.

Tu'ber (Bot.) Lat. a fwelling or protuberance; applied to a thickened portion of a root-ftalk; alfo a genus of Fungi, which contains the Truffle.

I'u'berose (Bot.) a foolifh inftance of a Latin fpecific name (tuberofa) being turned into an Englifh generic one, as if connected with Rofe, which it is not in any way; applied to the Polyanthes, a genus of I.iliaceæ.

Tubero'sus-a-um (Ent., Bot.) Lat. full of protaberances; e.g. Irathyrus tuberofus.

Tubicinel'la (Zool.) dim. of tubicen-inis, a trumpeter; a genus of Cirripedes. Tubula'ria ) tubulus, a little pipe; a genus, family, and fub-

Tubulari'adæ $\{$ (Zool.) $\{$ family of Zoophytes.

Tubuli'pora

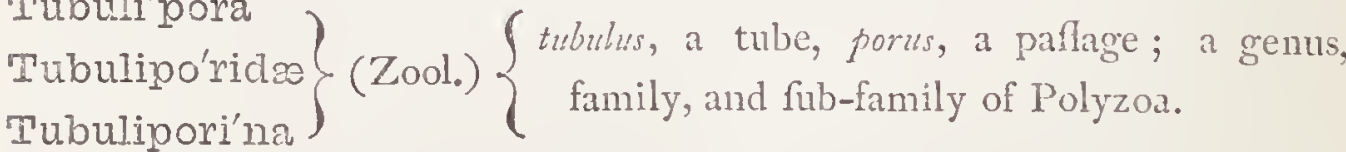

Tulba'ghia (Bot.) P. N. in honour of Tulbagh, a Dutch Governor at the Cape of Good Hope; a genus of Liliacer.

Tulipa (Bot.) Perfian thoulyban, a turban; a genus of Liliacex. The common garden tulip is Tulipa Gefneriana.

Tulipi'ferus-a-um (Bot.) Lat. bearing flowers refembling tulips; e. g. Hedaroma tulififera. 
Tulipifor'mis-e (Zool.) tulipa, tulip, forma, Inape.

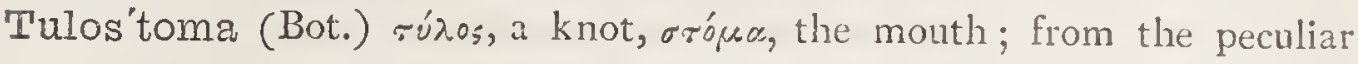
form of the orifice; a genus of Fungi.

Tumidel'la (Ent.) tumidus, fwelling.

Tunica'ta (Fos. Zool.) tunica, a coat; mollufes having no thells, but protected by an elaftic leathery-looking tunic; Tunicaries.

Tunny or Thunny (Ichth.) Húvos, Lat. thynnus; the Thynnus Thynnus.

Tupaia (Zool.) Malay tupai; a genus of Mammalia, family Talpida.

Tupelo (Bot.) the Tupalo-tree is the Nyfla denticulata, Nat. Ord. Alangiacere.

Tupidan'thus (Bot) $\tau u \pi i s-i 005$, a mallet or hammer, üutos, flower; a genus of Araliacex.

Tupis'tra (Bot.) dimin. of rutis, a hammer; alluding to the peculiar form of the flower; a genus of Liliacex.

Turbi'nidæ (Zool.) turbo, a whipping-top; the Top-fhells; a family of Mollufea.

Turbini'na (Zool.) the 'True Top-Thells; a group of Mollurca.

Turbino'lia (Zool.) turbo, a whipping-top; a genus of Zoophytes.

Turbinulina (Zool.) dim. of turbo; a genus of Folfil Foraminifura.

Turbot (Ichth.) Scaliger thinks from Lat. turbo, a top; French, urbot Dutch, tarbo; the Pleuronectes maximus.

Turdoi'des (Ornith.) turdus, a thruh, eidos, likenefs.

Turdus (Ornith.) Lat. a thrufh; a genus of 'Tenuiroftral Palleses.

Turge'nia (Bot.) turgeo, to fwell, i. e., the feeds; a genus of Apiaceie.

Turgeniop'sis (Bot.) the genus 'Turgenia, ö $\downarrow$ s, likenefs; a genus of Apiacex.

Tu'rgicus-a-um (Zool., Bot.) Lat. fwollen, inflated.

Turgo'sea (Bot.) ufed erroneouly for Pyrgofia, from rúpros, a tower; alluding to the clufters of flowers; a genus of Crafulacea.

Tu'rio (Bot.) Lat. a young thoot.

Turiona'na (Ent.) turio, a hoot; alluding to the habit of the larva, which attacks the hoots of fir-trees.

Turkey (Ornith.) the name of this domeftic bird has no comnertion with the Turkifh dominions, fince it was firft brought from America, and is an infance of arbitrary localization. Turkeys were formerly, from a limilar error in France, called poulets d'Inde, or coqs d'Inde: the fcientific name is Meleagris Galloparo.

Turkey-Buz'zard (Ornith.) the Catharifa Aur; alfo called the Carrion Vulture. 
Tar'meric (Bot.) procured from the rhizome of Curcuma longa.

rurnep or Turnip (Bot.) the nep, (Anglo-Sax.nope; Lat. napus,) which is as round as if turned in a lathe; the Braffica Rapa.

Tu'rnera (Bot.) P. N. in honour of William Turner, M.D., who lived in the reign of Edward VI., and was the author of our earlieft Herbal. I- we was Prebendary of York, Canon of Windfor, and Dean of Wells; typical genus of Turneraceæ.

Turpin'ia (Bot.) P. N. in honour of M. Turpin, a French botanical artift; a gerus of Celaftracere.

Turræ'a (Bot.) P. N. in honour of Giorgio Turra, Profeftor of Botany at Padus; a genus of Meliacex.

rur'ris (Zool.) Lat. a tower, Irom its caltellated form; a genus of Acalephæ or Sea.Nettles.

Purni'tis (Bot.) turris, a tower, from its pyramidal growth; a genus of Cruciferz.

Tur'tle (Ornith.) Lat. turtur; Anglo-Sax. turtle; Dutch, tortel ; Fr.tourterelle: the Turtle or Turtle-dove is Turtur Auritus.

Tur'tle (Zool.) this name feems to have been firft applied to the featortoifes (Cheloniidæ) in America, probably as a nautical term of afrection.

Tuxtur (Ornith.) Lat. the Turtle-dove.

Tusaila'go (Bot.) tufis, a cough; from its medical qualities; Coltsfoot; a genus of Compofitæ.

Tut'san (Bot.) from its French name, La toute faine, the leaves having been formerly applied to frefh wounds; the Hypericum Androfamum.

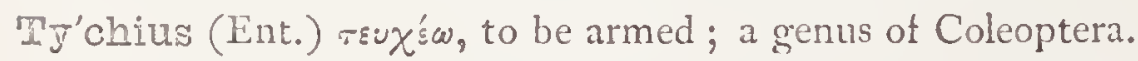

Ty'chus (Ent.) fame derivation; a genus of Coleoptera.

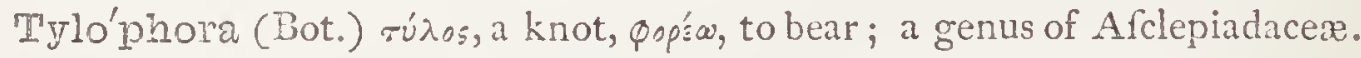

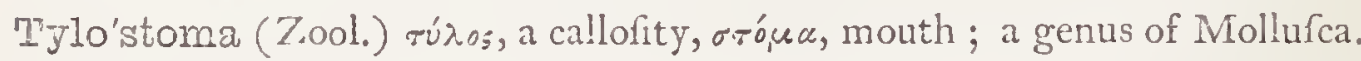
Tym'panis (Bot.) rúkravov, a drum; from the refemblance of the young velum; a genus of Fungi.

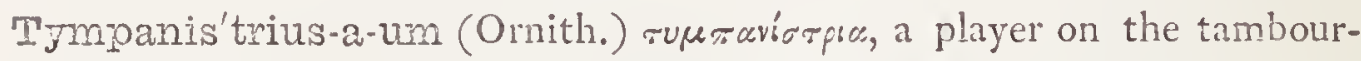
ine; fpec. name of Periftera tympanifria, the Tambourine Ground -dove' from refemblance of the cry of the male to the found of a tambourine.

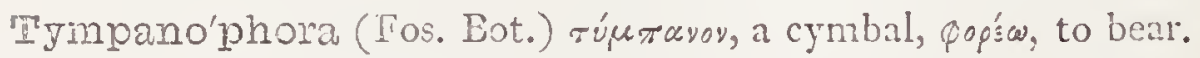

IJm'panum (Zool. Bot.) Lat. a drum; in Botany the veil which covers the thece of urn-molies.

Ty'pha (Bot.) rípos, a marh, from its habitation : Reed-maca, Cat's-tail, or Club-ruhn; a genus of "Iyphacuit. 
Typhæ'a (Ent.) $\tau \tilde{u} \varphi \circ$, ftupor, on account of their feigning death; a genus of Coleoptera.

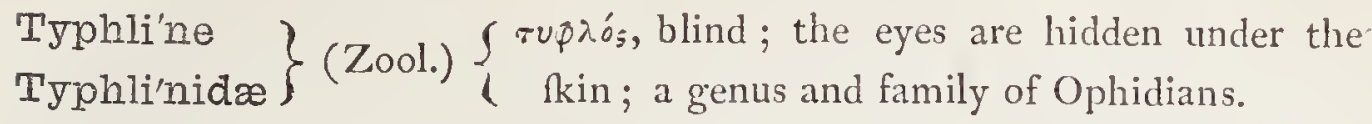

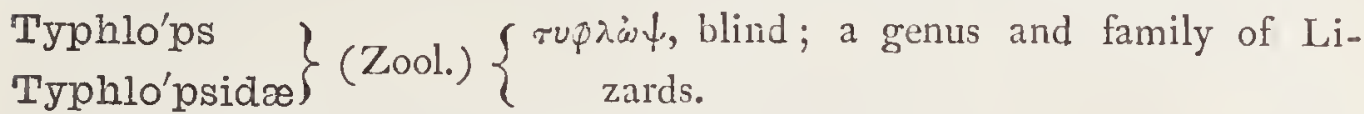
Ty'phlus (Zool.) ruфjós, blind; applied to a mole.

Typhœ'us (Ent.) rūpos, ftupor; on account of their feigning death; a genus of Coleoptera.

Ty'phula (Bot.) dimin. of Typha; from the heads refembling this (the bull-rufh) in miniature; a genus of Fungi.

$\left.\begin{array}{l}\text { Tyranni'næ } \\ \text { Tyran'nus }\end{array}\right\}$ (Ornith.) $\left\{\begin{array}{c}\text { tyrannus, a defpot or tyrant; the Tyrant } \\ \text { Shrikes; a fub-family and genus of Inceflores. }\end{array}\right.$

Udarna (Ent.) udus, contracted from uvidus, wet, damp.

Uddmannia'na (Ent.) P. N. in honour of $I s$. Uddmann, a naturalif of the laft century, whofe "Differtations" are alluded to by Linnwus.

Udo'ra (Bot.) idwp, water; it is generally found in canals; a genus of Hydrocharidacex.

Ufea'lis (Ent.) iф̣áw, to weave.

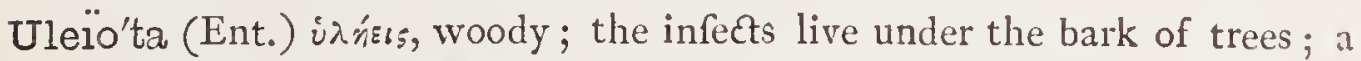
genus of Coleoptera.

U'lex (Bot.) Lat. furze; Furze; a genus of Leguminofr.

Ulica'na (Ent.) ulex, furze, gorfe, upon which the infect feeds.

Ulicolel'la (Ent.) ulex, a furze-buh, colere, to frequent; referring to the food-plant of the infect.

Uligino'sus-a-um (Ent., Bot.) Lat. damp, marfhy.

Ullo'a (But.) P. N. in honour of Antonio Ulloa, a Spanifh naturalint; a genus of Solanacex.

Ulma'ta (Ent.) feeds on elm (ulmus campeitris).

Ulma'ces (Bot.) the Nat. Ord. of plants of which Utmus is the type;

Elm-worts.

Ulmus (Bot.) Lat. an elm ; the Flm; typical gonus of Ulmacer.

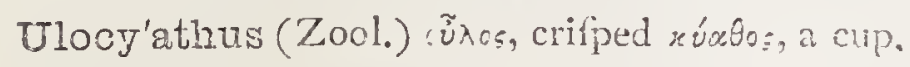

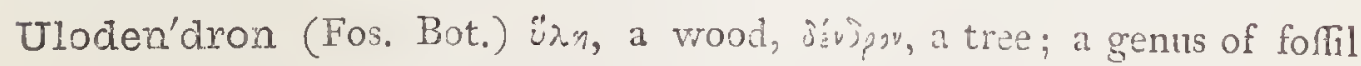
coal meafure tree-ftems.

Ulo'ma (Ent.) oũरos, corn, becaufe found in meal; a genus of Coleoptera.

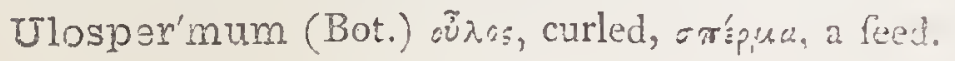


Ulo'ta (Bot.) ìn, wood or forent, its ufual habitat being on trees; a genus of Mufci.

U'lothrix (Bot) ¿ũros, twifted, $\theta$ ph hair ; a genus of Confervoid Algæ. J'lulus.a-um (Ornith.) ululo, to howl; howling; e.g. Sumia ulula, the Screech-owl.

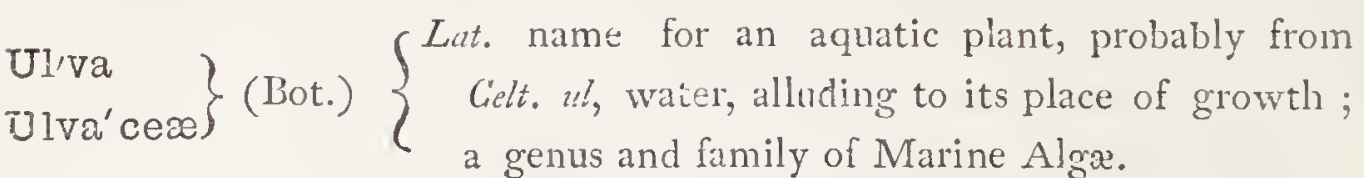

Umbel (Bot.) umbella, a parafol or umbrella; a form of inforefcence.

Umbelli'feræe (Bô.) the natural order of plants in which the form of inflorefcence is that of Umbel.

TTmbilica'ria (Bot.) umbilicus, a navel, from the peltate frond or thallus; a genus of Gymnocarpous Lichenes.

Umbilicus (Bot.) Lat. the navel; it is hollow-leaved; a genus of Graftulaceæ.

Umbo ( $/$ ool.) Lat. a bofs; the apex of the wholl-haped fhells.

Umbona'tus-a-um (Bot.) umbo, a bofs; round, with a projecting point in the centre, like the bofs of an ancient fhield.

Umbraculi'ferus-a-um (Bot.) umbraculum, anything that furnithes fhade, fero, to bear; fpecific name of the Talipot palm, Corypha umbraculifera.

Umbra'tica (Ent.) Lat. in the Thade, retired from the world. The larva hides by day under the lower leaves of Sow-thittles.

Umbri'na (Ichth.) umbra, the thade; appearing like a cloud in the water; a genus of Sciænoid Filhes.

Umbro'sus-a-um (Boi.) Lat. Thady, e.g. Saxifraga umbrofa.

Unangula tus-a-um (Ent.) unis, one, angitus, an angle.

Un'ca (Ent.) uncus, a hook; from the hook-like marks on the forewings.

Unca'ria (Bot.) uncus, a hook ; the "Grapple-plant" of South Africa ; a genus of Pedaliacere.

Uncina'tus-a-um (Ornith.) Lat. barbed, furnihed with hooks, $e$. $g$. Cymindis uncinatus, the Crook-billed faicon.

Inci'nia (Bot.) uncimus, a hook; the awn being hooked; a genus of Gramina. Uncíola (Zool.) dim. of zmcus, a hook; a genus of Crultacea.

Unda'tus-a-um (Ornith., Ent.) Lat., waved; having wave-like markings; e. g., Sylvia undata, the White-throat.

Undula'tus-a-um (Ornith., Ent.) Lnt. marked as with waves, e. gr.

Melopfittacus undulatus.

Unga'lia (Zool.) ungo, to befmear; a genus of Ophidians. Jngui'culus-a-um (Nnt.) dim. of unguis, a claw ; clawed. 
Unguifo'rmis (Zool.) Iat. claw flaped.

Uni'solor (Ornith.) Lat. all of a fingle colour.

U'nicorn (Zool.) unus, one, cormu, horn.

Unifascia'tus-a-um (Ent.) unus, one, fofcia, a band; having a fingle band or ftripe.

Uniloculi'na (Zool.) unus, one, loculus, a compartment; a genus of Foraminifera.

Unimacula'tus-a-um (Z.ool.) umıs, one, macula, a pot; fingle-ipotted.

U'nio (Zool.) Lat. a pearl; a genus of Mollufca.

Uniola (Bot.) umus, one, alone; having united glumes; a genus of Gramiua.

Unisulca'tus-a um (Zool.) Lat. one-grooved.

Upe'neus (Ichth.) isinn, the beard; a bearded filh, allied to the Mullets.

U'pupa (Ornith.) Lat. the honpoo; a word uted by Pliny; the Hoopoe.

Uralen'sis-e (Omith., Boi.) Lat. belonging to the Uralean mountains, e.g. Anragahns Uraler:iss.

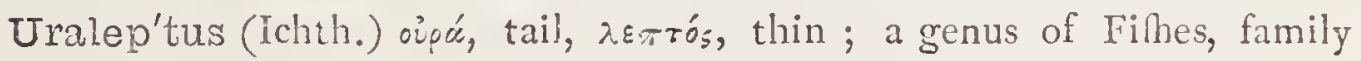
Gadidx.

Ura'nia (Bot.) oupóvro;, sublime, from its fatelinefs; a genus of Mufaceie.

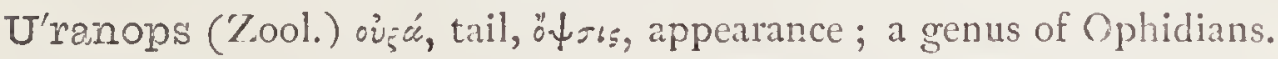

Urano'scopus (Ichth.) ouprovoromos, that contemplates the firy; fo-called from the poljtion of the eye, which it turns upwards in fwimming; a genus of Percoid Fines.

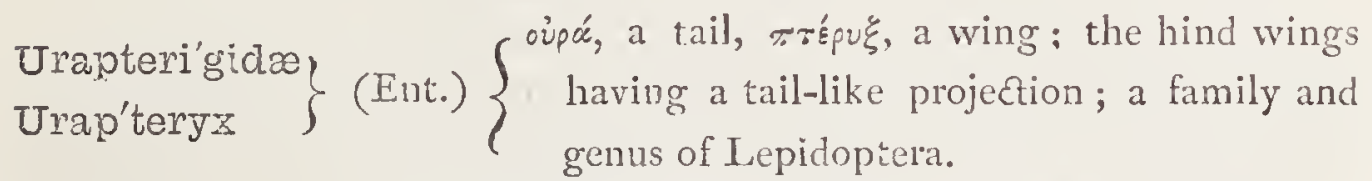

U'raster (7,ool.) oúpú, a tail, ¿́rt'inp, a ftar; the Cross-fin, one of the Seaftars.

Ur'bicus-a-um (Ornith., Pot.) Isa . of the ciry; e.g. Chelidon urbica, the Houfe Martin, Chenopodium wúvirn.

Urce'ola (Bot.) arceolus, a little pitcher, from the form of the corolla; a genus of Apocynaceæ.

Urceola'ria (Bot.) urceolus, a little pitcher; fiom the hollowed form of the apothecia; a genus of Gytumocurpous Lichenes.

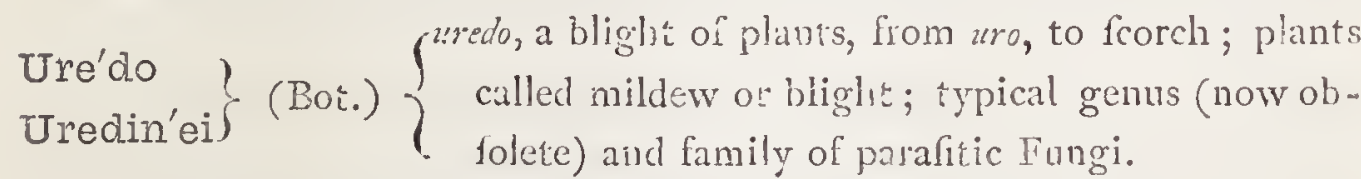
Ure'na (Bot.) uren, its name in Malabar; a genus of Malvacex. U'rens (Bot.) Lat. biting; burning; e.g. Caryota urens. 
Uro'chroa (Ornith.) ovpé, tail xpóce, colour; a genus of Humming-birds. Urococ'cus (Bot.) oúpú, tail, xó»»os, berry; from the peduncular procefles on the cells; a genus of Confervoid Algx.

Urocon'ger (Ichth.) cupú, a tail, conger, a kind of fifh callcd by fome a conger-eel, to which this genus is allied.

Urogal'lus (Ornith.) ougos, mountain, gallus, a cock; fpecific name of the Capercailzie.

Urogle'na (Bot.) oupre, tail, yr.ńnn, cavity (cell), from the bafal prolongation; a genus of Confervoid Algre.

Uro'lepis (Ent.) oupá, a tail, $\lambda \varepsilon \% i \xi$, a fcale.

Urolep'tus ('Kool.) oupú, tail, $\lambda \varepsilon \pi \tau^{\prime} o_{s}$, thin; a genus of Infuforia.

Uromas'tix ('Lool.) oúpú, tảil, $\mu a ́ \sigma \tau b \xi$, a whip; a genus of Saurians, family Agamidæ.

Urone'ma (Zoo!.) oúfá, tail, iñu, filament; a genus of Infuforia.

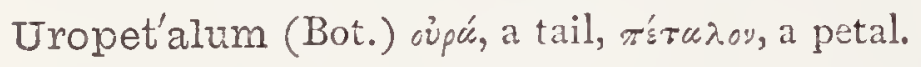

Uropy'gium (Ornith.) cúó, tail, zuy'n, rump; the extremity of the body of birds, which fuftains the tail.

Uro'plates (Zool.) oúú, a tail, $\pi \lambda$ curv́s, broad; a genus of Reptiles.

Urophasiæ'nus (Ornith.) oĩpos, mountain, fluafianus, pheafant; fpecific name of the Cock of the Plains.

Uro'psophus (Zool.) ov̉zá, a tail, łópos, a noife; a genus of Rattlefnakes.

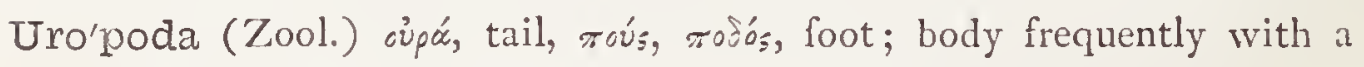
caducous anal peduncle; a genus of Arachnida.

Uropra'stix (Zool.) oúpá, tail, tpúsøw, to work; a genus of Reptilia.

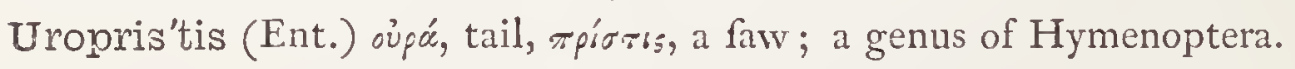

Uroskin'nera (Bot.) P. N. given in honour of Mr. Ure Skinner, a London merchant, by Dr. Lindley, who thus apologizes:- "We therefore truft that verbal pedants will not quarrel with the manner we have contrived to efcape from the difficulty of there being already a Skinnera in the Botanical field, but agree with us, that Ure Skinner may be fairly blended into a name which fhall unmiftakably record the labours of one who ought to compete with any other Skinner whatever."

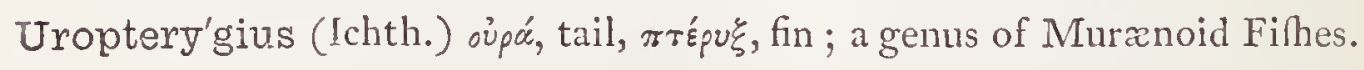
Urostic'te (Ornith.) oupú, a tail, orıxтos, dappled; a genus of Hummingbirds.

$\left.\begin{array}{l}\text { Ur'sidæ } \\ \text { Ur'sina }\end{array}\right\}$ (Zool.) $\left\{\begin{array}{l}\text { a family and fub-family of Mammalia, of which Urfus } \\ \text { is the type ; the Bear family. }\end{array}\right.$ Ursi'nus-a-um (Bot.) Lat. bear-like, hairy; e.g. Allium urfimm.

U'rsus (Zool.) Lat. a bear; a genus of Mammalia. 
Urti'ca (Boti) Lat. a nettle, from uro, to burn, from its ftinging qualities; the Nettle; typical genus of Urticacex.

Urtica'lis (Ent.) feeds on the nettle (urtica).

U'rus (Zool.) Lat. a wild bull; the animal mentioned under this name by Cæfar was the Bos Bifon of Linnæus, Bifon Bonaflus of Dr. J. E. Gray, Bifon prifcus of Owen.

Urvil'lea (Bot.) P. N. in honour of $D$. d'Uroille, a French navigator and botanift; a genus of Sapindacex.

Us'nea (Bot.) Arab. âchneh, or âithen (axneeh, or ufnee, according to Dillenius), the name of fome tree-lichen; a genus of Gymnocarpous Lichenes.

$\left.\begin{array}{l}\text { Ustila'go } \\ \text { Ustilagi'nei }\end{array}\right\}$ (Bot.) $\left\{\begin{array}{l}u f f u s, \text { fcorched, from its appearance; a genus and } \\ \text { family of parafitic Fungi, which produce the } \\ \text { difeafe called fmut in corn and other gramina. }\end{array}\right.$ Ustomacula'na (Ent.) uffus, burnt, macula, a fpot.

Ustula'tus (Ent.) Lat. fcolched; e.g. Othius ufulatus.

Utricula'ria (Bot.) utriculus, a little bottle; from the form of the roots; Bladder-wort; a genus of Lentibulariacer.

Utri'culus (Bot.) Lat. a little bottle; a one-celled fruit, originating from a carpel, as in Chenopodium.

Uva'ria (Bot.) uva, a clufter of grapes; its fruit grows in bunches, like grapes; a genus of Anonacex.

Uvigeri'na (Zool.) uva, a clufter or bunch, gero, to carry; a genus of Foraminifera.

Uvel'la (Zool.) dim. of uva, a bunch of grapes; from the aggregating: together of individual monads fo as to form a grape or mulberry-like mafs; a genus of Infuforia.

Uvula'ria (Bot.) formerly ufed in difeafes of the uvula; a genus of Melanthacex.

Vaccin'ium (Bot.) an ancient Latin name, perhaps from bacca, a berry; Whortle-berry; typical genus of Vacciniacex. "The Vaccinia of the ancients were not fruits, but fome kind of flowers, poffibly hyacinths, fince a line in Virgil, which includes the name Vaccinium, is an adaptation of one in Theocritus, where the hyacinth is manifertly the flower intended."-(Eclog. ii. I 8 ; Idyll. x. 28.) There is alfo the paftage in Claudian-

"Sanguineo fplendore rofas, vaccinia nigren

Induit, et dulci violas ferigine pingit." 
"This likewife would feem to point to the hyacinth, or, if not to that, at leaft to fome dark-complexioned flower."-_Grindon's Britilh and Garden Botany."

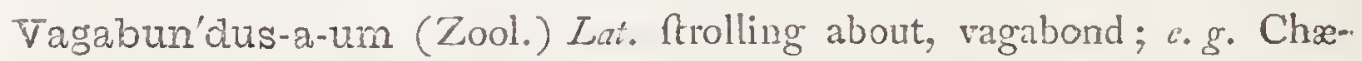
codon vagabundus.

Va'gans (Ent., Bot.) Lal. wandering, rambling; e.g. Erica vagans.

Vagini'cola (Zool.) vagina, a Meath, colo, to inhabit; a genus of Infuforia.

Vaginuli'na (Zool.) dim. of vagina, a meath; a genus of Foraminifera.

Valan'tia (Eot.) P. N. in honour of Sebaftian Vaillunt, a French botanif;

a geuns of Stellatx.

Valex'ia.(Enc.) P. N., the name of a celebrated family in arcient Roman hiftory; a gemus of Lepidoptera.

Va'lgus (Ent.) Lat. bow-legged; a genus of Coleoptera.

Valeria'na (Boi.) valere, to be in health; or Valerius, a king? this was probably the fpikenard of the ancients. 'The root is fill ufed as a perfume in India.

Valla'ris (Bot.) vallo, to enclofe; it is ufed for fences in Java; a genus of Apocynacex.

Valle'sia (Bot.) P. N. in honour of F. Tallefo, phyfician to Philip II, of Spain; a genus of Apocynacer.

Valli'gera (Ent.) vallum, a palifade, gevere, to carry; from the form of the markings.

Valisne'ria (Bot.) P. N. in honour of Antonio Valifneri, an Italian botanift; a genus of Hydrocharidaces.

Valke'ria (Zool.) P. N. in honour of Dr. Walker, a former profelior in Edinburgh ; a genus of Polyzoa.

Vallo'ta (Bot.) P. N. in honour of Pierre Vallot, a French botanin; a genus of Amaryllidacex.

Talvulina (Zool.) dim. of rabur, a valve; its allufion to the valvular operculum; a genus of Foraminifera.

Vampi'rus (Zool.) Fr. vampire; Ital. and Span.vampiro; Dutch and Germ. rampir; the Vampire Eat; a genus of Mammalia, order Cheiroptera.

Van'da (Bot.) Hindoo name of the original fpreies; a genus of Orchidacer. Vandel'lia (Bot.) P.N. in honour of Dr. Louis Vindelli, Profeflor of Botany at Coimbra, Portugal; a genus of Scrophulariacer.

Vanes'sa (Ent.) "probably from Swift's poem of Cadenus and Vanefar, in which the Dean (Decanus) tells the ftory of lis love for Enther (E/a) I anhombrugh. Sodofiky propofes Phaneffa, from Фúvns, a Neo- 
Platonic name of the God of Love;" (Acc. Lift of Brit. Lepid.;) a genus of Lepidoptera.

Vanguie'ra (Bot.) voa-vangruier, its Madagafcar name; a genus of Rubiaceæ. Vanil'la (Bot.) Span. vaynilla, a little knife or fciffor-cafe, the fruit being long and cylindrical, and like the theath of a knife; a genus of Orchidacex.

Vara'nidæ)

Vara'nus $\}$ (Zool.) unexplained; a family and genus of Lizards.

Varia'îilis (Ornith., Bot.) Lat. changeable, uncertain.

Varia'tus-a-um (Ent.) Lat. changeable, varied.

Varico'rnes (Ent.) varius, diverfified, cornu, horn (antennx); one of Stephen's fections of Coleoptera.

Variega'tus-a-um (Zool, Ent.) Lat. variegated, of different forts or colours. Variola'ria (Bot.) variola, meafles; from the eruptive afpect of the fructification; a genus of Lichenes.

Va'rius-a-um (Zool., Eot.) Lat. variegated, fpotted, party-coloured; e. g. Lupinus varius.

Varro'nia (Bot.) P. N. in honour of $M . T$. Varro, a celebrated Roman, A.c. I $6:$ a genus of Cordiacex.

Vasco'a (Bot.) P. N. in honour of Vafco de Gama, a celebrated Portuguefe circumnavigator, who died in 1525 ; a genus of Leguminofx.

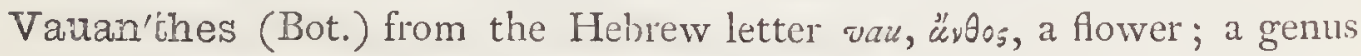
of Craftulacex.

Vauche'ria (Bot.) P. N. in honour of the Rev. M. Vaucher, of Geneva, anthor of "Conferves d'eau douce;" a genus of Confervoid Algx.

Vesorda'lis (Ent.) recors, filly, foolifh.

Vegetable Ivory (Bot.) applied to the bony albumen of the feeds of the palm called Phyrelephas macrocarpa.

Ve'leda (Ent.) P. N., a Geiman virgn!n who received divine honours from her countrymen; applied to a fpecies of fpider.

Vele'zia (Boí.) P. N. in hourour of G. Velez, phyfician and botanift at Madrid; a genus of Caryophyllacex.

Vel'la (Bot.) Latinized from velar, the Celtic name of the crefs; a genus of Cruciferæ.

Velle'ja (Bot.) P. N. in honour of Major Velley, who was fkilled in Algæa; a genus of Goodeniaceæ.

Velleius (Ent.) etymology uncertain; a genus of Coleoptera.

Velocel'la (Ent.) dim. of welox, fwift.

Ve'lox (Zool.) Lat. fwift; fwift-Aying. 
Velthei'mia (Bot.) P. N. in honour of F. A. de Veltheim, a German botanift; a genus of Liliacex.

Vena'ticus-a-um (Zool.) Lat. belonging to or ufed for hunting.

Veneni'flua (Bot.) fpecific name of a 'Tanghinia which produces the ordeal poifon of Madagafcar ; from venenum, poifon, fluo, to flow.

Veni'dium (Bot.) etymology unknown; a genus of Compolitæ.

Veni'lia (Ent.) P. N., a nymph, the mother of Turnus.-VIRG. Fn. x. 76 ; a genus of Lepidoptera.

Veno'sus-a-um (Ent., Bot.) Lat. veiny.

Ventila'go (Bot.) ventilo, to be expofed to the wind, ago, to drive away;

in allufion to the fruit being winged, and fcattered by the wind; a genus of Rhamnacex.

Venu'sia (Ent.) the name of a town in Italy, the birthplace of the poet Horace; a genus of Lepidoptera.

Venus'tus-a-um (Bot.) Lat. graceful, charming, e.g. Pentftemon venuftum. Vera'trum (Bot.) vere, truly, ater, black; referring to the colour of the roots; Hellebore; a genus of Melanthacex.

Verbasca'lis (Ent.) feeds on the mullein (verbafcum).

Verbas'cum (Bot.) ancient name of a plant, probably mullein; Mullein;

a genus of Scrophulariacex.

Verbe'na (Bot.) quafi Herbena, vervain, which is probably from Celtic ferfuen. The word originally denoted all herbs that were held facred on account of their being employed in the rites of facrifice :-

"Verbenasque adole pinglies, et mafcula thura."-VIRG. Eclog. viii.

"Ara caftis vincta Verbenis."-Hor. Od. I I, Lib. iv.

Verbesi'na (Bot.) altered from verbena; a genus of Compofitæ.

Verguli'na (Zool.) vergula, a little wand; a genus of Foraminifera.

Veretil'lew (Zool.) the Sea-pens, of which Veretillum is the type.

Veretil'lum (Zool.) veretilla, penis; a genus of Sea Pens.

Vermical'1a (Zool.) vermis, a worm, «á $\lambda \lambda$. s, beauty; a genus of Colubrine ophidians.

Vermicula'ria (Bot.) vermiculus, a little worm; from the arrangement of the feeds; a genus of Fungi.

Vermi'vorus-a-um (Ornith.) vermis, a worm, vorare, to devour ; e. $g$.

Mniotilta vermivora.

Verna'ria (Ent.) verms, appearing in the fpring.

Verna'tio (Bot.) ver, Spring; vermation is applied like prefoliation or gemmation, to the arrangement of the leaves in the bud.

Verni'cia (Bot.) Low L.utiu, vernix, varnilh; yields an oil ufeful for painting. 
Verno'nia (Bot.) P. N. in honour of William Vernon, a botanift and traveller in North America; a genus of Compofitæ.

Verneuili'na (Zool.) P. N. in honour of M. Vineuil, a celebrated French geologift; a genus of Foraminifera.

Vero'nica (Bot.) from Arabic viroo nikoo, beautiful remembrance; Speedwell; a genus of Scrophulariacer.

Ver'pa (Bot.) a Latin word fynonymous with phallus; a genus of Fungi.

$\left.\begin{array}{l}\text { Verru'ca } \\ \text { Verru'cidæ }\end{array}\right\}$ (Zool.) Lat. a wart; a genus and family of Cirripedes.

Verruca'ria (Bot.) verruca, a wart ; the plant is fo called from the wart.

like procefles of the fhields; a genus of Lichenes. The ancients applied the name to fome plant which removed warts.

Verruca'tus-a-um (Bot.) verruca, a wart ; warty.

Verruco'sus-a-um (Bot.) Lat. warty; e.g. Pforalea verrucofa.

Versi'color (Bot.) Lat. many-coloured; e.g. Crocus verficolor.

Versu'tus-a-um (Ent.) Lat. cunning.

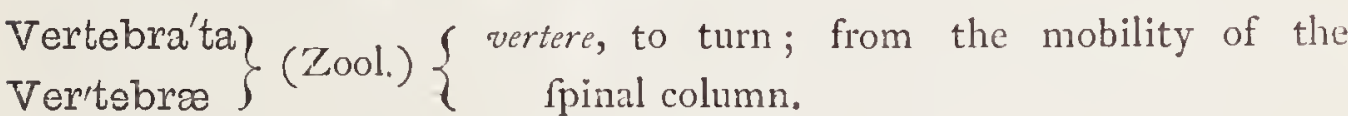

Vertebrali'na (Zool.) from the compant vertebra-like, unforaminated texture of the Thell; a genus of Foraminifera.

Verticilla'tus-a um (Zool.) verticillus, a whorl; having whorls.

Verticil'ium (Bot.) verticillus, a whorl; from the verticillate arrangement of the fporiferous branches; a genus of Fungi, family Mucedinex.

Ver'vain (Bot.) Celtic, ferfaen ; Fr., verveine; Latin, verbena; q..

Vesica'ria (Bot.) vefica, a bladder; from its inflated flicles; a genus of

Crucifera.

$\left.\begin{array}{l}\text { Vesicula'ria } \\ \text { Vesiculariadæs }\end{array}\right\}$ (Zool.) $\left\{\begin{array}{c}\text { veficula, dim. of vefica, a bladder; a genus } \\ \text { and family of Polyzoa. }\end{array}\right.$ Ves'pa (Ent.) Lat. a wafp; a genus of Hymenoptera. Vesperti'lio $\left.\begin{array}{l}\text { Vespertilion'idæe }\end{array}\right\}$ (Zool.) $\left\{\begin{array}{l}\text { time of appearance; a genus and family } \\ \text { of Mammalia, family Cheiroptera. }\end{array}\right.$ Lat. a bat; from vesper, the evening, its

Ves'pidæe (Ent.) vefpa, fam. term. ide; a family of Hymenoptera, of which $V e f p a$ is the type; the Wafp family.

Ves'tia (Bot.) P. N. in honour of Dr. Veft, of Clagenfurth; a genus of Solanaceæ.

Vesti'tus-a-um (Zool., Bot.) Lat. clothed; e. g. Erica veftita.

Vetch (Bot.) Latin, vicia; Ital. veccia; Fr. vefce.

Vet'ula (Ichth.) Lat. an old wife; the filh called the Sea-wife. 
Vexilla'rius (Ornith.) Lat. a ftandard-bearer; e.g. Caprimulgus vexillarius, which has flag-like expanfions of the wings.

$\mathrm{V}$-fla'va (Ent.) farous, yellow; the marks taking the form of the letter $\mathrm{V}$. Vibicel'la (Ent.) vibex, a fcar, or the mark of a fripe.

Vibor'gia (Bot.) P. N. in honour of Eric Viborg, a Danifh botanift; a genus of Leguminofie.

Vibra'na (Ent.) vibro, to move rapidly, to fet in tremulous motion.

Vi'brio $\}$ (Zool.) $\{$ vibro, to thake; from the undulatory ferpent-like Vibrio'nia\} (Zool.) $\{$ motions; a genus and family of Infuforia.

Vibu'rnum (Bot.) this old name for a plant is probably from vieo, to bind up as with twigs; Viburnum Lantana is faid to have been the plant called Viburnum by VIrgr, Eclog. i. 26.

Vícia (Bot.) Lat. a vetch; a genus of Leguminofie.

Vid'ua (Ornith.) Latinized form of the name of the Whydah-bird, which has led to the natural corrupition of the Widow-bird.

Vidua'ria (Ent.) viduzs, widowed; the wings, white fprinkled with black, appear to be in mourning.

Vieusseu'xia (Bot.) P. N. in honour of $M$. Vieufeux, a phyfician at Geneva; a genus of Iridacex.

Vi'gilax (Ent.) Lat. watchful.

Vigin'tipuncta'tus (Ent.) virinti, twenty, pinctatus, fpotted.

Vigma (Bot.) P. N. in honour of Dominic Vigna, a commentator on Theophrafus ; a genus of Leguminofæe.

Viguie'ra (Bot.) P. N. in honour of L. G. A. Viguier, of Montpelier, botanift; a genus of Compofite.

Villar'sia (Bot.) P. N. in honour of Villars, a diftinguifhed French botanift; a genus of Gentianacer.

Villare'sia (Bot.) P. N., a genus of Aquifoliaceæ.

Villi (Zool, Bot.) pl. of villus, a tuft of hair; in Zoology, minute folds of mucous membrane of the fmall intefines; in Botany, foft, flender filaments.

Tilmorin'ia (Bot.) P. N. in honour of M. Vilmorin, member of the Agri.. cultural Society of Paris; a genus of Leguminofr.

Vimena'ria (Bot.) vimen, a twig, in reference to the naked twig-like appearance of the plant; a genus of Leguminoiæ.

Vimina'lis-e (Ent.) Lat. pertaining to or living amongft ofiers.

Vimina'ta (Ent.) Lat. vimen, an ofier.

Vin'ca (Bot.) Lat. the plant periwinkle; Periwinkle; a genus of Apocynacese. 
Vin'ula (Ent.) vinum, wine; Linnæus defcribes the larva as "e rima fub capite humorem acrem expellens."

Vi'ola (Bot.) fabled to have fprung up for food for $Y_{0}$, who was changed into a cow by Jupiter: the Viola of the ancients was a kind of Iris; typical genus of Violacex.

Viola'ceus-a-um (Zool., Bot.) Lat. violet.coloured, purple; e.g. Mituphaga violucea.

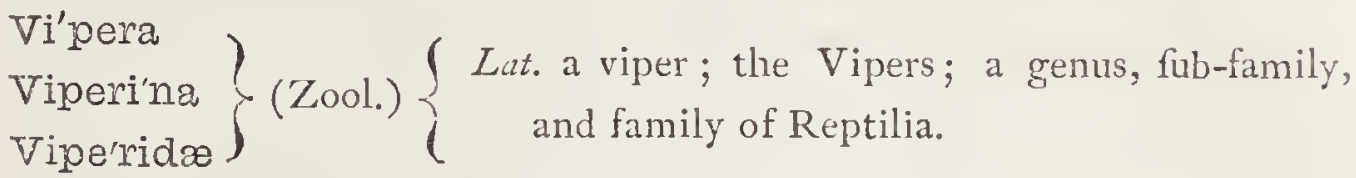

Vi'rens (Ichth., Bot.) Lat. ftrong-growing; e. g. Crepis virens.

Vireta'ta (Ent.) viretum, green-fward, turf.

Virgi'lia (Bot.) P. N., given by Lamarck, in honour of the poet Virgil; ir genus of Leguminofie.

Virgula'ria (Zool.) virgula, a little rod, dim. from virga; a genus of 7oophytes.

Virguli'na (Zool.) virgula, a wand; a genus of Foraminifera.

Vlrgulto'sus.a-um (Bot.) virgultum, a buh ; buhy, fhrubby, e. g. Myrtus virgultofa.

Viricla'ta (Ent.) viridis, green.

Vir'idis-e (Zool., Bot.) Lat. green, e.g. Helleborus vividis.

Viscerella (Ent.) vifcera, the entrails; from the gut-like appearance of its mine in elm luaves.

Visci'vorus-a-um (Ornith.) vifcum, miftletoe, voro, to eat.

Vis'cum (Bot.) Lat. the miftletoe, from vifus, clammy, from the nature of

the berries; Miftletoe; a genus of Loranthaceæ.

Vismia (Bot.) P. N. in honour of $M$. de Vifme, a Lifon merchant; a genus of Hypericaceæ.

Vital'ba (Bot.) vitis alba, white vine; the Wild Clematis.

Vitalba'ta (Ent.) taken on the wild clematis, (Clematis vitalba.)

Vi'tex (Bot.) rieo, to bind, from its flexible twigs; a genus of Verbenacez. Vi'tis (Bot.) Lat a vine; the Vine-plant; typical genus of Vitacex.

Vitman'nia (Bot.) P. N. in honour of F. Vitmann, Profeflor at Milan, I 792 ; a genus of Rhamnacex.

Vitri'na (Zool.) vitrim, glafs; the fhells are flender, thin, and transparent; a genus of Mollufca.

Vit'tre (Bot.) pl. of vitta, a fillet or band; applied to imperfect fepta in the valves of Diatoms, and to the refervoiss of fpecial fecretion (chiefly oily) in certain fruits. 
Vitta'ria (Bot.) vitta, a riband; from the hape of the narrow fronds; a genus of Polypodioid Filices.

Vitta'tus-a-um (Ent., Bot.) Lat. dreffed with ribbons; as fpec. name for Amaryllis vittata, it alludes to the gay ftriped appearance of the flowers.

Vittel'la (Ent.) vitta, a band.

Vituli'nus-a-um (Zool.) Lat. calf-like, e.g. Phoca vitulina, the Seal.

$\left.\begin{array}{l}\text { Viver'ra } \\ \text { Viverri'na }\end{array}\right\}$ (Zool.) $\left\{\begin{array}{l}\text { viverra, a ferret; the Ferrets; a genus and fub. } \\ \text { family of Mammalia. }\end{array}\right.$

Voandzei'a (Bot.) voandzon, its name in Madagafcar; a genus of Leguminofx.

Vochy'sia (Bot.) the original name of the Caribes; typical genus of Vochyaceæ.

Volkame'ria P. N. in honour of 7 . G. Volkamer, a German botanift; a genus of Leguminofe.

Voi'tia (Bot.) P. N., a genus of Mufci.

Voliman'nia (Fos. Bot.) P. N. in honour of Volkmann; a provifional genus of coal-meafure ftems.

Vol'tzia (Fos. Bot.) P. N. in honour of Voltz, of Strafburg; a genus of fortil Coniferous plants.

Volute'lla (Bot.) dim. of volutus, rolled; a genus of Fungi.

Volu'tus-a-um (Bot.) Lat. rolled.

Volva'ria (Zool., Bot.) volva, a wrapper, from volvo, to roll; a genus of Gafteropod Mollufca ; in Botany, a genus of Fungi.

Volvoci'nex (Bot.) a family of Confervoid Algx, of which Volvox is the typical genus.

Vo'lvox (Bot.) volvere, to turn; from the rolling motion which it derives from the innumerable cilia ; a genus of Confervoid Algr.

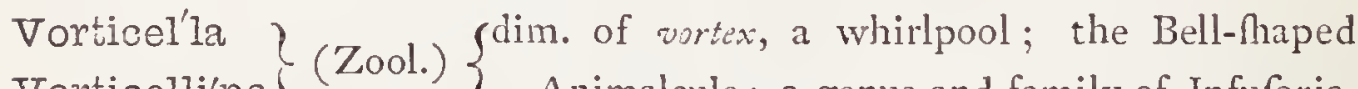
Vorticelli'nas (Zool.) $\{$ Animalcule; a genus and family of Infuforia. Vrie'sia (Bot.) P. N. in honour of Dr. W. de Vriefe, Profefior of Botany at Leyden; a genus of Bromeliacer.

Vulga'ris-e (Zool., Bot.) Lat. common, ordinary, e. g. Polypodium vuloare. Vulnera'rius-a-um (Bot.) vulnus, a wound; wound-healing, e.g. Anthyllis vulneraria.

Vul'pes (Zool.) Lat. a fox; a genus of Mammalia, "family Canina. Vulpi'nus-a-um (Zool.) Lat. crafty, ny, fox-like.

Vul'tur (Ornith.) Lat. a vulture; a genus of the Nat. Ord. Accipitres, family Vulturidæ. 
Vulvuli'na (Zool.) vulmula, a little matrix or womb; a genus of Fora.. minifera.

Wachendor'fia (Bot.) P. N. in honour of E. F. Wachendorf, a Dutch botanift; a genus of Hæmodoraceæ.

Wæberia'na (Ent.) P. N. in honour of Baron de Waber, formerly one of the Therefian Profeffors at Vienna.

Wahlenber'gia (Bot.) P. N. in honour of G. Wahlenberg, M.D., author of "Flora Lapponica;" a genus of Campanulacex.

$\mathrm{W}$-al'bum (Ent.) fo called on account of the white $\mathrm{W}$ on the under wings, (albus, white.)

Wal'chia (Fos, Bot.) P. N., a genus of foffil coniferous plants.

Walckenäera (Ent.) P. N in honour of $M$. Walckenäer, a diftinguifhed French naturalift lately deceafed.

Waldstei'nia (Bot.) P. N. in honour of Francis von Waldfein, a German botanift; a genus of Rofacex.

Walke'ra (Bot.) P. N. in honour of Richard Walker, founder of the botanic gardens at Cambridge, a genus of Ochnace:

Walli'chia (Bot.) P. N. in honour of Nathaniel Wallich, M.D., formerly Superintendent of the botanical gardens at Calcutta; a genus of Cinchonacer, and alfo of Palmacer.

Wallro'thia (Bot.) P. N. in honour of F. Wallroth, M.D., a German botanift; a genus of Umbelliferæ.

Walsu'ra (Bot.) conftructed from zuallurfi, its Telinga name; a genus or Meliaceæ.

Wal'nut (Bot.) Anglo-Sax. wualch linut, foreign nut, as in German zülfche $n u f_{s}$; fruit of the Juglans regia.

Wal'rus (Zool.) this Norwegian word fignifies literally "whale horfe"; the Trichecus Rofmarus.

Walthe'ria (Bot.) P. N. in honour of $A$. $F$. Walther, Profeflor of Medicine at Leipfic; a genus of Sterculiacex.

Wa'nderoo (Zool.) a popular name in Ceylon for a monkey, the Macacus Silenus.

Wangenhei'mia (Bot.) P. N. in honour of F. A. F. Wangenheim, a German botanift; a genus of Gramina.

War'nea (Zool.) P. N. in honour of Mifs Elizabeth Warne, who tranflated Lamonroux's "Polypiers flexibles."

Wasp (Zool.) Anglo-Sax. weeps, Latin, vefpa. 
Watso'nia (Bot.) P. N. in honour of W. Watfon, a London apothecary; a genus of Iridacex.

Wea'sel (Zool.) Anglo-Sax. zugle; the common Weafel is Muftela vulgaris.

We'bera (Bot.) P. N. in honour of G. H. Weber, a German botanift; a genus of Bryoid Mufci.

Webbi'na (Zool.) P. N., a genus of Foraminifera.

Wede'lia (Bot.) P. N. in honour of George Wolfgang Wedel, a German botanif, who died in I 721 ; a genus of Compofite.

Wes'ver (Ichth.) the name of this filh, the ftinging Weever, is faid by Dr. Badham to be derived from the French la vive, defignating the frong tenacity of life manifefted by the filh; it is, however, moft probably derived from the Angrlo-Sax. vivere, a ferpent or wivern; common name of the Trachinus draco.

Wee'vil (Ent.) Anglo-Sax. zuelf or wifel; common name of various beetles of the family Curculionida.

Weinma'nnia (Bot.) P. N. in honour of $\mathcal{F}$. W. Weinnann, a German botanift of Ratilbon; a genus of Cunoniacex.

Weira'na (Ent.) P. N. in honour of $M r$. F. Fenner Weir, of Blackheath.

Wentle-trap (Zool.) a corruption of German zvendle-treppe, a winding ftaircafe; the Scalaria communis.

Weis'sia (Bot.) P. N. in honour of F.W. Weifs, of Gottingen, a German cryptogamic botanift; a genus of Mufci.

Wendlan'dia (Bot.) P. N. in honour of Henry Ludovicus Wendland, curator of the botanic garden at Hanover; a genus of Cinchonacex.

Welwit'schia (Bot.) P. N. in honour of Dr. Welcuitfch, its difcorerer; a genus of Gnetacer.

Werne'ria (Bot.) P. N. in honour of Abraham Gotlieb Werner, the celebrated mineralogil, who died in I $\delta_{1} 7$; a genus of Compoitix.

Westrin'gia (Bot.) P. N. in honour of F. P. Wagring, phyfician to the king of Sweden; a genus of Labiatre.

Wethere'llia (Fos. Bot.) P. N. in honour of Mr. Wethera!l; one of Mr. Bowerbanks' genera of follil fruits from the London clay.

Whale (Ichth.) Anglo-Saw. hrool; the Greenland whale is Balæna myfticetus.

Wheat (Bot.) Anglo-Sax. hrexte; common wheat is Triticum rulgare.

Whitla'via (Bot.) P. N, in honour of Francis Whitla Efq., of Belfalt; a genus of Hydrophyllacex.

Willdeno'via (Bot.) P. N. in honour of Charles Lousis Willdunor', Profellor of Botany at Berlin; a genus of Reftiacer. 
Willeme'tia (Bot.) P. N. in honour of $P$. R. Willemet, author of "Herba* rium Mauritiantm ; " a genus of Compofitze.

Wil'low (Bot.) Ainglo-Sax. avilg or zudig, willing, i. e. like falix, from falio. The common willow is Salix fragilis.

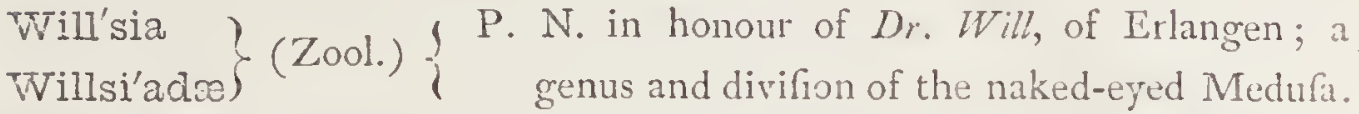
Willughbe'ia (Bot.) P. N. in honour of Francis Willughby, F.R.S., a diftinguihed Englifh naturalitt, the friend and pupil of Ray; a genus of A pocynacex.

Vilso'nia (Bot.) P. N. in honour of Fohn Triljon, of Kendal, an enthufaftic lorer of plants in humble life, of whom it is faid, that he was once on the point of felling his only cow, in order to purchafe a bota. nical work, when a lady generoully prefented him with a copy; a genus of Convolvulacer:

Wimmera'na (Ent.) P. N. in honour of Baron von Wimmer.

Wintera cea (Bot.) P. N. in honour of William Winter, a Captain in the Royal Navy, who failed round the world with Sir Francis Drake; a family of Exogenous Plants.

Wire-worm (Ent.) applied to the larve of various fpecies of beetle moltly belonging to the family Elateridiu.

Wista'ria (Bot.) P. N in honour of Cappar Wigfur, a Profeflor in the Univerfity of Pennfylvania; a genus of Leguminofic.

Witherin'gia (Bot.) P.N. in honour of Dr. W. Wiliering, a Britifh botanilt, author of a "Botanical Arrangement of the Vegetables of Great Britain," I 776 ; a genus of Solanacer.

Witse'nia (Bot.) P. N. in honour of $M \mathcal{L}$. Witfen, a Dutch patron of botany; a genus of Iridacer.

Woad (Bot.) Anglo-Sax. avadt; Celtic, givel ; the Ifatis tinctoria, formerly used by the ancient Britons as a dye.

Vrockëel'Ia (Ent.) P. N. in honour of Dr. Wock, of Brefla, Pruffia.

Wolf (Zool.) Anglo-Sax. ruulf; Lat. vulpes.

Wood'bine (Bot.) fynonyme for the Wild honeyfuckle, Lonicera Periclymenum.

Wood'cock (Omith.) derivation obvious; the Scolopax nulticola; Fr.

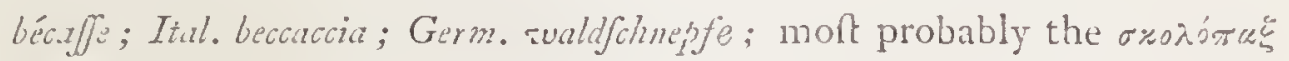
of Arinotle.

Wood'sia (Bot.) P. N. from Jofeph Wools, an Englifh botanift; a genus of Polypodioid Filices. 
Woodwar'dia (Bot.) P. N. in honour of Thomas Jonkinfon Woutzuard, an Englifh botanif ; a genus of Polypodioid Filices.

Wor'mia (Bot.) P. N. in honour of Olaus Wormius, a celebrated Danifh phyfician and naturalift; a genus of Dilleniacex.

Worm'wood (Bot.) Anglc-Sux. rvermod; German, rvermuth; the Artemifia Abfinthium.

Woundwort (Bot,) the Anthyllis Vulneraria was fo named from its fup. pofed properties in curing wounds, probably by means of the down; now applied to the genus Stachys.

Wranse'lia (Bot.) P. N. in honour of $M$. Wrangel; a genus of Algre.

Wren (Ornith.) Angio-Sax. zurenan.

Wrigh'tia (Bot.) P. N. in honour of Dr. W. Wright, a Scotch phyfician; a genus of Apocynacex.

Wulfe'nia (Bot.) P. N. in honour of F. Y. Wulfen, a German botanift; a genus of Scrophulariacex.

Wurm'bea (Bot.) P. N. in honour of $F$. voir Wurmb, Secretary to the Academy of Sciences at Batavia: a genus of Melanthaceæ.

Viych-elm (Bot.) the Ulmus montana.

Wydle'ria (Bot.) P. N. in honour of H. Wydler, a botanift; a genus of Umbelliferi?.

Xantharpy'ia (Zool.) $\xi a v \theta$ ó, yellow, äpruic, a harpy.

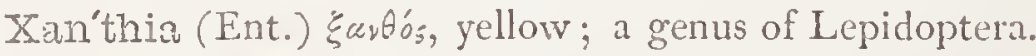

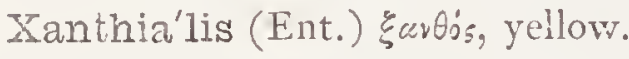

Xanthi'dia (Fos. Bot.) dim. from $\xi * v \theta_{0}^{\prime}$, yellow; applied to forfll bodies from flint, confring of the fporangia of the Definidiacere.

Xanthi'dium (Bot.) fame derivation; a genus of Defmidiacer.

Xan'thium (Bot.) $\xi a v \theta_{s}$, yellow; it was ufed by the Greeks to dye the hair; Burweed; a genus of Compofitæ.

Xan'tho (Zool., Bot.) $\xi a v \theta_{o s}$, yellow; in zoology, a genus of Cruftacea; in botany, a genus of Compolitis.

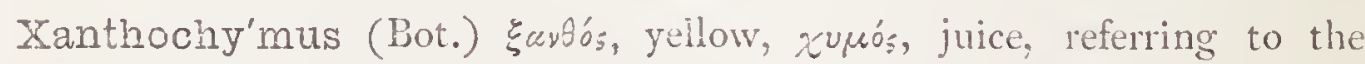
fruit; a genus of Clufiacer.

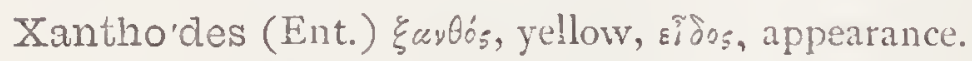

Xantho'genys (Zool., Ornith.) $\xi a v \theta_{0}^{\prime}$, yellow, y'śṽ s, the cheek; yellowcheeked; e.g. Parus xanthogenys, the Yellow-cheeked Titmoufe.

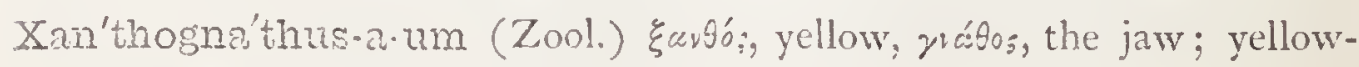
checked. 


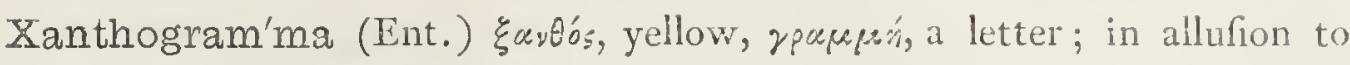
the wing marks.

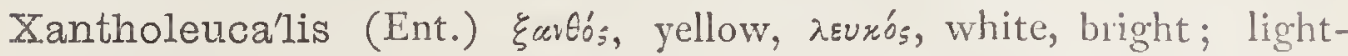
yellow.

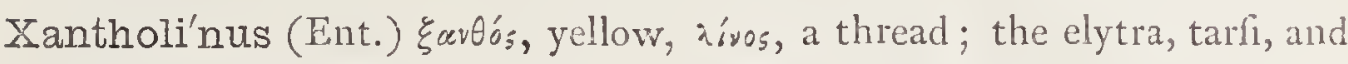
antennæ are red; a genus of Coleoptera.

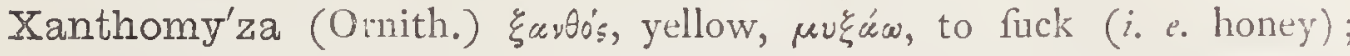
fometimes inaccurately written Zanthomyza; a genus of Meliphagidx or Honey-fuckers.

Xanthop'tera (Ent.) $\xi a \nu \theta_{0}$ s, yellow, $\pi \tau \varepsilon$ póv, a wing.

Xanthor'nis (Ornith.) $\xi a v 6 o_{s}$, yellow, öpvss, bird; a genus of Orioles.

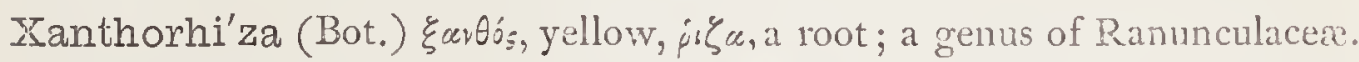
Xanthorrhœ'a (Bot.) $\xi \alpha v \theta_{o}$, yellow, $\dot{\rho} \xi \omega$, to flow; alluding to the gum; a genus of Liliacere.

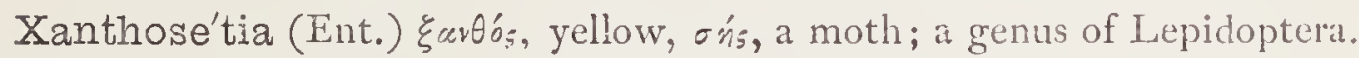

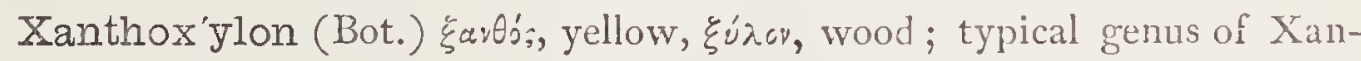
thoxylacex.

Xe'nia (Ornith.) etymology doubtful; a genus of Sea-gulls, family Laridx.

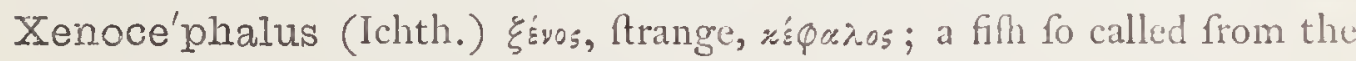
largenefs of its head.

Xenoder'mus (Zool.) $\xi^{\prime} \operatorname{sos}$, ftrange, $\delta_{\xi}^{\prime} \xi \mu \alpha$, a kin; a genus of Ophidians. Xeno'dochus (Bot.) ' 's'vos, Arange, dox'n, a receptacle; a genus of Fungi.

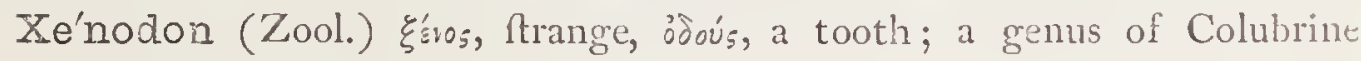
ophidians.

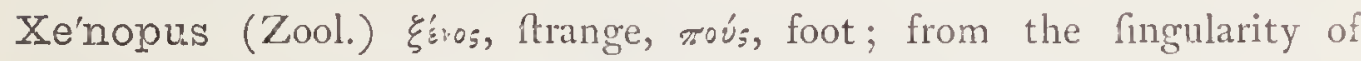
poffeffing nails on its feet; a genus of Batiachia.

Xe'nops (Ornith.) $\xi^{\prime} \dot{\varepsilon}{ }^{\prime}$, ftrange, $\ddot{\omega} \psi$, an eye; a genus of Birds.

Xe'nos (Ent.) ¿̌nvós, a footlefs trunk; a parafitic genus of Strepfiptera.

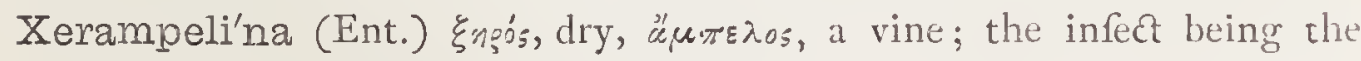
colour of diy vine leaves.

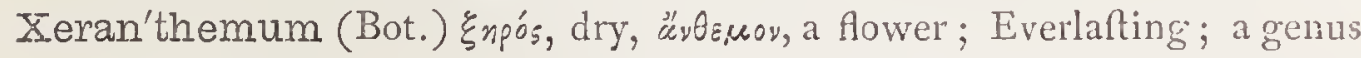
of Compolitæ.

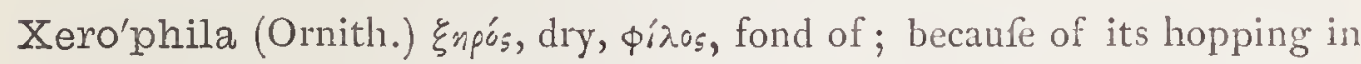
dufty streets.

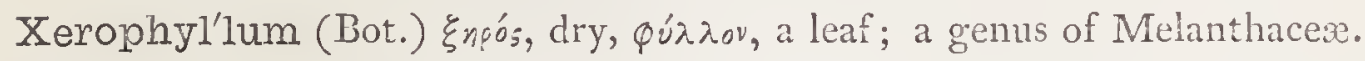
Xero'tes (Bot.) Gnoórns, drynefs; from the aridity of the herbage; a genus of Juncaceæ.

Ximene'sia (Bot.) P. N. in honour of Fufph Ximenes, a Spanifh apothecary; a genus of Compofitie. 
Xime'nia (Bot.) P. N. in honour of Francis Ximenes, a Spanifh monk, who wrote upon medicinal plants; a genus of Olacaceæ.

Xiph'ias (Ichth.) छ'pos, a fword; the Sword-filh.

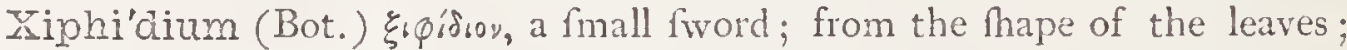

a genus of Hæm modoracex.

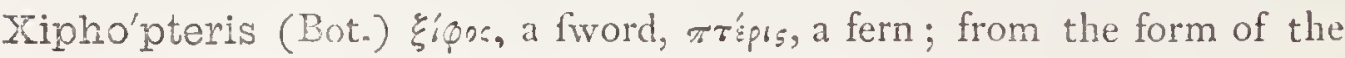
fronds; a genus of Polypodioid Filices.

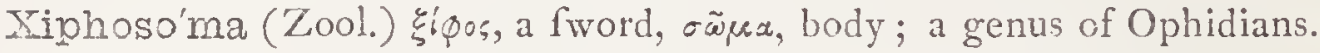

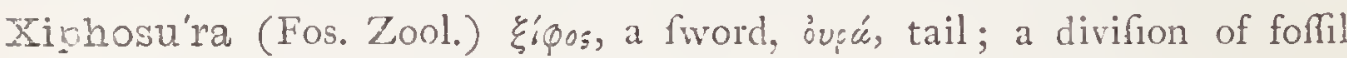
Entomoltracous Cruttaceans.

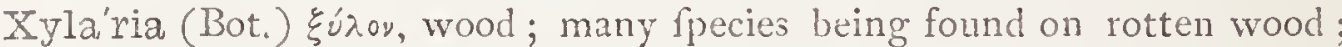
a genus of Fungi.

Xyle'tinus (Ent.) Gúnov, wood, riva, to injure; a genus of Coleoptera.

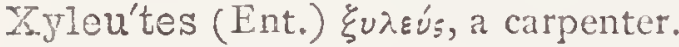

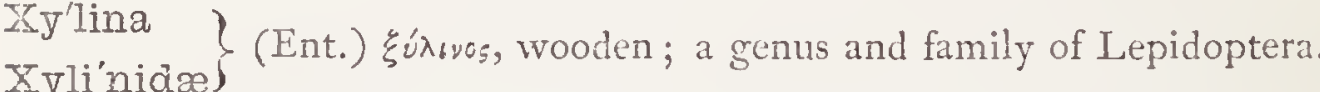

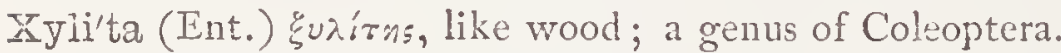

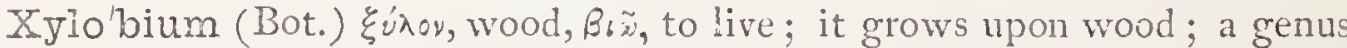
of parafitic Orchidacex.

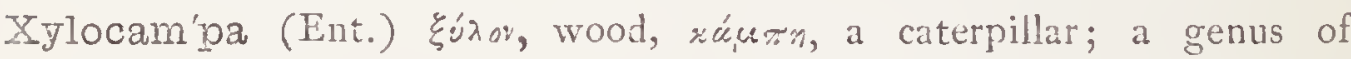
Lepidoptera.

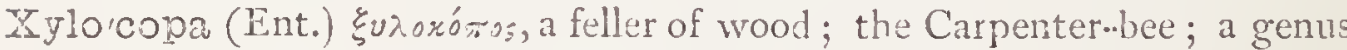
of $\mathrm{H}$ ymenoptera.

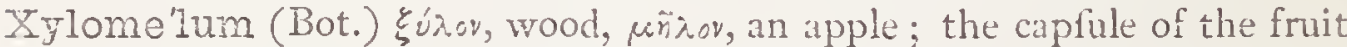
being wood-like; a genus of Proteacex.

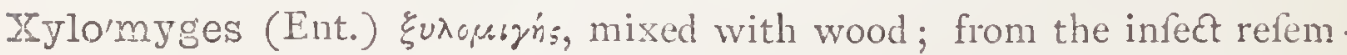
bling wood; a genus of Lepidoptera.

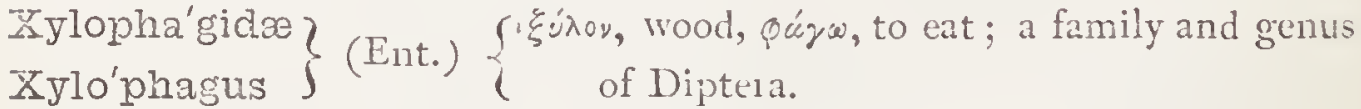

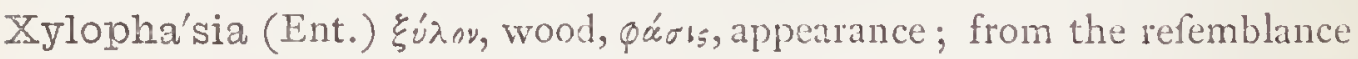
of the infect to a piece of wood; a genus of Lepidoptera.

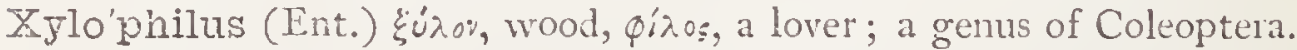

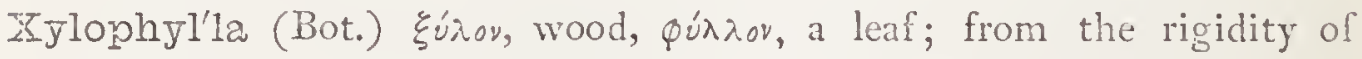
growth of the foliage; a genus of Euphorbiacere.

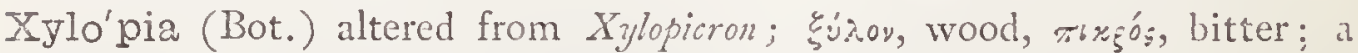
genus of Anonacex.

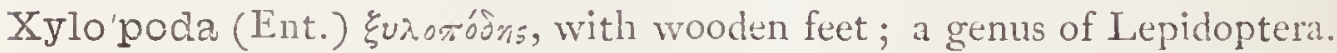

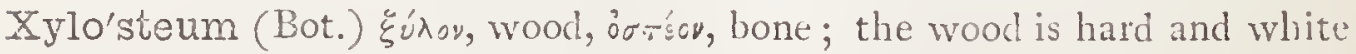
like bone; fpec, name of 1 sonicera Xylofteum. 


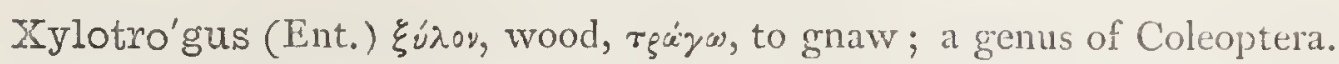

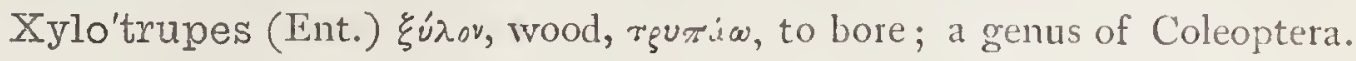
Xy'ris (Bot.) छupós, a razor; the name of a plant named by Diofcorides, probably from its razor-like leaves; typical genus of Xyridaceæ.

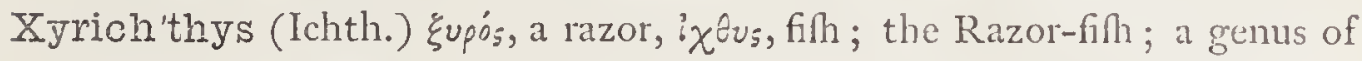
family Labridx.

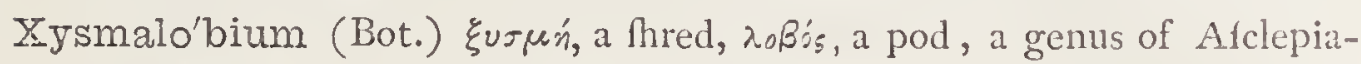
dacea.

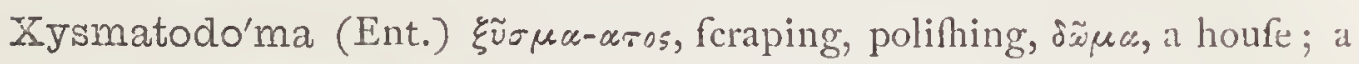
genus of Lepidoptera.

Yeast-plant (Bot.) probably the conidial form of Penicillium glaucum; in fome of its other forms it has the name of Vinegar-plant. Vite Microg. Dict.

Yew (Bot, probably a corruption of the Saxon iru, green; the Taxus baccata.

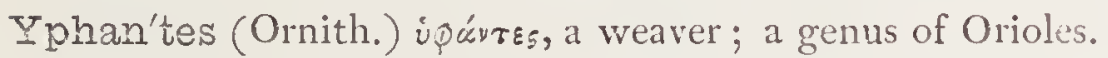

Yponomeu'ta (Ent.) irrovoreviu, to hollow out; a genus of Lepidoptera.

Yuc'ca (Bot.) yuca, its name in St. Domingo; Adam's needle; a genus of Liliacer.

Yunx (Ornith.) Lat. the Wry-neck; a genus of Scanforial birds, famiiy Picida.

Za'brus (Ent.) לaßpós, furious, greedy; a genus of Coleoptera.

Zacyn'tha (Bot.) it grows in the illand of Zacinthus, now Zante; a genns of Compolitx.

Zaluza'nia (Bot.) altered from Zalufianfia, an obfcure Polifh botanift; a genus of Compofitix.

Za'menis (Zool.) לapev'ns, brave, high-fpirited; a genus of Colubrine ophidians.

Zam'ia (Bot.) Lat. lofs; from the fterile appearance of the male fructif. cation; a genus of Cycadacex.

Zannichel'lia (Bot.) P. N. in honour of Fohn Ferome Zanichelli, a Venetian apothecary; a genus of Naiadacex.

Zapa'nia (Bot.) P. N. in honour of $P . A$. Zappa, an Italian botanif; a genus of Verbenacex.

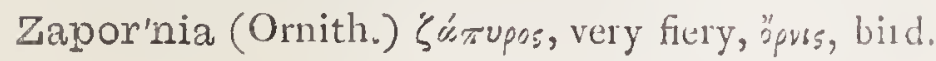


Ze'a (Bot.) 'sab́e a fort of grain, from $\zeta \omega$, to live; becaufe it is ufed as food; Indian corn is Zea Mays; a genus of cereal Gramina.

Ze'bra (7ool.) Ital. zebra; Fr. zibre; Span.cebra; the Afinus Zebra.

Zeilan'icus-a-um (Zool.) Lat. relating to Ceylon; alfo Zeylanicus.

Zelle'ria (Ent.) P. N. in honour of Profeffor P. C. Zeller, of Glogau; a genus of Lepidoptera.

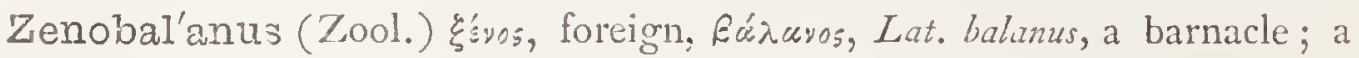
genus of Cirripedes.

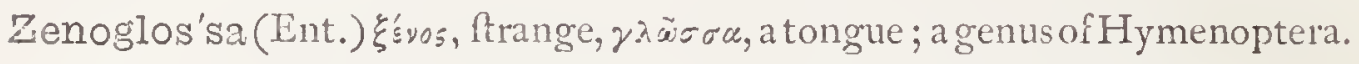

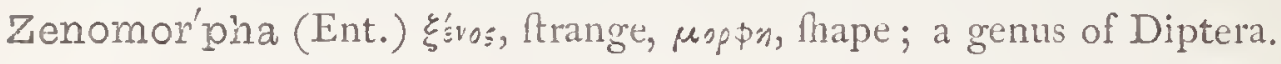

Zen'zera (Ent.) Ital. zenzara, a gnat ; from zenzero, ginger, on account of the pungency of its bite; a genus of L,epidoptera.

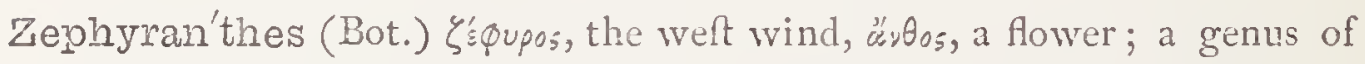
Amaryllidacex.

Zere'ne ${ }^{\prime}$ Zere'nidæ $\}$ (Ent.) $\left\{\begin{array}{c}\text { "a name of Venus" (Treitfchke); a genus and } \\ \text { family of Lepidoptera. }\end{array}\right.$ Ze'thus (Ent.) derivation uncertain; a genus of Hymenoptera.

Zeu'glodon (Fos. Zool.) לeũzos, a yoke, ỏdoús, a tooth; a tertiary mammal of the whale kind, fo called by Profefor Owen from the peculiar form of its molar teeth.

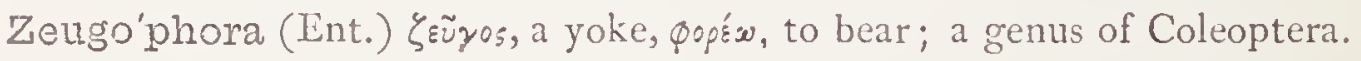

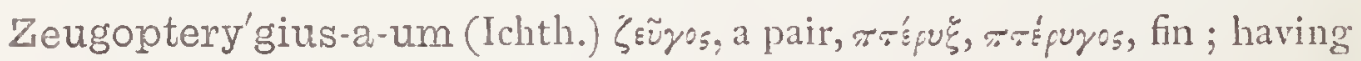
the fins arranged in pairs.

Zeus (Ichth.) Cab'; the dory, from the name of Jupiter, Zeus, fhowing the high opinion in which it was held by the ancients; the Dory is Zeus faber.

Zexme'nia (Bot.) an anagram of Ximenefra; a genus of Compofitr. Zibe'thicus-a-um (Zool.) Lat. relating to the Civet.

Zic'zac (Ent.) from the "zic-zac" pofition of the larwe when at reft.

Zie'ria (Bot.) P. N. in honour of $M$. Zier, a learned botanift; a genus of Rutacer.

Ziete'nia (Bot.) probably the name of fome obfure botanift; a genus of Lamiacex.

Zilla (Bot.) the name of an Egyptian plant; a genus of Cruciferæ.

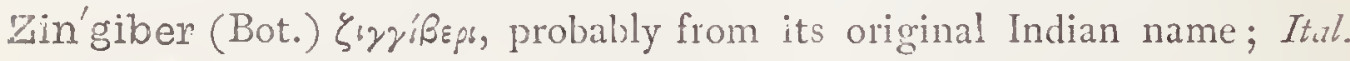
zenzovero or zensero; Sp. gengibre; Fr. gingembre; ginger; a genus of Scitaminex.

Zin'nia (Bot.) P. N. in honour of Foln Godfry Zim, Profellor of Botany at Göttingen; a genus of Compofitiu. 
Ziza'nia (Bot.) Greek name of clarnel; a genus of Gramina.

Ziz'ia (Bot.) P. N. in honour of J. B. Zizii, a German botanift.

Zizi'phora (Bot.) $\approx i \approx i$, the Indian name of a fruit, opśc $^{\prime}$, to bear.

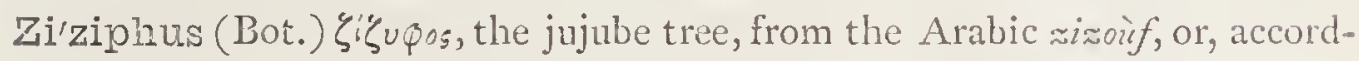
ing to Loudon, altered by the Greeks from afiffic the $Z$. Lotus is the

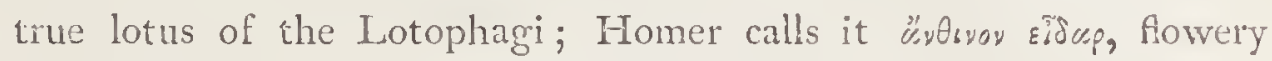

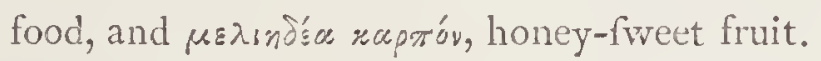

Zoan'trina) (Zool.) $\left\{\begin{array}{c}\zeta \tilde{\omega} \text { ov, an animal, } \ddot{\alpha} \cdot \theta_{05}, \text { a flower; names applied to } \\ \text { a family and genus of Zoophytes. }\end{array}\right.$ Zoar'ces (Ichth.) 'woxprńs, maintaining life; in allufion to its being viviparous; the Eelpout.

Zoëga'na (Ent.) P. N. in honour of 7 . Zoega, who captured the fpecies at Hammarby, the refidence of Linnxus near Upfala.

Zœ'gea (Bot.) P. N. in honour of 7 . Zoega, MT. D., who publifhed a Flora Iflandica; a genus of Compofitix.

Zona'ria (Bot., Ent.) 'óvn, a girdle, from the tranfverfe lines; a genus of Fucoid Algx.

Zona'tus-a-um (Zool.) Lat. girdled.

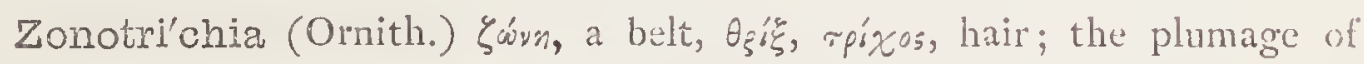
the head has three wliite ftripes.

$\left.\begin{array}{l}\text { Zonu'ridæa } \\ \text { Zonu'rus }\end{array}\right\}$ (Zool.) $\left\{\begin{array}{c}\zeta w n n, \text { a band, oup a, a tail; a family and genus of } \\ \text { Lizards. }\end{array}\right.$ Zoono'mia (Zool.) Jovo, an animal, vómos, a law; the fcience which treats of the laws of organic life.-See Darwin's Zoonomia.

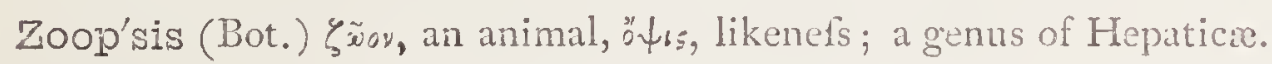

Zoot'cca (Zool.) לworórss, begetting or producing a living creature; viviparous; the female of this fpecies of lizard retains the eggs within her body until the young are ready to leave them, and thus they are produced alive.

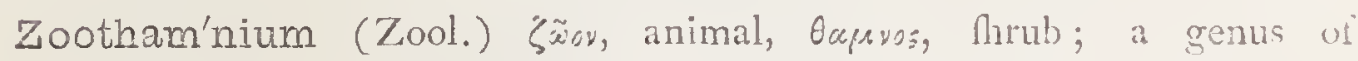
Infuroria.

Zornnia (Bot.) P. N. in honour of $\mathcal{F}$. Zorn, an apothecary and botanical author, at Kempton, Bavaria.

Zo'ospores (Bot.) "the name given to the ciliated active gemnse or Gonidia, produced either fingly or, more frequently after fegmentation, in numbers, out of the contents of ordinary or fpecial cells of the Algæ."--HENTRE:.

zozi'mia (Bot.) P. N. in honour of A. N. $\circlearrowleft$ Z Zozima, ditinguilhed editors of Greek claffics; a genus of Umbellifera. 


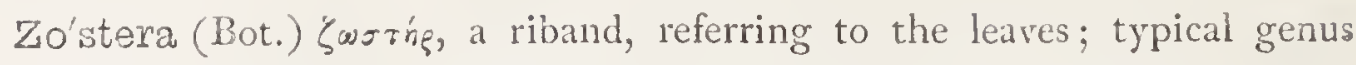
of Zolteracer.

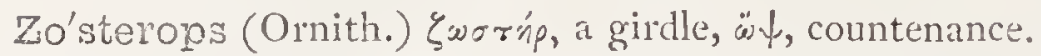

Zuccag'nia (Bot.) P. N. in honour of $A$. Zuccagni, garden fuperintendent at Florence.

Zygade'nus (Bot.) Juyós, a pair, ád'iv, a gland; having two glands in the fepals; a genus of Melanthacex.

ZJgæ'na (Ichth., Ent.) ל'́rawa, the hammer-headed fhark, perhaps from

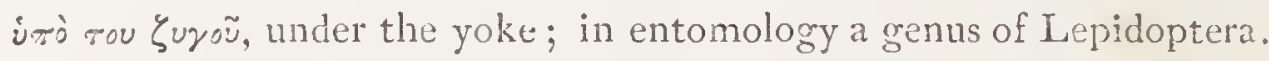
Zyzæ'nidæ (Ent.) a family of Lepidoptera, of which Zygana is the type. Zygne'ma Surós, a yoke, vñpar, a filament; the filaments

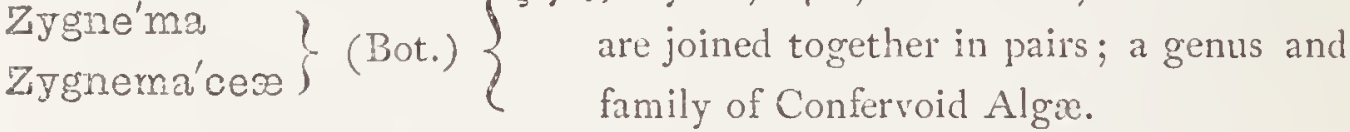

Zy'godon (Bot.) Gujos, a pair, ojown, a tooth; the teeth are arranged in pairs; a genus of Mufci.

ZУgogóniurn (Bot.) '̌ujós, a pair, gonium; a genus of Confervoid Algx.

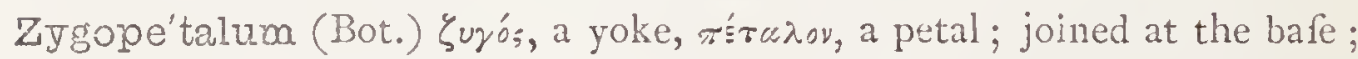
a genus of Orchidacex.

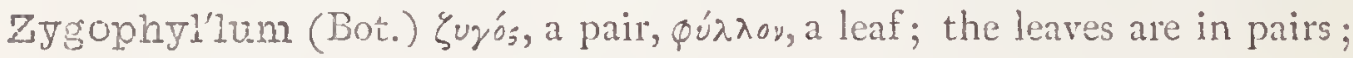
typical genus of Zygophyllacex.

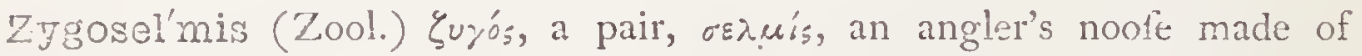
hair; movement ; its movements are effected by two fimilar fagelliform filaments, incerfantly in action; a genus of Infuforia.

THE END. 


\title{
LOVELL REEVE \& CO.'S
}

\author{
PUBLICATIONS IN
}

\section{datural Srime, aravels,}

\author{
ANTTQUTTIES, ETC.
}

\section{"None can express Thy works but he that knows them; \\ And none ean know Thy works, which are so many \\ And so eomplete, but only he that owes them."}

George Herbert.

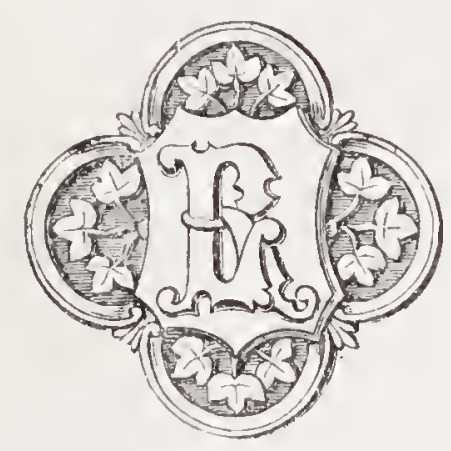

LONDON :

LOVELL REEVE AND CO., 5, HENRIETTA STREET, COVENT GARDEN. 


\section{Curtis' Botanical Magazine;}

Comprising the Plants of the Royal Gardens of Kew, and of other Botanical Es. tablishments in Great Britain, with suitable Descriptions. By Sir W.J. Hooker, D.C.L., F.R.S., Director of the Royal Gardens of Kew. Third Scrics.

Royal 8vo, 6 coloured plates by Fitch, $3 s .6 d$. monthly.

Vols. I. to XVIII., cach, with 72 coloured plates, $42 \mathrm{~s}$.

A Complete Set of the Second Serics, in 17 vols., new, £35. 14s. The only copy remaining.

Vols. I. to XLV. of the First Scries, bound in 24 vols., whole calf (cxcept the last vol., which is in Numbers), $£ 18$.

\section{The Floral Magazine.}

Comprising Figures and Descriptions of New Popular Garden Flowers, and a Companion, containing New and Original Articles on Subjects connected with Floriculture. By the Rev. H. H. Dombrain.

Imperial 8vo, 4 colourcd plates by Andrews, $2 s .6 d$. Monthly.

Vols. I. and II., cach, with 64 coloured plates, $42 \mathrm{~s}$.

\section{The Rhododendrons of Sikkim-Ilimalaya;}

Being an Account of the Rhododendrons rccently discovered in the Mountains of Eastern Himalaya. By J. 1). Hooker, M.D., F.R.S. Imperial folio, 30 colourcd plates by Fitch, $23.16 s$.

\section{Illustrations of Siklim-Himalayan Plants.}

Chiefly selected from Drawings made in Sikkim under the superintendence of the late J. F. Cathcart, Esq., Bengal Civil Scrvice. The Botanical Descriptions and Analyses by J. D. HookeR, M.D., F.R.S.

Folio, 24 coloured plates and illuminated title-page by Fitch, $\mathfrak{f} 5.5 s$.

\section{The Victoria Regia.}

By Sir W. J. IIоокrR, F.R.S.

Elephant folio, 4 coloured plates by Fitch, $21 s$.

\section{Pescatorea.}

Figures of Orchidaccous Plants, chiefly from the Collection of M. Pescatore. Edited by M. Linden, with the assistance of MM. G. Ludmeman, J. E. PlanChON, and M. G. Reichenbach.

Folio, Parts I. to XII., each, 4 coloured plates, 7 s.

\section{The Tourist's Flora.}

A Descriptive Catalogue of the Flowering Plants and Ferns of the $\mathrm{Br}$ itish Islands, France, Germany, Switzcrland, and Italy. By Joseph Woods. 8vo, 18.s.

\section{Journal of Botany and Kew Miscellany.}

Original Papers by eminent Botanists, Communications from Botanical Travellers, eic. Editer by W. J. Hooker, D.C.L., F.R.S.

Vols. IV. to IX., each, 12 platcs, some coloured, \&1. $4 s$. A complete sct in 9 vols, half calf, $\mathbb{1 0}$. $16 \mathrm{~s}$. 


\section{The London Journal of Botany.}

Editcd by Sir W. J. Hooker, D.C.I., F.R.S., Director of the Royal Gardens of Kew.

Vol. VII., completing the Series, 23 plates, plain, $30 s$.

\section{Icones Plantarum.}

Figures of New and Rare Plants, By Sir W. J. Hooken, D.C.L., F.R.S. New series. Vol. V., 100 plates, $31 s .6 d$.

\section{COLONIAL AND FOREIGN FLORAS.}

Flora Australiensis.

A Description of the Plants of the Australian Territory. By G. Brntham, F.R.S.,

P.L.S.; assisted by Ferdinand Mueller, M.D., F.R.S. and I..S., Govermment

Botanist, Melbourne, Victoria.

Flora Hongtiongensis ;

Vol. I., 20s.

A Description of the Flowering Plants and Ferns of the Island of Hongkong.

By George Benthan, V.P.L.S. With a Map of the Island.

In One Yolume, 550 pages, $16 s$.

Flora of the British West Indian Islands.

By A. H. R. Grisebach, M.D., Professor of Botany in the University of Göttingen.

Parts I. to V., 5s. cach. To be completed in 7 Parts.

The Botany of the Antarctic Voyage

of H.MI.SS. "Erelus" and "Terror" in the years 1839-1843, under the command of Captain Sir J. C. Rose, R.N., F.R.S. By Joseph Dalton Hooklr, M.D., F.R.S.

1. Flora of Lord Auckland and Campbell's Island's, and of Fuegia, the Falkland Istands, etc.

In 2 vols., 200 plates, $£ 10.15 s$. eoloured; $£ 7.10 s$. plain.

2. Flora of New Zealand.

In 2 vols., 130 plates, $213.2 s .6 d$. coloured; $29.5 s$. plaiu.

3. Flora of Tasmania.

In 2 vols., 200 plates, $£ 17.10$ s. coloured; 212.10 s. plain.

\section{Cryptogamia Antarctica;}

Or, Cryptogamic Plants of the Antaretic Islands. Issued separatcly.

In One Volunc, quarto, et. 4 s. coloured; $\& 2.17$ s. plaiu.

On the Flora of Australic,

Its Origin, Affinities, and Distribution: being an Introductory Essay to the 'Flora of 'Tasmania.' By Joseph Dalton Hooker, Ml.D., F.R.S.

128 pages, quarto, $10 s$. 


\section{On the Fllora of New Zealand;}

Its Origin, Aflinitics, and Gcographieal Distribution; being an Introductory Essay

to the 'Flora of New Zealand.' Jy Josepll Dalíon Hooker, M.D., F.R.S.

49 pages, quarto, $2 s$.

\section{Outlines of Elementary Botany,}

As Introductory to Iucal Floras. By George Ben'ruam, V.P.T.S.

45 pages, stitched, $2 s .6 d$.

\section{The British Ferns.}

\section{FERNS.}

Coloured Figures and Deseriptions, with Analyses of the Fructification and Venation, of the Ferns of the British Isles, Systematically Arranged. By Sir W.J. ПоOKER, K.H., D.C.I., cte.

$$
\text { Royal Sro, } 66 \text { colorred plates by Fitch, } 82.2 s \text {. }
$$

\section{Garden Ferns.}

Coloured Figures and Descriptions, with Analyses of the Fructification and Venation, of the Ferns best adapted for Cultivation in the Garden, Ilothouse, and Couservatory. By Sir W. J. HookLR, K.H., D.C.L., ete.

Royal 3vo, 64 coloured plates by Fitch, f2. $2 s$.

\section{Irilices Exotica.}

Century of Exotic Ferns, particularly of such as are most descrving of Cultivatiou. By Sir W. J. Moоkek, K.Li., D.C.L.

Royal 4to, 100 coloured plates by Fitch, $£ 6.11$ s.

\section{Ferny Combes.}

$\Lambda$ Ramble after Ferns in the Gleus and Valleys of Devonshire. By Chardotie Chantex. Sccond Edition.

Fep. Svo, 8 coloured plates by Fitch, and a Map of the County, $5 s$.

\section{MOSSHS.}

\section{Handbook of the British Mosses;}

Being a Description of all the Mosses inhabiting the British Isles, with Coloured Figures and Dissections of $75 S$ speeies, from Original Drawings by W. Fren. By the Rev. M. J. BEREELeY, M.A., F.L.S. 24 coloured plates, $21 s$.

\section{SEA WEIDS.}

\section{Synopsis of Rritish Seaweeds.}

1)escriptions, with Critical Remaks, of all the known Specics, abridged from Professor Harvey's 'Ply yologia Britannied.'

A pocket volume, 220 pages, 5 s. 


\section{Phycologia Britannica.}

A History of the British Seawecls; containing eoloured Figures and Deseriptions of all the Species of Algx inhabiting the Shores of the British Islands. By WILuiam Henry Harvey, M.D., F.R.S., Professor of Botany to the Dublin Suciety. In 4 vols. royal 8vo, 360 coloured plates, 26 . tis.

\section{Phycologia Australica.}

A History of Australian Seaweeds, containing Coloured Figures and Descriptions uniform with the 'Phycologia Britannica.' By Wildiam Henky Harver, M.1)., F.R.S.

Completc in 5 vols. Vols. I. to IV., cach, containing 60 coloured plates, 30 s.

Vol. V., with Indexes, $33 s$.

\section{Nereis Australis.}

Figures and Descriptious of Marine Plants collected on the Shores of the Cape of Good Hopc, the extra-tropical Australian Colonies, 'T'usmania, New Zealand, and the Antaretic Regions. By Professor Harvey, M.D., F.R.S.

Impcrial 8vo, Two Parts, cach, containing 25 coloured plates, \&1. 1 s.

\section{FUNGI.}

\section{Outlines of British Fungology,}

Containing Characters of above a Thousand Specics of Fungi, and a Complete List of all that have been deseribed as Natives of the British Isles. Byy the Rev. M. J. Berkeley, M.A., F.L.S. With Coloured Figures and Dissections of 170 Species by FiTcir,

8vo, 24 coloured plates, $30 \mathrm{~s}$.

\section{The Esculent Funguses of England.}

An Account of their Classical History, Uses, Characters, Development, Nutritions Properties, Modes of Cooking, etc. By C. D. Badham, M.D. Now Edition, Edited by Fred. Currey, M.A., F.R.S., F.L.S. 8 vo, 12 coloured plates, $12 s$.

\section{Tllustrations of British Mycology.}

Figures and Descriptions of the Funguses of interest and novelty indigenous to Britain. By Mrs. Hussey.

Royal 4to; First Series, 90 coloured plates, $27.12 s .6 d$;

Second Series, 50 plates, \&4. $10 s$.

\section{ZOOLOGY.}

\section{Zoology of the Voyage of H.M.S. Samarang,}

Under the command of Captain Sir" Edward Belcher, C.B., F.R.A.S., during the Ycars 1843-46. Edited by Artuur Adass, F.L.S.

The Vertebrata, with 8 plates, by John Edward Gray, F.R.S.; the Fishes, with 10 plates, by Sir John Richardson, F.R.S.; the Mollusea, with 24 plates, by Arthur $\Lambda$ dams, F.L.S., and Lovell Reeve, T.L.S.; the Crustacea, with 13 plates, by Arthur Adams, F.I.S.S., and Adam White, F.L.S.

Royal 4 to, 55 coloured plates, $6 ?$. $70 s$. 


\section{INSECTS.}

\section{Curtis' British Entomology.}

Illustrations and Descriptions of the Genera of Insects found in Great Britain and Ireland, containing coloured figures, from nature, of the most rare and beautiful species, and, in many instanees, of the plants upon which they are found.

Complete in 8 vols., 8 vo, 770 coloured copper plates, 216 . 16 s.

\section{Curtis' British Entomology in Monographs.}

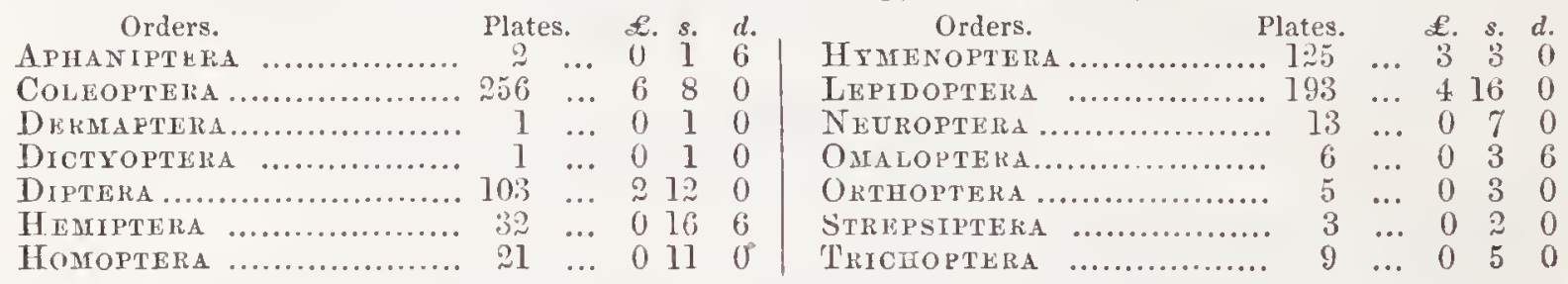

A Reissue of the Orders Coleoptera, Diptera, Iymenoptera, and Lepidoptera, in Mouthly Parts, each containing 5 plates, with text, price $2 s .6 \mathrm{~d}$., commenced Jamiary 1st, 1863.

\section{Tnsecta Britannica;}

Vols. II. and III., Diptera. By Francis Walker, T.L.S.

8vo, each, with 10 jlates, $25 s$.

\section{MOLLUSTS AND SHELLS.}

\section{The Land and Freshwater Mollusks}

Indigenous to and Naturalized in the British Isles. By Lovet. Revere, F.L.S. With finely-exeeuted Wood-Lngravings of the Shell of each Species by G. B.

Sowerby, and of the Living Animal of each Genus by O. Jewitt.

$$
\text { Svo, } 10 s .6 d \text {. }
$$

\section{Thlements of Conchology;}

An Introduction to the Natural History of Shells, and of the Anmals which form them. By Lovelu Reeve, F.L.S.

$$
2 \text { vcls., } 62 \text { coloured plates, } 22.16 s \text {. }
$$

\section{Conchologia Systematica.}

A Complete System of Conchology; in which the Lepades and Conchiferous MolJusea are deseribed and elassified aceording to their Natural Organization and Habits. By Loveli Reeve, F.L.S.

$$
2 \text { vols. } 4 \text { to, } 300 \text { coloured plates, } \& 8.8 \text { s. }
$$

\section{Conchologia Iconica.}

Figures and Descriptions of the Shells of the Mollusea, with Remarks on their Affnities, Synonymy, and Geographical Distribution. By Lovel. Renve, F.L.S., F.G.S. The Drawings by G. B. Sowerby, F.L.S. Monthly. In Parts, demy 4to, each, containing 8 colonred plates, 10s. Parts 225 aud 229 just published. 


\section{CONCHOLOGIA ICONICA IN MONOGRAPHS.}

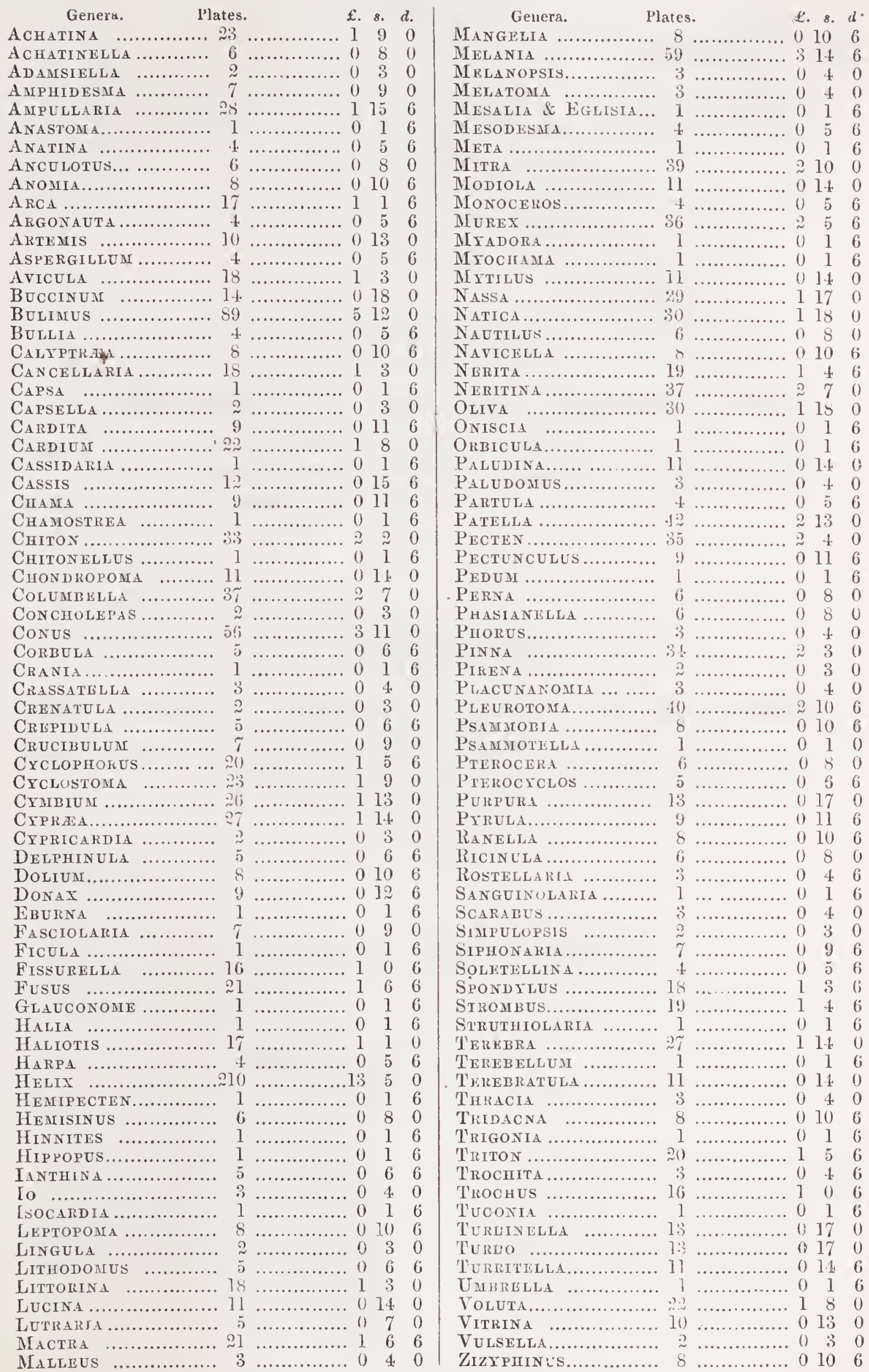




\section{GEOIOGY.}

\section{The Geologist.}

A Magazinc of Reology, Palacontology, and Mincralogy. Illustraten with highly finished Wood Engravings. Edited by S. J. MackiE, F.G.S., T.S.L. I'ublished Monthly. Price 1s. 6 d.

Vol. V., numcrous Wood Engravings, 18 s.

\section{CHEMISTRY.}

Chemical Analysis, Quatitative and Quantitative.

By Henry M. Noa 1, Ph.D., F.R.S., W.C.S., Lecturer on Chehistry at St. George's llospital. Part I., 'QUALITATIVE,' Wood-Engravinge, $6 s$.

[Part JI., Quantitative, in the Press.

\section{GEOGRAPHY.}

A Survey of the Early Geography of Western Europe, as connected with the First Inhabitants of Britain, their Origin, Language, Religions Rites, and Edifices. By Henry Lawes Long, Esy.

8 vo, $6 s$.

\section{VOYAGES AND TRAVELS.}

\section{Three Cities in Russia.}

By Professor C. Pinzzi Suyth, H.R.SS.L. \& E., Astronomer Roval for Scotland, Author of 'Tencriffe, an Astronomer's Experiment,' ctc.

2 Vols., post Svo, Maps and Wood-Engravings, $26 \mathrm{~s}$.

\section{Travels on the Amazon and Rio Negro,}

With an Account of the Native Tribes, and Obscrvations on the Climate, Geology, and Natural Thistory of the Amazon Valley. By Alfled R. WALlace, Escl. With Remarks on the Vocabularies of Amazonian languages, by R. G. Latham, M.D., T.R.S. 


\section{Western Himalaya and Tibet;}

Narrative of a Journey through the Mountains of Northern India. By Tuoms

Thomson, M.D., Assistant-Surgeon, Bengal Army.

Svo, Tinted Lithographs and Map, 15 s.

\section{Travels in the Interior of Brazil,}

Prineipally through the Northern Provinees and the Gold and Diamond Districts.

By George Gardner, M.D., H.L.S. Second Edition. Svo, Plate and Map, 12s.

\section{Narrative of a Walling Tour in Briltany.}

By John Mounteney Jepison, B.A., F.S.A. Aceompanied by Notes of a Photographie Expedition by LoveLL ReEve, T.L.S.

Royal 8vo, with Map by Arrowsmitll, and Stercoseopic Frontispicec, 12s.; or with 90 Photographic Viguettes, $£ 2.2 s$.

${ }_{*}^{*}$ Issued separately are 90 stereograplis, mounted on cards for use iu the Stereoseope, in box with lock and key, $\mathfrak{l} 4.4 s$.

\section{The Conway.}

Narrative of a Walking Tour in North Wales; accompanied by Descriptive and Historieal Notes. By J. B. DAvinson, Esq., M1.A.

Extra gilt, 20 stereographs of Welsh Scencry, 21s.

\section{ANTIQUITIES.}

\section{Manual, of British Archaology.}

By the Rev. Charress Boutell, M.A.

Contents.-Chap. 1. Architecture.-2. Architectural Aecessorics. - 3. Sejulchral Mlonuments.-4. Ileraldry.-5. Seals,-6. Coins.-7. Palrography, Illuminations and Inscriptions.-S. Arns and Armour.-9. Costunnes and Personal Ornaments.-10. Pottery, Poreclain and Glass.--11. Miscellaneons Suljects.

Royal 16mo, 20 eoluured plates, $10 \mathrm{~s}$. fid.

\section{IIore Ferales.}

Studies in the Archæology of the Northern Nations. By the late Joun M. Kembif, M.A. Ldited by R. G. Latiaas, M.D., F.R.S., and Augustus W. Pranis, T.S.A. 


\section{PHOTOGRAPHY.}

\section{Portraits of Men of Eminence in Titerature, Science,}

and Art. With Biographical Mcmoirs. The Portraits photographed from Life by. Erinest EDWARDS, B.A.

In Monthly Parts, cach containing Three Portraits with Memoirs, 2s. 6d. The following have appeared :-

\section{PART I.}

Earl Stanhope.

Sir Charles Lyell.

J. H. FOLEX, R.A.

PAR'I II.

W. M. ThackJray.

Sir R. J. Murchison.

David Roberts, R.A.
PART III.

Dr. WhEWELL.

Professor Owen.

George Gilbert Scott, R.A. PAR'T IV.

Sir Gardner Wilkinson.

Sik W. J. HoOKer.

Professor Sterndale Bennett.

PART $T$.

R. G. Latham, M.D., F.R.S.

IV. Fergusson, H.R.S.

Solomon HakT, R.A.

\section{Sketches in India.}

Taken at Hyderabad and Secunderabad, in the Madras Presidency. By CAPrain

Allan N. Scott, Madras Artillery. Edited by C. R. Weld.

100 Photographic Viguettes, £3. 3s. Mounted as Slides for the Stereoscope, £5. ǒs.

\section{The Stereoscopic Magazine.}

A Gallery for the Stereoseope of Landscape Scenery, Architceture, Antiquitics,

Natural History, Rustic Character, ete. With Deseriptions. 2s.6d. Monthly. 4 vols., cael completc in itself and containing õ0 Stercographs, £2. $2 s$.

Stereographs in Sets.

Stonyhurst College and its Environs; Photographed by Roger Fenton. 15 slides, $15 s$.

The Conway Stereographs. 20 slides, 20 s.

The Brittany Stereographs. 90 slides, in box with lock and key, $\& 4.4 s$.

The Isle of Wight Stereographs. 22 slides, 21 s.

Interior of the Britisl Museum. By Roger Fenton, Esq. 25 slides, 25 s.

English Castles and Abbeys. 14 slides, 14s.

Foreign Castles and Abbeys. 24 slides, 24s.

English Cathedrals and Churches. 21 slides, $21 s$.

Foreign Cathedrals and Churches. 38 slides, 38s.

Calvaries and Crosses. 10 slides, $10 s$.

Druidical Remains. 6 slides, $6 s$.

* * Auy of the above Stereographs may be lad singly at $1 s$. cach; also a Iist of 4.40 subjects.

Folding Stcreoscopes in eases, $3 s .6 d$. cach. 


\section{MISCELLANEOUS.}

Dictionary of Natural History Terms, with their Derivation; including the various Orders, Genera, and Species. By David II.

M'Nicoli, M.D., Member of the Royal College of Physicians.

Crown Sro. $12 s .6 \mathrm{~d}$.

\section{The Gate of the Pacific.}

By Commander Bedforn Pim, R.N., F.R.G.S., Assoc. Inst. C.F.

Demy 8 vo, 8 Chromo-Lithographs, Maps and Plans. $18 s$.

\section{Phosphorescence;}

Or, the Emission of Light by Mincrals, Plants, and Alimals. By Dr. $\Gamma$. L. Phipson, F.C.S., Member of the Chemical Society of Paris, ete. cte.

Numerous Illustrations, $5 s$.

\section{Shakespeare's Sonnets,}

Facsinile, by Ploto-Zincouraphy, of the First Printed cdition of ]609. From the Copy in the Library of Bridgewater House, by permission of the Right Hon. the Earl of Ellesmere.

$10 s .6 d$.

\section{Iiterary Papers on Scientific Subjects.}

By the late Professor EDward Fonbes, F.R.S., selected from his Writings in the 'Literary Gazettc.' With a Portrait and Memoir.

Small svo, $6 s$.

A Treatise on the Growth and Future Treatment of Timber Trees. By G. W. Newton, of Ollersett, J.P.

Half-bound calf, $10 s .6 d$.

Parks and Pleasure Grounds;

Or, Practical Notes on Country Residences, Villas, Public Parks, and Gardens.

By Charles H. J. Smith, Laudscape Gardencr.

Crown 8 vo, $6 s$.

The Planetary and Stellar Universe.

A Series of lectures. With Illustrations. By R. J. MANN. $12 \mathrm{mo}, 5 s$.

The Artificial Production of Fish.

By Piscaruus. Third Edition. 1s.

The Antiquity of Man.

An Examination of Sir Charles Lyell's recent Work. By S. R. PAtrison, F.G.S. Second Edition. Svo, 1s.

Cotton, and the Want of it.

2 coloured plates by Fitch, $1 s$. 


\section{NEW SERIES OF BRITISH NATURAL HISTORIES.}

\section{British Flora.}

By G. Bentinam. $12 s$.

British Ifungology.

By the Rev. M. J. BERKELEY. $30 s$.

\section{British Ferns.}

By Sir W. Hooker. 4\%s.

British Field Plants.

(The Ficld Botanist's Companion.) By 'Thomas Moork. 21s.

British Land and Freshwater Molluslis.

By LovelL Reeve, F.L.S. 10s. 6 d.

British Mosses.

By the Rev. M. J. Berkeley. $21 s$.

\section{SERIALS.}

\section{Portraits of Men of Eminence.}

With Biograplieal Memoirs. The Photographs by Elenest Edwards, B.A. Threc Portraits, with Memoirs in cach Part.

$$
\text { 2s. 6d. Monthly. }
$$

Illustrated Handbooly of the British Flora.

By G. Bentham, T.R.S., President of the Linnean Society. Wood Engravings,

with Dissections, of every Species, from original Drawings by W. Fiteh. $2 s .6 d$. Nonthly.

Botanical Magazine.

New and Rare Plants. With Deseriptions by Sir W. Hooker, D.C.L., F.R.S., and 6 eoloured plates, with Dissections, by W. Fiteh.

Floral Magazine: $3 s .6$. Monthly.

New Popular Garden Flowers. With Deseriptions by the Rev. H. H. Domriraln, 4. eoloured plates by Audrews.

$$
\text { 2s. } 6 d \text {. Monthly. }
$$

\section{Select Orchidaceous Plants.}

By R. WARner, F.R.H.S.

Folio, 4 superbly coloured plates, 10s. 6d. Quarterly.

Concholegra Lconicu.

By Loverd, ReEve, F.T.S.

Geologist.

$$
4 \text { to, } 8 \text { coloured plates, } 10 s \text {. Monthly. }
$$

Illustrated Magazine of Geology, Palicontology, and Mineralogy.

Wood cngravings, $1 s$. Gr. Monthly. 


\section{Curtis' British Coleoptera.}

5 eoloured eopper-plates, $2 s .6 d$. Monthly.

Curtis' British Lepidoptera.

5 eoloured eopper-plates, $2 s .6 d$. Monthly.

Curtis' British Hymenoptera.

5 coloured copper-plates, $2 s .6 d$. Monthly.

Curtis' British Diptera.

Stereoscopic Margazine.

5 eoloured eopper-plates, 2s. 6d. Monthly.

3 stereographs, with Deseriptions, $2 s .6 d$. Monthly.

\section{RECENT WORKS.}

M'Nicoll's Dictionary of Natural History Terms. $12 s .6 d$.

Badham's Esculent Frunguses.

New Edition. 12 coloured plates, $12 \mathrm{~s}$.

Berkeley's Mosses.

24 eoloured plates, $21 \mathrm{~s}$.

Benthan's Flora Australiensis.

Vol. I. $20 \mathrm{~s}$.

Noad's Chemical Analysis.

Part I., Qualitative, Wood-Engravings, $6 s$.

Captain Pim's Gate of the Pacific.

8 Chromo-Lithographs, Maps, and Plans. $18 \mathrm{~s}$.

Reeve's British Land and Freshwater Mollusks.

Wood Engravings. 10s. 6d.

Phipson's Phosphorescence.

Coloured Frontispicee and Wood Engravings, 5 s.

Moore's Field Botanist's Companion. 24 eoloured plates, $21 s$.

Professor Smyth's Three Cities in Russia.

2 vols., Maps and Mllustrations, $26 \mathrm{~s}$.

Shakespeare's Sonneis. Facsimile of the Pirst Eitition. $10 s .6 d$.

IIoward's Nueva Quinologia.

30 colourcd plates, $\in 6$. 
Hooker's British Irerns.

66 eoloured plates, $42 s$.

Hooker's Garden Ferns.

64 eoloured plates, $42 s$.

Berkeley's Fungology. 24 coloured plates, $30 \mathrm{~s}$.

Captain Scott's Sketches in India.

100 photographs, with Deseriptions, £3. 3 s.

Grisebach's Flora of the West Indies. Parts I. to V., each 5 s.

Harvey's Phycologia Australica.

Vol. V., completing the Work, 33s.

Pattison's Antiquity of Man.

Second Edition. Is.

Cotton, and the Want of it.

2 eolonred plates, $1 s$.

\section{FORTHCOMING WORKS.}

Shakespeare and his Birthplace.

Illustrated with Photographs.

[In November.

Chemical Analysis, Qualitative and Quantitative.

By Dr. Henry M. Noad, F.R.S.

[Part II., Quantitative, in the Press.

Bentham's Illustrated Handbook of the British Flora.

[Publishing Monthly.

Curtis' British Entomology in Orders.

Coleoptera.

LEPIDOPTERA.

[Publishing Monthly.

HYMENOPTERA.

Diptera.

Hore Ferales.

By the late Join M. Kembre, M.A. Edited by Dr. Iatham and A. W. Franks.

[Nearly ready.

Seemann's Flora Titiensis.

Flora Australiensis :

A Description of the Plants of the Anstralian Territory. By George Bentuan, F.R.S., P.I.S., assisted by Ferdinand Mueduer, M.D.,F.R.S. and L.S., Government Botanist, Melbourne, Victoria.

[Vol. IT. in preparation. 

BOUND BY
BONE BONE \& SON 76. FLEET STREET
LONDON.

I LONDON. 
